\title{
EL IMPACTO DE LA GUERRA DE MARRUECOS EN SALAMANCA (1906-1925)
}

\author{
MARÍA GAJATE BAJO
}

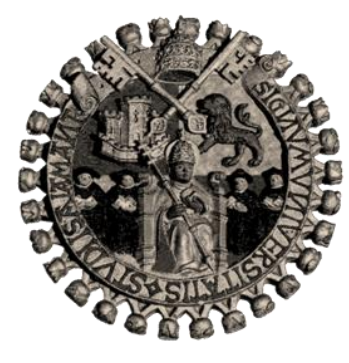

DIRECTOR: Dr. FRANCISCO DE LUIS MARTÍN

FACULTAD DE GEOGRAFÍA E HISTORIA. Curso: 2010-2011 UNIVERSIDAD DE SALAMANCA 



\section{ÍNDICE}

INTRODUCCIÓN..............................................................................................................................

LAS RAÍCES DE LA PRESENCIA ESPAÑOLA EN MARRUECOS ............................

NUESTRO ESCENARIO: SALAMANCA AL FILO DEL SIGLO XX .........................11

LA OPINIÓN PÚBLICA ESPAÑOLA Y LOS ASUNTOS MARROQUÍES.

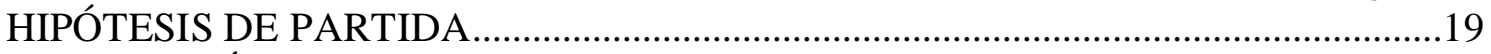

LA ELECCIÓN DE SALAMANCA. OBJETIVOS ..........................................................24

LA UTILIDAD DE LA PRENSA COMO FUENTE HISTÓRICA. LA

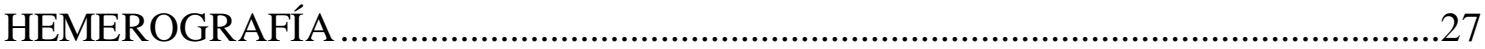

CONTRIBUCIONES RECIENTES AL ESTUDIO DE LA RELACIÓN ENTRE LA

PRENSA, LA OPINIÓN PÚBLICA Y LA CUESTIÓN MARROQUÍ .............................. 31

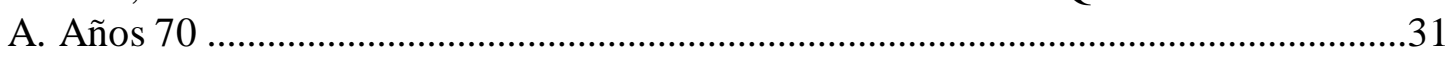

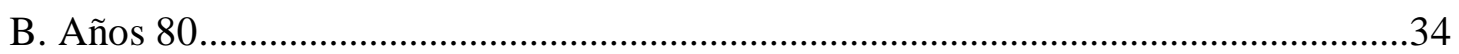

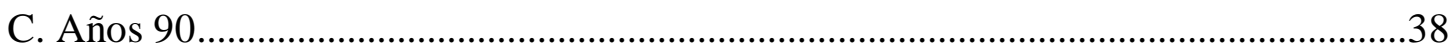

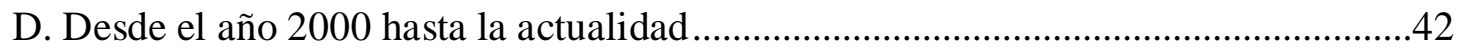

FUENTES EMPLEADAS EN LA REALIZACIÓN DE ESTE TRABAJO ...................50

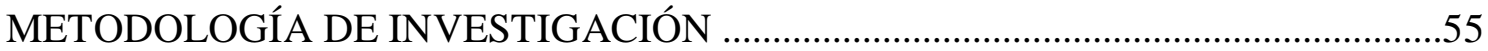

\section{OPINIÓN PÚBLICA Y OPINIÓN PUBLICADA. LA CONTROVERTIDA RELACIÓN DE UN INQUEBRANTABLE MATRIMONIO.................................59}

EL PUNTO DE PARTIDA: FASES PARA LA CONSTRUCCIÓN DE UN

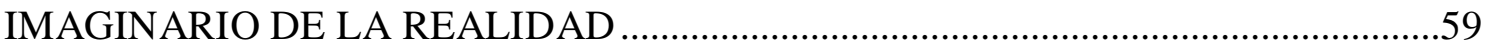

PERIODISMO Y PERIODISTAS A PRINCIPIOS DEL SIGLO XX...........................67

La misión del periodismo: la visión de Walter Lippmann ..........................................67

La función social del informador. El largo camino hacia su reconocimiento

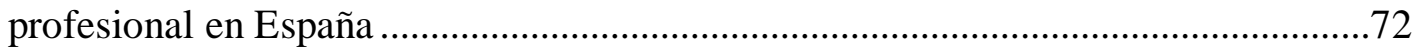

La libertad de expresión en la España de Alfonso XIII. La prensa durante la

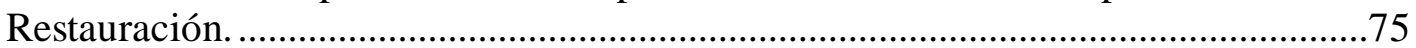

A. La Primera Guerra Mundial ..............................................................................90

B. La dictadura de Miguel Primo de Rivera ..........................................................93

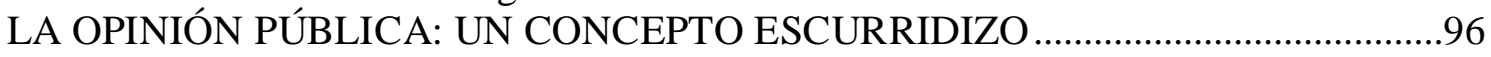

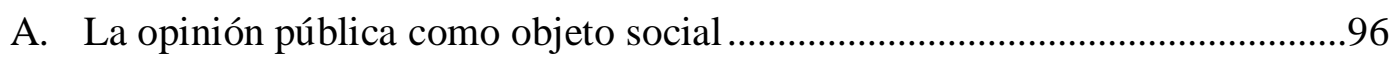

B. Breve historia de la investigación del proceso de comunicación.................... 100

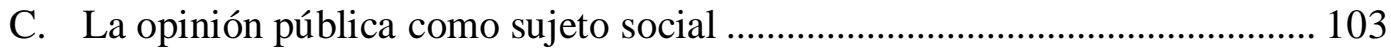

MARRUECOS EN EL HORIZONTE DE LA PRENSA ESPAÑOLA......................... 106

La percepción en España de la política exterior. Creadores de esa percepción: el corresponsal de guerra en Marruecos y el "estratega de café" .................................. 106

Periodistas sui generis: Marruecos y los intelectuales............................................. 114 
SALAMANCA Y LOS INICIOS DE LA AVENTURA COLONIAL: DE ALGECIRAS A LA GUERRA DE MELILLA (1906-1909)........................................ 120

AQUELLA CIUDAD EN AQUELLA ESPAÑA....................................................... 120

ANTECEDENTES: LOS PRIMEROS TRATADOS PARA EL REPARTO DE

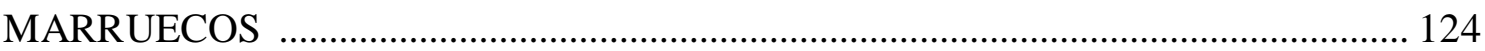

El Tratado non nato de 1902 a través de la prensa salmantina ............................... 124

El Tratado hispano-francés de 1904 a través de la prensa salmantina .................... 132

SALAMANCA Y LA CONFERENCIA DE ALGECIRAS ......................................... 139

Antecedentes: El "trompetazo" de Tánger ................................................................ 139

El desarrollo de la Conferencia de Algeciras ......................................................... 145

LA OPINIÓN PÚBLICA LOCAL, TESTIGO DE LOS ACUERDOS DE

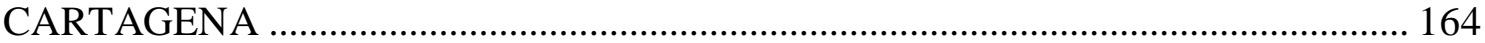

EL DRAMA DE CASABLANCA... ¿Y EL LETARGO DE SALAMANCA? ........... 171

SALAMANCA Y LA GUERRA DE MELILLA (1909-1911) ..................................... 199

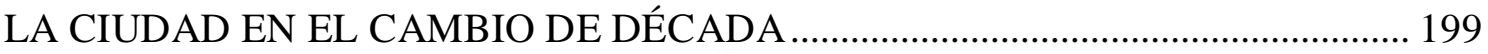

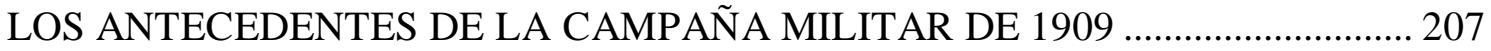

La ocupación de la Mar Chica .............................................................................. 209

La Nota franco-alemana del 9 de febrero de 1909, la embajada de Merry y la

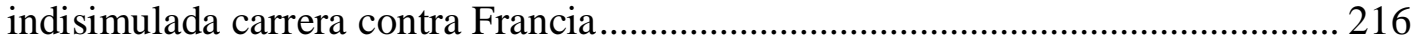

Primeros rumores de guerra. La Nota del gobierno Maura ................................... 221

La delicada situación de Hafid ................................................................................... 225

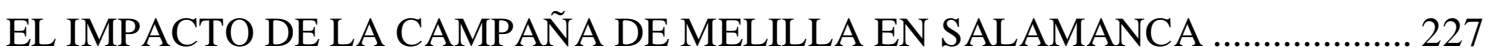

El relato periodístico de los primeros enfrentamientos ........................................... 229

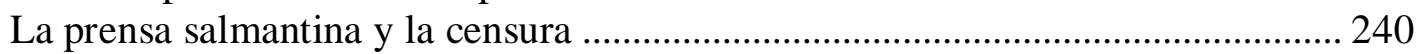

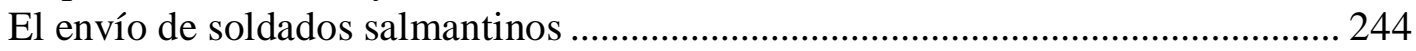

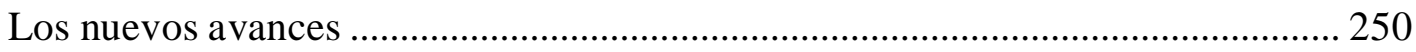

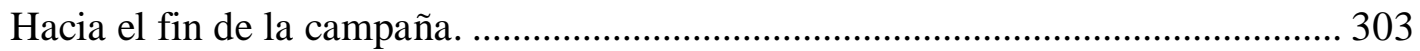

Los gestos de apoyo de los salmantinos para sus combatientes ............................ 333

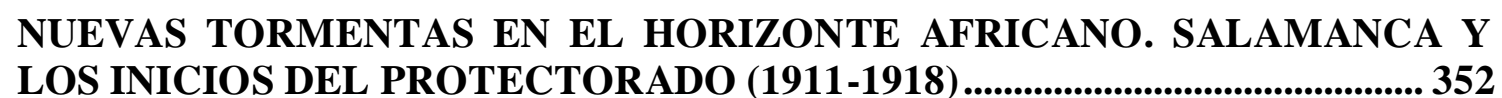

ECOS DE UNA CRISIS INTERNACIONAL: AGADIR Y LA GESTACIÓN DEL

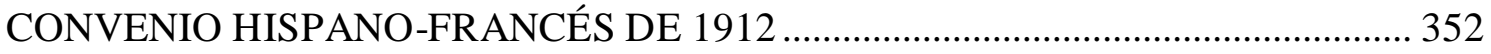

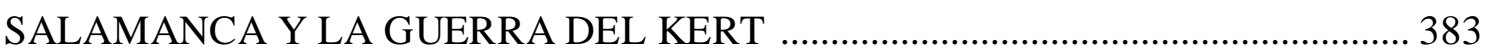

LA NUEVA REGLAMENTACIÓN DEL SERVICIO MILITAR …........................... 395

LOS INICIOS DEL PROTECTORADO: LA CONQUISTA DE TETUÁN Y LA GUERRA CONTRA EL RAISUNI CONTEMPLADAS DESDE SALAMANCA .... 400 EL DESPERTAR DE LA CIUDAD: CONFICTOS Y PREOCUPACIONES

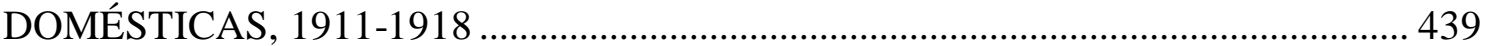

SALAMANCA Y LA CUESTIÓN MARROQUÍ DURANTE LA $1^{\mathrm{a}}$ GM ................... 452

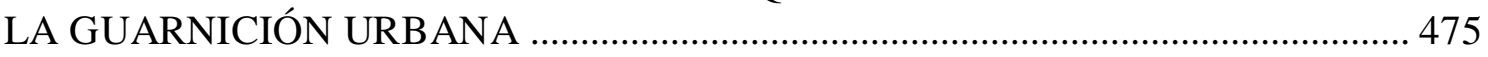




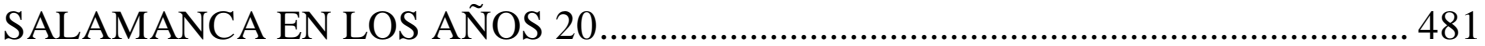

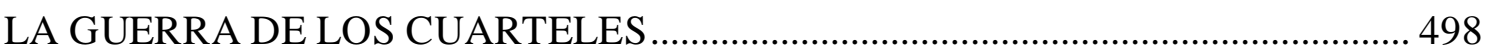

SALAMANCA Y EL CAMINO HACIA EL DESASTRE MARROQUÍ ................... 503

SALAMANCA Y LA TORMENTA DE ANNUAL ……................................................ 514

Los periódicos locales ante el magno Desastre. Reacciones inmediatas ¿Quiénes

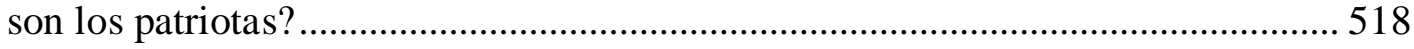

La Victoria en la guerra. El afecto salmantino hacia sus expedicionarios ............. 530

EL CIELO NO ESCAMPA: LA CIUDAD, SUS SOLDADOS, LOS PRISIONEROS Y

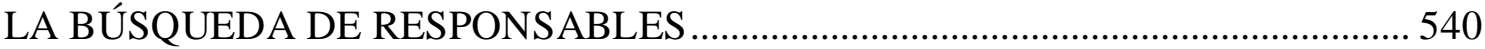

Patriotismos que flaquean. Las variadas actitudes de la prensa local .................... 541

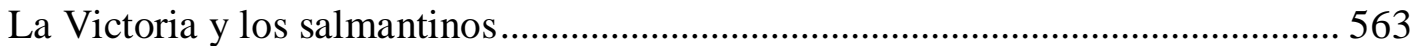

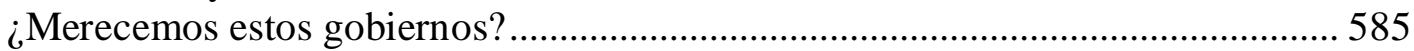

Miguel de Unamuno: líder anticolonialista en la Salamanca de los años 20 .........606

EL FINAL DE LA PESADILLA. SALAMANCA Y EL DESEMBARCO DE ALHUCEMAS (1923-1925) ............................................................................................ 629

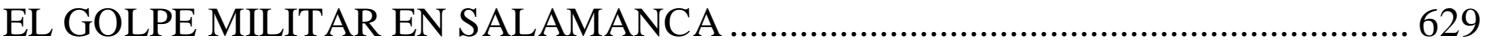

PRIMEROS PASOS DEL DIRECTORIO EN MARRUECOS: SALAMANCA, EL PLEITO DE LAS RESPONSABILIDADES Y LA RETIRADA DE XAUEN ............635

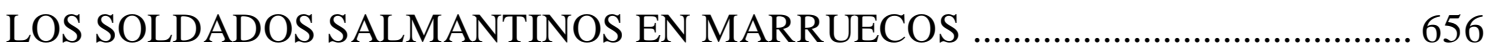

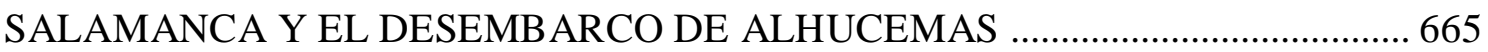

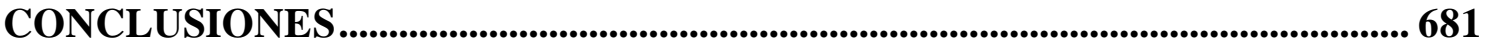

APÉNDICE DOCUMENTAL ........................................................................................... 692

FUENTES Y BIBLIOGRAFÍA ...................................................................................... 758 



\section{INTRODUCCIÓN}

\section{LAS RAÍCES DE LA PRESENCIA ESPAÑOLA EN MARRUECOS}

El objeto la presente tesis doctoral es determinar cómo las sucesivas campañas marroquíes afectaron a la población de Salamanca: una población en un altísimo porcentaje de procedencia agraria, inculta, endogámica y bastante intimidada por una élite caciquil con mucho arraigo.

La opinión pública salmantina, por tanto, se convierte en la protagonista de nuestro trabajo. Entendemos que es este concepto precisamente, el de opinión pública, uno de los que se erige como fundamental para la comprensión de la modernidad. Pero dada la ausencia de instrumentos para su medición, en boca de cualquier político, intelectual o periodista de la Restauración se transformó en un elemento de prestigio y autoridad, con una mágica facultad: la de provocar un efecto psicológico en el auditorio. Todos ellos, gobernantes de distinta significación, pensadores y cronistas, en reiteradas ocasiones, defendieron que representaban a la opinión, eran sus portavoces o adalides y en nombre de ella, de sus pensamientos y emociones, reclamaban una cosa $\mathrm{y}$, paralelamente, su contraria.

Para ir concretando, nos proponemos explicar cómo los salmantinos conocieron y qué juicio les merecieron las turbulentas relaciones con Marruecos entre los años 1906 y 1925. Desde las Revoluciones Liberales, la opinión pública se vinculaba con la voluntad nacional y la prensa se consideraba su órgano más autorizado de expresión. A ella se le encomendaba la tarea de ilustrarla; ella vociferaba que encarnaba a la opinión; y ella, finalmente, conformaba uno de los principales escenarios de la batalla política. Pero, desde luego, no el único.

Dicho de otro modo, pretendemos, en primer lugar, saber hasta qué punto los salmantinos estaban al tanto de lo que ocurría en el Sultanato para, a partir de ahí, intentar establecer un nexo entre la opinión publicada y la pública. Conscientes de que el régimen canovista nunca tuvo un carácter auténticamente representativo, deseamos acercarnos a las informaciones, más o menos numerosas, más o menos verídicas, y más o menos independientes, que los habitantes de la capital del Tormes tuvieron a su disposición y contribuyeron a que se posicionasen, si es que lo hicieron, sobre un asunto tan controvertido y verdaderamente absorbente como fueron las campañas militares africanas de principios del siglo XX. Evidentemente, junto con la prensa y otras 
publicaciones, algunos salmantinos también pudieron conocer, puntualmente y de manera directa, la realidad marroquí a través de su estancia en aquel territorio como soldados.

Los lazos históricos entre los territorios que hoy constituyen los reinos de España y Marruecos se remontaban a la época prehistórica. La permeabilidad demográfica entre ambas orillas del Estrecho no es algo novedoso, del mismo modo que la búsqueda de una mayor prosperidad económica tampoco es la única razón explicativa de ese continuo peregrinaje en el que unos invasores suceden a otros. Las cuestiones estratégicas y comerciales, entendidas como garantes de la soberanía y el prestigio nacional, han ejercido un destacado protagonismo en este devenir reiteradamente entrelazado y siempre conflictivo entre ambos países. Como consecuencia, el diálogo entre ambas orillas del Estrecho ha resultado complejo y, al mismo tiempo, inevitable, debido a que la vecindad física nunca se puede ignorar ${ }^{1}$.

A principios del siglo $\mathrm{XX}$, las potencias europeas asignaron a España y Francia el papel de colonizadores de Marruecos, si bien la carrera imperialista entre las grandes potencias mundiales se había iniciado ya en la década de 1870. En el caso del continente africano, el pistoletazo de salida para su ocupación se produjo en 1884, coincidiendo con la celebración de la Conferencia de Berlín. España poseía, desde hacía mucho más tiempo, varias plazas en las costas del Rif con plena soberanía: Melilla, desde 1497; el peñón de Vélez de la Gomera, desde 1508; Ceuta, desde 1668; el peñón de Alhucemas, desde 1673; y las Islas Chafarinas desde 1848. Así pues, tanto por motivaciones de índole cultural y religiosa, como por voluntad de enriquecimiento y de consecución de una buena reputación internacional, el gobierno de Madrid aceptó el área de influencia (después protectorado) que se le confirió.

El argumento al que recurrentemente apelarían los políticos de turno para justificar su participación en el reparto colonial consistió en asegurar que si España no actuaba, sus competidores europeos, y principalmente Francia, tomarían la delantera ${ }^{2}$.

\footnotetext{
${ }^{1}$ Como balance de estas complejas relaciones hispano-marroquíes, siempre plagadas de prejuicios y malentendidos, consideramos muy interesante el trabajo del embajador DEZCALLAR, Jorge: "Una reflexión sobre las relaciones hispano-marroquíes" en VALLE, A. y VERDÚ, J. (Dir.): España y Marruecos en el centenario de la Conferencia de Algeciras. FMV: Madrid, 2007, pp. 31-42. Más emotivas, pero igualmente interesantes, resultan las valoraciones a propósito de las campañas hispanomarroquíes del coronel Barrio Jala. Véase BARRIO JALA, Manuel del: "Reflexiones sobre la Guerra de África", Revista de Historia Militar, Año XLVI, no 92, Madrid, 2002, pp. 209-255.

${ }^{2}$ Los Tratados de 1904 y de 1907 son suscritos por gobiernos conservadores; mientras que el intercambio de Notas con Francia en septiembre de 1905, el Acta de Algeciras y el Acuerdo hispano-francés de Protectorado se aprueban bajo mandato liberal.
} 
Mientras tanto, el interés por los minerales de la región quedaba, al menos en la esfera de lo oficial y público, relegado a un segundo plano.

Sin embargo, la política interior española de todo este periodo se caracterizó por la inestabilidad: los ejecutivos se sucedían a un ritmo vertiginoso e, incluso, muy atropelladamente a partir de 1917, y ello dificultaba la definición de unas claras pautas de actuación en el ámbito exterior. La derrota militar ante los EEUU había hecho de España una muy modesta nación, cuya única relevancia en el escenario internacional derivaba del interés británico por controlar el Estrecho de Gibraltar. A decir verdad, el 98 provocó una honda crisis de la conciencia nacional, que no de la economía, y el surgimiento de múltiples exigencias de renovación política. No obstante, con el advenimiento del jovencísimo Alfonso XIII, en 1902, dio comienzo una nueva etapa del régimen de la Restauración, una fase impregnada de regeneracionismo. Primero, Antonio Maura, con su anhelada "revolución desde arriba" y, posteriormente, José Canalejas y su reformismo social encarnarían este insaciable, ambiguo y también contagioso espíritu de la época.

El sistema político creado por Antonio Cánovas del Castillo había logrado alejar el fantasma del pronunciamiento militar, tan característico del turbulento siglo XIX. Durante el reinado de Alfonso XII y a lo largo de la regencia de María Cristina se había construido un Estado centralizado, apoyado en un fraudulento sistema bipartidista y con una Constitución, la de 1876, que conjugaba la defensa de valores típicamente tradicionales, tales como la propiedad, la religión y el orden, con un muy tenue apoyo estatal a las clases sociales más desfavorecidas.

En la esfera internacional, el periodo de recogimiento, auspiciado igualmente por Cánovas del Castillo, había concluido. Y no había salido de balde. Al contrario, su precio fue la pérdida de las últimas colonias ultramarinas porque España se halló sin aliados frente a los EEUU. El "autismo" no podía ser una opción en tiempos de plena efervescencia imperialista. A muy duras penas, tanto los conservadores como los liberales, tras ese fatídico 1898, concretarían los objetivos de la acción diplomática española en el afianzamiento de la dinastía y del régimen, la salvaguarda de la integridad territorial de la nación y la defensa de los derechos españoles en Marruecos. Sus pasos siempre fueron titubeantes ya que ambos partidos dinásticos actuarían bajo la coacción de la alta política europea y ante el retraimiento (¿espontaneo o forzoso?), aunque no siempre, como ya se comprobará, de la opinión pública. 
También intervino como agente diplomático de primerísimo orden el mismo Alfonso XIII, con sus caprichos iberistas y sus ensueños africanos. Conviene advertir, además, que el monarca siempre se sintió muy identificado con los intereses del Ejército, al que consideraba esencia histórica y moral de la nación ${ }^{3}$.

Con certeza, el descalabro español sufrido en 1898 tuvo una repercusión muy directa en el ánimo de muchos ministros; y especialmente la tendría en el destino de Marruecos ${ }^{4}$. Las tradicionales reivindicaciones de los pensadores africanistas, sin excesivo arraigo social, lograron entonces un verdadero eco político. Desde una posición de pretendida inhibición, aunque en la práctica complaciente con la política antifrancesa de Bismarck, España, paradójicamente, acabaría por vincularse a la Entente franco-británica, a través de su firma de un Tratado con Francia, en octubre de 1904, y de su participación en los Acuerdos de Cartagena de 1907. Aunque estas alianzas serían puestas en entredicho por algunos sectores políticos y sociales posteriormente, sobre todo al estallar la Gran Guerra, y también durante la campaña de "reconquista" que siguió al Desastre de Annual.

Asimismo, jamás debe perderse de vista el hecho de que el Ejército, tras el fatídico 98, necesitaba recuperar su prestigio ante la opinión pública y también su credibilidad en el Parlamento. El Rif ofrecía la posibilidad de dar rienda suelta al espíritu imperialista de muchos oficiales y de hacer brillantes carreras con rápidos ascensos. Mientras, en las guarniciones peninsulares, la oficialidad menos temeraria estaría condenada a llevar una vida grisácea. Su descontento profesional y malestar económico cristalizaría, en 1917, en el movimiento de las Juntas de Defensa, que tan contradictorios juicios ha merecido ${ }^{5}$.

\footnotetext{
${ }^{3}$ Para una ligera aproximación a este fuerte intervencionismo regio, véase FERRERA CUESTA, Carlos: "Formación de la imagen monárquica e intervencionismo regio: los comienzos del reinado de Alfonso XIII (1902-1910)", Hispania, LXIV/1, nº 216, 2004, pp. 237-266.

${ }^{4}$ Aunque, ya se habrá deducido, el Desastre de 1898 no actuó como motor único para el desenvolvimiento del colonialismo español en el Noroeste de África. Nuestra política africana no debe ser interpretada sólo en clave de política interior. La pérdida de las colonias antillanas y de Filipinas, eso sí, sirvió para acentuar un interés hispano antiguo por el Sultanato, si bien algo difuso y discontinuado. Véase MARTÍN CORRALES, Eloy: "El Protectorado español en Marruecos (1912-1956). Una perspectiva histórica" en NOGUÉ, Joan y VILLANOVA, José Luis (Eds.): España en Marruecos (19121956). Discursos geográficos e intervención territorial. Lleida: Editorial Milenio, 1999, pp.145-158.

${ }^{5}$ A propósito de la pérdida de Cuba, afirma Gabriel Cardona lo siguiente: "El Ejército que salió del Desastre cubano de 1898 estaba moralmente abatido y exasperado. Las instituciones militares están constituidas para la guerra. Son la organización que articula los más importantes recursos coactivos del Estado. Y todas las guerras son crueles, pero, sobre todo, las coloniales y las civiles. El conflicto cubano fue una guerra civil y una guerra colonial que reunió la violencia de ambas (...) Un Ejército sin enemigos pierde toda perspectiva de misión y de utilidad social. Desde el 98 esta misión y esta utilidad se concretaron en el mantenimiento del orden público, y en la lucha contra las reivindicaciones catalanas y vascas. En 1909 se abrió la nueva posibilidad de intervenir en Marruecos". Véase CARDONA, Gabriel:
} 
El primer choque militar contemporáneo entre España y Marruecos había estallado algunas décadas antes de procederse al reparto de zonas de influencia, constituyendo lo que se denominó la Guerra de África (1859-1860). De esta primera campaña causa asombro lo intrascendente de su detonante y el precedente simbólico que generó entre los soldados españoles que la protagonizaron, ya que el patriotismo más vocinglero inundó toda la propaganda periodística, artística y literaria. Quizás, el ejemplo más conocido es el de Pedro Antonio de Alarcón y su triunfalista Diario de un testigo de la Guerra de África ${ }^{6}$. Aunque lejos de su glorioso relato, la campaña fue durísima, caracterizada por torrenciales lluvias y una espeluznante epidemia de cólera que ocasionó enormes estragos. A ciencia cierta, éste fue uno de los escasísimos momentos del siglo XIX, casi excepcional, en que se consolidó un ideal común entre los españoles.

Pero en las contiendas marroquíes posteriores, es decir, durante las campañas de Melilla de 1893 y, más tarde, 1909 con la celebérrima derrota española en el Barranco del Lobo, en las operaciones del Kert, los enfrentamientos de 1913 y la sangrienta Guerra del Rif, ese apoyo incondicional de los ciudadanos acabaría esfumándose. Semejante cambio de pareceres suele atribuirse al protagonismo creciente de las ideologías de izquierda, de algunos nacionalismos periféricos y la pasmosa y prolongada ineptitud gubernamental. Desde luego, nos hallamos ante un fenómeno, la evolución del "sentir popular", que por su carácter discontinuo e intermitente, repleto de "vuelcos", merece ser atentamente analizado.

\section{NUESTRO ESCENARIO: SALAMANCA AL FILO DEL SIGLO XX}

Por lo que respecta a Salamanca, aunque el periodo de la Restauración ha merecido investigaciones de carácter bastante desigual, sabemos que no era una ciudad, en absoluto, ajena a los problemas nacionales. Sin embargo, mientras que los estudios sobre la propiedad de la tierra y los análisis socio-profesionales se presentan como los temas estelares de la historiografía local, queda mucho camino por recorrer en el conocimiento de los comportamientos electorales y la conflictividad social.

El poder militar en la España Contemporánea hasta la Guerra Civil. Madrid: Siglo XXI, 1983, pp. 1920.

${ }^{6}$ ALARCÓn, Pedro Antonio de: Diario de un testigo de la Guerra de África. Ceuta: Biblioteca Municipal de Ceuta, 2009. 
En los últimos años la polémica acerca de los derroteros que ha de seguir la historiografía española, en busca de la síntesis o recorriendo el sendero de la dispersión cognoscitiva, parece haber cedido su protagonismo a cuestiones de método. Ello es síntoma inequívoco, entre otras cosas, de que la historia local ha logrado la tan ansiada legitimidad científica. Abandonados los paradigmas, nuestra disciplina está abocada al debate permanente y a la aceptación del pluralismo epistemológico ${ }^{7}$. La historia local ha superado su prueba de fuego, y pese a las cuantiosas censuras, hoy en día mantiene toda su vigencia. Se ha impuesto una historia local muy pendiente de la historia general, atenta a problemas teóricos, partidaria del empleo de metodologías interdisciplinares y que busca el ámbito municipal para analizar y profundizar en el entendimiento de cuestiones generales. Desde esta óptica, no resulta excesivamente distante del modelo de la microhistoria italiana practicada por Grendi, muy vinculado con la antropología y la sociología ${ }^{8}$. Aunque es verdad que poco se ha avanzado en el camino hacia la síntesis $^{9}$, el precio del relativismo cognitivo es reconocer que la historiografía no tiene por qué seguir vías ya trazadas.

A día de hoy, por desgracia, la historiografía castellana tiene un carácter mucho más provincial que regional porque el diálogo entre profesionales es bastante escaso y porque no existe excesiva seguridad en la defensa histórica de nuestra comunidad. En contrapartida, este último elemento ha permitido un reciente giro hacia una historia bastante plural y sin excesivas desfiguraciones. A la historiografía "regional" debemos la superación de muchos tópicos, pero no hay por ello que ocultar los desequilibrios y carencias que se registran en su devenir. Valorando su desarrollo temático, es innegable la preeminencia de los análisis socioeconómicos frente a la historia política y cultural; metodológicamente, y como ya se ha señalado, es una historia bastante desarticulada ${ }^{10}$. Así, en el año 2000 y abundando en esta materia, el profesor Carasa Soto hacía hincapié en la idea de que las distorsiones historiográficas son el resultado del

\footnotetext{
${ }^{7}$ JULIÁ, Santos: "La historia social y la historiografía española", Ayer, no 10, Madrid, 1993, p. 33.

${ }^{8}$ SERNA, Justo y PONS, Anaclet: "El ojo de la aguja. ¿De qué hablamos cuando hablamos de microhistoria?", Ayer, no 12, Madrid, 1993, pp. 93-103.

${ }^{9}$ FORCADELL ÁLVAREZ, Carlos. "La fragmentación espacial en la historiografía contemporánea: la historia regional/local y el temor a la síntesis", Studia Histórica. Historia Contemporánea, no 13-14, Salamanca, 1995-1996 p. 26.

${ }^{10}$ CARASA SOTO, Pedro: "La memoria herida de Castilla y León" en CARASA SOTO, Pedro (Coord.): La memoria histórica en Castilla y León. Historiografía castellana en los siglos XIX y XX. Salamanca: Junta de Castilla y León, 2003, pp. 18-19. Mucho más exhaustivo es, en la misma obra, un artículo colectivo titulado "La renovación de la historia de Castilla y León a fines del milenio", pp. 457-562. Incluye, además de un amplio estado de la cuestión sobre la producción historiográfica castellanoleonesa, un repertorio de algunos proyectos de investigación financiados entre los años 1982 y 2000.
} 
“desequilibrio existente en Castilla entre la abundancia de estudios sobre las fuerzas económicas decimonónicas o sobre algunos aspectos de prensa y marginación, y la carencia de análisis de las fuerzas sociales y de la cultura política tanto en el nivel de las élites como de los grupos populares, y lo que es peor aún, la incomunicación e incluso divorcio entre ambos tipos de estudios"11.

El caso salmantino no escapa a esta tónica general. Los estudios de historia salmantina han sido promovidos fundamentalmente por la Universidad y el Centro de Estudios Salmantinos. En 1989, en un primer balance de los mismos, el profesor Ricardo Robledo equiparaba el desarrollo historiográfico local no ya con un edificio en ruinas, sino con una construcción inexistente. Se lamentaba de los cuantiosos vacíos temáticos, de la escasísima atención al territorio provincial y de que las publicaciones fuesen mayoritariamente artículos de revista. En un intento de ilustrar la penosa situación, señalaba que para la Edad Contemporánea había un total de casi 130 años de los que apenas se sabía algo: los periodos 1814-1868, 1898-1931 y 1940-1980². Una década después, Santiago Díez Cano denunciaba también el deplorable estado de nuestra historiografía ${ }^{13}$. Y es que, efectivamente, no se puede obviar el hecho de que existen en ella enormes lagunas. Por de pronto, casi nada sabemos sobre la evolución histórica de la opinión pública.

Es, por cierto, también Díez Cano quien, con Pedro Carasa Soto, menciona para Salamanca, la existencia de tres etapas diferenciadas en el desarrollo de la Restauración $^{14}$. Indican, ambos autores, que el lustro final de los años 70 se caracteriza por la proclividad hacia la violencia; los años 80, en cambio, representan un periodo de significativa apertura. Según sus propias palabras, es el momento de "el germinar de espacios alternativos a la política oficial" debido a una eclosión periodística e, igualmente, por una creciente tendencia al asociacionismo ${ }^{15}$. Así, por ejemplo, es ahora cuando propietarios, comerciantes e industriales crean la Liga de Contribuyentes, de la

\footnotetext{
${ }^{11}$ CARASA SOTO, Pedro: "Los poderes municipales en relación con el Estado y el cambio social en Castilla", en CARASA SOTO, P. (Coord.): Ayuntamiento, Estado y Sociedad. Los poderes municipales en la España Contemporánea. Valladolid: Ayuntamiento de Valladolid, 2000, p. 179.

${ }^{12}$ ROBLEDO, Ricardo: "Salamanca en la Historia Contemporánea: ¿un desierto historiográfico?" en VVAA: I Congreso de Historia de Salamanca, Vol. 3. Salamanca: Diputación de Salamanca, 1992, pp. 10-14.

${ }^{13}$ VVAA: "El puzzle de historias provinciales desde 1960" en CARASA SOTO, Pedro (Coord.): La memoria histórica ... Op. Cit., pp. 268-274 (es un epígrafe de L. Santiago Díez Cano, titulado "Los estudios de Historia Contemporánea de la provincia de Salamanca").

${ }^{14}$ CARASA SOTO, Pedro y DÍEZ CANO, L. Santiago: "Epílogo: La Restauración (1875-1898)" en ROBLEDO, Ricardo (Coord.): Historia de Salamanca, Vol. IV. El siglo XIX. Salamanca: Centro de Estudios Salmantinos, 2001, pp. 523-535.

${ }^{15}$ Ibidem, p. 526.
} 
que luego emerge la Cámara de Comercio. Además, se constituyen en esta década muchísimas sociedades de socorros mutuos, antecedente remoto de las organizaciones obreras. Precisamente, la creciente fuerza de diversas asociaciones y la enorme vitalidad de la prensa son los elementos que inducen a pensar que "la política es algo más que la versión oficial de la misma"16; por último, la década final del siglo XIX, y pese a la trascendencia de la implantación del sufragio universal, supone una progresiva crisis del sistema que se acentúa tras el funesto 98. No obstante, a partir de esta fecha es cuando más claramente se puede constatar la capacidad adaptativa del turnismo, debido a que era todavía muy considerable tanto la influencia económica como el arraigo de los latifundistas.

Al iniciarse el siglo XX, la imagen de una capital de provincia moribunda, aferrada a su pasado, tal y como la presentaban algunos viajeros, era constantemente combatida por una prensa muy abundante y variopinta, que acogía la opinión de partidos dinásticos, republicanos, católicos integristas y moderados, obreros, grupos profesionales... Los periódicos locales son los primeros, los más comprometidos, en combatir el famoso cliché sobre el aletargamiento de los salmantinos. Son ellos los que, con sus campañas propagandísticas, hacen más dinámica la vida local, sobre todo desde que finaliza la Primera Guerra Mundial. Salamanca se distancia, de este modo, del machacón comodín del "feudo reaccionario".

Sin embargo, es verdad que su aspecto resultaba desolador. En el imaginario colectivo, nada sorprendía la identificación de Salamanca con un poblado rifeño; totalmente sintomática, por otra parte, de la aversión que lo moruno suscitaba entre los vecinos de la capital. Así lo confesaba Muñoz Orea: “Con haber merecido Salamanca por sus monumentos el nombre de Roma la Chica, merece por sus casas el dictado de aduar africano. Hemos visitado algunas y dudamos que las chozas morunas sean peores" ${ }^{\prime 17}$.

Pero, al menos, ya no era esa "ciudad cerrada (...) por murallas" de la que hablaba Sánchez Estevan ${ }^{18}$. Enseñas de los nuevos tiempos fueron la apertura de la calle de la Rúa, la construcción del puente de Enrique Estevan, un nuevo matadero y un gran mercado junto a la Plaza Mayor. Muchos vacíos urbanísticos, en buena medida

\footnotetext{
${ }^{16}$ Ibidem, p. 529.

${ }^{17}$ MUÑOZ OREA, Manuel: Datos para la geografía médica de Salamanca. Tesis doctoral, Barcelona, 1911, pp. 28-29.

${ }^{18}$ Citado en SANTAMARÍA, Jesús L.: "Señora de gran nobleza a la que le huelen los pies. La ciudad de Salamanca a finales del siglo XIX", Studia Histórica. Historia Contemporánea, Vol. IV, n ${ }^{\circ}$ 4, Salamanca, 1986, p.87.
} 
originados durante la Guerra de la Independencia, estaban siendo colmatados por la acción especulativa de una naciente burguesía. La misma que levantaba su voz contra el pésimo estado de la higiene pública: y es que la mayoría de las calles presentaba un aspecto deplorable; además, el alumbrado tan deficiente provocaba incontables accidentes. Pero, ante todo, la carencia de agua y alcantarillado constituía la preocupación dominante de los salmantinos, en su conjunto, y la clave de todas las políticas municipales. En 1905, Salamanca era la capital de España con un mayor índice de mortalidad por gastroenteritis infantil. Todavía en 1911 apenas el 10\% de las casas disponían de agua potable ${ }^{19}$. Para evitar una nueva epidemia colérica, como la ocurrida en 1885-1886, se hacía urgente primero elevar las aguas del Tormes y, acto seguido, depurarlas. Pero con el recurso exclusivo a las arcas municipales, el proyecto de saneamiento urbano resultaba sencillamente impensable. La prosperidad de Salamanca pendía, por consiguiente, de una operación de empréstito.

En 1900, Salamanca tenía 23.756 habitantes ${ }^{20}$; y la ciudad siguió creciendo mientras que todos los restantes distritos de la provincia entraron en franco retroceso demográfico entre 1910 y $1930^{21}$. La economía urbana atraía a la emigración provincial, pero los desplazamientos internos también obedecían a una situación de crisis y reconversión agraria. La población activa capitalina ascendía a 7.522 personas, o lo que es lo mismo, el 24,2\% de los salmantinos. La base de la pirámide social estaba conformada por obreros (56,1\% de la población activa), artesanos (9,9\% de la población activa), algunos trabajadores de cuello blanco (14,9\% de la población activa), gentes dedicadas al sector agropecuario $(0,9 \%$ de la población activa) y por los marginados ( $2 \%$ de la población total). Su existencia transcurriría en condiciones de suma precariedad. Vivían bajo la permanente amenaza del hambre y enfrentadas a una

\footnotetext{
${ }^{19}$ ROBLEDO, Ricardo: "Dejar el campo, comprar la tierra: economía, población y sociedad, 1880-1930" en ROBLEDO, Ricardo (Coord.): Historia de Salamanca, Vol. V. El siglo XX. Salamanca: Centro de Estudios Salmantinos, 2001, p. 72-73.

${ }^{20}$ Todos los datos derivados del análisis de los padrones municipales de 1900 y 1920 han sido tomados de ESTEBAN DE VEGA, Mariano, GONZÁLEZ GÓMEZ, Santiago y REDERO SAN ROMÁN, Manuel: Salamanca, 1900-1936: la transformación limitada de una ciudad. Salamanca: Diputación de Salamanca, 1992.

${ }^{21}$ Hasta 1922 Salamanca no presenta un crecimiento vegetativo positivo de cierta consideración. El incremento de habitantes se explicaba por las aportaciones de las zonas rurales.

Por otro lado, entre 1900 y 1930, casi 90.000 personas abandonaron la provincia. Junto a las motivaciones económicas, el temor a las quintas también estuvo igualmente presente en el imaginario colectivo. El rechazo hacia el servicio militar había sido el detonante de algunos incidentes violentos en el bienio 1872-1874, cuando quedó incumplida la promesa de su supresión. Iniciada la nueva centuria, las campañas de Marruecos se convertirían en acicates para el éxodo.
} 
oligarquía terrateniente, los "cuernócratas" de los que nos habla Miguel de Unamuno, que en buena medida coincidía con la élite parlamentaria.

Junto con estos grandes propietarios (2,6\% de la población activa), la clase alta salmantina estaría conformada por el grupo profesional englobado en el Padrón de aquel año, 1900, bajo el epígrafe "industria, comercio y banca” (6,4\% de la población activa) $\mathrm{y}$, también, por los altos funcionarios y profesionales liberales $(8,2 \%$ de la población activa). La ciudad poseía, consecuentemente, un carácter polarizado, sin apenas clase media. Sus habitantes eran mayoritariamente obreros y artesanos, aunque los servicios administrativos, docentes, asistenciales, domésticos, hospedaje, comercio y banca constituían los pilares de su actividad económica.

A pesar de todo ello, Salamanca no podía presumir de una moderna industria. Ni tan siquiera ya en la tardía fecha de 1920. En este año, y si atendemos nuevamente a los datos del Padrón, Salamanca contaba con 29.451 habitantes. Es decir, se había registrado un incremento del $23,9 \%$ en su población. Sobre todo, la urbe se extendía entonces hacia el norte, también se adivinaba el nacimiento de nuevos barrios como Pizarrales o el Rollo y los edificios iban ganando en altura. Pero la estructura profesional de Salamanca permaneció estable. La población activa constituía el 24,7\% de la población total. De ella, el 55,6\% eran obreros; el 9,5\% se dedicaba a la artesanía; y un $6,8 \%$ de la población activa aparecía catalogada en el conjunto "industria, comercio y banca". Únicamente cabe referirse a un ligero proceso de crecimiento y renovación en la industria tradicional y en el comercio local.

Aunque la Gran Guerra significaría una demanda adicional de bienes, no alentaría ninguna modificación en la estructura económica salmantina. Las primeras víctimas de la conflagración fueron las encinas. Más de 200.000 se talaron para dedicar la superficie que ocupaban al cultivo de cereal. Del mismo modo, con el empleo intensivo de abonos químicos se pretendió abastecer el mercado exterior. Los segundos sacrificados fueron los consumidores de la capital, testigos de una subida espectacular en el precio del pan. Pero no adelantemos acontecimientos.

La Universidad, por otra parte, atravesaba una crítica situación, bajo el dogal de la insolvencia económica (hay que esperar hasta 1903 para que las facultades de Medicina y Ciencias logren ser reconocidas como oficiales), con pocos alumnos y profesores. Era una institución, además, carente de dinamismo y muy sometida a las directrices del Poder central. Aunque el hecho quedaba oculto tras el prestigio de un 
profesorado de enorme talla intelectual, encabezado por, cómo no, Miguel de Unamuno $^{22}$.

A pesar de todas estas notas adversas, también es cierto que se palpaba en la atmósfera salmantina una creciente incertidumbre; se respiraban aires de cambio y parecían inagotables las esperanzas depositadas en el futuro, en el resurgimiento de esa "Roma la Chica". No han de sorprender, en consecuencia, los numerosos proyectos de mejoras urbanísticas y sanitarias, tal vez el rasgo más sobresaliente de este periodo. Casi todos ellos se pudieron llevar a buen término, aunque a costa de no pocos sacrificios. Sin duda, los más sobresalientes fueron las obras de alcantarillado, tras un fatigosísimo y embrolloso proceso legal que implicó al Ayuntamiento y la empresa concesionaria de los trabajos; y la construcción de dos cuarteles, uno para la caballería y otro para la infantería. En el ámbito provincial, no conviene olvidar el dificultoso y ambicioso proyecto, por sus implicaciones internacionales, de los Saltos del Duero ${ }^{23}$; ni de la apertura de minas de wólfram en Barruecopardo y Navasfrías ${ }^{24}$.

Lo cierto es que durante las dos primeras décadas del siglo $\mathrm{XX}$, las fuerzas públicas y la Cámara de Comercio se preocuparon sobremanera por traer a la ciudad algún regimiento militar. El deseo de ampliar la guarnición había sido reiterado entre los salmantinos: los soldados servirían como estímulo para el comercio local y las obras de edificación de los cuarteles se traducirían en nuevos puestos de trabajo. Pero durante mucho tiempo, más de diez años, el ministerio de Guerra desatendió esa pretensión ciudadana. La construcción de los cuarteles se inició a finales de 1919 y tardarían más de un lustro en concluirse. No deja de resultar insólita esa tardanza, el abandono para con una ciudad bastante bien comunicada con Madrid, tan cercana a Portugal y, consecuentemente, vital en caso de necesitarse movilizar tropas para una intervención armada en el país vecino. De hecho, desde 1908, coincidiendo con el asesinato de Carlos I, la situación de Portugal preocupó de forma constante a Alfonso XIII, convencido de que una república supondría un apoyo muy peligroso para sus

\footnotetext{
${ }^{22}$ HERNÁNDEZ DÍAZ, José Ma: "Entre las resistencias al cambio y la universidad deseada, 1900-1936" en VVAA: Historia de la Universidad de Salamanca, Vol. I. Trayectoria y vinculaciones. Salamanca: Universidad de Salamanca, 2002, pp. 283-312.

${ }^{23}$ CHAPA, Álvaro: La construcción de los Saltos del Duero, 1903-1970. Historia de una epopeya colectiva. Pamplona: Ediciones Universidad de Salamanca /Enusa, 1999.

${ }^{24}$ FERNÁNDEZ, Ricardo: Salamanca. Crónica Siglo XX. Salamanca: Diputación de Salamanca, 2001, p. 18.
} 
correligionarios en España. Su deseo, consecuentemente, fue tener una fuerza cerca de la frontera y en pie de guerra ${ }^{25}$.

Por otro lado, esta potente voluntad de cambio también cristalizaría en el terreno de la política. A pesar de lo que pueda pensarse, no todo era paz y armonía ${ }^{26}$. En realidad, los distritos de Salamanca y Peñaranda eran los únicos de la provincia en los que el caciquismo funcionaba medianamente bien. Sin embargo, ello no debe conducirnos a la mecánica aceptación de esa imagen de la capital como granero de votos monárquicos. Al contrario, la vitalidad política de la urbe no admite vacilaciones.

Salamanca fue uno de los focos de gestación y desarrollo del Partido Reformista (Filiberto Villalobos); y Salamanca fue el hogar de Unamuno. Simultáneamente, aquí también vivió Diego Martín Veloz, cacique singular donde los haya y todopoderoso diputado a Cortes desde 1919 (de igual modo, nacería en esta ciudad, años más tarde, la CEDA de Gil Robles). Llegados a 1923, cuando en abril se celebraron unas nuevas elecciones, las fuerzas sociales que en la capital contemplaban a este hombre como salvaguarda de los intereses salmantinos eran una minoría ante aquellos que lo consideraban un tipo autoritario y bastante caricaturesco. Su paranoica concepción del orden público condujo a la extenuación ciudadana. Así que se terminó constituyendo una coalición muy diversa -incluidos Unamuno, Maldonado y Clairac- al objeto de privarle de su inmunidad parlamentaria, aquella que le otorgaba carta blanca para todo tipo de excesos. Aún así, supo hacerse con la victoria electoral en el distrito de Peñaranda.

\footnotetext{
${ }^{25}$ HALL, Morgan C.: Alfonso XIII y el ocaso de la monarquía liberal, 1902-1923. Madrid: Alianza, 2005, p. 105.

${ }^{26}$ CARASA SOTO, Pedro y DÍEZ CANO, L. Santiago: "Caciques, dinero y favores. La Restauración en Salamanca" en ROBLEDO, R. (Coord.): Historia de Salamanca, Vol. V. El siglo XX. Salamanca: Centro de Estudios Salmantinos, 2001, p. 90. Ambos autores efectúan en este capítulo un breve repaso de los avatares electorales en los siete distritos electorales salmantinos entre 1891 y 1923. El propósito de su análisis es demostrar que la coexistencia de un cauce oficial y otro "marginal" en el desarrollo de la política es la prueba de que Salamanca no era una ciudad hundida en la rutina.

Para conocer el perfil de la élite política salmantina es imprescindible el capítulo de CARASA SOTO, Pedro y DÍEZ CANO, L. Santiago: "La élite parlamentaria salmantina" en CARASA SOTO, P. (Dir.): Élites castellanas de la Restauración. Una aproximación al poder político en Castilla, Vol. II. Valladolid: Junta de Castilla y León, 1997, pp. 311-348. Una versión resumida se puede encontrar en CARASA SOTO, Pedro y DÍEZ CANO, L. Santiago: "La élite parlamentaria salmantina de la Restauración", Studia Histórica. Historia Contemporánea, vol. 13-14, Salamanca, 1995-1996, pp. 39-61. También se puede profundizar en los instrumentos políticos empleados durante la Restauración en MARCOS DEL OLMO, $\mathrm{M}^{\mathrm{a}}$ Concepción: Voluntad popular y urna. Elecciones en Castilla y León durante la Restauración y la Segunda República (1907-1936). Valladolid: Universidad de Valladolid, 1995. Particularmente interesante es el capítulo segundo, titulado "Castilla-León en la crisis de la Restauración: el modelo político regional", pp. 15-63.
} 
En conclusión, modernización y progreso, sí; pero con un ritmo pausado, miedoso, porque con miedo vivían los salmantinos: miedo al hambre; a la enfermedad; al desahucio; pavor hacia Dieguito, el tirano local; y, por supuesto, hacia la guerra.

\section{LA OPINIÓN PÚBLICA ESPAÑOLA Y LOS ASUNTOS MARROQUíES. HIPÓTESIS DE PARTIDA}

Hace algo más de tres décadas, un combativo Miguel Martín, pseudónimo que entonces empleaba el periodista Fernando López Agudín, sentenciaba que "ningún proletariado de país colonizador se opuso con la firmeza de la clase obrera española a las aventuras colonialistas (...) los sindicatos y partidos obreros españoles mantuvieron sistemáticamente una oposición a la conquista colonial y una defensa de la independencia del Estado marroquí, escribiendo páginas heroicas en la historia del movimiento obrero español, 27 .

Bastante más recientemente y rescatando un comentario de José Manuel Allendesalazar, Oscar Javier Sánchez Sanz, en su muy concienzuda tesis doctoral sobre la política exterior española durante el periodo $1890-1914$, afirmaba lo siguiente: " $L a$ opinión mayoritaria española no deseaba esa guerra colonial. Aunque un viciado sistema electoral impidiese que este sentimiento llegase en toda su intensidad a las Cortes españolas, era evidente que, a diferencia de 1859, toda acción militar en Marruecos durante el siglo XX iba a ser percibida por la opinión española como un acto insolidario, y por tanto, impopular y repulsivo" ${ }^{28}$.

Ante tales aseveraciones cabe preguntarse cómo se gestó este cambio de actitud entre la campaña de 1859 y las posteriores luchas del siglo XX ¿Por qué la ocupación de Marruecos acabó convirtiéndose en una empresa impopular, únicamente sostenida por las oligarquías económica y castrense? Y, sobre todo, ¿qué ocurrió en Salamanca? En síntesis, queremos saber si la condena hacia las operaciones militares en el Sultanato fue constante a lo largo del primer tercio del siglo XX y si fue compartida por todo el país.

Historiadores como Jesús Menéndez Pérez han dudado de la fuerza del anticolonialismo con anterioridad a 1914. A su juicio, la opinión pública que se opuso a la expansión colonial fue escasa y, además, se hallaba mal organizada. La realidad se

\footnotetext{
${ }^{27}$ MARTín, Miguel: El colonialismo español en Marruecos (1860-1956). París: Ruedo Ibérico 1973, p. 33. El tono tan reivindicativo de la obra es fruto, sin duda, del momento en que se publicó y de la clara militancia política de su autor, aunque resulta bastante llamativo para cualquier joven investigador.

${ }^{28}$ SÁNCHEZ SANZ, Oscar Javier: Diplomacia y política exterior. España, 1890-1914. Tesis doctoral inédita, Universidad Complutense, 2006, p. 516.
} 
caracterizaba porque "con frecuencia eran problemas internos, reveses militares, por ejemplo, los que movían a la opinión pública en contra de aventuras coloniales. La idea del 'derecho de los pueblos a disponer de sí mismos' era extraña, y más aún referida a las naciones colonizadas. En cambio, la idea de la comunicación entre 'civilizados' y 'bárbaros' había calado profundamente en Europa, y no fue puesta en discusión"29. El autor sostiene, por tanto, que el darwinismo social, esa idea de que quien no crece perece, había logrado un enorme respaldo público. Es exactamente el mismo juicio que sostienen, más recientemente, José Antonio González Alcantud y Eloy Martín Corrales: “Las sucesivas derrotas coloniales agravaron las crecientes fracturas de la sociedad española (...) Sin embargo, no hay que creer que, a tenor de lo expuesto anteriormente, en el seno de la sociedad española se hubieran forjado una o varias corrientes anticolonialistas. Nada más lejos de la realidad: las simpatías para con la expansión colonial eran profundas y estaban generalizadas $" 30$.

Pero sigamos desenredando esta liadísima madeja historiográfica: frente a lo apuntado por Menéndez Pérez, la idea de que las protestas callejeras contra la guerra estallaban con motivo de las derrotas militares, hoy en día la tesis más en boga en el análisis de la opinión pública y la cuestión marroquí es la de Javier Ramiro de la Mata. Básicamente, este profesor entiende que la reacción ciudadana ante las intermitentes campañas bélicas en el norte africano no fue lineal: se regía por un constante dualismo euforia-tragedia. Las soflamas en defensa de un honor supuestamente pisoteado se desataban únicamente coincidiendo con los descalabros de nuestras armas, mientras que normalmente lo que primaba era un sentimiento de apatía, de absoluto mutismo cuando no miedo hacia cualquier aventura en el exterior ${ }^{31}$.

Hechas estas presentaciones y como ya se habrá deducido, cabe sostener que la actitud mostrada por la opinión pública ante las operaciones militares allende el Estrecho posee bastante atractivo historiográfico y despierta juicios contradictorios, además de un notable interés académico. Quizás porque la opinión pública es un sujeto

\footnotetext{
${ }^{29}$ MENÉNDEZ PÉREZ, Jesús: "La guerra de Marruecos en la novelística española”, Estudios Africanos, n 25-26, Madrid, 1999-2000, p. 126. El propósito de este autor, como se deduce del encabezamiento del artículo, no es un estudio de la opinión pública. Pero traemos a colación este trabajo porque sus comentarios despertaron nuestra curiosidad y ya que creemos que Menéndez Pérez tiene muy presente la diferencia conceptual que existe entre anticolonialismo y antibelicismo.

${ }^{30}$ GONZÁLEZ ALCANTUD, José Antonio y MARTÍN CORRALES, Eloy (Eds.): La Conferencia de Algeciras en 1906: un banquete colonial. Barcelona: Bellaterra, 2007, pp. 14-15.

${ }^{31}$ RAMIRO DE LA MATA, Javier, "España y el Protectorado en Marruecos. Aproximación a un proceso colonial", Anales de Historia Contemporánea, ${ }^{\circ}$ 24, 2007, pp. 291-305. Una explicación más minuciosa puede hallarse en RAMIRO DE LA MATA, Javier: Origen y dinámica del colonialismo español en Marruecos. Ceuta: Ciudad Autónoma de Ceuta, Archivo Central, 2001, pp. 209-265.
} 
histórico de vital importancia para la correcta comprensión de la España contemporánea.

Mientras que Miguel Martín y Sánchez Sanz aluden a una oposición pública constante ante los choques armados -y sistemática en el caso del primer autor- desde que se inicia la nueva centuria, Menéndez Pérez hace hincapié en que las críticas ciudadanas contra las aventuras coloniales se desencadenan exclusivamente cuando se producen derrotas militares y que, además, en los años previos a la Primera Guerra Mundial, no revistieron excesiva gravedad. Por tanto, la imagen que nos presenta es la de una opinión pública conformista. Sobre todo, en los momentos de tranquilidad, ésta se muestra entre benévola e indiferente. Ramiro de la Mata, al contrario, incide en el hecho de que las tragedias en Marruecos sirven de estímulo para las exaltaciones nacionalistas (idea también compartida, a grandes rasgos, por Pablo La Porte, al que más adelante nos referiremos). El dualismo euforia-tragedia tiene, en cambio, como contrapartida que en los momentos de inactividad en África, la actitud imperante en España es silenciosa, resignada.

En definitiva, estos dos últimos investigadores alcanzan similares conclusiones cuando analizan el comportamiento de la opinión pública nacional en periodos de paz, pero no cuando estalla el conflicto. Quizás, porque los dos historiadores -también Miguel Martín y Sánchez Sanz- tienden a contemplar la opinión pública, en un periodo puntual, como algo monolítico.

Una visión dual de la opinión pública, en cambio, es la que nos ofrece JeanMichel Desvois, autor de un trabajo clásico sobre el Desastre de Annual y sus efectos en la prensa nacional de mayor tirada ${ }^{32}$. Él sí traza una frontera entre un discurso mayoritario y otro menos representativo socialmente que se formulan con posterioridad a la derrota de 1921. Según su interpretación, para la opinión hegemónica Annual no fue más que un contratiempo pasajero causado por la ineficiencia de los políticos, el fuerte temperamento del general Silvestre y la defección de las tropas indígenas. El patriotismo demostrado por las gentes debía ser correspondido con el esclarecimiento de los hechos, pero la obligación prioritaria del país era recuperar el territorio perdido. Frente a estos argumentos, un sentir minoritario defendía que España no estaba

\footnotetext{
${ }^{32}$ DESVOIS, Jean-Michel: La guerra de Marruecos y la opinión pública española, del Desastre de Annual al golpe de Primo de Rivera (1921-1923). Tesis doctoral inédita, Universidad de Pau, 1981. Un resumen de algunas de sus conclusiones puede hallarse en DESVOIS, Jean-Michel: "La prensa frente al Desastre de Marruecos, de Annual a Monte Arruit, 23 de julio a 13 de agosto de 1921" en VVAA: Metodología de la historia de la prensa española. Madrid: Siglo XXI, 1982, pp. 233-244.
} 
preparada para asumir tareas civilizadoras en África y la responsabilidad de la catástrofe de Annual recaía, en último término, en la figura de Alfonso XIII.

Si bien Desvois atribuye a la opinión pública un carácter eminentemente dicotómico y disparejo, no oculta la existencia de un amplio consenso entre la prensa y el gobierno en los días inmediatos al mazazo militar. La prensa se convirtió, por lo tanto, en un elemento importantísimo de cohesión social.

A nuestro juicio, ambas interpretaciones rescatadas por el profesor francés coexistieron, indudablemente, pero ni fueron las únicas ni presentaron unos contornos tan claros.

Sostenemos, como hipótesis de partida, que la opinión pública española no se mostró unánimemente en contra de las campañas bélicas en Marruecos. Pero de igual modo afirmamos que no las apoyó al unísono. Tampoco la opinión pública española fue sencillamente dual ni, por descontado, la mera suma de todas las opiniones individuales. Porque la opinión pública es siempre, por naturaleza, un fenómeno de carácter poliédrico, complejo, escurridizo y cambiante.

Entendemos, como consecuencia, que la opinión pública sólo puede comprenderse de forma adecuada cuando se examina su evolución haciendo hincapié en la distinción entre el corto y largo plazo; y, además, definiendo unas coordenadas espaciales concretas. También intuimos que éste es el único camino viable para encontrar un por qué a esos bruscos "vuelcos" o cambios de opinión que se registran entre los momentos de inactividad y de combate en Marruecos. E, igualmente, consideramos que se impone caminar con muchísima cautela a la hora de emplear conceptos tales como anticolonialismo, antibelicismo y antimilitarismo. No son sinónimos: el antimilitarismo tiene un componente de espontaneidad mucho más acentuado que el anticolonialismo. En cuanto al antibelicismo, tendremos que asumir, y resulta obvio, el hecho de que para oponerse a una guerra, primero es necesario saber que ésta existe. Por ello nos preguntamos cuándo se les habló a los salmantinos -o a los españoles, por extensión- abiertamente de ésta: ¿cuándo se abandonaron las cansinas alusiones a "operaciones de policía”, "escarceos", "breves refriegas”, “escaramuzas” o "recientes días de intranquilidad"?

Por último, pensamos que esos periodos de tregua, el sosiego que precede a la tempestad, tienen una importancia crucial, tal vez no lo suficientemente valorada por la historiografía, en la conformación de la opinión. Ese alto el fuego supone un pequeño respiro para el gabinete de turno y permite reforzar la tendencia al secretismo con la que 
los diplomáticos y la administración solían proceder al sur de Tarifa. Además, ese parón era recibido con inimaginable alivio entre los sectores sociales más desfavorecidos. Estos padecían elevadísimas tasas de analfabetismo y eran propensos a desinteresarse de las cuestiones internacionales complejas, y más si les resultaban lejanas. Pero, simultáneamente se sabían condenados a padecer las angustias y penalidades de la contienda porque el sistema de reclutamiento vigente tenía cauces que lo permitían. Deseaban, evidentemente, vivir de espaldas al vecino marroquí. Necesitaban creerse la ficción de que Marruecos no desgarraría a sus familias.

En suma, creemos que los círculos oficiales callaban y un sufrido pueblo se complacía con ese silencio. Pero, ¿también se calló la prensa? ¿Y los publicistas de la época? ¿Qué protagonismo público asumieron? ¿Cómo se relacionaron una y otros con las élites políticas? Serán cuestiones que intentaremos resolver en estas páginas.

Volviendo a la exposición de los hechos, en 1912, irónicamente, España asumió formalmente un protectorado que buscaba imponer un modelo europeo de administración, cuando la propia metrópoli se hallaba en un estado permanente de crisis. Pero incluso, todavía un año después, un intelectual como Unamuno defendió públicamente el intervencionismo en Marruecos porque creía que "el dinero y la vida que costaría la campaña sería una cuestión secundaria frente a la posibilidad que se nos ofrece de hacer una patria" ${ }^{33}$.

La zona norte del Marruecos español, según lo acordado en 1912, contaba con una superficie de 22.790 kilómetros cuadrados, que representaban una mínima concesión ante los 415.000 kilómetros cuadrados de Protectorado francés. Se trataba, como se sabe, de un terreno bastante montañoso, con un régimen hidrográfico muy pobre -únicamente el Muluya y el Lucus tienen un caudal permanente, aunque ríos como el Kert, el Nekur y el Guis riegan valles bastante fértiles- y una climatología poco propicia. La población, hacia 1912, era de unos 750.000 habitantes, con una fuerte densidad de poblamiento - entre cincuenta y cien habitantes por kilómetro cuadrado- y predominio étnico de los beréberes. Vivían en el Protectorado sesenta y seis tribus diferentes y el espacio agrícola aprovechable no representaba más que el $15 \%$ de la superficie total, por lo que se puede imaginar que el estilo de vida de estas gentes era durísimo $^{34}$. Además del cultivo, fundamentalmente de cereal y leguminosas, debían

\footnotetext{
${ }^{33}$ Entrevista a Miguel de Unamuno, publicada en Nuevo Mundo, 12 de julio de 1913.

34 AZIZA, Mimoun: La sociedad rifeña frente al Protectorado español en Marruecos, 1912-1956. Barcelona: Bellaterra. Colección Alborán, 2006, pp. 29-40.
} 
recurrir a la pesca, la ganadería, la artesanía, la piratería y la emigración coyuntural. Sin embargo, la implantación de la economía colonial acarrearía la proletarización de la población, al ser empleada ésta en el trabajo en la minas, la construcción de vías férreas y como peones agrícolas.

Desde el inicio de la aventura africana, la tópica contraposición entre penetración pacífica y armada no fue clara, pues la primera se mostró improductiva apenas a sesenta kilómetros de Melilla, quedando sin controlar gran parte del país. Así, cuando las tropas españolas, finalizada la Guerra Mundial y reanudados los avances que habían quedado temporalmente interrumpidos, alcanzaron el límite de su elasticidad, sobrevino una gran hecatombe militar. Para España, el Desastre de Annual, en 1921, supuso la derrota más costosa de su larga nómina colonial y aceleró la crisis del sistema restauracionista. Aunque en Marruecos, Abd-el-Krim se afianzó en su puesto de caudillo del movimiento de resistencia marroquí, en la península, Annual se convirtió en el asunto más espinoso del debate parlamentario y de las polémicas de la prensa, precipitó un golpe de Estado y aupó, tras el desembarco de Alhucemas, a una facción militar ultranacionalista y extremadamente violenta a la cumbre de la gobernación del país.

Al margen de la discusión sobre su fuerza real, las dos posturas más fácilmente defendibles ante la opinión pública fueron, a nuestro entender y pese a su carácter diametralmente opuesto, la abandonista y la del avance "a sangre y fuego" ${ }^{35}$. Pero entre ambas, y esto es lo que pretendemos mostrar, hubo muchas otras actitudes intermedias.

\section{LA ELECCIÓN DE SALAMANCA. OBJETIVOS}

¿Qué efectos pudo tener esa carrera diplomática y militar por el reparto de Marruecos en una pequeña capital de provincia como Salamanca, arrinconada en la vieja y deprimida Castilla? De entrada, tal vez convenga afirmar que, efectivamente, los asuntos africanos provocaron repetidas convulsiones en esta ciudad.

En líneas generales, la historiografía actual contempla las campañas de Marruecos, jalonadas con estruendosos fracasos, como la ejemplificación del creciente

\footnotetext{
${ }^{35}$ Historiadores actuales como Salafranca siguen, a día de hoy, sosteniendo esta última opción: " $L a$ acción en Marruecos se planteaba o debía haberse planteado desde el principio como una acción militar, o por el contrario no debíamos habernos comprometido internacionalmente. El intentar jugar a las dos barajas y decidirse tímidamente a destiempo y sin medios por la acción militar-única posible en el Rifnos condujo a tres campañas llenas de desastres, la de 1909, la de 1911-12 y la de 1921-27'. Véase SALAFRANCA ORTEGA, Jesús F.: El sistema colonial español en África. Málaga: Algazara, 2001, p. 117.
} 
desgaste de la monarquía de Alfonso XIII. Los interminables choques armados convirtieron en agua de borrajas su proyecto regenerador porque la creación de una sólida conciencia nacional debía fundamentarse en la eficiencia y el éxito, generando al convencer, que no imponer- un sentimiento de orgullo por pertenecer a un grupo. Desde luego, no parecía el caso.

Si bien la lectura de varias novelas sobre el conflicto del Rif fue la que despertó inicialmente nuestro interés por las campañas africanas y, en particular, por los africanistas y su visión del conflicto, el tema ya había merecido una notable atención entre los investigadores. Así que a sabiendas de que la bibliografía existente sobre la actuación militar española en el Norte de África era vastísima y con los inestimables consejos de nuestro director de tesis, consideramos preciso efectuar un giro argumental. La guerra puede ser entendida tanto como un elemento aglutinador de las conciencias ciudadanas o como un agente debilitador de las mismas. Cuando se estudian los estímulos que contribuyen a la creación de un nosotros, es habitual destacar factores de carácter simbólico, emocionales y psicológicos. Algunos de los más valorados, por su efectividad, son las banderas, los himnos, las enseñanzas de los libros de historia, los triunfos deportivos, las canciones, el culto a los héroes, la presencia estatal a lo largo y ancho del territorio y, de seguro, las confrontaciones violentas. Por ejemplo, en el caso de las naciones con un sentimiento de identidad fuerte, las disputas victoriosas por la emancipación se transforman en símbolos de esa naciente patria, mientras que las naciones aún no constituidas como Estados tienden a santificar las derrotas porque sirven para fomentar los deseos de revancha.

En el particular caso español, se ha repetido hasta la saciedad que los conflictos civiles desarrollados a lo largo de los siglos XIX y XX, al igual que las luchas por la independencia de las colonias americanas, debilitaron profundamente el espíritu nacional. Lo mismo harían las campañas de Marruecos ${ }^{36}$. Pero ¿existió esa uniformidad de pensamiento entre los coetáneos?

Entendemos, porque es una imposición metodológica, que el estudio de la conformación y evolución de la opinión pública ante las campañas hispano-marroquíes ha de efectuarse partiendo de coordenadas geográficas y temporales precisas. Es algo que ya hemos señalado. Originalmente, aunque sin reflexionar demasiado sobre la

\footnotetext{
${ }^{36}$ Véase ÁLVAREZ JUNCO, José: “El nacionalismo español como mito movilizador: cuatro guerras" en PÉREZ LEDESMA, Manuel y CRUZ, Rafael (Coords.): Cultura y movilización en la España Contemporánea. Madrid: Alianza Editorial, 1997, pp. 35-67.
} 
distinción entre opinión pública y publicada, ello fue lo que nos impulsó a la realización de un Trabajo de Grado sobre Salamanca y el Desastre de Annual. Éste se basó en el empleo exclusivo de la prensa local como fuente documental. La decisión venía motivada por un interés puramente personal y por razones de comodidad, pero acabó sorprendiéndonos la abundancia de información y la disparidad de juicios y argumentaciones que la guerra y el Protectorado merecieron en su momento. Así que decidimos continuar, aunque eso sí, partiendo de nuevos presupuestos metodológicos.

En las siguientes páginas indagaremos acerca del comportamiento de la opinión salmantina entre los años 1906, fecha de la celebración de la Conferencia de Algeciras, y 1925, momento del célebre desembarco en Alhucemas. Nos referiremos también, aunque muy brevemente, a los acuerdos internacionales anteriores al Acta de 1906.

Barajaremos en qué medida se publicitaron y comentaron los diferentes tratados que sancionaron la descomposición del Sultanato; qué se dijo a propósito del desarrollo de la Semana Trágica en Barcelona; cuál fue la actitud de los salmantinos en 1909; si se potenció el deseo de revancha o la condescendencia ante los rifeños; cómo fue contemplado el problema marroquí durante los años de la Gran Guerra; y cuál fue el peso mediático de la opción abandonista.

También a lo largo del presente trabajo de investigación se intentará precisar qué imágenes estereotipadas de los africanistas y de los marroquíes fueron potenciadas entre los salmantinos; en qué medida apoyaron éstos a sus soldados expedicionarios; cómo afrontó la ciudad el debate sobre las responsabilidades posterior al Desastre de Annual; qué discurso se impuso ante el pago de un rescate para lograr el regreso de los prisioneros; cuáles fueron las reacciones ante el desembarco en Alhucemas; cómo evolucionó la actitud salmantina ante los franceses... Son, en conclusión, muchísimos los interrogantes que nos rondan por la cabeza y para resolverlos se ha utilizado, como fuente de referencia principal, aunque ahora ya no única, la abundantísima prensa local salmantina. La cantidad de datos que ésta nos ha aportado es abrumadora, pero, sobre todo, su importancia reside en que los periódicos eran el recurso más barato, casi el único, para el conocimiento de la actualidad y del exterior en aquella época. Sin embargo, también hemos tomado en consideración el papel desempeñado por la publicística del momento, el posicionamiento de la Universidad, las manifestaciones de las autoridades religiosas locales, del Ayuntamiento, las informaciones sobre los expedicionarios conservadas en el Archivo General Militar de Madrid... 
El manejo de los periódicos por el historiador entraña varios riesgos. Aparte la extrema complejidad de la relación entre la opinión publicada y la pública, estos órganos de información y propaganda actúan, casi siempre, guiados por intereses partidistas y temerosos ante la censura, la ajena y la propia. Sin embargo, no pensamos que estos inconvenientes sean superiores a los que presentan otras fuentes. Los rotativos de las grandes ciudades, objeto de una notable atención historiográfica, pecan a veces de una excesiva proximidad al Poder. En cambio, la prensa de provincias puede servir como reducto de las tesis más críticas con el sistema. Paradójicamente, la curiosidad que los historiadores han mostrado hacia ella ha sido bastante menor. Así, las opiniones publicadas en los primeros se han identificado mecánicamente con la opinión pública nacional.

Pero, y sólo a modo de ejemplo, ¿verdaderamente la guerra se pudo sentir del mismo modo en una ciudad industrial, con puerto y fuerte sentimiento nacionalista imaginemos Barcelona- que en una ciudad agraria, caciquil y del interior? Parece lógico pronosticar que Salamanca está alejada del modelo de desarrollo existente en otras zonas más avanzadas del país. Esta circunstancia no dejó de tener consecuencias de variado signo, en la percepción "social" del conflicto bélico.

\section{LA UTILIDAD DE LA PRENSA COMO FUENTE HISTÓRICA. LA HEMEROGRAFÍA}

Las publicaciones periódicas no sólo merecen la atención de los teóricos del proceso de comunicación, sino que sirven como herramienta substancial para el conocimiento de la historia contemporánea. Por eso los estudios sobre la prensa española se han multiplicado en los últimos tiempos. No obstante lo cual, pervive cierta actitud pesimista sobre su validez documental.

Basta dirigir nuestra mirada hacia algunos estudiosos del Protectorado marroquí, para hallar significativos y recientes ejemplos de lo afirmado: en el año 2000, Madariaga, cuando prologaba una reedición de la entrevista del redactor Luis de Oteyza con Abd-el-Krim, denunciaba este hecho y advertía: “Quiero dejar constancia de que la desconfianza o los recelos de los investigadores hacia las informaciones periodísticas como fuentes fidedignas y la cautela con que se las tiene en cuenta, excepto cuando se 
trata, por supuesto, de estudios sobre opinión pública, no están siempre justificados, máxime cuando se trata de testimonios vivos, directos y sinceros" ${ }^{\text {,37. }}$.

Igualmente, dos años después, Bouzalmate, al inicio de su investigación afirmaba: "Dentro de la historiografía española, el tema de la prensa, en general, está todavía por estudiar. A pesar de los escasos - e interesantes-trabajos que se han hecho hasta la fecha, sin embargo queda mucho por hacer (...) no ha gozado del interés que se merece en el campo de la historia. Al hablar de la prensa es como si se hiciera de un pariente pobre de los estudios históricos (...) Los artículos periodísticos parece que se diluyen con los sucesos del momento, como si no hubieran existido. Y no deberían correr esta suerte en el sentido de que permiten entresacar otras interpretaciones para dar un visión múltiple de los eventos que tuvieron lugar y cuyos testigos de primera mano son los periodistas"

Ciertamente, los periódicos no acostumbran a ser, y no tienen por qué, fidedignos espejos de la realidad. Lo que nos descubren es cómo los testigos de una época entendían y juzgaban los acontecimientos en que estaban inmersos. Las noticias siempre presentan un carácter fragmentario o inacabado, inconexo, a veces resultan incomprensibles y son siempre subjetivas. Están sometidas a un proceso de criba y simplificación por parte del periodista, el dueño del rotativo y la agencia informativa.

La hemerografía es la disciplina académica que se ocupa del estudio de la prensa y procura describir los aspectos más variopintos de un periódico, desde el precio de la suscripción hasta su posicionamiento político ${ }^{39}$.

Los rotativos pueden ser, en primer lugar, objeto de estudios filológicos, ya sea desde el examen lingüístico o bien desde una perspectiva literaria. Mediante la denominada lingüística del texto, se desmenuza cada una de las informaciones contenidas en una publicación periódica para elaborar un resumen conceptual de las

\footnotetext{
${ }^{37}$ MADARIAGA, Ma Rosa de: Luis de Oteyza, un periodista liberal. Melilla: Servicio de Publicaciones de la Ciudad Autónoma de Melilla, 2000, p. 161.

${ }^{38}$ BOUZALMATE, Alhoucine: Marruecos y los intelectuales y publicistas españoles 1912-1923. Tesis doctoral inédita, Universidad Autónoma de Madrid, 2002, pp. 87-88.

${ }^{39}$ DELGADO IDARRETA, José Miguel: "La prensa: fuente historiográfica" en VVAA: Investigación humanística y científica en la Rioja. La Rioja: Aróspide/Instituto de Estudios Riojanos, 2003, pp. 245255. Dos interesantes estudios de casos en los que se reflexiona sobre el papel de la prensa en la conformación de la opinión pública desde una perspectiva histórica y sobre la metodología de trabajo con publicaciones periódicas son los de ARROYO VÁZQUEZ, M ${ }^{a}$ Luz: Industria y trabajo en el New Deal de Franklin D. Roosevelt a través de la prensa española, 1932-1936. Tesis doctoral inédita, Universidad Complutense de Madrid, 2001. Particularmente sugerente es el capítulo "Prensa e historia: conceptos y metodología" (pp. 17-41); y VAL CID, Consuelo del: Opinión pública y opinión publicada. Los españoles y el referéndum de la OTAN. Madrid: CIS/Siglo XXI, 1996.
} 
mismas. Mientras, desde un enfoque literario lo que se valoran son las cualidades estéticas de la noticia o editorial.

En esta categoría de estudios de carácter filológico también se incluyen los análisis registrales, que persiguen la confección de una biografía técnica de los diarios y revistas (sede de la administración y redacción, periodicidad, tirada, carácter matutino o vespertino...); los preocupados por la morfología de los mensajes, es decir, aquellos que examinan la presentación de las noticias (ubicación en según qué páginas, presentación de los titulares, superficie dedicada a la publicidad, determinación de la importancia cuantitativa de un mensaje en el conjunto del periódico, etc.); y los estudios de contenido. El análisis de contenido es, con seguridad, la metodología más controvertida para el examen de la prensa. Se utiliza como un método válido y preciso para el conocimiento de las opiniones más influyentes o extendidas en una sociedad y en un momento puntual. Pero hay investigadores que cuestionan la validez de un análisis que se fundamenta en aislar un texto de un periódico, sin contemplar el ejemplar completo. Otros prefieren subrayar, como principal aportación de esta técnica, la importancia de contextualizar el documento periodístico en las circunstancias que rodean al emisor y al receptor.

Un último método posible es el comúnmente conocido como humanístico. Queda fuera de los enfoques filológicos, aunque muy próximo a la última de las técnicas descritas. El objetivo del método humanístico es conocer la actitud de un periódico en su coyuntura espacio-temporal, perfilar cómo evoluciona la línea informativa de una publicación en relación con su contexto histórico. Se analizan, por tanto, sus mensajes de manera longitudinal, diacrónicamente. Una primera posibilidad de trabajo sería la técnica del muestreo, muy útil sobre todo para los enfoques a largo plazo, pero creemos que para conocer rigurosamente un asunto -independientemente de que sea a corto, medio o largo plazo-, es más adecuado el análisis de todos los ejemplares de cada una de las publicaciones escogidas.

Así que ésta será nuestra elección: el método humanístico sin el recurso a la técnica del muestreo. No ambicionamos, consecuentemente, hacer una historia de cada periódico seleccionado ni de las empresas que los sustentaban. Lo que deseamos es analizar la evolución de la opinión pública salmantina ante la cuestión marroquí a partir de la información publicada a su alcance, de la conducta de las autoridades y de los gestos de la misma ciudadanía. 
¿Cómo debemos proceder para conocer una fracción, una mínima porción de la historia de nuestra opinión pública? ¿Cómo conocer el posicionamiento de los salmantinos ante las campañas de Marruecos? Para empezar, olvidémonos de los sondeos de opinión cuya fiabilidad es hoy notablemente sobrevalorada. Entonces, al comenzar el siglo XX, ni existían. Tendremos que olvidarnos también de algunas categorías analíticas modernas de la Comunicación Política, tales como la circulación, audiencia, alcance, frecuencia y exposición ante los mensajes informativos. A muy duras penas podemos tan sólo aproximarnos a los datos de tirada de algunos rotativos; y para continuar, pensemos que la sociedad de masas y veloces telecomunicaciones hoy existente era por aquellos años, en la Salamanca del bravucón Martín Veloz, de un emprendedor Juan Mirat y del eterno Unamuno, algo incipiente.

El mundo no era un pañuelo. El concepto "globalización” no existía y el analfabetismo constituía una lacra con la que convivían la inmensa mayoría de los gobiernos. Sabido es que la influencia de la prensa oscila, lógicamente, según el grado de cultura del público, atendiendo al interés que éste muestre por un tema y según se publiciten o no variados posicionamientos sobre un asunto desde distintos órganos de opinión (o, incluso, dentro del mismo). Así, en condiciones idílicas de cultura, interés y pluralidad ideológica el público se convierte en auténtico sujeto de opinión; en el caso contrario, el público se transforma en una marioneta, constituye sólo teóricamente un poder social, pero quien lo ejerce en la práctica son las empresas de comunicación.

Si bien ya resulta complicado conocer las tasas de alfabetización de Salamanca durante el primer tercio del siglo XX, mayores dificultades se presentan a la hora de calibrar el interés de sus gentes hacia las cuestiones marroquíes. Aunque éste es evidente coincidiendo con los reveses militares, no nos atrevemos a hacer extensible esta afirmación para los periodos de inactividad bélica. Lo cierto es que partimos de una concepción bastante pasiva de la relación emisor/receptor del mensaje periodístico. Ésta es el producto de la conjunción entre unos poderosos medios y un público casi siempre alejado de la realidad marroquí, con tan sólo un concepto, una percepción, muy arraigada en su imaginario: la tradicional lucha contra el moro, un atávico sentimiento de repugnancia que alimentaba, casi inevitablemente, el choque entre dos culturas.

En cualquier caso, sí que disponemos de instrumentos para valorar la pluralidad de las informaciones periodísticas manejadas por los salmantinos curiosos. 


\section{CONTRIBUCIONES RECIENTES AL ESTUDIO DE LA RELACIÓN ENTRE LA PRENSA, LA OPINIÓN PÚBLICA Y LA CUESTIÓN MARROQUÍ}

Creemos que bastante ha sido el terreno desbrozado por la historiografía desde que, allá por 1905, Gabriel Maura publicara La cuestión de Marruecos desde el punto de vista español ${ }^{40}$. Fue este político, desde una posición pretendidamente legitimadora del proceder de su padre, el primero en indagar sobre asuntos tales como la opinión española ante el problema africano y sus intereses en aquellos territorios. Le seguirían muchísimos otros publicistas, casi siempre con el velado propósito de coaccionar a su clientela, de no permanecer al margen de los hechos. Diríase que pretendieron actuar como perros lazarillos para sus lectores, tanto a favor como en contra de la acción colonial.

Con posterioridad al desembarco de Alhucemas, aunque se siguieron publicando algunas obras de carácter muy general sobre el Protectorado, el interés hacia las campañas marroquíes, poco a poco, fue decayendo ${ }^{41}$. Habría que esperar hasta el momento final de la dictadura franquista para que recobrase vigor el estudio del colonialismo español en Marruecos.

Al revisar la bibliografía más reciente sobre el comportamiento de la prensa y de la opinión pública española ante las guerras hispano-marroquíes, lo primero que cabe apuntar es que el tratamiento que este tema ha merecido resulta, como a continuación se comprobará, ciertamente muy desigual porque las acotaciones espaciales, cronológicas y metodológicas a las que ha de someterse el investigador son inexcusables ${ }^{42}$.

\section{A. Años 70}

Las más destacadas aportaciones al conocimiento y comprensión de la opinión pública durante esta década se las debemos al periodista Pedro Gómez Aparicio y a los

\footnotetext{
${ }^{40}$ MAURA GAMAZO, Gabriel: La cuestión de Marruecos desde el punto de vista español. Madrid: Imprenta de M. Romero, 1905.

${ }^{41}$ La fuerza de la opinión pública sí aparece reconocida en obras tales como GARCÍA FIGUERAS, Tomás: Historia de la acción de España en Marruecos. Desde 1904 a 1927. Barcelona: Ediciones Fe, 1939; También véase CAMPOAMOR, José María: La actitud de España en la cuestión de Marruecos. Madrid: CSIC, 1951.

${ }^{42}$ Balances más globales sobre la producción historiográfica relacionada con el Protectorado y las relaciones hispano-marroquíes pueden hallarse en: MARTÍN CORRALES, Eloy: "Algunos problemas de la investigación histórica relativa a las relaciones hispano-marroquíes a los cincuenta años de la independencia de Marruecos" en LÓPEZ GARCÍA, Bernabé y HERNANDO DE LARRAMENDI, Miguel (Coords.): Historia y memoria de las relaciones hispano-marroquíes. Un balance en el cincuentenario de la independencia de Marruecos. Madrid: Ediciones del Oriente y de Mediterráneo, 2007, pp. 209-232; y MOGA ROMERO, Vicente: La cuestión marroquí en la escritura africanista. Barcelona: Bellaterra, 2008. El dramático capítulo de Annual también ha merecido un estado de la cuestión en la tesis doctoral de Pablo La Porte. Resumidamente, también éste se puede encontrar en LA PORTE, Pablo: "El Desastre de Annual, ¿un olvido historiográfico?", Cuadernos de Historia Contemporánea, $\mathrm{n}^{\circ}$ 19, Madrid, 1997, pp. 223-229.
} 
historiadores Víctor Morales Lezcano, Bernabé López García y María Rosa de Madariaga. Sus trabajos suponen una inicial aproximación, todavía tangencial y restrictiva, a la materia.

Pedro Gómez Aparicio fue el autor de un manual imprescindible, por su ambición, sobre la historia del periodismo español ${ }^{43}$. Dedica en su Historia del periodismo español sendos capítulos a propósito de la situación de la prensa a la altura de 1909 y también coincidiendo con el Desastre de Annual.

Para el caso de 1909, los periódicos del Trust acaparan la atención exclusiva de este autor. Con motivo de la primera campaña de Melilla en el siglo XX, el papel político opositor que asume la Sociedad Editorial de España -vulgarmente apodada el Trust y conformada por El Liberal, El Imparcial y Heraldo de Madrid- se presenta como transcendental. Aunque éste no fue su único ejemplo de "hostilidad implacable contra el gobierno Maura" - participación en la polémica por el precio del papel, rechazo de su ley contra el terrorismo, conformación del Bloque de las Izquierdas, el respaldo a una denuncia contra el gabinete de Macías del Real por prevaricación en la adjudicación a una casa británica de la construcción de tres acorazados- Gómez Aparicio juzga, en todo momento, que la vida del Trust constituye "uno de los más turbios episodios de la Historia del Periodismo español"44.

Al recrudecer, en julio de 1909, los enfrentamientos en las cercanías de Melilla "el Ministerio Maura hubo de llamar al servicio de las armas a varios contingentes de reserva, lo que proporcionó pretexto para un movimiento revolucionario" ${ }^{45}$. Parece, así, que Maura carecía de otras posibilidades de acción, como si se hallase absolutamente obligado a enviar a los reservistas de los años 1903-1905, en lugar de a las unidades de reemplazo que estaban al completo. Por lo que respecta al fusilamiento de Ferrer, acusado de inspirar los sucesos de la Semana Trágica, reconoce el profesor Gómez

${ }^{43}$ GÓMEZ APARICIO, Pedro: Historia del periodismo español. De las guerras coloniales a la dictadura. Madrid: Editora Nacional, 1974.

${ }^{44}$ Ibidem, p. 243-244. A propósito de su nacimiento, recoge este profesor la nota que el 16 de mayo de 1906 insertan simultáneamente en sus ejemplares El Imparcial, El Liberal y el Heraldo de Madrid. Confiesan que no pretenden ni monopolizar la influencia en la prensa política ni favorecer negocios particulares. Pero Gómez Aparicio no entiende el maridaje entre los dos primeros diarios: monárquico uno y republicano, El Liberal. Tampoco entiende cómo se gestó, desde una perspectiva financiera, la unión. De entrada, para comprar a Canalejas el Heraldo de Madrid, se necesitó un millón y medio de pesetas. Lo más curioso del asunto fue el nombre del prestamista: Juan de la Cierva. Y parece que fue más dinero de procedencia conservadora el que permitió la constitución de la Sociedad. Empleando reiteradamente las Notas de mi vida, redactadas por La Cierva, Gómez Aparicio sostiene que el origen de todas las discrepancias entre el Trust y el Gobierno Largo de Maura se hallan en que él, a la sazón ministro de Gobernación en 1907, rechazó reservarle algunos escaños a los protegidos del nuevo consorcio periodístico (directores de periódicos, redactores y amigos).

${ }^{45}$ Ibidem, p. 262. 
Aparicio que su procesamiento fue normal, pero sirvió también para alimentar la propaganda antigubernamental del Trust ${ }^{46}$. En suma, todo había sido una conspiración cuyo propósito perseguía la expulsión de Maura de la poltrona presidencial.

Algunos años después, el Desastre de Annual pilló desprevenida, al igual que en el caso anterior, a la opinión pública ${ }^{47}$. El interés de Gómez Aparicio se dirige, en esta ocasión, hacia las Juntas Militares de Defensa, cuyos intereses eran defendidos por La Correspondencia Militar; hacia la gravedad que revestía el asunto de los prisioneros; y hacia el enfrentamiento dialéctico entre Manuel Delgado Barreto, director del diario maurista La Acción, y La Libertad de Santiago Alba. La discusión venía alimentada por las alusiones del primero, para explicar el desaforado avance de las tropas españolas por el Rif, a turbios negocios mineros entre Horacio Echevarrieta y alguna enigmática personalidad conservadora. Todo ello a espaldas de los deseos de Abd-el-Krim. Horacio Echevarrieta era un afamado capitalista bilbaíno, además de amigo íntimo de Alba. En sus declaraciones admitió el haber iniciado negociaciones con Abd-el-Krim, pero siempre con absoluta independencia de cualquier plan de avance militar.

Termina Gómez Aparicio considerando que, en el momento del golpe de Estado el problema de Marruecos se hallaba "semiencarrilado", en tanto que el gobierno del marqués de Alhucemas había logrado la aprobación de un informe del Estado Mayor favorable a la reanudación de las operaciones. Este informe era el resultado del "sentir de una gran parte de la opinión, que propugnaba el enérgico castigo de la rebeldía" ${ }^{\text {48 }}$.

Víctor Morales Lezcano, por su parte, publica El colonialismo hispano-francés en Marruecos (1898-1927) en 1976 ${ }^{49}$. Fue el primer investigador español que realizó un estudio sistemático de los agentes impulsores del colonialismo español en Marruecos, lo que le condujo a enfatizar el protagonismo de los consorcios mineros, de las suspicacias tanto inglesas como alemanas y a establecer una distinción, hoy muy manida, entre una década de "penetración pacífica" y otra etapa de "escalada militar". El objetivo de Morales Lezcano no era, consecuentemente, el estudio de la opinión pública, pero empleó en su trabajo algunos periódicos, tales como La Época, $A B C$ o $L a$ Correspondencia Militar y también revistas como España en África porque asumió de modo muy natural su función como guía de la misma y buscó en sus páginas

\footnotetext{
${ }^{46}$ Ibidem, pp. 264-265.

${ }^{47}$ Ibidem, pp. 649-671.

${ }^{48}$ Ibidem, p. 681.

${ }^{49}$ MORALES LEZCANO, Víctor: El colonialismo hispano-francés en Marruecos (1898-1927). Madrid: Siglo XXI, 1976.
} 
incitaciones de los grupos colonialistas para defender la intervención española, cada vez más activa, al otro lado del Estrecho de Gibraltar.

Bernabé López García, también a lo largo de los años setenta, publicó tres artículos que nos interesa reseñar muy sucintamente. Junto con otros cuantos, han sido reeditados en 2007 bajo el título Marruecos y España. Una historia contra toda lógica ${ }^{50}$. La prensa se convierte en un recurso documental básico para efectuar un bosquejo del pensamiento africanista de algunos de nuestros intelectuales. Además, López García emplea las páginas de El Socialista para la comprensión del anticolonialismo obrero español ${ }^{51}$; España en África, fundada en 1905, también es merecedora de un trabajo monográfico; y el humor gráfico (El Socialista, El Liberal, $A B C$, Gedeón...), entendido como un valiosísimo elemento para el comentario y correcta "digestión" de la actualidad, tampoco escapa a su análisis.

Por último, María Rosa de Madariaga es la autora de otro artículo sobre el posicionamiento de los sectores obreros ante la revolución rifeña. Para su realización procedió al examen de varios discursos parlamentarios y huelgas, así como a la consulta de periódicos ${ }^{52}$.

\section{B. Años 80}

Es ahora cuando comienza a adquirir carta de naturaleza el estudio de la opinión pública ante las campañas marroquíes. Casi todas las obras a las que hemos de referirnos en estos años son tesis doctorales que o bien abordan ya de modo directo, monográfico, la cuestión (Desvois, García de la Rasilla y Bachoud) o bien indagan en la relevancia de la prensa y de la opinión pública como elementos condicionantes de los agentes colonizadores (Elisa Pérez Molina, Celso Almuiña). Además, de finales de esta década datan las primeras investigaciones sobre el comportamiento de la opinión pública en un marco geográfico provincial (García de la Rasilla) y desde una metodología plenamente humanística (también García de la Rasilla y Bachoud).

\footnotetext{
${ }^{50}$ LÓPEZ GARCÍA, Bernabé: Marruecos y España. Una historia contra toda lógica. Sevilla: RD Editores, 2007. Los títulos de los tres artículos mencionados son: "España en África: génesis y significación de la decana de la prensa africanista del siglo XX", pp. 61-83; "El socialismo español y el anticolonialismo. El socialismo español y los Congresos de la Internacional ante la penetración colonial en Marruecos (1898-1914)", pp. 163-213; y "Humor gráfico y guerra de Marruecos, (1909-1914)”, pp. 215-228.

${ }^{51}$ Ibidem, p. 176. López García señala que 1906 es "el punto de arranque de la conciencia anticolonial en el Partido Socialista Obrero Español". Con anterioridad, ésta estaba muy poco elaborada y condicionada por prejuicios eurocentristas. El autor reclama la necesidad de un estudio más amplio sobre las campañas anticoloniales del PSOE.

${ }^{52}$ MADARIAGA, María Rosa de: "Le Parti socialiste espagnol et le Parti communiste d'Espagne face à la révolte rifaine" en VVAA: Abd-el-Krim et la République du Rif. París: François Maspero, 1976, pp. 308-366.
} 
En 1981 concluye Desvois su tesis doctoral y en 1982 se publica en España un artículo a propósito de la prensa en los momentos inmediatamente posteriores al descalabro en Annual. Posee este trabajo un carácter a medio camino entre el análisis morfológico y el de contenidos y para su elaboración, el investigador francés manejó los principales periódicos de Madrid y Barcelona, además de El Liberal de Bilbao, entre el momento en que se hace público el fracaso de las armas españolas (23 de julio de 1921) hasta la rendición de Monte Arruit y el ascenso de Maura a la presidencia (12 de agosto de 1921$)^{53}$. Tras proceder a un minucioso análisis del diseño periodístico, dos fueron sus grandes conclusiones:

A. "La medición del porcentaje de la superficie total dedicada por cada periódico a la cuestión de Marruecos permite comprobar el gran impacto de aquellos acontecimientos para la prensa: sobre diecinueve publicaciones, cinco les consagran más del 33 por 100 de su superficie total (son estas publicaciones La Acción, Heraldo de Madrid, La Correspondencia Militar, El Imparcial y La Voz); nueve, entre el 23 y el 33 por 100 ( se refiere a La Época, El Liberal de Bilbao, la edición madrileña de este mismo diario, La Libertad, ABC, El Siglo Futuro, La Correspondencia de España, El Debate y Ejército y Armada), y cinco, menos del 23 por 100 (El Sol, La Publicidad, El Progreso, La Vanguardia y El Socialista). Puede verse también que los diarios de la tarde o noche les dedican un promedio del 31,99 por 100, y los de la mañana, el 24,43 por 100, cifras que pueden explicarse por el carácter más reflexivo de los diarios de la mañana, que no olvidan el resto de la actualidad. Por otra parte, cabe notar que los periódicos de Barcelona se encuentran clasificados netamente detrás de los de Madrid, pero son diarios de la mañana también. Por fin, podría sorprender el porcentaje bajísimo que da El Socialista, pero se explica por su decisión de no publicar nada sobre Marruecos a partir del día 25 de julio, en que se impone la censura previa, decisión que corrige muy parcialmente a partir del día 29”.

B. "La medición del porcentaje que representa la primera plana sobre la superficie total dedicada a Marruecos permite completar los resultados procedentes al indicar cuáles son los diarios que dan un carácter más

\footnotetext{
${ }^{53}$ DESVOIS, Jean-Michel: "La prensa frente a...", Op. Cit., pp. 233-244. Los diecinueve periódicos analizados son ABC, La Acción, La Correspondencia de España, La Correspondencia Militar, El Debate, Ejército y Armada, La Época, Heraldo de Madrid, El Imparcial, El Liberal, El Liberal (Bilbao); La Libertad, El Progreso, La Publicidad, El Siglo Futuro, El Socialista, El Sol, La Vanguardia y La Voz.
} 
sensacional a lo que allí ocurre; de nuevo puede constatarse que se clasifican en cabeza los diarios de la tarde o de la noche (figuran en los puestos principales del listado El Socialista, Ejército y Armada, El Progreso, El Liberal de Bilbao y La Voz; mientras que cierran la enumeración ABC, El Siglo Futuro y La Vanguardia), y de manera general, que los periódicos estudiados dan en su casi totalidad un carácter sensacional a sus noticias y comentarios sobre Marruecos ${ }^{, 54}$.

Algunos años después, $\mathbf{M}^{\mathrm{a}}$ del Carmen García de la Rasilla presenta su memoria de licenciatura, titulada Los problemas de Marruecos y la opinión pública vallisoletana $(1898-1927)^{55}$. Se trata de una minuciosa incursión en el estudio de los efectos del problema marroquí entre la opinión vallisoletana, con continuos desplazamientos desde el escenario nacional hasta el de la capital y fundamentado en el manejo y análisis de la prensa local, sobre todo, El Norte de Castilla y El Diario Regional. Esta profesora define la opinión pública como "el reflejo de las circunstancias socioeconómicas, religiosas y culturales en que se desenvuelve la vida de un lugar" y destaca que casi nada podía hacer España, "débil, retraída y no nacionalista”, en Marruecos. Su esfuerzo colonizador no triunfaría al carecer del respaldo de una sólida estructura capitalista. Poco más que un sueño parecía, por consiguiente, la voluntad de competir con Francia, una de las potencias imperiales más dinámicas del momento ${ }^{56}$. En cuanto al análisis de la opinión local, García de la Rasilla distingue, siguiendo a Morales Lezcano, una primera etapa, que se extiende hasta 1912, cuando se firma el Tratado de Protectorado, y un segundo periodo, que llega hasta 1927. En el primero se transita desde la apuesta por la penetración pacífica hasta la defensa del principio de la paz armada. Se persigue la familiarización de los lectores con los asuntos africanos mediante alusiones al salvajismo de los moros, a las posibilidades de regeneración patria que Marruecos ofrece $y$, finalmente, con informaciones sobre la riqueza minera del Rif; en la fase posterior, se alude a una polarización entre las tesis sostenidas por la prensa liberal y la conservadora. El Desastre de Annual alimenta una cantidad ingente de noticias, pero su carácter es caótico y mientras que los comentarios dedicados a las publicaciones obreras son escasos, los gestos de la ciudad para con sus soldados son descritos con enorme

\footnotetext{
${ }^{54}$ Ibidem, pp. 235-238.

${ }^{55}$ GARCÍA DE LA RASILLA ORTEGA, Ma del Carmen: Los problemas de Marruecos y la opinión pública Vallisoletana (1898-1927). Memoria de Licenciatura inédita, Universidad de Valladolid, 1985.

${ }^{56}$ Ibidem, p. 95.
} 
detalle. Tanto los periodistas como la élite política dirigente pusieron todo su empeño en socorrer al Ejército en operaciones.

De la misma autora, además, es el artículo "Palencia y la guerra de Marruecos (1909-1927)”, en el que se sacan a la luz muchas de las acciones asistenciales en beneficio de los combatientes y promovidas tanto por autoridades como por particulares ${ }^{57}$. García de la Rasilla defiende que así como las manifestaciones de júbilo se desatan coincidiendo con las victorias militares, la prensa local, en concreto El Diario Palentino y El Día de Palencia, se esfuerzan por infundir aliento entre la ciudadanía cuando las circunstancias son menos favorecedoras.

Otro trabajo que ha captado nuestra atención es la tesis doctoral inédita de Elisa Pérez Molina, defendida en 1986, y titulada El norte de Marruecos, de la Conferencia de Algeciras al Protectorado. Su repercusión en las Cortes españolas (1906-1912) ${ }^{58}$. En ella se recopila un enorme volumen de discursos y debates parlamentarios habidos a raíz de los sucesivos tratados internacionales y sancionadores del reparto de Marruecos. La autora comienza aludiendo al Acuerdo non nato de 1902 y concluye con la firma del Tratado de Protectorado. Además del análisis, de las intervenciones en ambas Cámaras del partido en el gobierno, el partido mayoritario en la oposición y otras fuerzas políticas, el contenido de los mensajes de los políticos se contrasta con el de los transmitidos por la Iglesia y el Ejército, así como con algunos mensajes periodísticos. Pérez Molina recurre, en este sentido y de modo muy escueto, a La Época y El Liberal.

Una nueva contribución de la Universidad vallisoletana al estudio de la opinión pública es un breve artículo de Celso Almuiña sobre el Desastre de Annual ${ }^{59}$. Tras una pequeña contextualización de la derrota en el marco del debate entre colonialistas y anticolonialistas, enfatiza la idea de que las campañas de opinión no estuvieron únicamente sostenidas por la prensa, siempre muy pendiente de los censores, sino también a través del empleo de tarjetas postales, la difusión de rumores, de relatos y

\footnotetext{
${ }^{57}$ GARCÍA DE LA RASILLA ORTEGA, María del Carmen: "Palencia y la guerra de Marruecos (19091927)" en VVAA: Actas del I Congreso de Historia de Palencia. Tomo III. Edad Moderna y edad Contemporánea. Palencia: Diputación Provincial de Palencia, 1987, pp. 715-723.

${ }^{58}$ PÉREZ MOLINA, Elisa: El norte de Marruecos, de la Conferencia de Algeciras al Protectorado. Su repercusión en las Cortes españolas (1906-1912). Tesis doctoral inédita, Universidad Autónoma de Madrid, 1986. Existe otra tesis doctoral que analiza las repercusiones parlamentarias del Desastre de Annual. Pese a que en ella se estudien las posiciones de los distintos partidos políticos y se aluda reiteradamente al impacto de algunos debates en Cortes entre la opinión pública, el trabajo está confeccionado sin el recurso a la prensa. Véase COMALADA, Ángel: España: El ocaso de un Parlamento, 1921-1923. Barcelona: Ediciones Península, 1985.

${ }^{59}$ ALMUIÑA, Celso: "El Desastre de Annual (1921): su proyección sobre la opinión pública española", Investigaciones Históricas. Departamento de Historia Moderna y Contemporánea, $\mathrm{n}^{\circ}$ 8, Valladolid, 1988, pp. 181-245.
} 
novelas... En su opinión, el debate a propósito de las responsabilidades se convirtió en el más flagrante síntoma del hundimiento del régimen.

Por último, y a punto de finalizar la década de los ochenta, la gran aportación de la historiografía francesa es la obra de Andrée Bachoud Los españoles ante las campañas de Marruecos $^{60}$. Tanto el marco cronológico como los planteamientos metodológicos de Bachoud son distintos a los anteriormente utilizados por Desvois. La investigadora dirige su mirada hacia las repercusiones del conflicto marroquí en España durante el periodo comprendido entre 1909 y el estallido de la Primera Guerra Mundial. Mediante el recurso a informaciones periodísticas y también con las procedentes del Quai D’Orsay y del antiguo Servicio Histórico Militar, la autora francesa especula, siguiendo la estela de Morales Lezcano, sobre las fuerzas motrices del africanismo español, relativizando la importancia de los intereses mineros en favor de una apelación al excesivo intervencionismo militar y regio ${ }^{61}$. Además, también incide en cómo las protestas contra las movilizaciones, identificadas como la única forma de expresión pública de las masas, contribuyeron a la consolidación de los partidos revolucionarios y sindicatos obreros. No olvida, por otro lado, aludir al comportamiento de las fuerzas políticas dinásticas así como al de los sectores intelectuales y escritores.

\section{Años 90}

Juzgamos que éstos constituyen años de afianzamiento, sobre todo la segunda mitad de la década, en la atención historiográfica hacia la relación entre la opinión pública y las campañas de Marruecos. Resulta muy satisfactorio comprobar que un creciente número de investigadores conciben la opinión pública como un agente esencial para la comprensión de las relaciones con Marruecos. El interés ya no deriva exclusivamente del estudio de los motores, agentes y secuelas de la colonización (Pablo La Porte), sino que la opinión pública adquiere vigor como elemento condicionante, y en ocasiones determinante, de los contactos diplomáticos de España con otros países europeos (Susana Sueiro Seoane, Mª del Carmen García Velilla). Desafortunadamente, sólo encontramos un trabajo monográfico sobre la repercusión pública internacional de

\footnotetext{
${ }^{60}$ BACHOUD, Andrée: Los españoles ante las campañas de Marruecos. Madrid: Espasa-Calpe, 1988.

${ }^{61}$ Ibidem, p. 82. Bachoud alude a un fuerte sentimiento francófilo por parte de Alfonso XIII del que intentó aprovecharse el gobierno galo. Sin embargo, no resulta nada evidente una vez que estalla la Primera Guerra Mundial. Así, Gabriel Cardona, en una muy reciente biografía sobre el Rey enfatiza el hecho de que, casado éste con una inglesa e hijo de una austriaca, se comportó mucho más como un Habsburgo que como un Borbón. Véase CARDONA, Gabriel: Alfonso XIII, el Rey de espadas. Barcelona: Planeta, 2010, p. 127. La correspondencia del monarca con el káiser Guillermo II revela que moralmente estaba de su parte. Desde Alemania se le intentaba seducir con la promesa de una futura ampliación de los dominios africanos y a sabiendas de que el ingreso de Portugal en la contienda, al lado de la Entente, le había producido una enorme desilusión pues truncaba sus planes de invasión.
} 
la Guerra del Rif (Tayeb Boutbouqalt); dos artículos a propósito de El Socialista y la prensa de sectores nacionalistas tras el Desastre de Annual (José Moreno Juste y María Rosa de Madariaga); y dos investigaciones, con carácter local y ya muy al final del período, sobre las secuelas de la Semana Trágica (Carlos Gil Andrés y Mª José Ruiz Acosta).

En 1990, Antonio Moreno Juste efectúa un escueto análisis de El Socialista y su posicionamiento ante la sacudida de $1921^{62}$. Destaca de este diario, ante todo, su voluntad de movilizar a la opinión contra una sangrienta aventura colonial y su decidida exigencia de responsables.

Asimismo, Susana Sueiro Seoane publica su tesis doctoral, España en el Mediterráneo. Primo de Rivera y la “cuestión marroqui”, 1923-1930, en el año $1992^{63}$. Además de cuantiosas fuentes archivísticas, la autora también repara en algunos periódicos nacionales ( $A B C$, El Liberal, El Sol, La Voz, La Época, Informaciones...) y prensa francesa e italiana con el objeto de explicar las motivaciones de la política africana del dictador, siempre reacio a lanzarse a la aventura, y en un contexto internacional adverso, de subordinación ante Francia. Con una sólida argumentación, la autora explica los cambios que se operan en el Directorio y en la opinión desde el estallido francófobo de 1923, coincidiendo con la revisión del estatuto de Tánger (entonces cristaliza todo el rencor acumulado en España por el empleo de la estrategia conquistadora de Étienne, conocida como "la mancha de aceite"), y hasta el momento en que se logra una alianza militar hispano-francesa, en 1925. A las fuentes hemerográficas le atribuye muchos "problemas y limitaciones", pero no puede resistirse a su empleo, consciente de que el Directorio se valía de la prensa, y también de su censura, como "vehículo de opinión" "64. En definitiva, gracias a su utilización y análisis, Sueiro Seoane puede referirse a un pesado ambiente diplomático, marcado por recíprocos recelos hispanos-franceses; apela al argumento de la necesidad psicológica de los españoles de buscar un culpable tras el Desastre de Annual; a Primo de Rivera le atribuye una permanente búsqueda de una "solución honorable" para el Protectorado, una continua obsesión por "vender" éxitos diplomáticos a la opinión española; entiende las relaciones hispano-italianas como coqueteos amenazadores para el ejecutivo galo;

\footnotetext{
${ }^{62}$ MORENO JUSTE, Antonio: "El Socialista y el Desastre de Annual: opinión y actitud socialista ante la derrota", Cuadernos de Historia Contemporánea, nº 12, Madrid, 1990, pp. 103-132.

${ }^{63}$ SUEIRO, SEOANE: España en el Mediterráneo. Primo de Rivera y "la cuestión marroqui", 19231930. Madrid: UNED, 1992.

${ }^{64}$ Ibidem, p. XXII.
} 
analiza los persistentes roces con Francia posteriores al desembarco de Alhucemas y el deseo público de que se acaben las operaciones militares...

Coincidiendo con la edición de la tesis de Susana Sueiro, Tayeb Boutbouqalt publica La Guerre du Rif et la réaction de l'opinion internationale, 1921-192665. Se trata de un examen de las políticas informativas adoptadas por Francia y España ante la revolución iniciada por Abd-el-Krim. El autor presta particular atención al papel asumido por los corresponsales de guerra. También hay espacio para el estudio de sus repercusiones en la prensa de terceras potencias.

De 1997 data la muy sugerente tesis doctoral de Pablo La Porte, El Desastre de Annual y la crisis de la Restauración en España (1921-1923). Con el recurso a una enorme disparidad de archivos españoles -Servicio Histórico Nacional, AGA, ArchivoBiblioteca del Ministerio de Hacienda...-, además de ingleses y franceses, y con el empleo puntual de las cabeceras de algunas grandes ciudades (ABC, El Sol, La Libertad, El Socialista, La Correspondencia Militar, La Época, La Voz, El Liberal...), este investigador repasa los orígenes del Desastre de Annual y, sobre todo, escarba en sus secuelas. Hace particular hincapié en las consecuencias de carácter parlamentario, militar y entre la opinión pública. Si bien al exponer las causas de la debacle militar, consideramos que el autor carga excesivamente las tintas contra las Juntas de Defensa/Comisiones Informativas ${ }^{66}$, sus juicios sobre las derivaciones del mismo nos parecen bastante más acertados.

En el desarrollo del trabajo, las alusiones al comportamiento de los españoles al hilo de los acontecimientos marroquíes son continuas: el Tratado de 1904 y el Acta de 1906 pasan desapercibidos ante la opinión; la violencia desatada en 1909 ejemplifica los peligros de adquirir compromisos internacionales sin informar previamente al pueblo, mientras que la tregua establecida durante el mes de agosto de ese año se traduce en una

\footnotetext{
${ }^{65}$ BOUTBOUQALT, Tayeb: La Guerre du Rif et la réaction de l'opinion internationale, 1921-1926. Casablanca: Najah El Jadida, 1992.

${ }^{66}$ LA PORTE, Pablo: El Desastre de Annual y la crisis de la Restauración en España (1921-1923). Tesis doctoral inédita, Universidad Complutense de Madrid, 1997. La Porte sostiene que Annual es el fruto del clima moral que se impone tras la pérdida de la posición de Abarrán. Al general Silvestre le achaca una errónea apreciación de la gravedad de la situación reinante entonces; y a los demás oficiales y mandos, un muy escaso espíritu militar. Ahora bien, esta flaqueza moral es, a su vez, la principal consecuencia de la perniciosa política practicada por las Juntas Informativas y su imposición, para acabar con los favoritismos en los ascensos, del turno obligatorio en África desde 1918.

Nos llama la atención el hecho de que son muy escasas las ocasiones en que aparece la palabra "africanista" en la investigación de La Porte. Su responsabilidad en la catástrofe resulta casi por completo diluida. En su lugar, la administración del Protectorado se presenta como una obligación, casi un trabajo forzoso, que ha de desempeñar el Ejército porque así lo han acordado los políticos dinásticos ante Europa. Por descontado, sin tomarse la molestia de ilustrar a la opinión pública a propósito de los intereses españoles en Marruecos.
} 
inmediata reacción de tranquilidad; el Tratado de 1912 y la ocupación pacífica de Tetuán topan otra vez con la indiferencia ciudadana; una nueva fase de huelgas y protestas contra los envíos de soldados a África había recorrido el país en 1911 y se repetirá, en 1913; una ola de fervor patriótico sacudirá a las ciudades españolas tras conocerse el descalabro de Annual y el apoyo a la campaña será continuado hasta diciembre de 1921.

La satisfacción con que son contemplados los primeros embarques de soldados se entiende, según el juicio de La Porte, debido a la inexistencia de noticias certeras sobre el alcance de la derrota; por la prevención mostrada por el gobierno al enviar exclusivamente soldados en el primer o segundo año de servicio, además de "cuotas"; porque la atención pública se dirigía hacia la suerte de la columna del general Navarro; y por la debilidad de las fuerzas políticas y sindicales.

Asimismo, si esta unidad ciudadana se pudo mantener tras hacerse pública la masacre de españoles ocurrida en Monte Arruit fue, en gran medida, por la actitud cohesionada que mantuvieron todos los grupos políticos; por el trabajo de los periodistas dentro de los cauces marcados por la censura; y debido al papel de las corporaciones municipales, con sus agasajos, los gestos benéficos de multitud de particulares, de la Iglesia, los "cuotas" ${ }^{67}$... El tono belicoso de la prensa se empieza a moderar, sin embargo, desde principios de 1922 y la opinión se polariza en torno a cuestiones como el rescate de los prisioneros, las responsabilidades, la repatriación, la prolongación de las operaciones... hasta despejar el camino, ese famoso "plano inclinado", hacia una dictadura ${ }^{68}$.

La opinión pública también se halla bastante presente en la tesis doctoral de María del Carmen González Velilla, Orientación general de la política exterior

\footnotetext{
${ }^{67}$ Ibidem, pp. 232-233 y 279-287. No obstante, la campaña del "aguinaldo del soldado" de 1921 ya no es entendida como un gesto de adhesión a la guerra (p. 363). ¿Por qué los gestos anteriores sí lo eran? Consideramos que se debería enfatizar la diferencia existente entre apoyar a los soldados -que son contemplados casi siempre como víctimas- y sostener un sentimiento de desquite, esgrimido por buena parte de la prensa y, sobre todo, por los oficiales africanistas y el gobierno de Antonio Maura para alimentar la campaña militar.

${ }^{68}$ Véase también LA PORTE, Pablo: La atracción del imán. El Desastre de Annual y sus repercusiones en la política europea (1921-1923). Madrid: Biblioteca Nueva, 2001. El autor trata de insertar el Desastre de Annual en su contexto internacional y, además, dedica a Abd-el-Krim y a la República del Rif un capítulo interesantísimo (pp. 89-134). En el examen de la campaña de 1909 sobresale la idea de que pudo ser un "cebo", un pretexto concienzudamente diseñado por las autoridades melillenses, para ocupar militarmente nuevos territorios (p. 44); las alusiones a las Juntas de Defensa como responsables de la catástrofe de 1921 desaparecen (pp. 63-73); y el análisis de las repercusiones nacionales de la derrota acaba transformado en un breve y claro resumen de su tesis doctoral (pp. 83-88).
} 
española entre 1898 y 1907: los compromisos internacionales ${ }^{69}$. Es una clave, de importancia indudable, para la comprensión de las directrices seguidas por los Estados europeos con relación al Sultanato y que se manifiestan en la firma de varios y laboriosos tratados.

Por su parte, entre los trabajos de carácter local, podemos mencionar el de Carlos Gil Andrés sobre el impacto de los trágicos sucesos de 1909 en Calahorra ${ }^{70}$. A través de La Rioja podemos seguir el desarrollo de las protestas contra el envío de soldados a Marruecos, que concluyeron con la clausura de la Sociedad "Unión Obrera" y la detención de una treintena de jóvenes.

María Rosa de Madariaga, de nuevo, aporta su granito de arena en 1998. En esta ocasión, y gracias a la consulta de Aberri y La Publicitat, publica un artículo sobre el posicionamiento de los sectores nacionalistas vascos y catalanes en el luctuoso verano de $1921^{71}$.

Casi coetánea es la investigación de María José Ruiz Acosta sobre la actitud de la prensa sevillana ante el mismo drama ${ }^{72}$. En este caso, el objeto de estudio lo constituyen El Correo de Andalucía, que justifica la censura informativa por la "insana curiosidad" de los hispalenses, y El Liberal, muy crítico con el proceder de Maura en el Rif.

\section{Desde el año 2000 hasta la actualidad}

En los últimos tiempos asistimos a una verdadera explosión en el número de trabajos interesados por la opinión y las reacciones públicas ante las campañas de Marruecos. Se registra, además, un muy llamativo repunte a partir de 2006, coincidiendo con el centenario de la celebración de la Conferencia de Algeciras. Siguen predominando los análisis de contenidos o sincrónicos sobre los estudios de carácter humanístico o diacrónico. Por último, cabe apuntar que un creciente número de trabajos poseen un carácter provincial o regional.

Javier Ramiro de la Mata, al que ya nos hemos referido, es el autor de una de las obras más atractivas y ambiciosas sobre la génesis del proceso colonizador del Norte de

\footnotetext{
${ }^{69}$ GONZÁLEZ VELILLA, María del Carmen: Orientación general de la política exterior española entre 1898 y 1907: los compromisos internacionales. Tesis doctoral Inédita, Universidad Complutense de Madrid, 1998.

${ }^{70}$ GIL ANDRÉS, Carlos: “¡Abajo la guerra! Repercusiones de la Semana Trágica de 1909 en Calahorra”, Kalakorikos, n 3, Calahorra, 1998, pp. 127-138.

${ }^{71}$ MADARIAGA, María Rosa de: "Nacionalismos vasco y catalán frente a la revolución de Abd-elKrim", Historia 16, Año XXII, no 268, Madrid, 1998, pp. 69-77.

${ }^{72}$ RUIZ ACOSTA, María José: “Oposición y colaboración: la prensa sevillana ante los sucesos de Barcelona de 1909", Revista Latina de Comunicación social, nº 24, La Laguna, 1999. http://www.ull.es/publicaciones/latina/a1999adi/04mjruiz.htm.
} 
África, Origen y dinámica del colonialismo español en Marruecos, publicada en el año $2001^{73}$. Recurre, para el análisis de la opinión pública, a fuentes hemerográficas tales como El Correo, La Correspondencia de España, El Liberal, La Época, El Socialista, $A B C$, Tierra y Libertad... Además de referirse a la duplicidad de reacciones, según el momento, a la que aludíamos más arriba, este autor resalta las diferencias presentes entre las actitudes exhibidas por los españoles en 1909 y en 1921. Así que, en cierto modo, indirectamente, modera o matiza su apuesta por la dualidad euforia-tragedia. Según él, la oleada de fervor patriótico desatada en 1909 rebasa a la del cataclismo de Annual. El cansancio (Ramiro de la Mata alude a un aletargamiento de la conciencia nacional de revancha), la desilusión colonial es más claramente perceptible ahora porque el sistema político se hallaba, también, mucho más desgastado y porque la magnitud de la catástrofe era muy superior a la del Barranco del Lobo. Ya no se confía, como corolario final, en una solución rápida del problema y únicamente los africanistas conservan la ilusión colonial ${ }^{74}$.

Algo diluida aparece la cuestión marroquí en el libro colectivo Valencia, 1900. Movimientos sociales y conflictos políticos durante la guerra de Marruecos, 1906$1914^{75}$. Sus autores, Martínez Gallego, Chust Calero y Hernández Gascón, contemplan la cuestión marroquí como "el crisol en el cual se fundieron, de manera más clara y cruel, las realidades de una sociedad en conflictividad"76. Quizás por este motivo, Marruecos es el pretexto para combatir la arquetípica imagen de Valencia como una ciudad agraria y apacible. En su lugar, lo que nos presentan es un bastión del republicanismo y una ciudad tomada, con demasiada frecuencia, por las Fuerzas Armadas. El empleo de fuentes hemerográficas, tales como Las Provincias, El Mercantil Valenciano y El Pueblo, sirve para argumentar que los intereses económicos de la burguesía local en Marruecos eran abundantes y para indagar en la vieja hipótesis de que "el regeneracionismo se sacrificó en el altar del imperialismo"77. Mientras, las

\footnotetext{
${ }^{73}$ RAMIRO DE LA MATA, Javier: Origen y dinámica del colonialismo español en Marruecos. Ceuta: Ciudad Autónoma de Ceuta, Archivo Central, 2001, pp. 211-212.

${ }^{74}$ Obsérvese que esta lectura de los hechos es antagónica a la efectuada por La Porte. No obstante, entendemos que cuando Ramiro de la Mata se refiere al impacto público de la derrota de 1921 no tiene en mente tanto el mes de julio como los meses y el desánimo algo posteriores.

75 MARTÍNEZ GALLEGO, Francesc A.; CHUST CALERO, Manuel y HERNÁNDEZ GASCÓN, Eugenio: Valencia, 1900. Movimientos sociales y conflictos políticos durante la guerra de Marruecos, 1906-1914. Castellón de la Plana: Universitat Jaume I, 2001. Creemos que la cuestión marroquí esta algo desenfocada en este libro. Sin embargo, por su brillante estilo narrativo y sus clarísimas explicaciones, la obra merece toda nuestra admiración.

${ }^{76}$ Ibidem, p. 279.

77 Ibidem, p. 27.
} 
motivaciones de carácter geoestratégico son infravaloradas por los autores como motor de la acción colonial.

Tampoco faltan alusiones a la opinión pública en la conocida obra de Sebastian Balfour, Abrazo mortal. De la guerra colonial a la Guerra Civil en España y Marruecos (1909-1939) ${ }^{78}$. Si bien el objetivo del autor es vincular el surgimiento y consolidación de una casta militar durante la primera de las confrontaciones con su protagonismo durante la segunda, el comportamiento de las gentes ante las campañas marroquíes es descrito en los primeros capítulos del libro: de la indiferencia ante el Acta de Algeciras ${ }^{79}$ y pasando por el "paradójico" efecto del Barranco del Lobo -que moviliza a la población en pro de la ofensiva, cuando tres semanas antes el envío de reservistas a Marruecos había desencadenado la Semana Trágica ${ }^{80}$ - hasta 1921, cuando la nueva campaña colonial encuentra el apoyo inicial de la opinión, motivado por el deseo tan reiterado de venganza y por el asunto de los prisioneros y no tanto por la defensa del honor mancillado ${ }^{81}$.

Otro de los mayores conocedores de las turbias relaciones hispano-marroquíes es el prolífico investigador Eloy Martín Corrales. A él debemos agradecerle la edición de Marruecos y el colonialismo español (1859-1912). De la Guerra de África a la "penetración pacifica",82, una obra colectiva centrada en Cataluña y en el análisis de los agentes económicos impulsores del africanismo, así como de las secuelas de las primeras operaciones militares en el norte marroquí. En sus páginas se desecha el esfuerzo de cierta corriente historiográfica moderna empeñada en ensalzar la fuerza anticolonialista del catalanismo y en presentar la penetración armada en Marruecos como una obra exclusiva de los españoles; se apela, en cambio, a las motivaciones económicas del grupo Comillas; al tándem Dulce-Prim en la movilización de los Voluntarios Catalanes, partícipes de la Guerra de Tetuán; a la debilidad del obrerismo ${ }^{83}$; y del republicanismo... Se recurre al empleo de fuentes oficiales, de la abundante literatura colonialista y a la consulta de periódicos tales como La Veu de Catalunya, La Publicitat, La Vanguardia, etc. Aunque no se deja de subrayar el hecho de que las

\footnotetext{
${ }^{78}$ BALFOUR, Sebastián: Abrazo mortal. De la guerra colonial a la Guerra Civil en España y Marruecos (1909-1939). Barcelona: Ediciones Península (Historia, Ciencia y Sociedad), 2002.

${ }^{79}$ Ibidem, p. 31.

${ }^{80}$ Ibidem, p. 58.

${ }^{81}$ Ibidem, p. 170.

${ }^{82}$ MARTÍN CORRALES, Eloy (Ed.): Marruecos y el colonialismo español (1859-1912): de la Guerra de África a la "penetración pacífica”. Barcelona: Bellaterra, 2002.

${ }^{83}$ Ibidem, p. 205. Reivindica Martín Corrales que es preciso un estudio más extenso que hasta los ahora efectuados sobre la conducta seguida por el socialismo entre 1909 y 1923, porque "casi no sabemos nada al respeto ya que la atención de la historiografía apenas ha dirigido su atención hacia esta cuestión".
} 
protestas sociales van en aumento desde 1909. Además, Annual sirve como auténtico revulsivo contra la contienda entre los sectores nacionalistas. Pero no tanto porque se rechace la idea de la expansión colonial, sino porque rápidamente se percibe la utilidad de la derrota en África como arma política, como instrumento para destapar la ineficacia del gobierno madrileño ${ }^{84}$.

Entre las investigaciones más recientes también debemos traer a colación la tesis doctoral del profesor de periodismo Antonio Rubio Campaña ${ }^{85}$. Preocupado por el tratamiento más inmediato que los principales periódicos nacionales otorgaron al torbellino iniciado en Annual, he aquí las trece cabeceras que constituyen el núcleo de su análisis. En buena medida coinciden con las utilizadas por Desvois: El Sol (al comentario de este diario le dedica Rubio Campaña diez y seis páginas de un total de cuarenta y siete, lo cual resulta un tanto desproporcionado), La Libertad, El Liberal, La Tribuna, El Debate, ABC, El Socialista, La Voz, Heraldo de Madrid, La Época, El Telegrama del Rif y La Correspondencia de España. Cabe reprocharle al autor el hecho de que no quede claro el criterio empleado para la elección de las fechas de su análisis.

Una de las mayores expertas en la historia de las relaciones entre España y Marruecos, además de muy prolífica investigadora, es la ya aludida María Rosa de Madariaga. Su tesis doctoral, adaptada y revisada, ha sido objeto de varias reediciones bajo el título España y el Rif. Crónica de una historia casi olvidada ${ }^{86}$. Si bien la obra que nos interesa comentar ahora es la más divulgativa En el Barranco del Lobo. Las guerras de Marruecos ${ }^{87}$. Se trata de un amplio repaso de la historia de la presencia militar española en el Rif, desde la romántica campaña de Tetuán hasta la rendición de Abd-el-Krim, con un capítulo específicamente dedicado al análisis de la opinión pública $^{88}$. Madariaga -mediante el repaso, entre otras fuentes, de El Socialista, Aberri, la prensa dinástica y las sesiones de Cortes- se refiere brevemente a los distintos posicionamientos de los partidos dinásticos, republicanos, obreros y nacionalistas.

\footnotetext{
84 Ibidem, p. 202.

${ }^{85}$ RUBIO CAMPAÑA, Antonio: Periodistas españoles en la Guerra del Rif (Marruecos): 1921-1923. Origen del periodismo de investigación en España. Tesis doctoral inédita (su publicación está pendiente desde junio de 2008), Universidad Complutense de Madrid, 2005, pp. 106-153. La atención proritaria del investigador, no obstante, recae sobre los escritos de Manuel Aznar Zubigaray, López Rienda, Luis de Oteyza y Víctor Ruiz Albéniz.

${ }^{86}$ MADARIAGA, María Rosa de: España y el Rif. Crónica de una historia casi olvidada. Melilla: La Biblioteca de Melilla, 1999 (existe una tercera edición del 2008).

${ }^{87}$ MADARIAGA, María Rosa de: En el Barranco del Lobo. Las guerras de Marruecos. Madrid: Alianza Editorial, 2005.

${ }^{88}$ Ibidem, p. 164-202.
} 
También esta autora, como hiciera La Porte, alude a un cierto aletargamiento público posterior al Desastre de Annual y que se prolonga hasta inicios de $1922^{89}$.

De 2007 data un trabajo de Luis Arias González, que lleva por título "El sentimiento popular ante la Guerra de África" y en la que se intenta esclarecer qué pensaba la población asturiana sobre sus fuerzas armadas y el conflicto ${ }^{90}$. Para ello, el autor procede a la consulta de periódicos tales como El Carbayón, El Noroeste y El Comercio, si bien no oculta ni su partidismo ni su sujeción a la censura. El análisis se ajusta a los dos momentos de máxima conmoción pública: 1909, cuando se habla de “pasividad conformista” y escasez de artículos de carácter profesional; y 1921, cuando predomina un clima de pánico colectivo y exacerbado paternalismo para con los expedicionarios. El profesor Arias es, además, el editor de Alfredo García García, Adeflor. En la Guerra de África $(1921)^{91}$. Se recogen aquí las 116 crónicas que este periodista, director de El Comercio, envió a sus paisanos a lo largo de cuatro meses, entre agosto y diciembre de 1921, para informarles de la situación del Protectorado. Junto con los editoriales de Adeflor, el libro cuenta con un extenso capítulo introductorio en el que Luis Arias nos recuerda cuáles fueron las grandes coordenadas históricas del período en que vivió este improvisado cronista de la contienda. Para ello alude tanto a la crisis general del sistema canovista, muy anterior a 1921, como al fin de la bonanza económica en su región natal, coincidiendo con el hundimiento de los precios del carbón. Se refiere también el editor a la importancia que adquieren las informaciones periodísticas en aquellos trágicos momentos y repasa, con bastante minuciosidad, el posicionamiento de los principales diarios asturianos ante la catástrofe militar. Todos los rotativos supieron valerse de la curiosidad ciudadana para, dosificando cuidadosamente sus noticias, mantener "enganchado" al público y procurar conservar apaciguados sus ánimos.

Deseamos también hacer mención de algunos sugerentes artículos incluidos en la obra colectiva La Conferencia de Algeciras en 1906: un banquete colonial, editada por José Antonio González Alcantud y, nuevamente, por el profesor Eloy Martín Corrales $^{92}$. Aparte de varios análisis interesados en la historia de las relaciones diplomáticas, del mismo Martín Corrales merecen destacarse dos trabajos sobre la

\footnotetext{
${ }^{89}$ Ibidem, p. 177.

${ }^{90}$ ARIAS GONZÁLEZ, Luis: "El sentimiento popular ante la guerra de Marruecos" en GIRÓN GARROTE, José. (Ed.): Historia militar de Asturias. Oviedo: Silverio Cañada editor, 2006, pp. 116-134.

${ }^{91}$ ARIAS GONZÁLEZ, Luis (Ed.): Alfredo García García, Adeflor. En la Guerra de África (1921). Gijón: Vtp Editorial, 2008.

${ }^{92}$ GONZÁLEZ ALCANTUD, José Antonio y MARTÍN CORRALES, Eloy (Eds.): Op. Cit.
} 
prensa catalana y balear. En el primero de ellos, "La Conferencia de Algeciras en la prensa catalana: entre el pragmatismo económica de La Vanguardia y el imperialismo orsiano de La Veu de Catalunya", el investigador, plenamente conforme con los argumentos ya conocidos de Ramiro de la Mata, hace hincapié en esa idea del paulatino distanciamiento de la sociedad de las aventuras coloniales. No obstante, igualmente, los reveses para las armas españolas llevaban aparejado un fortalecimiento del patriotismo revanchista. En el segundo análisis, y junto con Margalida Ensenyat, "La Conferencia de Algeciras contemplada desde las Baleares", se someten a revisión La última hora y La Almudaina; de Monika Bosse es un capítulo a propósito del comportamiento de la prensa satírica internacional (“Un baile primaveral con el Sultán de Marruecos. Perspectivas satíricas europeas sobre la Conferencia de Algeciras"); González Alcantud examina la actitud de las publicaciones periódicas granadinas ("Reflejos de la Conferencia de Algeciras en la ciudad vórtice: Granada") y lo mismo hacen Dolores López Enamorado y Ana Torres García con la sevillana ("La prensa sevillana y la Conferencia de Algeciras"), así como Morales Lezcano y Fernando Navarro Beltrame con los rotativos de Las Palmas de Gran Canaria ("La Conferencia de Algeciras vista por la prensa de Las Palmas de Gran Canaria").

Gracias al esfuerzo de Enrique Cerro Aguilar, poseemos uno de los trabajos más pacientemente documentados sobre la prestación del servicio militar en Albacete y su provincia durante los años inmediatos a la segunda gran derrota de los españoles en Marruecos ${ }^{93}$. Si bien la formación y vivencias de los soldados albaceteños en África constituyen el meollo del libro Camino de Annual. Albacete y el Desastre de 1921, el protagonismo informativo asumido entonces por dos periódicos, El Diario de Albacete y Defensor de Albacete, en los momentos posteriores al mazazo de julio, también merece un detenido comentario. El autor subraya que la prensa es una fuente documental "preciosa" y sus noticias le sirven para confirmar una hipótesis originalmente esgrimida por Pablo La Porte: el fervor patriótico vivido tras el seísmo de Annual es fruto de la interesada colaboración ideológica de los periodistas con la administración, de la decisión de enviar "cuotas" al frente de batalla y del miedo a quedar en ridículo ante Europa ${ }^{94}$.

\footnotetext{
${ }^{93}$ CERRO AGUILAR, Enrique: Camino de Annual. Albacete y el Desastre de 1921. Albacete: Instituto de Estudios Albacetenses "Don Juan Manuel”, 2007.

${ }^{94}$ Ibidem, pp. 43-45.
} 
En 2008 se publica las actas del Congreso La Conferencia Internacional de Algeciras de 1906. Cien años después, celebrado dos años antes con motivo de la efeméride $^{95}$. De entre las muchas ponencias y comunicaciones presentadas, nos interesa mencionar la de Luis Gómez Barceló sobre la prensa de Ceuta y Melilla (El África y El Telegrama del Rif); y también la de Jesús Marchán Gustems a propósito de El Diario de Tarragona.

No queremos concluir sin citar el trabajo, todavía en curso, de la doctoranda Jennifer Guerra Hernández sobre el problema marroquí durante el Gobierno Largo de Maura y su contemplación a través de las publicaciones periódicas canarias ${ }^{96}$.

La mayor parte de las publicaciones a las que hemos aludido son posteriores al ingreso español en la Unión Europea y se concentran, sobre todo, coincidiendo con los centenarios del Desastre de Cuba y de la Conferencia de Algeciras. No podemos dejar de subrayar que, si bien el estado de la cuestión descrito se define por su carácter enormemente fragmentario (y con sorprendentes lagunas, como en el caso de la prensa gallega o extremeña), el futuro no parece demasiado oscuro.

\footnotetext{
${ }^{95}$ VVAA: Actas del Congreso Internacional. La Conferencia de Algeciras de 1906. Cien años después. Algeciras: Fundación Municipal de Cultura José Luis Cano, 2008. También figura en esta obra el trabajo ya comentado del profesor Eloy Martín Corrales sobre la prensa catalana.

${ }^{96}$ Un avance puede hallarse en la siguiente dirección: http://www.scribd.com/full/31173373?access key=key- 1 mgt83rt5dlgfmrranrn
} 


\begin{tabular}{|c|c|c|c|c|c|c|c|}
\hline EDICIÓN & AUTOR & Título & FECHA & OPINIÓN & INTERESES PRINCIPALES & IMPORTANCIA PRENSA & MÉTODO EMPLEO PRENSA \\
\hline 1974 & Pedro Gómez Aparicio & "La Sociedad Editorial de España" & 1909 & Nacional & Comportamiento Trust & Fuente primaria & Contenidos \\
\hline 1974 & & "El desastre de Annual" & 1921 & Nacional & Secuelas del desastre & Fuente primaria & Contenidos \\
\hline 1976 & Victor Morales Lezcano & El colonialismo hispano-francés en Marruecos & $1898-1927$ & Nacional & Motores y agentes coloniales & Fuente secundaria & Contenidos \\
\hline 1976 & Bernabé López García & "España en África : génesis y significación...." & $1905-1925$ & Nacional & Evolución ideología africanista & Fuente primaria & Humanistico \\
\hline 1976 & & "El socialismo español y el anticolonialismo..." & 1898-1914 & Nacional & Movimiento obrero y guerra & Fuente secundaria & Contenidos \\
\hline 1976 & & "Humor gráfico y guerra de Marruecos" & $1909-1914$ & Nacional & Humor y anticolonialismo & Fuente primaria & Contenidos \\
\hline 1976 & María Rosa de Madariaga & "Le Parti Socialiste Espagnol et le Parti ..." & 1921-1926 & Nacional & Movimiento obrero y guerra & Fuente secundaria & Contenidos \\
\hline 1981 & Jean-Michel Desvois & La guerra de Marruecos y la opinión pública... & 1921-1923 & Nacional & Opinión pública & Fuente primaria & Contenidos/Morfológico \\
\hline 1982 & & "La prensa frente al desastre de Marruecos..." & 1921 & Nacional & Opinión pública & Fuente primaria & Contenidos/Morfológico \\
\hline 1985 & M Carmen García de la Rasilla & Los problemas de Marruecos y la opinión pública... & $1898-1927$ & Valladolid, capital & Opinión pública y labor asistencial & I Fuente primaria & Humanistico \\
\hline 1986 & Elisa Pérez Molina & El norte de Marruecos, de la Conferencia de Algeciras... & $1906-1912$ & Nacional & Discursos parlamentarios, tratados & s Fuente secundaria & Contenidos \\
\hline 1987 & M² Carmen García de la Rasilla & "Palencia y la guerra de Marruecos" & 1909-1927 & Palencia, capital & Labor asistencial & Fuente primaria & Contenidos \\
\hline 1988 & Celso Almuiña & "El desastre de Annual (1921): su proyección..." & 1921 & Nacional & Politicas informativas & Fuente primaria & Contenidos \\
\hline 1988 & Andreé Bachoud & Los españoles ante las campañas de Marruecos & $1909-1914$ & Nacional & Agentes colonizadores, Opinión pública & Fuente primaria & Humanístico \\
\hline 1990 & José Moreno Juste & "El Socialista y el desastre de Annual..." & 1921 & Nacional & Opinión pública & Fuente primaria & Contenidos \\
\hline 1992 & Susana Sueiro Seoane & España en el Mediterráneo. Primo de Rivera ... & $1923-1930$ & Nacional & Relaciones internacionales & Fuente secundaria & Contenidos \\
\hline 1992 & Tayeb Boutbouqalt & La guerre du Rif et la réaction de l'opinion... & 1921-1926 & Internacional & Opinion pública, políticas informativas & s Fuente primaria & Contenidos \\
\hline 1997 & Pablo La Porte & El desastre de Annual y la crisis de la Restauración... & 1921-1923 & Nacional & Secuelas del desastre & Fuente secundaria & Humanistico \\
\hline 1998 & $M \supseteq$ del Carmen García Velilla & Orientación general de la politica exterior española ... & 1898-1907 & Nacional & Relaciones internacionales & Fuente secundaria & Contenidos \\
\hline 1998 & Carlos Gil Andrés & ¡Abajo la guerra! Repercusiones de la Semana Trágica... & 1909 & Calahorra & Conflictividad social & Fuente secundaria & Contenidos \\
\hline 1998 & $M \stackrel{2}{2}$ Rosa de Madariaga & 'Nacionalismo vasco y catalán frente a la revolución...' & '1921-1923 & País Vasco, Cataluña & Nacionalismos y guerra & Fuente primaria & Humanistico \\
\hline 1999 & $M^{2}$ José Ruiz Acosta & "Oposición y colaboración: la prensa sevillana..." & 1909 & Sevilla & Conflictividad social & Fuente primaria & Contenidos \\
\hline 2001 & Javier Ramiro de la Mata & Origen y dinámica del colonialismo español ... & $1898-1927$ & Nacional & Motores, agentes y secuelas coloniales & is Fuente primaria & Humanistico \\
\hline 2001 & F. Martínez Gallego et al. & Valencia, 1900 . Movimientos sociales y conflictos ... & 1906-1914 & Valencia & Conflictividad social & Fuente primaria & Contenidos \\
\hline 2002 & Sebastian Balfour & Abrazo mortal. De la guerra colonial a la Guerra Civil... & 1909-1939 & Nacional & Militares africanistas & Fuente secundaria & Contenidos \\
\hline 2002 & Eloy Martín Corrales & "El nacionalismo catalán y la expansíon colonial..." & $1860-1912$ & Cataluña & Nacionalismos y guerra & Fuente primaria & Humanisitico \\
\hline 2005 & Antonio Rubio Campaña & "El desastre de Annual en la prensa" & 1921 & Nacional & Opinión pública, políticas informativas & s Fuente primaria & Contenidos \\
\hline 2005 & María Rosa de Madariaga & En el Barranco del Lobo... Las guerras de Marruecos & $1860-1927$ & Nacional & Guerras hispano-marroquies & Fuente secundaria & Contenidos \\
\hline 2007 & Luis Arias González & "El sentimiento popular ante la guerra de Marruecos" & $1909 ; 1921$ & Asturias & Opinión pública, políticas informativas & s Fuente primaria & Contenidos \\
\hline 2007 & & En la guerra de África (1921) & 1921 & Asturias & Opinión pública, políticas informativas & Is Fuente primaria & Contenidos \\
\hline 2007 & Eloy Martín Corrales & "La Conferencia de Algeciras en la prensa catalana..." & 1906 & Cataluña & Opinión pública, políticas informativas & is Fuente primaria & Humanistico \\
\hline 2007 & Eloy Martin y Margalida Ensenya1 & 1 "La Conferencia de Algeciras contemplada desde..." & 1906 & Baleares & Opinión pública, políticas informativas & is Fuente primaria & Humanisitico \\
\hline 2007 & Monika Bosse & "El baile primaveral con el Sultán de Marruecos..." & 1906 & Internacional & Opinión pública, políticas informativas & Is Fuente primaria & Contenidos \\
\hline 2007 & José Antonio González Alcantud' & "Reflejos de la Conferencia de Algeciras en la ciudad..." & 1906 & Granada & Opinión pública, políticas informativas & is Fuente primaria & Humanistico \\
\hline 2007 & Dolores López y Ana Torres & "La prensa sevillana y la Conferencia de Algeciras" & 1906 & Sevilla & Jpinión públicas, políticas informativas & as Fuente primaria & Humanistico \\
\hline 2007 & V. Morales Lezcano y F. Navarro & "La Conferencia de Algeciras vista por la prensa de..." & 1906 & Las Palmas & Opinión pública, políticas informativas & is Fuente primaria & Humanistico \\
\hline 2007 & Enrique Cerro Aguilar & Camino De Annual. Albacete y el desastre de Annual & $1918-1923$ & Albacete & Servicio militar, opinión, labor asistencial & Fuente primaria & Humanistico \\
\hline 2008 & José Luis Gómez Barceló & "La Conferenica de Algeciras vista por la prensa de..." & 1906 & Ceuta y Melilla & Opinión pública, políticas informativas & Is Fuente primaria & Humanistico \\
\hline 2008 & Jesús Marchán Gustems & "El diario de Tarragona y la Conferencia de Algeciras..." & 1906 & Tarragona & Opinión pública, políticas informativas & is Fuente primaria & Humanistico \\
\hline 2010 & Jennifer Guerra Hernández & "Argumentos para la presencia europea en ..." & 1907-1909 & Canarias & Motores $y$ agentes coloniales & Fuente primaria & Contenidos \\
\hline
\end{tabular}




\section{FUENTES EMPLEADAS EN LA REALIZACIÓN DE ESTE TRABAJO}

Por constituir el grueso de nuestra documentación primaria, empezaremos refiriéndonos a la prensa local. Decía Jesús María García García que “los periódicos nacen y mueren en un contexto histórico, social, económico, cultural del que difícilmente se pueden sustraer. Comprender la aparición o desaparición de una publicación periódica implica inmiscuirse en los entresijos sociales de la época, conocer a los personajes que le dieron vida, desentrañar las motivaciones, en definitiva, que arrastran a los hombres a hacer pública su voz" $" 97$.

En este sentido, Salamanca y su provincia gozaron de una increíble buena salud periodística a lo largo de todo el siglo XIX. Principalmente, desde mediados de esa centuria, la construcción de varias ramas ferroviarias potenció la creación de distintos órganos periodísticos, ocupados en sembrar la polémica al discutir todas las ventajas e inconvenientes de su recorrido. Aunque no todos los diarios y semanarios pudieron presumir de una larga vida, sí que todos contribuyeron a la gestación de una época dorada para el periodismo salmantino, la que siguió a la aprobación de la Ley de Policía de Imprenta de 1883.

Cuando se manejan y analizan informaciones periodísticas hay que actuar con ciertas prevenciones, con prudencia. Sin embargo, pecando de reduccionistas, podemos afirmar que existen dos grandes tipos de información periodística: la descriptiva, en la que se informa llanamente sobre lo ocurrido, y la valorativa, en la que se cuela consciente y voluntariamente una opinión. Para distinguirlas, siempre hay que evaluar el grado de precisión de la noticia y su calidad. Aunque sobre estas cuestiones abundaremos en el siguiente capítulo, como anticipo, debemos señalar que el tan cacareado afán de objetividad del periodista tropieza con procesos mentales tales como la selección de datos, la omisión de otros, su minusvaloración, la extensión... La información nunca puede ser puramente objetiva. Y, además, su ubicación en el periódico también supone una forma inevitable de manipulación.

Los titulares son particularmente interesantes para determinar el nivel de objetividad de una noticia. Pueden limitarse a resumir el contenido de la misma o llamar la atención sobre un aspecto particular. Su impacto sobre el lector es inmediato, aunque conviene considerar que estos muestran distintos grados de permeabilidad ante los mensajes mediáticos. Mientras que la prensa industrial procura un sondeo general de la

\footnotetext{
${ }^{97}$ GARCÍA GARCÍA, José María: Prensa y vida cotidiana en Salamanca (siglo XIX). Salamanca: Universidad de Salamanca, 1990, p. 12.
} 
opinión y adecuarse a ella para vender el máximo número de ejemplares, la prensa de opinión recurre a un patrón comunicativo más directo y unívoco. Su vocación adoctrinadora es explícita. Su sustento es la afinidad, la lealtad de un grupo de lectores que saben descodificar los mensajes tal y como desea el emisor.

Como norma habitual, la influencia de los periódicos es tanto mayor en cuanto recurre a los géneros valorativos. Sobre todo en los editoriales, los hechos vienen distorsionados por la opinión del propietario de la cabecera. Se transmiten ideas y también se interpretan. El artículo firmado por una autoridad o un testigo presencial de los hechos, por su parte, plasma un sentir que redunda en el periódico en forma de prestigio y, simultáneamente, le permite distanciarse de ese posicionamiento individual, no asumiendo responsabilidades demasiado directas.

El otro principio esencial de funcionamiento es que la influencia de la prensa también es mayor cuanto más presume de su capacidad de identificación con los lectores. Con este objetivo, los periódicos recurren a equiparar la opinión pública con su particular ideología.

Expuestas estas generalidades, nos detendremos ahora en una breve presentación de los periódicos seleccionados para cubrir los objetivos del presente estudio. Sólo conocemos los datos de tirada de algunos de ellos. Los cuatro primeros rotativos enumerados, por ser los de mayor vigencia temporal, son los que hemos explotado más intensamente:

-El Adelanto es el más antiguo de los diarios manejados, aparecido el 22 de julio de 1883 y editado en la imprenta de Francisco Núñez Izquierdo, uno de los empresarios más conocidos en la capital y quien también se hizo con su propiedad un año después. Su hijo, Mariano Núñez Alegría, ejerció la dirección de este rotativo desde 1905 y hasta 1937. Se trataba de un periódico diario, bastante ecléctico y defensor de una ideología a caballo entre el liberalismo progresista y el republicanismo. Contó con un considerable respaldo social de las clases media y obrera salmantinas, fruto de esa línea editorial tan pragmática. Hacia 1927, y según la Estadística de Prensa, su tirada era de 7000 ejemplares, cifra que convertía a El Adelanto en el periódico más leído de la capital.

- El Lábaro se funda en marzo de 1897 y rapidísimamente adquiere periodicidad diaria. Sobrevive hasta el 21 de noviembre de 1910. El obispo fray Tomás Cámara y Castro se había introducido en el mundo de la prensa, en la temprana fecha de 1886, con la promoción del semanario La Semana Católica de Salamanca. Siempre en disputa con los liberales y acosado por los integristas, El Lábaro representó el paso más rotundo del 
obispo agustino para defender los ideales de la Buena Prensa. Dirigido por Martín Domínguez Berrueta (con la salvedad del año 1907, en el que asume el timón Florencio Marcos Martín; y durante el último mes de vida del rotativo, cuando la función es desempeñada por Fernando Íscar Peyra), este diario fue el adalid del conservadurismo católico frente al creciente racionalismo, particularmente notable en cierto sector universitario encabezado por Dorado Montero y Unamuno.

- El Castellano funciona entre 1904 y 1915, pero su publicación se hace bisemanal desde 1910 hasta finales de 1914. Los números que se corresponden con este lapso temporal no se hallan disponibles, lamentablemente, en la Biblioteca de la Universidad de Salamanca. Aunque sí podemos aprovechar sus informaciones para acercarnos al convulso año de 1909. Desde el 1 de octubre de 1914 se convierte nuevamente en diario. Dirigido por el poeta Cándido Rodríguez Pinilla, mantuvo un tono tranquilo y respetuoso, presentándose como "bien informado, serio y respetuoso, lo menos político posible". Entre sus colaboradores frecuentes figuraron Unamuno y Ramón Barco.

- El Salmantino comenzó su andadura en octubre de 1907 y desde junio de 1910 adopta carácter diario. A partir de julio de 1919 retorna, nuevamente, a una periodicidad semanal y termina por desaparecer tres meses después, el 11 de septiembre de ese mismo año. Fue el órgano de prensa del integrismo salmantino y propiedad del terrateniente Juan Lamamié de Clairac, vicepresidente de la Junta Carlista. En él colaboraron, entre otros, Manuel Sánchez Asensio, el más convencido de los periodistas del integrismo, y Nicasio Sánchez Mata, jefe del Círculo Tradicionalista de la región. Este último adquirió, junto con José García Revillo, el diario en 1910. Fue un rotativo con clarísimo afán adoctrinador, con constantes editoriales en los que se vituperaba al Liberalismo y a los católicos no tradicionalistas. La información fue escasa y, al contrario, la publicidad, abundante.

- El Obrero: disponemos de algunos números de 1909 y correspondientes al periodo 1915-1917. Pertenecía a la Federación Obrera de Salamanca, con periodicidad mensual y entre sus colaboradores figuraron Dorado Montero, el concejal Santa Cecilia y el incombustible Unamuno. De manera muy tangencial, también hemos empleado, como instrumentos del pensamiento socialista y republicano La Verdad y La Lucha.

- La Ciudad existe, con carácter semanal, entre diciembre de 1911 y mayo de 1913. Dirigida por Fernando Íscar Peyra, luchó por constituir un ejemplo de pluralismo y contó con las firmas de Unamuno, Luis Maldonado o Cándido R. Pinilla. Se cerró 
lamentando el ambiente de creciente opresión por el que se veía rodeado: "Las cosas han llegado a un punto de pasión en el ambiente moral que respiramos que se nos hace imposible no escribir con pasión, y preferimos no escribir".

- La Libertad, con carácter semanal, sale a la calle entre febrero de 1913 y julio de 1916. Órgano por excelencia del pensamiento maurista en Salamanca -se subtitulaba con la famosa sentencia "La libertad se ha hecho conservadora" -, una de sus notas constantes fue el empeño por dirigirse de modo muy directo a los sectores obreros para desvirtuar las ideologías de izquierdas.

- La Gaceta Regional vio la luz el 20 de agosto de 1920. Editada por la sociedad Editorial Salmantina, esta publicación era propiedad de la sociedad anónima "Sociedad Castellana”, que tenía como máximos accionistas a José María Gil Robles, José Cimas Leal y muchos otros miembros del Bloque Agrario Salmantino. La dirección recayó inicialmente en Buenaventura Benito Núñez, y desde diciembre de ese año, quedó en manos de Fernando Íscar Peyra. Nació, como se podrá deducir, para defender los intereses del latifundismo, y también estrechamente vinculada a la opinión católica. A partir de los datos proporcionados por la Estadística de Prensa de 1927, se puede cifrar su tirada en 3000 ejemplares diarios. Su antecesor directo fue El Salmantino, del que empleó tanto las mismas instalaciones en la vieja iglesia de San Isidro como su plantilla de redactores.

- El Pueblo es el semanario imprescindible para acercarnos a la opinión del grupo social extra-dinástico más relevante de la época. Este rotativo nació en 1920, aunque lamentablemente la Biblioteca General de la Universidad de Salamanca sólo cuenta con los fondos publicados a partir de abril de 1921. Era un periódico quincenal, propiedad de la Federación Obrera Salmantina, dirigido por Rafael de Castro y editado en Béjar. Su publicación siempre estuvo limitada por muchísimas dificultades financieras, hasta el extremo de que el 12 de mayo de 1923 se interrumpió su edición. Reapareció en marzo de 1924, y comenzó, en esta nueva fase de su andadura, a imprimirse en Salamanca. Socialmente, dispuso del respaldo de obreros y jornaleros pero se desconocen los datos de la Estadística de Prensa de 1927 sobre su tirada ${ }^{98}$. Precisamente, en este año echó el cierre.

98 SAMANIEGO BONEU, Mercedes et alii: Publicaciones periódicas salmantinas, 1793-1936. Salamanca: Universidad de Salamanca, 1984; SANTANDER, Teresa (Dir.): Publicaciones periódicas salmantinas existentes en la Biblioteca Universitaria (1793-1981). Salamanca: Biblioteca Universitaria, 1986. Además de ambos catálogos: HERNÁNDEZ SÁNCHEZ, Galo: "Las empresas de prensa diaria en Castilla y León", Salamanca, Revista de Estudios, no 35-36, Salamanca, 1995, pp. 225-228; y 
A la consulta de la prensa, se debe sumar el empleo de la abundante publicística del momento. Es colosal la cantidad de bibliografía publicada sobre Marruecos por políticos, militares y periodistas, a lo largo del primer tercio del siglo XX. Muchos de estos libros se pueden consultar tanto en la Biblioteca Nacional Española como en la Biblioteca Tomás Navarro Tomás, perteneciente al CSIC. De todas estas obras cabe destacar su tremenda carga ideológica, generalmente muy superior a su pretensión didáctica. Al fin y al cabo, son libros y folletos que no nacen con un interés científico, sino fruto de un afán o bien apologético o bien censor. Sirven como sustento de una atmósfera siempre proclive a la discusión, al contraste de ideas y como aproximación al sentir de algunos de los directamente implicados en los hechos bélicos o en la política.

También se ha prestado atención a los discursos parlamentarios del obrerismo español, con la esperanza de poder ahondar en el pensamiento abandonista de $E l$ Pueblo, y al expediente Picasso, imprescindible para profundizar en el debate sobre las responsabilidades militares del Desastre de 1921.

La documentación de la Casa-Museo Unamuno ha resultado, por otra parte, vital para conocer el pensamiento, próximo al socialismo, del más célebre Rector de la Universidad de Salamanca, así como de algún otro miembro del profesorado de esta casa. Nos estamos refiriendo, básicamente, a infinidad de contribuciones periodísticas, enormemente dispersas entre la prensa nacional.

Determinante del clima de opinión existente entre 1906 y 1925 era, igualmente, la situación de los soldados expedicionarios salmantinos en África. De sus movimientos tenemos constancia a través de las crónicas, cartas y telegramas insertos en la prensa. También gracias a los fondos documentales conservadas actualmente en el Archivo General Militar de Madrid.

La consulta de las actas municipales y de los boletines de la Diputación y del obispado nos ha ayudado a conocer las gestiones de carácter asistencial organizadas por las autoridades civiles y religiosas de Salamanca. Por último, los fondos del Centro de Documentación de la Cruz Roja Española, con sede en Madrid, han resultado útiles a la hora de conocer las actividades de la delegación local de esta institución a favor de los soldados salmantinos.

FRANCIA, Ignacio: "Periodismo salmantino en el siglo XX", Salamanca, Revista de Estudios, n 45 , Salamanca, 2000, pp. 377-400. 


\section{METODOLOGÍA DE INVESTIGACIÓN}

Como ya se ha indicado en páginas anteriores, nos hemos decantado para el conocimiento de la relación entre la opinión pública salmantina y las campañas marroquíes por una metodología histórica aplicada a la prensa y sin el empleo de técnicas de muestreo. Así, han sido consultados un total de 11.409 ejemplares de periódico.

El "vaciado" o "peinado" de las pubicaciones periódicas y ordenación de los artículos ha sido posible gracias a la construcción de una base de datos. En ella se han registrado todas las noticias y editoriales según su ubicación en el periódico y atendiendo a una división en grandes bloques cronológicos y en casi una veintena de apartados temáticos.

He aquí esos bloques cronológicos. Acto seguido, detallaremos cuáles son los apartados temáticos. Tal vez, los límites temporales de los mismos sean discutibles resultan, para cualquier simple observador, muy desiguales en su duración y, además, podríamos haber diseñado un mayor o menor número de los mismos-, pero, en cualquier caso, han facilitado el manejo informático de noticias muy dispersas.

1. El período de penetración diplomática. Pese a no estar muy conformes con esta nomenclatura, es la generalmente aceptada por la historiografía. Nos referimos al periodo de tiempo transcurrido desde finales de 1902, momento en el que tiene lugar un infructuoso contacto hispano-francés para abordar los asuntos marroquíes, hasta comienzos de 1909, cuando la prensa local comienza a denunciar una situación anómala en las cercanías de Melilla.

2. Antecedentes inmediatos del Desastre en el Barranco del Lobo. Se incluyen aquí todas las noticias sobre Marruecos insertas en la prensa salmantina desde que se inicia el año 1909 y hasta el 27 de julio de ese mismo año, fecha de la catástrofe militar española.

3. La campaña de 1909. En este bloque recopilamos las informaciones publicadas al hilo de las operaciones militares efectuadas tras el fallecimiento del general Pintos, la firma del armisticio con Marruecos y llegamos hasta abril de 1911, momento en que la posición del Sultán en el poder se presenta como sumamente delicada.

4. La campaña del Kert. Si bien el incidente que sirve como detonante para una nueva fase de avance militar español se produce el 24 de agosto de 1911, al ser agredida una comisión topográfica del Estado Mayor en las inmediaciones de este río, la creciente tensión se palpa desde meses antes. Damos por concluido este bloque 
coincidiendo con la firma en París del Tratado de Protectorado, el 27 de noviembre de 1912.

5. El establecimiento del Protectorado y el inicio de su andadura. Aquí agrupamos todas las noticias que salen a la luz desde la rúbrica del Acuerdo con Francia, en la fecha recién anotada, y hasta el estallido de la Gran Guerra, en el verano de 1914.

6. La Primera Guerra Mundial. Además de los Balcanes, Marruecos fue la segunda "zona caliente" del planeta con un papel crucial en el desencadenamiento de la conflagración mundial. Por eso, creemos que es necesario observar el seguimiento que la prensa local hizo de la situación del Protectorado en estos cuatro años.

7. Los años "prósperos" de Berenguer en la Alta Comisaría. La firma del armisticio, en noviembre de 1918, vino casi a coincidir con la llegada del general Dámaso Berenguer a Tetuán y con la intensificación de las operaciones militares en ambas zonas, la oriental y la occidental, del Protectorado español. Pero el edificio se vino abajo en julio de 1921, cuando se produjo el casi completo hundimiento de la Comandancia General de Melilla.

8. Annual. Sólo hemos incluido en este bloque las noticias publicadas durante el infausto verano de 1921 y hasta el reinicio de las operaciones de avance en la región oriental, cuando se recobran posiciones tales como Nador, Zeluán y Monte Arruit.

9. El "plano inclinado" hacia la Dictadura. Marruecos, y sobre todo la depuración de responsabilidades y el rescate de los prisioneros de Axdir, se convierten en la gran obsesión de los salmantinos (y de los españoles) durante casi todo el mandato de Maura (fijamos el "corte" de inicio de este bloque a mediados de septiembre de 1921, aunque el gobierno de concentración nacional de Maura se constituyó un mes antes), Sánchez Guerra y el marqués de Alhucemas. También el problema marroquí, así como la violencia en Cataluña, estuvieron muy presentes a la hora de explicar el golpe del general Primo de Rivera.

10. La colaboración hispano-francesa en Marruecos. La Conferencia de Madrid y Alhucemas (8 de septiembre de 1925). Se justifica este bloque porque la prensa salmantina, desde que se produce el golpe de Estado, el 13 de septiembre de 1923, y hasta el desembarco en la bahía de Alhucemas, dedica un enorme espacio a los acontecimientos marroquíes. Las operaciones de pacificación prosiguen hasta el verano de 1927, pero con una cobertura mediática no comparable a la de los años previos.

En cuanto a los apartados temáticos adoptados, han sido los siguientes: 
1. Contexto urbano: noticias sobre élites políticas, hacienda, servicios higiénicos mínimos, movimiento obrero y sociedad.

2. Contexto nacional: política, economía, sociedad.

3. La gestión de los asuntos marroquíes: este apartado constituye el grueso de la presente tesis doctoral. En él incluimos, hasta convertirlo en algo muy similar a un cajón de sastre, las informaciones con una densa carga ideológica y que juzgamos como sustanciales para la orientación de la opinión pública salmantina. Se refieren a aspectos tan diversos y ambiguos como nuestras obligaciones en Marruecos, intereses y objetivos; las políticas que conviene adoptar en África; las relaciones con Francia y terceras potencias; aparecen llamamientos directos a la opinión; las imágenes que se promueven de los musulmanes y del Ejército español, la descripción de acciones bélicas, alusiones a cabecillas rebeldes; relatos personales; el asunto de los prisioneros, las responsabilidades...

4. Noticias sobre los regimientos salmantinos: distinguiendo entre las fuerzas de guarnición en Salamanca y los expedicionarios.

5. Gestos de apoyo hacia los combatientes en Marruecos.

6. Manifestaciones de rechazo hacia la guerra.

El resultado ha sido la recopilación de un total de 6.169 noticias/fichas que admiten múltiples criterios de búsqueda y ordenación. Si a esta cifra restamos las informaciones alusivas al contexto urbano y nacional, obtenemos que 4.081 se refieren directamente a Marruecos. Mientras que la búsqueda de informaciones sobre la cuestión marroquí ha sido exhaustiva, no podemos aplicar el mismo calificativo para la recogida de noticias de carácter contextual. Ésta ha sido absolutamente subjetiva. De hecho, inicialmente no planeamos la creación de esas dos categorías en nuestra base de datos; pero sobre todo la primera, la del contexto urbano, ha terminado por ser imprescindible para comprender el microcosmos en el que se movían los salmantinos. Porcentualmente, es significativo que nuestro interés por el contexto nacional y capitalino aumente -o lo que es igual, el porcentaje de noticias sobre Marruecos merme-, de modo inconsciente, precisamente en los meses inmediatamente previos a las dos grandes catástrofes militares (Bloques 2 y 7). Tal vez se explique por un intento de ponderar el peso de la cuestión africana en el universo de las preocupaciones de los salmantinos. También asciende ese porcentaje coincidiendo con la Gran Guerra (Bloque 6). En este último caso, la explicación es más evidente: el número absoluto de noticias publicadas sobre 
Marruecos disminuye. Pero no desaparece y, de hecho, su tono, unas veces pedagógico y, en otras ocasiones, muy persuasivo, nos ha llamado poderosamente la atención.

Es una cantidad, 4.081 noticias, de considerable magnitud: la suficiente para pensar que la cuestión marroquí despertó curiosidad y preocupación entre los salmantinos. Quizás, si el tema no hubiese interesado, la prensa local no se habría molestado en concederle tanto espacio.

\begin{tabular}{|c|c|c|c|c|c|c|c|c|c|c|}
\hline & $\begin{array}{c}\text { Bloque } \\
\mathbf{1}\end{array}$ & $\begin{array}{c}\text { Bloque } \\
\mathbf{2}\end{array}$ & $\begin{array}{c}\text { Bloque } \\
\mathbf{3}\end{array}$ & $\begin{array}{c}\text { Bloque } \\
\mathbf{4}\end{array}$ & $\begin{array}{c}\text { Bloque } \\
\mathbf{5}\end{array}$ & $\begin{array}{c}\text { Bloque } \\
\mathbf{6}\end{array}$ & $\begin{array}{c}\text { Bloque } \\
\mathbf{7}\end{array}$ & $\begin{array}{c}\text { Bloque } \\
\mathbf{8}\end{array}$ & $\begin{array}{c}\text { Bloque } \\
\mathbf{9}\end{array}$ & $\begin{array}{c}\text { Bloque } \\
\mathbf{1 0}\end{array}$ \\
\hline $\begin{array}{c}\text { Noticias } \\
\text { recopiladas }\end{array}$ & 337 & 249 & 916 & 449 & 402 & 513 & 679 & 320 & 1.802 & 502 \\
\hline $\begin{array}{c}\text { Noticias } \\
\text { Marruecos }\end{array}$ & 273 & 142 & 639 & 317 & 284 & 261 & 308 & 278 & 1.166 & 413 \\
$(81 \%)$ & $(57 \%)$ & $(69,8 \%)$ & $(70,6 \%)$ & $(70,7 \%)$ & $(51 \%)$ & $(45,4 \%)$ & $(86,9 \%)$ & $(64,7 \%)$ & $(82,3 \%)$ \\
\hline
\end{tabular}

Atendiendo, ya para finalizar, al contenido de la presente tesis doctoral, ésta se inicia con una reflexión sobre esa complicada vinculación entre la opinión pública y la publicada. En los siguientes cinco capítulos se pretende analizar y explicar el proceso evolutivo - y subrayamos "proceso" porque es algo rebosante de vida y, como tal, nace, se desarrolla y muere- de la opinión pública salmantina ante los acontecimientos marroquíes: la gestación de los tratados internacionales de reparto del Sultanato, los sucesos de Casablanca, el Desastre en el Barranco del Lobo, Agadir, la situación del Protectorado hispano-francés durante la Guerra Mundial, la primera etapa de Berenguer en la Alta Comisaría, Annual, el desembarco en Alhucemas... Terminaremos con unas imprescindibles conclusiones y con el apartado referido a los archivos y la bibliografía. 


\section{OPINIÓN PÚBLICA Y OPINIÓN PUBLICADA. LA CONTROVERTIDA RELACIÓN DE UN INQUEBRANTABLE MATRIMONIO}

\section{EL PUNTO DE PARTIDA: FASES PARA LA CONSTRUCCIÓN DE UN IMAGINARIO DE LA REALIDAD}

“'La voz del pueblo! ¿Pero es que el pueblo tiene lenguaje articulado, tiene algo que decir y lo dice? He aquí lo que se preguntan muchos. Y hay que confesar que lo más de nuestro pueblo es un pueblo mudo. Nada dice, o porque nada tiene que decir o porque no sabe decirlo.Aun hay más, y es que por no saber decirlo no tiene nada que decir. Y no me toméis a paradoja. Muchas veces los niños no saben dónde les duele hasta que, requeridos por sus padres, que les oyen quejarse, tienen que fijarse y averiguan dónde radica el mal",

La opinión pública y la opinión publicada guardan una estrechísima conexión, una íntima vinculación. Parece algo incuestionable. Por eso a diario escuchamos que la gente cree lo que lee. Seguramente más que lo que ve o escucha ${ }^{2}$. No resulta tan sencillo, sin embargo, precisar en qué consiste esa relación, cuál es el lazo entre la opinión pública y la publicada.

La opinión publicada puede moldear o configurar la opinión pública. Recuérdese lo ocurrido en 1898. Muchos de nuestros antepasados creían entonces, a pies juntillas, que la letra de molde no mentía. Los periódicos, al unísono, jalearon a sus lectores para enfrentarse con la armada estadounidense. ¿Alguien se atrevió a dudar de la fuerza del quijotismo español? Muy pocos; y luego, cuando llegó el momento de la depuración de responsabilidades, los periódicos se lavaron las manos y descargaron su culpa en los políticos y militares ${ }^{3}$. Atrás quedaba una campaña propagandística marcada por la imprudencia y el sensacionalismo. Transitoriamente, tan sólo eso, la prensa sufrió el mayor de los descréditos, mientras que el desinterés por las cuestiones exteriores se convirtió en patrón habitual de conducta.

\footnotetext{
${ }^{1}$ Miguel de Unamuno: "La voz del pueblo", La lucha de clases, 17 de junio de 1905.

${ }^{2}$ A propósito de este asunto, observa el sociólogo Amando de Miguel que, pese al actual protagonismo de la televisión como medio de comunicación de masas, ignoramos una enorme parte de sus contenidos y continuamos otorgando infinita más credibilidad a la prensa escrita. No puede, sin embargo, dejar de subrayar este autor que la prensa es un producto de consumo fungible. No la considera una institución y por tanto, se niega a escribir la palabra con mayúscula.

Hoy en día los medios de información escrita están siendo desplazados por los medios informáticos. Pero hace un siglo no ocurría esto y la fe en la información publicada por escrito era, incluso, todavía muy superior a la actual. Véase MIGUEL, Amando de: "Qué significa la lectura de periódicos", en ALMUIÑA, Celso y SOTILLOS, Eduardo (Coords.): Del periódico a la sociedad de la información. Vol. 2. Madrid: España Nuevo Milenio, 2002, pp. 357-362.

${ }^{3}$ Francisco Silvela publicó en el periódico El Tiempo, en agosto de 1898, su célebre artículo "Sin pulso". Entendido como paradigma del sentimiento de bochorno originado por la derrota ante la armada estadounidense, Silvela culpaba tanto al pueblo como a la prensa de lo ocurrido en Ultramar. Del primero, le repugnaba su pasividad, mientras que a los periódicos les achacaba demasiada frivolidad.
} 
En otras ocasiones, a la inversa, parece ser la opinión pública la que encauza a la opinión publicada; es la primera la que demanda informaciones concretas. Las noticias de carácter económico -índices de cotizaciones en bolsa, grandes operaciones empresariales, acuerdos financieros internacionales- constituyen un buen ejemplo, tal vez porque de modo más o menos directo afectan a los ahorros de la mayoría.

¿Es la opinión publicada la generadora de la opinión pública?

¿O es, a la inversa, la opinión pública la que actúa como fuerza conductora de la opinión publicada?

Acaso, ¿siempre opera una como comparsa de la otra?

Ocasionalmente, la opinión pública y la publicada se han mostrado del todo coincidentes, como si una fuese el espejo en donde se reflejase, sin la más nimia distorsión, la otra. Pero también hemos tenido la oportunidad de comprobar que la opinión pública y la publicada no siempre corren de la mano. De hecho, incluso, pueden apuntar en direcciones absolutamente divergentes. Sigamos, por tanto, planteándonos más interrogantes:

¿Por qué en ocasiones opinión pública y publicada convergen y en qué circunstancias sus caminos se bifurcan? ¿Cómo se relacionan la opinión pública y la censura? ¿De qué forma se origina la opinión pública en materia de política internacional? ¿Desempeña la opinión pública un papel importante a la hora de diseñar las relaciones diplomáticas? ¿Lo hace hoy igual que ayer? Y por otro lado: ¿Hay, de verdad, sólo una opinión pública? ¿O, por el contrario, tiene una manifestación dual? ¿Es, acaso, un fenómeno multiforme?...

No es posible hallar respuestas simples para cuestiones tan complejas. Y no lo es porque en todas las incógnitas planteadas figura un enigmático fenómeno. Todas pivotan en torno al mismo eje: la opinión pública. A ella acuden los gobiernos tanto para justificar decisiones políticas como para acusarla de inoportunismo.

Son incontables las tentativas de definición del concepto "opinión pública". Tantas ha habido que, precisamente, la vaguedad epistemológica es el primer inconveniente con el que nos topamos y al que hemos de hacer frente. Tal vez por esto, por su insuperable ambigüedad conceptual, José Luis Dader concluía su obra El periodista en el espacio público con el muy elocuente epígrafe "Y al fin, ¿qué diablos es la opinión pública?". Muchísimos autores se han volcado en explicar qué es, qué tipologías presenta, qué funciones desempeña y, sobre todo, cómo se mide. Proceden estos curiosos investigadores, fundamentalmente, de los campos de la sociología y la 
politología, así como también de las ciencias de la información. Sociólogos y politólogos acuden con frecuencia a la opinión pública en su intento de encontrar explicaciones racionales para determinadas conductas colectivas. Sienten, en resumidas cuentas, fascinación por el papel social y político que desempeña ésta. Por su parte, los investigadores de los procesos de comunicación contemplan la opinión pública más que como un motor social, que también, como el fruto de una complejísima y difícilmente ponderable suma de estímulos que se superponen al sentir individual. Nos estamos refiriendo a un caótico conjunto de fríos datos, prejuicios, odios, experiencias pasadas, costumbres, expectativas, etc. Su interés, por tanto, se localiza no tanto en la funcionalidad de la opinión pública como en la formación, tipificación y medición de la misma.

Muy pocos conceptos se muestran, consecuentemente, tan idóneos como la opinión pública para el estudio interdisciplinar. Tampoco abundan los que pueden presumir de semejante solera. Quizás de ahí derive su atractivo científico.

Pero, paradójicamente, el estudio de la opinión pública no ha sido excesivamente cultivado por los historiadores hasta hace escasas décadas. Resulta muy llamativo, teniendo en cuenta la estrechísima dependencia entre este fenómeno y las coordenadas espacio-temporales. Creemos adivinar dos explicaciones para ello. En primer lugar, el historiador se siente abrumado ante el colosal corpus teórico existente sobre la materia. Causa sorpresa la gran variedad de asuntos que han sido objeto de análisis por parte de los estudiosos de la opinión pública. Desde trabajos sobre la función del informador o los potenciales receptores de los mensajes mediáticos hasta complejísimos métodos estadísticos para medir y valorar los cambios de opinión, pasando por sesudos exámenes sobre el papel de los líderes de opinión o análisis sobre la legislación reguladora de la libertad de expresión. El aturdimiento, como ya se ha señalado, puede resultar considerable.

Además, en segundo término, el grado de abstracción alcanzado en buena parte de los ensayos sobre la opinión pública es desconcertante para los profanos, sobre todo para quien muestra enorme apego por los datos al desnudo. La historia no siente particular interés por la construcción de modelos teóricos, sino que se preocupa por el análisis de casos concretos.

Felizmente, sin embargo, este desinterés historiográfico se va, poco a poco, corrigiendo. En este sentido, el análisis de la opinión publicada, sin olvidar el recurso a otras fuentes, se convierte en una vía de aproximación a la opinión pública. Pero, antes 
de continuar, tal vez convenga, como apunte aclaratorio y empleando un criterio historicista, distinguir dos grandes contextos o marcos de gestación de la opinión pública: aquél que encontramos en las sociedades primarias; y el propio de las sociedades de masas ${ }^{4}$. Entenderemos a las masas como formas débiles de vinculación social en las que se impone lo irracional y se difumina la identidad personal. Como se comprobará, en el presente trabajo nos centraremos en este segundo esquema.

En las sociedades primarias, la opinión pública nacía de la asociación de los habitantes de una aldea o comunidad con el propósito de alcanzar un acuerdo sobre cuestiones públicas. La discusión se restringía a problemas locales o morales: asuntos tales como la educación, los impuestos, el funcionamiento de instituciones públicas o la conveniencia de tal o cual obra. Se procuraba el consenso y se fijaba una acción común.

La Revolución industrial, acarreó, sin embargo, importantes transformaciones tanto en el sistema político como en las estructuras económicas y sociales de los distintos países. Por de pronto, las relaciones interpersonales tendieron a transformarse en algo más superficial y cortés. Las asambleas del pueblo perdieron su carácter original y el proceso de elaboración de la opinión pública se fue transformando: su alcance y medios de estimulación se ampliaron enormemente, así como la naturaleza de los problemas dejó de centrarse en lo local para alcanzar una dimensión global (al igual que las relaciones económicas, políticas y sociales).

La cantidad de noticias a que se halla expuesto un ciudadano es tan colosal que ninguna persona puede obtener toda la información que necesita de un modo directo. Tiene que recurrir a fuentes indirectas y secundarias de información e interpretación: los medios de comunicación de masas. Se acepta comúnmente que gran parte de lo que hacemos, creemos y sentimos se halla mediatizado por la realidad simbólica que los medios crean ${ }^{5}$. Mientras que las masas guardan un lazo de carácter sensorial, al público se le atribuye un vínculo intelectual. Cree el profesor Roda Fernández, al sostener esta distinción conceptual, que "la función principal de los mass media es subordinar la pertenencia a clases o grupos, a la pertenecía a un público, creando un interés común por encima de los intereses particulares" $" 6$.

\footnotetext{
${ }^{4}$ GARCÍA BEAUDOUX, Virginia y D'ADAMO-FLAVIA, Orlando: “Opinión pública y comunicación: El doble flujo de la comunicación política", Iconos. Revista de Ciencias Sociales, n 7, Quito, pp. 136146.

${ }^{5}$ RODA FERNÁNDEZ, Rafael: Medios de comunicación de masas. Su influencia en la sociedad y en la cultura contemporáneas. Madrid: Centro de Investigaciones Sociológicas, 1989, p. IX.

${ }^{6}$ Ibidem, p. 37.
} 
En concreto, la importancia que la prensa posee en el mundo contemporáneo, su potencial como sujeto transformador de la sociedad, está fuera de toda duda y la utilidad de los periódicos como fuente para la reconstrucción histórica se ha revalorizado enormemente. En los años a los que nos referiremos en esta investigación, casi toda la gente culta capta la realidad exterior a través de los periódicos. Así que estos se convierten en agentes históricos de primer orden y, de paso, en fuentes historiográficas de muy considerable interés.

Muchísimo camino han recorrido los historiadores españoles desde los primeros coloquios promovidos por Tuñón de Lara en la Universidad de Pau (Francia), en los años setenta, hasta llegar a las reuniones que anualmente, desde 1995, celebra la Asociación de Historiadores de la Comunicación ${ }^{7}$. Es la manifestación palpable de que la historia puede enriquecer aún más el estudio y comprensión de la opinión pública, así como de que los estudios históricos se pueden enriquecer con la comprensión de la opinión publicada.

Y todo ello porque el entendimiento de este fenómeno, la opinión pública, exige un análisis poliédrico, a medio camino entre las ciencias sociales y la filosofía, ya que "la opinión pública no sólo tiene entidad política, no siempre es plural, no sólo se da en sociedades democráticas, no necesariamente habrá de existir una concordancia entre las corrientes de opinión de los ciudadanos de a pie y las corrientes de opinión organizadas en instituciones políticas. Y sobre todo: que la mera existencia de diversas opiniones condensadas no garantiza ni la libre adhesión a las mismas de sus supuestos portadores, ni la existencia de las condiciones de un diálogo plural”.

Esa disciplina, el punto de encuentro entre las distintas áreas interesadas en la comprensión de la opinión pública, es lo que se ha dado en llamar "Comunicación Política". Su principal dogma de fe es que la opinión no surge de la nada. Las creencias, los valores, las ideas acerca de la sociedad y del sistema político, el conocimiento de las normas, las vivencias... son los factores que participan en el proceso de formación de la opinión pública.

Queda claro, tras lo señalado, que la opinión pública es un concepto extremadamente escurridizo. No se ve, no se toca, pero se siente: como la presión

\footnotetext{
${ }^{7}$ Entre medias se pueden citar los dos "Encuentros sobre Historia de la Prensa" de la Universidad del País Vasco, en 1986 y 1988; los Coloquios de Rennes de 1986 y 1987; el "Congrès Internacional de Periodisme", celebrado en Valencia en 1990; las "Jornadas sobre Prensa y Sociedad" de La Rioja en 1991; o el Congreso "Presse et pouvoior en Espagne", desarrollado en Burdeos en 1993.

${ }^{8}$ DADER GARCÍA, José Luis: El periodista en el espacio público. Barcelona: Bosch, 1992, p. 21.
} 
atmosférica ${ }^{9}$. Y por ello ni el más tiránico de los dictadores gobierna de espaldas a la opinión. Equivaldría a cavar su propia tumba. Sin embargo, a lo largo de la historia, más que valorada, la opinión pública ha sido despreciada. Descalificada y ninguneada, sí; pero su control ha sido concebido como absolutamente trascendental para mantenerse en el Poder. En suma, el respaldo de la opinión pública es siempre deseado por los gobernantes, pero, a la vez, su fuerza es temida.

Reiteramos que, en las sociedades de masas, por incipientes que éstas sean, uno de los principales agentes de creación de la realidad social y modelación de la opinión pública son los medios de comunicación y, entre ellos, la prensa. Por ser ésta el objeto preferente de nuestra investigación, a ella dedicaremos un comentario más extenso en los siguientes epígrafes. Como paso previo, conviene especificar cuáles son estas fases para la construcción de un imaginario de la realidad.

El cometido de los mass media va mucho más allá de ser elementales suministradores de información sobre la actualidad. La politóloga Inmaculada Szmolka nos describe de modo muy sucinto este proceso de construcción de imágenes y representaciones sociales ${ }^{10}$. Advertimos que se trata de una exposición muy genérica $-\mathrm{y}$ también excesivamente mecánica-, así que necesitará matizaciones.

Los medios de comunicación se ocupan de seleccionar los hechos que consideran noticiables, los interpretan y convierten en productos periodísticos acordes con sus percepciones o con su deseo de cómo quieren que se perciban. Estos hechos son difundidos públicamente y asumidos por los individuos, integrándose en su universo cognitivo y de valores.

Es lo que en la década de los años 70, Bauhmauer describió como "sistema psicosocial de la opinión pública". Así explicaba él su ciclo de funcionamiento: -input de informaciones (o recepción de un clima de opinión)/ transformación de la información recibida/ -output de opiniones diversas compartidas por grupos más o menos numerosos y representativos (o participación en una corriente de opinión) ${ }^{11}$. Cuatro son las fases a distinguir en el proceso de construcción de un imaginario de la realidad: selección de la información, interpretación de la misma, difusión de la noticia y asimilación por el receptor.

\footnotetext{
${ }^{9}$ Ibidem, p. 99. Dader recoge unas declaraciones de Pablo Morata para el Diario de Navarra.

10 SZMOLKA, Inmaculada: "Marruecos en la prensa española" en LÓPEZ GARCÍA, Bernabé y HERNANDO DE LARRAMENDI, Miguel (Coords.): Op. Cit., pp. 433-439.

${ }^{11}$ Una explicación más extensa del proceso se halla en DADER GARCÍA, José Luis: Op. Cit., 139.
} 
En un primer momento, el correspondiente a la selección de hechos noticiables, entran en juego los intereses de los distintos actores comprometidos: empresas de comunicación, periodistas y también fuentes y públicos a los que se dirigirá el producto. No todas las noticias se convierten en tal. El proceso de newsmaking silencia los hechos que no interesan a los protagonistas ya mencionados. En esta selección de noticias interviene un doble tamiz: el del propio periodista, porque él es quien decide sobre qué escribe en base a lo que espera interese al lector y a la empresa periodística; y también el del jefe de la redacción porque selecciona qué información es publicable y cuál no. Se convierte en responsabilidad del gatekeeper establecer la agenda temática, fijar la trascendencia de los temas y decidir su periodo de circulación en los medios.

Gran parte de la selección de noticias, con todo, se efectúa desde criterios puramente organizativos, normas profesionales y según rutinas, por encima de consideraciones ideológicas del periodista. Los factores organizativos son los más universales y de ellos se derivan algunas repercusiones ideológicas: los medios de comunicación otorgan preponderancia a los fenómenos a gran escala; les gustan los acontecimientos claros e inequívocos, fáciles de captar y referir; pero saben también de la inclinación del receptor informativo hacia lo inesperado o novedoso dentro de los límites de lo familiar, el deseo de continuar con los sucesos que anteriormente ya han sido destacados por su actualidad y la pretensión de conservar un equilibrio entre los distintos acontecimientos de los que se informa.

También hay, como cabía esperar, algunas normas en lo tocante a las noticias que suelen omitirse: no interesan demasiado las informaciones sobre países lejanos o con escasa relevancia política, son desatendidas las personas que no forman parte de la élite y se silencian los procesos poco espectaculares o con desarrollo a muy largo plazo.

En la segunda fase del proceso se procede a la interpretación de los acontecimientos seleccionados y su conversión en noticias. Los medios de comunicación no son un espejo de la realidad. Lo que ofrecen son versiones de la misma. Su propósito es tratar de reflejar una realidad parcial, la de su propia concepción del presente. Como consecuencia, las percepciones de la sociedad están doblemente mediatizadas a través de las impresiones de los mismos individuos y de las valoraciones de los medios de comunicación. 
La forma y el tono empleados por éstos influyen en la visión que el público tiene de la actualidad ${ }^{12}$. El discurso, ya sea oral u escrito, mantiene una estrecha vinculación con la ideología, con la organización de los pensamientos. El emisor nunca es dueño absoluto de su lenguaje, sino preso de un credo. Y no todas las noticias merecen el mismo tratamiento. Si centramos nuestro interés en la prensa ${ }^{13}$, hemos de conocer cuáles son los instrumentos recurrentes para destacar un acontecimiento: su aparición como noticia en primera plana; dedicándole un editorial, artículos de opinión o viñeta de humor gráfico; reservándole espacio en páginas impares, así como zonas lateral y superior del folio, que captan rápidamente la atención del lector; utilizando grandes titulares y formatos al máximo de columnas; con la inclusión de fotografías... Las técnicas son muy variadas.

Hay una tercera etapa en el ciclo de construcción del imaginario social. Es la fase de difusión de la información. Ésta permite fijar unas coordenadas ambientales, un clima de opinión que orienta al individuo, refuerza sus convicciones ideológicas en el momento de expresarse públicamente. Particularmente poderosos son, en este sentido y por seguir centrándonos en el papel de la prensa, los editoriales. Sobre todo si el autor es presentado como una autoridad intelectual, cuando el "martilleo" ideológico es constante y además coherente -porque habitualmente los "cambios de chaqueta" se traducen en falta de credibilidad- o, finalmente, si el grado de conocimiento del lector sobre el asunto abordado escasea. Es así como los medios de comunicación pueden crear corrientes de opinión y conformar la opinión pública.

Finalmente, el proceso concluye cuando el individuo asimila los estímulos de información y opinión de los medios de comunicación, pasando a formar parte de su propio conocimiento de la realidad y de la forma en la que entienden ésta. Los medios de comunicación acaban generando un universo de valores compartidos.

Pero no seamos reduccionistas. Este universo es complejísimo. Funciona por acumulación, también por retroalimentación y en él se deben valorar otros elementos como son la propia experiencia individual y la acción de otros agentes de socialización, tales como el ambiente familiar o las simpatías así como animadversiones personales. Pero, ¿qué sabían sobre estos asuntos los periodistas de principios de la pasada

\footnotetext{
12 ALMUIÑA FERNÁNDEZ, Celso: "Fondos y metodología para el análisis de la prensa local" en VVAA: Fuentes y métodos de la historia local. Actas. Zamora: Instituto de Estudios Zamoranos "Florián Ocampo", 199, pp. 389-399.

${ }^{13}$ Tal vez convenga aclarar que, en las páginas siguientes, en varias ocasiones identificaremos prensa y medios de comunicación de masas. Emplearemos ambos conceptos indistintamente, ya que para la época a la que vamos a referirnos la prensa era el único medio de comunicación de masas.
} 
centuria? ¿Hasta qué punto eran conscientes de la repercusión de su oficio sobre el público?

\section{PERIODISMO Y PERIODISTAS A PRINCIPIOS DEL SIGLO XX}

\section{La misión del periodismo: la visión de Walter Lippmann}

En 1916, el gobierno de W. Wilson, ejerciendo un enorme control sobre los media, supo convertir una población serena, la estadounidense, en otra histérica, avivando el miedo y el fanatismo patriotero. La llamada Comisión Creel se ocupó de inventar y difundir infinidad de salvajadas teóricamente cometidas por los alemanes. Aunque su objetivo era dirigir el pensamiento de todos los americanos, su obligación de corto alcance, la cuestión clave, era controlar el pensamiento de los hombres políticamente más formados de aquella sociedad. Ellos servirían como cadena de transmisión de la propaganda belicista que estaba siendo confeccionada para crear un clima propicio que justificase la guerra.

Codiciaban los miembros de la Comisión poner en práctica lo que ya entonces era una clara intuición: que cuando la propaganda difundida por un Estado recibe el apoyo de las clases culturalmente dominantes y no se permite ningún extravío en su contenido, su efecto puede ser demoledor ${ }^{14}$. Los monopolios informativos anulan el pluralismo ideológico y constituyen la prueba irrefutable de cuántos son los límites a la libertad de juicio y expresión.

La fabricación del consenso social no es una labor sencilla. La Comisión Creel lo pudo comprobar. Se requiere un dominio minucioso del flujo informativo y por eso los Estados se reservan la facultad de regular el derecho a la libertad de expresión: para controlar, entre otros elementos, las incitaciones a la violencia.

Los teóricos de la democracia moderna sostienen que ésta no existe cuando la gente no dispone de los recursos para participar significativamente en la gestión de sus asuntos particulares y cuando los medios de información son parciales. Sin embargo, una mirada alternativa ha considerado que el funcionamiento democrático se aseguraba cuando los ciudadanos no se hacían cargo de sus propios asuntos y cuando los medios de comunicación se sometían a ciertos controles. Esta es la idea que históricamente ha mostrado mayor peso. Fue la que imperó en el proceder de la Comisión Creel.

\footnotetext{
${ }^{14}$ Para obtener más información sobre los trabajos de esta comisión, consúltese CHOMSKY, Noam: Cómo nos venden la moto. Información, Poder y concentración de medios. Barcelona: Icaria, 2002, pp. 729.
} 
Viene el anterior apunte a colación porque este grupo de teóricos norteamericanos de la democracia liberal estaba encabezado por una gran figura, merecedora de nuestra atención: Walter Lippmann. Además de su experiencia como propagandista, sus juicios sobre la función del periodista entre las masas resultan, todavía hoy, de enorme interés. Creía el decano de la prensa estadounidense que "los intereses comunes esquivan totalmente a la opinión pública y sólo una clase especializada de hombres responsables lo bastante inteligentes puede comprenderlos y resolver los problemas que de ellos se derivan"15. Aludía Lippmann a un "rebaño desconcertado", muy peligroso cuando "brama y pisotea". Para que la clase gobernante o privilegiada pudiese domesticar a las ovejas necesitaba fabricar un consenso.

El primer requisito consistía en segregar a la muchedumbre en su acceso a los medios de comunicación, las escuelas y la enseñanza superior. Así se perfilará la barrera entre una minoría académicamente muy formada y una mayoría de gentes ingenuas y distraídas. Las primeras, continuando con la argumentación de Lippmann, acudirían a las técnicas de propaganda para recabar el apoyo de las segundas.

La propaganda es a la democracia, lo que el garrote a los mandatos autoritarios. Permite que ese rebaño se comporte como un mero espectador. Porque "las palabras pueden llegar a tener la misma fuerza que las armas"16. Lippmann sabía que el apoyo de la población era y es imprescindible de cara a las aventuras en el exterior. La población tiene que ser estimulada y para ello, el camino más corto es el del miedo. Si se desea una sociedad violenta que avale la utilización de la fuerza en beneficio del "pastor" es necesario, como primer paso, ensalzar los valores marciales (lo que casi siempre va de la mano de exaltaciones raciales, religiosas y nacionalistas); también es preciso falsificar la historia: aparentar que cuando embestimos y aniquilamos a alguien lo que estamos haciendo en realidad es defendernos de unos monstruos. El empleo de la propaganda es inseparable de la historia de la guerra, con ella se convence y conmueve a las masas, se atrapa su corazón. Si el poder político llegara a poseer el control total de los medios de comunicación, el sistema educativo y a disponer de la aquiescencia de los intelectuales, cualquier campaña propagandística podría resultar letal. Su capacidad de persuasión sería ilimitada y las consecuencias, imprevisibles e incontrolables. Ejemplos no faltan: el nazismo, el comunismo...

\footnotetext{
${ }^{15}$ LIPPMANN, Walter: La opinión pública. Langre: Madrid, 2003, p. 253.

${ }^{16}$ PIZARROSO QUINTERO, Alejandro: "Propaganda y propaganda de guerra" en VVAA: Propaganda en guerra. Salamanca: Consorcio Salamanca 2002, 2002.
} 
Creía, no obstante, Lippmann que el consenso total no existía y por esta razón, el trabajo de los propagandistas debía ser permanente: nunca podrían cesar en la fabricación de lobos feroces. Al pueblo se le amedrenta para que así glorifique al líder salvador de la destrucción.

Lippmann representa la vanguardia de la reflexión periodística en los umbrales de la pasada centuria: su pensamiento, ocasionalmente presentado con una escritura un tanto farragosa, tenía como premisa esencial la infravaloración del papel de la cultura política en el gobierno de los pueblos:

"Esa idea de que la humanidad debe progresar y estudiar el mundo para así poder gobernarlo, ha tenido un papel muy secundario en el pensamiento político. Es lógico que haya figurado tan poco, dado que en términos relativos la maquinaria que nos proporciona información útil sobre el mundo para que podamos dirigirlo casi no progresó durante el tiempo transcurrido desde la época de Aristóteles hasta que se establecieron las premisas de la democracia ${ }^{, 17}$.

Subrayaba este autor que en los albores de las democracias modernas, los políticos asumían que el pueblo siempre manifestaba su voluntad. Estaban convencidos de que la sabiduría flotaba en el ambiente y siempre que existiese un régimen de libertades civiles la verdad se impondría sobre la calumnia. Pero las libertades civiles no garantizan el triunfo de la verdad. Es un error presuponer que ésta sea espontanea.

Cuando el entorno se convierte en invisible, este principio no es aceptable. La verdad sobre cuestiones lejanas o intrínsecamente complejas no es evidente. Precisamente, Lippmann llamaba la atención sobre la curiosidad que le despertaba el escaso interés de la ciencia política hacia el papel desempeñado por la prensa. Universalmente se admitía entonces que los diarios constituían el principal medio de contacto con el entorno, una ventana al mundo, y que de ellos emanaba la verdad. Pero pocos caían en la cuenta de que la maquinaria recopilatoria de información era y continúa siendo técnica y cara ${ }^{18}$.

La relación entre lectores y prensa era tildada por este norteamericano como “fortuita y unilateral". También como anómala. La creencia en que la verdad no entraña esfuerzo es una derivación de nuestros prejuicios económicos como lectores de periódicos. Argumentaba que no existe ninguna actividad mercantil equiparable al periodismo. Desde un enfoque puramente ético, los diarios (semanarios, revistas, etc.) son similares a la Iglesia o los colegios, en ellos -siempre según Walter Lippmann- se plasma un oficio desinteresado. Aunque los primeros no reciben subvenciones públicas.

\footnotetext{
${ }_{17}^{17}$ LIPPMANN, Walter: Op. Cit., p. 259.

${ }^{18}$ Ibidem, p. 261.
} 
Tampoco el trabajo como periodista es equiparable a una profesión liberal. No se siente la necesidad de adquirir información por "medios artificiales" porque se considera que ésta debe alcanzarse por vía natural ${ }^{19}$. Lippmann estaba cuestionando, por tanto, la tradicional tesis de la misión sacerdotal del periodismo, pero era consciente de que aún el público no estaba dispuesto a pagar demasiado por conocer la actualidad.

Sentenciaba el periodista estadounidense que la difusión de un periódico era “ $u n$ medio para obtener un fin". En otras palabras, ya sabía que la prensa es un negocio fructífero cuando goza del apoyo de sus anunciantes. Pero si los periódicos enfadan a sus objetivos publicitarios más rentables, se convierten en un mal negocio. Consecuentemente, los rotativos tienen la obligación de respetar el punto de vista de su público cliente. El mundo del periodismo es un negocio especulativo y los editores tienen como meta "transformar a un grupo de clientes heterogéneos en un grupo devoto de lectores leales" $" 20$.

La lealtad del público se explicaba por motivaciones múltiples. A la cabeza de ellas figuraba la tendencia del lector a juzgar los periódicos en función del tratamiento que se dispensase a las noticias con las que se sintiese más involucrado. Lippmann subrayaba el hecho de que la prensa sirviese como vehículo para el conocimiento de un enorme volumen de sucesos, más o menos próximos. El modo de abordar los asuntos de los que el ciudadano tiene experiencia directa es determinante en la configuración de un público cliente. Es así como nacen las relaciones de confianza o repudio. Los editores son muy conscientes de que los lectores adoran las informaciones sobre bodas de conocidos, funerales, viajes, premios... Los diarios locales se convierten por esta causa en los predilectos de las grandes ciudades (de hecho, en España, la prensa regional y local puede presumir de una larga tradición). Parece absolutamente lógico que la gente tienda a informase de aquello que le afecta de un modo más directo. Aunque simultáneamente, también exigirán el acercamiento a una realidad más amplia ${ }^{21}$. "Los individuos exigirán cuentas a la prensa con todo rigor, no como lectores no especializados, sino como abogados defensores particulares de cuestiones relacionadas con su propia experiencia" ${ }^{, 22}$. Cuanto mayor sea la distancia entre el asunto abordado por un periódico y el público, menores son las facultades del lector para aplicar su

\footnotetext{
${ }^{19}$ Ibidem, p. 262.

${ }^{20}$ Ibidem, p. 265.

${ }^{21}$ Enriq Sopena afirma que sólo escapan a esta doble exigencia los "cultivadores de la teoría del ombligo". Véase SOPENA, Enriq: "La dialéctica entre la prensa local, regional y nacional" en ALMUIÑA, Celso y SOTILLOS, Eduardo (Coords.): Op. Cit., pp. 155-156.

${ }^{22}$ LIPPMANN, Walter: Op. Cit., p. 268.
} 
peculiar estándar de exactitud. Le es imposible distinguir la realidad de la ficción. El sobresalto servirá únicamente para captar su atención inicial, pero para mantener vivo ese interés habrá que recurrir a otras estratagemas. Precisamente, lo que sucede con la política internacional es que el interés o apasionamiento por los resultados acostumbra a ser elevadísimo, pero los medios para verificar las opiniones publicadas son muy pobres. Es imprescindible inducir ciertos sentimientos en el lector para que se identifique con lo que lee. La indiferencia se combate alimentando al monstruo de la irritabilidad.

Ésta es la conclusión a la que llegaba Lippmann:

"La situación en que se encuentran los directores de los periódicos es bastante peculiar. Su negocio depende de los 'impuestos indirectos' que los anunciantes cobran a sus lectores; el patrocinio de los anunciantes, a su vez, depende de la capacidad de los directores para mantener la cohesión de un grupo efectivo de clientes. Por otra parte, éstos se forman sus opiniones atendiendo a su experiencia particular y a expectativas condicionadas por sus estereotipos, dado que por naturaleza carecen de conocimientos imparciales sobre la mayor parte de las noticias que leen. Cuando se formen opiniones positivas, los editores lograrán obtener un ámbito de difusión que resulte rentable, pero para ello deberán evitar depender exclusivamente de las noticias relativas al entorno exterior. Como es lógico, todos intentan tratar tales noticias de la manera más interesante posible, pero la calidad de las noticias generales, especialmente las que se refieran a asuntos públicos, no permite por sí misma que un número amplio de personas establezca diferencias entre unos periódicos y otros ${ }^{, 23}$.

El periodista norteamericano jamás creyó que la ambición empresarial, la especulación a la que ya nos hemos referido, fuera la responsable de las deficiencias informativas de la prensa. Al contrario, él apuntaba hacia una dificultad técnica suscitada por una realidad cada día más compleja. Se mostraba plenamente consciente de que para el periodista resultaba poco menos que misión imposible transformar todo lo reseñable en noticia. Pese a que en el reporterismo de sucesos locales se encontraba el fundamento del negocio, era la especialidad peor remunerada, mientras que la cobertura de noticias del exterior exigía enormes inversiones y, aún así, presentaba deficiencias. De esta tarea se ocupaban las agencias de información. Son ellas las que confeccionan una imagen del mundo que es la que desean que el público observe. Trabajan, al mismo tiempo, como censores y propagandistas. Porque, debe recordarse que los periódicos siempre procuran el respaldo de los publicistas.

El periodista no utiliza información de primera mano, sino que su materia prima ya ha sido mediatizada por un intermediario. Y todo porque la estandarización de la mercancía - la información, los datos- redunda en una creciente economía de tiempo y

\footnotetext{
${ }^{23}$ Ibidem, p. 270.
} 
esfuerzo $^{24}$. La conclusión es, lo reiteramos, que las noticias no son un espejo de las condiciones de una colectividad ya que muy pocos individuos saben verdaderamente intuir qué es lo relevante antes de que cristalice como asunto de actualidad. Menos aún disponen de la capacidad para hacer su propia selección de los hechos antes de que el periódico se imprima. La criba inicial es efectuada por las agencias de prensa al servicio de unos publicistas. Aunque Szmolka no las menciona cuando presenta las cuatro fases del proceso de comunicación política, su papel en el proceso de comunicación y gestación de la opinión pública es vital.

Ahora bien, dirijamos nuestra atención hacia la España de la Restauración: ¿qué impide que esos publicistas sean los mismos aparatos de los partidos o los caciques locales? Nada. ¿Acaso no coincidían, casi siempre, la élite política y la élite económica durante aquellos años? Por ello, esta élite dirigente fue determinante en la configuración de las líneas editoriales de la prensa.

\section{La función social del informador. El largo camino hacia su reconocimiento profesional en España}

El periodista es la persona que se ocupa de informar a la sociedad sobre cuestiones de actualidad. Posee una relevancia social y política indiscutible (el famoso y también controvertido cuarto poder), como ya se habrá deducido, en el proceso de fabricación de un imaginario de la realidad. Sobre todo, en sus dos primeras fases. A priori se le atribuye una mayor capacitación intelectual y más facilidades técnicas que al hombre de a pie para cumplir con su responsabilidad. A pesar de ello, cabe preguntarse si, efectivamente, esto es verdad y si lo ha sido en épocas pasadas.

Hoy en día, todos los programas académicos de cualquier Facultad de Ciencias de la Comunicación insisten en recordar que ni toda la realidad social puede ser detectada por los periodistas (u otros mediadores públicos) ni el universo de nuestras preocupaciones debiera simplificarse a lo que entendemos por opinión pública. Estos profesionales acaparan, en gran medida, la facultad de definir, valorar y canalizar los asuntos y circunstancias que puedan merecer interés. Es lo que se conoce como función de agenda setting. Quien posee el control de los medios también ejerce un considerable monopolio para fijar la realidad susceptible de convertirse en objeto del interés colectivo. Su trabajo como mediadores o "aduaneros" debiera ir acompañado, por tanto, de una enorme sensibilidad y un permanente ejercicio de la autocrítica en cuanto

${ }^{24}$ Ibidem, pp. 275-287. 
a las repercusiones de su actividad, ya que son capaces de condicionar las actitudes y comportamientos individuales y grupales.

Pero la rutina y las prisas acaban por coaccionar su selección de "lo noticioso", trivializando lo que puede requerir un examen profundo. Todo sea en nombre de la extendida obsesión por "hacer digerible" un mundo intrínsecamente complejo y cambiante.

El periodista debe ser muy consciente de su papel como nuevo "Rey Midas", con la facultad de convertir en público aquello que toca. Sus obligaciones incluyen mostrar enorme disciplina para seleccionar las informaciones de acuerdo con estrictos criterios de importancia social. No resulta válida esa pretensión de ofrecer al público lo que éste pide. El periodista jamás debe asumir el papel de un ciudadano medio más, tendría que abdicar de su adoración hacia el Dios del éxito comercial. Porque el cometido de los reporteros es actuar como guías para la opinión pública, convirtiendo lo incomprensible o indetectable de una materia en asunto cercano para el público. Pero en lugar de portentosos intelectuales, lo que encontramos, con mayor frecuencia de la deseable, son trabajadores que se conforman con proporcionar una comprensión veloz y sencilla de la actualidad. Simplicidad y claridad no son conceptos equiparables. El espacio público que así se configura no permite el desarrollo de una opinión pública plural y sabia. Al contrario, la realidad se convierte en ininteligible ${ }^{25}$.

¿Ocurría algo similar hace cien años? ¿Cómo trabajaban los periodistas de aquella época?

El periodista era entonces un proletario más. Desconocía los horarios fijos, no tenía derecho al descanso dominical y, por descontado, trabajaba sin contrato. El oficio era exclusivamente apto para bohemios. No recibían, por otro lado, ningún tipo de formación especializada, pues estaba increíblemente extendida la idea de que el cronista de la actualidad lo era por nacimiento y la experiencia hacía el resto. Sólo en 1924, ya bajo la dictadura de Miguel Primo de Rivera, cuajó la primera Escuela de Periodismo de España, fundada por Ángel Herrera Oria.

El periodismo sólo se convertiría en una profesión a medida que se consolidasen las empresas periodísticas.

No era un proceso sencillo. La génesis del problema radicaba en un mal planteamiento económico del negocio. El empresario Nicolás Urgoiti, hacia 1915,

\footnotetext{
${ }^{25}$ José Luis Dader, en la obra ya referida, formula una serie de pecados capitales en los que no debe incurrir el periodista. Véase DADER GARCÍA, José Luis: Op. Cit., pp. 151-178.
} 
atribuía la escasa tirada de los periódicos españoles a la falta de interés de las informaciones. No obstante, creemos que sería más acertado apuntar hacia las elevadas tasas de analfabetismo imperantes. Y a esa extendida mentalidad, a la que aludía Lippmann, de que no era preciso pagar por conocer la actualidad. Sea como fuese, el sueldo de un periodista medio no era suficiente para vivir. Por ejemplo, a la Sociedad Editorial de España, en 1920, se le acusaba de pagar salarios absolutamente irrisorios a sus empleados. Eso sí, al menos lo hacían con regularidad. No podían decir otro tanto los pequeños periódicos de partido. Los periodistas, con la notable salvedad de los integrantes de la redacción del $A B C$, tenían que buscarse la vida como podían. Para ello recurrían a los fondos reservados del ministerio de la Gobernación o se procuraban algún cargo en cualquier otro ministerio o en un ayuntamiento ${ }^{26}$.

Normalmente, el oficio como periodista se iniciaba sin cobrar nada, ya que los editores se beneficiaban de la pedantería y deseo de notoriedad de los aprendices. Hasta 1919 no estalló una primera huelga de periodistas, con la que se logró fijar unas condiciones salariales mínimas. Pero continuó siendo muy sencillo esquivar estas exigencias legales. Bastaba con contratar a periodistas experimentados bajo la fórmula de "aspirante a periodista". Sólo desde 1928, de nuevo bajo la dictadura de Primo de Rivera, se convirtió en obligatoria la existencia de contratos de trabajo para los periodistas.

La indefinición laboral hacía del reportero una clase escasamente reivindicativa. En 1895, en Madrid y gracias a la iniciativa de Miguel Moya, se había creado la Asociación de la Prensa. Sin embargo, muy poco trabajaba en la defensa de los intereses del gremio. Habría que esperar hasta 1927 para el nacimiento del sindicato Agrupación Profesional de Periodistas y hasta 1932 para su ingreso en la UGT.

En el ambiente regeneracionista que todo lo inundaba durante el cambio de centuria, surgen varios nombres interesados en la historia del periodismo español, preocupados por el futuro de una profesión aún en ciernes, así como por asuntos tales como la formación del periodista, su función social y la organización más conveniente de la empresa periodística. Fueron éstos hombres como Rafael Mainar, Augusto Jerez Perchet o Basilio Álvarez, entre otros varios ${ }^{27}$. El primero de los citados, con su popular El Arte del periodista, publicado en 1906, ha sido el personaje que más atención

\footnotetext{
${ }^{26}$ SEOANE, M ${ }^{\mathrm{a}}$ Cruz Y SÁIZ, M ${ }^{\mathrm{a}}$ Dolores: Historia del periodismo en España. El siglo XX: 1898-1936. Alianza: Madrid: 1996, pp. 44-45.

${ }^{27}$ GARCÍA GALINDO, Juan Antonio: "Estudios de periodismo. Los primeros tratadistas españoles" en DESVOIS, Jean-Michelle: Prensa, impresos, lectura en el mundo hispano contemporáneo. París: PILAR, 2005, pp. 179-191.
} 
historiográfica ha recibido ${ }^{28}$. Nos ofrece Mainar, a lo largo de su obra, un fresco de la situación de ese gremio merecedor de considerable atención.

Mainar apostó, desde el más firme convencimiento, por el triunfo del periodismo industrial frente al ya convaleciente periodismo de opinión. He aquí la razón:

"Porque su vida depende de la acumulación de lectores, de eso su fuerza y de eso, que es el fin, sus medios. Todo ello se alcanza mediante la exactitud de las informaciones, su rapidez, su abundancia, las excelencias de la presentación, la serenidad del juicio. ¡Negocio! ¡Negocio! Se dice despectivamente, y no hay razón. ¿Negocio? Sea en buena hora porque para hacerlo hay que hacer periódico,29.

Creía que el mayor inconveniente para el prosperar del anhelado negocio eran las elevadas tasas de analfabetismo. Y por ello reconocía:

"El periódico moderno tiene más de narrativo que de didáctico; más de conversación que de discurso. El periodista, si habla de ciencia, ha de ser vulgarizando, y el lenguaje técnico le estorba; si de arte, ha de presuponer un nivel medio de cultura, siempre bajo, para no sublimar los conceptos ni las frases; si de política, el escepticismo del público le impone el ser escéptico y humorista ${ }^{, 30}$.

La tradicional visión mesiánica del periodismo, la ética que debía imperar en el trabajo del periodista, iba siendo desplazada también en España por una mentalidad mucho más utilitarista. El pragmatismo era el camino a seguir para lograr la dignificación de la profesión, así como para combatir a los intrusos. Muy sórdidamente contemplaba Mainar el presente del periodismo al afirmar: “'Gran cosa es tener ideas propias! Pero al periodista le es más útil y necesario tener las propias... de quien las paga"31.

\section{La libertad de expresión en la España de Alfonso XIII. La prensa durante la}

\section{Restauración.}

Cuando hablamos de libertad de expresión entendemos el derecho de cualquier sujeto, ya sea un individuo o una colectividad, a declarar libremente, públicamente y con transcendencia pública, sus pensamientos e ideas de toda índole, en cualquier momento y lugar, sin verse coaccionado, ni perseguido, ni castigado, incluyéndose aquí el derecho a la crítica pública al Poder establecido de cualquier orden. La libertad de expresión se convierte en soporte exclusivo de la democracia porque en caso de no existir el derecho a denunciar públicamente a la autoridad por sus abusos y desmanes, la

\footnotetext{
${ }^{28}$ MAINAR, Rafael: El arte del periodista. Barcelona: José Gallach Editor, 1906.

${ }^{29}$ Ibidem, p. 22.

${ }^{30}$ Ibidem, p. 84.

${ }^{31}$ Ibidem, p. 24.
} 
sociedad está condenada a soportar despotismos ${ }^{32}$. Pero ¿hay límites a la libertad de expresión? Y en tal caso, ¿dónde se fijan?

El cimiento, la condición sine qua non garante de la libertad de expresión es el derecho a informar y ser informado. No se puede informar en y con libertad sin todos los datos precisos. La multiplicidad de canales informativos es lo que da fiabilidad al mensaje y lo que permite hablar de libertad. Consecuentemente, la pluralidad de pensamientos y la posibilidad real de comparar y contrastar pareceres son los pilares de una opinión pública responsable.

En el preciso instante en que este principio de libertad de expresión pase a depender del poder político de turno, habrá una autoridad que quiera imponer su criterio. Sin embargo, existen muy distintos grados de tolerancia ante las manifestaciones públicas y por esta razón se impone el estudio de casos.

El ciudadano posee el derecho y también la obligación de estar debidamente informado de todo, pero también el Estado y las empresas poseen el derecho a defender sus legítimos intereses. El choque tiene lugar cuando un ciudadano desconoce lo que tiene derecho a saber porque las autoridades estatales equivocan, confunden, manipulan, ocultan hechos y desinforman con la disculpa de proteger a la sociedad ${ }^{33}$. Para las cuestiones de Estado, las relaciones internacionales, la defensa de intereses comerciales o industriales, etc. los gobiernos saben mostrarse enormemente prudentes. Son materias capitales para la nación y apelan a este argumento para concretar los "límites de la información”. Justifican, en otras palabras, la censura.

En España, las primeras leyes reguladoras de la libertad de imprenta nacen con la Guerra de la Independencia. Y si bien el reinado de Fernando VII significó un retroceso en la aprobación de derechos y libertades, bajo la monarquía de Isabel II asistimos a un nuevo período de afianzamiento progresivo de la libertad de prensa. A partir de 1868 la libertad sería total (Decreto-Ley de Sagasta de 23 de octubre de 1868 y Ley de 20 de junio de 1869).

Durante la Restauración, la Ley de Imprenta de 26 de julio de 1883, comúnmente apodada como la Ley de Policía de Imprenta, vino a desarrollar el artículo 13 de la Constitución de 1876. Supuso un enorme triunfo para el Partido Liberal, después de que Cánovas del Castillo sometiese a la prensa a una auténtica dictadura. En

\footnotetext{
${ }^{32}$ Esta definición es una síntesis de la ofrecida por PASCUAL MARTÍNEZ, Pedro: Escritores y editores en la Restauración Canovista. Tesis doctoral inédita, Universidad Complutense de Madrid, 1992, pp. 72 73.

${ }^{33}$ Ibidem, pp. 87-90.
} 
1875 había promulgado un Decreto sobre imprenta muy restrictivo: se prohibieron todos los ataques al sistema monárquico de gobierno, al Rey, al Ejército, a la religión, a los soberanos de otros países y a sus representantes... La ambigüedad de las medidas punitivas permitió todo tipo de abusos estatales. Y aunque el panorama se entibió ligeramente, con la aprobación del Decreto de 18 de Mayo de 1875, el líder conservador volvió a las andadas con el Real Decreto sobre libertad de imprenta del 1 de enero de 1876.

Puede pensarse que Cánovas estaba obsesionado con los periódicos; probablemente porque los contemplaba como muy peligrosas vías de propaganda, con enorme alcance en un país de iletrados. De hecho, por idéntica razón, los libros no le inquietaron. Sin embargo, resulta absolutamente sorprendente la falta de precauciones ante los sermones, arengas, las manifestaciones en teatros, tabernas y cafés cantantes. Era una incongruencia legal para un país como España, donde tantísima importancia tuvo la oratoria como forma de manifestación pública. ¡Lástima que la huella histórica de estos discursos y tertulias de café sea tan pobre!

En realidad, jamás Cánovas tuvo en mente la construcción de un régimen de opinión, basado en la voluntad mayoritaria ${ }^{34}$. No; sus obsesiones fueron la estabilidad y el orden. La defensa del sistema, del artificioso turno gubernamental, se basó en la desmovilización política de la gran mayoría de la población. Y la clave para ello fue la falta de una cultura cívica y de los cauces precisos para la participación ciudadana.

El estadista andaluz vivió persuadido de que "las minorías inteligentes gobernarán siempre el mundo". Cánovas sintió desdén hacia la muchedumbre analfabeta, repudió la sociedad de masas, fruto de los avances en la industrialización y en la urbanización. Renegó del sufragio universal y célebre es aquella sentencia suya de que "el proletariado no necesita representantes, sino patrones". El político malagueño restringió la verdadera opinión pública a una minoría de propietarios y gentes cultas. Ellos encarnaban la auténtica conciencia nacional, frente a una opinión caprichosa, frívola y mal enterada de los asuntos públicos. Y la prensa, con seguridad, no servía como vehículo de expresión de esa genuina opinión pública. Al contrario, lo que le suscitaba era enorme desconfianza.

Hagamos un paréntesis. Ese concepto, el de conciencia nacional, no es accidental sino muy meditado y fruto de un estratégico cambio político en las filas del

\footnotetext{
${ }^{34}$ FUENTES, Juan Francisco y FERNÁNDEZ SEBASTIÁN, Javier: Historia del periodismo español. Prensa, política y opinión pública en la España Contemporánea. Madrid: Síntesis, 1997, pp. 137-139.
} 
conservadurismo. En él han reparado y hecho hincapié, muy recientemente autores como Gonzalo Capellán y Aurora Garrido, debido a que fue una expresión acuñada por la opinión católica, en las décadas finales del siglo XIX, para referirse a un muy concreto orden moral, social y político, de impronta cristiana, frente a la opinión pública, concepto de origen liberal y equiparable a una especie de nueva deidad -pero efímera y "desviada" a ojos de los católicos- sustituta de la vieja gracia divina que legitimaba el ejercicio de la soberanía ${ }^{35}$.

En cuanto a la Ley de Policía de Imprenta decía el artículo decimotercero que "todo español tiene derecho a emitir libremente sus ideas y opiniones, ya de palabra, ya por escrito... sin sujeción a la censura previa". Como la eliminación de todo control previo tenía rango constitucional, este derecho se superponía a la Ley. Además, el artículo 17 de la Constitución insistía en que "las garantías expresadas en los párrafos primero, segundo y tercero del artículo 13 no podrán suspenderse en toda la monarquía, ni en parte de ella, sino temporalmente y por medio de una ley"36.

Sin ningún género de dudas, resultó abusivo el empleo de la suspensión de garantías. Veintitrés veces se hizo entre 1898 y 1923 y nueve de estas suspensiones afectaron a todo el territorio nacional. Decía Unamuno a propósito de este deprimente recurso que "en vista de la presión de la caldera, optaban por quitar el manómetro"37. Aún así, la prensa gozó de bastante libertad, sobre todo, cuando los periódicos tenían pequeñas tiradas. Cierto que las relaciones entre Poder y medios de información nunca fueron simples, particularmente bajo mandato conservador, pero a los políticos no les interesaba procurárselos como enemigos.

Más habitual que la suspensión de garantías o la simple censura ${ }^{38}$, y también más eficiente, fue el envío de circulares a los periódicos prohibiendo abordar algunos

\footnotetext{
${ }^{35}$ CAPELLÁN DE MIGUEL, Gonzalo y GARRIDO MARTÍN, Aurora: "Los intérpretes de la opinión. Uso, abuso y transformación del concepto Opinión Pública en el discurso de la Restauración (18751902)", Ayer, n ${ }^{\circ}$ 80, Madrid, 2010, pp. 87-114. Junto con las muy oportunas citas históricas, apreciamos la multitud y riqueza de epítetos empleados para referirse a la opinión pública. Algunos de ellos son: bandera de identificación política, "la salsa que todo lo sazona" (tomado de El Siglo Futuro), palabra mágica, arma arrojadiza, la insana opinión, el nervio del sistema, la etérea opinión, la nueva reina del mundo, la todopoderosa opinión, el cuarto poder convertido realmente en primero, la fantasmagórica noción de opinión pública...Todos ellos revelan ese carácter polisémico y controvertido de nuestra protagonista.

${ }^{36}$ Tomamos estos fragmentos de PASCUAL MARTínEZ, Pedro: Op. Cit., p. 13.

${ }^{37}$ Miguel de Unamuno: “Apuntes para la historia de Rusia”, El Socialista, 30 de noviembre de 1922.

${ }^{38}$ Una breve historia de la evolución de la censura de prensa en la España Contemporánea puede encontrarse en ALMUIÑA, Celso: "Prensa y Poder en la España contemporánea", Investigaciones Históricas. Departamento de Historia Moderna y Contemporánea, $\mathrm{n}^{\circ}$ 1, Valladolid, 1979, pp. 297-323. También en VALLE, José Antonio del: "La censura gubernativa de prensa en España (1914-1931)", Revista de Estudios políticos, n 21, Madrid, 1981, pp. 73-126.
} 
temas. Y más vergonzosa, sobre todo por no estar sujeta a ningún procedimiento de carácter legal, resultó la interrupción de comunicaciones telegráficas o telefónicas, dirigida desde Gobernación y con la complicidad de la Dirección General de Correos y Telecomunicaciones. Especialmente, coincidiendo con la explosión de bombas en Barcelona, los movimientos de buques durante la Primera Guerra Mundial o cuando estallaba algún altercado en Marruecos. Por eso muchos corresponsales en África, según el juicio del periodista francés León Rollin, empleaban el correo postal o viajaban en barco hasta Málaga para así esquivar la censura telegráfica ${ }^{39}$.

Existieron, en síntesis, dos mecanismos de represión de las publicaciones: la censura previa y la posterior a publicación. La primera sólo podía establecerse cuando las garantías constitucionales se hallaban suspensas. Esta función censora era asumida en las provincias por los gobiernos civiles. Entonces los censores tachaban con lápiz algunos párrafos y los artículos acababan publicándose mutilados, con espacios en blanco. En ocasiones, el exceso de "huecos" condujo a que los funcionarios responsables de la "señá Anastasia" acabasen rechazando la totalidad de la información, para que así no se convirtiese ésta en un método de denuncia de la censura.

Otra modalidad de control gubernamental sobre la prensa fue la represión de artículos a posteriori, cuando ya la publicación había salido a la calle y era objeto de una denuncia. El artículo 11 de la Ley de Policía de Imprenta dictaba que el director de un periódico debía presentar en el acto de su publicación tres ejemplares de cada número en el gobierno civil o alcaldía del lugar de publicación (y la prensa madrileña, además, debía presentar otros tres ejemplares ante el ministerio de Gobernación). De los recibidos en provincias, uno se enviaba a Gobernación, otro al fiscal y el último permanecía en depósito allá donde había sido entregado. Pero desde 1906, cuando entró en vigor la Ley de Jurisdicciones, ese último ejemplar se destinaría a la autoridad militar.

Los fiscales eran los competentes para denunciar una publicación cuando ésta dañaba la figura del Rey o alguna otra institución. Fueron muy frecuentes en la Restauración las denuncias, recogidas y suspensiones de periódicos y procesamiento de periodistas. Aunque resultó imposible cumplir a rajatabla todos los preceptos legales en una época de tantísimo dinamismo periodístico.

\footnotetext{
${ }^{39}$ El Sol apodó a esta grotesca maniobra represora como el "tartamudeo telegráfico". Piénsese que nos estamos refiriendo a la censura de la prensa que llegaba a los civiles. Pero en el caso de las campañas de Marruecos, la censura también fue ejercida por los mandos militares para evitar el contacto de los soldados con algunos periódicos que llegaban desde la Península.
} 
La Ley de Policía de Imprenta ha sido entendida como un calco de la homóloga de la República francesa de 1881. Ambas establecían disposiciones mínimas para controlar las publicaciones impresas y eliminaban tanto la figura del censor como la del tribunal de prensa. Se sometían los delitos de imprenta al código civil y a la jurisdicción ordinaria. Constituía, de esta forma, el germen para el nacimiento de una prensa moderna y actual. Esto es lo que pensaba su promotor, Sagasta, sobre el cometido de los periódicos:

"La elevada misión de la profesión periodística en todos los países de adelantada civilización es en nuestra patria más importante y transcendente que en ninguno, pues que estas publicaciones son las fuentes de instrucción del pueblo, a cuyo fácil alcance no se encuentra el libro por el excesivo precio que comparativamente aquí se le señala (...) El periódico en España es libro del obrero, y en él encuentra la pauta de sus derechos, así como la norma de sus obligaciones (...) Difundir las luces de este medio, dar a la emisión del pensamiento escrito la esfera de acción más ancha, la libertad más amplia, es la misión de un gobierno que trata de llevar la instrucción de los pueblos al mayor de los límites posibles (...) facilitando por medio de una rebaja considerable en los derechos de timbre, la mayor publicidad a todo género de escritos ${ }^{, 40}$.

El año 1906 marca otro hito, esta vez por su carácter coercitivo, en el desarrollo de la legislación restauracionista sobre la imprenta. Se aprueba el 23 de marzo la narcotizadora Ley de Jurisdicciones. Tras un serio altercado entre dos publicaciones catalanistas y la milicia, esta disposición legal reconoce la competencia castrense para juzgar delitos de opinión contra el Ejército, el honor nacional y su bandera, el himno... Tres han sido sus rasgos básicos más destacados: lo que supuso de ampliación de la jurisdicción marcial con relación al previo Código de Justicia Militar de 1890; el establecimiento del ambiguo concepto de delito contra la patria; y el empleo del procedimiento sumario en los procesos de esta naturaleza ${ }^{41}$. La ley permanecerá vigente hasta la proclamación de la Segunda República. Durante todo ese tiempo, tanto en la prensa como en el Parlamento, fue objeto de infinidad de protestas.

A partir del estallido de la Primera Guerra Mundial, como se comprobará, habrá nuevas reglamentaciones del derecho a la libertad de expresión.

\footnotetext{
${ }^{40}$ PASCUAL MARTÍNEZ, Pedro: Op. Cit., pp. 182-183. Comenta el autor que Sagasta hace gala de un pensamiento a la par paternalista y cínico: puesto que el obrero no lee libros, caros por lo habitual, que lea periódicos. Pero, ¿por qué no luchar por la elevación del salario obrero? De cualquier modo, la Ley de Policía de Imprenta supone un enorme avance con respecto a la legislación canovista: ya no se entorpece el acceso a los periódicos.

${ }^{41}$ VALLE, José Antonio del: Op. Cit., p. 79. Defiende este investigador que, más que expresión del poder militar, la Ley de Jurisdicciones fue una maniobra de Moret para perjudicar al catalanismo. Además, pone en entredicho la efectividad real de esta norma a falta de un examen detallado. Por su parte, Pedro Pascual Martínez entiende que la Ley de Jurisdicciones fue el resultado de una sensibilidad militar exacerbada, el "nudo gordiano que los periodistas no pudieron y los militares y los políticos no quisieron cortar". Para mayores detalles, consúltese PASCUAL MARTÍNEZ, Pedro: "Prensa, Ejército y Parlamento en la Guerra de Marruecos", Historia 16, n 276, Madrid, 1999, pp. 63-77.
} 
A propósito de ese derecho y obligación individual a estar debidamente informado, hacia 1930, aún el analfabetismo afectaba a más de la tercera parte de los españoles y los periódicos eran un lujo para muchísimos bolsillos.

No existían los quioscos, ni tampoco las librerías, tal y como hoy las concebimos. La venta de periódicos por suscripción era todavía más común que la distribución callejera. Pero los precios de esas suscripciones marginaban a los sectores más populares, a buena parte de la clase media y a toda la población rural. Por eso los cafés, con sus debates y tertulias, funcionaron como agentes multiplicadores de los efectos de la comunicación ${ }^{42}$. A la altura de 1900 el precio habitual de un diario eran cinco céntimos y no siempre estaba al alcance de, pongamos por caso, un trabajador madrileño, cuyo jornal podía oscilar entre las 2,90 pesetas y las 3,50.

Sin embargo, la prensa pudo sostener su trayectoria ascendente. La rutinaria transmisión oral de la actualidad y la publicación de las noticias más destacadas en lugares concurridos -en el caso de Salamanca se eligió la Plaza Mayor- restaron gravedad a esos inconvenientes apuntados: el analfabetismo y la pobreza generalizados. El país deseaba abrirse al mundo y los periódicos se leían, pero también, más si cabe, se escuchaban.

Por cierto, y a modo de nuevo inciso, también las noticias se escuchaban cuando el silencio era impuesto desde el Poder. En este sentido, Jean-François Botrel nos recuerda que durante la campaña de Melilla de 1909 los pregones de los ciegos sirvieron para compensar los decretos de La Cierva. Y por eso El Mundo denunciaba, al iniciarse agosto "las coplas subversivas, canciones antipatrióticas compuestas para entibiar cualquier entusiasmo y apartar del cumplimiento del deber". De igual manera, después del Desastre de Annual, se elaborarían canciones con los relatos de los ex-cautivos de Abd-el-Krim ${ }^{43}$.

\footnotetext{
${ }^{42}$ MUÑOZ ALONSO, Alejandro et alii: Opinión pública y comunicación política. Madrid: Eudema, 1990. Cándido Monzón es el autor del capítulo cuarto de esta obra, titulado "Manifestación y medida de la opinión". Subraya en él que el público necesita cuatro medios adecuados para poder formarse una opinión: la instrucción básica, la información, la articulación de la vida política y el uso de los medios de comunicación: "Si no hay enseñanza básica, difícilmente se podrá acceder a la cultura; si no hay información, difícilmente se podrá participar en la vida pública; si no hay elecciones, difícilmente podrá participar el pueblo en las tareas de gobierno; y si no hay medios de comunicación o es muy difícil su acceso a ellos, difícilmente podrá existir libertad de expresión". El público español encontrará, a lo largo del primer tercio del siglo XX, trabas en todos y cada uno de esos elementos agentes de la opinión. Por eso, la comunicación se desarrollará por vías informales, dando pábulo al rumor.

${ }^{43}$ BOTREL, Jean-François: "Propaganda y opinión pública en la España contemporánea: el papel de los ciegos" en NIETO SORIA, José Manuel; ENCISO RECIO, Luis Miguel et allii: Propaganda y opinión pública en la historia. Valladolid: Universidad de Valladolid, 2007, pp. 97-101.
} 
Se registró, además, un efectivo aumento en las tiradas editoriales y en el número de lectores. El progreso educativo, es preciso subrayar, es sólo un aspecto más del cambio social que se produjo a lo largo del primer tercio del siglo XX. España logró aumentar sus niveles de desarrollo económico, de salud pública e incluso de emancipación femenina (resultado del descenso de la natalidad más el aumento de la alfabetización de las mujeres) $^{44}$.

Es prácticamente imposible aportar cifras exactas sobre la difusión de un periódico. Aunque existen Estadísticas Oficiales para los años 1913, 1920 y 1927, su fiabilidad es escasa porque los datos eran proporcionados por los mismos directores de las cabeceras. Obviamente, tendían a la exageración. Algunos autores han intentado aportar números a partir de las cantidades abonadas a Hacienda en concepto de timbre concertado por circulación a través del correo (Real Orden del 27 de junio de 1904), pero la información obtenida tampoco se presenta como creíble.

A la expansión de esta industria contribuyó, como de todos es sabido, la incorporación de nuevos alicientes, tanto técnicos como de ocio, para su adquisición: la inclusión de ilustraciones, la celebración de campeonatos y concursos, notas informativas sobre sociedad y espectáculos teatrales, las populares novelas en fascículos, las páginas especializadas femeninas, las notas de higiene y medicina... Mientras, en las grandes capitales -desde luego, no en Salamanca-, la información taurina se va convirtiendo en el símbolo de la "vieja España".

No es descabellado el que la mayoría de los estudiosos daten en estas fechas la conversión del periodismo en un cuarto poder, probablemente con una capacidad de influencia muy superior a la actual. El reinado de Alfonso XIII fue, desde muchas perspectivas, un momento de tránsito entre lo viejo y lo nuevo. Fue la prensa, en gran medida, la creadora de un clima de opinión pública: un sentimiento de crisis de identidad, algo similar a una conciencia colectiva que se transmitía oralmente y se compartía grupalmente.

Los inicios del siglo XX son, en resumen, desde la perspectiva periodística, el momento de transición, aunque también todavía de coexistencia, entre el periódico de opinión y el de empresa ${ }^{45}$. Resulta, de todos es sabido, una distinción que remite exclusivamente a la potencia financiera de la casa, a la luz de que los llamados

\footnotetext{
${ }^{44}$ AVILÉS, Juan: "España en el reinado de Alfonso XIII", en AVILÉS, Juan (et al.): Historia política y social moderna y contemporánea. Madrid: UNED, 2001, p. 471-501.

${ }^{45}$ SEOANE, M ${ }^{\text {a }}$ Cruz y SÁIZ, M ${ }^{\text {a }}$ Dolores: Op. Cit., pp. 23-68. El primer capítulo, titulado "Aspectos generales" es una excelente investigación sobre este proceso de afianzamiento empresarial.
} 
periódicos industriales también defendieron concretas opciones políticas. Siguieron sin poder escapar de los tentáculos de las grandes personalidades políticas, que utilizaban sus páginas para promocionarse y defender sus opciones ideológicas. Así, Canalejas empleó al Heraldo de Madrid como su órgano propagandístico, mientras que Santiago Alba fue el propietario de Libertad.

Si bien el descomunal número de publicaciones - Madrid y Barcelona acapararon casi el $40 \%$ de los nuevos títulos- puede inducirnos a pensar que nos hallamos en un periodo de auge del periodismo, predominaban las empresas pequeñas. Además, muchas de estas publicaciones tuvieron una vida fugaz. De hecho, al intelectual Luis García de los Ríos, totalmente ajeno a las preocupaciones regeneracionistas del momento, los periódicos le merecían un juicio muy negativo. Nos referimos a él porque fue el segundo autor español que publicó, en el Madrid de 1910, una tesis doctoral sobre la opinión pública. El primero fue Alberto López Selva, en 1890. García de los Ríos creía que la prensa española era "vulgar, rastrera, autobombeante, que tiene sobre sí dos grandes simas: el de no digerir los problemas que discute y el de colocarse siempre al lado de la plebe inculta; bien para alargarla sus pasiones o bien para dirigirla hacia mortales abismos" $"$.

En cualquier caso, intelectuales como Maeztu ya antes de 1900 daban por finalizada la época del periódico evangelizador en beneficio del factory system $^{47}$. El periodismo de opinión se definió por su predominio ideológico y por la dependencia de partidos o personalidades, en contraposición al periodismo industrial, concebido ya como un negocio y con una amplia variedad temática, aunque siempre respetuosos con las instituciones y el sistema. El incremento en el número de lectores permitió la consolidación de este segundo modelo: agencias de noticias, desarrollo del telégrafo y del teléfono, surgimiento de nuevos géneros periodísticos, la dignificación del periodista como profesional, la consolidación de la prensa regional y local, la generalización de nuevos géneros periodísticos como la crónica, el reportaje y la interview... Paralelamente, los pequeños periódicos de izquierdas lucharon por sobrevivir a duras penas; las publicaciones periódicas de inspiración católica lanzaban

\footnotetext{
${ }^{46}$ Citado en MUÑOZ ALONSO, Alejandro et alii: Op. Cit., p. 131-132. A este severo juicio, añadía: "El periódico, cualquiera que sea su color y objeto, tiene el inconveniente de someter el criterio de los lectores al suyo, de modo que, en breve tiempo, éstos rara vez aceptan otros datos para formar juicio que los ofrecidos por su periódico, ni discurren sino por la lógica de la redacción y renunciando sin repararlo al buen uso de la propia inteligencia, aplauden lo que su periódico aplaude, reprueban lo que su periódico reprueba; esperan cuando manifiestan esperanza, y se abaten cuando aparece abatido".

${ }^{47}$ Ibidem, p. 23.
} 
sus dardos contra las que calificaban como "impías"; y la prensa obrera y nacionalista logra, paso a paso, ganar adeptos.

Tal y como apunta Otero Carvajal, la aparición del telégrafo eléctrico transformó completamente el mundo periodístico de la segunda mitad del siglo XIX. Con el telégrafo eléctrico se ensancharon los horizontes del público lector, que podía tener conocimiento de lo que sucedía a miles de kilómetros el día anterior, fue una auténtica revolución que cambió la percepción del tiempo y del espacio ${ }^{48}$.

Mientras que casi todos los noticieros de Madrid se imprimían en rotativa, en las provincias pervivió la linotipia. Pero se registraron considerables avances entre 1913 y 1930: de 36 rotativas y 15 linotipias en 1913 se pasa en 1930 a 31 y 213. En 1930, 565 publicaciones disponían de imprenta propia, mientras que en 1913 la cifra se reducía a $270^{49}$. Destacó, entre los adelantos de carácter tipográfico, la sustitución del huecograbado por la técnica del fotograbado, que permitían imprimir a la vez texto y foto. Los rotativos disfrutaban alardeando de sus noticias "recibidas por teléfono". Evidentemente, la cantidad y calidad de la maquinaria empleada por las empresas informativas era un indicio de la importancia de su tirada comercial. Hasta entonces, la mayoría de los periódicos contaban con cuatro páginas. Su tamaño podía variar entre el cuarto, el folio, el tabloide o el tipo sábana. Su confección será progresivamente más horizontal -irán desapareciendo las rígidas y extenuantes columnas-, más sistemática desde el punto de vista de los contenidos y la publicidad irá esparciéndose, lentamente, por todas sus páginas. En los anuncios reside, junto con el aumento del público cliente, una de las claves para el mantenimiento económico de la empresa. Y precisamente la insuficiente publicidad será el gran problema de la prensa de aquellos años. Sobre todo esto fue una realidad muy patente en los rotativos de provincias. Las esquelas funerarias se convirtieron en la materia publicitaria más relevante y de ahí, su habitual protagonismo en la primera plana.

Unas pocas grandes agencias telegráficas internacionales se hicieron con el total control del mercado informativo. Se convirtieron en canales fundamentales para la circulación de propaganda política y, por tanto, también en receptoras de la máxima atención gubernamental (recuérdese lo comentado sobre los abusos en la interrupción de comunicaciones como un método de censura informativa). Los pequeños diarios y la

\footnotetext{
${ }^{48}$ OTERO CARVAJAL, Luis Enrique: "Las telecomunicaciones en la España Contemporánea, 18552000”, Cuadernos de Historia Contemporánea, no 29, 2007, p. 120.

49 PIZARROSO QUINTERO, Alejando: "El convulso siglo XX" en VVAA: Periodismo y periodistas. De las Gazetas a la red. Barcelona: España Nuevo Milenio, 2001, p. 72.
} 
prensa local dependían en gran medida de la información de estas agencias: en 1832 nació Havas; en 1849, la Agencia Wolff; y en 1851 se creó Reuters. En 1859 las tres llegaron a un primer gran acuerdo, el primero de muchos, para el reparto de esferas de influencia y el intercambio de información. Hacia 1900 ya se había constituido un extenso sistema informativo internacional que manejaba a escala mundial la transmisión de la información ${ }^{50}$.

España fue asignada a la francesa Havas a través de una intermediaria, la agencia Fabra (hubo otras agencias, pero bastante menos poderosas). Siempre hubo quien receló de la uniformidad y empobrecimiento de la información sobre el extranjero que esta situación acarreaba. Hasta el estallido de la Gran Guerra, España careció de corresponsales fijos en capitales europeas. Pero ante todo, la dependencia se hacía particularmente peligrosa y notoria cuando los comportamientos de Francia en Marruecos dañaban el sentimiento de amor propio nacional ${ }^{51}$.

Muchos de los autores consultados -Pizarroso, Gómez Aparicio, Seoane y Sáizcoinciden en afirmar que el proceso de transformación de la prensa española no fue completo. El contexto no era el adecuado porque factores como la persistente inestabilidad política, el elevado analfabetismo, las deficiencias urbanísticas así como en las redes de comunicación y la relativa escasez del posible mercado jugaban en contra. Es por eso que no encontramos la tópica frontera entre el gran diario informativo y el de carácter popular. Lo que hallaremos será una especie híbrida, con enorme brillantez intelectual y estilística, pero irregular en su carga informativa ${ }^{52}$. Los periódicos de estos años siempre bascularon entre la información y la propaganda, pendientes de sortear el garfio de la censura. Una tradicional gran empresa como La Correspondencia de España fue superada, coincidiendo con el cambio de centuria, por El Imparcial. De enorme popularidad gozó igualmente el moderadamente republicano y anticlerical El Liberal. Y nada tuvieron que envidiarle Heraldo de Madrid o La Vanguardia.

Pero todas estas grandes empresas debieron aprender a convivir con el flamante y monárquico $A B C$, de Torcuato Luca de Tena y Álvarez Ossorio, o el ultraconservador El Debate. El aprendizaje no fue un sendero de rosas. El Liberal optó por extenderse

\footnotetext{
${ }^{50}$ PIZARROSO QUINTERO, Alejandro: Historia de la propaganda. Notas para un estudio de la propaganda política y de guerra. Madrid: Eudema, 1990, pp. 208-209.

${ }^{51}$ ÁLVAREZ GUTIÉRREZ, Luis: "Intentos alemanes para contrarrestar la influencia francesa sobre la opinión pública española en los años precedentes a la Primera Guerra Mundial" en VVAA: Españoles y franceses en la primera mitad del siglo XX. Madrid: CSIC, 1986, pp. 1-21.

${ }^{52}$ SEOANE, $M^{\mathrm{a}}$ Cruz y SÁIZ, M ${ }^{\mathrm{a}}$ Dolores: Op. Cit., pp. 27-28.
} 
por varias provincias y después de asociarse con los Gasset de El Imparcial, que así hallaban remedio a su crisis de decadencia, y de adquirir Heraldo de España, nació la Sociedad Editorial de España, el famosísimo Trust ${ }^{53}$. En 1906 logró imponer su voluntad sobre la Papelera Española, presidida entonces por Nicolás María Urgoiti, al impedir la aprobación de un arancel que gravase el papel extranjero (aunque Rafael Gasset formaba parte de ese gabinete, como ministro de Fomento, utilizó su órgano, El Imparcial, para hacer campaña contra el proyecto de ley). A partir de 1907 amplió su cobertura provincial con la adquisición de El Defensor, de Granada, y El Noroeste, de Gijón.

El Trust - con la actualización de tarifas unificadas de publicidad más bajas que las de otros diarios y la compra conjunta de servicios informativos, máquinas y papel rápidamente rivalizó con la Buena Prensa, la asociación de la prensa católica ${ }^{54}$, y despertó muy variopintos recelos. Encarnó un bloque político-periodístico de carácter liberal y sustentador de unas libertades que parecían gravemente amenazadas por la oleada autoritaria iniciada, sobre todo, tras la formación del conocido como Gobierno Largo de Maura, en enero de 1907. La Correspondencia de España decidió encabezar sus números con un recuadro que rezaba "este periódico no pertenece al Trust" e inmediatamente fue emulada por muchos otros diarios. La Sociedad Editorial de España, sin embargo, logró subsistir hasta 1922 (anteriormente se desgajó del grupo El Imparcial. Urgoiti intentó comprarlo a los Gasset, aunque sin éxito), pero se resintió enormemente con el fallecimiento de Miguel Moya en 1920.

En 1909 el Trust, nuevamente, realizó una exhibición de fuerza. Pese a los muchos intereses compartidos por partidos políticos y grupos periodísticos, en este verano se asiste a un violento enfrentamiento entre el ejecutivo de turno, presidido por Antonio Maura, y la prensa más independiente por ser más crítica con él y con su gobierno. El desencadenante fue el rechazo a la llamada a filas de los reservistas con el objeto de asegurar la posición militar española en el Norte de Marruecos. Las

\footnotetext{
${ }^{53}$ Para más detalles sobre su constitución, véase SÁNCHEZ ILLÁN, Juan Carlos: Prensa y política en la España de la Restauración. Rafael Gasset y El Imparcial. Madrid: Biblioteca Nueva, 1999, pp. 189-202. También este autor, como Gómez Aparicio, alude a la participación económica de La Cierva en el nuevo proyecto empresarial y a su intercesión ante José Maestre. Nos aclara que éste era un propietario minero de Cartagena, amigo de La Cierva y con estrechos lazos familiares en el Partido Liberal. Él fue el que aportó el dinero preciso para la compra de Heraldo de Madrid, órgano canalejista.

${ }^{54}$ Con el propósito de fomentar la preparación de sus periodistas, la prensa confesional organizó varias asambleas: Sevilla, 1904; Zaragoza, 1908; y Toledo, 1924. La pluma del periodista católico estaba perdiendo resonancia porque su tono moralista no podía competir con una prensa cada día más sensacionalista. Esta acuciante necesidad de fomentar una mayor preparación profesional entre los periodistas católicos fue la que inspiró a Herrera Oria para crear su Escuela de Periodismo.
} 
publicaciones liberales y obreras iniciaron una campaña contra el discriminatorio sistema de reclutamiento, que condenaba al pobre a acarrear, en solitario, con todo el peso de la guerra, al no poder recurrir a la redención en metálico ni a la sustitución; el desarrollo de la Semana Trágica y la sonora protesta nacional e internacional en defensa de Ferrer impulsaron a Alfonso XIII a prescindir de los servicios de don Antonio. Resultaba patente cómo se había desmoronado el funcionamiento hasta entonces pacífico del turnismo.

La prensa salmantina, por su parte, constituyó un perfecto ejemplo de hibridación, de ese modelo de transición al que se refieren con insistencia Seoane y Sáiz. Y con el añadido de que la capital del Tormes era una de las capitales españolas con mayor tradición periodística y número de publicaciones, si bien la mayoría no gozaron de excesiva estabilidad organizativa ni financiera ${ }^{55}$. De la decena de periódicos estudiados, hoy únicamente sobreviven dos, precisamente aquellos que más rápidamente supieron captar el nuevo sentido empresarial de la profesión. Estos dos diarios son El Adelanto y La Gaceta Regional. Muy pronto contemplaron el periodismo como un negocio en el que se debía procurar la cabida de información, entretenimiento y opiniones, pero sin llegar a prodigarse en labores adoctrinadoras; publicando "homilías". Así era como, por recoger un ejemplo, José Luis, uno de los redactores de La Gaceta, contemplaba su profesión:

"La forma improvisada y rápida con que hay que producir un diario es de una tiranía enorme y motiva con frecuencia que la producción de la pluma sea fragmentaria e inconexa, desarticulada e incompleta (...) Pasaron los tiempos en los que el periódico era un mero instrumento de partidismo político. El espíritu crítico de los tiempos y el escepticismo público que caracteriza la época actual, obligan a modelar otra clase de prensa, pues hoy el periódico es una verdadera cátedra ambulante que debe ilustrar, que debe enseñar, que debe educar y que, al mismo tiempo, debe recoger, encauzándolas, las ansias y aspiraciones colectivas. Debe llenar a satisfacción su doble aspecto de instrumento de cultura y de órgano de opinión. No de otra forma se abre campo el periódico moderno; no de otra forma pueden sostenerse las empresas periodísticas ${ }^{3,56}$.

Mientras que en el caso del órgano de Núñez Izquierdo, el proceso de modernización técnica es muy palpable a lo largo de las primeras tres décadas del siglo XX, La Gaceta adopta desde el mismo instante de su nacimiento -ya en 1920- las

55 SAMANIEGO BONEU, Mercedes et alii: Publicaciones periódicas salmantinas, 1793-1936. Salamanca: Universidad de Salamanca, 1984; SANTANDER, Teresa (Dir.): Publicaciones periódicas salmantinas existentes en la Biblioteca Universitaria (1793-1981). Salamanca: Biblioteca Universitaria, 1986. Además de ambos catálogos: HERNÁNDEZ SÁNCHEZ, Galo: "Las empresas de prensa diaria en Castilla y León", Salamanca, Revista de Estudios, no 35-36, Salamanca, 1995, pp. 225-228; y FRANCIA, Ignacio: "Periodismo salmantino en el siglo XX", Salamanca, Revista de Estudios, $\mathrm{n}^{\circ}$ 45, Salamanca, 2000, pp. 377-400.

${ }^{56}$ José Luis: "El ingrato periodismo", La Gaceta Regional, n 1.096, 5 de abril de 1924, p. 1. 
técnicas más modernas de maquetación, con abundancia de fotografías y huyendo de las agotadoras columnas. Además, sale a la calle con tamaño tabloide, mientras que el formato sábana de El Adelanto jamás resultó de fácil manejo. Uno de sus redactores, José Sánchez Gómez, mucho más conocido como "Un Repórter", comentaba a propósito de ese progreso industrial lo siguiente:

"Aquí, en provincias, somos más modestos y disponiendo de menos elementos que los de la corte, hacemos también nuestro periódico diario, poniendo en él todos nuestros esfuerzos, toda nuestra actividad y, en ocasiones, gran parte de nuestra vida y de nuestra alma. Pasaron para nunca más volver aquellos tiempos en que El Adelanto, pequeñito, sin apenas información telegráfica, muy escaso el servicio de corresponsales en los pueblos de la provincia, y muy escasa también la tirada, se hacía sobre las blancas mesas de mármol del café Suizo... en menos de media hora (...) El Adelanto, andando el tiempo, sufrió notables evoluciones que fueron mejorando su publicación (...) Ya no era El Adelanto aquél de Huebra, ni de Muñoz, ni de Ramos, pequeñito, político, algo guasón, sino hoja seria, grande, informativa, que era precisamente lo que el público pedía y deseaba; lo que es hoy ${ }^{, 57}$.

Otro columnista de la casa, por continuar con los ejemplos, comentaba en 1917 lo siguiente sobre el papel social asumido por la prensa y el que, teóricamente, debiera desempeñar:

"En los pueblos modernos y en las categorías políticas se ha dibujado frente a los tres poderes estatuidos en los códigos constitucionales, otro cuarto poder, de influjo evidentísimo en la formación de conciencia civil de los países. ¿Quién discute la influencia ejercida por la prensa en la opinión colectiva? (...) La función social de la prensa debiera ser un magisterio sagrado. En puridad, está reducida a ser el vehículo la intermediación entre el elemento activo que dirige, gobierna, enseña o cultiva, y los sectores pasivos que reciben con la propaganda la divulgación de todo el movimiento poliforme del pais" ${ }^{, 58}$.

Los editoriales, en ambos rotativos, solían insertarse en la primera plana o, en su defecto, en la segunda y muy raramente ocupaban más de dos columnas. Habitualmente, también se incluían en estas hojas las noticias de carácter local, los sucesos trágicos y las gigantescas esquelas (lo que más nos sorprendió la primera vez que consultamos un periódico antiguo), así como los apuntes de sociedad, páginas especializadas, espectáculos teatrales y taurinos. La tercera página se destinaba a las informaciones telegráficas y telefónicas, siempre encabezadas con un muy visible titular. Aclaremos que El Adelanto nunca fue un integrante del Trust, pero muy frecuentemente, en esta sección, además de alusiones a asuntos del extranjero, recogió fragmentos publicados en diarios que sí pertenecían a la Sociedad Editorial. Por último, la cuarta plana estaba ocupada con pequeños anuncios y con novelitas publicadas por fascículos.

\footnotetext{
57 "Un Repórter": "El Adelanto de antaño y El Adelanto de hogaño", El Adelanto, no 7.534, 8 de enero de 1909 , p. 2.

58 “De ayer a hoy. ¿En qué quedamos?”, El Adelanto, no 10.260, 16 de noviembre de 1917, p. 1.
} 
Los criterios organizativos del resto de la prensa salmantina, en cambio, fueron mucho menos estrictos; barulleros si se prefiere; las informaciones del exterior, bastante más escasas (con la salvedad de El Lábaro); y el contenido doctrinal y moralizante, muy superior a los dos casos anteriores. Esta es una cualidad que merece destacarse, sobre todo, al referirnos a tres publicaciones: el católico El Lábaro; El Salmantino, órgano del integrismo local, además de miembro de la Buena Prensa y destacado combatiente antitrust $^{59}$; y, para terminar, El Pueblo, instrumento de la Federación Obrera local, aunque, como en el caso de La Gaceta, de nacimiento tardío.

En efecto, una nota característica de la sociedad salmantina al filo del siglo XX fue el persistente enfrentamiento entre grupos liberales y clericales. Por supuesto, la prensa local se hizo eco de ello y, particularmente, la más ideologizada adquirió un papel vital en esta guerra al convertir sus páginas en el escenario de la batalla. Lo enunciado se puede fácilmente observar en la siguiente cita. Aunque sea bastante extensa, también es reveladora de esa atmósfera de hostilidad entre los círculos de opinión católica y el naciente obrerismo; una hostilidad, por otra parte, cada vez más agudizada por el colosal poder que se le atribuía a los mass media y a sus anunciantes. Esto era lo que, en 1907, “C. P.” escribía en El Lábaro sobre la prensa obrera:

"La acción poderosa que la palabra ejerce sobre el hombre, adquiere una influencia ilimitada cuando se transmite por medio de la prensa (...) El poder de la prensa periódica es irresistible, formidable. Lo que no consigue hoy lo alcanzará mañana (...) Sus páginas llevan la dicha y el dolor, el aliento y la desesperación, la paz y la guerra, la vida y la muerte. Los autores de anuncios y reclamos saben muy bien la influencia de esos asaltos periódicos y repetidos. La primera vez que aparece un anuncio, dicen, el suscriptor no lo lee, ni siquiera repara en él; a la segunda lo lee; a la tercera se fija más en él y a la cuarta, por fin, se decide y compra (...) Los asaltos a la virtud son más terribles aún que los asaltos al bolsillo. En manos de los sectarios, el periódico se convierte en poderosísimo ariete de destrucción (...) En el periódico destinado a corromper a la clase obrera no hay que buscar ni lógica ni moralidad (...) En él se falsifica la filosofía, se inventa la historia, se ultraja a Dios (...) El obrero que lee esos periódicos, si no tiene arraigadas convicciones, los cree y los cree a ciegas, como el turco al Corán. No desconfía, no piensa, no raciocina, no compara, no consulta, ni aun sabe acordarse de las decepciones de la víspera: cree a secas (...) porque el periódico es su evangelio ${ }^{\prime 60}$.

\footnotetext{
${ }^{59}$ Los enfrentamientos con El Adelanto fueron muy habituales. Así, al fragmento de "Un Repórter" que hemos reproducido en la anterior página, en el que se hacía hincapié en la solera del diario, un tal "S." respondía sentenciando que el periódico de Núñez Izquierdo siempre había sido liberal si bien "antaño tenía la franqueza de confesarlo a todas horas; mientras que hogaño se le muda la color en cuanto Unamuno tira de la manta. Cuerda floja de mi alma, El Adelanto dirá: Si buenas hambres me quitas, iqué tragos me haces pasar!". Consúltese "S.": "Política menuda", El Salmantino, n 67, 23 de enero de 1909 , p. 1.

60 “C. P.”: "El poder de la prensa", El Lábaro, nº 3.548, 21 de febrero de 1907, p. 1.
} 
¿Cómo no pensar en Lippmann y su rebaño? Aunque, aclarémoslo, esto se escribió quince años antes de la publicación de su gran libro. ¿Cómo no recordar las palabras de Sagasta a propósito de la función educadora de la prensa?

Sin duda, la incursión en el mundo del periodismo del gran capital, con intereses diversificados en otros sectores económicos, coaccionaba al periódico, a su dueño y a los componentes de su redacción. Pero la miserable situación de los periódicos de opinión igualmente había restado y aún lo hacía a éstos libertad de expresión.

¿Quién no conocía entonces los célebres "fondos de reptiles"? ${ }^{61}$. Eran las cantidades reservadas del ministerio de Gobernación para el pago de algunos rotativos. En cierto momento, Gumersindo de Azcárate comentó que el pucherazo y los fondos de reptiles eran las dos caras de la misma moneda, ya que "al fin y al cabo, si el Ministro de la Gobernación hace diputados, y en ocasiones hasta trae alguno del bando enemigo para que dé juego, ¿por qué no le ha de ser lícito hacer opinión pública alimentando los hornos en que ésta se forma y produce?"62.

Las irregularidades, como se verá, prosiguieron durante la Primera Guerra Mundial.

\section{A. La Primera Guerra Mundial}

A lo largo de la historia del periodismo español, ésta fue una coyuntura particularmente interesante. Se despierta ahora un creciente interés hacia los asuntos internacionales; vemos una población ávida de noticias, habiendo ya olvidado el escepticismo que la embargó después de 1898. Jesús Pabón, refiriéndose a estos años, sentenciaba que "germanófilos y aliadófilos batallaron incansablemente en la prensa, en el café, en las academias y en las familias". La guerra provocó un aumento en el número de lectores, el languidecimiento de la prensa de partido -muchos prácticamente desaparecen, saliendo a la calle muy puntualmente; son los sapos-y, como contrapartida, la consolidación de la empresa periodística. Se afianzan en estos años periódicos como ABC o El Debate y surgen otros como El Sol, La Libertad o Informaciones. Ya entonces existían algunos grandes grupos como Sociedad Editorial de España (1906), Prensa Española (1909) y la Editorial Católica (1912).

No fue tarea sencilla el mantenimiento de la neutralidad española entre 1914 y $1918^{63}$. Eduardo Dato se vio en la obligación de aprobar un Real Decreto el 4 de agosto

\footnotetext{
${ }^{61}$ La expresión aludía a una de las políticas recurrentes del canciller Bismarck.

${ }^{62}$ FUENTES, Juan Francisco y FERNÁNDEZ SEBASTIÁN, Javier: Op. Cit., p. 145.

${ }^{63}$ Es descomunal la normativa de estos cuatro años que afecta a la libertad de expresión. En VALLE, José Antonio del: Op. Cit., pp. 80-96. Particularmente turbulentos fueron los años 1915 y 1917.
} 
de 1914 con el objeto de procurar que los enfrentamientos periodísticos entre aliadófilos y germanófilos no perturbasen la neutralidad oficial del país. Antonio Maura, por su parte, también hizo público su convencimiento de que España "ni podía, ni quería, ni debía ir a la guerra". Por ello aprobó el 7 de agosto de 1918 la Ley contra el Espionaje. Se legitimaba con ella la censura previa para todo lo relacionado con la contienda, sin necesidad de recurrir a la suspensión de garantías constitucionales.

Pero, paradójicamente, la sociedad española rápidamente se escindió en dos bandos. Y de igual manera, los periódicos se convirtieron en combatientes, en medios de propaganda, encrespando los ánimos, incluso, de la intelectualidad española.

Sostuvieron la causa aliada los liberales, republicanos y reformistas por medio de diarios como La Correspondencia de España, El País, El Imparcial, El Socialista, El Sol, La Mañana, El Liberal, El Radical, Heraldo de Madrid y el semanario España. En Salamanca, El Adelanto mostró una actitud bastante benévola hacia ellos, aunque nunca apostó de manera explícita por el abandono de la neutralidad. Mientras, se decantaron por los imperios centrales los mauristas, carlistas, militares y buena parte del clero. Sus instrumentos propagandísticos fueron La Acción, El Debate, El Universo, Nueva España, El Correo Español, El Día, El Mundo, La Tribuna, El Siglo Futuro, ABC y La Correspondencia Militar. Los abanderados locales de la causa imperial fueron $E l$ Salmantino y La Libertad. Algunos de estos periódicos recibieron subvenciones extranjeras, dado que los bandos contendientes estaban muy interesados en influir en la opinión pública española con informaciones favorables a su causa. Así fue el caso de La Correspondencia Militar o La Acción, El Imparcial y la revista España. Y también hubo diarios que se enorgullecieron por actuar por convicción, sin mediar beneficio económico alguno, tales como $A B C$ o El Liberal.

Cada ejemplar costaba, como ya se sabe, cinco céntimos y se financiaba a través de su venta, siendo más común, como ya indicamos, la suscripción que la venta callejera. Una segunda fuente de obtención del capital era la publicidad. Sin embargo, la guerra hizo que descendiese la inclusión de publicidad extranjera, con el consecuente varapalo económico para el periodismo nacional. Pero, sobre todo, el gran problema de esta coyuntura fue el encarecimiento del precio del papel. La solución vendría de la mano del discutido sistema del anticipo reintegrable.

La tendencia alcista en el precio del papel supuso enormes quebraderos de cabeza para todas estas empresas periodísticas. La preciada materia prima pasó de costar 380 pesetas la tonelada, en 1914, a 1.100, en 1916. El importe del papel 
representaba la tercera parte del precio final de un ejemplar del periódico y la Papelera Española nunca había sido capaz de competir con el papel extranjero ni en precios ni en calidad $^{64}$. Hasta el momento, había malvivido cobijada a la sombra del Estado, obteniendo beneficios gracias a los considerables aranceles para el papel importado. Así que la caída de las importaciones de papel, coincidiendo con el desarrollo de la conflagración de mundial, tuvo una repercusión muy negativa en las casas informativas. Si exceptuamos los escasísimos periódicos que disponían de servicios de papelería propios, la mayoría tuvieron que sufrir la escasez de suministro.

Se llegó, entonces, a justificar la intervención directa del Estado: “La prensa no puede vivir si ha de costear por sí misma el precio del papel. El anticipo reintegrable es de necesidad apremiante y absoluta". Ésta fue la síntesis ofrecida por Heraldo de Madrid. Con el Decreto de 19 de octubre de 1916 nacía el polémico anticipo reintegrable, aunque no se acabaría de regular esta figura hasta la aprobación de la Ley de 29 de julio de 1918. Ésta es la última de las disposiciones legales del periodo constitucional con repercusión en el derecho a la libertad de expresión, si bien de modo un tanto subrepticio y por aquello de que el que paga manda ${ }^{65}$.

La Hacienda Pública adelantaría a la Central Papelera el crédito necesario para cubrir la diferencia entre el precio que tenía el papel en 1914 y el que fuera fijándose más adelante ${ }^{66}$. Este anticipo sería devuelto por los periódicos a través de la creación de un impuesto de cinco céntimos por kilogramo de papel adquirido. Central Papelera

\footnotetext{
${ }^{64}$ Véase GUTIÉRREZ POCH, Miquel: "Control de mercado y concentración empresarial: La Papelera Española, 1902-1935", Revista de Historia Industrial, n 10, Barcelona, 1996, pp. 183-199. Este proyecto empresarial, nacido en diciembre de 1901 e impulsado por Rafael Picavea y Urgoiti, no produjo frutos hasta 1909, cuando por fin hubo reparto de beneficios entre los accionistas

${ }^{65}$ El periodista Antonio Rubio Campaña, a propósito de esta disposición legal comenta: "Las subvenciones, como era lógico, motivaron que muchos periódicos y periodistas se echaran a los brazos del Poder y que fueran muy pocos los que permanecieron independientes y sin ayudas estatales". Véase RUBIO CAMPAÑA, Antonio: Op. Cit., p. 89.

También relacionado con el anticipo reintegrable, consúltese AUBERT, Paul: "Crisis del papel y consecuencias de la industrialización de la prensa (1902-1931)" en DESVOIS, Jean-Michelle: Prensa, impresos, lectura en el mundo hispano contemporáneo. París: PILAR, 2005, pp. 73-95. Señala este investigador que, tras la aprobación del Real Decreto, cuando el 27 de septiembre de 1916 se abrió la sesión parlamentaria, La Cierva censuró al ministro de Hacienda, Santiago Alba, por favorecer prácticas ilícitas según el Código Penal. Argumentó que, desde el inicio del conflicto internacional, la industria papelera había multiplicado por diez sus exportaciones mientras dejaba insatisfecha la demanda interior. Y además, para colmo, iba a recibir una ayuda estatal. Alba contestó que la medida más económica era centralizar el cobro del anticipo en la Central Papelera y que si vendía al exterior era porque necesitaba compensar la debilidad del mercado interior. No obstante, pocos meses después se prohibieron las exportaciones y se redujo la producción. Los periódicos protestaron entonces por la acentuada escasez de papel.

${ }^{66}$ Así, como Central Papelera, es rebautizado el cártel papelero tras una remodelación en 1914. Central Papelera fue la agrupación de las principales fábricas guipuzcoanas, algunas catalanas y la vieja Papelera Española, con un papel hegemónico. Su producción y venta se limitó al papel para impresión, satinados ordinarios y embalajes.
} 
actuaría como intermediaria con Hacienda. La disposición benefició a 234 diarios no oficiales y el Estado acabó anticipando casi 80 millones de pesetas -que no recuperó-. La rechazaron algunos como El Socialista, El Mundo, La Vanguardia, La Veu y El Sol.

De todos modos, Papelera no supo aprovechar la coyuntura, marcada por el aumento de las tiradas, para mejorar su producción (era enormemente dependiente de la pasta y los productos químicos extranjeros, pero sí mejoró sus dividendos). Además, en 1921, como ya ocurriera en 1906, perdió la batalla de los aranceles frente a las empresas periodísticas.

Los periódicos, a la altura de 1920 -había concluido la contienda pero persistía la tendencia desmesurada al encarecimiento del papel-, se encontraban ante esta disyuntiva: elevar el precio por ejemplar o reducir el número de páginas. El gobierno no había autorizado, en tiempos de la conflagración mundial, el primer camino porque deseaba mantener una relación cordial con la prensa, confiando en que ésta colaboraría para la conservación de la neutralidad. Por otro lado, la segunda opción, recordando que ya muchos periódicos contaban con únicamente cuatro páginas, conducía al ridículo. Sin embargo, El Sol, nacido en 1917 y con una calidad superior a todo lo confeccionado hasta entonces, tomó la iniciativa al elevar, en 1918, el precio de la suscripción a diez céntimos, una "perra gorda" (y la paginación a 12). Entre los miembros de la Sociedad El Sol figuraba el casi omnipresente Urgoiti, quien se había procurado un diario consonante con sus intereses, aunque acabó endeudándose con la Papelera. El encarecimiento del ejemplar fue entonces muy criticado. Pero finalmente, terminada la lucha armada y abolido el anticipo reintegrable, un Real Decreto de 13 de junio de 1920 fijó el nuevo precio del ejemplar en diez céntimos. Como no existía una moneda fraccionaria inferior a cinco céntimos, fue necesario duplicar el importe. No obstante, hubo quien sugirió la creación de la moneda de siete céntimos.

\section{B. La dictadura de Miguel Primo de Rivera}

Otra coyuntura históricamente muy interesante en la evolución del periodismo español es la que siguió al pronunciamiento militar del 13 de septiembre de $1923^{67}$. La dictadura significó el golpe de gracia para los moribundos periódicos políticos. Terminaron ahogándose cuando se suprimió su tubo de respiración: los partidos. Particularmente dura fue la dictadura con la prensa anarquista, la imberbe comunista y la nacionalista. El Real Decreto de 15 de septiembre de 1923 significó la declaración del

${ }^{67}$ SÁIZ, Ma Dolores: "La prensa y la opinión pública durante la dictadura de Primo de Rivera" en ALMUIÑA, Celso y SOTILLOS, Eduardo (Coords.): Del periódico a la sociedad de la información. Vol. 1. Madrid: España Nuevo Milenio, 2002, pp. 243-257. 
Estado de Guerra y la consecuente suspensión en España de todas las garantías constitucionales, si bien no llegó a afectar a la publicación de libros. Al día siguiente, todos los rotativos aparecieron con la advertencia "Este periódico ha sido visado por la censura". El objetivo de la censura fue primordialmente político: impedir una crítica libre y bien instruida en algunos temas.

Coloquialmente conocida como "la señá Anastasia", se ejerció siempre de un modo arbitrario, incongruente e, incluso, tontorrón. De hecho, se permitió el cuestionamiento público de su propia existencia ${ }^{68}$. Y como el número de censores fue escaso y estaban mal pagados, en las provincias no se pudieron establecer turnos nocturnos y la vigilancia se hizo de un modo bastante informal. Eso sí, informalidad no se equipara con suavidad. El control ejercido por los gobernadores civiles y la autocensura de los directores de los rotativos fue, en ocasiones, más estricto que el del poder central.

El Estado de Guerra, a la postre, se mantuvo hasta el 16 de mayo de 1925. Fue el de mayor duración de los declarados durante el reinado de Alfonso XIII. Evidentemente, de entre todos los derechos ciudadanos, la libertad de expresión es el más difícil de mantener en suspenso por mucho tiempo, ya que perjudica a los intereses de las empresas periodísticas, difíciles de silenciar.

La instauración de la censura no supuso, pese a lo que pudiera apriorísticamente pensarse, una interrupción del proceso mencionado de modernización empresarial porque el silencio impuesto sobre asuntos políticos obligó a potenciar otras preocupaciones, otras opciones de entretenimiento. En suma, más sensacionalismo. Los espectáculos deportivos y los sucesos desgraciados cobraron un notable protagonismo.

Ya estabilizado el precio del papel, habiendo ascendido el ejemplar a diez céntimos desde 1920, los diarios aumentaron su paginación y decidieron que dado que el régimen no toleraba las críticas, ellos tampoco se iban a prodigar en halagos. Aún así, los posicionamientos ante el alzamiento fueron bastante variados, oscilando entre el absoluto beneplácito de $\mathrm{El}$ Debate hasta el contundente rechazo por parte de La Libertad, órgano de Santiago Alba (no nos estamos refiriendo al periódico salmantino con el mismo nombre). Lugares más ambiguos ocuparon $E l$ Sol y $A B C$, mientras que $L a$ Nación, bajo la dirección de Manuel Delgado Barreto, y la prensa socialista -hasta

\footnotetext{
${ }^{68}$ Pedro Rico Parada, ex gobernador civil de Gerona fue el primero en asumir la dirección de la Oficina de censura previa. En 1925 le sustituyó Eduardo Hernández Vidal, más conocido por su seudónimo: Celedonio de la Iglesia; y después de algunos incidentes surgidos a raíz del trato privilegiado recibido por La Nación, las competencias censoras fueron transferidas a los gobernadores civiles.
} 
1927- se convirtieron en las niñas bonitas del nuevo gobierno autoritario. En Salamanca, la prensa en su conjunto digirió el golpe con notable sumisión. Puede que alguno de los periódicos actuase así por puro instinto de conservación. La Gaceta, por su parte, no escatimó halagos.

Mediante el empleo de sus célebres notas oficiosas, Primo de Rivera lamentó reiteradamente la parquedad informativa de los diarios. Le ofendió, particularmente, que éstos no publicitasen las muestras de adhesión ciudadana tras el desembarco en Alhucemas (¿fueron gestos espontáneos?), con motivo de las actividades de la Unión Patriótica... Han sido varios los autores que han sometido a examen las aficiones periodísticas del dictador, su búsqueda del respaldo social, su extrema locuacidad y potencial demagógico. Una de las decisiones más relevantes bajo su mandato fue, en este sentido, la nacionalización de la Agencia Fabra. Primo de Rivera tenía como meta acabar con el colonialismo informativo francés. Aunque la situación de dependencia apenas se modificó y, de hecho, según el juicio del ex embajador Quiñones de León, la imagen exterior de España empeoró.

Beneficioso, en cambio, resultó para la profesión, además de la mencionada creación de la primera Escuela de Periodismo de Herrera Oria (bajo inspiración católica), el esfuerzo de los Comités Paritarios de Prensa. Consiguieron mejorar en algo las condiciones de trabajo, contratos, salarios, vacaciones, etc.

Concluido este repaso, resumamos lo descrito hasta ahora: se inició el capítulo con la presentación de algunos grandes interrogantes y la exposición de las cuatro fases que se suceden en la construcción de un imaginario social, según Szmolka; del análisis del pensamiento vanguardista de Walter Lippmann pasamos luego a la descripción del panorama periodístico español a principios del siglo XX. Subrayamos entonces que el tránsito del periodismo de opinión al factory system no fue completo, sino que ambos modelos coexistieron. Se destacó seguidamente que las relaciones entre prensa y Poder suelen ser conflictivas. De ahí las distintas leyes reguladoras de la libertad de expresión y la práctica de la censura. Con todo, paulatinamente, el redactor de noticias sí logró mejorar sus condiciones de trabajo, al igual que se incrementó el número de lectores.

Llegados a este punto, queda claro que el cronista, la empresa periodística y las grandes agencias asumen el protagonismo en las fases de selección e interpretación de las noticias. Pero, ¿cómo se origina ese clima de opinión que orienta al individuo? ¿Cómo asimila el lector los estímulos emanados de la prensa? 
Los efectos de la prensa, de los medios de comunicación masiva, han sido objeto de múltiples interpretaciones, controversias y estudios empíricos. Sin duda, las fases tercera y cuarta del esquema original de Szmolka son las que entrañan una mayor complejidad analítica. Así que empecemos con la teoría.

\section{LA OPINIÓN PÚBLICA: UN CONCEPTO ESCURRIDIZO}

\section{A. La opinión pública como objeto social}

Jean Jaques Rousseau fue el primer pensador que empleó el término opinión pública en su Discurso sobre las ciencias y las artes de 1750. Aunque el ginebrino es más conocido por la utilización de la expresión "voluntad general". Entendía la voluntad general como un juicio de tipo moral, una especie de censura ejercida por la mayoría desde las costumbres hasta los actos de gobierno. Pero el concepto opinión pública va más allá del sentir común de los ciudadanos. Locke, y con él los liberales, lo entendieron como el mecanismo formador del consenso que permitiría la gestación de las democracias modernas, el ejercicio de la soberanía popular para la elección de un gobernante.

Desde esta óptica, la opinión pública adquiere una dimensión comunicativa y no solamente política: es determinante en el establecimiento de un consenso o disenso y ambos implican un intercambio y discusión de opiniones.

Pero todos los intentos frustrados de definición del concepto han querido resaltar una cara del fenómeno, minusvalorando forzosamente otras. Para los historiadores, la opinión pública ha sido un concepto particularmente incómodo. Así, Reig Cruañes subrayaba en su tesis doctoral que "tratándose de un concepto que ha tenido un tratamiento casi exclusivamente empírico (...) los historiadores habrían agradecido un conjunto más compacto de fuentes documentales para su conocimiento (...) La historia no puede enfrentarse al concepto de opinión pública sin un bagaje teórico depurado historiográficamente (...) Lo relevante del concepto de opinión pública no es que se compone de opiniones, sino que algunos sistemas políticos la han definido como su fuente de legitimación. Es decir, lo relevante del concepto se encuentra más bien fuera de é ${ }^{\prime \prime 69}$. En suma, los límites del objeto de estudio se muestran muy imprecisos. Ha sido habitual restringir la opinión pública a las opiniones de un público político o, más equivocadamente, a lo que pueden registrar los sondeos. Y también ha sido práctica

\footnotetext{
${ }^{69}$ REIG CRUAÑES, José: Opinión pública y comunicación política en la Transición democrática. Tesis doctoral inédita, Universidad de Alicante, 2000, p. 3.
} 
común arrinconar el peso de las actitudes, costumbres, estereotipos o modas en la gestación de la misma. Siempre los detentadores del Poder han intentado seducirla y someterla, conscientes de su multiplicidad de funciones: la determinación de lo socialmente loable o reprobable; la legitimación de la autoridad; su capacidad de cohesionar a las gentes y su funcionamiento como mecanismo básico de evolución...

El concepto opinión pública es muy frecuentemente entendido como una expresión de moralidad colectiva. Se identifica con lo hegemónico, con los valores básicos abstractos de una sociedad o cultura. Se acude a ella en defensa de las "causas justas".

En la época contemporánea nos encontramos con tres grandes conceptualizaciones en torno a la opinión pública ${ }^{70}$ : la político-valorativa de Jurgen Habermas; la antropológico-social, defendida por Elisabeth Noelle-Neumann; y, por último, la sociopolítica-funcionalista, también llamada visión institucionalista y encabezada por Niklas Luhmann.

El primer enfoque, continuador de una tradición iniciada con los sofistas, Platón, Maquiavelo o Bentham, ha conseguido relacionar la existencia de un Estado democrático con la legitimación popular de la opinión pública. Con tal propósito recurre a la reflexión sobre la relación entre gobernantes y gobernados, los derechos ciudadanos de expresión y de protesta, las vías para el diálogo político... Sus censores le responsabilizan de suministrar un concepto utópico y peligroso de opinión pública, muy racional frente a una realidad que es miedosa, irracional y gregaria.

Por su parte, Noelle-Neumann concibe la opinión pública como la suma de manifestaciones de la conducta que reflejan las mentalidades de una colectividad, ya sean de carácter político, cultural o cualquier otro. De un modo restrictivo, la opinión pública sería la corriente central que en cada tema polémico goza de más apoyo por parte del público. Defiende esta autora que todo individuo posee una especie de "sexto sentido" que le permite localizar la opinión socialmente más apreciada en cada coyuntura. Así, la presión ambiental, la preocupación por lo bien visto, coacciona a las minorías, las condena al silencio para evitar gestos de rechazo social. Este enfoque es heredero de las reflexiones de Locke en cuanto que contempla la opinión como un instrumento de coerción social. Y contradice por completo los planteamientos de Habermas. Para ella, el poder de la reputación es muy superior a cualquier visión

\footnotetext{
${ }^{70}$ Una exposición mucho más amplia de estos enfoques puede hallarse en el capítulo "El concepto problemático de opinión pública. Principales enfoques sobre el objeto formal de la especialidad Opinión Pública" en DADER GARCÍA, José Luis: Op. Cit., pp. 95-136.
} 
racionalista de la opinión. Además, reivindica que el concepto no posee solamente un mero significado político, legitimador de las democracias.

Según la tercera interpretación, la de Luhmann, la opinión pública es el consenso más primario para el reconocimiento de algunos asuntos como de interés general. Este investigador alemán sí convierte a la opinión pública en el pilar de la democracia en cuanto que es un sistema que funciona en base a la integración comunicativa de todos sus miembros, aunque muestra absoluto desinterés por el análisis de la mayor o menor racionalidad que rige en el proceso. El Parlamento se convierte en la única y más realista expresión de la opinión pública, y también es el remedio ante los esperables problemas de convivencia surgidos en una democracia demasiado directa.

Subyace a esta disparidad de interpretaciones una irresoluble polémica en torno a cuál es la clave del comportamiento de la opinión pública. Todo gira en torno al acento que se ponga sobre la dicotomía racionalidad/irracionalidad. Veámoslo: algunos investigadores parten de una visión racionalista de la misma, propia de la más pura tradición ilustrada y liberal, así como sustentadora de las modernas democracias. Según ésta, los hombres nacen libres, iguales y poseen el derecho a defender distintos puntos de vista sobre sus intereses. Partiendo de la racionalidad innata del hombre y de que todos honestamente persiguen la verdad, la coincidencia de opiniones servirá como indicadora del proceder más racional sobre cualquier asunto a debatir. Otra cosa es verificar si realmente expresan sus opiniones tantas personas como las reciben; si las instituciones oprimen al público; o si, en definitiva, se dan las condiciones para la existencia de una auténtica comunicación pública.

En el polo contrario, una visión irracionalista de la opinión pública la contempla como un mecanismo de presión social, fruto de prejuicios y actitudes intransigentes. Así, la "voz del pueblo" se convierte en ignorante, caprichosa y manipulable. Insiste este enfoque, de clara inspiración freudiana, en que los instintos son los autores originales de todo comportamiento humano.

A medio camino entre las dos visiones descritas se halla el enfoque marxista. Para éste, la posición en la estructura de producción determina el tipo de pensamiento. Existen tantas opiniones públicas como clases sociales, pero no compiten en igualdad. La opinión pública oficial se identifica con la opinión de la clase dominante y al pueblo se le intenta convencer de que sus intereses, opiniones o ideas son los mismos que los de la oligarquía. Los medios, desde esta interpretación, serían empleados siempre en pro de la conservación del statu quo ideológico imperante. Bastante similitud con este punto 
de vista guarda la rotulada como visión intelectualista. La alusión a la clase social, es remplazada, de acuerdo con este análisis, por los condicionamientos históricos. Muy pocos individuos pueden, aisladamente, crear las opiniones que luego defienden. Elementos como una religión, etnia, sentimiento nacional o afinidad política son los que determinan su ideología. Estas excepcionales figuras, capaces de superar las opiniones particulares son los intelectuales. Son, por definición, innovadores y en gran medida responsables del progreso humano. Este enfoque se presenta como una actualización de la visión racionalista de la opinión pública. Por otro lado, responde a una interpretación de naturaleza dual de la misma. Si la opinión pública que sustenta a la acción de los gobiernos está dominada por la "opinión vulgar", se impone el pesimismo de las visiones irracionalistas, pero si esta opinión pública está instruida por los intelectuales, entonces se recupera el optimismo racionalista.

La visión institucionalista, por su parte, identifica el Parlamento como representación más genuina de la opinión pública. Pero de ello se extrae que las opiniones que no alcanzan representación aquí, no importan. La misión de este órgano consiste en simplificar la compleja realidad.

En último lugar, la visión crítica de la Escuela de Frankfurt, encabezada por T.W. Adorno, también defiende una interpretación dualista de la opinión pública. Cree que el irracionalismo imperará mientras no existan las condiciones para un debate en libertad. Y no es suficiente una mera reglamentación formal de la libertad, sino la garantía de canales de información eficaces para conocer a fondo la realidad sometida a discusión. En otras palabras, los ciudadanos despreocupados por la calidad de las informaciones sobre la actualidad que reciben, pierden su capacidad real de participación. Es, en puridad, una defensa del intelectualismo generalizado.

Con toda esta enunciación de confusas elucubraciones a propósito de la opinión pública lo que pretendemos es dejar constancia de que "el conjunto de corrientes y climas de opinión que componen en cada momento y lugar concretos el caleidoscópico mosaico del espacio público de una comunidad ha de ser visto, por fuerza, como una suma desigual y movediza de fenómenos de racionalidad y de irracionalidad colectiva" ${ }^{, 71}$.

Concluimos el presente apartado asumiendo, palabra por palabra, esta concreta definición de la opinión pública y lo hacemos ya que nos parece la más compleja y operativa de las múltiples consultadas. En primer lugar, porque en ella se destaca su

\footnotetext{
${ }^{71}$ DADER GARCÍA, José Luis: Op. Cit., p. 124.
} 
carácter variable en función de las coordenadas territoriales y temporales; en segundo término, porque apela a un espacio público siempre complejo y en el que conviven distintas corrientes y climas de opinión. Aclaremos que por espacio público, diferenciado tanto del terreno privado como de la esfera social, entendemos aquél en que se desarrollan actividades potencialmente observables y enjuiciables por toda la comunidad en cuanto que toda ella puede resultar afectada por esas acciones; y, finalmente, porque no olvida mencionar ese controvertido grado de irracionalidad que interviene en la gestación del fenómeno de la opinión pública.

\section{B. Breve historia de la investigación del proceso de comunicación}

Adentrémonos ahora en la historia de la investigación del proceso de comunicación a lo largo del siglo XX. Se pueden diferenciar cuatro grandes etapas en la historia de la interpretación de las repercusiones sociopolíticas y culturales de los mass media:

El primer momento coincide con la fase de auge de las bautizadas como teorías del impacto directo, que serán las imperantes hasta el inicio de los años cuarenta. Éstas llaman la atención sobre la pérdida de autoridad por parte de las tradicionales élites e igualmente inciden en el poder omnipotente de los medios para homogeneizar las mentes y controlar la sociedad; sin embargo, durante las dos décadas siguientes, hasta llegar a mediados de los sesenta, las conclusiones de los científicos de la comunicación pendularon hacia una posición diametralmente opuesta a las anteriores, es decir, defendieron que los medios tienen una capacidad de influencia social muy inferior a la de otros agentes sociales; en una tercera fase, la que comprende la segunda mitad de los años setenta y la siguiente década, tendremos que referirnos a las conocidas como teorías de la transición, que insisten en la moderada capacidad de influencia de los medios; y, para concluir, a partir de los años ochenta y hasta la actualidad, los presupuestos de los científicos de la comunicación retornan a su punto de origen, de nuevo insistiéndose en la portentosa capacidad de influencia de los medios.

Hasta que comienza la década de los cuarenta - por tanto, esta primera fase se corresponde con los años que son objeto del presente trabajo-, a la prensa se le atribuía una enorme eficacia a la hora de cambiar opiniones y formas de pensamiento, así como para moldear la conducta. ¿Acaso no se ha deducido ya que era Walter Lippmann el principal exponente de esta visión? Su defensa de la capacidad casi ilimitada, alienante, de los medios para transformar la opinión y el comportamiento fue vulgarmente 
bautizada como "la teoría de la bala mágica" o "el modelo hipodérmico" 72 . La simplicidad derivada de esta teoría sirvió como estímulo para otras reflexiones sobre el papel de los medios. De hecho, el modelo Estímulo-Respuesta nunca ha desaparecido por completo de los esquemas de trabajo de las ciencias de la comunicación, sino que se halla en el fondo de todas las investigaciones empíricas de los años siguientes, obsesionadas por dilucidar qué contestación concreta sigue a un estímulo específico.

El excesivo mecanicismo de las teorías del impacto directo acabó, con todo, siendo puesto en entredicho y, en consecuencia, desde 1940 y hasta mediados de los años sesenta, se transita hacia el polo opuesto de la balanza y se impone la hipótesis, arropada por el funcionalismo, del influjo mínimo de los media. En su lugar, el papel que adquiere el grupo y, particularmente, el líder de opinión sirve como fuerza moderadora o refractaria de las influencias externas. Si acaso, los mensajes de carácter persuasivo contenidos en los mass media pueden reforzar opiniones ya existentes, antes que modificarlas. Las masas, desde esta óptica, no son amorfas y pasivas y el concepto opinión pública tiene un mayor significado psicosocial que político. (Nos resulta curiosísimo que entonces, a mediados del pasado siglo, se asumía que los líderes de opinión actuaban de modo adverso a los medios. Se creía que restringían el alcance de sus informaciones. Hoy, en cambio, se les contempla como intermediarios, eslabones de una cadena y, sobre todo, como amplificadores de los mensajes contenidos en los medios de comunicación).

No obstante, los efectos psicológicos generados, sobre todo, por la popularización de las televisiones acabaron siendo incontestables. Y la experimentación, cada vez más rigurosa y empírica, se fue decantando por los resultados a largo plazo en la modificación de las conductas.

Por eso, desde mediados de los años sesenta y hasta finalizar la década de los setenta, se desarrolla un período de transición, de desarrollo de muchísimos modelos de investigación positivista, en el que se le reconoce a los medios una capacidad moderada de repercusión sobre la sociedad. El más clásico de esos modelos de trabajo es, como en breve se explicará -esperaremos hasta llegar al epígrafe sobre la percepción en España de la política exterior-, la teoría de la "difusión en múltiples pasos", simplificable, a su vez, en la teoría del doble flujo de la comunicación. Otro de los esquemas de análisis más atractivos es el conocido como modelos de la "difusión en J" (se refiere a la forma que adopta una curva de distribución sobre las posibilidades de difusión de una noticia).

${ }^{72}$ RODA FERNÁNDEZ, Rafael: Op. Cit., pp. 73-75. 
Veamos en qué consiste éste: la premisa de partida es que no todas las noticias llegan al conocimiento de la audiencia fundamentalmente a través de los mass media. Al contrario, existen noticias que nos llegan, sobre todo, a través de canales informales. Sería posible distinguir tres tipos de acontecimientos: los hechos de escasa importancia general pero de muy elevado interés personal; los acontecimientos de interés general grande, pero que no nos afectan de modo inmediato; y, por último, los acontecimientos de altísimo interés general y simultáneamente enorme implicación generalizada a título personal.

Es en este último caso en el que, sobre todo, se imponen los canales interpersonales de comunicación. Mientras, los medios de comunicación masiva se moverán en esta disyuntiva: u ofrecer inmediatamente mucha información sobre el hecho crítico para así reducir la ansiedad y el alcance de los rumores; o inhibirse, cuando no censurar las noticias, y dificultar el esclarecimiento de los sucesos. De este modo, los canales interpersonales acaban remplazando a los oficiales.

Finalmente, desde inicios de los ochenta y hasta la actualidad asistimos a un reverdecimiento de la hipótesis sobre la poderosa capacidad de influencia de los medios en las masas. Son concebidos hoy como un filtro muy potente en cualquier descripción de la realidad. Pero no se confía, como se hizo en los años veinte y treinta, en ese influjo absolutamente tiránico sobre la población. Las teorías que en nuestros días cuentan con mayor reconocimiento internacional son la "espiral del silencio" y la "agenda setting", así como el "modelo de la dependencia". La primera concibe la opinión pública como un instrumento de coacción social, de creación de una moral pública. La segunda, la apuesta por el efecto "agenda setting", es la teoría estelar en la explicación del influjo de los mass media en la formación de la opinión pública. Su propósito es analizar, a través del examen de contenidos (al que nos referimos en la introducción), cómo los medios canalizan la atención ciudadana hacia unos temas de preocupación pública. Y la última defiende que hoy los medios aceptan o rechazan mensajes atendiendo exclusivamente a criterios comerciales.

Aunque la que mayor curiosidad nos despierta, por lo que tiene de renovadora, es la teoría del "inventario funcional". En lugar de interrogarse acerca del impacto de los media en la gente, reflexiona sobre las funciones que éstos están en condiciones de cumplir. Pero su aplicación empírica es increíblemente dificultosa, muy subjetiva.

Tuvieron, en suma, que transcurrir varias décadas para determinarse posibles efectos cognoscitivos, emocionales o conductuales de la prensa y también para discernir 
entre el plano individual, grupal, institucional, social-global y cultural. La conclusión que se extrae es el principio de la reversibilidad en la comunicación política, que nos lleva, finalmente, a distinguir entre las posibles relaciones emisor/receptor: una relación dinámica, fruto de una concepción medianamente persuasiva de los medios y moderadamente selectiva de los públicos (Marx, Escuela de Frankfurt, teoría institucionalista, teoría de los efectos limitados) o una relación estática, en la que se conjugan una concepción todopoderosa de los medios y una visión del público como muy permeable (teoría hipodérmica, espiral del silencio y agenda setting). En cualquier caso, las actitudes han acabado cobrando una importancia capital a la hora de valorar los frutos de la comunicación de masas. Por eso hoy es imposible definir qué se entiende por opinión sin referirse explícitamente al concepto actitud.

\section{La opinión pública como sujeto social}

La opinión pública también puede ser analizada si se identifica con la obra de los sujetos que en un particular momento constituyen una opinión socialmente influyente. La opinión masa se identificaría con la opinión anónima, carente de organización, aunque generalizada de modo más o menos intuitivo; la opinión grupal, a diferencia de la anterior, sí que estaría organizada y estructurada. Es a lo que comúnmente nos referimos cuando hablamos de corrientes de opinión; y, finalmente, la opinión popular sería la registrada por los sondeos, la suma de opiniones individuales provocadas.

Mientras que la opinión pública versa sobre asuntos desarrollados en el espacio público, las opiniones particulares no se hallan subordinadas a este requisito. De idéntico modo, la opinión publicada por cualquier particular $-\mathrm{y}$ ya nos centramos en el mass media que será objeto de nuestra atención preferente: la prensa-, aunque tenga cierto reconocimiento social, no se identifica automáticamente con la opinión pública. Aunque sí puede servir como catalizador para la creación de corrientes de opinión. Al contrario, tampoco todas las corrientes de opinión de una sociedad alcanzan una representación medianamente significativa en los medios.

Habermas fue uno de los primeros teóricos que estableció la distinción entre "el sistema de las opiniones informales, personales y no públicas" y "el de las opiniones formales, institucionalmente formalizadas" ${ }^{73}$. En el primer grupo se incluirían los principios éticos más extendidos, las conclusiones derivadas de experiencias personales y las evidencias fruto de la publicidad en las culturas industriales; mientras, en la

\footnotetext{
${ }^{73}$ HABERMAS, Jürgen: Historia y crítica de la opinión pública. México: Gustavo Gili, 1986, pp. 269270.
} 
segunda categoría se podrían distinguir las opiniones restringidas a la prensa y las opiniones institucionales. Todo este segundo apartado de opiniones públicamente manifestadas es lo que debiera llamarse opinión publicada. Los medios sirven de conexión entre los ámbitos formal e informal de la opinión pero, de paso, anulan el debate racional entre ambos y reducen el alcance del espacio público.

Por eso, la relación entre opiniones públicas y publicadas tiene que ser establecida con muchas precauciones, con infinitas cautelas. Ortega y Gasset, en su momento, diferenció entre una opinión pública profunda o verdadera y una opinión pública manifiesta, la de los que escriben y leen periódicos. Creía que la prensa dirigía la opinión, pero era igualmente mandada por ella ${ }^{74}$. Es lo que en nuestros días sostienen autores tales como García Beaudoux y D’Adamo-Flavia: “El proceso dinámico de formación de la opinión pública puede ser descrito como una serie de momentos interdependientes, de flujo y reflujo y complementarios entre sî" ${ }^{\text {75 }}$. Había y hay, en conclusión, una retroalimentación continua.

Estamos conformes con tal aseveración. En caso de que el receptor no pudiese contestar al contenido de la comunicación, sería mucho más vulnerable a su influencia. Pero el hecho de poder argumentar en su contra, deriva también en que un periódico pierde parte de sus lectores cuando ignora la existencia de discrepancias ${ }^{76}$.

Sin embargo, aunque la relación entre periodista y público lector no es unidireccional, tampoco se desarrolla nunca en un plano de igualdad. Para eso se inventó la propaganda política. Los periódicos no sólo reflejan la opinión pública de un modo pasivo, sino que sutilmente, con el recurso a mensajes persuasivos y subliminales, pueden crear un clima de opinión que los ciudadanos acaban compartiendo: o bien refuerzan las actitudes vigentes entre los lectores, o bien incitan al cambio. Pueden constituir un agente de conservación o, por el contrario, un motor para la transformación. Y también pueden ser medios de creación de la opinión pública.

No es más que una consecuencia del carácter habitualmente dual que se le presupone a la opinión pública sobre la que se pretende influir: una opinión pública espontánea, que se forma por una necesidad, noticia u hecho ante el que el público

\footnotetext{
${ }^{74}$ SEOANE, $\mathrm{M}^{\mathrm{a}}$ Cruz y SÁIZ, M ${ }^{\mathrm{a}}$ Dolores: Op. Cit., p. 33.

${ }^{75}$ GARCÍA BEAUDOUX, Virginia y D'ADAMO-FLAVIA, Orlando: Op. Cit., p. 137. Esos momentos interdependientes se pueden sintetizar en cuatro etapas: la toma de conciencia sobre la existencia de un problema que compromete a la comunidad o a un sector importante de la misma; la adopción de consideraciones preliminares por medio de debates, mítines, editoriales, conversaciones informales, etc.; la presentación de conductas de actuación contrapuestas; y la consecución del deseado consenso, más o menos sólido.

${ }^{76}$ RODA FERNÁNDEZ, Rafael: Op. Cit., p. 7.
} 
reacciona en un determinado sentido (una subida de precios, un deficiente servicio público, un desastre natural, etc.). Los medios de comunicación pueden optar entre mantener esa opinión o bien intentar transformarla, magnificarla o silenciarla. Pero también puede darse el caso de que el Estado o un grupo de presión utilicen a la prensa para crear una opinión pública sobre algo hasta entonces desapercibido. En este caso, hablaremos de una opinión pública elaborada.

En conclusión, la prensa refleja la opinión pública, pero sobre todo, en los años de la Restauración, periodo al que nos referiremos en los capítulos venideros, la conforma e interpreta la realidad social ${ }^{77}$. Los acontecimientos sirven como pretexto para adoctrinar al lector y los rotativos asumen un papel de opositores, críticos o sustento de una política. La deformación de la realidad implica una ideologización, una particular interpretación de los hechos concretos.

Y a propósito de la propaganda: empleamos ese término habitualmente muy a la ligera, pero ¿qué es la propaganda? Propaganda hay en los diarios, en los himnos y banderas; propaganda son algunas obras arquitectónicas y festividades tradicionales; se escucha en los mítines y en las huelgas; la propaganda está presente en los rumores, los bulos, los chistes... lo invade todo. Pizarroso ha combatido frecuentemente, sin embargo, el sentido peyorativo que por lo común se le atribuye ${ }^{78}$. La propaganda no es lo mismo que la mentira.

Su funcionamiento puede descomponerse en estas etapas: control del flujo de la información, dirección de la opinión y manipulación, no forzosamente negativa, de los modelos de conducta. En terminología política su propósito es lo que se conoce como "procurar el consenso social" (lo que tanto preocupaba a Lippmann hace ya un siglo). El meollo del asunto no reside en si la información transmitida es verdadera o no, sino en convencer al receptor del mensaje para que piense lo que nosotros pretendemos que piense, para que haga lo que le sea dictado. Y además, que mantenga la ilusión de que toma sus decisiones en libertad.

\footnotetext{
${ }^{77}$ Insiste en este cometido de la prensa la profesora María Arroyo Cabello cuando reconoce la enorme vinculación entre el periodismo y la política durante la Restauración y afirma "la prensa era poco o nada representativa de la opinión pública. La prensa era el altavoz que difundía lo que se decía en el Parlamento, en las conferencias o en los mítines, y precisamente por eso acudían a ella todos los que querían influir en la vida pública". Véase ARROYO CABELLO, María: El artículo como arma política. La prensa y el declive de la Restauración (1905-1930). Textos para comentar. Granada: Port Royal Ediciones, 2001, p. 10.

${ }^{78}$ PIZARROSO QUINTERO, Alejandro: "Justificando la guerra. Manipulación de la opinión pública en los conflictos más recientes", Comunicación. Revista internacional de comunicación audiovisual, publicidad y estudios. Vol. 1, nº 6, Sevilla, 2008, pp. 3-19.
} 
En un contexto bélico, el recurso a la propaganda y al engaño son consustanciales a la justificación del conflicto. Para las Ciencias de la Comunicación, este empleo de la mentira como técnica de persuasión se conoce como "desinformación” (ya sea censura, simplificación o distorsión de la información). Mientras que la propaganda no es siempre desinformación, la desinformación es absolutamente siempre propaganda.

Vayamos concretando: ¿Cómo funcionaron la desinformación y la propaganda durante las campañas de Marruecos?

\section{MARRUECOS EN EL HORIZONTE DE LA PRENSA ESPAÑOLA}

La percepción en España de la política exterior. Creadores de esa percepción: el corresponsal de guerra en Marruecos y el "estratega de café"

Las primeras intervenciones armadas de España en Marruecos se remontan a mediados del siglo XIX, cuando el estado nominal de Marruecos, encabezado por un Sultán cada día más impotente, empieza a ser objeto de las ambiciones imperialistas de algunas potencias europeas. La voluntad de ciertos sectores sociales y políticos consorcios empresariales fundamentalmente interesados en la riqueza mineral del país africano, militares deseosos de gloria, africanistas civiles llamados a desempeñar una pretendida misión civilizadora, el propio Alfonso XIII, etc. -, la presión ejercida por terceras potencias y la propia configuración geográfica de la zona impidieron a España permanecer al margen de la cuestión marroquí.

En 1906 y en virtud de los acuerdos alcanzados en la Conferencia internacional de Algeciras, a España se le reconoció su posición en el Rif, además de la posesión de varias regiones fronterizas. Pero en Algeciras no se alcanzó la paz europea, sino que más bien se acrecentaron las discordias internacionales que se venían gestando desde hacía décadas, y que particularmente enfrentaban a Francia con la Alemania del káiser Guillermo II.

Algeciras, por otra parte, supuso un importantísimo jalón en ese trágico proceso de descomposición del Sultanato. En su desintegración, España estaba llamada a detentar una tarea muy significativa.

La política exterior era frecuentemente identificada por el pueblo con el riesgo. No podía constituir el centro de la atención ciudadana ya que la gente estaba condicionada (y lo está todavía, aunque se olvida) por la escasa información de la que disponía y se perdía en la complejidad de los asuntos, excepto cuando la tensión creada 
derivaba en un potente sentimiento nacionalista. Sólo entonces, bajo esas circunstancias de crisis, los organismos responsables de la política exterior creaban unos servicios de información. Pero en la mayor parte de las ocasiones la diplomacia ignoró totalmente a la opinión pública, esquivó a la prensa e, incluso, actuó de espaldas a un buen número de diputados y senadores.

De todos modos, los medios de comunicación han desempeñado un papel trascendental en las relaciones entre España y Marruecos. En líneas generales, los diarios (o con más exactitud terminológica, las publicaciones periódicas) son importantísimos actores de la vida pública, hasta el punto que durante el reinado de Alfonso XIII contribuyeron, y mucho, al desmoronamiento del carcomido régimen de la Restauración. Las sucesivas campañas de Marruecos se convirtieron en una de las preocupaciones esenciales de la élite política española durante el primer tercio del siglo XX, así como en objeto de atención preferente por parte de las empresas periodísticas. Siempre ellas han influido en el modo en que se percibe al país vecino, y los poderes públicos, eventualmente, se han valido de este hecho. Ocurrió en la era de los imperialismos.

La propaganda imperialista/colonialista tuvo dos destinatarios ${ }^{79}$ : la propia población metropolitana y la población colonizada. Ante la primera hubo que justificar un proceso, llamado a ser desempeñado por soldados de remplazo (aunque no sólo), cuyo precio podría ser muy alto, superior a su rentabilidad. En 1922, aseguraba Antonio Ríos que la prensa española se introdujo en Marruecos para pregonar y justificar el ideario colonial, ya que "la literatura no es patrimonio exclusivo de un pueblo, sino ley general del progreso. Los sentimientos se extienden y generalizan precisamente por el adueñamiento de los espíritus" ${ }^{80}$. Pero, ¿todos los habitantes de la metrópolis preocuparon de igual modo a las élites gobernantes de la Restauración? Nos tememos que no. Precisamente, esta sospecha será otra de nuestras hipótesis de partida. Intuimos que quienes verdaderamente despertaron inquietud entre las autoridades fueron los votantes de las capitales de provincia, unas más que otras, y no tanto los habitantes rurales, sometidos fuertemente al yugo del cacique. Era conveniente que los aldeanos se mantuviesen en la ignorancia, que pudiesen seguir constituyendo fácil carne de cañón (o de gumia rifeña y de "pacos" ocultos). En este sentido, la deficiente red de carreteras

\footnotetext{
${ }^{79}$ PIZARROSO QUINTERO, Alejandro: Historia de la propaganda... Op. Cit., pp. 212-216.

${ }^{80}$ RÍOS, Antonio: Una tesis sobre nuestro Protectorado en Marruecos. Madrid: Tipografía Anónima Mefar, 1922, p. 14.
} 
contribuyó a mantenerlos desinformados porque en muchos casos dificultó, cuando no directamente impidió, la llegada de periódicos.

Aunque, era evidente, las penurias de la disputa no podían ser totalmente silenciadas. Así, Unamuno, en un artículo titulado "La Patria y el Ejército", escrito ya a finales de 1905, comentaba al recordar aún la Guerra de Cuba la impopularidad creciente con que era contemplado el Ejército, con variables cotas según la zona, y señalaba:

"En el campo, en los pequeños lugares, entre la población rural, conspiran contra esa popularidad, según he podido observar más de una vez, los que han servido en filas, los que han vuelto del servicio. En las ciudades se une a esto la profunda antipatía con que aquí y en todas partes miran a los institutos armados los obreros de fábricas y talleres ${ }^{, 81}$.

Para convencer a los metropolitanos de las maravillas de la colonización, además, hay que invalidar, cómo no, el discurso sostenido por los propagandistas anticolonialistas del interior (en plena efervescencia organizativa) y también los posibles comentarios insidiosos de otros países. Y es que la expansión colonial tiende a agudizar las tensiones internacionales y exalta, de paso, la propaganda nacionalista. Tendremos muchas ocasiones para comprobarlo.

Por otro lado, a la población colonizada es preciso persuadirla de las ventajas del nuevo sistema de gobierno. El estallido del conflicto, el recurso a la fuerza, se hace casi siempre imprescindible para proceder a la ocupación. No es verosímil que las potencias actúen con fines civilizadores o por mera curiosidad científica (aunque hay casos excepcionales: misioneros, médicos, maestros...). La educación, el diseño de unos muy interesados planes de estudio para el colonizado, adquiere, en este sentido, un valor primordial tras la conquista.

Meditando acerca de los elementos condicionantes de la política internacional, un esclarecedor artículo de los profesores Ricardo M. Martín de la Guardia y Guillermo A. Pérez Sánchez comienza con esta aseveración, que juzgamos muy acertada: “ $L a$ política exterior de una nación está en función, por una parte de su poder en ese momento según determinen, además de sus factores estructurales y su geografía, su estabilidad política e institucional. Por otro lado, la política exterior también depende de las percepciones que sus élites dirigentes y el pueblo tengan" ${ }^{\prime 2}$.

\footnotetext{
${ }^{81}$ URRUTIA, Luis: Obras Completas. Vol. III. Nuevos Ensayos. Madrid: Escelicer, 1971. pp. 843-844.

${ }^{82}$ MARTIIN DE LA GUARDIA, Ricardo M. y PÉREZ SÁNCHEZ, Guillermo A.: "Opinión pública y medios de comunicación" en PEREIRA, José Carlos (Coord.): La política exterior de España (18002003): historia, condicionantes y escenarios. Barcelona: Ariel, 2003, pp. 153-168. La cita entrecomillada aparece en la página 153.
} 
Desde esta perspectiva, el papel que los medios de comunicación, a través del suministro de información más o menos veraz, desempeñan en la gestación de esas percepciones es cada vez más notable en los dos últimos siglos. Son los responsables de que nuestra mirada se dirija hacia el mar Mediterráneo. Porque, efectivamente, después de las pérdidas del 98, las guerras de África son los temas internacionales que mejor cobertura reciben en los medios informativos españoles.

Pero, ¿cómo se desarrolla este proceso? Comenzamos este capítulo con varios interrogantes. Uno de ellos era cómo se originaba la opinión pública con relación a los asuntos internacionales. Un lugar común de nuestra historiografía es el reconocimiento de que la memoria histórica de los españoles en política internacional, está marcada por las nociones de "grandeza pretérita", "la Península como un lugar aparte” (¿a quién no le resulta familiar, por muy discutido que resulte, eso de Spain is different? ${ }^{83}$ ), "la identificación del Sur con la frontera" $\mathrm{y}$, desde inicios del siglo XX -aunque creemos que esta fecha se puede retrotraer hasta 1868, con la Guerra Larga de Cuba, o incluso hasta el reinado de Fernando VII-, "el país asolado por las guerras coloniales". Marruecos, nuestro "avispero", sirvió para reforzar todos estos clichés y, especialmente, el último.

Partiendo de la premisa de que la ideología ejerce un papel determinante en las relaciones exteriores, parece muy razonable el estudio de su transmisión por las élites y los medios de comunicación para precisar las pautas que sirven de guía a la opinión en esta materia. Los autores arriba señalados, Martín de la Guardia y Pérez Sánchez, no titubean al afirmar que "los condicionantes de la opinión pública fueron ejercidos casi exclusivamente por las élites dirigentes hasta al menos la entrada en el novecientos". Si bien resulta imposible omitir que fue el pueblo quien respondió a la invasión francesa de 1808, medio siglo después, coincidiendo con el desarrollo de la Guerra de Tetuán, el papel de los medios sobre la opinión fue absolutamente crucial. Y andando el tiempo, la prensa contribuyó enormemente a la generalización de una "psicosis antifrancesa", una forma de dar salida al rencor generado por las imposiciones en el reparto colonial del norte de África.

\footnotetext{
${ }^{83}$ Es una manifestación del gran paradigma del fracaso del que habló Santos Juliá. El régimen de la Restauración ha sido tradicionalmente contemplado como una hermosa fachada que a duras penas lograba ocultar un interior ruinoso. No obstante, hoy gran parte de la historiografía está rectificando ese balance, al reparar en aspectos tales como la modernización política y económica que España experimentó desde finales del siglo XIX.
} 
En gran medida, los creadores de esta percepción, los que escribían para ser luego leídos y comentados por los "estrategas de café" -a los que seguidamente nos referiremos-, fueron los enviados especiales a Marruecos.

Sobre todo coincidiendo con el desarrollo de la Primera Guerra Mundial, cobró enorme trascendencia la figura del corresponsal. Fue entonces cuando algunos de nuestros pensadores, Salvador de Madariaga, Ramiro de Maeztu o Luis Araquistain, dieron el salto a la palestra pública. Gracias a su trabajo los grandes periódicos pudieron ofrecer, desde las principales capitales mundiales, información de primera mano sobre el desarrollo de la conflagración. Pero su trabajo no era, desde luego, novedoso.

El reportero de guerra reunía un carácter especialmente arriesgado y aventurero junto con un enorme deseo por experimentar el miedo y el heroísmo. Ha desempeñado y lo continúa haciendo, sin duda, un papel vital en la historia del periodismo universal, permitiéndonos conocer escenas de enorme dramatismo. Aunque su oficio no carecía de cierto grado de mitificación. A nadie le extraña esa imagen de seres taciturnos y solitarios, amigos del alcohol, las mujeres y las broncas. Todavía no hace demasiado tiempo, Manuel Leguineche, experimentadísimo “enviado especial” y autor de un conocido libro de carácter divulgativo sobre el descalabro de Annual ${ }^{84}$, se refería a ellos como "la tribu". De ellos destacaba su afición desmedida por la sangre y su fascinación por las conductas más viscerales del hombre ${ }^{85}$.

España ha contado con excelentísimos ejemplos de reporteros-escritores. Y muchos de ellos, además, desarrollaron su labor durante las campañas de Marruecos. Algunas obras cumbres de nuestra literatura contemporánea, de hecho, salieron de las manos de estos reporteros-escritores (y también militares). En Salamanca, El Adelanto fue el diario salmantino más espléndido a la hora de contratar los servicios de reporteros de campaña. Dispuso, a lo largo de la historia de las peleas hispano-marroquíes, de las crónicas de muchísimos soldados de cuota y, coincidiendo con las operaciones en Alhucemas, se permitió las colaboraciones de Rafael López Rienda y Antonio de Lezama.

"Periodismo bélico", "reporterismo de conflicto" o "periodismo de trinchera" son algunas de las expresiones más frecuentemente empleadas para referirse a esta especialidad de las ciencias de la información. Javier Reverte fecha su nacimiento a mediados del siglo XIX, coincidiendo con el estallido del conflicto de Crimea, aunque

\footnotetext{
${ }^{84}$ LEGUINECHE, Manuel: Annual, 1921. El Desastre de España en el Rif. Madrid: Alfaguara, 1996.

${ }^{85}$ CARCEDO, Diego: "El corresponsal" en ALMUIÑA, Celso y SOTILLOS, Eduardo (Coords.): $O p$. Cit., Vol. 2, pp. 267-274.
} 
quizás sea un oficio tan antiguo como el del propio periodista. En España, su labor se inaugura coincidiendo con la campaña de África $(1859-1860)^{86}$. Los tres enviados que más destacaron fueron Francisco Peris Mencheta, Gaspar Núñez de Arce y Pedro Antonio de Alarcón. El viaje del primero, el parco Mencheta, fue sufragado por El Mercantil, El Cosmopolita, El Popular y La Correspondencia de España. Núñez de Arce, por su parte, trabajó como enviado de La Iberia. Y Alarcón prefirió viajar por deseo propio. Las crónicas de este último fueron primitivamente recogidas por varios periódicos y, algún tiempo después, recopiladas en un libro, Diario de un testigo de la Guerra de África, que obtuvo gran éxito comercial (muy acorde con el estilo teatral y amanerado de entonces).

En décadas posteriores, con motivo de la campaña de Melilla de 1893, la afluencia de periodistas, además de dibujantes y fotógrafos, a la zona fue masiva. Tanto la proximidad geográfica con la península como el desarrollo notable de la prensa escrita favorecieron estos desplazamientos. Todos ellos se esforzaron por dejar abundantes testimonios a propósito de la molesta censura ejercida por las autoridades militares y el difícil acceso al cable telegráfico. El aún joven Francisco Hernández Mir, empleado por El Porvenir de Sevilla, Luis Morote, redactor de El Liberal y Rodrigo Soriano, que entonces colaboraba con La Época y El Imparcial, fueron los enviados que mayor protagonismo acapararon. El apasionamiento de la ciudadanía fue, en buena medida, una consecuencia de la atención que mereció esta campaña en las publicaciones periódicas $^{87}$.

A la altura de 1898 el trabajo de los enviados especiales había logrado constituir un género perfectamente cuajado ${ }^{88}$. La siguiente campaña de Melilla, en 1909, recibió una amplísima atención por parte de los principales periódicos españoles: Leopoldo Romero fue el enviado de La Correspondencia de España; Francisco Sánchez Ocaña y el fotógrafo Goñi trabajaron para $A B C$; Carmen de Burgos, más conocida como Colombine, y el fotógrafo Alfonso estuvieron al servicio de Heraldo de Madrid;

\footnotetext{
${ }^{86}$ SAHAGÚN, Felipe: El mundo fue noticia. Corresponsales españoles en el extranjero: La información internacional en España. Madrid: Fundación Banco Exterior. Colección Investigaciones, 1986.

${ }^{87}$ MARTÍNEZ SALAZAR, Ángel: "Pero no, la guerra no es bonita. Aproximación a la figura del corresponsal de guerra", Sancho el Sabio: Revista de cultura e investigación vasca, $\mathrm{n}^{\circ}$ 7, Vitoria-Gasteiz, 1997, pp. 107-130.

${ }^{88}$ REVERTE, Javier: "El periodismo de trinchera" en ALMUIÑA, Celso y SOTILLOS, Eduardo (Coords.): Op. Cit., Vol. 2, pp. 261-265. Una importante lección para los militares de la guerra de Vietnam, que para este autor simboliza el culmen del periodismo de trinchera, fue la mayor consideración de los peligros representados por el gremio de los periodistas. Los corresponsales de guerra supieron fortalecer el natural sentimiento popular de repulsa hacia el conflicto. Por esta razón, décadas más tardes, la Guerra del Golfo resultó absolutamente invisible para la opinión pública.
} 
Leopoldo Bejarano envió sus crónicas a El Imparcial; Víctor Ruiz Albéniz, El Tebib Arrumi, hizo lo mismo para Diario Universal... Tanto el enorme despliegue técnico como la categoría profesional de los enviados constituyeron un claro gesto de pompa y exhibición de la prensa.

Eugenio Noel envió sus crónicas, también a lo largo de la campaña de 1909, a España Nueva, mientras Ciges Aparicio trabajó para El Pueblo de Valencia y también para El Socialista en los años que median entre esta campaña y la posterior del Kert. El primero se convirtió en un símbolo de la política represiva maurista, tras topar con la Ley de Jurisdicciones, acusado de injurias al Ejército, y pasar un tiempo en prisión. Mediante una suscripción pública, como gesto de homenaje, muchos de sus artículos fueron editados en un libro titulado Diario de un Voluntario, de enorme valor documental. Por lo que respecta a Ciges Aparicio, sus artículos para el rotativo obrero fueron reunidos en Entre la paz y la guerra, un agrio ataque contra el militarismo más irreflexivo. Pero sin llegar a constituir una condena moral de la acción de España en Marruecos.

Finalmente, el Desastre de Annual y las operaciones subsiguientes, hasta el desembarco en Alhucemas, otorgaron un indiscutido protagonismo a la prensa en un ambiente marcado por el escándalo, los continuos ataques a Francia, el sensacionalismo y el apasionamiento exacerbado. Las informaciones inexactas, los rumores y calumnias se extendían como reguero de pólvora. Y hacían de los desmentidos públicos el pan nuestro de cada día. Para acabar con este caótico, casi esquizofrénico panorama, Juan de la Cierva, ministro de la Guerra, se procuró un grupo de corresponsales afines. Necesitaba, más que nunca, propagandistas de la misión de España en Marruecos. Entre los periodistas-africanistas especialmente destacados figuraron Tomás García Figueras, el ya aludido Ruiz Albéniz, Manuel Aznar Zubigaray, Tomás Borras, Rafael López Rienda, Leopoldo Romeo y, sobre todos ellos, Cándido Lobera a la cabeza de El Telegrama del Rif. Otros como Indalecio Prieto, Luis de Oteyza y multitud de periodistas enviados por pequeños periódicos de provincias, a costa de enormes dispendios, permanecieron ajenos a la voluntad de temido ministro.

Si nos trasladamos a un plano estrictamente teórico, hoy en día, una de las tesis de la Comunicación Política que goza de mayor aceptación es la elaborada por Karl Deutsch. Él diseñó un modelo en cascada que describía cómo se forma la opinión pública en materia de política exterior. Constaba su propuesta de una secuencia descendente con cinco momentos a diferenciar: 
1. En la cúspide de la pirámide comunicativa es donde circula las ideas de las élites nacionales (élites que son contempladas, fundamentalmente, desde una perspectiva económica).

2. Esas ideas son recogidas por las élites políticas y de gobierno.

3. El tercer nivel lo integran las redes de comunicación, los hacedores y propagadores de los mensajes que circulan en esas redes. Se incluyen aquí, por tanto, los corresponsales de guerra a los que nos acabamos de referir.

4. Encontramos en este cuarto estadio a los líderes de opinión en el ámbito local, las gentes muy interesadas en las informaciones de los medios de comunicación.

5. El peldaño inferior de la pirámide lo conforman los ciudadanos.

El dinamismo y la solvencia que se derivan de este esquema obedecen a que, en primer lugar, el papel desempeñado por los líderes de opinión no se restringe al cuarto estadio, sino que, verdaderamente, pueden actuar como intermediarios en todos los niveles. Además, siempre funciona el principio de retroalimentación en el proceso de formación de la opinión pública. Es decir, el esquema no sólo funciona como una cascada, sino también como un geiser. Y por último, en cada uno de los peldaños hay espacio para la discordancia. No son estadios aislados, sino interactivos ${ }^{89}$. Quizás, el aspecto más atractivo de este planteamiento teórico sea el peso que se les otorga a los líderes de opinión, la importancia que adquieren las relaciones interpersonales en la comunicación política como amplificadores, como refuerzo, de las ideas vertidas en los mass media. Era algo que se intuía desde la década de los cuarenta.

Adelantamos ya que encontraremos muchísimas alusiones a ellos en la prensa salmantina de principios del siglo XX. Serán los apodados como "estrategas de café".

Desde una visión muy amplia, en todos los grupos sociales encontramos individuos que se muestran particularmente activos y sensibles antes los intereses del grupo, bien dispuestos a expresar abiertamente sus opiniones. Actúan como puente entre los medios de comunicación y los sectores sociales políticamente menos dinámicos. Aunque, obviamente, en el proceso reinterpretan el contenido de las comunicaciones, añaden juicios de su cosecha.

Este mecanismo por el que se rige la transmisión de la información se conoce como "doble flujo de la comunicación" o two-step flow. Implica, primeramente, que el líder de opinión criba las noticias que recibe directamente de los medios. Pero este

\footnotetext{
${ }^{89}$ DEUTSCH, Karl: El análisis de las relaciones internacionales. Buenos Aires: Paidos, 1970.
} 
proceso tiene una segunda y capital consecuencia: "Los mensajes de los medios de comunicación de masas serán efectivos siempre y cuando los grupos que son importantes para el individuo suscriban sus contenidos, porque los efectos de los media serían consecuencia de la extensión de un proceso más básico y complejo que es el de influencia personal" 90 . En suma, convenciendo a los "estrategas de café", se puede influir en la mayoría no lectora. Tengámoslo siempre presente. Sobre todo, porque en Salamanca hubo un líder de opinión que sobresalió entre la multitud: Miguel de Unamuno, el más genial "estratega de café" de nuestra historia y para quien esta ciudad meseteña constituyó una de las claves vertebradora de su pensamiento: "Siempre que os hablo de mi España, de cualquier cosa, os estoy hablando de Salamanca" "91. Aunque con una particularidad: careció del soporte de la prensa local a la hora de abordar los asuntos marroquíes. Y ni siquiera protestó por ello. No lo necesitó.

Lo que subyace bajo esta interpretación del proceso comunicativo es que la sociedad de masas no está tan desestructurada como frecuentemente se cree. Los individuos no conocen y asimilan las informaciones aisladamente, en solitario, sino que se integran en grupos tales como la familia, los amigos, los clubs, el trabajo... y cualquier relación social es un marco potencial de comunicación.

\section{Periodistas sui generis: Marruecos y los intelectuales}

Ya para concluir el capítulo, y abundando en esta idea de cuán importantes son los marcos de comunicación en la gestación de corrientes de opinión sobre la política exterior, se debe reparar en una última figura: la del intelectual. Entendemos que todos los intelectuales se comportan como "estrategas de café", pero, en cambio, muy pocos "estrategas de café" alcanzan la categoría de intelectual.

No sólo a Miguel de Unamuno le dedicaremos atención en los capítulos siguientes. Aunque nos resulte hoy un completo desconocido, Pascual Meneu fue también un respetado erudito, profesor de la universidad salmantina y un asiduo de la prensa local. Gracia a su pluma, los salmantinos pudieron conocer algunos de los entresijos del Acuerdo de Protectorado sobre Marruecos. Por esta razón, es conveniente reflexionar sobre cuál era el papel asumido por estos personajes en su época.

El historiador Santos Juliá afirma que un intelectual es aquella persona capaz de acaparar la atención pública por medio de conferencias, periódicos y ensayos, pero sin llegar a tener responsabilidad en asuntos prácticos. No nos atrevemos a ser tan

\footnotetext{
${ }^{90}$ BEAUDOUX, Virginia y D’ADAMO-FLAVIA, Orlando: Op. Cit., p. 141.

${ }^{91}$ La sentencia aparece reproducida en MORALES MOYA, Antonio: "Salamanca y sus hombres: una visión de la ciudad”, Salamanca. Revista de estudios, n 33-34, Salamanca, 1994, p. 17.
} 
restrictivos. El intelectual conjuga la insumisión con, casi siempre, la inexperiencia política (Pérez Galdós presidió la Conjunción Republicano-Socialista, mientras que Benavente, y sólo por citar dos conocidos ejemplos, militó en el Partido Conservador. Los grados de compromiso político, como se observa, fueron variables, no atendieron a una ley matemática) y es un personaje obligatoriamente mediático.

Desde el siglo XVIII, sobre todo la prensa había sido el instrumento esencial para la difusión de la cultura. Con el transcurso de los años, los periódicos de la Restauración canovista alcanzaron cuotas deslumbrantes desde la perspectiva intelectual y literaria. El diario se convirtió en el ámbito natural del intelectual -y, por tanto, las fronteras entre los puntos 3 y 4 del esquema de Deutsch no son siempre efectivas-, con un papel considerablemente más importante que el desempeñado por el libro ${ }^{92}$. Unamuno lo expresaba “dado el horror al libro que en España domina", además de por el carácter tan elitista de la Universidad ${ }^{93}$. A los periódicos, indiscutiblemente, la colaboración de los intelectuales les resultaba más rentable que los grandes despliegues informativos. Las escasas tiradas y la insuficiente publicidad normalmente no les permitían implicarse en demasiados gastos. Estos escritores, por su parte, contemplaban los periódicos como su fuente de ingresos principal, conscientes de que el mercado de libros era escasísimo. En el caso de que desempeñasen otra actividad laboral, el periódico significaba un sobresueldo. Pero, ante todo, la prensa permitía a los intelectuales divulgar y predicar sus ideas entre sus conciudadanos.

El periódico debía servir como educador de la opinión, no como su adulador. Los intelectuales españoles desempeñaron, consecuentemente, una función pedagógica. Regenerar España, sin ser arrastrados por el pesimismo del momento, sobreponiéndose a la adversidad, se convirtió en su asignatura pendiente. La acometieron con orgullo y disfrutando del reconocimiento así logrado.

Tal vez, quien mejor se amolda, en los años a los que venimos aludiendo, a la definición arriba expuesta del intelectual es, precisamente, Miguel de Unamuno. Fue un muy prolífico escritor de artículos periodísticos y un habitual conferenciante, con permanentes inquietudes políticas (militó en el socialismo hasta 1897) y sociales. Además, supo obtener enorme rédito económico de ambas actividades.

Políticos como Antonio Maura, al contrario que el Rector salmantino, rechazaron el papel de los periódicos como exponentes de la verdadera opinión pública.

\footnotetext{
92 JULIÁ, Santos: "Intelectuales y prensa en el siglo XX" en ALMUIÑA, Celso y SOTILLOS, Eduardo (Coords.): Op. Cit., Vol. 1, pp. 197-213.

${ }^{93}$ Citado en SEOANE, Mª Cruz y SÁIZ, Ma Dolores: Op. Cit., p. 62.
} 
En cierta ocasión, en 1904, durante el desarrollo de una sesión en el Congreso, apeló a las "masas neutras" porque quienes no leían periódicos sumaban más votos que sus lectores. Unamuno, apenas trascurridos unos días, argumentó que esa frase era una perogrullada: pese a que los que no leían periódicos eran mucho más numerosos que los que no sabían leer y, lógicamente, muchísimos más que los que sí leían, aquellos no tenían opinión; Unamuno apelaba al poder de los que "se agitan y se mueven y trabajan la opinión y leen periódicos". Insistiría, años después, en los beneficios derivados de la profesión periodística: “La prensa ha hecho que el público se haga público (...) es la que más ha contribuido a hacer conciencia popular nacional" ${ }^{94}$.

Ante el desarrollo de las campañas africanas muy pocos intelectuales permanecieron en silencio. $\mathrm{Su}$ posicionamiento ideológico ante la cuestión de Marruecos ha sido objeto de algunos análisis cronológicamente muy parciales, tales como los de A. Bachoud, P. Aubert o Bernabé López García y, más recientemente, el núcleo de la muy meditada tesis doctoral de Alhoucine Bouzalmate, que cubre el periodo $1912-1923^{95}$. Sus criterios para la selección de pensadores varían porque es muy difícil determinar hoy en día de cuánta notoriedad disfrutaron los autores elegidos entre sus coetáneos y más complejo aún es establecer una jerarquización ${ }^{96}$. Justificaba

\footnotetext{
${ }^{94}$ Ibidem., pp. 32-33. Procede la cita de un artículo escrito por Unamuno para El Sol, el 5 de mayo de 1932.

${ }^{95}$ Véase BACHOUD, Andrée: Op. Cit., pp. 335-363 y un resumen de la misma autora en el capítulo titulado "Los intelectuales y las campañas de Marruecos (1909-1913)" en TUÑóN DE LARA, Manuel, ELORZA, Antonio y LEDESMA, Manuel (Eds.): Prensa y sociedad en España. Madrid: Edicusa/Cuadernos para el Diálogo, 1975, pp. 271-181; AUBERT, Paul: "Los intelectuales y la cuestión marroquí (1914-1918)", Bulletin du Département de Recherches hispaniques Pyrenaica, n 30, Pau, 1984, pp. 19-32; LÓPEZ GARCÍA, Bernabé: Marruecos y España. Una historia contra toda lógica. Sevilla: RD Editores, 2007, pp. 229-261 y BOUZALMATE, Alhoucine: Op. Cit.

${ }^{96}$ Nos llama la atención el siguiente comentario de la investigadora francesa: "El artículo se inscribe en un tiempo determinado, único y fugitivo, el del día o la semana de su aparición, a veces prolongado por los ecos que suscita, pero siempre destinado, prescindiendo de su calidad, a desaparecer de la memoria del lector; el libro, por el contrario, tiene una densidad hecha de duración, la de su preparación, de su tiempo de publicación, del tiempo que se prolonga su venta y, más tarde, la de su presencia en la biblioteca de su lector. Implica, por tanto, una voluntad de compromiso mayor por parte de su autor y unas perspectivas más amplias de influencia que el artículo de periódico" (en p. 342). Consideramos un tanto apriorístico (incluso, anacrónico) subordinar esa actitud comprometida del editorial a la exhibida en un libro. A principios del siglo XX el mercado periodístico era más vigoroso que el de libros, la repercusión de los editoriales era superior a la actual (algunos llegan hasta hoy: ¿quién no recuerda los editoriales "Sin pulso", de Silvela, o el artículo "Neutralidades que matan"?) y los reporteros/intelectuales eran muy conscientes de su labor como orientadores del público lector. Por otro lado, buena parte de los libros que se editaron sobre la cuestión de Marruecos fueron recopilaciones, sin modificación alguna, de artículos periodísticos previos (casos como el de Eugenio Noel, Ortega y Gasset, Teresa de Escoriaza, Vila San-Juan, Prieto, Guixé, etc.). Por tanto, el compromiso que los intelectuales y escritores mostraron en sus editoriales lo siguieron manteniendo en sus libros posteriores.

Otra observación que debemos formular es que Bachoud insistentemente reconoce que muchos intelectuales y escritores españoles mostraron con relación a Marruecos un nacionalismo "crispado", "místico" o "espiritualista". Indudablemente, todos ellos se valieron de la prensa para caldear los ánimos
} 
este último investigador, Bouzalmate, la ausencia de clasificaciones ideológicas porque "las opiniones de los intelectuales no son definitivas ni categóricas. Cambian en función de las circunstancias" $"$.

Junto al aludido Unamuno, Isaac Muñoz, Eugenio Noel, Galdós, Maeztu, Pablo Iglesias, Baroja, Marcelino Domingo, Costa, Ortega y Gasset, Soriano, Azaña...todos formularon sus interpretaciones y quejas sobre el tema. $\mathrm{Y}$ todos contribuyeron a la conformación de una imagen pública muy marcada por lo bélico ${ }^{98}$. Sus artículos gozaron de enorme difusión, eran comentados en las tertulias y reproducidos en periódicos de lo más dispares. El editorial "La cuestión del Rif y la prensa", escrito por Costa e inserto en El Imparcial el 4 de octubre de 1909, fue también reproducido en España Nueva, El Liberal, El País, El Correo, El Diario de Huesca y El Radical.

Ya a la altura de 1909 Joaquín Costa admitía la posibilidad de que España renunciase a la "protección” de la zona marroquí que se le había asignado. Alejado de la vida política desde 1906, la entrevista que concedió en octubre de 1909 a un redactor de El Imparcial se convirtió en un emotivo alegato contra una guerra infructuosa. Parecía, al fin, haber perdido la fe en esa triple política africana de la que había hablado hacía décadas: política reparadora, política de intimidad y política de restauración ${ }^{99}$. Pérez Galdós acusaba un enorme partidismo, sobre todo manifiesto durante la campaña del ¡Maura, no! Unamuno, por su parte, contemplaba inicialmente Marruecos como la oportunidad para la reconstitución nacional, pero terminó decantándose hacia el abandonismo. También Ortega, que en 1911, trabajando para El Imparcial, había mostrado su conformismo con la política colonial de Canalejas, evoluciona hacia posiciones mucho más amargas y desbordantes de pesimismo. Maeztu defendía que sólo contaban con autoridad para abordar el tema marroquí los que hablasen árabe o hubiesen vivido en el país ${ }^{100}$. Azaña, después del descalabro de 1921 se muestra

francófobos. Pero cabe admitir que no fue una labor difícil, pues sí existió una base empírica para hablar de agresiones francesas.

${ }^{97}$ BOUZALMATE, Alhoucine: Op. Cit., pp. 17-18. Su análisis finaliza coincidiendo con el golpe de Estado de Primo de Rivera porque es entonces cuando, según su criterio, se impone una "opinión dominante y panegírica".

${ }^{98}$ MARTÍN, Miguel: Op. Cit., pp. 137-138.

${ }^{99}$ Muy lejana se percibía esa famosa sentencia costiana "el Estrecho no nos separa, como si fuese una cordillera; el Estrecho nos une, como si fuese un río".

${ }^{100}$ Elisa Pérez Molina recoge en su tesis doctoral una interesante cita de Maeztu: "al ser interrogado sobre su posición como intelectual respecto a Marruecos dirá: 'Pero, ¿qué conciencia pública puede haber sobre el problema de Marruecos, si nosotros mismos, los intelectuales, no sabemos nada?". Véase PÉREZ MOLINA, Elisa: Op. Cit., p. 29. 
absolutamente derrotista y, para terminar, Baroja ocupó siempre una muy clara posición $\operatorname{antimilitarista~}^{101}$.

La publicidad de una opinión (ya sea de un intelectual, un enviado al frente de batalla, el miembro de la redacción de un periódico o su mismo director) puede ser la consecuencia de su interés público. Sin duda, Marruecos constituyó una preocupación recurrente de los españoles después de 1898. Se ha pretendido mostrar, a lo largo de este capítulo, que la prensa jugó un papel trascendental en la España del primer cuarto del siglo XX. Sirvió, a través del desempeño de esa función de agenda setting, como guía o faro de la opinión pública y también, aunque sospechamos que en menor medida, como reflejo o espejo de la misma.

Y no sólo en el asunto de las campañas marroquíes. Aunque éste constituirá nuestro centro de interés en las páginas siguientes.

En 1914, alguien que firmaba con el pseudónimo Un Africanista Más se interrogaba acerca de las reacciones suscitadas por la guerra en la gente. Esto es lo que escribió:

"Muchas veces nos ha preocupado el caso de un ciudadano español de buena fe, patriota y deseoso, por encima de todo credo político, del engrandecimiento de la nación, que se haya puesto a meditar sobre el problema de Marruecos. ¿Qué opinión habrá formado acerca de él con los elementos de juicio que hasta ahora han puesto a su disposición las informaciones periodísticas, las declaraciones de los políticos y hombres de gobierno, las manifestaciones de los mítines y las réplicas de los militares? (...) ¿Qué opinión puede tener de Marruecos ese supuesto excelente ciudadano, que no ha pasado ni piensa pasar el Estrecho, para enterarse por sí mismo de lo que hay en la otra orilla? Él se atiene a los hechos, y éstos son bien poco satisfactorios; como además, entre el polvo de la pelea entablada se le escamotean las responsabilidades, que sospechan deben ser muchas y muy graves, pero de las que no ha oído hablar, desiste de formar juicio porque no quiere volverse loco, y decide no volver a ocuparse de la cuestión, asqueado de Marruecos, de la zona de influencia y del Tratado. Así se elabora el desdeño, mejor dicho, la repugnancia de la nación entera a las cosas de África. Nosotros conocemos a un señor culto y bueno que no lee en los periódicos tres cosas: los toros, los crímenes y las guerras" $" 102$.

Ciudadano de buena fe, patriota, engrandecimiento de la nación, informaciones periodísticas, declaraciones gubernamentales, mítines, réplicas militares, hechos poco satisfactorios, responsabilidades... Y, sobre todo, asco, repugnancia hacia la cuestión marroquí. Compartimos con Un Africanista Más toda esa curiosidad. Por eso nos preguntamos si ese asco fue siempre la reacción imperante y hasta qué punto la prensa contribuyó a crear ese clima de confusión, de locura, al que más arriba se alude.

\footnotetext{
${ }^{101}$ SAHAGÚN, Felipe: Op. Cit., pp. 171-172.

${ }^{102}$ Un africanista más: La guerra y el problema de África. Unas cuantas verdades. Burgos: Tipografía de Marcelino Miguel, 1914, pp. 5-7.
} 
Los motivos por los que se ha elegido Salamanca ya han quedado expuestos en la introducción. 


\section{SALAMANCA Y LOS INICIOS DE LA AVENTURA COLONIAL: DE} ALGECIRAS A LA GUERRA DE MELILLA (1906-1909)

\section{AQUELLA CIUDAD EN AQUELLA ESPAÑ̃...}

"Cuenta, no sé si un historiador o un guasón, que la zarina de Rusia, Catalina I, se propuso visitar su imperio para aprender de visu las necesidades de sus súbditos y remediarlas en lo que de ella dependiera. Y añade que el primer ministro de dicha soberana (...) alquiló millares de rusos, construyó pueblos transportables, pintó decoraciones que parecían naturales, y la zarina (...) ratificó a aquellos su confianza y no volvió a hacer caso de las quejas de cuatro descontentos. ¿Que por qué recuerdo esto? Por el tacto de codos que el gobierno aconseja a los gobernadores civiles tengan con el pueblo. El ministro quiere que sus representantes visiten las localidades que estimen oportuno: pregunten e inquieran las necesidades de sus habitantes (...) Y los gobernadores, seguramente, procurarán cumplir las órdenes de su superior. Pero toda su buena voluntad se estrellará, y si no al tiempo, en la conspiración que los caciques de mayor y menor cuantía urdirán para que las cosas sigan como están. Los caminos se arreglarán para que en un día determinado puedan transitar carruajes, aunque a diario se atranquen carros y caballerías; las escuelas estarán limpias y a ellas asistirán los niños; los Ayuntamientos serán balsas de aceite; las calles lo parecerán y no fangales indecentes, y durante horas, las que el gobernador esté en cada pueblo, la vida local será remedo de lo que debiera ser siempre,"1.

El periodista Manuel Rubio escribía estas líneas en marzo de 1909, en El Adelanto, y a la espera de que se cumpliesen unas recientes instrucciones del ministro La Cierva. Pretendía éste pulsar el ambiente político del país previo a unas elecciones, pero, evidentemente, el redactor tenía la convicción de que la España real era una absoluta desconocida para la España oficial. O, expresándolo de otro modo, que las élites de la Corte carecían de "anclajes" en la calle.

Es, sobre todo, en los últimos renglones de la anterior cita donde queda perfectamente retratada Salamanca: porque aquí, en esta urbe meseteña, ya se ha apuntado, las deficiencias en los servicios públicos estaban generando un problema sanitario de proporciones alarmantes y que la prensa local denunciaba de continuo.

Sin embargo, nuestra ciudad no constituía, desde luego, un caso excepcional en la España de la Restauración; tan sólo uno más. Y tan digno de estudio como cualquier otro: ¿podremos nosotros aproximarnos a esa Salamanca real?, ¿podremos entender cómo vivieron los salmantinos el cataclismo de 1909 ?

En la memoria histórica de muchos españoles este año aparece asociado a un gran descalabro militar en Marruecos: el Desastre en el Barranco del Lobo. El 9 de julio de 1909, por primera vez a lo largo del cruento siglo XX, España participó en una batalla en suelo africano. Esta batida fue la fulminante contestación de la Comandancia General de Melilla al ataque rifeño sobre un pequeño grupo de obreros, empleados en la

\footnotetext{
1 “Uno": "De cursiva. Tacto de codos", El Adelanto, no 7.586, 10 de marzo de 1909, p. 1.
} 
construcción de un puente para el ferrocarril en Beni Enzer, muy cerca de la Mar Chica. Seis trabajadores fallecieron, así que, tal y como dictaban los cánones del momento, se imponía la necesidad de vengar el agravio.

Aunque en Salamanca nada parecía presagiar un desastre, desde hacía ya meses, ciertas noticias que circulaban por los periódicos de Madrid y Melilla advertían que algo inusual estaba ocurriendo en Marruecos. También a esas anomalías aludió el liberal Miguel Villanueva durante una sesión del Congreso, en mayo de aquel año:

"Una fuerza militar marroquí dependiente de una autoridad acompañada, según se dice, de algunos oficiales franceses vestidos con el traje moro y llevando en su compañía interesados en alguna de las sociedades mineras francesas, atravesó el Muluya y se acercó a Zeluán, camino de las minas de Beni-bu-Ifrur, y hubo de retirarse por encontrar alguna resistencia en parte de aquellas cábilas, pero anunciando el propósito de volver hasta realizar el plan que se había propuesto "2.

En repetidas ocasiones, durante el siglo XIX, tanto Ceuta como Melilla habían sido objeto de agresiones por parte de los cabileños, siempre reacios al progresivo aumento de la influencia extranjera en su tierra. De igual forma, venía siendo habitual que los piratas rifeños atacasen las embarcaciones españolas, al tiempo que el Sultán hacía oídos sordos ante las subsiguientes reclamaciones. Por estas razones empezó, paulatinamente, a abrirse camino entre los gobernantes madrileños la idea de una respuesta bélica a las agresiones. Las fricciones entre la cábila de Anyera y las autoridades ceutíes condujeron a un primer enfrentamiento armado en 1859 -parece que los cabileños destrozaron las obras de un nuevo puesto de guardia y profanaron con excrementos el escudo de España-; y una segunda "campaña patriótica”, popularmente conocida como la Guerra de Margallo, se vivió en 1893, en las inmediaciones de Melilla, cuando otros trabajos de fortificación, en esta ocasión muy próximos a un morabito, fueron desbaratados por los rifeños.

Aquí, en territorio peninsular, ambas campañas sirvieron para avivar el arraigado sentimiento popular de odio hacia el moro. De sobra es sabido que casi toda la prensa se esmeró en espolear a la opinión en esta dirección, presentando ambos conflictos como cruzadas. Una vez emprendido este camino hacia la aventura y el falso prestigio, la idea del "destino magrebí" empezó a cobrar vigor. El siempre tan agudo embajador Alfonso de la Serna comentaba al respecto: "España era un país en crisis y Marruecos era un país en caos. Lanzarse a la aventura marroquí, ignorando casi todo de nuestras posibilidades y de las realidades profundas de la sociedad marroquí, era igual que

\footnotetext{
${ }^{2}$ Esta cita aparece en PASCUAL MARTÍNEZ, Pedro: “Prensa...", Op. Cit., pp. 69-70.
} 
abrir la puerta a 'paces chicas', 'semanas trágicas', 'barrancos' siniestros y 'desastres' militares"'.

Sin embargo, a la altura de 1909, las circunstancias en que se desarrollarían unos nuevos avances militares serían muy distintas. Empecemos recordando los hechos más conocidos: el regeneracionismo conservador -sobre todo simbolizado en los proyectos de ley de Justicia Municipal, de Reforma Electoral y de Administración Localatravesaba sus horas más bajas, desgastado por un polémico Proyecto de Ley Antiterrorista que había aunado los intereses de liberales, republicanos y algunos periodistas. Pese a todo, donde Maura hallaría finalmente su talón de Aquiles sería en Marruecos: la decisión de respaldar la intervención del general Marina en los alrededores de Melilla tropezó con el rechazo de muchos. Por eso, en cuanto tuvo ocasión, al abrirse las Cortes, la oposición acusó al presidente de actuar en defensa de exclusivos intereses privados.

Si bien es cierto que el gobierno nada hizo por atraerse a la opinión pública, es lícito preguntarse si toda la prensa mantuvo una posición contraria a la acción bélica. No buscar el respaldo de la misma, escudarse únicamente en el empleo de la censura, fue un tremendo error de cálculo por parte del político mallorquín. Pese a que él subestimó el poder de los rotativos, los hechos demostraron que debía contar con ellos. El Trust y los órganos de la izquierda no dejarían pasar por alto la oportunidad para desacreditarle, sobre todo, con motivo del procesamiento y ejecución de Francisco Ferrer y Guardia.

Valga como ejemplo ilustrativo el siguiente editorial, del 12 de julio, en el que La Correspondencia de España exhibía, con ayuda de la pluma de Leopoldo Romero, toda su furia:

“Contra un país es imposible luchar. Y España no quiere oír hablar de Marruecos. A excepción de media docena de caballeros políticos, de unos cuantos bolsistas de sube y baja y de otros cuantos pescadores a ríos revueltos, nadie desea ni aventuras, ni provocaciones, ni ocupaciones innecesarias, ni expediciones fuera de tiempo y de lugar... Supongamos que nuestras tropas salen de Melilla y ocupan diez, 20, 30, 100 kilómetros. Ya están ocupados. ¿Y qué? Pues para nada. Absolutamente para nada, como no sea para gastar una centena de millones, que aqui hacen mucha falta y que alli no servirán para nada... No lo olviden los gobiernos que gobiernan y los reyes que reinan. Mil veces más peligroso que no ir a Marruecos será ir".

¿Qué estaba ocurriendo? ¿Dónde se hallaba Beni-bu-Ifrur? ¿Cuál era ese plan al que se refería Villanueva y qué hacían los franceses en las cercanías de Melilla? ¿Por

\footnotetext{
${ }^{3}$ SERNA, Alfonso de la: Op. Cit., pp. 175-176.
} 
qué esa advertencia al Rey? La incertidumbre estaba sembrada; y también el pánico: la llamada a los reservistas, con un Real Decreto, el 11 de julio, fue la desencadenante de la Semana Trágica de Barcelona. Además de tener que separarse de sus familias, la forma de reclutamiento, muy perjudicial para la gente sencilla, ocasionaba un enorme sentimiento de rechazo entre los mozos. Respondieron, consecuentemente, al decreto con protestas y aunque en Madrid la revuelta pudo ser prontamente sofocada, la situación no se repitió en la ciudad catalana.

Mientras tanto, desde el 20 de julio los ataques rifeños se aproximaron peligrosamente a Melilla. Tras una primera emboscada en el barranco de Alfer, el 27 de julio la brigada de Cazadores de Madrid, bajo el mando del general Pintos, que estaba vigilando las estribaciones del Gurugú, fue aniquilada en el Barranco del Lobo. Se contabilizaron un total de 752 bajas, sumando fallecidos y heridos ${ }^{4}$.

Alfonso de la Serna llamó la atención a propósito del modo en que se procedió a la ampliación de la zona bajo control militar español durante estos años: las iniciativas expansionistas siempre partieron desde Melilla -luego, con el transcurso de los años, también desde Ceuta-, que en términos jurídicos, no era costa marroquí, sino territorio soberano español. Así, entre los militares se empezó a producir una cierta confusión entre territorios "soberanos" y "protegidos", como si ambos fuesen lo mismo ${ }^{5}$. Sin duda, ésta sería, desde la perspectiva militar, una de las principales consecuencias de la campaña de 1909.

Ahora bien, ¿Cómo se había llegado a aquella dramática situación? ¿Quién había conducido a unos compatriotas hasta los tan inhóspitos parajes marroquíes?

Pero, sobre todo, y atendiendo al objeto de la presente tesis: ¿Qué sabían los salmantinos de toda esta historia? ¿Cuáles eran sus intereses en la región? ¿Qué opinarían de la guerra que se cernía sobre su horizonte? ¿Entenderían sus orígenes? ¿La apoyarían? ¿O se opondrían a ella?

Por de pronto, en aquellos aciagos días de julio de 1909, noticias contradictorias, confusos testimonios y absurdos rumores llegaban a Salamanca en tropel, circulaban de boca en boca y acrecentaban el estado de perplejidad de un público entre molesto y afligido. Sin embargo, para responder a las cuestiones arriba planteadas, es preciso remontarse algunos años atrás en el tiempo.

\footnotetext{
${ }^{4}$ MADARIAGA, Rosa María de: En el Barranco... Op. Cit., p. 54.

${ }^{5}$ SERNA, Alfonso de la: Al sur de Tarifa. Marruecos-España: un malentendido histórico. Madrid: Marcial Pons, 2001, p. 218.
} 


\section{ANTECEDENTES: LOS PRIMEROS TRATADOS PARA EL REPARTO DE MARRUECOS}

\section{El Tratado non nato de 1902 a través de la prensa salmantina}

Hasta 1909 sólo muy puntualmente Marruecos había acaparado la atención de los españoles. En Salamanca, concretamente, las noticias sobre el Sultanato habían llegado con cuentagotas, incluidas, por norma, en la sección de información telegráfica de la prensa local, y casi siempre refiriéndose a la débil posición del Sultán, amenazado por el rebelde de turno, o bien calumniando la conducta de la administración parisina.

Por supuesto, esta "sequía" informativa no saciaba la curiosidad ni, mucho menos, las expectativas de las empresas periodísticas salmantinas. Una intensísima y extraordinariamente compleja historia diplomática se estaba desarrollando entre bastidores: las cancillerías europeas vivían, al emprender su andadura el nuevo siglo, continuamente agitadas en torno a la cuestión marroquí, pero ni las agencias ni, por extensión, los periodistas y reporteros tuvieron apenas acceso a ello; y, de ahí, su proclividad a la especulación. La opinión pública estaba siendo ninguneada. En el capítulo anterior, recuérdese, señalamos que el derecho a la libertad de expresión se hallaba durante la Restauración muy regulado y limitado. Hemos topado con uno de esos límites: la gestión de la política exterior y, más en concreto, el tratamiento de los conflictos diplomáticos.

Tenemos que retrotraernos a septiembre de 1902 para encontrar la primera referencia, en Salamanca, a la inminente intervención de España en Marruecos a través de una alianza internacional. Entonces, un redactor enviado a Madrid, José Bermúdez, comunicaba al director de El Adelanto:

"Mi querido Director: La comidilla del día en la Corte es la próxima y probable alianza. Hay diplomáticos de menor cuantía que aseguran ser ya un hecho el abrazo de España, Francia, Rusia e Italia, con la ayuda de Mónaco. Y hay ministro de Estado (...) que da como cosa cierta el matrimonio de nuestra nación con Inglaterra y Alemania. Los hombres sensatos, los cerebros firmes, predican sin descanso la discreción más absoluta y afirman que en las cuestiones internacionales no deben mezclarse para nada las masas. Y, a mi juicio, tienen razón (...) ¿Qué tiene que ver la masa (esa colección indocta de mendrugos) con los gastos, sacrificios y riesgos que trae consigo el codearse con las grandes potencias? ${ }^{\prime 6}$.

Bermúdez indicaba, por tanto, la existencia de dos bloques de poder enfrentados y presentaba al gobierno madrileño como más propenso a unirse al grupo conformado por Inglaterra y Alemania. Pero la información ni se comprendía fácilmente - ¿de dónde

\footnotetext{
${ }^{6}$ José Bermúdez: “Crónicas madrileñas”, El Adelanto, no 5.446, 16 de septiembre de 1902, pp. 1-2.
} 
salían esas alianzas?- ni estaba confirmada. Sólo era la "comidilla de la Corte". Además, de forma aparentemente gratuita, las masas eran retratadas como estúpidas y absolutamente ajenas a los vericuetos de la política internacional. Seguramente, porque con ese "aguijonazo" se pretendía lograr la imagen opuesta: la de una muchedumbre picada por la curiosidad. Y el rumor, he aquí el concepto clave, era el camino más breve y efectivo para conseguirlo. El Adelanto buscaba alertar a sus lectores sobre lo que se estaba cociendo.

Para que proliferen los rumores, no obstante, se requieren dos condiciones: que el tema al que se alude suscite interés público y que sobre ese asunto reine la falta de información y la ambigüedad. Eso es precisamente lo que revela esta carta: desconocimiento, confusión. Por otra parte, desde luego, a la altura de 1902, el hecho de que España pudiera integrarse en una alianza internacional preocupaba. Por eso la diplomacia rehuía de la prensa. Este pacto podía conducir a la guerra y, al fin y al cabo, sólo habían transcurrido cuatro años desde el Desastre de 1898.

David Senabre López se ha ocupado, en un trabajo monográfico, del estudio de las contiendas de Cuba y su repercusión en Salamanca ${ }^{7}$. No vamos a insistir, por tanto, en esta cuestión. Nos conformamos con recordar dos de sus conclusiones: que tanto el Ayuntamiento como la prensa local -El Adelanto y El Lábaro son los rotativos que emplea el autor- hicieron ostentación de una actitud muy belicosa ante los EEUU y promovieron multitud de iniciativas solidarias; $y$, en segundo término, que tras la derrota, El Adelanto se decantaría hacia actitudes mucho más pragmáticas ${ }^{8}$. En suma: transcurridos cuatro años, el momento seguía sin presentarse, ante los ojos del periódico liberal, como oportuno para un compromiso internacional.

Conviene aclarar que las pretensiones españolas respecto a Marruecos, durante los primeros años del siglo $\mathrm{XX}$, oscilaron desde el respeto a su statu quo hasta el deseo manifiesto de intervención. Terminaría imponiéndose esta última aspiración como corolario, en buena medida, del juego de equilibrios establecido entre las grandes potencias coloniales; pero también como consecuencia de la situación interna marroquí.

\footnotetext{
${ }^{7}$ SENABRE LÓPEZ, David: Salamanca en 1898. Salamanca: Ayuntamiento de Salamanca, 1998.

${ }^{8}$ Ibidem, p. 91. El autor reproduce este interesante fragmento: "Ha pasado la época de la espada y la lanza (...) No hay pues que olvidarse de que una nación no es grande y fuerte por su extensión, por sus millares de soldados y sus numerosos buques de guerra (...) una nación es grande, lo ha dicho un sociólogo recientemente, cuando produce lo más posible, tanto en concepto económico como en el intelectual", en J. F. Gascón: "Hábito de trabajo", El Adelanto, 6 de noviembre de 1898, p. 1. Pero, ¿a quién se le había de vender toda esa producción? Parece irrebatible que este discurso se hallaba en las antípodas ideológicas del pensamiento darwinista que entonces arrasaba en Europa.
} 
Dos inquietantes materias absorbían el pensamiento de los profesionales de la diplomacia al alumbrar el siglo: las bautizadas como "la cuestión de Oriente" y "el reparto de África". Este continente, gracias a las numerosas expediciones de científicos y misioneros, había dejado de ser un desconocido para convertirse en un objeto de deseo, la joya que todos codiciaban. Para la promoción de estas exploraciones, nacieron muchísimas sociedades geográficas y asociaciones coloniales. Gradualmente, algunos de esos viajes dieron paso a ocupaciones, así que en 1885, por primera vez, en la Conferencia de Berlín, tuvieron que ser examinados los numerosos pleitos geográficos suscitados por los asentamientos en posiciones costeras. De aquí, de esta reunión, salió el principio rector de un nuevo imperialismo: el derecho a la penetración territorial fundamentado en la ocupación; y no en el descubrimiento, en la historia ${ }^{9}$. El darwinismo político era el cimiento del imperialismo, la filosofía que legitimaba el empleo de la fuerza: la creencia en la superioridad racial y cultural del hombre blanco occidental, llamado a civilizar el resto del mundo ${ }^{10}$. Con la aplicación estricta de este dogma, de la ley de la selva, las únicas esperanzas coloniales que le restaban a España en África eran la península de Río de Oro y Guinea Ecuatorial.

En España, sin embargo, los contenidos ideológicos de ese imperialismo fueron asimilados de un modo dificultoso y limitado. La Porte, de hecho, lo bautizó como "imperialismo de supervivencia": carente de tradición en el Mediterráneo Occidental desde que se descubriera América, sin objetivos claros y sin demasiado respaldo social. Por ello, no sirvió para redimir a la raza española, tal y como soñaban los regeneracionistas, sino para desencadenar crisis $^{11}$.

\footnotetext{
${ }^{9} \mathrm{M}^{\mathrm{a}}$ del Carmen González Velilla explica este nuevo proceso de redistribución territorial insistiendo en que la concurrencia entre las grandes potencias industriales, la avidez de mercados reservados en exclusiva, el desarrollo de las industrias navales y de armamento, la misma evidencia de que la conquista y ocupación de territorios había dejado de ser materia de iniciativa autónoma para transformarse en objeto de agrias negociaciones que sólo la fuerza podía respaldar, constituían los principales condicionamientos de la política colonial. Véase GONZÁLEZ VELILLA, Mª del Carmen: Op. Cit., p. 23.

${ }^{10}$ Recomendamos para una explicación más amplia de las secuelas de los imperialismos la lectura de PARDO, Rosa: "Colonización e imperialismo", en VVAA: Historia política y social moderna y contemporánea. Madrid: UNED, 2001, pp. 395-421. He aquí su sintética y meridianamente clara visión de los factores económicos que coadyuvan a la dominación imperial (pp. 405-406): "Primero los grupos financieros prestan dinero y asumen el control de las finanzas de un país, cuyo mercado abren a la economía metropolitana; mientras, los diplomáticos despejan el camino de la intervención. Luego los bancos imponen durísimas condiciones que las autoridades locales no pueden cumplir. La intervención militar se realiza a fin de controlar las aduanas para garantizar el pago de la deuda. Después llega el control de todo el sistema financiero y, por fin, la ocupación territorial".

${ }^{11}$ LA PORTE, Pablo: "Liberalismo y política colonial en la Restauración: la zona de influencia de España en Marruecos (1898-1931)" en SUÁREZ CORTINA, Manuel: Las máscaras de la libertad. El liberalismo español, 1808-1950. Madrid: Marcial Pons, 2003, pp. 471-490.
} 
Tras este pacto se inició una feroz y frenética batalla entre viejas y nuevas potencias, las dying nations y living nations del famosísimo discurso de Salisbury, por el reparto del Continente Negro: una lucha siempre atenta a la defensa de los intereses nacionales respectivos y, también, en todo momento, pendiente de la búsqueda del equilibrio de poderes en la convivencia internacional. Porque nacionalismo y equilibrio son las aspiraciones claves de la Europa de Bismarck ${ }^{12}$. Y una lucha, además, que acabó por transformar la secular rivalidad franco-británica en una crisis abierta cuando sus "ejes de avance" por África chocaron.

A pesar de esos deseos de equilibrio, ni Bismark ni el encuentro en Berlín pudieron evitar que, con el paso de los años y el acrecentamiento de los imperios, el régimen de concierto entre cinco potencias europeas diera paso a un sistema mundial de superpotencias militares.

Desde 1830 Francia estaba asentada en Argelia y asumía que Marruecos y Egipto constituían el espacio natural para su expansión en el Norte de África. Mientras tanto, Gran Bretaña velaba por la construcción de un eje Norte-Sur en ese continente y por el control del tráfico comercial mediterráneo a través de Gibraltar y Suez ${ }^{13}$. El desagradable e inevitable encontronazo entre ambos países se produjo en julio de 1898, en un pueblo sudanés: Fashoda. A punto de escucharse el tronar de los cañones, Salisbury y Delcassé se avinieron a negociar y Francia claudicó. Renunció a Sudán a cambio de algunas compensaciones.

Es difícil adivinar si esa vieja enemistad anglo-francesa hubiera persistido sin la entrada en escena de un tercero en discordia: Alemania. Quizás, tras una crisis tan seria como la habida en Fashoda, de las relaciones franco-británicas únicamente cabía esperar una mejora ${ }^{14}$. Sin embargo, estamos convencidos de que a la opinión pública salmantina le resultó imposible intuir el inicio de ese acercamiento. Porque lo que se publicaba en la prensa no apuntaba en esa dirección. Cuando Bermúdez escribía su crónica para el director de El Adelanto, casi un lustro después del incidente, Francia e Inglaterra figuraban todavía en bloques de poder enfrentados: para el corresponsal aún no resultaba visible el verdadero juego de alianzas.

\footnotetext{
${ }^{12}$ PABÓN, Jesús: Cambó. Volumen II, $1^{a}$ parte, Barcelona: Editorial Alpha, 1952, p. 242. Una brevísima presentación de los tratados sancionadores del reparto de Marruecos en MARTíNEZ CARRERAS, José U.: "España y Marruecos a comienzos del siglo XX" en MARTíNEZ CARRERAS, J. U. (Coord.): Relaciones entre España y Marruecos en el siglo XX. Madrid: Asociación Española de Africanistas, 2000, pp. 9-21.

${ }_{13}^{13}$ MOHA, Edouard: La relaciones hispano-marroquíes. Málaga: Editorial Algazara, 1992, p. 73.

${ }^{14}$ Consúltese ALLENDESALAZAR, José Manuel: La diplomacia española y Marruecos, 1907-1909. Madrid: MAE y Agencia Española de Cooperación Internacional, 1990, p. 9.
} 
Pero la nueva orientación que Guillermo II estaba imprimiendo a la política exterior germana, desde su llegada al trono en 1888, allanaría el camino hacia el entendimiento entre Gran Bretaña y Francia. Con el tiempo, contribuirían a alicatar su unión (que también incluiría a Rusia). Porque el joven káiser era un joven impulsivo, arrogante e inseguro; quizás debido a que vivía acomplejado por un defecto de nacimiento en su brazo izquierdo ${ }^{15}$.

Después de la humillación en Fashoda, "el 98 francés", simbolizado con la retirada de las tropas del general Marchand, Francia concedió a los asuntos marroquíes un creciente protagonismo, asumiendo que el avance hacia Egipto le estaba vedado. Fue aquí, en Marruecos, donde volcó todas sus esperanzas coloniales, a sabiendas de que, hasta entonces, España era el único país que podía mediante la expansión de sus hinterlands alrededor de Ceuta y Melilla ampliar su campo de seguridad y emprender negociaciones con el Sultán, como nación europea más favorecida para ello. Sin embargo, pese a esta situación ventajosa de partida, no sería España la que obstaculizase la realización de las aspiraciones francesas en Marruecos. En cambio, el gobierno galo chocaría, de continuo, con los intereses alemanes.

El órgano de Núñez Izquierdo, El Adelanto, fue el único que destinó un mínimo espacio a esta noticia internacional en 1902 y el único que se asustó ante lo que podía avecinarse en caso de que España vinculase sus intereses con los franceses. Una semana después de publicarse la carta de Bermúdez, llegó a la redacción un telegrama de la Agencia Almodóvar con información mucho más precisa. Ya se hablaba abiertamente de un convenio hispano-galo y se señalaba que no había sido ultimado debido a algunas cortapisas parisinas ${ }^{16}$. Pero no se explicaban los puntos del mismo y la reserva nuevamente se impuso hasta que terminó el año.

Ocurría que una vez fijado Marruecos como gran objetivo, Delcassé, ministro francés de colonias de 1894 a 1895 y de asuntos exteriores entre 1898 y 1905, además de conocido germanófobo, había tomado la iniciativa en la firma de una serie de

\footnotetext{
${ }^{15}$ Ibidem, p. 16. Las relaciones entre Guillermo II y su tío, Eduardo VII de Inglaterra, nunca fueron fluidas. El estudioso José Manuel Allendesalazar afirmaba que el Rey inglés se complacía mostrándole a su sobrino el abismo existente entre las civilizaciones inglesa y alemana.

16 "Telegramas", El Adelanto, $\mathrm{n}^{\circ}$ 5.452, 22 de septiembre de 1902, p. 3. Este era el telegrama remitido por la Agencia Almodóvar: "Madrid 22. La Correspondencia de España afirma haber oído al marqués de Valdeiglesias asegurar que están aprobadas, por los dos gobiernos, las bases para un tratado de alianza franco-española. Parece que si no se ha ultimado ya el convenio, ha sido por las pretensiones que Francia tiene de que en las plazas de Mahón y Ceuta se pusieran guarniciones mixtas, compuesta de tropas españolas y francesas".
} 
acuerdos bilaterales para legitimar la ocupación francesa: con Italia, Francia firmó un pacto en diciembre de 1900 y otro, en noviembre de 1902.

España, por su parte, había aprendido del conflicto antillano que no podía continuar aislada en materia de política internacional. Necesitaba una garantía exterior para sus dominios insulares porque sentía pánico ante la posibilidad de verse involucrada en una guerra entre potencias europeas. Consecuentemente, se iniciaron algunos contactos con Inglaterra. Pero ante las desmesuradas exigencias de ésta verdaderamente leoninas-, que prometía protección a cambio de la indefensión de Sierra Carbonera, la ocupación transitoria de la bahía de Algeciras y de las bases navales de Baleares y Canarias, Sagasta prefirió negociar con Francia ${ }^{17}$.

Los gabinetes de París y Madrid, firmaron un Tratado en 1900 por el que se reconocían las posesiones de éste en Guinea y el Sáhara Occidental; y dos años después, nuevamente, Francia y España negociaron otro Convenio para el reparto de influencias sobre Marruecos.

Detengámonos en el análisis del documento, finalmente no ratificado, de 1902: el territorio que Francia asignaba a España era inmenso, pero a sabiendas de que se trataba de una potencia débil y, previsiblemente, el poder galo toparía con nulas restricciones para la ampliación de sus competencias. La propuesta inicial francesa no incluía la ciudad de Fez, pero hubo de ser modificada ante la perseverancia del embajador León y Castillo (siempre recordado por esta famosa sentencia: "La cuestión de Marruecos se resolverá en breve con nosotros o sin nosotros, y en este caso, contra

\footnotetext{
${ }^{17}$ Aunque el gabinete español tranquilizó al inglés con el compromiso de no levantar fortificaciones en las inmediaciones de Gibraltar (a Gran Bretaña le obsesionaba su posesión no porque fuese todavía la fortaleza que dominaba el Estrecho - ya había submarinos-, sino porque servía como refugio para su flota en caso de avería y cuando necesitasen carbón y municiones). Y es que durante el conflicto con los EEUU, ante una amenaza de la escuadra americana sobre las costas españolas, el gobierno inició unos trabajos de artillado en posiciones muy próximas al peñón. Véase sobre el problema de la garantía internacional de las posesiones españolas ROBLES MUÑOZ, Cristóbal: "España y Marruecos: antecedentes de los Acuerdos con Francia (1898-1904)" en DÍEZ TORRE, A. R.: Ciencia y memoria de África: Actas de las III jornadas sobre expediciones científicas y africanismo. Madrid: Servicio de Publicaciones de la Universidad de Alcalá de Henares, 2002, 197-228; también ROSAS LEDEZMA, Enrique: "Las relaciones hispano-británicas a comienzos del siglo XX: los caminos del entendimiento", Revista de Estudios Internacionales, $\mathrm{n}^{\circ}$ 1, Madrid, 1980, pp. 53-60; y TORRE DEL RÍO, Rosario de la: "Entre 1898 y 1914: La orientación de la política exterior española" en VVAA: Política española y política naval tras el Desastre (1900-1914). Cuadernos monográficos del Instituto de Historia y Cultura Naval, $\mathrm{n}^{\circ}$ 15, Madrid, 1991, pp. 7-21. De la misma autora es esta colaboración en una obra colectiva: "De ultramar a la frontera meridional. Iniciativas en busca de una garantía internacional para España, 18981907” en GÓMEZ FERRER, G. y SÁNCHEZ, R. (Eds.): Modernizar España. Proyectos de reforma y apertura internacional (1898-1914). Madrid: Biblioteca Nueva, 2007. Ella es quien más insiste en lo paradójico de que tras una larga etapa política de orientación hacia Alemania, España intentase recurrir, en 1898, al socorro de Francia, Gran Bretaña y Rusia. También en sus trabajos es notoria la voluntad de relativizar la significación de los Acuerdos de Cartagena.
} 
nosotros"); en cambio, la proposición original sí incluía la cesión de Tánger, aunque se anunciaba una posible neutralización en el futuro.

Sin embargo, terminadas las negociaciones, León y Castillo escribió al ministro de Estado confesándole cierta sorpresa ante una de las consultas francesas. Y es que ésta ponía en entredicho la apariencia pacífica del Convenio: Delcassé solicitaba que, mientras se conservase el statu quo marroquí, ambos países se informasen de cualquier acción militar que decidiesen emprender ${ }^{18}$. Ni Sagasta, primero, ni Silvela, que formó gobierno el 6 de diciembre de 1902, se atrevieron a firmar este Tratado, por el temor a una mala reacción británica. Creían que la inteligencia franco-española acarrearía la automática enemistad inglesa. Silvela asumió la responsabilidad (aunque estando en la oposición había escrito un famoso artículo en el que apostaba por un intervencionismo decidido). Pero fue Abárzuza, el ministro de Estado, quien rechazó tajantemente el documento, al tiempo que Maura, en la cartera de Gobernación, confesó que esa firma le habría quitado el sueño ${ }^{19}$.

Esta negativa ha sido objeto de multitud de investigaciones y de una dilatadísima y encendida polémica historiográfica. El trato maquinado en 1902 fue el único ventajoso para los españoles, el único que diseñaba un reparto medianamente equitativo (no en superficie, pero sí en número de habitantes y en distribución de competencias) con Francia. Hasta el punto de que había despertado infinidad de recelos entre el grupo colonialista francés. Quizás, por esta razón, Francia intentó mantenerlo oculto. Ahora bien, para explicar la generosidad de Delcassé, hay que recurrir a la más que plausible hipótesis de que Francia estaba actuando coaccionada por alguien: Gran Bretaña era el árbitro de la situación. Ese Convenio, pese a todo, no amenazaba las aspiraciones inglesas sobre el Estrecho ni sobre Tánger. Si el Acuerdo se rechazó fue porque el entendimiento franco-británico era insospechado entre los políticos españoles. No se imaginaron que el 98 francés acabaría con la secular enemistad de ambos países como tampoco supieron interpretar que Inglaterra atravesaba por una fase de relativo descrédito militar, tras su duro enfrentamiento con los bóers, y ello le servía como acicate para buscar nuevos aliados.

\footnotetext{
${ }^{18}$ RAMIRO DE LA MATA, Javier: Op. Cit., p. 105. El autor reproduce una carta escrita por León y Castillo el 23 de noviembre de 1902.

${ }^{19}$ Entre los historiadores actuales que más enfáticamente denuncian la negativa a firmar el Convenio de 1902, consúltese SALAS LARRAZÁBAL, Ramón: El Protectorado de España en Marruecos. Madrid: Mapfre, 1992, p. 76.
} 
Al concluir 1902, como ya anunciamos, nuevamente la prensa salmantina se hace eco de los asuntos del Sultanato. Aunque en esta ocasión adquiere tintes más dramáticos, pues ahora se habla de preparativos militares por parte de la administración española ante la actitud hostil de El Rogui. Simultáneamente, se alude a cierto nerviosismo reinante entre los círculos oficiales y periodísticos en Francia, Inglaterra y Alemania. Los tres gobiernos se atrincheraban en la defensa del statu quo y rogaban que Madrid se abstuviese de intervenir:

"Madrid 31. El gobierno español continuará los aprestos militares en previsión de que se agrave el conflicto de Marruecos (...) Madrid 31. Se confirma oficialmente la noticia de que Francia e Inglaterra están resueltas á mantener en Marruecos el statu quo (...) Madrid 31. Por fortuna estas dos naciones conceptúan que el conflicto, como de carácter interior, debe ser resuelto única y exclusivamente por los mismos marroquíes. De idéntica opinión es la prensa alemana. Ésta opina que el gobierno de España no debe extralimitarse, concretándose a defender el statu quo ${ }^{~} 20$.

Al lector de estos telegramas, forzosamente, debían planteársele muchísimas incógnitas. Semejante bombardeo con breves noticias descontextualizadas resultaba incomprensible. Tan sólo dos editoriales, publicados algunos días después, podrían servir de ayuda y esclarecer mínimamente lo que estaba ocurriendo al Sur de Tarifa. En el primero de ellos, firmado por alguien que empleaba el pseudónimo de "Lucano", se ponían en tela de juicio los intereses españoles en Marruecos. El Desastre de Cuba estaba muy presente a la hora de explicar la voluntad de aislamiento de los españoles, pero no era una actitud compartida por el Poder. Y contra ello alertaba este reportero:

"Es la consigna (...) nuestra obligada expansión al otro lado del Estrecho. Que nos convenga o no, parécenos muy problemático, y tentado estoy por decir que no me convencen los partidarios de esas expansiones; pero no es mi propósito discutir ahora ese tema. Basta señalar un hecho. El pueblo parece curado de su funesta patriotería. La prensa escribe sobre el conflicto marroquí y no lanza notas belicosas. Ayer soñábamos con conquistar Nueva York; hoy reconocemos que sería cosa digna de meditación previa el bombardear un aduar rifeño. Algo nos ha enseñado la experiencia (...) Los únicos que no aprenden son nuestros gobernantes, ${ }^{, 21}$.

El segundo editorial de interés, que no aparecía firmado, contenía algunas notas biográficas sobre El Rogui. Se le reconocía su enorme agudeza intelectual y su capacidad de liderazgo. Sus predicaciones contra el Sultán Abd-el-Aziz le habían convertido en el único poder efectivo de un amplio territorio, aquel que se extendía en un radio de más de cien kilómetros alrededor de Fez y en todo el Rif, desde el Muluya

\footnotetext{
20 "Telegramas", El Adelanto, n 5.550, 31 de diciembre de 1902, p. 3. El telegrama era remitido por la Agencia Almodóvar.

21 "Lucano": "España y Marruecos", El Adelanto, n 5.552, 2 de enero de 1903, p. 1.
} 
hasta las inmediaciones de Tánger. Su meta era convertirse en el dueño del país. Y había comenzado por adoptar los símbolos del Sultán:

"El Pretendiente marroquí, que, según parece, gobierna con acierto sus huestes, ha establecido cerca de su persona la etiqueta de la Corte jerifiana, con todos sus detalles, sin que le falte el característico de la sombrilla verde para cubrir su augusta persona ${ }^{, 22}$.

No era un dato baladí: Abd-el Aziz perdería su paciencia al conocer que El Rogui empleaba su símbolo sagrado, ese parasol verde.

No obstante, en la sección telegráfica de El Adelanto, sólo de manera muy ocasional, volverían a reseñarse algunas de las acciones protagonizadas por este rebelde. El Sultanato se consumía en una interminable lucha civil. Pero no merecía mayores explicaciones. Mientras, ese primitivo Convenio hispano-francés, acabaría cayendo absolutamente en el olvido. Marruecos aparecía ante los ojos de cualquier salmantino como un país enigmático y su futuro debía ser, forzosamente, un galimatías. Pero no habiendo "salpicaduras" en la península, tampoco había excesivas preocupaciones.

En definitiva, en 1902, El Adelanto constituyó la excepción en el panorama ofrecido por la prensa local al interesarse y advertir a la opinión sobre un tratado en ciernes. Aunque El Lábaro también anotó el rumor sobre una próxima alianza hispanofrancesa, no le dedicó ni el más insignificante comentario ${ }^{23}$. Mientras, los demás periódicos permanecieron absortos relatando los preparativos para una visita del conde de Romanones a Salamanca.

\section{El Tratado hispano-francés de 1904 a través de la prensa salmantina}

Si muy decepcionantes, por insuficientes, resultan las alusiones en los periódicos de Salamanca a las conversaciones con Francia en 1902, más aún lo son las informaciones sobre el importantísimo Tratado que se firma con su gobierno en octubre de 1904 (en realidad, una declaración y un convenio). Ya no es El Adelanto el único periódico salmantino que difunde la noticia. Sin embargo, su sección telegráfica, por lo voluminoso y dispar, sigue constituyendo un lugar de referencia entre la prensa local:

"Madrid 4. Telegramas de París dan cuenta de que se ha firmado por el Ministro de Estado de la República y nuestro embajador en aquella capital, el Tratado francoespañol, referente a Marruecos. E1 Tratado tiene una parte pública, que se conocerá el miércoles, y otra secreta que sólo se dará a la publicidad cuando lo acuerden ambas naciones ${ }^{, 24}$.

\footnotetext{
22 "El Rogui", El Adelanto, n n $^{\circ} 523,3$ de enero de 1903, p. 2. Adviértase que los errores en la numeración son muy frecuentes entre la prensa salmantina.

${ }_{23}^{23}$ "Telegramas", El Lábaro, no 1.716, 11 de octubre de 1902, p. 2.

24 “Telegramas", El Adelanto, no 6.266, 4 de octubre de 1904, p. 3.
} 
Dicho Acuerdo era, a su vez, el fruto de unas negociaciones previas anglofrancesas. Y pese a que, igualmente, este diario había dado cuenta, también telegráficamente, de las mismas, la vinculación existente entre ambos pactos permanecía oculta $^{25}$. ¿Por qué? ¿Por pura ignorancia o por una cuestión de orgullo herido?

Delcassé, ante las persistentes largas de Silvela, había optado por prescindir de España y volcar su interés, más abiertamente, hacia Gran Bretaña, con la aquiescencia de su homólogo Lansdowne. Si bien los primeros contactos fueron timidísimos, hubo un primer viaje oficial de Eduardo VII a París, en 1903, y otro viaje del presidente Loubet a Londres algunos meses después. El 8 de abril de 1904, finalmente, concluyeron las negociaciones entre ambas naciones. Atrás quedaban varios siglos de enemistad ${ }^{26}$.

Aunque es frecuente contemplar a la Conferencia de Algeciras como el antecedente del Tratado hispano-francés de Protectorado de 1912, realmente, el reparto de Marruecos fue acordado por Francia e Inglaterra en estas conversaciones de 1904. Aquí se gestó la Entente Cordiale. Aclaremos que una entente es el instrumento -casi siempre secreto- que normaliza las relaciones entre grandes potencias, y entre ellas con potencias inferiores, y supone un grado de compromiso menor al requerido por una alianza. Con la entente se persigue el reparto de un territorio a costa de un tercero que ni participa ni tiene conocimiento -al menos oficialmente- de la negociación ${ }^{27}$.

Ya se habrá adivinado que, en este caso, el tercero era España ${ }^{28}$. A la par que Francia garantizaba a Gran Bretaña libertad de acción en Egipto, también ella lograba lo mismo en Marruecos. Se aseguraba, asimismo, la libre circulación de ambas potencias por el Estrecho de Gibraltar y el Canal de Suez, y se preveía, en el artículo VIII, una particular consideración hacia los intereses españoles en África. La causa: los recelos

25 "Telegramas", El Adelanto, no 6.092, 9 de abril de 1904, p. 4. "Madrid 9. En París se ha firmado el Convenio anglo-francés que comprende cuatro protocolos. Francia se compromete á apoyar la reorganización de Marruecos, velando por la tranquilidad del imperio. Los derechos comerciales serán iguales para todas las naciones, durante un plazo de treinta años".

${ }^{26}$ El Acuerdo franco-británico constaba de cuatro documentos: la declaración sobre Egipto y Marruecos; una declaración secreta (que garantizaba la independencia de acción de ambas potencias en sus respectivas zonas en caso de guerra); un convenio relativo a Terranova; y una declaración relativa a Siam, Madagascar y Nuevas Hébridas.

${ }^{27}$ Sebastian Balfour escribe a propósito del nacimiento de la Entente: "podríamos decir que se estableció un ménage à trois que, como muchos menages, no era una cohabitación entre iguales. Pero lo que más empujó al establecimiento de esa alianza triangular era el intruso, el huésped inoportuno, Alemania". Véase BALFOUR, Sebastian: "España, Marruecos y las grandes potencias, 1898-1914" en GÓMEZ FERRER, G. y SÁNCHEZ, R. (Eds.): Modernizar España... Op. Cit., p. 145.

${ }^{28}$ Rodríguez San Pedro, ministro de Estado durante este mandato maurista, defendería en el Congreso que los gobiernos francés e inglés habían llevado la negociación siempre contando con España. Pero fue desmentido allí mismo (Miguel Villanueva) y también en la Cámara de los Comunes. Véase PÉREZ MOLINA, Elisa: Op. Cit., pp. 60-61. 
británicos ante la presencia de una potencia tan fuerte como Francia frente al Estrecho de Gibraltar. Por tanto, tras el pacto con los ingleses, Francia se ocupó de negociar con España un Tratado al que se le añadió un Protocolo Adicional en septiembre de 1905, en el que se delimitaban las esferas de influencia de ambas potencias en Marruecos, aunque no se conocería públicamente hasta 1911.

Si bien El Adelanto, en su sección telegráfica, había intentado disimular la subordinación del Convenio hispano-francés de octubre al Tratado de la Entente, sí que declaraba sin ambages, al día siguiente y por boca de uno de sus redactores, su rechazo hacia la maniobra que las autoridades galas venían practicando desde septiembre en el Sultanato. El mariscal Lyautey se había lanzado, utilizando el conocido banderín de la penetración pacífica, a la conquista de posiciones estratégicas en Marruecos. Parece, consecuentemente, justificado preguntarse qué pretendía el diario liberal cuando el día 4 de octubre reseñaba brevísimamente la firma de un Acuerdo hispano-francés y al día siguiente, "Lokente", en su "Crónica extranjera", se dedicaba a denigrar la actuación parisina al tiempo que acusaba a ese gobierno de traición:

"Nuestra hermanita mayor, la que cuántas veces ha recordado la unidad de raza para sus fines particulares, procede así con España, haciendo traición a ésta y a Rusia, su aliada; se entiende con Inglaterra por el Tratado de 8 de Abril. Da largas a nuestras justas reclamaciones y, mientras los calores del estío hacen necesario paralizar éstas, sus soldados ocupan puntos estratégicos en el imperio marroquí, comenzando el inicuo despojo que nuestros vecinos llaman penetración pacífica. La conducta de Francia merece los mayores anatemas. Y todavía nuestros políticos, a cambio de unos cuantos bombos en la prensa francesa, se deshacen en alabanzas de la buena amistad galaica (...) Basta ya de 'penetración pacífica'. O la retirada o la guerra. Una guerra sin cuartel, encarnizada y sangrienta, que dislocará el Ejército de la Argelia y destruirá la fuerza militar de Francia en Europa. Una guerra larga, sin gloria y sin nobleza, en que las simpatías del mundo civilizado estarán por los moros ",29.

En suma, El Adelanto soñaba con que Francia fuese desacreditada internacionalmente porque eso de la penetración pacífica era contemplado como una mera falacia. También conocida como la estrategia de "la mancha de aceite", sus inspiradores eran Eugéne Étienne, amo y señor en la sombra de la política colonial francesa, y Hubert Lyautey, un veterano de Indochina, que al cargo de las zonas en litigio entre Argelia y Marruecos empezó a adueñarse de territorios tales como el nudo de comunicaciones de Béchar y Ras el-Aini ${ }^{30}$.

\footnotetext{
29 “C. Lokente": "Crónica extranjera”, El Adelanto, n” 6.267, 5 de octubre de 1904, p. 3.

${ }^{30}$ A propósito de Étienne comenta Bastenier "Este veterano terrateniente de Argelia, hombre sin apenas cultura, varias veces ministro de la III República y esgrimidor de una de las peores sintaxis que se han conocido en los pasillos ministeriales francés, exhortó a los grandes propietarios de Argel a no pelearse por un magro botín cuando tenían las feraces tierras marroquíes, supuestamente ricas en toda clase de
} 
En esta crónica sí que se intuye que el reciente Tratado hispano-francés está subordinado al Acuerdo franco-británico. A España le estaban "haciendo la cama” y Antonio Maura, por ahora no importa si a regañadientes o con su beneplácito, había aceptado un compromiso que quizás arrastrase a España al campo de batalla. Por este motivo, el periódico local sentía miedo y expresaba sus recelos y frustración. Su reacción era meramente defensiva, un asunto de puro amor propio. Tan sólo hacía dos años Francia había apelado al mantenimiento del statu quo cuando España quiso actuar contra El Rogui, pero ahora era el gobierno parisino el que tomaba la iniciativa sin importarle el parecer de su homólogo madrileño.

Igualmente vagas y confusas fueron las referencias a este Convenio en las páginas de $E l$ Lábaro $^{31}$. La particularidad de este rotativo radicó en su constante apelación a que nuestra soberanía en Marruecos era, además de un imperativo geográfico e histórico, una garantía para el futuro. Ignoraba, por consiguiente, esa prescripción de los derechos históricos cuando no se acompañaban de una ocupación:

"Se reconoce el Protectorado de Francia sobre Marruecos. Se mantiene el statu quo en el imperio y en las costas de España. No se compromete España a hacer ningún gasto ni enviar tropas. Preguntado el señor Maura respecto a este particular, ha dicho: 'Ni siquiera a hacer un camino vecinal' (...) El señor Maura se muestra regocijadísimo del Tratado, diciendo que ya sabe que hoy España nada puede; pero ve con orgullo como español que renace nuestra patria, y que ese Tratado dentro de cuarenta años nos abrirá nuevos caminos ${ }^{, 32}$.

Evidentemente, la alusión a un protectorado francés y, acto seguido, al mantenimiento del statu quo marroquí era una enorme incongruencia. Pero, en síntesis, si Maura estaba satisfecho, todos los españoles debían estarlo porque este Tratado no suponía la adopción de ningún compromiso financiero ni militar.

El Castellano, para terminar, también reparó en la firma del Tratado hispanofrancés y, al contrario que El Adelanto, lo presentó como un éxito personal de Antonio Maura $^{33}$. Su clarísima intención consistía en hacer de la necesidad virtud, aunque sin abandonar, en ningún momento, su tan característico tono muy sosegado. En el único

minerales, al alcance de la mano". Por otro lado, de Lyautey subraya el mismo autor: "Declarado homosexual, hombre muy culto, entusiasta de la literatura y de la música, fue, sobre todo, un estratega admirable, un publicista interesado, que a través del Comité du Maroc manejó los hilos de buena parte de la prensa". Véase BASTENIER, Miguel Ángel: "La Conferencia de Algeciras. El reparto de Marruecos", Los grandes hechos del siglo XX, nº 69, Madrid, 1982, pp. 97-108.

31 "Marruecos. El Convenio de Francia y España. Por telégrafo", El Lábaro, no 2.294, 1 de octubre de 1904, p. 1. La información procede de la Agencia Mencheta; "Telegramas", El Lábaro, no 2.297, 5 de octubre de 1904, p. 2. En esta ocasión, la noticia es proporcionada por Fabra.

32 "De política", El Lábaro, no 2.298, 6 de octubre de 1904, p. 1.

33 "Por telégrafo", El Castellano, no 526, 1 de octubre de 1904, p. 5; "Por telégrafo", El Castellano, n ${ }^{\circ}$ 541, 7 de octubre de 1904, p. 3; "Por telégrafo", El Castellano, n' 542, 8 de octubre de 1904, p. 3. 
editorial que publicó para comentar este asunto, si bien quedaba clara la dependencia de este Acuerdo con respecto al previo franco-inglés, la reacción era de lo más benévola. Además, el escrito contenía alguna tergiversación:

"Desde luego, España tenía que reconocer la intervención francesa en Marruecos, y así se declara ahora en forma de adhesión al Acuerdo franco-inglés de 8 de abril último (...) Varios extremos importantísimos quedan ahora resueltos, siendo para nosotros el más importante el que se refiere a la neutralidad de Ceuta y demás posesiones emplazadas frente a Gibraltar, cláusula en la que se afirma que Tánger y Tetuán están comprendidos en la esfera que se concede a la influencia española (...) La neutralización de la costa de Marruecos, entre Melilla y las alturas de la orilla derecha del Sebú, y la conservación de las posesiones que España tiene en aquel territorio, constituyen otras dos de las bases fundamentales del Tratado, pero a propósito de la segunda debe tenerse en cuenta que para la mayor extensión de derechos (...) habrá de ser previamente discutida con el gobierno marroquí, pero de acuerdo con el gabinete francés ${ }^{, 34}$.

Aunque seguidamente el autor, "P. G. C”, manifiesta sus temores a propósito de la posesión de Tánger, cree que lo pactado es un acierto. En consecuencia, el sueño tangerino se antepone a la expansión por los alrededores de Ceuta y Melilla. Y éste será un permanente anhelo en la historia del africanismo español. Pero con todo, este apunte era un bulo porque, en el artículo noveno del Convenio, a Tánger se le asignaba un "carácter especial"; por otro lado, el autor transmite la falsa impresión de que es España la que autoriza a Francia para intervenir en Marruecos; y no pone objeciones cuando concluye que los detalles permanecerán secretos porque no se necesita una ratificación parlamentaria. Delcassé, efectivamente, no deseó otorgarle demasiada difusión a este Acuerdo, siempre preocupado por las reacciones del grupo colonialista francés. Pero es de suponer que al gobierno de Maura tampoco le convenía un exceso de publicidad. El 98 todavía pesaba en las conciencias y los liberales podrían argumentar que el proyectado Acuerdo de 1902 hubiese sido más ventajoso para los intereses españoles.

A esto quedó reducido el Tratado capital, básico, hispano-francés sobre Marruecos de 1904. Sin embargo, este documento suponía muchísimos recortes territoriales para España con respecto a lo proyectado en 1902. Acaso, ¿tenían los conservadores algún margen de maniobra? Tal vez. Pero una negativa española al Acuerdo habría implicado, a largo plazo, el abandono definitivo de Marruecos: la pérdida de los viejos presidios y de las oprimidas plazas de soberanía. Así que el gabinete de Antonio Maura se decantó por aceptar un "regalo". El Tratado no era, por tanto, un éxito de la diplomacia maurista; tan sólo la respuesta a una política de hechos

\footnotetext{
34 “P. G. C.”: "El Tratado franco-español sobre Marruecos", El Castellano, nº 565, 11 de octubre de 1904, p. 2.
} 
consumados. Por descontado, eso sí, tenemos la convicción de que Antonio Maura sabía que el Acuerdo de 1904 tendría contraprestaciones en el futuro. Porque la diplomacia es el arte de la compra-venta de intereses nacionales y la ingenuidad no figuraba entre los defectos del político mallorquín. Si lo defendió públicamente fue, claro es, porque lo contrario habría sido suicida.

A ciencia cierta, esta historia no la pudieron contemplar como tal los salmantinos. Los esporádicos "chispazos" mediáticos no compensaban el habitual hermetismo diplomático: el guión de la política exterior española no se entendía cuando a la opinión pública se le escamoteaban casi todos sus capítulos. Probablemente, porque los propios políticos dinásticos desconocían ese guión. Se limitaban a actuar con objetivos un tanto imprecisos y a la defensiva. Así que pese a la existencia de un mínimo de pluralismo ideológico en la prensa salmantina a la altura de 1904, creemos que se hubiesen necesitado muchos más editoriales para fomentar el debate público alrededor del Convenio hispano-francés. Naturalmente, la angustia de El Adelanto contrastaba con el beneplácito de El Castellano y, sobre todo, El Lábaro ante la política exterior maurista, pero la cuestión marroquí era, aún en 1904, percibida por los salmantinos como muy distante.

Por cierto, casi dos décadas después, Romanones escribiría a propósito de este Tratado: “La opinión pública española ni se conmovió, como siempre, ni tomó parte en la labor internacional. La acción diplomática de España en problemas de vital interés como éste tropezaba con la indiferencia nacional "35. Pero, ¿cómo participar en algo que le estaba vedado? El socialista Pablo Iglesias había dado con la contestación ya en 1912, cuando pronunció lo siguiente en el Congreso:

"Os quejáis de que el país preste poca atención a estos asuntos; pero, ¿cómo tratáis vosotros al país? ¿No le tratáis como a un menor de edad? ¿De qué cosas procuráis que se entere el país? Estos días sabe algo por lo que dicen los periódicos, pero la inmensa mayoría del pueblo español no sabe nada de esto (...) ¿Creéis que no es necesario que se sepa para que haya unidad de pensamiento y se puedan hacer campañas nacionales? ${ }^{36}$.

La opinión pública no intervino como sujeto histórico en este reparto de Marruecos. Aún así, en ella se escudó el Conde de Romanones, para insinuar que la política exterior de Maura fue impopular. A esto quedaba limitada su fuerza en 1904: a la lucha partidista.

\footnotetext{
${ }^{35}$ FIGUEROA, Álvaro de (Conde de Romanones): Las responsabilidades del Antiguo Régimen, 18751923. Madrid: Renacimiento, 1923, p. 52.

${ }^{36}$ PÉREZ MOLINA, Elisa: Op. Cit., pp. 78-79.
} 
Ahora bien, este pacto entre Delcassé y el embajador español en París, León y Castillo, sería la pieza maestra en la estrategia británica de seguridad en la zona del Estrecho. En el Convenio se distinguía una zona septentrional, limitada al norte por el Mediterráneo desde el río Muluya hasta el Atlántico, a la altura de la laguna de Zerga, aunque exceptuando Tánger; y al sur por una línea que, partiendo de las cercanías de dicha laguna corría hacia el este, pasando al sur de Alcazarquivir y al norte de Uazza, Fez y Taza, hasta encontrarse de nuevo con el Muluya. La zona meridional de influencia estaba delimitada por un punto en la costa atlántica situado entre Agadir e Ifni y la línea que desde ahí se extendía en dirección meridional hasta el Río de Oro ${ }^{37}$. Tánger, la ciudad por todos pretendida, conservaba un "carácter especial", derivado de "la presencia del cuerpo diplomático y sus instituciones municipales y sanitarias". Era la ciudad más cosmopolita de todo Marruecos, ya que desde 1865 una comisión internacional se ocupaba de la construcción y gestión del faro del cabo Espartel, imprescindible para garantizar la seguridad de los barcos que cruzaban el Estrecho.

El Acuerdo se ajustaba con absoluta exactitud al mapa de reparto trazado por Inglaterra y Francia en abril y detallaba un programa de acción para el porvenir: si Marruecos era capaz de conservar su independencia, habría un primer periodo, de quince años, durante el cual Francia podría actuar en la zona española con un simple previo aviso. Terminado este periodo, Francia no intervendría en nuestra área de influencia más que contando con la explícita aprobación del gobierno madrileño. Pero si, como se presagiaba, el status quo de Marruecos era insalvable, cada potencia actuaría libremente en su zona.

El sueño francés comenzaba a hacerse realidad: su meta era explotar el suelo y el subsuelo potencialmente ricos de un Estado políticamente agónico, militarmente endeble y financieramente insolvente. Contemplado en perspectiva, muchos obstáculos había derribado Francia desde 1880. En aquel año se habían reunido en Madrid representantes del Sultán y de las potencias europeas para revisar el controvertido régimen del derecho de protección. Se trataba de un sistema fijado a favor de los marroquíes que trabajaban para agentes consulares y comerciales extranjeros y que los sustraía de la jurisdicción imperial: les concedía inmunidad judicial y les eximía de pagar tributos. Tal régimen era el origen de muchos fraudes y delitos, así que ocasionaba continuas protestas por parte del Sultán al contemplar como la autoridad

\footnotetext{
${ }^{37}$ SERNA, Alfonso de la: Al Sur de Tarifa: España-Marruecos, un malentendido histórico. Madrid: Marcial Pons, 2001, pp. 209-210.
} 
sobre sus súbditos se resquebrajaba. Aunque los países europeos no alcanzaron un compromiso (España e Inglaterra aceptaban limitar ese sistema, pero Italia y Francia no claudicaban), la reunión sirvió para advertir que la solución de la cuestión marroquí era inaplazable. Francia fue la potencia que más tempranamente lo supo apreciar.

Con la solicitud de empréstitos exteriores cada vez más abultados, el Sultán terminaría hipotecando todas sus fuentes de ingresos, hasta perder su capacidad de maniobra y tener que aceptar la tutela de la República Francesa, una protección que su pueblo no había solicitado. Pero conviene apuntar que España fue una de las primeras naciones en contribuir a esa asfixia económica porque impuso una fuerte indemnización de guerra tras aquella "romántica" campaña de $1859^{38}$.

Por de pronto, en el verano de 1904 Abd-el-Aziz hubo de hacer frente a la bancarrota con un préstamo a cargo de un consorcio con funcionarios del gobierno francés y hombres de la Banque de Paris et des Pays-Bas. Su valor: 48 millones de francos. El Sultán suscribía una deuda de 62.500.000 francos franceses para reembolsar otros créditos previos. El préstamo tenía como garantía el 60\% de los ingresos aduaneros durante los siguientes 35 años. Sin embargo, en la práctica el Majzén únicamente dispondría libremente de la sexta parte de este capital y se vería obligado a invertirlo en la lucha contra las tropas de El Rogui.

Francia caminaba con paso firmísimo hacia el establecimiento de un protectorado: comenzaron las negociaciones para formar batallones indígenas bajo el mando de oficiales franceses; se fundó una banca estatal con representación de las grandes compañías francesas presentes en Marruecos; varias empresas galas se adueñaron de los contratos sobre obras públicas... y todo ello rebasó los límites de la paciencia alemana.

\section{SALAMANCA Y LA CONFERENCIA DE ALGECIRAS}

\section{Antecedentes: El "trompetazo" de Tánger}

La Conferencia de Algeciras marcó un importantísimo hito en el calamitoso proceso de desmoronamiento del Sultanato. Esta reunión internacional vino motivada por una desafiante visita del káiser, Guillermo II, a Tánger, el 31 de marzo de 1905. A Delcassé, por de pronto, esta “excursión" le costó su cargo como gran defensor y negociador de los intereses franceses en Marruecos. Además, el plan francés de reformas para el Sultanato, para cuyo desempeño se había enviado a Fez una misión

\footnotetext{
${ }^{38}$ BOUARFA, Mohamed: España y Marruecos. El eterno problema. Málaga: Algazara, 2002, pp. 43-45.
} 
diplomática encabezada por Saint-René Taillandier, quedó en punto muerto. Delcassé tenía que saber que había vulnerado los usos diplomáticos de la época al no molestarse en ofrecer una compensación a Alemania cuando le impuso su solución sobre el problema marroquí ${ }^{39}$. Así que Rouvier, el presidente francés, optó por forzar su dimisión y asumir él mismo la cartera de Negocios Extranjeros.

Los Convenios de 1904 habían inquietado, de sobra es conocido, a Alemania. Aunque el káiser no estaba alarmado por el establecimiento de Francia en Marruecos, ya que creía que así ese gobierno olvidaría la herida de Alsacia-Lorena, el canciller Bülow temía una alianza contra Alemania. Se impuso, al fin, su voluntad y por este motivo Guillermo II acabó presentándose en Tánger como adalid de la independencia marroquí, exigiendo la celebración de una nueva reunión internacional y argumentando que los Acuerdos de Madrid habían sido quebrantados ${ }^{40}$. Aunque los resultados de esa Conferencia acabarían siendo contraproducentes para Alemania, este nuevo episodio en la historia del reparto de Marruecos, de carácter muy hostil y que a punto estuvo de desencadenar el temido enfrentamiento franco-germano, acaparó un poco más de atención, comparado con los años previos, de las Agencias Fabra y Mencheta. Ya no nos hallamos ante una gestión diplomática, sino ante una bravuconada, un golpe de efecto que somete a examen la reciente alianza franco-inglesa y que hace saltar las alarmas mediáticas.

De ambas agencias mencionadas se nutrían regularmente las cabeceras locales de Salamanca, amplificando lo publicado tanto en la prensa internacional como en los grandes diarios de la Corte. Pero aparte las acotaciones telegráficas, el incidente relatado con esas tan habituales notas de superficialidad e indiferencia para con todo lo que no involucrase directamente a España en Marruecos- no mereció demasiada atención periodística. Los rotativos mantuvieron una actitud de mucha reserva. Perduraba, claro está, esa vieja filosofía autodefensiva de no entrometerse en los conflictos entre grandes países; Cánovas, al preconizar la doctrina del recogimiento no hacía sino reconocer y apoyar el sentir de un pueblo extenuado por tantos enfrentamientos. A decir verdad, tal vez fue ésta una de las excepcionales ocasiones en que su mandato se fundamentó en un dictamen de la opinión pública. Con ese

\footnotetext{
${ }^{39}$ TORRE DEL RÍO, Rosario de la: "Preparando la Conferencia de Algeciras: el Acuerdo hispanofrancés de 1 de septiembre de 1905 sobre Marruecos", Cuadernos de Historia Contemporánea, ${ }^{\circ}$ extraordinario, Madrid, 2007, p. 315. La autora explica que, pese a los recortes territoriales que el Tratado de 1904 suponía respecto al de 1902, Delcassé se había mostrado bastante generoso con España para evitar su alineamiento con Alemania.

${ }^{40}$ GONZÁLEZ VELILLA, M ${ }^{\mathrm{a}}$ del Carmen: Op. Cit., p. 327.
} 
pretendido "autismo", ilusamente, se creía que el país podría escapar de innecesarias complicaciones. Los acontecimientos no tardarían en revelar lo equivocado de esta creencia.

Jamás el "trompetazo" de Tánger apareció en una primera página de los periódicos de Salamanca; ninguno de los mismos manifestó su preferencia por un bando; no hubo un mínimo de discrepancia ideológica en su presentación; y así, apenas descrito el conflicto, la gravedad del mismo no pudo trascender ante la opinión salmantina. De facto, ni siquiera hubo opinión pública formada al respecto. No, al menos, en ese preciso momento. Pero, ¿Sería esta situación extensible a otras provincias?

Además del viaje de Guillermo II a Tánger, otros dos asuntos coparán, a lo largo de 1905, los telegramas de la prensa local referidos a Marruecos: el desarrollo de las relaciones germano-marroquíes posteriores a este incidente y un intercambio de Notas el 8 de julio, entre Francia y Alemania, preparatorio de la futura Conferencia.

Para los periodistas de El Adelanto, órgano del progresismo salmantino, la espléndida recepción tributada al káiser en Tánger pasó, en buena medida, desapercibida. Se entendió como una frívola parada en el transcurso de un crucero con otros varios actos programados. Únicamente los telegramas destacaron que los franceses parecían muy irritados por la visita, mientras que el cuerpo consular español fue presentado como mediador entre ambas partes ${ }^{41}$. Ni más, ni menos: como si el incendiario discurso de Guillermo II no existiese.

Al contrario, El Lábaro es el periódico local que más se explayó con la crisis de Tánger y el único rotativo al que se le puede adjudicar un tímido posicionamiento profrancés. Pero no porque se publicasen editoriales en este sentido, sino porque sus informaciones telegráficas procedían mayoritariamente de la Agencia Fabra (Havás). Consecuentemente, este periódico católico actuó como caja de resonancia para las opiniones vertidas en la prensa francesa, fundamentalmente en Le Matín y Le Fígaro. Rebatió la idea de que Alemania hubiese sido apartada de Marruecos con la firma del Tratado franco-inglés de $1904^{42}$. En cambio, se subrayó que lo que intentaba hacer Alemania era "sacar tajada" del dramático momento por el que atravesaba Rusia, la aliada francesa, después de su derrota militar ante Japón. El viaje del káiser a Tánger,

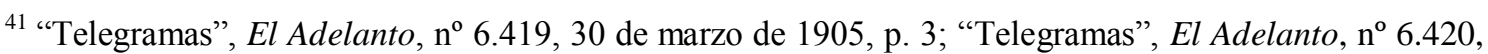
31 de marzo de 1905, p. 4; "Telegramas", El Adelanto, no 6.421, 1 de abril de 1905, p. 4.

42 "De Marruecos", El Lábaro, no 2.442, 29 de marzo de 1905, p. 1. Telegrama de la Agencia Fabra; “Telegramas", El Lábaro, no 2.444, 31 de marzo de 1905, p. 2. Telegrama de la Agencia Fabra.
} 
por tanto, no debería ser entendido como un gesto de protesta o revancha. Y no habiendo ofendido tampoco había pecado. Así que Francia no tenía por qué adoptar cambios en su política marroquí. En otros términos: El Lábaro sustentaba la política de penetración pacífica emprendida con Delcassé y remachaba, además, que contaba con el firme respaldo británico ${ }^{43}$.

Por otra parte, la tutela informativa francesa se percibía también a través del obsesivo seguimiento al que son sometidos los contactos diplomáticos de Guillermo II. En los telegramas de El Lábaro constantemente se previene a la opinión ante acercamientos al Sultán, a Italia, a EEUU, a la propia España ${ }^{44} \ldots$

El Castellano, en cambio, guardó silencio sobre el tenso momento. Tal vez, sospechamos, no por falta de interés, sino de espacio. De ordinario, hay que subrayarlo, su sección telegráfica fue muy breve porque no se amoldaba al nuevo periodismo industrial en auge.

Los telegramas de El Adelanto también dejarían ver esos recelos franceses ante un posible entendimiento germano-marroquí. Dichos tratos saldrían a la palestra, sobre todo, con la concesión por parte del Sultán a varias casas alemanas de un contrato para la construcción de algunos remolcadores. Sintomática, del mismo modo, sería la aprobación de un empréstito en beneficio de Abd-el-Aziz por valor de tres millones de marcos. Al unísono, tanto este diario como también El Lábaro y El Castellano, que ahora sí rompe su silencio, recogieron la reivindicación del Sultán -fundamentada en la Conferencia de Madrid de 1880- en defensa de su libertad para hipotecarse e invertir lo prestado libremente, al margen de la voluntad parisina ${ }^{45}$. Sería precisamente éste uno de los últimos puntos en litigio a la hora de acordarse el programa del siguiente encuentro internacional. Mientras que Alemania defendería que Francia actuaba con una excesiva sensibilidad a flor de piel, los diplomáticos galos insistirían en que el primer objetivo de la Conferencia debía ser la creación de un Banco de Estado y el inmediato reembolso de ese dinero ${ }^{46}$.

\footnotetext{
43 "Del extranjero", El Lábaro, n 2.445, 1 de abril de 1905, pp. 1-2 (Fabra).

44 "Guillermo II en Tánger", El Lábaro, no 2.446, 3 de abril de 1905, p. 1 (Fabra); "De Marruecos", El Lábaro, no 2.447, 4 de abril de 1905, p. 1 (Fabra); "De Marruecos", El Lábaro", no 2.448, 5 de octubre de 1905, p. 1 (Fabra); "De Marruecos. Memorándum”, El Lábaro, no 2.450, 7 de octubre de 1905, p. 1 (Fabra).

45 “Telegramas", El Adelanto, $\mathrm{n}^{\mathrm{o}}$ 6.425, 6 de abril de 1905, p. 4; "Telegramas", El Adelanto, $\mathrm{n}^{\circ}$ 6.534, 10 de agosto de 1905, p. 4; "De Marruecos", El Lábaro, no 2.447, 4 de abril de 1905, p. 1(Fabra); "De Marruecos", El Lábaro, no 2.555, 16 de agosto de 1905, p. 1; "El empréstito alemán", El Lábaro, no 2.558, 19 de agosto de 1905, p. 2 (Mencheta); "De Marruecos", El Lábaro, no 2.571, 4 de septiembre de 1905, p. 1 (Fabra); "Por telégrafo", El Castellano, no 802, 4 de abril de 1905, p. 2.

${ }^{46}$ GONZÁLEZ VELILLA, M ${ }^{\text {a }}$ del Carmen: Op. Cit., p. 354.
} 
Finalmente, un tercer bloque de telegramas, el más interesante (aunque $E l$ Castellano otra vez enmudece), tuvo como protagonista el intercambio de Notas entre Francia y Alemania que posibilitó la realización de la reunión entre plenipotenciarios. El presidente francés, Rouvier, y el embajador alemán en París, Radolín, asumieron la responsabilidad de las negociaciones, pero muy poco de las mismas trascendió a la prensa, con la salvedad de la perseverancia alemana a la hora de defender la libertad comercial en Marruecos.

El Adelanto incidió en que el camino hacia el entendimiento no era nada sencillo $^{47}$. Incluso el lugar de celebración del encuentro sirvió como objeto para la polémica. Además, Francia amenazaba con ocupar Uxda tras la captura por el Majzén de uno de sus súbditos argelinos. El Lábaro, mientras tanto, volvía a ser el periódico salmantino con informaciones más tendenciosas. Aunque coincidía con El Adelanto en que la preparación de la Conferencia no resultaría un sendero de rosas ${ }^{48}$, se consagraba a la búsqueda de culpables. Por ello, dirigía su mirada hacia el gobierno de Berlín y comentaba el arrepentimiento germano por haber enardecido a los rebeldes ${ }^{49}$. Era Francia, en cambio, la que debía afrontar las consecuencias. La víctima de la infortunada visita alemana a Tánger acababa siendo ese súbdito que era encarcelado y por el que el gobierno parisino exigía una reparación del Sultán. De lo contario, movilizaría su escuadra ${ }^{50}$.

En definitiva, aunque ambos periódicos reflejaron los mismos incidentes, a través de la lectura de El Adelanto, se concluye que Francia era una potencia con iniciativa, fuerte; mientras que para El Lábaro este país actuaba a la defensiva, es la potencia cuyos intereses se están viendo lesionados.

Detengámonos en las reseñas sobre la Nota franco-alemana finalmente aprobada el 8 de julio, aunque las conversaciones se prolongarían hasta el 28 de septiembre de

\footnotetext{
47 “Telegramas", El Adelanto, n 6.503, 5 de julio de 1905, p. 4; "Telegramas", El Adelanto, no 6.506, 8 de julio de 1905, p. 4; "Telegramas", El Adelanto, no 6.507, 10 de julio de 1905, p. 4; "Telegramas", El Adelanto, no 6.509, 12 de julio de 1905, p. 4; "Telegramas", El Adelanto, no 6.545, 23 de agosto de 1905, p. 4.

48 "Francia y Alemania", El Lábaro, no 2.564, 26 de agosto de 1905, p. 2 (Mencheta); "De Marruecos", El Lábaro, no 2.565, 28 de agosto de 1905, p. 1 (Fabra); "De Marruecos", El Lábaro, no 2.568, 31 de agosto de 1905, p. 2 (Fabra); "La cuestión de Marruecos", El Lábaro, no 2.570, 2 de septiembre de 105, p. 1 (Fabra).

49 "De Marruecos", El Lábaro, no 2.452, 10 de abril de 1905, p. 1 (Fabra); "De Marruecos", El Lábaro, n 2.550, 9 de agosto de 1905, p. 2 (Fabra); "De Marruecos", El Lábaro, no 2.553, 12 de agosto de 1905, p.1 (Fabra).

50 "La cuestión internacional", El Lábaro, no 2.556, 17 de agosto de 1905, p. 2 (Mencheta); "De París", El Lábaro, no 2.561, 23 de agosto de 1905, p. 2 (Mencheta); "De Marruecos", El Lábaro, no 2.564, 26 de agosto de 1905, p. 1 (Fabra); "De Marruecos", El Lábaro, no 2.569, 1 de septiembre de 1905, p. 1 (Fabra).
} 
1905, fecha del definitivo Arreglo franco-alemán ${ }^{51}$. El Adelanto inserta estos telegramas enviados por Alfredo Rivera, su corresponsal permanente en Madrid:

\begin{abstract}
"Bases del Acuerdo: Madrid, 11. Las proposiciones de Alemania se apoyarán sobre las siguientes bases: Soberanía e independencia del Sultán, integridad del imperio, libertad económica para la reforma financiera y reconocimiento de cuanto tiene Francia en sus posesiones de Argelia. La contestación: Madrid, 11. Mr. Rouvier lee la contestación de Francia diciendo que en vista de la carta de Mr. Radolín, ésta acepta la Conferencia de ambos gobiernos, y el pensamiento de llamar a Tánger las comisiones establecidas en Fez. Apenas se reúna la Conferencia se acordará aconsejar al Sultán la fijación del programa de gobierno. La Conferencia tendrá como base las cartas cambiadas entre Mr. Rouvier y monsieur Radolín ",52.
\end{abstract}

En El Lábaro, mientras, se publicaba el siguiente extracto:

"Francia se adhiere a la Conferencia internacional. Alemania reconoce la situación especial en que se encuentra Francia, que por limitar con Argelia está siempre expuesta a tener que contener cualquier movimiento que pueda producirse en Marruecos. Alemania toma acta de los tratados cerrados entre Francia y otras naciones concernientes a Marruecos (Estas noticias no se nombran en la Nota). Será reconocida la soberanía del Sultán; la integridad del territorio marroquí será proclamada, lo cual impediría a Alemania conseguir concesión territorial alguna. Se menciona el sostenimiento de la puerta abierta. Se asegura que el gobierno francés acepta el principio de internacionalización para los bancos de Marruecos. Se asegura (con toda reserva) que Francia aceptará la internacionalización de las fuerzas de policía en Marruecos ${ }^{\text {,53 }}$.

Como viene siendo habitual, si atendemos exclusivamente a las informaciones de El Adelanto, Francia adoptaba una posición dominante, habida cuenta de que ella finalmente sería la consejera del Sultán; mientras que, según El Lábaro, el gobierno galo era infinitamente más transigente que el de Bülow, sobre todo, en lo tocante al régimen bancario y a la futura organización de la policía. Ya se adivinan, por tanto, cuáles serán los temas más espinosos de la Conferencia. Por otro lado, debemos aclarar que, en la Nota del 8 de julio, Alemania sí se comprometía a respetar los tratados

\footnotetext{
${ }^{51}$ Marruecos carecía de recursos para el funcionamiento de su administración. La fiscalidad interior estaba en crisis porque en 1901 se habían sustituido los impuestos coránicos por uno general, el tertib, rechazado por la población. Los tributos aduaneros se habían convertido, por tanto, en la única fuente de ingresos del Majzén. Al terminar 1902, la Banque de Paris et des Pays-Bas, junto con otros ocho bancos, concedió al Sultán un préstamo de 7,5 millones de francos. Este préstamo se renovó al año siguiente, cuando el grupo inglés de Ernst Cassel y el Banco de España aportaron otros 7,5 millones de francos cada uno. Tras la firma de la Entente Cordiale, se procedió al contrato con la Banque de Paris de ese gran préstamo de 62,5 millones de francos. Pero Alemania quiso contrarrestar esta influencia con el anticipo de 12,5 millones de francos. Cuando el 28 de septiembre de 1905 se alcanzó el Arreglo franco-alemán, a la Banque de Paris se le retornó la mitad del importe de su anticipo. Pero en ese intento por alcanzar una paridad económica entre ambas grandes potencias, se marginaron las subparticipaciones inglesa y española. Esto es denunciado, en 1912, por el marqués de Cortina en el Congreso. Sabía que España había perdido "el derecho a mandar". Véase PÉREZ MOLINA, Elisa, Op. Cit., p. 67.

52 "Telegramas", El Adelanto, $\mathrm{n}^{\circ} 6.508,11$ de julio de 1905, p. 4

53 "De Marruecos", El Lábaro, n 2.525, 10 de julio de 1905, p. 3 (Fabra).
} 
previamente firmados por Francia ${ }^{54}$. Por tanto, El Lábaro faltaba a la verdad cuando afirmaba, entre paréntesis, "estas noticias no se nombran en la Nota". Manifestaba con ello recelo a que una posible inteligencia franco-alemana hiciese peligrar lo obtenido por España en Marruecos.

Tan sólo la opinión de una autoridad en asuntos marroquíes fue reproducida entre los telegramas de la prensa local: la del ministro de Marina, Miguel Villanueva, quien claramente señalaba y confiaba en que en Algeciras se resolvería el contencioso franco-alemán. Mucho más pesimista se mostraba, en cambio, para todo lo que afectase al Sultanato ${ }^{55}$.

El 1 de septiembre de 1905 tuvo lugar otro intercambio de Notas, en esta ocasión entre Montero Ríos, como presidente, y Cambon, embajador francés en Madrid. Su objetivo consistía en ultimar algunos flecos de la Convención de 1904, todo ello con vistas a la preparación de la futura Conferencia (policía de puertos, contrabando de armas, intereses financieros y apoyo diplomático mutuo). La iniciativa, esta vez sí, correspondió al gobierno madrileño. Temía que un futuro acercamiento franco-alemán repercutiese de modo negativo sobre su zona marroquí. Pero la prensa salmantina, sin embargo, ignoró la noticia. La diplomacia volvía a operar en secreto. Así evitaban comentarios insidiosos, malentendidos con otras potencias y rumores como los habidos en 1904. Con todo, el margen de maniobra de los representantes españoles era muy reducido debido a que el mecanismo de las consultas conjuntas, el que habían empleado Francia y Alemania para alcanzar el arreglo del 28 de septiembre, la relegaba un papel secundario con respecto a Francia.

El siguiente capítulo en la carrera diplomática por el reparto de Marruecos no podría, sin embargo, permanecer oculto para la opinión. Aunque sólo fuese porque la ciudad gaditana de Algeciras sirvió como sede del evento.

\section{El desarrollo de la Conferencia de Algeciras}

El problema de Marruecos, como ya se habrá deducido, no era exclusivamente un asunto de vecindad y fronteras. Pese a que así quisieran creerlo, sobre todo, Francia y

\footnotetext{
${ }^{54}$ La Nota íntegra franco-alemana del 8 de julio puede consultarse en PÉREZ MOLINA, Elisa: $O p$. Cit., p. 99. Aquí recogemos únicamente su encabezamiento: “El gobierno de la República se ha convencido por las conversaciones habidas entre los representantes de ambos países, tanto en París como en Berlín, de que el gobierno imperial no perseguiría, en la Conferencia propuesta por el Sultán de Marruecos, fin alguno que comprometiese los legítimos intereses de Francia en aquel país, o que fuera contrario a los derechos de Francia, resultantes de sus Tratados o Arreglos".

55 "La cuestión de Marruecos", El Lábaro, no 2.573, 6 de septiembre de 1905, p. 1 (Fabra).
} 
España, era una cuestión de garantías internacionales y tendría que alcanzarse para su solución, por tanto, un acuerdo entre todas las naciones afectadas.

El Sultanato se presentaba a ojos de Europa, desde mediados del siglo XIX, como una monarquía de carácter teocrático y en plena descomposición ${ }^{56}$. Federico Villalobos nos recuerda que se han barajado dos grandes versiones historiográficas acerca de la situación de Marruecos hacia 1900. Una de ellas, la más tradicional, incide en cuál fue la consecuencia de la disolución del Imperio jerifiano: la necesidad de la intervención europea. Hasta la saciedad se ha enfatizado la distinción entre "Bled-elMajzén" y "Bled-es-Siba", territorios sumiso y rebelde a la autoridad del Sultán respectivamente. Ninguno se ajustó jamás a una representación estática sobre el mapa, pero esta dicotomía sirvió para deslegitimar el poder del Majzén, de su administración, y justificar de este modo la ocupación europea. Las potencias del Viejo Mundo vieron en el desorden interno marroquí la oportunidad para satisfacer sus ambiciones imperialistas ${ }^{57}$.

A día de hoy, cuenta con muchos más defensores una segunda interpretación que se preocupa por las causas del desorden y defiende, a la inversa, que la anarquía habría sido promovida por los occidentales para justificar sus "mordiscos" de tierra.

Ciertamente, la situación precaria por la que atravesaba el Imperio marroquí respondía tanto a factores endógenos como exógenos: si bien es verdad que cualquier descendiente del Profeta podía aspirar al trono y ello alimentaba el surgimiento de pretendientes y el estallido de continuas guerras civiles, estos rebeldes eran sistemáticamente estimulados por los europeos; y los mismos extranjeros, además, prometían ayudar al Sultán, que cada día se sabía más desacreditado por sus claudicaciones.

La Conferencia de Algeciras tuvo finalmente lugar entre el 16 de enero y el 7 de abril de 1906 y en ella participaron los delegados de trece Estados: Alemania, AustriaHungría, Bélgica, España, EEUU, Francia, Gran Bretaña, Italia, Marruecos, Países Bajos, Portugal, Rusia y Suecia. Oficialmente, su objetivo era introducir reformas en

\footnotetext{
${ }^{56}$ VILLALOBOS, Federico: El sueño colonial. Las guerras de España en Marruecos. Barcelona, Ariel, 2004, pp. 31-38.

${ }^{57}$ David S. Woolman indica que "para los observadores europeos habituados a formas de gobierno menos caóticas, Marruecos aparecía en un estado de constante anarquía, pero el verdadero panorama era algo diferente. No había falta de autoridad central en Marruecos. El Sultán era reconocido por todos como jefe de Estado espiritual, pero su reconocimiento como jefe de Estado político solamente tenía lugar en aquellos territorios (...) bajo el control del Ejército real y de los recaudadores de impuestos". Véase WOOLMAN, David S.: Abd-el-Krim y la Guerra del Rif. Barcelona: Biblioteca Tau, 1971, p. 14. Otro autor que también ensalza el Islám y la cultura árabe como fuerzas integradoras del Sultanato es De la Serna. Consúltese SERNA, Alfonso de la: Op. Cit., p. 148-158.
} 
Marruecos fundamentadas en el triple principio -fijado en la Nota del 8 de julio- de respeto a la soberanía del Sultán así como a la integridad territorial del país y de reconocimiento de la igualdad económica entre las potencias participantes. Pero el texto del Acta creaba, en la práctica, un protectorado hispano-francés, sometido a un difuso control internacional ${ }^{58}$.

Inicialmente los plenipotenciarios se ocuparon de asuntos poco conflictivos, como los relativos al contrabando de armas y a los impuestos y aduanas, postergando las cuestiones del Banco de Estado marroquí y, sobre todo, la organización de la policía en los puertos. Así, se lograría la aprobación de un proyecto para la represión del contrabando de armas, tanto por vía terrestre como marítima. Francia y Marruecos asumieron esta competencia en la frontera de Argelia, a la par que España y Marruecos harían lo mismo en el Rif y en las zonas fronterizas con las plazas bajo soberanía española (aunque ni franceses ni españoles podrían ejercer el derecho de visita sobre buques alemanes sospechosos de contrabando. Lo tendrían que hacer las autoridades británicas de Tánger o Gibraltar).

En cuanto a la aduanas, los alemanes propondrían un recargo global del 21,5\% sobre los derechos de importación, mientras que los gravámenes sobre las exportaciones debían reducirse para favorecer el tráfico comercial. Aunque esta propuesta no generaba, en principio, conflictos los franceses reclamaron el llamado derecho de control para los tenedores del empréstito de 1904. Y lo consiguieron, pese a las protestas de la delegación alemana.

Para la organización del Banco de Estado se requirieron gestiones muy laboriosas y se presentaron dos proyectos: uno alemán que apostaba por la creación de una entidad concesionaria por cincuenta años, con sede en Tánger y con capital suscrito en pesetas aportado en partes iguales por las potencias asistentes a la reunión; y otro francés, que frente a la tesis de la internacionalización financiera, perseguía garantizar la preponderancia francesa al suscribir la mayor parte del capital social. Si bien el duque de Almodóvar intentó terciar en la materia, elevando la participación española en el capital del Banco, acabaría apoyando las aspiraciones francesas, que de nuevo apelaban a los derechos de los tenedores del empréstito francés de 1904. Revoil logró que la Banque de Paris et des Pays-Bas fuese autorizada a fundar, con capital internacional, un Banco de Estado con el privilegio exclusivo de emitir billetes y regido por leyes

\footnotetext{
${ }^{58}$ VALLE, Alejandro del y VERDÚ, Jesús (Dirs.): España y Marruecos en el centenario de la Conferencia de Algeciras. FMV: Madrid, 2007.
} 
francesas. Se acabó dividiendo el capital del mismo en catorce participaciones: una para cada potencia signataria, pero con la salvedad francesa, a quien se le atribuyeron dos.

El auténtico caballo de batalla en la Conferencia, ya para terminar con esta síntesis de las conversaciones, fue el de la organización conjunta de la policía. Pero también aquí Francia acabó por salirse con la suya. La organización de la policía se encomendaría a instructores españoles y franceses y únicamente se aceptó una enmienda de la delegación austro-húngara, según la cual la inspección de la totalidad de la policía marroquí recaería en el Cuerpo Diplomático y, más concretamente, en un Inspector General suizo. España resultó un poco perjudicada con relación al reparto de zonas convenido en 1904. Su control policial quedaría limitado a los puertos de Tetuán y Larache, mientras que Francia asumiría la responsabilidad en los de Rabat, Mazagán, Saffi y Mogador. En Tánger y Casablanca, sin embargo, el cuadro de instructores sería mixto. Evidentemente, la prioridad de Francia y España consistía en garantizar la seguridad de los europeos residentes en las ciudades portuarias. La seguridad en el interior marroquí fue una cuestión desatendida por los conferenciantes ${ }^{59}$.

No faltarían en el desarrollo de las sesiones momentos en que Francia desconfiase de las pretensiones de los delegados españoles. De hecho, a Revoil no le agradó el que España preparase un cuestionario sobre el Banco y que se inclinase inicialmente hacia Alemania en el tema de la policía. Pero tras la intervención directa de Moret y la mediación británica, la cordialidad se restauró en la relación entre ambas naciones ${ }^{60}$.

En conclusión, Marruecos tenía sus días de independencia contados y no podía extrañar que el Sultán se resistiese a firmar el Acta hasta el 18 de junio de 1906; porque nada significaba el reconocimiento de la Soberanía del Sultán cuando muchas de sus facultades le eran arrebatadas. Aunque, por de pronto, se había evitado una conflagración en Europa, un logro bastante apreciado por la prensa local.

Por primera vez, El Adelanto, El Lábaro y El Castellano dedicaron una considerable superficie, a veces incluso en primera plana, a esta reunión internacional. Pero con todo, otra cuestión distinta es dilucidar si la calidad y el pluralismo de las informaciones allí vertidas se correspondían con ese protagonismo espacial. A El Adelanto pertenece, en esta ocasión, la cobertura más completa del encuentro. Aunque no es, desde luego, excepcional. Más bien, todo lo contrario. Era lo esperable al tratarse

\footnotetext{
${ }^{59}$ ALLENDESALAZAR, José Manuel: Op. Cit., p. 30.

${ }^{60}$ GONZÁLEZ VELILLA, M ${ }^{\mathrm{a}}$ del Carmen: Op. Cit., pp. 376-377.
} 
del diario que mayor significado otorga a la Conferencia; y el más consciente de que la ciudad andaluza hacía las veces, durante algunas semanas, de escaparate español ante el mundo; le preocupaba sobremanera la idea de una conflagración; y fue, además, éste el diario salmantino que más se esforzó en escudriñar las directrices por las que se orientaría la diplomacia europea en Marruecos.

Para los otros dos periódicos salmantinos a los que venimos refiriéndonos, en cambio, la Conferencia de Algeciras fue un mero pretexto con el que pulsar el estado de las relaciones franco-alemanas. No hallamos apenas editoriales; y las conversaciones diplomáticas a propósito del futuro del Imperio marroquí no fueron abordadas de forma relevante. En el caso de El Lábaro sorprende -y agota- la colosal cifra de desconcertantes y contradictorios telegramas, procedentes de Fabra, en los que se reseñan los comentarios de las cabeceras extranjeras sobre la marcha de las sesiones. El interés por los mismos alcanza cotas inauditas en la segunda quincena de febrero, dado que precisamente las sesiones se suspendieron entre el día 17 de este mes y el 3 de marzo por los muchos obstáculos que se planteaban en las conversaciones. Una cuarentena de cabeceras europeas fueron empleadas asiduamente con la intención de generar, creemos, un ficticio estado de ansiedad pre-bélica. Por otro lado, también el mismo periódico contrató los servicios de la Agencia Mencheta con el objeto de conocer, de primera mano, lo que ocurría en Algeciras.

Deseamos subrayar, antes de proceder al repaso más exhaustivo de los contenidos de los periódicos locales, dos notas comunes de la prensa salmantina en este periodo: en primer término, la marginación de los comentarios efectuados en los periódicos de la Corte a propósito del desarrollo de la Conferencia. Pareciera como si los órganos oficiosos de nuestros partidos políticos nada tuviesen que opinar. No obstante, conviene añadir un matiz: Alfredo Rivera, quien trabajó como corresponsal de plantilla para El Adelanto desde Madrid y encargado, a lo largo de esta veintena de años que nos ocupa, de su sección de noticias telegráficas y telefónicas, también fue uno de los redactores de El Imparcial. El Adelanto rara vez pregonó esta doble condición del periodista, pero sería absolutamente revelador de cómo funcionaban los tentáculos del Trust.

Por otro lado, ni los redactores de El Lábaro ni los de El Castellano pusieron demasiado empeño en alimentar el debate público sobre la Conferencia. Tampoco lo hizo el personal de la casa de Núñez Izquierdo aunque, debemos efectuar una segunda aclaración: al menos, se molestó por contratar un servicio informativo especial. Toda 
esa cautela denota, a nuestro entender, la enorme dificultad existente para emitir desde Salamanca un juicio sobre la cuestión marroquí. Por consiguiente, a duras penas pudo el periodismo local desempeñar una función pedagógica, actuar como guía para la opinión pública, cuando los cronistas no sabían a qué atenerse. Ellos mismos estaban cuestionando la utilidad de ese constante martilleo con brevísimas noticias de agencia.

Las primeras acotaciones de El Adelanto pintaban un ambiente animado, de enorme expectación y dominado por el deseo de inteligencia franco-alemana ${ }^{61}$. El tono de las comunicaciones de Alfredo Rivera era marcadamente costumbrista porque las sesiones transcurrían serenamente ${ }^{62}$ : Almodóvar es designado como presidente ${ }^{63} ;$ los diplomáticos visitan los alrededores de la ciudad; el hotel Reina Cristina ofrece unas maravillosas instalaciones... Aunque no se pasa por alto el hecho de que los diplomáticos no pronuncien jamás declaraciones "de provecho" ante los periodistas y se ridiculiza a los delegados marroquíes porque, hasta cuando se les pregunta por su salud, actúan como si se hallasen ante una cuestión de estado y muestran increíbles recelos ${ }^{64}$. La composición de la delegación española constituía un clarísimo indicador de la relevancia que el gobierno liberal de Segismundo Moret otorgaba a la Conferencia: estaría presidida por Almodóvar del Río, ministro de Estado con enorme preparación en cuestiones internacionales; y con Juan Pérez Caballero, embajador de España en Bruselas, como secretario. Sus instrucciones consistían en buscar la solución del conflicto franco-alemán y velar por la preservación del Convenio hispano-francés. Con un total de diecinueve integrantes, sorprendía la ausencia de militares: muy probablemente porque un grupo de ellos ya se había manifestado contrario a los tratados

\footnotetext{
${ }^{61}$ Alfredo Rivera: "Telegramas", El Adelanto, no 6.670, 16 de enero de 1906, p. 4.

${ }^{62}$ Con un similar enfoque costumbrista, haciendo hincapié en el significado de la celebración de la Conferencia en la propia ciudad gaditana de Algeciras, deseamos recomendar la lectura de FERNÁNDEZ MOTA, Manuel: Memoria histórica de una Conferencia (Algeciras, 1906). Algeciras: Fundación Municipal de Cultura "José Luis Cano", 2001. A propósito del trabajo de los reporteros en el patio de la Casa Consistorial de la localidad, comenta Fernández Mota (pp. 123-124): “Los periodistas comentaban, discutían, comunicaban noticias adquiridas de forma más o menos interesante, o simplemente extendian bulos que a veces se agrandaban como dunas gigantescas (...) nada tiene tanta fuerza convincente como la palabra escrita en la prensa diaria. Porque además de tener el calor de la vigencia temporal, de la actualidad, y conservando la facultad de ser voz y opinión que se abre como una flor diaria ante los ojos de millones de hombres (...) también tiene la posibilidad de conservarla para el conocimiento de generaciones futuras". También es útil para aproximarse al impacto de la Conferencia en la propia ciudad gaditana TORREMOCHA SILVA, Antonio: "Algeciras en tiempos de la Conferencia de 1906" en VVAA: Actas del Congreso Internacional. La Conferencia de Algeciras de 1906. Cien años después. Algeciras: Fundación Municipal de Cultura José Luis Cano, 2008, pp. 601-613.

63 Alfredo Rivera: "Telegramas", El Adelanto, no 6.671, 17 de enero de 1906, p. 4.

${ }^{64}$ Alfredo Rivera: “Telegramas”, El Adelanto, no 6.672, 18 de enero de 1906, p. 4.
} 
internacionales y demandaba una acción militar fulminante y contundente en Marruecos ${ }^{65}$.

El día 19 de enero, en portada, publicaba el diario de Núñez Izquierdo un detallista grabado del salón de sesiones. Lo acompañaba un editorial, sin firma y sin desperdicio:

"Algo más trascendental para nosotros que el porvenir del Magreb ha de decidirse en Algeciras: la paz europea y el porvenir de España en Marruecos. Las corrientes conciliadoras iniciadas en estos últimos días hacen abrigar esperanzas de que la Conferencia no se verá interrumpida para dejar la palabra a los cañones; pero nada se sabe en cuanto al papel que a España se le reservará en Marruecos No obstante estar interesada cual la que más en todo cuanto a Marruecos se refiera, como es de las menos poderosas, de las que no pueden imponerse amenazando, es más que probable que nuestra patria salga maltrecha de la Conferencia, para que otras, con menos derechos, puedan saborear el suculento plato que la historia y la geografía señalan para nosotros. Pero en medio de nuestra desventura debemos darnos por muy satisfechos si todo el mal que para nosotros pueda salir de la Conferencia queda reducido a que nuestros intereses en Marruecos no tengan la satisfacción que les corresponde, ${ }^{3,66}$.

Tanto el grabado como el editorial se incluían bajo el encabezamiento general "Servicio especial de El Adelanto" y sospechamos que el autor del escrito era D. A. Morais porque en otras ocasiones posteriores aparecería esta misma sección junto con su nombre. El redactor admitía que el objetivo básico de los delegados internacionales era evitar una conflagración europea, y no tanto garantizar el orden y el progreso en el Magreb; aceptaba, por otro lado, con total resignación, que sí eso se conseguía, poco importaba que España perdiese sus derechos ancestrales y legítimos en el Sultanato. A fin de cuentas, tampoco contaba con demasiados medios como para "saborear el suculento plato". Morais sabía, por tanto, que la diplomacia española tenía perfecta conciencia de su propia debilidad y ello le avocaría a actuar como segundona de Francia.

Desde que se había procedido al reparto de zonas de influencia en 1904, el gobierno francés se empeñaba en arrastrar al de Madrid hacia una política común de penetración y conquista en Marruecos. Era ésta la vía elegida para procurarse un mínimo de legitimidad internacional con que garantizar las comunicaciones entre Argelia y el Atlántico.

\footnotetext{
${ }^{65}$ FARAMIÑÁN GILBERT, Juan Manuel de y GUTIÉRREZ CASTILLO, Víctor Luis: La Conferencia de Algeciras y las relaciones internacionales. Sevilla: Fundación Tres Culturas, 2007, p. 255

66 "La Conferencia de Algeciras", El Adelanto, n ${ }^{\circ}$ 6.673, 19 de enero de 1906, p. 1.
} 
Pero el mantenimiento del statu quo marroquí era para España, y más a raíz del Desastre del 98, una condición necesaria para su propia reconstrucción interior ${ }^{67}$. Los partidos dinásticos buscaban un remedio para el estado de debilidad militar y naval del país. Incluso, ya en el temprano año de 1887, España había firmado un pacto con Italia cuyo objetivo era garantizar la estabilidad de la zona mediterránea. Este Tratado conectaba a España con la Triple Alianza y tenía una clara vocación antifrancesa. Ciertamente, el norte de África se consideraba como la frontera meridional de España y la más horrenda pesadilla entre los gobernantes de Madrid consistía en que Francia se estableciese allí y nos “emparedase”. El pacto se renovó en 1891, pero no en 1895 , cuando estalló la gran insurrección cubana ${ }^{68}$. Daba así comienzo un tímido viraje en la política internacional española: aquél que conduciría a un primer Tratado con Francia en 1900.

El régimen del statu quo, decíamos, procuraba la defensa de un sistema económico de puertas abiertas en el Sultanato, postergando la decisión sobre su previsible reparto político. El nacimiento del africanismo español no supuso una seria amenaza para la defensa oficial de este statu quo. En buena medida, porque la vigilancia inglesa sobre el Estrecho frenaba el desarrollo del mismo ${ }^{69}$.

\footnotetext{
${ }^{67}$ A propósito de las dificultades para sostener el régimen del statu quo marroquí, cabe destacarse el esfuerzo del historiador Bernabé López García por recuperar algunos textos de nuestros más conocidos arabistas. Tal es el caso de la serie "La cuestión de Marruecos", de Julián Ribera y Tarragó, recogidos originalmente en la Revista de Aragón entre 1901 y 1902. Hoy se pueden localizar en la Revista de Estudios Internacionales Mediterráneos, $\mathrm{n}^{\circ}$ 6, Madrid, 2008, pp. 172-190. A lo largo de cinco meditados editoriales, el insigne arabista reflexionaba sobre nuestras perspectivas de futuro en Marruecos y concluía: "El statu quo, como la conquista, exige de nosotros la debida preparación (...) ha de comenzar a formarse opinión (...) los gobernantes, en lo de Marruecos, participan, además, del confuso y desacertado concepto que el vulgo español tiene formado del asunto. Para ellos no hay otros elementos que preparar, más que los militares (....) ¡Qué ceguedad de espíritu!". También sobre este conocido arabista, consúltese LÓPEZ GARCÍA, Bernabé: "Julián Ribera y su taller de arabistas. Una propuesta de renovación" en LÓPEZ GARCÍA, B. (Ed.): Marruecos y España ...Op. Cit., pp. 85-104.

${ }^{68} \mathrm{La}$ renuncia a esta renovación del Tratado con Italia constituye un punto bastante oscuro de nuestra historia diplomática. Algunos de los autores que hemos consultado aluden al creciente miedo a una previsible mala reacción francesa. Otros, por el contrario, apuntan a que España estaba totalmente dispuesta a integrarse en una alianza antifrancesa si con ello lograba respaldo militar frente a los insurrectos cubanos. Sea como fuere, España se desvinculó de Italia e, indirectamente, de Alemania. Nuestro propósito, en cualquier caso, no es el estudio minucioso de las relaciones exteriores españolas a comienzos de la centuria. Si estamos desmenuzando, hasta el momento, los tratados referidos al reparto de Marruecos es para demostrar que los antecedentes diplomáticos del Protectorado eran, casi por completo, desconocidos entre los salmantinos (y, por extensión, entre el resto de españoles). Paradójicamente, los gobiernos españoles se lamentaron en reiteradas ocasiones ante la política francesa de hechos consumados, pero ellos siguieron una idéntica conducta ante su opinión pública.

${ }^{69}$ SÁNCHEZ SANZ, Oscar Javier: Op.Cit., 2006, p. 566. El término "africanismo" ha conocido, con posterioridad, una reducción semántica: de las inocentes reivindicaciones de una minoría de intelectuales -Coello, Costa, Saavedra, etc. - en busca de la regeneración nacional a la brutal actuación de las tropas de choque, decisiva en el largo plazo para la gestación de la Guerra Civil. Sobre los orígenes históricos del pensamiento africanista, la idea de África como "destino manifiesto", consúltese REGUERA
} 
Encontramos, consecuentemente, un africanismo -con dos núcleos, afincados en Madrid y Granada- que si bien aboga por una penetración civilizadora desde las plazas de soberanía ${ }^{70}$, siempre se muestra respetuoso con la soberanía y la integridad del Imperio marroquí. Sus objetivos, en líneas generales, eran la defensa de los derechos históricos de España sobre determinados territorios; la potenciación de exploraciones y viajes y la movilización social en defensa del colonialismo. Las sociedades geográficas y asociaciones coloniales desempeñaron un papel hegemónico en todo este proceso. Impulsadas por la burguesía decimonónica, apostaban por la penetración pacífica basada en los intercambios mercantiles ${ }^{71}$.

Pero coincidiendo con la firma del Convenio de 1904, el africanismo iniciaría un moderado proceso de mutación: se distanciaría de los estudios arabistas y de esa sublimación quijotesca de valores tales como la fraternidad y la generosidad para ser adoptado como ideología de algunos grupos neocolonialistas ${ }^{72}$. Se encontrarían aquí

RODRÍGUEZ, Antonio T.: "La formación de la conciencia africanista en España" en DÍEZ TORRE, A. R.: Ciencia y memoria de África: Actas de las III jornadas sobre expediciones científicas y africanismo. Madrid: Servicio de Publicaciones de la Universidad de Alcalá de Henares, 2002, pp. 23-45. También: MARTÍNEZ CARRERAS, José U.: "El africanismo español" en PEREIRA, J. C.: La política exterior ... Op. Cit., pp. 357-369. Para un conocimiento más pormenorizado del africanismo decimonónico, PEDRAZ MARCOS, Azucena: Quimeras de África. La Sociedad Española de Africanistas y Colonialistas. El colonialismo español de finales del siglo XIX. Madrid: Polifemo, 2000. Sobre la mutación en la percepción española de Marruecos coincidiendo con el desarrollo de la Guerra de Tetuán, véase MORALES LEZCANO, Víctor: España y el mundo árabe: imágenes cruzadas. Madrid: Agencia Española de Cooperación Internacional, 1993 (sobre todo, el capítulo "Especificidad africanista del Orientalismo español, 1850-1930", pp. 57-71).

${ }^{70}$ Conviene puntualizar que este africanismo no es el que existía a la altura de 1859-1860. En sus primeras formulaciones el africanismo "romántico" llamaba a la tradición, a la cruzada y el espíritu de la Reina Católica. Pero desde los años setenta, se articula un discurso más filantrópico, fundado en una supuesta obligación civilizadora. El historiador Youssef Akmir, por ejemplo, sintetiza sus aspiraciones en tres puntos: su primera ambición consistió en aprovechar el estado de desunión entre el pueblo marroquí y el Majzén con el objeto de ampliar la superficie de las dos plazas españolas y apropiarse de los terrenos en toda la zona norte de Marruecos. El segundo objetivo tenía mucho que ver con la cuestión de asegurar la soberanía en estas plazas. Y el tercer motivo se fundamentó en la necesidad de garantizarse un territorio para cuando se rompiese el statu quo. Véase AKMIR, Youssef: "Reflexiones sobre la sociedad marroquí y la política de atracción española (1898-1912)" en MARTÍNEZ CARRERAS, J. U. (Coord.): Relaciones entre España y Marruecos en el siglo XX. Madrid: Asociación Española de Africanistas, 2000, p. 33.

${ }^{71}$ NOGUÉ, Joan y VILLANOVA, José Luis: "Las sociedades geográficas y otras asociaciones en la acción colonial española en Marruecos" en NOGUÉ, J. y VILLANOVA, J. L.: España en Marruecos (1912-1956). Discursos geográficos e intervención territorial. Lleida: Editorial Milenio, 1999, pp. 184224. Destacaron, por citar algunos ejemplos, la Sociedad Geográfica de Madrid (1876), la Sociedad Española de Africanistas y Colonialistas (1883) o la Liga Africanista Española (1913). También fueron instituciones muy interesadas en fomentar los intercambios comerciales la Compañía Comercial Hispano Africana (1885) o los Centros Comerciales Hispano-Marroquíes (1904). Potenciaron muy variados encuentros, como la Conferencia de Madrid (1880), el Congreso Español de Geografía Colonial y Mercantil (1883), el Mitin del Teatro Alhambra de Madrid (1884) o los Congresos Africanistas de Madrid (1907 y 1910), Zaragoza (1908) y Valencia (1909).

${ }^{72}$ La responsabilidad de ese distanciamiento también recayó en los propios arabistas. Véase LÓPEZ GARCÍA, Bernabé: "Arabismo y orientalismo en España: radiografía y diagnóstico de un gremio escaso y apartadizo", Awraq. Estudios sobre el mundo árabe e islámico contemporáneo, Vol. XI, Madrid, 1990, 
implicados industriales catalanes, compañías navieras, aseguradoras y comerciantes de frutas de Levante y Andalucía; igualmente interesados se mostrarían los inversores mineros y en obras de infraestructura. Por último, y ya muy a las claras desde 1909, se desarrollaría una nueva corriente, compuesta mayoritariamente por tradicionalistas y militares, defensora de la expansión militar y colonial en África.

En 1906 el statu quo marroquí ya era insalvable y los plenipotenciarios, a diferencia de lo ocurrido en Madrid en 1880, no iban a permitir que el Sultán intentase aprovecharse de las rivalidades europeas ${ }^{73}$. Ahora, los delegados estaban preparados para intervenir en Marruecos cuanto antes. Por eso, algunas de sus políticas ya habían sido coordinadas previamente. Los editoriales de Morais para El Adelanto constituyeron una ilustrativa serie de notas biográficas sobre los más destacados personajes que asistieron a la Conferencia. El 23 de enero salió a la luz, junto con un nuevo grabado, el perfil de Visconti Ventosa, el enviado italiano. Su designación se podía interpretar exclusivamente como un golpe de efecto contra Bülow, ya que era un viejo diplomático conocido por su francofilia:

"Se ha calificado de golpe de maestro la elección de Visconti Ventosa para delegado de Italia en la Conferencia de Algeciras é indudablemente el calificativo es justo y harto merecido (...) ¿Quién es y qué représenla ese diplomático, cuya elección para delegado en la Conferencia ha sido recibida con tanto disgusto en Berlín y con tanta satisfacción en el resto de Europa? (...) En la Conferencia de Algeciras significa la concordia y que Italia, posponiendo las más o menos discutibles pretensiones de uno de sus aliados, al bien general, a la paz europea, a los derechos adquiridos por las potencias mediterráneas, no está dispuesta a hacerse solidaria de los belicosos desplantes de Alemania, aunque esta la acuse de veleidosa y de faltar a los deberes morales que la imponen su existencia en la Triple Alianza. Visconti Ventosa es un sincero amigo de Francia $^{\text {"74 }}$.

Morais subrayaba, de este modo, los propósitos conciliadores con los que Italia acudía al encuentro internacional, pese a su comprometidísima situación diplomática: aliada de Alemania, ligada históricamente a Inglaterra y amiga de Francia. Sus buenas intenciones no dejarían de despertar enormes suspicacias (sobre todo, cuando en la sesión del 3 de marzo Visconti votó a favor de una propuesta británica relativa al orden de las negociaciones: primero la cuestión de la policía -que era el asunto que Alemania

pp. 35-69; MARÍN, Manuela: "Orientalismo en España: estudios árabes y acción colonial en Marruecos (1893-1943)", Hispania, LXIX/1, n 231, 2009, pp. 117-146.

${ }^{73}$ LAARBI MESSARI, Mohamed: "Reflexiones desde el sur de Tarifa: Algeciras, un hito en la historia de Marruecos" en GONZÁLEZ ALCANTUD, J. A. y MARTín CORRALES, E. (Eds.): Op. Cit., pp. 159-169.

${ }^{74}$ D. A. Morais: "Los hombre de la Conferencia. Visconti Ventosa", El Adelanto, no 6.676, 23 de enero de 1906, p. 1. 
pretendía postergar- y seguidamente la cuestión bancaria) ${ }^{75}$. Inculcaba Morais a sus lectores, simultáneamente, la idea de que las relaciones exteriores estaban muy condicionadas por las formas de trato, la empatía, entre sus gestores; no se podían simplificar a una sucesión de fechas y firmas de tratados.

El día siguiente, 24 de enero, se publican dos nuevas entregas, con grabados incluidos, sobre los delegados internacionales: las de El Mokri y Tattenbach ${ }^{76}$. El primero es el personaje con mayor carisma mediático de entre los asistentes a la Conferencia.

"Por su impenetrable reserva, su tranquilidad ante los delegados europeos. Al ver su aire de indiferencia diríase que tiene absoluta seguridad del triunfo de la misión que le ha sido encomendada o que ha ido a la Conferencia con la firme convicción de que su causa está perdida. Pero no, no creemos esto último. Esa impenetrabilidad de que se rodea, su augusto silencio (...) no son otra cosa que las características de su pueblo, la invulnerable coraza en que oculta el marroquí los pensamientos, los juicios, los planes, las sorpresas que guarda como un tesoro para confundir con ellas al enemigo en el momento más oportuno. Como se le cree el verdadero autor de la Conferencia, el que indujo a Guillermo II a adoptar las resoluciones que un día pusieron en peligro la paz europea, no falta quien vea encarnada en él la resistencia marroquí (...) a los políticos europeos".

La imagen tan inmutable del "moro" como individuo traicionero y rebelde estaba muy presente en este bosquejo biográfico. Lógicamente, porque tenía una enorme eficacia propagandística entre la opinión pública metropolitana. Sirvió como argumento legitimador de la anhelada misión civilizadora de los occidentales en África. Serviría después para explicar también, maniqueamente, una guerra ${ }^{77}$. Así que, durante

\footnotetext{
${ }^{75}$ GARCÍA SANZ, Fernando: "La política exterior de Italia en el norte de África: de Adua a la Conferencia de Algeciras" en GONZÁLEZ ALCANTUD, J. A. y MARTÍN CORRALES, E. (Eds.): $O p$. Cit., pp. 101-119.

${ }^{76}$ D. A. Morais: "Los hombres de la Conferencia. El Mokri y Tattenbach", El Adelanto, no 6.677, 24 de enero de 1906, p. 1.

${ }^{77}$ Existe una línea de investigación interesantísima y muy potente que se ocupa de estudiar la imagen del marroquí en la memoria colectiva de los españoles mediante el empleo de muy variopintas fuentes. Quien desee profundizar en este tema, debería consultar MADARIAGA, Rosa María de: "Imagen del moro en la memoria colectiva del pueblo español y retorno del moro en la Guerra Civil", Historia 16, Año XXVI, no 319, Madrid, 2002, pp. 8-35. Este artículo es una breve reseña del siguiente trabajo: MADARIAGA, Rosa María de: Los moros que trajo Franco... La intervención de tropas coloniales en la Guerra Civil Española. Barcelona: Ediciones Martínez Roca, 2002. Para la autora, la formación de un imaginario colectivo concreto sobre un pueblo implica una larguísima historia de intercambios y choques culturales, fácilmente sujeta a las manipulaciones interesadas. También atiende a la construcción del "moro" como enemigo Sebastián Balfour. Según este investigador, los militares coloniales estuvieron muy interesados en exagerar la ferocidad del enemigo moro porque ello les otorgaba la oportunidad de ser fácilmente ascendidos. Véase BALFOUR, Sebastián: "El otro moro en la guerra colonial y la Guerra Civil" en GONZÁLEZ ALCANTUD, J. A.: Marroquíes en la Guerra Civil Española. Campos equívocos. Barcelona: Antrhopos, 2003, pp. 95-110. No obstante, a nuestro juicio, el más profundo conocedor del imaginario español a propósito del "moro" es Eloy Martín Corrales. El volumen de fuentes que emplea en sus investigaciones es colosal (prensa, literatura, carteles, fotografía, cine...) y su exposición, muy clara. Véase MARTÍN CORRALES, Eloy: La imagen del magrebí en España. Una perspectiva histórica: siglo XVI-XX. Barcelona: Ministerio de Educación, Cultura y Deportes, 2002.
} 
la Conferencia, la delegación marroquí fue sistemáticamente marginada y siempre resultaron desestimadas sus peticiones de tiempo, pese a ser la parte más interesada en el resultado de las conversaciones.

Mientras tanto, del delegado alemán se enfatiza el odio que suscita entre los diplomáticos franceses:

“'Qué mal suena este apellido tudesco en los oídos franceses! (...) La astucia con que se condujo cerca de su majestad jerifiana durante su estancia en Fez, para estropear los planes de Francia y conseguir beneficiosas concesiones para Alemania, le han hecho famoso a la par que temible a los ojos de nuestra vecina nación (...) Carece de voto en la Conferencia, y, sin embargo, acaso dependa de él, más que de ningún otro representante, las conclusiones en que se base el futuro Tratado de Algeciras. Radowitz es la cabeza de la delegación alemana y Tattenbach el espíritu que inspira sus decisiones".

A juicio de Morais, indudablemente, Tattenbach era el plenipotenciario más intrigante.

El último de los editoriales de Morais, aparecido el 6 de febrero, versaba precisamente sobre su superior en la delegación, Radowitz. Sin duda, él se llevaba los comentarios más peyorativos:

"El plenipotenciario alemán en la Conferencia de Algeciras, barón de Radowitz, pertenece a la categoría de los diplomáticos que tienen mala suerte (...) ha fracasado en cuantas misiones de interés le han sido confiadas (...) no serán para Radowitz las glorias que la delegación alemana pueda arrancar a la de Francia en sus discusiones sobre el porvenir de Marruecos; pero ;ahí si hubiera fracasos; si la influencia de la vecina república llegara a eclipsar a la del gran imperio de los Hohenzollern!",78.

En esta misma reseña, se sacaba a colación un comentario realizado por Bismarck: "Es un buen perro, pero nunca trae nada". Poco se le puede añadir. Irrebatiblemente, Morais estaba presagiando el fracaso de la delegación germana en la Conferencia. Y, en efecto, muy poco tardaría en comprobarse la situación de aislamiento en que se hallaba Alemania. Todas sus propuestas toparían con el muro de la intransigencia gala. Porque éste sería el coste de haber convocado una reunión que nadie deseaba; de emplear la cuestión marroquí como pretexto para excitar los ánimos europeos contra Francia; y de la irracional política armamentística del káiser. Aunque la Weltpolitik de Guillermo II fue más una iniciativa de grandes palabras que de realidades. El káiser pretendió evitar una revolución social en el interior de Alemania y halló tanto en la expansión colonial como en la construcción de una armada de guerra los vehículos para cautivar a enormes sectores de la opinión, para distraerlos de su animadversión contra "el matrimonio del hierro y la cebada". Estas iniciativas

\footnotetext{
${ }^{78}$ D. A. Morais: “Los hombres de la Conferencia", El Adelanto, nº 6.688, 6 de febrero de 1906, pp. 1 y 4.
} 
acabarían, sin embargo, reportándole la hostilidad inglesa y produciendo un cierto enfriamiento de sus relaciones con Italia y Japón. ${ }^{79}$.

Recapitulando, El Adelanto publicó un primer editorial sobre los peligros de una inminente contienda y la debilidad diplomática española, además de cuatro perfiles biográficos que tenían como protagonistas a los integrantes de las delegaciones italiana, marroquí y alemana.

Hubo, asimismo, otros dos envíos especiales, firmados por un tal "Poliuto", para este diario: uno publicado el 12 de febrero; y el otro, inserto el 15 de marzo. El correo de febrero consistió en una caricatura de las principales potencias participantes en el encuentro, acompañada con una breve composición poética:

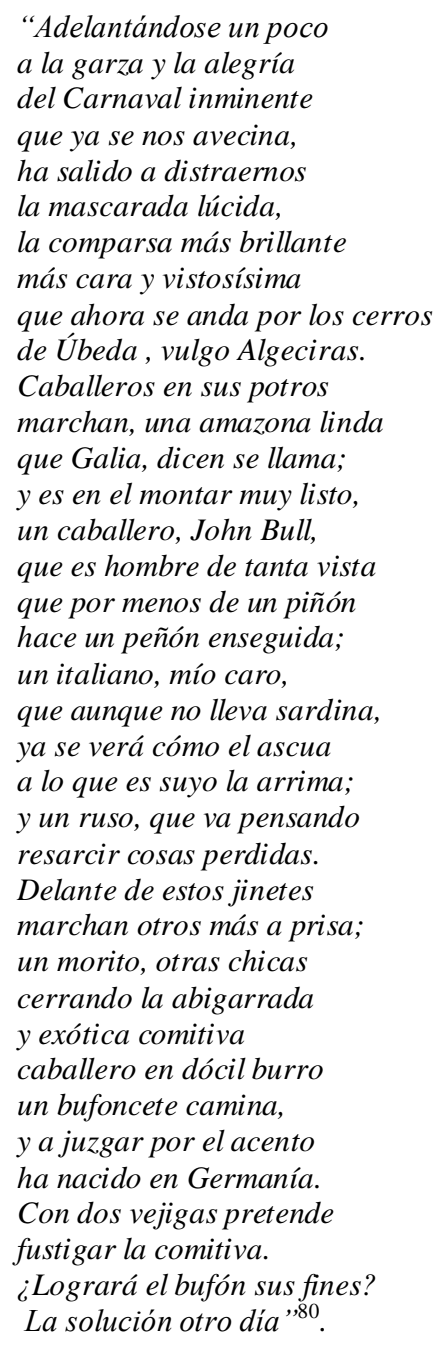

\footnotetext{
${ }^{79}$ Véase JANUÉ I MIRET, Marició: "Del "prestigio mundial" al aislamiento: la Conferencia de Algeciras y los errores del Weltpolitik alemana" en GONZÁLEZ ALCANTUD, J. A. y MARTÍN CORRALES, E. (Eds.): Op. Cit., pp. 73-100. También sobre la política de rearme naval del káiser y sus secuelas véase SOLAR CUBILLAS, David: "El mundo en vísperas de Algeciras" en VVAA: Actas del Congreso Internacional. La Conferencia de Algeciras de 1906. Cien años después. Algeciras: Fundación Municipal de Cultura José Luis Cano, 2008, pp. 15-24.

80 "Poliuto": "Caricaturas internacionales", El Adelanto, nº 6.693, 12 de febrero de 1906, p. 3.
} 
El envío del 15 de marzo pretendía, en cambio, censurar las lujosas aficiones de Abd-el-Aziz:

"En tanto los diplomáticos franceses, allá en Algeciras, tratan de preparar el terreno para que en época más o menos próxima llegue a ser su país, el dueño y señor de Marruecos, el joven Abd-el-Aziz juega y se divierte con los inventos que para recreo y alegría de los poderosos han creado las ciencias y la mecánica moderna, como si no tuviera relación alguna con el porvenir de su soberanía lo que Europa discute hoy, o cual si pretendiera hallar en sus diversiones la esponja que borrara de su mente presentimientos y temores harto justificados, ${ }^{\text {,281 }}$.

Sin embargo, no corría él con los gastos puesto que siempre había europeos dispuestos a ganarse sus favores. Una de sus entretenimientos más conocidos era la elevación de globos aerostáticos, así que a ello se le dedicó un grabado.

Su padre, Muley Hassán, había reinado desde 1873 a 1894 y fue el último Sultán con una voluntad de poder fuerte ${ }^{282}$. En cambio, Abd-el-Aziz se comportó como un gobernante débil y tremendamente europeizante. Mal visto por su pueblo, su mandato se entendió como un intento por cristianizar al imperio y por cambiar los tributos de tradición islámica por un sistema impositivo fundado sobre la propiedad de la tierra (el tertib). Reinó hasta 1908 y hubo de hacer frente a un feroz caudillo: el Rogui; y a su hermano, líder de una protesta nacionalista contra la penetración europea: Muley Hafid, "hombre vengativo y cruel, obsesionado por el erotismo, dado a la juerga etílica y buen catador de droga" ${ }^{283}$. Éste iniciaría su reinado en 1908, alcanzando el reconocimiento internacional en enero de 1909, y lo concluiría en 1912, al firmar el texto del Protectorado. Le sucedería Muley Yusef hasta 1927.

No fue un gran despliegue informativo el de El Adelanto, pero sí superior a los efectuados hasta el momento, al menos, por su claridad. Sin embargo, ¿cómo explicar el silencio a propósito de los delegados de la Entente? Intuimos que la redacción del diario juzgó poco adecuado verter opiniones sobre las "hermanitas mayores" de España en Marruecos: ni buenas, porque no las tenían; ni malas, porque resultaba inoportuno. El Convenio hispano-francés de 1904, ciertamente, no había agradado a este rotativo y, mucho menos, apreciaba la política francesa de penetración pacífica en el Sultanato. Pero no era éste el momento para denunciarlo, cuando se le habían visto las orejas al lobo alemán.

\footnotetext{
281 "Poliuto": "El Sultán se divierte", El Adelanto, n 6.720, 15 de marzo de 1906, p. 3.

${ }^{282}$ Un buen resumen de la historia de los Sultanes marroquíes a lo largo del siglo XIX puede hallarse en PASTOR GARRIGUES, Francisco Manuel: España y la apertura de la cuestión marroquí (1897-1904). Tesis doctoral inédita, Universidad de Valencia, 2006, pp. 101-162.

${ }^{283}$ BASTENIER, Miguel Ángel: Op. Cit., p. 105.
} 
Lo cierto es que la Conferencia de Algeciras, pese a su importancia, ni siquiera despertó un excesivo interés en las Cortes. Básicamente, porque las conversaciones previas se habían llevado a cabo con misterio; por esa conciencia derrotista a la que ya hemos aludido; y porque existía, aunque sólo teóricamente, la posibilidad que no aprobar el Acta final ${ }^{284}$. El senador republicano Labra fue una de las escasísimas personalidades que defendió el derecho del pueblo a estar informado sobre el desarrollo de las sesiones. A lo que Moret le respondió:

"Tiene razón el señor Labra, es preciso que esto lo sepa la opinión. Allá en Cataluña y en las demás provincias de Levante se piensa, sí, algo en Marruecos, porque afecta a su comercio y a su navegación; pero la masa, la generalidad no se ha figurado que hay en Marruecos más que la vaga y generosa idea del testamento de Isabel la Católica ${ }^{\text {,285. }}$.

La conducta adoptada por las delegaciones francesa e inglesa, así como la de otros representantes diplomáticos, se puede examinar, afortunadamente, por otra vía. Porque el diario de Núñez Izquierdo siguió con atención y reseñó el desarrollo de las sesiones, merced al trabajo de Alfredo Rivera. Pese a que también estas noticias telegráficas abundaron en detalles -bastante más que en el caso de El Lábaro y El Castellano-, carecieron de la vocación pedagógica/adoctrinadora de los escritos de Morais.

La calma imperante durante las primeras jornadas cedió paso a momentos de enorme tensión, alimentados, si nos guiamos por este diario, por la intransigencia germana. En un apéndice, el lector puede encontrar una síntesis cronológica de todas conversaciones y eventos recopilados por Rivera desde Madrid. No la incluimos en este punto para procurar que la lectura sea menos farragosa. Nos limitaremos a extraer unas conclusiones muy generales:

1. Los asuntos más preocupantes son la represión del contrabando, el régimen aduanero, la organización de la policía y la creación de un Banco de Marruecos. La primera cuestión es muy delicada para los intereses de marroquíes y españoles; a propósito del régimen aduanero casi todos los diplomáticos tienen algo que sugerir; mientras que las potencias más afectadas por los restantes temas, el de la policía y el banco, son Alemania y Francia.

\footnotetext{
${ }^{284}$ PÉREZ MOLINA, Elisa: Op. Cit., p. 120.

${ }^{285}$ Ibidem, p. 153. Se trata de un fragmento recogido en el Diario de Sesiones del Senado el 24 de febrero de 1906.
} 
2. El Mokri siempre es retratado como un individuo de trato difícil, mientras que a Pérez Caballero se le asigna el papel de hábil negociador y experimentado orador.

3. No se vierte ningún comentario relacionado con la firma del Acta de la Conferencia.

Cambiado ya de órgano periodístico, también el despliegue telegráfico del católico El Lábaro fue enorme. Aunque, por el contrario, no le dedicó ningún editorial a la Conferencia. Como ya se ha señalado, emplearon los servicios de la Agencia Fabra para conocer, básicamente, los comentarios vertidos en la prensa europea sobre el estado de las relaciones franco-germanas. He aquí un resumen de los más repetidos a lo largo de los casi tres meses de sesiones:

Periódicos italianos: buena parte de la prensa italiana teme la comprometida situación de su país en la Conferencia. Italia no pretende actuar como comparsa de Guillermo II.

Periódicos rusos: siempre se reproducen extractos que sirven para legitimar la presencia francesa en Marruecos. Creen que Alemania ha arrastrado a Europa al borde de un precipicio, pero carece de la suficiente fuerza para enfrentarse a la Entente. No puede defender la internacionalización de la policía porque ello contradice el Acuerdo franco-inglés de 1904.

Periódicos franceses: la prensa francesa defiende la buena disposición de su gobierno para aceptar un régimen de puerta abierta en Marruecos. Pero no claudicará en lo tocante a la internacionalización de la policía y el banco. Es preferible la conservación del statu quo; los periódicos de orientación socialista, en cambio, defienden que el pueblo no desea ninguna misión de policía en Marruecos; Algunos periodistas reproducen unas polémicas declaraciones de Miguel Villanueva, quien considera una provocación el establecimiento de una factoría francesa en la Mar Chica, previo arreglo con El Rogui; Referencias a El Mokri con términos muy halagadores; a la diplomacia alemana constantemente se le adjudica un enorme exceso de ambición. Desde el inicio de las sesiones, se prevé su aislamiento. Con el tiempo, cunde el desánimo y el temor a la guerra entre algunos redactores por las muchas divergencias surgidas.

Periódicos alemanes: actitud muy tranquila de la prensa alemana e insistencia en la idea de que Guillermo II es el verdadero defensor de los intereses marroquíes. Francia 
ha sido la responsable de la ruptura del statu quo. Cederle la organización de la policía equivale a anular el principio de puerta abierta. A medida que transcurren las sesiones, se aprecia entre los periodistas germanos una creciente indiferencia.

Periódicos ingleses: en general, la prensa británica recela de los planes alemanes en la Conferencia. Creen que su deseo es hacerla fracasar y los periodistas siguen con detenimiento los encuentros entre los delegados germanos y marroquíes, así como las reuniones, en Fez, entre el Sultán y el Cónsul de Alemania. Su apoyo a las pretensiones francesas sobre la policía y el banco es inquebrantable. Se muestran convencidos de que la conflagración no está próxima.

De manera excepcional, una de las noticias remitidas por la Agencia Fabra recogió las declaraciones hechas por León y Castillo ante un periodista francés. El diplomático se lamentó por la existencia de una campaña mediática española contra Francia. Sin embargo, esa campaña apenas llegó a Salamanca.

Curiosamente, El Lábaro recurrió, además, a la Agencia Mencheta para ocuparse de las discusiones entre los delegados internacionales. El número de telegramas remitidos por esta empresa a la redacción es, sin embargo, bastante menor que el de los pertenecientes a Fabra. Peris Mencheta, desplazado al escenario de los acontecimientos, sintió predilección por los debates relacionados con la represión del contrabando así como por las noticias procedentes de la Mar Chica y mostró algunos recelos hacia la política francesa. Nadie más lo haría. De todos modos, sus comunicaciones para El Lábaro no admiten comparación con la viveza y capacidad crítica de las remitidas a El Noticiero Sevillano, periódico del que era director y propietario $^{286}$. Seguramente, la dirección del periódico católico no sabía bien a qué atenerse y evitaba otorgar publicidad a opiniones demasiado comprometidas.

En la Restinga, una localidad situada en la estrecha franja de tierra que separa la Mar Chica del Mediterráneo y muy cercana a Melilla, dos súbditos franceses lograron abrir, en noviembre de 1905 y con el permiso de El Rogui, una factoría. Desde allí se pretendía introducir armas en la región para fomentar los conflictos tribales. Así que en febrero de 1906 -con el consiguiente revuelo entre los plenipotenciarios que debatían en Algeciras-, el único barco de combate que poseía Marruecos destruyó esa factoría. Sin embargo, el general Marina, mientras tanto, le había prometido al cabecilla rebelde

\footnotetext{
${ }^{286}$ LÓPEZ ENAMORADO, M Ma Dolores y TORRES GARCÍA, Ana: "La prensa sevillana y la Conferencia de Algeciras" en GONZÁLEZ ALCANTUD, J. A. y MARTÍN CORRALES, E. (Eds.): $O p$. Cit., pp. 271-301.
} 
ayuda para adueñarse de la aduana de Dyennada con el objeto de distraerlo de sus tratos con los franceses. Después de la intervención marroquí, el comandante general de la plaza seguiría negociando con El Rogui y dos sociedades mineras se beneficiarían de contratos con el mismo ${ }^{287}$. Volveremos sobre este asunto más adelante.

Si dirigimos ahora nuestra mirada hacia El Castellano, hemos de comenzar señalando que únicamente encontramos dos editoriales sobre el desarrollo de la Conferencia de Algeciras. Su servicio de informaciones telegráficas vuelve a se, además, el más deficiente entre los periódicos manejados. Al igual que con El Adelanto, nos referiremos primeramente a esos editoriales. Salen a la luz los días 9 y 24 de marzo; su autor aparece bajo el pseudónimo "H."; y ambos escritos son bastante críticos con la conducta adoptada por los delegados internacionales.

En el primero de esos editoriales, se sugiere que la Conferencia debe ser suspendida ante la falta de voluntad, de inteligencia, y la pereza mostrada por los plenipotenciarios:

"Es posible que los lectores no lo hayan notado, por estar distraídos o por tener otras cosas en la cabeza. Pero yo creo que la Conferencia de Algeciras continúa lo mismo. Se sabe que Francia no quiere hacer más concesiones, y que Alemania no hará nada. Por consiguiente, los delegados debían ya haber hecho sus maletas sin inconveniente alguno. Pero, sin duda, quieren prolongar su temporada de recreo (...) porque no son ellos los que pagan la cuenta del hotel, ${ }^{288}$.

En el segundo, "H." reincide en que las conversaciones transcurren con demasiada parsimonia y con perjuicio directo para los intereses españoles:

"Durante este tiempo Europa ha esperado impaciente: todo está suspendido y la vida normal no se puede restablecer, porque los diplomáticos de por allá se conducen como gitanos negociando la venta de un caballo (...) Alemania sabe muy bien la suprema concesión que le acomoda hacer, y Francia sabe igualmente la última condescendencia que tiene reservada; pero ni la una ni la otra se deciden a hablar, contando con la quimérica esperanza de obtener por el cansancio de la parte adversa mucho más de lo que puede presumirse. Y nosotros, con gran detrimento de nuestros intereses, estamos con la boca abierta y el alma en un hilo, esperando el fin de esta pueril comedia "289.

Una nada disimulada irritación es lo que se desprende de ambos artículos. Tanto la diplomacia francesa como la alemana actúan por amor propio, con enorme terquedad y, mientras tanto, al gobierno español le toca esperar, a la par que los ciudadanos se desentienden del desarrollo de las sesiones por puro aburrimiento.

\footnotetext{
${ }^{287}$ BOUARFA, Mohamed: Op. Cit., pp. 60-61. Mucho más suavizada, porque se insiste en que las autoridades españolas carecían de margen de maniobra ante El Rogui, es la versión que de este episodio nos ofrece ALLENDESALAZAR, José Manuel: Op. Cit., pp. 135-136.

288 "H.":"'La Conferencia", El Castellano, n' 1.089, 9 de marzo de 1906, p. 1.

289 "H.”: "Cosas de la diplomacia”, El Castellano, n' 1.104, 24 de marzo de 1906, p.1.
} 
La acción francesa estaba, de hecho, totalmente condicionada por la pretensión de garantizar su asentamiento en Argelia. Pero Francia no podía decantarse por la simple penetración armada en Marruecos, ya que ello alteraría de modo muy notable el equilibrio de fuerzas en Europa. Aún así, los franceses incumplieron sistemáticamente su compromiso de respetar la soberanía del Sultán y, en su lugar, provocaron a los cabileños para justificar acciones de represalia. Gran Bretaña, por su parte, se conformaba con apoyar los esfuerzos franceses orientados al quebrantamiento de la Triple Alianza. Había sido la primera potencia capaz de alcanzar un tratado comercial con el Sultán en 1856. Pero sus intereses en el Sultanato siempre fueron económicos y estratégicos: utilizaría Marruecos como moneda de cambio, con la única condición de que se garantizase la seguridad de Gibraltar. Más allá de esta prevención, sus intereses coloniales se asentaban en el Pacífico.

De las informaciones reproducidas telegráficamente por El Castellano (también en los apéndices), queremos subrayar que son, por norma, menos descriptivas que las de El Adelanto y El Lábaro; las conversaciones sobre el régimen aduanero apenas interesaron; el papel desempeñado por cada plenipotenciario pasó más desapercibido; y Alemania, si bien es la potencia que finalmente claudica, no es presentada como una perdedora.

Tenemos que concluir que el seguimiento que los rotativos salmantinos hicieron de la Conferencia de Algeciras fue discreto, si bien más atento que el prestado en periodos previos. Sus informaciones son mucho más pobres que las vertidas en los periódicos de otras ciudades, sobre todo, las costeras (y que han recibido, como hicimos constar en el capítulo introductorio, bastante atención por parte de los historiadores con motivo del centenario de la reunión). Quizás, aventuramos siguiendo los juicios de Segismundo Moret, porque el beneficio económico que Marruecos podía reportar a Salamanca era apenas percibido por esas familias y redes clientelares que manejaban la prensa periódica. Únicamente, Morais calificó a aquel país de "suculento plato", pero valía la pena renunciar a él si con ello se evitaba una contienda. Por entonces, el Sultanato ni siquiera era contemplado como un posible destino para los emigrantes. A decir verdad, y esto es lo que consideramos más importante, tampoco se presagiaba que Marruecos acarrease gastos para los salmantinos. Ninguno de los telegramas ni editoriales comentados refleja ya miedo ante los posibles compromisos que España adquiriese en África. Se estaba iniciando un viraje en todas las opiniones publicadas: no 
solamente el statu quo marroquí era improrrogable, sino que se daba por sentado que el amargo recuerdo del 98 debía reducirse a eso: un triste episodio que no condicionara el quehacer diplomático.

Aunque el texto del Acta, aparentemente, salvaguardaba el statu quo marroquí, permitía a Francia, en la práctica, ejercer una acción política predominante cerca del Sultán. A España, la Conferencia le sirvió para fortalecer sus vínculos con la Entente, sellados además con el matrimonio entre Alfonso XIII y una princesa inglesa en mayo. El 23 de febrero de 1907 se firmaría un nuevo Acuerdo franco-español relativo a la policía, ya que en Algeciras no se había especificado cómo se debía proceder exactamente en los puertos de Tánger y Casablanca: ambas ciudades quedarían divididas en dos zonas, la urbana y la extraurbana. A los instructores españoles les correspondería la zona urbana de Tánger y la extraurbana de Casablanca, mientras que los franceses se ocuparían de la extraurbana de Tánger y la urbana de Casablanca. Este Convenio, sin embargo, pasó totalmente inadvertido entre los cronistas salmantinos.

\section{LA OPINIÓN PÚBLICA LOCAL, TESTIGo DE LOS ACUERDOS DE CARTAGENA}

Absolutamente inmersos ya en la dinámica de la bautizada como "paz armada", la búsqueda de una garantía internacional para las posesiones insulares españolas se presentaba como un problema acuciante a ojos de los políticos españoles. Había sido una de sus recurrentes preocupaciones desde 1898; pero debido, sobre todo, a los deseos expansionistas germanos, estaba adquiriendo ahora tintes muy dramáticos. La explicación residía en que el desarrollo de un fuerte poder naval requería tiempo, así que se imponía, como inmediato remedio, la obligación de alcanzar una fórmula diplomática que satisficiese las necesidades defensivas del país ${ }^{290}$.

Ésa fue, precisamente, la pretensión del gabinete Maura en la reunión de Cartagena. Los salmantinos fueron testigos del protocolario encuentro, protagonizado por Eduardo VII de Inglaterra y el Rey Alfonso XIII, a través de El Adelanto y El Lábaro. El Castellano, en esta ocasión, se mantuvo completamente al margen.

A pesar de la trascendencia de esta entrevista regia, mediante la lectura del primero de los diarios, apenas se llega a intuir la enorme significación del nuevo evento internacional: el mismo 8 de abril de 1907, en su sección telegráfica, Rivera describe el

${ }^{290}$ RAMIRO DE LA MATA, Javier: Op. Cit., p. 127. 
boato y la alegría que desatan los monarcas a su paso por la localidad: se prepara una gran exhibición de fuerzas navales; la ceremoniosa visita a un hospital; vendedores ambulantes que comercian con los retratos regios; agasajos para las reinas... y mientras tanto, recordándonos lo ya ocurrido en Cartagena, el personal diplomático niega ante los periodistas que la reunión entre monarcas posea un carácter político ${ }^{291}$. Durante los dos días siguientes, el corresponsal madrileño no refiere más que continuos brindis, el nombramiento del Rey inglés como capitán general honorario del Ejército español y los buenos deseos de entendimiento entre naciones unidas por estrechos lazos familiares ${ }^{292}$. La visita de los británicos concluye con una muy pomposa cena a bordo de su yate y, de inmediato, con una breve entrevista, de tan sólo quince minutos, entre los Reyes. Pero de su contenido, nada se sospecha ${ }^{293}$.

Y, en efecto, Alfredo Rivera no lo sospechaba. Sin embargo, en el mismo ejemplar se compensaba esa carencia informativa ante los lectores salmantinos mediante la reproducción, en primera página, de un esclarecedor editorial de La Época. Poco le importaba al periódico de Núñez Izquierdo, acostumbrado a comulgar con las ideas de republicanos y liberales, conceder la máxima autoridad en esta materia al órgano oficioso del maurismo. En ese artículo se reconocía, para empezar, que la cita dinástica era el tema de todas las conversaciones políticas; además, se insistía en la idea de que España necesitaba fortalecer su posición internacional y Marruecos debería asumir un protagonismo básico en tal cometido:

"España, no obstante sus desgracias, y a pesar de sus enormes quebrantos, tiene todavía en el mundo una importantísima representación (...) Por su posición en el África occidental, y por sus incuestionables derechos en Marruecos (...) Esa representación no puede ejercerse en el aislamiento, sino que impone vivir en la comunión de todos los pueblos, y exige que, al par que se cultiva la amistad de todas las naciones, se frecuente el trato y se menudee el cambio de impresiones con aquellos pueblos que en cada momento histórico y -en la Historia la circunstancias se prolongan a veces durante la vida de algunas generaciones-coinciden con nosotros en sus aspiraciones y en sus necesidades (...) Las aclamaciones del pueblo de Cartagena, llevan la voz de todo el pueblo español ${ }^{, 294}$.

En otras palabras, el descalabro del 98, ese enorme quebranto, no era tan severo como inicialmente se creyó, debido a que España, por sus derechos históricos en Marruecos y por su posición geográfica, estaba llamada a desempeñar una importante tarea en el juego entre las potencias europeas. Naturalmente, cómo no, el respaldo de la

\footnotetext{
${ }^{291}$ Alfredo Rivera: "Información telegráfica", El Adelanto, no 6.987, 8 de abril de 1907, pp. 1 y 4.

${ }^{292}$ Alfredo Rivera: "Información telegráfica", El Adelanto, no 6.988, 9 de abril de 1907, p. 4.

${ }^{293}$ Alfredo Rivera: "Información telegráfica", El Adelanto, no 6989, 10 de abril de 1907, p. 4.

294 “Notas políticas", El Adelanto, n $6.989,10$ de abril de 1907, p. 1.
} 
opinión, que se daba por supuesto al juzgar el entusiasmo reinante en Cartagena, se esgrimía como pretexto para justificar la conocida anglofilia del presidente, Antonio Maura.

Si algo más se pudo conocer sobre la entrevista entre Eduardo VII y Alfonso XIII, fue transcurridos unos días después de la misma: el 12 de mayo, de nuevo, Alfredo Rivera reseñaba un artículo de Le Temps en el que, curiosamente, se recalcaba el protagonismo diplomático del Rey español y en el que León y Castillo, el embajador español en París con una dilatadísima experiencia en asuntos marroquíes, era presentado como su brazo ejecutor. Por descontado, se le otorgaba una enorme relevancia diplomática al encuentro ${ }^{295}$.

Asimismo, al mes siguiente de hacerse efectivo el intercambio de Notas diplomáticas -ése fue el cometido real del encuentro-, el 17 de junio, se intentaba ahondar en el contenido de las mismas y transmitirlo a los lectores. El Adelanto empleaba este consabido encabezamiento: "Desde París llegan importantísimas noticias...”. ¿Por qué “desde París”?

Se hablaba abiertamente, y a pesar del desmentido por parte del ministro de Estado, Allendesalazar, de la existencia de un "arreglo" -no pasemos por alto la ambigüedad del término: se sabía que no era una alianza- entre Francia, Inglaterra y España con el objeto de mantener el statu quo en las posesiones del Mediterráneo y asegurar las buenas comunicaciones entre los dominios españoles en este mar y en el Océano Atlántico ${ }^{296}$. Pero aquí concluyeron las explicaciones del diario liberal sobre la reunión entre monarcas.

La gestación de los Acuerdos de Cartagena de 1907, sin embargo, se remontaba bastante atrás en el tiempo. Concretamente, unos meses después del "trompetazo" del káiser, el 8 de junio de 1905, en el transcurso de una visita oficial a Londres por parte de Alfonso XIII, Lansdowne, el secretario de Estado para el Foreign Office, formuló ante Villa Urrutia, entonces ministro de Estado del gabinete conservador de Fernández Villaverde, una primera propuesta de acuerdo anglo-español. Si España se comprometía, por un lado, a no ceder a una tercera potencia sus posesiones estratégicas (Baleares, Melilla, Ceuta, Canarias y Fernando Poo) y, en segundo término, favorecía la seguridad de Gibraltar frente a un hipotético atacante, obtendría el apoyo militar británico para enfrentarse a cualquier país que le pretendiese arrebatar esos mismos

\footnotetext{
295 Alfredo Rivera: "Información telegráfica", El Adelanto, no 6.991, 12 de abril de 1907, p. 4.

${ }^{296}$ Alfredo Rivera: "Información telegráfica”, El Adelanto, no 7.046, 17 de junio de 1907, p. 4.
} 
puntos geográficos. Sin embargo, las negociaciones se ralentizaron muchísimo debido a la inestabilidad de los gobiernos españoles y ese intermedio fue aprovechado por Francia para desviar a Inglaterra de su oferta original ${ }^{297}$.

El visible malestar alemán ante el término del encuentro en Algeciras, incita a Francia, por medio de su embajador Jules Cambon, a presentar en Madrid un nuevo borrador de acuerdo con un carácter tripartito ${ }^{298}$. En él, para disgusto de los británicos, no se mencionaba a Gibraltar y, además, se hacía más clara la pretensión de excluir a Alemania del Mediterráneo Occidental. Dio comienzo, de este modo, una enrevesada pugna de borradores entre Francia y Gran Bretaña. Y es que también al concluir 1906, aprovechando el nombramiento de Villa Urrutia -aportaba un ingrediente de continuidad- como embajador español en Londres, el Foreign Office retomó sus planes y se dispuso a preparar unas bases, más perfiladas que en 1905, para la negociación. Los roces terminarían con una intervención directa de Alfonso XIII -que por cierto, contradijo a Maura, deseoso de un acuerdo con mayores compromisos y efecto moralapoyando el proyecto británico ${ }^{299}$.

\footnotetext{
${ }^{297}$ Entiéndase que, hasta el momento, España está vinculada con la Entente a través de la firma del Tratado hispano-francés de 1904; sin embargo, no existía ningún acuerdo directo entre los gobiernos londinense y madrileño. Gran Bretaña temía las consecuencias de una posible guerra hispano-francesa porque el artículo VII de la Convención secreta franco-española de octubre de 1904 estipulaba la renuncia de España a ceder los territorios marroquíes bajo su influencia a una tercera potencia. Pero, ¿qué ocurriría con Gibraltar si Francia se adueñaba de esa zona? Más si cabe, Gran Bretaña deseaba defender su hegemonía económica en las islas Canarias: Alemania había iniciado unas conversaciones con España con el propósito de tender una línea telegráfica desde Vigo, pasando por Marruecos y el archipiélago hasta América del sur. El problema radicaba en que tanto empresas inglesas como francesas también competían por esa ruta comercial e informativa. Francia, por su parte, también intentaría evitar que Alemania utilizase las Baleares como base naval (derechos de carboneo) en caso de guerra. Véase ROSAS LEDEZMA, Enrique: "Las declaraciones de Cartagena (1907): Significación en la política exterior de España y repercusiones internacionales", Cuadernos de Historia Contemporánea, $\mathrm{n}^{\circ} 2$, Madrid, 1981, pp. 214-229.

${ }^{298} \mathrm{El}$ borrador francés fue presentado coincidiendo con la visita de despedida que Jules Cambon hace a Maura y Allendesalazar antes de su traslado como Embajador a Berlín.

${ }^{299}$ Este intervencionismo regio aparece enfatizado en GONZÁLEZ VELILLA, $\mathrm{M}^{\mathrm{a}}$ del Carmen: Op. Cit., pp. 421-425. Por otro lado, la autora admite que Francia acabaría igualmente, si bien a regañadientes, aceptando el procedimiento del canje de Notas por temor a una mala reacción diplomática alemana. La prensa germana estaba caldeando el ambiente al difundir varios rumores sobre el apoyo financiero inglés para la reconstrucción de la flota española.

Autores como Sánchez Sanz (tanto su tesis doctoral como la de González Velilla han sido efectuadas bajo la supervisión de Rosario de la Torre del Río) y Allendesalazar, en cambio, hacen hincapié en la idea de que prevaleció la opinión de Maura sobre la voluntad real. Alfonso XIII consideraba innecesario un acuerdo triple, pues el statu quo marítimo se podía mantener con la aquiescencia británica, mientras que para la conservación de la seguridad peninsular bastaba con la ayuda portuguesa. Véase SÁNCHEZ SANZ, Oscar Javier: Op. Cit., p. 618; y ALLENDESALAZAR, José Manuel: Op. Cit., pp. 53-55.

Creemos, sin embargo, que la fórmula finalmente adoptada, el canje tripartito de Notas, fue una solución intermedia: Francia, para satisfacción del político conservador mallorquín, sí participó en el acuerdo, lo cual no formaba parte del plan inicial británico; sin embargo, no se llegó a la firma de una alianza militar, peligrosa a juicio del monarca español, aunque insinuada en el borrador francés.
} 
Allendesalazar se ocuparía de transmitir a Villa Urrutia las pertinentes instrucciones para "limar" el documento final: evitar el empleo de la palabra "garantía", demasiado agresivo; rehuir de menciones explícitas a Gibraltar ("las posesiones marítimas respectivas así del Mediterráneo como de la parte del Atlántico que baña las costas de Europa y África"); y, reemplazar el compromiso de "no ceder" por el de "mantener" intactas las posesiones de cada uno.

Cartagena sirvió, en definitiva, como solemne y visible escenario para la ultimación de estas dilatadas negociaciones y la visita de Eduardo VII fue la devolución a la celebrada anteriormente por Alfonso XIII. Un pacto bilateral hispano-inglés habría disgustado a Francia, pero la alianza tripartita habría desencadenado la furia alemana. Así que se optó por un intercambio tripartito de Notas para el mantenimiento del statu quo territorial en la zona del Estrecho de Gibraltar. El canje efectivo de documentos tuvo lugar el 16 de mayo de 1907, simultáneamente, en Londres y París. Aunque pudiera parecernos más práctico que la doble permuta se celebrase en Madrid, los usos diplomáticos de la época dictaban que el "socio menor" se trasladase a las capitales de las "grandes potencias". La existencia de las Notas, de manera oficial, se comunicó el 15 de junio ante los gobiernos de Roma, Viena, Berlín y San Petersburgo. Es por este motivo que El Adelanto no pudo referir el contenido de las mismas hasta el 17 de junio de 1907. Y tuvo acceso al mismo a través de la prensa francesa, pero no mediante los cauces oficiales españoles. La opinión pública, no sólo la de Salamanca, de nuevo estaba siendo abandonada por sus mandatarios. Las acusaciones de negligencia llegaron, en esta ocasión, a escucharse en el Parlamento porque el Convenio no se leyó allí íntegramente hasta el 25 de junio de $1907^{300}$.

El Lábaro, cambiando de órgano periodístico, únicamente se refirió a la cita real celebrada en Cartagena en dos ocasiones. Lo hizo, sin embargo, con muchísima contundencia, plasmando su indisimulada oposición hacia el proceder de casi todos sus colegas. Al día siguiente del encuentro, en su primera página, aparecía el siguiente editorial:

"Un cielo azul y un mar más azul, sirvieron de fondo a aquel cuadro imponente, en el cual nuestro Giralda, seguido de dos torpederos que parecían otras tantas miniaturas, eran recibidos amorosamente por seis monstruosos acorazados y varios cruceros, que con sus hélices movían el mar como si levantasen un temporal para pulverizar nuestro pequeño Carolina, y con el humo de sus cañones elevaban al cielo una inmensa nube blanca. ¿Qué tal, lectores? Esto es encomiar la marina española y hacer literatura

${ }^{300}$ PÉREZ MOLINA, Elisa: Op. Cit., p. 237. 
internacional. Y así son de precisas y determinadas las noticias que hoy publica la gran prensa, ${ }^{, 301}$.

El recurso al sarcasmo no era, obviamente, más que el instrumento para denunciar que la reunión de Cartagena estaba resultando un gran negocio periodístico, pero políticamente constituía todo un misterio. Proseguía el reportero haciendo hincapié en los perjuicios derivados de su subordinación ante la prensa madrileña. Denunciaba que esa restringidísima y tan puntual canalización de la información diplomática -desde los ministerios a un limitado número de periodistas acreditados- constituía una forma de censura. El cronista provinciano únicamente podía alimentarse de rumores; se le forzaba a no interesarse por asuntos más allá del precio del pan y el alquiler de la vivienda; y, evidentemente, como corolario, no podía precisar si Eduardo VII y Alfonso XIII se habían dedicado a confirmar la ocupación francesa de Uxda; o a adoptar una posición común sobre política armamentística de cara a la próxima asamblea de La Haya. No quedaba otro remedio que esperar, aunque no estaría de más tener presentes ciertos comentarios de Le Journal que apuntaban a que España estaba siendo arrastrada hacia la órbita inglesa.

El segundo editorial de El Lábaro, publicado en junio de 1907, también después de la difusión de las Notas, ponía de relieve el hecho de que entre la opinión pública se estuviese extendiendo la idea de que España necesitaba una alianza con una gran potencia; algo que este diario católico juzgaba sumamente perjudicial para nuestros intereses. Los recelos ante los franceses y, más si cabía, ante los ingleses eran enormes entre los miembros de su redacción y se preveía que intentaran aprovecharse de la buena situación topográfica española. Forzoso parece detenernos en este hecho. El palpable partidismo de las noticias que hasta el momento había remitido la Agencia Fabra a este diario es por completo rebatido cuando los periodistas de la casa toman directamente la pluma. Pero no es un cambio repentino. Recordemos que durante la celebración de la Conferencia de Algeciras, este rotativo ya había solicitado los servicios de Mencheta. ¿Acaso no estaba intentando liberarse de la excesiva tutela informativa francesa? Creemos que sí. Además, las evidencias serán mucho más claras en los años venideros. Por de pronto, en 1907, esto escribía uno de sus columnistas:

"Nosotros creemos que ni la alianza con Inglaterra, ni la alianza con Francia nos ha de ser útil (...) Debemos procurar nuestro engrandecimiento por nuestros propios esfuerzos, emprendiendo el camino que nos conduzca a este fin, sin soñar en que el engrandecimiento perdido lo hemos de hallar con la ayuda de quienes siempre tuvieron

301 "De política", El Lábaro, no 3.054, 10 de abril de 1907, p. 1. 
puesta su mirada en nosotros para debilitarnos, y que cuando nos vieron en el infortunio nos dejaron completamente abandonados ${ }^{, 302}$.

Se jugaba, otra vez, con el amargo recuerdo del 98, pero no tanto para preconizar una política internacional aislacionista, que también, sino para atizar la llama del odio contra la Entente.

La valoración conjunta de las informaciones a las que nos hemos referido no reviste, en esta ocasión, complejidad alguna. El encuentro regio es presentado con una pasmosa simplicidad. La redacción de El Adelanto no le dedica al evento casi ningún comentario propio. Y es que el periódico de Núñez Izquierdo prefiere escudarse en los argumentos de La Época y Le Temps. El Lábaro, al contrario, se muestra mucho más preocupado por la trascendencia de la reunión y se atrinchera en la idea de que Marruecos constituye un "coto privado" de España.

Buena parte de la historiografía reciente sigue sosteniendo, sin embargo, que la reacción interna tras el encuentro de Cartagena fue muy positiva. El diplomático Allendesalazar estimó que "tanto el acuerdo con Francia e Inglaterra como el plan de reconstruir la Marina de guerra respondían a un sentimiento impreciso pero real de la opinión española (...) La opinión española quería que se recuperase un cierto grado de respetabilidad internacional (...) Todo iba a ir bien a Maura mientras buscase para España un lugar al sol sólo por medios pacíficos ${ }^{\prime 303}$. De igual manera, por aportar otro ejemplo, Sánchez Sanz señala que "la opinión pública aplaudió con unanimidad la reinserción nacional en el tablero exterior" ${ }^{, 304}$.

Sin embargo, basta con fijar nuestra atención en una capital de provincia, Salamanca, para comprobar, que esa armonía de pareceres no fue tal: el desconocimiento y el rechazo estuvieron muy presentes en las páginas de su presa local. La explicación parece lógica: el acceso a la información sobre el extranjero estaba plagado de obstáculos; y el lenguaje empleado en las Notas y amplificado, cuando se pudo, por los periódicos, repleto de eufemismos. Indescifrables para una inmensa mayoría de la población - no encontramos editoriales con una vocación pedagógica, en los que se detallen y expliquen las cláusulas de los documentos-, estimamos que ese deseo de "respetabilidad internacional" tuvo un alcance muy limitado. Porque en una ciudad empobrecida, con tantas desigualdades sociales y con un apabullante problema

\footnotetext{
302 "El Convenio franco-inglés-español”, El Lábaro, no 3.109, 18 de junio de 1907, p. 1.

${ }^{303}$ ALLENDESALAZAR, José Manuel: Op. Cit., p. 60.

${ }^{304}$ SÁNCHEZ SANZ, Oscar Javier: Op. Cit., p. 631. Algo menos contundente, si bien también alude a una aceptación pública general, es RAMIRO DE LA MATA, Javier: Op. Cit., p. 130.
} 
higiénico, como lo fue Salamanca, las preocupaciones de sus gentes eran, forzosamente, mucho más terrenales.

Sea como fuere, en Cartagena se consiguió robustecer la seguridad de los puntos estratégicos españoles ante Alemania, pero también nuestra política exterior quedó más sometida a los intereses de la Entente. En efecto, los pactos eran para España una garantía de la integridad de sus posesiones insulares; también eran un indicador de la adopción de objetivos exteriores más activos, de su intención de perseverar en la política de entendimiento con Inglaterra y Francia. Todo ello, precisamente, cuando cristalizaban dos bloques antagónicos en Europa: la Triple Alianza y la Triple Entente (el 23 de septiembre de 1907 se firmó el Acuerdo que confirmaba la inteligencia entre el Zar, amigo desde hacía años de Francia, y el Rey inglés). El problema surgiría cuando la cuestión marroquí dejase de percibirse como una empresa obligada (algo más palpable en el discurso -no tanto en la obra -de los conservadores que en el de los liberales) para transformarse, ya sin tapujos, en un objeto de deseo imperialista.

\section{EL DRAMA DE CASABLANCA... ¿Y EL LETARGO DE SALAMANCA?}

Después de la Conferencia de Algeciras, la violencia, alimentada por la xenofobia, alcanzó en el territorio marroquí proporciones inauditas. Quizás, para los anales de "nuestra" historia, la más perfecta encarnación de ese tempestuoso proceder venga de la mano de El Raisuni, un intrépido personaje que, mediante la extorsión, había obtenido de Abd-el-Aziz el cargo de gobernador de Fahs, la cábila más próxima a la europeizada Tánger.

En el devenir de Marruecos, al contrario, la insurrección de los hafidistas revestiría bastante mayor peso político. A diferencia de El Raisuni, el patriotismo de Muley Hafid no ofrecía todavía dudas. Su capacidad de liderazgo le condujo a encabezar una rebelión más coherente contra su débil hermano, el Sultán, y contra los "perros cristianos" (luego tanto más bochornosa resultó su claudicación ante los franceses). Poco a poco, los escarceos aislados y desorganizados, casi inadvertidos por los periódicos salmantinos, fueron cediendo protagonismo a levantamientos mucho más serios y amenazadores para los intereses europeos.

Precisamente, los conocidos como "sucesos" de Casablanca, inspirados por algunos de los agentes de Hafid, formalizarían esa rebelión contra el extranjerizante gobierno de Fez. Pero, sobre todo, harían más tangible el sueño colonial francés. 
Ciertamente, estos incidentes sí despertaron la atención de la gran prensa y, de igual modo, de la de provincias. No porque se debatiese el futuro del Sultanato; no. Marruecos servía como termómetro de las tensas relaciones europeas y los acontecimientos de Casablanca apuntaban hacia un muy ostensible tambaleo en el juego de equilibrios. Un juego en el que España entraba con muy mermadas facultades. Por eso en El Adelanto y también en las páginas de El Lábaro las referencias al estado de enorme inquietud reinante entre la población fueron la tónica dominante. Por otra parte, las denuncias del caos informativo también fueron continuadas.

El gabinete francés había decidido aprovechar cualquier desorden interno para ampliar su control sobre Marruecos. Consideraba ya el Acta de Algeciras como papel mojado y la constitución de una policía indígena, como una idea utópica. Por eso en mayo de 1907 tomó Uxda; y en agosto del mismo año (para ser precisos, entre el 31 de julio y el 7 de agosto), pretextando el ataque sobre unos obreros europeos, bombardearía y ocuparía Casablanca. Estos trabajadores se encargaban del transporte de piedra para unas obras portuarias y empleaban un tren cuya línea férrea pasaba junto a un cementerio. Y acto seguido, las tropas francesas iniciaron su avance por la circundante región de la Chauia. Para todo ello, el gabinete parisino siempre alegó, sin dudarlo, la necesidad de reprender una fatal agresión.

Comencemos fijándonos en las noticias de El Adelanto: este diario alude, por primera vez, el 5 de agosto de 1907, a la situación desesperada de 205 españoles que se hallan refugiados en el consulado de Casablanca. El encargado de transmitir la noticia es Alfredo Rivera. Este corresponsal únicamente reseña que los marroquíes han atacado a unos europeos y que desde el Galilei han desembarcado tropas francesas que recorren la población. Hay, además, más efectivos galos preparados en Orán y la rebeldía amenaza con generalizarse también en Mazagán ${ }^{305}$.

Dos días después, este breve apunte se amplía considerablemente: un periodista explica que en todas las conversaciones políticas se recalca lo peligrosa que es la acción en Marruecos. Pero, no tanto debido a la hostilidad de los marroquíes, sino a la quebradiza situación internacional en que ésta se desenvuelve. El anónimo columnista, inmediatamente, sentencia que España no puede renunciar a la defensa de sus intereses en Marruecos y subraya, al tiempo, que hay que actuar junto con Francia, aunque sin subordinarse a ella "porque a ello obliga la política que ambas naciones vienen

${ }^{305}$ Alfredo Rivera: “Información telegráfica", El Adelanto, no 7.088, 5 de agosto de 1907, p. 3. 
siguiendo en Marruecos antes y después de la Conferencia de Algeciras; pero sin que ello indique subordinación, remolque ni nada de esas cosas que por afán de oposición se dicen" ${ }^{306}$. Es significativo el hecho de que no se explique en qué consiste ese problemático contexto internacional; no se detallan cuáles son los intereses de España en Marruecos; y tampoco se aclara el por qué Francia ha tomado la iniciativa en Casablanca. En otras palabras, no se ilustra a la opinión salmantina; únicamente se le adoctrina. Para terminar, el informador reproduce un enorme fragmento tomado de un editorial de El Imparcial. Diríase que, nuevamente, ante la falta de conocimiento entre los redactores locales sobre los asuntos marroquíes, se busca el enjuiciamiento ajeno.

A decir verdad, el recurso a los géneros periodísticos de carácter valorativo sigue una trayectoria creciente entre las páginas de la prensa local ${ }^{307}$, pero ¿qué impacto podría tener entre los salmantinos esa habitual apelación a opiniones de diferentes órganos? En otro lugar señalamos que estas noticias persuasivas ejercen sobre el lector, ayer y hoy, una mayor influencia que las crónicas únicamente descriptivas. Sobre todo, cuando van acompañadas de la firma de una reconocida autoridad en la materia. Pero, al mismo tiempo, escudarse sistemáticamente en los veredictos de terceros no dejaba de revelar la notoria impotencia, la relativa indiferencia y el desconocimiento entre los periodistas de la casa sobre los asuntos marroquíes. En el extracto en cuestión se alegaba que la abstención de España sería imperdonable, si bien el Acta de Algeciras llamaba a la prudencia. De tal forma, por el momento no se planteaba ninguna solución para el galimatías africano.

De igual manera, las anotaciones telegráficas de ese día, 7 de agosto, eran más detalladas que las de jornadas previas: pese a que las comunicaciones llegaban desde Tánger con enorme lentitud, Rivera aseguraba que Casablanca había sido bombardeada y sufría grandes destrozos:

"Había gentes optimistas que no creían en un ataque a la ciudad, opinando que la presencia de las fuerzas navales en las aguas de Casablanca se reduciría, como ocurrió otras veces, a intimidar a los marroquíes, ante la vista de tan importantes elementos de combate. No faltaban, por el contrario, gentes que auguraban el bombardeo y ocupación de Casablanca. Fundábanse los que así auguraban, en la gravedad de los

\footnotetext{
306 "Notas políticas", El Adelanto, no 7.090, 7 de agosto de 1907, p. 1.

${ }^{307}$ Conviene señalar que nos resulta muy gratificante el hecho de superar la casi absoluta dependencia, hasta ahora, de las caóticas y abrumadoras anotaciones telegráficas para el conocimiento de la cuestión marroquí. Pero no imaginamos el pánico que debió sacudir a los lectores, al hilo de estos incidentes, cuando con anterioridad apenas se les había informado de los compromisos internacionales adquiridos por su gobierno?
} 
hechos perpetrados por los moros y en la poca o ninguna esperanza de que se enmendaran sin recibir un duro y ejemplar castigo ${ }^{, 308}$.

Aunque se aludía a la necesidad de un correctivo, sin embargo, nada se comentaba sobre los excesos cometidos por los cabileños. Se concedía, en cambio, margen para la propagación de rumores. Rivera, por otra parte, no olvidaba mencionar que el comandante del Galilei mandó desembarcar a 70 hombres, a pesar de que el jefe de las tropas marroquíes le había manifestado que la ciudad ya estaba tranquila. Entre líneas, se podía apreciar una censura hacia el ardor guerrero de nuestros vecinos.

Francia apelaba a su necesidad de actuar en previsión de futuros sangrientos desórdenes, si bien el mismo desembarco constituía un gesto de provocación y, por tanto, avivaba la insurrección. Inmediatamente después de que las tropas pisasen tierra firme, se escucharon los primeros disparos de los rebeldes, seguidos por el restallar de las granadas francesas (1.200) sobre la población civil. Las tropas galas se apoderaron de su consulado, donde se refugiaban sus compatriotas, y cuarenta soldados españoles, llegados a bordo del Álvaro de Bazán, aprovecharon para hacer lo propio con su sede diplomática. Sin duda, no querían quedarse rezagados. Terminaba Rivera insistiendo en la idea de que la opinión pública se encontraba muy ansiosa y con unas declaraciones de La Cierva, según las cuales los atacantes de los europeos ya habían sido castigados y llegaba el momento de un nuevo arreglo diplomático con el Sultanato.

El encrespamiento de ánimos que la cuestión marroquí estaba suscitando era, con certeza, más notorio de día en día. El 8 de agosto, un columnista local -eran los que, por norma, no firmaban- anuncia abiertamente la pronta terminación del problema por la vía del conflicto. Se trata de un editorial ya bastante comprometido con la causa colonial:

"El problema marroquí toca a su solución definitiva, y lo que comenzó bajo auspicios pacíficos en la Conferencia de Algeciras parece que terminará violentamente, según dejan adivinar las tropelías cometidas por los moros, las revanchas que en Uxda y Casablanca se ha tomado Francia, y el deseo de las naciones todas de civilizar Marruecos por buenas o por malas, quitando de las cercanías de Europa el baldón que significa un estado salvaje, y procurando sacar de obra tan civilizadora el mejor partido posible. No puede resolverse la cuestión planteada sin la cooperación de España, que tiene títulos mejores que el resto de Europa para defender nuestros intereses (...) Pero es lo malo que la mayoría del país desconfía de la sagacidad de nuestros diplomáticos y la independencia de nuestros estadistas y teme que España vaya a Marruecos, no como astro sino como satélite (...) Querrían unos que ya hubiera en Marruecos un cuerpo de Ejército español, encargado de vengar a nuestros compatriotas asesinados, y de aumentar el territorio nacional con medio imperio, y

${ }^{308}$ Alfredo Rivera: “Información telegráfica”, El Adelanto, n 7.090, 7 de agosto de 1907, p. 3. 
otros claman porque procuremos restañar heridas que aún sangran, y colonizar nuestra península antes de meternos en nuevos libros de caballería (...) No sabemos cuál será la opinión que prevalezca en el ánimo de nuestros gobernantes, ni los compromisos que a éstos rodeen. Pero Dios quiera que acierten ",309.

La carga ideológica de este artículo es tremenda: moros traidores, franceses ambiciosos, civilismo europeo frente a salvajismo marroquí, derechos españoles, recelos de la opinión pública, secretismo diplomático, conquistas imperiales, el Desastre cubano, mentalidad caballeresca, autismo gubernamental... Empieza a resultar innegable que el Acta de Algeciras se está convirtiendo en un estorbo para Francia y también, de paso, para España.

El diario estaba anunciando el avance hacia una política de cooperación militar franco-española. Sin embargo, también El Adelanto reconocía que la opinión pública salmantina era contraria a la misma. La explicación: Maura era contemplado como un político muy perspicaz, pero también como un hábil encantador de serpientes en el que no se podía confiar. Hasta el momento, esa política, tan suya, de hacer de "perro del hortelano", estaba resultando contraproducente: la fórmula del statu quo era ya del todo insostenible, y Francia avanzaba con pasos de gigante en Marruecos.

Durante los días siguientes, en efecto, se suceden las comunicaciones y telegramas en los que se recalca que lo ocurrido en Casablanca es transitorio, que la intervención de franceses y españoles está plenamente justificada, que actúan de común acuerdo y que ambos países respetarán lo pactado en la reunión internacional ${ }^{310}$. El objetivo parece muy claro: infundir calma al pueblo ante lo que se avecina. Pese a ello, a éste no le podían dejar de causar asombro y miedo los continuos rumores sobre movimientos de tropas y buques. Tampoco era de su agrado la reserva informativa alrededor de las conversaciones entre Maura, Allendesalazar y Revoil. Y eso que nada podían sospechar sobre las infructuosas, aunque muy perseverantes, embestidas del representante francés para convencer a Maura de la necesidad de ocupar Tánger y los otros seis puertos enumerados en el Acta de Algeciras ${ }^{311}$. Quizás algunos lectores

\footnotetext{
309 “España en Marruecos.”, El Adelanto, no 7.091, 8 de agosto de 1907, p. 1.

310 "Los sucesos de Casablanca", El Adelanto, no 7.091, 8 de agosto de 1907, p. 2; Alfredo Rivera: "Información telegráfica", El Adelanto, no 7.091, 8 de agosto de 1907, p. 3.

${ }^{311}$ Francia presentó muchas otras propuestas de intervención armada, pero no logró seducir al gabinete español. Sus ofertas cesaron cuando se le hizo una contrapropuesta de "permuta" entre Casablanca España retiraría sus tropas y no estorbaría a Francia- y Tánger. La responsabilidad de estas negociaciones recayó, sobre todo, en el ministro de Estado, Allendesalazar porque Maura estaba de vacaciones en Bretaña. No obstante, era constantemente informado sobre el desenvolvimiento de la cuestión y su determinante voluntad de adquirir un compromiso mínimo con Francia fue la que se impuso. Véase ALLENDESALAZAR, José Manuel: Op. Cit., pp. 76-81.
} 
lograron tranquilizarse cuando el ministro de la Guerra, Fernando Primo de Rivera, declaró que el coste de todos estos envíos ya había sido presupuestado en aquella reunión internacional.

Sostenemos que nunca antes la opinión pública había acaparado semejante protagonismo en el desenvolvimiento de la cuestión marroquí. Lógicamente, porque sus recelos atemorizaban al gobierno. ¿Asumió este periódico local como misión propia, como un compromiso patriótico, lograr el asentimiento público ante los sucesos de Casablanca? Muy probablemente, sí. El diario se hizo eco de cierta campaña entre la prensa inglesa en la que se denunciaba el comportamiento de algunos periódicos españoles por animar a Maura a eludir sus responsabilidades en Casablanca y censurar el envío de tropas ${ }^{312}$. A modo de respuesta, los esfuerzos de esta redacción se encaminaron en el sentido contrario: la acción franco-española era, por descontado, una obra civilizadora que, de ningún modo, podía ocasionar protestas de otras potencias y sus antecedentes se hallaban en el asesinato del doctor Mauchamp ${ }^{313}$.

Éste había sido un integrante del servicio médico francés, con residencia en Marraquech. En su terraza instaló unos postes para tomar medidas por triangulación que le permitieran elaborar un plano de la ciudad. Pero algunos marroquíes creyeron que se disponía a preparar un telégrafo y le apuñalaron. Francia encontró así la ocasión idónea para ocupar Uxda, no Marraquech. Marraquech no era una ciudad costera; y no figuraba, consecuentemente, en el listado de puertos mencionados en el Protocolo de Algeciras. No obstante, se podía ir trazando una tenaza sobre ella desde el lado opuesto y fronterizo con Argelia: por eso Uxda fue el primer peón derrotado de esta trágica partida de ajedrez.

La voluntad de fijar algunos acontecimientos como indiscutibles impulsa al diario liberal, El Adelanto, a reconocer que el desembarco hispano-francés se hizo con el previo consentimiento del Majzén ${ }^{314}$. No se trataba, por tanto, de un gesto hostil. En cambio, la agresión mora sí era absolutamente ilegítima y ello lo revelaba el hecho de que las propias autoridades marroquíes se disculpasen tras el bombardeo ante el

\footnotetext{
312 "Los sucesos de Casablanca", El Adelanto, no 7.091, 8 de agosto de 1907, p. 2. Aclaremos que las críticas procedían exclusivamente de la prensa, mientras que las informaciones que transmitía el marqués de Villalobar, el Encargado de Negocios en Londres, apuntaban a que el gobierno británico estaba satisfecho con el cauteloso proceder español.

313 "Notas políticas", El Adelanto, n ${ }^{\circ} 7.092,9$ de agosto de 1907, p. 1

${ }^{314}$ Y era cierto, pero todo había sido orquestado por Saint-Aulaire, el Primer Secretario de la Legación francesa en Tánger. Este personaje mostró una rapidez asombrosa, tras los asesinatos en el muelle, al preparar una carta, que Mohammed Torres debió firmar, y en la que se solicitaban refuerzos a París. Véase ALLENDESALAZAR, José Manuel: Op. Cit., p. 67.
} 
comandante de la expedición francesa. Por último, todos estos incidentes animaban a organizar, cuanto antes, la policía ${ }^{315}$.

Muy ardua, verdaderamente, era la tarea que tenía por delante El Adelanto. ¿Cómo podía apaciguar a la opinión salmantina cuando la situación se agravaba por momentos? ¿Cómo no dudar sobre la conveniencia de intervenir en los asuntos marroquíes de la mano de Francia? Obviamente, en el seno de la misma redacción surgirían escisiones porque no era una tarea sencilla contemporizar con el proceder galo.

La posición internacional de España era sumamente frágil. Para colmo, un nuevo y brutal bombardeo francés, de casi cuatro horas de duración, se registró el día 7 de agosto: las noticias llegan con enorme desorden (incluso, se confunden las fechas), pero todas coinciden al subrayar que Casablanca ha sido prácticamente arrasada, que el cuerpo de sanidad militar se halla desbordado, temeroso ante las epidemias futuras, y que, además, hay cerca de 1500 fallecidos marroquíes. No faltan las referencias a la heroica carga de bayoneta de un grupo de españoles. Sin embargo, este tipo de literatura elogiosa no es, por el momento, la nota dominante en la prensa salmantina:

"Los sucesos de Casablanca van complicándose cada vez más (...) La opinión pública se muestra alarmadísima y siempre recelosa de los resultados que nuestra intervención en Marruecos pueda acarrearnos. La debilidad que padecemos y la poca o ninguna fuerza de nuestras palabras, que no encuentran resonancia en parte alguna, legitiman y fundamentan el estado de alarma que reina en la opinión de nuestro pueblo. Témese y con razón que Francia nos arrastre y mezcle en complicaciones internacionales de solución dificilísima y de fin trágico, fin que hará caer sobre nosotros los celos y enemistad de la poderosa Alemania, deseosa de hallar un pretexto para entendérselas con Francia (...) El señor La Cierva dijo que no era ocasión oportuna para profetizar en cuestión tan delicada y dudosa, manifestándonos que no había otro remedio que esperar con calma el desarrollo de los sucesos ${ }^{, 316}$.

Sin duda, se estaban poniendo en entredicho las verdaderas motivaciones de la política francesa en Casablanca porque podían alimentar los intempestivos arranques del káiser Guillermo II. Diríase que la redacción de El Adelanto empezaba a compartir ese discurso de la oposición, al principio refutado, que denunciaba la subordinación de la política maurista ante nuestros vecinos.

Temía que por ese excesivo celo francés el país se viese involucrado en una guerra franco-germana. Sin embargo, en el fondo, todavía no la contemplaba como una amenaza real, sino más bien como el escudo en el que se parapetaba Alemania para

\footnotetext{
315 "Notas políticas", El Adelanto, nº 7.093, 10 de agosto de 1907, p. 1.

316 Alfredo Rivera: "Información telegráfica", El Adelanto, no 7.093, 10 de agosto de 1907, p. 3.
} 
obtener compensaciones económicas en Marruecos. A España, por descontado, no le convenía ese conflicto, pero se daba la paradoja de que la inteligencia entre ambos gigantes industriales tampoco le beneficiaba en modo alguno. Es la deducción que se extrae de la referencia a ese "pretexto para entendérselas con Francia". En la ecuación no aparecía España porque el articulista presumía que Francia negociaría a costa de la zona de influencia española. A fin de cuentas, ya lo había hecho en 1904 con Gran Bretaña. Pero, ¿sabrían entenderlo así los lectores salmantinos?

Simultáneamente, también los delegados internacionales, reunidos en Tánger, manifestaban ante los periodistas que los rebeldes marroquíes actuaban contra los franceses, pero no contra la totalidad de los europeos ${ }^{317}$. Ni tan siquiera a ellos les convencían los arrebatos belicosos galos. De hecho, hasta parte de la prensa francesa empezaba a lamentar el sueño megalómano de Delcassé. Francia estaba sentando un peligrosísimo precedente y cabría la posibilidad de que fuese imitada por Gran Bretaña y ésta se lanzase a ocupar Tánger ${ }^{318}$.

El creciente arrojo y furia de los marroquíes servía, como de costumbre, para reincidir en el tópico del fanatismo moro. Por eso, el diario de Francisco Núñez Izquierdo reproducía algunos fragmentos del Corán: para persuadir a sus lectores de la sed asesina del enemigo ${ }^{319}$. Aunque, de todos modos, también elogiaba su carácter valiente y su sangre fría ${ }^{320}$. Suponemos que, excepcionalmente, y atendiendo al oportunismo con que esto se publicaba, las diatribas contra el moro no se estaban empleando para llamar a la lucha, sino al abandono: el mismo mensaje mediático podía desempeñar contradictorias funciones propagandísticas.

Es, en definitiva, el pánico ante el agravamiento del conflicto, quien alimenta un cambio ideológico en las entrañas del rotativo liberal, al menos, entre algunos de los redactores:

"Los sucesos de Marruecos han servido para demostrar, una vez más, que los vicios de nuestro país son eternos; que la historia, con sus tremendas lecciones, nada nos ha enseñado, y que las mismas causas que antaño precipitaron y apresuraron nuestro vencimiento, van a intervenir en los sucesos que se preparan y acaso den los mismos frutos que antaño. Mientras la guerra con los Estados Unidos, era cada periódico un tratado de estrategia y cada español un consumado táctico, y en tertulias y cafés

\footnotetext{
${ }^{317}$ Después del encuentro en Algeciras, el palacio de la Alcazaba de Tánger sirvió como escenario para las largas reuniones celebradas entre Mohammed Torres, representante del Sultán, y los miembros del Cuerpo Diplomático acreditados para el desarrollo de una serie de reglamentos que habían quedado inconclusos en la Conferencia. Véase ALLENDESALAZAR, José Manuel: Op. Cit., pp. 41-43.

318 "Notas políticas", El Adelanto, no 7.095, 13 de agosto de 1907, p. 1.

319 "La guerra santa", El Adelanto, no 7.095, 13 de agosto de 1907, p. 2.

${ }^{320}$ Alfredo Rivera: "Información telegráfica", El Adelanto, no 7.095, 13 de agosto de 1907, p. 3.
} 
diseccionábase la marcha de las operaciones y las negociaciones diplomáticas, se publicaban datos que habrían estado mejor callados, se imponían resoluciones y se hacia el papel de directores cuando era precisa una absoluta disciplina. Lo mismo ocurre ahora. Disparados los primeros tiros en Marruecos, nuestros colegas han echado por la calle del medio, y unos patrocinan el envío al Imperio de un formidable Ejército, abogan otros por la alianza cordial con Francia, pregunta los de más allá a dónde vamos, y casi todos tratan esta cuestión, que debiera ser nacional, bajo el estrecho prisma de los intereses de partido. Y como nadie sabe qué compromisos tienen contraídos los actuales gobernantes, y como de la bondad de los procedimientos que éstos pongan en práctica para la mayor gloria y provecho nacionales han de hablar los resultados que nadie puede proveer, parécenos que ser la mejor que discutir esperar, y a que con ello nada se pierde, y en cambio se tiene la seguridad de proceder en justicia ${ }^{, 321}$.

Aparece aquí ese estratega de café al que aludíamos en las primeras páginas de este trabajo. Éste no hace sino amplificar el desorden informativo ya existente. Y, mientras, el diario liberal prefiere llamar a la calma y se esfuerza por presentarse a sí mismo como un observador imparcial.

Pero las noticias siguen llegando atropelladamente desde Tánger y Casablanca. Unas aluden a la heroicidad de los marines españoles, abriéndose camino hasta su consulado y defendiendo una misión franciscana; otras revelan que el relato de esas acciones heroicas no es más que un instrumento para disimular el mal estado de la artillería del Álvaro de Bazán. La fractura ideológica también se observa, por ejemplo, en el tratamiento que se le dispensa a las tropas dirigidas por el general Drude: junto con el urgente envío del Álvaro de Bazán, la misión española en Casablanca quedó mejor definida cuando se acordó el traslado en el Río de la Plata, como jefes del destacamento, de aquellos oficiales que ya habían sido elegidos para instruir a la futura policía marroquí: el comandante Santa Olalla, el capitán Óvilo y tres sargentos. Ese contingente llegó a la ciudad algunos días después, el 16 de agosto: trescientos hombres de infantería, cien de caballería y cuatro ametralladoras. Desde París, por otro lado, se había enviado al comandante Magin, que también era el previsto instructor francés de la policía. Pero se decidió que le acompañara Drude, un gran experto en cuestiones coloniales que rápidamente asumió el auténtico mando sobre la ciudad. Por tanto, el inicial reparto de competencias, aquél acordado el 23 de febrero de 1907 -y que no advirtió la prensa local-, quedaba así un tanto desdibujado.

El columnista Bernardo Navarro achacaba al general francés un comportamiento muy cauteloso al rebasar los límites de Casablanca y solicitar un refuerzo de casi 20.000 hombres:

321 “La virtud de esperar", El Adelanto, no 7.096, 14 de agosto de 1907, p. 1. 


\begin{abstract}
"Esas cargas de la caballería cabileña, que no son dadas por escuadrones, sino por la aglomeración momentánea de las cábilas, de las cuales el contingente de hombres de guerra se bate la mayoría con el caballo de su propiedad y con el fusil que adquirió por el robo o con su dinero, se repetirán a diario; y como hombre conocedor de los hábitos y costumbres de los moros, el general Drude obró prudentemente rebasando Casablanca y acampando en terreno donde su artillería tuviera amplio espacio para jugar y donde los soldados evitaran que los montaraces jerfianos entraran en Casablanca, ${ }^{, 322}$.
\end{abstract}

Paradójicamente, otro columnista, "Fray Lesco", reflexionaba, casi al mismo tiempo, sobre la torpeza de Francia motivada por su exceso de agresividad. El editorial llevaba por título "Don Quijote en Marruecos":

"Francia acredita de desatentada su política en Marruecos con la empresa que allá tiene ahora entre manos. Ya pareció desde luego un tanto excesivo el bombardeo de Casablanca; pero lo que se ha ido aclarando después pone de manifiesto la torpeza o la imprudencia de Francia en los asuntos marroquies. Fuera de duda está ya el tanto de culpa que le cabe. Francia ha ido a Marruecos sirviendo de gendarme a sus banqueros, a los prestamistas del Sultán; ha intervenido las aduanas y sus exigencias han ido tan allá que han llegado a justificar en cierta manera las protestas y las venganzas de los moros (...) La penetración armada es una insensatez. ¿En qué cabeza cabe que la Conferencia de Algeciras pueda significar una aquiescencia internacional de la política francesa en Marruecos??"323.

Perseveraba el reportero en la idea de que Algeciras no había autorizado a Francia para proceder como lo estaba haciendo y concluía: " $Y$ no es lo malo que don Quijote ande suelto en Marruecos, si no fuera con las intenciones de Sancho Panza, esto es, tras el gobierno de la consabida ínsula”.

La interpretación que del Acta efectuaba Francia parecía, indiscutiblemente, muy violenta. Teóricamente, repetimos, a Francia le correspondía la instrucción de la policía interior, mientras que España era la responsable de la seguridad extramuros. Por eso ella había tomado la iniciativa después de los asesinatos habidos en el puerto. Sin embargo, el salvaje bombardeo de Casablanca había desatado el odio; y el conflicto civil, entre el Sultán y su hermano Hafid, se había convertido en una guerra santa. La Chauia reclamaba venganza y Drude se disponía a responder. En semejantes circunstancias, a España le resultaba imposible garantizar el orden en los alrededores de la ciudad.

El destacamento español tenía tajantes órdenes para no participar en la pugna. Así que la indignación entre la tropa y la oficialidad, forzadas a la inactividad, aumentaba al ser objeto de mofa en la prensa europea. Las protestas de Santa Olalla

\footnotetext{
${ }^{322}$ Bernardo Navarro: "Los sucesos de Casablanca", El Adelanto, no 7.096, 14 de agosto de 1907, p. 2.

323 "Fray Lesco": "Don Quijote en Marruecos", El Adelanto, no 7.101, 20 de agosto de 1907, p. 1.
} 
nunca fueron escuchadas $y$, finalmente, a principios de noviembre, tras varios rifirrafes con Maura, el comandante fue remplazado por el teniente-coronel Fernández Bernal. Éste permanecería en Casablanca hasta septiembre de 1908, pero su gestión ya no sería objeto de la atención mediática. Drude, por el lado francés, también sería sustituido por el general D'Amade, quien continuaría atrapado en una brutal contienda (y, a su vez, sería desplazado por Lyautey en 1912). La presencia francesa en Casablanca, otro peón derrotado, se prolongaría hasta 1956.

Ese atrincheramiento de Maura en el cumplimiento del Protocolo de Algeciras también experimentó un momento de debilidad: cuando Pichon, el ministro francés de Negocios Extranjeros, le ofreció la posibilidad de negociar la permuta entre Casablanca y Tánger ${ }^{324}$. La intervención aquí también parecía inminente porque los seguidores de El Raisuni se aproximaban y las tropas de Abd-el-Aziz no recibían su paga. Pero como cabía prever, Eduardo VII no aceptó esta solución (ni tan siquiera consentiría el ejercicio español de un mando similar al de Drude en Casablanca) y así se lo hizo saber al embajador Villa Urrutia.

Para seguir ilustrando esa escisión en el diario liberal, se debe señalar que mientras, a mediados de agosto de 1907, se inserta un artículo absolutamente premonitorio sobre las posibles consecuencias de la creciente oposición socialista al envío de soldados a Marruecos y la necesidad de abolir el sistema de redención en metálico, otro corresponsal diserta sobre la inmensa riqueza del Sultanato y la lógica necesidad de colonizarlo.

El sistema de reclutamiento militar era sacado a colación para comentar la exitosa campaña del "o todos o ninguno". Y es que los problemas de Casablanca estaban sirviendo como acicate para solicitar la reforma del mismo:

"Los sucesos de Marruecos, en los que han comenzado a intervenir directamente las tropas españolas, que acaso se vean obligadas a reñir nuevos y sangrientos combates, han puesto sobre el tapete cuestión tan trascendental y hecho ver la necesidad de resolverla pronto y en la forma que la equidad demanda, para evitar así, si por desgracia tuviéramos que sostener una guerra, que a los peligros del exterior se juntasen los disturbios interiores. La contribución de sangre, la más tremenda y costosa, no debe gravitar sobre una sola clase social, ni debe encargarse de defender todo a los que nada tienen, y además comprenden peor que sus conciudadanos, por el estado de incultura en que se hallan, lo honorífico y grande de la misión que se les confía. El servicio militar debe ser prestado por todos, directa y corporalmente, aunque se arbitre la forma de hacerlo llevadero, en lo que al acuartelamiento se refiere, y de coordinarle con los intereses de las familias y de los mismos soldados ${ }^{, 325}$.

\footnotetext{
${ }^{324}$ ALLENDESALAZAR, José Manuel: Op. Cit., pp. 97-100.

325 "O todos o ninguno", El Adelanto, no 7.100, 19 de agosto de 1907, p. 1.
} 
Parecía seguro que los proletarios serían los que más morirían en la lucha y, además, los más explotados en sus trabajos para sufragar los gastos de la contienda. Constituía para ellos un enorme agravio ver cómo los hijos de las clases más favorecidas resultaban exonerados del servicio gracias al pago de un sustituto o bien de una cantidad en metálico. Habría que esperar, sin embargo, a la aprobación de la ley del 12 de febrero de 1912 para que se estableciese la universalidad de la prestación militar. Aunque su alcance real se vería limitado por la creación de la figura del "cuota".

Frente a este compasivo editorial, otro cronista responsabilizaba al conjunto de los españoles de tener un concepto enormemente equivocado de Marruecos y sus gentes. La riqueza del Sultanato era enorme y España debía aprovechar el momento de extrema debilidad por el que atravesaba Abd-el-Aziz:

\begin{abstract}
"Marruecos, que está a las mismas puertas de nuestra casa, es menos conocido aquí que en Alemania (...) No es un país tan pobre como generalmente se pretende, sino, al contrario, una nación en donde abundan los territorios fértiles, que ya quisieran para sí muchas comarcas peninsulares que se reputan como ricas (...) En cuanto a las riquezas del subsuelo, si bien inexploradas, se consideran fabulosas; pues hay en él indicios ciertos de antimonio, estaño, hierro, piorno, mercurio, níquel, zinc, cobre, plata y platino, y yacimientos de petróleo, fosfatos, mármoles, nitratos, etc. Los productos agrícolas son variadísimos y de excelente calidad; la fauna, rica; la pesca abundantísima, y en total los recursos del país se pueden calificar de inagotables (...) La autoridad del Sultán, más o menos eficazmente, sólo se extiende a una parte del país, que es lo llamado Bled-el-Majzen; y en cuanto al resto, o Bled-el-Siba, resulta puramente nominal ${ }^{, 326}$.
\end{abstract}

¡Por fin salió a la luz pública el asunto de las minas! Y, por fin, también, encontramos un editorial en el que se aclaran cuáles son los posibles intereses económicos de España en Marruecos. En otras dos ocasiones, igualmente al hilo de los incidentes violentos de Casablanca, aparecerían descripciones detalladas sobre la actividad económica de dos grandes ciudades marroquíes: Rabat y Mazagán ${ }^{327}$.

Si bien la zona de influencia española era áspera y pobre, desde siempre habían circulado rumores sobre sus fabulosas riquezas mineras. Así, en la cábila de Beni Urriaguel, se decía, se alzaba una montaña de oro, el Yebel Hammam. Aunque pocos daban crédito a esta leyenda, sí que se conocía que el hierro abundaba en la comarca de Guelaya, entre Melilla y el río Kert. También se sabía de la existencia de ricos yacimientos de cobre y plomo en el interior del Rif.

\footnotetext{
326 “Lo que es Marruecos”, El Adelanto, no 7.100, 19 de agosto de 1907, pp. 1-2.

327 "Poliuto": "Los sucesos de Marruecos", El Adelanto, no 7.093, 10 de agosto de 1907, p. 2; "Poliuto": “Los sucesos de Marruecos", El Adelanto, no 7.095, 13 de agosto de 1907, p. 2.
} 
$\mathrm{Al}$ iniciarse el siglo XX, España era el único país europeo cuya balanza de pagos con Marruecos resultaba desfavorable. Las importaciones (carne, legumbres, simientes oleaginosas, cuero, corcho, sedas) sumaban unos ocho millones de pesetas, frente a unas exportaciones (tejidos de algodón, calzado, muebles y maderas labradas, vino, plata amonedada) que no pasaban de 1.300 .000 pesetas ${ }^{328}$. Por ejemplo, en el puerto comercial de Casablanca, aunque los españoles representaban más de la mitad de los residentes extranjeros, el comercio con España se había reducido de 16\% a un 6\% entre 1905 y $1909^{329}$. Hacia 1909, la participación española en el comercio exterior marroquí únicamente suponía el 1,5\% del total ${ }^{330}$. Precisamente, autores como Morales Lezcano aseguran que la intensificación de este tráfico comercial fue el principal interés de España en Marruecos, relativizando con ello la importancia de los beneficios mineros.

Afirma este investigador canario que la riqueza minera de Marruecos constituía un "cebo apetitoso" para los grupos de presión financieros ${ }^{331}$. Sin embargo, esta producción de mineral fue drenada en su mayor parte hacia otros países europeos, fundamentalmente Alemania, mientras que España se convirtió en "un país geopolíticamente interpuesto entre los dos términos de un circuito" ${ }^{\text {332 }}$. Para Melilla, la explotación minera tampoco acarreó la industrialización de la zona. La falta de carbón y el mismo comportamiento de las empresas privadas, hicieron que el mineral se exportase tal y como se obtenía. A decir verdad, el gran negocio español en Marruecos sería el abastecimiento del Ejército colonial y de los colonos españoles ${ }^{333}$. España intentaba encontrar, de esta manera, un mercado con el que sustituir al americano, y al mismo tiempo, y por extraño que resulte, continuar la misión evangelizadora iniciada por los Reyes Católicos ${ }^{334}$. Por todo ello, nosotros nos planteamos hasta qué punto si, más que un "cebo" para los empresarios, las míticas riquezas del Rif fueron un pretexto esgrimido por el capitalismo español para persuadir a la opinión pública de la conveniencia de ir a África. Se prometieron enormes beneficios y posibilidades de prosperidad para todas las clases sociales, pero las ganancias sólo llegaron a unos pocos.

${ }^{328}$ CAMPOAMOR, José Manuel: La actitud de España ante la cuestión de Marruecos (1900-1904). Madrid: Instituto de Estudios Africano, 1951, p. 115.

${ }^{329}$ Ibidem, p. 116.

${ }^{330}$ ULLMAN, Joan C.: La Semana Trágica. Barcelona: Ariel, 1972, p. 267.

${ }^{331}$ MORALES LEZCANO, Víctor, Op. Cit., p. 75.

${ }^{332}$ Ibidem, p. 71.

${ }^{333}$ MARTÍN CORRALES, Eloy: "El Protectorado español en Marruecos (1912-1956). Una perspectiva histórica", en NOGUÉ, J. y VILLANOVA, J. L. (Eds.): España en Marruecos (1912-1956). Discursos geográficos e intervención territorial. Lleida: Editorial Milenio, 1999, p. 153.

334 AZIZA, Mimoun: La sociedad rifeña frente al Protectorado español de Marruecos (1912-1956). Barcelona: Bellaterra. Colección Alborán, 2003, p. 69. 
Mientras que el comercio hispano-marroquí, antes y durante la conocida como fase de "penetración pacífica" (1904-1912), fue muy limitado tanto en cantidad como calidad, a partir de 1912 y paralelamente a la "escalada militar", la ecuación exportaciónimportación se incrementó brutalmente ${ }^{335}$.

Si retomamos el análisis de los mensajes periodísticos al alcance de la opinión pública salmantina, tenemos que subrayar que, en medio de toda esta esquizofrenia informativa, la noticia que más despierta nuestra atención, por su tono tan frívolo, es una breve columna que pretendió mostrar la conexión existente entre las condiciones de vida de los salmantinos y las de los pobladores de Casablanca:

"Entre los lectores que de los sucesos de Casablanca haya en España, serán pocos los que se hayan formado idea más aproximada a la verdad que los salmantinos, del aspecto de aquel puerto marroquí y de cuanto exagera la meridional imaginación de los corresponsales al pintar como imposible, la vida de los que se han salvado de la última sarracina comenzada por los moros y acabada por los cañones de los barcos europeos. La ciudad en ruinas; las calles llenas de porquerías que despiden olores pestilentes; grupos de cabileños que recorren aquéllas, insultando a los transeúntes (...) Serán muchos los salmantinos que al pensar en el estado de suciedad de las calles de esta población, al recordar las nubes de mendigos que pululan por aquí, los olores que se soportan, las pedreas que se aguantan y las alarmas continuadas en la Plaza Mayor, se harán cargo de lo que pasa en Casablanca y no creerán que allí no se puede

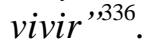

Pero, ¿quién se estaba atreviendo a relativizar así la gravedad de los sucesos marroquíes? ¿Quién achacaba a los corresponsales de guerra un exceso de imaginación y dramatismo? Alguien que firmaba como "Uno".

Por fortuna, en esta ocasión, sí que podemos identificar a la persona que se oculta detrás de este seudónimo: Manuel Rubio, el autor de la cita inicial de este capítulo. Se trataba de un colaborador fijo de El Adelanto a quien todo lo sucedido en Casablanca no parecía preocuparle en exceso, puesto que juzgaba que los salmantinos tenían asuntos más inmediatos de los que ocuparse, empezando por sus ruinosas condiciones de vida. Muy probablemente, no sería el único en sostener semejante pensamiento. Marruecos continuaba estando muy lejos de Salamanca.

Mientras tanto, los combates en los alrededores de Casablanca no amainaban y la situación también se tornaba muy dramática en Fez y Alcázar. ${ }^{337}$. Además, arreciaba

\footnotetext{
${ }^{335}$ MORALES LEZCANO, Víctor, Op. Cit., pp. 89-90. Las exportaciones españolas se multiplican por nueve entre 1913 y 1919, hasta alcanzar un máximo absoluto en 1922 y un máximo relativo en 1924. El descenso gradual se produjo entre 1925-1930. La tendencia general de las importaciones, con notables irregularidades, es al alza, especialmente tras la pacificación del territorio (p. 101).

336 "Uno": "Lo mismo que aquí", El Adelanto, no 7.096, 14 de agosto de 1907, p. 1.

${ }^{337}$ Alfredo Rivera: "Información telegráfica", El Adelanto, no 7.101, 20 de agosto de 1907, p. 3.
} 
la campaña de comentarios insidiosos en la prensa inglesa y francesa contra el comportamiento de las tropas españolas. La acusación de cobardía e indecisión, particularmente machacona en el caso de Le Fígaro, sin embargo, auna voluntades en la redacción de El Adelanto. Nada tiene esto de inesperado o sorprendente. Al contrario, se trata de un fenómeno al que ya aludimos, aunque muy de pasada, en páginas anteriores: la expansión colonial sirve como alimento de la propaganda nacionalista:

"No han terminado aún de pisar la tierra africana las tropas que para la defensa de nuestros compatriotas y para hacer honor a las conclusiones adoptadas por las potencias en la célebre Conferencia de Algeciras, y ya comienza la prensa anglofrancesa a exteriorizar opiniones y hacer juicios, relacionados con las tropas españolas, que serían tristes si fueran ciertos, pero que resultan ofensivos en alto grado, siendo como son falsos, y demuestran la cariñosa benevolencia que merecemos á nuestros aliados (...) En el primer choque que ocurrió en Casablanca, cuando las cábilas saqueaban la ciudad y degollaban a europeos y judíos, los marinos españoles lucharon como héroes (...) Después, cuando el general francés pretendió hacer que nuestros soldados salieran de Casablanca para embarcarse en una aventura loca y expuesta a riesgos tremendos, hízose arma de la patriótica actitud del jefe de las fuerzas españolas, que se negó á tales propósitos y manifestó que España había enviado sus soldados para defender las vidas y haciendas de sus hijos, pero no para comenzar la guerra contra Marruecos ${ }^{, 338}$.

En suma, España estaba cumpliendo irreprochablemente con sus compromisos internacionales, mientras Francia actuaba con suma imprudencia.

Inmediatamente Primo de Rivera intentaba terciar en el conflicto y declaraba ante los periodistas que el general Drude estaba alarmando en exceso a la opinión y que no estimaba necesario el envío de más fuerzas militares españolas a Marruecos ${ }^{339}$ • ¿Qué credibilidad tendrían sus palabras cuando, de acuerdo con todas las informaciones telegráficas, la prensa de la Entente estaba intentando espolear al ejecutivo español para adoptar una posición más belicosa? Probablemente, no demasiada. Así que también Allendesalazar tomó cartas en el asunto y manifestó, a través de una nota oficiosa, que las relaciones entre Francia y España eran perfectamente cordiales ${ }^{340}$. Pese a ello, los combates persistían ante la inacción de las tropas españolas.

El aburrimiento caracterizaba el ánimo de los oficiales tras un largo periodo de inactividad. Desde 1898 experimentaban un estado de enorme desprestigio y su imagen, además, se veía muy perjudicada ante la opinión pública por la tendencia de los gobiernos a recurrir a las fuerzas armadas para mantener el orden en las calles (Ley de

\footnotetext{
338 "Los primeros contratiempos", El Adelanto, no 7.102, 21 de agosto de 1907, p. 1.

339 Alfredo Rivera: "Información telegráfica", El Adelanto, no 7.103, 22 de agosto de 1907, p. 3.

340 "Lo de Marruecos", El Adelanto, no 7.104, 23 de agosto de 1907, p. 2.
} 
Jurisdicciones) $)^{341}$. Por tanto, parecería comprensible que un gran sector del Ejército se congratulase ante la prometedora aventura marroquí. A pesar de ello, por el momento, Maura los frenó.

En esta dificilísima coyuntura internacional, los primeros rumores sobre la proclamación de Muley Hafid como Sultán vinieron a acrecentar el desasosiego público reinante. Pero es muy poco lo que se conoce sobre su persona a través del diario liberal. Las noticias por entonces reproducidas en El Adelanto se limitaron a enfatizar su intransigencia religiosa y su buen trato con los alemanes. Sus aspiraciones, sin embargo, constituían un absoluto misterio ${ }^{342}$.

Si dirigimos ahora nuestra mirada hacia El Lábaro, debemos comenzar subrayando que también este diario practicó un seguimiento muy exhaustivo de los sucesos de Casablanca. El 3 de agosto F. Romero informaba del asesinato de seis franceses, tres españoles y un italiano a la par que recalcaba el enorme alcance político de la noticia. Presumía que, en poco tiempo, se comprobaría cómo el Acta de Algeciras iba a imponer un enorme sacrificio para España:

"En aquella Conferencia todos los honores fueron para España, honores que quizá tengamos que pagar a precio muy subido, y todo por nuestra hidalguía tradicional (...) España llevó al Acuerdo internacional el mayor número de sacrificios; nuestros tratados con Marruecos quedaron completamente anulados, y nuestros indiscutibles derechos históricos confundidos con los que invocaban por razones de comercio e industria, las demás naciones de Europa ${ }^{, 343}$.

Acto seguido, nuestra vinculación con la Entente aparecería en el epicentro del problema. Ni Francia ni Inglaterra, a juicio del redactor, estaban cumpliendo su compromiso, ya que ninguna prisa se daban para organizar la policía y para crear un banco internacional. E iba más allá el redactor en su caza de brujas:

"Aún está reciente el asesinato del doctor francés Mauchamps. Pues bien, aquel suceso bárbaro e inhumano fue preparado por el mismo Mauchamps quizá con la anuencia, o al menos con la tolerancia del gobierno de la vecina república (...) no he llegado a convencerme (...) de que nuestras ententes con Francia e Inglaterra puedan sernos favorables. iSon tan elocuentes las enseñanzas de la historia! (...) Si no demostráramos

\footnotetext{
${ }^{341}$ BALBÉ, Manuel: Orden público y militarismo en la España Constitucional (1812-1983). Madrid: Alianza, 1985 ( $2^{\mathrm{a}}$ ed.), pp. 18-316. Para profundizar en la mentalidad militar imperante durante la Restauración canovista, y en particular, conocer sus recelos frente a la sociedad civil, véase NÚÑEZ FLORENCIO, Rafael: "La mentalidad militar en el marco de la Restauración Canovista", Cuadernos de Historia Contemporánea, $\mathrm{n}^{\circ}$ 14, Madrid, 1992, pp. 31-53. Este recelo también aparece muy palpablemente a lo largo de toda la obra de Tomás García Figueras: Historia de la acción de España en Marruecos. Desde 1904 a 1927. Madrid: Ediciones Fe, 1939.

${ }^{342}$ Alfredo Rivera: "Información telegráfica", El Adelanto, n' 7.102, 21 de agosto de 1907, p. 3; Alfredo Rivera: "Información telegráfica", El Adelanto, no 7.103, 22 de agosto de 1907, p. 3; "Lo de Marruecos", El Adelanto, $\mathrm{n}^{\circ} 7.108,28$ de agosto de 1907, p. 2.

${ }^{343}$ F. Romero: “¿Traerá cola?”, El Lábaro, n⿳ $3.145,3$ de agosto de 1907, p. 2.
} 
energía nuestros conciudadanos en el imperio marroquí dirían y con razón que cuando se asesina un francés, una ciudad pierde su independencia... cuando se asesina a tres españoles, todo se arregla con discreteos diplomáticos".

El mensaje era clarísimo: había llegado el momento de prescindir del Acta de Algeciras y aventurarse a la conquista del Sultanato. La opinión que se está defendiendo no difería demasiado de la sostenida inicialmente por El Adelanto: se cree en una política más activa en Marruecos. Pero ésta se sustenta en juicios distintos y el tono persuasivo es más potente que el empleado en el diario liberal: no se confía en la cooperación con Francia; sino que se da por sentada su enemistad, su deseo de arrebatarnos nuestros indiscutibles derechos históricos.

La actuación del Galilei, ya lo sabemos, sembró el pánico en la ciudad, tanto entre la población marroquí como entre los refugiados europeos ${ }^{344}$. La llegada de la Legión francesa y de los tiradores argelinos, además de la publicación de una Nota de Mohamed Torres solicitando la salida de los europeos de Rabat evidenciaba que el conflicto tomaba un cariz muy preocupante ${ }^{345}$.

El columnista J. Román confesaba paradójicamente, su sorpresa ante la disparidad de apreciaciones que los incidentes marroquíes suscitaban en la prensa europea. Mientras que la alemana, en su mayoría, responsabilizaba a Francia por jugar a canjear súbditos muertos por ciudades conquistadas y también por no haber previsto la organización de la policía, los diarios italianos se lamentaban porque sabían que sus intereses se verían muy mermados en Marruecos y debido a que anticipaban una ocupación francesa definitiva. Mientras tanto, casi todos los periódicos ingleses reconocían a Francia y España el derecho a obrar rápidamente; y en Rusia toda la cuestión marroquí era contemplada como el resultado de las intrigas alemanas. Terminaba el redactor subrayando su deseo de que "de la prensa española no hablemos. Todos podemos ver lo discorde de sus apreciaciones, muchas veces más inspiradas en malevolencias políticas, que en sólido patriotismo"346. Sobre los periódicos franceses, tampoco ningún comentario. Sin duda, se estaba silenciando a todos aquéllos que recomendaban a España prudencia.

El Lábaro abundaba en la idea de que Casablanca constituía el centro de atención de todas las miradas europeas. $\mathrm{Y}$ aportaba su explicación: "El puerto de

344 "Noticias de Casablanca", El Lábaro, no 3.146, 5 de agosto de 1907, p. 1.

345 "De Marruecos", El Lábaro, no 3.147, 6 de agosto de 1907, p. 1; "Ocupación de Casablanca", El Lábaro, no 3.147, 6 de agosto de 1907, p. 3; "Del extranjero", El Lábaro, no 3.148, 7 de agosto de 1907, p. 1 (Fabra).

346 J. Román: “La prensa y Marruecos”, El Lábaro, no 3.148, 7 de agosto de 1907, p. 2. 
Casablanca, aunque abrigado de los vientos de Levante y Poniente, está expuesto a los del Norte, que obligan muchas veces a los buques a hacerse a la mar para no ser estrellados contra las rocas de la costa, y éste es el inconveniente que se quería evitar con las obras del puerto, origen de los sucesos allí últimamente ocurridos"347. A decir verdad, el puerto de esta ciudad era el más importante de la costa atlántica marroquí y su intenso tráfico comercial obedecía a la exportación de cereales procedentes de la región de la Chauia. Francia, como cabía adivinar, era el país que más comerciaba con esta plaza, a pesar de que la colonia de españoles constituía la mayor de la urbe: "España era en tiempos no muy lejanos la única nación que comerciaba con Casablanca y hoy se ha quedado a la zaga no sin vergüenza y baldón para nuestro honor nacional". Una vez más, nuestra histórica rivalidad con Francia era instrumentalizada para instigar a los lectores a respaldar una intervención decidida en Marruecos.

Sin embargo, a juicio de El Lábaro - que nuevamente contrata los servicios de la Agencia Mencheta-, el mayor problema al que entonces se enfrentaban los españoles era la desorientación gubernamental. La reserva ministerial así como un viaje de Maura a Alemania, con escala en París, inquietaban excesivamente a la opinión salmantina. Ésta, consecuentemente, no sabía a qué atenerse, si protestar o aplaudir. Pero para el diario conservador, resultaba del todo incuestionable que garantizar la seguridad de los europeos en Marruecos exigiría un enorme, inmediato y duradero esfuerzo militar:

"La represión enérgica en Casablanca con motivo de los asesinatos cometidos por los cabileños, producirá allí efecto mientras haya en aquel puerto buques de guerra y en aquella ciudad soldados españoles y franceses. Pero lo hecho en Casablanca habrá que repetirlo en Mazagán, Rabat, Larache, Tetuán y aun en Tánger. Es decir, que si Francia y España han de responder de las vidas y haciendas de los europeos en África, tendrán que armar ambos países una flota respetable, y desembarcar en todos los puertos del Norte de África un cuerpo del Ejército, todo para garantir la seguridad de los europeos, pero no el orden en aquel imperio, donde mandan todos menos Abd-elAziz, ${ }^{, 48}$.

Ciertamente, la prensa salmantina, y en general, toda la prensa nacional, fue muy poco prolija en el problema de los dos sultanes. Esa lucha civil no constituía su interés preferente. Francia y España habían reconocido a Abd-el-Aziz, pero la primera no olvidaba que con su asentimiento se celebró la reunión de Algeciras. Soñaba con su

\footnotetext{
347 “Casablanca”, El Lábaro, no 3.148, 7 de agosto de 1907, p. 2.

${ }^{348}$ Mencheta: "El día político", El Lábaro, n 3.149, 8 de agosto de 1907, p. 1.
} 
abdicación, a sabiendas de que seguidamente Hafid tendría que claudicar para ser reconocido como Jefe de Estado ${ }^{349}$.

Unido a ese silencio ministerial, el diario del conservadurismo católico salmantino denunció reiteradamente sus dificultades para proveer de informaciones a sus lectores. Ni las constantes interrupciones del cable telegráfico entre Ceuta y Algeciras ni el misterio que rodeaba las conversaciones en San Sebastián entre Allendesalazar y el embajador francés le complacían. Atendiendo a los círculos oficiales, lo único que este diario podía asegurar era que Ferrándiz, ministro de Marina, había confirmado la buena disposición española en caso de ser preciso el envío de nuevas tropas a Marruecos. Incluso, si se plantease la necesidad, se podría recurrir a los buques de la Transatlántica ${ }^{350}$.

Efectivamente, los desplazamientos de tropas se intensificaron y muy pronto, en la primera quincena de agosto, se anunció la salida hacia Casablanca del crucero Río de la Plata y el cañonero Destructor ${ }^{351}$. Se propagan, a la par, también nuevos rumores sobre un bombardeo conjunto en Rabat y Mazagán; y se confirma, tras algunas jornadas de incertidumbre, que Casablanca ha sido otra vez bombardeada. ${ }^{352}$

El dramático rumbo que adoptaban los acontecimientos animó a Mencheta a reincidir en sus reproches hacia el Protocolo de Algeciras: éste era el documento que condenaba a España a actuar en Marruecos como auxiliar de Francia. No obstante, el gobierno galo parecía anhelar una intervención sin ataduras de ninguna clase. El dilema, por tanto, que se le plantea a Maura es muy simple: o abandona Marruecos o colabora en la imposición de la paz a cañonazos. Semejante disyuntiva iba acompañada, por supuesto, de un muy tendencioso comentario: el comportamiento mostrado hasta el momento por las tropas españolas estaba siendo heroico y las autoridades marroquíes carecían de toda fuerza. De hecho, Muley Hassim, el jefe de las tropas marroquíes en Casablanca, se había visto obligado a solicitar protección francesa ${ }^{353}$. ¿No sería, por tanto, el momento más idóneo para lanzarse a la aventura?

\footnotetext{
${ }^{349}$ BOUARFA, Mohamed: Op. Cit., p. 63.

350 "Lo de Casablanca", El Lábaro, no 3.149, 8 de agosto de 1907, p. 3 (Fabra). El Lábaro se hace eco de que la confusión mediática alcanza tal calibre que periódicos como Diario Universal y La Correspondencia de España confirman un supuesto ataque marroquí sobre Tánger. Véase Mencheta: "El día político", El Lábaro, no 3.153, 13 de agosto de 1903, pp. 1-2.

${ }^{351}$ Mencheta: "El día político", El Lábaro, no 3.150, 9 de agosto de 1907, p. 1.

352 "Lo de Casablanca", El Lábaro, no 3.150, 9 de agosto de 1907, p. 3 (Fabra).

${ }^{353}$ Mencheta: "El día político", El Lábaro, no 3.151, 10 de agosto de 1907, p. 1; "Lo de Casablanca", El Lábaro, no $3.151,10$ de agosto de 1907, p. 3 (Fabra).
} 
A pesar del desconocimiento de los detalles y de los desmentidos gubernamentales concernientes a nuevos aprestos militares ${ }^{354}$, la opinión pública salmantina respondía a la defensiva. Uno de los redactores de El Lábaro se empeñaba, en cambio, en hacerla vacilar con la vieja estrategia de aplaudir su sensatez y granjearse así su atención y empatía para, a continuación, contradecirla y atraerla hacia sus posicionamientos. Veamos, primero, cómo se gana su favor:

"Pudiera ser que ahora, del brazo de Francia y empujados por Inglaterra, nos lanzáramos a la conquista armada de Marruecos (...) pero, a lo que parece, no está el horno para bollos, ni tenemos ganas de meternos en libros de caballerías. La misma gran prensa rotativa, la acusada por la prensa inglesa de proceder en estos asuntos de Marruecos con demasiada prudencia y timidez, ha vertido en sus columnas gran dosis de palabras prudentes y calmantes; no se parece en nada a la que en vísperas del rompimiento con los Estados Unidos ponía pólvora en sus rotativos y bayonetas y cañones en sus editoriales (...) No sé que habrán visto en el horizonte marroquí de temeroso y espeluznante (...) tal vez por aquello de que el gato escaldado del agua fría huye, se hayan vuelto tan prudentes (...) Y ese algo deben haberlo visto también los franceses ${ }^{, 355}$.

Diríase, a priori, que la cautela honraba tanto a los periodistas, cuyo comportamiento nada tenía que ver con el de 1898, como a la opinión pública. Además, también el gabinete parisino parecía, últimamente, avenirse a razones. Dos eran las opciones que barajaba el reportero para explicar este reciente cambio de conducta (por otro lado, más imaginado por él que real): o bien un ánimo excesivamente belicoso por parte de Inglaterra, deseosa de consolidar su posición en Egipto, o bien la sorprendente complacencia del káiser Guillermo II, preocupado por ganar tiempo para afirmar su amistad con Austria y Rusia. Inmediatamente, sin embargo, y como segundo paso para sembrar la duda entre sus lectores, el redactor refutaba las consecuencias de esa venerada prudencia: "Es preciso andar con pies de plomo en estas cosas, vocea la opinión; y con pies de plomo creo yo que se va cerca, porque son muy pesados. Por eso creo que no iremos más allá de Casablanca, y que desde allí nos volveremos a casita. $Y$ después, que cada cual se arregle como pueda". El tono empleado en este editorial es absolutamente clave para entender su pretensión: con ese retintín del "nos volveremos a casita" y una aparente despreocupación al aceptar que "cada cual se arregle como pueda", precisamente, lo que se insinuaba era la necesidad de acompañar a las tropas francesas más allá de Casablanca. Así, mediante estas puntuales filtraciones en la

\footnotetext{
${ }^{354}$ Mencheta: "El día político", El Lábaro, no 3.152, 12 de agosto de 1907, p. 1.

355 “¿A dónde iremos?”, El Lábaro, no 3.153, 13 de agosto de 1907, p. 1.
} 
opinión publicada, se intentaba imbuir en la opinión pública el renovado espíritu de la conquista.

Durante la segunda quincena de agosto, varias de las noticias publicadas en $E l$ Lábaro, sobre todo las contenidas en su sección telegráfica, siguieron dando cuenta del persistente agravamiento de las hostilidades y del reagrupamiento de los rebeldes ${ }^{356}$. El diario intentaba minimizar su impacto $\mathrm{y}$, contradiciendo lo que en sus propias páginas publicaba, aseguraba que las informaciones que se recibían pecaban de exageradas y fantasiosas. El Sultán estaba absolutamente decidido a castigar a los asaltantes de Casablanca y los europeos limitarían su acción a lo acordado en la reunión de $1906^{357}$. Se volvía a reiterar que esto, el respeto a lo pactado en Algeciras, era lo que deseaba la opinión y también la mayoría de los ministros. Bastaba con dotar a los puertos marroquíes de una policía internacional y sólo así, es decir, huyendo de una política de aventuras, se podía mantener el superávit y sostener el crédito. No olvidemos que Maura se resistía a dejar de lado su Ley de Bases del Régimen Local y su proyecto para la construcción de una flota naval ${ }^{358}$. Pero no faltó la nota discordante: Fernando Primo de Rivera, ministro de Guerra, rechazaba la idea de que las fuerzas españolas en Casablanca fuesen inferiores a las francesas y es por ello que viajó hasta San Sebastián para lograr el respaldo regio ${ }^{359}$.

Finalmente, este diario hubo de rendirse ante la evidencia y admitir, el 21 de agosto, que no se vislumbraba ningún remedio, nada semejante a un periodo de inacción, ante el problema marroquí:

"Cuando ya parecía que el conflicto marroquí había entrado en un periodo de franca tranquilidad (...) la bola de nieve de las venganzas marroquíes ha rodado de zoco en zoco empujada por los santones que predican la guerra santa, y siete mil cabileños, feroces y sanguinarios, han caído sobre la ciudad ocupada (...) Podrán los buques barrer toda la costa, podrán los Ejércitos pasear triunfalmente por todo el imperio, a costa de mucha sangre y mucho oro, pero su dominio no pasará más allá del radio de acción de sus cañones, ni de las tiendas de campaña de sus soldados; más allá dominará el fanatismo, dominarán los santones, y al fin de una guerra de tremendas represalias, no se habrá llegado a una paz verdadera y durable, porque la venganza de un pueblo, el odio de una raza, no se acaba sino con la raza misma (...) La civilización a cañonazos no ha entrado en ninguna parte, ni entrará en el imperio del Magreb. $Y$ necias serán las naciones que lo pretendan ${ }^{, 360}$.

\footnotetext{
356 “Lo de Casablanca", El Lábaro, no 3.156, 17 de agosto de 1907, p. 3 (Fabra); "Lo de Casablanca", El Lábaro, $\mathrm{n}^{\mathrm{o}}$ 3.158, 20 de agosto de 1907, p. 3 (Fabra). También se informa de que Santa Olalla ha efectuado una primera inspección por los alrededores de Casablanca y que a la ciudad llegan víveres y municiones sin dificultades.

${ }^{357}$ Mencheta: "El día político", El Lábaro, no 3.155, 16 de agosto de 1907, p. 1.

358 SANCHEZ SANZ, Oscar: Op. Cit., p. 639.

${ }^{359}$ Mencheta: "El día político", El Lábaro, no 3.154, 14 de agosto de 1907, p. 1.

360 “La marea sube", El Lábaro, no 3.159, 21 de agosto de 1907, p. 1.
} 
Sin lugar a dudas, nos hallamos ante otro editorial claramente premonitorio: o lucha sin cuartel o abandono del país.

El Lábaro terminó por abrazar la idea de que la imposición de la "civilización a cañonazos" no constituía una opción viable. Pero, ¿por qué esa abdicación de sus anteriores planteamientos? ¿Por temor a una intempestiva reacción alemana? ¿O por la desconfianza suscitada por el monumental enfado de la prensa británica? ¿Se trataba simplemente de impotencia ante el fanatismo? Algunos escritos publicados en el órgano del conservadurismo salmantino a finales de agosto nos animan inclinarnos hacia la tercera hipótesis barajada: el sencillo reconocimiento de la incapacidad para someter a los rebeldes porque los castigos no resultaban eficaces:

"Si en Marruecos hubiera una autoridad que se dejara sentir en todo el imperio, importarían poco los sucesos de Casablanca; pero como allí las cábilas que rodean todos los puertos marroquíes se hallan en igual estado de rebeldía y sienten los mismos odios contra los europeos, si hallan ocasión y pueden harán lo mismo que los de Casablanca",361.

Había, pese a todo, quien defendía el éxito de la "política del palo": buena parte de los oficiales que prestaban sus servicios en Marruecos.

A ciencia cierta, el problema de África se había convertido en el asunto estelar de todos los periódicos, a medida que la solución parecía irse alejando:

“¿Qué es lo que sucederá? (...) Necesariamente ha de ser una de estas dos cosas: o un arreglo pacífico o un arreglo a cañonazos (...) La cuestión no depende de España únicamente; depende más directamente de Francia. Y en la vecina república dominan temperamentos belicosos (...) En España abundan los temperamentos de paz. Nos hemos abroquelado con la Conferencia de Algeciras (...) Sin embargo, las complicaciones pueden ser tales, de tal modo pueden desarrollarse los sucesos, que nos veamos arrastrados a una guerra de conquista ${ }^{, 362}$.

Casablanca no sólo planteaba a España una cuestión de habilidad militar frente a los marroquíes, sino de efectividad diplomática ante los franceses. Así que el redactor, Mencheta, se conformaba con solicitar un camino "noble y airoso". No explicaba cuál.

Convenientemente, el cronista F. Romero de nuevo hacía notar, por su parte, que la situación de España en Marruecos era extremadamente indefinida y enmarañada; aportaba, además, su propia cosmovisión de los hechos. Es una de las interpretaciones más elaboradas de entre las recogidas por la prensa salmantina; y su cariz francófobo resulta abrumador:

\footnotetext{
${ }^{361}$ Mencheta: "El día político", El Lábaro, no 3.159, 21 de agosto de 1907, p. 1.

362 “Crónica política”, El Lábaro, no 3.161, 23 de agosto de 1907, p. 1.
} 
"Las potencias europeas que firmaron el Acta de Algeciras, dispusieron que Francia y España debían cuidarse de facilitar jefes e instructores de las tropas jerifianas, encargadas de velar en nombre del Sultán por el orden y tranquilidad en los puertos, para hacer en ellos posible al menos la vida de los extranjeros, y facilitar al mismo tiempo las relaciones comerciales. Si este Acuerdo se hubiera cumplido y desde el $1^{\circ}$ de Enero del presente año hubiera comenzado a funcionar la policía jerifiana, quizás los sucesos de Casablanca que ahora están excitando la atención de todos los políticos europeos, se hubieran cortado en sus comienzos. Francia ocupó Uxda tomando como pretexto el asesinato del doctor Mauchamp, y faltando abiertamente a todo lo tratado. Posteriormente fueron asesinados en Casablanca seis franceses y tres españoles, y Francia quiso de nuevo tomar la revancha (...) Francia, al ver el cariz de los acontecimientos, invitó a España a cumplir los Acuerdos de Algeciras (...) y nuestros gobernantes entonces, con una prudencia que merece los más cumplidos aplausos (...) ordenaron el envío de auxiliares españoles que suplieran las funciones de mentada policía ${ }^{, 363}$.

Pese al acierto español, el contacto inevitable entre las tropas había generado algunos roces. Si bien el redactor se esforzaba por minimizar o disfrazar el alcance de los mismos, recogía que buena parte de la prensa ultrapirenaica parecía regocijarse con la abstención de la tropa española y recelaba del viaje de Maura a Berlín. Había, seguidamente, una clarísima llamada de prudencia porque se presumía que, a no mucho tardar, Drude se quedaría inmovilizado en la Chauia. De lo contrario, es decir, si el general francés lograba persistir en su avance, los soldados españoles se convertirían, en solitario, en defensores de la plaza de Casablanca. Sin embargo, sus hombres no parecían suficientes y en apenas quince días los barcos europeos no podrían permanecer en el puerto, porque iban a empezar a arreciar los vientos del Norte. Terminaba Romero: "No falta quien sueña con empresas guerreras, quizá movido por un espíritu patriótico mal entendido, acaso por el deseo de glorias inmarcesibles y de laureles inmortales; pero no está España por ahora para meterse a desfacer agravios o enderezar entuertos, que harto tiene que hacer en su casita, para pensar en meterse en la del vecino".

El regreso de Maura de su viaje no se tradujo en un incremento de la tensión política. Las Cortes permanecían cerradas y reconocía Mencheta que a duras penas hallaba pretextos para el comentario acerca del desenvolvimiento de los asuntos públicos: " $Y$ es que nuestros políticos, en su casi total mayoría a lo menos, perfectos conocedores de las intrigas y menudencias de la política interior, están ayunos en cuestiones de orden internacional, de las que saben y se enteran a veces por lo que dicen los periódicos" ${ }^{364}$. Termina el cronista reconociendo que "la opinión se ha

\footnotetext{
${ }^{363}$ F. Romero: “Crónica política”, El Lábaro, n’ 3.164, 27 de agosto de 1907, p. 1.

${ }^{364}$ Mencheta: "El día político", El Lábaro, no 3.165, 28 de agosto de 1907, p. 1.
} 
manifestado desde los comienzos del conflicto clara y precisa, los conspicuos callan y, y es lo mejor que pueden hacer".

Pero las circunstancias se modificaron al conocerse la proclamación como nuevo Sultán de Muley Hafid y el recrudecimiento de los combates. El Lábaro se hacía eco de la opinión de numerosos diplomáticos, que desconfiaban de la subordinación de éste a los compromisos de Algeciras ${ }^{365}$. El momento era aprovechado para la publicación de un cuentecillo sobre la historia de la guerra con marcada intención moralizante:

"Es hija de la ambición y del odio (...) En aquellos siglos benditos, cuando el mundo era aún cuna de la humanidad, no había nacido la guerra (...) Y creció la humanidad (...) Y una edad, que llamaron Media, fueron los hombres de hierro y de hierro las cosas: leyes, códigos, costumbres. Y la virtud de morir fue hija del pecado de pelear (...) Y llegaron las edades vecinas (...) Todo ha cambiado de aspecto. Los hombres se llaman hermanos (...) La guerra huyó de los campos y se refugió en las fábricas y en los astilleros. No pelea ya con los enemigos, sino con sus amigos; no son sus víctimas los hombres, son los presupuestos. Murió la guerra y nació la paz armada (...) Hay que odiar la paz armada más aún que la guerra. La Haya y Marruecos. Mejor es Marruecos. El hombre vestido de pieles y armado de huesos, es más hermoso que el hombre armado de números y arropado con la civilización ",366.

Era la primera vez que un editorial reconocía, sin ambages, la existencia de una guerra en Marruecos y el lastre económico que ello representaba. Por otro lado esa mención de que "no pelea ya con los enemigos, sino con sus amigos" era una forma discreta de admitir que no se percibía el choque con Alemania como inminente, pero sí que España tenía un muy serio conflicto planteado con Francia por el dominio de Marruecos.

La excitación e impaciencia pública estaban alcanzando niveles insospechados porque el gobierno continuaba sin realizar manifestaciones públicas. A propósito de este mutismo comentaba "G.":

"No deja de extrañarnos un silencio tan antiespañol (...) Aquí donde todo se publica y se vocea y el charlatanismo parlamentario es enfermedad endémica (...) Desde que sonó el primer cañonazo en Casablanca, todos los españoles leídos, y aún los no leídos, se preguntan a voces: ¿Qué hará España? ¿Cuáles son los propósitos del gobierno? Y la prensa, esa gran curiosa impertinente, esa gran consejera más impertinente todavía, ha extremado sus ataques, ha multiplicado sus asaltos (...) Vino el presidente y en vano hemos esperado sus palabras (...) Nos habíamos olvidado que el gran orador dijo una vez: yo no gobierno en la calle ${ }^{, 367}$.

\footnotetext{
365 "Lo de Casablanca", El Lábaro, no 3.165, 28 de agosto de 1907, p. 3. También se rumorea que los partidarios de Hafid han atacado Fez, mientras que su hermano se halla preso en palacio. Pero entre los rifeños, la rebelión no parece tener demasiada repercusión, ya que su único y verdadero amo continúa siendo El Rogui (aunque se halla muy enfermo y se teme por su vida). Véase Mencheta: "El día político", El Lábaro, $\mathrm{n}^{\circ} 3.567,30$ de agosto de 1907, p. 1.

${ }^{366}$ J. Gómez Santiago: "Crónica. La guerra”, El Lábaro, no 3.166, 29 de agosto de 1907, p. 1.

367 "G.": "Crónica política", El Lábaro", n 3.167, 30 de agosto de 1907, p. 1.
} 
En efecto, el conocido desprecio de Maura hacia la opinión pública era lo que inducía a ésta a albergar serias incertidumbres sobre el futuro proceder de España en Marruecos.

Como cabía prever, las declaraciones del presidente ante el ilustre africanista, además de médico militar, Felipe Óvilo, para el $A B C$ tuvieron una enorme resonancia mediática. Antonio Maura dedicó enormes alabanzas a la prensa, aunque lamentó que algunos periódicos protestasen ante el prolongado silencio ministerial. Aprovechó el presidente también para recalcar que España estaba cumpliendo lo pactado en Algeciras y para anunciar que no habría más expediciones a Casablanca: no se perseguían aventuras, pero tampoco el gobierno deseaba sorpresas. El líder conservador terminaba su declaración pública describiendo las relaciones con Francia como cordiales; señalando que se habían producido ciertas exageraciones en el relato de los hechos; y apuntando que los planes de Hafid constituían una incógnita ${ }^{368}$. Tras estas manifestaciones, El Lábaro se congratulaba por la coincidencia de pareceres entre gobierno y opinión: “Es cosa vista y probada que la opinión pública no quiere la guerra (...) pero como con hombres como Maura no es la opinión pública la que gobierna (...) de ahí que el pueblo español no las tuviese todas consigo"369. Pero, aún así, un nubarrón seguía cerniéndose sobre el horizonte: “España no está para aventuras y procurará evitarlas (...) pero queda un cabo por atar (...) Dice un refrán que a la fuerza ahorcan, y contra nuestra voluntad pueden llevarnos a la guerra. Peligrosas son las belicosas tendencias de Francia”. Y por alguna razón, en Algeciras continuaban concentrándose fuerzas y elementos militares ${ }^{370}$.

La complejidad de la situación marroquí radicaba, a juicio de este diario, en el carácter ladino de la diplomacia jerifiana y en la ineficaz autoridad del Sultán. El hecho de que éste fuese incapaz de castigar a los rebeldes, que de continuo recibían nuevos refuerzos, constituía una violación del Acta de Algeciras y la proclamación de su hermano como Sultán agravaba, aún más, el panorama. Por todo ello, la mejor opción para España era no rebasar los límites de Casablanca ${ }^{371}$. En cuanto a Francia:

"No puede encaminarse más que a asegurar los intereses europeos y a vengar agravios y daños a los mismos causados, sin esperanza de satisfacciones ni de indemnizaciones,

\footnotetext{
368 "Lo de Casablanca", El Lábaro, no 3.167, 30 de agosto de 1907, p. 3.

369 "Crónica política", El Lábaro, no 3.168, 31 de agosto de 1907, p. 1. La entrevista sigue comentándose en Mencheta: "El día político", El Lábaro, no 3.168, 31 de agosto de 1907, p. 1; y "Las frases de Maura", El Lábaro, no 3.168, 31 de agosto de 1907 p. 2.

${ }^{370}$ Mencheta: "El día político", El Lábaro, no 3.173, 6 de septiembre de 1907, p. 2.

371 "De Marruecos", El Lábaro, no 3.175, 9 de septiembre de 1907, p. 1.
} 
porque los cabileños de Chauia, autores de las matanzas del 30 de julio, no habrán de darlas, ni pueden pedirse a ninguno de los dos sultanes, ni al o por Europa ni al proclamado en Marraquech ${ }^{, 372}$.

Los destinos de España y Francia en Marruecos parecían distanciarse.

Los temores públicos hacia un posible cambio de parecer en el seno del gobierno de Maura permanecerían, sin embargo, vivos hasta mediados de septiembre. De nuevo, Primo de Rivera se hallará en el trance de tener que desmentir el envío de tropas ${ }^{373}$. Por su parte, El Lábaro, merced a la colaboración de Mencheta, acabará disculpando la belicosidad francesa y presentando la contienda como un mal exclusivamente suyo:

"Hay que no olvidar, que ha dicho un jefe militar, que la acción que Francia está desarrollando en Casablanca no puede despertar recelos en nadie. Después del bombardeo del 31 de Julio, los cabileños han atacado a los franceses reiteradas veces con grande encarnizamiento, y era natural que las tropas francesas hicieran lo que están haciendo; atacar para alejar al enemigo, castigándolo severamente ${ }^{\text {374 }}$.

A decir verdad, los sucesos de Casablanca suponen para Francia el comienzo de una guerra crónica, enquistada, y con enormes costes humanos ${ }^{375}$. Todavía a principios de 1908 Allendesalazar insistía en la idea de que España únicamente atendería a lo pactado en Algeciras, con independencia de las intenciones del gabinete francés. Sin embargo, su mensaje no dejaba de estar repleto de ambigüedad, pues el ministro aseguraba que no se podía ya desandar el camino iniciado en 1904 y que, por tanto, las metas de España y Francia en Marruecos no podían ser opuestas:

"La opinión de que los intereses españoles y franceses en Marruecos sean antagónicos, equivale, en fin, a negar la política que desde 1904 los partidos conservador y liberal, con la adhesión, puede decirse que unánime, del sentir público, vienen siguiendo. Independientemente del error fundamental de la tesis, no es posible, en materias internacionales, desandar el camino o improvisar rumbos a diario ${ }^{, 376}$.

¿Acaso no se estaba ya advirtiendo una nueva orientación en la política africana?

Tal vez, ahora el lector pueda intuir por qué en las páginas previas asegurábamos que la opinión pública era un sujeto vivo y muy escurridizo. Realmente, alcanza con examinar la opinión publicada en la prensa local salmantina para apreciar la gran cantidad de estímulos a que aquélla, la opinión pública, estaba sometida: del hermetismo relativo a la firma de tratados con Francia y Gran Bretaña, se había transitado a una situación caracterizada por el aluvión de muy equívocos telegramas y

\footnotetext{
372 Mencheta: "El día político", El Lábaro, no 3.177, 11 de septiembre de 1907, p. 1.

${ }^{373}$ Mencheta: "El día político", El Lábaro, no 3.179, 13 de septiembre de 1907, p. 1.

${ }^{374}$ Mencheta: "El día político", El Lábaro, no 3.180, 14 de septiembre de 1907, p. 1.

375 "Lo de Marruecos", El Adelanto, no 7.108, 28 de agosto de 1907, p. 2; "Lo de Marruecos", El Adelanto, $\mathrm{n}^{\circ} 7.110,30$ de agosto de 1907, p. 2.

376 “Lo de Marruecos", El Adelanto, no 7.255, 15 de febrero de 1908, p. 2
} 
contradictorios editoriales, que tan pronto abogaban por el castigo de los marroquíes como predicaban calma. Con seguridad, la cuestión marroquí dejó de ser una desconocida para los salmantinos. Pero aún no podía ser percibida como una preocupación familiar: éstos ignoraban qué hacía España en Marruecos; e ignoraban casi todo el contenido de los compromisos internacionales. Aunque, eso sí, temían las posibles salpicaduras de la política colonial francesa: Marruecos era un lastre, el precio de esa anhelada reinserción española en la carrera imperialista entre grandes potencias.

Creemos que las lecturas practicadas tanto por El Adelanto como por El Lábaro de los sucesos de Casablanca guardaron bastantes paralelismos: ambos diarios secundaron, en principio, una intervención española decidida en Marruecos; y también ambos terminaron por decantarse hacia posiciones más cautelosas. Además, los dos periódicos locales recelaron del silencio ministerial y lamentaron, reiteradamente, el aturdimiento reinante entre la opinión pública salmantina. Finalmente, eso sí, uno y otro se convencieron de que esa desorientación no era tal. Más bien, se trataba de un rechazo silencioso, pero incuestionable, hacia la política exterior de Antonio Maura.

En lo que no coincidían El Adelanto y El Lábaro era, en primer término, en el tono empleado. Siempre fue más agresivo y directo el segundo diario. Además, fue también muy significativo el hecho de que para este medio católico los incidentes de Casablanca mereciesen tan considerable cifra de editoriales. Sin duda, se contrarrestaban así los posibles efectos originados por los cada vez más escasos telegramas de Fabra. Por el contrario, El Adelanto, guiado por un muy desarrollado espíritu empresarial, intentaba captar lectores con un discurso menos apasionado y acogiendo opiniones más dispares.

En segundo lugar, también difirieron, sobre todo, sus respectivas valoraciones del juego de alianzas internacionales. Defendemos que aquí reside la clave para entender el miedo de la opinión pública salmantina ante los sucesos de Casablanca y su oposición a una intervención militar decidida. Es más, los juicios vertidos en los dos periódicos examinados siguieron una evolución, del todo, antagónica. Y, además, no deja de resultar asombroso el hecho de que se formulasen ahora muchas más reflexiones a propósito del Acta de Algeciras y su significado que en el momento de su firma. Ciertamente, la actitud inicial del diario liberal hacia los procedimientos franceses fue muy benévola, habida cuenta de que se trataba de una potencia amiga. Pero, con el transcurso de las semanas, se generalizaron las denuncias hacia el sistemático 
incumplimiento del Protocolo de 1906 y se extendió entre los miembros de la redacción el pánico hacia un posible efecto "arrastre”. De ahí, el retraimiento final.

El Lábaro se condujo de modo inverso. Inmediatamente después de producirse los primeros incidentes en Casablanca, el diario católico inició una campaña propagandística de duras diatribas contra la política expansionista francesa y contra las obligaciones impuestas a España en Algeciras; precisamente, azuzando ese odio contra el país vecino, se intentó convencer a la opinión de la capital del Tormes de la necesidad de no permanecer a la espera; pero, finalmente, a la vista de las muchas complicaciones que a Francia se le planteaban en su avance por la Chauia, el rotativo acabó apostando por la prudencia. De todos modos, el diario se esforzó, de algún modo, en entender el proceder galo, su necesidad de reparar una ofensa. A fin de cuentas, Francia era nuestra aliada en Marruecos y pudiera darse el caso, en un futuro no muy lejano, de que también a España le correspondiese vengar posibles ultrajes.

En suma, ambos diarios, en diferentes momentos, intentaron atraerse a la opinión pública salmantina hacia la causa colonial mediante la publicación de improperios contra los avances franceses. Y ambos se rindieron a la evidencia: ésta no deseaba secundar las decisiones de la administración parisina. ¿Por qué? Porque el recurso al nacionalismo antifrancés era un arma propagandística muy potente, pero no suficiente. Se necesitaba, como en el siglo XIX, una afrenta contra el honor nacional.

Para concluir, se podrá objetar, por descontado, que la opinión pública lectora era minoritaria (si bien los periódicos, no lo olvidemos, sobre todo se escuchaban), pero, indiscutiblemente, por primera vez, los salmantinos tuvieron a su alcance una información abundante y opiniones relativamente variadas sobre los acontecimientos marroquíes. Desafortunadamente, también cabía achacarle a las comunicaciones un carácter muy caótico.

¿Serviría la campaña militar de 1909 para perfeccionar las técnicas de contraste de la información? ¿Serviría para alentar el debate entre los salmantinos sobre la cuestión marroquí? Y, finalmente, ¿continuarían los redactores locales confundiendo patriotismo y periodismo? 


\section{SALAMANCA Y LA GUERRA DE MELILLA (1909-1911)}

\section{LA CIUDAD EN EL CAMBIO DE DÉCADA}

"Es una ciudad que crece, aunque lentamente; una ciudad que extiende su comercio, y aunque en menor escala, también su industria y su agricultura. Crece sin ruido y sin fantasía. Y una ciudad alegre, intimamente alegre (...) Aquí la gente murmura, como en todas las ciudades pequeñas y también en las grandes, pero murmura de todo; una veces de lo chico, otras de lo grande, unas de lo humano y otras hasta de lo divino", .

Salamanca era, en estos años iniciales del siglo XX, una ciudad que crecía, aumentando a expensas del vecindario de los arrabales. En gran medida, la expansión se debía a los aportes de la inmigración: gentes que llegaban de los pueblos próximos, huyendo de la amenaza del desahucio y buscando mejores condiciones de vida ${ }^{2}$; y no tanto obedecía a la reducción de las tasas de mortalidad. La población, de este modo, había rebasado su recinto amurallado, con nuevas construcciones delimitadas por la línea férrea de Portugal y la vía de Plasencia. Mientras, en la zona intramuros, muchos viejos caserones eran remodelados, añadiéndoseles un piso adicional, o se levantaban modernos edificios con una planta más racional.

A pesar de los cambios, esta urbe meseteña no perdía su carácter ganadero, universitario y clerical. La capital servía como centro de intercambios comerciales y centro de control de una red económica dominada por el latifundio ganadero. La expansión demográfica y arquitectónica, tan observable sobre el mapa, contrastaba con el retraso en el desarrollo de algunas infraestructuras urbanísticas y, fundamentalmente, con la adopción de un moderno sistema de alcantarillado y de suministro de agua

\footnotetext{
${ }^{1}$ URRUTIA, Luis: Obras completas. Vol. I. Paisajes y Ensayos. Madrid: Escelicer, 1971, p. 421. Unamuno describía de este modo Salamanca en el cambio de década.

${ }^{2}$ Para profundizar en las causas del éxodo rural durante el primer tercio del siglo XX, véase ROBLEDO, Ricardo: "Dejar el campo, comprar la tierra: economía, población y sociedad (1880-1930)" en ROBLEDO, R. (Coord.): Historia de... Op. Cit., pp. 15-85. El autor asocia el éxodo rural con la crisis agraria finisecular: la competencia internacional, sobre todo en la producción de cereal, y la revolución en el mundo de los transportes, condujeron a una enorme acumulación de stocks agrícolas castellanos y a la consiguiente y brutal caída de la renta de la tierra. La demanda y adopción de medidas proteccionistas resultó insuficiente -véanse los trabajos de ESTEBAN DE VEGA, Mariano: "Propietarios y proteccionistas en la Restauración: Salamanca, 1883-1892", Salamanca. Revista provincial de estudios, $\mathrm{n}^{\circ}$ 20-21, Salamanca, 1986, pp. 201-216 y también ESTEBAN DE VEGA, Mariano y LÓPEZ SANTAMARÍA, Jesús: "El Congreso Agrícola de Salamanca de 1887. Un episodio de la movilización proteccionista castellana", Studia Histórica. Historia Contemporánea, Vol. IV, nº 4, Salamanca, 1986, pp. 71-86-. La consecuencia última de este proceso fue la concentración de la propiedad y el ascenso social del gran arrendatario, y, en segundo término, un paralelo fenómeno de consolidación de la propiedad parcelaria. El capital del campesinado para la adquisición de estas tierras procedía de las rentas logradas con la emigración temporal y de los créditos procedentes de los sindicatos católicos y la Caja de Ahorros de Salamanca.
} 
potable. A decir verdad, la ciudad meseteña se hallaba muy lejos de cumplir con las reglas más elementales de higiene.

Durante el siglo XIX, el acarreo de agua desde el Tormes había sido el medio más habitual de abastecimiento entre los vecinos de la localidad. Sin embargo, el caudal del río era muy escaso, reducido constantemente por los riegos, y además, las turbias veraniegas lo dejaban prácticamente seco. Con el propósito de remediar la insuficiencia e incomodidad de este sistema, en la segunda mitad de la centuria se prepararon dos tomas de agua en los parajes de Villasandino y en la Glorieta, disponiéndose un sistema de canalización subterránea hasta varias fuentes públicas. Pero no bastaba: las colas de vecinos que se formaban en estas instalaciones municipales eran enormes y el suministro, muy frecuentemente, se veía interrumpido.

Del año 1872 data el primer proyecto municipal de abastecimiento basado en la elevación del agua con potentes motores, instalados en el Camino de la Aldehuela, y su traslado hasta dos grandes depósitos para su posterior distribución. La realización resultó un fiasco: los motores se estropearon y el barro se filtró en los estanques. Lamentablemente, no sería el único fracaso.

El plan de saneamiento urbano se basaba en el empleo de pozos negros comunales, algo nada inusual en la España de la Restauración, pero la epidemia de cólera que sacudió brutalmente a Salamanca en 1885 sirvió para concienciar a los concejales de la necesidad de mejorar tanto la calidad del agua como el método de evacuación de residuos. Desde este momento, la prensa no cejaría en su empeño de denunciar una mortalidad exorbitante y de solicitar unas calles más transitables. No lo eran, efectivamente, por su suciedad y pestilencia; pero también por su estrechez, su falta de alumbrado, los socavones que provocaban infinidad de accidentes... He aquí el origen de aquel constante paralelismo con los poblados morunos.

Se diseñaron, por tanto, más proyectos: uno de desagüe en 1889; un nuevo plan de abastecimiento en 1892; otro en $1893 \ldots$ Pero el problema persistía: o bien la fuerza del caudal para limpiar la red era muy débil o bien las obras se volvían muy costosas ${ }^{3}$. Y, mientras, el vecindario padecía innumerables enfermedades gastrointestinales y permanecía a la espera de una solución. Ése era, muy seguramente, su mayor deseo y más urgente preocupación al iniciarse el año 1909.

\footnotetext{
${ }^{3}$ SENABRE LÓPEZ, David: Salamanca en 1898. Salamanca: Ayuntamiento de Salamanca, 1998, pp. 54-62.
} 
Si reparamos ahora, mínimamente, en la estructura social salmantina en esa misma fecha, debemos apuntar que la polarización era la nota dominante. La élite política parlamentaria coincidía, en gran proporción, con los grupos económicamente hegemónicos y, también, con el profesorado universitario; se definía, aparte, por su endogamia y por una fuerte procedencia nobiliaria. Para el conjunto de la provincia, no obstante, las investigaciones más recientes sobre la configuración de los grupos de poder castellanos en la Restauración evidencian que Salamanca era uno de los espacios con mayor hueco para los partidos no turnantes. Aunque éste no era el caso del distrito capitalino. Al contrario, aquí se registraba un balance bastante equilibrado entre los dos partidos dinásticos (lo mismo ocurría en el distrito de Peñaranda, pero no en las cinco circunscripciones electorales restantes) ${ }^{4}$.

La vida municipal, con todo, transcurría por otros cauces, permitiendo más fácilmente la actuación de fuerzas políticas alternativas al sistema. En efecto, la presencia socialista en el Consistorio fue muy temprana. Si bien temprana no es sinónimo de fuerte. La Federación Obrera de Salamanca se constituyó en 1900 y la Agrupación Socialista de Salamanca nació dos años después. Su líder, Primitivo Santa Cecilia asumiría una concejalía, de forma continuada, entre 1905 y 1917. Los republicanos, por su parte, alcanzarían mayores cuotas de poder en el Consistorio, aunque sus progresos políticos se ajustaron a un ritmo más irregular. En todo caso, 1909 fue un año de importancia excepcional para ellos. Además, estos sectores guardaron una estrecha conexión con cierto sector universitario, encabezado por personajes como Unamuno, Dorado Montero, Wenceslao Roces...

Ajenos al poder político y económico, topamos con una masa sometida a unas condiciones de vida lamentables y dolorosas. Los profesores Mariano Esteban de Vega y Jesús López Santamaría han sido quienes más han profundizado en la condición del

\footnotetext{
${ }^{4}$ Cabe destacar la meticulosa labor de los profesores Pedro Carasa Soto y L. Santiago Díez Cano, huyendo de interpretaciones maniqueas y reduccionistas, sobre este apartado. Todas sus investigaciones arrancan de la siguiente premisa: se pone en entredicho el tradicional paradigma de la opresión económica como clave única para la comprensión de la naturaleza del poder político. En su lugar, toman en consideración para entender ésta elementos tales como el pacto y el ejercicio del liderazgo social; y el distrito electoral, junto con las redes personales, se convierten en el pilar de su análisis. Abundando en la caracterización de la élite política salmantina, deseamos reproducir el siguiente comentario: "En Salamanca se observa un dinamismo y participación política cada vez más alejada del caciquismo clásico de intercambio de favores personales, de patronazgos deferenciales. No tardan en pasar a la coacción, a la compra de votos y a la movilización electoral". Véase CARASA SOTO, Pedro (Dir.): Élites castellanas... Op. Cit., p. 69.
} 
obrero en Salamanca durante la Restauración ${ }^{5}$. Su existencia estaba del todo marcada por la extrema precariedad, doméstica y laboral, y por la incertidumbre ante el porvenir. Su alimentación era muy deficiente: apenas consumían verdura, carne, pescado o leche; vivían, casi siempre, hacinados y en lugares insalubres; su vestido era pobre; las tasas de analfabetismo demoledoras; cualquier enfermedad o accidente laboral podía tener efectos fatales para sus familiares; tenían que lidiar con la estacionalidad de muchos trabajos... Pero aún así, tal vez sea conveniente aclarar que, en términos relativos, los porcentajes provinciales de analfabetismo entre individuos mayores de 10 años se situaban en cifras inferiores a la media nacional. En 1910, el 52\% de los españoles eran analfabetos (el $42 \%$ de los hombres y el $61 \%$ de las mujeres), mientras que en Salamanca la cifra se reducía al 36\% (el 23\% de los hombres y el $48 \%$ de las mujeres) y hemos de suponer que la cantidad sería aún menor en la capital, sobre todo, tratándose de un foco universitario ${ }^{6}$.

Por el momento, esta masa no protestaba demasiado; aunque las circunstancias cambiarían en años futuros. De los orígenes del movimiento obrero en esta urbe es muy poco lo que se conoce ${ }^{7}$. Pero parece que la ideología socialista no tuvo una excesiva implantación entre esos depauperados obreros durante la primera década del siglo. Ello obedecía, principalmente, al alto nivel de atomización empresarial de la ciudad. En Salamanca no existían centros industriales en los que se aglomerasen cientos de trabajadores. Al contrario, lo que hallamos son relaciones laborales caracterizadas por el paternalismo patronal; una atmósfera muy dominada por la doctrina social de la Iglesia; una escasa tradición sindical; y gran organización y concienciación entre las clases dominantes frente a la "amenaza marxista". Tal vez, quien mejor encarnó esta acometida de los grupos económicamente hegemónicos fue la Cámara de Comercio,

\footnotetext{
${ }^{5}$ ESTEBAN DE VEGA, Mariano y LÓPEZ SANTAMARÍA, Jesús: "La condición obrera en Salamanca durante la Restauración" en VVAA: I Congreso... Op. Cit. pp. 57-63.

${ }^{6}$ VILANOVA RIBAS, Mercedes y MORENO JULIÁ, Xavier: Atlas de la evolución del analfabetismo en España de 1887 a 1981. Madrid: Ministerio de Educación y Ciencia, 1992, pp. 192, 194 y 196.

${ }^{7}$ FERNÁNDEZ TRILLO, Manuel y MCINIIS, Elisabeth: "Implantación obrera: socialistas y comunistas en Salamanca durante la II República", Salamanca. Revista de Estudios, n ${ }^{\circ}$ 15, Salamanca, 1985, pp. 87163. Para un repaso más exhaustivo del asociacionismo provincial en el año 1931, véase DÍEZ CANO, L. Santiago y CARASA SOTO, Pedro: "Caciques, dinero y favores. La Restauración en Salamanca" en ROBLEDO, R. (Coord.): Historia de... Op. Cit., p. 106-110 y 151-157. Hasta tal extremo es difícil analizar la trayectoria ideológica y política de las asociaciones obreras que ni siquiera la catalogación como "obreras" coincide en ambos trabajos citados: su cifra asciende a 15 según el cómputo de Fernández Trillo y McIniis, confeccionado en base al análisis de Censo Corporativo Electoral de 1928 (con un total de 2751 afiliados). Sin embargo, en el trabajo de Díez Cano y Carasa Soto, fundamentado en el Registro de Asociaciones de 1931, podemos contabilizar 19 asociaciones dependientes de la Casa del Pueblo hasta 1928 (y que no siempre coinciden con las anteriores).
} 
fundada en 1886. Desde luego, la minoría obrera militante en Salamanca tuvo enormes dificultades para movilizar a la totalidad de la clase en un momento tan crucial de su historia como lo fue el año 1909. Así, por ejemplo, cuando el 13 de julio intentaron celebrar un mitin para protestar contra la movilización de los reservistas, el gobernador civil lo prohibió y ellos lo acataron sin parecer molestos ${ }^{8}$.

En su repaso de la Salamanca Contemporánea, Enrique Esperabé de Arteaga, gran figura aglutinadora del sector universitario contrario a Unamuno, efectuaba un balance de lo más pasmoso para este año ${ }^{9}$. Los hechos que él consideraba cruciales se limitaban al repaso de algunos fallecimientos y a la celebración de los Juegos Florales Hispano-Portugueses. Mientras, la campaña militar de 1909 parecía no haber tenido lugar. Tal vez, porque a nuestro autor no le agradaba recordar la caída del gobierno maurista.

Al menos, al reseñar 1908 Esperabé sí que dio cuenta del nacimiento de El Fomento. Y es que en un ambiente social tan dividido y con el acuciante problema del agua al que nos hemos referido, se creyó ver la solución a todos los males en la fundación, en diciembre de 1908, de esta nueva sociedad. La fuerza del asociacionismo -aunque más allá del ámbito estrictamente obrero, insistimos- era descomunal en aquella Salamanca. La explicación es simple: esta capital, ante todo y sobre todo, se sentía olvidada y abandonada por el poder central. Hasta el extremo de que, en alguna ocasión, ya finalizada la Guerra de Melilla y a la vista de las incontables disposiciones dictadas para Marruecos, El Adelanto lamentó las escasas inversiones para la mejora agrícola de la provincia, clamando: “;Mejor estar en el Rif!" 10 . El investigador Ricardo Fernández, abundando en esta materia, ha puesto últimamente de relieve lo fácil que era crear, por esa misma razón, un estado de ánimo propicio para marchar a Madrid cuando los diarios locales situaban al enemigo en las Cortes o en Valladolid ${ }^{11}$.

Si bien la aspiración confesa de El Fomento consistía en atender los requerimientos de la opinión pública local, en la práctica, constituía una alcaldía paralela a la oficial y desestabilizaba, más si cabía, la situación política salmantina. Precisamente, las actuaciones de El Fomento, reclamando muchísima mayor atención

\footnotetext{
${ }^{8}$ BACHOUD, Andrée: Op. Cit., p. 167.

${ }^{9}$ ESPERABÉ DE ARTEAGA, Enrique: Salamanca Contemporánea. La vida de la ciudad desde 1868 hasta 1933. Sus principales acontecimientos. Sus políticos. Salamanca: Imprenta de Francisco Núñez Izquierdo, 1933, pp. 205-212.

10 "De cursiva. ¿Y Salamanca", El Adelanto, no 7.845, 12 de enero de 1910, p. 1.

${ }^{11}$ FERNÁNDEZ, Ricardo: Op. Cit., p. 45.
} 
para la higiene urbana, monopolizaban toda la atención de la opinión pública salmantina en el momento en que se desencadenó el conflicto en las cercanías de Melilla ${ }^{12}$. Sus gestiones, relatadas con todo lujo de detalles, eran el tema protagonista de la prensa local. Servían, además, de acicate para los gestores municipales. Aunque, al mismo tiempo, éstos intentaban eludir responsabilidades ${ }^{13}$. En realidad, también la sensación de abandono que motivó el surgimiento de El Fomento había entregado la victoria en las elecciones municipales de mayo de 1909 a los republicanos ${ }^{14}$. La campaña previa había sido bastante animada, sobre todo, gracias a la apuesta del Círculo Mercantil por una candidatura conjunta, emulando el ejemplo de la Solidaridad, y a la celebración de una gran asamblea el 22 de abril en su sede ${ }^{15}$. Sin embargo, el experimento resultó frustrado.

El nuevo alcalde, el liberal Antonio Díez González, junto con los recién nombrados concejales republicanos, fue el primer interesado en viajar a Madrid para solicitar ayuda. Se había hecho público un escandaloso informe, elaborado por el doctor Pinilla y encargado por El Fomento, en el que se recogían las cifras de la mortalidad salmantina para el periodo 1904-1909 y se denunciaba la sobrecogedora incidencia de las fiebres tifoideas en la ciudad (casi 600 fallecimientos en ese lustro), resultado de la suma de la irresponsabilidad individual y colectiva ${ }^{16}$. Aunque en febrero ya se había negociado la obtención de un empréstito para las obras de alcantarillado con una Sociedad franco-belga ${ }^{17}$, las conversaciones se acabaron interrumpiendo y el desánimo se apoderó del vecindario ${ }^{18}$. De ahí, la urgencia del viaje. Aún era mayor, si cabía,

\footnotetext{
12 “La salud pública”, El Adelanto, n 7 7.547, 23 de enero de 1909, p. 1; "Opinión unánime”, El Adelanto, $\mathrm{n}^{\mathrm{o}} 7.589,13$ de marzo de 1909, p. 1. Algo posteriores, aunque nos parecen interesantes balances sobre la actividad de esta asociación, son los artículos: "La salud pública", El Lábaro, n 3.782, 6 de octubre de 1909, p. 1; “¿Hay ambiente de solidaridad?”, El Castellano, $\mathrm{n}^{\circ}$ 1.642, 18 de noviembre de 1909, p. 1; "Klío": "Hojas en blanco", El Castellano, no 1.665, 15 de diciembre de 1909, p. 1. Otro que reiteradamente se mostró muy indignado por la conducta antihigiénica de los salmantinos fue Miguel de Unamuno: "O todo o nada", El Castellano, $\mathrm{n}^{\circ}$ 1.667, 17 de diciembre de 1909; y también del Rector: "Segundo golpe", El Castellano, no 1.616, 31 de diciembre de 1909, p. 1.

13 “Ayuntamiento", El Adelanto, n ${ }^{\circ} 7.557,4$ de febrero de 1909, p. 1.

14 "Resultado de las elecciones en Salamanca", El Adelanto, $\mathrm{n}^{\circ}$ 7.630, 3 de mayo de 1909, p. 1.

15 "La asamblea popular. Iniciativa fracasada", El Adelanto, no 7.623, 23 de abril de 1909, pp. 1-2; "Juan de Salamanca": "Vida local. De política", El Adelanto, no 7.625, 26 de abril de 1909 p. 1; "Sem Tob": "Crónicas. Salamanca quiere ser ciudad", El Lábaro, no 3.656, 21 de abril de 2909, p. 1.

16 "Fomento de Salamanca", El Adelanto, no 7.554, 1 de febrero de 1909, p. 2; "El Fomento de Salamanca", El Lábaro, no 3.595, 2 de febrero de 1909, p. 1; Pedro Casi: "Salamanca al día", El Castellano, $\mathrm{n}^{\circ} 1.353,1$ de enero de 1909, p. 1; Pedro Casi: "Salamanca al día. Tema obligado", El Castellano, n1 1.375, 21 de enero de 1909, p. 1.

17 "El empréstito municipal. Buenas impresiones", El Adelanto, no 7. 575, 25 de febrero de 1909, p. 1.

18 “¿Qué hay del empréstito?”, El Adelanto, n 7.600, 26 de marzo de 1909, p. 1.
} 
debido a la proximidad de los mentados Juegos Florales ${ }^{19}$. Se consideraba, por último, muy probable la visita de la reina con motivo de tal celebración ${ }^{20}$.

El mandato de Antonio Díez no llegó ni a los dos meses. A principios de julio era remplazado por el conservador Florencio Marcos Martín, mientras que el asunto del empréstito y del abastecimiento con agua potable continuaba sin resolverse ${ }^{21}$. En una fecha tan calamitosa como la del 23 de julio de 1909, Fernando Felipe, uno de los pioneros del socialismo salmantino, además de redactor de El Adelanto, comentaba con un tono verdaderamente apocalíptico: "Malo es, malísimo, que los moros maten a los españoles, pero si así lo exige la dignidad de la Patria, habrá que soportarlo como una desgracia casi inevitable. Lo que es malísimo y fácil de evitar, es que un día se maten aquí españoles y españolas porque las fuentes de la población les den motivo o siquiera pretexto para ello",22.

La resignación con la que se contemplaba la política africana no hallaba parangón cuando se debatía sobre preocupaciones de carácter local. Es algo que ya advertimos en un capítulo anterior y forma parte de ese espíritu empresarial con el operaba parte de la prensa salmantina. Sin embargo, Marcos Martín hallaría también muchos escollos en el desempeño de su mandato: el principal fue la falta de solvencia económica municipal. Su relación con los concejales republicanos, por otra parte, no fue fluida. Habrá ocasión de comprobarlo, por ejemplo, cuando algunos concejales luchen por sacar adelante una proposición de rechazo hacia los acontecimientos violentos del Rif. Finalmente, en noviembre de 1909 le sucedería por designación regia, de nuevo, Antonio Díez ${ }^{23}$.

Pero lejos de desear convertir el contexto del presente trabajo en el objeto del mismo, aquí interrumpimos el relato. Sin duda, queda muchísimo camino por recorrer en el conocimiento de la vida municipal salmantina, pero nos conformamos apuntando

\footnotetext{
19 "Los Juegos Florales de Salamanca", El Adelanto, no 7.637, 11 de mayo de 1909, p. 1; "Los Juegos Florales. Reunión en el Gobierno Civil", El Adelanto, no 7.638, 12 de mayo de 1909, p.1; "Moret, mantenedor", El Adelanto, n 7.658, 4 de junio de 1909, p. 1; "Empecemos a hacer algo", El Lábaro, no 3.727, 20 de julio de 1909, p. 1; "Con ocasión de la feria”, El Lábaro, no 3.732, 26 de julio de 1909, p. 1; Ramón Barco: "Miscelánea”, El Castellano, no 1.568, 24 de agosto de 1909, p. 1.

20 "Juan de Salamanca": "Vida local. Su majestad la higiene", El Adelanto, no 7.643, 18 de mayo de 1909, p. 1; "En el Ayuntamiento. Las sesiones de anoche", El Adelanto, no 7.673, 22 de junio de 1909, p. 1; "Esperemos", El Adelanto, no 7.676, 24 de junio de 1909, p. 1.

21 "Política municipal”, El Adelanto, n1 7.681, 1 de julio de 1909, p. 1; "La política en el Concejo", El Castellano, $\mathrm{n}^{\circ} 1.740,17$ de junio de 1909, p. 1.

22 "Juan de Salamanca": "Vida local. Las fuentes públicas", El Adelanto, no 7.699, 23 de julio de 1909, p. 1.

23 "En el Ayuntamiento. Toma de posesión del alcalde", El Adelanto, no 7.797, 15 de noviembre de 1909, p. 1; "Maurismo salmantino", El Castellano, no 1.658, 7 de diciembre de 1909, p. 1.
} 
que la aparente parsimonia de la ciudad no era tal. Como último apunte, la reina no acudió a los Juegos de septiembre de 1909, que resultaron al igual que las tradicionales Ferias un tanto deslucidos por las trágicas circunstancias de la guerra ${ }^{24}$.

El empréstito sufrió una nueva cancelación en octubre, debido a un defecto de forma en el proyecto ${ }^{25}$. Sin embargo, éste se pudo sacar finalmente adelante tras algunas modificaciones y gracias a las gestiones del diputado liberal Pérez Oliva, en marzo de $1910^{26}$. De todos modos, las dificultades no desaparecían: para la financiación de las obras del alcantarillado, además de para muchos otros conceptos que se pretendían cubrir con la operación financiera - reparación de deudas, obras de pavimentación y electrificado, etc.-, se necesitaba el concurso de los capitalistas locales ${ }^{27}$; y El Fomento no se mostraba demasiado satisfecho con algunas de las condiciones legales ${ }^{28}$. Así que la subasta pública quedó en dos ocasiones desierta: la primera, en mayo de $1910^{29}$; y la segunda, en agosto ${ }^{30}$. Parecía poco menos que imposible lograr la cooperación exterior a tenor de la caótica situación de la hacienda municipal: "No pueden pedirse cuatro millones y medio de pesetas al crédito local, nacional o mundial por una Corporación que no sabe lo que debe" ${ }^{31}$. En efecto, año tras año, los presupuestos que se

\footnotetext{
24 "Los Juegos Florales", El Adelanto, no 7.729, 27 de agosto de 1909, p. 1; "Nuestros Juegos Florales", El Lábaro, $\mathrm{n}^{\circ} 3.579,26$ de agosto de 1909, p. 1.

25 "Devolución de las bases del empréstito municipal", El Adelanto, n 7.782, 28 de octubre de 1909, p. 1; "El saneamiento de la ciudad", El Lábaro, n 3 3.812, 29 de octubre de 1909, p. 1. El Castellano ya había anticipado este fracaso: "El empréstito enterrado", El Castellano, no 1.594. 23 de septiembre de 1909, p. 1.

${ }_{26}$ "Su autorización por el gobierno", El Adelanto, no 7.893, 9 de marzo de 1910, p. 1; "Juan de Salamanca": "Vida local. La nueva Salamanca", El Adelanto, no 7.895, 11 de marzo de 1910, p. 1; "El empréstito municipal", El Lábaro, no 3.914, 4 de marzo de 1910, pp. 1-2.

27 "El empréstito municipal", El Adelanto, no 7.909, 29 de marzo de 1910, p. 1; "El empréstito municipal. Sus bases", El Adelanto, no 7.910, 30 de marzo de 1910, p. 1; "Las inscripciones del empréstito", El Lábaro, n" 3.938, 5 de abril de 1910, p. 2; "La inscripción para el empréstito", El Lábaro, n ${ }^{\circ} 3.490,7$ de abril de 1910, p. 2; "El día del empréstito", El Lábaro, no 3.951, 20 de abril de 1910, p. 1 . Gracias a esta contribución de los sectores más adinerados de Salamanca se pudieron recaudar 800.000 pesetas, cifra insuficiente para cubrir el coste de las obras. Por cierto, en estas circunstancias, Unamuno aprovecharía para arremeter contra el Ayuntamiento, al que le atribuye escaso interés en el saneamiento urbano: "Más sobre el empréstito. La opinión del señor Unamuno", El Adelanto, n 7.935, 28 de abril de 1910, p. 1.

28 "El empréstito municipal", El Adelanto, no 7.917, 7 de abril de 1910, p. 1; "El empréstito municipal", El Adelanto, no 7.920, 11 de abril de 1910, p. 1; "Defendiendo el empréstito", El Lábaro, no 3.944, 12 de abril de 1910, pp. 1-2; "Nueva reunión del Fomento de Salamanca", El Lábaro, no 3.957, 15 de abril de 1910, pp. 1-2.

29 "El empréstito y las obras municipales. No hay fracaso", El Adelanto, no 7.950, 16 de mayo de 1909 p. 1; "Del empréstito", El Lábaro, no 3.987, 3 de junio de 1910, p. 1.

30 "La segunda subasta", El Adelanto, n1 7.986, 27 de junio de 1910, p. 1; "S.": "El empréstito municipal", El Salmantino, no 52,4 de agosto de 1910, p. 1.

31 "El empréstito municipal. Su fracaso. Las causas", El Adelanto, no 8.025, 11 de agosto de 1910, p. 1
} 
confeccionaban pecaban de irreales y el déficit se había convertido en una enfermedad crónica $^{32}$.

La Guerra de Melilla, lógicamente, vino a ensanchar el horizonte de preocupaciones de la opinión pública salmantina. De hecho, durante la segunda mitad de 1909, se convirtió en el tema estelar de los rotativos salmantinos. La prensa local, a través del ejercicio de su función agenda setting, canalizó la curiosidad y angustia de la ciudadanía hacia Marruecos. Sin embargo, su atención y, por tanto, también en gran medida su efecto, exceptuando a aquellas familias que sufrieron directamente las calamidades del conflicto, fue sólo coyuntural.

\section{LOS ANTECEDENTES DE LA CAMPAÑA MILITAR DE 1909}

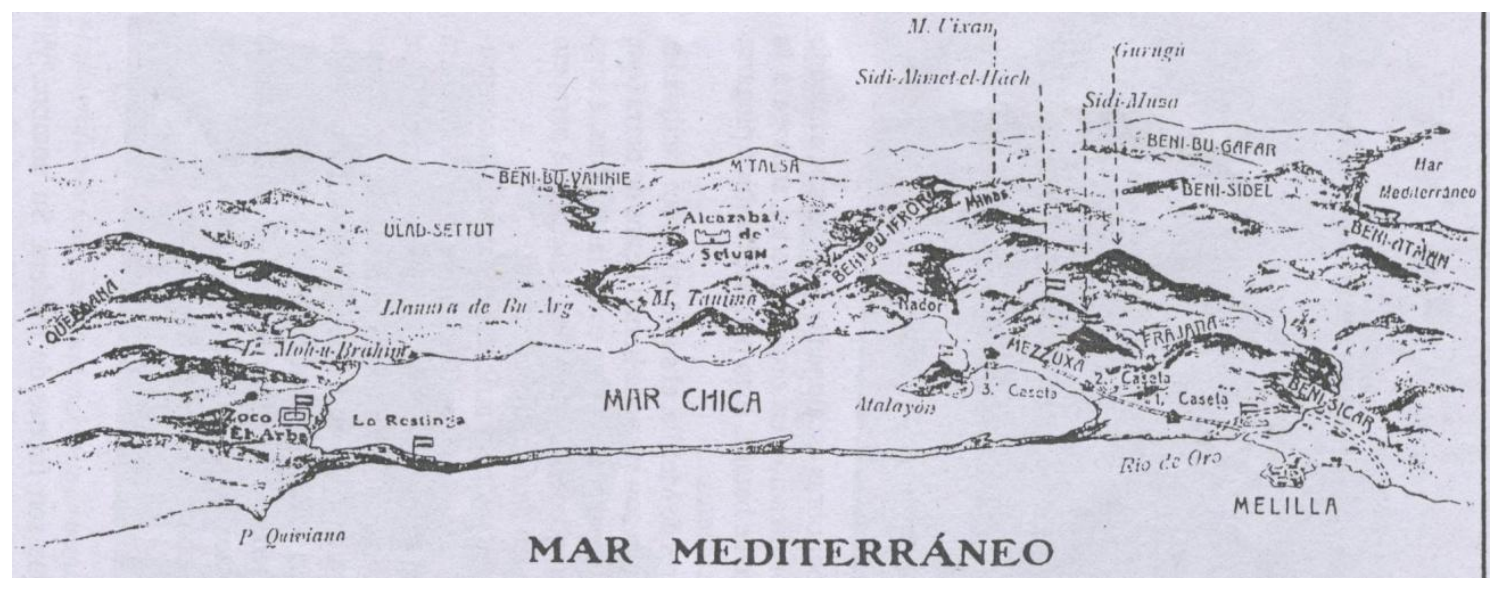

Fuente: DÍEZ SÁNCHEZ, Juan: “Melilla, 1909. Álbum gráfico”, Aldaba, nº 15, Melilla, 1990, p. 142.

La Guerra de Melilla fue el resultado de una gran equivocación tanto gubernamental como militar y su historia estuvo muy ligada a uno de los cabecillas rebeldes más carismáticos de la región: El Rogui.

Coincidiendo con el desarrollo de esta nueva campaña militar, bastantes jóvenes salmantinos hubieron de trasladarse, por primera vez en el siglo XX, al escenario de la batalla. Desperdigados en cerca de una decena de regimientos, su participación en los hechos de armas es muy difícilmente rastreable a través de la documentación de los archivos militares, precisamente, debido a esa dispersión. Las fuerzas de la Albuera que

\footnotetext{
${ }^{32}$ Por ejemplo, resultó absolutamente revelador de esta situación de desgobierno el hecho de que al concejal republicano Villalobos no se le pudiera proporcionar un resumen de las deudas municipales, cuando lo solicitó, porque se desconocía el dato. Véase: "La deuda municipal", El Adelanto, no 8.013, 28 de julio de 1910, p. 1. En el acta de la sesión, sin embargo, se elude este incidente: Actas de las Sesiones Municipales. Archivo Histórico Municipal, vol. 1910, fol. 125 (r).
} 
guarnecían la ciudad, en cambio, no fueron movilizadas. Y es que se hallaban muy mermadas en la capital, así que su traslado hubiera sido una medida muy impopular. Aunque en el futuro estas circunstancias cambiarían (y nosotros podremos seguir con mayor facilidad su pista).

En todo caso, desde este momento, la opinión pública salmantina no estaría únicamente expuesta a las opiniones publicadas por redactores y corresponsales más o menos duchos en los asuntos marroquíes, sino también muy atenta a los testimonios de sus soldados y a la actuación de las autoridades locales. El bienestar de los combatientes, de hecho, se convirtió en una de las grandes preocupaciones de los vecinos de Salamanca y se tradujo en multitud de iniciativas, tanto institucionales como particulares, de carácter solidario.

La prensa local seguirá constituyendo, lógicamente, el principal elemento articulador de la opinión pública salmantina, debido, especialmente, a la inmediatez con la que funcionaba. Emplearemos para el análisis de la opinión publicada en Salamanca los mismos rotativos que hasta el momento hemos venido utilizando: El Adelanto, El Lábaro, El Castellano y, además, como novedad, El Salmantino (el que sería el antecesor directo de La Gaceta Regional). La ordenación atiende, como en el capítulo anterior, a un criterio permanente: de mayor a menor vocación empresarial o, si se prefiere, de menor a mayor carácter doctrinal.

Contamos, como se observa, con dos periódicos de inspiración católica: $E l$ Lábaro y El Salmantino. Pero, lamentablemente, con ninguno obrero. No podemos, por tanto, dejar de constatar que la Iglesia, aunque dividida en dos bandos, asumía un papel dominante en la vida salmantina y actuaba como elemento aglutinador del pensamiento más conservador ${ }^{33}$. Su gran enemigo político era el Liberalismo y para combatirlo, para rearmarse ante la "amenaza de descristianización" que esa ideología supuestamente encubría, la Iglesia recurrió a la publicística y a la prensa.

El agustino padre Cámara se convirtió en el adalid de la causa. Sin duda, la defensa a ultranza del imperio de la fe sobre el de la razón actuó como aglutinante entre

\footnotetext{
${ }^{33}$ Para un mayor conocimiento de esta cuestión véase ESTEBAN DE VEGA, Mariano: "Católicos contra liberales: notas sobre el ambiente ideológico salmantino de la Restauración", Studia Histórica. Historia Contemporánea, Vol. IV, $\mathrm{n}^{\circ}$ 4, Salamanca, 1986, pp. 51-69; y ROBLES, Laureano: "Corrientes ideológicas en la Salamanca de finales del siglo XIX y principios del siglo XX" en VVAA: I Congreso de Historia de... Op. Cit., pp. 85-120. También es muy recomendable para el conocimiento de esa confrontación social, aunque sólo se refiere a un periodo previo al que a nosotros nos interesa (18901902), la obra de RABATÉ, Jean-Claude: 1900 en Salamanca. Salamanca: Universidad de Salamanca, 1997.
} 
los miembros de la redacción de El Lábaro. Pero también sirvió como abono para su competidor, el semanario integrista El Salmantino. Tras la agresión mora del 9 de julio ambos rotativos se convertirían en los más aguerridos defensores locales de la tesis del desquite, de la cruzada. Curiosamente, renegando de la teoría de la evolución, del darwinismo biológico, acabaron defendiendo postulados idénticos a los de los defensores del darwinismo social: el colonialismo como elemento de progreso de la humanidad.

\section{La ocupación de la Mar Chica}

Comencemos por el repaso muy sucinto de los hechos: la ocupación militar española de la costa marroquí se inició a principios de 1908 con la toma de La Restinga, en el extremo sudeste de la Mar Chica, y el Cabo de Agua, posición que cierra la curva costera en cuyo centro se ubica Melilla. El general Marina, que por entonces era el gobernador militar de la ciudad, intentaba de este modo impedir la reconstrucción de una fábrica francesa de armas, autorizada por El Rogui, en las cercanías de la plaza ${ }^{34}$. Muy pronto, no obstante, la opinión pública asistiría al primer serio tropiezo militar de España en el siglo XX.

Los telegramas de la prensa salmantina recogieron ambas ocupaciones, pero sin concederles demasiada importancia. En el caso de El Adelanto, Rivera señaló que la toma de La Restinga se podía justificar atendiendo al Convenio de 1894 y a que no era previsible la más mínima protesta internacional. Hacía cuatro años que el Sultán incumplía su compromiso de tener unas tropas en los alrededores de Melilla para garantizar la tranquilidad en la región. Por eso, ya en 1907, una representación diplomática enviada a Rabat y encabezada por Llavería, el delegado español en Tánger, y con el propio general Marina, había expuesto lo dramático de la situación y reclamado una solución ${ }^{35}$. En su lugar, obtuvieron el silencio como respuesta.

Ciertamente, Abd-el-Aziz decidió al fin formar un Ejército contra El Rogui. Esta tropa desembarcó en la desembocadura del Muluya, a medio camino entre Melilla y la Argelia francesa, con la pretensión de paralizar simultáneamente también a los galos. Pero, repentinamente, el Sultán la abandonó a su suerte. En mayo de 1907, como último esfuerzo, la mehalla ocupó La Restinga y allí permaneció, bloqueada por los roguistas y sin recursos ni moral ofensiva. Si la fuerza imperial se hallaba, a principios

\footnotetext{
${ }^{34}$ MADARIAGA, Rosa María de: España y el Rif... Op. Cit., pp. 375-377.

${ }^{35}$ Paralelamente, se desplazó a Rabat otra delegación francesa, que sí logró ultimar un nuevo empréstito para Abd-el-Aziz por valor de 2.100.000 francos. He aquí otro incidente que enardecería la guerra civil.
} 
de 1908, por completo desatendida se debía a que su lealtad era puesta en entredicho. Muchos de sus miembros, según algunos rumores, eran seguidores de Hafid.

En consecuencia, la Comandancia había de soportar un creciente estado de anarquía en el Rif y ello dañaba la prosperidad comercial de la plaza: "La mehalla que operaba en los alrededores de Melilla, después de permanecer largos meses acampada frente a los rebeldes sin librar combates decisivos, interrumpiendo el tráfico de la plaza española con el interior, y abandonada totalmente del Sultán, ha acabado por refugiarse en nuestros límites" 36 .

Esto es lo que había ocurrido el 29 de enero de 1908: el general Marina había decidido prestar socorro a las tropas imperiales sin que entre las cancillerías europeas se levantara ninguna voz. Habían transcurrido tres semanas desde aquello. El articulista daba, no obstante, ahora cuenta de la nueva operación y explicaba:

"Ante la situación que eso crea, relacionada con la entrada en vigor de la represión marítima eficaz del contrabando de armas, el gobierno se ha resuelto a ocupar La Restinga, donde estaba emplazada la factoría de Mar Chica, que sirvió al pretendiente de base de aprovisionamiento de material de guerra. Allí se instalará provisionalmente un contingente militar español que supla al que el Sultán debía facilitar con arreglo al artículo $4^{\circ}$ del Convenio de 1894. La medida es puramente transitoria ".

De este modo anunciaba El Adelanto el primer avance del Ejército español rebasando los límites del campo de Melilla. El Rogui -o "pretendiente", aunque también se le apodaba como Bu-Hamara, "el hombre de la burra", debido a que era habitual que recorriese así los poblados buscando adeptos a su causa- era entonces sobradamente conocido en la región por haberse enriquecido a costa de vender tierra marroquí a los españoles. Pero los orígenes de este bandido resultaban bastante enigmáticos y curiosos: había nacido cerca de Uazzan y había ocupado algunos puestos en la administración militar y religiosa del Imperio. Haciéndose pasar con éxito por el hijo mayor del Sultán Hassan I, enarboló la bandera de la expulsión de los cristianos y logró un considerable apoyo social. En 1903, fijó su residencia en Zeluán, a unos treinta kilómetros de Melilla, porque el inicial emplazamiento de su corte en Taza no le ofrecía demasiadas seguridades. De hecho, en tres ocasiones las tropas de Abd-el-Aziz habían intentado apresarle. Eso sí, todas las operaciones resultaron frustradas.

Zeluán sí le permitiría, en cambio, una más fácil defensa ante el Sultán y también le facilitaría el contacto con los cristianos de ultramar. Desde aquí, El Rogui se convirtió en el nuevo administrador de la aduana marroquí, ubicada a las puertas de la

36 "Lo de la Mar Chica”, El Adelanto, no 7.257, 18 de febrero de 1908, p. 3. 
plaza española, y ejerció un poder tiránico sobre las cábilas de Guelaya. Algunos pobladores se mantendrían leales al Sultán de Fez y otros no, pero no tanto por convicción sino porque así era como se resolvían los roces entre cábilas vecinas. En todo caso, la presencia de $\mathrm{Bu}$-Hamara puso fin a la calma hasta entonces reinante en el territorio.

Para poder costear un Ejército que le garantizase su hegemonía, el pretendiente emprendió una serie de negociaciones con distintos grupos europeos, origen tanto de la Compañía Norte Africana como de la Compañía Española de las Minas del Rif. Ambas estaban extraordinariamente interesadas en la riqueza mineral de la región de Beni-buIfrur $^{37}$; y ambas obtuvieron el permiso para la construcción de un ferrocarril que transportase el mineral hasta el puerto de Melilla. El gobierno español exigió, sin embargo, que la salida del mineral se hiciera por aquí ya que se había invalidado la idea de una factoría en La Restinga.

La "pequeña operación quirúrgica” sobre este punto geográfico, el 14 de febrero de 1908, preparada con muchas cautelas ante la previsible protesta de El Rogui -por otro lado falsa: tenía que salvaguardar su imagen de rebelde ante sus seguidores, pero se estaba enriqueciendo con las cesiones mineras- quedaba justificada por la inseguridad

\footnotetext{
${ }^{37}$ Con anterioridad al incidente en La Restinga de 1906, este impostor había entablado conversaciones con un consorcio minero francés contradiciendo así todas sus exhortaciones previas. En 1904 había cedido la explotación de unas minas de plomo de Beni-bu-Ifrur, por un periodo de 99 años, a los hermanos Baille. Tres años después, en mayo de 1907, cedió a Enrique McPherson y a Alfonso del Valle otras minas de hierro, también emplazadas en la cábila de Beni-bu-Ifrur. Mientras tanto, Clemente Fernández, un consolidado comerciante, dirigió muy precavidamente y en primer término una petición al Sultán para poder explotar dos minas, una de plomo argentífero y otra de hierro magnético en Beni-buIfrur. La primera era la que ya El Rogui había entregado a los Baille (y su socio comercial, Massenet) y la segunda, a Mcpherson y del Valle. En una segunda fase, Clemente Fernández dirigió estas mismas peticiones a El Rogui, que aunque era la única autoridad efectiva en el Rif oriental, no pudo negarse a la cesión de los derechos solicitados y así lo confirmó el 9 de junio de 1907. Después de una competición encarnizada, los dos grupos españoles rivales se asociaron, en junio de 1908, formando la Compañía Española de Minas del Rif. Por su parte, el grupo francés, que hubo de contentarse con las minas de plomo de Afra, había formado el 21 de agosto de 1907 la Compañía Norte Africana.

Según David S. Woolman la cesión de El Rogui a los españoles fue un gesto de agradecimiento por el apoyo prestado desde Melilla ante un ataque del Sultán en el verano de 1907. Véase WOOLMAN, David S.: Op. Cit., p. 53. Madariaga ha señalado posteriormente que El Rogui justificó su postura alegando un retraso francés en el pago de los derechos de explotación contratados en 1904. Véase MADARIAGA, Rosa María de: En el Barranco del Lobo... Op. Cit., p. 46. Y, a modo de resumen de todos estos negocios mineros, consúltese también MADARIAGA, Rosa $\mathrm{M}^{\mathrm{a}}$ de: "Melilla y la fiebre minera en el primer cuarto del siglo XX”, Aldaba, n 19, Melilla, 1990, pp. 183-202 (También se puede localizar este trabajo, además de un análisis de los concesionarios y empresarios mineros, en la conocida obra, revisión editada de su tesis doctoral, España y el Rif. Crónica de una historia casi olvidada). En contraste, autores como Saro Gandarillas relativizan el significado de las explotaciones mineras en el desarrollo de la campaña del Rif de 1909 y minusvaloran los tratos entre El Rogui y las autoridades melillenses. En su lugar, este autor alude a la asfixia comercial de la plaza y a la encarnizada competencia gala, sobre todo, después de su declaración como puerto franco en 1863. Consúltese SARO GANDARILLAS, Francisco: "Los orígenes de la campaña del Rif de 1909”, Aldaba, n² 22, Melilla, 1993, pp. 97-129.
} 
que amenazaba a la región tras la deserción imperial. Con esta ocupación se evitaba el contrabando marítimo en la zona, tal y como explicaba el columnista, pero además España adquiría el control sobre el territorio que atravesarían los ferrocarriles mineros.

En El Adelanto se reproducían, asimismo, las declaraciones de un amigo íntimo de Maura -sin especificarse su nombre para eludir posibles responsabilidades-, quien aseguraba que el avance militar había sido preparado por el presidente y que era una sabia decisión de cara a la defensa de Melilla. En el fondo, sin embargo, se trataba de emular lo que Francia hizo en Uxda:

"El aludido señor, conocido político, dijo también que nos convenía muy mucho retener ese terreno para defender más fácilmente la plaza moruna, en caso de posibles contingencias, que bien pueden surgir al querer cualquier nación establecer una factoría en dicha zona, y esto hay que evitarlo. Otra influencia, que no sea la española, anularía el comercio de Mar Chica y por eso nos interesa doblemente, por su carácter comercial, la conservación de susodicha posesión. Por último, el amigo del presidente dijo que lo mismo que hoy hacíamos nosotros en Mar Chica, había hecho Francia en Uxda y en Argelia, 38 .

Además, también rápidamente, se subrayó el acierto de la decisión alegando que, había generado una enorme satisfacción y tranquilidad entre las cábilas ${ }^{39}$. Hasta tal extremo llegaba esa supuesta alegría, que en algún telegrama se comentaba que los marroquíes de Melilla animaban al gabinete madrileño a ocupar Sierra Bullones y Tetuán; y el triunfo era aprovechado, con evidente ánimo vengativo, para traer a colación la persistente mala suerte de los franceses, con D'Amade al frente, en la región de Casablanca ${ }^{40}$.

No obstante, las tropas españolas se limitaron a ocupar, el 12 de marzo de 1908, Cabo de Agua. Contarían para la realización de esta acción con la aquiescencia de la cábila de Quebdana ${ }^{41}$. A decir verdad, la solicitud de auxilio por parte de los quebdaníes fue el nuevo argumento que el gobierno de Maura esgrimió ante Europa para justificar la operación militar. Sin embargo, con la posesión de Cabo de Agua se afianzaba el dominio sobre las islas Chafarinas y, por su cercanía al Muluya, se podían controlar los movimientos franceses desde Argelia y Uxda. El Adelanto se valió, excepcionalmente, de este avance para publicar un largo y moralista cuento llamado "El solar de la Espadaña”. Nos encontramos con un típico relato sobre la grandeza y la decadencia nacional; y sobre unas gentes con un carácter casi sobrenatural y:

\footnotetext{
${ }^{38}$ Alfredo Rivera: “Telegramas. Lo de la Mar Chica”, El Adelanto, no 7.257, 18 de febrero de 1908, p. 3.

${ }^{39}$ Alfredo Rivera: “Telegramas", El Adelanto, no 7.258, 19 de febrero de 1908, p. 3.

${ }^{40}$ Alfredo Rivera: "Telegramas. De Marruecos”, El Adelanto, no 7.259, 20 de febrero de 1908, p. 3.

${ }^{41}$ Alfredo Rivera: “Telegramas. De Marruecos", El Adelanto, no 7.278, 13 de marzo de 1908, p. 3.
} 


\begin{abstract}
"fama de ricos y de guerreros; fama que fue creciendo (...) Y no se los temía solamente porque vociferasen haciendo alarde de valentía y heroísmo, sino que llegó un día en que los vecinos y ya propietarios del solar de la Espadaña fueron dueños de algunos otros solares (...) Día llegó en que su engreimiento les hizo fatuos, quizá por su soberbia. Tuvieron la debilidad de creer que serían héroes y ricos eternamente (...) $Y$ como era natural, la decadencia no se hizo esperar mucho: lo que antes había sido un emporio, pasó a ser un erial (...) Otro solar en el mismo caso habría hecho esfuerzos inauditos por volver a tener su preponderancia, pero el solar de la Espadaña no lo hizo así; se limitó a desearlo, creyendo sin duda que con el deseo se llega a la posesión, dando lugar con su proceder a que solares que antes no hubieran podido existir sin su concurso; solares que carecían en absoluto de historia, pero ávidos de engrandecimiento, solares un tanto avariciosos, pero desconocedores tal vez del honor, se envalentonaran y arrebataran al solar de la Espadaña dominios de su legítima propiedad ${ }^{, 42}$.
\end{abstract}

Muchísimo había llovido desde la conquista de América. Aunque de modo disimulado El Adelanto parecía comprender la lógica con la que estaba procediendo el general Marina: deseaba una intervención más activa en Marruecos, más inspirada en el Tratado de 1904 que en el Acta de Algeciras y que le liberase de la incómoda situación creada por la presencia de la autoridad de derecho (la mehalla) cuando los tratos con una autoridad de hecho, El Rogui, resultaban más fructíferos.

Paradójicamente, aunque fiel, eso sí, a los constantes titubeos en su línea editorial sobre la gestión de la política marroquí, el mismo periódico seguía recelando de la acción gubernamental porque al país no se le hablaba con claridad:

"Poco a poco va enredándose la madeja en el Norte de África y España va adueñándose de algunas posesiones como Mar Chica y Cabo de Agua que no sabemos qué beneficios podrán reportarnos el día de mañana ni a qué conflictos podrán abocarnos en un porvenir muy próximo (...) Hasta ahora, los moros han recibido a nuestros soldados como hermanos (...) Pero cualquier día puede ocurrir una disputa (...) España se verá envuelta en una guerra sangrienta, interminable, costosísima, y a la que deberá destinar millones que le serían necesarios para atenciones interiores, no diremos que más importantes, pero sí más urgentes. Por ello debiera el gobierno hablar claro, presentar a las Cortes su programa, y preparar todo como si la guerra fuera segura, antes de verse arrastrado por los acontecimientos y que éstos le cojan desprevenido. España está cansada de aventuras, pero no considera como tal tomar posiciones en Marruecos, ya que sabe que de ello depende su vida futura como potencia europea. Si es necesario, afrontará la guerra, no con entusiasmo, sino por deber, pero para afrontarla, quiere saber a dónde se la conduce y cuáles son los propósitos del gobierno. No es mucho pedir ${ }^{, 43}$.

De nuevo, hallamos en este editorial esa permanente desconfianza hacia la política exterior seguida por Maura en Marruecos ${ }^{44}$. Pero también encontramos grandes

\footnotetext{
${ }^{42}$ Maximiliano Arconada: "El solar de la Espadaña”, El Adelanto, n 7.281, 17 de marzo de 1908, p. 2.

43 "España en África", El Adelanto, no 7.282, 18 de marzo de 1908, p. 1.

${ }^{44}$ Un año después, en julio de 1910, Maura se defendería ante el Congreso de aquellas opiniones que le responsabilizaban de haber engañado a la opinión pública, transmitiendo la falsa impresión de que, al igual que en Casablanca, tampoco intervendría en el Rif. Defendió que él únicamente pretendió garantizar
} 
dosis de resignación. Indiscutiblemente, éste es el artículo más visionario de los comentados hasta el momento. La guerra $-\mathrm{y}$ esta es la palabra que se emplea, no la expresión "operación de policía" -ya aparecía a la vuelta de la esquina y, aunque se presumía que iba a distraer muchísimos recursos económicos, se justificaba y se apoyaba, con un estoicismo pasmoso, mientras se le explicase a la nación.

En el caso de El Lábaro, cambiando ahora de rotativo, Mencheta fue el primero en relatar, brevísimamente, que los españoles habían ocupado la Mar Chica. A pesar de la oposición del los roguistas, no se habían registrado bajas entre los peninsulares, cuyo comportamiento era tildado de heroico ${ }^{45}$. En los alrededores de Melilla, se insistía, la vida transcurría apaciblemente ${ }^{46}$. Durante tres días, de hecho, Mencheta exploró la región de Beni-bu-Ifrur y, aunque no pudo entrevistarse con El Rogui, dio cuenta de que los trabajos mineros se desarrollaban con absoluta normalidad y de la satisfacción reinante en la cábila de Beni Sicar por las ocupaciones ${ }^{47}$. Mientras, en Casablanca, los franceses habían de seguir haciendo frente a la encarnizada rebeldía de los hafidistas ${ }^{48}$.

El seguimiento que El Castellano efectuó de ambas ocupaciones fue mucho más superficial: se limitaba a la reproducción de tres escuetos telegramas ${ }^{49}$, al tiempo que se daba cuenta de la cada vez más comprometida situación de Abd-el-Aziz, aislado en Rabat, frente a su hermano Hafid ${ }^{50}$.

la soberanía española sobre la plaza de Melilla, pero no pudo explicar por qué se procedió a la ocupación y permanencia en nuevas posiciones. Véase PÉREZ MOLINA, Elisa: Op. Cit., pp. 343-344. Como análisis más general sobre la política marroquí de Antonio Maura, consúltese GONZÁLEZ HERNÁNDEZ, Ma Jesús: El universo conservador de Antonio Maura. Biografía y proyecto de Estado. Madrid: Biblioteca Nueva, 1997, pp. 300-322. Para esta autora, en el desencadenamiento de la Guerra de 1909, antes que los intereses económicos o políticos primaron los deseos de los militares, espoleados por el propio Alfonso XIII. La política que se siguió en Marruecos apenas halló defensores, sin embargo, casi todos los hombres del régimen mancharon sus manos de sangre en aquel país. De hecho, Maura fue la más célebre víctima de una cruel ironía, pues conociéndose su "repugnancia" hacia la penetración militar en Marruecos, se convirtió en uno de sus más aventajados heraldos.

45 "Noticias por telégrafo", El Lábaro, no 3.308, 15 de febrero de 1908 , p. 3.

46 "Noticias por telégrafo", El Lábaro, no 3.310, 18 de febrero de 1908, p. 3; "Noticias por telégrafo", El Lábaro, no 3.613, 19 de febrero de 1908, p. 3.

${ }^{47}$ Mencheta: "Mencheta en Marruecos", El Lábaro, no 3.316, 25 de febrero de 1908, p. 2; "Noticias de Marruecos", El Lábaro, no 3.317, 26 de febrero de 1908, p. 3.

48 “De Marruecos", El Lábaro, no 3.311, 19 de febrero de 1908, p. 1 (Fabra); "De Marruecos", El Lábaro, n 3.312, 20 de febrero de 1908, p. 1 (Fabra); "Noticias de Tánger", El Lábaro, no 3.312, 20 de febrero de 1908, p. 3; "Noticias de Marruecos. Franceses y cabileños", El Lábaro, no 3.313, 21 de febrero de 1908, p. 3; "De Marruecos", El Lábaro, no 3.314, 22 de febrero de 1908, p. 2 (Fabra); "De Marruecos", El Lábaro, no 3.315, 24 de febrero de 1908, p. 2 (Fabra); "De Marruecos", El Lábaro, no 3.316, 25 de febrero de 1908, p. 2 (Fabra); "De Marruecos. Las condiciones de paz”, El Lábaro, no 3.333, 16 de marzo de 19908 , p. 3.

49 “Telegramas", El Castellano, no 1.710, 15 de febrero de 1908, p. 1; "Telegramas", El Castellano, no 1.719, 19 de febrero de 1908, p. 3; “Telegramas", El Castellano, no 1.720, 20 de febrero de 1908, p. 3.

50 “Telegramas”, El Castellano, no 1.711, 17 de febrero de 1908, p. 3. 
Finalmente, por lo que respecta a El Salmantino, este periódico ni siquiera reseñó los avances españoles, aunque sí comentó el recrudecimiento del movimiento antifrancés en la frontera argelina ${ }^{51}$.

Lo cierto era que desde enero de 1908, la ciudad de Fez se había proclamado a favor de Hafid. Anteriormente, lo había hecho Safi y en el verano le seguirían Tetuán, Larache y Tánger. Sin embargo, las convulsiones internas de Marruecos seguían sin merecer la atención de la prensa. El Sultán abdicó a finales de agosto y Hafid, previa aceptación del Acta de Algeciras, demás tratados y contratos con particulares, fue solemnemente reconocido como la máxima autoridad marroquí por Europa el 5 de enero de 1909.

El fin de la guerra civil entre hermanos tendría una repercusión inmediata en el Rif: España había sabido ganarse el favor de Hafid a través de los inteligentes servicios prestados por el doctor Balaguer. Incluso, tuvo al alcance de su mano la posibilidad de instruir y armar a las tropas del nuevo dirigente. Pero éste puso precio a su amistad: un préstamo de veinte millones de francos. Maura hubo de rechazar el ofrecimiento. Así que Hafid acabó inclinándose hacia el lado francés y relegando al olvido las luchas en la región de la Chauia. Por otra parte, como la ocupación de la Mar Chica se había justificado ante la falta de seguridad en las inmediaciones de Melilla, el nuevo Sultán rápidamente prometió ocuparse de imponer orden, aunque condicionándolo al abandono español de la Mar Chica. Evidentemente, también estaba determinado a acabar con El Rogui.

No sólo las autoridades melillenses habían ignorado la existencia de una autoridad legítima, sino que muy pronto se manifestó el rechazo de los cabileños a la presencia extranjera en la zona. La hostilidad se plasmó en un levantamiento de las cábilas contra El Rogui, que fue obligado a abandonar Zeluán en diciembre de 1908, refugiándose en Taza. Todo ello ocurrió tras una frustrada expedición contra los Beni Urriaguel y después de vengar el ataque cabileño sobre unos obreros españoles ${ }^{52}$. El

\footnotetext{
51 “Crónica de la semana", El Salmantino, no 21, 7 de marzo de 1908, p. 1.

${ }^{52}$ El resultado de esta expedición de El Rogui contra los Beni Urriaguel fue objeto de una acaloradísima discusión en el Congreso. Los protagonistas de la misma fueron el ministro conservador Allendesalazar y el diputado liberal Miguel Villanueva. Éste acusó al gobierno de haber reconocido primero como verdadera autoridad en el Rif al pretendiente y, luego, de haberle expulsado del territorio al prestar socorro, simultáneamente, a los urriagueles. A juicio de Villanueva, el gabinete de Antonio Maura era directamente responsable de la anarquía en la región melillense por la contradictoria política adoptada ante Bu Hamara. La Comandancia de la plaza tenía que haber apoyado a la única autoridad efectiva de la región. Sin embargo, lo que hizo fue minar su poder.
} 
gobierno español sabía que una actitud en exceso tolerante hacia Bu-Hamara no le resultaría beneficiosa y optó por respetar el deseo de las cábilas de suspender los trabajos en las minas.

Pero el orden prometido por el Majzen seguía sin apreciarse.

\section{La Nota franco-alemana del 9 de febrero de 1909, la embajada de Merry y la indisimulada carrera contra Francia}

Cumpliendo con los cánones diplomáticos del periodo, en marzo de 1909, una embajada española encabezada por Merry del Val, nuestro representante en Tánger, fue enviada a Fez con el propósito de saludar y reconocer al nuevo Sultán. No obstante, éste no era más que su aparente cometido porque lo que en realidad se trataba de procurar con el viaje era tomar posiciones ventajosas frente a una homóloga legación francesa para asentarse en Marruecos. Debía, sobre todo, recabar del nuevo mandatario la colaboración necesaria para la pacificación de la región rifeña, posibilitándose así la reanudación de los trabajos mineros.

El Adelanto era muy consciente de que, pese a los recientes avances militares, la situación española en las inmediaciones de Melilla era muy débil. España había quedado nuevamente rezagada en la disputa tras la firma de un nuevo Acuerdo francoalemán y, lo que era peor, aceptaba permanecer en ese segundo puesto. Al menos, eso era lo que aseguraba el diario liberal.

Buena parte de las asperezas latentes en las relaciones franco-alemanas se difuminaron con la firma de ese importante Acuerdo en febrero de 1909. A la par que se garantizaba la libertad económica de Alemania en Marruecos, Francia se aseguraba ciertos privilegios políticos $^{53}$. El Adelanto rápidamente entendió que la Nota suponía un

Villanueva se dejó arrastrar por el pesimismo, y meses después de este enfrentamiento, en diciembre de 1908, confesaba que "unas veces por los hechos, y otras por las apreciaciones, apreciaciones que llegan a algo tan grave como eso de haber creído que vosotros podíais dominar a las cábilas e imponer alli el orden, por todo esto, mi temor de que no llegue a las alturas del Poder Soberano una información exacta, se confirma cada día". Nos hallamos ante una tremenda declaración de impotencia sobre la capacidad colonizadora española. Pero, además, se reconoce que el Rey está mal informado sobre las características de la zona de Marruecos asignada a España. Sin embargo, las noticias que le llegaban a la opinión pública nada importaban a los hombres del régimen. Véase PÉREZ MOLINA, Elisa: $O p$. Cit., pp. 308-317.

${ }^{53}$ SÁNCHEZ SANZ, Oscar Javier: Op. Cit., pp. 648-651. España, al igual que en 1904, contemplaba nuevamente cómo su misión en Marruecos quedaba convertida en un "subproducto". Inglaterra, por su parte, guardó silencio. León y Castillo, para disimular la humillación gestionó la firma de un documento hispano-alemán, similar al pacto franco-alemán, pero ya en junio de 1909; ALLENDESALAZAR, José Manuel: Op. Cit., p. 199-201 y 217-223. El estado de alarma se generalizó entre la diplomacia española, al gestionar este acercamiento de posturas, porque se reabrió el viejo asunto del cable telegráfico entre Marruecos y Canarias. El resultado inmediato de este Acuerdo franco-alemán fue, por otro lado, la conformación de la Unión de Mines Marocaines, integrada por las más fuertes compañías de los Estados 
cese en la "política de alfilerazos" de ambos países. Pero también el diario liberal supo apreciar que España sería la potencia más perjudicada por este pacto:

“No habrá en Europa un pueblo cuyos intereses económicos y políticos sufran perjuicios a consecuencia de ese Convenio? Desaparecido en Marruecos el fantasma de Alemania, ¿se mantendrá Francia dentro de los límites del Acta de Algeciras? ¿No es de temer que la ambición de alguna parte de sus financieros e industriales la empuje a terreno ajeno, con perjuicio de los intereses del propietario mismo? Malo es que hay el precedente de Casablanca y el no menos importante de la apatía de los gobernantes, capitalistas e industriales españoles" $"$.

Ahora su actitud no tenía nada de titubeante, sino que más bien pretendía alertar a la opinión pública, de nuevo, de la necesidad de adoptar una posición resuelta: “Cuando el señor Merry del Val llegue a Fez, Monsieur Regnault ya habrá terminado su misión cerca de la corte de Hafid, y nuestro representante tomará lo que aquél no haya querido, bien por su escaso valor, bien porque era prudente dejar algo para el que detrás venía y más sabiendo que con ese algo quedaría satisfecho el rezagado" El tono empleado por el columnista era de manifiesta inconformidad: se resistía a que España siempre quedase subordinada a los intereses galos en Marruecos. Sin embargo, inmediatamente el rotativo tenía que anunciar que el Sultán había renunciado a la protección inglesa a favor de la francesa ${ }^{56}$.

La recepción oficial tuvo lugar el 13 de marzo, pero las conversaciones se prolongaron enormemente y durante días persistió la ansiedad por conocer el papel que Francia había reservado a España en Marruecos, sin que Rivera lo aclarase ${ }^{57}$. Lo cierto es que la cobertura que El Adelanto prestó a la embajada de Merry fue paupérrima. Tal vez, sospechamos, porque el pesimismo había inundado la redacción y se estaba perdiendo la fe en una solución diplomática para la cuestión marroquí.

La rivalidad hispano-francesa no se manifestaba, ciertamente, sólo a través de las noticias sobre esta embajada. De la debilidad del Estado español en esta carrera por el dominio de Marruecos también se hacían muy amargo eco los Centros HispanoMarroquíes de Madrid, Barcelona, Ceuta y Tánger. Llegaron al extremo de enviar una

signatarios de Algeciras y cuyo objetivo consistía en asegurarse las concesiones mineras anteriores e ilegales. La vida de esta Unión fue efímera y la Norte-Africana fue la primera empresa en desgajarse del proyecto y emprender su particular carrera.

54 “X. y Z.": “Servicio especial de El Adelanto. El Acuerdo franco-alemán”, El Adelanto, no 7.567, 16 de febrero de 1909 , p. 1.

55 "X. y Z.": "Servicio especial de El Adelanto. Merry del Val, camino de Fez", El Adelanto, no $7.578,1$ de marzo de 1909 , p. 1.

${ }^{56}$ Alfredo Rivera: “Conferencias telegráficas”, El Adelanto, no 7.579, 2 de marzo de 1909, p. 3.

57 "X. y Z.": "Servicio especial de El Adelanto. La embajada española en Fez", El Adelanto, no 7.599, 25 de marzo de 1909 , p. 1. 
carta de reclamación al ministro de Hacienda; carta que fue reproducida por $E l$ Adelanto, el 5 de marzo, y en la que se manifiesta su deseo por:

“alcanzar para la nación española el puesto que por su historia y situación geográfica le corresponde en Marruecos (...) Es de interés nacional, bajo todos los conceptos, no olvidar la política africana, que encierra toda una acción colectiva del Estado y del país, como base de nuestra expansión comercial y elemento impulsivo para el engrandecimiento de la patria, ${ }^{, 58}$.

Su objetivo era denunciar el incumplimiento del artículo 37 del Acta de Algeciras: aunque se había podido instalar en Tánger una agencia del Banco de España, con todo lo que conllevaba como elemento de influencia política y económica, no se había podido hacer efectivo el privilegio de admitir la moneda española con fuerza liberatoria. También estos centros se dolían por la eliminación del idioma y de la moneda española en las subastas del Majzén. Su idea permanente consistía en que los franceses les estaban comiendo terreno:

"El conflicto había de surgir forzosamente desde que apareció en el Acta de Algeciras una contradicción manifiesta, cual es el reconocimiento de la moneda española con fuerza liberatoria y el establecimiento del Banco de Estado marroquí en moneda francesa, que carece de dicha fuerza liberatoria; pero aparte de que una excepción no hace la regla, ésta debe prevalecer, en cuanto significa el reconocimiento de los derechos de España en Marruecos ${ }^{\text {,59. }}$.

Son, de todos modos, escasísimas las alusiones de El Adelanto a este permanente contencioso con Francia. El sentimiento de desengaño era el amo de la redacción liberal.

El Lábaro, por su parte, únicamente abordó el tema de la embajada española una vez que ésta había fracasado. Comentando la actitud intransigente del Sultán, aparecía lo siguiente entre sus informaciones telegráficas:

"Atribúyese esta conducta del Sultán a influencias de Francia o al menos de algunos súbditos franceses. Francia no se aviene a dejar la Chauia mientras España no desaloje La Restinga y Cabo de Agua. Opina nuestro enviado, y esta opinión ya había sido emitida por muchos periódicos españoles, que si ahora no desarrollamos una acción enérgica militar, lo habremos perdido todo en Marruecos $"$ "60.

\footnotetext{
58 “Un Repórter": “Centros comerciales hispano-marroquíes”, El Adelanto, no 7.582, 5 de marzo de 1909, p. 2.

59 “España en África”, El Adelanto, no 7.655, 1 de junio de 1909, p. 2.

60 "Informaciones telegráficas. Lo de Marruecos", El Lábaro, no 3.673, 12 de mayo de 1909, p.3. La misma idea, menos desarrolladas se reiteran en: "Informaciones telegráficas. De Marruecos", El Lábaro, no 3.675, 14 de mayo de 1909, p. 3; y “Informaciones telegráficas. De Marruecos”, El Lábaro, no 3.695, 8 de junio de 1909, p. 3. En esta última, se le concede, además, gran trascendencia a la concentración de la flota francesa y al anuncio de próximas maniobras por parte de buques ingleses. Todas las informaciones telegráficas de este diario son ahora remitidas por la Agencia de Prensa Asociada.
} 
Se estaban justificando los preparativos militares del gobierno: aunque Linares, ministro de Guerra, acababa de negar ante los periodistas que las tropas fuesen a efectuar grandes maniobras en las plazas africanas, resultaba preocupante su esfuerzo por relativizar la importancia del crédito extraordinario de 400.000 pesetas que el ejecutivo acababa de obtener para la gestión de la cuestión marroquí.

En contraste con las informaciones de El Adelanto, El Castellano, que habitualmente era el periódico salmantino más sereno, comentaba el éxito inicial en las gestiones de la legación española porque afirmaba y creía que tanto el Banco de Estado de Marruecos como la agencia del Banco de España en Tánger recibirían las monedas españolas con su pleno valor ${ }^{61}$. Ninguna relación guardaba esta confiada respuesta del rotativo con la de los Centros Hispano-Marroquíes.

La atención que este diario prestó al desarrollo de estas conversaciones diplomáticas fue bastante considerable. Ningún otro periódico salmantino fue tan consciente de todo lo que se estaba jugando España.

Después de esos primeros juicios favorables, sin embargo, el diario de Rodríguez Pinilla tuvo que reconocer la existencia de serias desavenencias entre el Sultán y Merry del Val. El primero demanda la inmediata evacuación de las posiciones de Cabo de Agua y Mar Chica y se negaba a prolongar las conversaciones diplomáticas mientras no se satisficiese este deseo. El Castellano entendía que esta postura era el fruto de la necesidad del Majzén de reforzar su poder interior y se consolaba pensando que, tal vez, se lograse una solución, cuando la análoga embajada marroquí acudiese a Madrid $^{62}$. Al fin y al cabo, el periódico también reconocía que en el interior de Fez existían ciertos sectores sociales que no aprobaban la intransigencia exhibida por Hafid ante España ${ }^{63}$.

El Castellano, excepcionalmente, fue el único periódico local que vinculó el fracaso de la embajada de Merry con el precipitado cierre de las Cortes el 4 de junio: "Maura esta vez quiso huir el combate, cuando ya se percibió el olor a la pólvora"64. El presidente deseaba tener mayor operatividad ante lo que ocurriese en el Rif. Y, efectivamente, el 9 de junio, el Consejo de Estado aprobó un crédito extraordinario con

\footnotetext{
61 "La moneda española en Marruecos", El Castellano, no 1.382, 29 de enero de 1909, p, 1.

62 "Correo de Madrid. La embajada española", El Castellano, no 1.439, 11 de mayo de 1909, p. 1.

63 "Correo de Madrid. Moros amigos", El Castellano, no 1.441, 17 de mayo de 1909, p. 2.

64 "Final rápido", El Castellano, no 1.462, 7 de junio de 1909, p. 1. Lo habitual hubiera sido que las sesiones parlamentarias se prolongasen hasta finales de julio.
} 
el que reforzar la guarnición de Melilla, adquirir material de guerra y preparar tres brigadas mixtas.

Por otro lado, la actitud de la prensa francesa le resultaba a este diario molestísima: los continuos ataques a la gestión del Embajador no constituían más que una vulgar reacción autodefensiva ${ }^{65}$. Cuando regresó a Madrid, Merry del Val tuvo que salir al paso de las voces que le acusaban de haber dirigido algunos comentarios muy ofensivos contra el Sultán ${ }^{66}$. También Allendesalazar, el ministro de Estado, pronunció algunas declaraciones en su favor y anunció la llegada de la embajada marroquí para los primeros días de julio ${ }^{67}$.

El Salmantino, por último, abordó el asunto de la embajada de Merry en fecha muy tardía, el 15 de mayo, habiendo transcurrido dos semanas desde que las negociaciones hispano-marroquíes se interrumpieron. $\mathrm{Su}$ posicionamiento era muy claro: no importaban las razones que alimentan la intransigencia del Sultán:

"Viene en estos días la prensa periódica ocupándose con preferencia a otros asuntos, en el conflicto marroquí (...) Mas sea que no ha habido suerte en elegir el momento oportuno para tratar con Su Majestad Jerifiana, nada tranquilo en sus reales palacios (...) sea, como algunos suponen, el respirarse en aquellas regias moradas un ambiente bastante desfavorable a España; sea, como quieren otros, procedimientos dilatorios (...) el emperador de Marruecos se halla encerrado en no tratar con España asunto alguno sin que antes fuera un hecho tangible la evacuación de Mar Chica y Cabo de Agua, ${ }^{168}$.

Pero sí era preocupante el rechazo de la opinión pública hacia las gestiones del diplomático español ${ }^{69}$. Aunque el fracaso no era absoluto, ya que se había confirmado el envío de una embajada marroquí a Madrid. Ante lo que el redactor concluía:

“¿Qué sucederá? Ocurrencias desgraciadas no muy lejanas deben servir a la prensa de lección para que, en este asunto tan delicado, la opinión no se extravie y abandonando toda populachería, ponerse de parte de quien tiene el deber de resolver negocio tan arduo, ayudando a que se termine con la dignidad y acierto convenientes".

¿A qué "ocurrencias desgraciadas" se estaría refiriendo? Debemos suponer que nuestro redactor estaba recordando los sucesos de Casablanca y la necesidad de lograr el respaldo popular ante una previsible intervención armada.

\footnotetext{
65 "Correo de Madrid. Información tendenciosa", El Castellano, nº 1.445, 21 de mayo de 1909, p. 1.

66 "Correo de Madrid. Las declaraciones de Merry", El Castellano, no 1.463, 8 de junio de 1909, p. 1.

67 "Correo de Madrid. La cuestión marroquí", El Castellano, no 1.465, 11 de junio de 1909, p. 1.

68 "Lo del día", El Salmantino, no 83, 15 de mayo de 1909, p. 1.

${ }^{69}$ Ciertamente, la composición de esta Embajada, popularmente bautizada como "la embajada de los curas", fue muy inadecuada. Merry, además de ser un personaje con no demasiado tacto, amigo personal de Alfonso XIII y hermano del secretario del Estado Vaticano, iba acompañado por un franciscano en calidad de conocedor del país y de intérprete. La prensa francesa se cebó con su figura, plasmando así la tensión que dominaba las relaciones entre Regnault y el propio Merry en Tánger, y buena parte de los rotativos españoles la emularon.
} 
El semanario integrista decidió concederle crédito a las taxativas declaraciones de Merry de Val, negando todas las calumnias que se le atribuían en sus conversaciones con el Sultán. En su lugar, reveló la existencia de un enfrentamiento periodístico entre López Ballesteros, director de El Imparcial e impulsor de los ataques al embajador español, y La Época. Evidentemente, el rotativo local compartía los juicios de este último: Merry era un diplomático de enorme valía; España y Francia seguían actuando de común acuerdo en Marruecos; y Maura se proponía perseverar en su política de paz con los rifeños.

En resumen, ni El Adelanto ni El Lábaro siguieron atentamente el desarrollo de las gestiones de Merry ante el Sultán para lograr una mayor protección de la plaza melillense. El primero, defendemos, por pura desesperación e impotencia para alcanzar en el Imperio una situación equiparable a la de los franceses; y el segundo, porque, de entrada, reclamaba una mayor dureza de nuestra política ante la intransigencia del Sultán. Al contrario, El Castellano sí que permaneció atento a los trabajos de Merry; confió en sus posibilidades, a pesar de las censuras francesas; se esforzó por contemporizar con las peticiones de Hafid; y terminó vinculando el fracaso del diplomático español con el cierre de las Cortes. Frente al creciente alarmismo entre la redacción de Rodríguez Pinilla, El Salmantino, por último, hizo gala de la actitud más confiada entre las sostenidas por la prensa local.

\section{Primeros rumores de guerra. La Nota del gobierno Maura}

Al finalizar mayo, por primera vez, El Adelanto se hacía eco de los rumores sobre la existencia de mucha agitación a favor nuevamente de El Rogui y en contra de la presencia española en los alrededores de Melilla. No obstante, por el momento eran acogidos como si se tratase de grandes exageraciones ${ }^{70}$. Además, se insistía en que éste animaba a los guelayas para que favoreciesen la explotación de las minas ${ }^{71}$.

En efecto, días más tardes, el 8 de junio, el incansable Alfredo Rivera comunicaba, por fin, a la redacción de Núñez Izquierdo que se habían reanudado los trabajos en las minas ${ }^{72}$. El mismo Hafid, mediante una carta, había exhortado a los rifeños para que respetasen la prosecución de los trabajos ${ }^{73}$. Pero inmediatamente corrieron como la pólvora las voces sobre lo peligroso de la situación que se estaba generando. El Adelanto no dudaba en posicionarse junto al gobierno:

\footnotetext{
${ }^{70}$ Alfredo Rivera: “Conferencias telegráficas”, El Adelanto, no 7.645, 20 de mayo de 1909, p. 3.

${ }^{71}$ Alfredo Rivera: “Conferencias telegráficas”, El Adelanto, no 7.649, 25 de mayo de 1909, p. 3.

72 Alfredo Rivera: "Conferencias telegráficas”, El Adelanto, no 7.661, 8 de junio de 1909, p. 3.

${ }^{73}$ Alfredo Rivera: “Conferencias telegráficas”, El Adelanto, no 7.663, 10 de junio de 1909, p. 3.
} 


\begin{abstract}
"Las noticias y rumores que, relacionados con Marruecos, circulan por la prensa y corren de boca en boca y de oído a oído, han causado impresión enorme en el país (...) No creemos, como nuestros colegas de la Corte, que el actual gobierno tiente aventuras ni invente conflictos que le den pretexto para proclamar la guerra santa: confiamos, y a ello nos mueve la serenidad demostrada por Maura en momentos difíciles, en la patriótica prudencia que inspira los actos de los que hoy rigen los destinos de la Nación. Pero aun con tales seguridades, tememos, y creemos hay fundamento para tales temores, que España se vea metida en una nueva aventura, en la que ninguna responsabilidad directa cabría al gobierno ",74.
\end{abstract}

Sin embargo, esta ciega confianza en el gabinete Maura tenía un límite, tal y como a continuación se señalaba: "Ni para defender empresas de minas que pudieron emplear su dinero en veneros españoles más ricos y cercanos; ni para conquistar terrenos colonizables, cuando media España espera ser colonizada, puede ni debe gastarse un sólo céntimo".

El gobierno intentó salir al paso de esas acusaciones que predicaban que la guerra en ciernes era consecuencia de una provocación española, con una nota oficiosa $^{75}$. En la misma, el gabinete aseguraba que en Marruecos no había una autoridad efectiva y la Comandancia se sentía obligada a intervenir por el permanente estado de conflicto entre las cábilas $^{76}$. El Adelanto abundaba, además, en esta idea, seguramente con el propósito de mostrar su apoyo al gabinete maurista, con la inclusión de una noticia de El Telegrama del Rif, en la que se comentaba el estado de división entre los rifeños y las presiones que estaban sufriendo aquellas cábilas que deseaban proseguir trabajando para los españoles ${ }^{77}$.

A mediados de junio, ya había en Melilla 25.000 soldados, mientras se preparaban otras tres brigadas, con casi un millar de hombres, en la península ${ }^{78}$. Rivera, sin embargo, seguía hablando de una situación tranquila ${ }^{79}$. Pero ello entraba en flagrante contradicción con los comentarios que, simultáneamente, se tomaban de la prensa francesa. Ésta ya confesaba que las nuevas “operaciones de policía” que se adivinaban en el horizonte iban a convertirse en algo de mayor calado. No discutían la legalidad de

\footnotetext{
74 “¿Otra aventura?”, El Adelanto, no 7.666, 14 de junio de 1909, p. 1.

${ }^{75}$ Hoy en día, buena parte de la historiografía africanista está escindida entre aquéllos que aún sostienen la tesis de la provocación española, tal y como hiciera entonces Ruiz Albéniz, y los que entienden la Guerra de 1909 como el fruto de la voluntad, por parte del general Marina, de atenerse a los compromisos internacionales, rechazando los tratos con El Rogui.

76 "Lo de Marruecos. Noticia oficiosa", El Adelanto, no 7.666, 14 de junio de 1909, p. 1

77 "Marruecos", El Adelanto, no 7.668, 16 de junio de 1909, p. 1. Para abundar en la política intervencionista auspiciada por El Telegrama del Rif, véase LOBERA, Cándido: El problema rifeño. Melilla: Imprenta de El telegrama del Rif, 1909. Su objetivo era hacer de Melilla "un gran centro comercial que irradie sobre el Rif la luz de la civilización" (p. 39).

78 “España en Marruecos", El Adelanto, no 7.670, 18 de junio de 1909, p. 1.

${ }^{79}$ Alfredo Rivera: “Conferencias telegráficas”, El Adelanto, no 7.670, 18 de junio de 1909, p. 3.
} 
un gesto de castigo ante posibles desmanes de los rifeños, pero insinuaban que los españoles habían excitado los ánimos de las tribus vecinas de Melilla. Además, añadían que las nuevas operaciones no eran nada oportunas cuando se acababa de asentar en el trono un Sultán muy celoso de su independencia ${ }^{80}$.

Si nos fijamos ahora en El Lábaro, debe señalarse que este rotativo también reprodujo la Nota del gobierno ${ }^{81}$. Pero no se molestó en contextualizarla apenas. Atendiendo al juicio de "M. de B.", nada parecía turbar la tranquilidad veraniega de los españoles $^{82}$.

En cuanto a El Castellano, el 4 de mayo de 1909, fue el único diario salmantino que se hizo eco, aunque sin poder llegar a confirmarlo, de la noticia sobre aquella expedición francesa que traspasó la margen izquierda del río Muluya ${ }^{83}$. Tres días después aseguraba que la Norte-Africana había fracasado en su intento de ocupar las minas de Beni-bu-Ifrur, pese a haber distribuido muchos sobornos entre los cabileños:

"Se sigue comentando en Melilla la fracasada ocupación de las minas de Beni-bu-Ifrur por parte de la compañías francesa (...) Los expedicionarios avanzaron escoltados por tropas indígenas, y si la expedición fracasó es porque los cabileños de la Alcazaba de Zeluán se opusieron (...) El plan de la compañía consistía en apoderarse de las minas y reanudar sus trabajos ${ }^{, 84}$.

La alarma empezó a cundir, sobremanera, en esta redacción cuando se confirmó que el gobierno había iniciado algunos preparativos militares y había solicitado un crédito extraordinario (aquél por un valor de 400.000 pesetas al que nos referimos más arriba). Por muchas llamadas a la calma que el gobierno realizase, ésta era insostenible en un contexto marcado por el sonoro fracaso de Merry del Val ante el Sultán, la clausura precipitada de las Cortes y a sabiendas de que se estaban reforzando las guarniciones de Ceuta y Melilla. Demandar tranquilidad cuando el gobierno era el primero que mostraba inquietud constituía una absoluta incoherencia.

Por eso, la nota oficiosa de Maura era, a juicio de este periódico, un clarísimo reconocimiento de que el país se encaminaba hacia la guerra. Resultaba muy significativo el que se hubieran ya ocupado unos terrenos al margen de lo especificado en la Conferencia de Algeciras y parecía como si se deseara emular el proceder francés en Casablanca. Asimismo, en el mismo editorial en el que se comentaba el significado

\footnotetext{
80 "Lo de Marruecos. Cómo piensan los franceses", El Adelanto, no 7.671, 19 de junio de 1909, pp. 1-2.

81 "La cuestión de Marruecos", El Lábaro, no 3.687, 14 de junio de 1909, p. 2.

82 “M. de B.”: "Impresiones de política”, El Lábaro, no 3.708, 26 de junio de 1909, p. 1.

83 "De Melilla", El Castellano, no 1.430, 4 de mayo de 1909, p. 2.

84"Moros y franceses", El Castellano, no 1.433, 7 de mayo de 1909, p. 2.
} 
de esta Nota, se aclaraba, aunque mínimamente y como de pasada, lo ocurrido con la Embajada española: "No dice el gobierno que España ha ocupado en Marruecos unos terrenos cuya evacuación pide el actual Sultán con arreglo al Tratado de Algeciras. El gobierno no dice que a esto se ha contestado con altanería y poca fortuna, diciendo el enviado español que de eso no había nada que tratar, porque no tenía instrucciones". Y terminaba el articulista: “¿Con quién está, pues el gobierno? ¿Es su nota oficiosa lo suficientemente clara para que la opinión pública coopere a sus actos?"85. Parece muy evidente la respuesta: el mensaje de la Nota era tan diáfano, apuntaba tan claramente hacia la batalla, que la opinión pública carecía de pretextos para apoyar las intenciones de Maura.

El Sultán, por otra parte, amenazaba con suspender el viaje de su embajada si los preparativos militares españoles proseguían ${ }^{86}$. Finalmente esto no ocurrió y el 8 de julio salió de Tánger la representación diplomática marroquí, pero la polémica continuó porque Maura rechazó, en un principio, interrumpir sus vacaciones para recibir a los delegados ${ }^{87}$. A juicio de El Castellano, sin embargo, se les debería recibir con todos los honores por una cuestión de simple decoro.

El 9 de julio, el mismo día en el que se desataba la abierta hostilidad en el Rif, la embajada arribaba en Puerto de Cádiz, donde era recibida por Merry del Val ${ }^{88}$. Ante la gravedad de los acontecimientos melillenses, Maura se vio obligado a regresar de Santander a la Corte. Y es por esto que asistió, tras infinidad de chascarrillos, a la recepción de los diplomáticos. Así lo manifestó ante los periodistas. Para él nunca se trató de una cuestión de formas ${ }^{89}$. Por otro lado, la misma seriedad de lo ocurrido, también impulsó a los embajadores marroquíes a anunciar su retorno, cuanto antes, a su país ${ }^{90}$. Su situación se hizo aún más delicada, si cabía, al propagarse el rumor de que el Rogui había entrado en Fez ${ }^{91}$.

\footnotetext{
85 "Lo de Marruecos", El Castellano, no 1.467, 14 de junio de 1909, p. 1. Además del comentario, se incluye aquí la nota oficiosa del gobierno.

86 "Correo de Madrid. Un telegrama", El Castellano, no 1.471, 18 de junio de 1909, p. 1.

87 “Correo de Madrid. La embajada marroquí y Maura", El Castellano, n 1.487, 8 de julio de 1909, p. 1; “Correo de Madrid. ¿Vendrá Maura?", El Castellano, no 1.488, 9 de julio de 1909, p. 1.

88 "Correo de Madrid. La embajada en Cádiz", El Castellano, no 1.488, 9 de julio de 1909, p. 1.

89 "Correo de Madrid. Consejo de Ministros", El Castellano, no 1.490, 12 de julio de 1909, p. 1.

90 "Telegramas", El Castellano, no 1.490, 12 de julio de 1909, p. 2. En efecto, regresaron los diez comisionados el 25 de julio, pero el embajador marroquí permaneció en Madrid, dando a entender la voluntad marroquí de seguir negociando.

91 "Correo de Madrid. El Rogui en Fez", El Castellano, no 1.492, 14 de julio de 1909, p. 1; Gándara: "Conferencias telegráficas", El Castellano, no 1.492, 14 de julio de 1909, p. 2. Pero El Castellano, y en particular Gándara, otorgan muy poca credibilidad a esta noticia, amplificada por Fabra. El día antes se había asegurado que el cabecilla rebelde había fallecido, y ahora se decía que había triunfado en Fez.
} 
Para El Salmantino, en cambio, el temprano cierre de las Cortes estuvo perfectamente justificado porque la gestión de la política exterior era un asunto muy serio y no se podía asumir el riesgo de responder a interpelaciones de grupos políticos carentes de "tacto" "92. También este periódico, por descontado, recogía íntegramente la nota oficiosa del gobierno. Pero, al igual que El Lábaro, no le dedica ningún comentario; la aceptaba sin ningún reparo ${ }^{93}$.

El 26 de junio daba por sentado que la guerra era una realidad inminente: la actitud de los guelayas era muy hostil y estaban convencidos de que el general Marina les iba a atacar para así proteger la explotación de las minas concedidas por El Rogui ${ }^{94}$.

En conclusión, la imagen que nos ofrece la prensa salmantina en estos momentos es la de que el conflicto en el Rif es inevitable y el gobierno español ha de ser respaldado por la opinión pública. Tan sólo El Castellano pareció atemorizado.

\section{La delicada situación de Hafid}

Como de costumbre, la atención de las publicaciones locales hacia las convulsiones internas marroquíes pecó de pobre y caótica. La permanencia de Hafid en el trono fue periódicamente puesta en tela de juicio por El Adelanto, El Lábaro y El Salmantino durante estos meses, ya que éste encontraba enemigos en cada rincón del país. En cambio, El Castellano se mostró un poco más prudente porque consideraba que la "política mora" siempre se desarrollaba por cauces muy lentos. En todo caso, El Raisuni consiguió ser reconocido como gobernador de Arcila e inmediatamente, Anyera se escindió entre detractores y fieles a su autoridad ${ }^{95}$. Por otra parte, se propagaron también rumores sobre el nombramiento en Rabat, como nuevo Sultán, de un tal Muley Kevir $^{96}$. No faltaron, ni tan siquiera, los incidentes en los alrededores de Ceuta, nuevo foco de tensiones entre la autoridad militar española, García Aldave, y el Majzén ${ }^{97}$. Y, para colmo de desgracias, ya se ha señalado, los roguistas empezaron a amenazar con la

\footnotetext{
92 "Noticias. La cuestión de Marruecos", El Salmantino, no 87, 12 de junio de 1909, p. 3.

93 “Lo de Marruecos", El Salmantino, no 88, 19 de junio de 1909, p. 2.

94 “Lo de Marruecos. ¿Peligro inminente?”, El Salmantino, no 89, 26 de junio de 1909, p. 2.

${ }^{95}$ Alfredo Rivera: "Conferencias telegráficas", El Adelanto, no 7.579, 2 de marzo de 1909, p. 3; Alfredo Rivera: "Conferencias telegráficas", El Adelanto, no 7.588, 12 de marzo de 1909, p. 3; Alfredo Rivera: “Conferencias telegráficas", El Adelanto, no 7.659, 5 de junio de 1909, p. 3; "Correo de Madrid. Derrotas de Hafid", El Castellano, no 1.474, 22 de junio de 1909, p. 1; "Correo de Madrid. El Sultán peligra”, El Castellano, $\mathrm{n}^{\mathrm{o}}$ 1.476, 24 de junio de 1909, p. 1.

${ }^{96}$ Alfredo Rivera: "Conferencias telegráficas”, El Adelanto, no 7.676, 25 de junio de 1909, p. 3; Alfredo Rivera: "Conferencias telegráficas", El Adelanto, no 7.677, 26 de junio de 1909, p. 3; "Correo de Madrid. Se confirma el envenenamiento", El Castellano, no 1.478, 26 de junio de 1909, p. 1; "Correo de Madrid. En Wazán y en Fez. La embajada marroquí, El Castellano, no 1.486, 7 de julio de 1909, p. 1.

97 “Asuntos de Marruecos", El Lábaro, n 3.621, 8 de marzo de 1909, p. 3; "Lo de Ceuta”, El Castellano, $\mathrm{n}^{\circ} 1.402,22$ de febrero de 1909 , p. 1.
} 
idea de atacar $\mathrm{Fez}^{98}$. El Salmantino, de hecho, publicó unas elevadísimas cifras sobre el Ejército que se estaba preparando contra Hafid: "Hay quien hace elevar al número de sesenta mil los hombres decididos que forman su Ejército (...) Añaden otros que cuenta con los elementos más prestigiosos del imperio y con los santones de más autoridad"99. Sin embargo, el pretendiente sería prontamente capturado por las tropas del Sultán ${ }^{100}$, trasladado a la capital y torturado hasta la muerte.

Toda esta agitación era la que, se aseguraba, animaba al gobierno español a intervenir mediante el envío de refuerzos a las dos plazas bajo su soberanía. El Adelanto respondía con pesimismo, aceptando los comentarios de la prensa francesa: "Nada provechoso para nosotros debemos esperar de la aventura que se intenta o se quiere provocar" $"$. Muy al contrario, El Salmantino, confesando su sorpresa ante la actitud de Maura y evitando el empleo de la palabra "provocación", terminaba justificando la necesidad de una "guerra preventiva". Esto es lo que escribía un miembro de su redacción el 3 de julio:

"Cuando todos confiábamos que durante el Ministerio Maura, se seguiría una política completamente ajena a la guerra con Marruecos, o al menos que este peligro marroquí no sería, en modo alguno, iniciativa nuestra (...) Tal y tan repentino brío y tales muestras belicosas, por sí poco tranquilizadoras, llevaron la inquietud a los espíritus, repercutiendo por modo lamentable en nuestros valores públicos que suelen ser el termómetro de la política de los gobiernos (...) También los franceses (...) recriminan ahora a España (...) Más si esto se contiene dentro de un saludable aviso, que haga entrar en cuenta al soberano marroquí, sobre las consecuencias que para él, principalmente, pudiera traer un rompimiento violento entre ambas naciones, quizá tuviéramos que alabar estas medidas previsoras del gobierno ${ }^{, 102}$.

\footnotetext{
98 “Servicio especial de El Adelanto. Cosas de Marruecos", El Adelanto, nº 7.681, 1 de julio de 1909, p. 1; Informaciones telegráficas. La situación de Marruecos", El Lábaro, no 3.674, 13 de mayo de 1909, p. 3; "Correo de Madrid. El Rogui a las puertas de Fez", El Castellano, no 1.390, 8 de febrero de 1909, p. 1; "Correo de Madrid. Lo de Marruecos", El Castellano, no 1.474, 22 de junio de 1909, p. 1.

99 “Extranjero. Tánger”, El Salmantino, no 84, 22 de mayo de 1909, p. 3.

${ }^{100}$ Hemos hallado bastantes noticias donde se alternan los rumores sobre su captura y muerte y otras en las que se desmiente lo anterior. Por ejemplo, sobre su captura véase: Alfredo Rivera: "Conferencias telegráficas", El Adelanto, n' 7.722, 19 de agosto de 1909, p. 3. Luego es desmentida en Alfredo Rivera: "Conferencias telegráficas", El Adelanto, n ${ }^{\circ}$ 7.723, 20 de agosto de 1909, p. 3. También consúltese: "Prisión de El Rogui", El Castellano, n ${ }^{\circ}$ 1.441, 3 de abril de 1909, p. 2. En este telegrama se recoge un primer rumor sobre su captura. Y aquí otro: "H. M": "Moros y cristianos", El Castellano, no 1.577, 3 de septiembre de 1909, p. 1; Después se niega su muerte: “¿Vive El Rogui?”, El Castellano, no ${ }^{\circ} 1.633,8$ de noviembre de 1909, p. 1; Por último: "Extranjero", El Salmantino, n 98, 28 de agosto de 1909, p. 1. La muerte de este caudillo fue, por cierto, una de las más dramáticas de la historia del Rif: primero fue colgado de un moro y disparado; seguidamente, Hafid ordenó que lo arrojaran a un león, aunque éste sólo le desgarró un brazo; $\mathrm{y}$, finalmente, fue apuñalado y quemado vivo.

101 "Servicio especial de El Adelanto. Cosas de Marruecos", El Adelanto, n 7.681, 1 de julio de 1909, p. 1.

102 “Lo de Marruecos", El Salmantino, no 90, 3 de julio de 1909, p. 1.
} 
Sin embargo, la mecha de la batalla ya había prendido: el 31 de junio se registró una primera agresión sobre obreros españoles en las cercanías de Melilla ${ }^{103}$. Los incidentes se repitieron al día siguiente y también el 5 de julio, cuando la vía férrea fue obstruida con una barricada hecha de piedras y madera ${ }^{104}$. Cábilas como las de Mazuza y Beni Sicar permanecían fieles a España, pero la fuerza de caídes como El Chaldy y, sobre todo, El Mizzian era incontestable en Beni-bu-Ifrur ${ }^{105}$.

Precisamente, el mismo día que la embajada marroquí tomaba rumbo hacia España, el 8 de julio, El Castellano aludía a la existencia de problemas muy serios en el campo fronterizo de Melilla:

"Comunican de Melilla que la situación del campo fronterizo, al ser ocupado por las tribus guelayas (...) es muy poco satisfactoria. Hoy se han despedido voluntariamente de las obras los obreros moros, alegando, como pretexto, que las compañías explotadoras de las obras donde trabajan, rechazan la forma en que ellos desean cobrar su jornal ${ }^{, 106}$.

Asimismo, se informaba del levantamiento de algunos metros de la vía férrea de la compañía francesa. De hecho, una de sus locomotoras estuvo a punto de descarrilar.

\section{EL IMPACTO DE LA CAMPAÑA DE MELILLA EN SALAMANCA}

La reanudación de los trabajos mineros en las cercanías de Melilla, desde el 11 de junio, había estimulado las llamadas a la guerra santa contra los cristianos. A la agresión rifeña del 9 de julio, el general Marina contestó cubriendo con un destacamento de 2.500 hombres los ochos kilómetros de distancia entre la plaza y el lugar de las obras ${ }^{107}$. Pero ese estiramiento tan precario de la guarnición exigía el envío urgente de refuerzos peninsulares.

En efecto, con la ayuda de las brigadas de Cazadores de Barcelona y del campo de Gibraltar, para el 29 de septiembre todas las alturas alrededor de Melilla ya habían sido ocupadas y Maura se precipitó a dar por concluida oficialmente la campaña. De ahí, el efecto demoledor de la posterior debacle española en el Zoco El Jemis...

Entonces, ya había en África casi 40.000 soldados expedicionarios. Muchos de ellos estaban mal equipados y carecían de una mínima instrucción militar. Por eso fue

\footnotetext{
${ }^{103}$ Alfredo Rivera: "Conferencias telegráficas", El Adelanto, $\mathrm{n}^{\circ}$ 7.681, 1 de julio de 1909, p. 3.

${ }^{104}$ Alfredo Rivera: "Conferencias telegráficas", El Adelanto, no 7.682, 2 de julio de 1909, p. 1; Alfredo Rivera: "Conferencias telegráficas", El Adelanto, no 7. 765, 6 de julio de 1909, p. 3.

${ }^{105}$ Alfredo Rivera: “Conferencias telegráficas", El Adelanto, $\mathrm{n}^{\mathrm{o}} 7.687,8$ de julio de 1909, p. 3.

106 "Correo de Madrid. Los moros cortan la línea férrea. La embajada mora", El Castellano, nº 1.487, 8 de julio de 1909, p. 1.

${ }^{107}$ Para un breve repaso de las operaciones militares llevadas a cabo desde Melilla, véase VILLALOBOS, Federico: Op. Cit., pp. 155-177.
} 
necesario dedicar buena parte del mes de agosto a preparar fortificaciones defensivas y a adiestrar a los combatientes.

Al concluir septiembre, las labores mineras continuaban, sin embargo, en suspenso, el Ejército se hallaba absolutamente desacreditado, la supervivencia del gobierno pendía de un hilo y la opinión europea descubría escandalizada la barbarie de Barcelona ${ }^{108}$. El asesinato de Ferrer, por último, proporcionó un mártir a las izquierdas e hizo renacer todos los tópicos de nuestra vieja Leyenda Negra. Se requirió un año más para la firma de la paz oficial con Marruecos.

Desde una perspectiva estrictamente castrense, la Guerra de 1909 permitió a muchos oficiales revanchistas vengar heridas acumuladas desde 1898. Marruecos despertó, de nuevo, el espíritu imperialista, un estado de enardecimiento bélico, entre buena parte de la oficialidad. Muchos empezaron a contemplarse a sí mismos como los adelantados de la civilización moderna entre la barbarie, además de como los únicos defensores de la identidad nacional; se erigieron como baluarte de los valores regeneradores de la patria; y algunos no pudieron resistir el atractivo exótico del país africano. Aparecían en escena los militares africanistas y se iniciaba, de este modo, una escalada bélica en Marruecos que se prolongaría hasta $1927^{109}$.

Por su parte, la Entente, sobre todo en julio, mantuvo una actitud de silencio, ya que, al fin y al cabo, Francia había hecho lo propio en la Chauía. Sostuvieron, por tanto, la tesis de que España practicaba una simple operación de policía. Sin embargo, Francia seguiría albergando el sueño de hacerse dueño de todo Marruecos. Especialmente, porque imaginó que los liberales, tras la caída de Maura, no desearían aventurarse en nuevos conflictos que alimentasen la revolución. Se equivocaría.

\footnotetext{
${ }^{108}$ Los incidentes de la Semana Trágica de Barcelona son sobradamente conocidos, así que no nos vamos a detener en ellos. Véase ULLMAN, Joan C.: La Semana Trágica. Barcelona: Ariel, 1972. Más reciente es la publicación de VOLTES, Pedro: La Semana Trágica. Madrid: Espasa-Calpe, 1995.

${ }^{109}$ Para profundizar en este asunto véase MAS CHAO, Andrés: La formación de la conciencia africanista en el Ejército español (1909-1926). Madrid: SGE, 1988. Una reflexión extensa y meditada sobre el concepto "africanista", puede encontrarse en MOGA ROMERO, Vicente: La cuestión marroquí en la escritura africanista. Una aproximación a la contribución bibliográfica y editorial española al conocimiento del norte de Marruecos (1859-2006). Melilla: Bellaterra, 2008.
} 


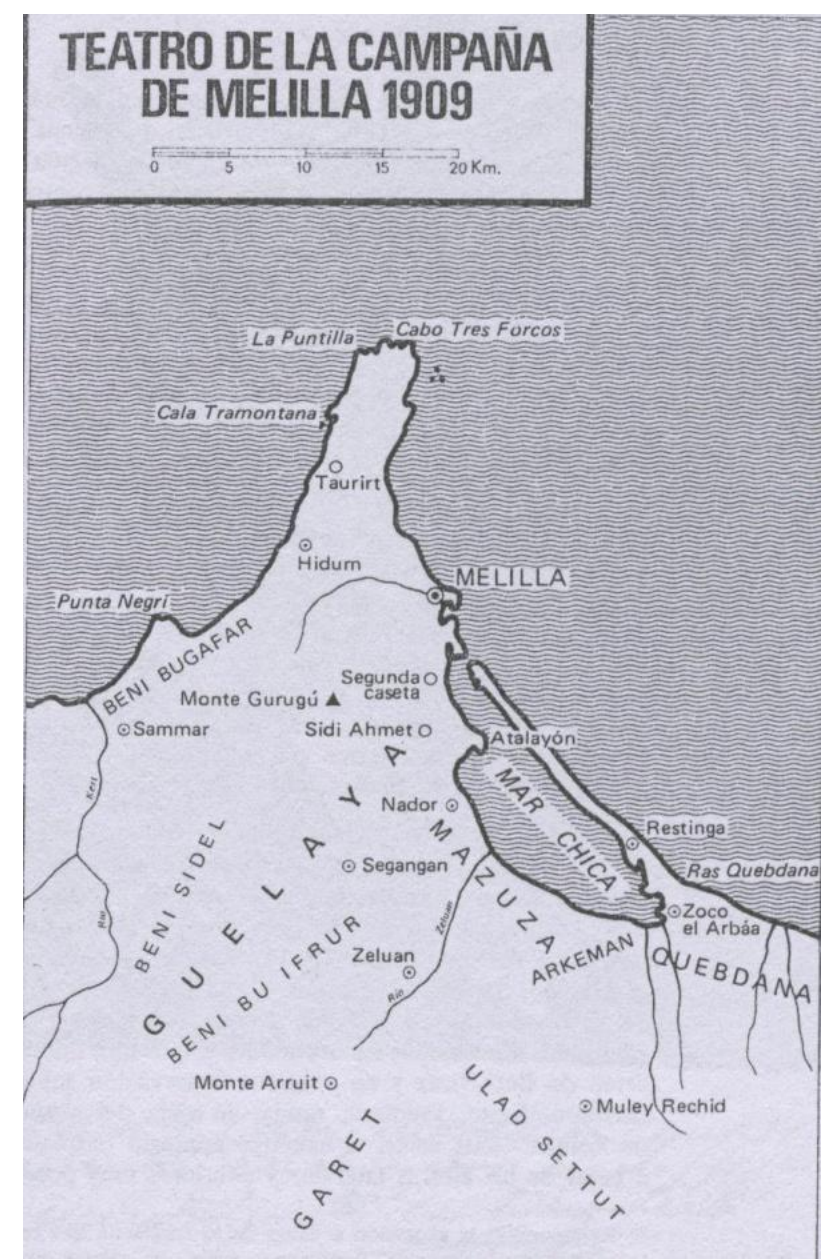

MARTÍNEZ DE CAMPOS, Carlos: España bélica. El siglo XX. Marruecos. Madrid: Aguilar, 1969, p. 89.

\section{El relato periodístico de los primeros enfrentamientos}

$\underline{\text { El combate del } 9 \text { de julio }}$

El Adelanto, en su ejemplar del 10 de julio y a través de Rivera dio cuenta del sangriento combate del día previo. Su relato fue de lo más aséptico. Se explicaba que, muy de mañana, fueron atacados trece obreros empleados en la cimentación de un puente sobre el arroyo de Sidi-Muza. Se especificaba, además, que los atacantes eran de la cábila de Quebdana. Los refuerzos españoles llegaron inmediatamente al escenario del ataque y, además, el gobierno español presentó una fulminante queja ante el embajador marroquí, aprovechando su estancia en Madrid. Pero éste había respondido con notable indiferencia. Al parecer, porque sufría un cólico después de haberse comido doce kilogramos de pasteles durante el trayecto. Así las cosas el general Marina había optado, en respuesta, por tomar el Atalayón ${ }^{110}$.

${ }^{110}$ Alfredo Rivera: “Conferencias telegráficas”, El Adelanto, no 7.689, 10 de julio de 1909, p. 3. 
Aunque los posteriores telegramas del corresponsal madrileño describían como tranquila la situación en las inmediaciones de Melilla, lo cierto es que el embarque de refuerzos era continuo y que la disidencia se propagaba por Beni Said y Beni Sicar ${ }^{111}$. Por otro lado, resultaba difícil confiar en ese supuesto estado de calma cuando en aguas de la Mar Chica se estaba preparando una pequeña flotilla de lanchas armadas para barrer con fuego la llanura de Nador y las barracas de Beni-bu-Ifrur, Arkerman y Zeluán ${ }^{112}$.

El Lábaro, el 10 de julio, se decantó por reproducir el telegrama oficial enviado por La Cierva, ministro de Gobernación, y recibido en el gobierno civil sobre lo ocurrido en Melilla.

"Ministro de la Gobernación a gobernador:

Gobernador militar de Melilla comunica lo siguiente: Esta mañana, a eso de las ocho, cayeron grupos moros sobre trabajadores de las vías férreas, pasando a cuchillo a varios españoles.

Inmediatamente salí con brigada disciplinaria y seis compañías de África, seguidas de cerca por otras de Melilla (...) Convenientemente cañoneada la posición, han sido desalojadas sucesivamente de tres alturas (...) Las bajas, aunque sensibles, no parecen numerosas hasta ahora (...) Carece el hecho de importancia bastante para alarmar a la opinión "113.

Éste mensaje ya había sido colgado, la noche antes, en los tablones publicitarios de la Plaza Mayor de Salamanca. El ministro restaba importancia a la operación con el objeto de no alarmar a la opinión. Por su parte, el diario católico no formulaba ningún comentario al respecto. Permanecía en su estado de absoluto mutismo. Asimismo, también se incluyeron en el mismo número todos los telegramas oficiales en los que se informaba del envío de refuerzos; y unas declaraciones de La Cierva, según las cuales Maura consideraba que los enfrentamientos en las inmediaciones de Melilla, no afectarían a la marcha de las conversaciones con la embajada marroquí, ya que aquello nada tenía que ver con la voluntad del Sultán. Además, los embajadores moros, habían lamentado muchísimo los incidentes violentos ${ }^{114}$.

El día 12 de julio se insertaban nuevos telegramas remitidos por el general Marina al gobierno. La situación se describía, al igual que hiciera El Adelanto, como tranquila; muchos caídes prometían su adhesión a España; y continuaban las obras sobre la línea férrea. Sin embargo, acto seguido se notificaba que se había iniciado el

\footnotetext{
${ }^{111}$ Alfredo Rivera: "Conferencias telegráficas”, El Adelanto, no 7.690, 12 de julio de 1909, p. 3.

112 Alfredo Rivera: “Conferencias telegráficas”, El Adelanto, no 7.691, 13 de julio de 1909, p. 3.

113 "Lo de Melilla", El Lábaro, no 3.719, 10 de julio de 1909, p. 2.

114 "Informaciones telegráficas", El Lábaro, no 3.719, 10 de julio de 1909, p. 3 (Prensa Asociada).
} 
embarque de soldados en Barcelona, sin registrarse incidentes ${ }^{115}$. Y además, un día después, al referirse al Consejo de Ministros celebrado de modo urgente, el periódico reconocía que la embajada marroquí había reclamado, de nuevo, la evacuación del Rif. Pero el gobierno rechazaba unánimemente la propuesta; se aludía también al bombardeo de Beni Said desde el María de Molina ${ }^{116}$.

A pesar de la tremenda seriedad de todas estas breves noticias, de ningún modo, el periódico católico se avenía a reconocer el dramatismo del momento. Al fin y al cabo, los trabajos mineros proseguían; eso sí, no pudo acallar la noticia de que se tuvo que fortificar extraordinariamente la Segunda Caseta para garantizar la seguridad de los empleados ${ }^{117}$.

Asimismo, El Castellano insertó entre sus telegramas del 10 de julio la noticia del serio combate habido con los quebdaníes. Al asesinato de cuatro obreros españoles, el general Marina respondió con el envío de una columna para castigar a los agresores: componían esa columna la brigada de Disciplinarios, seis compañías del batallón de Cazadores de África, otras seis del de Melilla y una compañía de ingenieros. El combate se saldó con aproximadamente treinta bajas españolas, si bien como consuelo, se aseguraba que las pérdidas rifeñas eran bastante más elevadas ${ }^{118}$.

En el mismo ejemplar, en otro bloque de informaciones telegráficas que aparecían acompañadas por la firma del señor Gándara, se detallaban algunos aspectos sobre el escenario de operaciones ${ }^{119}$ : las fuerzas comandadas por Marina habían ocupado El Atalayón y la estación de Nador. Así que, gracias a estas acciones, el territorio español se había ensanchado en un radio de unos quince kilómetros. Además, el diario precisaba que el número de fallecidos españoles ascendía a siete, mientras que los heridos eran veintitrés. También se ponía de relieve el hecho de que los rifeños manejasen armas modernas y que Alfonso XIII siguiese, desde La Granja, muy atentamente el desarrollo de las hostilidades.

En cuanto al urgente Consejo de Ministros, Gándara recogía el 12 de julio estas declaraciones de Maura:

"El señor Maura ha dicho hablando de la cuestión de Marruecos que si nosotros no intervenimos en el Rif, correríamos el peligro de que intervinieran otros. $Y$ ha añadido: la prensa, aunque mostrándose prudente, debe rechazar con energía la

\footnotetext{
115 "Informaciones telegráficas", El Lábaro, no 3.720, 12 de julio de 1909, p. 3 (Prensa Asociada).

116 "Informaciones telegráficas", El Lábaro, no 3.721, 13 de julio de 1909, p. 3 (Prensa Asociada).

117 “Informaciones telegráficas", El Lábaro, no 3.722, 14 de julio de 1909, p. 3 (Prensa Asociada).

118 "Telegramas de la mañana", El Castellano, no 1.489, 10 de julio de 1909, p. 1.

119 Gándara: “Conferencias telegráficas”, El Castellano, no 1.489, 10 de julio de 1909, p. 2.
} 
petición, si llega a formularla la embajada marroquí, de que nuestras tropas evacuen los territorios del Rif ${ }^{, 120}$.

Por su parte, La Cierva se apresuró a desmentir que se fuesen a aprobar nuevos créditos para la financiación de la guerra ${ }^{121}$. En definitiva, como venía siendo habitual desde principios de 1909, a El Castellano correspondía, otra vez, el enfoque más ambicioso, por lo pedagógico, del conflicto.

Para terminar, entre las noticias de última hora de El Salmantino del día 10 de julio igualmente figuraba el relato del duro combate habido en las inmediaciones de Melilla el día anterior: se explicaba que su detonante había sido el asesinato de varios obreros españoles; y que la embajada marroquí se había lamentado grandemente por lo ocurrido. Aunque inmediatamente se enviaron desde la plaza fuerzas españolas de todas las armas, las bajas ascendían hasta la treintena. Pero se consideraba que no era demasiado; y, además, como dato positivo, se había tomado El Atalayón ${ }^{122}$.

Este semanario no tardó en vaticinar que lo que se había iniciado por "causas muy leves" iba a derivar en un conflicto grave. Pero se apresuró también en señalar al culpable: Marruecos era un país de fanáticos, repleto de gentes excesivamente apegadas a la voluntad de los santones.

Por otro lado reconoció, al igual que El Castellano, que la situación de la embajada marroquí se presentaba excesivamente frágil, sobre todo coincidiendo con la propagación de rumores sobre la toma de Fez por El Rogui. Aunque su análisis iba más allá que el del diario de Rodríguez Pinilla:

"He aqui que se anuncia haber caído en poder del Rogui la capital de aquel imperio, ignorándose la suerte que ha corrido su Soberano. ¿Qué giros, pues, tomarán ahora las negociaciones entabladas si ni siquiera hay seguridad de haber persona con quien tratar? Si el Sultán no ejerce ya la soberanía, la embajada ha fracasado por completo, y nuestro gobierno habrá de resolver por sí mismo, mientras aquel pueblo no proclame un Embajador con el cual podamos entendernos ${ }^{, 123}$.

He aquí otro argumento justificador de la guerra: Marruecos, además de estar dominado por fanáticos, carecía de autoridad garante del orden.

A modo de balance, todas las informaciones de la prensa local salmantina siguieron esquemas muy similares: se refirieron al ataque sobre los mineros como casus

\footnotetext{
${ }^{120}$ Gándara: "Conferencias telegráficas", El Castellano, no $1.490,12$ de julio de 1909, p. 2.

121 "Correo de Madrid. Antes del Consejo", El Castellano, no 1.491, 13 de julio de 1909, p. 1; "Correo de Madrid. Disponiendo recursos", El Castellano, no 1.493, 15 de julio de 1909, p. 1. Por fin me entero de que el primer crédito tenía un valor de tres millones y medio.

122 "Última hora", El Salmantino, no 91, 10 de julio de 1909, p. 3.

123 "Lo de Marruecos", El Salmantino, n 92, 17 de julio de 1909, p. 2.
} 
belli, presentaron el escenario geográfico, elogiaron a las tropas españolas e intentaron aportar cifras sobre las bajas producidas. La nota más positiva de la jornada del 9 de julio, destacada por toda la prensa local, fue la toma de El Atalayón. Sin embargo, el general Marina también ocupó las alturas de Sidi Musa, Sidi Ali, Sidi Hamet y la Segunda Caseta. La ubicación de todas ellas era sumamente precaria y pudieron ser fácilmente batidas por las tropas rifeñas. Sin embargo, este hecho no fue documentado por los rotativos salmantinos ${ }^{124}$. En general, predominó la descripción sobre la explicación o la valoración, con algunas salvedades entre las informaciones de El Castellano y también de El Salmantino. La misma tónica se mantuvo en la narración de los combates posteriores.

Los combates del 18 y 20 de julio

El día 18 de julio, la tercera brigada mixta de Cazadores, procedente de Barcelona y recién desembarcada, fue conducida a las posiciones de Sidi Ahmed, Sidi Muza y Sidi Alí, que estaban siendo duramente hostilizadas. La ofensiva rifeña resultó particularmente dura en la primera de las posiciones y la jornada se cerró con 18 muertos y 32 heridos. Aunque, por supuesto, con vistas a evitar la desmoralización del público lector, estos datos no fueron recogidos por la prensa local. Así operaba la autocensura.

El combate del día 20 revistió aún mayor gravedad y mortandad (18 fallecidos y 32 heridos): los rifeños atacaron de nuevo Sidi Muza y sólo pudieron ser dispersados tras catorce horas de combate, bajo el implacable sol africano. De haberse perdido el dominio sobre esta posición, también habría caído la Segunda Caseta, que servía como depósito de las cinco posiciones a las que estamos aludiendo. Todas ellas se habrían quedado aisladas.

A través de las informaciones telegráficas, Rivera continuó relatando el desarrollo de los mismos. Sin embargo, sus envíos siguieron definiéndose por ser los menos jugosos de la prensa salmantina, como si se hallara en un estado de perplejidad. A propósito del primer combate, la respuesta española ante los tiroteos desde el Gurugú fue fulminante, si bien se precisaron refuerzos de Melilla. El número de bajas no se

\footnotetext{
${ }^{124}$ El general Marina, de hecho, recibiría bastantes censuras por estas ocupaciones. Véase CAPITÁN X: Verdades amargas (La campaña de 1909 en el Rif). Madrid: Imprenta artística española, 1910, pp. 30-33. $\mathrm{Y}$, al contrario, un propagandista que incondicionalmente aplaudió sus gestiones fue Peyra Anglada. Consúltese PEYRA ANGLADA, Gustavo: España en el Rif (1909). Barcelona: Pons y Compañía, 1910, p. 154.
} 
pudo precisar ${ }^{125}$. En cuanto al segundo enfrentamiento, en esta ocasión los rifeños atacaron desde el Atalayón, mientras que el Ejército español tuvo que emplear más de cinco horas para dispersarlos ${ }^{126}$. Nada más comentaba el corresponsal madrileño.

El Lábaro, a propósito del escarceo del día 18 de julio, empezaba subrayando que tuvieron que solicitarse refuerzos del Hipódromo debido a su carácter tan reñido. Sin embargo, rápidamente elogiaba la eficacia de la artillería española. Por último, en el mismo bloque de noticias, se publicaba que, a juzgar por el cariz que tomaban los acontecimientos, el gobierno se planteaba el envío de la brigada del general Pintos ${ }^{127}$.

El día 19 de julio, el diario católico aportaba nuevos detalles sobre la enconada batalla. En los círculos militares, se consideraba muy urgente el envío de esa brigada. Todos, además, mostraban su asombro ante el descomunal arrojo de los rifeños, que llegaban a atacar con palos y piedras ${ }^{128}$.

El combate del día 20 también fue descrito en la sección telegráfica, sin mayor comentario $^{129}$. Mientras, los discursos ministeriales reclamando calma sonaban, de día en día, más huecos ${ }^{130}$.

El Castellano, al referirse al enfrentamiento del día 18 de julio, insistía en que el general Marina había solicitado refuerzos por prudencia, pero no por auténticas razones de necesidad. Mientras que el número de bajas españolas era desconocido, se aseguraba que los rifeños sí habían sufrido muchas ${ }^{131}$. Acerca del segundo combate, este periódico amplificaba algunas declaraciones del general Marina: los rifeños combatían con enorme furia, pero los soldados peninsulares eran muy tenaces y hacían gala de "un heroísmo difícil de ponderar" ${ }^{\prime 132}$.

\footnotetext{
${ }^{125}$ Alfredo Rivera: “Conferencias telegráficas", El Adelanto, no 7.695, 19 de julio de 1909, p. 3.

${ }^{126}$ Alfredo Rivera: "Conferencias telegráficas", El Adelanto, no 7.967, 21 de julio de 1909, p. 3.

127 "Informaciones telegráficas", El Lábaro, no 3.726, 19 de julio de 1909, p. 3 (Prensa Asociada).

128 "Informaciones telegráficas", El Lábaro, no 3.727, 20 de julio de 1909, p. 3 (Prensa Asociada). También se mencionan algunos incidentes habidos en Reus en el momento del embarque. El día 27 se publicará la nota oficial sobre la declaración del Estado de Guerra en Barcelona. En "El Estado de Guerra en Barcelona", El Lábaro, n 3.733, 27 de julio de 1909, p. 2.

Más detalles sobre el combate del día 18 se conocen a través de un relato tomado de $L a$ Correspondencia de España, reproducido el 24 de julio. Consúltese: "Interesantísimos informes de la guerra", El Lábaro, n 3.731, 24 de julio de 1909, p. 2. En la misma columna, se reconoce que muchas de las pérdidas materiales en la batalla no son responsabilidad del enemigo, sino de las tropas indígenas aliadas.

129 “Conferencias telegráficas", El Lábaro, no 3.728, 21 de julio de 1909, p. 3.

130 "Telegrama oficial”, El Lábaro, no 3.729, 22 de julio de 1909, pp. 2-3. En este telegrama oficial se niegan los incidentes en Cataluña y se afirma que impera la calma en los alrededores de Melilla.

131 "Correo de Madrid. Palabras del Rey. Declaraciones de Maura. Informes oficiales", El Castellano, $\mathrm{n}^{\circ}$ $1.495,17$ de julio de 1909 , p. 1 .

132 "Correo de Madrid. Habla Marina”, El Castellano, no 1.500, 23 de julio de 1909 p. 1.
} 
La censura estaba empezando a funcionar. La Cierva la implantó el 21 de julio de 1909.

En último lugar, El Salmantino, debido a su carácter semanal, comentó muy parcamente sólo el combate del día 20 y lo hizo algunos días más tarde. Se limitó a contabilizar las bajas marroquíes de aquel día: 118 muertos y aproximadamente 250 heridos ${ }^{133}$.

\section{El combate del 23 de julio}

El 23 de julio se repitieron los ataques rifeños sobre el campo atrincherado cercano a Melilla: la Posada del Cabo Moreno, los Lavaderos y el Hipódromo. El Adelanto dedicó íntegramente su sección telegráfica del día 24 de julio al relato de los mismos. La información estaba plagada de notas de heroísmo y también se incluía un telegrama remitido por el general Marina a Linares, con los mismos comentarios elogiosos hacia los combatientes peninsulares ${ }^{134}$.

El Lábaro, mientras tanto, no desperdiciaba la ocasión para promocionarse:

"A las siete de la mañana hemos expuesto en nuestro encerado del Novelty, el primer telegrama recibido en Salamanca refiriéndose el último combate (...) Ante nuestro encerado ha habido estacionado, durante toda la mañana, grupo numeroso de lectores, demostradores del interés con que son seguidas todas las incidencias de la lucha en el Rif. El celo y actividad desplegados por nuestra Agencia telegráfica son grandes, pues los despachos de El Lábaro, desde la primera acción de Melilla hasta la de ayer, han sido los primeros en traer a Salamanca noticias de los graves sucesos" $" 135$.

Dos días después presumía de que Mariano Urbano, redactor jefe de la agencia de Prensa Asociada, había sido enviado como corresponsal a Melilla:

"Teniendo nuestra agencia noticias directas de Melilla, nuestra información se hará en condiciones excelentes de prontitud y veracidad (...) Por lo demás, El Lábaro, obedeciendo órdenes (...) evitará el empleo de grandes titulares y cuantos epígrafes no correspondan con exactitud al texto de los telegramas oficiales. Esperando, no obstante, dentro de los límites impuestos por la censura dar a nuestros lectores la más amplia información que respecto a tan importantes sucesos ha de tener el público de Salamanca ${ }^{, 136}$.

En la sección de informaciones telegráficas se aseguraba que lo que había empezado como una escaramuza los días 20 y 21 ya se había convertido en una lucha muy violenta y con sensibles pérdidas para los españoles; también se describía ampliamente el fallecimiento del coronel Álvarez Cabrera; se insistía en que la moral de

\footnotetext{
133 "La campaña de Melilla”, El Salmantino, no 93, 24 de julio de 1909, p. 3.

${ }^{134}$ Alfredo Rivera: "Conferencias telegráficas. La campaña de Melilla", El Adelanto, no 7.700, 24 de julio de 1909 , p. 3.

135 "Los telegramas de El Lábaro", El Lábaro, no 3.731, 24 de julio de 1909, p. 2.

136 “Las noticias de la guerra", El Lábaro, no 3.732, 26 de julio de 1909, p. 2.
} 
las tropas peninsulares parecía excelente y se esperaba, de una momento a otro, la llegada de la brigada del general Pintos ${ }^{137}$.

Atendiendo a El Castellano, el combate fue terrible, con muchos cañoneos y disparos de la artillería, porque las fuerzas rifeñas continuamente se recomponían. A pesar de ello, pudieron ser dispersadas ${ }^{138}$. Su discurso era el más pesimista de los contenidos en la prensa local, si bien la censura entorpecía la difusión de lo ocurrido:

"Noticias que llegan a nosotros al cerrar esta edición de la mañana, por conductos que no ha sabido ni podido tapar el ministro de la Gobernación pese a sus empeños titánicos (...) nos permiten asegurar que la situación de Melilla se agrava por momentos (...) Según nuestros informes, el último ataque de los rifeños ha sido tan formidable, que ha logrado interrumpir las comunicaciones entre la plaza y las posiciones avanzadas de nuestro Ejército (...) La ansiedad que este hecho ha producido en Melilla es grande, pues se teme que aislados los destacamentos puedan ser de nuevo atacados con más dureza "139.

En otro bloque de noticias aparecía una estimación de las bajas, entre las que, por descontado, se aludía al fallecimiento del coronel Álvarez Cabrera ${ }^{140}$. El relato más amplio de este combate fue, sin embargo, el del día 26; en él se le dedicaban palabras muy elogiosas al teniente coronel Ibáñez Marín, también fallecido, gran experto en historia militar y que estaba al mando del batallón de Cazadores de Figueras ${ }^{141}$.

El Salmantino también aludió a la batalla del 23 de julio, pero sin demasiada amplitud, únicamente remarcando el valor y la heroicidad mostrados por el Ejército español este día ${ }^{142}$. Quizás, porque la redacción no quería magnificar aquellos combates en los que las tropas españolas encontraban, en realidad, una muy tenaz resistencia. Por otra parte, con certeza, su carácter semanal le obligaba a cuidar mucho cómo distribuía su tan limitado espacio. Por esta razón, en este semanario abundaban las columnas de opinión, sobre todo cuando la información en cuestión se consideraba satisfactoria, y no

\footnotetext{
137 “Informaciones telegráficas. La Guerra en el Rif”, El Lábaro, no 3.731, 24 de julio de 1909, p. 3 (Prensa Asociada). Los combates, con menor intensidad, prosiguen al día siguiente. Se siguen aportando detalles sobre su desarrollo; se informa del ascenso de Marina a teniente general; y de la aprobación de un nuevo crédito extraordinario para la guerra. Véase: “Informaciones telegráficas. La Guerra en el Rif”, El Lábaro, $\mathrm{n}^{\circ}$ 3.732, 26 de julio de 1909, p. 3 (Prensa Asociada).

138 “La Guerra en el Rif”, El Castellano, no 1.501, 24 de julio de 1909, p. 2.

139 “QQué pasa en Melilla? Situación grave”, El Castellano, no 1.501, 24 de julio de 1909, p. 2

140 “La Guerra en el Rif”, El Castellano, no 1.501, 24 de julio de 1909, p. 2.

141 "Correo de Madrid. Ibáñez Marín”, El Castellano, n 1.502, 26 de julio de 1909, p. 1; "Correo de Madrid. La Guerra en el Rif”, El Castellano, no 1.503, 27 de julio de 1909, p. 1. En este ejemplar se reproducen varios de los telegramas remitidos por el general Marina a Linares, ministro de la Guerra. También se recoge la incertidumbre con que el Sultán está viviendo los sucesos de Melilla y su búsqueda desesperada de un préstamo -prefiere el dinero alemán, y de hecho está negociando con Mannesmann-, pues teme que el gobierno de París exija, a cambio, el control absoluto sobre las aduanas y una intervención financiera aún mayor- para combatir al pretendiente Muley Kevir.

142 “La campaña de Melilla”, El Salmantino, n 93, 24 de julio de 1909, p. 3.
} 
las meras descripciones, tanto más escuetas cuando lo que se transmitía no era del agrado de la redacción. Se comprobará prontamente.

El combate del 27 de julio: el Desastre en el Barranco del Lobo

"Noticias particulares aseguran Melilla combate brigada Pintos. Añaden bajas". He aquí el primer telegrama llegado a Salamanca, el 28 de julio de 1909, sobre el combate en el celebérrimo Barranco del Lobo. Alfredo Rivera lo envió a las dos menos cuarto de la tarde y llegó a esta capital una hora después. Impreciso y, sobre todo, parco: debido a los rigores de la censura, las diez y ocho palabras originales del corresponsal madrileño quedaron reducidas a la mitad: nueve palabras que cambiarían la vida de los salmantinos. Porque la noticia más breve era, por supuesto, la más alarmante.

Varias horas más tarde, siendo ya casi media noche, la ciudad recibía un nuevo telegrama de Rivera, informando del fallecimiento de Pintos y de otros dos centenares de muertes:

"Ayer las cábilas marroquíes destrozaron la línea férrea que conduce a las minas francesas. De la plaza salió un convoy de agua escoltado por fuerzas mandadas por los coroneles Fernández, Cuervo y Azo, y destinado el convoy a aprovisionar las tropas españolas que guarnecen nuestras avanzadas. La brigada Pintos debía apoderarse de algunas posiciones que dominaban el camino que el convoy había de recorrer. Cumplió perfectamente su cometido, pero teniendo que librar un combate tenaz, en el que fueron muertos el general Pintos y los tenientes coroneles señores Ortega y Palacios, que mandaban respectivamente, los batallones de cazadores de Arapiles y las Navas. Nuestras bajas comprobadas de oficiales y tropa, entre muertos y heridos, pasan de doscientas. Las de moros son mucho mayores ${ }^{, 143}$.

De modo excepcional, El Adelanto, en su ejemplar del 29 de julio, incluyó estos cables telegráficos en su primera plana. En el mismo número, aprovechándose de informaciones de La Época, la redacción reconocía que el contrabando había permitido a los rifeños estar convenientemente armados y que si, además, estaban bien entrenados, era porque varios oficiales europeos habían trabajado tanto con las tropas de El Rogui como en la instrucción del Ejército de Abd-el-Aziz ${ }^{144}$. En la tercera página, Rivera, de nuevo, incluía un primer relato, evidentemente con el visto bueno de la censura, sobre el fallecimiento de Pintos:

"El general Pintos, apeado del caballo y dando muestras de una serenidad pasmosa y de un valor extraordinario, dirigía el combate en medio de una torrencial lluvia de

\footnotetext{
143 "Los últimos combates. Nuestros telegramas y la censura", El Adelanto, no 7.704. 29 de julio de 1909, p. 1 .

144 “La campaña de África”, El Adelanto, n 7.704, 29 de julio de 1909, p. 2. Días después, se destacaría el papel de los renegados del Disciplinario de Melilla como instructores y, sobre todo, médicos. Véase: “La campaña de África”, El Adelanto, no 7.720, 17 de agosto de 1909, p. 2.
} 
balas enemigas (...) El movimiento envolvente que el general Pintos pensó realizar era excelente. Cuando iba a dar órdenes de avanzar y llegar al Gurugú, para tomar, en combate decisivo, aquellas posiciones enemigas, una bala, entrándole por la órbita de un ojo, le hizo caer al suelo muerto instantáneamente. De no morir, Pintos, con su brillante táctica, hubiera conseguido tomar las alturas del Gurugú, pues los soldados le seguían con sin igual entusiasmo, vitoreándole sin cesar. Hubo en el combate momentos en que nuestras tropas realizaron supremos esfuerzos en el avance ${ }^{, 145}$.

Y el 31 de julio se publicaba una nueva narración, muchísimo más extensa:

"Las Navas y Llerena estaban triturados (...) Entonces avanzó Pintos con dos batallones. Llevaba, según decían los suyos emocionados, llorosos, llenos de estupor y de rabia, de desaliento y de coraje, llevaba un grito digno de Prim. Gritaba a los suyos, enardecía a los oficiales y electrizaba a los soldados (...) El fuego enemigo se hizo más nutrido y más numeroso al ver que los cazadores, con la vieja tenacidad española, iban a hacer suya la posición. Pintos cayó con un balazo en la cabeza,"146.

Nadie diría que el combate había sido más calamitoso que ningún otro. El honor militar quedaba a salvo de cualquier censura.

El Lábaro, por otra parte, sacando ventaja del hecho de ser un periódico vespertino, pudo incluir las informaciones sobre lo sucedido en Melilla el día 28 de julio. Pero minimizó, de forma insólita, toda su gravedad. El protagonismo de su sección telegráfica recayó en los sucesos de Barcelona. Los datos que manejaba sobre los asuntos marroquíes no eran los de los partes oficiales, sino los proporcionados por la Agencia de Prensa Asociada:

"Melilla, 28. Los moros han cortado la línea del ferrocarril francés, con objeto de impedir el paso de un convoy que se destinaba a las posiciones avanzadas.

Para proteger dicho convoy se organizaron dos columnas, que escoltaban mientras otras fuerzas se apoderaban de algunas alturas cercanas a la falda del Gurugú, desde la que los moros atacan (...) Secundaron la acción de las tropas las baterías del Hipódromo con su incesante cañoneo.

Por su parte, el Pinzón y el Numancia ametrallaron a los moros desde el mar "147.

Ni más ni menos. Ciertamente, se desconocía el fallecimiento de Pintos, pero sí se sabía que su situación era muy comprometida. Sin embargo, nada se comentaba al respecto.

El Castellano, en cambio, también en su ejemplar del 28 de julio, incluía únicamente los telegramas oficiales. Aún así, no logró reprimirse a la hora de tildarlos

\footnotetext{
${ }^{145}$ Alfredo Rivera: "Conferencias telegráficas", El Adelanto, no 7.704, 29 de julio de 1909, p. 3.

146 "La campaña de África", El Adelanto, no 7.706, 31 de julio de 1909, p. 2. Y un mes después, El Adelanto reproduce la carta de un cabo de las Navas en la que se describe otra vez el combate, pero ahora desde la vivencia personal: "La campaña de África", El Adelanto, no 7.730, 28 de agosto de 1909, p. 2. Las descripciones más macabras de la degollina hubieron de esperar hasta el 5 de octubre, cuando se reprodujo un fragmento de un periódico malagueño en el que se abordaba el asunto: "La campaña de África", El Adelanto, no 7.762, 5 de octubre de 1909, p.2.

147 "Informaciones telegráficas", El Lábaro, no 3.734, 28 de julio de 1909, p. 3 (Prensa Asociada).
} 
de "lacónicos" "148 . Un día más tarde, en este diario proseguía el goteo de partes oficiales. Se relataba entonces la "gloriosa muerte" del general Pintos y se elevaba la cifra de bajas a 500 individuos $^{149}$.

Finalmente, terminemos refiriéndonos al semanario integrista: El Salmantino ofreció su primera información sobre lo sucedido en el Barranco del Lobo en fecha muy tardía: el 31 de julio ${ }^{150}$. Y no se trataba de un editorial, sino que se limitaba a la reproducción de los ya conocidos telegramas oficiales:

"Según el señor La Cierva, en Melilla ha habido otro combate importante el día 27; fue rudísima la lucha; tuvimos bastantes bajas (...) El general Pintos ha muerto gloriosamente al frente de su brigada y al frente de sus batallones también han muerto los jefes de Arapiles y las Navas (...) Las bajas entre muertos y heridos, de oficiales y tropa, comprobadas hasta ahora, pasan de 200 (...) Las noticias de Melilla, confirmadas por despachos oficiales han producido honda sensación (...) La retirada de las tropas fue una operación brillantísimas. Fueron retirándose por escalones sin dejar de hacer fuego y causando muchas bajas al enemigo "151.

Pero en la guerra rifeña, como se verá, las retiradas, en contadísimas ocasiones, fueron una medida acertada. Solían traducirse en una elevación de la moral enemiga. Algunos años después, en efecto, así lo explicaría Francisco Franco: “El moro aprovecha los momentos de la retirada para echarse encima, ganar la cresta y sorprender con su fuego a la tropa en los momentos del repliegue. En las retiradas, en que una fuerza se para a hacer un escalón, recorriendo el espacio que le dicen los reglamentos, si el enemigo ha ganado la cresta, aumentará muchísimo el número de bajas, y si la moral de las tropas no es excelente y la zona está muy enfilada, se acaba abandonando a los heridos y sembrando en ella el germen del chaqueteo"152.

La parquedad, en suma, fue la nota dominante entre las informaciones publicadas por la prensa local salmantina. Se explicaba por la imposición de la censura,

\footnotetext{
${ }^{148}$ El Castellano, $\mathrm{n}^{\mathrm{o}} 1.504,28$ de julio de 1909, p. 1.

${ }^{149}$ El Castellano, $\mathrm{n}^{\circ} 1.505,29$ de julio de 1909, p. 1.

${ }^{150} \mathrm{Y}$ el 14 de agosto encontramos publicada una cancioncilla de ánimo para esos soldados que combatían el día 27 de julio. Véase: Nilo Fabra: "El combate del día 27”, El Salmantino, n 96, 14 de agosto de 1909 , p. 1.

151 "Los sucesos de Melilla y Barcelona", El Salmantino, no 94, 31 de julio de 1909, p. 2.

${ }^{152}$ FRANCO, Francisco: Papeles de la guerra de Marruecos. Madrid: Fundación Nacional Francisco Franco, 1986, p. 177. Idéntica observación sobre la inconveniencia de los repliegues encontramos en el siguiente informe del Estado Mayor Central del Ejército: Enseñanzas de la campaña del Rif en 1909. Madrid: Talleres del Depósito de la Guerra, 1911, p. 31. Además, en el mismo documento se subrayaba lo erróneo de la movilización de los reservistas (p. 38) y la urgente necesidad de introducir cambios en la instrucción y educación patriótica del soldado (pp. 71-77). Otro publicista que sostenía criterios muy similares fue BANÚS Y COMAS, Carlos: Reflexiones acerca de las enseñanzas de la campaña del Rif en 1909. Madrid: Imprenta del Memorial de ingenieros del Ejército, 1912, p. 19.
} 
por supuesto; pero también, más si cabía, por la práctica de la autocensura en circunstancias excepcionalmente dramáticas.

\section{La prensa salmantina y la censura}

El 24 de julio, el escritor Benigno Pallol, oculto tras el pseudónimo de “Argos”, recogía la prohibición de La Cierva, ministro de Gobernación, de publicar informaciones telefónicas o telegráficas sobre la contienda, a no ser que se tratase de noticias oficiales. El redactor contestaba con indignación ante semejante disposición y confesaba que "todos los partidos de oposición, incluyendo a los solidarios barceloneses, reclaman la apertura de las Cortes. Maura rehúye mostrarse a plena luz y entre taquígrafos (...) Madrid y toda España, moralmente yacen, esta es la palabra justa, yacen en las sombras"153. Y algunos días después, también algún otro redactor de El Adelanto, tildada la medida de "calomardesca"154.

Sin embargo, el periodista Fernando Felipe, quien firmaba normalmente bajo el seudónimo de "Juan de Salamanca" o "Sir-ve”, sí que apoyó la decisión de La Cierva. Y no dejaba de constituir algo absolutamente inesperado: el pionero del socialismo salmantino defendiendo el proceder de Maura y La Cierva ante la prensa. Lamentablemente, carecemos de un estudio biográfico sobre este personaje, pero parece indiscutible, a tenor de los editoriales que escribió en 1909, su distanciamiento del pensamiento obrero.

A su juicio, la censura estaba del todo justificada porque la guerra "está muy distante y nadie sabe, con seguridad, qué es lo que allí pasa. La distancia agranda o achica lo ocurrido de un modo extraño" $" 155$.

Ocurrido el descalabro en el Barranco del Lobo, el endurecimiento de la censura fue la primera y fulminante reacción del gobierno presidido por Antonio Maura. La misma brutalidad del combate animó al diario de Núñez Izquierdo, El Adelanto, a contemporizar más abiertamente con el empleo de la medida. Por tanto, esta dicotomía de pareceres, ejemplificada en los editoriales de "Argos" y "Juan de Salamanca", desapareció:

"Somos de los que sacrificamos los éxitos periodísticos en aras de los intereses patrios, y comprendemos que los gobernantes tienen que cumplir deberes penosos en momentos determinados y que acaso ayer estuviera disculpada la detención de nuestro telegrama. Pero en la generalidad de los casos nos parece que bastarán dos censuras, las de

\footnotetext{
153 “Argos": "Madrid al día”, El Adelanto, no 7.700, 24 de julio de 1909, p. 2.

154 "Aviso al público", El Adelanto, no 7.701, 26 de julio de 1909, p. 1.

155 "Juan de Salamanca": "Vida local. Muy bien, señor alcalde", El Adelanto, no 7.702, 27 de julio de 1909. P. 1.
} 
Melilla y Madrid, para evitar a este gobierno civil un trabajo ímprobo e inútil. Lo que sí rogamos encarecidamente al señor gobernador, es que, cuando las circunstancias hagan que, a juicio suyo, no deban circularse los telegramas de prensa, adopte las oportunas disposiciones para que las noticias contenidas en los mismos no trasciendan al público por indiscreciones lamentables (...) Por orden del señor gobernador civil queda prohibido a los periódicos fijar carteles con noticias o telegramas, en los encerados de la Plaza Mayor. Han sido suspendidas las garantías constitucionales en toda España $" 156$.

Si bien buena parte de la prensa madrileña se sentía muy molesta por la dureza de las disposiciones de La Cierva, y más aún por la interrupción del cable telegráfico de Melilla durante todo el 28 de julio, El Adelanto creía la versión oficial: se produjo un error en la oficina melillense de telégrafos y, en todo caso, "esa censura, ejercida por la autoridad militar, es elemental, tratándose de noticias referentes a las operaciones en campaña"157.

“Argos”, más poético, se desdecía de sus escritos previos y comentaba: "Los árboles jóvenes, flexibles, se inclinan al paso del huracán, y así salvan su existencia; los más arraigados y fuertes oponen su poderoso tronco y sus exuberantes ramas al viento, y el viento los troncha, los desarraiga, los tumba convertidos en leña. Seamos arbolillos flexibles mientras pasa el ciclón" ${ }^{\prime 158}$.

Más tempranamente, el 22 de julio de 1909, El Lábaro, cambiando ya de rotativo, recogía una amenaza de La Cierva: la censura, instaurada desde el momento en el que se registraron los primeros incidentes en Barcelona, se endurecería si los periódicos persistían en no respetar la información oficial remitida desde Melilla ${ }^{159}$.

Este diario católico, sobre todo después del fatídico combate del 27 de julio, también justificó el empleo de la medida represora a través de la pluma de "Munio". El convulso momento histórico lo exigía y a la prensa le tocaba resignarse para mostrar su patriotismo:

"La censura es una medida de prudencia en todo conflicto grave; lo es más en tiempo de guerra.

La censura radicalísima impuesta a la prensa en España, produce algarabía porque es desusado en este país el que se pueda hacer sentir todo el rigor de un sacrificio costoso. $Y$ si hay que sacrificar, no ya los céntimos partidos al medio, que puede dar a las empresas el afán de noticias por un público que tiene muy despierta esta ansiedad, sino lo que es legítimo ideal de prensa, el aventajar en informaciones, el amor propio de la

\footnotetext{
156 "Los últimos combates. Nuestros telegramas y la censura", El Adelanto, nº 7.704, 29 de julio de 1909, p. 1.

157 "La campaña de África", El Adelanto, no 7.704, 29 de julio de 1909, p. 2.

158 "Argos": "Madrid al día", El Adelanto, no 7.705, 30 de julio de 1909, p. 2.

159 "Telegrama oficial", El Lábaro, n 3.729, 22 de julio de 1909, pp. 2-3.
} 
pericia y de la actividad, hagamos esta prueba de abnegación por el bien de España ${ }^{, 160}$.

En el mismo ejemplar en el que se incluía este editorial, el día 29 de julio, se publicaba también el Real Decreto por el cual se suspendían todas las garantías constitucionales en España ${ }^{161}$. No obstante, la actitud de este diario fue, puntualmente, contradictoria, ya que al gobernador civil le reprochó haber tenido durante muchas horas uno de sus telegramas sobre la muerte de Pintos:

"El señor gobernador civil, en atención a miras de prudencia y de alto interés, que nosotros somos los primeros en acatar y aplaudir, tuvo retenidos hasta después de las doce de la noche de ayer, nuestra segunda conferencia telegráfica y un despacho urgente en que se nos daba cuenta del combate en que pereció el general Pintos (...) Nos dolemos de que ayer no se confiase en nuestra discreción, retrasándosenos tanto la entrega de nuestras noticias (...) Ahora más que nunca antepondremos nuestros deberes de patriotas a nuestra misión de periodistas" ${ }^{, 62}$.

En suma ¿demandaba un trato de favor con la promesa de no hacer pública la información que le llegase a la redacción? ¿O estaba, quizás, disculpándose porque el rotativo, el día previo, no había prestado a la derrota en el Barranco del Lobo el protagonismo mediático que merecía? Nos decantamos por la segunda hipótesis: El Lábaro se resistía a admitir el fracaso, y con ser ciertas las cortapisas del gobernador, los rumores sobre un posible infortunio entre las tropas de Pintos estaban presentes en las calles salmantinas desde que El Adelanto hiciera público en su tablón el primer cable de Rivera, aquél de nueve palabras. Únicamente en su tercera plana del día 29, entre las informaciones telegráficas remitidas por la Prensa Asociada, se relataba con bastante detalle, por fin, el fallecimiento del general.

Al día siguiente, "Crotontilo", curiosamente otro de los pioneros del socialismo en la provincia, insistía también en lo acertado de las disposiciones de La Cierva:

"Claro está que de esta humildísima opinión mía, no participará la mayoría de los españoles, que desea la llegada del periódico para leer con avidez los emocionantes sucesos que la prensa le hubiera ofrecido de no impedirlo el ministro.

A mí me parecería muy bien la protesta de los patriotas, que quieren saber hora por hora, minuto por minuto, lo que ocurre en Melilla, si realmente su ansia por saber estuviera fundamentada en un sentimiento verdaderamente patriótico, noble, elevado (...) ¡Privarnos del comentario estúpido de café (...) eso es una atrocidad, que está pidiendo venganza!

Lo malo es que hay muchísimos españoles, tan españoles como los otros, los que gritan y se quedan afónicos, de garganta y de alma, lo malo es, digo, que somos muchos los que pensamos que ante problemas tan arduos y serios como el actual, lo

\footnotetext{
160 "Munio": "De cada día. La censura", El Lábaro, no 3.735, 29 de julio de 1909, p. 2.

161 "Suspensión de las garantías constitucionales en toda España", El Lábaro, no 3.735, 29 de julio de 1909 , p. 2.

162 “Patriotas primero. Periodismo después", El Lábaro, n 3.735, 29 de julio de 1909, p. 3.
} 
verdaderamente patriótico y beneficioso para España, es rendir el juicio propio, abdicar la voluntad, anularse, en suma, para sellar los labios ${ }^{\text {,163. }}$.

Y todavía un mes después, a punto ya de emprenderse el avance español, "Munio" volvía a la carga mostrando su absoluta aprobación de la censura y aconsejando paciencia. Probablemente, porque la atmósfera que se respiraba era cada día más tensa:

"Es muy digno de compasión el público que lee periódicos. El que llevado de un máximo deseo de saber lo que ocurre allá en Melilla entre españoles y moros, se eche a la vista y lea telegramas y telefonemas, artículos, relatos, reseñas, correspondencias directas, informaciones oficiales y particulares, acabará por una excitabilidad horrible o por una anestesia insensible.

Vuelvo a decir que hay una tendencia salvadora, vigilante, por el estado de equilibrio de la mentalidad de los ciudadanos, en la afición del señor ministro de la Gobernación a la censura (...) Al día siguiente de la alocución del general Marina, hubo telegramas del avance, ecos del tiroteo. Y las gentes, ansiando, sugestionadas por ese hilito, constante despertador de la curiosidad, las noticias del avance, del triunfo, de la conquista.

¡El avance! Hay quien cree que es cosa de decirlo y que ya estamos al otro lado del Gurugún ${ }^{\prime 164}$.

El Castellano fue, sin duda y como cabía esperar, el periódico salmantino que más se lamentó por las imposiciones de la censura. Paradójicamente, sin embargo, sus críticas hacia la misma no toparon con obstáculos para su publicación. Así que la ocasión fue la perfecta para achacar a Maura una conducta muy prepotente:

"Deberíamos hablar mal del gobierno, pero están suspendidas las garantías constitucionales (...) El gobierno ha dicho necesario investirse a sí mismo de mayores facultades y abrogarse todos los poderes; ¿para qué? Para devolvernos la paz, para hacer que vuelva a imperar el orden, alterado bajo su imperio, y quién sabe si por su imperio mismo; pero no le regateemos ningún sacrificio, porque la patria pasa por una crisis, de la que es necesario sacarla incólume" ${ }^{\text {"165. }}$.

Su redacción sostuvo que el gobierno atravesaba un episodio de locura. Maura cometía una tremenda equivocación al creer que su único deber en África consistía en enviar más y más soldados. Asimismo, el trabajo de La Cierva, amañando los partes de la guerra, tendría una consecuencia nefasta: el distanciamiento entre el Ejército y el pueblo.

"El gobierno puede hacer callar al telégrafo y enmudecer a la prensa; puede imponer el silencio, amordazando todas las bocas (...) pero no podrá contener los latidos del corazón del pueblo (...) Ante el peligro que nos amenazaba en África, el gobierno ha perdido la cabeza, y ha creído que su único deber consistía en enviar soldados y más soldados a pelear y a morir, a triunfar a costa de su sangre, pero sin darles el derecho

\footnotetext{
163 “Crotontilo": “A escape”, El Lábaro, no 3.736, 30 de julio de 1909, p. 1.

164 "Munio": "De cada día", El Lábaro, no 3.754, 20 de agosto de 1909, p. 2.

165 “Salgamos del pantano", El Castellano, no 1.506, 30 de julio de 1909, p. 1.
} 
a que se conozcan sus proezas (...) El valor y las heroicidades de nuestros soldados no caben en los estrechos límites de un parte oficial, todavía reducido por la censura (...) La nación no es dueña de sus destinos, al Ejército se le obliga a batallar en silencio, se hace del heroísmo una obligación sin recompensa de gloria, y se mira a la prensa como a un enemigo ${ }^{, 166}$.

Por esta razón, el periódico aplaudió efusivamente la protesta de la prensa madrileña contra las estratagemas empleadas por La Cierva:

"La Cierva se empeña en que no admitamos más noticias que las que él nos proporciona, en provincias, por ejemplo, por medio de extensas circulares telegráficas, y en Madrid por medio de amigables consejos telefónicos. Dice el señor ministro que mediante esos consejos quiere evitar que muchos periodistas caigan dentro de la Ley de Jurisdicciones. Cariñosamente quiere evitarnos los rigores de la ley y no sabe que la prensa con alguna mayor libertad hubiera contribuido poderosamente a dar al pueblo de Barcelona y al pueblo español en general, una tranquilidad moral de que carece hace tiempo. La prensa está callando muchas cosas que se dicen al oído, en la calle y en los café y cuyos efectos son más perniciosos que el más desenfrenado lenguaje periodístico ${ }^{, 167}$.

El Castellano había asumido, forzosamente, una supuesta misión patriótica en Marruecos, pero sentía que el gobierno no contemplase la utilidad de instrumentalizar su poder público. Toda justificación de la censura topaba con su radical incomprensión: "Lamentamos esa falta de sentimiento de solidaridad, esa ausencia de sentido propio, y convengamos, que en España es únicamente donde pueden darse ministros que persiguen a la prensa, porque hay todavía prensa capaz de consentir y contemporizar con sus perseguidores"168.

El Salmantino, para terminar, no se preocupó por comentar la implantación de la censura. En este punto, su actitud se adivinaba más por lo que callaba que por lo que publicaba. Se limitó a cumplir, con enorme disciplina, los designios gubernamentales.

\section{El envío de soldados salmantinos}

Después de los ataques del 9 de julio, los reservistas recibieron el aviso de estar preparados para cualquier contingencia. Por este motivo, la presencia de soldados recorriendo las calles salmantinas se convirtió en una escena habitual, adornada con su triste y desarrapada figura. La prensa local desempeñó un papel esencial a la hora de socorrer a estos jóvenes, sirviendo como vehículo a través del cual las instituciones se dirigieron a la sociedad. Pero su papel fue mucho más allá: los periódicos, mayoritariamente, apelaron al patriotismo de los lectores frente a las voces contrarias al

\footnotetext{
166 “Situación imposible", El Castellano, no 1.504, 28 de julio de 1909, p. 1.

167 "La protesta de la prensa", El Castellano, no 1.590, 18 de septiembre de 1909, p. 1.

168 "La prensa contra sí", El Castellano, no 1.592, 21 de septiembre de 1909, p. 1.
} 
sistema de reclutamiento. Porque la lástima era un sentimiento muy extendido. De este modo lo confesaba "Un Repórter":

"Ayer, mientras tomábamos café, plácida y tranquilamente en los soportales del Pasaje y un señor daba vueltas y revueltas con la mirada a un plano topográfico de nuestras posesiones en Melilla, pasaron algo taciturnos y cansinos, quemados los rostros por el sol, y encallecidas las manos por las herramientas de trabajo, varios soldados reservistas de los recientemente llamados a filas. Iban luciendo unos lamentables uniformes de cazadores; las verduzcas franjas del pantalón, pardusqueaban atrozmente; las guerreras les caían irrisoriamente por aquellos cuerpos que ya habían perdido la marcialidad militar, y los gorros, los graciosos gorros del soldado español, balanceábanse en aquellas cabezas repletas de largos y lacios cabellos. Uno de los reservistas exhibía en el lado izquierdo del pecho una cruz meritoria, y, siguiéndoles a todos, iban unas viejas mujeres y unas frescas muchachas. De alguno de mis contertulios de café, salieron frases de piedad para aquellos pobres reservistas que acudian solícitos al llamamiento de un ministro, dejándolo todo; sus padres, sus amores, sus campos, y, quizás alguno de ellos, sus mujeres y sus pequeñuelos "169.

De hecho, esa compasión era la que impulsaba también al "Quisicosero" a criticar amargamente la conducta de los estrategas, que pretendían convencer a sus contertulios de que la toma del Gurugú era una labor sencilla, pero nada les espanta el derroche de sangre que se avecinaba ${ }^{170}$.

Sin embargo, a la imagen deprimente de estos reservistas salmantinos, no tardaría en contraponerse otra: la del estoicismo. Porque la guerra era una obligación y ante la marcha de los jóvenes únicamente se podía responder prestándoles todo el socorro posible:

"Con alegre marcialidad, que honra a esta tierra y demuestra que Castilla sigue siendo el rincón venerado donde al patriotismo se rinde el más acendrado culto, marchan los reservistas a la guerra, dejando aquí pedazos del alma (...) Todos cumplen su deber con exceso, y esto es heroísmo. Todos dan a la patria cuanto tienen, sangre o sufrimientos, y todos merecen que los que aquí quedamos, haciendo votos porque vuelvan pronto, sanos y vencedores, procuremos quitarles una preocupación, la más grande, que ha de hacerles pasar sobresaltos y tristezas cuando en las montañas rifeñas recuerden las estepas castellanas. La mayoría de los reservistas son pobres, trabajadores que con su jornal sostienen a madres ancianas, a sus tiernos hijos, a sus amantes compañeras. Al cambiar por el fusil las herramientas de su oficio, podría cambiarse en algún hogar la serena y dulce tranquilidad de contar con las más apremiantes necesidades satisfechas, por el desasosiego del incierto porvenir en que con nada se cuenta, y esto es lo que queremos evitar, recurriendo a Salamanca,"171.

A renglón seguido, se anunciaba el inicio de una suscripción popular en beneficio de los reservistas y soldados en filas de la provincia. Para su gestión, se creó una Junta, presidida por el alcalde, Florencio Marcos Martín. Tanto El Castellano como,

\footnotetext{
169 "Un Repórter": "De la calle. Los reservistas”, El Adelanto, no 7.694, 17 de julio de 1909, p. 1.

170 "Quisicosero": "Quisicosas", El Adelanto, no 7.710, 5 de agosto de 1909, p. 1.

171 "Por los reservistas salmantinos. Suscripción patriótica", El Adelanto, no 7.703, 28 de julio de 1909, p. 1.
} 
sobre todo, El Lábaro se apresuraron a dar la bienvenida a esta iniciativa y a prestar sus instalaciones para la colecta y sus columnas para la publicación de la lista de los donativos ${ }^{172}$. También El Salmantino dio cuenta de la misma, pero muy tardíamente ${ }^{173}$.

En efecto, el 27 de julio, por la noche, salieron en tren los primeros reservistas salmantinos que habían de incorporarse a los regimientos del Rey, Wad-Ras y Covadonga. Catorce hombres fueron despedidos en la estación de trenes y obsequiados con tabaco y vino ${ }^{174}$.

Las peregrinaciones populares hasta este lugar, la estación, se convirtieron en habituales en los días siguientes ${ }^{175}$. Mientras, el cabo Pérez explicaba en El Adelanto que los actos de despedida de los reservistas no eran tan tristes como pudiera pensarse: "Abundan los ejemplos de patriotismo heroico en los humildes, en los que todo lo dejan para ir a defender una bandera que hace palpitar sus corazones con amor grande y hermoso, en quienes todo lo posponen y sacrifican a la Patria" ${ }^{\prime 176 .}$

También "Juan de Salamanca" se refería a estas concurridas despedidas, repletas de conmovedoras escenas, señalando:

"Los salmantinos entienden que lo verdaderamente útil para la patria, es animar a los soldados y darles esperanzas.

De esto último, de lo que hacen los salmantinos, es de lo que hoy quiero hablar a los lectores de El Adelanto.

Hace ya días, casi desde que empezaron a circular las noticias de la guerra, se ven por las calles de Salamanca soldados de diferentes regimientos, que no están aquí de guarnición.

Cuando llega la noche, los soldados van a la estación, y salen para el sitio a donde les llaman.

Esa hora, la de la salida de los trenes, es la que han elegido los patriotas salmantinos para despedir y agasajar a los soldados.

La estación se halla invadida por gente de todas las clases. Familias de obreros que van a despedir al hijo que parte para la guerra, gentes acaudaladas que salen de veraneo, familias de la clase media que van como curiosos o como entusiastas del Ejército. Voces y cantos alegres de los soldados; lágrimas y ayes de los parientes, y saliendo por cima de todo un iViva España!, que se oye de tiempo en tiempo y que todos corean ${ }^{, 177}$.

\footnotetext{
172 "Por los reservistas", El Castellano, no 1.505, 29 de julio de 1909; "Por los reservistas. Feliz iniciativa", El Lábaro, no 3.735, 29 de julio de 1909, p. 3; "Suscripción para las familias de los reservistas", El Lábaro, no $3.736,30$ de julio de 1909, p. 2.

173 "Salamanca", El Salmantino, no 96, 14 de agosto de 1909, p. 3.

174 "Despedida de los reservistas", El Adelanto, $\mathrm{n}^{\circ}$ 7.703, 28 de julio de 1909; "Los reservistas salmantinos", El Castellano, no 1.504, 28 de julio de 1909; "A Melilla", El Lábaro, no 3.734, 28 de julio de 1909, p. 2.

175 "En la estación. Despedida de los reservistas", El Adelanto, no 7.704, 29 de julio de 1909; "En la estación. Despedida de los reservistas", El Adelanto, n 7.705, 30 de julio de 1909, p. 1.

${ }^{176}$ El Cabo Pérez: "Diario de la guerra", El Adelanto, no 7.698, 22 de julio de 1909, p. 1.

177 "Juan de Salamanca": "Vida local. Los patriotas", El Adelanto, no 7.704, 29 de julio de 1909, p. 2.
} 
Y "Un Repórter", asimismo, ensalzaba el brillante ejemplo de patriotismo que estaban ofreciendo los salmantinos al país:

"En el tiempo de guerra que llevamos, aquí no se ha registrado acto alguno que vaya en desdoro de la patria, sino que todos, soldados y familias, particulares y autoridades, van poniendo, en estos críticos momentos de las dolorosas partidas y de los conmovedores adiós, algo dulce y halagador que es el nombre augusto de la patria, el sentimiento unánime de luchar por su honor y que a todos se nos ha ido metiendo muy hondo del pecho (...) Aprendan, pues, de Salamanca, esos sediciosos barceloneses, y sepan que aquí, con la misma tranquilidad con que leemos un periódico, sabemos tomar las armas cuando se nos llama y cuando la patria, como ahora, nos necesita.

$Y$ este nuestro, no es el patriotismo de la célebre marcha de Cádiz: es el patriotismo del honor nacional ${ }^{\prime 178}$.

Sin embargo, las impresiones de El Castellano no eran tan optimistas:

"No van en marcha triunfal, al eco de las músicas sonoras (...) van tristes, sin ruido, en grupos, en parejas o rodeados de mujeres y niños, a quienes miran con una honda impresión de melancolía; pero van.

Ni por un solo momento han pensado resistir sin demora el cumplimiento de la orden que en términos precisos se les ha comunicado; y al recorrer las calles de la ciudad no han encontrado ni quien les infunda alientos para seguir adelante, hablándoles de la heroica empresa que van a realizar, ni menos quien les inspire el deseo de formular ni una protesta ni una queja con criminal espíritu de rebeldía.

Los reservistas salmantinos no parece que van a la batalla, sino al sacrificio; pero si falta marcialidad en su continente, rasgos de viril acometividad en su rostro, hay en el fondo de su alma tesoros de abnegación y un venero inagotable de sentimientos patrióticos ${ }^{, 179}$.

Y a otro redactor, Modesto Pérez, las emotivas despedidas le servían para

formular un comentario bastante crítico:

"Yo soy de los que creen que los pueblos no pueden vivir sin ideales, y que España, para expansiones de espíritu y de comercio, tiene grandes deberes que cumplir en África (...) Salamanca y los soldados que de ella parten ponen a España por encima de apasionados intereses políticos (...) Las clases directoras que no manden a sus hijos a las filas ni a la guerra no están autorizadas para llamar antipatriota a nadie; por eso será más hermoso cuanto el pueblo haga ${ }^{, 180}$.

El Castellano fue el único periódico local que suscribió, palabra por palabra, el famoso escrito de Benito Pérez Galdós, “Al pueblo español”, -que también reprodujo íntegramente- contra el gobierno de Antonio Maura y su irresponsable conducta en Barcelona y Marruecos ${ }^{181}$.

\footnotetext{
178 "Un Repórter": "Notas de un periodista. Nuestro ejemplo", El Adelanto, n 7.705, 30 de julio de 1909, p. 1 .

179 "Los reservistas de Salamanca", El Castellano, no 1.498, 21 de julio de 1909, p. 1.

${ }^{180}$ Modesto Pérez: "Los albaceas de Isabel la Católica”, El Castellano, no 1.507, 31 de julio de 1909, p. 1.

${ }^{181}$ Benito Pérez Galdós: “Al pueblo español”, El Castellano, no 1.607, 8 de octubre de 1909, p. 1.
} 
El 30 de julio, el diario de Núñez Izquierdo anunciaba que algunas familias ya habían recibido las primeras cartas de los reservistas ${ }^{182}$. Y, a los pocos días, "Juan de Salamanca" comentaba el entusiasmo y tranquilidad que estas cartas inspiraban ${ }^{183}$. Como si de una carrera se tratara, El Lábaro se apresuró a publicar una de ellas. Eran las breves notas enviadas por el trompeta Martiniano (sin mayores presentaciones):

"Los rifeños son muchos y no pelean al descubierto, sino escondidos entre piedras y maleza; de ahí no hay quien los saque más que la potente y honrosa artillería.

Los jefes y oficiales, todos muy valientes y serenos, dando vivas a España y al Rey, cuando nos invitan a la pelea.

Salud les deseo en compañía de las familias. Nosotros completamente sin novedad: salud buena, a pesar de los grandes calores.

Humor, todavía nos queda, a pesar de las muchas fatigas pasadas, pero con orgullo y mucho corazón, por ser todo en defensa de la patria" "184.

El Adelanto contraatacaba con otras. Así, a modo de ejemplo, esta misiva, perteneciente a varios soldados salmantinos del Batallón de Ferrocarriles, era publicada al terminar agosto:

"Muy señor nuestro: Después de saludar a usted y a su popular periódico, pasamos a decirle que el objeto de ésta es el siguiente:

Ayer tarde nos reunimos unos cuantos paisanos de los muchos que en el campo de batalla nos encontramos defendiendo nuestra bandera. Estábamos celebrando la buena suerte que hasta ahora hemos tenido, y Dios quiera que sigamos con la misma.

Estando en esta reunión, vimos al señor Martín Veloz, el cual nos saludó amablemente y nos entregó para que celebrásemos una merienda.

Agradecimos el obsequio, no precisamente por la propina, sino porque la alegría que teníamos al vernos juntos y sanos, tan lejos de nuestra querida ciudad de Salamanca, nos llenó de júbilo a todos. Verdaderamente los salmantinos hemos tenido hasta hoy el santo de cara, como se suele decir, y en todos los combates en que hemos entrado, parece hasta mentira la suerte que nos protege.

Los salmantinos que abajo firmamos, peleamos decididos por la patria y saludamos a nuestro querido pueblo.

Muchas gracias, señor Director," 185 .

A finales de agosto se marcharon algunos excedentes de cupo de $1908^{186}$; y a principios de octubre, cuando hubieron de marchar más soldados salmantinos hacia la guerra, El Adelanto publicó otra emotiva carta remitida por un grupo de ellos. Se iban entusiasmados a cumplir con su deber ${ }^{187}$.

El Castellano también fue un alumno aventajado en esta labor de reproducir cartas entre sus páginas. Por ejemplo, a principios de agosto, publicó la de Santos

\footnotetext{
182 "La salud de los salmantinos en Melilla", El Adelanto, no 7.705, 30 de julio de 1909, p. 1.

183 "Juan de Salamanca": "Vida local. Una carta", El Adelanto, n' 7.708, 3 de agosto de 1909, p. 1.

184 "De cada día. La carta de Melilla", El Lábaro, no 3.740, 4 de agosto de 1909, p. 2.

185 "Los soldados salmantinos en Melilla. Su buena suerte", El Adelanto, no 7.728, 26 de agosto de 1909, p. 1.

186 “Los excedentes de 1908”, El Lábaro, no 3.762, 30 de agosto de 1909, p. 1.

187 "Buenos patriotas y buenos salmantinos", El Adelanto, no 7.764, 7 de octubre de 1909, p. 1.
} 
Rubiano, un médico militar bastante conocido en Salamanca por haber servido en el regimiento de Albuera:
"A un lado mi tienda, hay un monte sombrio de picachos altivos dorados por el sol, y a otro lado sonríe, o se encrespa bravio, un mar que trae suspiros del hogar español tierra es ésta hoy de muerte, abierta sepultura que tiene su epitafio en el patrio dolor; el mar, es el mar nuestro de perenne dulzura, imán de nuestras almas, senda de nuestro amor. Más si éste nos arrulla con caricias templadas y plácido nos brinda sus orillas... en pos de ese monte sombrío, de lomas ya sagradas el porvenir de España guarda a la raza Dios ${ }^{, 188}$.

Semejante tarea no la pudo acometer, sin embargo, El Salmantino. Creemos que debido a su carácter semanal, el seguimiento que hizo tanto de los soldados salmantinos como de las iniciativas caritativas fue, en general, pobre. No obstante, también encontramos alguna misiva y cancioncilla patrióticas ${ }^{189}$.

Y, mientras, no faltaron las informaciones sobre gentes que deseaban acudir voluntariamente al terreno de batalla ${ }^{190}$. Éstas aumentaron exponencialmente, sobre todo, tras el Desastre en el Barranco del Lobo. Era muy abundante la cobertura mediática prestada a los aristócratas que, pese a la posibilidad de redención, participaban en la campaña. El propósito apaciguador de estas informaciones resultaba muy evidente: "Hay en la campaña de Melilla algunos jóvenes, bizarros y valientes, que llevan títulos de Castilla y grandezas de España, y que desdeñan, en aras de la patria, el muelle sosiego que les brindaran su nacimiento y su fortuna. La aristocracia de hoy se muestra a la altura de sus timbres" ${ }^{\prime 191}$. Aunque el 4 de agosto se contabilizan en la guarnición de Melilla casi $22.200 \operatorname{soldados}^{192}$, la cifra no era suficiente. De ahí, que se publicitase el ejemplo de los voluntarios, especialmente, en los días inmediatamente previos al avance ${ }^{193}$. "Argos" fue uno de los redactores que más emoción experimentó al conocer el alistamiento de estos aristócratas:

"Yo sigo con creciente interés y con cierta emoción el avance de la ola voluntaria; creo que, de seguir así (...) habríamos resuelto el problema del servicio militar: no sería

\footnotetext{
188 "Versos de un médico", El Castellano, no 1.607, 8 de octubre de 1909, p. 1.

189 "Crónica hebdomadaria", El Salmantino, no 98, 28 de agosto de 1909, p. 1; "Cancionero de la guerra", El Salmantino, no 100, 11 de septiembre de 1909, p. 1; "Cancionero de la guerra”, El Salmantino, no 101, 18 de septiembre de 1909 , p. 1.

${ }^{190}$ Alfredo Rivera: “Conferencias telegráficas”, El Adelanto, no 7.701, 26 de julio de 1909, p. 3.

191 "La campaña de África”, El Adelanto, no 7.704, 29 de julio de 1909, p.2.

192 "La campaña de África", El Adelanto, no 7.709, 4 de agosto de 1909, p. 2.

193 “A la guerra. Un voluntario salmantino”, El Adelanto, no 7.730, 28 de agosto de 1909, p. 1.
} 
obligatorio, las redenciones no se harían mediante dinero; todos los espontáneos ocuparían el sitio de los obligados por la ley. ¡Qué hermosa sustitución! ¡Qué sublime redención! ‘Y qué feliz sería la nación! ’’94.

El Lábaro, cambiando de órgano periodístico, fue el otro periódico salmantino que con mayor regularidad se ocupó del reclutamiento de voluntarios ${ }^{195}$; y también se recreó con el ejemplo de capellanes que acudían al campo de batalla ${ }^{196}$. El 9 de agosto publicó la Real Orden por la que éstos eran llamados al combate y durante las semanas posteriores destacó el elevado número de aristócratas e integrantes de órdenes militares que se hallaban en filas ${ }^{197}$.

El Castellano, por último, también mostró su satisfacción ante estos alistamientos voluntarios ${ }^{198}$.

\section{Los nuevos avances}

La creación de un clima de opinión pro-bélico en Salamanca

¿Cómo persuadir a la población metropolitana de la necesidad de secundar la lucha? Se necesitaba una precisa estrategia de comunicación y a su diseño se encaminaron los esfuerzos de casi toda la prensa salmantina: una estrategia fundamentada en un mensaje sencillo, más enfocado hacia lo interesante que hacia lo importante y capaz de distraer a los incontables estrategas de café; basada también en un mensaje estereotipado, en el que día tras día los buenos siguiesen siendo buenos y se confirmase que los malos también lo eran; y, por último, en un mensaje consciente de que la política se desarrollaba más en el mercado de las emociones que en el de las razones. En suma, se necesitaba propaganda de guerra. Había llegado el momento de poner en marcha una maquinaria (des)informativa cuyo objetivo no consistía en contar la verdad, sino en justificar un enorme esfuerzo bélico ante la opinión pública salmantina. Y todo ello gracias a la publicación de valoraciones cargadas de dogmatismo y de una recurrente impresión de unanimidad. Así se fabricaba el consenso y así lo entendió buena parte de la redacción de Núñez Izquierdo, los seguidores del padre Cámara y el integrismo.

\footnotetext{
194 “Argos": "Madrid al día", El Adelanto, no 7.722, 19 de agosto de 1909, pp. 1-2.

195 "Recluta voluntaria", El Lábaro, no 3.745, 9 de agosto de 1909, p. 1; "Un voluntario de Salamanca", El Lábaro, no 3.759, 26 de agosto de 1909, p. 2.

196 "De la guerra. El capellán Moreno", El Lábaro, no 3.751, 17 de agosto de 1909, p. 1. Se recogía aquí el relato del capellán-médico Jesús Moreno, del batallón de las Navas.

197 "De la guerra", El Lábaro, no 3.746, 11 de agosto de 1909, p. 1; "De la guerra", El Lábaro, no 3.747, 12 de agosto de 1909 , p. 1.

198 "Por sus hijos", El Castellano, no 1.512, 6 de agosto de 1909, p. 2.
} 
En El Adelanto, desde que se registraron los primeros enfrentamientos, fueron habituales los editoriales con marcado tono belicoso, siempre fundamentados en una visión maniquea de la cuestión marroquí. El siguiente editorial de B. Pallol, planteado a modo de diálogo entre dos estrategas de café, puede servirnos de muestra: Uno de ellos sostenía como idea crucial de su discurso que "o nos metemos en el ajo de hoz y de coz, o nos birlan nuestras posesiones allende el Estrecho. Este es el dilema: o política de aventuras, o recogernos en nuestra casita"199 . A lo que su interlocutor le respondía:

"Conseguirán abrirnos las carnes; morirán nuestros hijos en ese abrasadero que llamamos África; llorarán las pobrecitas madres de los soldados; nuestros campos tonarán a estar yermos; las fábricas no funcionarán... Y aquella política hidráulica, aquellas reformas de la enseñanza que prometían transformarnos en un pueblo sano, fuerte y culto, se evaporarán".

El debate resultaba, sin embargo, infructuoso porque ninguno de los interlocutores renunciaba a sus convicciones y concluía con esta aseveración del primer participante: “¿A qué dar coces contra el aguijón? (...) Toda la sangre, todas las lágrimas, todo el dolor puesto a tributo para la consecución de tan alta y soberana empresa".

El quijotismo castellano quedaba demostrado cuando Salamanca, muy tempranamente, obsequiaba a los combatientes castellanos con 1.500 tiendas de campaña. Coincidiendo con este gesto, el redactor Julio escribía:

"Nuevamente vuelve España a combatir contra el moro, nuevamente van allá los españoles a buscar asunto para las leyendas que contarán a sus hijos. Ya han surgido las estratagemas de café (...) Unos teorizan simplemente, desarrollando vastos planes de campaña que nos permiten dominar a Marruecos en cuarenta y ocho horas. Otros son hombres prácticos, gentes macizas que demuestran la verdad de sus afirmaciones, con unos alfileres de cabeza negra que van clavando en un mapa (...) 'Esta es Castilla, que hace sus hombres y los gasta', y contentos podemos llamarnos, aunque no ganemos territorios, ni conquistemos mercados, ni recibamos indemnizaciones, si podemos hacer que nuestros soldados entrevean la gloria desde la tienda de campaña. Así tendrán algo que contar a sus nietos, 200 .

Además de ansiedad, en el diario liberal también encontramos algunos editoriales que apelaban a la guerra como garantía de nuestra independencia nacional. En este sentido, furia era lo que suscitaba, en el cabo Pérez, la noticia de que en las aguas del Peñón de Alhucemas había sido interceptado un barco italiano practicando el contrabando. La ocasión era aprovechada para argumentar que a la contienda se iba por obligación y la labor protectora de Occidente no debería ser torpedeada por otros

\footnotetext{
${ }^{199}$ B. Pallol: “Crónica. La actualidad”, El Adelanto, no 7.694, 17 de julio de 1909, pp. 1-2.

${ }^{200}$ Julio: "De la guerra. Las tiendas de campaña. Ayer salieron de Salamanca para Melilla 150 tiendas de campaña", El Adelanto, nº 7.697, 21 de julio de 1909, p. 1.
} 
europeos $^{201}$. Sin embargo, días después y a través de una noticia recogida en La Época, El Adelanto tenía que rendirse ante la evidencia de que también los españoles practicaban el comercio ilegal. Al parecer, la actividad era frenética en Tánger, Lisboa y Puerto Real ${ }^{202}$.

Aunque sin duda, en el seno de la redacción de El Adelanto, el abanderado del intervencionismo en Marruecos fue "Juan de Salamanca": él creía en la dominación previa por la fuerza para la implantación de la civilización en el Rif y consideraba al Ejército español como un instrumento al servicio del progreso nacional. A los pocos días del combate en el Barranco del Lobo, publicaba un buen artículo, de lo más sugerente, sobre el ambiente que reinaba en Salamanca a propósito de la guerra:

"Elijamos un sitio donde a diario se reúna mucha gente de diferentes clases sociales, para tener la medida aproximada del común sentir. Vayamos a la estación, a donde todas las noches acude media Salamanca, con objeto de despedir a los reservistas (...) Oyendo a unos y a otros, se ve claramente que cuantos hablan de la guerra, lo mismo los que pronostican un feliz resultado que los que le auguran malo, ponen su confianza en la cultura, seguros de que vencerán los más cultos (...) Si los españoles fueran pacíficamente al Rif, serían degollados, lo mismo si iban a poner escuelas, que si iban a establecer industrias o a cualquier cosa análoga (...) Si en estos momentos puede haber algún consuelo para los que aquí quedan es el de que el que marcha a la guerra, aprovechó los años del colegio y puede mandar noticias a los suyos en cuanto tenga un momento para escribir. De todo cuanto yo he visto estas noches, al ir a despedir a los soldados, no he visto nada que me haya hecho tanta impresión como una mujer del pueblo que decía: 'Si mi hijo supiera escribir, sería muy diferente, ${ }^{\text {,"203 }}$.

Fe ciega en nuestra capacidad civilizadora era lo que revelaba este editorial de Fernando Felipe ¡Qué distinto es este cuadro al que más tarde, y fundamentado en su conocimiento directo, nos pintaría Arturo Barea!

Incluso, el mismo redactor llegó a ensalzar los beneficios que la pelea reportaba a Salamanca:

“QQuién va a negar que tiene beneficios, viendo cómo Salamanca ha despertado de su eterno sueño? Hablo de Salamanca, porque aquí pueden todos ver la verdad de lo que digo (...) Sólo cuando la guerra nos ha hecho despertar, es cuando esperamos los periódicos con ansiedad, cuando salimos a la calle a esperar a los vendedores y cuando todo lo que los periódicos dicen nos parece muy poco, porque quisiéramos saber todo lo ocurrido con todos los detalles, ${ }^{\text {"204 }}$.

\footnotetext{
${ }^{201}$ El cabo Pérez: "Diario de la guerra", El Adelanto, no 7.698, 22 de julio de 1909, p. 1.

202 "La campaña de África", El Adelanto, $\mathrm{n}^{\circ} 7.709,4$ de agosto de 1909, p. 2. Se describe el proceder de los contrabandistas en: "La campaña de África", El Adelanto, no 7.772, 16 de octubre de 1909, p. 2. Se emplean pequeñas barcas de pesca; siempre se actúa por la noche; los rifeños pagan en el momento de la entrega; y todo se produce con mucha rapidez.

203 "Juan de Salamanca": "Vida local. La guerra y la cultura", El Adelanto, n 7.706, 31 de julio de 1909, p. 1.

204 “Juan de Salamanca": "Vida local. Los beneficios de la guerra", El Adelanto, n 7.710, 5 de agosto de 1909, pp. 1-2.
} 
También el testimonio de los veteranos del 60 fue empleado para alentar el fervor patriótico. Por eso "Un Repórter" reproducía las palabras de don Pedro, un anciano combatiente muy satisfecho con el renacer espiritual español, deprimido desde 1898. En su boca colocaba el siguiente comentario:

"Los combates que ha habido, especialmente los del 23 y los del 27 del pasado, me han entusiasmado. Y me han entusiasmado, porque tanto los jefes y oficiales, como los soldados que en ellos pelearon, nos han horado a los que antes peleamos allí. Esa heroicidad y esa valentía nuestra, es la que trato de dejar bien sentada... Si ahora me muriera, me moriría tranquilo, porque veo que mi pueblo español sigue siendo el pueblo heroico, valiente, decidido de siempre. Y para esos infames catalanes que no sienten el amor de la patria, como lo sintieron los que en la pasada guerra pelearon a mi lado, vaya, amigo mío, el mayor desprecio ",205.

De manera excepcional, una nota discordante, y curiosísima, en todo este periodo de arrebato belicoso fue la que nos ofreció Pascual Meneu, un convencido de lo que se bautizó como "propaganda científica". Además de ser un reputado catedrático de hebreo y árabe en la Universidad de Salamanca, se había ocupado de la promoción de esta lengua en la escuela del barrio de San Vicente y, anualmente, se responsabilizaba de que algunos niños rifeños pasasen el verano en Salamanca para convertirse en "hombres de carrera". La idea que yacía es su proyecto educativo era sencilla: "Si este plan se hubiera seguido desde el año 60 del siglo pasado, después de nuestras guerras con África, hoy serían otras nuestras relaciones con Marruecos"206.

Creado ya un clima de opinión dominado por el miedo y la ansiedad, llegaba el momento de combatir. La campaña patriótica se dirigió entonces, por esta razón, a solicitar la resignación de la opinión pública ante inevitables, aunque necesarias, contingencias. El 9 de agosto Alfredo Rivera telegrafiaba que se registraba enorme movimiento de tropas en el campo de operaciones, preparándose ya el avance sobre el Zoco El Arba y las inmediaciones de la Mar Chica ${ }^{207}$. Muy oportunamente, en el mismo ejemplar se subrayaban los beneficios que del empleo de la aerostación se derivarían para el desarrollo de la campaña, sobre todo, un mejor conocimiento del terreno ${ }^{208}$.

Y un día después, sin ambages, "Juan de Salamanca" exponía su fe en el porvenir y en la buena disposición de los españoles para el combate:

“¿Qué pasará? Que llegaremos victoriosos hasta Zeluán, contestan a coro todas las voces. Es necesario, sin embargo, que ahora que van a comenzar las operaciones no olvidemos lo que se ha estado repitiendo todos los días, durante la semana última. Es

\footnotetext{
205 "Un Repórter": “Cómo pelean los moros”, El Adelanto, no 7.701, 26 de julio de 1909, p. 2.

206 "El problema marroquí. La propaganda científica”, El Adelanto, no 7710, 5 de agosto de 1909, pp. 1-2.

${ }^{207}$ Alfredo Rivera: “Conferencias telegráficas”, El Adelanto, no 7.713, 9 de agosto de 1909, p. 3.

208 "La campaña de África", El Adelanto, n 7.713, 9 de agosto de 1909, p. 2.
} 
necesario no olvidar que el enemigo, lejos de ser insignificante, es verdaderamente temible: que por sus condiciones de bravura, de número y de conocimiento del terreno, será en todos los momentos un fuerte obstáculo para el avance de nuestras tropas ${ }^{, 209}$.

La tranquilidad reinante, durante aquellos primeros días de agosto de 1909, en el campo de operaciones era únicamente aparente; la calma que precedía a la tempestad. Y de todos era sabido que, mientras tanto, los caídes aprovechaban para predicar la guerra santa contra España entre los soldados del harca ${ }^{210}$. Sólo cabía confiar, por tanto, en el proceder del Ejército español.

En quien no confiaba "Juan de Salamanca" era, en cambio, en los estrategas de café. A estos les achacó un exceso de arrogancia, sobre todo, por los ataques que vertían contra el general Marina:

"Dejaríamos de ser españoles si no tuviéramos cada uno nuestro plan de combate. En cualquier sitio donde se hallen reunidas dos personas, y se hablen dos docenas de palabras, oiréis repetir lo mismo: 'iSi yo fuera el general Marina!'. Es decir, si el general Marina tuviera este talento que Dios me ha dado, y supiera lo que yo sé de táctica, de balística, de geografía y de otra porción de cosas, estábamos ya en Tetuán, y habían regresado lo militares españoles con laurel para guisar durante veinte años ",211.

En otro de sus editoriales, repleto de fina ironía, se burlaba de aquellos que creían poder arreglar todo a su antojo, ajenos a la realidad. Para ello, recreaba, de nuevo, un absurdo diálogo entre estrategas. Indiscutiblemente, Fernando Felipe fue el periodista local que más interés mostró por la descripción del ambiente bélico salmantino; un ambiente caricaturizado, pero quizás no carente de cierto realismo. El columnista, en el fondo, se esforzaba en denunciar la frivolidad de estos incontables líderes de opinión; si bien él era uno más.

"En la Plaza Mayor, un grupo formado por cuatro o cinco muchachos, discute acaloradamente las cosas de la guerra (...) Los muchachos, de vez en cuando, se detienen para dar más solemnidad a la discusión, y cuando notan que alguno de los paseantes fija en ellos la mirada, levantan la voz para hacerse visibles.

Uno habla de la necesidad absoluta de hacer la guerra por mar, para lo cual no habría más que comprar a Inglaterra todos los buques que tiene y llevarlos a Marruecos.

Otro desprecia los acorazados recordando lo de Santiago de Cuba y lo de Cavite, que se imagina de una manera muy extraña, hablando de los soldados (de infantería), que echaron a pique los barcos españoles a fuerza de disparos.

La discusión se va enzarzando, hasta que toma la palabra Emilio, que es la autoridad inapelable para la reunión.

\footnotetext{
209 "Juan de Salamanca": "Vida local. Calma, mucha calma”, El Adelanto, $\mathrm{n}^{\circ}$ 7.714, 10 de agosto de 1909, p. 1 .

${ }^{210}$ Alfredo Rivera: "Conferencias telegráficas", El Adelanto, no 7.714, 10 de agosto de 1909, p. 3; "La campaña de Melilla", El Adelanto, no 7.718, 14 de agosto de 1909, p. 3.

211 "Juan de Salamanca": "Vida local. Un plan de campaña", El Adelanto, no 7.716, 12 de agosto de 1909, p. 1.
} 
Emilio puede tener hasta nueve años cumplidos, ha visto Nuevo Mundo y Actualidades, ha leído Heraldo y El Adelanto, y se ha dado cuenta, tanto de las causas de la guerra como del terreno en que tiene lugar, y de las condiciones de los combatientes.

Ahora, que ha tomado la palabra, óiganle ustedes con atención, porque vale la pena. -Vosotros, qué sabéis. Esto es como si fuera Melilla; aquí, abajo están los españoles, que es la plaza; y arriba, en el tejado, que es el Gurugú, están los moros.

El primer día, va y sale el general Marina, y dice: 'Bueno, pues que hay que subir al Gurugü:

Sale el general Pintos, y dice: 'Pues yo voy, mi general. Bueno, pues coja usted los soldaditos que necesite'.

Coge los más valientes y suben tal como el primer, pero los moros siguen tirando tiros y pedradas y aceite hirviendo; (sí, señor, aceite hirviendo, que lo he leído yo), y matan al general Pintos y a muchos soldados.

Al otro día, sale otro general español, con más soldados y aunque los moros siguen tirando la mar de tiros, suben al segundo piso.

Al otro día, y viendo que ya falta poco por subir al Gurugú, sale el general Marina, reúne a todos los soldados y les dice: 'Hijos mios, y qué tal, qué sé yo' y suben todos al primero, y después al segundo, y luego al tercero y luego al tejado, que es el Gurugú. Pero, ¿vosotros creéis que está ya allí el harca? Cuando suben los españoles, los moros han echado a correr y se han llegado a unas cuevas que las llaman los aduares, contra las que sólo puede la artillería.

Emilio ha terminado su perorata y los amigos siguen el paseo, convencidos de que, a pesar de ser mиy valientes los españoles, les costará trabajo llegar al fin, y cuando lleguen se encontrarán con que el harca ha desaparecido" "212.

A decir verdad, los lugares de recreo, tales como casinos y cafeterías, constituyeron importantísimos centros de sociabilidad en esa vieja Salamanca, asumiendo un papel absolutamente vital como agentes de movilización política ${ }^{213}$. Si bien a finales del siglo XIX, estos espacios servían para marcar las fronteras entre los distintos grupos sociales, a medida que avanzó la nueva centuria, estas divisiones se tornaron algo más difusas. El Casino de Salamanca, no obstante, continuó siendo el lugar de reunión de las familias aristocráticas, de profesionales liberales, catedráticos, concejales, comerciantes e industriales; en cambio, El Pasaje poseía una clientela más modesta de sectores procedentes de la clase media. Y, finalmente, en El Círculo Mercantil se aglutinaban los hombres procedentes del comercio y la industria. En cuanto a los cafés, El Suizo, El Términus y El Novelty eran algunos de los más afamados en los años que nos ocupan: lugares de ocio en los que los tertulianos comentaban los acontecimiento de mayor actualidad, núcleos de propaganda y de adquisición de conciencia política.

\footnotetext{
212 "Juan de Salamanca": "Vida local. La harca moruna", El Adelanto, no 7.722, 19 de agosto de 1909, p. 1.

${ }^{213}$ CALLE VELASCO, María Dolores de la: "Aspectos de la vida cotidiana salmantina a principios del siglo XX" en KENT, C. (Coord.): Salamanca en el siglo XX. Delaware: Ohio; Salamanca: Librería Cervantes, 1997, pp. 53-65.
} 
“Juan de Salamanca" no fue el único escritor que se ensañó con los estrategas de café. Otro reportero también muy crítico con el papel comunicativo que éstos desempeñaron fue Manuel Rubio. Fundamentalmente, les recriminó el hecho de que su impaciencia e imprudentes comentarios pudiesen minar un monolítico discurso periodístico. "Escepticismo" jamás podría significar "patriotismo". Había que evitar el debate público, desacreditar a aquellos que sostuviesen opiniones contrarias a la guerra, y llamar al estoicismo entre la opinión salmantina. Por estas razones, a Manuel Rubio le parecía muy desvergonzada la actitud de esos tertulianos, que no escatimaban críticas para el Ejército cuando experimentaba una derrota, pero no dudaban en atribuirse sus victorias:

"Confieso con rubor y pena que nada he hecho y que, ahora, como antes, pienso que no es lo mismo hablar de moros que andar a tiros con ellos. Recuerdo, oyendo hablar a esos colilleros de la gloria, el siguiente chascarrillo: el lego de un convento, que tenía que trasmitir a sus compañeros las órdenes del prior, lo hacía en la forma siguiente: 'Ha dicho el prior, que bajemos a la huerta y que cavéis y que después vayamos a la bodega y que bebamos'. ¡Con que caballeros, ya que no se ha cavado, dejen ustedes que beban quienes se han desollado las manos! ${ }^{, 214}$.

Junto con las provocaciones contra estos tertulianos, la guerra de la pluma también se desarrolló en otros frentes: así, por ejemplo, El Adelanto se empeñó en trazar muy bien la división entre villanos y héroes. Los primeros, los rifeños, no tenían rostro ni nombre. Deshumanizar al enemigo se presentó como el camino más breve para procurar odios contra él ${ }^{215}$. La prensa salmantina no concedió demasiado espacio a esos "moros traidores" ni a sus objetivos o motivaciones. Apenas se puede seguir, a través de sus páginas, el rastro de El Rogui, El Raisuni, el moro Valiente, El Chaldy... y tantos otros. La explicación, insistimos, es sencilla: esa vaguedad es un arma propagandística. Sirvió para generar angustia, para crear monstruos y para fomentar un estado de opinión a favor del combate.

Excepcionalmente, el periódico liberal intentó ahondar en la composición de la confederación de Guelaya:

"Las cábilas más inmediatas a la plaza de Melilla son Mazuza, Beni Sicar, Beni Sidel, Beni Said y Beni-bu-Ifrur. Entre las cinco forman la provincia de Guelaya. Estas cábilas pueden poner en todo momento en pie de guerra: Mazuza, con su hijuela

\footnotetext{
214 “Uno": "De cursiva. Nuestras victorias", El Adelanto, no 7.757, 29 de septiembre de 1909, p. 1.

${ }^{215}$ Sí que hemos encontrado una descripción bastante extensa de un moro enemigo. Se trata de El Chaldy, presentado como un mercenario y embaucador. Véase "Sir-ve": "El Chaldy",

El Adelanto, no 7.729, 27 de agosto de 1909, p. 2. "Sir-ve" era el otro de los pseudónimos empleados habitualmente por Fernando Felipe.
} 
Frajana: 5.000 hombres; Beni Sicar, 4.000 idem; Beni Sidel, 6.000 idem; Beni Said, 7.000; Beni-bu-Ifrur, 5.000 idem. Total: 27.000 hombres ${ }^{\text {,216. }}$

Constituía, por tanto, un poderoso enemigo. Y también este diario utilizó fragmentos de la obra de Alarcón, Diario de un testigo de la Guerra de África, para explicar que aunque se desconocía, con exactitud, la cifra de combatientes, se desplazaban muy ágilmente tanto a pie, emboscándose en el terreno, como a caballo y resultaba obligado desconfiar siempre de ellos dado que eran hombres altivos y sagaces: “Cada mata, cada piedra vomita uno de esos seres fantásticos; los bosques se cuajan de ellos; descuélganse de las cordilleras como copos de lana; surgen, como la niebla, desde el fondo de los barrancos, materialmente erizan toda la línea del horizonte"217. Se comportaban, además, como excelentísimos tiradores, y se sentían muy motivados por la captura de botín ${ }^{218}$.

Su belicosidad, no obstante, pareció mermar después del serio combate del 27 de julio:

"No ha vuelto a registrarse ningún combate, y únicamente nuestra artillería foguea incesantemente las alturas del Gurugú. Los rifeños han desaparecido de estas posiciones, por hallarse completamente desalentados para continuar resistiendo el bravo empuje de nuestras fuerzas. Carecen de municiones y de alimentos, y son muchos los moros que se disgregan del harca, resultando inútiles cuantos esfuerzos hacen los jefes para contener la deserción considerable de las hordas marroquíes ",219.

Esta quietud, el hecho de que no se detectasen movimientos en las alturas del Gurugú, preocupaba muchísimo en la plaza: por el modo rifeño de combatir, la tranquilidad acostumbraba a indicar que se estaban recibiendo refuerzos con miras a efectuar un nuevo ataque ${ }^{220}$.

En efecto, el 2 de agosto se registró otro intento por cortar la vía férrea. Pero, en esta ocasión, no tuvo éxito. En la misma información, se aludía a las dificultades de El Chaldy para mantener la cohesión entre sus tropas ${ }^{221}$.

Tan sólo en una ocasión, “Un Repórter” dedicó un editorial a dos moros amigos, Maimón y El Gato. Ellos no eran retratados con las habituales notas de salvajismo,

\footnotetext{
216 “Las cábilas del Rif”, El Adelanto, n 7.700, 24 de julio de 1909, pp. 1-2.

217 "Cómo pelean los moros", El Adelanto, no 7.701, 26 de julio de 1909, p. 2.

218 "La campaña de África", El Adelanto, n' 7.711, 6 de agosto de 1909, p. 2.

${ }^{219}$ Alfredo Rivera: "Conferencias telegráficas", El Adelanto, no 7.706, 31 de julio de 1909, p. 2.

${ }^{220}$ Alfredo Rivera: "Conferencias telegráficas", El Adelanto, no 7.707, 2 de agosto de 1909, p. 3.

${ }^{221}$ Alfredo Rivera: "Conferencias telegráficas", El Adelanto, no 7.708, 3 de agosto de 1909, p. 3; Alfredo Rivera: "Conferencias telegráficas", El Adelanto, $\mathrm{n}^{\circ}$ 7.722, 6 de agosto de 1909, p. 3; Alfredo Rivera: "conferencias telegráficas", El Adelanto, no 7.712, 7 de agosto de 1909, p. 3.
} 
debido a que "fuman habanos y comen con tenedor y tienen grandes elogios para la mujer y aspiran a diputados y a remedar a Prim"222.

En la segunda quincena de agosto, cuando las tropas españolas se disponían para el combate, se multiplicó en El Adelanto el número de noticias sobre la composición y el funcionamiento del harca. Su punto débil residía en que, puesto que cada combatiente debía proveerse a sí mismo, se desmoralizaban cuando los combates se prolongaban excesivamente ${ }^{223}$. Únicamente a finales de septiembre hallamos una estimación sobre su número: 14.000 rifeños integraban entonces el harca. De paso, el reportero señalaba que los Guelaya habían solicitado la colaboración de los Beni Urriguel, muy ensoberbecidos tras su victoria frente a El Rogui, pero sin éxito ${ }^{224}$. Más adelante, otra noticia, infinitamente más catastrofista señalaba que si todo el Rif se levantara en armas, los combatientes podrían sumar 70.000 infantes y casi 16.000 jinetes $^{225}$.

También a mediados de septiembre, y sólo a modo de ilustración, Ramiro Blanco señalaba que " $n i$ rastros hay en Marruecos de la gloriosa civilización árabe (...) Si algo conserva el pueblo es la barbarie de la Edad Media, en que parece haberse estancado" 226 . El mismo columnista reiteraba esta idea cuando, a los pocos días, deslegitimaba el pensamiento africanista de Joaquín Costa ${ }^{227}$ :

"Este ilustre publicista, con todo su notorio y reconocido talento, no puede convencer de que exista hoy ese estrecho vínculo, esa intima fraternidad hispano marroqui que se esfuerza en probar; no, cada pueblo ha ido por su lado, y no hay actualmente tal fraternidad, mal que pese a la historia, a la geografía y al cruce fisiológico. Cuanto más, podrá ser que España y Marruecos sean hermanos como lo sean dos hijos de un mismo padre, que habiendo recibido principios muy opuestos, resulten en la edad viril, el uno un caballero culto, educado e instruido, y el otro un gañán grosero e ignorante.

\footnotetext{
222 "Un Repórter": "Notas de un periodista. El Maimón y El Gato", El Adelanto, n $7.718,14$ de agosto de 1909 , p. 1. En otro artículo, en cambio, "Argos" manifestaba su desconfianza hacia ambos. Véase "Argos": "Madrid al día", El Adelanto, no 7.738, 7 de septiembre de 1909, p. 1.

223 "La campaña de África", El Adelanto, no 7.722, 19 de agosto de 1909, p. 2; "La campaña de África", El Adelanto, no 7.723, 20 de agosto de 1909, p. 2; "La campaña de África", El Adelanto, no 7.728, 26 de agosto de 1909, p. 2; "La campaña de África", El Adelanto, no 7.731, 30 de agosto de 1909, p. 2.

224 "La campaña de África", El Adelanto, no 7.753, 24 de septiembre de 1909, p. 2.

225 "La campaña de África", El Adelanto, no 7.764, 7 de octubre de 1909, p. 2.

${ }^{226}$ Ramiro Blanco: "Para El Adelanto. Porvenir de Marruecos", El Adelanto, no 7.748, 18 de septiembre de 1909, pp. 1-2.

${ }^{227}$ Esta deslegitimación del candoroso pensamiento africanista de Joaquín Costa no era algo novedoso. Véase MAURA GAMAZO, Gabriel: La cuestión de Marruecos desde el punto de vista español. Madrid: Imprenta de M. Romero, 1905, p. 49. La posibilidad de una pacífica convivencia entre españoles y rifeños fue un argumento prontamente rechazado por este político, pero Marruecos planteaba, inevitablemente, un problema de equilibrio para las potencias europeas y si España deseaba intervenir, requería la aquiescencia de la opinión pública. El camino para lograrla pasaba por dotar a la guerra en ciernes de un carácter defensivo. Unos planteamientos muy similares a los de Gabriel Maura (la tesis de Marruecos como frontera meridional y la acérrima defensa del proceder de Antonio Maura) también fueron sostenidos por CANALS, Salvador: Los sucesos de España en 1909. Crónica documentada. Madrid: Imprenta Alemana, 1911.
} 
Entre España y Marruecos existe hoy, no diré que un abismo moral, pero sí (valga el símil), una zanja profunda, un barranco, un vacío... algo difícil o imposible de salvar de un salto. Los españoles, por lo visto, no podemos mirar impasibles ese atraso de nuestros "parientes" y nos sentimos tocados del afán europeo de meternos en África, tanto para cumplir así una misión civilizadora como para impedir que por esa parte se deslice otra nación (también hermana o prima), poniendo en peligro nuestra seguridad e independencia ${ }^{, 228}$.

Sea como fuere, al adversario era preciso conocerlo muy bien para así combatirlo con mayor eficacia. Y los rifeños eran, ante todo, maestros en la guerra irregular. El elemento que más incertidumbre generaba entre los españoles era, como ya se habrá deducido, que se desconocía la cifra de combatientes, pues la composición del harca variaba a diario y los informes de los espías carecían de fiabilidad. El Ejército expedicionario había de procurar, por tanto, la ventaja en el empleo de la artillería ${ }^{229}$.

Precisamente, y porque resultó muy fructífero para la creación de un adecuado ambiente pro-bélico, constantemente El Adelanto utilizó y contrapuso al ardor rifeño el argumento de la superioridad tecnológica de nuestras tropas. En particular, se publicitaron los efectos terribles ocasionados por el empleo de los cañones Schneider ${ }^{230}$; y se reprodujeron bastantes cartas repletas de arrojo militar ${ }^{231}$.

De hecho, los héroes de la campaña, miles de soldados españoles, aparecieron siempre asociados a una infinidad de virtudes tales como el brío, la fuerza, la bravura, el patriotismo ${ }^{232} \ldots$ A punto de terminar la guerra, se aseguraba que "el soldado de infantería español es pequeño, muy a menudo endeble, pero es también muy varonil. No bebe por costumbre, es de ánimo alegre, y a causa de su pobreza está acostumbrado a comer poco. Lleva su equipo de 50 libras bien y con ligereza. Su constitución es generalmente buena" 233 .

Todos estos rasgos hallaron su más perfecta encarnación en un hombre: el famosísimo cabo Noval. A las páginas de nuestra historia pasaría como un icono de

\footnotetext{
${ }^{228}$ Ramiro Blanco: "Para El Adelanto. Porvenir de Marruecos", El Adelanto, $\mathrm{n}^{\circ}$ 7.749, 20 de septiembre de 1909, pp. 1-2.

229 "La campaña de África", El Adelanto, no 7.719, 16 de agosto de 1909, p. 2. En la misma noticia se comentaban las recientes agresiones rifeñas sobre la plaza de Alhucemas.

${ }^{230}$ Alfredo Rivera: "Conferencias telegráficas", El Adelanto, no 7.716, 12 de agosto de 1909, p. 3.

${ }^{231}$ El Adelanto sintió predilección por la correspondencia de los soldados aristócratas. Véase: "La campaña de África", El Adelanto, no 7.717, 13 de agosto de 1909, p. 2; "La campaña de África", El Adelanto, $\mathrm{n}^{\circ} 7.718,14$ de agosto de 1909, p. 2.

${ }^{232}$ Algo más atípica fue la imagen que la prensa proyectó de Ibáñez Marín, ya que a su talento militar se le unían sus inquietudes intelectuales. Véase Mariano Prestamero: "Los muertos de la guerra. El teniente coronel Ibáñez Marín", El Adelanto, nº 7.730, 28 de agosto de 1909, p. 2.

233 "De la campaña. Nuestro Ejército ante el extranjero", El Adelanto, no 7.806, 26 de noviembre de 1909, p. 2.
} 
aquellas sufridas tropas. Rivera, por descontado, rindió a su figura un sentido homenaje en el diario liberal salmantino ${ }^{234}$.

En cuanto a la oficialidad, el general Marina simbolizó el culmen de las virtudes castrenses. Además de los escritos laudatorios de "Juan de Salamanca", en El Adelanto también encontramos cartas muy elogiosas hacia el general. Por ejemplo, una remitida por un integrante del Estado Mayor a la redacción al finalizar agosto:

"Cuanto se diga del valor indomable del general Marina, es pálido ante la realidad (...) nunca he presenciado un caso de valor más sereno y de más imponderable heroísmo (...) La guerra esta es dura, amigo Mariano, y no todo han sido las gloriosas jornadas del 9 de julio y otras fechas. Pero tenga la seguridad de que con un general del temple de Marina, a quien las balas respetan con acatamiento, la victoria es nuestra y de la manera más gallarda ${ }^{, 235}$.

Del mismo modo, se llegaron a recoger, incluso, artículos de carácter encomiástico publicados en The Times y en The Daily Telegraph ${ }^{236}$.

El 16 de agosto, Rivera reprodujo la alocución patriótica que el general Marina dirigió a sus tropas. Y un día después se anunció la movilización de los excedentes de cupo de 1908 con el objeto de cubrir bajas ${ }^{237}$. El inminente avance generaba una enorme expectación en Melilla. Mientras, en el campo enemigo, El Chaldy seguía alimentando la propaganda guerrera contra España ${ }^{238}$. Un columnista anónimo disertaba sobre la solemnidad de la espera:

"El alma española está hoy preocupada y no puede apartar el pensamiento de aquella tierra de África en que 30.000 soldados españoles, ya preparados para el avance, se dispone a comprar la victoria a cualquier precio, pagándola, si es preciso, con torrentes de su sangre generosa (...) Hay que esperar y aconsejar calma y sosiego a la opinión; aconsejarla confianza en los que hoy tienen en sus manos el prestigio nacional ${ }^{3239}$.

\footnotetext{
${ }^{234}$ Alfredo Rivera: "Conferencias telegráficas", El Adelanto, no 7.928, 20 de abril de 1910, p. 3. Y algo muy similar también hallamos en El Lábaro, que además se reniega por la oposición de los socialistas ovetenses al homenaje que se le pretende tributar: "Información telegráfica", El Lábaro, no 3.733, 27 de julio de 1909, p. 3 (Prensa Asociada); "La duración de la guerra", El Lábaro, n 3.796, 11 de octubre de 1909 , p. 1.

235 "El heroísmo del general Marina", El Adelanto, no 7.729, 27 de agosto de 1909, p.2.

236 "La campaña de África", El Adelanto, no 7.749, 20 de septiembre de 1909, p. 2; "La campaña de África", El Adelanto, no 7.764, 7 de octubre de 1909, p. 2. Aunque también se atacó a la prensa extranjera que se regodeó en el desastre militar, "Juan de Salamanca": "La campaña de África", El Adelanto, no 7.708, 3 de agosto de 1909, p. 2.

237 "Los excedentes de cupo", El Adelanto, no 7.720, 17 de agosto de 1909, p. 1.

${ }^{238}$ Alfredo Rivera: "Conferencias telegráficas", El Adelanto, no 7.719, 16 de agosto de 1909, p. 3; Alfredo Rivera: "Conferencias telegráficas", El Adelanto, no 7.720, 17 de agosto de 1909, p. 3; Alfredo Rivera: "Conferencias telegráficas", El Adelanto, no 7.722, 19 de agosto de 1909, p. 3. El discurso íntegro de Marina se recoge en: "La campaña de África", El Adelanto, n ${ }^{\circ} 7.721,18$ de agosto de 1909.

239 "Esperanza patriótica", El Adelanto, n 7.723, 20 de agosto de 1909, p. 1.
} 
Para terminar, una última herramienta al servicio de la propaganda bélica que también esgrimió El Adelanto fue el simple recordatorio del Tratado de 1904. Porque bajo él latía la hipótesis del reparto territorial. Curiosamente, ahora se le prestó bastante más publicidad que en el momento de su firma; aunque ello tampoco requería desmesurados esfuerzos. Un redactor se refería al citado pacto como "Convenio fundamental que no es público. Claro está, que estos secretos cancillerescos, no son nunca tan absolutos que no permitan que un rayo de luz penetre en sus tinieblas (...) Podemos afirmar, sin temor de equivocarnos, que ese Tratado franco-español contiene toda la 'esencia' del problema marroqui",240.

El Lábaro no hizo un comparable hincapié en la atmósfera de preocupación entre los salmantinos. En su lugar, presentaba la situación melillense, a comienzos de agosto, bajo control y jamás pareció impacientarse ante el inicio de los avances militares. Al contrario, se deleitó explicando las increíbles ventajas comerciales que se derivarían del dragado de la Mar Chica ${ }^{241}$; y ofreció a sus lectores algún que otro artículo sobre las interioridades del $\mathrm{Rif}^{242}$. Obviamente, al igual que ocurría con $E l$ Adelanto, los rifeños salían muy mal parados en estas descripciones, mientras que a los reservistas se les atribuía una elevadísima moral y, sobre todo, enorme disciplina ${ }^{243}$. Uno de los editoriales más logrados, en este sentido, fue el de Gorgonio B. Jiménez:

"Con pocas ideas en el cerebro, pero con mucha fe en el corazón. Curtido el rostro y encallecidas las manos, pero limpia la conciencia (...) Fuerte y enérgico, como educado en el campo, en el ambiente de trabajo que vigoriza los músculos y entona los nervios.

Su vista no ha abarcado más horizontes que los limitadísimos de su pequeña aldea (...) ni su inteligencia se ha abierto a más nociones que a las sencillas máximas cristianas (...) No toma parte en luchas políticas: ignora la marcha de los sucesos en otras esferas más altas y elevadas que la suya (...) Pero es fuerte y honrado, y esto basta para que sea materia apropiable para los grandes sacrificios. Por eso, cuando llega del otero, cansado de la ruda tarea de domeñar la tierra, recibe la noticia de su próxima partida en defensa de aquella otra madre, tan cristiana y tan buena como la que le enseñó a orar, ni desmaya ni se abate; rechaza indignado la idea de su sustitución (...) y ni siquiera se para a discurrir si la ley que le arranca el calor de tanto cariño, puede en su enredada trama deshilacharse a favor de algún ser más privilegiado.

Él no ha nacido para discutir: ;le mandan y obedece!"244.

\footnotetext{
240 "La campaña de África”, El Adelanto, no 7.730, 28 de agosto de 1909, p. 2.

241 "Informaciones telegráficas", El Lábaro, no 3.736, 30 de julio de 1909, p. 3 (Prensa Asociada); “Informaciones telegráficas", El Lábaro, no 3.737, p. 3 (Prensa Asociada); "De la guerra", El Lábaro, no 3.756 , p. 1 .

242 "De la guerra. El Rif por dentro", El Lábaro, no 3.748, 13 de agosto de 1909, p. 1; Más tardío y referido a la riqueza agrícola del Rif, es "De la guerra", El Lábaro, no 3.762, 30 de agosto de 1909, p. 1.

243 "La prensa militar", El Lábaro, n' 3.737, 31 de julio de 1909, p. 2.

${ }^{244}$ Gorgonio B. Jiménez: "Un patriota”, El Lábaro, no 3.741, 5 de agosto de 1909, p. 1.
} 
Tenemos, por consiguiente, aquí el retrato perfecto de aquel tan deseable habitante metropolitano llamado a ser carne de gumia o de "paco". Parece difícil, además, no asociar esta figura a la de la oveja ingenua de Lippmann, desesperadamente necesitada de un pastor. Al inocente no había que explicarle el porqué de la guerra; el aldeano no tenía por qué ser convencido de nada; porque a él sólo le correspondía obedecer.

Pero acaso ¿encajaba esta descripción con la realidad salmantina? Defendemos que sólo de manera parcial. La actitud de los soldados salmantinos ante la contienda fue, ciertamente, de enorme resignación, pero, para entenderlo, no importan tanto las deficiencias educativas como las carencias informativas; carencias que coaccionaban a la opinión pública de la provincia. De hecho, y si bien no disponemos de datos para 1909, podemos asegurar que, a la altura de 1913, el porcentaje de reclutas alfabetizados de esta provincia era uno de los más elevados del conjunto nacional: la cifra ascendía al casi $91 \%$, lo que colocaba a Salamanca en el sexto puesto del ranking nacional, únicamente aventajada por Álava, Segovia, Santander, Burgos y Valladolid ${ }^{245}$. No obstante, también nos encontramos con la práctica ausencia de un discurso periodístico opositor; circunstancia agravada, además, porque la prensa local llegó con notables dificultades y tardanza a los habitantes del medio rural. Por todo ello consideramos que, para Jiménez, el residente capitalino era el único destinatario del anterior mensaje: se le intentaba persuadir, frente a los posibles efectos nocivos de la propaganda obrera, de la necesidad de una férrea disciplina de combate para ganar la guerra. Pero, por contraste, el redactor mostraba fe ciega en la obediencia del aldeano.

Ahora bien, ¿se dejaría el mozo salmantino arrastrar por la conducta tan ejemplar del aldeano? Más adelante, en el próximo capítulo, lo veremos.

A medida que avanzaban los preparativos militares, el periódico católico inició una campaña de ensalzamiento de la Iglesia y de su fe en la consecución del triunfo. Por eso, "Munio" escribió:

"Cuando azota la guerra, la Iglesia pone en boca de sus sacerdotes oraciones propias para intermediar con Dios y pedirle el triunfo de la justicia, la victoria de las armas, la luz de la paz, armando nuestros brazos y nuestros espíritus con el poder de la fe y de la esperanza (...) Orar por los muertos en la campaña. Pedir a Dios el triunfo, la victoria, la paz, ${ }^{246}$.

\footnotetext{
${ }^{245}$ QUIROGA VALLE, María Gloria: El papel alfabetizador del Ejército de Tierra español (1893-1954). Madrid: Ministerio de Defensa, 1999, p. 82.

246 "Munio": "De cada día. ¡Te rogamos, oh, señor!”, El Lábaro, n 3.749, 14 de agosto de 1909, p. 2.
} 
Con el mismo propósito, algunos días después, se reproducía la conferencia pronunciada por el doctor Maestre, además de senador conservador, en el Círculo Militar de Cartagena. Éste divagaba sobre el carácter santo de la contienda y su papel como elemento revitalizador a lo largo de toda la historia de España ${ }^{247}$. Además, anticipaba que Zeluán era el objetivo de la campaña, ya que Melilla no ofrecía buenas condiciones como puerto exportador, pero, en cambio, la Mar Chica, fácilmente controlable desde esa posición, sí que lo permitía ${ }^{248}$.

El Castellano también defendió, aunque empleando un tono más frío, la figura de Marina. Por de pronto, el corresponsal Gándara se ocupó de refutar las críticas ultra pirenaicas contra su habilidad estratégica ${ }^{249}$.

Más que un sentimiento de zozobra suscitado por el próximo inicio de las operaciones, lo que se percibe a través de sus páginas es mucho desasosiego por el retraso en el mismo. Diríase que la redacción pretendía despertar suspicacias entre los lectores. Desde principios de agosto, el avance se consideró inminente. Un indicio inconfundible era que el gobierno había recrudecido la censura sobre las noticias llegadas de Melilla ${ }^{250}$. Por eso, los editoriales que en este rotativo se publicaron en aquellas fechas fueron absolutamente reveladores de ese estado de opinión entre enloquecido y asfixiante. He aquí uno de ellos:

"La nación está pendiente del cable que une a la península con el continente africano. España quiere saber a todas horas, en cada momento, qué es lo que ocurre y qué es lo que puede ocurrir en Melilla; iy cómo no, si tiene allí puesto el corazón y el alma entera!

Grande es la ansiedad que se siente por recibir noticias que anuncien o confirmen el avance de nuestras tropas dentro del campo moro, porque la nación está cansada de esta guerra defensiva (...) nosotros necesitamos tomar la ofensiva (...) Pero mayor interés que en conocer el avance del Ejército español, debemos mostrar en poseer la certidumbre de que al avanzar, nuestras tropas no han de tener que retroceder ni un paso (...) Para ello es preciso saber si el general Marina cuenta con todos los elementos indispensables (...) Un periódico acreditadísimo por la seriedad con que trata los asuntos de la campaña, ha interpretado una de las frases contenidas en la célebre orden de la plaza dirigida a las tropas por el esforzado general en un sentido que engendra fundados temores (...) Hay que creer que al general Marina no le faltan ni uno solo de los elementos que ha juzgado precisos ${ }^{, 251}$.

Y al día siguiente, el 18 de agosto de 1909, el mismo corresponsal volvía a la carga y manifestaba cuál era el sentir unánime del país: “Claro es que siente el natural

\footnotetext{
247 "De la guerra. Conferencia notable", El Lábaro, no 3.753, 19 de agosto de 1909, p. 1.

248 "De la guerra. Conferencia notable", El Lábaro, no 3.755, 21 de agosto de 1909, p. 1.

${ }^{249}$ Gándara: "Conferencias telegráficas", El Castellano, no 1.509, 3 de agosto de 1909, p. 1. Y, muy oportunamente, denunció la práctica de contrabando en la misma sección.

250 “Correo de Madrid", El Castellano, no 1.563, 18 de agosto de 1909, p. 1.

251 "Esperando el triunfo", El Castellano, no 1.564, 19 de agosto de 1909, p. 1.
} 
anhelo, la obligada impaciencia de quien espera el cumplimiento de una promesa y la satisfacción de un ardiente deseo" ${ }^{252}$. El nerviosismo popular estaba, a su juicio, absolutamente justificado por dos razones: la orden dictada por el general Marina el 14 de agosto apuntaba a que el avance era ya una realidad. Además, la tregua en el envío de refuerzos peninsulares también constituía un indicio de que en Melilla ya estaba todo dispuesto para la ofensiva. Consecuentemente, el gran interrogante del columnista era porqué las operaciones se estaban retrasando. Y él mismo intentaba, acto seguido, plantear una respuesta: por una parte, las explicaciones emanadas desde las esferas gubernamentales sobre la necesidad de esperar al dragado de setenta toneladas de arena de la Mar Chica le parecían pueriles ya que consideraba innecesaria la intervención de buques de gran calado en esta guerra.

Pero había otra posible justificación, un rumor, que le enervaba: "Que no se hable de combinaciones diplomáticas, de conveniencias de política europea, de obstáculos de cancillería, porque con nada de esto puede armonizarse el honor de nuestro Ejército (...) Son las armas, son los soldados y no las cancillerías ni los diplomáticos los que tienen que resolver la cuestión de Marruecos".

¿Qué ocurría? En efecto, como reguero de pólvora se había extendido la noticia de que Hafid había enviado una misión diplomática al Rif para que interviniese como mediadora entre las cábilas rebeldes y las autoridades militares españolas ${ }^{253}$. La Correspondencia Militar entendió que, en estas circunstancias, el avance ya no se efectuaría. El rumor llegó a todos los rincones del país. Así que el gobierno tuvo que salir del paso presentando el avance como imprescindible para garantizar el orden en el campo de Melilla. Maura, además, manifestó ante los periodistas que 16.000 soldados se hallaban en pie de guerra en el Campo de Gibraltar y en Málaga, preparados para cualquier imprevisto tanto en Melilla como en Ceuta.

El 25 de agosto, toda esa inicial ansiedad se había convertido en desesperación. El aplazamiento indefinido de las operaciones en el Rif caía como un jarro de agua fría en ese redactor de El Castellano:

"Ya no es la apretura del canal de Mar Chica por lo que se espera, ni por el envío de camellos que transporten la impedimenta, ni por la habilitación de vagones blindados, ni por la llegada de mayores refuerzos (...) Más terrible que la espera sería la duda; pero ese largo esperar es de donde sacamos, es el que precisamente alimenta y sostiene nuestra confianza ${ }^{, 254}$.

\footnotetext{
252 “¿Quién retrasa el avance?”, El Castellano, no 1. 565, 20 de agosto de 1909, p. 1.

253 "Correo de Madrid", El Castellano, no. 1567, 23 de agosto de 1909, p. 1.

254 “Aplazamiento largo", El Castellano, no 1.569, 25 de agosto de 1909, p. 1.
} 
A decir verdad, el autor de este escrito terminaba resignándose; y concluía que lo que el general Marina precisaba para garantizar el éxito eran más soldados. Paradójicamente, no hacía tanto, este diario había reprochado a Maura el que redujese sus obligaciones al envío de más y más tropa.

Ya para terminar con este epígrafe, creemos que la redacción de El Salmantino fue la que más se esmeró a la hora de llamar a la opinión pública salamantina al desquite. Lo que, de ninguna manera, significó obviar la responsabilidad de Maura por la situación creada en Melilla:

"Más que una zona perteneciente a una nación organizada, es un país que goza de perfecta independencia (...) Son aquellos rifeños de carácter fiero e indomable (...) ¿Cómo podía, pues, esperarse que sucediese otra cosa que la ocurrida estos últimos días? (...) Hemos de reconocer que si una nación pretendiera invadir nuestro territorio con propósito de ensanchar las posesiones suyas que con éste limitaban, hallaría seguramente tenaz resistencia antes de conseguirlo. Queremos decir con esto que era preciso estar muy obcecados para no prever lo que habia de sucedernos ${ }^{, 255}$.

Evidentemente, la tesis de la provocación también flotaba en la redacción de este periódico. Sin embargo, responsable no era lo mismo que culpable: no, al menos, ante los ojos de El Salmantino. Por eso el columnista inmediatamente trataba de reorientar su argumentación:

"Llegadas ya las cosas al punto en que se encuentran, debe abandonarse toda lamentación, que a la postre, resultaría estéril; y pensar solamente que nuestros soldados se encuentran ya en la dura necesidad de batirse con un pueblo guerrero y temerario (...) Nada de sensiblerías, ni de lágrimas mujeriles: ante la tribulación debemos presentarnos serenos y unidos, rechazar con valor toda contrariedad. Tiempo habrá de acusar, si alguno se merece ser acusado. Hoy es tiempo de callar”.

Al referirnos a este periódico debemos partir, antes que nada, de una doble consideración: su carácter semanal justifica la tardanza en la transmisión de noticias; pero, además, éste se incrementa por su escrupuloso acatamiento de la censura. Nos encontramos, por lo tanto, ante un rotativo que se nutre de telegramas oficiales, no de rumores vertidos en otros órganos de prensa.

Para prender la llama de la venganza entre sus lectores, la redacción jugó con ambos elementos: cuando en un mismo número había que dar cuenta de varios hechos de armas, unos victoriosos y otros adversos, sistemáticamente los reporteros se volcaron en la glorificación de los primeros y en la disculpa de los segundos. Así se lograba una

255 "Lo de Marruecos", El Salmantino, n 93, 24 de julio de 1909, p. 3. 
imagen global optimista sobre el desarrollo de los acontecimientos rifeños. Tenían la habilidad de diluir el efecto catastrófico de las derrotas.

Para empezar, el 31 de julio, después de que las tropas españolas pudiesen ahuyentar a los cabileños que operaban desde el Gurugú y reforzar las guarniciones de La Restinga y Cabo de Agua, "R. R." abría el ejemplar en cuestión incitando a sus lectores a la represalia $\mathrm{y}$, a la par, dirigía grandes encomios hacia las tropas combatientes. Su crónica ocupaba tres extensas columnas, algo bastante excepcional, desmesurado, para referirse a una acción puramente defensiva. En cualquier caso, efectivamente, ésta era la noticia más reciente:

"Se dice que hay a toda costa que continuar y acabar la guerra cuanto antes; pero no sin dejar durísimamente escarmentados a los rifeños, temerosos de España para siempre; no sin haber hecho pagar cara a los enemigos la sangre y las lágrimas derramadas; no sin habernos indemnizado con toda la largueza que sea posible, y sobre todo, no sin haber recabado garantías suficientes de que jamás volverán a las andadas las tribus vecinas de Melilla.

Así debió pensarse desde el principio, y escribirse desde el principio. No se hizo y no hay que extrañarlo: una guerra, tras las de Melilla del 93 y la de Cuba del 98, podía muy bien turbar a los más serenos, sobre todo si son meridionales y nerviosos.

Afortunadamente (...) la raza persiste, y en hechos y episodios de los soldados de hoy y de la campaña de hoy reaparecen los soldados y las proezas de los que fueron a Orán con Cisneros, o a Túnez con Carlos V, o a Lepanto con don Juan de Austria.

¡Loor a las tropas españolas, al Ejército que es el de siempre, al uniforme que parece tener la virtud de arrancar la costra libertaria y no puede cubrir bajo sus paños sino el viejo infanzón de los antiguos terciarios! "256.

Sin embargo, el relato de lo ocurrido en el Barranco del Lobo, el primero que ofrecía este periódico, se ubicaba en la segunda página. Lógicamente, la derrota militar ya se conocía en Salamanca; con lo que pudiera ser comprensible que no mereciese la primera plana. Pero sí sorprende, en cambio, que tampoco mereciese ningún comentario de la casa. Sencillamente se insertaban los telegramas oficiales, que abundaban en episodios heroicos. Los momentos más dramáticos se obviaban o, como mucho, se glosaba alguna "muerte gloriosa".

El efecto final era evidente: se presentaba a un Ejército español muy fuerte y merecedor de la completa adhesión ciudadana. Además, durante los días siguientes, este periódico insertó los relatos de muchos testigos de las batallas. Éstos aludían, habitualmente, a episodios menores, incluso anecdóticos, protagonizados por los

256 "R. R.”: “A la hora de ahora”, El Salmantino, no 94, 31 de julio de 1909, p. 1. 
siempre animosos soldados españoles y contribuyeron a fomentar ese ambiente de histerismo bélico que este periódico deseaba y el gobierno necesitaba ${ }^{257}$.

Idéntica intención latía en un editorial de A. Rubio Polo, publicado el 14 de agosto. Se volcaba también el autor en la tarea de mostrar la grandeza del soldado español. Pero iba más allá: al hilo de los acontecimientos marroquíes y barceloneses, presentaba al Ejército y también a la Iglesia como las esencias patrias:

"Mientras nuestro bravo Ejército, mientras los hijos de la leyenda medieval combaten en el suelo africano, defendiendo en épicas jornadas la bandera española, con los fueros de su Dios y de su patria, la canalla atea, los cobardes asesinos revolucionarios levantan sus pendones y combaten contra la Iglesia, contra la patria y el Ejército.

$Y$ hay que confesarlo, el clero y el Ejército son los fundamentos de nuestra nacionalidad (...) Pero ved cómo los enemigos de Dios son los enemigos de nuestras instituciones seculares... La prensa francesa, inspirada en el odio al pueblo español, genuinamente cristiano, clama y reprocha y escarnece al soldado ibero, y a sus mentiras y calumnias hay que contestar con el desprecio ${ }^{, 258}$.

Aunque, de hecho, los comentarios de la prensa francesa no siempre nos fueron adversos. Por este motivo, pudieron ser instrumentalizados por El Salmantino. Al periódico tradicionalista local, más que a ningún otro, le preocupaba enormemente la imagen que las cabeceras europeas estaba difundiendo sobre España.

Así, en el número del 7 de agosto de 1909, cuando aún estaba muy vivo el recuerdo del calamitoso Barranco del Lobo y de la Semana Trágica, el rotativo integrista contemporizaba con los ataques germanos hacia nuestros tratados con la Entente y compartía su rechazo hacia la figura del presidente mallorquín, presentado como un títere de la política francesa (porque el periódico germano presumía que esta guerra iba a desacreditar a España en el Rif y consecuentemente, allanar el camino a Francia para dominar el Magreb). De la prensa inglesa, en cambio, se reproducía un comentario favorable al gobierno de Maura, pero sólo mientras castigase con enorme contundencia a los rifeños. En relación, por último, a los periódicos franceses, que eran los más extensamente analizados, se recogía la enorme preocupación de éstos por la seguridad de Argelia. En todos los fragmentos que se reproducían, España aparecía como un país asolado por guerras intestinas, amenazado por una revolución socialista y totalmente desorientado en materia internacional ${ }^{259}$.

\footnotetext{
257 "Los sucesos de Melilla y Barcelona", El Salmantino, no 94, 31 de julio de 1909, p. 2; "M. A.”: "El soldado español", El Salmantino, no 95, 7 de agosto de 1909, p. 1; "La campaña de Melilla. Una escaramuza", El Salmantino, no 95, 7 de agosto de 1909, p. 5.

${ }^{258}$ A. Rubio Polo: "De actualidad", El Salmantino, n' 96, 14 de agosto de 1909, p. 1.

259 “Marruecos", El Salmantino, no 95, 7 de agosto de 1909, p. 2.
} 
Junto con su acendrado militarismo, la exacerbación del nacionalismo antifrancés fue una baza segura, por su eficacia, para el discurso propagandístico de $E l$ Salmantino. Bajo esta estrategia latía la conocida tesis de que Marruecos constituía nuestra garantía de independencia ante Francia.

También el general Marina, como no podía ser de otro modo, mereció el mayor respeto y admiración entre la redacción integrista. Al hilo de su alocución a los soldados, el periódico rememoraba la victoria alcanzada en la campaña de 1859-1860 y soñaba con otra similar. La nostalgia también era un recurso útil para estos "heraldos del hierro":

"Confiamos que ahora será también con nosotros, y sin participar de los arrebatos legendarios de algunos, ni de los contraproducentes pesimismos de otros, creemos que nuestra misión en Marruecos es muy digna, y repetimos lo que hace un año decíamos en este semanario.

'Ni Quijotes ni Sanchos. Españoles'

Respecto a los planes de campaña, hácense mil conjeturas y suposiciones, que no pasan de atisbos proféticos.

Lo único que parece acordado como base de los mismos es la conquista del Gurugú, ${ }^{, 260}$.

En conclusión, El Adelanto recurrió a la propaganda de guerra empleando, fundamentalmente, como banderín de enganche ante la opinión pública salmantina el argumento de la misión civilizadora de los españoles en Marruecos. Mientras, El Lábaro prefirió insistir en el carácter santo y revitalizador de la contienda. El Castellano, por su parte, se dedicó a sembrar la duda sobre la capacidad técnica del Ejército español, forzado a retrasar el avance sin conocerse muy bien los motivos. Finalmente, El Salmantino mostró su adhesión incondicional hacia las tropas y no escatimó en censuras contra los franceses. Estrategias, en suma, muy distintas, pero con un idéntico propósito: llamar al desquite entre la opinión pública salmantina.

\section{El avance militar español}

Desde el 20 de agosto, Rivera empezó a reseñar, muy brevemente, los continuos escarceos habidos en el campo de Melilla. Su tono no era ni alarmista ni épico; sino bastante neutro. No obstante, las noticias llegaban con tal lentitud que la ansiedad pública alcanzó cotas inimaginables ${ }^{261}$. Así por ejemplo, el 25 de agosto reinaba una

\footnotetext{
260 “Crónica hebdomadaria”, El Salmantino, no 97, 21 de agosto de 1909, p. 3.

${ }^{261}$ Alfredo Rivera: "Conferencias telegráficas", El Adelanto, no 7.734, 21 de agosto de 1909, p. 3; Alfredo Rivera: "Conferencias telegráficas", El Adelanto, no 7.725, 23 de agosto de 1909, p. 3; Alfredo Rivera: "Conferencias telegráficas", El Adelanto, n ${ }^{\circ}$ 7.726, 24 de agosto de 1909, p. 3; Alfredo Rivera: "Conferencias telegráficas", El Adelanto, no 7.729, 27 de agosto de 1909, p. 3.
} 
enorme agitación en todo el país, según comentaba Rivera, porque se había propagado el rumor del avance decidido sobre el Gurugú ${ }^{262}$.

Y, en efecto, dos días después, el día 27 se notificaba la toma del Zoco El Arba. La buena nueva se intentaba aprovechar, muy interesadamente, para infundir calma entre la opinión ${ }^{263}$.

Del $A B C$ se tomaban, sin embargo, las declaraciones de un oficial sobre las dificultades existentes para un avance rápido de las tropas. La razón fundamental de la tardanza residía en la pesadísima indumentaria con la que se desplazaban los soldados, forzados a cargar con víveres, armas y municiones, vestuario de repuesto, bolsa sanitaria... Pero el esfuerzo merecería la pena y el público no debiera impacientarse porque, tal y como concluía el redactor:

"Si la guerra se hace en mangas de camisa, se come y se bebe donde se puede (y en el caso presente no hay de qué comer ni beber en parte alguna, como no se lleve), se tira hasta que se acaba la cartuchera, y se echa luego mano a la navaja o se ponen los pies en polvorosa, sobran todas las cargas, todas las municiones y todo plan de operaciones, aunque las consecuencias sean que la potencia militar de un país quede a la altura de las hordas rifeñas que de esta manera se baten ${ }^{\text {,264. }}$.

Gracias a artículos de este tipo, los salmantinos podían atisbar el tipo de guerra que se desarrollaba en el Rif.

Otro argumento para llamar a la tranquilidad fue el relato sobre la marcha de las conversaciones con la embajada marroquí. No hay que olvidar este asunto, pues Allendesalazar seguía laborando en el terreno diplomático. El 4 de septiembre, se anunciaba, o eso creía la redacción de El Adelanto, un cambio en la actitud de Muley Hafid hacia posturas más conciliadoras que las previas al estallido del conflicto:

"Según aseguran personas que están bien informadas de cuanto ocurre en el curso de las negociaciones, el Sultán de Marruecos está dispuesto a acceder a cuanto nuestro gobierno con justicia desee, antes de llegar a un rompimiento en la cordialidad de relaciones, que ahora, más que nunca, quiere mantener y estrechar con decidido empeño nuestro excelente amigo Muley Hafid. Asegúrase, por tanto, que ya no habrá dificultades para que España conserve definitivamente las posiciones ocupadas en Mar Chica y Cabo de Agua, así como las que creamos conveniente ocupar desde el Muluya hasta el Cabo Tres Forcas, para asegurar nuestra dominación en aquella parte del Rif $^{, 265}$.

Sin embargo, al finalizar el mes, el mismo periódico volvía a reconocer que Hafid, bajo ningún concepto, admitía la ocupación del Cabo de Agua y Mar Chica. Sus

\footnotetext{
${ }^{262}$ Alfredo Rivera: “Conferencias telegráficas”, El Adelanto, no 7.727, 25 de agosto de 1909, p. 3.

263 Alfredo Rivera: “Conferencias telegráficas”, El Adelanto, no 7.729, 27 de agosto de 1909, p. 3.

264 "La campaña de África", El Adelanto, no 7.726, 24 de agosto de 1909, p. 2.

265 "La campaña de África”, El Adelanto, no 7.736, 4 de septiembre de 1909, p. 2.
} 
protestas, de hecho, se concretaban contra la posesión de las minas de Beni-bu-Ifrur; demandaba la salida de las tropas españolas del campo de Melilla; censuraba sus inmotivados ataques en Quebdana; recriminaba el envío de más tropas de Ceuta y el ataque a ciertas posiciones de Anyera ${ }^{266}$. El Adelanto, en días venideros, intentó suavizar la situación e insistió en que nada tenía que ver la voluntad del Sultán con la marcha de las negociaciones entre su embajada y Allendesalazar. Éstas se desarrollaban, se aseguraba, en términos muy amistosos ${ }^{267}$.

A lo largo de septiembre, las impresiones que se obtuvieron de las operaciones fueron muy optimistas. Por eso mismo abundaban los relatos anecdóticos y repletos de entusiasmo: se elogiaba el heroísmo de Aguilera y del coronel Larrea; la valentía de los generales Tovar y Sotomayor; había espacio para la descripción de la Mar Chica y el Cabo de Tres Forcas; alegría por el desarrollo de la batalla de Addara; entusiasmo ante la toma de Nador y Zeluán ${ }^{268}$... y alguna que otra disertación en materia de estrategia. Así, Benigno Pallol señalaba:

"El avance hasta Tres Forcas, el avance hasta el monte Tauima comprende una línea muy extensa y es a modo de dos brazos que pudieran abarcar el Gurugú (...) Si la acción política pudiera ser algún día motivo de censura, la acción militar, entonces y siempre, será digna de aplauso. Ella lo ha improvisado todo en el transcurso de dos meses; y, asegurando una serie de posiciones a lo largo del mar, donde los rifeños, por faltarles buques, no tienen señorío, ha logrado afianzar al Ejército para que, sin temer a sus enemigos por la espalda en toda la línea de posiciones, pueda emprender el avance con pocos soldados, 269 .

Como cabía esperar, todos estos avances ejercían un efecto demoledor sobre los combatientes rifeños: las deserciones se multiplicaban entre los moros, a la vez que se insistía en que el espíritu de las tropas españolas era excelente. El Adelanto se complacía ante estas noticias y aprovechaba para felicitarse por los rápidos y útiles

\footnotetext{
${ }^{266}$ Alfredo Rivera: “Conferencias telegráficas”, El Adelanto, no 7.753, 24 de septiembre de 1909, p. 3. 267 "La protesta del Sultán”, El Adelanto, no 7.758, 30 de septiembre de 1909, p. 1.

${ }^{268}$ Alfredo Rivera: "Conferencias telegráficas”, El Adelanto, no 7.732, 31 de agosto de 1909, p. 3; "La campaña de África", El Adelanto, no 7.733, 1 de septiembre de 1909, p. 2; Alfredo Rivera: "Conferencias telegráficas", El Adelanto, no 7.734, 2 de septiembre de 1909, p. 3; "De la guerra. La batalla de Addara", El Adelanto, no 7.735, 3 de septiembre de 1909, p. 1; Alfredo Rivera: "Conferencias telegráficas", El Adelanto, $\mathrm{n}^{\mathrm{o}}$ 7.737, 6 de septiembre de 1909, p. 3; Alfredo Rivera: "Conferencias telegráficas", El Adelanto, no 7.739, 8 de septiembre de 1909, p. 5; "Argos": "Madrid al día", El Adelanto, no 7.740, 9 de septiembre de 1909, p. 3; "La campaña de África", El Adelanto, no 7.742, 11 de septiembre de 1909, p. 4; Alfredo Rivera: "Conferencias telegráficas", El Adelanto, no 7.752, 23 de septiembre de 1909, p. 3; "Argos": "Madrid al día", El Adelanto, no 7.755, 27 de septiembre de 1909, p. 1; Alfredo Rivera: “Conferencias telegráficas”, El Adelanto, no 7.755, 27 de septiembre de 1909, p. 3; "Toma de Zeluán. Los moros abandonan el Gurugú", El Adelanto, no 7.756, 28 de septiembre de 1909, p. 3; "La campaña de África", El Adelanto, no 7.757, 29 de septiembre de 1909, p. 2; Alfredo Rivera: "Conferencias telegráficas", El Adelanto, no 7.757, 29 de septiembre de 1909, p. 3; "Manifestaciones del señor León y Castillo", El Adelanto, n $7.758,30$ de septiembre de 1909, p. 1.

${ }^{269}$ B. Pallol: “Crónica. La guerra y la corte”, El Adelanto, no 7.752, 23 de septiembre de 1909, p. 1.
} 
servicios prestados por Alfredo Rivera ${ }^{270}$. No por casualidad, era ahora, al celebrarse la toma de El Arba, Aograz, Benisicar, Nador y Zeluán, cuando se publicaron algunos de los editoriales con mayor ardor patriótico:

"Los soldaditos españoles han curtido sus cuerpos con el sol africano, y sus almas, con el ansia de gloria; han puesto la primera piedra del edificio que han de levantar a la patria grande y gloriosa sus hijos, y la bandera augusta que civilizó América y convirtió en naciones las tribus, flota enhiesta en las lomas rifeñas y es símbolo de la cultura y del progreso que, de la mano de España, penetrarán en las salvajes regiones donde no hubo, hasta ahora, ni más ley que la fuerza, ni más vida que la primitiva. ¿Qué lejanos y esfumados aparecen, para dicha de todos, aquellos primeros días de la guerra en que el patriotismo parecía eclipsado momentáneamente, y en que las convulsiones interiores semejaban cantos funerales dirigidos al cadáver de España!',271.

Procurando ese acercamiento entre el lector y la guerra, buscando una implicación personal, se espoleaba, previsiblemente, el sentimiento patriótico entre la opinión pública salmantina:

"Siempre es curioso saber cómo vive el soldado en campaña, y cuando vive bien, es para el periodista muy satisfactorio el comunicarlo, porque ha de agradar a millares de familias.

En este campamento se toca diana a las cinco. En un minuto está el Ejército en pie, pasando fácilmente del reposo del sueño a la actividad de la vida de campaña.

A poco de levantarse se acomete la labor de cuartel, cuyo relato omito por ser sabido de todos.

Diariamente van las tropas al baño, mientras las parejas de caballería hacen la acostumbrada descubierta.

Cumplido ese precepto de higiene, se organiza la columna de reconocimiento, que hace el obligado paseo militar del día, con el que se consiguen dos fines: movilizar constantemente a las tropas y vigilar la extensión del campamento y los aduares amigos.

Entre diez y once se sirve un abundante rancho, con mucha carne, repetido entre cinco y seis de la tarde con la misma abundancia y suculencia.

Los víveres abundan, porque además de los que traen los convoyes, los moros de Quebdana, que nos son afectos, acuden todos los días con aves, huevos, leche y otros artículos alimenticios vendidos a moderado precio.

Los sargentos compran cuantas gallinas pueden, sacrificándolas en riquísimas paella, bien rociadas con vino -no en la cacerola, sino en el estómago-. Y los oficiales se procuran, cuando es posible, latas de conserva, que es lo que diferencia su plato del de los sargentos, porque la buena paella y el sabroso estofado están allí a la orden del día. El desayuno de la tropa en general es el café, y al acostarse la copa de ginebra, reguladora de la digestión y reconfortante en sumo grado.

A las nueve, con el toque de silencio se interrumpe la vida de campaña hasta rayar el día siguiente.

Tal es la vida del soldado en este campamento",272.

\footnotetext{
${ }^{270}$ Alfredo Rivera: "Conferencias telegráficas", El Adelanto, no 7.753, 24 de septiembre de 1909, p. 3; Alfredo Rivera: "Conferencias telegráficas", El Adelanto, no 7.754, 25 de septiembre de 1909, p. 3; "La Guerra de Melilla y nuestros telegramas", El Adelanto, no 7.757, 29 de septiembre de 1909, p. 1.

271 "Resurgimiento", El Adelanto, no 7.757, 29 de septiembre de 1909, p. 1.

272 "La campaña de África", El Adelanto, no 7.743, 13 de septiembre de 1909, p. 4.
} 
Estos relatos "costumbristas" no coincidían en nada con el retrato que, a posteriori, efectuarían Arturo Barea o Ramón J. Sender. Y si bien es cierto que el empleo de sus obras literarias como fuente histórica no deja de entrañar algunos problemas, tampoco se puede silenciar que gracias a ellas conocemos con bastante detalle aspectos tales como la picaresca empleada por los soldados para eludir el combate, su caracterización física y procedencia regional, el hambre y la ignorancia como rasgos comunes, las novatadas, etc ${ }^{273}$.

En los blocaos, el tedio era el sentimiento imperante, sólo interrumpido por los ocasionales "paqueos" - el ruido provocado por los fusiles de los francotiradores rifeños- y por el pánico que se imponía en las marchas, que por otro lado se realizaban en unas circunstancias extenuantes. En los campamentos de primera línea del frente, aunque las comodidades eran mayores, el sueño siempre era dificultado por los cambios de guardia, los mosquitos, las ratas, los aullidos de los chacales, los crujidos de los catres del burdel ambulante, los insultos rifeños... Los demonios del hambre y, sobre todo, la sed dominaban las vidas de estos hombres. Únicamente servía como distracción la lectura del correo, mientras que el juego, el alcohol y el sexo se convertían para muchos en obsesiones.

Apenas disponían de ropa o calzado apropiados. Por descontado, la tropa no se bañaba a diario. Las condiciones higiénicas de los campamentos eran deplorables -todas las mañanas la tropa se entretenía "leyendo el periódico" que era como se conocía a la tarea de despiojar la ropa- y todo ello, evidentemente, se reflejaba en el alarmante número de enfermos. Para colmo de males, con la salvedad de los hospitales de la Cruz Roja, todos los restantes se hallaban en condiciones precarias. Ante esta realidad, se comprende perfectamente el odio hacia el servicio militar, el funcionamiento de muchas “agencias de deserción” y el bajísimo estado moral de las tropas ${ }^{274}$.

\footnotetext{
${ }^{273}$ La trilogía de novelas más citada para acercase a la vida del soldado raso en el Rif y a picaresca empelada para eludir el combate es: BAREA, Arturo: La forja de un rebelde, Vol. II. La Ruta. Barcelona: Debate, 2000; SENDER, Ramón J.: Imán. Barcelona: Destino, 2001; y DÍAZ FERNÁNDEZ, José: El blocao. Madrid: Viamonte, 1998.

Una clasificación muy exhaustiva de la narrativa española de tema marroquí (atendiendo a la evolución desde planteamientos exotistas hasta posicionamientos anticolonialistas) puede hallarse en LÓPEZ GARCÍA, David: El blocao y el oriente: una introducción al estudio de la narrativa del siglo XX de tema marroquí. Murcia: Universidad de Murcia, 1994. Con un criterio de ordenación cronológico, LÓPEZ BARRANCO, Juan José: El Rif en armas. La narrativa española sobre la guerra de Marruecos (1859-2005). Madrid: Marenostrum, 2006.También puede consultarse VARGAS GONZÁLEZ, Alejandro: La guerra de Marruecos en la literatura. Málaga: Algazara, 2001; y GONZÁLEZ PÉREZ, Bernardino: Narrativa española en torno a la guerra de Marruecos. Tesis doctoral microfilmada, Universidad de Oviedo, 1992.

${ }^{274}$ BALFOUR, Sebastian: Abrazo mortal... Op. Cit., pp. 415-435.
} 
La dura vida en campaña, ya sin edulcorantes, sirvió, por otra parte, como caldo de cultivo para una nueva mentalidad africanista. Y algo se podía intuir, en este sentido, en la prensa salmantina: "El peligro creó nuevos lazos de cariño para los que ya eran hermanos en ideales (...) Una unión, un afecto tan sincero, sólo al calor de la guerra puede incubarse ${ }^{, 275}$.

Aunque quien más abundó en este asunto fue el conocidísimo Ruiz Albéniz, que ocasionalmente colaboró con El Adelanto. Rápidamente se percató, sobre todo, del significado que la nueva guerra adquiría para la oficialidad:

"Es natural, es lógico el decir que la noticia de la guerra con el Rif fuera objeto de grandes regocijos entre la oficialidad de nuestro Ejército. España, el pueblo, con las injusticias hijas de su dolor por los desastres coloniales, había perdido la confianza, el afecto que siempre tuvo en el Ejército. Un ambiente hostil se había formado después de nuestras últimas guerras contra el Ejército, como si él fuese culpable de toda aquella serie de calamidades que sobre nuestra patria cayeron (...) Para la oficialidad de nuestro Ejército fue el día 9 de julio día de inmenso regocijo. En esa guerra estaba su rehabilitación, estúpidamente puesta en duda; en ella estaba su honor, su prestigio, su personalidad toda ${ }^{, 276}$.

Sin duda, lo más interesante de este editorial era que no se hallaba exento de un mínimo contenido crítico: "Para la oficialidad del Ejército del Rif ha sido esta campaña un éxito, aun cuando se cuidaron más de demostrar su valor personal que su habilidad militar (...) Otra culpa cabe en la oficialidad, que ni es grave ni deja de ser disculpable: su impaciencia. También algún día se hablará de esto". Aunque, finalmente, Ruiz Albéniz reconocía su heroísmo, justificado, sobre todo, por las difíciles circunstancias en que se movían: “Llevaron en contra nuestros oficiales, primero, la falta de confianza en el soldado; después, el desconocimiento del terreno y la salvaje ligereza del enemigo, que le daban centuplicadas sus fuerzas".

Finalmente, la alegría se desbordó al telegrafiarse, a bombo y platillo, la toma del Gurugú ${ }^{277}$. Rivera le dedicó a este acontecimiento, de hecho, una plana al completo $^{278}$. Algunos días antes de la fenomenal noticia, también El Adelanto había reproducido un artículo de La Correspondencia Militar en el que se detallaba por qué la posesión del Gurugú significaba tanto para el Ejército español. Su dominio era

\footnotetext{
275 "La campaña de África”, El Adelanto, no 7.751, 22 de septiembre de 1909, p. 2.

276 "La campaña de África", El Adelanto, no 7.783, 29 de octubre de 1909, p. 2.

277 La Diputación de Salamanca se apresuró a enviar un telegrama de felicitación al presidente del Consejo y también al general Marina "por el triunfo de nuestro Ejército en la campaña de Melilla". Actas de la Diputación de Salamanca. Archivo de la Diputación provincial, vol. 1907-1912, fol. 36 (r)-37 (v).

278 "Hacia el fin de la campaña. La conquista del Gurugú", El Adelanto, n' 7.758, 30 de septiembre de 1909, p. 3.
} 
imprescindible para garantizar las comunicaciones de Melilla al Atalayón y a SidiAhmet el Hach ${ }^{279}$.

He aquí una primera impresión del júbilo que inundó Salamanca al conocerse la ansiada ocupación:

"Ayer, cuando Salamanca conoció la fausta nueva, la alegría explotó en manifestaciones de entusiasmo y el sentimiento de la patria hizo latir todos los corazones, con el mismo ritmo con que latirían los de los valientes soldados que vieron ondear nuestro pabellón en los picachos que sirvieron de fortaleza a la barbarie rifeña. Los telegramas oficiales recibidos por la prensa, dieron a conocer la buena noticia, y El Adelanto, que recibió en las primeras horas de la tarde la nueva de la toma del Gurugú y dos conferencias de cinco y diez minutos, con detalles de tan importante operación, trasmitió al pueblo la síntesis de tan importantes operaciones, en un extraordinario que repartimos gratuita y profusamente (...) Nuestro director, redactores, operarios de la imprenta, se honraron haciendo de repartidores de los dos mil suplementos que tiramos, y El Adelanto llevó a los más apartados hogares, la información detallada de la victoria conseguida por las armas españolas "280.

Algo más emotivo, al prestar mayor atención a la reacción ciudadana, fue este segundo relato:

"La animación por las calles, especialmente en la plaza Mayor, era extraordinaria.

El reloj de la Casa Consistorial fue tocado ruidosamente, mientras la bandera de la patria era izada en los edificios públicos.

El vecindario de la Plaza Mayor, dando pruebas de loable patriotismo y de sincero contento por la victoria de nuestras tropas fue el primero que adornó sus balcones, muchos de ellos con colgaduras de los colores nacionales.

El ejemplo cundió en los vecindarios de otras calles, tales como las de la Rúa, Toro y Zamora, que también colgaron sus balcones.

El Casino de Salamanca y el Círculo Mercantil, hicieron ondear la bandera española en los balcones de sus edificios, que también aparecían engalanados.

Entre tanto, muchos particulares, especialmente comerciantes e industriales, disparaban cohetes y bombas, y de vez en vez, oíase sincero y entusiasta un jviva España!, que era contestado con ardor.

A los pocos momentos, las campanas de algunas iglesias fueron echadas a vuelo, y, ya anochecido, hubo en la plaza un animado paseo y una animación grandiosísima.

-Iluminación y concierto musical.

Por la noche, siguieron la alegría y el entusiasmo. Algunas casas particulares lucieron iluminaciones, entre ellas, la del alcalde, señor Marcos Martín.

Como día de júbilo para la patria, la banda del $1^{\circ}$ de Mayo dio un concierto en el templete de la Plaza Mayor, que fue un pretexto para que se organizase un concurrido paseo.

Un grupo muy nutrido de mozalbetes, al frente de los cuales marchaba uno empuñando la bandera nacional, recorrió las principales calles de la ciudad, dando entusiastas vivas a España y al Ejército y mueras a los rifeños.

En algunas casas particulares, según pudimos comprobar, se festejó en grande el triunfo de nuestros soldados, con bailes y reuniones, en los que se cantó y se hizo música, habiendo en las jotas sus coplillas alusivas a la brillante victoria.

\footnotetext{
279 "La campaña de África”, El Adelanto, no 7.748, 18 de septiembre de 1909, p. 2.

280 “'Gloria al Ejército!”, El Adelanto, no 7.758, 30 de septiembre de 1909, p. 1.
} 
Esto es los que hubo en Salamanca, al conocerse la toma deseada del famoso monte Gurugú, ${ }^{, 281}$.

Cambiando ya de rotativo, a partir del 21 de agosto, también El Lábaro, en su bloque de informaciones telegráficas, se refirió a los continuos tiroteos en los alrededores de Melilla. Pero la situación no parecía, a su juicio, revestir demasiado peligro $^{282}$.

Evidentemente, la fe depositada en el general Marina era absolutamente ciega ${ }^{283}$; y ahora se alababa, más que nunca, su figura y se remachaba este apoyo con el recurso a las palabras del diputado Llorens ${ }^{284}$. Incluso, empleando algún que otro editorial francés, tomado del Journal del Debats, se reconocía el genio militar del jefe de las tropas españolas ${ }^{285}$.

Además, este diario fue el que más se extendió en las descripción de las posiciones avanzadas, tales como Sidi-Ahmet el Hach y Sidi Musa ${ }^{286}$; dedicó mucha de su atención al territorio de Quebdana ${ }^{287}$; y ofreció un listado con los nombres de todos los fallecidos en campaña hasta el 31 de agosto $^{288}$.

Pero, sobre todo, la carta francesa fue explotada para lograr una mayor adhesión a la idea del desquite. La Nota que, a finales de septiembre, enviaron los representantes del Sultán a Regnault, decano del Cuerpo Diplomático de Tánger, y en la que se denunciaba la enorme concentración de soldados españoles en Melilla fue filtrada por la prensa gala con evidente disgusto del gabinete madrileño. Con semejante gesto, se estaban cuestionando públicamente los propósitos gubernamentales ya que, con 60.000 hombres, se perseguía más que el simple castigo por la muerte de unos trabajadores ${ }^{289}$. El rotativo católico, por supuesto, se apresuró a denunciar la filtración como una imperdonable intromisión.

"Munio", entre tanto, insistía en que el objetivo militar de la campaña se restringía a la toma del Gurugú y que se debía lograr mediante la habilidad técnica:

\footnotetext{
281 "Un Repórter": "Regocijo popular. La toma del Gurugú en Salamanca”, El Adelanto, no 7.758, 30 de septiembre de 1909, p. 1.

282 "Informaciones telegráficas", El Lábaro, no 3.755, 21 de agosto de 1909, p. 3 (Prensa Asociada); "Informaciones telegráficas", El Lábaro, no 3.757, 24 de agosto de 1909, p. 3 (Prensa Asociada); “Telegramas”, El Lábaro, no 3.759, 26 de agosto de 1909, p. 3.

283 "Informaciones telegráficas", El Lábaro, no 3.750, 16 de agosto de 1909, p. 3 (Prensa Asociada).

284 "De la guerra. Interesante juicio de Llorens", El Lábaro, no 3.763, 31 de agosto de 1909, p. 1.

285 "De la guerra", El Lábaro, no 3.774, 14 de septiembre de 1909, p. 3.

286 "De la guerra", El Lábaro, no 3.779, 20 de septiembre de 1909, p. 1.

287 “De la guerra. Quebdana”, El Lábaro, no 3.781, 23 de septiembre de 1909, p. 1.

288 "Muertos y desaparecidos", El Lábaro, no 3.781, 23 de septiembre de 1909, pp. 1-2.

289 “La Nota del Sultán”, El Lábaro, n 3.783, 25 de septiembre de 1909, p. 2.
} 
“'Será mucho decir que presenciamos por primera vez una campaña, con un propósito definido, con un plan sabiamente meditado, con una táctica militar serena, callada, segura, de talento y de corazón? (...) Los inquietos, los comentaristas de café y de casino, los que creían que todo consistía en subir al Gurugú y poner un pico en lo alto, vean ahora cómo se avanza a paso seguro, economizando sangre, asediando y cercando al enemigo, haciendo impotente su ferocidad ante la táctica hábil, de mayor inteligencia, que domina y ata, que hace huir y desalojar poblados y chumberas, las lomas y las cañadas ${ }^{, 290}$.

Además, también respondió a ciertos ataques de Benito Pérez Galdós hacia la jerarquía católica:

"Como si se hubiera llegado al enloquecimiento precursor de la perdición, así andan de desatinadas ciertas gentes.

No se les cae de la boca lo de exigir responsabilidades (...) Así ocurrió cuando la Guerra de Cuba, cuando nos metieron en liza con los yanquis, cuando liquidamos las colonias en París (...) Ahora esos mismos fiscales andan poniéndose la toga de la libertad y de la democracia para delatar a los responsables. Van a llevar a la barra al gobierno, a exigirle responsabilidades de... el encarcelamiento de Ferrer... y del extrañamiento de Sol y Ortega ... y de la sangre morisca derramada en el Rif a cuenta del fanatismo de la reacción.

Las responsabilidades de lo otro... de los sucesos, de los incendios, del salvajismo, de la enseñanza de odios a España, al Ejército... de la obra de incultura, de libertinaje de palabra y de hechos.

¡Eso es atentatorio a la libertad, a la democracia! ${ }^{, 291}$.

La dominación del Gurugú, como no podía se otra forma, despertó el entusiasmo entre la redacción. De hecho, este fue el periódico local que mayor cobertura prestó al acontecimiento. El 29 de septiembre, a bombo y platillo, se publicaban los primeros telegramas sobre la misma y, de paso, el diario, se felicitaba por su eficacia informativa:

"La primera noticia que ha llegado a Salamanca de la toma del Gurugú por nuestras tropas ha sido la de El Lábaro.

A la una y cuarto transcribimos en nuestro encerado del Novelty el telegrama urgente en que la Prensa Asociada nos participaba el brillante coronamiento de la guerra en el Rif $^{, 292}$.

Incluso, un día después, no faltó quien empleó este triunfo como un arma arrojadiza contra aquéllos que se habían manifestado contrarios a la guerra:

"Hoy se hace más infame, más denigrante, la culpa de los que, mezclando con sus pasiones políticas lo más santo, lo más sagrado, pusieron en el alma del pueblo el veneno de la sedición.

Hoy deben quedar relegados al desprecio, avergonzados con el estigma de enemigos de España (...) Está escrita una página inmortal para la historia de España.

Página inmortal: laurel para el Rey, para el gobierno, para el Ejército, para España.

\footnotetext{
290 "Munio": "De cada día. El Gurugú", El Lábaro, no 3.784, 27 de septiembre de 1909, p. 2.

291 "Munio": "De cada día. Responsabilidades", El Lábaro, no 3.785, 28 de septiembre de 1909, p. 2. En esta misma idea, la del descrédito que rodea a los firmantes del Tratado de París, se insiste en "M.": "Impresiones de política. Los demócratas", El Lábaro, no 3.793, 7 de octubre de 1909, p. 1.

292 “Telegramas. La toma del Gurugú”, El Lábaro, no 3.786, 29 de septiembre de 1909, p. 3.
} 
¡Vergüenza de deshonra para los que desde dentro han laborado por la victoria de los rifeños!,"293.

La segunda plana de este número estaba dedicada a la descripción de la atmósfera reinante en Salamanca ante la noticia. La euforia era el sentimiento dominante, mientras que el órgano católico presumía, de nuevo, porque sus ventas del día previo ascendían a los 2.690 ejemplares.

"Seamos ligeramente inmodestos una vez más, ya que el público lo quiere, y de su sentir hemos de hacernos intérpretes. El éxito alcanzado ayer por El Lábaro fue formidable (...) La noticia oficial, transmitida por el ministro de la Gobernación a la primera autoridad de la provincia, llegó con unas horas de retraso a la nuestra. Durante dos horas no hubo en Salamanca más fuente de información que a de El Lábaro. Cuantas personas amigas leían la grata nueva, a nuestra redacción acudían en busca de pormenores (...) El número ordinario de El Lábaro puede decirse que, apenas salió a la calle. Los vendedores no pudieron llegar a la plaza, pues en las calles del tránsito materialmente les era arrebatado el número de las manos. Nuestra extraordinaria tirada de ayer se vendió como pan bendito (...) En vista de la demanda, nos decidimos a tirar en una hoja suplementaria la tercera plana, donde se contenía la detallada información (...) Corría oculto el entusiasmo en todos los pechos. Se limitaba toda la gente a congratularse de la nueva. Hizo falta para desbordar el entusiasmo, que de la torre de la Casa Consistorial, cayesen las sonoras campanadas, como gotas de plomo derretido, que encendían el estupor popular, predispuesto a la algarabía (...) Había entusiasmo, mucho entusiasmo que se traducía en griterío de chiquillos y el susurro zumbador de todos los comentarios ${ }^{, 294}$.

El mérito de toda operación se le atribuía, por descontado, al general Marina ${ }^{295}$.

En el caso de El Castellano, el 26 de agosto se publicaron los primeros rumores y conjeturas a propósito del inicio del avance. Se subrayaba que el objetivo urgente era la toma de Zeluán, pero los planes globales del gobierno constituían aún un misterio: "Zeluán es poco menos que un aduar al que no puede dar importancia el que allí se halle la vieja alcazaba de El Rogui. Ese es punto geométrico más que estratégico, y para defender su posesión se necesitaría una larga línea de destacamentos"296.

Curiosamente, los victoriosos avances del Ejército español durante el mes de septiembre fueron prácticamente silenciados. Y es que pese a la imposición de la censura, El Castellano se negaba a prestarle publicidad a la guerra.

No obstante, el tratamiento periodístico que se le prestó a la toma del Gurugú fue prácticamente idéntico al de las páginas de El Adelanto y El Lábaro: el momento de absoluto entusiasmo popular era aprovechado para publicitarse y no faltaba la extensísima recreación de la atmósfera salmantina:

\footnotetext{
293 "La patria", El Lábaro, no 3.787, 30 de septiembre de 1909, p. 1.

294 “Telegramas", El Lábaro, no 3.787, 30 de septiembre de 1909, p. 2.

295 "La ocupación del Gurugú", El Lábaro, no 3.789, 2 de octubre de 1909, p. 2.

296 "Correo de Madrid", El Castellano, no 1.570, 26 de agosto de 1909, p. 1.
} 


\begin{abstract}
"No acostumbramos a darnos bombos a nosotros mismos (...) pero para que no se tome nuestra modestia por absoluta falta de méritos (...) haremos hoy constar que la noticia de la toma del Gurugú fue ayer conocida en nuestra redacción a las dos de la tarde, por el telegrama enviado a la una y diez desde Madrid, por nuestro corresponsal señor Gándara (...) Tan pronto como el señor alcalde tuvo conocimiento oficial del suceso ordenó que se hiciera sonar la campana del reloj del Ayuntamiento (...) A la puerta del Ayuntamiento íbase reuniendo numeroso gentío, del cual se desprendió un grupo de entusiastas patriotas, que concibió la idea de realizar un acto, una pública manifestación (...) En el Casino de Salamanca, con una benevolencia que honra a los socios de este Círculo, se les facilitó la hermosa bandera que el Casino posee. Llevando delante la gloriosa enseña, los manifestantes entraron en la Plaza Mayor (...) Los vivas a España, al Ejército y a la bandera española eran ensordecedores (...) Por la noche, en el templete de la Plaza Mayor, la banda $1^{\circ}$ de Mayo ejecutó algunas piezas amenizando el paseo, para solemnizar el fausto acontecimiento ${ }^{, 297}$.
\end{abstract}

El tono empleado por los tres periódicos fue, en resumidas cuentas, idéntico.

Para acabar, a través de las páginas de El Salmantino, aquella atmósfera de tensa espera ante el inicio de las operaciones no se llegó ni a respirar. Quizás, sostenemos, porque el alarmismo podría entenderse como un síntoma de debilidad. Así que este periódico se limitó a reproducir los amplios telegramas sobre el triunfal avance español. Por esta razón, desde principios de septiembre, reinó el entusiasmo en su redacción, sobre todo, al relatar la victoria del general Aguilera en la llanura de Arkeman:

“iBendito sea el señor Dios de los Ejércitos! Él ha querido que tras los días de luto y las horas de angustia y de horror que tendieron sobre España negros crespones y anegaron las almas en mares de amargura y de odios, luzca el sol de la esperanza, anunciándonos tiempos mejores.

Del campo de la guerra llegan a nosotros noticias consoladoras y halagüeñas, que nos llenas de orgullo y de entusiasmo.

El Ejército de operaciones ha comenzado a desarrollar el plan de avance, y en los primeros encuentros ha conseguido arrollar a la morisma, dando un alto ejemplo de valor heroico de la hidalga raza española ${ }^{3298}$.

En telegramas posteriores, la gloria militar también alcanzó a los coroneles Larrea y Primo de Rivera. Aunque, por supuesto, quien más aplausos mereció fue el general Marina. En cualquier caso, la campaña no debería finalizarse hasta alcanzar el Kert para doblegar así, por completo, a los guelayas. ${ }^{299}$.

Los informes oficiales sobre la conquista de Nador, Zeluán y el Gurugú fueron reproducidos, conjuntamente, el 2 de octubre de 1909 (para entonces, ya habían perdido el carácter de actualidad, debido al tropiezo en El Jemis al que nos referiremos en breve)

\footnotetext{
297 "La toma del Gurugú", El Castellano, no 1.600, 30 de septiembre de 1909, pp. 1-2.

298 "Crónica hebdomadaria", El Salmantino, no 99, 4 de septiembre de 1909, pp. 1-2.

299 "De la guerra", El Salmantino, no 100, 11 de septiembre de 1909, pp. 2-3; "De la guerra", El Salmantino, $\mathrm{n}^{\circ} 101,18$ de septiembre de 1909, p. 2.
} 
En todos ellos se relataron infinidad de pormenores militares. Pero no hubo ningún comentario a propósito de su repercusión entre la opinión pública salmantina ${ }^{300}$.

En síntesis, la prensa liberal continuó haciendo uso de una maquinaria propagandística muy bien engrasada, seguramente porque sabía que, sin visos de una solución para el problema africano, la adhesión de la opinión salmantina empezaba a resquebrajarse. El Lábaro, en cambio, mantuvo una postura mucho más serena y se escudó en su habitual nacionalismo antifrancés. El Castellano, por su parte, preservó una actitud incrédula ante los planes militares de Maura y, finalmente, El Salmantino se congratuló con las conquistas, pero huyó tanto de los comentarios alarmistas como de los relatos emotivos.

Nuevos sinsabores

En medio de la alegría, no obstante, sobrevino otra catástrofe y una nueva oleada de desaliento recorrió el país.

El Adelanto se apresuró a llamar a la serenidad ${ }^{301}$. El 2 de octubre, Alfredo Rivera ocupó toda la segunda plana de este diario con el relato del durísimo combate habido en El Jemis el día 30 de septiembre, en las cercanías de Beni-bu-Ifrur ${ }^{302}$. Las bajas eran abrumadoras: fallecieron un general, catorce capitanes, veintidós tenientes y sesenta y ocho soldados; además de varios centenares de heridos.

A la par que se había emprendido el avance militar por las inmediaciones de Melilla, El Adelanto había publicado los primeros rumores sobre la terminación pronta de la campaña. La contradicción era solo aparente porque el propósito de estos bulos fue siempre el mismo: transmitir una falsa impresión de fortaleza y calma. De hecho, incluso, a comienzos de septiembre el gobierno Maura expuso su deseo de que los combates no se prolongasen más allá del 1 de octubre. Además, anunció que tan pronto esto ocurriese, se volvería a admitir la redención en metálico del servicio militar. La explicación residía en que entonces ya había una primera estimación de las pérdidas que la guerra había ocasionado en este sentido: 13 millones de pesetas había perdido el Tesoro $^{303}$.

\footnotetext{
300 "De Melilla. La toma de Nador", El Salmantino, no 103, 2 de octubre de 1909, pp. 2-3.

301 Alfredo Rivera: "Conferencias telegráficas", El Adelanto, no 7.759, 1 de octubre de 1909, p. 3; "Serenidad", El Adelanto, n' 7.760, 2 de octubre de 1909, p. 1.

302 "En el camino de Beni-bu-Ifrur. El sangriento combate de ayer", El Adelanto, n $\mathrm{n}^{\circ}$ 7.760, 2 de octubre de 1909 , p. 2.

303 "La campaña de África", El Adelanto, nº 7.738, 7 de septiembre de 1909, p. 2.
} 
A pesar de las manifestaciones gubernamentales, y como nota excepcional, algún redactor del periódico liberal no ocultó su incredulidad, sino que puso el acento en que se desconocía el objetivo de las operaciones y entonces estaba todavía la división de Sotomayor concentrándose en la Corte ${ }^{304}$. ¿Por qué se continuaban acumulando tropas para la campaña si ésta se daba por concluida?

Apenas emprendidos los primeros movimientos, se intentó esclarecer ese cometido de los militares:

"El objetivo de esta guerra es, pura y sencillamente, desarmar a los rifeños; es decir, obligarles a que entreguen sus armas y a que se conformen a vivir como lo hacemos en este punto los pueblos civilizados (...) Este es el objetivo de la guerra, y eso bien claramente se deduce de su origen, que fue una agresión de los rifeños a los que trabajaban en su territorio construyendo un ferrocarril, y la subsiguiente salida del general Marina para castigar semejante atropello; se deduce de las palabras del gobierno, tantas veces repetidas, de que la misión que nos proponemos en el Rif no es de conquista o señorío, sino política; se deduce, finalmente, de la proclama del general Marina, en que sin ambigüedades ni distingos se consigan que España cumple en el Rif un encargo de civilización universal ${ }^{, 305}$.

Qué poco convincente debía resultar esta explicación, sin embargo, a juzgar por el empacho de patriotismo periodístico tan visible durante aquellos días.

“Argos", el 23 de septiembre, volvía a abordar el asunto de la impaciencia pública ante el final de las operaciones. Pero con una novedad: dejaba caer la idea de que Maura seguía ajustándose al estricto cumplimiento de lo pactado en Algeciras ${ }^{306}$. E, inmediatamente después de la toma del Gurugú, daba por concluida la guerra y equiparaba el territorio conquistado con un desquite por lo perdido en $1898^{307}$.

Pero ocurrido el traspie en El Jemis, tocaba rectificar. Curiosamente también fue “Argos” el que ahora salía al quite explicando que siempre había temido la desgracia:

"Somos en España excesivamente impresionables y damos crédito fácil a la lisonja, venga de los hombres o de la suerte. Pasamos sin transición desde el abatimiento y sus humildades a la jactancia y sus soberbias (...) Cuando supe que en el Gurugú, en las posiciones eminentes conquistadas, junto a la radiosa bandera, quedaban cuatro compañías y dos baterías solas, me eché a temblar (...) yo no podía creer en el anonadamiento militar de la morisma, y templé mis entusiasmos (...) Ni aquel fausto suceso me embargó los sentidos con la embriaguez de la victoria ${ }^{\text {’308. }}$.

\footnotetext{
304 “Crónica. La guerra y la política”, El Adelanto, n 7.740, 9 de septiembre de 1909, p. 1.

305 "La campaña de África", El Adelanto, no 7.743, 12 de septiembre de 1909, p. 4.

306 "Argos": "Madrid al día", El Adelanto, no 7.752, 23 de septiembre de 1909, p. 2.

307 "Argos": "Madrid al día", El Adelanto, no 7.759, 1 de octubre de 1909, p. 1.

308 "Argos": "Madrid al día”, El Adelanto, no 7.761, 4 de octubre de 1909, p. 1.
} 
Obviamente, la alarma entre la opinión pública se tradujo en un creciente estado de ansiedad por ver terminada la campaña. Por este motivo, algún que otro reportero intentó contraatacar explicando esto:

"Siempre se creyó en España que la conquista del Gurugú habría de costar torrentes de sangre, y el fatídico monte fue nuestro sin disparar un tiro: por el contrario, parecía que Beni-bu-Ifrur habíase de llegar en un paseo militar, y el intentarlo nos ha costado el combate más encarnizado de la campaña, en el que, aun venciendo, nada hemos adelantado para el objeto final de la operación. La guerra es lo imprevisto, lo ilógico, y hacer calendarios sobre ella, es escribir en arena o intentar contar estrellas ${ }^{\text {"309. }}$.

Se trataba de una pueril disculpa. El autor de este fragmento se esforzaba en pasar por alto -con ese "siempre se creyó" y no con un, por ejemplo, "nosotros pregonamos" - la irresponsabilidad en que había incurrido buena parte de la prensa al poner fecha al fin de las operaciones militares. Habían arrojado la piedra, pero ahora escondían la mano.

Quien también insistía en la inutilidad de todo cálculo fue el propio general Marina. El Adelanto publicó, el 9 de octubre, una larga entrevista realizada por Ruiz Albéniz. En ella, el militar recalcaba que la guerra no concluiría mientras el enemigo siguiese batiéndose ${ }^{310}$.

A la espera de mayores refuerzos para avanzar por la conocida región minera, “Un Repórter" reitera las llamadas a la calma. Sin duda, lo que imperaba en la calle era un desesperante estado de impaciencia:

"Es preciso, y es necesario que en este compás de espera que ahora se ha abierto, cesen esos planes de café y esas discusiones inverosímiles, y esos temores infundados, y es anonadamiento estúpido, impropio de españoles, y que, con facilidad asombrosa, hace cernir, sobre este ambiente de patriotismo sincero, una no muy halagadora esperanza de triunfo "311.

El Lábaro, al igual que con la toma del Gurugú, le dedicó a la operación en El Jemis muchísimo espacio. Y se esforzó, como ningún otro medio lo hizo, en convertir un durísimo combate en una victoria española. He aquí las impresiones que se anteponían a las anotaciones telegráficas de la tercera plana:

"Otro éxito de las armas españolas en el Rif.

\footnotetext{
309 "La guerra y el país", El Adelanto, no 7.762, 5 de octubre de 1909, p. 1.

310 "La campaña de África", El Adelanto, n $\mathrm{n}^{\circ} 7.766,9$ de octubre de 1909, p. 2. La entrevista también fue reproducida, dos días después, por El Lábaro: "La duración de la guerra", El Lábaro, no 3.796, 11 de octubre de 1909, p. 1.

311 "Un Repórter": "Nota del día. Compás de espera”, El Adelanto, no 7.763, 6 de octubre de 1909, p. 1; También se refieren los nuevos preparativos militares en: Alfredo Rivera: "Conferencias telegráficas", $E l$ Adelanto, $\mathrm{n}^{\circ}$ 7.762, 5 de octubre de 1909, p. 3; Alfredo Rivera: "Conferencias telegráficas", El Adelanto, $\mathrm{n}^{\mathrm{o}}$ 7.771, 15 de octubre de 1909, p. 3; Alfredo Rivera: "Conferencias telegráficas", El Adelanto, n ${ }^{\circ} 7.780$, 26 de octubre de 1909 , p. 3.
} 
El combate de Beni-bu-Ifrur alejó al enemigo del baluarte a que se había acogido, tras el empuje vigoroso del aguerrido Ejército, que subió a las cumbres del Gurugú. Van las tropas expulsando a los audaces rifeños de sus escarpadas guaridas.

Aún cuando la nueva victoria nos costó sensibles bajas, victoria es y grande.

Que sería risible insensatez creer al enemigo sin medios de combate y sería infantil pretensión querer hacer una guerra sin sangre.

A morir se va la pelea, y el derramar una lágrima y el ofrecer una oración por las víctimas, no ha de impedir celebrar el triunfo de nuestros soldados, que combatieron el salvaje empuje de la horda rifeña con el singular denuedo, que es blasón del heroico Ejército español ${ }^{\text {’312. }}$

La gravedad de la batalla quedaba diluida entre tanta resignación. Este periódico católico, al igual que El Adelanto, había recogido aquellas declaraciones en que Maura anticipaba el fin de la campaña para octubre y el retorno al sistema de redención en metálico. Pero no le otorgó demasiado crédito $^{313}$. Ahora se confirmaban sus presagios inconfesables. Y "Munio", siguiendo la tónica general, recomendaba entereza:

"Era ayer día para aumentar la ansiedad, por lo mismo que se carecía de noticias nuevas, y la imaginación del pueblo avanza y se exalta. Ya se creía acabada la guerra con la toma del Gurugú: ya se cree perdido todo por el combate del zoco de Beni-buIfrur (...) Los español, lo loable, es no debilitar el espíritu público, y poner por encima de las pasiones y de los intereses chicos de los partidos, la causa grande del honor y de la vida de España. Lo español es poner cada cual el hombro y sus armas para defender la patria ${ }^{\prime 314}$.

El general Marina, por otra parte, continuó siendo objeto de infinitas alabanzas y absoluta adhesión. Conservaba su status de héroe de la campaña. Si bien cierta prensa extranjera cargaba las tintas contra su autoridad, estas críticas no merecían ninguna consideración:

"Quien quiera escribir o hablar con sinceridad tendrá que reconocer que España ha hecho un brillantísimo papel en el Rif, en todos los aspectos (...) He aqui el nombre que irá por siempre más unido a la primera guerra seria de la España contemporánea. Militar inteligente, hombre reflexivo, tipo espartano que no admite como colaborador a la opinión pública en los negocios técnicos, el general Marina ha tenido la gloria de representar a España dignamente y a su Ejército, delante de los países del mundo, y sobre todo de Europa, 315 .

\footnotetext{
312 “El combate de Beni-bu-Ifrur”, El Lábaro, no 3.789, 2 de octubre de 1909, p. 3.

313 “¿Acabará la campaña antes de octubre”, El Lábaro, no 3.767, 3 de septiembre de 1909, p. 2. Simultáneamente se recogían algunos artículos de la prensa francesa que, rompiendo la tónica habitual, dedicaban elogios al general Marina: "De la guerra", El Lábaro, n 3.764, 1 de septiembre de 1909, p. 1; "Un elogio a nuestras tropas", El Lábaro, n 3.770, 9 de septiembre de 1909, p. 1.

314 "Munio": "Impresiones de política", El Lábaro, no 3.790, 4 de octubre de 1909, p. 1.

315 "Opiniones ajenas. Elogio de la campaña", El Lábaro, no 3.792, 6 de octubre de 1909, p. 1. Y también publicó la carta de un universitario francés que, desmarcándose de los comentarios dominantes entre la prensa gala, felicitaba al general Marina: Maurice Legendre: "Pro España", El Lábaro, nº 3.805, 21 de octubre de 1909, p. 1.
} 
Y tampoco merecían atención las cada vez más insistentes críticas hacia la imprevisión de Maura $^{316}$. En cambio, la redacción católica se complacía con las buenas palabras de la prensa inglesa ${ }^{317}$.

Únicamente a mediados de octubre, uno de los colaboradores de El Lábaro pareció dejarse arrastrar por la impaciencia de ver la campaña concluida. Sin duda, constituyó la nota excepcional de este diario:

"Considero incontrovertible la afirmación de que la guerra es la mayor de las violencias; es la más horrible y asoladora enfermedad que conoce la extensa patología moral de las naciones. No se me oculta, que hoy por hoy, debido a que aún no hemos alcanzado el nivel de cultura necesario para poder suprimirla, es inevitable, pero esto no demuestra que sea cierta la teoría de Burguete, que considera al hombre nacido para la guerra y ésta el elemento natural y más propicio de aquél. Lo que demuestra es lo ridículo de nuestra vanidad cuando nos enorgullecemos de haber nacido en estos tiempos de progreso indudable, pero relativo, ${ }^{\text {,318. }}$.

Igualmente, El Castellano también se esmeró en la tarea de infundir sosiego en estos trágicos momentos. Su actitud había sido más prudente que la de El Adelanto, sin arrebatos comparables a los de "Argos". En ningún momento este periódico equiparó la dominación del Gurugú con el fin de la campaña. Y, por tanto, tuvo que realizar un menor esfuerzo para convencer a sus lectores de la necesidad de esperar. Su discurso no poseía ese carácter autoexculpatorio. La redacción se limitó a confiar en la superioridad tecnológica española:

"Del último revés sufrido por nuestras tropas en Melilla, se deduce, a nuestro juicio, que hay que ser más prudente en hacer pronósticos sobre los asuntos de Marruecos y poner sordina a ciertos entusiasmos (...) Nuestro definitivo éxito, en el cual creemos, y debemos creer toda España, no ha de ser encomendado al saber morir, sino al saber vivir, porque lo primero también lo saben los moros.

Nuestro éxito final ha de ser por tener el arte y la ciencia militares ${ }^{, 319}$.

Además, transcurridos algunos días, el mismo periódico esgrimía un novedoso argumento al objeto de que la opinión pública salmantina siguiese respaldando al general Marina: el apoyo diplomático inglés. Pero el escrito no era original, sino que procedía de The New York Herald y estaba firmado por "Un estudiante de diplomacia". No obstante, su publicación era, ciertamente, de lo más oportuna. Si en 1893 Margallo no se atrevió a comportarse como ahora lo estaba haciendo el general Marina, es decir, rebasando los límites del campo de Melilla, se debía a que:

\footnotetext{
316 “De la guerra", El Lábaro, no 3.794, 8 de octubre de 1909, p. 1.

317 "De la guerra", El Lábaro, no 3.803, 19 de octubre de 1909, p. 2.

${ }_{318}$ Mario Graco: "Crónica. Ofrenda", El Lábaro, n' 3.124, 19 de octubre de 1909, p. 2.

319 “Triunfemos nosotros", El Castellano, no 1.603, 4 de octubre de 1909, p. 1.
} 
"La presente campaña española es el resultado del convenio que se concertó a poco de realizarse el matrimonio de don Alfonso. Este tratado se negoció por Maura, quien, después del Desastre de 1898, fijó el designio de modificar el sentido de la política internacional española (...) En él se estipula que España alcanza con él la cooperación diplomática y material de Inglaterra para la extensión de los dominios españoles en África. En compensación, España se compromete a que Inglaterra pueda ocupar temporalmente puntos estratégicos de la costa de África, que necesitaría si se hallara en guerra con otra potencia (...) Las ventajas que Inglaterra obtiene de este tratado secreto son manifiestas. Todos saben que Gibraltar ha perdido importancia estratégica por virtud de los progresos de la artillería ${ }^{, 320}$.

Evidentemente, el autor se estaba refiriendo al canje de Notas de Cartagena; pero incurría en un error al explicar su contenido: a España no se le consentía la expansión por África en ese documento, sino la conservación de lo que ya poseía.

Sin embargo, los avances militares se paralizaron tras la derrota en El Jemis y tanto la opinión pública española como las cancillerías europeas comenzaron a inquietarse. Un redactor de la casa exigió explicaciones porque "es la segunda vez que durante la campaña en el Rif ocurre un hecho de esta naturaleza; y por segunda vez habrá que pedir que se aclaren esos misterios" ${ }^{321}$. Ni el rumor sobre el inicio de un acercamiento diplomático ni las posibles cortapisas francesas -extraíbles de una entrevista concedida por D'Amade a la prensa gala y muy comentada aquí- satisfacían al autor. Una semana después, de modo muy tendencioso, se insertaba la carta de una melillense con la petición de que las tropas se apoderasen de la cábila de Beni-bu-Ifrur, para evitar más tristes sorpresas como la del 30 de septiembre ${ }^{322}$. El Castellano se había sumergido, de lleno, en la lógica de la conquista.

El Salmantino también se sumó a la ola de lamentaciones tras el tropiezo de El Jemis. Y, por descontado, recomendó una actitud paciente entre sus lectores, confiando en la grandeza del Ejército. “J. M.” fue el primer redactor que se refirió a la tragedia:

“A última hora de ayer llegó a nosotros la noticia del combate del 30 en el zoco El Jemis. Tras las alegrías por la ocupación de Nador, Zeluán y el Gurugú, ha venido a llenarnos de tristeza el resultado de esta última operación (...) Los combates del 23 y 27 de Julio nos llevaron a un pesimismo infundado; la ocupación del Gurugú nos hizo cantar victoria antes de tiempo; y ahora el reciente combate del 30 nos hace volver al pesimismo anterior. Tengamos más calma; reconozcamos que el triunfo no es tan fácil ni tan inmediato como creíamos; pero no desconozcamos tampoco que las posiciones ocupadas días atrás son de importancia suma; y confiemos en la pericia de nuestros generales y en el valor y disciplina de nuestro Ejército" ${ }^{~} 323$.

\footnotetext{
320 "Un artículo sensacional", El Castellano, no 1.605, 6 de octubre de 1909, pp. 1-2.

321 “Nos detenemos o nos detienen?”, El Castellano, no 1.608, 9 de octubre de 1909, p. 1.

322 "Una carta desde Melilla", El Castellano, no 1.615, 18 de octubre de 1909, p. 1.

323 "De la guerra", El Salmantino, no 103, 2 de octubre de 1909, p. 1.
} 
El editorial de “J. M." era breve, no llegaba a ocupar una columna completa; y mientras que el Ejército salía muy bien parado, se percibía cierto reproche hacia el carácter volátil de la opinión pública salmantina ${ }^{324}$. No obstante, eran las opiniones publicadas, especialmente aquellas que tantísimo exageraban la importancia de las victorias militares, las que explicaban esa misma naturaleza cambiante de la opinión.

En este mismo ejemplar del periódico tradicionalista, con fecha del 2 de octubre de 1909, también eran descritas, por primera vez y aparte la brevísima alusión contenida en el fragmento previo, las tomas de Nador, Zeluán y el Gurugú. Las nuevas conquistas ocupaban, al completo, la segunda y tercera plana y constituían, cómo no, la prueba irrefutable de la brillantez con que operaban las tropas expedicionarias. En suma, la estrategia del periódico consistía, ya se ha apuntado, en contrarrestar el efecto de una noticia devastadora con otra triunfal. La redacción se recreaba con los detalles de esta segunda y, si bien cedía la primera plana al editorial sobre la derrota en El Jemis que, ciertamente, era la información más reciente y la que acaparaba todos los comentarios en la calle, dedicaba muchísima más superficie a las victorias militares. Intentaba, creemos, dejar al lector un buen sabor de boca.

Cabe destacarse que El Salmantino nunca se atrevió a anticipar el fin de la campaña. Recordemos ese fragmento, reproducido más arriba, en el que se presentaba el "Gurugú" como base de los avances, pero no como fin. Al contrario, tan sólo el ensalzamiento de los militares africanistas constituyó la clave de su discurso.

El 9 de octubre, la redacción, como ya hiciera en agosto, volvió a publicar numerosos fragmentos de la prensa inglesa y francesa. En esta ocasión, una vez ocupados Nador, Zeluán, El Gurugú y El Jemis, todos los textos tenían como denominador común los aplausos hacia el Ejército español. Pero mientras que la admiración inglesa se consideraba como un gesto honesto, la sinceridad de los periódicos galos era muy cuestionada. El Salmantino aseguraba que a los franceses no

\footnotetext{
${ }^{324}$ Uno de los más célebres publicistas de la campaña de 1909 fue Eduardo Gallego Ramos, quien, en repetidas ocasiones, lamentó el carácter extremadamente impresionable de la opinión pública española. Testigo de la desesperación que se apoderó del pueblo tras el combate del 27 de julio, comentaba sobre la función de la prensa diaria: "La prensa, dándose por fin cuenta de lo pernicioso de su antigua conducta, comienza a reaccionar en sentido altamente favorable al interés patrio, y a partir del mes de agosto, los embarques e verifican entre aclamaciones y vítores, las suscripciones a favor de los reservistas, de los inutilizados y heridos en la campaña y de la víctimas de ella se multiplican en toda España y el espíritu público comienza, en una palabra, a confortarse, estimulando al Ejército y glorificando a sus héroes, conocidos o anónimos, que es lo menos que puede hacerse en honor de los que en los campos del Rif han perdido su vida luchando valerosamente por el honor de las armas y prestigio de la Nación". Véase GALLEGO RAMOS, Eduardo: La campaña del Rif de 1909: orígenes, desarrollo y consecuencias. Madrid: Imprenta de A. Marzo, 1909, p. 143.
} 
les beneficiaban los progresos militares españoles y, para ello, reproducía un artículo del diputado Garriga y Massó, ya que en él se sintetizaba buena parte de su sistema de creencias respecto a la cuestión marroquí. En dicho escrito, para empezar, se descalificaba al Trust por afirmar que con la Guerra de Melilla se favorecían intereses privados cuando lo que estaba en juego era un asunto vital: la independencia nacional. El relato, arrancaba, en 1904:

"Entonces se nos encargó de dominar en el Rif.

Anduvimos remisos en cumplir el encargo, más después de las visitas de Loubet y Eduardo VII; la ida a Tánger de Guillermo; y la Conferencia de Algeciras, se produjeron los desórdenes de las minas rifeñas y, aunque de mala gana, invadimos el Rif, comprendiendo que nos podíamos eludirlo (...) Si Francia dominase en Marruecos sin oposición, convirtiéndolo en una segunda Argelia, teniendo detrás su inmensa colonia... España sería el camino natural de unión entre Francia y sus dominios.

No creo necesario ponderar lo peligroso de esta situación (...) Esto explica el interés de Francia en abultar nuestros yerros para demostrar a Europa que ella sola se encuentra en condiciones de penetrar en Marruecos y finalmente nada tendría de extraño que la acción y la influencia de ciertas asociaciones francesas en los sucesos interiores, estuvieran de cerca o de lejos relacionados con la política colonial francesa, ${ }^{, 325}$.

Dicho de otro modo, se lanzaba la idea de que la violencia barcelonesa había sido alimentada por los franceses con el objeto de obtener réditos en Marruecos, desacreditando políticamente a España. Pero es que, además, se aseguraba que el gobierno de París había contemplado con buenos ojos la contienda porque vaticinaba un fracaso militar español. No obstante sus predicciones estaban siendo erróneas. Y, lo más importante: debían continuar siendo así. La victoria militar se convertía en la garantía de la independencia nacional y la guerra pasaba a ser meramente defensiva ${ }^{326}$. Porque, no lo olvidemos, al Rif se iba “de mala gana”. Pero, nos preguntamos: ¿no se estaba confundiendo el hecho de firmar tratados internacionales a regañadientes con eso de ir a Marruecos de mala gana? Precisamente, El Salmantino fue uno de los periódicos salmantinos con mayor voluntad de penetración en el continente africano.

En este mismo número del periódico tradicionalista, realmente, se solicitaba el envío de más refuerzos a Melilla. Se estimaba que entonces había allí 42.000 soldados españoles. Pero, si todo el Rif se sublevase, el harca podría reunir 71.000 infantes y casi 16.000 jinetes. Y esto era lo que se temía: la guerra iba a entrar en una nueva fase porque el general Marina había asegurado que en la batalla de El Jemis participaron

\footnotetext{
325 "España ante el extranjero", El Salmantino, no 104, 9 de octubre de 1909, pp. 2-3.

${ }^{326}$ En este ejemplar también se copiaba la entrevista concedida por D'Amade a Le Matin. El general declara que era imprescindible que el camino francés hacia Taza permaneciese expedito. Véase: "Última hora", El Salmantino, nº 104, 9 de octubre de 1909, p. 3.
} 
tropas imperiales; y, además, el Sultán se estaba rearmando y había logrado un empréstito francés por valor de 180 millones de francos ${ }^{327}$. En definitiva, se estaba vaticinando una contienda larga.

Pero lo que se impuso, por el momento, fue un compás de espera. El semanario integrista explicó que obedecía al exceso de lluvias y a las inundaciones ${ }^{328}$. El 6 de noviembre, sin embargo, las informaciones oficiales ya apuntaban a la reanudación de movimientos ${ }^{329}$.

\section{$\underline{\text { La débil crítica hacia la campaña militar de } 1909}$}

La contestación a la Guerra de Melilla no es fácilmente rastreable en la prensa local salmantina. Pero sospechamos que ello no obedeció únicamente a la actuación del censor. En primer término, porque éste actuaba, por norma, de modo más estricto en las grandes ciudades que en las pequeñas capitales de provincias. Parecía lógico: cuanto menor fuese la tirada de un rotativo, menor peligro social entrañaba. Consecuentemente, los periódicos de provincias gozaron de mayor libertad que la de la Corte u otras grandes urbes industriales. En segundo lugar porque, como ya se habrá deducido, ni siquiera resultó imprescindible la implantación de la censura en Salamanca. Con la excepción de El Castellano, las opiniones publicadas en la restante prensa local no variaron sustancialmente su orientación ideológica ni su tono entre los momentos previo y posterior al establecimiento de la misma.

No obstante, consideramos que sí hubo algunas preocupaciones colaterales y, sobre todo, viejas reivindicaciones colectivas, puestas de relieve con el conflicto, que no pudieron disimular cierto malestar, todavía bastante pasivo, ante la contienda.

\section{A. Críticas generales contra la guerra}

Casi desde el preciso momento en que estallaron las hostilidades, se publicaron en El Adelanto tímidos artículos de rechazo hacia la contienda. Así, el 16 de julio, un columnista anónimo presentaba, con evidente amargura, la lucha como un conflicto nacido del aburrimiento, particularmente notorio entre los militares:

"Llevábamos tanto tiempo en paz y en gracia de Dios que ni esto parecía España, ni los periódicos tenían interés, ni los cuartos del Tesoro se sabía en qué gastarlos, ni los soldadillos nuestros tenían dónde disparar unos cuantos tiros y pasar el rato. Por fortuna, parece que todo ha cambiado, gracias a la amabilidad de los rifeños que se sirvieron fusilar a unos cuantos españoles, y ya hay telegramas emocionantes, barcos que navegan, cañones que disparan y camas ocupadas en los hospitales. ;Guerra,

\footnotetext{
327 “Datos interesantes sobre el Rif”, El Salmantino, no 104, 9 de octubre de 1909, p. 2.

328 "De la guerra", El Salmantino, no 108, 6 de noviembre de 1909, pp. 2-3.

329 "Última hora", El Salmantino, no 108, 6 de noviembre de 1909, p. 3.
} 
guerra al infiel marroquí! (...) Conquistaremos medio Marruecos, haremos en él escuelas, construiremos caminos y ferrocarriles, civilizaremos a salvajes cabileños y con todo ello mereceremos elogios del mundo culto que nos alienta a tan altas empresas. Y los que hablan, sin razón y sin motivo, de que fuera mejor que llevar tanta bienandanza fuera de casa, establecerla en ésta, que se aguanten y se muerdan la lengua. Los españoles pueden esperar a que se les den maestros, médicos y caminos, y lo mismo les dará emigrar, si no tienen paciencia, un poco antes que un poco después. Que hubieran nacido en el Rif y serían los primeros ${ }^{, 330}$.

Además, la marcha de los reservistas de Madrid, que más tarde compondrían la brigada de Pintos, ofreció a "Argos" la oportunidad para reflexionar sobre las lecciones aprendidas en 1898. El siguiente editorial, clara manifestación de su animadversión hacia la pelea, es uno de los más conmovedores que hemos hallado. En él, el columnista aludía a la existencia de una conciencia popular, que no nacional -recuérdese lo que señalamos muchas páginas atrás sobre la impronta cristiana de esta expresión- muy débil, pero esperanzadora. Muy probablemente, con su publicación pretendió que el ejemplo de ciudades como Madrid o Barcelona también cundiese en Salamanca. Apenas hallaría respuesta:

"La oposición, débil todavía, que se hace a la guerra en estos momentos, punible según la letra codificada, pero obediente a un hondo sentir altruístico; esos chispazos de luz clarísima que despide la conciencia popular; esos intentos que aquí, en Barcelona y donde quiera que se remueve a los hombres jóvenes, sanos, fuertes, productores, para lanzarlos a la matanza, se hacen con objeto de impedir el estéril sacrificio, pruebas son de un mayor estado de cultura interna, de un humanismo latente, contenido por la presión secular, embrutecedora, y que, al expansionarse en un medio adecuado, transformará la sociedad vieja, podrida, cuyos cimientos, amasijo de sangre y de barbarie, están a punto de disolución. Desde el año 1898 hemos aprendido mucho (...) La hoja que sin razón o con razón salió de la vaina, tiene que volver con honor a ella. Bien está. Y mejor estará que en lo sucesivo el pueblo impida a sus gobernantes sacar el acero temerariamente; porque no es bien que sufran las consecuencias de su temeridad, a lo menos sin previa consulta y consentimiento expreso, ${ }^{\text {,331. }}$.

Pero el Desastre en el Barranco del Lobo supuso un punto de inflexión para buena parte de la redacción liberal. Así, "Argos", no volvió a sostener posturas tan ponderadas y pacifistas como la que acabamos de ver. Al contrario, prestó su apoyo incondicional al gobierno y acató la censura.

Únicamente en octubre rebrotó el escepticismo. El clima de la opinión salmantina era entonces muy agrio y de acuerdo con las palabras de un corresponsal, la campaña no tenía visos de terminar. Señalaba el cronista que ya duraba tres meses y que todo el mundo sabía que el objetivo eran las minas, pero que se necesitaban más refuerzos para que la Comandancia de Melilla no se expusiese a un nuevo fracaso.

\footnotetext{
330 "De cursiva. La guerra santa", El Adelanto, no 7.793, 16 de julio de 1909, p. 1.

331 “Argos": "Madrid al día", El Adelanto, no 7.698, 22 de julio de 1909, p. 2.
} 
Marruecos era un callejón sin otra salida; pero no había cabida para las protestas, tan sólo para la resignación: “La guerra actual hay que acabarla haciendo sentir a los rifeños el poder y el valor de España, y las contemplaciones hay que guardarlas para quienes conozcan y aprecien lo que son y lo que significan. Ni crueldad ni clemencia; justicia seca y que aprendan los rifeños que no pueden cometerse atrocidades sin purgarlas ${ }^{332}$.

El Castellano, reiteramos, defendió desde muy tempranamente la tesis de la provocación española. Ramón Barco, por ejemplo, en su editorial del 22 de julio, escribía que la guerra de conquista era la más absurda y anacrónica de las guerras. Y por ello mismo argumentaba lo que sigue:

"No estoy yo lejos de pensar como aquellos que creen que en el fondo de toda esa cuestión marroquí, palpita, inconsciente o conscientemente, otro problema que no es el del honor nacional ni el de trasnochados quijotismos, sino algo más tangible... y contante, algo sanchopancesco (...) Cada época histórica tiene, por decirlo así, su espíritu (...) y el de la nuestra no es precisamente el de las aventuras guerreras (...) En España tuvo su última manifestación en aquella otra campaña con África del año 60. Por eso entonces no hubo ni una sola voz discordante que se opusiera al batallar, y ahora sí; ahora las opiniones están bien divididas ${ }^{, 333}$.

Después de sugerir que esa escisión tenía un origen económico, asumía el autor que la conflagración no despertaba el más mínimo sentimiento patriótico. Al contrario, impotencia y rechazo era lo que experimenta el columnista al ser testigo de sus efectos sobre los estrategas de café: "Los discutidores de la guerra, los que se pasan horas y horas, en estas ocasiones, hablando desconcertadamente de los que no entienden, formando planes, señalando marchas y contramarchas, simulando un interés hondo que solo es mera curiosidad y charla vana. A estos, no los resisto y huyo de ellos como de una calamidad". Aunque se diese la paradoja de que esos pseudoexpertos eran los individuos más atentos a los juicios periodísticos.

A El Castellano, sobre todo, debemos agradecer uno de los artículos más singulares, por sus brutales implicaciones, a propósito de la Guerra de Melilla. Aclaremos, antes que nada, que en él se no rechazaba la guerra de Marruecos como tal. Muy al contrario, su autor era un reputado militar y colaborador de excepción, Genaro Alas, y lo que hacía era abogar abiertamente por la conquista de la región melillense mediante la fuerza bruta. Pero cualquier otra fórmula de dominio, y he aquí la crítica

\footnotetext{
332 "Situación insostenible", El Adelanto, no 7.778, 23 de octubre d e1909, p. 1.

333 "Miscelánea", El Castellano, no 1.599, 22 de julio de 1909, p. 1.
} 
fundamental, no merecía su respeto; consideraba preferible el abandono. De paso, cómo no, desprestigiaba toda la política marroquí de "medias tintas", auspiciada por Maura.

Sin embargo, la tesis de la conquista requería la aquiescencia popular. A decir verdad, podemos considerar este artículo como un excelente compendio del credo africanista a la altura de 1909. Además, el militar proporcionaba muy jugosos datos sobre las concesiones mineras. E, igualmente, el editorial revelaba el escaso cariño profesado por el mundo castrense hacia la diplomacia:

"Lo primero que pregunta toda persona discreta es lo siguiente: ¿Es que por el Convenio de Algeciras, y por otros convenios estamos obligados a amparar todas las aventuras industriales o comerciales que a cualquier europeo le plazca atentar en el Rif? (...) De fijo no hay gobierno español que haya cometido semejante imprudencia (...) Cierto es que hasta la fecha se sabe quién, con poderes constitucionales suficientes para ello, otorgó la protección del Estado español a las empresas mineras (...) pero eso, indudablemente, se aclarará en sentido de no haber habido culpabilidad, sino un error de apreciación ${ }^{, 334}$.

Todo esto era traído a colación porque, como seguidamente explicaba Alas, entonces se comentaba que el Sultán intentaba procurar un nuevo empréstito de una sociedad francesa y estaba dispuesto a concederle a ésta el derecho de abrir minas en todo el imperio y de expropiar cuantas estuviesen ya abiertas ilegalmente. El resultado de esas negociaciones podía ser demoledor para los intereses hispanos:

"Resultará que sin comerlo ni beberlo el pueblo español, va a estar sujeto por tiempo indefinido a la carga costosa y sangrienta de garantizar a la compañía francesa prestamista del Sultán, los rendimientos de la operación financiera (...) Nuestros costosos esfuerzos ni siquiera pueden tener la mezquina satisfacción de adquirir para el estado territorios en el Rif. Para que nos desangremos en esa difícil y pobrísima comarca se invoca por nuestros gobiernos las obligaciones contraídas en Algeciras, obra maestra de imbecilidad diplomática por nuestra parte”.

Para Genaro Alas, el gobierno de Antonio Maura no había actuado en defensa de negocios mineros privados, logrados a costa de tratos con un falso pretendiente -el militar aludía a "aventuras industriales o comerciales" -, pero sí que lo había hecho otro "ente" con poderes constitucionales. Y para más señas, este personaje no era culpable, sino víctima de una apreciación errónea. ¿Qué figura pública merecía semejante apoyo incondicional de Leopoldo Alas? Indiscutiblemente, se trataba de Alfonso XIII.

El Rey no merecía, consecuentemente, ninguna reprobación. En cambio, la diplomacia resultaba muchísimo peor parada debido a que se había comprometido en Algeciras a respetar la integridad del Sultanato. En síntesis, las torpezas históricas de los diplomáticos tenían que remediarse ahora gracias al esfuerzo de los militares: "Es

\footnotetext{
${ }^{334}$ Genaro Alas: “Lo que opina un militar”, El Castellano, no 1.575, 1 de septiembre de 1909, pp. 1-2.
} 
preciso mientras llega la hora de dar una soberana paliza a los moros, es preciso, digo, empezar a rectificar muchos errores que arrancan del Acta de Algeciras". Alas reclamaba para España, a renglón seguido, el derecho exclusivo a la apertura de minas en el Rif: "Y si a esto no se avienen las grandes potencias (...) hay que renunciar al protectorado". Este militar deseaba, en fin, convertir el Protocolo de 1906 en letra muerta, convencido plenamente de que los militares eran el colectivo mejor capacitado para la defensa de los intereses regios.

Maura, por lo tanto, recibió críticas por su actuación en Marruecos procedentes de la sociedad civil, pero también de la militar. El Rif empezaba a ser contemplado como un "coto privado", un feudo, de los oficiales españoles. Lamentablemente, únicamente El Castellano plasmó esta realidad.

Por otra parte, ni en El Lábaro ni en El Salmantino hallamos el menor atisbo de comentario crítico contra la guerra.

\section{B. El sistema de reclutamiento sometido a examen}

En el año 1837 se aprobó la primera ordenanza española reguladora del servicio militar obligatorio. Sin embargo, ésta admitía su conmutación por dinero, es decir, la redención en metálico; y más tarde se añadió la opción de la sustitución hombrehombre ${ }^{335}$. Evidentemente, la obligatoriedad quedó así convertida en una cláusula más teórica que real porque redimir a un hijo del servicio se convirtió en una necesidad mucho más urgente que darle un oficio o carrera. Si bien la Constitución de 1876 reiteraba esta exigencia de la defensa forzosa de la patria en caso de guerra, nada cambió en la práctica: préstamos de sociedades crediticias; asociaciones entre los vecinos de un pueblo para comprar la redención de los hijos; contratos con compañías de sustitución... Infinidad de métodos para esquivar el odioso servicio ${ }^{336}$, más horroroso, incluso, después de la pérdida de los últimos restos del imperio español y de la ruptura de las bases de la convivencia que el Desastre significó ${ }^{337}$. Porque a la

\footnotetext{
335 SALES, Nuria: Sobre esclavos, reclutas y mercaderes de quintos. Barcelona: Ariel, 1974, pp. 209-219.

${ }^{336}$ También es conveniente recordar los intentos reformistas, aunque frustrados, de Cassola; de Polavieja y de Weyler.

337 ALONSO BAQUER, Miguel: "La Guerra hispano-americana de 1898 y sus efectos sobre las instituciones militares españolas", Revista de Historia Militar, Año XXVII, nº 54, Madrid, 1984, pp. 127151; CACHINERO, Jorge: "Intervencionismo y reformas militares en España a comienzos del siglo XX", Cuadernos de Historia Contemporánea, $\mathrm{n}^{\mathrm{o}}$ 16, Madrid, 1988, pp. 155-184 (llama la atención su condescendencia hacia los militares, en contraste con las críticas dirigidas hacia los partidos turnistas); MARTÍNEZ SANZ, José Luis: "Prisión, humillación y castigo: los frutos del 98 para los militares", Cuadernos de Historia Contemporánea, no 20, Madrid, 1998, pp. 191-203. Quien, probablemente, más incide en la sensación de injusticia que el Desastre provocó entre los oficiales y que, con el tiempo, derivó en un espíritu muy agresivo es Sebastian Balfour. Véase BALFOUR, Sebastián: El fin del Imperio
} 
pobreza de la vida cuartelera se sumó una hostilidad ambiental; y un clima de opinión aún más enrarecido tras la aprobación de la Ley de Jurisdicciones.

El entusiasmo loco de muchos jóvenes oficiales llegados a Marruecos pronto chocó con la desesperación de los reclutas. Centenares de hombres llegarían a África procedentes de un medio pobre, fundamentalmente rural, mal alimentados, separados de su familia y aterrorizados ante la perspectiva de la guerra contra el moro, ante la idea de matar para no morir. Nada podría sorprendernos, por consiguiente, su tendencia al desánimo. Pero si pésima era la situación del mozo llamado a filas, mucho peor lo fue la de los reservistas de 1909. Además de exponerse a la pérdida de su trabajo, se daba la circunstancia de que algunos llevaban más de cuatro años sin recibir instrucción ${ }^{338}$.

Como ya se indicó, la alarma llegó a Salamanca, sobre todo a este elemento joven y a los reservistas -soldados y clases que en los últimos cinco años hubiesen servido en batallones de Cazadores-, cuando desde la alcaldía, a finales de junio, se les previno para estar dispuestos a incorporarse a sus regimientos en cuanto surgiese el menor contratiempo. Lógicamente, se temía que muchos hombres casados se viesen afectados por semejante disposición ${ }^{339}$.

Varios meses antes, en El Adelanto encontramos una primera consideración sobre el funcionamiento del sistema de quintas. Venía al hilo del reconocimiento de que la emigración constituía, indudablemente, el problema más serio de la provincia y el miedo al servicio militar repercutía en un incremento de la misma:

"La legislación de quintas viene obligando a constituir un depósito de garantía al emigrante que no ha salido de quintas, y esto era un consuelo para las víctimas responsables subsidiariamente del cupo de cada pueblo, porque si fuera letra viva lo del depósito para el que emigra, los padres del emigrante pagarían el soldado o sufrirían el arresto o pena consiguiente a la insolvencia. Pero ahora, ni ese consuelo

Español (1898-1923). Barcelona: Crítica, 1997. En particular, y por su atención hacia la prensa militar del periodo y a la Ley de Jurisdicciones, es muy sugerente el capítulo 6 del citado libro: "La escopeta sin blanco: Los militares después del Desastre" (pp. 171-214). En este mismo apartado, el autor recalca la idea de que los militares, en los años inmediatamente posteriores al Desastre, mostraban un escaso interés hacia África. Lo que deseaban, en cambio, era "hacer patria".

${ }^{338}$ Uno de los testimonios más desgarradores sobre la situación de estos soldados, además de tratarse de una de las reflexiones más meditadas sobre el significado de la campaña de Melilla y los peligros del militarismo, es el de Eugenio Noel. A propósito de la necesidad de esclarecerse el nombre de los responsables de la guerra, este periodista encarcelado sentenciaba: "Es muy español y muy marroquí no recordar, creer inútil la enseñanza que se desprende del hecho. El buen don Alonso Quijano nos hizo mucho daño cuando nos impuso aquel adagio 'Mejor es no meneallo'. La revisión no se conoce en España, porque la responsabilidad, que es el triunfo de la moral moderna, no se acepta en la trasnochada y religiosa educación nuestra, con todas sus enérgicas consecuencias". Véase NOEL, Eugenio: Notas de un voluntario. Madrid: Imprenta de P. Fernández, 1910. $2^{\mathrm{a}}$ edición, p. 43.

339 "Lo de Marruecos. Alarma fundada", El Adelanto, n 7.672, 21 de junio de 1909, p. 1. 
queda, desde que por virtud de la Real orden del ministerio de la Gobernación, de 11 de Febrero de 1909, queda virtualmente ineficaz, ${ }^{, 340}$.

El periódico, a través del redactor "L. A." llamaba la atención del gobernador civil y de los integrantes de la Comisión Mixta de Reclutamiento, a sabiendas de que ningún mozo quería cargar con la pena del servicio, porque temía la proximidad de conflictos: "Conflictos para los pueblos y que pueden afectar, y desde luego afectan a la Patria en días no lejanos si no se opone un fuerte correctivo a tales desmanes". ¿No había ya algún redactor preocupado por la situación marroquí?

A decir verdad, muy poco tiempo después, concretamente en abril de 1909, el Consejo de Ministros aprobó un nuevo proyecto de ley de reclutamiento ${ }^{341}$. A la espera de su tramitación parlamentaria, El Adelanto se interesó bastante por él, prestando publicidad a parte de su articulado ${ }^{342}$. Por ejemplo, "H." consideró muy ambicioso su deseo de alfabetizar a los nuevos reclutas. El "desasne" de los veinteañeros se presentaba como una tarea ardua e ingrata porque el problema de fondo, el analfabetismo imperante, era muy serio y arrastraba a la confusión, a una relativa yuxtaposición de competencias, entre las instituciones públicas: "la escuela para hacer buenos ciudadanos y la milicia para convertir a éstos en soldados. Si se usase el mismo rigor con los prófugos o desertores de la escuela que con los del Ejército, otro gallo nos cantara $^{\$ 43}$. Las pretensiones de la nueva ley, no obstante, iban más allá de ese deseo de mejorar los niveles educativos de la juventud: la supresión de la redención en metálico era su aspecto más controvertido.

El redactor Fernando Felipe, más conocido como "Juan de Salamanca", ya había argumentado, muy tempranamente y a los largo de dos sugerentes editoriales, que esta medida resultaría perjudicial, al entorpecer la obtención de dinero por parte del ministerio de la Guerra (y que por norma se invertía en el acondicionamiento de los cuarteles). Sin embargo, en un esfuerzo por incentivar el debate público - gesto que le honraba-, también reconoció que la posibilidad de redención era, en el extranjero, algo absolutamente incomprensible. Sus dos contribuciones periodísticas llevaban por título "Haciendo patria". Esto decía en la primera de ellas:

\footnotetext{
340 "L. A.": "La emigración y las quintas. A la Comisión Mixta de Reclutamiento", El Adelanto, n 7.591 , 16 de marzo de 1909, p. 1.

341 "Notas militares. La ley de reclutamiento", El Adelanto, n 7.607, 3 de abril de 1909, p. 2.

342 "Proyecto de ley de reclutamiento. El servicio militar obligatorio", El Adelanto, no 7.609, 6 de abril de 1909 , p. 2. El Salmantino también publicó las bases de la ley, pero sin verter ningún comentario. Consúltese "Más sobre el reclutamiento", El Salmantino, no 81, 1 de mayo de 1909, pp. 2-3.

343 "H.": "Notas militares", El Adelanto, n 7.529, 2 de enero de 1909, p. 2.
} 
"¿Qué significa este 'haciendo patria”? ¿Por qué antes era frase desconocida y ahora se emplea tanto? ¿Es que nuestra patria, la patria española, no está hecha o es que hay algo que la ha deshecho, y que debe desaparecer, para que la patria se rehaga? (...) He conocido franceses que se avergonzaban de no haber hecho el servicio militar, aunque se lo impidió una enfermedad. He oído hablar de un alemán que para no hacer el servicio militar, marchó al extranjero, y cuando volvió, sus padres lo echaron de casa. ¿Qué quiere decir esto? Muchos son los que abogan por el servicio obligatorio, sin embargo, son muchos los que lo combaten por creerlo muy perjudicial. Indudablemente, ésta no es una manera de hacer patria. Hay otra manera en la que se deben poner todas las esperanzas. ¿Cuál? La de que todos los españoles lleguen a conocerse $^{, 344}$.

Evidentemente, el artículo quedaba, a propósito, inconcluso y le daba pie a "Juan de Salamanca" para publicar un nuevo editorial. En esta segunda parte, el autor comenzaba reconociendo que el asunto que pretendía abordar era absolutamente trascendental y poseía un atractivo irresistible:

“'Hacer patria' es hoy una preocupación no sólo de políticos profesionales, sino de escritores y de oradores que nada tienen que ver con los politicos. ¿Cómo se hace patria? Para mí es axiomático que no hay más que una manera de hacerla: hacer primero todo lo que constituye la patria. Si ésta se compone de individuos, familias, pueblos, provincias y regiones, hacer todos elementos será hacer patria (...) Sólo una patria formada por individuos que se reconozcan llenos de deberes, será una patria tal como imaginan los mejor intencionados. Si llegara un día en que todos los españoles hicieran una revolución, no para reclamar derechos, sino para pedir que se les señalaran los deberes que habían de cumplir, la patria estaría hecha ${ }^{, 345}$.

Con mucho mayor descaro, tras el estallido del conflicto en el Rif, encontramos en El Adelanto a quien justifica el buen funcionamiento de las quintas, incluso reconociendo que constituía una lacra la posibilidad de redención en metálico. Con todo, era positivo el hecho de que se pudiese movilizar con gran velocidad a los reservistas. Y, en cualquier caso, el dolor de los familiares era compensado por el correcto espíritu militar de los soldados. Maura, desde luego, había actuado de acuerdo con la legislación vigente:

"Un principio de ética militar aconseja que cuando una unidad (llámese regimiento, batallón, escuadrón, etc.) sale a campaña, se nutra con los soldados que antes se alistaron bajo sus banderas. En este caso se encuentran los reservistas. Allí cada uno tiene su armamento, las prendas de su equipo que ya usara; allí encontrará a los compañeros con quienes aprendió la instrucción, y a cuyo lado tuvo germen el espíritu militar, que reaparecerá ahora vigoroso (...) Al llegar a su antiguo Cuerpo el reservista, salvo contadas excepciones, se encuentra con los mismos jefes y oficiales que en otro tiempo le mandaron y instruyeron (...) Todas estas incidencias, pequeñeces $y$ detalles, son las que forman el total, llamado espíritu de Cuerpo, que tiene un alto valor militar, y que en ocasiones puede ser hasta decisivo ${ }^{, 346}$.

\footnotetext{
344 "Juan de Salamanca": "Vida nacional. Haciendo patria", El Adelanto, no 7.534, 8 de enero de 1909, p. 1.

345 “Juan de Salamanca": "Vida local. Haciendo patria", El Adelanto, no 7.539, 14 de enero de 1909, p. 2.

346 “Por qué van los reservistas a Melilla", El Adelanto, no 7.700, 24 de julio de 1909, p. 2.
} 
Sin duda, callaba que los reservistas eran hombres con instrucción militar, algo oxidada, pero en todo caso su empleo ofrecía ventajas frente a los excedentes de cupo, que no habían recibido formación. Seguramente, este fue el motivo por el que un año después, ya gobernando Canalejas, se intentó paliar dicho inconveniente, ordenando el destino a Cuerpo, que no la incorporación, de los excedentes de cupo ${ }^{347}$.

$Y$ en cuanto al sufrimiento de los familiares, se trataba de una explicación que el diario liberal ni siquiera consideraba. Al contrario, la campaña que entonces, por ejemplo, estaba protagonizando el Grupo Feminista Socialista Madrileño le provocaba una repugnancia visceral ${ }^{348}$.

El gobierno era muy consciente de la animadversión que los llamamientos militares suscitaban. En tan fatídica fecha como el 27 de julio de 1909, El Adelanto publicaba unas manifestaciones del general Linares, ministro de Guerra desde febrero Primo de Rivera justificó, entonces, su retirada por problemas de salud-, anunciando una nueva y masiva movilización de tropas. Había entonces casi 24.000 hombres en la plaza y se aspiraba a reunir 40.000 soldados con el propósito de terminar con la campaña cuanto antes. El ministro conservador aprovechó también la entrevista para manifestar que el espíritu de los combatientes era excelente, pese a que los infundios en esta materia habían contribuido a posicionar a la opinión contra la guerra. Reconocía que era necesario despertar el patriotismo popular, "dejar a salvo el honor de nuestro Ejército", mientras que la depuración de posibles responsabilidades quedaba relegada a un segundo plano. Por último, sus palabras hacia Marina eran muy elogiosas, deseando su pronto ascenso a teniente general ${ }^{349}$.

Pero a pesar de estas declaraciones, a principios de agosto, se haría precisa la anulación de la redención en metálico. Desde la redacción del periódico liberal ahora también hubo quien defendió la justicia de la medida, aunque, paradójicamente, entendía la reacción de aquellos padres de familia que se intentaban querellar con las sociedades aseguradoras, reticentes a devolverles sus ahorros ${ }^{350}$.

Por otra parte, con el tiempo se comprobaría que había bastante de mentira en esos comentarios a propósito de la moral de los mozos contra los que se encaraba el

\footnotetext{
347 "Los excedentes de cupo. Alarma infundada", El Adelanto, no 8.036, 5 de septiembre de 1910, p. 1.

348 "Las madres españolas", El Adelanto, no 7.703, 28 de julio de 1909, p. 1.

349 "Lo que dice el ministro de la Guerra", El Adelanto, no 7.702, 27 de julio de 1909, p. 1.

350 "La redención a metálico", El Adelanto, no 7.715, 11 de agosto de 1909, p. 1.
} 
ministro. De otro modo, no se podría entender lo que ocurrió en el momento del alistamiento de 1910; una muy triste realidad que denunciaba "Un Repórter":

"Nuestra juventud, a lo que se deduce de las operaciones de quintas, practicadas días pasados en el Ayuntamiento, está de 'capa caída'.

Quien no es corto de talla, aparece tullido; quien posee buena estatura, es estrecho de pecho; quien disfruta de buen semblante, es cojo, manco, tuerto, sordo, y... otros entorpecimientos por el estilo que no les permite ser soldados.

De más de 200 mozos que en el actual reemplazo han 'entrado en quintas', casi la mitad o acaso más, se quedarán en sus casas buscando reposo a sus maltrechos cuerpos y salud a sus quebrantados organismos.

El Ejército pierde una buena remesa de muchachos con los que habría contado antes, haciendo números para la defensa y servicio de la Patria.

La de este año ha sido una quinta de inválidos, de enfermos y de cortos de talla, sin contar con los hijos de viuda, padres sexagenarios y otros que, en casos análogos, son relevados por la ley de ir al servicio.

Esto, que a primera vista no parece tener gran importancia, la encierra y muy grande, porque en ello trae aparejado una porción de causas ique dicen muy poco en pro de nuestra invicta ;ay! raza, esa raza hercúlea, sana, culta, vigorosa, con la que sueña Eugenio Noel, el buen patriota y mejor escritor!

No sé yo si a estos muchos se les podrá decir con el poeta, aquello de 'iOh, juventud, primavera de la vida!', o si sería mejor, parodiando estas frases, decirles: ¡Oh, juventud, antesala de la muerte! Esto será todo lo horroroso que ustedes quieran, pero al fin y al cabo se acercaría más a la realidad ${ }^{, 351}$.

De hecho, un auténtico escándalo se generó a mediados de julio de 1910 cuando, mediante una Real Orden, fueron llamados a filas los excedentes de cupo de 1908 y 1909, unos 1.300 salmantinos. Tal fue el número de exceptuados, tras el conflicto, que hubo de recurrirse a semejante medida. Se creía, sin embargo, que era una disposición con la que se pretendía ensayar la implantación del servicio militar obligatorio $^{352}$.

El Lábaro, si centramos ahora nuestra atención en este diario conservador, no se mostró tan pendiente del asunto de las quintas, sino que su interés fue más oportunista. Así, también reprodujo otras declaraciones de Linares el 4 de agosto, precisamente cuando el gobierno acordó suspender la redención en metálico. En ellas, el ministro se dedicaba a defender sus gestiones frente a los comentarios de los sectores críticos. Sostuvo que había sido muy eficaz y prevenido con su rápido envío de fuerzas y material a Melilla (sobre todo, hacía hincapié en el envío de reflectores para garantizar el aprovisionamiento de agua, en los servicios médicos y en la dotación de cartuchos) ${ }^{353}$.

\footnotetext{
351 "Un Repórter": "Notas de un periodista. Los quintos de este año", El Adelanto, n 7.895, 11 de marzo de 1910, p. 1.

352 "Los excedentes de cupo de Salamanca", El Adelanto, nº 8.003, 16 de julio de 1910, p. 1.

353 "Declaraciones del ministro de la Guerra", El Lábaro, no 3.740, 4 de agosto de 1909, p. 2.
} 
De todos modos, este periódico católico se postuló como contrario a la redención. Aunque tampoco aplaudió la disposición derogatoria del gobierno de Maura. Lo que hizo fue secundar una opinión de prestigio: la de España Futura. Esta publicación puso en tela de juicio la legalidad de la disposición maurista. Pero, simultáneamente, desechó la idea de un servicio militar obligatorio sin restricciones. Su propuesta, por tanto, apuntaba hacia un Ejército de voluntarios, similar al modelo británico. Por esta razón, se enorgullecía muchísimo con el ejemplo proporcionado por los aristócratas alistados ${ }^{354}$; y también le satisfacía, para terminar, la actitud resignada de las madres y esposas salmantinas ${ }^{355}$.

El Castellano, asimismo, publicó el 12 de julio otras manifestaciones de Linares que suponían un enorme gesto de apoyo hacia Marina: el gobierno le ratificaba sus instrucciones para que actuase según su “inspiración” "356. Además, se disponía al envío urgente de dos brigadas de Cazadores: la de Barcelona -que, en efecto, inició su embarque ese mismo día ${ }^{357}$ - y la de Madrid $^{358}$.

También la decisión gubernamental de suprimir la redención en metálico durante la campaña -medida solicitada por Pablo Iglesias, junto con el cese en el envío de soldados a Marruecos, en una sesión del Ayuntamiento de Madrid, el 24 de julio ${ }^{359}$-, fue muy contestada por El Castellano. Uno de sus columnistas consideró que era una imprudencia enorme; pero no por su fondo, sino por las formas:

"El gobierno sin reparar acaso que en los actuales momentos, su concesión puede parecer una gran debilidad y el reconocimiento inoportuno de un error en que ha perseverado, por largos años, ha decretado lo que demandan las huestes democráticas, y lo que no siempre se ha pedido con los debidos respetos.

Pero lo peor y lo más grave es que el gobierno del señor Maura ha puesto por delante de sí al adoptar esa suprema resolución el nombre de Su Majestad",360.

El redactor, seguidamente, se congratulaba por el significado inmediato de la disposición, confiando en que se paliasen las diferencias entre clases sociales a la hora de acudir al combate, pero denunciaba el escaso respeto de Antonio Maura hacia la

\footnotetext{
${ }^{354}$ Juan D. Berrueta: "La voluntad en la Guerra”, El Lábaro, no 3.786, 29 de septiembre de 1909, pp. 1-2. 355 Julio Arias Camisón: "Rápida", El Lábaro, no 3.792, 6 de octubre de 1909, p. 1.

356 "Telegramas de la mañana. Lo que dice Linares", El Castellano, no 1.490, 12 de julio de 1909, p.1.

357 "Lo de Melilla", El Castellano, no 1.490, 12 de julio de 1909, p. 2.

358 “Telegramas", El Castellano, no 1.490, 12 de julio de 1909, p.2. También Alfonso XIII, según se recogía de La Correspondencia de España, confesó su satisfacción por el comportamiento de Marina y por la rápida movilización de los reservistas: "Correo de Madrid. Palabras del Rey. Declaraciones de Maura. Informes oficiales", El Castellano, no 1.495, 17 de julio de 1909, p. 1.

359 "Última hora", El Castellano, n' 1.500, 23 de julio de 1909, p. 2; "De la guerra", El Lábaro, no 3.756, 23 de agosto de 1909, p. 1.

360 "Servilismos peligrosos", El Castellano", no 1.512, 6 de agosto de 1909, p. 1.
} 
Constitución. Había hecho del monarca una figura tangible: "Para que el Rey reine y no gobierne, como pide la pureza del régimen, preciso es que a ninguna disposición buena o mala se le atribuya un real origen". A decir verdad, meses antes del estallido de la guerra, este periódico ya había hecho gala de una actitud bastante antipática hacia las agencias de deserción. Las responsabilizaba de enriquecerse a costa del sufrimiento de los jóvenes y las tildaba de estafadoras ${ }^{361}$.

Nos figuramos que es el mismo periodista quien abundó en la cuestión unos días después. La citada Real Orden del 4 de agosto planteaba un absurdo jurídico porque equivalía a la derogación de otra previa, del 19 de junio de 1908. Esta Real Orden había dispuesto que los excedente de cupo de ese año no podían pagar la redención salvo en el caso de que fueran llamados a filas. Ahora, no obstante, eran llamados a filas pero seguían sin poseer derecho a la redención ${ }^{362}$.

Por último, El Salmantino se limitó a recoger telegráficamente que el gobierno había decidido, mientras se prolongase el conflicto, suprimir la redención en metálico. No formuló ningún comentario; únicamente subrayó la satisfacción entre la prensa madrileña ${ }^{363}$.

Resumiendo, casi todos los rotativos locales se hicieron eco de distintos comentarios vertidos por fuentes oficiales, fundamentalmente por el ministro de Guerra, con una permanente intención autoexculpatoria. Evidentemente, la supresión de la redención fue la disposición que generó una mayor controversia porque bajo ella latían muy distintas concepciones de las "obligaciones patrióticas" del ciudadano. El Salmantino únicamente insinuó su rechazo a la medida conservadora. Al hacer hincapié en la alegre reacción de la prensa madrileña, guarida clave del Trust, lo que realmente estaba denunciando era su equivocación. La contestación de El Castellano también fue negativa, pero fundamentada en un defecto de forma y en una censura al gobierno Maura por su falta de oportunidad. Sin embargo, el fondo de la disposición, la defensa de un mayor igualitarismo, merecía su aplauso. En El Adelanto, como viene siendo frecuente, hallamos una división de pareceres: "Juan de Salamanca" rechazó la abolición de la redención a cambio de dinero, mientras que otros redactores la justificaron debido a la excepcionalidad del momento. Por último, El Lábaro fue el periódico local que, en esta ocasión, sostuvo un criterio más moderno o acorde con

\footnotetext{
${ }^{361}$ Frich: "Las quintas y los seguros", El Castellano, no 1.368, 13 de enero de 1909, p. 1.

362 "Redención y no redención. Absurdo jurídico", El Castellano, no 1.518, 13 de agosto de 1909, p. 1.

363 "La campaña de Melilla. Una escaramuza", El Salmantino, n 95, 7 de agosto de 1909, p. 5.
} 
parámetros actuales: ni un régimen de privilegios ni de obligatoriedad; soldados voluntarios y profesionales.

\section{El temor al déficit}

Además del endurecimiento de la censura, ésta fue otra consecuencia, más a largo plazo, de la prolongación de los combates. El Adelanto no tardó en revolverse contra "el positivismo imperante" porque juzgó mezquino poner precio al sacrificio de los soldados españoles: "Hay algo en las almas verdaderamente patrióticas que rechaza toda idea de manejar cifras y ponerse a echar cuentas sobre el dinero que podrá costar una empresa en la que están en juego el honor de las armas, nuestro prestigio como nación y la vida de tantos nobles hijos de la madre España"364. Desconocemos el nombre del redactor de las anteriores líneas. Pero básicamente, lo que hacía a continuación era recoger algunos datos manejados por el Diario Universal para explicar que, según los cálculos gubernamentales, la guerra podía suponer unos 33 millones de pesetas anuales, si bien el Tesoro disponía entonces de casi 97 millones. En conclusión, no había cabida para comentarios agoreros.

Pero a principios de octubre, tras el sangriento enfrentamiento en el camino hacia Beni-bu-Ifrur, en cambio, el diario liberal ya no parecía tan convencido ante la anterior explicación. Y es que los gastos militares rozaban entonces los 100 millones de pesetas. Por esta razón, el gobierno había anunciado que, tan pronto como se reabriesen la Cortes, presentaría un proyecto de ley para cubrir el importe de las obligaciones contraídas. Pero como se aseguraba que no se iba a emplear ningún sobrante de los presupuestos generales, ni se iba a emitir deuda, no se aclaraba la procedencia de los recursos $^{365}$.

Las dudas se despejaron dos semanas después: El Adelanto respondía con auténtica furia al hacerse público el nuevo proyecto del gobierno maurista. Como consuelo, en efecto, las cifras aportadas días atrás se rectificaban, ya que se estimaba que los gastos efectuados más las nuevas inversiones hasta fin de año supondrían unos 68 millones de pesetas. Pero, para cubrirlos, se recurriría primero al superávit, que se situaba en 50 millones, y en segundo término, se procedería a la creación de un nuevo impuesto. Y aquí es donde surgía el problema: se trataba de un tributo de 500 pesetas por mozo que deberían satisfacer los reclutas redimidos y los excedentes de cupo de los seis remplazos comprendidos entre los años 1903 y 1908. Las estimaciones más a la

\footnotetext{
364 "La guerra y la Hacienda", El Adelanto, no 7.707, 2 de agosto de 1909, p. 1.

365 “La campaña de África”, El Adelanto, no 7.760, 2 de octubre de 1909, p. 3.
} 
baja elevaban el número de afectados a 300.000, con lo que si todos pagasen, el Tesoro podría recaudar 150 millones de pesetas. En suma, se trataba de una carga fiscal desmesurada. Pero, además, también inconstitucional: en el proyecto no se explicaba por qué eran exceptuados de tributación los redimidos y excedentes de cupo de 1909. Mientras que estos redimidos del último año apenas habían empezado a pagar sus cuotas, los de anualidades previas se veían en la tesitura de pagar otra vez por un trato de privilegio que teóricamente ya se habían asegurado:

"Desnaturaliza y tuerce el carácter de la redención militar. Según la ley vigente, los redimidos sólo quedan exceptuados del servicio ordinario de guarnición, y se hallan sujetos a instrucción militar y a prestar servicio militar en tiempo de guerra. El proyecto del gobierno libraría de aprobarse, por 500 pesetas, del servicio de ocupación militar, que es una prolongación del servicio de guerra.

El impuesto de 500 pesetas sería una carga, especialmente para los pobres, los cuales serían los castigados con su aprobación.

Dice el proyecto que quedan exceptuados los pobres en el sentido legal, añadiendo que para ello se computará con el jornal o sueldo de los mozos los que disfruten sus padres. Quiere esto decir que únicamente los que tengan diariamente, entre los dos jornales o sueldos, menos de cuatro o seis reales, serían los exceptuados. Esto es, que todo obrero del campo que con su jornal y el de sus padres reúna seis reales diarios, tendría que abonar el impuesto de 500 pesetas, o en caso contrario, ir a Melilla, y que le ocurriría lo mismo al obrero de la ciudad que con su jornal y el de sus padres reúna más de tres o cuatro pesetas diarias, y al funcionario del Estado, al empleado particular, al pequeño labrador, al modesto industrial, al comerciante, a todos, en fin, los que con su esfuerzo manual o intelectual, ganen en las ciudades de veinte a veinticinco duros mensuales, y de ocho a doce duros en los pueblos y aldeas.

$Y$ todos esos se han librado ya del servicio militar por su suerte o por el dinero reunido sabe Dios después de cuántos sacrificios.

¿Puede darse nada más odioso? "366.

Tal vez sorprenda, sobre todo, esa distinción entre el pobre en sentido legal y el pobre real. El Adelanto hacía uso de ella para mostrar que las redenciones estaban más extendidas de lo que, en principio, pudiéramos esperar. Pero ello, desde luego, no era síntoma de bonanza económica, sino el fruto de un cínico cálculo estatal. Sin embargo, con la nueva ley, las posibilidades de liberarse del servicio militar se recortarían drásticamente para la mayoría. Como alternativa I. M. y Mendoza planteaba que:

"Lo justo, lo equitativo y racional es que al redimido se le excluya de tal contribución (...) Que a los excedentes de cupo se les grave con tal impuesto, porque ningún servicio directo, indirecto, ni personal han prestado, ni tampoco han contribuido pecuniariamente a levantar hasta ahora las cargas de la nación y de esa campaña. $Y$, por último, que a los mismos se les admita la excepción mediante el pago de las 500 pesetas, pero el que no las satisfaga, porque no quiera, o no pueda, contribuya con su prestación personal, y de ese modo todos cooperarán por igual en el modo y forma que cada cual lo haga a esa apremiante necesidad de la campaña en que estamos empeñados, y de no lograrse con esa redención del servicio extraordinario de los

366 "Proyecto absurdo", El Adelanto, no 7.774, 19 de octubre de 1909, p. 1. 
excedentes de cupo los diez y ocho millones que se esperan obtener de tal impuesto, acúdase a otro de los mil elementos de esta producción de que dispone el Estado ${ }^{\text {"367. }}$.

Evidentemente, librarse del servicio exigía abundantes sacrificios, pero no era imposible, y, de ahí, que el columnista reclamase que los redimidos no fuesen sometidos a nuevas cargas fiscales.

El Lábaro también, aunque de manera bastante más puntual, se preocupó por las derivaciones económicas de la contienda. Así, a mediados de septiembre y siguiendo el criterio marcado por la Revista de Economía y Hacienda, apostaba por un incremento de las tributaciones para 1910 y rechazaba la idea de emitir deuda pública. Además, le reconfortaba el hecho de que las declaraciones de Besada, ministro de Hacienda, parecían apuntar en este mismo sentido: la reforma de Villaverde era una obra duradera y la Bolsa apenas se resentía por la campaña: si previamente los francos valían 9,40 pesetas, ahora se cotizaban a $9,10^{368}$.

Asimismo, El Castellano se ocupó extensamente de este asunto. Por este motivo, reprodujo íntegramente en sus páginas el proyecto del ministro Besada. Y lo comentó, con bastante mayor esmero que el exhibido por el diario católico. El ministro se mostraba reticente a la idea de que se recargasen los impuestos ya existentes, consciente de que tal disposición sería muy injusta para aquellos contribuyentes que ya hubiesen experimentado las inclemencias de la campaña. De ahí la idea de crear esa nueva carga fiscal sobre los reclutas redimidos y los excedentes de cupo de los seis remplazos comprendidos entre los años 1903 y $1908^{369}$. La idea merecía la aprobación de este diario, ya que concordaba con su creencia de que todo régimen de privilegio debía ser combatido.

En el caso de El Salmantino, para terminar, sólo en 1911, al hacerse públicos los ambiciosos proyectos del ministro de Fomento, Gasset, hallamos una mínima consideración económica con relación a la campaña militar:

"Surge la guerra con el moro y para hacer frente a la campaña y preparar sus contingencias, el Estado tuvo que agotar sus reservas y economías, surgiendo necesariamente la siniestra figura del déficit, para volver a consolidar su entronizamiento en todos los presupuestos (...) No obstante, el poder ejecutivo, conociendo estas dificultades, todavía se aventura a reorganizar la escuadra y para ello, pidió a la riqueza nacional nuevos sacrificios, lo cual es imposible que pueda atender, y por si esto fuera poco, aparece ahora Gasset, requiriendo 320 millones, ${ }^{, 370}$.

\footnotetext{
${ }^{367}$ I. M. y Mendoza: "Los gastos de la guerra”, El Adelanto, $\mathrm{n}^{\mathrm{o}} 7.776,21$ de octubre de 1909, p. 1.

368 "De la guerra", El Lábaro, no 3.774, 14 de septiembre de 1909, p. 2.

369 "Gastos de la guerra", El Castellano, no 1.617, 20 de octubre de 1909, pp. 1-2.

370 "Los proyectos de Gasset", El Salmantino, n 235, 13 de marzo de 1911, p. 1.
} 
En definitiva, en lugar de encontrar francas censuras contra la contienda, lo que hallamos son protestas contra sus derivaciones económicas y reformulaciones del nuevo proyecto impositivo del gabinete presidido por Maura. Así, El Salmantino antepuso las obligaciones militares a todo lo demás y no se molestó ni en comentar el citado proyecto. Tampoco El Lábaro se dejó arrastrar por los apremios económicos del momento. En cambio, El Adelanto rechazó el plan conservador, a sabiendas de que la redención se iba a convertir en un privilegio de carácter sumamente elitista. Por su parte, El Castellano entendió y compartió tanto su urgencia como su significado.

\section{Críticas a la guerra fundamentadas en la estrategia de combate}

A pesar de ese encumbramiento permanente del Ejército español, de la glorificación de sus acciones guerreras y a pesar, incluso, de la vigencia de la censura, muy puntualmente también aparecieron en la prensa salmantina algunos comentarios negativos relacionados con el comportamiento de los combatientes. El Adelanto, ya el 28 de julio, cuando todavía se sabía muy poco de la derrota sufrida, fijaba su mirada en la desproporción entre las bajas de jefes y oficiales y soldados en Melilla. El problema era puramente estratégico y consistía en que las tropas españolas estaban ocupando las partes bajas de los montes, con lo que la fusilería y la artillería carecían de facilidades para actuar, mientras los rifeños gozaban de ventaja en las distancias cortas. Sin duda, la llegada de refuerzos y de baterías se hacía indispensable:

"Pasado el tiempo de llegada de refuerzos y acopio de los elementos para el avance indispensables, habremos de ir a buscar a los moros, comenzarán éstos a ver llover granadas en sus filas cuando se hallen a tres y cuatro kilómetros de nuestro frente; experimentarán los estragos del fusil máuser antes de llegar a los 1000 metros; entre 1200 y 600 se librará la mayor parte de la lucha, y cuando a tales distancias se combata, estarán ya sumamente quebrantados. Ahora, en cambio, pueden, rastrando por laderas ocultas a nuestra vista y fuegos, llegar a lomas dominantes, ${ }^{, 371}$.

El 5 de agosto de 1909, una fecha que nos parece sorprendentemente temprana, encontramos, por primera vez, una clara reprobación hacia la estrategia de combate adoptada por el general Pintos, fundamentada en la búsqueda del combate frontal; y también una censura ante el arrojo imprudente de Marina. Pero no hablaba El Adelanto; sólo se hacía eco de una columna de La Correspondencia Militar ${ }^{372}$.

Al finalizar octubre, sí que es la propia redacción de El Adelanto quien exponía su verdad sobre el desarrollo de las batallas: "Todos los combates de esta guerra en que

\footnotetext{
371 "Las bajas de la campaña", El Adelanto, no 7.703, 28 de julio de 1909, p. 2.

372 “La campaña de África”, El Adelanto, no 7.710, 5 de agosto de 1909, p. 2.
} 
la infantería se ha lanzado al ataque sin previa preparación del fuego de los cañones han sido sangrientos para ella, confirmando el axioma de que, ante el armamento moderno, no hay más defensa que abrumar previamente con una lluvia de balines a los tiradores enemigos ${ }^{\prime 373}$.

El Lábaro, al contrario, dos días después de la batalla en el Barranco del Lobo, sacaba pecho por lo bien que se conocía la orografía de Marruecos gracias a un mapa de la editorial barcelonesa de Alberto Martín ${ }^{374}$. La actuación de las tropas españolas fue, a su juicio, siempre brillante.

El Castellano, en cambio y refugiándose tras las autorizadas palabras del doctor Maestre, reclamó la necesidad de emplear más artillería y de ocupar, incluso, Tetuán y Larache, para aliviar la tensión militar en el Gurugú ${ }^{375}$.

En El Salmantino, finalmente, toda crítica de carácter estratégico hubiese chocado con su defensa a ultranza de las armas españolas.

\section{Hacia el fin de la campaña...}

$\underline{\text { La apertura de las Cortes y la caída de Maura }}$

Desde la apertura de las Cortes, el 18 de octubre, las sesiones transcurrieron en un ambiente marcado por la creciente agresividad. Por esas fechas, y según un informe presentado por el Estado Mayor, había en África, a disposición del comandante en jefe del Ejército de operaciones, 42.019 hombres (y una tercera división expedicionaria, preparada en la Península, con 7733 soldados).

En la primera sesión parlamentaria, y como paso previo al resto de tareas legislativas, González Besada, ministro de Hacienda, leyó el proyecto de ley de créditos que, con carácter urgente, debían proveer a los gastos militares del Rif. Pero, Moret se apresuró a abrir el debate sobre el caso Ferrer. Si bien Maura intentó explicar por qué suspendió las garantías constitucionales, Moret reaccionó pidiendo a la mayoría que no siguiera apoyando al gobierno.

El día 20, todas las miradas se dirigieron hacia La Cierva, ministro de la Gobernación y responsable directo de las medidas punitivas aplicadas en Barcelona. La Cierva se defendió apelando a la manipulación por parte del Trust. Creía que las manifestaciones antiespañolas en Europa eran el fruto de una bien orquestada campaña de difamación, ante lo que Miguel Moya respondió amenazándole con el Código Penal.

\footnotetext{
373 "La campaña de África”, El Adelanto, $\mathrm{n}^{\circ}$ 7.777, 22 de octubre de 1909, p. 2.

374 "Mapa de Marruecos", El Lábaro, no 3.735, 29 de julio de 1909, p. 1.

${ }^{375}$ Tomás Maestre: "La Guerra de África. Opinión razonada", El Castellano, $\mathrm{n}^{\mathrm{o}} 1.506,30$ de julio de 1909, p. 1.
} 
La sesión terminó con el abandono del Congreso por parte de las minorías liberal y demócrata, después de que en el tiempo de réplica, La Cierva responsabilizase a Moret del atentado contra los Reyes en la Calle Mayor.

Después de esto, los liberales decidieron interrumpir todas sus relaciones parlamentarias con el gobierno: no participarían en las Comisiones ni colaborarían en la aprobación del proyecto de ley que proveía a los gastos militares del Rif.

En esta tan dramática coyuntura, finalmente, el día 21, con motivo de la celebración de un Consejo de Ministros, Maura se dispuso a presentar su dimisión ante Alfonso XIII. Pero antes de hacerlo, y para su sorpresa, el Rey se le adelantó y le agradeció los servicios prestados. Fue, ante todo, un movimiento de la opinión pública internacional el que impulsó al monarca a actuar así. La caída de Maura demostró, de todas formas, que el Parlamento no era tampoco representativo de la opinión pública nacional y también evidenció, por descontado, lo grande que era el poder de la Corona.

Para la redacción de El Adelanto, el derecho a la información había quedado por completo subordinado al interés patriótico. Por eso, entre sus integrantes se había generalizado el miedo ante la reanudación de los debates parlamentarios:

"El país, que ha prodigado la sangre de sus hijos y el dinero de sus arcas para la campaña rifeña, tiene derecho perfecto a que se le diga cuanto en Melilla y sus alrededores ha ocurrido, pero las operaciones militares no han terminado, la disciplina es producto de la confianza, y mientras esté frente al enemigo, no pueden ni deben discutirse gestiones ni personas que en su mano tienen la suerte de España y a las que, acaso, las censuras quitaran la serenidad que el mando exige ${ }^{, 376}$.

Es decir, el momento no era el oportuno para poner en tela de juicio la actuación del general Marina ${ }^{377}$. La nota discordante venía en esta ocasión de la pluma de “Argos", quien desdiciéndose por enésima vez - primero rechazó la censura, luego la acató; anticipó apresuradamente el fin de la campaña, pero con posterioridad al desastre en El Jemis aseguró que siempre había temido una catástrofe así-, deseaba el pronto hundimiento de Antonio Maura porque creía de este modo interpretar el sentir público mayoritario:

"Se extiende como un reguero de pólvora por toda España la protesta de la prensa, hecha contra el estado de opresión en que nos tiene el gobierno, y lo bueno del caso es que los políticos, liberales, demócratas y republicanos, sienten el tremendo empuje de la opinión (...) Sobre dos puntos gira este magno problema nacional; sobre las consecuencias de la representación llevada por nuestros compañeros a las gradas del trono y sobre la problemática apertura de Cortes (...) La cuerda está demasiado tirante

\footnotetext{
376 “La campaña parlamentaria”, El Adelanto, no 7.768, 12 de octubre de 1909, p. 1.

${ }^{377} \mathrm{Al}$ contrario, para apoyar al Ejército de África, lo que tocaba era empezar a discutir sobre recompensas y condecoraciones: "La campaña de África”, El Adelanto, no 7.769, 13 de octubre de 1909, p. 2.
} 
y a punto de romperse. No podemos resistir más, y si no hacen los hombres un milagro salvador, lo hará la Providencia, pues ya sabéis que hay una Providencia para los pueblos que se ahogan.

Quizás venga de África en esta ocasión. Grandes acontecimientos nos anuncian los corresponsales. Lo que allí suceda en breve, tendrá una enorme trascendencia ${ }^{\text {,378. }}$.

Poco después, "Argos" se apresuraría a celebrar la crisis ministerial y a desmentir la idea de que los liberales se negasen a aprobar nuevos créditos para la guerra $^{379}$. "Juan de Salamanca", en cambio, se conformó sólo reflexionando sobre la insignificante repercusión de un cambio gubernamental en la vida local ${ }^{380}$.

El Lábaro, por su parte, dio extensa cuenta de la virulenta sesión del día 18, con un encendido discurso de Segismundo Moret contra el proceder de Maura en Marruecos y Barcelona ${ }^{381}$. Lamentó profundamente el hundimiento del líder conservador, mientras que a Don Segismundo le acusó de carecer de un programa de gobierno ${ }^{382}$.

Una actitud muy similar a la de "Argos" fue la sostenida por la redacción de $E l$ Castellano. Si bien había prestado su visto bueno al proyecto de financiación de la contienda, la despreciaba en sí y le repugnaba cómo se había procedido a la supresión de la redención en metálico. Por eso su oposición al gobierno conservador era unánime y confiaba en que éste se viese desacreditado ante las Cortes:

"Los partidos liberales y democráticos, de la extrema derecha hasta la extrema izquierda, sin excluir el partido socialista, se preparan a emprender una ruda campaña contra el actual gobierno, a fin de que se restablezca la normalidad constitucional y cese este estado de cosas que se prolonga indefinidamente y cuya gravedad se aumenta a medida que el tiempo pasa.

Es de notar la unanimidad de pareceres que se manifiesta dentro de todos esos partidos, que reconocen sin discrepancia los peligros que entraña para la vida de la nación la conducta del ministerio que preside el señor Maura, dictador constitucional, que se empeña en seguir ejerciendo el poder del modo más anómalo posible ${ }^{\text {383 }}$.

Desde El Castellano, evidentemente, se celebró la caída de Maura, aunque no faltó la nota de lamento: su derribo se explicaba más por las presiones internacionales, que no por la fuerza de las Cortes españolas ni de una opinión pública contraria y bien articulada: “Maura cae y (...) no caerá por una votación contraria en las Cortes que no la tendría nunca (...) ni por un movimiento de opinión pública, cuya existencia negaría, aunque sea tan evidente como lo es en efecto. Maura cae por los golpes espirituales

\footnotetext{
378 "Argos": "Madrid al día", El Adelanto, no 7.749, 20 de septiembre de 1909, p. 1.

379 "Argos": "Madrid al día", El Adelanto, n" 7.778, 23 de octubre de 1909, p. 1.

380 "Juan de Salamanca": "Vida local. Los liberales", El Adelanto, n' 7.782, 28 de octubre de 1909 , p. 1.

381 "El día parlamentario", El Lábaro, no 3.803, 19 de octubre de 1909, p. 2.

382 "Munio": "De cada día. La evolución de los partidos", El Lábaro, n 3.823, 12 de noviembre de 1909, p. 2 .

383 "Movimiento político", El Castellano, n' 1.596, 25 de septiembre de 1909, p. 1.
} 
que da Europa entera" ${ }^{384}$. En otras palabras, el régimen no era mínimamente representativo y después de la Semana Sangrienta, el miedo impedía cualquier otra protesta pública.

Por último, en las páginas de El Salmantino, Clairac, más que recelar ante los posibles ataques que en las Cortes se vertiesen contra el jefe de las tropas en Melilla cuestión que ni siquiera mereció su consideración-, renegó del parlamentarismo:

"Triste es volver los ojos a los partidos politicos, y ver que pronto, el 18, se abrirán las Cortes, y que la dignidad de nuestra Patria y la sacrosanta Religión, tan escarnecida en Cataluña poco ha, en vez de ser defendidas serán ultrajadas y pisoteadas por esas comparsas de vividores, que no tienen más Dios y Patria que el estómago (...) iQué contraste entre el espectáculo que nos da en Melilla nuestro Ejército, y el que dentro de poco nos han de ofrecer los hombres del día, los que viven como parásitos chapando el jugo de la nación!, 385.

A decir verdad, desde El Salmantino, la caída de Maura se contempló inicialmente con cierta indiferencia. Aunque "S." reconocía la inteligencia política del líder conservador, no dejaba de pertenecer a la familia del Liberalismo. Eso sí, lo que se avecinaba, el gobierno de Segismundo Moret, parecía mucho peor que lo conocido ${ }^{386}$.

Y, en efecto, un año después, El Salmantino se enfurecía al recordar las circunstancias en que se produjo su advenimiento al Poder:

"El partido conservador, al concluir la guerra que sostuvimos con los rifeños, creyó era un deber inexcusable el de presentarse ante la representación nacional para obtener la unánime aprobación de los actos gubernamentales efectuados en el interregno parlamentario.

Iniciado el debate político el señor Moret, jefe nominal de las mesnadas liberales dinásticas y de aquel otro conglomerado que se llamó bloque, declaró rota la solidaridad que durante todo el periodo de la restauración habían mantenidos los dos organismos que la monarquía necesita para subsistir.

¡Con qué perentoriedad reclamaba este hombre funesto el poder! ${ }^{\text {387. }}$.

En resumen, El Castellano fue el único periódico salmantino que sostuvo, con convicción y a la vista de la represión en Barcelona, la existencia de un clima de opinión pública contrario al conflicto, si bien no dejó de remarcar lo inoportuno de este

\footnotetext{
384 "La caída de Maura”, El Castellano, no 1.617, 20 de octubre de 1909, p. 1.

${ }^{385}$ José M M $^{\mathrm{a}}$ L. de Clairac: "Crónica política", El Salmantino, no 104, 9 de octubre de 1909, p. 1. También en El Castellano, "Fa-Presto", coincidiendo con el anuncio de la apertura de las Cortes, escribía: "En la gran urbe tienes enemigos invisibles, Y se da el caso de que te denuncian un día por ser lector de algún periódico rojo o morado o por recibir visitas extrañas o por tener frascos de ácido sulfúrico en el tocador y ya está empapelado, disgustado y policeado (...) La libertad de tus movimientos y de tus modos de pensar, te conviene aunque por hoy no te muevas (...) Porque has de saber que así como necesita la Iglesia herejes, tu quietismo necesita de grandes agitadores. La revolución es un momento de la evolución. Y cuando los hombres ponen muros al curso de las aguas, tiene que calcular muy bien la fuerza de los aluviones. Por lo cual Maura ha preferido abrir las Cortes y devolvernos las garantías". Véase "Fa-Presto": "Palique", El Castellano, no 1.600, 30 de septiembre de 1909, p. 1.

386 "S.": "Ni contigo ni sin ti...", El Salmantino, no 106, 23 de octubre de 1909, p. 1.

387 "I. E.": “Catorce meses en el Poder", El Salmantino, no 172, 27 de diciembre de 1910, p. 1.
} 
sentimiento de malestar ${ }^{388}$. En cambio, tanto El Adelanto como El Lábaro y El Salmantino minimizaron su significado como protesta organizada, racional y vigorosa, justificando el proceder de Antonio Maura en la ciudad condal ${ }^{389}$.

La prensa salmantina y el gobierno de Moret: los créditos de la guerra, la ocupación de Atlatén y el inicio de las repatriaciones

Una de las primeras actuaciones del general Luque al aterrizar como nuevo ministro de Guerra fue anunciar su intención de acabar, cuanto antes, con la campaña africana $^{390}$. Y otra de las novedades gubernamentales, totalmente previsible, consistió en rechazar el proyecto ya comentado de financiación de la misma ${ }^{391}$. Por eso, el 1 de noviembre se anunció un decreto que concedía un crédito extraordinario al gobierno. Su valor: los 68 millones de pesetas requeridos ${ }^{392}$. Además, en estas mismas fechas se advirtió un primer acercamiento diplomático con Marruecos. Se rumoreaba que, a cambio del abandono de Zeluán, España sería compensada con los territorios de Benibu-Ifrur y Beni Sicar ${ }^{393}$.

Coincidiendo con el cambio en el gobierno, también se abrió la veda para las disputas dinásticas internas. Así, muy sonada fue una entrevista en la que el capitán general Fernando Primo de Rivera acusó al general Linares, su sucesor en el ministerio de Guerra, de absoluta ineficacia a la hora de movilizar a las tropas: ésta había afectado a miles de reservistas pero no a los 16.000 hombres que él ya había dispuesto para el embarque. Se trató del primer indicio que hallamos en la prensa salmantina sobre la necesidad de esclarecimiento de algunas responsabilidades:

"Yo fui encargado, como ministro de la Guerra del gabinete Maura, de la preparación $y$ de la iniciación de la campaña. Mi primer cuidado fue, naturalmente, fortificar los puntos que ocupábamos ya y que debían ser la base de nuestras operaciones en el Rif, entre otros, Cabo de Agua y la Restinga. Como además era muy probable que el general Marina necesitara refuerzos, hice completar los efectivos de los batallones de cazadores llamados del Campo de Gibraltar, y organicé además en pie de guerra la división del general Orozco, con elementos de las tres armas y todos los servicios accesorios. Había previsto todo, hasta el más ínfimo detalle: efectivos completos y material en el debido estado. Y para transportar rápidamente estas tropas a Melilla hice un convenio con la Compañía Trasatlántica española, la cual se comprometía a efectuar el transporte de las primeras en veinticuatro horas con sólo prevenirla cuatro

\footnotetext{
388 "Fa-Presto": "Andar y ver. Desde Barcelona", El Castellano, no 1.574, 31 de agosto de 1909, p. 1.

389 "La prensa y la censura", El Adelanto, no 7.709, 4 de agosto de 1909, p. 1; "Los sucesos de Barcelona y los periódicos", El Adelanto, no 7.710, 5 de agosto de 1909, p. 1; "Es una vergüenza", El Lábaro, nº 3.736, 30 de julio de 1909, p. 1; A. Rubio Polo: "De actualidad", El Salmantino, no 96, 14 de agosto de 1909 , p. 1;

390 "Los planes del ministro de la Guerra", El Adelanto, no 7.781, 27 de octubre de 1909, p. 1.

391 "El proyecto de las 500 pesetas", El Adelanto, no 7.783, 29 de octubre de 1909, p. 1.

392 "La campaña de África", El Adelanto, no 7.785, 1 de noviembre de 1909, p. 1.

393 "La campaña de África", El Adelanto, no 7.786, 2 de noviembre de 1909, p. 2.
} 
horas antes. La expedición fue preparada; pero yo, por motivos políticos, hube de separarme entonces del gabinete Maura ${ }^{\text {,394; }}$.

En síntesis, al menos desde febrero de 1909, el conflicto se suponía inminente. Además, añadía el viejo ministro, la decisión de movilizar a las tropas catalanas constituyó un monumental error porque había dejado muy mermada la guarnición de Barcelona, una ciudad extremadamente virulenta.

Los objetivos militares de la campaña ya se reconocían entonces como cumplidos. Restaba la fortificación de nuevas posiciones y la construcción de caminos $^{395}$. Al menos, eso era lo que manifestaba Marina, a mediados de noviembre, en unas declaraciones también bastante comentadas por los rotativos locales:

"Nuestra línea militar tiene ya, longitudinalmente, cerca de cien kilómetros, y ejercemos, si no soberanía, porque esta palabra estaría reñida con el Acta de Algeciras, protección, mejor dicho, dominio en un territorio que abarca un área de 300 kilómetros aproximadamente (...) Ahora queda un importante período: el de robustecer y fortificar convenientemente la línea militar establecida, y al mismo tiempo desarrollar una adecuada política, que consolide lo conseguido por la acción de las armas y que evite la exacerbación de odios, que convertirían la lucha en crónica ${ }^{\text {,396. }}$.

Entre las voces discordantes figuraba, por ejemplo, la del diputado carlista Llorens, convencido de que las tropas españolas debían extenderse hasta el Kert si deseaban evitar nuevos levantamientos ${ }^{397}$. Y, en efecto, los altercados no habían concluido $^{398}$.

El Lábaro, por otro lado, se escudó en el criterio de El Telegrama del Rif para afirmar que los resultados de la campaña militar eran, a principios de noviembre, muy positivos y el dominio español estaba asegurado desde el Muluya hasta el cabo de Tres Forcas $^{399}$.

En lo referido al acercamiento diplomático desconfiaba, por lo pronto, del éxito de las negociaciones entre Marina y los cabileños por la conocida informalidad de los marroquíes $^{400}$.

El 3 de noviembre, también El Castellano se hacía eco de ese acercamiento diplomático hispano-marroquí, aunque no disimulaba sus recelos: "Nosotros no hemos

\footnotetext{
394 "La política y la guerra. Declaraciones del general Primo de Rivera", El Adelanto, n 7.787, 3 de noviembre de 1909 , p. 2.

${ }^{395}$ Alfredo Rivera: "Conferencias telegráficas", El Adelanto, no 7.794, 11 de noviembre de 1909, p. 3.

396 "El fin de la guerra. Declaraciones del general Marina", El Adelanto, n 7.795, 12 de noviembre de 1909 , p. 2.

397 "De la guerra. Declaraciones importantes", El Adelanto, no 7.800, 18 de noviembre de 1909, p. 2.

${ }^{398}$ Alfredo Rivera: "Conferencias telegráficas", El Adelanto, no 7.805, 25 de noviembre de 1909, p. 3.

399 "Los resultados de la campaña”, El Lábaro, no 3.817, 5 de noviembre de 1909, p. 2.

400 "Telegramas. Haciendo la paz", El Lábaro, no 3.824, 13 de noviembre de 1909, p. 3.
} 
infligido a aquellos bárbaros aquella severa lección que hace tres meses veníamos procurando darles $" 401$. Sorprendentemente, este diario se mostraba ahora como el más acérrimo defensor del desquite porque hallaba incoherente la política del nuevo gobierno. Y como consecuencia, sospechaba que no se obtendría el máximo rédito de una victoria contundente que no se había producido. Para tanto como eso, preferible hubiera sido negociar el mismo10 de julio de 1909 y evitar la contienda.

Dos semanas después, en cambio, reconocía como concluida la etapa de operaciones en Melilla. Si esa deseada gran victoria de las armas españolas seguía sin registrarse, de repente prefería pasar por alto tan significativo detalle:

"El Ejército de Melilla puede decirse que, después de mil sufrimientos y heroicidades, ve por fin terminada su obra con gloria para él, y provecho para la nación (...) No ha terminado ciertamente todo dolor para los españoles en el Rif (...) Quedan las escaramuzas y los tiroteos que a la continua nos obligaran a una vigilancia exquisita (...) Pero lo grande está hecho y al gobierno toca consumar la obra, con una paz gloriosa y duradera que aleje las sospechas que en la semana pasada sembraron ciertas prematuras intervenciones del emisarios del Sultán ${ }^{, 402}$.

Precisamente, este asunto de los enviados de Hafid había despertado una tremenda preocupación y enfado en la redacción de El Castellano. Desde julio, se conocían los propósitos del Sultán de formar una comisión para incitar a los rifeños a que cesasen las hostilidades. En estas circunstancias, la figura de El Bachir Ben-Sem Nah había merecido una extensa descripción. Por norma, El Castellano no prestó tanto protagonismo al marroquí como hiciera, recuérdese, El Adelanto. Aunque, sin duda, se le atribuía un carácter salvaje. No obstante, un caso excepcional fue el de El Bachir. De hecho, este personaje fue el único marroquí que le mereció enorme respeto al diario salmantino. Se trataba del antiguo jefe de aquella mehalla abandonada a su suerte, en La Restinga. Prefirió abandonarla antes que renunciar a combatir a El Rogui y acabó apoyando la causa de Hafid. Era un personaje muy apreciado en la Comandancia de Melilla, valeroso y admirado ${ }^{403}$. Él era el comisionado para interceder ante los guelayas y llamar a la sumisión. Pero toda mediación era, a juicio de El Castellano, inadmisible, un deshonor para las armas españolas. Por eso el periódico se empeñaba en recalcar que el desarrollo de los planes del comandante en jefe del Ejército no se iba a ver alterado $^{404}$.

\footnotetext{
401 “OOtra paz de París?”, El Castellano, no 1.627, 3 de noviembre de 1909, p. 1.

402 "Lo de Melilla", El Castellano, $\mathrm{n}^{\circ} 1.635,10$ de noviembre de 1909, p. 1.

403 "Cosas del extranjero. El Bachir Ben-Sem Nah", El Castellano, n' 1.632, 6 de noviembre de 1909, p. 1.

404 “La comisión marroquí", El Castellano, no 1.636, 11 de noviembre de 1909, p. 1.
} 
Para El Salmantino, la negociación de la paz hispano-marroquí fue un tema muy delicado. La redacción, por eso, se limitó a reproducir editoriales ajenos, cuyas ideas suscribía. Nos resulta tremendamente chocante, a tenor de su encendido discurso militarista, el hecho de que no compartiese con El Castellano esa idea de que el concierto diplomático constituía, en las circunstancias presentes, un acto degradante para España. Éstas eran algunas de las informaciones que manejaba El Salmantino: a principios de noviembre de 1909, y tomando como fuente de autoridad un editorial de El Mundo, se indicaba que el tratado estaba ya casi ultimado. España conservaría el dominio sobre todo lo ocupado. Además, se legalizaría la explotación de las minas de Beni-bu-Ifrur y se conseguiría el destierro de El Chaldy. Acto seguido, sin embargo, el órgano tradicionalista comunicaba que Moret había desmentido esta noticia y, sobre todo, lo referido a las minas ${ }^{405}$.

Una semana después, el periódico se escudaba en el juicio de El Correo Catalán. Aquí, un tal "C." había publicado un muy preocupante balance sobre la contienda de Marruecos. España, escribía el editorialista, atravesaba su momento más crítico desde la Guerra de la Independencia. Retroceder militarmente en el Rif repercutiría muy negativamente en nuestro prestigio internacional; pero, prosiguiendo con los avances, también se corría un enorme peligro. Y, en este preciso punto, por primera vez, $E l$ Salmantino recogía una consideración hacia la guerra de carácter estrictamente económico. Sostenemos que a su equipo de redacción no le agradaban, ni lo más mínimo, este tipo de formulaciones. Por eso, intentaba desvincularse del asunto con el auxilio de la pluma de “C.”. De todos modos, aún así, le prestaba mucha publicidad: lo contemplaba como una realidad, muy triste, pero indiscutible.

Por eso consideramos que el integrismo local estaba, muy disimulada e interesadamente, renunciando a sus acostumbradas creencias. Se estaba rindiendo: si, desde la óptica militar, no era conveniente ni el retroceso ni el avance, el camino alternativo pasaba por la negociación. Éstas se estaban desarrollando en cuatro escenarios diferentes: París; Melilla-Tánger; Fez; y Madrid. Pero todas las conversaciones, evidentemente, estaban sujetas a la voluntad de un Sultán, Hafid ${ }^{406}$, al que se le tachaba de fanático independentista y personaje ávido de la sangre de sus súbditos (no dejaba de constituir una incongruencia recoger semejante opinión en un

\footnotetext{
405 "De la guerra", El Salmantino, no 108, 6 de noviembre de 1909, pp. 2-3.

${ }^{406}$ Sobre las exigencias del Sultán, El Salmantino reproduce un artículo de El Anunciador, un periódico de Gibraltar. Se asegura que formula reclamaciones relacionadas con la campaña de 1859: "De Melilla. Lo que quieren los rifeños", El Salmantino, n 110, 20 de noviembre de 1909, p. 3.
} 
semanario que jamás reparó en las cifras de soldados españoles enviados al Rif). Puesto que no se confiaba, por tanto, en su voluntad de arreglo, correspondía a la diplomacia española hacer un esfuerzo para lograr una paz rápida y evitar la ruina económica. Pero ¿cuándo El Salmantino había mostrado respeto por el trabajo de los diplomáticos españoles? Nunca. Y ¿Acaso confiaba en Moret? Por descontado, no. En suma: este editorial suponía un total reconocimiento de nuestra incapacidad colonizadora:

"El soldado español es valeroso, abnegado y sufrido como ninguno, pero las guerras se hacen hoy con algo más que con héroes. El Cid, sin cuenta corriente en el Banco de Londres y crédito para comprar ametralladoras y fusiles, iría hoy al sacrificio estéril a pesar de su temeridad gloriosa.

España es pobre (...) Una complicación grave en Marruecos nos podría lanzar a una campaña de varios meses de duración en la que tendríamos que soportar un gasto de 5 a 6 millones de pesetas diarios (...) Se ha lanzado una moneda al aire. Está al caer. El anverso es una paz hecha con más o menos acierto y prisa. El reverso una ruptura con Muley Hafid, la guerra santa, 407 .

Para El Salmantino, el futuro de España en el Rif se presentaba muy negro: más oscuro, de hecho, cuando se vislumbraba una paz oficial que durante la contienda; más turbio gobernando Moret que bajo el mandato de Antonio Maura. Las sumisiones entre los cabileños seguían un ritmo muy caótico y ello desesperaba a la redacción integrista. El 20 de noviembre, por fin, sin recurrir a ningún intermediario, abundaba en esta cuestión:

"Estamos frente al eterno problema, al problema nacido de aquellas torpezas de antaño, de aquella insana política de cábilas, que hizo huir a El Rogui de Zeluán y convertir lo que casi era una Monarquía absoluta, con un Sultán responsable, omnímodo y obedecido de todos, en una verdadera olla de grillos, en la que cada cual hace a su gusto, sin aprender órdenes ni consejos, y creyéndose cada hombre un rey y cada familia, un poderoso reino.

Difícil será que esas negociaciones se llevan a buen puerto, porque no habrá posibilidad de encontrar un con quien entenderse, y con todos no hay quien en realidad se entienda, ${ }^{, 408}$.

Marruecos era un atolladero y el quehacer diplomático se veía obstaculizado por la ausencia de una estructura estatal, en el sentido occidental del término. La escasez de jefes de prestigio entre las cábilas suponía un enorme escollo para la acción española y, sin duda, coadyuvaba a que los militares se decantasen por el simple dominio armado. Aunque, por otra parte, los partidos políticos dinásticos también eran verdaderas jaulas de grillos. Pero, en resumen, de modo insólito, el pensamiento integrista, tan receloso

\footnotetext{
407 "El problema de Marruecos. Un balance", El Salmantino, no 109, 13 de noviembre de 1909, p. 3.

408 “De Melilla", El Salmantino, no 111, 27 de noviembre de 1909, p. 3.
} 
frente a Moret, acababa sosteniendo aquella vieja tesis de otro liberal, Villanueva, sobre la política errónea adoptada ante El Rogui ${ }^{409}$.

El entusiasmo, de nuevo, se desbordó a partir del 26 de noviembre porque en esta jornada se produjo la toma de Atlatén, con la que se aseguraba el dominio español sobre la península de Tres Forcas ${ }^{410}$. El Adelanto se apresuró a anunciar la consecuencia inmediata de la operación: quedarían en los campos de Melilla las fuerzas puramente necesarias para conservar las posiciones y se licenciarían a las restantes ${ }^{411}$. Comenzaron, además, a propagarse los primeros rumores sobre la creación de un futuro Ejército colonial permanente en Marruecos, formado íntegramente, tanto la tropa como la oficialidad, por voluntarios ${ }^{412}$.

No obstante, inmediatamente “Argos" se ocupó de rectificar la noticia. Si bien era cierto que el gobierno declaraba oficialmente el fin de la campaña, aún no había llegado el momento para el regocijo popular. Se imponía un último esfuerzo:

"No pueden volver los luchadores todavía al arrimo de sus dioses lares y penates. El laurel que han plantado en otro continente pide cuidadosa solicitud para arraigarse y crecer gentil y frondoso. Fuerza es que consumen su sacrificio, esperando la hora, por todos ansiada, de estrecharse en un abrazo fraternal pueblo y Ejército, pues son dos hermanos que aman y sirven a su madre, uno con las armas, manteniendo limpio su honor e íntegro su territorio, y otro con sus útiles de trabajo, enriqueciéndola y haciendo correr de continuo las fuentes de la vida, ${ }^{, 413}$.

A decir verdad, la tranquilidad militar no fue absoluta hasta 1927. Había surgido el "cáncer marroquí". Por de pronto, el 5 de diciembre se registró otro combate, con clara victoria para los españoles, en el mismo lugar del enfrentamiento del 30 de septiembre, muy cerca de Beni-bu-Ifrur. Y cinco días después, hubo nuevos altercados en Beni Sidel ${ }^{414}$. Al finalizar diciembre, se produjo un tiroteo en Alhucemas ${ }^{415}$; los rumores sobre predicaciones belicosas de El Mizzian adquirían ya un tono

\footnotetext{
409 Como ejemplo de estudiosos que actualmente defienden la política de acercamiento hacia El Rogui, véase SALAS LARRAZÁBAL, Ramón: Op. Cit., p. 94.

${ }^{410}$ Alfredo Rivera: “Conferencias telegráficas”, El Adelanto, no 7.807, 27 de noviembre de 1909, p. 3.

${ }^{411}$ Alfredo Rivera: "Conferencias telegráficas”, El Adelanto, no 7.808, 29 de noviembre de 1909, p. 3.

412 "Ejército colonial", El Adelanto, no 7.812, 3 de diciembre de 1909, p. 2; "Ejército colonial", El Adelanto, $\mathrm{n}^{\circ}$ 7.833, 29 de diciembre de 1909, p. 2.

413 "Argos": "Madrid al día", El Adelanto, no 7.809, 30 de noviembre de 1909, p. 1.

${ }^{414}$ Alfredo Rivera: “Conferencias telegráficas", El Adelanto, no 7.814, 6 de diciembre de 1909, p. 3; Alfredo Rivera: "Conferencias telegráficas”, El Adelanto, no 7.819, 11 de diciembre de 1909, p. 3.

${ }^{415}$ Alfredo Rivera: "Conferencias telegráficas", El Adelanto, no 7.834, 30 de diciembre de 1909, p. 3; Alfredo Rivera: "Conferencias telegráficas”, El Adelanto, no 7.836, 1 de enero de 1910, p. 3; Alfredo Rivera: "Conferencias telegráficas", El Adelanto, no 7.842, 8 de enero de 1910, p. 3.
} 
preocupante $^{416}$. Y, en suma, a lo largo de todo 1910 fueron constantes las alusiones de Rivera a permanentes altercados con los rifeños ${ }^{417}$.

Pero era preferible dejarse embargar por el optimismo del momento, si bien “Argos" reconocía que el futuro en Marruecos se presentaba repleto de obstáculos:

"Parece que el diablo no quiere permitirnos gozar de una tranquilidad absoluta (...) Son chispazos sueltos los de ahora, y pueden llegar más tarde a formar grandes hogueras (...) Yo estoy bien seguro de que (...) dado el primer paso en el camino de las aventuras, hay que llegar hasta el fin. Pero no lo haremos sin quebrantos y temores, y de aquí la intranquilidad a que antes me refería (...) Es triste sino el de esta desventurada España, que apenas endereza el rumbo al puerto de su bienestar, se lo oponen toda suerte de escollos con la maligna intención de que se detenga, retroceda o se estrelle.

Una enorme conjunción de hombres y partidos ha resuelto y puesto en práctica por arte milagrosa restablecer el imperio de la paz, ${ }^{, 418}$.

Consecuentemente, su confianza en el gobierno de Moret permanecía intacta. Y por otra parte, desde que el gobierno y Marina anunciaron el fin de la guerra, en $E l$ Adelanto, muy seguramente con el propósito de rebajar el tenso clima entre la opinión salmantina, se hicieron habituales las breves noticias de carácter costumbrista sobre el Rif: se abordaron algunos aspectos sobre su religión ${ }^{419}$, acerca de la alimentación del rifeño; fueron retratados algunos moros amigos ${ }^{420}$; se celebró la sumisión del moro Abd-el-Kader ${ }^{421}$; se publicaron reseñas sobre la dureza de la justicia marroquí ${ }^{422}$; notas

\footnotetext{
${ }^{416}$ Alfredo Rivera: “Conferencias telegráficas", El Adelanto, no 7.827, 21 de diciembre de 1909, p. 3; Alfredo Rivera: "Conferencias telegráficas", El Adelanto, no 7.888, 3 de marzo de 1910, p. 3; Alfredo Rivera: "Conferencias telegráficas", El Adelanto, no 8.266, 2 de junio de 1909, p. 3.

${ }^{417}$ Alfredo Rivera: "Conferencias telegráficas", El Adelanto, no 7.862, 1 de febrero de 1910, p. 3; Alfredo Rivera: "Conferencias telegráficas", El Adelanto, no 7.897, 14 de marzo de 1910, p. 3; Alfredo Rivera: "Conferencias telegráficas", El Adelanto, no 7.904, 22 de marzo de 1910, p. 3; "Agresión a nuestras tropas. Un soldado muerto", El Adelanto, $\mathrm{n}^{\circ} 7.915,5$ de abril de 1910, p. 2; Alfredo Rivera: "Conferencias telegráficas", El Adelanto, no 7.949, 14 de mayo de 1910, p. 3; Alfredo Rivera: "Conferencias telegráficas", El Adelanto, $\mathrm{n}^{\circ}$ 7.974, 13 de junio de 1910, p. 3; Alfredo Rivera: "Conferencias telegráficas", El Adelanto, no 8.082, 27 de octubre de 1910, p. 3; Alfredo Rivera: "Conferencias telegráficas", El Adelanto, $\mathrm{n}^{\circ}$ 8.084, 29 de octubre de 1910, p. 3; Alfredo Rivera: "Conferencias telegráficas", El Adelanto, no 8.092, 8 de noviembre de 1910, p. 3. Rivera también recogió la noticia de que el diputado Llorens, gracias a sus informantes de Melilla, sabía que se estaba preparando una nueva rebelión entre las cábilas de Beni Said y Beni Urriaguel: Alfredo Rivera: "Conferencias telegráficas", El Adelanto, no 7.995, 7 de julio de 1910, p. 3; "Los moros de Melilla", El Adelanto, no 7.997, 9 de julio de 1910, p. 2. Sin embargo, entre agosto y noviembre de 1910 encontramos muchas noticias que revelan la existencia de conflictos internos en el campo rifeño: Alfredo Rivera: "Conferencias telegráficas", El Adelanto, $\mathrm{n}^{\circ}$ 8.035, 11 de agosto de 1910, p. 3; Alfredo Rivera: "Conferencias telegráficas", El Adelanto, no 8032, 31 de agosto de 1910, p. 3 (hay un error de numeración en este ejemplar); "El Rif. El hijo del Chaldy", El Adelanto, no 8.036, 5 de septiembre de 1910, p. 2; Alfredo Rivera: "Conferencias telegráficas", El Adelanto, n' 8.050, 20 de septiembre de 1909, p. 3; Alfredo Rivera: "Conferencias telegráficas", El Adelanto, n n $^{\circ} .051,21$ de septiembre de 1910, p. 3; Alfredo Rivera: "Conferencias telegráficas", El Adelanto, $\mathrm{n}^{\circ}$ 8.109, 28 de noviembre de 1910, p. 3.

${ }^{418}$ B. Pallol: "De la guerra y de la patria", El Adelanto, no 7.840, 6 de enero de 1910, p. 1.

419 "La campaña de África", El Adelanto, no 7.796, 13 de noviembre de 1909, p. 2.

420 "La campaña de África", El Adelanto, no 7.802, 20 de noviembre de 1909, p. 2.

${ }^{421}$ Alfredo Rivera: "Conferencias telegráficas”, El Adelanto, n $\mathrm{n}^{\circ} 7.817,9$ de diciembre de 1909, p. 3.
} 
sobre la naciente armonía entre indígenas y soldados españoles ${ }^{423}$; alusiones al diseño de una medalla conmemorativa de la guerra ${ }^{424}$; algún que otro retrato de Burguete, ascendido a teniente coronel $^{425}$; la exitosa celebración de un zoco en Melilla ${ }^{426} \ldots$ Todo lo necesario para convencer a los lectores de que el entendimiento hispano-marroquí estaría garantizado por la superior fuerza civilizadora de los españoles.

Por fin, el 7 de diciembre, Rivera informó sobre el comienzo de la repatriación escalonada de los soldados ${ }^{427}$. "Argos" atribuyó todo el mérito de la decisión a Moret, al tiempo que cargó las tintas contra el anterior gabinete: “El gobierno del señor Moret está cada día más firme; el alabastro se ha convertido en mármol y resiste todos los golpes de los palillos de boj que los conservadores esgrimen, cuanto más los pincelazos del acuarelista Maura"428.

Los primeros beneficiados fueron los reservistas y las brigadas de Madrid y Cataluña. Pero los excedentes de cupo hubieron de esperar algo más. Por este motivo, el mismo "Argos" rogaba por su pronto retorno, al tiempo que contemplaba con muy buenos ojos la concesión de recompensas militares ${ }^{429}$.

Precisamente, ésta fue una de las cuestiones más arduas que hubo de abordar el gobierno, aunque es muy difícil examinarla a partir de la consulta de la prensa salmantina: la censura fue implacable en esta materia ${ }^{430}$. Sí que se atisba ahora, no obstante, por primera vez, el surgimiento de un problema que durante muchos años coleará en la historia de España, hasta el extremo de contribuir, y mucho, al estallido de una guerra civil: el de la disciplina militar. Muy brevemente, estos fueron los hechos: ante la propuesta ministerial de recompensas por la campaña de Melilla, un periódico castrense, La Correspondencia Militar, se posicionó en contra y se congratuló al

\footnotetext{
422 "De todas partes. La vida en Marruecos", El Adelanto, no 7.829, 23 de diciembre de 1909, p. 2.

${ }^{423}$ Alfredo Rivera: “Conferencias telegráficas”, El Adelanto, no 7.831, 27 de diciembre de 1909, p. 3.

424 “La medalla del Rif”, El Adelanto, n ${ }^{\circ} 7.854,22$ de enero de 1910, p. 1.

${ }^{425}$ V. Ruiz Albéniz: "Figuras de la campaña. Burguete”, El Adelanto, no 7.906, 24 de marzo de 1910, p. 2.

${ }^{426}$ Alfredo Rivera: “Conferencias telegráficas”, El Adelanto, no 8.075, 19 de octubre de 1910, p. 3.

${ }^{427}$ Alfredo Rivera: “Conferencias telegráficas”, El Adelanto, no 7.815, 7 de diciembre de 1909, p. 3. Sobre el final de la campaña, Riera, otro conocido publicista de la época, argumentó: “La gran masa de los españoles no ha comprendido jamás la necesidad que sienten algunos gobernantes de apoderarse del Norte de África o de dominar, por lo menos, como señores y dueños aquella región. Y por lo mismo que no lo comprende, no siente entusiasmo por una guerra que imagina que no puede producir en ningún caso buenos resultados. De ahí que la noticia de que cesaban las hostilidades fuera acogida con verdadero júbilo y más aún la de que pronto regresarán a sus hogares varios de los contingentes armados que habían ido a África desde el 18 de julio a principios de octubre”. Véase RIERA, Augusto: España en Marruecos. Crónica de la campaña de 1909. Barcelona: Maucci, 1910, pp. 401-402.

428 "Argos": "Madrid al día", El Adelanto, no 7.816, 8 de diciembre de 1909, p. 1.

429 "Argos": "Madrid al día. Impresiones", El Adelanto, no 7.820, 13 de diciembre de 1909, p. 1; "Los excedentes de cupo", El Adelanto, no 7.820, 13 de diciembre de 1909, p. 2.

${ }^{430}$ Alfredo Rivera: “Conferencias telegráficas”, El Adelanto, no 7.847, 14 de enero de 1910, p. 3.
} 
presenciar, a mediados de enero de 1910, una manifestación de apoyo ante la sede de su redacción, en Madrid, con las presencia de bastantes oficiales. ¿Por qué unos militares se oponían a la concesión de esos ascensos?

El Adelanto evitó formular juicios sobre el asunto. Pero sí que reprodujo oportunamente, dando a entender con ello que apoyaba sus consideraciones, un extenso editorial de otro periódico castrense, El Ejército Español, en el que se manifestaba que la división entre elementos militares solo contribuiría a enturbiar la "gloria inmarcesible alcanzada en la Guerra del Rif' ${ }^{431}$ Sin embargo, el mismo escrito iba mucho más allá al denunciar, amargamente, la instrumentalización política que los militares sufrían: se acusaba al diputado carlista Llorens de estar tras la campaña de La Correspondencia Militar con el objeto de desacreditar al ministro liberal de Guerra, el general Luque. El Adelanto contemporizaba con ese victimismo militar. Es lo que hemos estado viendo durante toda la campaña. La oficialidad era alababa por ser "tan pródiga de su sangre y de su vida, supliendo a fuerza de arrojo, a fuerza de abnegación, a fuerza de sacrificios, las deficiencias de una preparación para la guerra que no existe entre nosotros por penurias del Tesoro y falta de interés entre nuestros políticos".

A mediados de diciembre se anunció, por fin, el ansiado retorno de los reservistas salmantinos, previsto para el 12 de diciembre ${ }^{432}$. La alegría ante la óptima noticia era desbordante. Al día siguiente, El Adelanto, ocupó buena parte de sus primeras páginas con una amplia reseña del acto de bienvenida en la estación. El ambiente era descrito como de enorme animación y, si bien no se precisaba la cifra de hombres que regresaban a sus hogares, se insistía en su buen estado de salud ${ }^{433}$. El goteo de reservistas, sin embargo, se prolongaría durante algunos días más ${ }^{434}$.

Las esperanzas de los liberales fueron a más al pensar en el camino que le restaba por recorrer a España una vez finalizada la guerra: la penetración militar cedería paso a la civil:

"España, que ahora parece ocuparse y preocuparse algo más de los asuntos de Marruecos, que hasta aquí ha visto con una indiferencia incomprensible, manda a Melilla al ministro de Fomento señor Gasset, hombre joven, de iniciativas, sumamente culto, previsor y pensador, que con sus propios ojos verá sobre el terreno lo que en

\footnotetext{
431 “La cuestión del día. La opinión militar", El Adelanto, no 7.848, 15 de enero de 1910, p. 2.

432 "La llegada de los reservistas salmantinos", El Adelanto, no 7.819, 11 de diciembre de 1909, p. 1.

433 "La llegada de los reservistas", El Adelanto, no 7.820, 13 de diciembre de 1909, pp. 1-2; En El Salmantino sí se aclara que llegan 197 reservistas a la provincia: "El regreso de los reservistas", El Salmantino, $\mathrm{n}^{\mathrm{o}} 113,11$ de diciembre de 1909, p. 3.

434 "La llegada de los reservistas", El Adelanto, no 7.821, 14 de diciembre de 1909, p. 1; "Los que llegan", El Adelanto, $\mathrm{n}^{\circ}$ 7.822, 15 de diciembre de 1909, p. 1; "La repatriación de los soldados", El Adelanto, $\mathrm{n}^{\circ}$ 7.838, 4 de enero de 1910, p. 1 .
} 
Melilla hace falta, y estudiará el medio de crear en aquella plaza elementos propios de vida, pero no de esa vida esencialmente militar que hoy tiene, sino de una vida civil, comercial e industrial, que a la vuelta de unos cuantos años ha ya hecho de Melilla una población floreciente que sea la admiración de los moros, que los atraiga con su comercio y con su industria, que les quite todo recelo, que les haga nuestros verdaderos amigos, consolidando así una paz duradera y provechosa para esta nación, que desea vivamente ver ensanchados su dominios por el Norte de África" ${ }^{\text {"435. }}$.

Así, a principios de febrero El Adelanto anunciaba el viaje del general Marina a Nador y su satisfacción por el desarrollo de los trabajos en el ferrocarril ${ }^{436}$; al poco tiempo, inspeccionó la carretera entre el Cabo de Agua y el vado del Muluya ${ }^{437}$. Y a mediados de agosto, se anunció el término de la carretera entre Melilla y Nador ${ }^{438}$.

Y, del mismo modo, la redacción del periódico liberal copió el programa de reformas que la Cámara de Comercio de Melilla entregó a Gasset. Básicamente, lo que en él se procuraba era una mejora de las comunicaciones y la obtención de algunos privilegios comerciales ${ }^{439}$.

El diario de Núñez Izquierdo hizo hincapié en más ocasiones en la idea de que correspondía a la iniciativa privada el fomento de unas relaciones comerciales más intensas con Marruecos, sobre todo, porque se juzgaba como vergonzoso el hecho de que Gibraltar y Argelia aventajasen a España en este aspecto ${ }^{440}$. A decir verdad, este diario se esmeró muchísimo a la hora de promocionar cualquiera de nuestros progresos económicos en Marruecos. Tal vez, por ello reseñó ampliamente el viaje efectuado por el empresario, señor Paraíso, al Rif ${ }^{441}$. Y también prestó una respetable cobertura a la celebración del cuarto Congreso Africanista, centrado en la fomento de nuestra industria y comercio mediante la eliminación de trabas fiscales y burocráticas ${ }^{442}$.

A principios de mayo de 1910, una comisión de topógrafos, acompañados por un batallón de cazadores de Cataluña y el regimiento de $\mathrm{M}^{\mathrm{a}}$ Cristina fueron enviados a

\footnotetext{
435 "Gasset a Melilla", El Adelanto, no 7.837, 3 de enero de 1910, p. 2.

${ }^{436}$ Alfredo Rivera: “Conferencias telegráficas”, El Adelanto, no 7.868, 8 de febrero de 1910, p. 3.

437 "Después de la campaña", El Adelanto, no 7.880, 22 de febrero de 1910, p. 3. Y sigue con sus visitas de inspección en: Alfredo Rivera: "Conferencias telegráficas", El Adelanto, no 7.955, 21 de mayo de 1910, p. 3; Alfredo Rivera: “Conferencias telegráficas”, El Adelanto, no 7.959, 26 de mayo de 1910, p. 3; Alfredo Rivera: “Conferencias telegráficas”, El Adelanto, no 7.966, 3 de junio de 1910, p. 3.

${ }^{438}$ Alfredo Rivera: "Conferencias telegráficas", El Adelanto, no 8.030, 17 de agosto de 1910, p. 3. Y aquí se detiene, ya que por falta de presupuesto, no se puede prolongar su trazado hasta Zeluán y Atlatén. Véase Alfredo Rivera: "Conferencias telegráficas”, El Adelanto, no 8.032, 31 de agosto de 1910, p. 3.

439 "Programa de reformas en Melilla", El Adelanto, no 7.896, 9 de febrero de 1910, p. 2.

440 "Intereses nacionales. Melilla y el comercio español”, El Adelanto, no 7.895, 11 de marzo de 1910, p. 1.

441 “El viaje del señor Paraíso al Rif”, El Adelanto, no 7.914, 4 de abril de 1910, p. 1; Alfredo Rivera: “Conferencias telegráficas", El Adelanto, no 7.926, 18 de abril de 1910, p. 3.

442 "Cuarto Congreso africanista", El Adelanto, no 7.990, 1 de julio de 1910, p. 1; "Cuarto Congreso africanista”, El Adelanto, no 8.101, 18 de noviembre de 1910, p. 2.
} 
Nador y Zeluán para confeccionar un mapa de los territorios conquistados ${ }^{443}$. Y en agosto se celebró la apertura de una bocana en la Mar Chica, capaz de comunicar a ésta con el Mediterráneo ${ }^{444}$.

También fueron muy celebrados la construcción de una escuela en Melilla y el inicio de obras similares en Nador y el Cabo de Agua ${ }^{445}$. Se le dio la bienvenida a la noticia de que en Zeluán se ponía en funcionamiento una máquina potabilizadora ${ }^{446}$; y se aplauden los planes de repoblación forestal del general Aldave ${ }^{447}$.

En cuanto a El Lábaro, este rotativo también se sumó a la oleada de entusiasmo tras la toma de Atlatén, aunque sin anticipar nada relacionado con el regreso de las tropas $^{448}$. Además, los comentarios que apuntaban a la próxima creación de un Ejército colonial fueron muy bien recibidos ${ }^{449}$. Por otro lado, la paz parecía, día a día, más cercana y el periódico católico se hacía eco del viaje del señor García Berenguer, médico del Sultán, a Madrid. Se sospechaba que traería consigo instrucciones para los delegados marroquíes ${ }^{450}$.

El panorama se modificó, sin embargo, a mediados de diciembre de 1909. Entonces el periódico ya esperaba impacientemente el retorno de los reservistas a sus hogares. Así, "Munio" se prodigó en halagos para las tropas españolas y censuró a los grupos "sediciosos":

"Se hacen largos, interminables los días de espera (...) El Ejército y el pueblo son dos hermanos entrañables: se nutren de una misma sangre, viven la vida de los ideales de la patria (...) Por eso los enemigos del pueblo español, los españoles que han alquilado sus almas para morada del antiespañolismo, para asiento del odio a esta patria, quisieron poner en lucha fratricida al Ejército y al pueblo (...) Ellos, los malditos, los extranjerizados, se metieron entre el pueblo, sonando a sedición, impidiendo el embarque de los soldados: predicando el odio a la guerra, el odio al Ejército (...) y encendieron la guerra social (...) Ahoguemos esa infamia, esa vergüenza nacional, con un abrazo efusivo, perdurable, al Ejército",451.

Y otro redactor, Pérez Vázquez, reflexionaba sobre el valor simbólico de las despedidas y los gestos de bienvenida dispensados a los soldados:

"Afortunadamente, ha comenzado para nuestro victorioso Ejército de África, la vuelta de sus numerosas unidades a la madre patria (...) Al abandonar aquellas turbulentas

\footnotetext{
${ }^{443}$ Alfredo Rivera: "Conferencias telegráficas”, El Adelanto, no 7.943, 7 de mayo de 1910, p. 3.

${ }^{444}$ Alfredo Rivera: "Conferencias telegráficas", El Adelanto, no 8.017, 2 de agosto de 1910, p. 3.

${ }^{445}$ Alfredo Rivera: “Conferencias telegráficas”, El Adelanto, no 8.050, 20 de septiembre de 1910, p. 3.

${ }^{446}$ Alfredo Rivera: "Conferencias telegráficas”, El Adelanto, no 8.051, 21 de septiembre de 1910, p. 3.

447 Alfredo Rivera: “Conferencias telegráficas”, El Adelanto, no 8.127, 19 de diciembre de 1910, p. 3.

448 “Conferencias telegráficas”, El Lábaro, n 3.836, 27 de noviembre de 1909, p. 3.

449 "Ejército colonial", El Lábaro, no 3.841, 3 de diciembre de 1909, p. 1; "Ejército colonial", El Lábaro, no 3.867, 7 de diciembre de 1909, p. 2.

450 "La situación de Marruecos", El Lábaro, no 3.847, 11 de diciembre de 1909, p. 2.

451 "Munio": "De cada día. El Ejército y la Patria", El Lábaro, no 3.486, 10 de diciembre de 1909, p. 2.
} 
aguas de Melilla y las monstruosidades agrestes del Rif, sus corazones se habrán llenado de alegría y satisfacción, cuando dirigiéndoles su última mirada, hayan visto ondear en sus cumbres el emblema nacional (...) Son dos actos, la salida y repatriación, que siendo en sí tan opuestos y diferentes, producen, sin embargo, el mismo efecto entusiasta, convergen en el mismo fin, la glorificación de la Patria; el primero, por ir en busca de su gloria, de su honra, y el segundo, porque volviendo victoriosos, brilla con singular esplendor en la frente de sus héroes ${ }^{, 452}$.

Por último, este periódico no prestó ninguna atención al asunto de la división entre militares por la concesión de recompensas. Seguramente, porque no entendía el motivo de la protesta.

El Castellano, tras la toma de Atlatén, se conformó con la reproducción de los partes oficiales y con las fantásticas impresiones del general Luque. El júbilo reinaba tanto en Melilla como en la Corte ${ }^{453}$. Se vaticinó el término de la campaña y se adelantó la idea de que muchos soldados podrían pasar la Navidad en sus hogares. Además, abundaron las alabanzas técnicas a propósito del desarrollo de la última operación ${ }^{454}$.

El servicio telegráfico de El Salmantino, por último, informaba, el 27 de noviembre de 1909, de la atmósfera de nerviosismo previa a la reanudación de los avances y también publicaba el telegrama oficial en el que se le notificaba al ministro de Guerra la toma de Atlatén. La agencia informativa añadía este último comentario:

"Se cree que el general Marina estima la ocupación de Atlatén como la garantía de seguridad de posiciones tomadas anteriormente por nuestras tropas.

En este caso, la operación de hoy será la que haya puesto término a la campaña de Melilla, siendo opinión de muchos, y especialmente de quienes motivos sobrados tienen para saberlo, que inmediatamente serán repatriadas a la península algunas fuerzas ${ }^{\text {"455. }}$.

La penetración económica en el Rif constituía el sueño dorado de El Salmantino; otra cuestión fue que este objetivo se disfrazase con ese discurso tan lineal, sin fisuras y dogmático del patriotismo más ultramontano. Pero este "avance de la civilización" se contempló como una realidad imposible mientras gobernase Moret. Únicamente antes de su llegada a la presidencia y, por tanto, de la terminación oficial de las operaciones, hallamos un editorial del conocidísimo Lamamié de Clairac en defensa de este sueño colonial:

"El castigo eficaz de los moros que acabará por rendirles y hacerles entregar sus armas, da pie a una penetración pacífica en que España fomente la agricultura, la explotación minera y el comercio, haciendo someterse a los rifeños a su influjo y extendiendo con ello la civilización cristiana.

\footnotetext{
${ }^{452}$ G. Pérez Vázquez: “La repatriación”, El Lábaro, no 3.850, 15 de diciembre de 1909, p. 1.

453 "Lo de Melilla", El Castellano, no 1.650, 27 de noviembre de 1909, p. 2.

454 "La toma de Atlatén", El Castellano, no 1.651, 29 de noviembre de 1909, p. 1.

455 "De Melilla", El Salmantino, no 111, 27 de noviembre de 1909, p. 3.
} 
¡Pliegue al cielo que así lo comprendan nuestros gobernantes y en vez de contentarse con tener unos cuantos puntos estratégicos los tomen como base para extender y consolidar en la paz esa nuestra influencia en el Rif!" ${ }^{456}$.

El impulso de la agricultura se anteponía a la explotación minera y el desarrollo de comercio. Con seguridad, porque éste discurso era el que encontraba mayor respaldo público para la causa colonial en una ciudad como Salamanca. Pero nada similar, en este sentido, se publicó bajo mandato liberal.

Al igual que en las páginas de El Adelanto, no obstante, el final victorioso quedaría diluido ante las continuas y preocupantes llamadas a la guerra santa por parte de El Mizzian ${ }^{457}$. Y en lo tocante al asunto de los ascensos militares El Salmantino únicamente reprodujo, sin mayor comentario, el artículo de La Correspondencia Militar $^{458}$.

Prensa y opinión salmantina ante el final de la contienda

Hoy en día, buena parte de la historiografía argumenta que el conflicto de Melilla no fue tanto el resultado de las presiones de las compañías mineras españolas sobre Antonio Maura, como la respuesta a una velada amenaza francesa de recurrir a sus tropas para proteger los intereses de la Compañía Norte-Africana y que, en caso de haberse llegado a producir, habría tenido un coste inmediato para España en términos de pérdida de prestigio político ante Occidente.

Aunque, en efecto, entre la opinión pública española cundió el escándalo cuando se conocieron los estrechos lazos existentes entre los accionistas de las sociedades mineras y los políticos del régimen. Y es que el primer presidente de la Compañía Española de Minas del Rif, Miguel Villanueva, y uno de sus más destacados accionistas, el conde de Romanones, eran viejos caciques liberales. Otro de los accionistas, McPherson, se había enriquecido con los suministros para el Ejército de Cuba. Antonio García Alix, a la cabeza de la francesa Compañía Norte-Africana, había sido ministro conservador desde 1908 y también era el gobernador del Banco de España. El grupo inversor Comillas-Güell se enriquecía con las compañías de seguros contra el servicio militar. Pero era, simultáneamente, el fundador de la Sociedad Hispano-Africana,

\footnotetext{
${ }^{456}$ José M ${ }^{a}$ L. de Clairac: "Crónica política”, El Salmantino, n 104, 9 de octubre de 1909, p. 1.

457 "Los rifeños belicosos", El Salmantino, no 118, 8 de enero de 1910, p. 3. En El Salmantino también encontramos la referencia a esas informaciones de Llorens, delatoras de una situación crítica en Alhucemas: "Graves noticias de Alhucemas", El Salmantino, no 31, 9 de julio de 1910, p. 1. No obstante, el seguimiento de los escarceos es muy poco exhaustivo. Debido tanto al carácter semanal de la publicación como al hecho de que, finalizada oficialmente la campaña, la cuestión rifeña pierde actualidad.

458 “Artículo comentado", El Salmantino, n 118, 15 de enero de 1910, p. 1.
} 
subvencionada por el gobierno de Maura para invertir en obras públicas, y también accionista de la Compañía Trasatlántica, encargada del transporte de soldados a Melilla, ante la debilidad de la Armada española ${ }^{459}$. Entre las páginas de la prensa salmantina, estas noticias apenas tuvieron cabida y fue precisamente esa ausencia de un cauce más o menos oficial para su transmisión la que alentó algunas exageraciones, si bien no carentes de fundamento. El mayor esfuerzo ofensivo de los periódicos locales ante la opinión pública salmantina se orientó, en cambio, hacia la exaltación desmesurada de las pasiones populares en nombre del honor. Pero tras esa casi unánime defensa de la gloria militar -con la excepción de El Castellano- se ocultaba el miedo ante el imparable avance colonial francés.

A lo largo de toda la campaña militar, El Adelanto se esmeró en mantener un tono marcadamente belicoso. Incluso, todavía a finales de octubre, cuando el estado de la opinión era muy agrio porque no se avistaba una solución para el conflicto, hubo un cronista que insistió en la necesidad de un esfuerzo militar enorme y urgente. Ciertamente, los enfrentamientos se sucedían casi ininterrumpidamente desde hacía tres meses y se aseguraba que todo el mundo sabía que el objetivo eran las minas. Pero el redactor en cuestión rechazaba esta explicación: no eran sus riquezas las que justifican la enconada lucha, sino la búsqueda de un castigo justo y reparador de nuestro honor:

"La verdad ha llegado al país en cuenta gotas, con la misma parsimonia con que se han enviado a África soldados y recursos, y hay que variar de procedimientos y acabar la guerra inmediatamente, cueste lo que cueste, si no se quiere convertirla en algo crónico que, sin finalidad ni provecho, acabe con la paciencia y el dinero del pueblo español. Si los cincuenta mil hombres que en el Rif hay no son bastantes para aplastar a las hordas rifeñas, mándense los que hagan falta, pero de una vez e inmediatamente (...) La guerra actual hay que acabarla haciendo sentir a los rifeños el poder y el valor de España, y las contemplaciones hay que guardarlas para quienes conozcan y aprecien lo que son y lo que significan. Ni crueldad ni clemencia; justicia seca y que aprendan los rifeños que no pueden cometerse atrocidades sin purgarlas, ${ }^{, 460}$.

Pero fue, sobre todo, coincidiendo con el fin de las operaciones, cuando $E l$ Adelanto, por fin, reflexionó sobre el objetivo de la pugna y sobre lo que a la opinión pública se le había transmitido. El periódico liberal se agasajaba a sí mismo, confesando que la prensa había desempeñado una función informativa mucho mejor que el gobierno. "L. A.”, en un excelente editorial exponía su personal interpretación del porqué del "sentir colectivo". Aunque el texto es muy extenso, consideramos pertinente su reproducción, ya que en él se pone de manifiesto cómo periodistas y gobernantes

\footnotetext{
${ }^{459}$ VILLALOBOS, Federico: Op. Cit., p. 69.

460 “Situación insostenible”, El Adelanto, no 7.778, 23 de octubre de 1909, p. 1.
} 
intentan manipular la opinión publicada para granjearse una determinada opinión pública. Evidentemente, no siempre lo consiguen. En él, además, se percibía una tímida crítica hacia un patriotismo, según la opinión del redactor, mal entendido por los políticos:

"Apenas iniciada en julio último la fiera rebelión rifeña, hubo de preguntar el pueblo español: ¿qué ocurre en Melilla? Dio a la opinión cumplida respuesta más la prensa sensata y consciente de sus deberes que el gobierno, no muy acertado al llenar los suyos esencialísimos sobre la confección adecuada del juicio público. Preguntó el pueblo luego: ¿cuál es nuestro objetivo, nuestro cometido fundamental en la campaña que comienza? Fue respuesta el silencio. También entonces la prensa consciente y sensata se esforzó por responder a España entera, que interpelaba con indiscutible derecho a sus gobernantes; pero, en definitiva, rodeada de nebulosas y obstáculos la información periodística, resultó estéril su labor investigadora. $Y$, ni al principio, ni casi al fin de nuestra gestión armada, ha logrado saber el país cuál sea ésta, sus líneas capitales, su orientación básica. La nación ha entregado sus hombres y, con ellos, su Tesoro, y con ambos sus prestigios primarios de vida, a ciegas, sin norte concreto, por mandatos no razonados.

Porque no se razonan las ordenaciones de una nación democrática, invocando las supremas necesidades del patriotismo, sin más aditamentos. Gobernar así sería una explotación despótica de los más altos y puros sentimientos nacionales. Los estados modernos no pueden desenvolver su actividad sino mediante una intima trabazón entre las determinaciones de la soberanía y la voluntad colectiva.

España supo y sigue sabiendo cuanto en Melilla y su campo ha ocurrido de julio acá; pero los españoles hemos alegado en cien formas nuestro derecho a saber más, a saber a dónde se dirige, como meta sustancial, la acción de España.

Esto no lo sabemos, y esto debe decirse, porque puede decirse. Hemos repetido hasta la saciedad que, en decir tal cosa, no se arriesga en un ápice todo aquello que jamás puede ponerse en riesgo por gobiernos y por ciudadanos.

$Y$ es fuerza que insistamos una vez más, porque las consecuencias del error se están tocando ya. Envuelta desde su comienzo la campaña de Melilla en un ambiente de oscuridad, de silencio, de incógnita para la opinión pública -atmósfera tanto más viciosa cuanto que en ella vio el país pulular los gérmenes del magno problema marroquí, tan desconocido para los españoles- a poco que anduvo la mente popular, halláse desorientada. Comenzaron entonces a adquirir vida todas esas hipótesis sin fundamento que engendra la necesidad de saber lo que no se conoce y quiere conocerse. La fantasía pública dio libertad a sus alas, y con ellas recorrió un sendero de errores: desde la conquista de Marruecos por España, y nuestra ida a Fez y a Taza hasta el abandono total y definitivo de nuestro haber magrebita, y con él, de la dignidad nacional. ¿Para qué recordar las enormidades, y, en menor grado, las invenciones más o menos ingeniosas, dichas y escritas, si nadie las ignora ni las olvida?

Pero, no dejado aún de la mano divina, pudo notarse -y harto se notó- que si la opinión sufría la desorientación más completa y lamentable en punto al problema en África planteado, el sentimiento público tenía en la campaña sus objetivos populares; esos objetivos por patriótica intuición coincidieron con los técnicos. Hizo el pobre país lo más que pudo: tratar de orientarse a sí mismo y forjar un plan de ofensiva.

¿Qué sucedió luego? Luego, tras los heroísmos de Beni-bu-Ifrur vino una pausa. Logrados los objetivos del pueblo, supo éste que la campaña no estaba terminada. Su decepción fue grande; faltáronle, quizá, alientos y entusiasmos para sustituir con 
esperanzas doradas sus objetivos logrados, y el pueblo, desorientado, degeneró en suma estéril de espíritus decaídos " ${ }^{\text {"461 }}$.

En definitiva, la censura gubernamental había dejado de ser una medida comprensible. Sobre todo, porque el patriotismo de las capas populares estaba libre de cualquier duda.

También hubo ahora lugar para las discusiones terminológicas. Así, "C.”, en un esfuerzo por evitar confusiones entre sus lectores, intentó explicar lo que había significado, conceptualmente, la campaña militar:

"El alcance de las victoriosas operaciones del Ejército español en Melilla, es asunto de una importancia y actualidad indiscutibles.

Se dice y se escribe que hemos ocupado militarmente en el Rif determinados territorios. Se dice y se escribe también que conquistamos el suelo ocupado, ampliando las fronteras españolas. Lo así dicho y escrito, envuelve, supone una lamentable confusión de conceptos que extraviando el juicio público pudiera, en su día, producir consecuencias más lamentables aún. Hay que depurar el léxico para obtener la claridad y la firmeza de pensamiento, deslindando lo que es distinto y casi opuesto.

Ocupación militar y dominio territorial, son cosas diferentes, ${ }^{, 462}$.

Diríase que este comentario se dirigía, inequívocamente, contra El Salmantino.

La prensa católica salmantina, en lugar de esforzarse aportando razones para la desorientación entre la opinión pública, prefirió cebarse con el Trust. Así lo hizo El Lábaro $^{463}$. Particularmente le molestó a "M. de B." el hecho de que los periódicos de la Sociedad Editorial se hicieran eco de los comentarios insidiosos vertidos en los diarios franceses contra el general Marina ${ }^{464}$.

El órgano local del integrismo, por su parte, acostumbró a encabezar muchos de sus editoriales con un rótulo en el que subrayaba su adhesión a la Buena Prensa, una campaña que había emprendió La Correspondencia de España, y en muy reiteradas ocasiones defendió a ultranza el dogma católico ${ }^{465}$. Por esta razón, la creación del Bloque de las Izquierdas había acaparado mucha de su atención: la redacción lo consideraba innecesario en vista de que el Partido Conservador, decía, se ocupaba de

\footnotetext{
461 “L. A.”: "La campaña de África”, El Adelanto, no 7.799, 17 de noviembre de 1909, p. 2.

462 "C.": "De la guerra. Nuestra verdadera situación en África", El Adelanto, no 7.819, 11 de diciembre de 1909 , p. 2.

463 "La campaña de El Mundo", El Lábaro, no 3.778, 18 de septiembre de 1909, p. 1.

464 "M. de B.": "El colmo de la ignorancia", El Lábaro, no 3.799, 14 de octubre de 1909, p. 1. Idénticos planteamientos se recogen en: "Los enemigos de España", El Lábaro, no 3.801, 16 de octubre de 1909, p. 1.

${ }^{465}$ Dogma que había de ser aceptado íntegramente, sin ninguna modificación. Así, por ejemplo, M. S. Asensio explicaba que el Liberalismo y el Catolicismo eran dos doctrinas absolutamente incompatibles. Véase M. S. Asensio: “Catolicismo y liberalismo”, El Salmantino, no 68, 30 de enero de 1909, p. 1.
} 
violar el Concordato; además, para mayor irritación, el Bloque disfrutaba del enervante respaldo de la Sociedad Editorial.

A ciencia cierta, el proyecto de Segismundo Moret de "mandar al Catolicismo a la más oscura trastera", según las palabras de "S.", no agradaba a ninguno de los cronistas de la casa. Los mismos, por otro lado, se complacían ante la escasez de apoyos intelectuales para el Bloque. Y entre las explicaciones más curiosas de ese fracaso figuraba la idea de que "los españoles de ahora ya no formamos aquellas reatas, ni vamos atados a esos señores periodistas que mil veces nos han engañado haciéndonos ver que era blanco lo negro" $" 466$.

Ante el hecho de que los periódicos del Trust se opusieran a la práctica de la censura durante el desarrollo de la Guerra de Melilla, El Salmantino comentó: "Creemos que se equivocan como de costumbre" ${ }^{467}$. Ellos, recordemos, la acataron fielmente.

Y tras la toma del Gurugú, un redactor, "Ese", dirigió un rabioso ataque contra ese consorcio periodístico y contra lo que consideraba un acto desvergonzado: que se alegrasen por una conquista militar después de vociferar tanto contra la campaña melillense:

"Denunciados doscientas veces, enronquecidos otras tantas, y siempre inflados y descompuestos contra la Guerra del Rif, echaron aire a lo de Barcelona y al embarque de tropas, y no desperdiciaron ocasión ni motivo de presentarlo todo negro, muy negro, deprimiendo el ánimo nacional cuando nuestro Ejército luchaba frente al enemigo.

El patriotismo de estos caballeros de industria estuvo a la altura de sus babuchas; pero felizmente puesta nuestra gloriosa bandera en la cima del Gurugú y cubiertos de gloria nuestros valerosos soldados (...) cambian de frente, baten palmas ${ }^{, 468}$.

No obstante, todavía fue más furibundo el editorial que publicó, una semana después, José M $M^{a}$ de los Corrales. Se trata de uno de los editoriales más geniales, por su enorme carga ideológica y fuerza retórica, publicado en Salamanca a propósito del poder del Trust:

"Hasta los ciegos ven y los más ignorantes saben, que en la guerra en que está empeñada la sociedad actual, va de triunfo en triunfo, aquella parte que ha sabido adquirir y manejar la moderna arma que todo lo remueve, que todo lo avasalla, que todo lo puede y que a todos vence; arma prodigiosa, a cuyo poder nada resiste, a quien no hay nadie que no tema (...) La prensa, he ahí el arma, que debiendo ser la salvaguardia del orden, el apoyo de la autoridad, la defensora de la fe católica, la garantía de la paz, la pregonera y aliada del progreso, la que afianzase la verdadera libertad, es la que todo lo derrumba, todo lo pisa y de todo se mofa (...) Es decir, esa

\footnotetext{
466 “S.”: “¿Por qué no cuaja el bloque?”, El Salmantino, nº 66, 16 de enero de 1909, p. 1.

467 "De la guerra", El Salmantino, no 101, 18 de septiembre de 1909, p. 2.

468 "Ese": "Política menuda", El Salmantino, no 103, 2 de octubre de 1909, p. 1.
} 
prensa, esa arma que así combate y que, hoy por hoy, así triunfa o así destruye, es la prensa mala, la prensa liberal (...) La otra prensa, antiliberal, es la que hace frente, batiéndose con el más sublime de los heroísmo, tanto por su inferioridad numérica como por el abandono, indiferencia y tal vez disgusto con que por los mismos suyos, que debían ampararla y protegerla, se la ve ${ }^{, 469}$.

Y terminada la fase militar de la campaña, en enero de 1910, coincidiendo con el regreso de la brigada de Cazadores de Madrid, la publicación semanal, de nuevo, se indignaba porque fuese Moret $-\mathrm{y}$, por extensión, el Bloque y el Trust- quienes se atreviesen a encabezar el acto de bienvenida ${ }^{470}$.

El recién fundado Círculo Tradicionalista Salmantino organizó un variado ciclo de conferencias y éstas ofrecieron al rotativo integrista una nueva oportunidad para rebatir las ideas de la Sociedad Editorial ${ }^{471}$. Entre marzo y mayo de 1910 se celebraron cinco sesiones y El Salmantino recogió al completo todos los discursos allí pronunciados, a pesar de que ello precisase de la mitad de su superficie. A cargo de Ernesto Amador y Carrandi, profesor de la Facultad de Derecho, estuvieron cuatro exposiciones sobre la cuestión rifeña y en ellas se compendió, en efecto, todo el credo africanista del semanario. De ahí, que no le importase invertir tanto espacio en el asunto. Creemos que la reproducción de todas estas exposiciones, así como la insistencia en su carácter multitudinario, constituyeron el mayor esfuerzo pedagógico del semanario y, también, en cierto modo, su contraataque frente a las tesis que venía sosteniendo la prensa del Trust respecto al problema africano.

La primera sesión, celebrada el día 2 de marzo de 1910, se publicó tres días después. Amador y Carrandi presentaba el problema marroquí como una gran cuestión nacional, que debiera estar al margen de cualquier instrumentación política ${ }^{472}$. Esta conferencia inaugural se estructuró en dos bloques: en el primero, el profesor se refirió a la topografía de Marruecos, al fanatismo de sus gentes y a la necesidad imperial de reformar su Ejército; y en un momento posterior, disertó sobre las ambiciones de las potencias europeas y, en particular, sobre los intereses estratégicos de Francia en Argelia.

\footnotetext{
${ }^{469}$ José Ma de los Corrales: "El arma que vence", El Salmantino, no 104, 9 de octubre de 1909, p. 1. 470 "C.": "Los liberales y el Ejército", El Salmantino, no 119, 22 de enero de 1910, p. 1; "El regreso de las tropas", El Salmantino, no 120, 29 de enero de 1910, p. 3; "Crónica semanal", El Salmantino, n 126, 5 de marzo de 1910, p. 1.

${ }^{471}$ Sobre su fundación, véase: "El Círculo Tradicionalista", El Salmantino, no 118, 15 de enero de 1910, p. 2. Una actividad pedagógica similar ya había sido promocionada, por este mismo semanario en noviembre: un curso científico en la Congregación de San Luis, con el título "El Rif ante el derecho de conquista. Consúltese: "Una academia", El Salmantino, n 108, 6 de noviembre de 1909, p. 3.

472 "Las conferencias del Círculo Tradicionalista", El Salmantino, no 126, 5 de marzo de 1910, pp. 1-2.
} 
El 5 de abril, Ernesto Amador y Carrandi volvió a participar en las reuniones del círculo y su ponencia fue publicada por El Salmantino diez días después. En esta ocasión, evaluó, muy negativamente, el papel asumido por España en Marruecos, de acuerdo con los tratados internacionales ${ }^{473}$. Maura, al vincularse con la Entente, había echado por tierra nuestros derechos: "Un vínculo que nace de la convivencia histórica, que se nota hasta en el sedimento que ha dejado en nuestra lengua y en nuestra literatura (...) en los gustos y educación". De nuevo, se recalcaba aquella idea de que los militares únicamente intentaban reparar el desaguisado de los diplomáticos. Porque, según ellos, la audacia de la fuerza había de desplazar al derecho en la solución de los conflictos internacionales. El espíritu darwinista de la época había calado muy hondo entre la oficialidad.

La siguiente reunión tuvo lugar el 20 de abril y los discursos aparecieron reproducidos en el diario integrista a la semana siguiente. Ahora, nuestro conferenciante aludía a la agresiva política seguida por Francia en el Sultanato y a la Guerra del Rif: "La acción española no fue todo lo rápida y decisiva que hubiera sido de desear, pero, a pesar de ello, sus valientes consiguieron recorrer vencedores el valle del Muluya, extenderse hasta la ribera del Kert, posesionarse de la alcazaba de Zeluán y hacer tremolar la bandera de la patria sobre las cumbres del Atalayón, Nador y el Gurugú" ${ }^{474}$. Así pues, como de costumbre, cualquier posible equívoco militar era disculpado, pensándose únicamente en sus conquistas.

Finalmente, la última de las sesiones se celebró el 7 de mayo y se publicó el día 14 del mismo mes. Amador y Carrandi concluía su serie de pláticas con unas aclaraciones sobre la situación jurídica del Rif:

"Donde antes sólo se aspiraba el olor de la pólvora que enardece, se aspira ahora la deleitosa quietud que produce el silencioso trabajo que fecundizará aquellas comarcas (...) Magníficas carreteras hasta los puntos estratégicos sustituyen a los antes tortuosos e inseguros caminos; las vías férreas avanzan rápidamente en dirección a las minas, adornadas por pintorescas estaciones, y la normalidad de la vida con todos sus encantos parece que vuelve a renacer bajo la bandera de la civilización cristiana (...) El pueblo español que con viva atención seguía el desarrollo de los sucesos del Rif, respiró tranquilo, un solo sentimiento pareció agitar todos los corazones, una sola frase pareció salir de todos los labios: al fin hemos triunfado, la parte del Rif ocupada por nuestras tropas nos pertenece, es nuestra.

Pero, ¿será exacta esta afirmación? ’,475.

\footnotetext{
473 "Las conferencias del Círculo Tradicionalista", El Salmantino, no 133, 16 de abril de 1910, pp. 1-2.

474 "Las conferencias del Círculo Tradicionalista", El Salmantino, n $\mathrm{n}^{\mathrm{o}}$ 135, 10 de abril de 1910, p. 2.

475 "Las conferencias del Círculo Tradicionalista", El Salmantino, no 137, 14 de mayo de 1910, p. 2.
} 
Evidentemente, la respuesta era negativa: "En el Acta de Algeciras se determinaba de un modo claro y categórico (...) la integridad de Marruecos". Para el conferenciante, sin embargo, esto únicamente constituía el terreno de los principios, pero los hechos venían definidos por "el pensamiento ulterior de las naciones de cambiar la ocupación temporal en definitiva, la imposibilidad del Sultán de cumplir sus deberes internacionales y, como consecuencia, el tránsito de la ocupación temporal a la definitiva". Lo que primaba era frenar la estrategia gala de avance mediante "la mancha de aceite". El nacionalismo antifrancés constituyó para el pensamiento integrista el pilar básico de su propaganda bélica. Y al servicio de este axioma se glorificó al Ejército y se demonizó al Trust.

Sorprende, sin duda, el silencio de El Castellano. Seguramente, decidió acabar con la guerra tan pronto como se ocupó Atlatén.

\section{Canalejas y los asuntos marroquíes}

Una de las primeras medidas del nuevo ministro de Guerra, el general Aznar, con el evidente propósito de ganarse las simpatías populares, fue el licenciamiento de los reservistas del reemplazo de 1905. Se estimaba que la medida afectaría a unos cincuenta salmantinos que desde julio permanecían en tierras marroquíes ${ }^{476}$.

Por otro lado, la llegada al gobierno de ese general se tradujo en nuevos proyectos de reorganización del Ejército. Su base indispensable sería la implantación del servicio militar obligatorio ${ }^{477}$, pero en su mente también figuraba el aumento de fuerzas permanentes en África y la modificación del reglamento de recompensas ${ }^{478}$.

Al publicitarse las cifras sobre este incremento de fuerzas en Marruecos, $E l$ Adelanto comentó: “Como se ve, el Ejército tendrá elevación relativamente considerable en filas, que, redundando en beneficio de la instrucción militar, evitará llamamientos extemporáneos y dará la seguridad de que en todo momento, y sean

\footnotetext{
476 "Notas militares", El Adelanto, no 7.881, 23 de febrero de 1910, p. 2; "Llegada de licenciado", El Adelanto, $\mathrm{n}^{\circ} 7.885,28$ de febrero de 1910, p. 1. Por ejemplo, las noticias sobre las repatriaciones de los regimientos del Príncipe, Saboya y del Rey serán incesantes hasta finales de mayo de 1910: Alfredo Rivera: "Conferencias telegráficas", El Adelanto, $\mathrm{n}^{\circ}$ 7.931, 23 de abril de 1910, p. 3; Alfredo Rivera: "Conferencias telegráficas", El Adelanto, $\mathrm{n}^{\circ}$ 7.934, 27 de abril de 1910, p. 3; Alfredo Rivera: "Conferencias telegráficas", El Adelanto, $\mathrm{n}^{\circ}$ 7.938, 2 de mayo de 1910, p. 3; Alfredo Rivera: "Conferencias telegráficas", El Adelanto, $\mathrm{n}^{\circ}$ 7.941, 5 de mayo de 1910, p. 3; Alfredo Rivera: "Conferencias telegráficas", El Adelanto, no 7.962, 30 de mayo de 1910, p. 3; Alfredo Rivera: "Conferencias telegráficas", El Adelanto, n ${ }^{\circ} 7.971,9$ de junio de 1910, p. 3.

477 "El servicio militar obligatorio", El Adelanto, no 8.023, 9 de agosto de 1910, pp. 1-2; "El servicio militar obligatorio", El Adelanto, no 8.067, 10 de octubre de 1910, p. 1; "El servicio militar obligatorio", El Adelanto, $\mathrm{n}^{\circ} 8.094,10$ de noviembre de 1910, p. 1. Aquí ya se menciona la figura del "cuota" y se exponen los primeros detalles referidos a cuantías y modos de pago.

${ }^{478}$ Alfredo Rivera: "Conferencias telegráficas", El Adelanto, n $7.883,25$ de febrero de 1910, p. 3.
} 
cuales fueren las circunstancias, estará en disponibilidad de rendir el efecto útil preciso" ${ }^{479}$. Diríase que se pretendía corregir un error lamentable que la Guerra del Rif había dejado expuesto ante la opinión pública.

A través de El Adelanto, por otro lado, se pueden seguir en este periodo los debates parlamentarios, con algunas sesiones muy agrias. Por ejemplo, el 19 de julio de 1910 Rivera recogió el durísimo discurso pronunciado por Melquiades Álvarez en el Congreso contra Antonio Maura: no sólo le responsabilizó del estallido del conflicto en el Rif, al emprender unas obras para la construcción de un ferrocarril sin ningún tipo de autorización; sino que, sobre todo, le acusó de haber incurrido en una enorme imprudencia, detonante de la cólera popular. Maura mintió al pueblo porque prometió que no habría contienda y a la guerra no se puede jamás marchar contra la voluntad popular porque, en ese caso, el Ejército pierde su ideal, su espíritu ${ }^{480}$. Mientras, el político mallorquín se parapetó en el cumplimiento del Protocolo de Algeciras y en la defensa del prestigio internacional de España. Igualmente, aprovechó la ocasión para culpar a la prensa de confundir a la opinión: “Esta prensa, a la que le interesan más las revistas de toros y de crímenes, dijo a sus lectores que la Guerra del Rif se concretaba únicamente en un negocio minero que a la Patria le tenía sin cuidado". ${ }^{481}$ Seguramente, el diario intentaba, al reproducir estos desafortunados comentarios de Maura, dotarse de un pretexto que le sirviese para irse distanciando del tono tan belicoso sostenido meses atrás.

La dimisión del general Marina fue, aún así, una noticia recibida con tristeza en la redacción de El Adelanto, ya que se admiraba tanto su buen hacer político como militar. Quedaba como consuelo el hecho de que su sustituto, el general Aldave, también fuese una figura rodeada de prestigio ${ }^{482}$. Desde luego, el regreso a Madrid no significaría para el exjefe del Ejército de operaciones en Marruecos un descanso. Inmediatamente, hubo de hacer frente a las críticas, vertidas en El Mundo, por el senador Maestre ${ }^{483}$.

Por lo que respecta a la tramitación de la paz oficial, a mediados de diciembre de 1909, unas declaraciones de Pérez Caballero, el ministro de Estado, ante los periodistas

\footnotetext{
479 "El presupuesto de guerra", El Adelanto, no 8.083, 28 de octubre de 1910, p. 1; "El contingente para 1911”, El Adelanto, "n 8.112, 1 de diciembre de 1910, p. 2.

${ }^{480}$ Alfredo Rivera: "Conferencias telegráficas", El Adelanto, no 8.005, 19 de julio de 1910, p. 3.

${ }^{481}$ Alfredo Rivera: "Conferencias telegráficas", El Adelanto, no 8.006, 20 de julio de 1910, p. 3.

482 "El relevo del general Marina", El Adelanto, no 8.030, 29 de agosto de 1910, p. 2; "El general Aldave a Melilla", El Adelanto, no 8.043, 12 de septiembre de 1910, p. 2.

${ }^{483}$ Alfredo Rivera: "Conferencias telegráficas", El Adelanto, n' 8.041, 10 de septiembre de 1910, p. 3.
} 
madrileños ya habían sido comentadísimas por El Adelanto: aseguraba entonces el político que las conversaciones de paz con Hafid marchaban por un óptimo camino dado que nunca antes España se había hallado en mejores condiciones para ejercer su acción civilizadora en Marruecos. El Rogui había sido, durante años, el amo de la región circundante a la plaza y todos los sultanes, sistemáticamente, fracasaron ante él. Pero ahora, la victoria de las armas españolas legitimaba a la oficialidad para intervenir en la autoridad de los caídes y entrenar a las tropas indígenas con el objeto de garantizar el orden en la zona. Había llegado la hora de desempeñar nuestra misión civilizadora en África. El momento era, además, el idóneo para exigirle una indemnización a Hafid ${ }^{484}$.

Sin embargo, la negociación de la paz se ralentizaría muchísimo. La política de dilaciones, como se habrá deducido, era una nota constante, absolutamente definitoria, de la estrategia diplomática de los Sultanes. Al finalizar septiembre de 1910, estando ya en el gobierno José Canalejas, se trasladaba hasta Madrid El Mokri para transmitir los planes de Hafid; rechazaba el pago de una indemnización de guerra y exigía la evacuación española de las posiciones ocupadas. El Adelanto respondía mediante el recurso al viejo argumento del agravio comparativo.

"Marruecos indemnizó o se ha comprometido a indemnizar a Francia de los gastos y perjuicios de la campaña de Casablanca, menos lógica y razonable que la de Melilla, y en cambio se niega a reconocer a España el derecho de igual beneficio; Francia, sin protesta del Sultán, continúa ocupando Casablanca y la Chauia, y según conviene a sus intereses va extendiendo su acción sobre las regiones de la derecha del Muluya, para abrir nuevos campos de acción a su comercio; pero a España se la exige la evacuación de unos territorios sobre los cuales los emperadores de Marruecos nunca ejercieron más que una soberanía nominal ${ }^{\text {,485. }}$.

A decir verdad, Francia logró imponer al Sultán unas condiciones verdaderamente humillantes: las tropas galas permanecerían en las posiciones conquistadas, mientras que al Majzén le correspondería sufragar los gastos del Ejército de ocupación y pagar una nueva indemnización de 2.500.000 francos a las víctimas europeas de los sucesos de Casablanca. Todo ello fue, además, acompañado de la adquisición de otro gravoso empréstito ${ }^{486}$. Durante los días siguientes, los periodistas apenas pudieron conocer los detalles sobre el desarrollo de las reuniones ${ }^{487}$. Y, poco

\footnotetext{
484 “España en Marruecos. Lo que dice el ministro de Estado", El Adelanto, no 7.820, 13 de diciembre de 1909 , p. 2. Pero una afirmación de este tipo contrasta con la escasa cobertura mediática que, por ejemplo, recibió el Congreso Africanista de Valencia que simultáneamente se estaba desarrollando. Véase Alfredo Rivera: "Conferencias telegráficas", El Adelanto, $\mathrm{n}^{\circ}$ 7.823, 16 de diciembre de 1909, p. 3.

485 "La misión de El Mokri", El Adelanto, nº 8.059, 30 de septiembre de 1910, p. 1.

486 BOUARFA, Mohamed: Op. Cit., p. 65.

${ }^{487}$ Alfredo Rivera: "Conferencias telegráficas", El Adelanto, no 8.063, 5 de octubre de 1910, p. 3.
} 
después, Canalejas confirmó a El Imparcial, y así lo recogió también El Adelanto, que los diplomáticos se habían autoimpuesto un silencio absoluto para evitar rumores y maledicencias. Los únicos perfectamente al corriente de todas las negociaciones eran los propios delegados gubernamentales, Canalejas, Alfonso XIII y los embajadores francés y británico. El presidente aseguraba que en Marruecos siempre se marchaba de acuerdo con la Entente y era mentira que Francia planease la ocupación de Taza o que España previese asentarse en Tetuán ${ }^{488}$. Pero enormes ampollas, forzosamente, tuvo que levantar un artículo de Le Temps donde se combatía el derecho español a recibir una indemnización de guerra ${ }^{489}$. Y dudoso consuelo podían suponer las alusiones de Rivera a una protesta anti-francesa en ciernes, en la margen derecha del Muluya, debida a un exceso de presión fiscal gala sobre los marroquíes ${ }^{490}$. Las relaciones hispano-galas, por consiguiente, continuaban generando infinidad de suspicacias.

A principios de noviembre las aguas parecían, no obstante, retornar a su cauce: Marruecos transigía con la idea, tras un durísimo tira y afloja, de una indemnización por valor de 65 millones de pesetas. Pero, simultáneamente, ganaban fuerza los rumores de un inminente avance francés sobre Taza ${ }^{491}$. Por otro lado, además, las negociaciones también se vieron entorpecidas por la resistencia de El Mokri al establecimiento de una nueva aduana en Ceuta y a la creación de una policía mixta para la vigilancia de los anyera $^{492}$.

Finalmente, el 17 de noviembre, Alfredo Rivera reprodujo una nota con los principales puntos del Convenio hispano-marroquí para los lectores de El Adelanto. Se destacaban estos:

"La evacuación del territorio del Rif, que en la actualidad ocupan nuestras tropas, se efectuará el día que la policía sea capaz de asegurar el orden en aquellas comarcas, la libertad para ejercer el cobro de los impuestos y la seguridad en Ceuta, comprometiéndose el Majzén a no fortificar los puntos que fueran un grave riesgo para la plaza (...) El Majzén pagará 65 millones como compensación por los gastos militares y navales hechos por España durante la pasada campaña, pagaderos en 65 anualidades, ${ }^{, 493}$.

\footnotetext{
488 "España y Marruecos", El Adelanto, no 8.080, 25 de octubre de 1910, p. 1; Alfredo Rivera: “Conferencias telegráficas”, El Adelanto, n 8.087, 2 de noviembre de 1910, p. 3.

489 "Lo de Marruecos. ¿Francia contra España?", El Adelanto, no 8.083, 28 de octubre de 1910, p. 1. En otra ocasión más, tal y como Rivera copiará, recomendaría Le Temps serenidad a la diplomacia: "España y Marruecos", El Adelanto, no 8.088, 3 de noviembre de 1910, p. 2.

${ }^{490}$ Alfredo Rivera: "Conferencias telegráficas", El Adelanto, no 8.086, 1 de noviembre de 1910, p. 3.

${ }^{491}$ Alfredo Rivera: "Conferencias telegráficas", El Adelanto, no 8.089, 4 de noviembre de 1910, p. 3; Alfredo Rivera: “Conferencias telegráficas”, El Adelanto, no 8.092, 8 de noviembre de 1910, p. 3.

${ }^{492}$ Alfredo Rivera: "Conferencias telegráficas", El Adelanto, no 8.096, 12 de noviembre de 1910, p. 3; Alfredo Rivera: “Conferencias telegráficas”, El Adelanto, n 8.098, 15 de noviembre de 1910, p. 3.

${ }^{493}$ Alfredo Rivera: “Conferencias telegráficas”, El Adelanto, no 8.100, 17 de noviembre de 1910, p. 3.
} 
Y, al día siguiente, también Rivera aclaraba que el Tratado emulaba el ya firmado entre Francia y Marruecos después de la campaña de la Chauia ${ }^{494}$. Precisamente, éste era, sin ningún género de dudas, el aspecto que más celebraba la redacción de El Adelanto:

"El Tratado firmado en Madrid el día 16, parece calcado en sus partes más esenciales y en su espíritu del que hace poco más de un año se firmó en París entre El Mokri y el gobierno francés.

Además del arreglo del antiguo asunto de Santa Cruz de Mar Pequeña, del de los límites del campo de Ceuta, y de otros acaso más importantes, como el de las zonas de influencia, con lo que quedan solucionadas todas las reclamaciones y problemas que teníamos pendientes en Marruecos, el Majzén se compromete a pagarnos una indemnización en las mismas condiciones que a Francia, y a no pedir que nuestras tropas evacuen las posiciones que ocuparan en el Rif, en tanto él no garantice con fuerzas de policía la tranquilidad de los territorios vecinos a Melilla, y esto para el que sabe leer y para el que conoce los asuntos marroquies, tiene una significación harto clara (...) El Acta de Algeciras oblíganos a respetar la integridad del imperio mogrebino, y así lo hacemos, sin embargo, de hecho ocupamos una parte de él; porque si los pactos firmados nos prohíben las situaciones de derecho, nada dicen de las de hecho, ${ }^{, 495}$.

Magistral demostración de cinismo. El broche final a estas larguísimas negociaciones lo puso Alfonso XIII, con su visita a la zona de operaciones ${ }^{496}$.

De El Lábaro, para esta coyuntura que nos ocupa, atrae nuestra atención un artículo del obispo de Ciudad Rodrigo, dándole la bienvenida a los soldados que continúan aún llegando de África:

"En nuestra patria el celo religioso y el ardor bélico han hecho muchas jornadas juntos, y no es extraño que alguna vez, per accidens, trocados los papeles, el clérigo esgrima la espada y el soldado haga las veces de misionero.

La Iglesia de España se asocia hoy al entusiasmo general con que la patria recibe a sus hijos, que regresan triunfantes de una penosa y sangrienta campaña y la que bendijo, henchida de esperanzas, las armas de nuestro Ejército, hoy bendice sonriente sus coronas $^{\text {,497. }}$.

Por otra parte, este periódico se mostró muy preocupado ante las posibles derivaciones de unos incidentes franco-marroquíes en el Garb, convencido de que el presumible entendimiento posterior no beneficiaría a España ${ }^{498}$. Y en agosto, le dedicó

\footnotetext{
494 “El Convenio con Marruecos", El Adelanto, no 8.101, 18 de noviembre de 1910, p. 1.

495 "El Tratado con Marruecos", El Adelanto, n 8.102, 19 de noviembre de 1910, p. 1.

496 Alfredo Rivera: "Conferencias telegráficas", El Adelanto, no 8.113, 2 de diciembre de 1910, p. 3; "Viaje del Rey a Melilla", El Adelanto, no 8.118, 8 de diciembre de 1910, p. 1; Alfredo Rivera: "Conferencias telegráficas", El Adelanto, no 8.135, 28 de diciembre de 1910, p. 3.

${ }^{497}$ El obispo de Ciudad Rodrigo: "El Ejército y la Iglesia”, El Lábaro, no 3.891, 5 de febrero de 1910, p. 2.

498 “Telegramas. Francia en Marruecos”, El Lábaro, n 3.907, 24 de febrero de 1910, p. 3.
} 
mucho espacio a la reproducción del nuevo proyecto de ley de reclutamiento y remplazo ${ }^{499}$. Pero sin llegar a posicionarse al respecto.

La última información que vamos a reseñar de este diario es un formidable editorial de Eusebio Díaz. El Lábaro cerró sus puertas el 21 de noviembre de 1910, acosado por los continuos ataques del integrismo, sin llegar a comentar la firma de la paz. No obstante, sí que dejó muy clara su inquebrantable fe africanista:

"La vida moderna se desliza entre aspiraciones y sentimientos opuestos (...) El pacifismo, que fue en otro tiempo una ilusión quimérica de pocos, es ya hoy una aspiración por la que anhelan muchos (...) El socialismo ha hecho de tal tendencia un banderín de enganche, recogiendo este sentimiento humanitario como patrimonio exclusivo de su credo; agregan a esos impulsos motivos de índole económica y ponderan los trastornos que origina el arrancar a los campos y talleres los brazos más robustos para mecanizarlos en unidades militares (...) Son nobles deseos, bellas concepciones que dicen mucho de sus gestadores, pero ni hoy ni nunca traspasarán los umbrales del idealismo altruista (...) La vida actual marcha impulsada por necesidades imperiosas que exige el progreso y aviva el confort. Hay que darles satisfacción: la tierra esquilmada de las naciones viejas no produce suficiente, ni el desarrollo prodigioso de la industria tiene bastante consumo en el territorio del Estado (...) De ahí, la colonización, que se erige en el punto primordial de la vida económica moderna. No hay para qué decir el valor de las armas en la defensa de los países que conquistó la diplomacia; es menos preciso refutar la tesis de que solo la mano militar realiza el milagro de dominar colonias (...) La vida a que tiene derecho una raza, es a la vida espiritual (...) el mayor beneficio que puede ofrecérseles es orientarla por la espléndida vía del progreso (...) El impugnar la colonización por los horrores de la guerra o la violencia que a veces supone, es una exaltación sentimental que no debe apreciarse al lado de las ventajas que a todos engendra: importa no olvidarlo, no sería la paz la que imperara si triunfasen los enemigos sistemáticos de la guerra, sino la pereza pacifista (...) España tiene planteado el problema colonial del Rif. Quienes miran con ojo avizor la marcha de la política mundial, proclaman sin reservas el deber de perseverar en la obra allí comenzada (...) El día en que cerremos del todo los ventanales del caserón hispano, será el viejo solar nuestro sepulcro ${ }^{, 500}$.

La postura de El Castellano, lamentablemente, también nos es completamente desconocida en este aspecto, pues no se conservan los ejemplares correspondientes al año 1910.

El Salmantino, para terminar, experimentó un rechazo muy visceral hacia el gobierno de José Canalejas y hacia su política anticlerical; pero esta repulsa acabó extendiéndose a todos los ámbitos de la vida pública, incluida la política marroquí ${ }^{501}$. Además, el nuevo proyecto de servicio militar obligatorio no despertó ningún apego en

\footnotetext{
499 "Proyecto de ley de reclutamiento y remplazo del Ejército", El Lábaro, no 4.042, 10 de agosto de 1910, p. 1; "Proyecto de ley de reclutamiento y remplazo del Ejército", El Lábaro, no 4.043, 11 de agosto de 1910, p. 2.

${ }_{500}$ Eusebio Díaz: "Pacifismo y colonización”, El Lábaro, no 4.051, 22 de agosto de 1910, p. 1.

501 "E.": "La dignidad nacional", El Salmantino, nº 51, 3 de agosto de 1910, p. 1.
} 
la redacción del semanario integrista. Y es que su implantación se asoció, inmediatamente, con la agudización de la crisis agrícola:

"Pretendemos nosotros apuntar los males que a la clase agrícola ocasionaría el servicio militar obligatorio, para que se desista de tal reforma.

$Y$ es el primero el del aumento de los tributos ya insoportables que pesan sobre la tan sufrida clase agrícola. El servicio militar obligatorio tiene, entre otros defectos, de mayor importancia, el de ser más costoso que el actual sistema de remplazo y, por lo tanto, el de exigir el recargo en los tributos (...) Y es otro de los perjuicios que a la clase agrícola ocasiona el servicio obligatorio, el de disminuir el número de brazos que en las faenas del campo pueden emplearse, lo que unido a la sangría constante de la emigración contribuirá seguramente a que los campos se vean despoblados (...) Y no queremos hablar de los hábitos de indolencia o de aversión al rudo trabajo del campo que las costumbres militares han de producir ${ }^{1502}$.

En cuanto a la firma de la paz, este semanario aprovechó la etapa final de las negociaciones hispano-marroquíes para azuzar el odio contra el francés. A principios de octubre, Hernán de Z. aludió a la inspiración gala de los sucesos de la Semana Trágica y presentó a Pablo Iglesias y Lerroux como esbirros de aquel gobierno ${ }^{503}$. Al terminar dicho mes, también el diario integrista aireaba y denigraba un artículo de Le Temps, calificado como "muy insidioso", en el que se ponían en tela de juicio los derechos históricos de España en Marruecos. En el mismo escrito, se le recomendaba a José Canalejas hacer gala de una actitud más enérgica frente a este tipo de intromisiones ${ }^{504}$. E incluso, bastantes meses después de la firma de la paz, en marzo de 1911, el órgano integrista amplificaba unas declaraciones del doctor Maestre a favor de una alianza con Alemania $^{505}$.

Por fin, el 18 de noviembre, El Salmantino anunció la conclusión de las negociaciones con El Mokri y aportó algunos detalles sobre las mismas: la obtención por España de una indemnización de 65 millones de pesetas; el compromiso marroquí de creación de una policía indígena, aunque instruida por españoles, para la vigilancia de las posiciones recientemente conquistadas; y, para terminar, la existencia de algún tipo de arreglo minero al que, curiosamente, no se le otorgó importancia y no se detalló nada sobre su contenido ${ }^{506}$.

\footnotetext{
502 "La crisis agrícola y el servicio militar obligatorio", El Salmantino, no 75, 1 de septiembre de 1910, p. 1.

503 "Hernán de Z.": "La situación de España. Crónica diaria", El Salmantino, n 104, 6 de octubre de 1910 , p. 2.

504 "La cuestión de Marruecos", El Salmantino, no 123, 28 de octubre de 1910, p. 1.

505 "Información telegráfica. Madrid. Opinión sobre el problema de Marruecos", El Salmantino, no 245, 24 de marzo de 1911, p. 3. Simultáneamente, la situación de Hafid se contemplaba como muy vulnerable: "La situación de Marruecos", El Salmantino, no 247, 28 de marzo de 1911, p. 2.

506 "Por la paz", El Salmantino, n 140, 18 de noviembre de 1910, p. 1.
} 
El mismo día era reproducido el discurso del presidente del gobierno ante el Senado, dando cuenta de la firma del documento. Creía que era un símbolo del renacimiento español porque regulaba nuestra influencia legítima al sur de Tarifa ${ }^{507}$.

Entre el 23 y el 25 de noviembre, este periódico reprodujo todo el articulado del nuevo Convenio ${ }^{508}$. Acto seguido, su atención se desviaba hacia los preparativos de la inminente visita del Rey Alfonso XIII ${ }^{509}$.

\section{Los gestos de apoyo de los salmantinos para sus combatientes}

No debemos concluir este capítulo sin un repaso de las principales manifestaciones de apoyo de los salmantinos para con sus soldados. Habitualmente, los regalos a los reservistas fueron publicitados en la prensa local y sirvieron como pretexto para divulgar una concepción muy restringida del patriotismo. Pero hubo quien entendió la solidaridad de otro modo. Fue éste el caso de la minoría republicana en el Ayuntamiento. En la sesión municipal del 28 de julio presentaron una proposición en la que se hacía constar:

1. Que el Ayuntamiento de Salamanca veía con profunda pena la guerra entablada en nombre de España en Marruecos.

2. Que, asimismo, veía con igual pena que fuese sólo la clase proletaria la que engrosara las filas del Ejército combatiente.

3. Que a las familias de los reservistas en campaña, si éstos eran empleados municipales, se les abonase medio sueldo durante el tiempo del conflicto.

4. Que estos acuerdos fuesen comunicados al gobierno.

La discusión estalló tras la lectura del documento porque Florencio Marcos Martín rechazó taxativamente los dos puntos iniciales. El debate fue bastante acalorado durante casi dos horas, pero finalmente resultó victorioso el alcalde. Además, logró que se eliminase del acta final el relato de los incidentes habidos ${ }^{510}$.

En cambio los empleados municipales sí que acordaron ceder un día de su haber mensual, mientras se prolongase la campaña, en beneficio de las familias de los

\footnotetext{
507 “Cortes. Senado", El Salmantino, n140, 18 de noviembre de 1910, p. 2.

508 "Tratado hispano-marroquí, El Salmantino, no 144, 23 de noviembre de 1910, pp. 1-2; "Tratado hispano-marroquí", El Salmantino, no 146, 25 de noviembre de 1910, p. 2.

509 "De Melilla", El Salmantino, no 178, 3 de enero de 1911, p. 3.

${ }^{510}$ Actas de las Sesiones Municipales. Archivo Histórico Municipal, vol. 1909, fol. 103-105 (v). En este documento tan sólo se recoge la "profunda pena" por la situación creada en Melilla, pero se reconoce que las proposiciones primera y segunda no son urgentes; "Ayuntamiento", El Adelanto, n' 7.704, 29 de julio de 1909, p. 1.
} 
reservistas. Y, a modo de réplica, los recaudadores de consumos decidieron también secundar esta iniciativa ${ }^{511}$.

Otro de los gestos caritativos más tempranos fue el del Círculo de Obreros Católicos. Éste acordó eximir a los reservistas del pago de sus cuotas y concederles el socorro íntegro por enfermedad, en caso de resultar heridos. También resolvieron enviar al gobierno un telegrama de queja por la conducta de los catalanes ${ }^{512}$.

Asimismo, las madres de los soldados organizaron, el 6 de agosto, una misa en la catedral con el propósito de rogar para que sus hijos no resultaran heridos en la batalla. La ceremonia fue descrita muy ampliamente en El Adelanto, presentándose como un acto bastante concurrido y muy emotivo ${ }^{513}$. Siguiendo su estela, El Lábaro subrayaba su carácter humilde: "En extremo simpática y popular, con la espontaneidad de lo sincero, de lo sentido, la fiesta organizada por las madres y esposas que tienen seres queridos luchando contra el moro, ha dejado en mi alma una impresión sedante, acariciadora" $^{, 514}$.

Y, de igual modo, El Castellano le dedicó este comentario:

"Ha sido un acto de sencilla piedad, que ha pasado sin ruido y que es, sin embargo, profundamente conmovedor. Nada más propio de unas pobres madres de familia que han visto partir para la campaña a sus hijos, pedazos de su alma, y que se han resignado con su desgracia, porque las cosas de la patria son de aquellas que parecen dispuestas por Dios.

Esas madres, salmantinas al fin, no han gritado, ni se han sublevado; no han apedreado a la policía, ni han tratado de detener los trenes donde embarcaban los soldados (...) han formado una colecta y dispuesto una modestísima función religiosa

\footnotetext{
${ }^{511}$ Actas de las Sesiones Municipales. Archivo Histórico Municipal, vol. 1909, fol. 105 (r)-106 (v). En la sesión del día 2 de agosto quedó constituida una comisión municipal para el socorro de los reservistas e integrada por los concejales Cáceres, Durán y Hernández Sanz. Una semana después, el personal municipal entregó a la misma ese día de haber: Actas de las Sesiones Municipales. Archivo Histórico Municipal, vol. 1909, fol. 110 (r). También en: "Ejemplo que imitar", El Adelanto, no 7.714, 10 de agosto de 1909 , p. 1. Pero la vida de esta comisión sería lánguida, hasta el extremo de que en la sesión correspondiente al día 11 de octubre, el señor Cáceres lamentó "la falta de consignación adecuada para cumplir los acuerdos del Ayuntamiento". Propuso, como remedio, beneficiarse de los auxilios benéficos y del sobrante de lo presupuestado para las ferias: Actas de las Sesiones Municipales. Archivo Histórico Municipal, vol. 1909, fol. 144. Un mes más tarde, el 29 de noviembre, Hernández Sanz llegó a preguntar si aún funcionaba la comisión porque, siendo él uno de los integrantes, desconocía la respuesta. La contestación de Marcos Martín no quedó reflejada en parte alguna: Actas de las Sesiones Municipales. Archivo Histórico Municipal, vol. 1909, fol. 172. La última noticia que poseemos sobre el funcionamiento de la misma data del 20 de diciembre, cuando se procede al reparto de algunos socorros, sin especificarse cantidades: Actas de las Sesiones Municipales. Archivo Histórico Municipal, vol. 1909, fol. $178(\mathrm{r})$.

512 "Juan de Salamanca": "El Círculo de Obreros y los reservistas", El Adelanto, no 7.708, 3 de agosto de 1909, p. 1; "Por los reservistas", El Castellano, no 1.508, 2 de agosto de 1909, p. 2.

513 "Por los reservistas", El Adelanto, no 7.710, 5 de agosto de 1909, p. 2; "Crónica. En la Catedral", El Adelanto, $\mathrm{n}^{\circ} 7.712,7$ de agosto de 1909, p. 1.

514 "Una fiesta patriótica", El Lábaro, no 3.742, 6 de agosto de 1909, p. 2.
} 
para implorar del Santo Cristo de las Batallas (...) que libre a sus hijos de las balas enemigas $"$ "515.

Por otro lado, obedeciendo a los deseos de la Reina Victoria, se constituyó una Junta de Damas en Salamanca, presidida, por doña Juana Primo de Rivera en beneficio de los familiares de fallecidos y heridos en campaña ${ }^{516}$.

Siguiendo el ejemplo de la suscripción abierta por El Adelanto, de la que diariamente se ofrecía un balance ${ }^{517}$, el 13 de agosto de 1909, en el Boletín Oficial de la Diputación, apareció anunciada la apertura de otra suscripción provincial en apoyo de los reservistas ${ }^{518}$.

La decisión arrancaba de una reunión celebrada a principios de ese mes y en la que se acordó:

$1^{\circ}$ Reservar la plaza al escribiente meritorio de la Diputación, don Carlos Mayorga, llamado a filas recientemente para cumplir deberes con la patria y gratificar a su señor padre con 50 pesetas. Además, el señor Mayorga, a su regreso, sería preferido para ocupar la primera vacante de personal que ocurriese en las oficinas.

$2^{\circ}$ Este acuerdo se hacía extensivo para todos los empleados de la Corporación que fueran llamados a la campaña.

$3^{\circ}$ Socorrer a los soldados inutilizados en campaña, hijos de Salamanca, y

$4^{\circ}$ Dar auxilios (que oportunamente se fijarían) a los hijos de la provincia inutilizados en campaña, a las familias de los allí sucumbidos y recompensas a aquéllos que lo mereciesen por actos heroicos realizados en defensa de la patria ${ }^{519}$.

La junta que había de gestionar la recaudación quedó integrada por el gobernador civil, el presidente de la Diputación, el gobernador militar, los obispos de

\footnotetext{
515 "Por sus hijos", El Castellano, no ${ }^{\circ} 1.512,6$ de agosto de 1909, p. 2.

516 "Para los muertos y heridos en campaña", El Adelanto, no 7.722, 19 de agosto de 1909, p.1; "Socorro a los reservistas", El Adelanto, n' 7.726, 24 de agosto de 1909, p. 1; "Para la campaña. Junta de señoras", El Adelanto, $\mathrm{n}^{\circ}$ 7.728, 26 de agosto de 1909, p. 1; "Para las familias de los heridos y muertos en combate", El Lábaro, no 3.757, 24 de agosto de 1909, p. 2.

${ }^{517}$ Por ejemplo, el día 30 de julio, ya se habían recaudado 1.500 pesetas y un redactor de El Adelanto comentaba: "Salamanca va respondiendo, como era de esperar en esta tierra hidalga, y nuestra iniciativa, que es nuestra por derecho de prioridad, pero de todos por los afectos patrióticos que está poniendo a flor de piel, servirá para que haya pan en todos los hogares de los soldados". Véase: "Suscripción para las familias de los reservistas. Juicios de la prensa", El Adelanto, n 7.705, 30 de julio de 1909, p. 1.

${ }^{518}$ Boletín Oficial Extraordinario de la provincia de Salamanca, 13 de agosto de 1909. Se aclara que la Diputación inicia la suscripción con 1.000 pesetas. Además, el gobernador civil deposita otras 285 pesetas y el personal de oficinas, 115 pesetas.

${ }_{519}$ Actas de la Diputación de Salamanca. Archivo de la Diputación provincial, vol. 1907-1912, fol. 40-42 (v). "La Diputación y los reservistas", El Adelanto, no 7.797, 2 de agosto de 1909, p. 2; "A favor de los reservistas", El Lábaro, no 3.738, 2 de agosto de 1909, p. 2; "Salamanca", El Salmantino, no 96, 14 de agosto de 1909 , p. 3.
} 
Salamanca y Ciudad Rodrigo y el vicepresidente de la Comisión provincial de la Diputación. Nada más iniciarse, y gracias a las autoridades mencionadas, ya acumulaba 1.400 pesetas $^{520}$. Pero el balance final de su recaudación no se haría público hasta finales de $1910^{521}$.

Evidentemente, volviendo a El Adelanto, éste explotó al máximo su suscripción para promocionarse. Enorme satisfacción le produjo que, intentando sumarse a su esfuerzo, la asociación artística del $1^{\circ}$ de Mayo decidiera organizar una velada benéfica, el 7 de agosto, para contribuir a la misma ${ }^{522}$.

Por otro lado, algunos días después, se anunció una celebración similar, una función teatral en el Bretón, a cargo de la Sociedad Los Bohemios ${ }^{523}$. Quien más se extendió en la descripción de este acto fue El Castellano. Se trató de una celebración multitudinaria, si bien el espectáculo acabó resultando excesivamente $\operatorname{largo}{ }^{524}$.

A mediados de agosto, el diario liberal agradecía la colaboración de todos los suscriptores, aunque no faltaba un apunte crítico final:

"Aun contando, como contábamos con la caridad inagotable del pueblo salmantino, no pudimos esperar al iniciar nuestra suscripción en favor de los soldados de esta ciudad que en Melilla pelean por el honor nacional, que el éxito fuera tan grandioso y que la iniciativa de El Adelanto, secundada admirablemente por Salamanca entera, asegurara pan a las familias todas de quienes, con las armas en la mano, cumplen altos deberes de patriotismo (...) Lo que falta en nuestra suscripción, hasta ahora, es el óbolo pequeño, pero valiosísimo del pobre, que al unirse a las cantidades de importancia donadas por los ricos, fusione en un sólo amor y en un anhelo sólo, las aspiraciones y cariños de este pueblo (...) La suscripción de El Adelanto tiene el carácter de patriótica, y todos caben en tan hermosa calificación; el rico con sus billetes y el pobre con sus perrillas.

Lo que hace falta es que todos tengamos el orgullo de decir, en un mañana próximo y venturoso, que las lágrimas que la ausencia de los soldados salmantinos hizo derramar, fueron endulzadas por la caridad y el esfuerzo de Salamanca entera ",525.

\footnotetext{
520 "Para los reservistas", El Adelanto, no 7.719, 16 de agosto de 1909, p.1.

${ }^{521}$ Boletín Oficial de la provincia de Salamanca, $\mathrm{n}^{\circ} 173,11$ de diciembre de 1910, p. 4 (en el Apéndice). Hasta la llegada de las Navidades de 1909 se pudieron recaudar 4.356 pesetas. Sin embargo, cuando se publicó esta cifra, un año más tarde, se le sumó lo recaudado en 1910. Por eso, el monto final ascendió a 6.166 pesetas. De esta cantidad también informó en su momento el diario de Núñez Izquierdo: “A los reservistas de la provincia. Acuerdos importantes", El Adelanto, no 8.123, 14 de diciembre de 1910, p. 1. Con esta extraña argucia contable, creemos que la Diputación pretendía demostrar que su iniciativa había sido tan exitosa como la suscripción emprendida por El Adelanto. Pero no fue el caso. A los dos días, también en el Boletín se publicó, por cierto, un balance sobre las bajas ocasionadas por la campaña: Boletín Oficial de la provincia de Salamanca, $\mathrm{n}^{\circ}$ 174, 13 de diciembre de 1910, pp. 5-6 (también en el Apéndice).

522 "Suscripción”, El Adelanto, no 7.708, 3 de agosto de 1909, p. 1.

523 "Sociedad 'Bohemios'. A favor de los reservistas", El Adelanto, no 7.715, 11 de agosto de 1909, p. 2; "Sociedad 'Bohemios'. Para las víctimas de la campaña", El Adelanto, no 7.731, 30 de agosto de 1909, p. 2; "Salamanca", El Salmantino, no 96, 14 de agosto de 1909, p. 3; "Para los damnificados de la Guerra de Melilla", El Lábaro, no 3.761, 28 de agosto de 1909, p. 2.

${ }^{524}$ Pepe Luis: "Por la patria", El Castellano, no 1.573, 30 de agosto de 1909, p. 2.

525 "Nuestra suscripción y los pobres", El Adelanto, no 7.716, 12 de agosto de 1909, p. 1.
} 
Coincidiendo con la publicación de esta nota de agradecimiento, la Comisión Ejecutiva de la suscripción acordó gratificar con 125 pesetas a la madre del soldado Santiago Álvarez Santos ${ }^{526}$. Se trataba del único reservista, perteneciente al cupo de 1904, cuyo fallecimiento en la batalla del Barranco del Lobo se pudo confirmar ${ }^{527}$. Con mucho alivio, eso sí, se recibió la noticia de otros siete salmantinos se hallaban hospitalizados en Málaga ${ }^{528}$. Poco después, "Sir-ve" relataba la historia de uno de estos heridos, Juan Martín Salvador ${ }^{529}$.

Sin embargo, a la redacción del periódico liberal no se le escapaba el hecho de que era absolutamente imprescindible mantener la tensión guerrera para sostener la suscripción. Así lo reconocía "Juan de Salamanca”, inmediatamente después de la alocución del general Marina a sus tropas, cuando ya se habían recaudado más de 7.000 pesetas:

"Yo no sé si será esto un defecto o una cierta virtud, pero es lo cierto que todo el entusiasmo y los ardimientos que las noticias de la guerra despertaban hace unos días, han desaparecido desde que hemos dejado de tener noticias de importantes encuentros (...) La alocución del general Marina a las tropas españolas, parece que ha llegado a los oídos salmantinos, y que todos sienten tan intensamente como los soldados el entusiasmo bélico (...) Salamanca ha respondido a nuestro llamamiento, pero es necesario pensar que comienzan nuevamente las operaciones y que nuevamente se derramarán abundantes lágrimas en los hogares de los pobres.

Nuevamente se impone a todos los patriotas la obligación de acudir en auxilio de los necesitados ${ }^{, 530}$.

De hecho, alguno de los redactores sugirió que la suscripción se debía mantener abierta hasta la terminación de los Juegos Florales ${ }^{531}$.

Con la misma pretensión, la de mantener vivo el espíritu belicoso, El Adelanto publicó la carta de un voluntario salmantino, Paulino Tejera, preocupado por la escasa participación de los pueblos en la suscripción y por la desprotección hacia los huérfanos

\footnotetext{
526 "El primer socorro", El Adelanto, no 7.717, 13 de agosto de 1909, p. 1.

527 "Salmantino muerto en campaña”, El Adelanto, no 7.716, 12 de agosto de 1909, p. 1. Más adelante, a principios de octubre, El Lábaro confirmaría el fallecimiento de otro soldado, procedente de Macotera, en la jornada del 27 de julio: "Soldado salmantino muerto en la guerra", El Lábaro, n' 3.789, 2 de octubre de 1909 , p. 1.

528 "Heridos salmantinos", El Adelanto, no 7.717, 13 de agosto de 1909, p. 1; "Soldados salmantinos heridos", El Lábaro, no 3.746, 11 de agosto de 1909, p. 3.

529 "Un herido en Melilla", El Adelanto, no 7.731, 30 de agosto de 1909, p. 1. Aunque el periódico salmantino que más se vuelca con los relatos de los heridos fue El Lábaro: "Hablando con un herido. Interesante conversación", El Lábaro, no 3.791, 5 de octubre de 1909, p. 1; "Heridos salmantinos", El Lábaro, no 3.797, 12 de octubre de 1909, p. 2; "De la guerra", El Lábaro, no 3.798, 13 de octubre de 1909 , p. 2.

530 “Juan de Salamanca”: “Vida local. La suscripción”, El Adelanto, no 7.720, 17 de agosto de 1909, p. 1.

531 “Los juegos florales y el viaje regio", El Adelanto, no 7.722, 19 de agosto de 1909, p. 1.
} 
de la guerra ${ }^{532}$. Otros soldados, en cambio, lamentaban que la suscripción únicamente se destinase a los reservistas y no al resto de combatientes ${ }^{533}$. En todo caso, la idea que primaba, la más fomentada desde la prensa local, era la del agradecimiento que sentían los luchadores para con sus conciudadanos ${ }^{534}$.

El Castellano, por su parte, también recogió la protesta de tres soldados salmantinos de Ceriñola que no habían resultado beneficiados con la colecta ${ }^{535}$.

El Lábaro elogió la atención con la que Alfonso XIII seguía el desarrollo de los acontecimientos melillenses y su preocupación por el bienestar de los combatientes. Sin duda, pretendía explotar el valor ejemplarizante de su figura ${ }^{536}$. Pero, ante todo, destacó la labor caritativa de la Iglesia. Por esta razón, el 2 de septiembre de 1909, Fray Francisco Javier, obispo de Salamanca, se dirigió a los lectores y, a la vez que presentaba el conflicto melillense como una guerra de religión, hizo un llamamiento a los párrocos de la provincia para que socorrieran económicamente a los soldados ${ }^{537}$.

El objetivo final consistía en dividir, a partes iguales, el producto recaudado entre la suscripción nacional iniciada por la reina y la emprendida por El Adelanto. El mismo escrito, aunque con mayor extensión, se recogía en el Boletín del Obispado correspondiente. Y además se reproducía aquí, en fecha tan temprana como el 24 de julio, una Circular en la que se ordenaba que, en todas las misas de la provincia, se dijese una oración pro tempore belli ${ }^{538}$.

El Lábaro, por último, fue el único periódico local que reseñó las palabras de recuerdo hacia los combatientes con motivo de la celebración de la fiesta del Rosario en la iglesia de San Esteban ${ }^{539}$.

La oleada de caridad pervivió, de hecho, hasta bastante después de finalizados los grandes movimientos de avance. Así, en octubre de 1909, la Junta de Damas y el Casino deseaban organizar una kermesse; y los salesianos pensaban colaborar con ellas en la celebración de una función teatral ${ }^{540}$. Quizás, sospechamos, porque la batalla de El

\footnotetext{
532 “Carta de un salmantino”, El Adelanto, no 7.725, 23 de agosto de 1909, p. 1.

533 "Los soldados salmantinos en Melilla", El Adelanto, no 7.748, 18 de septiembre de 1909, p. 1.

534 "Los soldados salmantinos en Melilla. Una carta", El Adelanto, no 7.758, 30 de septiembre de 1909, p. 1.

535 "Una carta desde Melilla", El Castellano, no 1.657, 6 de diciembre de 1909, p. 2.

536 "El Rey y la campaña”, El Lábaro, no 3.753, 19 de agosto de 1909, p. 2.

${ }^{537}$ Fray Francisco Javier: "La Iglesia y la campaña”, El Lábaro, no 3.765, 2 de septiembre de 1909, p. 1.

${ }^{538}$ Boletín Oficial del Obispado de Salamanca, 1 de septiembre de 1909, no 9.

539 "La fiesta del Rosario", El Lábaro, no 3.791, 5 de octubre de 1909, p. 1.

540 "Para los soldados heridos. La fiesta de la Junta de Damas", El Adelanto, no 7.759, 1 de octubre de 1909, p. 1; "Para las víctimas", El Lábaro, n 3.789, 2 de octubre de 1909, p. 1; "La kermesse del casino", El Lábaro, no 3.791, 5 de octubre de 1909, p. 1; "La Junta de Damas”, El Lábaro, no 3.803, 19 de octubre
} 
Jemis tuvo un efecto demoledor entre los salmantinos. "Juan de Salamanca" intentaba, consecuentemente, evitar el amilanamiento de los lectores:

"Se nos dijo, y así lo creía la mayoría, que tomado el Gurugú, se podía dar por terminada la guerra (...) Los Ejércitos españoles llegan a Zeluán, y... nada. Los Ejércitos españoles llegan a Nador, y... nada. Los Ejércitos españoles llegan al Gurugú... y nada.

¿Era posible que a esto se redujera la guerra?

¿Los moros, que tan valientemente habían peleado algunos días, se habían hecho tan cobardes de repente, que huían ante la proximidad de nuestras tropas? (...) No debemos amilanarnos (...) Lo que debemos hacer, lo que en justicia se debe pedir a todos, es un pequeño esfuerzo para hacer algo en favor de los soldados.

En el número de ayer de El Adelanto se hablaba de los preparativos para el festival de la caridad que se celebrará en el Casino de Salamanca.

Deber de todos los salmantinos es, procurar que de ese festival resulten los mayores beneficios para los soldados.

Por fortuna, para nosotros, Salamanca, por su situación geográfica, se ve ahora libre de las consecuencias de la guerra, en una gran parte, pero esto no debe ser razón para que permanezcamos indiferentes ${ }^{, 541}$.

Más allá, la razón de fondo de ese abatimiento residía en un alarmante rumor: el más que probable traslado del regimiento de Cazadores de Albuera al Rif. En el supuesto de que se confirmara lo que corría de boca en boca, Salamanca se quedaría sin guarnición de ninguna clase ${ }^{542}$. Pero, por el momento, nada de esto sucedió.

Este murmullo, el del desguarnecimiento de Salamanca, rebrotó de nuevo a finales de febrero de 1910. Debido a las pésimas condiciones en que se hallaban alojadas en el Trilingüe, se comentó entonces que las fuerzas serían trasladadas a Medina del Campo, pero desde la Capitanía General se desmintió esta información ${ }^{543}$. De todos modos, la noticia no debió hallar mucho crédito entre las autoridades salmantinas, ya que un grupo de comisionados se dirigió hasta Madrid para solicitar explicaciones del mismo general Aznar, el ministro de Guerra. De nuevo, el traslado fue

de 1909, p. 2; "La Junta de Damas", El Lábaro, no 3.804, 20 de octubre de 1909, p. 1; "La Junta de Damas", El Lábaro, no 3.805, 21 de octubre de 1909, p. 2; "La Junta de Damas", El Lábaro, no 3.806, 22 de octubre de 1909, p. 1; "La Junta de Damas", El Lábaro, no 3.807, 23 de octubre de 1909, p. 2; "La Junta de Damas", El Lábaro, no 3.808, 25 de octubre de 1909, p. 1; Melchor García Sánchez: “Composición patriótica”, El Lábaro, no 3.809, 26 de octubre de 1909, p. 2. El Lábaro fue el periódico que de manera más regular informó sobre los donativos para la preparación de la kermesse.

541 "Juan de Salamanca": "Vida local. La kermesse", El Adelanto, no 7.763, 6 de octubre de 1909, p. 1.

542 “Sin guarnición?”, El Adelanto, no 7.765, 8 de octubre de 1909, p. 1; “Se va el regimiento?”, El Lábaro, no $3.795,9$ de octubre de 1909, p. 1.

543 "Sobre los rumores de la marcha del regimiento", El Adelanto, no 7.885, 28 de febrero de 1910, p. 1; ¿Traslado del regimiento de Albuera?", El Lábaro, no 3.905, 22 de febrero de 1910, p. 2; “La guarnición y el concejo", El Lábaro, no 3.906, 23 de febrero de 1910, p. 1. El Lábaro lanzó la idea de que debía procurarse el rápido acondicionamiento del Trilingüe para evitar el traslado. Además, se dolió porque consideraba que a los salmantinos no les inquietaba en exceso este asunto: "Se va el regimiento", $E l$ Lábaro, $\mathrm{n}^{\mathrm{0}} 3.909,26$ de febrero de 1910, p. 1; "Sobre los rumores de la marcha del regimiento", El Lábaro, $\mathrm{n}^{\circ} 3.910,28$ de febrero de 1910, p. 2. 
presentado como un bulo ${ }^{544}$. Aún así, en una sesión municipal a finales de mayo de 1910, los concejales Iscar Peyra y La Rúa propusieron la cesión del edificio de la Merced al ramo de Guerra con objeto de garantizar la estancia de las tropas en Salamanca $^{545}$. Su iniciativa resultó infructuosa y, por ello, el miedo al traslado de la guarnición permanecería como una amenaza latente, pendiente de remedio ${ }^{546}$.

Por otro lado, la kermesse, finalmente, se celebró, con muy notable éxito de asistencia, en la noche del 24 de octubre. Se pudieron recaudar casi 1.350 pesetas $^{547}$. En vista del triunfo logrado, a los pocos días, el 28 del mismo mes y, de nuevo, el 31 de octubre, se celebraron nuevamente en el Casino dos tómbolas. Como fruto, recaudaron 2.615 pesetas que se destinaron a engrosar la suscripción popular ${ }^{548}$.

En cuanto al festival teatral, celebrado en el Liceo, el 5 de noviembre, no parece que fuese una celebración concurrida. Al contrario, fue un acto elitista, si bien El Lábaro lo describió como muy agradable ${ }^{549}$.

Animado por todas estas iniciativas, el periódico católico sugirió, aprovechando la proximidad de las Navidades, la apertura de una nueva suscripción ${ }^{550}$. Si bien, durante algunos días el periódico dio cuenta del progreso de la misma ${ }^{551}$, la colecta perdió su razón de ser al anunciarse el regreso de los soldados. Tan sólo se habían acumulado 64 pesetas - porque las suscripciones pierden fuerza si no van acompañadas

\footnotetext{
${ }^{544}$ Alfredo Rivera: “Conferencias telegráficas”, El Adelanto, no 7.887, 2 de marzo de 1910, p. 3.

545 Actas de las Sesiones Municipales. Archivo Histórico Municipal, vol. 1910, fol. 91 (r); “Ayuntamiento", El Adelanto, n 7.963, 31 de mayo de 1910, p. 1; "La guarnición y el Ayuntamiento", n' 7.965, 2 de junio de 1910, p. 1.

${ }^{546}$ Actas de las Sesiones Municipales. Archivo Histórico Municipal, vol. 1910, fol. 96 (r)-97; También puede consultarse sobre la sesión del 6 de junio: “Ayuntamiento", El Adelanto, no 7.969, 7 de junio de 1910, p. 1. El rechazo de la proposición fue impugnado por De la Rúa en la sesión del 28 de julio de 1910: Actas de las Sesiones Municipales. Archivo Histórico Municipal, vol. 1910, fol. 125. Un par de meses después, el 5 de septiembre, desde el Consistorio y como remedio ante la amenaza de desguarnecimiento se efectuó un primer ofrecimiento de terrenos al ministerio de Guerra: Actas de las Sesiones Municipales. Archivo Histórico Municipal, vol. 1910, fol. 143 (r).

${ }^{547}$ F. de Santa Cruz: "La kermesse del Casino. Para las víctimas de la campaña. Musas de la caridad", El Adelanto, $\mathrm{n}^{\mathrm{0}} 7.779,25$ de octubre de 1909, $\mathrm{n}^{\circ} 7.779$, p. 1.

548 "Nota del día", El Adelanto, no 7.782, 28 de octubre de 1909, p. 1; "La tómbola", El Adelanto, n' 7.783, 29 de octubre de 1909, p. 1; "La Junta de Damas", El Lábaro, no 3.821, 10 de noviembre de 1909, p. 2.

549 “Sociedad El Teatro", El Lábaro, no 3.818, 6 de noviembre de 1909, p. 2.

550 "La Nochebuena en la guerra", El Lábaro, no 3.821, 10 de noviembre de 1909, p. 2; "La Nochebuena en la guerra", El Lábaro, no 3.822, 11 de noviembre de 1909, p. 2.

551 "La Nochebuena en la guerra", El Lábaro, no 3.823, 12 de noviembre de 1909, p. 2; "La Nochebuena en la guerra", El Lábaro, no 3.824, 13 de noviembre de 1909, p. 2; "La Nochebuena en la guerra", El Lábaro, no 3.825, 15 de noviembre de 1909, p. 2; "La Nochebuena en la guerra", El Lábaro, no 3.826, 16 de noviembre de 1909, p. 1; "La Nochebuena en la guerra", El Lábaro, no 3.834, 25 de noviembre de 1909, p. 2; "La Nochebuena del soldado", El Lábaro, n 3.837, 29 de noviembre de 1909, p. 1.
} 
de una enorme tensión belicista- y se decidió entregarlas a dos soldados huérfanos, que atravesaban una situación de enorme penuria económica ${ }^{552}$.

También, ya a finales de febrero de 1910, la Junta de Damas procedió al reparto del dinero que se le había asignado desde la Junta Central de Madrid, una vez concluida su suscripción nacional: 3000 pesetas que fueron divididas en tres partes iguales para los familiares de los tres fallecidos residentes en la capital: Carlos Mayorga, Francisco Hernández y Santiago Álvarez Santos ${ }^{553}$.

En efecto, con mucha tristeza se recibió la noticia del fallecimiento de Carlos Mayorga, aquel empleado de la Diputación al que ya aludimos y que había peleado en el regimiento de León ${ }^{554}$.

En el apartado de iniciativas anecdóticas, cabe citarse una tardía colecta de pañuelos $^{555}$.

A principios de diciembre, finalmente se anunciaba, como señalamos páginas atrás, el inminente regreso de los reservistas salmantinos:

"En estos días van a regresar a sus hogares, después de haber cumplido con exceso los deberes que impone al más acrisolado patriotismo, los reservistas salmantinos que abandonaron sus familias en momentos críticos y luctuosos para defender la bandera española, escarnecida en los barrancos rifeños por los bárbaros africanos.

En aquellos momentos en que España era presa de una epilepsia que parecía el comienzo del suicidio de una nación; cuando entre el humo de los conventos quemados y el fragor de la batalla reñida entre hermanos, parecía muerto el sentimiento de patria; mientras en otras regiones desertaban los reservistas poco menos que en masa o montaban en los trenes con la resignación de los impotentes, pero no con el entusiasmo de los convencidos, es de justicia proclamar que en Salamanca no hubo ni un sólo desertor, y que en las despedidas de los reservistas paisanos nuestros, lució un patriotismo y un entusiasmo de que no pueden vanagloriarse otras capitales.

Pobres y ricos ofrendaron su vida por la patria, y la generosa sangre castellana vertióse en el Rif para hacer más grande a España y para cimentar un civilización que nos glorifique.

\footnotetext{
552 "Nuestro aguinaldo para los soldados", El Lábaro, no 3.860, 28 de diciembre de 1909, p. 1. Sus nombres eran Cándido Muñoz Morales y Mariano Hernández Gil.

553 "Para las víctimas de la guerra”, El Lábaro, no 3.904, 21 de febrero de 1910, p. 1. Muchísimo más tarde, en mayo de 1913, la Junta de Damas procedió a una nueva distribución de ayudas, con un valor total de 8.000 pesetas, entre los familiares de fallecidos en la campaña de 1909: "Para las víctimas de Melilla. Reparto de socorros", El Adelanto, no 8.869, 14 de mayo de 1913, p. 1.

554 "Muerte de un salmantino", El Adelanto, no 7.775, 20 de octubre de 1909, p. 1. "Un Repórter" lamentó mucho el fallecimiento de quien había sido su ami go y compañero. Además, se dolía porque Mayorga no merecía demasiada consideración en Salamanca, pero en Madrid se planeaba levantarle un monumento junto a otros dos combatientes heroicos del regimiento de León. Véase "Un Repórter": "Notas de un periodista. Los héroes de la guerra. Un monumento a Carlos Mayorga", El Adelanto, no 7.844, 11 de enero de 1910, p. 1. De todos modos, en la sesión municipal del 13 de enero, y a propuesta del concejal Cuesta, se acordó poner a una calle salmantina el nombre de Carlos Mayorga: Actas de las Sesiones Municipales. Archivo Histórico Municipal, vol. 191o, fol. 19 (v).

555 "Idea hermosa", El Adelanto, no 7.766, 9 de octubre de 1909, p. 1; "Para los soldados. Hermoso proceder", El Adelanto, n 7.783, 29 de octubre de 1909, p. 1; "Para los soldados. Donativo entregado", El Adelanto, $\mathrm{n}^{\circ} 7.839,5$ de enero de 1910, p. 1.
} 
Los reservistas salmantinos, como los soldados todos de esta tierra hidalga, han cumplido como buenos durante la campaña, y ahora vuelven los que vuelven, pues algunos infortunados han muerto en Melilla, con la satisfacción del deber cumplido y del heroísmo demostrado.

Nada más puede exigírseles.

Pero Salamanca, que ha hecho por ellos cuanto ha podido, mientras han estado en filas; que ha subvenido generosamente a las necesidades de sus familias, por medio de la suscripción iniciada por El Adelanto y a la que acudió con esplendidez, que es su mejor galardón; que sufrió con sus penas y gozó con sus alegrías, y que fue, en suma, madre amante de su bizarros hijos, no ha terminado todavía sus deberes.

Vuelven ellos y debe pública y solemnemente honrar su valor y patriotismo y ceñirles el galardón que a tanta cosa han ganado",556.

La idea que, seguidamente, lanzaban consistía en hacer efectivo el reparto de donativos el día 23 de diciembre, como agasajo ${ }^{557}$. Por su parte, El Lábaro refirió brevemente el acto de bienvenida en la estación, señalando que habían retornado unos treinta salmantinos, todos pertenecientes al batallón de las Navas. La recepción había sido muy emotiva y los soldados habían recibido tabaco y licores ${ }^{558}$.

La Comisión gestora de la suscripción popular contaba en su haber, después de varios repartos entre los familiares, con unas 3.800 pesetas. Lógicamente se había recaudado más. Aunque el balance final de su gestión no se hizo público hasta el 26 de enero:

Importe de lo recaudado.... $7.828,15$ pesetas $^{559}$.

Agosto, primera contribución......125

Septiembre, ídem segunda...... 1020

Octubre, ídem tercera.

Noviembre, ídem cuarta 1.590

Diciembre (Melilla), ídem quinta....800

Diciembre, ídem sexta. $3.018,15$

Total. $7.828,15$ pesetas. $^{560}$.

Sea como fuere, ese sobrante, a principios de diciembre, de casi 4.000 pesetas se distribuyó del siguiente modo: 800 pesetas se remitieron a los combatientes

\footnotetext{
556 "Los reservistas salmantinos. Homenaje que es justicia", El Adelanto, $\mathrm{n}^{\circ}$ 7.817, 9 de diciembre de 1909 , p. 1.

${ }^{557}$ Idéntica iniciativa era propuesta en la carta de un tal Abelardo Fernández Redonet: "Remitido. La vuelta de los reservistas", El Adelanto, $\mathrm{n}^{\circ} 7.819,11$ de diciembre de 1909, p. 1.

558 "La vuelta de los reservistas", El Lábaro, no 3.848, 13 de diciembre de 1909, p. 2.

559 "La suscripción iniciada por El Adelanto", El Adelanto, no 7.775, 20 de octubre de 1909, p. 1. La suscripción se había concluido el 16 de octubre de 1909.

560 "La suscripción iniciada por El Adelanto", El Adelanto, no 7.857, 26 de enero de 1910, p. 1. En la misma información se incluía la carta de un salmantino muy agradecido y que escribía desde Zeluán.
} 
salmantinos, reservistas o no, que aún permanecían en Melilla ${ }^{561}$; y lo demás se dividió entre los 55 reservistas de las quintas de 1903, 1904 y 1905 que ya habían regresado y cuyos nombres eran, luego, $\operatorname{copiados}^{562}$.

Un mes más tarde, de El Lábaro surgía una nueva propuesta: la celebración de un homenaje a las tropas, coincidiendo con la entrada de la brigada de Cazadores de Madrid en la capital. La idea fue inmediatamente trasladada al gobernador civil, Queipo de Llano, y al alcalde, Antonio Díez. Ambos se mostraron entusiasmados ante el nuevo proyecto, articulado en torno a una alocución del alcalde y un desfile de la Albuera ${ }^{563}$. Lógicamente, la descripción que efectuó el periódico católico tanto de los preparativos del evento como de su desarrollo fue muy minuciosa. Por primera vez, él tomaba la delantera en un acto patriótico frente al tan activo diario liberal, El Adelanto. He aquí la alocución del alcalde a la ciudadanía:

\begin{abstract}
“iSalmantinos!
El heroico Ejército españoles se ha cubierto una vez más con los laureles inmarcesibles de la victoria.

Regresa triunfante de la ruda campaña del Rif, después de haber escrito con su preciada sangre una página más de nuestra brillante historia.

Justo es que el pueblo salmantino le tribute el homenaje a que se ha hecho acreedor, convirtiendo en fiesta popular el día de mañana, en que aquél hace su triunfal entrada en la Corte.

Colocad colgaduras en las fachadas de vuestras casas y acudid a la recepción y desfile que se efectuarán a las doce, en vuestra Casa del Consistorio y Plaza Mayor, para que podáis exteriorizar vuestros sentimientos de gratitud al grito de ;Viva el Ejército Español! "564.
\end{abstract}

En la misma página, se incluía la descripción del homenaje, un tanto deslucido por el mal tiempo, pero, según el testimonio del diario católico, muy emotivo y merecedor del agradecimiento del general Marina ${ }^{565}$. El Adelanto también comentó que “una vez más, Salamanca, con el hermoso acto que realizó el sábado pasado, ha hecho honor a sus tradiciones de hidalga, de patriótica y de sensata" ${ }^{\text {566 }}$. El Salmantino, como ya se ha apuntado, se sentía indignado al pensar que era el partido liberal quien recogía

561 "De Melilla. La Nochebuena del soldado salmantino", El Adelanto, no 7.831, 27 de diciembre de 1909, p. 2; "Los soldados y El Adelanto", El Adelanto, no 7.852, 20 de enero de 1910, p. 1. Las 800 pesetas se distribuidas entre casi sesenta salmantinos (13,80 pesetas por individuo).

562 "La suscripción iniciada por El Adelanto", El Adelanto, no 7.823, 16 de diciembre de 1909, p. 1.

563 "Homenaje al Ejército en Salamanca", El Lábaro, no 3.879, 21 de enero de 1910, p. 2; La Redacción: "Patria y Ejército", El Lábaro, no 3.880, 22 de enero de 1910, p. 1.

564 "Homenaje de Salamanca al Ejército", El Lábaro, no 3.880, 22 de enero de 1910, p. 2; También reproducida en: "Salamanca y el Ejército, El Adelanto, no 7.854, 22 de enero de 1910, p. 2.

565 "Después del homenaje", El Lábaro, no 3.881, 24 de enero de 1910, p. 2.

566 "Acto patriótico. El homenaje de Salamanca al Ejército español”, El Adelanto, no 7.855, 24 de enero de 1910, p. 2. También sobre el homenaje: F. J. Sánchez Novo: "Notas de un estudiante. Las lágrimas del soldado", El Adelanto, no 7.855, 24 de enero de 1910, p. 1; "Un telegrama del general Marina", El Adelanto, $\mathrm{n}^{\mathrm{o}} 7.856,25$ de enero de 1910, p. 2. 
los laureles de la victoria. Tal vez por esta razón, reseñó la celebración salmantina de modo muy sucinto ${ }^{567}$. En general, como ya se habrá observado, el seguimiento que este semanario hizo de las manifestaciones locales de apoyo hacia los combatientes fue muy pobre. Seguramente, porque ante sus limitaciones de espacio, se decantó por un discurso de enorme carga doctrinal.

A mediados de enero de 1910, el gobernador civil de la provincia, Alfredo Queipo de Llano, transmitió a los alcaldes de la provincia una circular para que empezasen a hacerse efectivo el reparto de lo recaudado por la Diputación provincial entre los heridos y familiares de víctimas de la contienda ${ }^{568}$.

En marzo, se anunciaba el ansiado aterrizaje en la ciudad de los últimos reservistas que aún permanecían en el campo de batalla. Indudablemente, el fervor guerrero ya había pasado:

"Pasaron los momentos de peligro y... pasó la guerra.

Ya es un hecho glorioso, que apenas se recuerda más que para sacar aplausos al final de un brindis.

Los que lucharon contra el moro, contra el hambre y contra las inclemencias, volvieron ayer a Salamanca. Si hubieran vuelto cuando se temía por sus vidas, iqué recibimiento se les hubiera hecho!

Ayer regresaron a Salamanca los reservista del 5 de los regimientos de Arapiles y Barbastro.

En la estación les esperaban sus familias, algunos concejales y algunos estudiantes.

Bajaron y recibieron entre lágrimas y sollozos, los abrazos de las madres y las hermanas. Tocó la música y se organizó una manifestación que, atravesando las Avenidas de Canals y Mirat y la calle de Zamora, llegó al Ayuntamiento. ¿No la vieron ustedes? Una manifestación sencilla, casi pobre, pero cariñosa, intima ${ }^{\text {"\$69. }}{ }^{\circ}$.

Sin duda, aquí estaba contenida una nueva crítica al carácter volátil de la opinión pública salmantina. Sin la guerra y sin un discurso periodístico empachosamente belicista, África no interesaba a los salmantinos

En julio de 1910, a punto de cumplirse el primer aniversario del Desastre en el Barranco del Lobo, "C." (Federico C. Alaguero, uno de los soldados que combatió el 27 de julio) propuso la celebración de otro homenaje destinado, en esta ocasión, a la memoria de los salmantinos fallecidos en campaña ${ }^{570}$. En concreto, apuntaba la

\footnotetext{
567 "Noticias. El desfile de hoy", El Salmantino, no 119, 22 de enero de 1910, p. 3.

568 "Por los reservistas", El Adelanto, no 7.850, 18 de enero de 1910, p. 1.

569 "Sir-ve": "La llegada de los reservistas salmantinos", El Adelanto, no 7.887, 2 de marzo de 1910, pp. 1-2; "Más licenciados salmantinos", El Adelanto, no 7.894, 10 de marzo de 1910, pp. 1-2; "Los reservistas", El Adelanto, no 7.898, 15 de marzo de 1910, p. 1.

${ }^{570}$ La propuesta fue leída y aprobada por el Consistorio en la sesión del 28 de julio: Actas de las Sesiones Municipales. Archivo Histórico Municipal, vol. 1910, fol. 143 (r).
} 
conveniencia de realizar unos funerales en la iglesia castrense y una velada literaria ${ }^{571}$. Evidentemente, la idea encontró el respaldo inmediato de aquellos reservistas que sí habían podido regresar a sus hogares ${ }^{572}$, que se apresuraron a constituir una comisión organizativa del evento ${ }^{573}$.

Semejante iniciativa no tardó en cobrar fuerza y los periódicos se afanaron en llamar a la colaboración ciudadana ${ }^{574}$. Así, a modo de ejemplo ilustrativo, Alfredo P. Rebollo se dirigía de este modo a los lectores de El Adelanto:

"No son los reservistas los que deben consagrar tan justo recuerdo a la inolvidable memoria de los héroes salmantinos. Todos los hijos de esta bendita tierra sin distinción de clases, desde el encopetado aristócrata que cubre su cabeza con el reluciente tubo y guarda sus pies en coquetonas botas de charol brillante, hasta el labrador más humilde que ostenta sus manos encallecidas por el honrado trabajo, tenemos todos el deber moral de tomar parte en ese simpático homenaje ${ }^{, 575}$.

¿Acaso no se percibe cierto tono de reproche? El fervor patriótico ya no era el de hacía un año y, por este motivo, la prensa tenía que recurrir a un estilo directo y agresivo.

La misa de campaña acabó siendo prontamente sustituida por una solemne ceremonia en la Catedral ${ }^{576}$. La Comisión logró, además de la desinteresada colaboración del Obispo de la ciudad, el apoyo económico de la oficialidad de la Albuera, la Cámara de Comercio, la Diputación y el Ayuntamiento; también unos electricistas prometieron montar un gran rótulo luminoso en el balcón central del Consistorio, con centenares de bombillas en rojo y gualda y con el mensaje "A los héroes de Melilla"; finalmente, se fijó el día 8 de agosto como la fecha para la celebración del homenaje ${ }^{577}$. También se acordó enviarle a los salmantinos que aún permanecían en Melilla una corona de plumas ${ }^{578}$.

\footnotetext{
571 “C.”: “Preparando un homenaje. ¿Vale la idea?”, El Adelanto, no 8.006, 20 de julio de 1910, p. 1.

572 "Los reservistas salmantinos. De acuerdo", El Adelanto, no 8.008, 22 de julio de 1910, p. 1.

573 "Los reservistas. Homenaje a los salmantinos muertos en Melilla”, El Adelanto, no 8.008, 22 de julio de 1910, p. 2; "Homenaje a los soldados salmantinos", El Lábaro, no 4.027, 22 de julio de 1910, p. 2. Integraba esa comisión: Antonio Rodríguez, Paulino Hernández y Federico C. Alaguero.

574 "Homenaje a los soldados salmantinos", El Lábaro, no 4.028, 23 de julio de 1910, p. 1.

575 Alfredo P. Rebollo: “Una idea simpática. Justo recuerdo”, El Adelanto, no 8.009, 23 de julio de 1910, p. 1.

${ }^{576}$ En sesión extraordinaria, el 1 de agosto de 1910, el Cabildo catedralicio acordó celebrar, sin remuneración, las solemnes exequias. Consúltese Actas Catedralicias, no 79, años 1902-1918, pp. 286. Al mes siguiente, como nueva demostración solidaria de las autoridades religiosas locales, sabemos que el Obispo de Salamanca es felicitado por el ministro de Guerra, y por conducto de la Capitanía General, por la cesión de terrenos en el cementerio para el enterramiento de soldados salmantinos fallecidos en activo. Véase la Carta escrita desde la Capitanía General de la Séptima Región al Obispo de Salamanca, Archivo Diocesano, Legajo 111-127.

577 "Los reservistas. Preparando el homenaje", El Adelanto, no 8.010, 25 de julio de 1910, pp. 1-2; "Los reservistas. Preparando el homenaje", El Adelanto, n 8.012, 27 de julio de 1910, p. 1; "Homenaje a los
} 
Otra institución que destacó por su colaboración con el acto fue la Universidad de Salamanca. Y a su cabeza, el Rector, Miguel de Unamuno, encantado con la cesión del Paraninfo para la celebración de la velada literaria. Se comprometió, además, a pronunciar un discurso en la misma ${ }^{579}$.

$\mathrm{Al}$ acercarse el día del solemne evento, se intensificaron las noticias sobre los últimos preparativos ${ }^{580}$, y además, "Juan de Salamanca" se empeñó también en calentar la atmósfera patriótica/patriotera:

"Se va a honrar a los salmantinos que murieron defendiendo la Patria, a los que, sin ninguna esperanza de recompensa, vivieron las privaciones de la guerra y recibieron la muerte en el campo de batalla.

Las palabras que bajan a la pluma, caldeadas por el recuerdo de aquellos desgraciados, se detienen antes de llegar al papel, pensando que la idea del homenaje es tan hermosa, que a los que pudieran leer mis cuartillas, les parecería superfluo cuanto yo dijera.

¿Qué menos puede hacerse por los soldados muertos, que rendirles homenaje un dia? ${ }^{, 581}$.

El mismo 8 de agosto, El Lábaro, después de rememorarse los ataques rifeños

del 9 de julio de 1909 y los avances militares subsiguientes, dedicaba estas palabras a los reservistas salmantinos:

"En tan grandioso poema viviente y nacional, tú, ¡Salamanca!, a la par que cuna de sabios, fuiste también madre de ilustres caudillos, de esforzados guerreros (...) Allí, luchando tus hijos con la barbarie y el fanatismo, sucumbieron al mortífero plomo (...) Nada más justo que hoy, traspasando los umbrales de la tumba, evoques su recuerdo y te pongas al habla con ellos, mediante una oración que envuelta entre espirales de incienso de tu hermosa Catedral, sea un tributo de gratitud a su heroísmo ",582.

reservistas", El Salmantino, no 48, 30 de julio de 1910, p. 2; "El homenaje a los reservistas", El Lábaro, $\mathrm{n}^{\mathrm{o}} 4.033,30$ de julio de 1910, p. 1 .

578 "Por los reservistas. Preparando el homenaje", El Adelanto, no 8.016, 1 de agosto de 1910, p. 1; "El homenaje a los reservistas", El Salmantino, no 49, 1 de agosto de 1910, p. 2; "El homenaje a los reservistas", El Lábaro, n 4.034, 1 de agosto de 1910, p. 1; "El homenaje a los reservistas", El Lábaro, no 4.037, 4 de agosto de 1910, p. 1.

579 "Los reservistas. Preparando el homenaje", El Adelanto, no 8.015, 30 de julio de 1910, p. 1.

580 "Por los reservistas. Preparando el homenaje", El Adelanto, no 8.019, 4 de agosto de 1910, p. 1; "Por los reservistas. Preparando el homenaje", El Adelanto, no 8.020, 5 de agosto de 1910, p. 1; "El homenaje a los reservistas", El Salmantino, n ${ }^{\circ}$ 53, 5 de agosto de 1910, p. 2; "El homenaje a los reservistas", El Lábaro, $\mathrm{n}^{\circ} 4.038,5$ de agosto de 1910, p. 2. He aquí un fragmento de la alocución que los reservistas dirigen a los ciudadanos: "Un sentimiento de sincero patriotismo, nacido al través de lamentables circunstancias, en las que dieron gallarda prueba de abnegación y heroísmo varios de nuestros paisanos que, luchando como buenos, sucumbieron valientemente en aras de la Patria, coronando con sus acciones el abolengo de nuestra raza, surgió en nosotros el pensamiento de realizar un acto grande, culto, digno (...) invitamos al pueblo de Salamanca a que nos honre y contribuya con su presencia a la mayor solemnidad de las exequias, y al comercio en general le rogamos que, en señal de duelo por tan triste aniversario, se digne no abrir sus puertas"; "Por los reservistas. Preparando el homenaje", El Adelanto, $\mathrm{n}^{\circ}$ 8.021, 6 de agosto de 1910, p. 1; "El regimiento de Toledo, número 35", El Adelanto, ${ }^{\circ}$ $8.022,8$ de agosto de 1910 , p. 1 .

581 "Juan de Salamanca": "Vida local. El homenaje a los soldados", El Adelanto, no 8.017, 2 de agosto de 1910, p. 1.

${ }^{582}$ G. Pérez Vázquez: "Los patriotas salmantinos", El Lábaro, no 4.040, 8 de agosto de 1910, p. 1. 
El Salmantino, excepcionalmente, también ocupaba gran parte de su ejemplar con la reseña del emotivo acto:

"Desde las primeras horas de la mañana notábase un movimiento desacostumbrado, siendo muchos los reservistas que se veían con sus uniformes (...) En la Catedral vimos al Excelentísimo e Ilustrísimo señor Obispo, al señor Gobernador Civil, Presidente de la Audiencia, Diputación Provincial, al Excelentísimo Ayuntamiento, al Coronel de la Zona y al de la Guardia civil, numerosas comisiones tanto civiles como militares, regimiento de Albuera, representación del regimiento de Toledo, guardia civil y numerosísima concurrencia.

Después de celebrado el santo Sacrificio de la Misa, el ilustrado canónigo, señor Cajal, pronunció elocuentemente oración fúnebre ensalzando las glorias de nuestro Ejército, que peleó en defensa de su patria y de su fe, ${ }^{, 583}$.

Tanto el diario de Núñez Izquierdo como el de Domínguez Berrueta, El Lábaro, dedicaban, el 9 de agosto, más de una plana al relato del homenaje. Desde el primero se comentaba: "Ha superado la realidad a los cálculos que sobre el resultado del grandioso homenaje, iniciado desde las columnas de El Adelanto, se hacían" ${ }^{584}$. Se efectuaba, seguidamente, un repaso de las autoridades y público asistente al evento para concluir reseñándose los discursos pronunciados en el Paraninfo de la Universidad. Entre ellos sobresalía, por su ensalzado tono patriótico, el del Rector:

"Hoy, en España, una de las más grandes necesidades, es continuar haciendo patria (...) depende la necesidad de nuestra acción en África, acción tan importante, que en ella se juega nuestra apariencia nacional. Si no nos hubiéramos introducido en esa parte de África, se hubieran introducido otros, que nos rodearían por todas partes y nos siguen oprimiendo. No se trata de los pobres rifeños hermanos nuestros. Se trata de llevar la civilización a todas partes, lo cual es una necesidad. Es cómodo censurar que se lleve la civilización a cañonazos, pero no hay otros medios, y lo doloroso es que haya espiritus mezquinos que creyeran que se trataba de unas minas".

También El Lábaro ofreció a sus lectores un relato extremadamente pormenorizado del desarrollo de la velada literaria y, por descontado, ovacionó las palabras de Miguel de Unamuno. Así terminaba su discurso:

"Tenemos la misión de cumplir cada uno nuestros deberes con la patria, y si ellos muriendo en la batalla cumplen de una vez, nosotros los vamos cumpliendo poco a a poco, día a día que hay muchas maneras de hacerlo.

Se trata del porvenir y de la verdadera independencia de España ${ }^{\text {,585. }}$

En suma: el evento fue presentado como un gran éxito y todavía, algunos días después, "Juan de Salamanca" rememoraba las escenas emotivas vividas en aquella jornada $^{586}$. Sin embargo, el homenaje concluyó con una nota adversa:

\footnotetext{
583 "Por los reservistas salmantinos", El Salmantino, no 55, 8 de agosto de 1910, pp. 1-2.

584 "Homenaje a los reservistas salmantinos muertos en Melilla", El Adelanto, no 8.023, 9 de agosto de 1910, pp. 2-3.

585 “La velada de ayer en la Universidad”, El Lábaro, n 4.041, 9 de agosto de 1910, pp. 1-2.
} 


\begin{abstract}
"Ocurrieron, al terminarse ayer las honras fúnebres en la Catedral y cuando los reservistas se disolvieron en la Plaza Mayor, varios incidentes desagradables, que no tuvieron extremada gravedad gracias a la prudencia de que dieron muestra los comerciantes que en ellos intervinieron como víctimas.

Centenares de chiquillos mal educados se empeñaron en que cerraran sus comercios los señores Peláez y Gay, que los habían abierto después de terminado el homenaje, y lograron su propósito gracias a la prudencia de ambos comerciantes y a la desacertada injerencia de la autoridad en un asunto en el que, de tomar alguna medida, no debió ser la que mereció generales censuras.

Afortunadamente, todo quedó en voces, y más vale asi'”.
\end{abstract}

Seguramente nos hallamos ante un gesto de rechazo hacia un patriotismo burgués, superficial, incapaz de sentir los daños generados por la guerra ${ }^{587}$.

El discurso de Miguel de Unamuno, tal vez, sorprenda porque nada tenía que ver con ese anticolonialismo del que hizo gala durante la Guerra de Cuba. Atendiendo a sus palabras, ni se opuso al conflicto marroquí ni tampoco al fusilamiento de Ferrer y Guardia. En su lugar, Unamuno temió un cerco francés, creyó en la misión civilizadora del Ejército español, justificó las operaciones militares y desechó la importancia de posibles intereses mineros en Beni-bu-Ifrur. Eso sí, guardó absoluto silencio sobre los tratados internacionales y defendemos que su visión de los rifeños siempre fue benévola, distante de las reiteradas y tópicas alusiones a su fanatismo y salvajismo. De hecho, simultáneamente a los hechos bélicos había escrito "Salutación a los rifeños", un poemilla en el que se censuraba el exceso de codicia de los europeos. Si bien es cierto que no lo publicó ${ }^{588}$.

Sabemos además que, estando de reposo en Bilbao, en julio de 1909, cuando el general Pintos y sus hombres caen en la celada del Barranco del Lobo, el Rector le escribió a su amigo Federico de Onís y claramente aprobó la guerra, aunque nada dijo sobre la represión en Barcelona: “ $Y$, fuera de esto, nada más que los comentarios a que da la guerra. Yo soy de la minoría, es decir, que me parece muy bien la guerra y convenientísima para España en todos sentidos, y sobre todo en el espiritual. Espero que esto acabe por levantarnos algo el abatido espíritu" ${ }^{\text {"59 }}$.

Insistía en la misma idea cuando publicó "Ambiente de guerra" en La Nación de Buenos Aires: “Empiezo por deciros que a mí me parece muy bien la guerra. Sin invocar el testamento de Isabel la Católica, ni aducir la probable hermandad de raza

\footnotetext{
586 "Juan de Salamanca": "Vida local. Un recuerdo", El Adelanto, no 8.025, 11 de agosto de 1910, p. 1.

${ }^{587}$ El Salmantino únicamente hizo referencia a "un pequeño alboroto por estar un comercio abierto".

${ }^{588}$ Véase URRUTIA, Luis: Obras completas. Vol. IX. Discursos y artículos. Madrid: Escelicer, 1971, pp. 851-855.

${ }_{589}^{2}$ RABATÉ, Colette y Jean-Claude: Miguel de Unamuno. Biografía. Madrid: Taurus, 2009, p. 283.
} 
entre nosotros, como a otros pueblos, nos conviene vernos en estos trances para que se despierte el espíritu colectivo nacional ${ }^{, 590 .}$.

Por último, el Rector pronunció otro discurso bastante similar al del Paraninfo en el Consistorio de Salamanca. A finales de septiembre de 1910, con motivo de la celebración de una sesión extraordinaria para debatir sobre los preparativos del futuro centenario de las Cortes de 1812, Unamuno señalaba:

"No olvidemos que si nuestros abuelos de Cádiz ganaron las libertades políticas frente a un pobre e indigno Rey entregado al invasor, nosotros acaso tengamos que pelear por la libertad del alma nacional frente a una secta o a un partido de hombres entregados a la furiosa vanidad del internacionalismo sin patria.

Ese peligro a que aludo puede llegarnos por la singular ceguera de no pocos españoles, los más de ellos de buena fe, que acaso un día sufran el desengaño que los afrancesados de hace un siglo sufrieron, españoles que se empeñan en no ver en nuestra acción en África nada más que un ensueño loco o una empresa de intereses privados. Españoles que amenazan con huelgas y motines si se persiste en reconquistar en África la independencia nacional española ${ }^{, 591}$.

Su distancia respecto a la Conjunción resultaba muy evidente.

Situado más a la izquierda que El Adelanto en el espectro ideológico de este periodo, pero sin vínculos con el movimiento obrero, encontramos el periódico La Verdad. Su fundación fue posterior a la campaña militar de 1909, pero en algunas de sus páginas era muy perceptible la conciencia de crisis que lo inundaba todo tras la contienda, aunque sirviese, simultáneamente, para despertar el espíritu de la ciudadanía $^{592}$, y su alegría ante el hundimiento político de Antonio Maura, símbolo de la España más negra ${ }^{593}$.

En síntesis, debemos concluir que Antonio Maura cometió muchísimas equivocaciones en Marruecos: para empezar, la solicitud de un crédito extraordinario, antes de que se registrara un ataque cabileño con víctimas mortales, despertó la ansiedad entre el público; además, la reanudación de los trabajos mineros, en un contexto tan hostil como el melillense, fue una absoluta irresponsabilidad y el envío de los reservistas catalanes, a juzgar por el tenso ambiente social de esta región, un imperdonable traspié. Negar la existencia de la guerra era incompatible con la simultánea movilización de aquellos hombres. Por otra parte, si el detonante de la

\footnotetext{
590 OUIMETTE, Víctor: De patriotismo espiritual. Artículos en La Nación de Buenos Aires, 1901-1914. Salamanca: Ediciones Universidad de Salamanca, 1997, pp. 175-179.

591 "Las Cortes de Cádiz", El Adelanto, n 8.055, 26 de septiembre de 1910, p. 1. Otro fragmento de este mismo discurso, pronunciado el 24 de septiembre de 1910, puede hallarse en ESPERABÉ DE ARTEAGA, Enrique: Op. Cit., p. 218.

592 "Deslinde de campos", La Verdad, n' 4, 13 de noviembre de 1909, p. 3.

593 “Arma al brazo", La Verdad, nº 2, 31 de octubre de 1909, pp. 1-2.
} 
movilización fue el asesinato de unos trabajadores mineros, resultaba evidente que el gobierno estaba defendiendo en el Rif los intereses de algunos capitalistas. Pero el error gubernamental más lamentable, el más garrafal, fue la despreocupación por informar y convencer a la opinión pública de todo aquel proceder ${ }^{594}$.

En Salamanca, no obstante, este papel fue apresuradamente asumido por los rotativos locales. La mayoría de las opiniones publicadas aquí se caracterizaron por su tono resignado y, precisamente esto, resignación y conformismo, es lo que definió a la opinión pública salmantina. Incluso, destacados militantes obreros con influencia mediática respaldaron la gestión maurista. Nos estamos refiriendo a "Juan de Salamanca" y "Crotontilo". Pero tampoco desde el ámbito universitario, entre los intelectuales, se alzó la voz contra la campaña militar. Ni tan siquiera Miguel de Unamuno lo hizo.

Por todo ello consideramos que en Salamanca, mientras se desarrolló la campaña militar de 1909, fundamentalmente experimentaron rechazo hacia la misma aquellas familias perjudicadas por las movilizaciones. La oposición al servicio militar tal y como estaba entonces regulado, el antimilitarismo, sirvió como elemento catalizador de ese descontento. Pero de la crítica circunstancial no se pudo transitar hacia la censura global y sólidamente argumentada del pensamiento africanista. O dicho de otro modo, hacia el anticolonialismo.

No había llegado esa hora para Salamanca: quizás porque se necesitaba un mayor conocimiento, más directo, de la realidad marroquí, fruto tanto del contacto intenso y continuado entre soldados salmantinos y rifeños, como de los deseables intercambios comerciales; se necesitaba también una realidad socio-laboral aún más asfixiante en la capital del Tormes, capaz de destruir el tradicional amodorramiento de sus ciudadanos, mezcla de un poderoso sentimiento de miedo, abandono e impotencia; se necesitaba a un Unamuno infinitamente más combativo, carismático y dispuesto a enfrentarse con el mismísimo Alfonso XIII; pero, sobre todo y ante todo, valorando su capacidad de persuasión y su rapidez en la divulgación, se necesitaban periódicos más plurales.

Se debe subrayar que los negocios informativos locales tendieron a simplificar en exceso las noticias sobre la guerra. La reiteración fue otra de sus técnicas habituales

\footnotetext{
${ }^{594}$ Alfonso de la Serna, con un tono bastante poético, efectuaba el siguiente balance de la Guerra de 1909: "Nos faltó el esfuerzo intelectual necesario, la información previa suficiente, la astucia política en el planteamiento de la acción, el método, la constancia, el realismo (...) Nos equivocábamos de época". Véase SERNA, Alfonso de la: Op. Cit., p. 192.
} 
de propaganda. Su fijación con algunos temas -los héroes de las campaña, el salvajismo rifeño, las suscripciones populares, el relato de los combates, la conveniencia de la censura- y la marginación de otras cuestiones - los negocios mineros, el coste económico de la campaña, el drama familiar que significaba la marcha de un soldadoimplicaron siempre una notable manipulación de la realidad. Sirvieron, además, para desviar el debate público hacia los aspectos menos "técnicos" del conflicto.

Asimismo, con demasiada frecuencia, las publicaciones salmantinas contemplaron la cuestión marroquí desde una perspectiva exclusivamente interna, olvidando las repercusiones internacionales del problema. Resulta llamativo que, mientras duró la pelea, de la prensa local desaparecieron casi todos los comentarios insidiosos que habitualmente se venían vertiendo contra la conducta francesa en Marruecos. Al final, se había seguido su estela.

Pero el discurso belicista, sin duda, triunfó y caló hondo entre la opinión pública: teoría de la "bala mágica", tesis de la espiral del silencio, la función agenda setting de la prensa, anuencia de los intelectuales... todo ello se conjugó en Salamanca, en el año 1909, para explicar el apoyo de sus ciudadanos a la guerra. 


\section{NUEVAS TORMENTAS EN EL HORIZONTE AFRICANO. SALAMANCA Y LOS INICIOS DEL PROTECTORADO (1911-1918)}

\section{ECOS DE UNA CRISIS INTERNACIONAL: AGADIR Y LA GESTACIÓN DEL CONVENIO HISPANO-FRANCÉS DE 1912}

"Conviene hacer notar que el año 1911 fue pródigo en huelgas, que titulaban revolucionarias y que al igual que el año 1909, la atención nacional derivó hacia el problema de Marruecos, al recrudecerse ahora, y entonces iniciarse la campaña. Hago esta observación pues su continua repetición en las distintas fases que tuvo la campaña marroquí, hacen pensar en algo más que en una rara coincidencia", .

Una vez firmada la paz entre España y el Sultanato, Marruecos no dejaría de constituir una preocupación recurrente para los hombres de la Restauración. Y por consiguiente, inútil resultaría desviar la mirada de aquel territorio: más que un problema sobrevenido de nuestra gran historia imperial, Marruecos se había convertido en el objetivo de los intereses exteriores españoles. De la actitud bastante pasiva y conformista de Maura en Cartagena se había avanzado hacia una posición mucho más activa e, incluso, revisionista (sobre todo, tratándose de Tánger); pero mientras tanto, desde 1907, la supremacía francesa en el país africano se había confirmado.

He aquí el origen de la gran contradicción: el aliado podría ser, en efecto, el auténtico adversario de las ambiciones internacionales de España ${ }^{2}$. Ante las nuevas claudicaciones del Sultán, la situación interna marroquí podía definirse como de absoluto caos: a la par que El Mizzian proseguía en las inmediaciones de Melilla con sus incitaciones a favor de la guerra $\operatorname{santa}^{3}$; en Ceuta, el problema del contrabando estaba a la orden del día ${ }^{4}$. Además, en Mequínez había sido proclamado un nuevo Sultán, Muley Zind; y la seguridad de la capital imperial, por último, se veía gravemente amenazada ${ }^{5}$. A resultas de todo ello, en Casablanca se preparaba una columna expedicionaria francesa para avanzar sobre Fez con el pretexto de socorrer tanto a los compatriotas galos como a Hafid ${ }^{6}$. Y, para colmo de males, el temor entre los

\footnotetext{
${ }^{1}$ ROMERO BASART, Luis: La guerra de Marruecos o cómo se engaña a un pueblo. Tetuán: Casa Gomariz, 1930, p. 10. El autor intentaba persuadir a sus lectores, a lo largo del libro, de que las campañas en Marruecos eran instrumentalizada por los políticos de la Restauración con fines "sedantes", para hacer olvidar a la opinión pública los móviles fundamentales del ejecutivo de turno y así poder sostenerse en el Poder.

${ }^{2}$ SÁNCHEZ SANZ, Oscar Javier: Op. Cit., p. 742-744.

${ }^{3}$ Alfredo Rivera: "Conferencias telegráficas", El Adelanto, no 8.225, 13 de abril de 1911, p. 3.

${ }^{4}$ Alfredo Rivera: “Conferencias telegráficas”, El Adelanto, no 8.245, 9 de mayo de 1911, p. 3.

${ }^{5}$ Alfredo Rivera: “Conferencias telegráficas”, El Adelanto, no 8.220, 7 de abril de 1911, p. 3; Alfredo Rivera: "Conferencias telegráficas", El Adelanto, no 8.221, 8 de abril de 1911, p. 3.

${ }^{6}$ Alfredo Rivera: "Conferencias telegráficas", El Adelanto, no 8.222, 10 de abril de 1911, p. 3; "Muley Hafid ante la insurrección de sus súbditos", El Adelanto, no 8.223, 11 de abril de 1911, p. 1; Alfredo
} 
círculos oficiales alemanes iba en aumento porque se auguraba una inminente intervención franco-española en Marruecos ${ }^{7}$.

Entretanto, Salamanca intentaba reconquistar su normalidad, retornar a esa vida apacible donde nada parecía quebrar el estado de aturdimiento de los salmantinos. Ahora bien, ¿hasta qué punto la opinión pública salmantina era consciente de los cambios que se estaban operando en el Sultanato?

Un redactor de El Adelanto, en tan dramáticas circunstancias, no podía disimular su miedo y, sobre todo, hastío ante la perspectiva de una nueva conflagración. Aunque en su discurso, al fin, lo que predominaba era la resignación:

"Si la guerra en Marruecos es absolutamente necesaria para la seguridad de España; si Europa ordena que intervengamos, y de no hacerlo hemos de ver a Francia dueña de aquel imperio y hemos de perder la esperanza de que parte del mismo sea una prolongación de nuestro país, cuantos sacrificios se impongan al país estarán justificados.

Pero si, por el contrario, es sólo el afán de correr aventuras lo que a Marruecos nos lleva; si Francia tiene las manos atadas y Europa nada nos indica respecto a la precisión de intervenir, bien está San Pedro en Roma y nuestros soldados en la península.

Piensen los ministros que Francia es país pletórico de dinero y sin la sangría de la emigración; que su Ejército de África es de mercenarios y no de franceses; que tiene caminos, canales, puertos, ferrocarriles, cuanto constituye la prosperidad material de un país, y no olviden que nada de eso posee España, y que antes de colonizar países extraños, es el fecundar el suelo propio con el oro y la sangre que habríamos de arrojar en suelo donde acaso no fructificara.

$Y$ si el honor de España lo consiente, y con nuestra pasividad no hipotecamos el porvenir, nada se pierde con esperar para arreglar la casa ajena, a tener arreglada la propia",

Sin embargo, las tropas españolas no supieron permanecer a la espera. De hecho, tan pronto se confirmó la llegada, a principios de mayo de 1911, del comandante galo Bremond a $\mathrm{Fez}^{9}$, Alfau, sucesor de Aldave en el gobierno de Ceuta, se adueñó de algunas posiciones cercanas a esta plaza y las protestas germanas estallaron inmediatamente (concretamente, ocupó Rincón de Medik, a 11 km de Ceuta. Meses antes, en su intento por proteger las obras de una futura carretera a Tetuán y ante las

Rivera: "Información telegráfica", El Adelanto, no 8.233, 24 de abril de 1911, p. 3; "La intervención francesa en Marruecos", El Adelanto, no 8.238, 29 de abril de 1911, p. 2.

${ }^{7}$ Alfredo Rivera: "Conferencias telegráficas", El Adelanto, no 8.236, 27 de abril de 1911, p. 3; Alfredo Rivera: "Conferencias telegráficas", El Adelanto, $\mathrm{n}^{\circ}$ 8.242, 5 de mayo de 1911, p. 3; Alfredo Rivera: "Conferencias telegráficas", El Adelanto, no 8.243, 6 de mayo de 1911, p. 3.

8 “'Más guerras?”, El Adelanto, $\mathrm{n}^{\circ}$ 8.225, 13 de abril de 1911, p. 1.

9 Alfredo Rivera: "Conferencias telegráficas", El Adelanto, no 8.241, 4 de mayo de 1911, p. 3. A principios de mayo de 1911, Alfredo Rivera se desplaza hasta Marruecos como corresponsal de guerra, enviado por El Imparcial. Véase "El Adelanto en Marruecos", El Adelanto, n 8.245, 9 de mayo de 1911, p. 1. Sus contribuciones para el diario liberal son, durante algunos meses, escasas. Mientras tanto, la corresponsalía en Madrid la asume "Interino". 
amenazas de El Raisuni, ya había avanzado sobre Cudia Fajama, Altos de la Condesa, Cudia Afersian y Monte Negrón) ${ }^{10}$. Además, en El Adelanto se multiplicaron las noticias en las que se denunciaba una situación muy tensa en Tetuán, anunciándose de esta manera, para el buen entendedor, nuevos avances militares españoles. También se advertía a los lectores, por último, contra posibles estratagemas de El Raisuni, nada interesado, se aseguraba, en el fortalecimiento español en la región entre Tánger y Tetuán ${ }^{11}$.

Sin embargo, hemos de anticipar que una vez ocupadas Larache y Alcazarquivir, éste no tardaría en confesar públicamente su sumisión ante Silvestre, jefe superior instructor de la policía jerifiana en la región ${ }^{12}$. Si bien era partidario de la independencia de Marruecos, el jerife había comprendido que las circunstancias, dada la debilidad del Sultán, no eran las idóneas y optaría, como mal menor, por el establecimiento de un protectorado español en la zona norte de su país antes que por un pleno dominio francés.

Precisamente ahora, las noticias sobre este cabecilla rebelde, acosado por los cabileños de Beni Aros, se convirtieron en muy habituales, aunque no demasiado aclaratorias, entre los cables telegráficos ${ }^{13}$. Y su cooperación, en efecto, resultó imprescindible para que las tropas españolas lograsen nuevas conquistas territoriales.

Entretanto, la opinión pública salmantina se hallaba muy desorientada, desconocedora del por qué de los acontecimientos:

"Nuestra política, política de misterio en la que al país apenas se deja entrever cuanto se proyecta, no es ahora más clara que lo fue antes, y si entonces el país sólo tenía noticia de minas y negocios mercantiles, ahora parece sólo saber que vamos a Marruecos por exigirlo las demás potencias.

Este desconocimiento que produjo luctuosos sucesos, puede hoy, por lo menos, hacer impopular esta guerra, y la responsabilidad debe corresponder a los que, obligados a informar a la opinión, la dejan abandonada a sí misma y a las ideas que con mayor o menor desinterés se quieren lanzar a la publicidad.

\footnotetext{
10 "Interino": "Conferencias telegráficas", El Adelanto, no 8.245, 9 de mayo de 1911, p. 3; "Interino": “Conferencias telegráficas", El Adelanto, no 8.248, 12 de mayo de 1911, p. 3; "Interino": "Conferencias telegráficas", El Adelanto, n ${ }^{\circ}$ 8.251, 16 de mayo de 1911, p. 3. Alfau, de todos modos, se mostró disgustado ante los periodistas al saber que se había divulgado de la falsa noticia de la ocupación de Sierra Bullones.

11 "Argos": "Madrid al día", El Adelanto, no 8.249, 13 de mayo de 1911, p. 1; "Interino": "Conferencias telegráficas", El Adelanto, no 8.250, 15 de mayo de 1911, p. 3; "Interino": "Conferencias telegráficas", El Adelanto, no 8.258, 24 de mayo de 1911, p. 3; "El Raisuni contra España”, El Adelanto, no 8.267, 3 de junio de 1911, p. 1.

12 "Interino": "Conferencias telegráficas", El Adelanto, no 8.301, 13 de julio de 1911, p. 3. La colaboración activa entre El Raisuni y Silvestre, más allá del mero beneplácito, fue posterior al desembarco español en estas dos plazas. Sin embargo, el periodista inglés Walter Harris difundiría la idea de una supuesta ayuda previa. Véase BARCELÓ SICILIA, Ricardo J.: "La actitud del Cherif Mulay Ahmed Raisuni ante el desembarco españolen Larache y toma de Alcazarquivir en 1911", Estudios Africanos, no 18-19, Madrid, 1996, pp. 101-107.

13 “Interino": "Conferencias telegráficas", El Adelanto, no 8.302, 14 de julio de 1911, p. 3.
} 
Cuando en el Congreso se ha preguntado qué ocurre en África, el presidente del Consejo ha contestado que se trata de una operación de policía.

Podrá llamarse a la guerra operación de policía y podrá llamársela como se quiera, pero con esto no se conseguirá más que disfrazar la verdad y que el país crea que con esto se le oculta algo que cree tener derecho a saber,"14.

¿Qué estaba sucediendo? El juego entre ajedrecistas estaba llegando a su final. Junto al sentimiento de desconfianza entre la opinión pública, también eran muchos los recelos mutuos entre los gobiernos madrileño y parisino ${ }^{15}$. Sin duda, ésta constituyó la nota dominante de la prensa local salmantina al iniciarse el año 1911: la toma de Fez sólo había acelerado los acontecimientos. Y mientras que Francia advertía contra una previsible ocupación española de Alcazarquivir, alegando que esta conducta no hallaría respaldo entre los firmantes de Algeciras ${ }^{16}$, García Prieto, a la sazón ministro de Estado del gobierno de Canalejas, sostenía tras el efectivo desembarco, el 8 de junio, que aquella plaza, al igual que Larache, se hallaban bajo nuestra zona de influencia ${ }^{17}$.

Evidentemente, el contencioso hispano-francés no era algo coyuntural, sino que se venía fraguando desde hacía algunos meses. Su origen radicaba en los crecientes recelos franceses tras la firma de la paz hispano-marroquí. Francia había reclamado, en enero de 1911, la instrucción y organización de las fuerzas jerifinas de Tánger en régimen de exclusividad, alegando que era un privilegio derivado de otro empréstito que se estaba negociando en París con El Mokri. Como respuesta, la diplomacia española, con Villa Urrutia a la cabeza, había intentado lograr el respaldo británico para frenar a los galos. Por supuesto, de día en día, Canalejas contemplaba alarmado la "tunificación" de Marruecos. El presidente liberal sabía que el establecimiento de un protectorado francés encubierto estaba muy próximo. Y para evitarlo, para garantizar la existencia de una zona de influencia española, tal y como se reconocía en el Tratado de 1904, el control de la policía en el triángulo formado por Tetuán-Tánger-Larache resultaba vital $^{18}$.

Diríase, en suma, que en 1911 estallaron buena parte de las tensiones acumuladas en Europa desde hacía años: a la par que Francia se había beneficiado de las

14 "Marruecos", El Adelanto, no 8.251, 16 de mayo de 1911, p. 1.

15 "La conducta de Francia en Marruecos", El Adelanto, no 8.247, 11 de mayo de 1911, p. 2.

16 "Interino": "Conferencias telegráficas", El Adelanto, no $8.271,8$ de junio de 1911, p. 3.

17 "Interino": "Conferencias telegráficas", El Adelanto, no 8.274, 12 de junio de 1911, p. 3.

${ }^{18}$ TORRE DEL RÍO, Rosario de: "La política exterior española en el año de la crisis de 1911 a través de la correspondencia del marqués de Alhucemas" en VVAA: Estudios históricos. Homenaje a los profesores José M ${ }^{a}$ Jover Zamora y Vicente Palacio Atard. Madrid: Universidad Complutense, 1990, pp. 381-406. A nuestro entender, uno de los mayores atractivos de este trabajo es el repaso de los tratados internacionales sobre Marruecos suscritos por España y, en particular, sobre la Convención secreta de 1904 y el Acta de Algeciras. 
dificultades del Sultán de Marruecos para enviar a Fez esa columna militar, en España, el gobierno de Canalejas había considerado roto el statu quo fijado en el Tratado de 1904. Por esta razón, el político liberal había ordenado la ocupación de Larache, Alcazarquivir y, algo después, Arcila. Pero la historia no concluía aquí.

Apenas si había comenzado: a pesar de esta demostración de fuerza y determinación españolas, una inmediata y contundente intervención alemana en el puerto de Agadir culminaría con una negociación entre París y Berlín, mientras Madrid, una vez más, sería marginada de las conversaciones ${ }^{19}$.

El Adelanto, a través de "Interino", se apresuró a presentar la intervención armada española en Larache y Alcazarquivir como una operación de policía necesaria y no como una medida revanchista. Si Francia se hallaba contrariada, ello resultaba del todo incomprensible y más a sabiendas de que sus tropas habían ocupado Fez y también habían entrado en Mequínez y aplastado al nuevo pretendiente ${ }^{20}$.

Más meditado y pesimista, como era habitual en sus escritos, "Argos" firmaba un editorial que trataba de arrojar luz sobre los entresijos del viejo Tratado hispanofrancés de 1904 con la esperanza de entender el por qué de tantas tensiones diplomáticas:

"La gente que se preocupa con los problemas internacionales, rabia por conocer en toda su profundidad las cláusulas del Tratado secreto hispano-francés (...) El redactor de ese documento protocolar y los refrendadores del mismo cometieron un lapsus tremendo (...) Impusieron a Francia la obligación de comunicarnos lo que hiciera o pensara hacer en el imperio marroquí, e impusieron a España la obligación de consultar a Francia lo que nosotros pensáramos hacer en el mismo imperio magrebita. $Y$ ese es el atolladero donde nos encontramos.

Francia se ha merendado a Fez (...) Nosotros nos hemos tomado la libertad de sorber unos huevos pasados por agua en Alcazarquivir y eso les parece a los franceses una incorrección y siempre apoyándose en las cláusulas secretas del Tratado secreto.

Hay su miaja de envidia en todas estas cosas (...) Los franceses continuarán merendándose los trozos más exquisitos de la gustosísima perdiz africana; y nos dirán a los españoles: -Hoy nos hemos comido un alón; hoy un muslo; hoy la pechuga... ¡Qué tierno y suculento es ese manjar! Ya no queda más en la cabeza. ¡Qué sabrosa es!

$Y$ nosotros, si queremos entretener el hambre con un pajarillo, calandra, gorrión o mosquitero, tendremos que consultarles, ¿nos permiten ustedes, señores franceses?"21.

Queda patente que la envidia y rencores acumulados eran enormes: tan grandes como el sentimiento de impotencia ante una Francia todopoderosa. Así que la prensa

\footnotetext{
${ }^{19}$ SÁNCHEZ SANZ, Oscar Javier: Op. Cit., pp. 719-727.

20 "Interino": "Conferencias telegráficas", El Adelanto, n 8.275, 13 de junio de 1911, p. 3. Por su parte, Rivera, un mes más tarde enviaba a la redacción de El Adelanto una carta tranquilizadora, repleta de detalles sobre el buen ambiente que imperaba en el campamento español, desde la misma posición de Alcazarquivir. Véase Alfredo Rivera: "El veraneo en Alcazarquivir. Carta abierta", El Adelanto, n 8.307, 20 de julio de 1911, p. 1.

21 "Argos": "Madrid al día", El Adelanto, nº 8.280, 19 de junio de 1911, p. 1.
} 
liberal se consolaba descargando culpas en Antonio Maura, Allendesalazar y León del Castillo, todos ellos máximos responsables del Acuerdo de 1904. Como nota excepcional, en Salamanca únicamente José Sánchez Rojas censuró al Partido Liberal por el precipitado cierre de las Cortes; precipitado y, sobre todo, inoportuno a juzgar por las tensas relaciones con la república vecina. Pero ninguna crítica o responsabilidad más parecía recaer en el gobierno de José Canalejas ${ }^{22}$ : se continuaba, por lo tanto, respaldando la intervención armada.

De todas formas, toda esta tirantez diplomática se desplazó a un segundo plano informativo al desencadenarse la crisis de Agadir. Sin duda, 1911 marcó el momento más violento en el desarrollo de todo este juego imperialista alrededor de Marruecos que venimos examinando. Sabemos ya que la toma por tropas expedicionarias galas de Fez, en el mes de mayo, bajo el pretexto de socorrer al Sultán Muley Hafid, había sido contestada con la ocupación española de Larache y Alcazarquivir, el 8 y 9 de junio respectivamente $^{23}$. Pero mientras que el gobierno francés estaba convencido de la existencia de un acuerdo secreto entre Berlín y Madrid y contraatacaba el mismo 8 de junio con la ocupación de Mequínez, Alemania creía que se hallaba ante una acción conjunta hispano-francesa. Así que el Reich decidió enviar, el 1 de julio de 1911, el cañonero Panther a la bahía de Agadir. De nuevo, como hiciera en Tánger años atrás, Guillermo II protagonizaba un golpe de efecto ante la colérica mirada gala ${ }^{24}$.

Los altercados entre tropas españolas y galas de aquellos días fueron, a ciencia cierta, el fiel reflejo de la tensión entre las embajadas europeas ${ }^{25}$. Pero apenas si fueron explicados en las páginas de la prensa salmantina. Sólo fugazmente se aludió al conocido como "incidente Boisset" ${ }^{26}$. Y tampoco tuvo mucho eco la noticia de que un teniente francés, Thiriet, había abofeteado a un cabo español ${ }^{27}$. El primer personaje era un agente consular francés y el segundo, un militar de la misma nacionalidad. Ambos formaban parte de un destacamento sultaniano presente en Alcazarquivir con anterioridad a la llegada de los españoles, con evidentes apetencias de dominio sobre la ciudad (adjudicada a España en el Tratado de 1904, por otro lado) y que protagonizarían sonados enfrentamientos con el intempestivo Silvestre.

\footnotetext{
${ }^{22}$ José Sánchez Rojas: “Comentarios. Vacaciones”, El Adelanto, no 8.284, 23 de junio de 1911, p. 1.

23 Aunque días antes, en el Congreso, Canalejas había manifestado, respondiendo a un diputado demócrata a propósito de la toma francesa de Fez, que "ni nosotros tenemos ni hemos tenido jamás propósitos belicosos". Véase PEREZ MOLINA, Elisa: Op. Cit., p. 391.

24 "Interino": "Conferencias telegráficas", El Adelanto, no 8.292, 3 de julio de 1911, p. 3.

25 "Silvestre", El Adelanto, no 8.303, 15 de julio de 1911, p. 1.

26 "Argos": "Madrid al día", El Adelanto, no 8.309, 22 de julio de 1911, p. 1.

27 "Interino": "Conferencias telegráficas", El Adelanto, no 8.309, 22 de julio de 1911, p. 3.
} 
Pero la crisis diplomática tuvo otra derivación: las protestas socialistas contra la conflagración en ciernes se recrudecieron en la república vecina ${ }^{28}$; y no sólo allí. También los mítines empezaban a extenderse aquí: en Madrid, el 7 de agosto; en Barcelona, un día después ${ }^{29}$; en Santander, el 20 de agosto $^{30}$. Aunque sólo su eco, nada más, se escuchaba en esta capital meseteña.

Por lo que respecta a El Adelanto, "Interino" fue el primero en comentar y barajar las consecuencias de este gesto alemán en Agadir. Si bien la prensa internacional hacía gala de una considerable prudencia, la conflagración mundial parecía inminente porque tanto Francia como Inglaterra habían anunciado su propósito de enviar un buque de guerra, cada una, hasta el puerto marroquí ${ }^{31}$. No obstante, acabaría imponiéndose la vía diplomática para la solución del contencioso.

Por su parte, “Argos", al hilo de todos estos sucesos y siempre más interesado en las secuelas para el país del conflicto internacional que en el propio litigio, empezaba a sospechar de las ambiciones de Canalejas en Marruecos y de su inquietante silencio $^{32}$. Y efectivamente, muy pronto, concretamente el 17 de agosto, se comprobó cómo la siguiente presa del gobierno madrileño, que de ningún modo estaba dispuesto a perder posiciones en esta competición, fue Arcila. De día en día, “Argos” tenía más claro el imperialismo conquistador que anidaba en el pensamiento del líder liberal y sentenciaba: "Lo primero es recogerse o encogerse; luego, saltar" ${ }^{\text {"33 }}$. Mientras tanto, las incitaciones a la guerra santa contra España también iban en aumento ${ }^{34}$.

La solución del incidente franco-alemán, por el momento, se presentaba distante. A pesar del secretismo en el que se desenvolvían las negociaciones, El Adelanto comentaba que Alemania exigía unas compensaciones exorbitantes por las ocupaciones territoriales francesas, pero de ninguna manera le convenía un choque armado que dañara sus proyectos comerciales ${ }^{35}$. Aún así, "Argos” ya adivinaba que la gran perdedora de toda esta historia sería España y se alegraba por ello:

"Nos permitirán el disfrute de las plazas fuertes y el del territorio constitutivo de nuestra vieja herencia, pero no nos autorizarán para el avance, y habremos de recluirnos en nuestros naturales términos, aquellos que nos demarcó la suerte antes de las aventuras mauro-laciervistas (...) iBenditas sean Francia y Alemania una y mil

\footnotetext{
28 "Los socialistas y la cuestión marroquí", El Adelanto, nº 8.309, 22 de julio de 1911, p. 1.

29 "Interino": "Conferencias telegráficas", El Adelanto, no 8.322, 7 de agosto de 1911, p. 3.

30 "Interino": "Conferencias telegráficas", El Adelanto, no 8.334, 21 de agosto de 1911, p. 3.

31 "Interino": "Conferencias telegráficas", El Adelanto, no 8.294, 5 de julio de 1911, p. 3.

32 "Argos": "Madrid al día", El Adelanto, n 8.296, 7 de julio de 1911, p. 1.

33 "Argos": "Madrid al día", El Adelanto, no 8.310, 24 de julio de 1911, p. 1.

34 "Interino": "Conferencias telegráficas", El Adelanto, no 8.314, 28 de julio de 1911, p. 3.

35 "Las negociaciones franco-alemanas", El Adelanto, no 8.323, 8 de agosto de 1911, p. 1.
} 
veces, pues nos obligan a ser buenos y felices! E Inglaterra, metida en el ajo, no merece menos nuestro afectuoso parabién. Son esas tres grandes naciones, otras tantas abuelas amables y previsoras, empeñadas en salvar sus nietezuelos descarriados, y sobre descarriados, testarudos ${ }^{136}$.

Pese a lo que pudiera parecer, no había ironía, sino más bien amargura y despecho, en el anterior fragmento. Ante el ensañamiento francés, "Argos" creía que a España no le restaba ningún margen de maniobra y por eso recomendaba prudencia en otra de sus inmediatas colaboraciones periodísticas:

"Un dia son Francia y Alemania, enfurruñadísimas, las que se van a romper las narices, a extirparse los mostachos, revolviendo el mundo. Y después, tan amigas, tan suaves, anuncian al mismo mundo las excelencias de la paz jabonada con jabón de los príncipes del Congo.

$Y$ otro día es Francia quien se atreve con esta pobre nación española, quien nos mete miedo y nos quiere arrancar la clásica perrilla por habernos alargado hasta Larache y Alcazarquivir.

Más tarde nos hace borococos para que traspasemos la Guinea y el Muni al Imperio germánico -jsiempre jugando por tabla esa gran carambolista!- y ahora nos mira de través en nuestra marcha hacia Ifni. ;La envidia!",37.

Apenas transcurridas un par de semanas, "Argos" desmentía que se hubiese pensado en la ocupación de Ifni, pero este asunto se presentaba, a su juicio, entre tinieblas $^{38}$. ¿Qué había ocurrido? Algo que a los salmantinos testigos de aquellos sucesos, les fue ocultado.

En efecto, sí se planeó un avance, dirigido por Burguete, sobre Ifni ${ }^{39}$. Las conversaciones hispano-francesas relativas a las esferas de influencia y subsiguientes a los avances sobre Fez, Larache, Alcázar, etc., se habían interrumpido en junio y se reanudaban ahora, en septiembre de 1911. Pero, evidentemente, el episodio de Agadir había obligado a modificar la postura francesa sobre la cuestión marroquí, mientras la prioridad de Canalejas se concretaba en definir el reparto de Marruecos en dos zonas, distintas en tamaño pero equivalentes en competencias.

Francia, escudándose en el antimilitarismo exhibido por la Conjunción, presentó al ministro de Estado, el 2 de septiembre de 1911, un primer borrador de acuerdo. En él, París reclamaba la región de Ifni como compensación por lo que debía pagar a Alemania. García Prieto, sorprendido ante la demanda del embajador Geoffray, le intentó hacer ver la importancia del enclave para la seguridad de las Islas Canarias. Pero el diplomático francés respondió de modo bastante amenazador: si el gobierno español

\footnotetext{
36 "Argos": "Madrid al día", El Adelanto, no 8.343, 31 de agosto de 1911, p. 1.

37 "Argos": "Madrid al día", El Adelanto, no 8.349, 7 de septiembre de 1911, p. 1.

38 "Argos": "Madrid al día", El Adelanto, no 8. 360, 20 de septiembre de 1911, p. 2.

${ }^{39}$ SÁNCHEZ SANZ, Oscar Javier: Op. Cit., p. 720; RAMIRO DE LA MATA, Javier: Op. Cit., p. 135.
} 
no abandonaba toda iniciativa sobre Ifni, Francia le exigiría la totalidad del sur de Marruecos o interpondría obstáculos para la administración española en el norte. Por fortuna para la diplomacia madrileña, a la espera de que se esclareciesen las exigencias alemanas sobre la cuestión marroquí, fue Gran Bretaña la que intercedió a favor de España: ni deseaba que los franceses se asentasen en la costa atlántica marroquí, ni que España, resentida con los galos, se acercase a Alemania.

Por descontado, en el terreno periodístico, tanto la campaña germanófoba como la hispanófoba se elevaban entonces en las páginas de la prensa francesa y magnificaban el contencioso a tres bandas (en realidad, cuatro eran los contendientes, pero el Sultán ya no tenía voz): mientras Alemania era presentada como un monstruo rebosante de ambición ${ }^{40}$, al gobierno madrileño se le exigía el abandono de Larache y Alcazarquivir ${ }^{41}$. A pesar de esta atmósfera de hostilidad, se acabó imponiendo el sentido común y se pudo alcanzar un primer arreglo: el Acuerdo franco-alemán el 4 de noviembre de $1911^{42}$, último escollo para el reconocimiento de un protectorado galo sobre Marruecos.

Tras la consecución de este pacto, fueron las presiones del Foreign Office sobre el Ministerio de Exteriores Francés las que permitirían reanudar, otra vez, en diciembre, las conversaciones entre Madrid y París conducentes al doble protectorado sobre Marruecos. Por descontado, la actitud británica ante la cuestión de Ifni fue vital en el camino hacia el entendimiento.

Con certeza, para contrarrestar el pensamiento tan desencantado y derrotista de “Argos”, y coincidiendo con esa reanudación del diálogo con Francia, El Adelanto publicitó los escritos de un personaje al que ya nos hemos referido: Pascual Meneu, aquél defensor de la "propaganda científica" a favor del colonialismo. Este personaje fue, además, un no muy conocido discípulo del prestigioso arabista Francisco Codera ${ }^{43}$.

\footnotetext{
40 "R. S. M.": "Franceses y, alemanes", El, Adelanto, no 8.356, 15 de septiembre de 1911, p. 1.

41 "España en Alcázar", El Adelanto, no 8.367, 28 de septiembre de 1911, p. 2. También a propósito del malestar francés, RAMIRO DE LA MATA, Javier: Op. Cit., p. 135.

${ }^{42} \mathrm{El}$ articulado de este Convenio era comentado tímidamente por Alfredo Rivera: "Información telegráfica", El Adelanto, no 8.399, 4 de noviembre de 1911, p. 3.

${ }^{43}$ La correspondencia que intercambió con el también reputado estudioso Julián Ribera fue estudiada por López García. Véase LÓPEZ GARCÍA, Bernabé: "Correspondencia de Julián Ribera a Pascual Meneu: una amistad en una etapa decisiva del arabismo", Sharq Al-Andalus, no 10-11, Teruel, 1993-1994, pp. 499-526. Sabemos que Meneu (1857-1934) se incorporó a la vida universitaria salmantina en 1909 y permaneció en esta institución, ocupando las cátedras de árabe y hebreo, hasta 1922, cuando se trasladó a Granada. Esta Universidad, a diferencia de la de Salamanca, sí poseía tradición arabista. En su juventud, había vivido en Tánger y junto con el franciscano padre Lerchundi había levantado la primera imprenta española con caracteres arábigos. De carácter campechano, práctico y muy culto, fue además compañero de excursiones, íntimo y fiel amigo de Miguel de Unamuno, lo que no impidió que sostuvieran algunas
} 
De nuevo encontramos, por tanto, en el periódico liberal una dicotomía en su línea editorial. Los artículos de este catedrático representaron el mayor esfuerzo persuasivo sobre la cuestión marroquí acometido por el diario liberal en este periodo. Sin embargo, este empeño, no podemos dejar de subrayarlo, fue estrictamente contemporáneo al planteamiento del problema, no previo al mismo. Creemos, por consiguiente, que es precisamente en este punto en el que reside la distinción entre la función divulgativa de la prensa, más constante, y la estrictamente persuasiva.

El primer editorial que encontramos con su firma data de enero de 1912, apenas resuelto el incidente de Agadir y cuando ya se reconocían como seguras algunas pérdidas para España:

"Después de la entrega de las bases de arreglo, que Monsieur Geoffray, embajador de la República francesa, ha entregado al señor García Prieto, ministro de Estado de España y luego de la réplica o anteproyecto de concordia que éste ha presentado a aquel, la prensa francesa renace a la discusión de los derechos de España en Marruecos (...) argumentando que sólo a Francia concede Alemania el Protectorado, y que el coste de éste, las cesiones de sus territorios congoleses a los germanos, quedarían sin digna compensación en Marruecos, si la vecina República no obtuviese dominio pleno con protectorado único en todo el territorio magrebino.

La prensa española, que hace causa nacional y no afrancesada en este asunto sale a la defensa de los intereses de la patria en el Magreb, asegurando que en las zonas Norte y Sur, España tiene seculares intereses, recientemente corroborados con sacrificios de sangre de sus valerosos hijos, con dispendios costosos del tesoro nacional, con esfuerzos mentales y pecuniarios de nuestros africanistas, lingüistas y filólogos y el no menos generoso de generales, jefes, oficiales y misioneros franciscanos, a la vez que los realizados por el comercio y las empresas de navegación, ${ }^{, 44}$.

Evidentemente, en Salamanca tan sólo se conocían los recientes dispendios en sangre y dinero, pero el discurso sobre el esfuerzo intelectual de los africanistas (en la acepción más amplia del vocablo) tenía que resultar, forzosamente, muy artificial por vago y apenas conocido. Seguramente por esta razón, algunas semanas después, Meneu abundaba en los derechos históricos de España en Marruecos, derivados de la cercanía geográfica $^{45}$. Pero, sobre todo, su mayor empeño consistía en prevenir a la opinión pública local contra previsibles agravios a España:

"Virtualmente, el Sultán de Marruecos queda bajo la protección de Francia y la de España también, puesto que ésta no puede quedar sin las dos zonas de influencia o de

discrepancias ideológicas, como fue la referida a la cuestión marroquí. Consúltese ROBLES, Laureano: "El arabista castellonense Pascual Meneu, amigo de Unamuno (Cartas inéditas)", Boletín de la Sociedad Castellonense de Cultura, $\mathrm{n}^{\circ}$ 70, Castellón, 1994, pp. 197-240. También del mismo autor: "Nuevas aportaciones sobre Meneu", Boletín de la Sociedad Castellonense de Cultura, nº 80, Castellón, 2004, pp. 355-399.

${ }^{44}$ Pascual Meneu: "La cuestión de Marruecos. La zona Sur", El Adelanto, no 8.448, 2 de enero de 1912, pp. 1-2.

${ }^{45}$ Pascual Meneu: "Posible solución de la cuestión de Marruecos", El Adelanto, no 8.458, 13 de enero de 1912 , p. 1. 
Protectorado, ya sean las convenidas con Francia e Inglaterra en 1904, ya aquellas se modifiquen ampliándolas en virtud de nuevas reglamentaciones, deslindes y compensaciones.

Un Sultán que ya no reina, sino que le hace reinar Francia (...) un Sultán en tan precaria situación material y moral, no debe ni puede vender tierras del dominio público a nadie, ni personas ni asociaciones, y menos aún si estas entidades son francesas ${ }^{, 46}$.

Tales ventas de tierra a los franceses, efectivamente, se estaban registrando en las cercanías de Larache. Sin embargo, más preocupantes resultaban algunos rumores que apuntaban a la pronta internacionalización de Tetuán y que, en la práctica, supondría el aislamiento y asfixia de Ceuta. En definitiva: Meneu defendía que España no debería transigir con semejantes ambiciones galas. Una vez más, la propaganda colonialista se fundamentaba en la explotación del sentimiento de rechazo contra nuestros vecinos ultrapirenaicos.

Abundando en la materia, a este catedrático también le inquietaba la defensa de nuestra soberanía sobre las Canarias, garantizada según el Convenio de 1904, pero que veía pendiente de un hilo:

"El menos avezado al estudio de las cosas de Marruecos, con sólo saber entender lo que significan los mapas, puede observar que la zona del Norte ofrecida a España en el Tratado de 1904, es el mínimo a que podemos aspirar, no tan sólo porque así lo reclama nuestro hinterland de Ceuta, Alhucemas, Vélez de la Gomera y Melilla, sino también porque esa zona es la expresión de lo que a Inglaterra conviene frente al Estrecho y en pugna con Francia y demás potencias, en consideración a la cual, más que mirando a España, Inglaterra la ha impuesto y defendido. Para que nuestra nación pueda ostentar triunfos propios, personales de su alta dignidad, se hace indispensable concederla por el Sur la zona demarcada en los tratados y que debe extenderse a lo menos por toda la orilla izquierda del río Sus, desde sus orígenes, como dice el Tratado franco-español de 1904, hasta la desembocadura, según reclama la vida de Canarias, su comercio, la agricultura, la industria y propia defensa.

Solamente así, podría España quedar satisfecha de sus altos dignatarios diplomáticos ${ }^{, 47}$.

Por último, el insigne africanista igualmente se alarmó ante la pretensión francesa de adueñarse del Cabo de Agua y una franja territorial al oeste del río Muluya, del valle del Uarga y de Alcazarquivir. En su conjunto, la actitud francesa era calificada de vergonzosa: estaban luchando por incumplir todo lo convenido en 1904 y despojar a España de su zona de influencia ${ }^{48}$.

\footnotetext{
${ }^{46}$ Pascual Meneu: "Tetuán no puede ser internacionalizada", El Adelanto, no 8.461, 17 de enero de 1912, p. 1.

${ }^{47}$ Pascual Meneu: "Las negociaciones franco-españolas", El Adelanto, no 8.485, 13 de febrero de 1912, p. 1 .

${ }^{48}$ Pascual Meneu: "Marruecos y las negociaciones", El Adelanto, no 8.547, 26 de abril de 1912, p. 1; Pascual Meneu: "Marruecos y las negociaciones II", El Adelanto, no 8.550, 30 de abril de 1912, p. 1. Meneu, en otro artículo para El Adelanto, también se ocuparía de ensalzar el trabajo de los franciscanos
} 
Aunque más deshonrosa, ante los ojos de Meneu, se presentaba la actuación de algún partido antidinástico que le seguía el juego al partido colonialista francés:

"Es bochornoso, aflictivo, desconsolador, ver los anuncios del partido republicano socialista español, señalando fechas próximas, casi inmediatas, para celebrar en ciudades y pueblos mitingueos contra la Guerra de Melilla, como si sin soldados ni Ejército bien organizado, fuera posible mantener muchos derechos consignados en los tratados, ni nuestra acción exigida a diario por la Patria grande aquende el Estrecho, y por la misma patria en Melilla, Ceuta, Baleares y Canarias allende los mares, pues toda ella y en todas sus partes, todas valiosas, se ventila y litigan en este gran pleito marroquí, verdadera pesadilla de todo buen español que tenga conciencia de lo que es y puede ser su amada Patria (...) No me arrepiento de la conferencia que di hace unos años en Castellón, defendiendo que los intereses de España en Marruecos estaban en oposición y en pugna con los de Francia y con los de Inglaterra, mientras iban a la par con los de Alemania (...) Es tarde pero hay que decir la verdad en todo tiempo ,49.

En fin, desde comienzos de 1912, el propio órgano del liberalismo salmantino publicitaba las opiniones de un pensador que sin ser germanófilo, justificaba sus razonamientos en materia exterior. El Adelanto, por su parte, le agradecía todas sus contribuciones periodísticas porque estaban repletas de datos y de un hondo "sentir patriótico". Pero también debido a que:

"en sostener nuestros derechos sobre Marruecos estamos conformes los españoles todos. Partidarios de la paz y amantes de la guerra, los que quieren arreglar la casa propia antes de intervenir en la ajena y los que consideran que es urgente encauzar la emigración española hacia Marruecos, todos estamos de acuerdo en considerar que parte de este imperio es necesario a nuestra vida nacional y en hacer los sacrificios necesarios para que la historia continúe desenvolviéndose, ${ }^{\text {,50 }}$.

Es evidente que la unanimidad de pareceres, a la que aludíamos páginas atrás, seguía esgrimiéndose como arma propagandística en defensa de la intervención española en Marruecos: el dominio sobre el norte de este país era presentado, sistemáticamente, como una garantía de la independencia nacional.

A mediados de abril, el Diario Universal propagó la idea de que el final de las conversaciones hispano-francesas estaba muy próximo. Francia había alcanzado otro acuerdo, el más anhelado, con el Sultán ${ }^{51}$, mientras que “Argos", con gran ironía, reflexiona sobre el significado del único tratado que quedaba pendiente:

"La alegría se nos sale por los bolsillos, como el júbilo le rebosaba a don Quijote por las cinchas de Rocinante, desde que el marqués de Alhucemas, nuestro gran ministro de Estado, ha puesto en manos de Monsieur Geoffray la contestación dada por España a las últimas proposiciones del gobierno franco.

en África. En Pascual Meneu: "Sacerdocio católico-hispánico en Marruecos", El Adelanto, no 8.465, 22 de enero de 1911, p. 1.

${ }^{49}$ Pascual Meneu: "La cuestión de Marruecos", El Adelanto, no 8.515, 19 de marzo de 1912, p. 1.

50 "Francia y Marruecos", El Adelanto, no 8.517, 21 de marzo de 1912, p. 1.

51 "Las negociaciones con Francia", El Adelanto, n ${ }^{\circ} 8.533,10$ de abril de 1912, p. 2. 
¡Alegría, hosanna y albricias, enhorabuenas, parabienes, felicitaciones! La cosa va como una seda lisa, porque la retorcida no tiene tanta suavidad (...) Éste es el final obligado de tantas conferencias diplomáticas, de tantas negociaciones, de tantos sustos y tantas amenazas de ruptura como nos han venido emocionando y aburriendo desde la iniciación del conflicto internacional entre la poderosa Francia y la humildísima España. Pero, aquí para entre nosotros, yo tenía descontado lo que ocurre. La diplomacia es una cortina muy transparente tras la cual se ocultan los gobiernos para fingir que trabajan los asuntos difíciles; mas, en realidad de verdad, el vino excelente y puro se escancia al principio y se consume previamente entre los grandes bebedores, quedándonos a nosotros el triste consuelo de la cortina ${ }^{, 52}$.

Mientras tanto, los despachos telegráficos daban cuenta de que la situación de Fez era extremadamente alarmante y de que también se incrementaba la excitación a orillas del Kert, donde los cabileños pretendían emular a los sublevados contra las tropas galas ${ }^{53}$.

El gobierno de Canalejas, ante toda la avalancha de comentarios sobre la marcha de las negociaciones hispano-francesas, optó por desautorizar, al terminar abril de 1912 , todas las noticias particulares hasta entonces publicadas ${ }^{54}$. Sin duda, este gesto constituye un buen ejemplo de cómo la opinión pública puede, y consigue, amedrentar a una administración cuando los intereses de la diplomacia están en juego. La rebeldía marroquí era, lógicamente, la contestación a la firma del Tratado entre Francia y Hafid. El Sultanato había perdido la poca independencia que conservaba y Hafid se veía forzado a abdicar ${ }^{55}$, mientras que el partido colonialista francés obtenía el reconocimiento a su labor con el nombramiento de Lyautey como Residente General ${ }^{56}$.

Las conversaciones entre España y Francia, por consiguiente, habían entrado en su recta final y Meneu se apresuraba a divagar sobre el criterio conveniente para la delimitación de zonas: atento a los accidentes geográficos antes que a la división en cábilas. Aunque no justificaba demasiado su razonamiento, limitándose al empleo de criterios historicistas, el catedrático sentenciaba que las regiones de Gomara y Yebala eran indiscutiblemente áreas de acción española ${ }^{57}$.

\footnotetext{
52 "Argos": "Madrid al día. Final de la comedia", El Adelanto, no 8.535, 12 de abril de 1912, p. 1.

53 "Interino": "Información telegráfica de El Adelanto", El Adelanto, no 8.541, 19 de abril de 1912, p. 3; "Interino": "Información telegráfica de El Adelanto", El Adelanto, no 8.544, 23 de abril de 1912, p. 3; "Interino": "Información telegráfica de El Adelanto", El Adelanto, no 8.561, 14 de mayo de 1912, p. 3; "Interino": "Información telegráfica de El Adelanto", El Adelanto, no 8.570, 24 de mayo de 1912, p. 3; "Interino": "Información telegráfica de El Adelanto", El Adelanto, no 8.575, 30 de mayo de 1912, p. 3.

54 "Argos": "Madrid al día. Estatuas y bandera", El Adelanto, no 8.547, 26 de abril de 1912, p. 1.

55 "Muley Hafid quiere abdicar", El Adelanto, no 8.566, 8 de mayo de 1912, p. 2; "El Mokri en desgracia", El Adelanto, no 8.659, 6 de septiembre de 1912, p. 2. Hafid era remplazado por Yussuf.

56 "Los sucesos de Fez. Un síntoma", El Adelanto, no 8.548, 27 de abril de 1912, p. 2; "El Residente General de Francia en Marruecos", El Adelanto, no ${ }^{\circ} .553,4$ de mayo de 1912, p. 2.

${ }^{57}$ Pascual Meneu: "Las negociaciones franco-españolas", El Adelanto, $\mathrm{n}^{\mathrm{o}} 8.562,15$ de mayo de 1912, p. 1.
} 
En cambio, para "Un Cónsul”, la región que, sin duda, planteaba más conflictos era el Rif. Aunque debido al silencio diplomático reinante, poco más se atrevía a pronosticar $^{58}$. En otro editorial sí se aventuraba a efectuar un balance sobre los demás puntos en litigio entre españoles y franceses: en primer lugar, en el valle del Uarga se había procurado, originalmente, una división natural de los terrenos, pero debido al desconocimiento de su cartografía, se descartó esta opción. Se había pensado entonces en un reparto de cábilas, pero como la superficie de una de ellas igualaba a todas las restantes unidas, los trabajos de demarcación fronteriza fueron al fin encargados a una comisión y se esperaba aún su resultado.

En segundo término, se anticipaba que el clero francés intervendría de modo exclusivo en su zona. Puesto que semejante disposición iba en perjuicio de los franciscanos españoles, hasta entonces los únicos autorizados por el Vaticano para emplearse como misioneros, a España se le prometía una futura concesión. Pero no se precisaba cuál.

Al mismo tiempo, "Un Cónsul” lamentaba lo sucedido en Fez y el drama que ahora sufrían las tropas francesas: "Desgraciadamente, el Barranco del Lobo reaparece en todos los rincones de Marruecos, y ojalá que los acuerdos firmes, los pactos hoy a terminar, obliguen a una acción común que nos libre de tales desastres, siquiera, ya que nos cueste tanto y tanto la aventura, libremos la sangre generosa de nuestros valientes ${ }^{, 59}$.

Únicamente estas dos colaboraciones de "Un Cónsul" sobre la cuestión marroquí se publicaron en El Adelanto. Si bien es cierto que carecieron del carácter técnico que, por costumbre, caracterizaba los escritos de Meneu (aunque nosotros omitimos sus retahílas de ciudades, ríos y puntos cardinales que acompañaban a sus disquisiciones

\footnotetext{
58 "Un Cónsul”: "Algo sobre las negociaciones franco-hispanas", El Adelanto, n 8.571, 23 de mayo de 1912, p. 1.

59 "Un Cónsul": "Las negociaciones franco-hispanas II", El Adelanto, n 8.581, 6 de junio de 1912, p. 1. Como nota curiosa, debemos señalar que, en fechas similares, "Argos" ya reflexionaba sobre las obligaciones que se derivarían para España del Acuerdo hispano-francés. Canalejas iba a necesitar mucho respaldo popular para emprender un plan militar, civil y colonizador en Marruecos. Por este motivo, su política ante los nacionalismos era instrumentalizada al servicio de su política africanista. Y de ahí, su urgencia por aprobar la ley de Mancomunidades. Ésta era calificada de "prenda material y legal" para satisfacer a los nacionalistas catalanes y evitar la repetición de dramáticos sucesos como los de la Semana Trágica. En este editorial se percibía cierta admiración, incluso envidia, hacia la capacidad de movilización política de aquella región, pero prevalecía el reproche: "Indiscutible es la hegemonía catalana sobre las demás regiones, incluso la central; años hace que nos subyuga con imperio, que decide nuestro destino, que empuja o detiene las grandes resoluciones concernientes al Estado. Si con el reconocimiento de su autonomía y de su poder opta por la República o por la Monarquía, monárquicos o republicanos seremos todos". Véase "Argos": "Madrid al día. Lo que Cataluña quiera...", El Adelanto, no 8.607, 6 de julio de 1912, p. 1 .
} 
geográficas), fueron probablemente los trabajos con un tono más ponderado de entre los publicados por la prensa local salmantina en los momentos previos a la fijación del Protectorado español. Además, este colaborador fue el primer columnista que abogó públicamente por la cooperación hispano-francesa en el país africano, sobreponiéndose al clima de opinión tan crispado, lleno de rencores acumulados, que imperaba en la prensa local. Lo hizo trece años antes de que, efectivamente, se produjese la operación anfibia de Alhucemas. Todo un hito: no era sencillo preconizar el entendimiento en aquellas circunstancias. Al contrario, lo habitual era que ambas potencias se alegrasen de los contratiempos y reveses experimentados por el otro ${ }^{60}$.

De hecho, en el mismo diario, a los pocos días, José Sánchez Rojas volvía a recordar que: "Francia ha compuesto toda una literatura para injuriarnos. Sus periódicos nos lo demuestran todos los días. No ha procedido nunca de buena fe con nosotros $"$ "61. Y cierta satisfacción se impuso entre los miembros de la redacción liberal cuando se supo que las tropas del país vecino debían hacer frente a una nueva revuelta en Mazagán ${ }^{62}$.

A punto ya de firmarse el Tratado hispano-francés, habiéndose ultimado todos sus detalles, El Adelanto consideraba que éste resultaba bastante beneficioso para Francia y doloroso para España, sobre todo, por los recortes sufridos en los alrededores de Ifni y también en el área septentrional con respecto al Convenio de 1904. Quedaba, tan sólo, como consuelo la idea de que si las negociaciones se habían prolongado tanto, ello obedecía a la tenacidad de la diplomacia española ${ }^{63}$. Por otra parte, ya se empezaba a barajar el nombre de Felipe Alfau como próximo Residente General (que no Alto Comisario) de España en Marruecos ${ }^{64}$.

En la capital, simultáneamente, Eloy Montero, discípulo de Meneu, organizaba una lección en el Seminario Pontificio, ante una audiencia de lo más elitista, con el

\footnotetext{
${ }^{60}$ Para abundar en esta idea, MADARIAGA, Ma Rosa de: "El Protectorado español en Marruecos: algunos rasgos distintivos y su proyección en el presente", Anales de Historia Contemporánea, Murcia, $\mathrm{n}^{\circ}$ 23, 2007, pp. 171-182.

${ }^{61}$ José Sánchez Rojas: “Comentarios. Los franceses”, El Adelanto, no 8.619, 20 de julio de 1912, p. 2.

62 "Bajo el Protectorado. Mirando al porvenir", El Adelanto, no 8.636, 9 de agosto de 1912, p. 2; "Argos": "Madrid al día. Confusión política", El Adelanto, n1 8.652, 29 de agosto de 1912, p. 1; "Abd-el-Aziz en danza", El Adelanto, no 8.662, 10 de septiembre de 1912, p. 1. Se comentaba aquí que Francia pretendía obtener la ayuda de Abd-el-Aziz frente a un nuevo pretendiente, Muley Hiba

${ }^{63}$ Alfredo Rivera: "Información telegráfica de El Adelanto", El Adelanto, no 8.696, 19 de octubre de 1912, p. 3; 1085. Hasta el último momento, circularon rumores sobre posibles escollos alemanes ante la firma del documento: "La actualidad del Tratado franco-español", El Adelanto, $\mathrm{n}^{\circ}$ 8.706, 31 de octubre de 1912 , p. 2.

${ }^{64}$ “Alfau, Residente General de España en Marruecos?”, El Adelanto, n ${ }^{\circ} 8.668,17$ de septiembre de 1912, p. 2.
} 
propósito de explicar la misión civilizadora de España en Marruecos. La motivación, si nos guiamos por sus palabras, era ésta: “"Hallarán próxima colocación centenares de españoles que emigran a América, país menos adecuado que el Magreb para la vida de la raza española, cuya sangre y complexión es congénere a las razas arábiga, hebrea y aun berberisca que pueblan la zona de influencia española"65.

Sin embargo, y con esto concluimos el análisis de El Adelanto para esta coyuntura histórica, hubo a quien este sueño, su máxima aspiración política, se le truncó de raíz: fue éste el caso de José Canalejas, asesinado dos semanas antes de la ratificación del Convenio hispano-francés. La redacción liberal, al unísono y completamente atónita, lamentó profundamente el hecho ${ }^{66}$.

Si dirigimos ahora nuestra atención hacia El Salmantino, convertido en una publicación diaria, hemos de subrayar que este órgano presentaba también la situación de Fez y la del Sultán Hafid, a principios de 1911, como absolutamente calamitosa ${ }^{67}$. Pero su discurso, a diferencia del de El Adelanto, más allá de la mera descripción y justificación -según qué redactor- de los hechos a posteriori, animaba a la intervención española. Como testigo enfurecido de lo que consideraban exceso de parsimonia militar española, este rotativo encontraba un culpable: Canalejas se convirtió en el blanco de todos sus ataques, incapaz de hacer frente al imbatible espíritu conquistador galo.

A decir verdad, la atención que el integrismo salmantino dedicó a la sublevación popular y ocupación francesa de Fez resultó muy superior a la prestada por el diario liberal. Sobre todo, su relato adoptó un carácter mucho más persuasivo: El Sultán, que solicitaba auxilios desesperadamente, había sido apresado por grandes masas de cabileños rebeldes, insatisfechos con el trato de favor que recibía el coronel francés Mangin; por otra parte, los instructores militares extranjeros se habían visto obligados a refugiarse en una vieja fortaleza de la capital. “A.” (¿Manuel Sánchez Asensio?) aprovechaba la ocasión para comentar, desde una actitud muy incrédula, unas declaraciones del presidente del gobierno español: José Canalejas había asegurado hallarse preparado para cualquier eventualidad en Marruecos. Sin embargo, todavía

\footnotetext{
65 "Conferencia en el seminario acerca de Marruecos", El Adelanto, $\mathrm{n}^{\circ}$ 8.697, 21 de octubre de 1912, p. 1.

66 "El asesinato de Canalejas", El Adelanto, $\mathrm{n}^{\circ}$ 8.716, 13 de noviembre de 1912, pp. 1-2; "Argos": "Madrid al día. Contra el atentado", El Adelanto, n 8.718, 15 de noviembre de 1912, pp. 1-2. La decisión de Antonio Maura de retirarse de la política, al conocer el nombramiento de Romanones como nuevo presidente del gobierno, fue muy censurada por el diario liberal: "La actualidad. La retirada de Maura", $E l$ Adelanto, $\mathrm{n}^{\circ}$ 8.759, 3 de enero de 1913, p. 1; "Argos": "Madrid al día. Los conservadores", El Adelanto, $\mathrm{n}^{\mathrm{o}} 8.760,4$ de enero de 1913, p. 1.

67 "Información telegráfica. Marruecos", El Salmantino, no 253, 4 de abril de 1911, p. 3; "Gravísima situación en Marruecos", El Salmantino, n ${ }^{\mathrm{o}}$ 254, 5 de abril de 1911, p. 1; "Información telegráfica. Marruecos", El Salmantino, no 257, 8 de abril de 1911, p. 3.
} 
coleaba en el ambiente el asunto de las responsabilidades por lo ocurrido en el verano de 1909:

“¿Pero será esto cierto? También el gobierno conservador manifestaba, poco antes de estallar los sucesos de Melilla de 1909, que se hallaba preparado, y, efectivamente, se habian dado las oportunas órdenes para formar una división reforzada, que se encontrase dispuesta para marchar al primer aviso. Más cuando llegó el momento de utilizarla (...) no tenía más que la mitad del efectivo que debía presentar (...) ¿Qué no sucederá hoy cuando el gobierno, ocupado solamente en dividir al país con sus proyectos, no se ha preocupado más que de conservarse a todo trance el Poder y sólo ahora, que por haber recibido los avisos de la diplomacia, no es posible hacerse el desentendido, pretende de un golpe tenerlo todo arreglado?" 68 .

En realidad, había transcurrido más de un año desde aquellas operaciones, pero únicamente ahora se aceptaba la tesis de la incompetencia de los mandos en el envío de refuerzos al Rif. Anteriormente, lo que se había impuesto, recordémoslo, fue un discurso militarista y xenófobo, sin fisuras. "A." terminaba su editorial solicitando, en efecto, una participación más decidida en el país africano. Pero rechazaba la idea de que Canalejas fuera el hombre idóneo para ello, sobre todo, porque el terreno de combate sería más amplio que el de 1909 y acarrearía, como consecuencia, superiores sacrificios: "Mucho tememos que el discurso vago e incoloro del señor Canalejas (...) aunque adornado con patrióticas frases, sea sólo una especie de fuegos de artífico, y si el conflicto estalla, nos encuentra desprevenidos y en malas condiciones, mientras Francia tiene ya dispuestas fuerzas".

La rivalidad con Francia también continuaba siendo instrumentalizada a favor de la causa colonial. En este punto sí había coincidencia de pareceres con El Adelanto. Pero mientras que los conservadores hallaron el respaldo ideológico del integrismo en 1909, a los liberales eso siempre se les negó.

Paradójica y simultáneamente, sin embargo, también se explotaba desde el integrismo la carta contraria: el periódico se consolaba al pensar que, con la excepción socialista, los restantes partidos políticos con representación parlamentaria se dejarían persuadir sobre la conveniencia de cooperar con Francia en la búsqueda de una solución para el problema marroquí. O dicho de otro modo, no se opondrían a la tesis de que era el mandato internacional el que obligaba a España a intervenir en Marruecos ${ }^{69}$. Porque la República vecina era, en el fondo, nuestra enemiga, pero, según los tratados, nuestra

\footnotetext{
68 “A.”: “¿Será verdad?”, El Salmantino, no 259, 10 de abril de 1911, p. 1.

${ }^{69}$ En cierto modo, la crisis de Fez, en 1911, originó en la prensa local salmantina unos discursos bastante similares a los desencadenados, años antes, con motivo de la crisis de Casablanca. Pero con una salvedad: entonces Maura se negó a intervenir y secundar a Francia en Marruecos. Canalejas, en cambio, sí intervendrá, pero desafiando a nuestros vecinos.
} 
aliada. Aunque, eso sí, se esperaban compensaciones territoriales y nada de restricciones algecireñas: en la anterior campaña melillense, 8.000 soldados españoles, aseguraba algún colaborador de la casa, habían "regado con su sangre" el suelo africano para después acabar replegándose. Eso no podía repetirse ${ }^{70}$.

Ciertamente, este periódico se complacía al observar cómo ahora Canalejas había de hacer frente a la oposición marroquí. El Salmantino jamás le perdonaría al presidente su colaboración con los sucesos de 1909. Al contrario, alegaría que, para conquistar el Poder, el líder liberal había infligido un daño irreparable a España ${ }^{71}$.

El mismo columnista, "A.", aclaraba el porqué de esa herida incurable. Al tiempo que lamentaba el tradicional desinterés con el que la opinión pública salmantina -y española, por extensión-, y los efímeros gobernantes contemplaban los asuntos marroquíes, señalaba que la diplomacia se hallaba presa por el Convenio anglo-francés de 1904 y los éxitos militares de 1909 habían sido anulados por el vergonzoso Acuerdo de paz de 1910, suscrito, cómo no, por Canalejas: “Inútil sería buscar ventajas de ninguna clase; sólo abandono de derechos y soberanía es lo que en el referido Tratado se encuentra (...) ¿Podremos tener gran confianza en quien, preocupado sólo de fabricar candados y leyes de asociaciones, abandona de este modo los sagrados intereses de la Patria?"72. Con certeza, aquí se hallaba el motivo profundo de tanto odio hacia el caudillo liberal. Su política religiosa chocaba de frente con el dogmatismo de $E l$ Salmantino.

En otro par de editoriales, “A.” también comentaba que el partido colonial francés había hallado en los desórdenes marroquíes la ocasión propicia para asentarse en el Sultanato y convertirlo, definitivamente, en una extensión de sus dominios sobre Argelia y Túnez. Ésta era la idea que siempre había anidado en el pensamiento de Etiénne $^{73}$. Sin embargo, el columnista rechazaba toda la retórica de la penetración pacífica, simplemente encubridora de una acción de conquista. En su lugar, subrayaba que Canalejas debería tomar cartas en el asunto:

"España debe tomar buena nota de las ambiciones, nada ocultas por cierto, de su aliada, no permitiéndola obrar sola. Ya que se cometió la torpeza de no ver claro, a su debido tiempo, debe ahora dirigir sus pasos, para que, tan pronto como las

\footnotetext{
70 “España ante Marruecos”, El Salmantino, no 264, 18 de abril de 1911, p. 1.

71 “Quien siembra vientos...." El Salmantino, no 266, 20 de abril de 1911, p. 1. Muy interesadamente, algunos días después, este periódico reproducía unas contundentes declaraciones de Jaime de Borbón en las que se subrayaba la necesidad de aplastar a "los socialistas y amigos de Ferrer". Véase "Declaraciones de don Jaime de Borbón", El Salmantino, no 278, 5 de mayo de 1911, p. 1.

72 “A.": "Política española", El Salmantino, no 269, 24 de abril de 1911, p. 1.

73 “Información telegráfica. Marruecos", El Salmantino, no 273, 28 de abril de 1911, p. 3.
} 
circunstancias lo permitan, se celebre una nueva conferencia, en la que, rectificando alianzas, como decía elocuentemente el señor Vázquez de Mella, pueda llevar a cabo el plan que por la Geografia y la Historia le corresponde ${ }^{\text {,74 }}$.

El mensaje integrista resultaba, claro está, bastante más directo que el de $E l$ Adelanto. En verdad, ni tan siquiera necesitó asistir a la entrada francesa en Fez para preconizar un cambio de alianzas internacionales. En cambio, el diario liberal esperó hasta el desarrollo de las negociaciones conducentes a la fijación del Protectorado y se escudó, recordémoslo, en una firma de autoridad, la de Meneu.

Lamentablemente, y siempre atendiendo a las palabras de este diario, José Canalejas se estaba dejando avasallar, ya que se había limitado a alertar para una posible movilización al regimiento de infantería de Marina de San Fernando. Como señal inequívoca de la ambición conquistadora gala “A." se fijaba en la ruta seguida por Bremond hacia la ciudad santa. El general estaba atravesando el corredor de Taza, en teoría enclavado en la zona de influencia española, pero el camino más directo hacia Fez. Por descontado, la raíz de todos los males, como siempre, residía en nuestra ineptitud diplomática. A propósito de Algeciras, este autor comentaba arrepentido:

"Teníamos el Magreb a nuestras mismas puertas. La historia y la gloria de las armas nos daban en él derechos y prestigios seculares a que ningún otro país podía igualar (...) Francia podría alegar derechos en la zona occidental en que Marruecos limita con su territorio, más no en la parte Norte, ni menos en el Oeste (...) Y, sin embargo, en el Acta de Algeciras se le concedió que formara la policía, no de su zona fronteriza de Argelia, sino de los puertos del Norte y Oeste,"75.

Como cabía adivinar, la entrada del comandante galo en Fez, de manera lógica, no podía dejar indiferente a nadie ${ }^{76}$. A la par que la prensa española, en líneas generales, dirigía furibundos ataques contra aquel gobierno ${ }^{77}$, el contrabando alemán de armas también alcanzaba proporciones alarmantes ${ }^{78}$. No obstante, el avance francés por el territorio marroquí había sido lento. Ante ello, el incisivo "A.” extraía sus propias

\footnotetext{
74 “A.": "Nuestra aliada", El Salmantino, no 268, 22 de abril de 1911, p. 1.

75 "A.": "Perdiendo terreno", El Salmantino, n' 279, 6 de mayo de 1911, p. 1.

76 “Información telegráfica. Marruecos", El Salmantino, no 272, 27 de abril de 1911, p. 3; Gazteizko-Baz: "La cuestión de Marruecos", El Salmantino, n 274, 29 de abril de 1911, p. 2. El autor reflexionaba aquí sobre el fortalecimiento del nacionalismo en Marruecos (aclaremos que en la prensa de la época se empleaba este concepto, aunque hoy la historiografía cuestiona su validez), derivación de las relaciones desiguales entre los sucesivo Sultanes y Europa; Sánchez Cuesta: "Información telegráfica. Marruecos", El Salmantino, $\mathrm{n}^{\circ}$ 275, 2 de mayo de 1911, p. 3; "Información telegráfica. Marruecos", El Salmantino, n ${ }^{\circ}$ 277, 4 de mayo de 1911, p. 3.

${ }^{77}$ Sánchez Cuesta: "Información telegráfica. Marruecos", El Salmantino, no 279, 6 de mayo de 1911, p. 3; Sánchez Cuesta: "Información telegráfica. Marruecos", El Salmantino, no 280, 8 de mayo de 1911, p. 3; "Crónica de Francia", El Salmantino, no 281, 9 de mayo de 1911, p. 1; Sánchez Cuesta: "Información telegráfica. Marruecos", El Salmantino, nº 287, 16 de mayo de 1911, p. 3.

${ }^{78}$ Sánchez Cuesta: “Información telegráfica. Marruecos”, El Salmantino, no 283, 11 de mayo de 1911, p. 1.
} 
conclusiones: “¿Cómo se explica esta lentitud exagerada para socorrer a una plaza que de un momento a otro se esperaba cayera en poder del enemigo levantado en armas? (...) ¿No parece la acción francesa actual más propia para asegurar el territorio para el día de mañana que una expedición que tiene necesidad de llegar pronto al punto de su destino?"79. A ciencia cierta, en el pensamiento de este columnista anidaba la idea de que Francia había dramatizado lo acontecido en Fez para satisfacer sus ambiciones territoriales; pero también con el objeto de poder legitimar ante su opinión pública el avance. Apenas transcurridos dos días, “A.” tomaba otra vez la pluma para reconocer:

"El pleito marroquí comienza a preocupar hondamente. Por todas partes se oye con frecuencia hablar de él (...) Se comprende que así sea. Cuando una nación tiene intereses importantes, juntamente con derechos y aspiraciones seculares en un Estado o territorio vecino, y ve de pronto disiparse todos sus ensueños por incuria de sus gobiernos y por el golpe de audacia de una nación que, llamándose amiga y aliada, se lo arrebata (...) ¿Cómo podrá permanecer impasible? "80.

En esta ocasión, seguidamente, “A.” dirigía su atención al Tratado fallido de 1902. De haberse firmado éste, la capital del Sultanato habría quedado incluida en la zona de influencia española. Además, la presencia francesa en Marruecos sería, forzosamente, menos dominante. Pero no fue ratificado porque "podría decirse que las ventajas obtenidas estaban en razón inversa de los derechos, colocándonos al fin entre dos Francias, que era lo que a todo trance quería evitarse. Nuestro interés estaba no en obtener un trozo de territorio, sino en alejar las armas francesas de Marruecos". Sin embargo, el Convenio de 1904 había resultado significativamente peor: nuestra zona de influencia se había visto muy reducida. Pero, además, carecía de valor estratégico y no podía ser fortificada. A tenor de todo ello, "A.", muy pesimista, concluía: "Hemos laborado por Francia (...) Nosotros hemos desbrozado el camino con nuestra alianza, hemos procurado y facilitado el reparto y (...) hemos dejado a Francia la casi totalidad del imperio".

La eterna cantinela de la incompetencia de los diplomáticos españoles latía como uno de los argumentos estelares del discurso del diario integrista. A la espera de que mayores refuerzos franceses llegasen a $\mathrm{Fez}^{81}$, en las plazas de soberanía española empezaban a registrarse algunas señales de inestabilidad: en Melilla se produjeron

\footnotetext{
79 “A.": "Hacia Fez”, El Salmantino, no 291, 20 de mayo de 1911, p. 1.

80 "A.": "El Convenio de 1902", El Salmantino, no 292, 22 de mayo de 1911, p. 1.

81 "Información telegráfica. Marruecos", El Salmantino, no 288, 17 de mayo de 1911, p. 3; "Información telegráfica. Marruecos", El Salmantino, no 290, 19 de mayo de 1911, p. 3; "Información telegráfica. Marruecos", El Salmantino, n 293, 23 de mayo de 1911, p. 3.
} 
algunos altercados con los moros; en Ceuta, corrían rumores sobre la próxima ocupación de Sierra Bullones $\mathrm{y}^{82}$, además, Alfau, estaba ocupando algunas posiciones aladeñas ${ }^{83}$.

Marruecos copaba, desde luego, toda la actualidad informativa y los recelos del integrismo hacia Canalejas eran infinitos ${ }^{84}$. Curiosamente, "Argos" también desconfiaría del presidente, pero por motivos diametralmente opuestos: le achacó una excesiva ambición intervencionista, que no falta de resolución. Los murmullos sobre una inminente crisis gubernamental eran, además, continuados porque la violencia obrera, de nuevo, estaba alcanzando cuotas preocupantes. Contrariando sus intereses, el diario integrista se veía en el trance de admitir que el momento no era el idóneo para semejante cambio.

En una brillante demostración de cinismo, un columnista de la casa apelaba al Acta de Algeciras y a la necesidad de cumplir con las obligaciones asumidas entonces, garantizando el orden en Marruecos. Ante posibles sectores descontentos, la solución propuesta era muy simple: “Canalejas continuará gobernado, con o sin el asentimiento de la opinión y de las Cortes. Para la primera prepara el máuser y para las segundas, el cerrojazo" ${ }^{\prime \prime 5}$.

Desde la redacción de El Salmantino, inmediatamente se adujo la urgencia de proseguir hasta Tetuán: en primer lugar, para acabar con la situación de intranquilidad en que vivía sumida aquella región. Pero, sobre todo, porque aunque las declaraciones oficiales francesas apuntaban a que sus tropas sólo permanecerían en la capital cinco semanas ${ }^{86}$, el órgano integrista no le otorgaba ningún crédito a éstas. Por tanto, España también debía exhibir una actitud resuelta en el país africano ${ }^{87}$.

El Salmantino soñaba con una intervención decidida al sur de Tarifa, libre de cortapisas parlamentarias $^{88}$. Y, en efecto, cuando se produjo el desembarco español en Larache, el 8 de junio de 1911, y seguidamente en Alcazarquivir, este periódico se abalanzó a justificarlos:

\footnotetext{
82 "Información telegráfica. Marruecos", El Salmantino, no 284, 12 de mayo de 1911, p. 3.

83 “Información telegráfica. Marruecos", El Salmantino, no 294, 24 de mayo de 1911, p. 3.

84 “Sobre Marruecos", El Salmantino, n’ 286, 15 de mayo de 1911, p. 1.

85 "No puede haber crisis", El Salmantino, no 287, 16 de mayo de 1911, p. 1.

86 “Información telegráfica. Marruecos", El Salmantino, no 296, 27 de mayo de 1911, p. 3. Además, Alfau había efectuado ante los periodistas unas declaraciones muy duras y contrarias al bajá de Tetuán, que servían para anticipar la ocupación de esta ciudad: "Información telegráfica. Marruecos”, El Salmantino, $\mathrm{n}^{\circ} 287,16$ de mayo de 1911 , p. 3.

87 "Los franceses en Fez", El Salmantino, no 298, 30 de mayo de 1911, p. 1.

88 “El cerrojazo", El Salmantino, no 309, 12 de junio de 1911, p. 1.
} 
“IImprudencia, España? (...) Ha sido preciso que en Larache se produjeran graves desórdenes y que algunos súbditos españoles fueran muertos y martirizados desalmadamente por los feroces cabileños, para que el gobierno se determinara a mandar a dicha localidad tres compañías de infantería (...) Si esta modesta iniciativa, reclamada con imperio por las circunstancias de Alcazarquivir, ha despertado de tal modo las suspicacias y el recelo de Francia, ¿quiere decirnos Le Temps hasta qué punto debiéramos nosotros haber elevado la alarma y la protesta, al ver que las tropas francesas cruzaban el imperio?" 89 .

Pero ésta no fue la única embestida del órgano integrista contra los comentarios de la prensa francesa. La redacción, como ya hiciera en el pasado, siguió optando también por el recordatorio de los tratados. En esta ocasión, por el de septiembre de 1905, aquel viejo arreglo que había pasado por completo desapercibido en el momento de su ratificación. Un redactor anónimo aseguraba que este documento derogaba el Tratado de 1904 y establecía para Marruecos un régimen de absoluta igualdad, "dándose a entender que, a pesar de lo que se pactara en Algeciras, Francia y España respetarían cuanto pudieren, dicho Tratado" ${ }^{90}$. Sin embargo, sostenemos que este desesperado intento por escudarse interesadamente en un Acuerdo, cuando de ordinario el periódico desacreditaba a los diplomáticos y sólo se conocía el contenido del pacto de 1904 por filtraciones, de nada servía para hacer frente ante el recurso a la fuerza bruta.

A Alemania, asimismo, también le desagradó la intervención militar española ${ }^{91}$. Pero su respuesta, ya lo sabemos, fue bastante más allá de la simple difamación a través de la prensa: con el envío del Panther a la bahía de Agadir, en realidad, se temió el estallido de una contienda mundial.

De todos modos, este periódico contemporizaba abiertamente con el proceder germano: "Alemania ha declarado de una manera oficial que el envío del cañonero Panther a Agadir no obedece al deseo de obtener compensaciones semejantes a las ventajas de Francia y España en Marruecos, sino de ejercer el derecho de protección que en aquellos territorios le corresponde para con las casas y establecimientos alemanes $" 92$. Incluso, la redacción llegaba a contemplar como más próxima que nunca antes una alianza entre España y Alemania ${ }^{93}$. Sus dardos envenenados continuaban dirigiéndose contra Francia. A esta potencia se le acusaba de falta de coherencia, ya que ahora no se le oía tanto como cuando España tomó Larache y Alcazarquivir:

\footnotetext{
89 “Los asuntos de Marruecos", El Salmantino, no 311, 14 de junio de 1911, p. 1.

90 "El Tratado secreto", El Salmantino, no 314, 19 de junio de 1911, p. 1.

91 “Información telegráfica”, El Salmantino, no 319, 24 de junio de 1911, p. 3.

92 “Información telegráfica. Marruecos”, El Salmantino, no 326, 4 de julio de 1911, p. 3.

93 "Información telegráfica", El Salmantino, no 327, 5 de julio de 1911, p. 3. El Salmantino también alegaba que, con la excepción inglesa, la opinión mayoritaria europea apoyaba el proceder alemán: "Información telegráfica", El Salmantino, n 319, 24 de junio de 1911, p. 3.
} 
"Francia, que sin tregua nos ha combatido por haber realizado la delegación de Europa, de restaurar la tranquilidad en Larache y Alcazarquivir, debiera hoy, si no organizar sus Ejércitos por imponer a su vecina Alemania el respeto a los acuerdos internacionales, cuando menos compelerla a que sus fuerzas se reembarcasen desapareciendo de las aguas de Agadir el crucero que las transportó porque la nación germana por la Conferencia de Algeciras, carece de facultades para intervenir en Marruecos.

Pero no lo hará, porque Alemania, el año 1870, al llegar hasta París, demostró a Francia su superioridad, y si por este incidente intentara en el presente momento llegar al casus belli, también conoce que se reproducirá la obra de hace cuarenta años "94.

Las conversaciones para llegar a un entendimiento serían larguísimas. Pero $E l$ Salmantino se resistió a creer que la diplomacia alemana fuese terca y tan sólo persiguiese compensaciones comerciales en los territorios del Congo y Camerún, tal y como apuntaban los periódicos galos ${ }^{95}$. Aunque a mediados de julio se ignoraba si España y Gran Bretaña serían invitadas a participar en las negociaciones, el órgano ultraconservador así lo deseaba: soñaba con una nueva conferencia internacional a la que acudir junto a Alemania. De la alianza con Francia, obviamente, no esperaba ningún fruto $^{96}$. Sin embargo, tanto Rusia como EEUU mostraron públicamente su apego hacia esta última ${ }^{97}$. Aún así, Alemania estaba plenamente convencida de que el Protocolo de Algeciras había sido vulnerado y sus reclamaciones tenían que ser atendidas ${ }^{98}$.

El "incidente Boisset" vino a perturbar más las ya tensas relaciones hispanofrancesas ${ }^{99}$. El Salmantino aprovechó para atacar a la minoría conjuncionista, capaz de respaldar al partido colonialista francés al presentar una reclamación contra la conducta del coronel Silvestre:

"Estas cuestiones internacionales deben preocupar seriamente a nuestros gobernantes e interesar a toda la nación. La prensa no deberá ante ellas hacer resonar la trompa bélica, pero si el honor de España lo requiere (...) la más elemental previsión aconseja poner bozales a los que hacen cuanto saben y pueden para crear un ambiente de debilidad indigno de nuestra raza" $" 100$.

Lo que ocurría era que precisamente esa trompeta guerrera era lo más destacado del mensaje integrista. Por eso, en otro editorial, el diario salmantino denunciaba que Canalejas desconocía el verdadero "sentir de España” ante la cuestión marroquí:

"Sepa el señor Canalejas, que para sostener incólume el honor nacional, estamos en torno suyo todos aquellos a quienes tanto ha maltratado (...) Esos republicanos,

\footnotetext{
94 "Francia ante España y Alemania", El Salmantino, no 329, 7 de julio de 1911, p. 1.

95 “Información telegráfica. Marruecos", El Salmantino, no 311, 10 de julio de 1911, p. 3; "Información telegráfica. Marruecos”, El Salmantino, n 333, 12 de julio de 1911, p. 3.

96 "Negociaciones diplomáticas”, El Salmantino, no 334, 13 de julio de 1911, p. 1.

97 “Información telegráfica. Marruecos", El Salmantino, no 334, 13 de julio de 1911, p. 2.

98 “Información telegráfica. Marruecos”, El Salmantino, no 338, 18 de julio de 1911, p. 3.

99 “Información telegráfica. Marruecos”, El Salmantino, no 340, 20 de julio de 1911, p. 2.

100 "Los enemigos interiores", El Salmantino, no 343, 24 de julio de 1911, p. 1.
} 
socialistas y ácratas (...) sólo tienen su potencia en la lengua y carecen de corazón, para cristalizar en actos sus propagandas (...) Si a los Iglesias, Lerroux, Soriano, Álvarez y hasta Azcárate, se les arranca la lengua, ese pueblo desgraciado que les corea, enmudecerá y volverá a readquirir el sentimiento de su dignidad, luego no desquiciando el discurso, no puede afirmarse que hay una gran opinión que sea opuesta a la guerra, sino que sólo son cinco desequilibrados" $" 101$.

Se trataba del escrito más insultante y violento sobre la cuestión marroquí publicado hasta el momento por el integrismo salmantino. Aunque, en el fondo, no era más que una manifestación de la impotencia e incertidumbre suscitadas por las conversaciones franco-germanas ${ }^{102}$.

Este sentimiento de frustración, con seguridad, se veía agravado porque el mes de julio estaba, de modo inevitable, asociado con algunos tristes recuerdos en la historia de España. Pero, incluso, había quien los pretendía utilizar interesadamente: “¡Combate de Santiago de Cuba, Semana Roja e infausta de Barcelona y la fatídica acción del Barranco del Lobo! (...) A la sangre de los héroes que en el Rif sacrificaron sus vidas por la patria y por la religión, se unió la de los mártires, sacrificados en la capital del principado (...) A todos dedicamos hoy un recuerdo" "103. ¿Por qué se recordaba a esos mártires? Porque lo que se pedía, entre líneas y jugando la emotividad del lector, era un cambio en la gestión de la política exterior.

No obstante, sobre todo, la decepción haría mella en esta redacción a principios de agosto, al confirmarse que Alemania únicamente pretendía una compensación territorial. La consecuencia: neutralizada esta gran potencia, Francia podría convertirse en la dueña de Marruecos. De todas formas, cualquier reproche hacia el káiser se disimuló en las páginas de este diario:

"Alemania ha demostrado que lo que le interesaba era obtener de su eterna enemiga, a cambio de garantizarle su libertad de acción en Marruecos, la cesión territorial de alguna colonia (...) Francia, resueltamente, va a actuar desde ahora como soberana en Marruecos, contando como cuenta, con la tácita neutralidad de Europa, y nosotros, aunque sea dolorosísimo declararlo, estamos en el Magreb como viajeros que esperan pasaje de vuelta para sus lares.

A esta finalidad nos conducirá el aislamiento internacional en que hemos vivido" ${ }^{104}$.

Aún así, los recelos entre ambos gigantes no desaparecerían, aunque avanzase el diálogo. El fantasma de la guerra europea no había desaparecido por completo y Francia

\footnotetext{
101 "La voz de la patria", El Salmantino, n” 344, 26 de julio de 1911, p. 1.

102 "Información telegráfica. Marruecos", El Salmantino, no 345, 27 de julio de 1911, p. 3; "Información telegráfica. Marruecos", El Salmantino, no 348, 31 de julio de 1911, p. 3; "Información telegráfica. Madrid", El Salmantino, no 350, 2 de agosto de 1911, p. 3; "Información telegráfica. Marruecos", El Salmantino, $\mathrm{n}^{\mathrm{o}} 353,5$ de agosto de 1911, p. 2.

103 "Recuerdos", El Salmantino, no 348, 31 de julio de 1911, p. 1.

104 “Consagración de un imperio", El Salmantino, no 357, 10 de agosto de 1911, p. 1.
} 
continuaría albergando recelos sobre un posible entendimiento hispano-germano ${ }^{105}$. El Salmantino, por su parte, también seguiría perseverando en esta idea. Pero, a corto plazo, la decepción fue la sensación dominante ante el previsible entendimiento francogermano. Roberto T. Alcover lo manifestaba con mucha socarronería al escribir esto:

"Cuando sumidos en apacible modorra, sentimos hace poco las cosquillas que nos hacían las insolencias de Francia, abrimos sobresaltados los ojos, y al ver asomando en Agadir los enhiestos bigotes del káiser, exclamamos alborotados: 'Santo Dios. ¿Qué va a ser esto?' (...) iY a fe que eran bellas las perspectivas que aquellas complicaciones, al parecer inminentes, presentaban a nuestra patria! Pero a través de los bigotes del káiser dibujóse al poco una conciliadora sonrisa (...) y tranquilos, sosegados (...) nos volvimos a recostar sobre la almohada de nuestras flacas y enjutas esperanzas ${ }^{, 106}$.

Porque la triste realidad era que España, incluso, se veía impedida por Francia para ocupar, con cierto propósito de resarcimiento moral, Ifni ${ }^{107}$. Así que el diario integrista no hallaba mejor remedio que desquitarse, en primer término y volviendo a las andadas, con los diplomáticos españoles: “La mayor parte de ellos no tienen noción en absoluto de lo qué es la política internacional" ${ }^{108}$. Los abusos de Francia le resultaban, sin duda, intolerables porque suponían una abierta vulneración de los tratados $^{109}$. En segundo lugar, también endurecieron sus críticas contra el partido socialista y, particularmente, contra los participantes en el famoso mitin de Santander: "Nunca el derecho de propaganda de ideas puede dar pie a la excitación punible, a la perturbación y a la rebeldía (...) ¿Puede, siendo esto así, el señor Canalejas, dejar que Pablo Iglesias vacíe toda la bilis contra lo que es patriótico?"110.

Atropello y expoliación eran las palabras más habitualmente empleadas por $E l$ Salmantino, al finalizar septiembre de 1911, para referirse a la actitud sostenida por Francia. A punto de reanudarse las conversaciones con ella, se temía lo peor:

"Las negociaciones que mantuvimos con Francia a principios del pasado verano, sobre la legitimidad del derecho que tenemos para posesionarnos de Larache y Alcazarquivir, inopinadamente fueron interrumpidas por la sobreveniencia del incidente suscitado por Alemania (...) Concretando la República sus aspiraciones a la soberanía de Marruecos, ha conseguido que Alemania le reconozca un protectorado (...) Suponiendo que Francia quiera ejercitar ya su protectorado, obligándonos a reintegrar al imperio

\footnotetext{
105 "Información telegráfica. Madrid”, El Salmantino, no 363, 18 de agosto de 1911, p. 2; “FFrancia, amiga!", El Salmantino, no 376, 2 de septiembre de 1911, p. 1.

${ }^{106}$ Roberto T. Alcover: "Durmiendo", El Salmantino, no 362, 17 de agosto de 1911, p. 1.

107 “¿Responderán los hechos a las palabras?”, El Salmantino, n 377, 4 de septiembre de 1911, p. 1.

${ }^{108}$ Cirici Ventalló: "España ante el problema internacional", El Salmantino, no 379,6 de septiembre de 1911, p. 1.

109 "Conversaciones internacionales", El Salmantino, no 382, 11 de septiembre de 1911, p. 1.

110 "Información telegráfica. Madrid", El Salmantino, no 353, 5 de agosto de 1911, p. 2; A. de Mirabal: "Labor antipatriótica", El Salmantino, no 371, 28 de agosto de 1911, p. 1; A. Xaulín: "Crónica de Alemania", El Salmantino, nº 396, 27 de septiembre de 1911, p. 1.
} 
el territorio fecundado por la sangre de nuestros soldados (...) podemos oponer en la esfera del derecho el mandato que recibimos de todas las potencias ",111.

Para combatir tan descorazonador horizonte en Marruecos, el redactor lleg aba a plantear un remedio novedoso: "el de unirnos al elemento musulmán e indígena para combatir los planes conquistadores de nuestra eterna enemiga". En otras palabras, el periódico apostaba por el fomento del contrabando.

Quizás, también al contemplar tan lamentable horizonte, El Salmantino consideró que había llegado el momento, en octubre de 1911, de instruir a la opinión pública sobre la gestación del problema marroquí y la rivalidad internacional desatada a su costa. Su reacción, otra vez, fue algo más precoz que la de El Adelanto (las colaboraciones de Meneu databan ya de 1912). Para el integrismo, el nuevo Convenio franco-alemán anularía todos los acuerdos previos y España sólo podía posicionarse de una forma: rechazando la idea de un protectorado exclusivamente francés sobre Marruecos:

"Las negociaciones que en breve se plantearán deben recaer sobre nuevos puntos de vista, dejando a un lado todos los Acuerdos públicos y secretos del año 1904 y 1905, porque éstos se relacionan con la penetración pacífica inventada por Francia, pero no con las pretensiones claras y manifiestas del gobierno de París hacia el Protectorado de Marruecos, que de ninguna manera podemos reconocer (...) Si para reconocer su protectorado, Francia ofrece compensaciones a Alemania, prepárese también para concederlas a las demás potencias signatarias de Algeciras y mucho más a España, que tiene en Marruecos la base de su porvenir e independencia y derechos reconocidos,"112.

Mientras que Alemania demostraba mucha firmeza en las negociaciones ${ }^{113}$, Francia era un país lleno de resentimiento:

“iPerder, en plena paz, un tercio del Congo! Es para Francia dolorosa amputación que subleva los ánimos (...) Si Francia se resiste a dar la proyectada compensación, Alemania pedirá su parte en Marruecos.

$Y$ he aquí por donde Francia, que precipitó su excursión a Fez para absorber Marruecos, habrá cometido el inmenso yerro para su política de precipitar el reparto" $" 114$.

Además, la república también era acusada de practicar el contrabando para perjudicar a los españoles en Marruecos ${ }^{115}$.

La tregua franco-alemana finalmente se selló el 4 de noviembre de 1911. Más que el interés por los pormenores de la misma, a este periódico le preocuparon

\footnotetext{
111 “Los pourpalers franco-españoles", El Salmantino, n’ 398, 29 de septiembre de 1911, p. 1.

112 "Gestación del problema marroquí", El Salmantino, no 411, 14 de octubre de 1911, p. 1.

${ }^{113}$ A. Xaulín: "Crónica de Alemania", El Salmantino, no 418, 23 de octubre de 1911, p. 1.

114 "Francia y Alemania", El Salmantino, no 417, 21 de octubre de 1911, p. 1.

115 "Las armas de los rifeños", El Salmantino, no 419, 24 de octubre de 1911, p. 1.
} 
sobremanera sus derivaciones para España. Curiosamente, el encargado de presentar las mismas ante la opinión pública fue el profesor Meneu.

Aunque también este diario publicó muy tempranamente un excelente artículo de "A." sobre el asunto. En su opinión, los propósitos que Francia albergaba respecto a España eran pérfidos y no se podían creer ingenuamente sus promesas de amistad ni en su voluntad de entendimiento:

"Los que a diario pretenden ultrajarnos, (...) los que publican jubilosos con gruesos caracteres, imaginarios desastres de nuestro Ejército, (...) los que solos, sin más que dirigir una nota a España, tan encargada como ellos de la policía en Marruecos, pisotean el Acta de Algeciras, permaneciendo en Fez con fútiles pretextos (...) quieren romper los tratados y pretenden que les cedamos nuestra parte en Marruecos a cambio de quedarnos con un poco de lo que ya antes nos correspondía",116.

Pero volviendo a Meneu, en su primera colaboración para este periódico, el catedrático divagaba sobre los orígenes de la crisis de Agadir e insinuaba que éstos se hallaban en la negativa francesa a permitir el amarre de un cable germano en Rabat. Por otro lado, los límites de las futuras zonas de España en Marruecos también eran puestos en entredicho: los del área norte, por su indefinición; y lo del sur, por considerarse que iban a ser tratados como moneda de cambio por parte de Francia ${ }^{117}$.

En una segunda contribución periodística, Meneu ahondó en las acotaciones de la región sur marroquí, que se cedería a España con objeto de garantizar la soberanía sobre las islas Canarias ${ }^{118}$. Pero, sin duda, fue su tercera aportación al periódico integrista la más interesante, debido a su agresividad. España perdería gran parte de Guinea y el catedrático comentaba: "Queda atada al carro triunfal de Francia y al menosprecio de Alemania, que no puso las garras de sus reales águilas en Agadir para amparar a la nación de los Reyes Católicos, sino para hacer su negocio"119.

Al hacerse público, ipor fin!, el articulado de los Convenios de 1904 y $1905^{120}$, el sentimiento de desazón en el rotativo integrista aumentó. Francia estaba viendo hecho realidad su sueño a costa de aplastar derechos reconocidos a España. La redacción se fustigaba aún más recordando el fallido pacto de 1902 , la eterna oportunidad perdida ${ }^{121}$.

\footnotetext{
116 “A.": "Nuestros buenos amigos los franceses", El Salmantino, no 428, 4 de noviembre de 1911, p. 1.

${ }^{117}$ Pascual Meneu: "La cuestión de Marruecos", El Salmantino, no 425, 31 de octubre de 1911, p. 1.

118 Pascual Meneu: "La cuestión de Marruecos (II)", El Salmantino, no 428, 4 de noviembre de 1911, p. 2.

${ }^{119}$ Pascual Meneu: "La cuestión de Marruecos (III)", El Salmantino, no 430, 7 de noviembre de 1911, p. 1.

120 "El Tratado de 1904”, El Salmantino, no 431, 8 de noviembre de 1911, p. 3; Jules Cambón: "España y Francia. Otro Tratado secreto", El Salmantino, no 435, 13 de noviembre de 1911, p. 1. También El Salmantino publica el último texto franco-alemán: "El Acuerdo franco-alemán. El texto del Tratado", El Salmantino, $\mathrm{n}^{\circ}$ 437, 15 de noviembre de 1911, p. 1.

121 “A.”: "Dos políticas”, El Salmantino, no 442, 21 de noviembre de 1911, p. 1.
} 
Y, de nuevo, descargaba culpas sobre los profesionales de la diplomacia porque "tienen abandonada su misión con la aquiescencia y consentimiento del gobierno" ${ }^{\text {122 }}$. Por otro lado, lamentaba también el que Francia se sintiese ahora legitimada para revisar las cláusulas del Tratado de 1904 referidas a Tánger ${ }^{123}$.

$\mathrm{Y}$ es que con el precedente del entendimiento franco-germano, las conversaciones hispano-francesas no podían marchar por buen rumbo. Las exigencias francesas resultaban desmesuradas. Así que la prensa francófoba animaba a la ruptura de las negociaciones ${ }^{124}$. Para El Salmantino, todo ello no era más que la confirmación de sus más terribles e iniciales sospechas: Alemania había sido la triunfadora en el conflicto internacional vivido y ahora Francia pretendía resarcirse a costa de España. Sin embargo, por primera vez, la actitud de José Canalejas merecía su completa aprobación: "Ni una pulgada de terreno cederé a Francia, ha dicho el señor Canalejas, como compensación territorial, porque España se ha atenido en su campaña de penetración al mandato que Europa le confirió"125.

Meneu, otra vez, se encargaba de presentar ante la opinión pública salmantina los pormenores de estas conversaciones diplomáticas. Como de costumbre, lamentaba los recortes que sufriría España y, sobre todo, las frustradas aspiraciones sobre Tánger y los regateos franceses en el río Sus ${ }^{126}$.

Firmado el Convenio franco-marroquí para el establecimiento del Protectorado, en marzo de $1912^{127}$, las negociaciones franco-españolas entraban, ya se ha apuntado, en su recta final. Y se empezaron a hacer públicos algunos detalles de las mismas: Los valles del Uarga y el Lucus quedarían divididos entre ambos países ${ }^{128}$; en Ifni, España efectuaría enormes concesiones con respecto a lo pactado en 1904; Tánger y el territorio habitado por la cábila de Fahs sería internacionalizado; y, por último, cada potencia gozaría de control aduanero en sus respectivas zonas ${ }^{129}$. Además, la zona española se hallaría bajo la autoridad de un jalifa, manteniéndose la ficción de la soberanía única de

\footnotetext{
122 "Nosotros somos...", El Salmantino, no 450, 1 de diciembre de 1911, p. 1.

123 “Información telegráfica. París", El Salmantino, no 452, 4 de diciembre de 1911, p. 2.

124 "Información telegráfica. Las negociaciones hispano-francesas", El Salmantino, no 511, 16 de febrero de 1912, p. 2; "Información telegráfica. París", El Salmantino, no 536, 18 de marzo de 1912, p. 2.

125 "Las negociaciones hispano-francesas", El Salmantino, n 538, 21 de marzo de 1912, p. 1.

${ }^{126}$ Pascual Meneu: "Momento solemne de las negociaciones sobre Marruecos", El Salmantino, no 539, 22 de marzo de 1912, p. 1; Pascual Meneu: "Último momento de las negociaciones", El Salmantino, n 540, 23 de marzo de 1912, p. 1.

127 "Información telegráfica. París", El Salmantino, no 551, 6 de abril de 1912, p. 2; "Los sucesos de Fez", El Salmantino, $\mathrm{n}^{\circ}$ 568, 26 de abril de 1912, p. 1.

128 "Los asuntos marroquíes", El Salmantino, no 608, 13 de junio de 1912, p. 1.

129 “El Tratado hispano-francés", El Salmantino, n 653, 7 de agosto de 1912, p. 1.
} 
un Sultán. Tetuán serviría como su residencia y estaría acompañado por un Alto Comisario, encargado de coordinarse con la acción militar francesa. Por su parte, Francia tendría que otorgar prioridad a la construcción de un ferrocarril entre Tánger y Fez, si bien cada gobierno trazaría un proyecto de línea en su zona respectiva ${ }^{130}$. La seguridad de las fronteras figuraba como una prioridad absoluta e, incluso, se reconocía la posibilidad de traspasar los márgenes territoriales en caso de necesidad. A lo que el rotativo integrista añadía: "Esta cláusula es de importancia capital para evitar rozamientos entre los dos países y permitir el castigo inmediato de todos los rebeldes" $" 131$.

$\mathrm{Si}$ en verdad el diario evitaba formular un juicio sobre el Acuerdo, su diagnóstico ya era conocido: España había sido la gran perdedora de esta carrera internacional por Marruecos y era necesario trabajar con determinación para hacer realidad el sueño africanista de Eloy Montero, aquel discípulo de Meneu que, poco antes de la ratificación, pronunciaba una conferencia en el Seminario Pontificio a propósito de los derechos españoles al Sur de Tarifa ${ }^{132}$.

Eso sí, transcurrida una semana de la firma, la redacción confesaba que había precisado un tiempo de reflexión para entender la trascendencia del pacto. Ante el “entusiasmo desbordante" de gran parte de la opinión pública, creía conveniente no prodigar "aplausos excesivos". La explicación aportada era sencilla: por una parte, se había derramado hasta el momento mucha sangre española y dinero en el territorio africano; por otro lado, el Tratado era muy impreciso en cuestiones referentes a las fronteras, la religión, la enseñanza, la economía o la organización militar... El motivo real del rechazo era aún más sencillo: aparte que había sido suscrito por un gobierno liberal, el Convenio confería más competencias a Francia en Marruecos que a España ${ }^{133}$.

De todos modos, el integrismo quedaría conmocionado al conocer el asesinato de Canalejas. Aunque no se desviaría de su discurso habitual, aquél que censuraba el exceso de tolerancia del difunto hacia los sectores que reivindicaban la democratización del sistema de gobierno, ni un ápice: “Esas teorías gubernamentales, basadas en la no delincuencia del pensamiento y en la libertad de propaganda de ideas malsanas, traen

\footnotetext{
130 “El Tratado hispano-francés”, El Salmantino, no 654, 8 de agosto de 1912, p. 1.

131 "El Tratado franco-español", El Salmantino, no 655, 9 de agosto de 1912, p. 1.

132 "Un amante de Marruecos": "Interesante conferencia africanista", El Salmantino, no 715, 21 de octubre de 1912, p. 1 .

133 "El Tratado marroquí", El Salmantino, no 751, 3 de marzo de 1912, p. 1. El Salmantino recogió los ataques que el conservador Urzáiz dirigió hacia García Prieto, ministro de Estado, por la aprobación del Tratado. A España, afirmaba, no se le reconocía "una personalidad libre e independiente en Marruecos": "La discusión del Tratado franco-español”, El Salmantino, no 762, 17 de diciembre de 1912, p. 2.
} 
como obligada consecuencia la ejecución de actos tan reprobables como el cometido en el día de ayer por un malvado"134. Se deducía, por tanto, que Canalejas había pagado con su vida los errores en el gobierno.

Ante semejantes circunstancias, el Convenio con Francia para el establecimiento del Protectorado sobre Marruecos fue firmado por el conde de Romanones. Tan pronto como éste ocupó la presidencia del gobierno, El Salmantino no dudó en denunciar que había tomado el poder por asalto; que era un individuo repleto de ambición; y que mostraba un exceso de condescendencia con el republicanismo ${ }^{135}$.

Tan pesimista como el diario integrista y ya a modo de apunte final, La Ciudad, semanario paradójicamente continuador de El Castellano (por su tono bastante comedido, pluralismo, por la composición de su redacción y también por su existencia efímera), atribuiría, meses después, todas las pérdidas territoriales sufridas por España Tánger, la imposibilidad de fortificar la costa rifeña y la falta de comunicación directa con Río de Oro- a la pérfida influencia inglesa. Con semejantes trabas, no había duda posible, la administración del territorio iba a ser una labor muy dificultosa ${ }^{136}$.

\footnotetext{
134 "R.": "El asesinato de Canalejas", El Salmantino, no 734, 13 de noviembre de 1912, p. 1.

135 "Romanones en el Parlamento", El Salmantino, no 740, 20 de noviembre de 1912, p. 1; "Habló Romanones", El Salmantino, no 800, 3 de febrero de 1913, p. 1; "Las Cortes", El Salmantino, no 860, 12 de abril de 1912, p. 1; "Palabras de Romanones", El Salmantino, no 885, 12 de mayo de 1913, p. 1. Maura, por otra parte, mereció la reprobación de El Salmantino al retirarse de la política activa: "Todos promiscuadores", El Salmantino, no 803, 6 de febrero de 1913, p. 1.

136 “Alianzas y sus efectos", La Ciudad, nº 74, 3 de mayo de 1913, p. 2.
} 


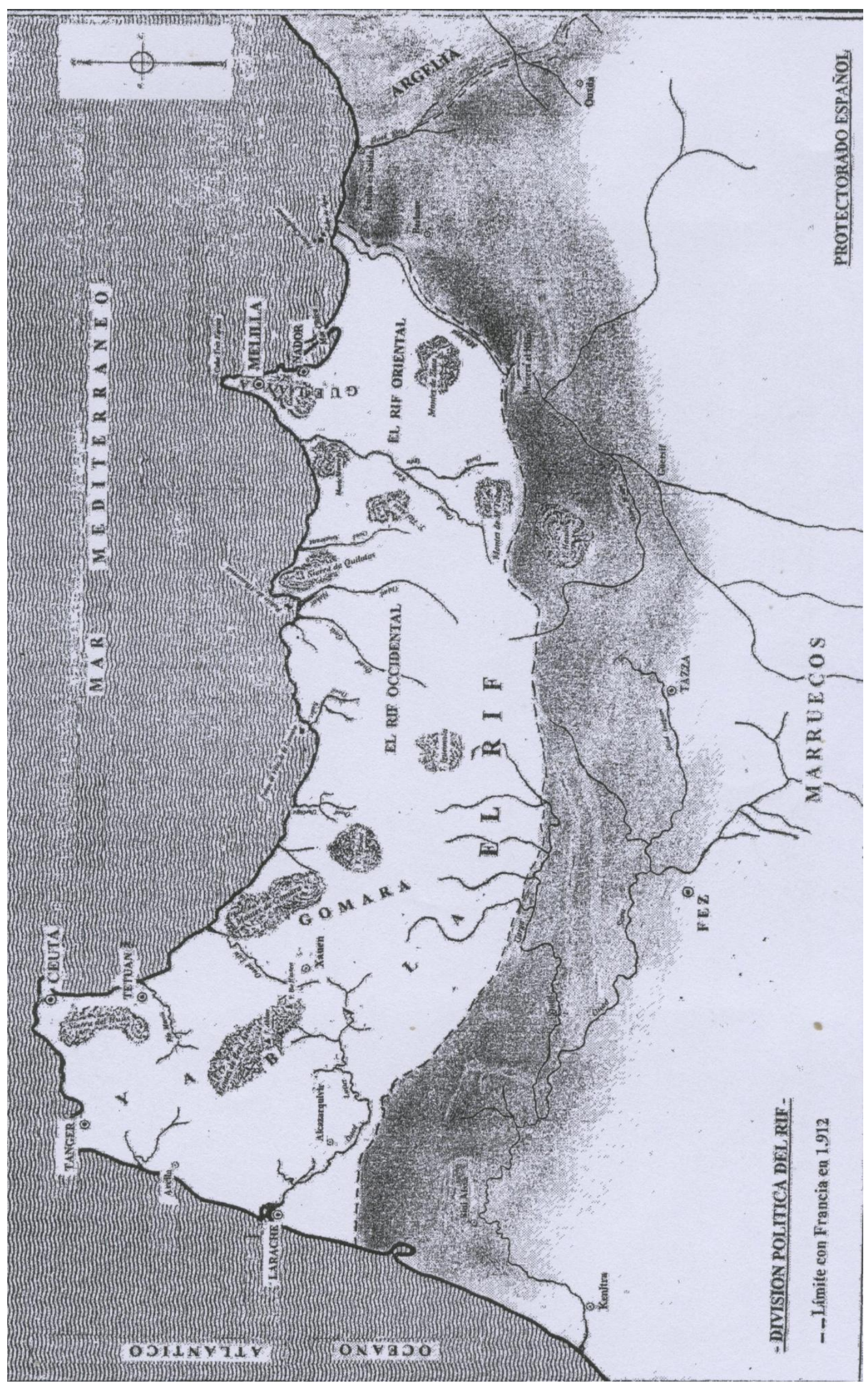

Fuente: COLOMAR CERRADA, Vicente Pedro: La forja de una tragedia (El Rif, 19201921). Madrid: CEP Editorial, 2008, pp. 4. 


\section{SALAMANCA Y LA GUERRA DEL KERT}

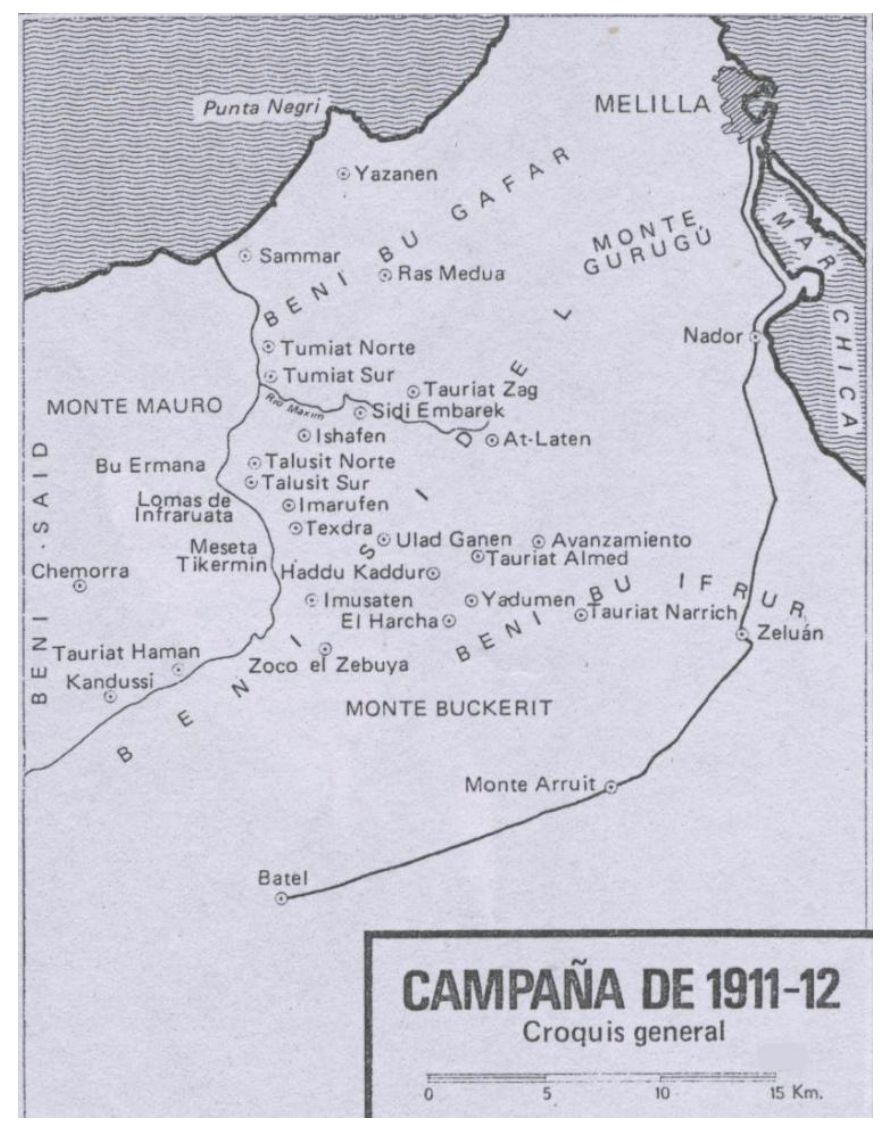

MARTÍNEZ DE CAMPOS, Carlos: Op. Cit., p. 101.

Coincidiendo con la crisis de Agadir y con las negociaciones franco-alemanas como telón de fondo, España acometió nuevos avances militares en las inmediaciones de Melilla.

En mayo de 1911, el mismo mes en el que los franceses se adueñaron de Fez y con el objeto de asegurar el control español sobre las minas de Beni-bu-Ifrur, el gobierno de José Canalejas decidió ampliar la zona de influencia española hasta las orillas del río Kert. Cuarenta salmantinos, pertenecientes al remplazo de 1911, fueron destinados a Melilla, en las mismas fechas para engrosar el regimiento de Caballería de Taxdirt $^{137}$. Y tanto en julio como en diciembre se producirían otras dos pequeñas movilizaciones de soldados locales, aunque ahora pertenecientes al remplazo de 1908 y ya conocedores del territorio africano ${ }^{138}$.

\footnotetext{
137 “Albuera y Taxdirt", El Adelanto, no 8.253, 18 de mayo de 1911, p. 2.

138 "Nuevo llamamiento. Los soldados salmantinos", El Adelanto, n' 8,447, 1 de enero de 1912, p. 2. El Adelanto siguió publicando sus cartas: "Soldados salmantinos en Melilla", El Adelanto, no 8.457, 12 de enero de 1912, p. 2; "Los salmantinos en la guerra. Gratas noticias. Una carta", El Adelanto, no 8.459, 15 de enero de 1912, p. 2; "Soldados salmantinos en Melilla", El Adelanto, no 8.469, 26 de enero de 1912, p.
} 
Si bien las operaciones para rodear el Gurugú y apoderarse definitivamente de sus accesos parecieron en su inicio sencillas ${ }^{139}$, El Mizzian llevaba semanas exaltando los ánimos cabileños contra los cristianos ${ }^{140}$, y el 30 de junio, por primera vez, una columna militar fue tiroteada.

Aunque en la campaña de 1909, los habitantes del Kert no habían tomado parte porque no se habían visto perjudicados por las ocupaciones territoriales, los hostigamientos se convirtieron en muy habituales durante el verano de 1911. Además del ataque de finales de junio, el Ejército español también pudo esgrimir, como detonante de las nuevas operaciones, el altercado que tuvo lugar el 24 de agosto, cuando un equipo topográfico fue atacado en Ras Medua, muriendo cuatro miembros del mismo. Enseguida se envió una columna de 5.000 hombres para efectuar una fallida operación de castigo. Otra expedición se emprendió el 2 de septiembre y, de hecho, los combates no cesaron hasta mediados de noviembre.

Cuando, finalmente, se dominó el Gurugú, el gobierno ordenó la repatriación de las fuerzas expedicionarias. Así que los rifeños se envalentonaron, y coincidiendo con las celebraciones navideñas, la posición de Tauriat Zag fue repetidamente atacada. Se hizo preciso, por consiguiente, el envío de más tropas y el afianzamiento de toda la región con la toma de Monte Arruit, el 18 de enero de 1912. Sin embargo, sólo con el fallecimiento accidental del cabecilla rebelde, El Mizzian, se terminó la campaña.

Las bajas españolas en esta campaña, para concluir con este somero repaso, fueron estimadas en unos 500 muertos y 1.900 heridos $^{141}$.

Desde El Adelanto, tan pronto como se produjo el ataque sobre Ras Medua, Rivera hizo notar que el miedo se había propagado como reguero de pólvora entre la opinión pública. Y por descontado, la implantación fulminante de la censura contribuyó a ello $^{142}$.

1; "Salmantinos en Melilla", El Adelanto, no 8.474, 31 de enero de 1912, p. 2. Los gestos de apoyo hacia los combatientes fueron, sin embargo, bastante escasos en este periodo: "Un donativo. Para los de Melilla", El Adelanto, no 8.691, 14 de octubre de 1912, p. 2. Se celebró una velada literaria en el teatro Bretón y el dinero recaudado, 217 pesetas, fue remitido a los soldados de Melilla; "Los excursionistas. Para los de Melilla", El Adelanto, no 8.699. 23 de octubre de 1912, p. 1. Se recaudan otras 35 pesetas coincidiendo con la celebración del centenario de Arapiles.

${ }^{139}$ Melilla aún no estaba completamente libre de la amenaza de cábilas hostiles. Si bien posiciones como la de Atlatén dominaban uno de sus principales accesos, los insumisos seguían desplazándose con notable facilidad por sus alturas y barrancos.

140 "Interino": "Conferencias telegráficas", El Adelanto, no 8.266, 2 de junio de 1911; Alfredo Rivera: "Conferencias telegráficas", El Adelanto, $\mathrm{n}^{\circ}$ 8.348, 6 de septiembre de 1911, p. 3.

${ }^{141}$ VILLALOBOS, Federico: Op. Cit., p. 189.

${ }^{142}$ Alfredo Rivera: “Conferencias telegráficas", El Adelanto, no 8.339, 26 de agosto de 1911, p. 3. 
A modo de paréntesis, conviene subrayar que si bien ésta, la censura, sólo se decretó al registrarse el mencionado incidente violento en las márgenes del Kert, de facto funcionaba desde que se desencadenó la crisis de Agadir. "Argos" así lo reconocía y, de paso, dejaba clara su repugnancia hacia las formas de gobierno adoptadas por José Canalejas y el doble rasero con el que la opinión pública lo juzgaba:

"El señor presidente del Consejo, con el tacto y la amabilidad que le distinguen, que le diferencian de don Antonio Maura, nos ha aconsejado a los periodistas una discreción y una mesura en los asuntos marroquíes propias de nuestra naturaleza, y por tanto, muy fáciles de observar.

Yo, mientras duren las actuales circunstancias -no quiero decir mientras se hallen en pie los actuales conflictos-, guardaré un silencio espartano sobre todo lo que ocurra en el próximo continente. Y hablaré de la mar, pero sin cruzar el Estrecho, puesto que siendo estrecho de suyo, ahora nos viene aún más estrecho a los periodistas españoles. He mentado a don Antonio, y no puedo por menos de pensar que si en sus días y por su orden se nos hubiera impuesto la discreción aconsejada ya referida, estaríamos trinando radicales y neutrales. Pero a don José no se le toman en cuenta sus mandatos para nada que no sea de razón; le obedecemos en todo con humildad y le quedamos agradecidos. iEs tan persuasiva su palabra, su yugo tan suave y su buena voluntad tan manifiesta! '143.

A pesar de que las tropas españolas disponían de la cooperación de Abd-elKader y también de los guelayas ${ }^{144}$, las agresiones cabileñas eran continuas; los combates de los días 29 de agosto y 7 y 8 de septiembre fueron muy sangrientos ${ }^{145}$; y, para mayor alarma social, el general Luque, desde Guerra, había ordenado al capitán general de Valencia que preparase a las tropas para una muy posible movilización ${ }^{146}$.

El horizonte marroquí pintaba, por consiguiente, muy oscuro. Quien más se apresuró a prevenir a los lectores salmantinos fue, de nuevo, “Argos". Temía una catástrofe militar de un momento a otro y debido a que ésa era la principal enseñanza de nuestra historia africana:

"Sí, señores; la opinión tiene ojos avizores y la suficiente cantidad de malicia o agudeza para no dejarse llevar tontamente al despeñadero (...) Cuando se le dice que nuestros soldados pelean tres días seguidos en un territorio hostil, lleno de naturales defensas y ofensivas posiciones aprovechadas por el enemigo, y se le asegura la destrucción de éste al propio tiempo que la intangibilidad estupenda de nuestros leales, siéntese inclinada la opinión, por santo patriotismo, a creer la especie milagrosa. Pero su experiencia, bien cimentada y afirmada en varios años de guerrear contra los moros $y$ de verlos gozando de buena salud mientras la patria sufre hondas heridas, le arguye en contrario con evidencia incontrastable ${ }^{, 147}$.

\footnotetext{
143 "Argos": "Madrid al día", El Adelanto, no 8.312, 26 de julio de 1911, p. 1.

${ }^{144}$ Alfredo Rivera: “Conferencias telegráficas”, El Adelanto, no 8.340, 28 de agosto de 1911, p. 3.

145 Alfredo Rivera: "Conferencias telegráficas", El Adelanto, no 8.342, 30 de agosto de 1911, p. 3; Alfredo Rivera: "Conferencias telegráficas", El Adelanto, no 8.351, 9 de septiembre de 1911, p. 3.

${ }_{146}$ Alfredo Rivera: “Conferencias telegráficas”, El Adelanto, n1 8.351, 9 de septiembre de 1911, p. 3.

147 “Argos": "Madrid al día", El Adelanto, no 8.352, 11 de septiembre de 1911, p. 1.
} 
Al día siguiente, 12 de septiembre, "Argos" volvía a referirse al "sarpullido" marroquí y no podía evitar el recuerdo de la catástrofe de 1909: “El grano es esa peste bélica que nos ha salido en Marruecos, que nos salió cuando Maura y se reproduce ahora con Canalejas, igualmente rojo -el grano-igualmente picante y con idénticas malas trazas. Este grano nos da mucho que rascar" ${ }^{148}$. Sobre todo, este redactor destacaba dos grandes coincidencias entre las campañas de 1909 y la actual. A saber: en primer término, el tratamiento periodístico que merecían los combates, siempre caracterizado por un tono triunfalista que despertaba muchos recelos:

"No pasan los años sobre nosotros.

Estamos en 1909.

Véase la muestra: 'Ataque audaz de los rifeños', 'Hechos gloriosos de nuestros soldados', 'Enormes pérdidas en el campo enemigo', 'Nuestras bajas son insignificantes'.

Y más: 'Grandes destrozos causados por la artillería', 'Poblados arrasados e incendiados', 'Los moros huyen a la desbandada', 'Un centenar de muertos'...

Los muertos, claro está, son todos creyentes en Mahoma. El Dios de los cristianos sigue protegiendo a los suyos y sólo permite la defunción de un católico por cada seis de los contrarios ${ }^{, 149}$.

Y el segundo paralelismo, bastante más difícil de apreciar, se refería al estilo provocador de Maura pero también de Canalejas, al margen del discurso de este último. Sobre el presidente liberal, “Argos” subrayaba mordazmente:

"Las oposiciones lo creen farruco, agresivo, idólatra de la fuerza y la represión. ¡No, cándidas oposiciones radicales! Don José amenaza para no verse obligado a pegar. Es cual un padre amoroso, que enseña a sus queridos chiquitines el flagelo pensando en traerlos al buen camino con sólo la conminación, y los cubre de besos después.

¡El igualarse a Maura! ;Oh, donosísimo disparate! Maura prometía y cumplía lo prometido. Nos prometió la revolución desde arriba, y empezó a cumplir su promesa, si bien España y Europa no le dieron tiempo para consumarla.

Canalejas promete... pero no cumple. ¿Cómo queréis comparar a don Antonio con don José?".

No debería resultar chocante una crítica tan ácida y feroz hacia Canalejas desde un diario afín al liberalismo; porque El Adelanto era un periódico de provincias y, por tanto, no tan sometido a las tiranías de la lucha partidista como los rotativos cortesanos. Ésa es una de las ventajas que nos ofrece el análisis de la prensa local. "Argos" no hacía más que ser permeable a las declaraciones de la Conjunción republicano-socialista y de su jefe, Benito Pérez Galdós, contra la guerra ${ }^{150}$.

Desde la redacción, no obstante, se intentaba tranquilizar a la opinión pública salmantina, y eso a pesar de que desde mediados de septiembre empezaban a llegar a

\footnotetext{
148 "Argos": "Madrid al día", El Adelanto, no 8.353, 12 de septiembre de 1911, p. 1.

149 "Argos": "Madrid al día", El Adelanto, no 8.357, 16 de septiembre de 1911, p. 1.

150 "Interino": "Conferencias telegráficas", El Adelanto, no 8.447, 1 de enero de 1912, p. 3.
} 
Melilla los refuerzos. Se hacía hincapié en que el enemigo moro se estaba sometiendo con facilidad, pero no faltaba el comentario oportunista: aprovechando el momento de tensión diplomática en Europa, un columnista, al barajar la posibilidad de realizar avances en el Rif, sentenciaba que "la ocasión es que ni de perlas" $" 151$. De hecho, se proyectó un desembarco en la bahía de Alhucemas para la noche del 18 de octubre. Pero, alertados los rifeños, hubo de suspenderse ${ }^{152}$.

Qué huecos tenían que resultar los mensajes que se esmeraban en llamar a la calma. Más aún durante aquellas Navidades de 1911 y tras la sangrienta jornada del 27 de diciembre ${ }^{153}$, cuando se soñaba con un canje de prisioneros entre El Mizzian y las autoridades melillense ${ }^{154}$, y cuando, de hecho, la reanudación de las sesiones parlamentarias hacía presagiar todo tipo de tensiones en el interior del país ${ }^{155}$.

La ocupación de Monte Arruit, posición hoy tan tristemente recordada, pasó incluso casi por completo desapercibida ante los ojos de la opinión pública salmantina ${ }^{156}$. Para combatir la alarma social, un combativo Meneu, salía en defensa del Ejército español y del papel vivificante de la guerra. He aquí la que consideramos su colaboración más enardecida, vehemente, en la prensa salmantina. Su pensamiento había transitado de aquella "propaganda científica" a favor del colonialismo hasta el militarismo más complaciente. E incuestionablemente, Francia y la tenacidad de sus diplomáticos habían tenido un peso determinante en la gestación de este cambio:

"Pensar actualmente sólo en los dispendios y sangre heroica que derrama la lucha, sin mirar en los beneficios momentáneos y postrimeros que la contienda bélica ha de traer, es ver con vista miope (...) Que Melilla no puede quedar encerrada en sus fortines; que Ceuta no ha de quedar embotellada o entaponada con la neutralización de Tánger y de Tetuán; que Alhucemas y Peñón de Vélez necesitan salir de sus rocas yermas, inhospitalarias, y trasladarse al interior del continente, a Axdir; que Santa Cruz de Mar Pequeña exige pronta posesión y anchuroso hinterland, por la feraz cuenca del Sus; son verdades de que depende la vida de la nación española en lo porvenir (...) ¿Por qué perdimos nuestro inmenso, rico territorio de Cuba y Filipinas? ¿Fue tan solo por la inepcia y falta de mentalidad y moralidad de nuestros políticos? (...) Más que esta gangrena fue el delirio del presupuesto de la paz, el del inocente aislamiento, el haber mirado con indiferencia el problema del Ejército de mar y tierra, cuando todas las naciones atendían preferentemente a las alianzas, a los grandes desembolsos para cruceros y acorazados, a la discreta organización del Ejército nacional sobre bases férreas y de acero en el orden material, y en el moral sobre cimientos inmovibles de justicia, equidad, en que para nada entrase en favor.

\footnotetext{
151 “Mirando al porvenir", El Adelanto, no 8.354, 13 de septiembre de 1911, p. 2.

${ }^{152}$ VILLALOBOS, Federico: Op. Cit., p. 185. Otro proyecto de desembarco en Axdir había tenido que suspenderse en septiembre de 1909. Véase BOUARFA, Mohamed: Op. Cit., p.89.

153 "La carga de la Zorrorra en Melilla", El Adelanto, no 8.455, 10 de enero de 1912, p. 2; "Desde Zeluán. Detalles de un combate", El Adelanto, no 8.456, 11 de enero de 1912, p. 1.

154 "Interino": "Conferencias telegráficas", El Adelanto, no $8.462,18$ de enero de 1912, p. 3.

155 "Castilla y las Cortes", El Adelanto, no $8.461,17$ de enero de 1912, p. 1.

156 "Interino": "Conferencias telegráficas", El Adelanto, no 8.463, 19 de enero de 1912, p. 3.
} 
La primera ventaja que nos ofrece la Guerra del Rif es la rehabilitación de nuestro Ejército ante el público propio y el extranjero, porque llegó a creerse infundadamente por muchos, que allá, en ultramar, no había cumplido con su deber (...) La finalidad de esta guerra no puede ser la posesión de las minas de Beni-bu-ifrur, asegurar su explotación, dominar Uixan, Atlatén, Arruit, que todo eso es la península de Tres Forcas, como la más pequeñas de nuestras provincias peninsulares en extensión. Todo eso ha sido conquistado como base de asegurar Melilla y de extender el dominio de España por comarcas, en que a estas horas se izaría la bandera francesa, si no hubiéramos dado los avances de 1909 y 1911, y lo que corre del actual (...) Esta guerra de 1912, como la de los años anteriores, es vivificadora del porvenir de España, y quien la contradiga es un afrancesado y reo de un delito de lesa Patria" ${ }^{\text {"157. }}$

Pero el asunto de los prisioneros mantenía en vilo a los lectores y El Mizzian se revelaba también como un duro negociador ${ }^{158}$. De los nueve cautivos, dos eran salmantinos: Ricardo Arribas y Eloy Hernández Vicente. Evidentemente, nadie deseaba que pasaran a engrosar el listado de fallecidos en el Kert, que entonces ascendía a nueve ${ }^{159}$. Por esta razón, su liberación, a mediados de febrero, fue muy bien acogida en la capital del Tormes ${ }^{160}$. De hecho, la historia de uno de ellos, la de Eloy Hernández Vicente, mereció bastante atención por parte de El Adelanto, sobre todo porque asistió al combate en Tauriat Zag y sobrevivió al cautiverio posterior, a pesar de hallarse muy gravemente herido -había recibido tres balazos-:

"Eloy Hernández Vicente es de mediana estatura, delgado, tostado el cutis (...) Habla pausadamente, sin exageraciones ni lirismos, y apenas hace comentarios sobre lo ocurrido, que relata con gran exactitud (...) Nos cogieron, nos hicieron 'piazos' la ropa y nos quitaron los gorros y los zapatos (...) Algunos nos decían: 'Paisa no tener miedo que no matar' (...) Al llegar ante El Mizzian nos desataron, nos hicieron coger de la mano y agarrados a los extremos de la cadena dos moros, que tiraban de nosotros, entramos corriendo, mientras disparaban tiros al aire.

De allí nos llevaron al encierro, que era una casucha de barro, en la que dormíamos sobre una estera.

Por la tarde nos dejaron salir a lavarnos la sangre de las heridas y luego nos dieron de comer patatas y pan de cebada (...) A los tres días, nos sacaron y celebraron una fiesta en la que estaba El Mizzian. Había un cerco hecho por millares de moros y corrieron la pólvora, disparando muchos tiros. Cuando llegamos al encierro, tres españoles que habian quedado alli, estaban llorando porque oyeron los tiros y creyeron que nos habían matado (...) Estoy muy agradecido al alcalde, que me ha dado 15 pesetas; al gobernador, que me ha dado 10; y al teniente coronel ${ }^{, 161}$.

\footnotetext{
${ }^{157}$ Pascual Meneu: "La guerra vivificadora", El Adelanto, $\mathrm{n}^{\circ}$ 8.467, 24 de enero de 1912, p. 1.

158 "Interino": "Conferencias telegráficas", El Adelanto, no 8.478, 5 de febrero de 1912, p. 3.

159 "Otro hijo de esta provincia muere en la campaña", El Adelanto, no ${ }^{\circ} 8.485,13$ de febrero de 1912, p. 2.

160 "Interino": "Conferencias telegráficas", El Adelanto, n1 8.484, 12 de febrero de 1912, p. 3; Julio Ramón y Laca: "Los prisioneros salmantinos", El Adelanto, no 8.489, 17 de febrero de 1912, p. 2.

161 "Sir-ve": "El salmantino canjeado", El Adelanto, no 8.494, 23 de febrero de 1912, p. 1; "Sir-ve": "El salmantino canjeado", El Adelanto, n ${ }^{\circ}$ 8.495, 24 de febrero de 1912, p. 1; "Eloy Hernández Vicente", El Adelanto, $\mathrm{n}^{\circ} 8.498,27$ de febrero de 1912, p. 1.
} 
Evidentemente, su resistencia era esgrimida desde la prensa local como un ejemplo de patriotismo. Y con las donaciones institucionales, sin duda, se pretendía animar a la opinión pública para que siguiera su estela.

Por otra parte, los hostigamientos de los marroquíes no cesaban -a punto de establecerse el Protectorado francés sobre Marruecos, recuérdese que la situación de Fez se tornaba desesperada y el clima insurreccional se extendía por todo el país africano- y aunque Aldave, sustituto del general Marina en Melilla, intentaba hacerles frente, ellos evitaban el combate abierto ${ }^{162}$. Al hilo de todos estos acontecimientos, "Argos", intuitivo como siempre, postulaba que España se iba a dejar arrastrar hacia una guerra de desgaste. Proseguía, además, estableciendo similitudes con la previa campaña de Melilla:

"Desde 1909 no sabíamos si la campaña de Melilla tenía carácter de campaña, de operación policíaca, de guerra formal; si habría de prolongarse indefinidamente, o terminar en un decir Jesús cuando menos lo pensáramos; si su objeto estaba limitado a castigar a unos bereberes que interrumpieron el laboreo de una minas entre francesas y españolas, o a defender nuestras posiciones seculares o a conquistar una zona de influencia cada vez mayor (...) ¿Tenemos plan definido? No hay que extremar las cosas hasta ese punto, no hay que ser exigentes; haremos lo que podamos hacer y como lo podamos hacer. La índole del terreno, la de los franceses, nuestros vecinos, y la de los moros, nuestros inquilinos, son tres índoles muy respetables, y debemos contar con ellas para ir modificando nuestro plan. ¡Plan, plan! No se hizo Zamora en una hora.

Pero ya conocemos lo principal de esa aventura: es una guerra de expansión necesaria, durará tres o cuatro años, y terminará en ventura para todos nosotros ${ }^{\text {"163 }}$.

En efecto, la ausencia de un plan de avance no sólo acarreaba complicaciones desde el punto de vista militar, sino que constituía una falta de respeto hacia la opinión pública. Consecuentemente, tanto Maura como Canalejas habían cometido el mismo pecado. Pero, por de pronto, el editorialista, B. Pallol, nuestro "Argos", terminaba su escrito cuestionando la viabilidad económica de esta conflagración, ya que "podría suceder que a la mitad del camino nos faltaran las tres cosas esenciales y precisas, según Napoleón, en toda guerra: ¡dinero, dinero, dinero!”. Su realismo, de hecho, contrastaba con el imperdonable quijotismo del que adolecían los políticos españoles y que tantos reproches merecía:

"Si hay que pelear contra molinos de viento y sufrir la rotura de las mandíbulas, bien está. Eso y mucho más merece la simpar Dulcinea de Toboso, quien no asoma por ninguna parte, ni por las señas, existe (...) No podemos retroceder... Tal es la consigna.

\footnotetext{
162 "Interino": "Conferencias telegráficas", El Adelanto, no 8.499, 29 de febrero de 1912, p. 3; "Interino": “Conferencias telegráficas", El Adelanto, no 8.505, 7 de marzo de 1912, p. 3; Interino: "Conferencias telegráficas", El Adelanto, no 8.507, 9 de marzo de 1912, p. 3; "Interino": "Conferencias telegráficas", El Adelanto, $\mathrm{n}^{\circ}$ 8.514, 18 de marzo de 1912, p. 3; "Interino": "Conferencias telegráficas", El Adelanto, no 8.516, 20 de marzo de 1912, p. 3.

163 “Argos": "Madrid al día. Nuestra misión”, El Adelanto, no 8.508, 11 de marzo de 1912, p. 1.
} 
Y yo mismo creo que no podemos retroceder (...) Y me duele en el corazón cuando hacen retiradas o repliegues, de lo cual se aprovechan los moros para saciar sus feroces instintos.

¡Dominar el Rif! ¡Infligir duro e inolvidable castigo a las tribus berberiscas! ¡Pero estamos haciendo otra cosa desde 1909! ¡Dominar a todos aquellos montaraces, sujetarlos, reducirlos, modificar su condición hasta emparentarla con la nuestra, dúctil y maleable! ¿Pero no habían quedado los señores políticos, los señores etnólogos, los señores estadistas en que tal empresa requiere centenares de millonadas en dinero contante y sonante? ¿Es que España no se encuentra en disposición de hacer tan cuantiosos dispendios? Y no habiendo terminado las negociaciones franco-españolas, por lo cual se ignora la parte del Rif que nos tocará, ¿no son esas bravatas un tanto prematuras?",164.

Únicamente a mediados de abril de 1912, por primera vez, Rivera anticipaba el fin de la campaña, ya que el harca se hallaba con sus fuerzas muy mermadas ${ }^{165}$.

Sin embargo, El Mizzian, desesperadamente, intentaba sostener la rebelión ${ }^{166}$. Con su fallecimiento inesperado terminaría la campaña ${ }^{167}$. Y mientras tanto, Francia había logrado su tan anhelado Protectorado y por la península circulaban infinidad de rumores acerca de la inmediata marcha sobre Tetuán ${ }^{168}$. En este punto, Sánchez Rojas denunciaba, embargado por la amargura, la indiferencia de la ciudadanía al escribir: "Muere El Mizzian y eso no le interesa al pueblo. Estamos pendientes de unas negociaciones difíciles con Francia, y eso tampoco logra sacar a la opinión de su quietud. ¡Torea el Gallo!”169. Había en estas palabras, desde luego, algo de exageración. Salamanca no se mostraba tan apática ante el problema marroquí como años atrás. Pero sí mucho más cansada ante la prolongación del conflicto.

El Salmantino, por otra parte, desde mayo de 1911 también denunciaba una situación anómala en los alrededores de Melilla ${ }^{170}$. Mientras que los musulmanes se ocupaban fortificando la región, Aldave solicitaba, sin éxito, refuerzos de la península y advertía a El Mizzian que si atacaba, las tropas españolas quemarían sus aduares ${ }^{171}$. Pero a finales de agosto, el periódico volvía a dar cuenta de la grave agresión sobre los miembros de la comisión topográfica que inspeccionaba las márgenes del Kert.

\footnotetext{
164 “Argos": "El problema del Rif", El Adelanto, no 8.523, 28 de marzo de 1912, p. 1.

165 "Interino": "Información telegráfica de El Adelanto", El Adelanto, no 8.534, 11 de abril de 1912, p. 3.

166 "Interino": "Información telegráfica de El Adelanto", El Adelanto, no 8.545, 24 de abril de 1912, p. 3;

"Quisicosero": "Quisicosas", El Adelanto, no 8.561, 14 de mayo de 1912, p. 1; "Interino": "Información telegráfica de El Adelanto", no 8.561, 14 de mayo de 1912, p. 3.

167 "Interino": "Información telegráfica de El Adelanto", no 8.563, 16 de mayo de 1912, p. 3.

168 "La ocupación de Tetuán”, El Adelanto, no 8.541, 19 de abril de 1912, p. 1.

169 José Sánchez Rojas: “Comentarios. El fanatismo”, El Adelanto, no 8.566, 20 de mayo de 1912, p. 1.

170 “Información telegráfica. Marruecos", El Salmantino, n 295, 26 de mayo de 1911, p. 3.

171 “Información telegráfica. Melilla”, El Salmantino, no 302, 3 de junio de 1911, p. 3.
} 
También indicaba, como hiciera El Adelanto, que la noticia había sido visada por la censura $^{172}$.

Las incitaciones de El Mizzian contra España persistirían ${ }^{173}$, y el 8 de septiembre se registró un combate particularmente duro ${ }^{174}$. Sin embargo, El Salmantino prefirió dedicar más atención al asunto del orden interior peninsular, a la huelga general de Bilbao, que al análisis de la pelea en Marruecos ${ }^{175}$. De hecho, el seguimiento que practicó de la campaña militar fue bastante deficiente. Con certeza, tal proceder fue un instrumento simple y efectivo para desgastar a Canalejas, reprochándole quiénes habían sido sus aliados políticos. Es cierto que, dos años atrás, esta publicación ya había dirigido comentarios enfurecidos contra los insurrectos barceloneses, pero era ahora cuando presentaba al país al borde de un precipicio. Curiosamente, la reacción de $E l$ Adelanto había sido la opuesta: en el diario liberal los altercados sociales de 1911 y la brutal represión subsiguiente pasaron mucho más desapercibidos que los de 1909, estando Maura en el poder. Aunque en este punto conviene también reconocer el talento propagandístico de Canalejas, su inteligente actitud ante la prensa y, en particular, al gestionar casi todos los indultos tras los sucesos de Cullera. Éstos le sirvieron para distanciarse de posibles comparaciones con Maura y con el recuerdo de la Semana Sangrienta.

Ocurrió, además, que la campaña pro-huelga de la prensa de izquierdas coincidió con la salida, a finales de septiembre, de las tropas hacia el país africano. Así que "A.”, testigo de los desórdenes, lanzó al viento la idea de que estos "cabileños del interior" actuaban en connivencia con los franceses para obstaculizar el triunfo de las armas españolas, y que, por ello, el país era objeto de escarnio en toda Europa ${ }^{176}$. Incluso, dos semanas después, a mediados de octubre, era la propia redacción integrista la que suplicaba por el mantenimiento de la censura. Así se dirigía la redacción a José Canalejas al conocerse su decisión de restablecer las garantías constitucionales:

"Al levantar la suspensión de las garantías, ha demostrado apodícticamente al país, que sus decantados amores a la opinión pública, eran alharacas pueriles para seducir a un pueblo (...) Medite un poco don José en la anormalidad reinante antes de la revolución de septiembre último y la tranquilidad que hoy se disfruta en el orden social,

\footnotetext{
172 “Información telegráfica. Melilla", El Salmantino, n 370, 26 de agosto de 1911, p. 2.

173 "Información telegráfica. Melilla", El Salmantino, no 372, 29 de agosto de 1911, p. 2.

174 “Información telegráfica. Madrid”, El Salmantino, no 381, 9 de septiembre de 1911, p. 2.

175 "La fuerza de los hechos", El Salmantino, no 391, 21 de septiembre de 1911, p. 1. Ni siquiera atendió al comportamiento de los soldados salmantinos en la campaña, limitándose a reproducir dos cartas de combatientes: Gumersindo Cornejo: "Remitido", El Salmantino, n 497, 31 de enero de 1912, p. 3; "Carta de un soldado", El Salmantino, no 522, 1 de marzo de 1912, p. 2.

176 “A.”: “Antipatriotismo", El Salmantino, no 396, 27 de septiembre de 1911, p. 1.
} 
y luego díganos si esta virtualidad no es debida a la suspensión de los derechos constitucionales (...) ¿Es que no representan nada para él la opinión neutra, ni los organismos conservador, integrista y carlista?" $" 177$.

El presidente, en efecto, tuvo que rectificar y mantener en suspenso las garantías hasta enero de 1912. En otras palabras, en el Kert se estaba dirimiendo un litigio del que dependía la vida de la nación española y por esta razón, era absolutamente preciso silenciar a la prensa del Trust. Sin embargo, otro columnista de la casa, una semana después, tomaba la pluma y escribía:

"Las noticias que se reciben de las operaciones militares que estamos realizando en África están produciendo en la opinión una ansiedad y alarma justificadísimas (...) Lo que acontece sencillamente es que el gobierno está ejecutando una acción en África ensombrecida de misterios (...) Todos sabemos que el general Luque ha ido a Melilla, pero todos ignoramos el motivo de su viaje. Y la nación que da su sangre y su dinero, ¿no tiene derecho a informarse de la misión que el ministro de la Guerra ha ido a desempeñar en el teatro de las operaciones que tan valiente y heroicamente está ejecutando el Ejército?",178.

Sin apenas disimulo, este redactor estaba justificando la violencia callejera y, sobre todo, se parapetaba en ella para deslegitimar al gobierno de Canalejas. Indiscutiblemente, un artículo semejante a éste habría sido impensable dos años atrás. Pero dando un paso más allá ahora, al finalizar octubre de 1911, resueltas las huelgas del mes previo, el periódico ultraconservador demandaba un cambio gubernamental ${ }^{179}$.

José Canalejas era, según su criterio, un gobernante débil, cuando los tiempos dictaban la preeminencia del irrebatible derecho de la fuerza. El mejor ejemplo y muy presente en la memoria de todos: "las heridas que causó a nuestra patria la rastrera ambición y sin entrañas del tío Sam" "180 . Lógicamente, esta prepotencia militar tenía que quedar demostrada en el Kert.

Aunque combates como el de Tauriat Zag, fruto de la ofensiva cabileña, la ponían por de pronto en entredicho ${ }^{181}$. En su lugar, desvelaban que la paz lograda en 1910 era, del todo, ficticia y que Francia espoleaba a los marroquíes contra España, con el objeto de desacreditarla militarmente y lograr el reconocimiento internacional de un protectorado único $^{182}$.

\footnotetext{
177 “Acuerdo funesto", El Salmantino, no 410, 13 de octubre de 1911, p. 1.

178 "El gobierno debe hablar", El Salmantino, no 416, 20 de octubre de 1911, p. 1.

179 "Inexplicable", El Salmantino, no 420, 25 de octubre de 1911, p. 1.

180 "El derecho de gentes...", El Salmantino, n1 452, 4 de diciembre de 1911, p. 1.

181 “Información telegráfica. Nuevo combate en el Rif", El Salmantino, no 469, 26 de diciembre de 1911, p. 2.

182 “Sobre Marruecos”, El Salmantino, n 472, 29 de diciembre de 1911, p. 1.
} 
A largo plazo, había que contraatacar y, precisamente, eso permitiría aunar pareceres entre el partido del gobierno y el integrismo. Muy distanciado ya de los sectores republicanos ${ }^{183}$, Canalejas terminó reconociendo públicamente la necesidad de una acción muy contundente en Marruecos ${ }^{184}$. Por primera vez, sus palabras merecieron el apoyo de la redacción, aunque no por ello se olvidaba de exigirle un plan concreto de intervención en Marruecos ${ }^{185}$. Por fortuna para las tropas españolas, El Mizzian moría poco tiempo después y el harca se descomponía ${ }^{186}$.

Concluida la guerra, El Salmantino consideraba que había llegado el momento de reafirmar su fe africanista y reflexionaba, de paso, sobre la influencia de los periódicos en el posicionamiento de la opinión pública ante el problema de Marruecos:

"Desde que el grito de guerra resonó en el Rif, no hay español que más o menos interesado en nuestros asuntos africanos no haya expuesto su juicio y haya resuelto el problema conforme a su criterio, las más de las veces hijo que la prensa diaria que saborea en sus ocios.

Es verdad que la campaña del Rif lleva mucho dinero; que la sangre española, a torrentes vertida, empapa las llanuras y montañas de aquella lúgubre región; pero no hay que trazar con negros rasgos nuestro porvenir (...) Poco españolismo lleva en su sangre quien arteramente lucha contra los entusiasmos de raza" ${ }^{, 187}$.

El discurso de El Salmantino conservaba, por tanto, su habitual monolitismo: la sempiterna guerra contra el moro definía la identidad española. El autor de este editorial terminaba afirmando, y para ello se amparaba en las palabras del senador Maestre, que en Marruecos se hallaban las tierras más fértiles del mundo y que, consecuentemente, este país ofrecía a España la oportunidad de restaurar toda su tan añorada gloria imperial.

Un mes después, en octubre de 1912, la redacción volvía a la carga e incidía en los mismos argumentos, pero utilizando la firma de un colaborador excepcional: Cándido Lobera, director de El Telegrama del Rif, era el encargado de llamar a la iniciativa privada para asentarse en Marruecos:

"Los enemigos de nuestra acción en Marruecos proclaman a los cuatro vientos que las costas y valles rifeños no valen la pena de mirarlos; pero los extranjeros lo entienden de otro modo, y hace muchos años que luchamos en el Rif, no sólo con los indígenas (...) Es de necesidad urgente, se impone de modo imperioso, excitar el celo de nuestros compatriotas, que aúnen sus esfuerzos y vengan a Melilla empresas serias (...) Salgan de su apatía capitalistas los hombres de negocios, industriales y agricultores, pues de no acudir con tiempo, de cerrar los ojos a la realidad, los que pueden contrarrestar el

\footnotetext{
183 “Información telegráfica. Madrid”, El Salmantino, no 494, 27 de enero de 1912, p. 2.

184 “Información telegráfica. Madrid”, El Salmantino, no 530, 9 de marzo de 1912, p. 2.

185 "Difícil actualidad", El Salmantino, n' 545, 29 de marzo de 1912, p. 1.

186 "Información telegráfica", El Salmantino, no 584, 17 de mayo de 1912, p. 2; "Información telegráfica", El Salmantino, no 600, 3 de junio de 1912, p. 2.

187 “Africanismo español”, El Salmantino, n 690, 21 de septiembre de 1912, p.
} 
laborantismo antiespañol, la sangre derramada por nuestro glorioso Ejército y el sacrificio de la nación, resultarán estériles" ${ }^{\text {"188 }}$.

A esto quedaba reducida la misión civilizadora que España estaba llamada a desempeñar en Marruecos: al fomento de la expansión económica.

Para "Fa-Presto", en cambio, semejante argumentación únicamente merecía desprecio. Desde La Ciudad, y ya como mero apunte final del presente epígrafe, este columnista denunciaría la hipocresía de ese pensamiento. Pero, muy curiosamente, se escudaría en nuestro pasado imperial en América para ensalzar la obra religiosa de entonces y denostar el imperialismo del presente:

"Palabra por palabra, y llamando hoy civilización a los que en los siglos XVI y XVII llamamos fe, los hechos, es decir, las guerras, quedan las mismas (...) Era, sin duda, nuestra plataforma guerrera más elevada y digna allá en la conquista de América (...) Nosotros íbamos a salvar el alma de los guaraníes, y de los aztecas y de los moztezumas, no a civilizarlos. Los engañamos, y los esclavizamos y los dejamos sin casa ni hogar, pero también destruimos la idolatría, y váyase lo uno por lo otro.

¡Civilizar! Habráse visto hipocresía semejante!

La conquista de hoy, consagración del derecho del más fuerte, como siempre, será para colonizar, para extender la posesión de la tierra, que ya es estrecha para dar de comer a los comerciantes, y a los industriales y a los hambrientos de gloria si se quiere. Pero eso no es civilizar (...) Hay que distinguir ${ }^{\text {,189. }}$.

Aunque El Salmantino también rememoró en varias ocasiones la época de la conquista americana al abordar el problema africano, lo hizo, pensémoslo, con un propósito distinto: no para denigrar las motivaciones del colonialismo contemporáneo, sino al servicio de la glorificación del Ejército español, heredero de una historia plagada de gestas; gestas que, y esto era lo importante, debían continuar.

En resumidas cuentas: una misma referencia histórica se podía emplear, interesadamente, al servicio de dos mensajes propagandísticos distintos. Pero no demasiado. Al fin y al cabo, "Fa-Presto" únicamente discutía el argumento con el que desde el integrismo se justificaba la expansión colonial, pero, desde luego, no renegaba de ésta. En cualquier caso, las opiniones publicadas en la prensa salmantina a propósito de la cuestión marroquí estaban plagadas de matices. La opinión pública salmantina, por consiguiente, no podía ser un ente monolítico.

\footnotetext{
${ }^{188}$ Cándido Lobera: "En el Rif. Necesidad urgente", El Salmantino, no 709, 14 de octubre de 1912, p. 1.

189 "Fa-Presto": "O civilizarse o morir", La Ciudad, n 6, 13 de enero de 1912, p. 2.
} 


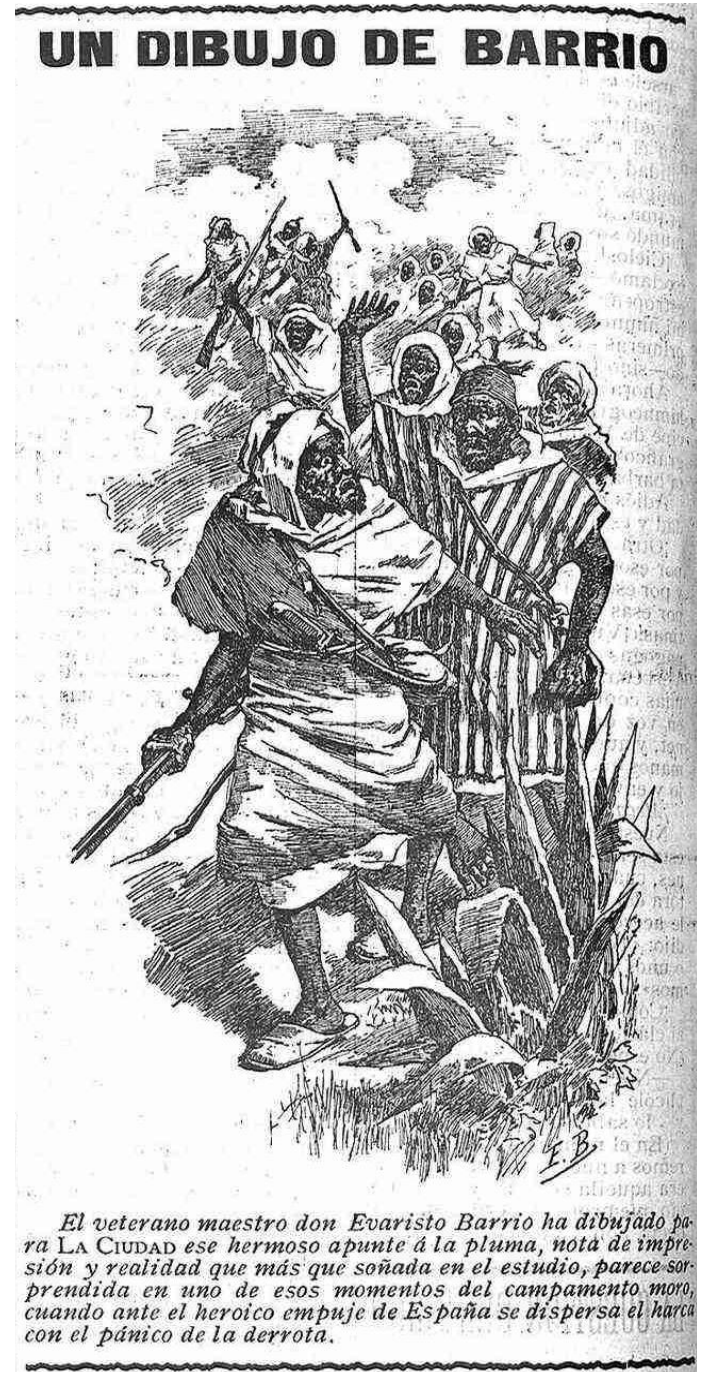

La Ciudad, no 9, 3 de febrero de 1912, p. 2.

\section{LA NUEVA REGLAMENTACIÓN DEL SERVICIO MILITAR}

El soldado de remplazo, indiscutiblemente, fue uno de los mayores perjudicados a lo largo de las campañas marroquíes ${ }^{190}$. Además, el antimilitarismo que venía

\footnotetext{
${ }^{190}$ Un trabajo clásico sobre la historia del reclutamiento en España es el siguiente: PUELL DE LA VILLA, Fernando: El soldado desconocido. De la leva a la mili. Madrid: Biblioteca Nueva, 1996. El repaso del autor se extiende desde el año 1700 hasta 1912, con la implantación de la figura del soldado de cuota. Otro de los trabajos más sugerentes, a caballo entre la antropología y la historia, a propósito del funcionamiento de las quintas y la repercusión de la vida cuartelera sobre el individuo, mediante la exaltación de valores tales como el patriotismo, la disciplina y la virilidad, es el de MOLINA LUQUE, J. Fidel: Quintas y servicio militar: Aspectos sociológicos y antropológicos de la conscripción (Lleida, 1878-1960). Tesis doctoral inédita, Universidad de Lleida, 2001. También recomendable sobre el funcionamiento del servicio militar es la investigación de GARCÍA MORENO, José F.: Servicio militar en España (1913-1935). Madrid: Servicio de Publicaciones del EME, 1988.

La publicística del periodo a favor del servicio militar y defensora del carácter entusiasta del soldado español en combate era abrumadora. Por ejemplo, Antonio Serra Orts, cuando rememoraba la campaña del Kert, escribía sobre el mismo: "Callado, sobrio, sufrido, alegre, obediente y con valor a toda prueba, aunque muy noblote con el enemigo y muy confiado; aguanta las inclemencias del tiempo con verdadera resignación, y a veces, para apartar de su mente la tristeza ante recuerdos del alma, canta, ríe y es
} 
predicando, sobre todo, el PSOE desde finales de la centuria anterior había ido, poco a poco, calando en la conciencia de los trabajadores. El origen de esta animadversión hacia el Ejército radicaba, en primer término, en que se había convertido en el verdadero poder tutelar del Estado canovista; en segundo lugar, el conflicto estaba motivado porque mientras los burgueses podían eludir el servicio militar, los campesinos y obreros no podían esquivar con tanta facilidad sus obligaciones castrenses.

Las campañas de Marruecos, a la fuerza, sirvieron para que la resistencia silenciosa hacia las levas se transformase en una rebeldía soterrada ${ }^{191}$. El malestar, de hecho, llegó hasta el extremo de que José Canalejas, quien había sido aupado a la gobernación del país cuando Alfonso XIII comprobó alarmado el éxito de la Conjunción en la alcaldía de Madrid, hubo de implantar, el 27 de febrero de 1912, la ley de servicio militar obligatorio ${ }^{192}$.

No obstante, las lamentaciones de los sectores sociales mejor acomodados le obligaron a hacer algunas concesiones y así surgió un sistema híbrido: en efecto, los hijos de la burguesía, desde entonces, tendrían que pasar por el cuartel y acreditar cierta formación tanto teórica como práctica, pero a cambio de pagar el equipo (incluido el caballo en caso de necesidad) y una cuota de 1.000 o 2.000 pesetas, podrían escoger guarnición. Asimismo, en lugar de tres años, servirían diez o cinco meses, según la cuantía aportada a las arcas del ministerio. Asimismo, desde enero de 1914 se admitirían los cambios de número entre reclutas de la misma quinta. Es decir, se permitiría la sustitución del servicio en campaña por servicios de guarnición en la península ${ }^{193}$.

ocurrente, con gracejo muy refinado, hasta en los momentos más críticos". Consúltese SERRA ORTS, Antonio: Recuerdos de la Guerra del Kert de 1911-1912. Barcelona: Elzeviriana de Borrás, 1914, p. 28.

${ }^{191}$ PUELL DE LA VILLA, Fernando: El soldado desconocido... Op. Cit., pp. 268-271 y 290-292. El investigador alude a que un profundo pacifismo, tras la debacle en el Barranco del Lobo y los sucesos de Barcelona, sería uno de los rasgos definitorios de la sociedad española del siglo XX, aunque chocase con la mentalidad de los oficiales; también repara en el contenido del artículo de Unamuno, "La Patria y el Ejército", al que ya nos referimos; e incide en que la clase política hubo de resignarse a la universalización del servicio militar, si bien pudo limitar su alcance con el nacimiento del "cuota". Un resumen de estas ideas en PUELL DE LA VILLA, Fernando: Historia del Ejército en España. Madrid: Alianza, 2000, p. 134 y 140.

${ }^{192}$ A propósito de las relaciones entre Canalejas y Alfonso XIII, Morgan C. Hall hace hincapié en la idea de que, a pesar de las discrepancias ideológicas entre ambos, motivadas fundamentalmente por el anticlericalismo y franca oposición a la Guerra de 1898 por parte del primero, Canalejas fue tal vez el presidente más efectivo del reinado, extremadamente cuidadoso con la imagen de monarca, sacrificado y mucho más dialogante de lo que se mostró Maura. Véase HALL, Morgan C.: Op. Cit., pp. 126-127.

${ }^{193}$ FERNÁNDEZ BASTARRECHE, Fernando: "El soldado ante la guerra de Marruecos" en VVAA: A la memoria de Agustín Díaz Toledo. Almería: Servicio de Publicaciones de la Universidad de Almería, 1995, pp. 351-360. 
Nuria Sales, en un trabajo ya clásico sobre el funcionamiento de las quintas y basándose en el análisis de las Estadísticas de Reclutamiento y Remplazo entre 1912 y 1920, subrayó la relación existente entre las cuotas de 1.000 y $2.000 \operatorname{pesetas}^{194}$. Los mayores porcentajes de cuotas totales se daban en la España más rica, en Navarra, Cataluña y el País Vasco, pero fue en la España más pobre donde el porcentaje de cuotas de 2.000 pesetas alcanzó valores mayores respecto al total de cuotas de esas provincias. La provincia de Salamanca, por de pronto, ocuparía, en ese ranking de porcentajes de cuotas totales, posiciones intermedias en el conjunto nacional. Es decir, Salamanca no se asemejó ni a Barcelona, donde entre 1912 y 1920 los cuotas rondaban el 25-30\% del contingente provincial; ni tampoco guardaba similitudes con provincias como la de Almería, cuyo porcentaje medio de cuotas en el mismo periodo ni siquiera rozaba el $2 \%$ del contingente provincial. He aquí el caso salmantino:

\begin{tabular}{|c|c|c|c|c|c|c|c|}
\hline $\begin{array}{c}\text { Contingente } \\
\text { aproximado }\end{array}$ & 1912 & 1913 & 1915 & 1916 & 1918 & 1919 & 1920 \\
\hline $1.500-2000$ & 10 & 9 & 8 & 6 & 7 & 16 & 18 \\
\hline
\end{tabular}

Fuente: Sales, Nuria.: Op. Cit., p. 26.

Si bien no existen datos para todos los años, las cifras expuestas revelan cómo, en término absolutos, el rechazo hacia el servicio militar aumentaría, particularmente, tras la crisis de 1917. En lo tocante a la relación entre cuotas de 1.000 y 2.000 pesetas, Salamanca, de igual, modo, también ocupó posiciones intermedias en el conjunto del país, aunque estaba más próximas, sorprendentemente, al modelo ofrecido por la España Norte. No obstante, se distanciaría de este esquema precisamente también tras la crisis de 1917: el porcentaje de “cuotas" de 2.000 pesetas descendió. ¿Cuál sería la explicación? Creemos que se trata de un indicio de que la oligarquía terrateniente estaba perdiendo su poder económico y político. De nuevo, he aquí los datos sobre el número absoluto y relativo de jóvenes pagadores de las distintas cuotas (aunque no se correspondan con los años de la tabla anterior debido a las deficiencias estadísticas del periodo):

${ }^{194}$ SALES, Nuria: Sobre esclavos, reclutas y mercaderes de quintos. Barcelona: Ariel, 1974, p. 221-222. 


\begin{tabular}{|c|cr|cr|cr|cr|}
\hline Provincia & \multicolumn{2}{|c|}{1915} & \multicolumn{2}{c|}{1916} & \multicolumn{2}{c|}{1918} & \multicolumn{2}{c|}{1920} \\
& 1.000 & 2.000 & 1.000 & 2.000 & 1.000 & 2.000 & 1.000 & 2.000 \\
\hline \multirow{3}{*}{ Barcelona } & 439 & 86 & 832 & 374 & 1.117 & 493 & 1.695 & 909 \\
& $83 \%$ & $17 \%$ & $68 \%$ & $32 \%$ & $69 \%$ & $31 \%$ & $65 \%$ & $35 \%$ \\
\hline \multirow{3}{*}{ Salamanca } & 98 & 29 & 69 & 34 & 106 & 32 & 222 & 75 \\
\hline \multirow{3}{*}{ Almería } & $37 \%$ & $23 \%$ & $67 \%$ & $33 \%$ & $80 \%$ & $20 \%$ & $74 \%$ & $26 \%$ \\
& $30 \%$ & $70 \%$ & $50 \%$ & $50 \%$ & $50 \%$ & $50 \%$ & $19 \%$ & $81 \%$ \\
\hline
\end{tabular}

Fuente: Sales, Nuria.: Op. Cit., p. 269.

Para complementar esta caracterización de los reclutas salmantinos, ha de reiterarse que las tasas de analfabetismo que presentaban aquellos jóvenes se situaban entre las más bajas de España y obedecían, en buena medida, a que la capital era un prestigioso foco universitario. Por ejemplo, para el año 1906, García Moreno alude a un $29{ }^{\prime} 3 \%$ de soldados analfabetos en la provincia. Se trata de una cifra prácticamente idéntica, y por seguir con las comparaciones, a la barcelonesa (29’5\%), pero muy distante de la de Almería (55\%) ${ }^{195}$. En cambio, el porcentaje de exclusiones por motivos físicos, sobre todo por la abundancia de tallas bajas, fue muy elevado: un 29’2\% de los quintados en 1906 no superaban 1'59 m. de altura, lo que situaba a Salamanca en el séptimo lugar del ranking nacional (únicamente adelantada por Zamora, con un $31 \%$ de jóvenes de muy corta talla, Valladolid, Segovia, Guadalajara, Toledo y Ávila. Es decir: las dos Castillas despuntaban en esta materia) ${ }^{196}$. Ahora bien, sería lícito interrogarse sobre si este dato únicamente revelaba las pobres condiciones de vida de aquellas gentes o bien si la cifra pudiera atribuirse a manipulaciones por parte de las Comisiones Mixtas de Reclutamiento y a sus manejos caciquiles. Quizás, ambas circunstancias se mezclaron. Pero, como dato fehaciente, hemos de quedarnos con que, para el periodo 1915-1924 los porcentajes de mozos excluidos por motivos físicos en Salamanca siempre se aproximaron al 10\% del total del alistados, mientras la media nacional rozó el $7 \%{ }^{197}$.

Centrándonos ya en el análisis de la opinión publicada, El Adelanto aludió en enero de 1912, por vez primera, a la figura del soldado de cuota (frente al soldado de

\footnotetext{
${ }^{195}$ GARCÍA MORENO, José F.: Op. Cit., p. 258.

${ }^{196}$ Ibidem, p. 255.

${ }^{197}$ Ibidem, p. 221.
} 
haber) y en febrero desmenuzó el contenido y aspiraciones de la nueva ley ${ }^{198}$. A pesar de ello, por de pronto, 8.000 nuevos soldados de primer año, con un mínimo de instrucción, tuvieron que ser movilizados con el objeto de remplazar a bajas y licenciados en Melilla ${ }^{199}$.

El diario liberal advirtió inmediatamente, una vez puesto en marcha el nuevo modelo de reclutamiento, que resultaba excesivo el número de mozos exceptuados en el reconocimiento médico: porque las condiciones mínimas que se exigían para ser declarados aptos eran $150 \mathrm{~cm}$. de altura, $48 \mathrm{~kg}$. de peso y un perímetro torácico de 75 $\mathrm{cm}$. Evidentemente, los mozos se sometían a dietas salvajes para quedar por debajo del listón. Y por consiguiente, el contingente del Ejército experimentó en 1912, atendiendo a las palabras de un redactor, un "duro golpe". Hasta el extremo de que de un total de 215 quintados en Salamanca, mientras que 46 jóvenes no se presentaron y fueron declarados prófugos, de los 169 restantes, 118 tuvieron que ser excluidos por defectos de talla, peso y perímetro. Al final, únicamente 51 mozos, una cantidad ínfima, pudieron ser declarados útiles ${ }^{200}$. Cantidad que, parece irrebatible, revelaba un creciente rechazo hacia la guerra.

Desde La Ciudad, el doctor Cándido Pinilla también sometió a examen, y bastante concienzudo, la nueva ley de reclutamiento. En líneas generales, consideraba su aplicación poco menos que imposible y, además, abierta a infinidad de abusos. El cuadro de inutilidades físicas reconocidas iba a permitir que se librasen del servicio muchísimos jóvenes. Y las relaciones entre talla, perímetro torácico y peso no tenían por qué considerarse, unívocamente, indicadores del vigor de un hombre ${ }^{201}$.

De La Libertad, instrumento del maurismo salmantino, lamentablemente, desconocemos su posición hacia la nueva reglamentación militar. Pero sí tenemos constancia de que se amparó, a mediados de 1913, en el criterio sostenido por La Época a la hora de evaluar y defender el voluntariado para África: "Pensar que el soldado de la metrópoli es bueno para la guerra colonial es una locura. Creer que los sistemas de reclutamiento forzosos pueden ser útiles para campañas en África es vivir apartados de

\footnotetext{
198 "El servicio obligatorio", El Adelanto, no 8.470, 27 de enero de 1912, p. 2; "El servicio militar obligatorio", El Adelanto, $\mathrm{n}^{\circ}$ 8.480, 7 de febrero de 1912, p. 2; "El servicio militar obligatorio", El Adelanto, $\mathrm{n}^{\circ} 8.487,15$ de febrero de 1912, p. 2.

199 "Sorteo de soldados para Melilla", El Adelanto, no 8.492, 21 de febrero de 1912, p. 1.

200 "El diablillo del Tormes”: “Salamanca y su provincia no dan el cupo de mozos que le corresponde?”, El Adelanto, $\mathrm{n}^{\text {o }}$ 8.506, 8 de marzo de 1912, p. 2; "Resultados de la nueva ley de reclutamiento", El Adelanto, $\mathrm{n}^{\circ} 8.550,30$ de abril de 1912, p. 1.

${ }^{201}$ Dr. Pinilla: “¿Soldados o momias?”, La Ciudad, no 22, 4 de mayo de 1912, p. 1.
} 
la realidad" ${ }^{, 202}$. No obstante, para el nacimiento del Tercio habremos de esperar hasta los años 20.

En cuanto a El Salmantino, por último, también en enero de 1912 comenzó a desmenuzar el contenido de la proyectada ley, pero sin emitir juicios ${ }^{203}$. Y, meses después, recogió la normativa acerca del voluntariado para África, convertida en decreto al concluir $1913^{204}$.

Para acercarnos a las valoraciones de esta redacción hemos de esperar hasta principios de 1914, cuando este rotativo emprendió una campaña a favor del soldado de cuota. Éste, argumentaba el rotativo, era obligado a permanecer en campaña más tiempo del reglamentado porque Dato, entonces presidente del gobierno, estaba siendo presionado por la conjunción republicano-socialista. El periódico, en esta ocasión, jugaba, para defender sus derechos, con la carta de que no había una guerra oficialmente declarada en Marruecos:

“¿A qué potencia tiene declarada la guerra España? (...) ¿Por qué a los de cuota, teniendo perfectísimo derecho a enviarles a sus casas, se les retiene en el servicio?

¡Ah! Se les detiene porque las izquierdas han levantado su voz y ante ellas el gobierno se ha atemorizado, ${ }^{, 205}$.

Serían muchos los medios informativos, publicistas y padres de soldados que, en el futuro, adoptasen esta estrategia.

\section{LOS INICIOS DEL PROTECTORADO: LA CONQUISTA DE TETUÁN Y LA GUERRA CONTRA EL RAISUNI CONTEMPLADAS DESDE SALAMANCA}

El establecimiento del Protectorado hispano-francés sobre Marruecos fue, como ya se ha comprobado, el resultado de una larga rivalidad internacional, jalonada con un Acuerdo entre Francia y Gran Bretaña; otro Convenio sellado por Francia con Alemania; y un último Tratado franco-marroquí en 1912. España no orquestó ninguna de las negociaciones y hubo de aceptar a regañadientes la internacionalización de Tánger, cuyo Estatuto no se aprobaría hasta febrero de 1924, y la competencia exclusiva

\footnotetext{
202 "El voluntariado para África", La Libertad, no 22, 17 de julio de 1913, pp. 2-3.

203 "El servicio militar obligatorio", El Salmantino, no 495, 29 de enero de 1912, p. 1

204 "Voluntarios para África", El Salmantino, no 606, 11 de junio de 1912, p. 1; "El voluntariado de África", El Salmantino, no 1.067, 20 de diciembre de 1913, p. 1.

205 "Los soldados de cuota", El Salmantino, no 1.147, 2 de abril de 1914, p. 1. Se trataba de una idea también esgrimida por conocidos publicistas de la época. Véase CEDRÚN DE LA PEDRAJA, Gonzalo: Los soldados de cuota. El Ejército de operaciones en Marruecos. Madrid: Victoriano Suárez, 1914, pp. 22-37.
} 
del Residente General Francés, Lyautey, con sede en Rabat, para todo lo relacionado con la política exterior marroquí ${ }^{206}$.

El Protectorado fue, además, en términos administrativos, una realidad muy compleja. Para empezar, las máximas autoridades en la zona de influencia española serían el Alto Comisario y un Jalifa, nombrado por el Sultán entre tres candidatos propuestos desde Madrid. Las atribuciones del Jalifa iban desde actuar como delegado del Sultán hasta como imán de los musulmanes, pero en la práctica su papel se limitó al de marioneta del Alto Comisario. A su vez, éste apoyó sus gestiones en tres Delegados: Asuntos Indígenas, Fomento y Servicios Tributarios. En cuanto a la administración territorial, recayó en caídes y bajás, auxiliados por vocales e interventores españoles y distinguiéndose cinco grandes circunscripciones:

- El extremo occidental o Lucus. En él se ubicaba el puerto atlántico de Larache.

- El Noroeste o región de Yebala. En esta zona se encontraba Tetuán.

- El Noreste o Gomara. Tenía como lugar emblemático la ciudad santa de Xauen.

- La región central o Rif.

- El extremo oriental o Kert. El enclave fundamental de esta región era Melilla.

Además, para hacer esta estructura aún más enmarañada, el Protectorado se dividió en tres Comandancias: Ceuta, Melilla y Larache y, cuando fue preciso abordar asuntos urgentes, se permitió a los comandantes generales entenderse directamente con la Legación Española en Tánger. Todo ello sin olvidar el afán intervencionista de Alfonso XIII.

Terminando con este tan fugaz repaso del organigrama administrativo del Protectorado marroquí, señalemos que, desde 1913, su dirección pasaría a depender del ministerio de Estado, con la llamada Sección de Marruecos, aunque los asuntos militares serían dirigidos desde el ministerio de la Guerra. Durante la Dictadura de Miguel Primo de Rivera se crearía la Oficina de Marruecos, dependiente de la Presidencia del Consejo de Ministros, y la Dirección General de Marruecos y Colonias. Ésta se vería sometida a infinidad de modificaciones, hasta que tras la Guerra Civil se adjudicase su dirección a Exteriores y, a partir de 1942, a la Presidencia del gobierno.

\footnotetext{
${ }^{206}$ SERNA, Alfonso de: Op. Cit., p. 216. Debido a estas circunstancias, en muchas ocasiones, las autoridades francesas cuestionaron la naturaleza del Protectorado español, considerándolo como un subprotectorado carente de personalidad jurídica en el ámbito internacional. Esta tesis fue muy combatida por los gobernante españoles de aquel periodo y también por historiadores actuales. Véase SALAS LARRAZÁBAL, Ramón: Op. Cit., p. 109.
} 
La clave de esta estructura debía ser el Servicio de Intervenciones Militares, controlado por la Delegación de Asuntos Indígenas. El interventor sería el hombre encargado de obtener información sobre las cábilas, su armamento, estado de salud, lecturas a su disposición...y todo ello porque la noción de protectorado suponía el mantenimiento de las formas de gobierno tradicionales del reino, aunque regidas por los colonizadores. La meta final consistía en arrastrar a los marroquíes hacia la “civilización”, o, como sintéticamente expresaba el comandante Díaz de Villegas, "vamos a Marruecos, no contra Marruecos, sino con Marruecos",207.

Pero la realidad, como se verá, resultó muy alejada de los presupuestos teóricos: España no tenía experiencia colonizadora previa, sino una larguísima historia de conquistas, y los militares acabaron adueñándose de la administración directa y excluyente del poder, al menos, hasta $1926-27^{208}$. Ni que decir tiene, éstos no estaban preparados para desempeñar una misión civilizadora. Sin embargo, el fomento de la llamada "acción política" fue la consigna adoptada por todos los gobiernos tras la ratificación del Acuerdo con Francia de 1912. Historiadores Richard C. Pennel precisamente ubicaron aquí el origen de todas las dificultades experimentadas por los españoles en el continente africano: "Al tratar de poner en práctica una política basada en conceptos erróneos acerca del carácter de la sociedad marroquí, el Ejército español

\footnotetext{
${ }^{207}$ DÍAZ DE VILLEGAS, José: Lecciones de la experiencia (enseñanzas de las campañas de Marruecos). Toledo: Sebastián Rodríguez, 1930, p. 128.

${ }^{208} \mathrm{La}$ inexperiencia española, las carencias legislativas y la resistencia de la población de la zona impidieron el ejercicio de de los interventores hasta 1927. Anteriormente, se impuso la gestión directa a cargo de los militares, que, por otro lado, jamás escatimaron esfuerzos para controlar estos cargos a lo largo de toda la historia del Protectorado. Instrumentos auxiliares de las Oficinas de Intervención fueron el "Consultorio de Moros" y la "Escuela de Moros". El médico y el maestro fueron hábilmente utilizados, tal y como señala Francisco Javier Martínez Alonso -consúltese la bibliografía-, para compensar los daños de la guerra y en el "tanteo político" de las cábilas, dado que ambos profesionales gozaron de una notable aceptación entre la población. Para profundizar en las funciones y formación de los interventores, véase VILLANOVA, José Luis: Los interventores. La piedra angular del Protectorado de España en Marruecos. Barcelona: Bellaterra, 2006; y, con un enfoque más amplio, VILLANOVA, José Luis: $E l$ Protectorado de España en Marruecos. Organización política y territorial. Barcelona: Bellaterra, 2004. También del mismo autor: "La formación de los interventores en el Protectorado español en Marruecos (1912-1956)" en RODRÍGUEZ MEDIANO, F. y FELIPE, H.: El Protectorado español en Marruecos. Gestión colonial e identidades. Madrid: CSIC, 2002, pp. 247-280; y VILLANOVA, José Luis: "La pugna entre militares y civiles por el control de la actividad interventora en el Protectorado español en Marruecos (1912-1956)", Hispania, LVI/2, no 220, 2005, pp. 683-716; También son interesantes los trabajos de MATEO DIESTE, Joseph: "La oficina de intervención como espacio de interacción sociopolítica en el Muraquib y la cábila: de la ideología colonial a las prácticas cotidianas" en RODRÍGUEZ MEDIANO, F. y FELIPE, H, Op.Cit., pp. 139-180. Para profundizar en el repudio de los africanistas hacia el Protectorado civil, véase: GÓMEZ JORDANA, Francisco: La tramoya de nuestra actuación en Marruecos. Madrid: Editora Nacional, 1976; y, por último, MOLA VIDAL, Emilio: Dar Akkoba. Páginas de sangre, de dolor y de gloria, en Obras Completas. Valladolid: Santarén, 1940.
} 
ayudó a que se creara una sólida resistencia"209. No le faltaba razón: las subvenciones para ciertos cabecillas desprestigiaron a los sectores colonialistas y trastocaron los equilibrios entre las cábilas. Pero, además, muchos de los "pensionados" acabaron volviéndose contra España.

Por otra parte, tres fueron las grandes opciones estratégicas que se plantearon con relación al Protectorado: la reducción del territorio ocupado a una extensión costera (Maura y Cambó); la ocupación absoluta (Berenguer y Romanones) y el abandono del territorio (Primo de Rivera e Indalecio Prieto) ${ }^{210}$. Aunque se intentarían las tres opciones, la indecisión de los sucesivos ministerios no acarrearía más que una creciente confusión de la opinión pública y la exasperación entre los militares.

${ }^{209}$ PENNELL, Richard C.: La Guerra del Rif. Abd-el-Krim el-Jattabi y su estado rifeño. Melilla: Biblioteca de Melilla, 2001, p. 72.

${ }^{210}$ ALONSO BAQUER, Miguel: "El problema de Marruecos" en HERNÁNDEZ SÁNCHEZ-BARBA, Mario y ALONSO BAQUER, Miguel: Historia social de las Fuerzas Armadas españolas, Vol. 5. La Restauración. Madrid: Alhambra, 1986 ( $3^{\text {a }}$ ed.), p. 228. 


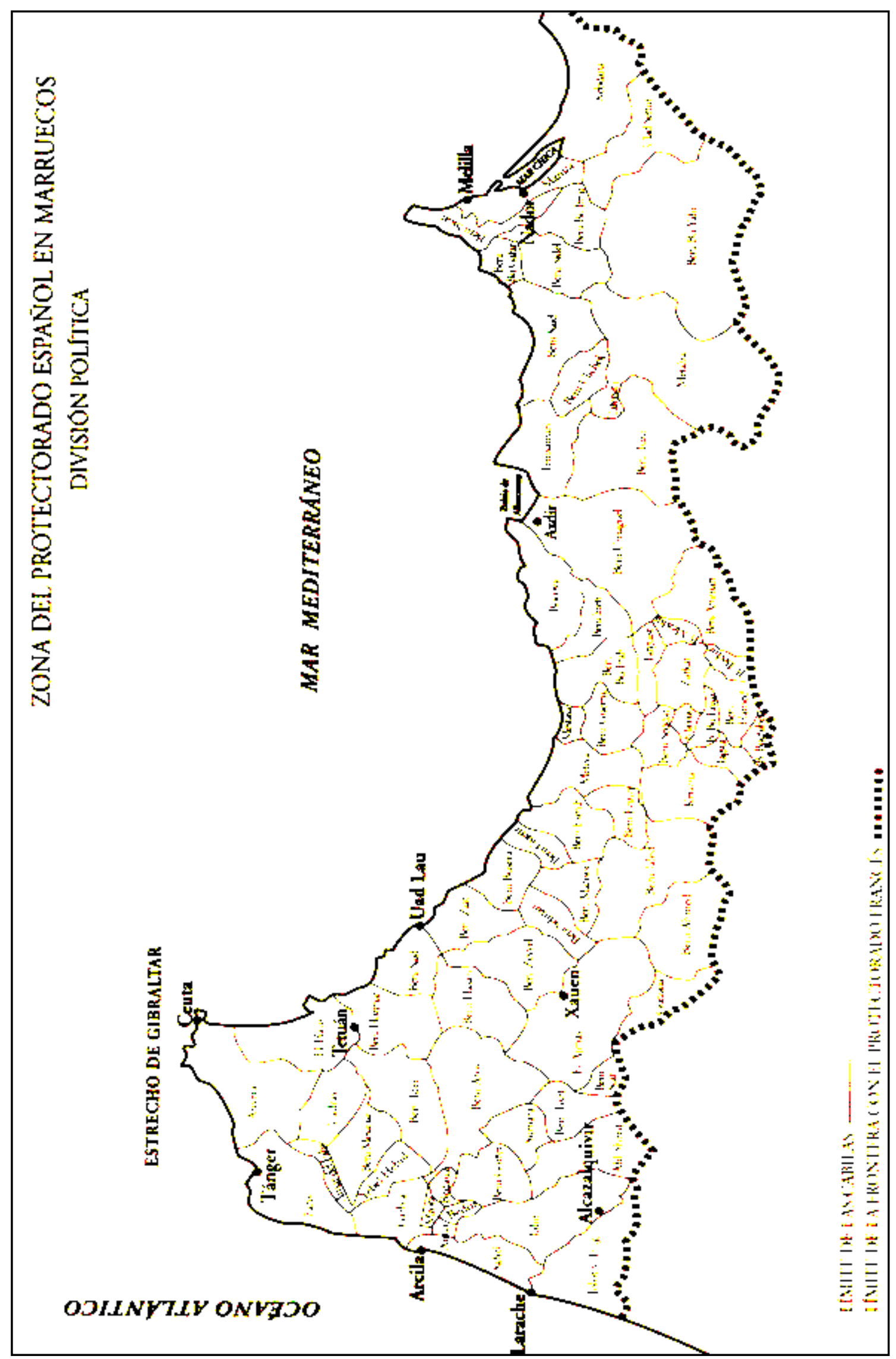

Fuente: MADARIAGA, María Rosa de: España y el Rif... Op. Cit., p. 4. 
En Salamanca, con la excepción de Pascual Meneu, la ratificación del Acuerdo de Protectorado no generó demasiada curiosidad, ni mucho menos entusiasmo, entre la opinión pública local. A decir verdad, para los salmantinos, para el país en general, se dibujaba una nueva fuente de complicaciones en el horizonte: porque, insistimos, el empeño teóricamente civilista con que se planteó el gobierno acudir a Marruecos -la "quijotada" que diría "Argos"211 - chocaría con la resistencia de los protegidos desde el principio $^{212}$.

En el caso de El Adelanto, las primeras informaciones que se publicaron sobre Marruecos tras la ratificación del Convenio con Francia se caracterizaron por su tono muy descriptivo, sin apenas valoraciones propias. Sólo de modo excepcional, un redactor subrayó que se acercaba el día en el que España podría ejercer libremente su acción en el Rif ${ }^{213}$. Mientras que "Argos”, más socarrón que nunca, desconfiaba de nuestro porvenir en Marruecos: "habremos de atender a la península y a la ínsula, con la particularidad auténtica de que Sancho se quedará en casa y don Quijote irá al gobierno isleño para sufrir al doctor Tirteafuera, vulgo Francia, que tiene la representación de los duques -las grandes naciones" $" 214$.

Si bien en el Kert los focos de rebeldía se consideraban ya apagados, en los alrededores de Tánger la situación se tornaba preocupante porque los anyera protestaban ante la presencia española en Arcila y desconfiaban de la lealtad de El Raisuni ${ }^{215}$.

El conde de Romanones, presidente del gobierno, se esmeraba en mantener informado a Alfonso XIII sobre sus proyectos para el Protectorado, sin que éstos trascendiesen a la opinión pública, y la colonización agrícola se presentaba como una de las grandes ventajas, sino como la mayor, derivada de la dominación española en el país africano $^{216}$. Además, el líder liberal se volcaba a la hora de mostrar sus buenos tratos

\footnotetext{
${ }^{211}$ En este trabajo únicamente nos estamos interesando por la faceta periodística de Benigno Pallol, cuando, en el fondo, él era un estudioso y especialista en la obra de Cervantes. Por eso, sus analogías habituales entre el africanista y Don Quijote, que luchan por la conquista imposible de Marruecos/Dulcinea del Toboso, nada tenían de accidental.

${ }^{212}$ SÁNCHEZ SANZ, Oscar Javier: Op. Cit., p. 736.

213 "El Acuerdo franco-español", El Adelanto, no 8.729, 28 de noviembre de 1912, p. 2.

214 "Argos": "Madrid al día. Problemas", El Adelanto, no 8.730, 29 de noviembre de 1912, p. 1.

215 Alfredo Rivera: “Información telegráfica de El Adelanto", El Adelanto, n 8.780, 28 de enero de 1913, p. 3.

216 "El plan del gobierno", El Adelanto, $\mathrm{n}^{\mathrm{o}}$ 8.786, 4 de febrero de 1913, p. 2; Alfredo Rivera: "Información telegráfica de El Adelanto", no 8.792, 11 de febrero de 1913, p. 3; Alfredo Rivera: "Melilla. Reparto de abonos. Discurso del general Jordana", El Adelanto, no 8.797, 17 de febrero de 1913, p. 3.
} 
con la diplomacia francesa ${ }^{217}$. En el Congreso, simultáneamente, García Prieto tenía palabras de recuerdo y encomio para José Canalejas ${ }^{218}$.

Alfredo Rivera fue el primer corresponsal que reseñó, dando cuenta de las fuerzas que intervinieron en la operación, la ocupación de Tetuán ${ }^{219}$. Por su parte, "Argos" no pareció demasiado satisfecho con la noticia. Con certeza, su idea de que los españoles no podían esperar de Marruecos más que problemas permanecía intacta: “¡Albricias! la ocupación de Tetuán se ha verificado sin disparar un tiro (...) El señor conde de Romanones (...) se congratula de que se haya realizado, como el ambiente público pedía tranquila y pacíficamente (...) Las cosas de África marchan divinamente $^{, 220}$.

Pallol, como es fácil adivinar, estaba censurando que la toma de la ciudad se justificase apelando a una demanda de la opinión pública. Más aún, se extrañaba ante esa sorprendente falta de violencia ${ }^{221}$. ¿A qué obedecería? Por el momento, la respuesta permanecía en el aire.

Otros miembros de la redacción liberal, en cambio, aprovechaban para rememorar la vieja Guerra de $1860^{222}$; y, en conjunto, lo que primaba era una actitud muy benévola hacia todos los nuevos y bienintencionados propósitos con los que el gobierno de Romanones pretendía regir el Protectorado: máximo respeto religioso, considerables inversiones en materia de enseñanza, así como en salud y en obras públicas, fomento de la riqueza agrícola e industrial, interés por su riqueza lingüística... pero ningún comentario referido a la internacionalización de Tánger o a la regulación de las explotaciones mineras ${ }^{223}$.

El goteo en el envío de soldados salmantinos al continente africano era, sin embargo, continuado y en la descripción de los actos de despedida, en la estación de

\footnotetext{
217 "Declaraciones de Romanones", El Adelanto, no 8.836, 4 de abril de 1913, p. 2; Alfredo Rivera: “Información telegráfica de El Adelanto”, El Adelanto, no 8.840, 9 de abril de 1913, p. 3.

${ }^{218}$ Alfredo Rivera: "Información telegráfica de El Adelanto", El Adelanto, no 8.743, 14 de diciembre de 1912, p. 3.

${ }^{219}$ Alfredo Rivera: "Información telegráfica de El Adelanto", El Adelanto, no 8.801, 21 de febrero de 1913 , p. 3.

220 "Argos": "Madrid al día. Fecha histórica", El Adelanto, no 8.802, 22 de febrero de 1913, p. 1.

${ }^{221}$ Donde sí se registro un ligero recrudecimiento de la violencia fue en Melilla porque los franceses se estaban aproximando peligrosamente a las márgenes del Muluya: Alfredo Rivera: "Información telegráfica de El Adelanto", El Adelanto, no 8.813, 7 de marzo de 1913, p. 3.

222 "La plaza de España", El Adelanto, no 8.803, 24 de febrero de 1913, p. 3.

${ }^{223}$ Alfredo Rivera: "Información telegráfica de El Adelanto", El Adelanto, no 8.808, 1 de marzo de 1913, p. 3; E. Torno: “Cosas de Marruecos", El Adelanto, n 8.810, 4 de marzo de 1913, p. 2; Alfredo Rivera: "Información telegráfica de El Adelanto", El Adelanto, no 8.819, 14 de marzo de 1913, p. 3. Navarro Reverter, ministro de Estado del nuevo gobierno liberal, había emprendido ya una serie de encuentros con una comisión mora, desplazada a Madrid, para abordar el asunto de la internacionalización de Tánger: Alfredo Rivera: “Información telegráfica de El Adelanto", El Adelanto, no 8.839, 8 de abril de 1913, p. 3.
} 
trenes, no faltaba la habitual nota de entusiasmo. Sin embargo, las llamadas a la opinión pública para tomar parte en la colonización agrícola del Rif lograban escaso eco. En marzo de 1913, la Alcaldía había confeccionado un listado, luego remitido al ministerio de Estado, con el nombre de cincuenta obreros dispuestos a marchar a Ceuta para asentarse allí. No obstante, al final, sólo diecinueve de ellos se atrevieron a dar el paso $^{224}$. No está demás subrayar que, a pesar del esfuerzo, la explotación agraria marroquí resultaría poco rentable a causa de la sequedad de la zona, de lo accidentado del relieve y del retraso técnico ${ }^{225}$.

A decir verdad, habían sido básicamente las fluidas comunicaciones entre los mandos militares y El Raisuni las que explicaban los progresos españoles. Aunque la opinión pública salmantina desconocía la naturaleza de esos tratos, El Raisuni, entonces bajá de Arcila, era presentado como fiel colaborador del coronel Fernández Silvestre, si bien El Adelanto no parecía tenerlas todas consigo ${ }^{226}$.

No le faltaba razón: su eterno juego del "tira y afloja" desconcertaba a las autoridades españolas y también a sus propios seguidores. Incluso todavía, a día de hoy, sus estudiosos no saben si presentarlo como un inteligentísimo, ambicioso y despiadado bandolero, un fanático religioso con una vida legendaria o un abanderado de la independencia marroquí ${ }^{227}$. Pero, de hecho, tan pronto se produjo la entrada del Jalifa en

\footnotetext{
224 "Sir-ve": "Salmantinos a Ceuta", El Adelanto, no 8.817, 12 de marzo de 1913, p. 1.

225 AZIZA, Mimoun: La sociedad rifeña frente al Protectorado español en Marruecos (1912-1956). Barcelona: Bellaterra, 2003, p. 69. En 1915 se fundó la Compañía Española de Colonización, con sede en Nador. Sus actividades especulativas sobre el Garet motivarían bastantes protestas obreras y, después de 1921, muchos colonos no tendrían más opción que trasladarse a Argelia.

226 "El Raisuni por España", El Adelanto, no 8.825, 20 de marzo de 1913, p. 2. Asimismo, "Argos" aprovechaba la ocasión para refutar la vieja idea de la fraternidad hispano-marroquí y su nula fe en las posibilidades de un sano entendimiento. Véase "Argos": "Madrid al día. Soldados africanos", El Adelanto, $\mathrm{n}^{\circ} 8.838,7$ de abril de 1913 , p. 1.

${ }^{227}$ Para un brevísimo estado de la cuestión sobre este personaje, véase VILLALOBOS, Federico: $O p$. Cit., pp. 97-108. Mucho más extensos son los trabajos de TESSAINER Y TOMASICH, Carlos Federico: El Raisuni, aliado y enemigo de España. Málaga: Algazara, 1998. Este trabajo, que fue una tesis doctoral originalmente, está escrito con el claro propósito de rehabilitar al personaje histórico. Entre las ideas más sugerentes que baraja el autor queremos destacar la que apuesta porque el jerife fue utilizado por el Majzen para frenar el empuje de los europeos residentes en Tánger, escandalizados ante su política de cabezas cortadas (p. 60 y 67). Y también TEMSAMANI, Abdelaziz Khallouk: País Yebala: Majzén, España y Ahmed Raisuni. Granada: Universidad de Granada, 1999. A diferencia del anterior investigador, éste ensalza las motivaciones puramente personales y materialistas de El Raisuni y pone en tela de juicio la instrumentalización de su figura por parte del Majzén (p. 33). Por último, muy recientemente ha sido publicado el testimonio de la viajera y aventurera inglesa Rosita Forbes, quien llegó a entrevistar al jerife. Véase FORBES, Rosita: El Raisuni, Sultán de las montañas. Madrid: Almuzara, 2010.

Con relación al surgimiento de éste y otros tantos caudillos en el territorio marroquí, Ramiro de la Mata, en su muy meditada tesis doctoral, sintetizaba del siguiente modo las circunstancias de su nacimiento: "Ante el empobrecimiento general, el debilitamiento del poder central y la autoridad de un caid, nombrado por el Majzén, puesta en duda constantemente surge el aventurero, el hombre atrevido
} 
Tetuán, en abril de $1913^{228}$, empezaron a registrarse los primeros estallidos violentos: algunas escaramuzas en las cercanías de Melilla ${ }^{229}$; y, lo que revestía mayor gravedad, en los alrededores de Tetuán, Larache, Alcazarquivir y Arcila ${ }^{230}$. El propio Silvestre había propuesto a El Raisuni para el cargo de Jalifa. Pero frustradas las a mbiciones de este cabecilla, su llamamiento a las armas en contra de los invasores había ganado mucha fuerza. Rivera, por ejemplo, aludía a 65.000 cabileños levantados contra España; apuntaba también a la existencia de una diferencia de pareceres, sin precisar cuál, entre el agresivo Primo de Rivera, al mando de las tropas, y el más contemporizador, Alfau, flamante Alto Comisario; y terminaba lamentando la indisimulada complacencia con que los franceses observaban lo que ocurría ${ }^{231}$.

“Argos", por su parte, intentaba explicar a sus lectores las raíces históricas de la nueva e incipiente guerra. Los tratados internacionales para el reparto de Marruecos figuraban en el epicentro del problema:

"Data la cosa por lo menos desde el Acta de Algeciras, aunque los conservadores finjan hacerse de nuevas y repugnen la alianza o la entente cordial. Esta obra se ha ido elaborando con el conocimiento y el consentimiento de todos por más que el pueblo bajo no la conociera ni pudiera consentirla a causa de no conocerla (...) Solos como nación no podíamos sobrevivir a Marruecos, el cual se halla en las últimas. ¿Íbamos a juntarnos con Alemania, que nos compró las Carolinas por tres ochavos? (...) ¿Con quién mejor que con la dueña de Gibraltar y con la potencia invasora de España en 1808 ?

Hemos echado pelillos a la mar y echaremos una segunda escuadra en holocausto de dich a triple ${ }^{, 232}$.

Dicho de otro modo, aunque Pallol no abogaba abiertamente por la política del aislamiento, sí que adivinaba cómo los compromisos con la Entente arrastrarían a España a su perdición (algo que le aproximaba, aunque resulte paradójico, a los planteamientos del integrismo). Absolutamente atónita, la opinión pública salmantina

que, por medio del chantaje adquiere una influencia y poder considerables". Véase RAMIRO DE LA MATA, Javier: Op. Cit., p. 169.

${ }_{228}$ Alfredo Rivera: "Información telegráfica de El Adelanto", El Adelanto, no 8.856, 28 de abril de 1913,

${ }_{229}^{\text {p. } 3 .}$ Alfredo Rivera: “Información telegráfica de El Adelanto", El Adelanto, no 8.857, 29 de abril de 1913, p. 3 .

${ }^{230}$ Alfredo Rivera: “Información telegráfica de El Adelanto", El Adelanto, no 8.883, 30 de mayo de 1913, p. 3. Muy prontamente se dispararon, además, los rumores sobre la dimisión de Alfau como Alto Comisario. Por ejemplo, consúltese "Argos": "Madrid al día. Todos felices", El Adelanto, no 8.862, 6 de mayo de 1913, p. 1. A propósito del encuentro entre Fernández Silvestre y El Raisuni un día después de la toma de Tetuán, el 20 de febrero, el $A B C$ insertaría en sus páginas aquella famosa sentencia, repetida hasta la saciedad, sobre el viento y la mar.

${ }^{231}$ Alfredo Rivera: "Información telegráfica de El Adelanto", El Adelanto, no 8.886, 3 de junio de 1913, p.

3; Alfredo Rivera: "Información telegráfica de El Adelanto", El Adelanto, n ${ }^{\circ} 8.889,6$ de junio de 1913, p.

3; Alfredo Rivera: "Información telegráfica de El Adelanto", El Adelanto, no 8.892, 10 de junio de 1913, p. 3 .

232 “Argos": "Madrid al día. Nuestras alianzas", El Adelanto, no 8.863, 7 de mayo de 1913, p. 1. 
no daba crédito a la belicosidad de la que hacían gala los marroquíes, apenas concluida la campaña del Kert. Al menos, esto era lo que aseguraba, a mediados de junio, un tal “Abdalá". Mientras que el gobierno francés ofrecía a sus conciudadanos, según escribía el susodicho, un excelente ejemplo de método colonizador, fundamentado en la sabia conjunción de las armas, la diplomacia y el fomento de la división intertribal, España perpetuaba sus errores:

"Es preciso que nuestras tropas salgan de la inacción enervante de los acuartelamientos de Ceuta, Melilla y Larache, para que los moros se convenzan de que los 50.000 hombres que España tiene acumulados en tierra de Tingitania, sirven para más que estar a la defensiva y expectativa, porque el musulmán no cree en la fuerza de aparato y de relumbrón que fascina y deslumbra a los ojos europeos, porque el berberisco, cabileño y muslin no cree en rigor mientras no lo siente en sus costillas con el látigo o en el combate, cayendo al peso y dolor del fuego mortífero, ${ }^{\text {,233. }}$.

Diríase, por tanto, que la posición de este columnista era más próxima a la de Primo de Rivera que a la de Alfau: apostaba por la intervención armada y por emular la conducta francesa. Y apenas transcurridos unos días, la redacción insistía en que las agresiones no debían quedar sin castigo porque "todos los españoles conscientes sabemos que Marruecos ha de costar a España mucha sangre y mucho dinero" ${ }^{\text {234 }}$. Pero, con una condición: "porque sabemos esto y porque tenemos fortaleza de espíritu podemos recibir las noticias exactas y completas".

Los combates en Beni Aros, en los territorios de Wad Ras y de Anyera eran muy sangrientos y los cabileños también se estaban envalentonando en las inmediaciones de Tánger ${ }^{235}$. Los salmantinos, mientras tanto, seguían muy de cerca su desarrollo, ya que muchos de los mozos de la ciudad estaban luchando en la brigada de Cazadores de Primo de Rivera ${ }^{236}$. Aunque los heridos eran cuantiosos (y se citaban 35 heridos salmantinos en los últimos enfrentamientos), afortunadamente, la suerte parecía acompañar a los españoles ${ }^{237}$.

\footnotetext{
233 “Abdalá": "Los acontecimientos de Marruecos", El Adelanto, no 8.893, 11 de junio de 1913, p. 1.

234 "Serenidad", El Adelanto, n' 8.896, 14 de junio de 1913, p. 1.

${ }^{235}$ Alfredo Rivera: "Información telegráfica de El Adelanto", El Adelanto, no 8.896, 14 de junio de 1913, p. 3; Alfredo Rivera: "Información telegráfica de El Adelanto", El Adelanto, no 8.897, 16 de junio de 1913, p. 3; Alfredo Rivera: "Información telegráfica de El Adelanto", El Adelanto, no 8.901, 20 de junio de 1913, p. 3.

236 "Los soldados salmantinos en la guerra", El Adelanto, n' 8901, 20 de junio de 1913, p. 1.

237 "Argos": "Madrid al día. Pesadillas", El Adelanto, no 8.897, 17 de junio de 1913, p. 1; "De la guerra. Detalles de la razzia a los Beni-Omar", El Adelanto, no 8.900, 19 de junio de 1913, p. 2.
} 
Al terminar junio, Rivera, nuevamente, se trasladaba al escenario marroquí ${ }^{238}$. A la vista de que los altercados se endurecían ${ }^{239}$, en El Adelanto surgían las habituales dudas y se reconocía la existencia de cierta hostilidad hacia la expansión marroquí:

"La desproporción entre los resultados conseguidos y los grandes esfuerzos realizados y los que se presumen, no es tampoco lo más eficaz para ganar la simpatía de la opinión. En cuatro años de actuación en Marruecos se han tenido, aparte de los crecidos gastos que han desequilibrado el presupuesto, tres campañas, de ellas dos en Melilla y la tercera ahora en Tetuán y Alcázar.

$Y$ como esto es solamente en las cercanías de la costa de las antiguas plazas españolas, y aún hay que penetrar en el interior del las montañas del Rif, el espíritu público no puede apartar de sí la pesadumbre de los hechos consumados y de los recelos que le inspira el porvenir ${ }^{, 240}$.

El lastre marroquí era enorme y la opinión pública salmantina temía, según comentaba este articulista, que las fuerzas militares enviadas (batallón de Covadonga, regimiento de Córdoba, de Borbón, Reina, Extremadura...) no fueran suficientes. No obstante, el diario de Núñez Izquierdo evitaba formular juicios sobre la gestión de Romanones, limitándose, por el momento, a reproducir por una parte un suelto de $E l$ Liberal, que furioso por el anuncio de nuevas operaciones en Tetuán sin un objetivo claro, acusaba al presidente de "jugar a los dados" $" 241$. Por otro lado, se hacía eco de que en Madrid se estaba preparando una manifestación socialista contra la guerra ${ }^{242}$.

Al iniciarse julio de 1913, mientras que en Salamanca cundía la pesadumbre al conocerse el fallecimiento en combate de un teniente de la Albuera, Casimiro Santander ${ }^{243}$, y ante el anuncio de una nueva movilización ${ }^{244}$, los cabileños empezaban a mostrar síntomas de agotamiento y se refugiaban en la zona internacional de Tánger ${ }^{245}$. Por eso, algún redactor soñaba con que la ocupación del Fondak, presentada ante la opinión salmantina como necesaria para garantizar las comunicaciones entre Tetuán, Tánger y Ceuta, no fuese precisa ${ }^{246}$. Y, en efecto, la operación no llegó a realizarse. Pero desde esta redacción tampoco se explicaron los motivos de la suspensión ${ }^{247}$.

\footnotetext{
${ }^{238}$ Alfredo Rivera: “Información telegráfica de El Adelanto", El Adelanto, no 8.902, 21 de junio de 1913, p. 3 .

239 “Argos": "Madrid al día. Ruede la bola", El Adelanto, no 8.907, 27 de junio de 1913, p. 1.

240 "La guerra", El Adelanto, no 8.906, 26 de junio de 1913, p. 1.

241 "La política del gobierno en África", El Adelanto, no 8.909, 30 de junio de 1913, p. 1; Tan sólo "Argos" demandó la urgente reapertura de las Cortes. Véase "Argos": "Madrid al día. Ruede la bola", El Adelanto, $\mathrm{n}^{\circ} 8.907,27$ de junio de 1913, p. 1.

242 "Las mujeres y la guerra", El Adelanto, no 8.912, 3 de julio de 1913, p. 1.

243 "Los muertos de la guerra. Don Casimiro Santander", El Adelanto, no 8.914, 5 de julio de 1913, p. 1.

244 "Notas militares. Fuerzas de Albuera, a África", El Adelanto, no 8.915, 7 de julio de 1913, p. 2.

245 Alfredo Rivera: "Información telegráfica de El Adelanto", El Adelanto, no 8.911, 2 de julio de 1913, p. 3.

246 “España en Marruecos. En víspera de una operación”, El Adelanto, no 8.914, 5 de julio de 1913, p. 1.

247 "Notas de la guerra", El Adelanto, no 8.917, 9 de julio de 1913, p. 1.
} 
En su lugar, y por primera vez, se reprodujo el testimonio de un desconocido que ofrecía detalles sobre el motivo de la ofensiva cabileña: Silvestre había hecho prisioneros a unos familiares de El Raisuni con el objeto de poder coaccionar a éste ${ }^{248}$. Sin embargo, el gobierno lo había desautorizado al obligarle a liberarlos. Como trasfondo de todo ello, permanecían sin esclarecerse las oscuras vinculaciones entre el cabecilla marroquí y algunos empresarios alemanes y se aludía, también, a un reciente viaje de Alfonso XIII a París, muy mal visto en la cancillería germana ${ }^{249}$. Al hilo de todo esto, la frustración e indignación entre los militares era, de día en día, mayor: los harqueños recibían ayudas de toda índole desde Tánger, mientras ellos se veían forzados a actuar, exclusivamente, a la defensiva ${ }^{250}$.

Alfredo Rivera, por su parte, publicaba tanto en El Imparcial como en El Adelanto una entrevista con un moro notable. En ella arrojaba otra explicación sobre el porqué de la hostilidad de El Raisuni. En efecto, Romanones había incumplido la promesa de designar a este personaje como Jalifa de la zona española. Pero, sobre todo, los anyera lo habían secundado y se habían sublevado contra España por la protección que en la plaza de Ceuta se le había dispensado a Abd Selam Salde, un irreconciliable enemigo de los cabileños de esta región ${ }^{251}$.

Reconociéndose ya, abiertamente, la enemistad de El Raisuni ${ }^{252}$, la redacción liberal aprovechaba la ocasión para publicar un retazo biográfico suyo, tomado de $E l$ Telegrama del Rif. Junto con la notable descendencia, se enfatizaba su faceta de bandolero, secuestrador y el apoyo a la causa de Hafid. Se recordaba también que sus tratos iniciales con Silvestre fueron muy amistosos, pero las relaciones personales entre ambos se habían deteriorado hasta llegar a las circunstancias actuales ${ }^{253}$.

La atención de la opinión pública salmantina, sin embargo, se dirigía preferentemente en aquellos días hacia otra triste realidad. Los soldados de la Albuera, una tropa de 125 hombres más cinco oficiales y el capitán Guillermo Laá al frente, eran calurosamente despedidos por sus vecinos el 12 de julio de 1913. El Adelanto se había destacado, desde que el día 6 se recibió el aviso de traslado en el gobierno militar, a la

\footnotetext{
${ }^{248}$ Con anterioridad a la firma del Acuerdo de Protectorado, Silvestre había tolerado los abusos de El Raisuni. Pero desde principios de 1913, el recién ascendido a coronel ya no admitiría las arbitrariedades del jerife. Consúltese BOUARFA, Mohamed: Op. Cit., p. 100.

249 "De la campaña. Impresiones de Larache", El Adelanto, no 8.919, 11 de julio de 1913, p. 1.

${ }^{250}$ Alfredo Rivera: "Información telegráfica de El Adelanto", El Adelanto, no 8.923, 16 de julio de 1913, p. 3 .

251 "De la guerra. Una interviú interesante", El Adelanto, no 8.928, 22 de julio de 1913, pp. 1-2.

${ }^{252}$ Alfredo Rivera: “Información telegráfica de El Adelanto", El Adelanto, no 8.937, 1 de agosto de 1913,

p.3. “De la guerra. La historia de El Raisuni", El Adelanto, nº 8.938, 2 de agosto de 1913, p. 2.
} 
hora de animar a las gentes y autoridades para proporcionar a los expedicionarios un cariñoso homenaje $\mathrm{e}^{254}$. Y había hallado una rápida contestación: el 10 de julio quedaba constituida una junta organizadora del acto. Presidida por el gobernador interino, el señor Brozas, y el alcalde igualmente interino, Pérez Criado, su gestión más destacada consistió en la apertura de una fulminante suscripción popular, con apenas tres días de duración, para obsequiar a los desafortunados. En esa misma primera jornada se recaudaron 495 pesetas -100 del Ayuntamiento ${ }^{255}$; la misma cuantía de la Diputación $^{256}$; 50 pesetas del periódico del Núñez Izquierdo, quien además formaba parte de la junta directiva, y otras tantas de La Libertad $^{257}$ - ; al día siguiente, la cifra se duplicó, hasta llegar a 1.006 pesetas $^{258}$, y la cantidad final ascendió a 2.390 pesetas $^{259}$.

Entre las donaciones, además de las ya mencionadas, figuraban las 50 pesetas de El Salmantino, la misma cifra dispensada por el Cabildo Catedralicio, otras 25 pesetas procedentes del Círculo Tradicionalista, 15 pesetas entregadas por la familia Moneo, otras 10 de la familia Mirat, e idénticas cantidades cedidas por Lamamié de Clairac e Isidro Segovia (médico y profesor perteneciente al sector más progresista de la Universidad), 25 pesetas de la Federación Obrera de Salamanca, 2 pesetas de alguien registrado bajo el título "Un contrario a la guerra"... En definitiva, un largo listado de socorros con participantes y cifras que tal vez sorprendan. Y también, por supuesto, con ausencias llamativas. En particular, dos: la de Diego Martín Veloz y la de Miguel de Unamuno.

\footnotetext{
254 “Albuera a África. Nuestro deber”, El Adelanto, no 8.916, 8 de julio de 1913, p. 1.

${ }^{255}$ En la sesión del 14 de julio de 1913 queda aprobada esta donación: Actas de las Sesiones Municipales. Archivo Histórico Municipal, vol. 1913, fol. 84 (v).

${ }^{256}$ Actas de la Comisión Permanente de la Diputación de Salamanca. Archivo de la Diputación provincial, vol. 1913, fol. 106 (r). La sesión tuvo lugar el 18 de julio.

257 "El homenaje de despedida a las tropas de Albuera", El Adelanto, no 8.918, 10 de julio de 1913, p. 1.

258 "El homenaje de despedida a las tropas de Albuera", El Adelanto, n ${ }^{\circ} 8.919,11$ de julio de 1913, p. 1.

259 "Salamanca y el Ejército. Un escuadrón de Albuera a África", El Adelanto, no 8.919, 11 de julio de 1913, p. 3.
} 


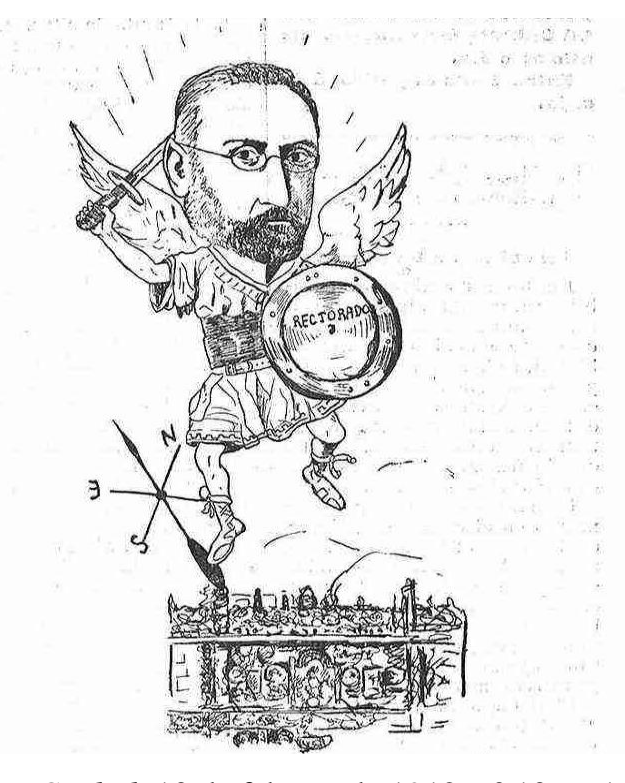

La Ciudad, 10 de febrero de 1912, nº 10, p. 1 .

A la vista de estos datos, debemos concluir que, en los momentos de máxima tensión bélica y emocional, tal como la producida por la marcha de los quintos, la prensa adquiría un enorme poder de persuasión con un mínimo esfuerzo propagandístico. Y estaba aprendiendo a aprovecharse de ello: bastaron tres días para recaudar una suma de dinero nada despreciable, ya que la solidaridad para con unos compatriotas se solía anteponer a las distintas opiniones con respecto a la cuestión marroquí. En otras palabras, figurar en la relación de nombres de la suscripción no significaba apoyar la guerra y, desde luego, tampoco el hecho de no aparecer en ella se traducía en una actitud de rechazo hacia el conflicto. Al contrario, Veloz y, todavía entonces, Unamuno eran encendidos defensores de la acción colonial y militar española al sur de Tarifa. ¿Por qué no participaron en la colecta? ¿Por tacañería? ¿O quizás consideraron que esa obligación sólo competía al Estado?

Entremos en el fangoso territorio de la conjetura.

No obstante, al perder actualidad el conflicto africano, como ocurriría por ejemplo coincidiendo con el desarrollo de la conflagración mundial, serían precisamente estos dos grandes ausentes, los personajes que con más luz propia brillaron en la historia salmantina del primer tercio del siglo XX, los únicos que espontáneamente mostrarían un interés muy acentuado en los asuntos marroquíes. El primero, Veloz, fue un acérrimo defensor del Ejército español durante toda su vida y en repetidas ocasiones se desplazó hasta el escenario del conflicto para distribuir quinina entre los soldados; el segundo, a partir de 1917, y debido a sus cuantiosas lecturas, sus relaciones personales y, sobre 
todo, a su envidiable espíritu, inquieto e irreverente, se retractaría de todas sus afirmaciones previas a propósito de la zona española en Marruecos para convertirse en azote del Rey. En suma, ya que sus opiniones no se fundamentaban exclusivamente en la lectura de periódicos ni tampoco se divulgaban siempre a través de ellos, no estuvieron tan expuestos a su fuerza de coacción. Pudieron actuar a contra corriente.

Pero esta realidad no fue extensible al resto de salmantinos. Aunque, eso sí, la prensa tendría que incrementar sus esfuerzos si quería recabar la atención y apoyo de la opinión pública, de aquellos sin tanto atrevimiento, formación o curiosidad como los líderes natos de opinión. Pero, ¿lo haría? ¿Cómo? ¿Intuirían la utilidad de fomentar el miedo, tal y como años después escribiría Lippmann? Pronto habrá ocasión de comprobarlo.

La suscripción ciudadana no fue el único gesto de manifestación de la opinión pública local ante el traslado de la Albuera a territorio africano: de signo contrario, el mismo día en que se recibió la orden de traslado, la Agrupación Socialista Salmantina organizó un mitin contra la contienda en el Frontón de San Bernardo. Sin embargo, no fue un acto demasiado concurrido ${ }^{260}$.

Al tiempo que la redacción de El Adelanto aplaudía el patriotismo de los vecinos del Tormes, Laá aleccionaba a la tropa a propósito del traicionero carácter moro; el periódico de Núñez Izquierdo se hacía eco de ello y, a la par, de una entrevista, concedida por Unamuno para Nuevo Mundo. En ella el pensador reflexionaba sobre la importancia de Marruecos como agente de regeneración espiritual y se situaba en el punto de mira de todos los tertulianos ${ }^{261}$. "Argos", sin embargo y por no variar, se desmarcaba de su periódico con un editorial de contenido muy abstracto y donde clamaba por un trato más misericordioso entre naciones: “Los pueblos guerrean unos contra otros y, con la capa de una paz armada, se aperciben a devorarse sin compasión"262. El motivo era el siguiente: "Cuando escasea la misericordia buena, buenísima, eficacísima e insustituible es la dulce y santa resignación la que aparece"; resignación que él, evidentemente, no soportaba; resignación que conducía a despedir afectuosamente a los soldados en lugar de intentar, más vivamente, evitar su movilización.

\footnotetext{
260 "El mitin de ayer tarde", El Adelanto, no 8.915, 7 de julio de 1913, p. 2.

261 "Don Miguel de Unamuno y la cuestión de Marruecos", El Adelanto, no 8.925, 18 de julio de 1913, p. 2.

262 “Argos": "Madrid al día. Carta abierta”, El Adelanto, no 8.919, 11 de julio de 1913, p. 2.
} 
Por el momento, sin embargo, el adiós a los jóvenes de la provincia, celebrado el 12 de julio y relatado muy ampliamente por el diario liberal el 14 de julio de 1913 (los domingos no había tirada), se presentó como majestuoso y multitudinario, con cerca de 7.000 asistentes y plagado de escenas conmovedoras ${ }^{263}$. Su viaje hasta Ceuta se desarrolló sin incidentes y de ello dio puntualmente cuenta el infatigable Alfredo Rivera $^{264}$.

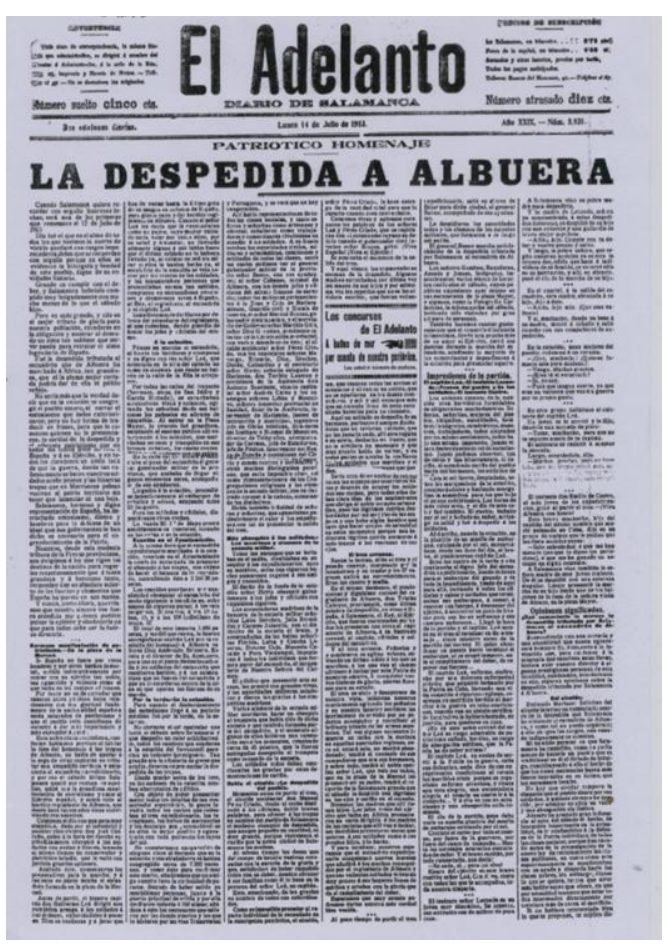

El Adelanto, n ${ }^{\circ} 8.921,14$ de julio de 1913, p. 1.

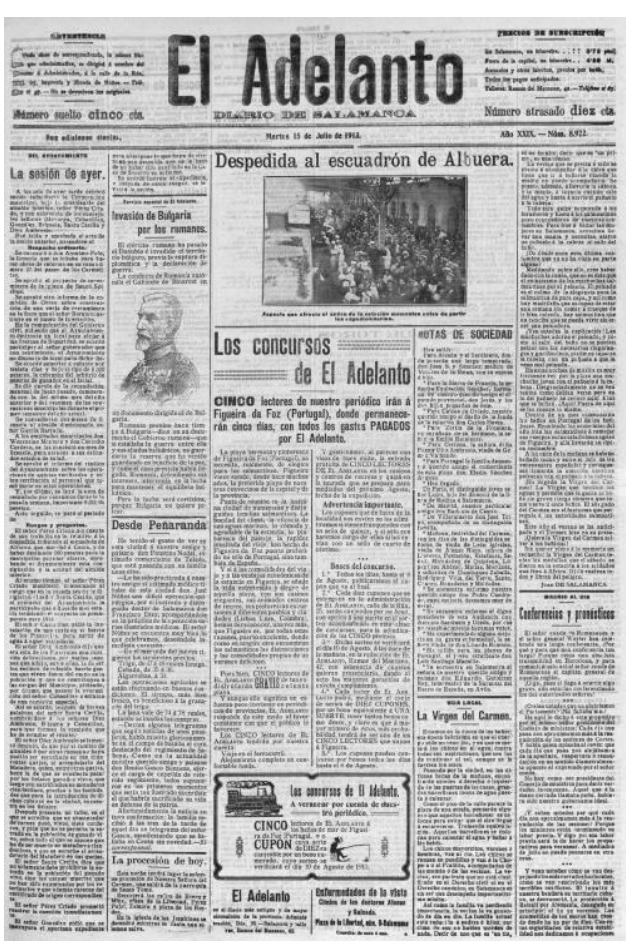

El Adelanto, $\mathrm{n}^{\mathrm{o}} 8.922,15$ de julio de 1913, p. 1.

Las buenas nuevas duraron un suspiro. Esas notas costumbristas que emplearon algunos periodistas en la campaña de 1909 al referirse a los soldados salmantinos y su estancia en el territorio marroquí no las hallamos ahora. El escuadrón de Albuera quedó inmediatamente a cargo de la seguridad de los convoyes que se desplazaban entre Tánger y Tetuán y sometido, por tanto, a los continuos tiroteos de los escurridizos, casi invisibles, enemigos moros (para un conocimiento pormenorizado de sus ocupaciones durante esta campaña, puede consultarse, en el apéndice final, el historial del regimiento, procedente del Archivo General Militar de Madrid) ${ }^{265}$. Aunque El Adelanto

\footnotetext{
263 "Despedida a la Albuera", El Adelanto, no 8.921, 14 de julio de 1913, p. 1.

264 "Hacia la guerra. El escuadrón de Albuera", El Adelanto, no 8.923, 16 de julio de 1913, p. 1.

265 "De la guerra. Los de Albuera en acción", El Adelanto, no 8.929, 23 de julio de 1913, p. 1.
} 
intentó tranquilizar a sus fieles con la inclusión de alguna que otra carta enviada desde el frente, su efecto hubo de ser, a tenor de la difícil labor que desempeñaban los combatientes, mínimo ${ }^{266}$. En realidad, el recuerdo de los expedicionarios y la preocupación por su bienestar estuvo siempre presente en la ciudad, y más aún, coincidiendo con la festividad de Santiago, patrón de la Albuera ${ }^{267}$.

El nerviosismo, además, aumentó exponencialmente al conocerse que el teniente Peral había resultado herido en el combate del 27 de julio de $1913^{268}$. Su agonía, de hecho, fue seguida con increíble expectación y dolor en Salamanca porque se trataba de una figura, natural de Béjar aunque residente en la capital, muy conocida y apreciada en la ciudad ${ }^{269}$. Mientras, el batallón de la Albuera, acampado desde su llegada en La Puntilla, a 7 kilómetros de Ceuta, siguió realizando servicios de exploración, descubiertas y conducción de convoyes, siendo los incidentes violentos continuados y el goteo de heridos, incesante y descorazonador para la opinión salmantina ${ }^{270}$.

El fallecimiento del joven teniente, publicitado el 4 de agosto $^{271}$, conmocionó a la ciudad e hizo aflorar, por boca de "Uno", un discurso sobre el sinsentido de la pelea: "Peléase sin saber por qué y tanto empuje ponen los naturales del terruño que no llegan a éste las ventajas que violentamente quieran implantar los que como conquistadores aparecen, como éstos en imponer a la fuerza lo que acaso la persuasión y la bondad hicieran fácil y fructuoso" ${ }^{272}$. Si bien el teniente acabó enterrado en Ceuta $^{273}$, el simultáneo funeral que se celebró en Salamanca, el 9 de agosto, como gesto de homenaje hacia Peral fue un acto muy concurrido y hondamente sentido ${ }^{274}$.

\footnotetext{
266 “Carta abierta. Los soldados salmantinos", El Adelanto, no 8.932, 26 de julio d3 1913, p. 1.

267 "La fiesta de Santiago Apóstol y el regimiento de Albuera", El Adelanto, n 8.932, 26 de julio de 1913, p. 1.

${ }^{268}$ Alfredo Rivera: “Información telegráfica de El Adelanto", El Adelanto, no 8.933, 28 de julio de 1913, p. 3.

269 "El teniente González Peral se encuentra moribundo", El Adelanto, nº 8.938, 2 de agosto de 1913, p. 1.

270 "Los de Albuera en la guerra. El teniente González Peral y el soldado Regueiros", El Adelanto, $\mathrm{n}^{\circ}$ 8.934, 29 de julio de 1913, p. 1; "Desde Ceuta. Albuera en campaña", El Adelanto, no 8.936, 31 de julio de 1913, p. 1.

271 "Desde Ceuta", El Adelanto, no 8.939, 4 de agosto de 1913, p. 1.

272 "Uno": "Palabras de un optimista. Paz en la guerra", El Adelanto, no 8.940, 5 de agosto de 1913, p. 1.

273 "Desde Ceuta", El Adelanto, no 8.940, 5 de agosto de 1913, p. 1; "Desde Ceuta", El Adelanto, $\mathrm{n}^{\circ}$ 8.946, 12 de agosto de 1913, p. 1.

274 "Esquela", El Adelanto, $\mathrm{n}^{\circ}$ 8.943, 8 de agosto de 1913, p. 1; "Por las víctimas de la guerra. Los solemnes funerales por don Germán G. Peral”, El Adelanto, no 8.945, 11 de agosto de 1913, p. 1.
} 
En aquellos mismos días, por cierto, y a modo de nota bastante anecdótica, otra iniciativa de apoyo a los combatientes recababa la atención de la ciudadanía: la de un festival benéfico organizado por el gremio de confiteros y pasteleros ${ }^{275}$.

A mediados de agosto, volvieron a intensificarse los ataques en la carretera de Tetuán sobre los hombres de Albuera. Dos soldados salmantinos, Feliciano Gago y Benito Quintas Pizarro, fallecieron, mientras que otros cuatro resultaron heridos ${ }^{276}$. La guarnición de la capital, por su parte, respondió con la celebración de otra misahomenaje en la Clerecía ${ }^{277}$.

Por si no fuera suficiente, otra nueva razón para la incertidumbre pública se presentó ante los ojos de los salmantinos: la estancia de Alfau en Madrid. Pallol barajó, inicialmente, dos motivos: "O el digno general y Alto Comisario en Marruecos, señor Alfau, viene a la corte para reponer su quebrantada salud y para cuidar de sus particulares intereses, o viene con licencia del gobierno y quizás llamado por el gobierno, para realizar un acto importantísimo" ${ }^{278}$. Y, a los pocos días, confirmaba lo que se había convertido en un secreto a voces. Es decir, su sustitución por el general Marina $^{279}$. La razón: que los reiterados intentos por llegar a un acuerdo con El Raisuni para restablecer las comunicaciones entre Ceuta y Tetuán habían fracasado. En realidad, los hostigamientos hacia las tropas españolas de ocupación serían continuados hasta el estallido de la conflagración mundial.

Mientras que algún redactor presentaba al ex-comisario como víctima de la política belicosa imperante, "Argos" volvía a la carga denunciando los negocios mineros de Romanones en Marruecos y la hipocresía del político liberal al manifestar “con la sencillez y la sinceridad en él tan características, que ni siquiera conoce la existencia de semejantes minas y sindicatos. Es más, no constan huellas de tales cosas en el Ministerio de Estado ni en el de la Guerra. ;Ganas de hablar por hablar!"280. Así que, ¿se hablaba otra vez de que el Ejército trabajaba para defender unas minas? Sin

\footnotetext{
275 "Los soldados salmantinos en Tetuán", El Adelanto, no 8.947, 13 de agosto de 1913, p. 1; "Del festival de los confiteros", El Adelanto, no 8.968, 6 de junio de 1913, p. 2.

276 "Desde Ceuta. Albuera en campaña", El Adelanto, no 8.951, 18 de agosto de 1913, p. 1; "Los muertos y heridos de Albuera", El Adelanto, no 8.953, 20 de agosto de 1913, p. 1; "Desde Ceuta. Postales de la guerra. Para El Adelanto", El Adelanto, no 8.958, 26 de agosto de 1913, pp. 1-2. Uno de los heridos, el teniente Ochando, fallecería también a los pocos días: "El teniente Ochando", El Adelanto, n 8.954, 21 de agosto de 1913, p. 2.

277 "Misas de réquiem", El Adelanto, no 8.953, 20 de agosto de 1913, p. 1.

278 “Argos": "Madrid al día", El Adelanto, no 8.947, 13 de agosto de 1913.

279 "Argos": "Madrid al día. Hastío", El Adelanto, no 8.949, 15 de agosto de 191913, p. 1.

280 "El relevo de Alfau", El Adelanto, no 8.950, 16 de agosto de 1913, p. 1; "Argos": "Madrid al día. Hablar por hablar", El Adelanto, no $8.967,5$ de septiembre de 1913, p. 1.
} 
duda, y mientras, en la sección telegráfica, se recogían unas primeras declaraciones de Marina en las que se recalcaba la necesidad de preparar a las tropas para una guerra irregular $^{281}$.

Desde Salamanca, en septiembre, partían otros diez soldados de Albuera para cubrir bajas ${ }^{282}$. Pero a pesar de los esfuerzos gubernamentales por acabar con la rebeldía, incluso, buscando la colaboración con Francia ${ }^{283}$, al finalizar octubre de 1913, el gobierno de Romanones tenía que ser remplazado por otro de signo conservador, encabezado por Eduardo Dato ${ }^{284}$.

Ante la opinión pública salmantina, no obstante, resurgía, envuelto entre tinieblas, aquel asunto de por qué no se había ocupado el Fondak. En El Liberal, Leopoldo Bejarano se había referido a la existencia de impedimentos alemanes ${ }^{285}$, así que "Argos", haciéndose eco de los rumores, se aventuraba a explicar lo ocurrido: no había que dar crédito a las malas lenguas que aseguraban que los hermanos Mannesmann habían laborado como mediadores entre El Raisuni y España, facilitando las ocupaciones de Larache, Alcazarquivir y Tetuán, y ahora obstaculizaban el avance español. Sin embargo, a renglón seguido, Benigno Pallol, con su característico sarcasmo, concluía: “'Nosotros, sólo nosotros pondremos un término fatal a las demasías morunas!"286. El mensaje transmitido era, evidentemente, el contrario.

Aunque la colaboración de El Raisuni con los españoles, en realidad, había topado con una limitación: el jerife había entendido que las autoridades españolas se conformarían con el dominio de las ciudades y el litoral, pero la montaña era su territorio. Por esta razón, no permitió que las tropas españoles sustituyeran a sus hombres en el Fondak ${ }^{287}$.

Más y más turbios se volvían, en cualquier caso, los tratos entre españoles, alemanes y El Raisuni. “Argos”, lógicamente, no podía aclarar nada, aunque lo deseara,

\footnotetext{
${ }^{281}$ Alfredo Rivera: "Información telegráfica de El Adelanto", El Adelanto, no 8,950, 16 de agosto de 1913 , p. 3.

282 "Soldados de Albuera a cubrir bajas", El Adelanto, no 8.977, 17 de septiembre de 1913, p. 1.

${ }^{283}$ Alfredo Rivera: "Información telegráfica de El Adelanto", El Adelanto, n 8.994, 7 de octubre de 1913, p. 3. A pesar de la reserva diplomática, en los círculos políticos se comentaba que Francia deseaba que España le consintiera el paso de las tropas argelinas por territorio marroquí en caso de que estallase la guerra contra Alemania.

${ }^{284}$ Las conversaciones con Francia prosiguieron, pero sin llegar a buen puerto por los muchos recelos existentes. Mientras que el objetivo francés consistía en la ocupación de Taza, los españoles pretendían desembarcar en la costa de Alhucemas para sofocar a los Beni-Urriaguel. Véase Alfredo Rivera: "Información telegráfica de El Adelanto", El Adelanto, no 9.127, 12 de marzo de 1914, p. 3; Alfredo Rivera: "Información telegráfica de El Adelanto", El Adelanto, n 9.131, 17 de marzo de 1914, p. 3.

285 "Argos": "Madrid al día. Contradicciones". El Adelanto, no 9.045, 5 de diciembre de 1913, p. 1.

286 "Argos": "Madrid al día. Incongruencias", El Adelanto, no 9.046, 6 de diciembre de 1913, p. 1.

${ }^{287}$ VILLALOBOS, Federico: Op. Cit., p. 105.
} 
porque la historia transcurría entre bambalinas. Pero, ¿cuál sería la reacción de los salmantinos en esta coyuntura? A los corresponsales y, sobre todo, a la opinión pública volvía a escamoteársele la información. Diríase, o al menos así lo entendemos nosotros, que la presencia española en Marruecos, en estas circunstancias, ya no generaba confusión. Muy al contrario, el veredicto de la opinión pública salmantina era clarísimo. El país africano se percibía como una colosal carga, los beneficios de la ocupación se desconocían y la falta de resolución por parte de los sucesivos gobiernos provocaba agotamiento.

La intrusión de los Mannesmann, que, en efecto, a principios de diciembre motivó un escrito de protesta por parte del ministro de Estado español ante su homónimo alemán, cuando a los mencionados empresarios se les ocurrió presentar una propuesta de cesión del Protectorado en alquiler, había acentuado el odio contra la guerra y a nadie se le escapaba que tan sólo primaban algunos intereses comerciales ${ }^{288}$. Aún con todo, la resignación era la respuesta pública dominante: "Si no fuera por el respeto que nos merecen los tratados y por lo vergonzoso de retirar nuestras fuerzas militares y nuestro predominio en las plazas del litoral, ya estaríamos recogidos en nuestros naturales términos"

Al iniciarse 1914, al tiempo que otros diez salmantinos eran enviados a Ceuta ${ }^{290}$, en el Protectorado se continuaba registrando el mismo estado de hostilidad, sobre todo, los territorios vecinos de Tetuán y Alcázar. Los padres de los soldados de cuota empezaban a mostrarse inquietos ante la larga permanencia de sus vástagos en el territorio africano. Y "Argos" se revolvía contra la hipocresía de sus demandas. Ciertamente, nuestro columnista reconocía la penuria de su situación: "Es triste lo que

\footnotetext{
${ }^{288}$ El documento de la proposición (para conocerlo, consúltese TESSAINER Y TOMASICH, Carlos Federico: Op.Cit. pp. 140-142 o TEMSAMANI, Abd-el-Arzia Khallouk: Op. Cit., pp. 109-110) no fue publicitado por la prensa salmantina, pero como un eco tardío llegaron aquí las denuncias del $A B C$ por las presencia del consorcio alemán en Madrid, y de ahí los comentarios de Argos.

289 "Argos": "Madrid al día. Contra la guerra”, El Adelanto, n 9.049, 10 de diciembre de 1913, p. 1.

290 "Soldados de Albuera a Ceuta", El Adelanto, no 9.079, 15 de enero de 1914, p. 1. El Adelanto reproducía, en las mismas fechas, dos cartas de "El músico Jeat" en las que se daba cuenta de lo encendido de la lucha a la que debían hacer frente los salmantinos: "Los soldados salmantinos. Carta de la guerra", El Adelanto, no 9.079, 15 de enero de 1914, p. 1; "Los soldados salmantinos. Carta de la guerra", El Adelanto, $\mathrm{n}^{\circ}$ 9.087, 24 de enero de 1914, p. 1. Por último, también se hacían entonces públicos los datos del actual remplazo. De un total de 604 quintos sorteados, 223 serían destinados prontamente, tras la instrucción, a África: "El sorteo de quintos para África”, El Adelanto, no 9.078, 14 de enero de 1914, pp. 1-2. El mismo periódico, días después, daría cuenta a sus lectores de algunos de los contenidos teóricos de esa instrucción: fortalecimiento del espíritu militar, la idea de la patria, la bandera, amor por la disciplina... Véase "Conferencias a los soldados", El Adelanto, n 9.105, 14 de febrero de 1914, p. 1.
} 
ocurre con los soldados de cuota. Después del sacrifico pecuniario, el sanguíneo, y perder la carrera, y acaso la vida..."291. Pero a ésta contraponía otra más lamentable:

"Señores, digo, labriegos: vuestros hijos, aquellos a quienes criasteis con mil fatigas, van a la campaña -no guerra- con una cuota de amor, y ya sois ancianos, y vuestros hijos, aquellos que habian de sosteneros en la porfía entablada contra la tierra esquilmada, contra la sequía, la inundación, el fisco y la cancerosa usura, no están con vosotros. Han ido, los han llevado a la campaña, a una operación de policía; cuando retornen, si retornan, ganarán otra vez su jornal, doblados sobre el ingrato terruño. Pero vosotros, ¿viviréis?"

La denuncia de este drama familiar, aclarémoslo, no fue demasiado corriente en las páginas de la prensa burguesa, pero sí constituyó un rasgo definitorio del pensamiento socialista. Por esta razón, entendemos que Pallol actuó ante la opinión pública salmantina como principal portavoz, el único por ahora, de esa ideología ${ }^{292}$. Además, reparemos, dado que ya se ha podido observar en otras ocasiones y es algo que anunciamos en la introducción de este trabajo, que el escritor jugueteaba con algunos eufemismos, tratando de evitar, o más bien simulándolo, la palabra maldita: la guerra. Pero, acaso, ¿no estaba así denunciando una grosera y reiterada estrategia de manipulación por parte de los gobiernos y periodistas? Ya no engañaban a nadie, con seguridad, y por ello tenían que perfeccionar sus estrategias propagandísticas. ¿Qué sentido tenían, si no, esos continuos, aunque minúsculos, envíos de soldados hacia el Protectorado? Evidentemente, se trataba de que pasaran tan desapercibidos como fuera posible; que no ocuparan la primera plana de los periódicos, sino algún rinconcito de la siguiente página. Todo ello con el claro propósito de evitar desórdenes sociales internos.

En efecto, no los hubo en Salamanca. Pero, eso sí, el 9 de febrero de 1914 tuvo lugar, en el edificio de su Federación, un mitin socialista contra la contienda. El discurso más encendido y documentado fue el de Filiberto Villalobos. Y su rasgo más

\footnotetext{
291 "Argos": "Madrid al día", El Adelanto, no 9.098, 6 de febrero de 1914, p. 1.

${ }^{292}$ A propósito de los primeros análisis que el PSOE realizó sobre la situación existente en el norte de África, recomendamos la lectura de un trabajo de Bernabé López García. Éste lleva por título "El socialismo español y el anticolonialismo. El socialismo español y los Congresos de la Internacional ante la penetración colonial en Marruecos (1898-1914)". Se trata de un artículo redactado en 1975, bastante influido por la obra de Miguel Martín y localizable en LÓPEZ GARCÍA, Bernabé: Marruecos y España... Op. Cit., pp. 163-213. El autor hace hincapié en los crecientes vínculos entre el socialismo español y el internacional - sobre todo, a partir de 1907, con el Congreso de Stuttgart-, puestos de relieve con la adopción de una nueva consigna contra la guerra: "Ni un hombre ni una peseta a África". El slogan clásico -y siempre el más popular y prestigioso-empleado por los trabajadores contra los conflictos coloniales había sido "O todos o ninguno". Sin embargo, desde 1907 El Socialista había advertido contra el radicalismo implícito en ese "ninguno": la guerra no se podía rechazar de modo tajante porque el derecho a la autodefensa era inalienable para los pueblos. La misma idea aparece en SERRANO, Carlos: “El PSOE y las cuestiones coloniales (1898-1914), Hispania, LVIIII/1, n 98, 1998, pp. 283-304.
} 
llamativo, la acusación de cobardía dirigida contra los intelectuales ${ }^{293}$. Lamentablemente, desconocemos qué efecto pudo tener este dardo envenenado sobre Miguel de Unamuno. ¿Acaso no deseó “entrar al trapo" arrojado por su amigo?

Por otra parte, también cierto sentimiento de desencanto y agotamiento empezaba a repercutir en el desenvolvimiento de algunas iniciativas caritativas. Así, la Junta de Damas de Salamanca, quizás la organización que mejor encarnaba el concepto burgués de patriotismo, había acordado recaudar dinero para los heridos y familiares de fallecidos en los combates durante el desarrollo de las misas y vendiendo florecillas por las calles ${ }^{294}$. Y si bien no se escatimaba el aplauso a la generosidad de los salmantinos ${ }^{295}$, tampoco faltaba ya el comentario crítico: "Es preciso que el poder central cumpla su deber con la misma generosidad de que España da pruebas un día y otro y que voten las Cortes, inmediatamente, una ley que ponga a los defensores de la patria inutilizados en el servicio de ésta, a cubierto de escaseces y miserias ${ }^{296}$.

La desesperación hacía mella en la redacción de El Adelanto, ya que la paz no vislumbraba, se temía por el déficit y los compromisos internacionales pesaban como una formidable losa:

"El sostenimiento de las fuerzas que un compromiso internacional, que bien puede ser calificado de ruinoso para España, nos ha obligado a llevar a Marruecos, es muy superior a nuestras fuerzas ordinarias, y de prolongarse aún mucho tiempo, es indudable que ha de conducir a nuestra Hacienda al más deplorable estado, y a las fuentes productoras al agotamiento, a la muerte.

Pero desgraciadamente el mal no para en esto. Un día y otro llegan por el cable noticias de combates, de tiroteos, de agresiones aisladas que cuestan mucha sangre y no pocas vidas. $Y$ si a cambio de tantas existencias sacrificadas y de tantos millones de pesetas consumidos, se hubieran dado algunos pasos en la obra de pacificación, menos mal; ipero se presiente tan lejana la paz! Sí estamos hoy como ayer, y de seguir el camino emprendido, mañana estaremos como hoy ${ }^{, 297}$.

\footnotetext{
293 "Mitin contra la guerra", El Adelanto, no 9.101, 10 de febrero de 1914, p. 1.

294 "Por los muertos y heridos en la guerra de Marruecos", El Adelanto, $\mathrm{n}^{\circ}$ 9.135, 21 de marzo de 1914, p. 1; "Las damas salmantinas. Por las víctimas de la guerra", El Adelanto, n 9.151, 9 de abril de 1914, p. 1; "Para las víctimas de la guerra", El Adelanto, no 9.153, 13 de abril de 1914, p. 1. En realidad, la idea de recaudar dinero durante el desarrollo de las misas se venía barajando desde finales de 1913, pues fue el $1^{\circ}$ de enero de 1914 cuando en el Obispado se recibió una solicitud de permiso, autorizada previamente desde Gracia y Justicia, para proceder a la colecta: "Para Salamanca de Madrid (...) La Asociación de señoras presidida por S. M. la Reina, que se ocupa en allegar fondos para heridos, familias, muertos campaña África, ha acordado hacer, con autorización de los prelados, una colecta en todas las iglesias de España durante las misas de un día de Enero, probablemente el 11 . Ruego a V. E. se digne a autorizar dicha colecta". Tomado del Boletín Oficial del Obispado de Salamanca, $1^{\circ}$ de enero de 1914, $\mathrm{n}^{\circ} 1$.

${ }^{295}$ Finalmente se recaudaron casi 4.500 pesetas: "Por los heridos de Melilla", El Adelanto, no 9.238, 20 de julio de 1914, p. 1.

296 "Puntos de vista", El Adelanto, no 9.153, 13 de abril de 1914, p. 1.

297 “Para El Adelanto. Tras la pacificación”, El Adelanto, n 9.119, 3 de marzo de 1914, p. 1.
} 
Un similar sentimiento de fatiga y postración generaban los debates parlamentarios. Alfredo Rivera, más exhaustivo que en ningún momento previo, se afanaba en señalar que, mientras en el Senado, los partidos dinásticos se esforzaban en evadir sus responsabilidades en el pleito africano ${ }^{298}$, en el Congreso, algunas comparecencias revestían bastante interés. Y, sobre todas las demás, la de Romanones. Indiscutiblemente, Rivera seguía con atención las declaraciones ministeriales porque confiaba en poder hallar en ellas una explicación sobre la marcha de los asuntos marroquíes. Los lectores salmantinos, por su parte, tendrían algo que agradecerle.

La intervención de Romanones sorprendía, desde luego, porque denotaba una actitud ultra defensiva. A su juicio, los españoles habían acudido a Marruecos por una fatalidad histórica, geográfica y, además, animados por Francia (que precisamente ahora se había adueñado de Taza) ${ }^{299}$. Por otro lado, el ex presidente aprovechaba para desprestigiar las gestiones del difunto Canalejas con un doble argumento: el Tratado de Protectorado no se avenía al carácter conquistador de los españoles; y don José fue el responsable de la acumulación de 72.000 soldados en aquel territorio. Además, explicaba su diferencia de criterio con Alfau a causa de la tan comentada operación sobre el Fondak. Éste había sugerido la toma de la posición, pero el gobierno, y especialmente Luque, ministro de Guerra, lo había descartado por hallarse peligrosamente cerca de la plaza de Tetuán. Sin, duda, y a tenor de la violencia reinante en las inmediaciones de la plaza, qué poco convincente resultó esta justificación ${ }^{300}$.

Otro redactor que no permaneció indiferente ante los debates sobre el Protectorado en el Congreso fue "Argos". Su pluma, en cambio, se dirigió hacia la denuncia de los tratados internacionales, al tiempo que manifestaba su escasa fe en el cumplimiento de cualquier propósito gubernamental:

"Hasta hoy, las opiniones manifestadas en el Congreso con suma elocuencia y profundo saber, son distintas, pero tienden a unificarse o armonizarse en el sentido de continuar la acción entablada más allá del Estrecho.

No es lógico ni conveniente denunciar los tratados, recluirnos en las antiguas plazas africanas, aislarnos del mundo (...) La guerra seguirá como he apuntado arriba, en la menor cantidad posible, desde luego. Se piensa reducir los contingentes bélicos,

\footnotetext{
${ }^{298}$ Alfredo Rivera: "Información telegráfica de El Adelanto", El Adelanto, no 9.175, 8 de mayo de 1914, p. 3. Por ejemplo, el Partido Conservador sostenía que el sistema de ocupación mediante el empleo de columnas volantes resultaba muy costoso. Desde las filas liberales, García Prieto aceptaba su responsabilidad en la firma del Tratado con Francia, en noviembre de 1912, pero censuraba la política puramente belicosa adoptada por el Partido Conservador.

299 "Los franceses en Taza", El Adelanto, n' 9 $^{\circ} 181,15$ de mayo de 1914, p. 3.

${ }^{300}$ Alfredo Rivera: "Información telegráfica de El Adelanto", El Adelanto, no 9.179, 13 de mayo de 1914, p. 3 .
} 
nombrar un comisario civil y hacer uso muy parco de las armas... si nos lo permiten los moros ${ }^{, 301}$.

Únicamente Pablo Iglesias, siempre muy sensible al tema marroquí, escapó de la tónica general parlamentaria. El líder socialista rechazaba los compromisos internacionales y exigía la urgente retirada de las tropas, sometidas frecuentemente a malos tratos por parte de la oficialidad ${ }^{302}$. Pero el político no hacía tanto una crítica del colonialismo, como de la debilidad del capitalismo español, enfatizando así la subsiguiente inutilidad del dominio colonial en el Norte de África ${ }^{303}$. Su voz, sin embargo, apenas hallaba respaldo en la Cámara. Y “Argos” se desquiciaba al conocer el rumbo que adquiría el debate: la apuesta por un protectorado civil. A lo que el columnista, respondía: "todo lo civil y todo lo político que se quiera, pero precedido, acompañado y segado de la acción militar, pues de otro modo no hay protectorado que valga"304.

Mientras Salamanca se volcaba en dispensar una calurosa acogida al capitán Laá, el héroe del momento que se hallaba en la ciudad por unos días ${ }^{305}$, las sesiones de día en día se volvían más turbulentas, con agresión incluida para el republicano Rodrigo Soriano $^{306}$. Pallol, rápidamente, asociaba este hecho a la sospecha, murmurada entre dientes a lo largo y ancho de la geografía nacional, de que lo que sucedía en Marruecos era más grave de lo que transmitían los partes oficiales y al gobierno le urgía buscar un remedio para la situación de los "cuotas" 307 . Y, en efecto, Rivera confirmaba, a mediados de julio de 1914 -apenas un mes antes del estallido de la Guerra Mundialque las comunicaciones entre Tánger, Tetuán y Larache se veían constantemente entorpecidas $^{308}$. Nada había cambiado.

\footnotetext{
301 “Argos": "Madrid al día. Debate luminoso", El Adelanto, no 9.188, 23 de mayo de 1914, p. 2.

${ }^{302}$ Alfredo Rivera: "Información telegráfica de El Adelanto", El Adelanto, no 9.191, 27 de mayo de 1914, p. 3.

${ }^{303}$ BORRELL MERLÍN, M Ma Dolores: "Visión progresista de las relaciones España-Marruecos: El antecedente de Pablo Iglesias", Anduli. Revista Andaluza de Ciencias Sociales, ${ }^{\circ}$ 2, Sevilla, 2003, pp. 59-76. Sólo una minoría de los discursos parlamentarios del líder socialista, reproducidos en este trabajo, apuntan hacia un muy tímido e impreciso pensamiento anticolonialista.

304 "Argos": "Elocuencia suicida", El Adelanto, n' 9.192, 28 de mayo de 1914, p. 1.

305 "Sir-ve": "Nuestras informaciones. Hablando con el capitán Laá", El Adelanto, no 9.184, 19 de mayo de 1914, p. 1.

306 "Argos": "Mentiras de mayo", El Adelanto, no 9.194, 30 de mayo de 1914, p. 1.

307 "Argos": "Madrid al día. Sustos y alegrías", El Adelanto, no 9.223, 3 de julio de 1914, p. 1; "Un ruego. Al ministro de la Guerra", El Adelanto, no 9.216, 25 de junio de 1914, p. 1; "El voluntariado para África", El Adelanto, $\mathrm{n}^{\circ}$ 9.236, 17 de julio de 1914, p. 1.

${ }^{308}$ Alfredo Rivera: “Información telegráfica de El Adelanto", El Adelanto, n 9.231, 11 de julio de 1914, p. 3 .
} 
Durante los cinco primeros meses de este año, España había invertido en Marruecos cincuenta millones de pesetas. La cifra se revelaba más alarmante si se pensaba que durante todo 1913, con una guerra más en firme, se habían consumido 20 millones. "Argos", y con esto terminamos el repaso de El Adelanto para este periodo, lo decía todo: “'Cuánto, pero cuánto nos cuesta proteger a los moros y meterles la civilización en la cabeza! ¡Ni que fueran españoles ignorantes y sin pan! -dirán innumerables indígenas de aquî ${ }^{309}$.

Pasemos ahora al comentario y análisis de La Libertad, semanario maurista, de tono extraordinariamente combativo y que vio la luz al mismo tiempo que se procedía a la ocupación de Tetuán, en febrero de $1913^{310}$. Empeñada en reivindicar la figura del exlíder conservador, poco después de su fundación, la redacción subrayaba que don Antonio se había visto atado de manos en Marruecos como consecuencia de los Acuerdos de Algeciras ${ }^{311}$; y publicaba tres editoriales de Gabriel Maura Gamazo en los que se desprestigiaba la labor de Romanones. A su juicio, en el Protectorado se estaba potenciando en exceso la acción militar, en lugar de una política de reformas ${ }^{312}$. Temía por ello que, muy probablemente, el resultado final resultase funesto:

"Llevamos camino de reproducir en Marruecos la vergüenza del desastre colonial, porque ni en lo civil ni en lo militar hemos aprendido y escarmentado (...) El delirio de grandeza se ha apoderado de los directores de nuestra política, hasta el punto de crear en la menguada zona española nada menos que tres Comandancias Generales, ${ }^{\text {,313. }}$

Los miembros de la redacción sostenían una postura bastante similar a ésta. También creían en la acción civil en, pero defendían que se presentaba como inexcusable una previa y muy contundente acción bélica. Por este motivo, hacia mediados de junio de 1913, La Libertad acusaba al gobierno de escatimar en el envío de refuerzos al territorio africano por miedo a que se desencadenasen problemas internos.

\footnotetext{
309 "Argos": "Saldo de cuentas", El Adelanto, no 9.235, 16 de julio de 1914, p. 1. Su pesimismo era más notorio en "Argos": "Madrid al día. Moros y ediles", El Adelanto, n 9.242, 24 de julio de 1914, p. 1. La actitud de "Argos" contrastaba, por las mismas fechas, con el entusiasmo y tono costumbrista del que hacía gala Meneu. Este catedrático, que había emprendido un viaje por Marruecos y Argelia, remitió al diario liberal varias crónicas, bajo el encabezamiento "Por Marruecos y Argelia", en los días 24, 27 y 29 de julio, 3, 15 y 29 de agosto.

${ }^{310}$ En su carta de presentación, titulada "A Maura", la redacción manifestaba: "Al salir al campo de la lucha política, sean nuestras palabras de adhesión inquebrantable, de cariñoso saludo y de sincero, respetuoso, entusiasta homenaje al insigne patricio que dedicó su vida toda al servicio de la patrio". Véase La Redacción: “A Maura”, La Libertad, n 1, 20 de febrero de 1913, p. 1.

311 “Obrero, ¿te engañan?", La Libertad, nº 5, 20 de marzo de 1913, pp. 1-2.

312 Gabriel Maura y Gamazo: "Palabras autorizadas. La política del gobierno en Marruecos", La Libertad, $\mathrm{n}^{\mathrm{o}}$ 18, 19 de junio de 1913, pp. 2-3; Gabriel Maura y Gamazo: "Palabras autorizadas. La política del gobierno en Marruecos", La Libertad, n' 20, 3 de julio de 1913, p. 1; Gabriel Maura y Gamazo: "Palabras autorizadas. La política del gobierno en Marruecos", La Libertad, n 21, 10 de julio de 1913, p. 2.

313 Gabriel Maura y Gamazo: "Palabras autorizadas. La política del gobierno en Marruecos", La Libertad, no 20,3 de julio de 1913 , p. 1 .
} 
Pero, sobre todo, rechazaba el pretexto económico tras el que se escudaba éste para no acometer una guerra rápida y rotunda. En realidad, aseguraban, el patrimonio se derrochaba muy interesadamente: "Se despilfarra el dinero en pensiones que no producen ni el más pequeño beneficio (...) Se dedican importantes sumas a rellenar los estómagos hambrientos de la prensa bullanguera (...) Y el pueblo ve todo esto y calla (...) Y el Ejército presencia su lánguida vida; y sufre los rigores de ajenos yerros; y se expone a funestos contratiempos"314.

En segundo lugar, la redacción también cargaba las tintas contra la opinión pública pacifista, con un comentario del todo injusto y desvergonzado: "Las protestas tendrían que haber salido a la luz pública cuando se firmaron los tratados, pero no ahora" ${ }^{\prime 15}$. De continuo, este periódico insistió en la idea de que los obreros estaban fanatizados $\mathrm{y}^{316}$, como también haría -y ya había hecho- El Salmantino, "X." responsabilizaba por ello a cierta prensa: "Es una lamentable costumbre, muy generalizada sobre todo entre los españoles, la de tomar como artículo de fe cuanto leemos en la prensa periódica, economizándonos de ese modo la molestia de pensar y el trabajo intelectivo que supone el comparar y discurrir para formar juicio propio"317. Por último, la alianza con Francia fue contemplada como una conducta "suicida"318. Sin duda, éste constituyó el rasgo más curioso de la publicación: porque los pactos con Francia, no lo olvidemos, habían sido ideados por Maura; pero la relación con la república vecina en Marruecos resultaba en 1913, a ojos de cualquiera, muy tormentosa.

Junto con la acérrima reivindicación de la obra de Maura, La Libertad también se caracterizó por servir como amplificadora de las opiniones vertidas en otros órganos de prensa nacionales. Así, de La Opinión, se tomó prestado un excelente editorial a propósito del Desastre de 1898 con el objeto de presionar a la opinión pública salmantina para no abandonar, en el presente, la misión africana: “No miremos lo que materialmente no ganamos, sino lo que ganamos espiritualmente, lo que ganamos militarmente, lo que ganamos internacionalmente, y miremos también, y sobre todo, lo mucho, lo casi imperdonable que sin el sacrificio hubiéramos perdido" ${ }^{\text {319 }}$. Con mayor detenimiento, y como si estuviera respondiendo al diario republicano La Lucha, la

\footnotetext{
314 "Hacia el desastre", La Libertad, no 18, 19 de junio de 1913, p. 3. Se abundaba en la misma idea en "El reinado de la farsa", La Libertad, no 19, 26 de junio de 1913, p. 2.

315 "En torno a la guerra", La Libertad, n' 21, 10 de julio de 1913, p. 1.

316 "C. de A.": "Los verdugos de la clase obrera", La Libertad, no 2, 27 de febrero de 1913, p. 6.

317 "X.": "Discurramos", La Libertad, no 3, 6 de marzo de 1913, p. 6. Muy similares ideas se barajaban en: "De moral periodista", La Libertad, no 13, 15 de mayo de 1913, p. 2.

318 "Insistiendo", La Libertad, no 14, 21 de mayo de 1913, p. 2.

319 "Del optimismo al pesimismo", La Libertad, n 22, 17 de julio de 1913, pp. 3-4.
} 
redacción, en otra ocasión, subrayaba que el juicio de la opinión pública estaba pervertido, aunque, sabido era, la guerra contra el moro se presentaba tradicionalmente como la más popular en España ${ }^{320}$.

$\mathrm{Su}$ mayor esfuerzo de persuasión a favor de la intervención en África, no obstante, consistió en la reproducción en abril de 1914, y a lo largo de varios días, de una conferencia muy polémica impartida por Gabriel Maura Gamazo sobre la cuestión marroquí. El discurso original, de todas formas, había sido pronunciado algunos meses atrás, en Santander, y había sido muy contestado por militares como Burguete ${ }^{321}$. Paradójicamente, el líder conservador confesaba que su padre siempre había sido enemigo de la guerra en Marruecos. Y desde este presupuesto, repasaba la campaña de $1909^{322}$; sus antecedentes y relaciones con El Rogui ${ }^{323}$; la decisión de Marina de ocupar Zeluán, luego respaldada, aunque sólo de forma transitoria, por el gobierno; la renuncia liberal a abandonar esta posición y la campaña del Kert; por último, responsabilizaba tanto a Romanones como a Dato de las operaciones de $1913^{324}$.

Por otra parte, poco después y efectuando de nuevo un gran despliegue, también se incluyeron en La Libertad las palabras pronunciadas por el propio Antonio Maura con respecto a la Guerra de 1909 en una sesión del Congreso, celebrada, el 22 de mayo de 1914 (siete planas a tres columnas), y en otra del 18 de junio del mismo año (seis planas, también a tres columnas). Mientras tanto, el semanario se congratulaba por la creciente fuerza del maurismo como fuerza política ${ }^{325}$. El ideario del mallorquín era prácticamente idéntico al de su hijo, aunque con dos novedades: la defensa de las negociaciones suscritas por él mismo en 1904; y la tímida censura hacia el afán conquistador que empezaba a aflorar en las mentes de algunos oficiales. Dicho de otro modo, su mensaje era claramente autoexculpatorio ${ }^{326}$.

\footnotetext{
320 "Contestando a unas preguntas", La Libertad, n 24, 31 de julio de 1913, p. 3.

321 "Los conservadores en Santander", La Libertad, no 30, 11 de septiembre de 1913, pp. 3-4; "El asunto Maura-Burguete. Lo que dijo Gabriel Maura", La Libertad, n 58, 6 de abril de 1914, pp. 4-5.

322 "Maura, enemigo de la guerra", La Libertad, no 61, 25 de abril de 1914, pp. 2-3; "Maura, enemigo de la guerra", La Libertad, no 62, 2 de mayo de 1914, p. 3.

323 "Maura, enemigo de la guerra", La Libertad, no 59,14 de abril de 1914, pp. 1-4.

324 "Maura, enemigo de la guerra", La Libertad, nº 63, 9 de mayo de 1914, pp. 2-4.

325 "Miscelánea política", La Libertad, n 66, 30 de mayo de 1914, p. 1.

326 "Don Antonio Maura. Sobre nuestra actuación en Marruecos", La Libertad, $\mathrm{n}^{\circ}$ extraordinario, 22 de mayo de 1914, pp. 1-7. De manera idéntica, un año antes, La Libertad reprodujo dos discursos de Antonio Maura, pronunciados el 29 de mayo de 1913, en los que argumentaba su retirada de la política activa. El tono también era claramente victimista: "Notable discurso parlamentario de Antonio Maura", La Libertad, $\mathrm{n}^{\circ}$ 16, 5 de junio de 1913, pp. 1-6; "Discurso de Maura", La Libertad, n ${ }^{\circ}$ 17, 12 de junio de 1913, pp. 1-6. Y merecía el apoyo unánime de la redacción: "Rasgos de la jornada", La Libertad, n 16, 5 de junio de 1913, pp. 6-7.
} 
Para La Libertad, en suma, mientras que la campaña de 1909 merecía un juicio positivo, ni de la Guerra del Kert ni las operaciones ahora sostenidas en Tetuán merecían alabanzas. Sobre todo porque Antonio Maura, suscribía esta redacción, no había engañado nunca a la opinión ${ }^{327}$. Aún así, de ningún modo, ello les impediría colaborar con los actos de homenaje y despedida para los soldados de la Albuera ${ }^{328}$. La solidaridad hacia unos compatriotas servía como motor para este tipo de gestos; no eran el fruto de una exitosa propaganda belicista.

Esto había comentado La Libertad tras la marcha de los jóvenes salmantinos: "Afortunadamente, la degeneración de la raza latina no ha contaminado, aún, a la inmensa mayoría de nuestro pueblo; y el nombre mágico de España y el de su valiente Ejército, levanta en los pechos españoles tempestades de entusiasmo y obra el milagro de romper el hielo de los hombres indolentes" ${ }^{329}$. El tono empleado en este breve fragmento, con esas alusiones a la raza, fue muy similar al de los editoriales de $E l$ Salmantino, que en breve comentaremos; pero su fondo, no lo sería. Mientras el integrismo se esforzará en potenciar y elogiar el carácter interclasista de la despedida, disimulando cualquier síntoma de malestar que pudiera desmoralizar a los combatientes, en el órgano maurista, percibiéndose también ese amplio respaldo ciudadano, primaba la resignación ante una decisión de Romanones, un hombre "indolente" y con un temperamento "de hielo". Las consecuencias no tardarían en verse: el sentido fallecimiento de Peral $^{330}$.

Los juicios contrarios al modo en que se desarrollaba la campaña militar, permitiendo el enquistamiento del problema, no pasaron, sin embargo, de las lamentaciones por escrito. Ni siquiera lograron eco entre los militantes mauristas de la ciudad. Y aunque el 19 de julio de 1914 estaba preparada una manifestación conservadora, a escala nacional, para protestar contra el rumbo de los acontecimientos, el Comité Maurista Salmantino, presidido por Torcuato Fernández Cuesta, reconocía el día antes que no la iba a secundar:

"Nosotros, lamentándolo profundamente, nos vemos imposibilitados de organizar mitin para ese día; pues en Salamanca queremos empezar nuestra labor de tribuna con un acto de verdadera resonancia, trayendo, para honrarnos con su presencia y deleitarnos con su verbo, a los más esforzados y elocuentes paladines de la causa maurista. Y en

\footnotetext{
327 "Unas cuantas verdades", La Libertad, no 58, 6 de abril de 1914, pp. 5-6.

328 "Homenaje popular", La Libertad, no 21, 10 de julio de 1913, p. 1; "Croniquilla", La Libertad, n 22, 17 de julio de 1913, p. 5.

329 "Por la patria", La Libertad, no 22, 17 de julio de 1913, p. 1.

330 "Croniquilla", La Libertad, n' 24, 31 de julio de 1913, p. 5; “(Título en blanco)”, La Libertad, no 25, 7 de agosto de 1913, p. 1; “Croniquilla", La Libertad, no 27, 21 de agosto de 1913, p. 4.
} 
los pueblos tampoco es fácil ni provechoso organizar acto alguno, ya que en los actuales momentos, las tareas agrícolas embargan por completo el tiempo y el pensamiento de los habitantes rurales, a quienes no es lícito, ahora, distraer ${ }^{, 331}$.

Pero, ¿de verdad se necesitaba a Maura o a su hijo para celebrar un acto de esta índole? A nadie se le escapaba que se trataba de una burda excusa ante la ausencia de capacidad de movilización de este sector político. El socialismo, en cambio, sí había empezado a cobrar fuerza movilizadora contra la guerra.

El Salmantino, por último y al contrario que El Adelanto, apenas reparó en las primeras medidas adoptadas para la organización del Protectorado español en Marruecos y se mostró, en general, mucho menos pendiente que el órgano de Núñez Izquierdo de la suerte de los salmantinos en aquellas tierras ${ }^{332}$. Pero sí celebró, y mucho, la ocupación de Tetuán ${ }^{333}$. Las tropas habían sido recibidas calurosamente, en medio de una atmósfera de entusiasmo porque desde hacía tiempo "se esperaba, y la opinión unánimemente aplaude la brillante operación ejecutada por Alfau con tan escasos elementos $" 334$.

En mayo, sin embargo, la redacción denunciaba la inseguridad imperante en los alrededores de esta plaza y también en Ceuta. La opinión pública salmantina, señalaba

\footnotetext{
331 "Los mítines del 19", La Libertad, no 73, 18 de julio de 1914, p. 1.

${ }^{332}$ Únicamente se refirió a la alegría desbordante que Romanones exhibía en las sesiones del Congreso y reprodujo algunos juicios críticos de Gabriel Maura: "Información telegráfica. Madrid", El Salmantino, n ${ }^{\circ}$ 760, 13 de diciembre de 1912, p. 2; "España y Francia", El Salmantino, no 771, 28 de diciembre de 1912, p. 1. El Salmantino, en cambio, sí comentó, y con detenimiento, el rumor de que Le Temps había sugerido una organización conjunta de la policía en el Sáhara, idea que el integrismo rebatía visceralmente porque Francia carecía de derechos históricos en la región: "No se puede pactar", El Salmantino, n 804, 7 de febrero de 1913, p. 1.

${ }^{333}$ Ya hemos constatado que, en Salamanca, "Argos" fue quien más prontamente temió las derivaciones de la ocupación de Tetuán. Entre la publicística del periodo, de hecho, hubo varios escritores que presentaron la toma de esta plaza como un gesto provocador ante los marroquíes y con secuelas para el orden interior de España: "Le debemos a la opinión toda la verdad, y no podemos ni debemos escamotearla. Porque éste es el verdadero origen de la protesta, en unos; de la indecisión, en otros, y de la frialdad en todos". El fragmento está tomado de Habla un Soldado: El problema de Marruecos. Un cuarto de espadas. Madrid: Imprenta Helénica, 1914, p. 137. Lo mismo argumentó el conservador Salvador Canals: "Todos se han apresurado a señalar aquello de 'sin disparar un tiro' y aquello otro de 'sin derramar una gota de sangre', como si de esa suerte se disculparan con la opinión populachera, y sin pensar que al pretender albricias por eso que no pasa de ser una noticia, gratísima, sin duda, pero una noticia, parece que pretenden que se crea que ello es su obra, y si es su obra que en unos casos no hay tiros ni sangre, será indefectiblemente su culpa, culpa de sus torpezas o de sus omisiones, el que haya en otros casos sangre". Véase CANALS, Salvador: España y la cuestión de Marruecos. Análisis de un debate parlamentario (Artículos publicados en la revista Nuestro Tiempo). Madrid: Imprenta "Alrededor del mundo", 1915, p. 98. No dejan de sorprendernos las concomitancias ideológicas entre figuras de muy distinto posicionamiento respecto a Marruecos ("Argos" y Canals).

334 "Información telegráfica para El Salmantino", El Salmantino, n 815, 20 de febrero de 1913, p. 2. En idénticas fechas, El Salmantino se esmeraba reproduciendo las extensas conferencias que entonces se celebraban en el cuartel de la Albuera a propósito del Rey, la patria... Véase "Conferencia militar en el cuartel de Cazadores de Albuera", El Salmantino, n 841, 21 de marzo de 1913, p. 1; "Conferencia militar en el cuartel de Cazadores de Albuera", El Salmantino, no 842, 22 de marzo de 1913, p. 1.
} 
el rotativo, no debía preocuparse de asuntos baladís como la apertura de las Cortes, sino del fortalecimiento y engrandecimiento del Ejército de África. Por otra parte, al gobierno de Romanones se le exigían medidas más previsoras en Marruecos ${ }^{335}$. Ante la ausencia de las mismas, se deseaba la crisis y se responsabilizaba al político liberal de la firma del desventajoso Convenio con nuestros vecinos ultrapirenaicos ${ }^{336}$. Y además, coincidiendo con el viaje del Rey a París, el periódico solicitaba un cambio en el juego de alianzas internacionales: de Francia nada cabía esperar, pero la alianza con Alemania, en un futuro próximo, facilitaría la dominación de Gibraltar y Portugal $^{337}$.

Aunque el presidente liberal se apresuró a desmentir que la situación fuese grave, El Salmantino daba crédito a las preocupantes noticias que circulaban por Francia y por eso recalcaba la necesidad de reprimir duramente a los cabileños vecinos de Tetuán ${ }^{338}$. No tardó, asimismo, en equipararlos con nuestros guerrilleros de la Guerra de la Independencia y en alertar a los lectores a propósito de su tenacidad ${ }^{339}$.

El integrismo recordaba, a principios de junio de 1913, que desde 1909, cuando se hicieron evidentes las responsabilidades adquiridas por España en la Conferencia de Algeciras, el país apenas había conocido periodos prolongados de paz. Los marroquíes, ya era sabido, se mostraban particularmente belicosos tras la recogida de las cosechas y así lo habían demostrado en el ataque sobre Kudia Fochar. En este punto, el diario se alzaba como "portavoz del sentir de la opinión pública" y renegaba de toda promesa de sumisión a España. El pueblo, aseguraba la redacción, deseaba el envío de tropas a Marruecos, no el transporte de recursos con cuentagotas. Su receta, básicamente, se fundamentaba en el duro escarmiento de los rifeños, no cesando la acción militar por el hecho de interrumpirse la ofensiva mora. Pero con una objeción:

"Antes de que hagamos estos sacrificios, debe saber también el país el carácter de la personalidad que ostenta España en Marruecos, porque si en aquellas estepas y pedriscos vamos a verter raudales de sangre, y la vida económica de la nación, sólo a título de mandatarios y administradores de Europa, no vale la pena (...) En cambio, si somos dueños y soberanos (...) entonces no reparemos en sacrificios, que todo es poco, cuando se emplea en mantener incólume y límpido el honor patrio "340.

He aquí planteado el dilema entre la conquista o el abandono. La angustia entre la opinión pública salmantina empezaba a alcanzar cuotas preocupantes y, mientras el

\footnotetext{
335 “De Marruecos. Rumores gravísimos", El Salmantino, no 891, 19 de mayo de 1913, p. 1.

336 "El quinquenio", El Salmantino, no 892, 21 de mayo de 1913, p. 1.

337 "El viaje de don Alfonso", El Salmantino, no 870, 24 de abril de 1913, p. 1.

338 "España en África”, El Salmantino, no 904, 5 de junio de 1913, p. 1.

339 “Guerra en Marruecos", El Salmantino, no 906, 7 de junio de 1913, p. 1.

340 "Nuestro Protectorado en Marruecos", El Salmantino, no 911, 13 de junio de 1913, p. 1.
} 
periódico ultra conservador confiaba en el buen hacer del Ejército, este juicio no era extensible al gobierno. Romanones, aseguraba la redacción, únicamente se preocupaba por aferrarse al poder y su trato condescendiente con los marroquíes resultaba del todo inefectivo: “Asusta pensar lo que puede suceder ante los problemas que España tiene planteados y cuyo gobierno tiene que acometer sin dilaciones",341.

El Salmantino se esforzaba por denunciar la creciente anormalidad en que se desenvolvía la vida del país. Así, la emprendía contra la Conjunción republicanosocialista y amenazaba: "Hoy pueden alucinar al pueblo, pero no olviden que el día en que las promesas tengan que cumplirlas, y no puedan, entonces será el momento de las supremas sanciones populares, que hace mucha falta que se ejecuten para que desaparezcan todos los histriones" ${ }^{, 32}$. Tampoco entendía por qué las conversaciones de los salmantinos se centraban en la descomposición del Partido Liberal, "asunto mezquino", en lugar de preocuparse exclusivamente las gentes por acabar con la insurrección marroquí. Para el integrismo ello constituía la prueba irrefutable de la degeneración que experimentaba la raza:

"Vergüenza da describir este cuadro de antipatriotismo, y nauseabunda repugnancia produce que aquí en esta tierra, admirable en todas las edades por sus gloriosas epopeyas, ahora se intente suspenderlas a título de mentido humanitarismo, y precisamente cuando todas las naciones sienten ideales expansionistas (...) ¿No descalifica a un pueblo que en estos críticos momentos que estamos, sosteniendo una sangrienta lucha en África, pida la retirada de su Ejército del campo a que se le ha retado, que a tanto equivale el predicar que no se invierta en la campaña un hombre ni una peseta, es decir: que abdique de su honor, y en contraposición a esto que se esté discutiendo si Romanones posee o no el decreto de disolución? ${ }^{\text {"343 }}$.

El desánimo, por tanto, cundía en El Salmantino al presenciar las protestas socialistas contra la acción de España en Marruecos y a medida que se avanzaba hacia la internacionalización de Tánger ${ }^{344}$. Incluso, el 6 julio de 1913, ya lo sabemos, tuvo lugar un mitin en Salamanca, organizado por la Agrupación Socialista ${ }^{345}$.

De todos modos, la opinión pública "verdadera" no tenía la culpa del "desatino suicida" en Marruecos, sino Romanones ${ }^{346}$. Este reproche, entendemos nosotros, era idéntico al que con anterioridad, y desde este mismo periódico, se había lanzado contra Canalejas. Pero curiosamente y al margen del discurso integrista, ambos políticos

341 "Momento difícil", El Salmantino, no 915, 18 de junio de 1913, p. 1.

342 "Los mítines contra la guerra", El Salmantino, no 917, 20 de junio de 1913, p. 1.

343 "Disolución de las Cortes", El Salmantino, no 919, 23 de junio de 1913, p. 1.

344 "El estatuto de Tánger y The Times", El Salmantino, no 918, 21 de junio de 1913, p. 1.

345 "El mitin de ayer contra la guerra", El Salmantino, no 931, 7 de julio de 1913, p. 2.

${ }^{346} \mathrm{Al}$ finalizar junio de 1913, El Salmantino, otra vez, reclamaba un cambio de gobierno y denunciaba el caos económico en el que vivía sumido el país: "Herencia repudiada", El Salmantino, no 922, 26 de junio de 1913, p. 1. 
liberales, hoy está fuera de toda duda, apostaron por una acción en África más decidida que la de los conservadores.

Lo que les distanció de Maura, en el fondo, fue la estrategia adoptada ante la prensa: más tolerante e inteligente que la seguida por el político mallorquín. ¿Por qué? Porque sabían que la opinión pública era una fuerza a la que se debía empezar a temer. La obsesión del integrismo, en cambio, se centraba en que Romanones permitía la circulación de "nefandas" y "aberrantes" propagandas. Un ejemplo: los discursos de Pablo Iglesias, que únicamente contribuían, explicaban, a la desmoralización del soldado y a difundir la "falacia" de que sólo los pobres acudían al escenario del conflicto. Para poner fin al movimiento sedicioso interno, evidentemente, lo más efectivo pasaba por la suspensión de las garantías constitucionales ${ }^{347}$. Y como argumento: "Nuestra acción armada en África, debieran decir los poderes públicos, ni se discute ni puede por nadie ser rechazada"348.

Si bien a principios de julio de 1913 muchos cabileños empezaban a solicitar perdón, el diario integrista volvía a asegurar que no había que dejarse embaucar por sus promesas de lealtad $^{349}$. La paz en la región de Yebala no era definitiva, así que se requería, por parte de las tropas, no abandonar las razias ${ }^{350}$, y por parte de la opinión pública, no dejarse embargar por el pesimismo económico ${ }^{351}$. Afortunadamente, a modo de gran argumento de autoridad, en las mismas fechas, unas declaraciones de Miguel de Unanumo ante un redactor de Nuevo Mundo estaban haciendo correr verdaderos ríos de tinta en la prensa nacional, pero más si cabía en Salamanca ${ }^{352}$. Su defensa, a ultranza, de la presencia española en Marruecos satisfacía enormemente al integrismo, que se sentía muy bien respaldado porque el Protectorado era, a juicio del Rector, la clave de la "resucitación nacional"353.

En las mismas fechas, la marcha de un escuadrón de la Albuera a Marruecos también ocupaba gran parte de la actualidad de la información local. El Salmantino animaba a sus lectores a respaldar la suscripción popular, recordando que desde la firma del Acta de Algeciras, España debía estar preparada para todo tipo de sacrificios en Marruecos y recuperando un lenguaje muy grandilocuente, similar al empleado durante

\footnotetext{
347 "Política colonizadora", El Salmantino, n’ 929, 4 de julio de 1913, p. 1.

348 "Ni se discute ni se rechaza", El Salmantino, no 921, 25 de junio de 1913, p. 1.

349 “Paz en Marruecos?”, El Salmantino, no 931, 7 de julio de 1913, p. 1.

350 "El pacifismo en Marruecos”, El Salmantino, no 955, 7 de agosto de 1913, p. 1.

351 "Nuestra acción en Marruecos", El Salmantino, n 965, 20 de agosto de 1913, p. 1.

${ }^{352}$ Francisco Romero: "La opinión del señor Unamuno y la guerra", El Salmantino, n 948, 28 de julio de 1913, p. 1.

${ }^{353}$ Francisco Romero: “Lo de la guerra”, El Salmantino, n 948, 29 de julio de 1913, p. 1.
} 
la campaña de $1909^{354}$. Aprovechaba también para resaltar la estrecha vinculación entre el sacerdocio y la milicia, ambos siempre empleados en la defensa de la integridad y grandeza de la patria, y agradecía la colaboración eclesiástica en la suscripción ${ }^{355}$. La reseña que finalmente confeccionó sobre el adiós a los soldados fue muy amplia ${ }^{356}$. En ella, sobre todo, se destacó su carácter interclasista:

"Salamanca la viviente, la conservadora de los timbres de gloria que heredó de sus ascendientes, puede sentirse enorgullecida con el acto que realizó el sábado al acudir toda entera y compacta a la estación (...) Imperecedera será la memoria de hecho consumado el sábado por Salamanca; el clero, las órdenes religiosas, la magistratura, las autoridades civiles, la administración, el poderoso, el indigente, el obrero intelectual, el manual, el comercio, la industria, la agricultura, la mujer, el niño, todos en una palabra (...) aparecieron como son; compenetrados, intimos, hermanos ${ }^{\text {"357. }}$.

El temor a los posibles desórdenes sociales subyacía, sin duda, en este editorial.

Por esta razón, en los días inmediatamente posteriores a la marcha, el órgano integrista explotaba la baza de las madres de los soldados, presentadas como auténticas heroínas e insertaba alguna que otra carta de agradecimiento de los hombres de Albuera hacia sus vecinos $^{358}$. Todo lo preciso para infundir calma. La malhadada aventura de estos jóvenes en África, sin embargo, no fue merecedora de excesiva atención ${ }^{359}$. Seguramente, porque el diario sabía que era un tema muy sensible para la opinión pública salmantina. En cambio, este periódico sí que dedicó bastante protagonismo a las acciones caritativas desarrolladas entonces: el simpático festival de confiteros y pasteleros y, sobre todo, los gestos de la Junta de Damas de Salamanca ${ }^{360}$.

De hecho, El Salmantino, en reiteradas ocasiones, y ahora con especial énfasis, cuestionó el proceder informativo de los distintos gobiernos de la Restauración. La opinión pública salmantina, la española por extensión, tenía un corazón volátil, y tarea vana era intentar persuadirla de lo que convenía en Marruecos. La meta del rotativo, por tanto, sólo consistía en distraerla; mientras que el gobierno, creía esta redacción, debía

\footnotetext{
354 "Salamanca patriótica”, El Salmantino, no 934, 10 de julio de 1913, p. 1; “¡Viva España!”, El Salmantino, $\mathrm{n}^{\circ}$ 935, 11 de julio de 1913, p. 1.

355 "El clero y la milicia", El Salmantino, no 936,12 de julio de 1913, p. 1.

356 "La despedida de los soldados de Albuera", El Salmantino, no 936, 12 de julio de 1913, p. 1.

357 "Salamanca inmortal", El Salmantino, no 937, 14 de julio de 1913, p. 1.

358 “QQue seas valiente, hijo mío!”, El Salmantino, no 937, 14 de julio de 1913, p. 1; "El regimiento de Albuera al pueblo de Salamanca", El Salmantino, n 937, 14 de julio de 1913, p. 2.

${ }^{359}$ Aunque, por supuesto, sí se refirieron algunos ataques y el fallecimiento del teniente Peral: "El escuadrón de Albuera atacado por los moros", El Salmantino, no 948, 28 de julio de 1913, p. 2; "Nueva acción del escuadrón de Albuera", El Salmantino, n 963, 18 de agosto de 1913, p. 1. También se notificó el envío de refuerzos a mediados de 1913: "Soldados de Albuera a Ceuta", El Salmantino, nº 989, 17 de septiembre de 1913, p. 1.

${ }^{360}$ Ceferino Pérez: "A los soldados salmantinos que se encuentran en Marruecos", El Salmantino, $\mathrm{n}^{\circ}$ 969, 25 de agosto de 1913, p. 1; "Para los soldados salmantinos", El Salmantino, n' 991, 20 de septiembre de 1913, p. 1; "Por los heridos de Melilla", El Salmantino, no 1156, 13 de abril de 1914, p. 1.
} 
actuar a sus espaldas y con inmediatez porque "ser caballerosos con un combatiente que no desperdicia momento en causarnos bajas de una manera innoble y asesina, esto es insensato" 361 . A resultas de estos planteamientos, cuando a mediados de septiembre, Luque anunció el envío de más soldados al otro continente, esto respondió el integrismo:

"Esto reputamos que no se ha debido expresar ni indicar (...) el poder ejecutivo si fuera preciso, hasta empleando una radical coacción, debe llevar a Marruecos cuantos medios requiera el honor nacional, y si se presumiera que habian de originarse perturbaciones y trastornos en el país, a los primeros que se les debía destruir son a esos elementos nocivos (...) No se debe participar a nadie que será preciso mandar más refuerzos ${ }^{\prime 362}$.

No se estaba defendiendo, en exclusiva, la censura de algunas informaciones. En realidad, lo que se sugería era que la gestión del Protectorado no debía estar sujeta a los vaivenes de la opinión. Para El Salmantino únicamente existía una vía de actuación: el avance a sangre y fuego. El abandono era una deshonra inadmisible y las fórmulas civilistas, un engaño. Únicamente en este último punto, el tiempo le otorgaría la razón al diario.

Aún así, el periódico no se resignaba ante la falta de ambiente con que se hacía la guerra y el disimulo requerido para movilizar a los batallones. Su remedio consistió en presentar a los soldados como figuras simpáticas y, para ello, en octubre de 1913, recurrió a la publicación de una serie de artículos de El Pueblo Vasco, incluidos todos bajo el epígrafe "Los que deben ir a África" y firmados con el pseudónimo de "A. Peral",363.

El Salmantino, más que suavizar su discurso militarista, se contradecía y pecaba de incoherente al apelar a la vieja tesis de la misión civilizadora española. Pero, ¿cómo se lo tomarían sus lectores? Seguramente, con incredulidad. Los franciscanos, sobre todo, estaban llamados a intervenir como heraldos de la civilización porque: " $L a$ penetración pacífica, si ha de hacerse con orden, con talento, requiere un gran número de individualidades, que tengan hábitos de disciplina, de obediencia, de sufrimiento" ${ }^{364}$.

\footnotetext{
361 "Nuestra acción en Marruecos”, El Salmantino, n 965, 20 de agosto de 1913, p. 1.

362 "La guerra en África", El Salmantino, no 985, 12 de septiembre de 1913, p. 1.

363 "A. Peral": "Los que deben ir a África", El Salmantino, no 1.001, 2 de octubre de 1913, p. 1; "A. Peral": "Los que deben ir a África", El Salmantino, no 1.102, 3 de octubre de 1913, p. 1; "A. Peral": "Los que deben ir a África", El Salmantino, no 1.003, 4 de octubre de 1913, p. 1; "A. Peral": "Los que deben ir a África", El Salmantino, no 1.006, 8 de octubre de 1913, p. 1; "A. Peral": "Los que deben ir a África", $E l$ Salmantino, no 1.010, 13 de octubre de 1913, p. 1; "A. Peral": "Los que deben ir a África", El Salmantino, $\mathrm{n}^{\mathrm{o}}$ 1.014, 17 de octubre de 1913, p. 1; "A. Peral": "Los que deben ir a África", El Salmantino, n 1.022, 27 de octubre de 1913, p. 1

364 “A. Peral": "Los que deben ir a África", El Salmantino, no 1.002, 3 de octubre de 1913, p. 1.
} 
En otro pasaje, “A. Peral” reflexionaba sobre la necesidad de poner en marcha una sensata política de colonización, de "europeizarnos": "Para la penetración sin armas ni combates, para la atracción y asimilación de un país por medio de la cultura y de la civilización de otro, lo mejor es sembrarlo de guerrillas de hombres abnegados y valientes, que con su ejemplo hacen simpáticos a sus hermanos" ${ }^{\text {„365. }}$.

¿A qué obedecía este viraje de timón? El manifiesto desprecio integrista hacia la fuerza de la opinión pública ${ }^{366}$, contrastaba con este nuevo intento por persuadirla. ¿Es que ningún rotativo era lo suficientemente irresponsable como para desatenderla? Sólo en parte. En realidad, todo este renovado discurso obedecía a un cambio de orden interno: el conservador Eduardo Dato había sucedido, en la presidencia del gobierno, al conde de Romanones. El Salmantino, por consiguiente, se sentía aliviado y se empeñaba ahora en no presentar el cielo africano tan plagado de oscuros nubarrones como bajo mandato liberal. En su lugar, la redacción se apuraba en demandar una vez más, y ya hemos perdido la cuenta, una rectificación en las alianzas internacionales y una solución para el problema de Tánger ${ }^{367}$.

La luna de miel entre el nuevo gobierno y el integrismo, no obstante, resultó efímera. Tan pronto como Dato confesó su sincera simpatía por la penetración amistosa, que iba más allá del estricto empleo como recurso propagandístico, útil para narcotizar a la opinión pública, se acabó este trato condescendiente. Más concretamente, el deseo de repatriar gran parte del contingente de 70.000 hombres que entonces se hallaban en Marruecos se tildó de infecundo. Resultaba inconcebible a ojos de la redacción salmantina. Curiosamente, sin embargo, la responsabilidad de esta decisión se intentaba disculpar: un gesto de condescendencia inimaginable para con Romanones. Una fórmula fija, en conclusión, guiaba el posicionamiento del integrismo: el malestar social ante la cuestión marroquí, gobernando los liberales, era fruto de su ineptitud como mandatarios; pero de esa misma inconformidad pública, bajo presidencia de los conservadores, tenía la culpa la propia opinión pública. ¿Por qué? Por su ignorancia:

"Indudablemente desconocen el país sobre el que laboramos.

\footnotetext{
365 “A. Peral”: "Los que deben ir a África”, El Salmantino, no 1.022, 27 de octubre de 1913, p. 1.

366 Un aspecto que, sin embargo, no experimentaría ninguna modificación en las páginas de $E l$ Salmantino fue su campaña pro-germana. Así, coincidiendo con la publicación de estos editoriales de $E l$ Pueblo Vasco, también se reprodujo un extensísimo artículo de Vázquez de Mella sobre la necesidad de modificar nuestras alianzas: "Las alianzas. ¿Con Francia o Alemania?”, El Salmantino, no 1.017, 21 de octubre de 1913, pp. 3-4.

367 "La víctima, España", El Salmantino, no 1.025, 30 de octubre de 1913, p. 1; "La nota de Maura al monarca", El Salmantino, no 1.026, 31 de octubre de 1913, p. 1.
} 
Éste es lo más indómito e irreductible del imperio de los Sultanes, hasta el extremo de que la autoridad del Príncipe de los creyentes de Mahoma, secularmente ha sido desatendida, viviendo en una perpetua lucha con las mehallas imperiales; y esto que ha realizado con los poderes constituidos de la misma raza, religión, lengua y costumbres, ¿era posible imaginar que no lo ejecutase con los de procedencia extraña? "368.

En la calle, entretanto, empezaban a circular insistentemente y a calar los rumores sobre la próxima pacificación del Protectorado y todo ello se asociaba con la presencia de los Mannesmann en Madrid. Para El Salmantino no se trataba más que de una quimera: un pueril recurso para convertir la presencia española en Marruecos en el derivado de un negocio minero. Su responsable: la Compañía Española de Minas del Rif; y su pretensión, la de absorber los derechos de propiedad adquiridos por estos hermanos alemanes:

"A pesar de cuanto se quiera discurrir y divagar, a España se le impuso, en la Conferencia de Algeciras, reconociendo en parte sus derechos históricos, realizar en África, juntamente con Francia, una misión civilizadora, sujeta a tres restricciones (...) Atribuir a negocios mineros la cruzada que desde 1909 con insignificantes intermitencias venimos sosteniendo, es una creencia cretina (...) Si la Sociedad Franco-Española del Rif, constituida por poderosos financieros e influyentes políticos, hubiera determinado al régimen a emprender la campaña africana para el adueñamiento de las minas que, según se dice, se están litigando, ¿no es presumible que los hermanos alemanes hubieran recabado la protección del gobierno germano para la defensa de sus derechos?",369.

Como de costumbre, la guerra en Marruecos era un conflicto con honor. Pero, entonces, ¿qué papel desempeñaban los empresarios alemanes en Madrid? ¿Por qué su presencia en la capital podía ser determinante para la consecución de una próxima paz o de una permanente guerra? Evidentemente, quedaba un flanco sin cubrir en las páginas de El Salmantino: las conversaciones entre España y Alemania con la intermediación de El Raisuni. De hecho, de la lectura aislada del diario integrista, se deducía que este cabecilla rifeño apenas tenía relevancia en el desenvolvimiento del Protectorado. Si ya eran escasas las informaciones sobre el jerife en El Adelanto, aquí eran prácticamente nulas. Pero acaso ¿no sería un deshonor para el Ejército avenirse a negociar con él? Lo que la prensa no reflejaba, obviamente tampoco podía comentarlo la opinión pública salmantina. Así era como el rotativo integrista distraía su atención y ejercía la función setting a la que nos referíamos en la introducción.

Sólo al iniciarse 1914, por fin, este diario conservador exponía su lectura de los hechos: la guerra en los alrededores de Tetuán derivaba de un error estratégico auspiciado, como no podía ser de otro modo, por los políticos liberales: bien por la

\footnotetext{
368 "La penetración pacífica", El Salmantino, no 1.048, 27 de noviembre de 1913, p. 1.

369 “España en África”, El Salmantino, no 1.050, 29 de noviembre de 1913, p. 1.
} 
existencia de obstáculos diplomáticos alemanes, o bien por ignorarse las recomendaciones de Alfau, el gobierno de Romanones había decidido no ocupar el Fondak. Y, con ello, había permitido que las comunicaciones de la región pudiesen verse de continuo interrumpidas:

“En qué consiste que la influencia francesa perturbó en 1909 nuestros avances en Melilla y Cabo de Agua, y en 1911, la campaña del Kert, incluso fomentando desórdenes en nuestro país? Porque podíamos adelantarnos a sus incursiones en el valle del Muluya; porque no se había firmado todavía el Tratado de 1912, más oneroso que favorable para nosotros.

¿En qué consiste que quien discute con nosotros ahora, es Alemania? Pues porque a ésta interesa muy poco nuestra mayor o menor penetración en Melilla, pero la preocupa el régimen y las influencias que puedan prevalecer en la zona de Tánger, cuestión ligada no sólo con la general de Marruecos, sino también con el problema del Estrecho.

Por eso Alemania, que inició la internacionalización de Tánger, es partidaria de que sea lo más amplia posible la zona internacionalizada. De ahí su protección encubierta a El Raisuni, las condiciones tal vez impuestas a nuestra entrada en Tetuán, la aparición periódica de los banqueros Mannesmann, y hasta la frecuencia con que circulan y se desvanecen después rumores de avance, que resulta detenido porque... no quiere el gobierno ${ }^{, 370}$.

En síntesis, la historia se repetía: primero, Francia había puesto trabas al avance español, incluso, contribuyendo al estallido de la Semana Trágica. Se volvía sobre la idea de la conspiración, aunque fuese una información por completo accesoria en las circunstancias presentes. Y se continuaba argumentando que ahora era Alemania la que obstaculizaba nuestro avance.

A decir verdad, la potencia más interesada en la internacionalización de Tánger fue siempre Gran Bretaña. Pero, de todos modos, Alemania tenía motivos fundados para actuar así, creía el periódico, porque la guerra en esta región nos era ajena (de nuevo un trato complaciente inimaginable para con Francia). De esta forma concluía el editorial de autor desconocido:

"El defender lo nuestro, pacificar y someter sus alrededores hasta donde la provisión racional aconseja, es nuestra misión propia; pero alejarnos de las costas, hacernos la ilusión de conquistar lo que tratados por nosotros suscritos, declaran territorio permanentemente marroquí, y complicar el asunto con las opuestas ambiciones de Francia, Alemania e Inglaterra, es navegar entre torbellinos, con riesgos de naufragio".

¿No sorprende esta llamada a la prudencia después de tantos discursos belicistas? La desesperación también cundía en las filas del integrismo. Pero lo que más inquietaba al periódico a estas alturas, en febrero de 1914, era el hecho de que la cronicidad de la campaña marroquí provocaba un creciente desinterés por el estudio del

370 "Nuestra política en África”, El Salmantino, n 1.089, 21 de enero de 1914, p. 1. 
problema a fondo. De nuevo, se explicaba que por culpa de la disparidad de opiniones, el gobierno de Dato estaba confuso:

"Con tales y variados pareceres, unos inspirados por móviles políticos, otros en el odio al Ejército, y las más de las veces en una sensiblería impropia de una raza fuerte, o en la ignorancia más supina del problema africano, se ha formado el Poder público una confusión tan lamentable, que se le ve irresoluto, sin saber qué camino optar, si por la paz o la guerra ${ }^{, 371}$.

Las protestas socialistas se repetían en Salamanca, al hilo de la campaña nacional para la recogida de un millón de firmas contra la guerra ${ }^{372}$. La raíz de todo el problema residía en la endiablada acción del Trust. “Abel Peregrín” lanzaba un ataque feroz contra sus integrantes, denunciando, de paso, su irresistible fuerza mediática:

"Los mayores crímenes políticos y las más grandes desventuras que llora nuestra patria son debidos en sus génesis a la acción perniciosa y deletérea de esa sociedad editorial llamada o conocida por el Trust periodístico (...) El periódico, que debiera ser el libro diario de moralización pública, viene a salir de sus antros, aplaudiendo rebeldías, excitando las pasiones, ocultando la verdad, calumniando inocencias, postergando méritos, endiosando nulidades y cual insecto inmundo revolcándose en el cieno de los crímenes pasionales, para con su asquerosas plumas hacer más interesante el vergonzoso vicio.

Por ellos fuimos engañados en la guerra con los Estados Unidos (...) ellos nos están desacreditando ahora en Marruecos, ${ }^{, 373}$.

Pero detengámonos, antes de continuar y aunque sea brevemente, en esa campaña de firmas. La historiadora francesa Bachoud ha sido quien más detenidamente ha analizado semejante iniciativa, concluyendo que las provincias con mayor número de adhesiones contra la guerra fueron, precisamente, aquéllas con una fuerte implantación de la UGT $^{374}$. Pero además, la misma autora confesaba su sorpresa ante el éxito de la empresa en tres provincias: Badajoz, Málaga y Salamanca. Si bien es verdad que ninguna de ellas alcanzó cifras comparables a las madrileñas, donde el 9\% de la población provincial firmó en contra del conflicto, en Salamanca, por concretar, se recolectaron 13.176 firmas (es decir, casi el 4\% de la población provincial).

Bachoud adoptaba en su análisis, como premisa, que el Partido Socialista supo emplear el rechazo de la masa campesina hacia la guerra de Marruecos como un muy efectivo banderín de enganche en las zonas latifundistas frente al anarquismo y al republicanismo (por cierto, contra esta idea, a su vez, se revuelve algún autor como Moreno Juste). Pero la excepcionalidad del caso salmantino, además del ofrecido por

\footnotetext{
371 "El problema de marroquí, El Salmantino, no 1.104, 7 de febrero de 1914, p. 1.

372 "El mitin de anoche", El Salmantino, no 1107, 10 de febrero de 1914, p. 3.

373 “Abel Peregrín”: “Guerra al enemigo nacional”, El Salmantino, no 1.164, 22 de abril de 1914, p. 1.

${ }^{374}$ Véase BACHOUD, Andrée: Op. Cit., pp. 210-212.
} 
Badajoz y Málaga, radicaba en que la implantación de esta ideología en las instituciones no fue, aseguraba la investigadora, realmente consistente hasta 1923.

Por nuestra parte, en primer lugar, debemos subrayar que la presencia socialista en los órganos de gobierno salmantino fue, hasta el golpe de Primo de Rivera, débil -y más en el ámbito provincial- pero constante. Porque, no lo olvidemos, el turno y el pucherazo, aunque con notables diferencias según los distritos, seguían funcionando. Además, el año 1923 no supuso un hito en su historia: incluso en la capital quienes ostentaban el poder eran los hombres procedentes de Acción Ciudadana (Anaya y Mirat), una agrupación nacida a partir de la Cámara de Comercio, como próximamente se verá, y animada por el deseo de resolver los problemas higiénicos de la ciudad.

En efecto, los hombres de Acción Ciudadana hicieron gala de una actitud muy dialogante para con el mundo obrero, además de enfrentarse en reiteradas ocasiones con Martín Veloz, pero, en ningún caso, militaron en el socialismo. Por consiguiente, hemos de concluir que la campaña de firmas tuvo tan inesperado éxito en Salamanca y su provincia porque la opinión pública local empezaba a contemplar con desprecio, por hastío, el conflicto; se estaba abriendo una brecha entre la opinión publicada y la pública. Por último, evidentemente, entendemos que concienciación política no implicaba, forzosamente, militancia partidista.

Efectuado este paréntesis, señalemos que a El Salmantino nada le complacía el hecho de que el 29 de abril de 1914, de nuevo, se celebrase otro mitin socialista contra la guerra de África en Salamanca. Sobre su desarrollo, de nuevo "Abel Peregrín" comentaba:

"Como profusamente estaba anunciado por pasquines (...) tuvo lugar anoche (...) el mitin contra la guerra (...) dicho sea en honor a la verdad, fue un mitin en el cual la mayor parte de los improvisados oradores hacían un mitin contra las ideas religiosas (...) tratando duramente a los soldados de cuota y las consideraciones inopinadas que el gobierno les guarda, ${ }^{, 375}$.

La redacción integrista, en suma, deseaba una solución urgente para el problema africano. Y, en concreto, exigía una victoria militar bien capitalizada por los políticos ${ }^{376}$. Pero al ser testigo de los debates parlamentarios, dudaba de que ello fuese posible. Si bien El Salmantino no dedicó a éstos una atención comparable a la prestada por $E l$ Adelanto, de algunas de sus informaciones se extraía una profunda insatisfacción con las declaraciones de Romanones, incapaz de explicar el por qué de la violencia en los

\footnotetext{
375 "En el Centro Obrero. Mitin contra la guerra", El Salmantino, no 1.171, 30 de abril de 1914, p. 2. En El Adelanto, en cambio, este acto pasó por completo desapercibido

376 "Lo más urgente", El Salmantino, n 1.163, 21 de abril de 1914, p. 1.
} 
aledaños de Tetuán, y también una manifiesta y creciente inconformidad hacia el proceder conservador ${ }^{377}$. La vigente política africana, la de la penetración pacífica, desquiciaba al rotativo local: primero, por costosa; y segundo, por inútil. En palabras de uno de sus redactores era "un contrasentido absurdo y sólo concebible en este desdichado país" ${ }^{, 378}$.

El argumento económico, en todo caso, estaba presente en su interpretación de la realidad marroquí, pero su remedio era el diametralmente opuesto al defendido, desde El Adelanto, por “Argos”. Mientras éste propugnaba el abandono, convirtiéndose así, como ya se ha señalado, en el abanderado del pensamiento socialista en la prensa salmantina, el integrismo se decantaba por una guerra rápida y sin cuartel.

\section{EL DESPERTAR DE LA CIUDAD: CONFICTOS Y PREOCUPACIONES DOMÉSTICAS, 1911-1918}

A lo largo de estos años a los que venimos refiriéndonos, la capital había crecido y también había registrado un cambio paulatino en su estructura social. Sobre todo, aumentó el número de obreros y también lo hicieron las confrontaciones ciudadanas. No ha de sorprendernos: las condiciones de vida de muchos trabajadores se definían por la enorme precariedad material. Y a ello, por supuesto, había que sumar las lacras del desempleo y la mendicidad. De todos modos, la situación de unos y otros pudo mejorar en términos absolutos, muy tímidamente, eso sí, en la medida en que se fueron implantando las reformas sociales estatales y ganó fuerza el asociacionismo.

Por otra parte, también se agriaron en este periodo los enfrentamientos electorales. El más sonado sería, andando el tiempo, el protagonizado, en 1918, por los candidatos a representante en Cortes, Isidro Pérez Oliva y Lamamié de Clairac. La victoria resultó muy amplia para el candidato liberal y terminó celebrándose con una alegre manifestación de apoyo a su figura. Recuérdese que cuando comentamos el funcionamiento del servicio militar en Salamanca y la evolución en el pago de las cuotas, subrayamos que la oligarquía terrateniente estaba perdiendo su dominio político $^{379}$. Consideramos esta victoria de Pérez Oliva como una evidencia de lo dicho.

\footnotetext{
377 "Información telegráfica", El Salmantino, no 1.181, 13 de mayo de 1914, p. 2; "El problema de Marruecos", El Salmantino, no 1.182, 14 de mayo de 1914, p. 1; "Las conclusiones de un debate", El Salmantino, $\mathrm{n}^{\mathrm{o}} 1.199,4$ de junio de $1914, \mathrm{p} .1$.

378 "Política marroquí", El Salmantino, no 1.237, 22 de julio de 1914, p. 1.

379 "La lucha electoral en Salamanca y Peñaranda", El Adelanto, no 10.345, 25 de febrero de 1918, p. 1; "El romanonismo al desastre", El Salmantino, no 2.296, 14 de febrero de 1918, p. 1; "Las elecciones de ayer. Sigue la farsa", El Salmantino, no 2.302, 25 de febrero de 1918, p. 1.
} 
No obstante, la contraofensiva no se haría esperar: en 1919, y lo adelantamos, asistiremos a la victoria electoral del líder de la Liga de Agricultores y Ganaderos, el simpar Martín Veloz.

Lo que sí permaneció como una realidad inmutable y molesta entre los salmantinos fue la sensación de abandono. A principios de 1911, incluso, llegó a producirse una grave crisis municipal cuando el alcalde liberal, Díez González, y la minoría republicano-socialista abandonaron el Consistorio. $\mathrm{Su}$ gesto era una manifestación de protesta ante la desidia gubernamental: se veían desbordados a la hora de afrontar el problema del saneamiento urbano sin ningún tipo de subvención ${ }^{380}$. A este acto le siguió, además, la celebración de un mitin multitudinario, con unos 3.000 asistentes, el 7 de mayo de 1911. Sin duda, se trataba de otra prueba de inconformidad ciudadana por la desatención hacia Salamanca desde las esferas ministeriales (aunque se opusieron algunos ediles, como Florencio Marcos Martín y Juan Mirat) ${ }^{381}$.

La obtención de un empréstito con el que acometer las obras de higienización de la capital no fue, en efecto, una tarea sencilla. A mediados de 1911, el Ayuntamiento se había recompuesto y pudo llegar a un acuerdo con una entidad bancaria francesa para la obtención de financiación ${ }^{382}$. Pero la discusión de las bases del mismo documento legal implicó larguísimas negociaciones y discusiones técnicas ${ }^{383}$. Para la opinión liberal, el Consistorio se conducía "a saltos" y de ahí su proclividad a los fracasos:

"En vez de trabajar continua y calladamente, de adoptar un plan y de sacrificarlo todo a su realización, nuestro Concejo procede a saltos, malgasta energías e iniciativas, emprende mil obras que abandona a poco de comenzadas y, como la ardilla de la fábula, da vueltas y revueltas que a nada práctico conducen ni cristalizan en obra duradera y definitiva.

\footnotetext{
380 "Siempre lo mismo", El Adelanto, no 8.218, 5 de abril de 1911, p. 1; "Dimisión del alcalde, del señor Díez y de la minoría republicano-socialista", El Adelanto, $\mathrm{n}^{\circ}$ 8.231, 21 de abril de 1911, pp. 1-2; "Salamanca y el gobierno", El Adelanto, no 8.233, 24 de abril de 1911, pp. 1-2; "El último plazo", El Adelanto, $\mathrm{n}^{\circ}$ 8.235, 26 de abril de 1911, p. 1; "Importante sesión en el Ayuntamiento. Dimisión del alcalde", El Salmantino, no 267, 21 de abril de 1911, pp. 1-2; "En el Círculo Mercantil", El Salmantino, nº 269, 24 de abril de 1911, pp. 1-2.

381 "La reunión del Mercantil”, El Adelanto, no 8.241, 4 de mayo de 1911, p. 1; "Por Salamanca. El mitin popular de ayer", El Adelanto, $\mathrm{n}^{\mathrm{o}} 8.244,8$ de mayo de 1911, pp. 1-2; "El mitin de ayer", El Salmantino, $\mathrm{n}^{\mathrm{o}}$ 280, 8 de mayo de 1911, pp. 1-2. Incluso Esperabé de Arteaga aplaudiría el proceder del alcalde y de los ediles al escribir: "Las izquierdas, en esa fecha, dieron una prueba de virilidad y de saber cumplir su misión". Véase ESPERABÉ DE ARTEAGA, Enrique: Op. Cit., p. 221.

382 "Empréstito municipal", El Adelanto, no $8.267,3$ de junio de 1911, p. 1; "El empréstito municipal", El Adelanto, $\mathrm{n}^{\circ}$ 8.271, 8 de junio de 1911, p. 1; "El empréstito municipal", El Adelanto, no 8.276, 14 de junio de 1911, p. 1.

383 "Excelente idea", El Adelanto, no 8.288, 28 de junio de 1911, p. 1; "La sesión extraordinaria", $E l$ Adelanto, no 8.303, 17 de julio de 1911, pp. 1-2; "Proposición importante", El Adelanto, no 8.310, 24 de julio de 1911, p. 1.
} 
Cada cuatro o seis meses se anuncia que el empréstito está hecho, se publican sus bases y condiciones, se echan las campanas a vuelo y el empréstito se entierra, una y otra vez, para resucitar, como el ave fénix, de sus propias cenizas ${ }^{\text {"384 }}$.

Por completo desgastado, Díez González fue remplazado a principios de 1912, y mediante Real Orden, por el conservador Hernández Sanz. Pero el peligro de la bancarrota continuaría amenazando seriamente a Salamanca ${ }^{385}$. Al menos, el nuevo alcalde lograría pactar unas bases para el saneamiento urbano ${ }^{386}$, aunque su firma definitiva se haría desear ${ }^{387}$. En el proyecto en cuestión se preveía la construcción de una red de alcantarillado y de abastecimiento de agua, con dos depósitos de 4.000 litros cada uno. Para el saneamiento de la ciudad se pensaba tender 34 kilómetros de red; todo en un plazo de cinco años y con un coste de 800.000 pesetas.

En lo social, al contrario, el balance de su mandato resultó más negativo. E1 número de sociedades de socorros mutuos y cooperativas había seguido una trayectoria muy claramente ascendente desde finales del siglo XIX y el estallido de la Primera Guerra Mundial, con todas sus implicaciones económicas, serviría de estímulo para su propagación. Por el momento, durante 1912, la ciudad conoció varias huelgas de canteros, albañiles y empleados ferroviarios ${ }^{388}$, al tiempo que los sectores agropecuarios

\footnotetext{
384 “Tiempo perdido", El Adelanto, no 8.318, 2 de agosto de 1911, p. 1.

385 "Programa sencillo", El Adelanto, $\mathrm{n}^{\circ}$ 8.452, 6 de enero de 1912, p. 1; "Constitución del nuevo Ayuntamiento", El Salmantino, no 474, 2 de enero de 192, pp. 1-2; "Los problemas municipales", La Ciudad, $\mathrm{n}^{\circ}$ 8, 27 de enero de 1912, p. 1.

${ }^{386}$ Actas de las Sesiones Municipales. Archivo Histórico Municipal, vol. 1912, fol. 66-71 (v). En esta sesión, correspondiente al 24 de abril se leyó una primera proposición de la Sociedad de Aguas y también un dictamen de la comisión de saneamiento; "El saneamiento de Salamanca. Bases del contrato", $E l$ Adelanto, $\mathrm{n}^{\circ} 8.560,13$ de mayo de 1912, p. 1.

387 "Los proyectos de saneamiento", El Adelanto, no 8.677, 27 de septiembre de 1912, p. 1; "Lo de las obras del cuartel del Trilingüe. Lo del contrato de alcantarillado", El Adelanto, no 8.717, 14 de noviembre de 1912, pp. 1-2; "Los proyectos de aguas y alcantarillado", El Salmantino, no 645, 29 de julio de 1912, p. 1; "Agua y alcantarillado", El Salmantino, $\mathrm{n}^{\circ} 721,28$ de octubre de 1912, p. 1; "Incógnita despejada", $E l$ Salmantino, $\mathrm{n}^{\circ} 725,2$ de noviembre de 1912, p. 1; "Los proyectos de agua y alcantarillado", $E l$ Salmantino, $\mathrm{n}^{\mathrm{0}}$ 740, 20 de noviembre de 1912, p. 1; "Sesión subsidiaria del Ayuntamiento. Los proyectos de agua y alcantarillado", El Salmantino, no 741, 21 de noviembre de 1912, p. 1; C. R. Pinilla: "Sin presupuestos", La Ciudad, n n $^{\text {13, }} 2$ de marzo de 1912, p. 2; El Duende: "El tema de la semana", La Ciudad, n $^{\circ}$ 13, 2 de marzo de 1912, pp. 1-2.

388 "La huelga de los canteros", El Adelanto, no 8.324, 12 de agosto de 1911, p. 1; "Los conflictos obreros en Salamanca", El Adelanto, no 8.512, 15 de marzo de 1912, p. 2; "Los conflictos obreros. Más de 600 trabajadores en huelga", El Adelanto, $\mathrm{n}^{\mathrm{o}}$ 8.527, 2 de abril de 1912, p. 1; "Las comisiones de patronos y obreros aceptan una fórmula de arreglo. Los obreros huelguistas la rechazan", El Adelanto, no 8.528, 3 de abril de 1912, p. 1; "La huelga, solucionada", El Adelanto, no 8.529, 4 de abril de 1912, p. 1; “PParo general?", El Adelanto, no 8.648, 23 de agosto de 1912, p. 1; "El conflicto obrero y su solución", $E l$ Adelanto, $\mathrm{n}^{\circ}$ 8.649, 26 de agosto de 1912, pp. 1-2; "La emigración", El Adelanto, $\mathrm{n}^{\circ}$ 8.659, 6 de septiembre de 1912, p. 1; "Nota del día", El Salmantino, no 548, 2 de abril de 1912, p. 1; "M. M.": "Después de los sucesos", La Ciudad, n 39, 31 de agosto de 1912, p. 1.
} 
empezaron a movilizarse al sentirse particularmente amenazados por los intereses catalanes $^{389}$.

En efecto, a medio camino entre el sindicalismo católico y el obrero se había fundado, en 1911, la Liga de Agricultores y Ganaderos. Ésta nació para protestar por una cuestión fiscal, pero, progresivamente, se fue definiendo por la defensa a ultranza del mercado triguero castellano, muy amenazado por la competencia del grano extranjero. Y fue, de hecho, en el seno de esta asociación donde cobró un desmesurado protagonismo Diego Martín Veloz. También desde aquí recabó sus primeros y más leales apoyos electorales ${ }^{390}$. La intensa actividad de la Liga se orientó tanto a la reclamación de medidas arancelarias, primeramente, como a la censura de los puertos francos por los que se permitía la importación de trigo para las fábricas harineras del litoral, durante el desarrollo de la conflagración mundial ${ }^{391}$.

Rodríguez Pinilla, desde La Ciudad, fue el primer personaje público que puso en tela de juicio los propósitos de aquel incipiente cacique al asegurar que el proteccionismo actuaba como un arma de doble filo. De lo que la agricultura salmantina estaba, en realidad, muy necesitada era de una profunda reforma en la estructura de la propiedad de la tierra, formas de arrendamientos y mecanismos de trabajo ${ }^{392}$. De todos modos, el gran abanderado en la denuncia de la penuria labriega y en la crítica hacia las “manos muertas" y la usura sería Filiberto Villalobos ${ }^{393}$.

También fue ese rotativo, por cierto, el que más se extendió en la denuncia de la actitud camorrista de Martín Veloz. En mayo de 1912 provocó, pistola en mano, un forcejeo con Luis Maldonado, profesor universitario y senador, en la estación de Medina del Campo. Además de convertirse en la comidilla urbana, esto fue lo que

\footnotetext{
389 "Castilla y las Cortes", El Adelanto, $\mathrm{n}^{\circ}$ 8.461, 17 de enero de 1912, p. 1; "Alrededor del problema", $E l$ Adelanto, $\mathrm{n}^{\mathrm{o}}$ 8.476, 2 de febrero de 1912, p. 1; “ “Alerta agricultores!", El Adelanto, $\mathrm{n}^{\circ}$ 8.558, 10 de mayo de 1912 , p. .1.

${ }^{390}$ ROBLEDO, Ricardo: "Dejar el campo, comprar la tierra: economía, población y sociedad (18801930)" en ROBLEDO, R. (Coord.), Historia de...Op. Cit., pp. 27-28. La Liga de Agricultores y Ganaderos, desde la esfera política, fue una organización interclasista y bastante ecléctica aunque, en el periodo que se analiza en este trabajo, declinó hacia el pensamiento radical de Martín Veloz. Para un acercamiento a este personaje, véase el manuscrito, redactado en 1955, de MARTÍN ESTEBAN, Alejandro: Memorias y recuerdos. Se puede encontrar en la Biblioteca Universitaria de Salamanca.

391 "La Liga de Agricultores. La última asamblea", El Adelanto, no 9.997, 3 de enero de 1917, p. 1.

${ }^{392}$ Cándido R. Pinilla: "El precio del trigo", La Ciudad, no 4, 30 de diciembre de 1911, p. 1; Cándido R. Pinilla: "La Liga de Agricultores", La Ciudad, no 5, 6 de enero de 1912, p. 1; Cándido R. Pinilla: "La Liga de Agricultores", La Ciudad, no 6, 13 de enero de 1912, p. 1.

393 "Una memoria notable", El Adelanto, no 9.084, 21 de enero de 1914, p. 1. Véase sobre este personaje salmantino ROBLEDO, Ricardo (Coord.): Sueños de concordia. Filiberto Villalobos y su tiempo histórico, 1900-1955. Salamanca: Caja Duero, 2005. Consúltese también LUIS MARTín, Francisco de: Filiberto Villalobos. Obra escrita. Textos, colaboraciones periodísticas e intervenciones parlamentarias. Salamanca: Caja Duero, 2005.
} 
comentó Fernando Iscar Peyra sobre tan singular personaje al hilo del violento incidente:

"El señor Martín Veloz es el Emperador de Salamanca, tiene su leyenda, su historia y su programa, todo ello bravo y audaz como la arenga de un conquistador. Su nombre se pronuncia en voz queda como una seña miedosa, se relatan sus hazañas como los cuentos embrujados, con voz opaca y temerosa que estremece (...) insulta a quien le descontenta y reparte la plata pródigamente cuando sus azarosas manipulaciones marchan favorablemente; su voluntad es su ley (...) La gente está indignada, pero el miedo ambiente les envuelve en una niebla densa que apaga las voces hasta reducir la gritería a un vago rumor.

El señor Veloz es el jefe político y social de la provincia; el día que se le antoje pega un puntapié al diputado y se calza el acta (...) Yo protesto simplemente, humildemente, encogidamente contra ese señor (...) Don Diego Veloz hubiera podido destacarse con aureola heroica en una sociedad primitiva (...) Acaso podría brillar también actualmente su arrogante empuje en las patrióticas empresas del Rif, pero en una ciudad civilizada y académica, sosegada y recogida, esos voluntariosos y peligrosos arranques deben estrellarse ante el desdén colectivo "394.

No ocurriría así, pero no perderían por ello su carácter visionario, acertadísimo, estas palabras. Durante los años veinte, tendremos ocasión de comprobarlo, Martín Veloz se convertiría en el señor todopoderoso de esta capital meseteña. Por de pronto, el retraimiento urbano generaba únicamente la indignación de algunos ediles, como Iscar $^{395}$. Veloz respondería a las palabras de "Fernandito" (así se refería en su carta al concejal, en tono marcadamente despectivo) algún tiempo después, por hallarse en Melilla prestando su apoyo moral a los combatientes, y rechazando todas las acusaciones $^{396}$.

Retornando al asunto de la higienización urbana, el inicio de las obras de abastecimiento de agua y evacuación de residuos seguiría haciéndose desear ${ }^{397}$. Por una parte, el Consistorio esperaba la aprobación en Cortes de una ley que le facultase para el cobro de un impuesto del $4 \%$ sobre la propiedad urbana, a modo de garantía de pago para la compañía contratante ${ }^{398}$. Por otro lado, la Sociedad Franco-Española era acusada

\footnotetext{
394 "El suceso de Medina”, La Ciudad, no 24, 28 de mayo de 1912, p. 1.

395 Marcelino M. González de Arco: "La autoridad en Salamanca", La Ciudad, no 25, 25 de mayo de 1912 , p. 1.

396 “Comunicado", La Ciudad, no 26, 22 de junio de 1912, p. 1.

${ }^{397}$ Esa impaciencia resulta muy perceptible no sólo en la prensa, sino en el mismo desarrollo de las sesiones municipales. El asunto acaparó gran protagonismo en la sesión extraordinaria del 30 y 31 de marzo de 1914; en la del 2 de abril; en la del 6 de abril; en la del 8 y 9 de julio; en la del 26 de octubre; también en la del 19 de mayo de 1915; y en la del 18 de agosto de 1915. Consúltese: Actas de las Sesiones Municipales. Archivo Histórico Municipal, vol. 1914, fol. 54 (r)-57 (v); 59-67; 68 (r)-75; 146147; 205 (r)-206 (v).

398 "Lo de las obras de saneamiento", El Adelanto, no 8.737, 7 de diciembre de 1912, p. 2; “¿Y esas obras?”, El Adelanto, no 8.829, 27 de marzo de 1913, p. 1; “Nuevo aplazamiento?”, El Adelanto, n⿳ 8.890, 7 de junio de 1913, p. 1; "El proyecto de saneamiento", El Adelanto, no 8.897, 16 de junio de 1913, p. 1; "Los lunes del concejo. La sesión de anoche", El Adelanto, n 9.101, 10 de febrero de 1914, p. 1; "En el Ayuntamiento. Lo del contrato de construcción de alcantarillado y traída de aguas", El Adelanto,
} 
de intentar introducir modificaciones técnicas en el proyecto de trabajo original con el objeto de abaratar sus costes, pero sin el visto bueno de la Comisión municipal de Saneamiento ${ }^{399}$.

Pese a todo, médicos como Manuel Muñoz Orea denunciarían, con acierto, que la ausencia de alcantarillado no debía servir como pretexto para hacer de las calles de Salamanca un estercolero. Y es que éstas ofrecían un aspecto lastimoso, con alumbrado insuficiente, inmundicias, baches ${ }^{400} \ldots$ que desvirtuaban, por ejemplo, la reciente inauguración del puente de Enrique Estevan ${ }^{401}$. Pero de la denuncia no se pasaba a la acción $^{402}$.

Salamanca registraba entonces un índice de mortalidad anual cercano al 35 por 1000, únicamente superado por los de Sevilla y Toledo. Entre los datos de interés que, además, aportaba el reputado doctor figuraba el hecho de que de las 4.063 casas que había en la capital, 1.763 carecían de agua y retrete; cada salmantino consumía solamente $47 \mathrm{~kg}$ de carne al año y 35 litros de leche, aunque la ingesta de patatas se elevaba a $230 \mathrm{~kg}$ y la de pan, hasta $292 \mathrm{~kg}^{403}$. En consecuencia, eran un cúmulo de circunstancias, con responsabilidades derivadas tanto para el Municipio como para el individuo, las que explicaban la alta incidencia de enfermedades infecciosas en Salamanca.

Como ya anunciamos, durante este periodo también se registró un cambio en las tendencias demográficas. Si bien se redujo la emigración a América con relación a etapas anteriores, Francia se convirtió en el nuevo destino de muchos salmantinos. Ricardo Fernández subraya que entre 1900 y 1920 emigraron de Salamanca la friolera de 62.256 personas. Tal cifra estaba indisolublemente ligada con el problema agrario y

n 9.143, 31 de marzo de 1914, pp. 1-2; "El saneamiento de Salamanca", El Adelanto, no 9.219, 29 de junio de 1914, p. 1; "El saneamiento de Salamanca", El Salmantino, no 899, 30 de mayo de 1913, p. 1; "Fondos insondables", La Libertad , no 17, 12 de junio de 1913, p. 7; "El saneamiento de Salamanca", La Libertad, $\mathrm{n}^{\circ}$ 64, 16 de mayo de 1914, pp. 4-5.

399 "Las obras de saneamiento", El Adelanto, no 9.165, 27 de abril de 1914, p. 1; "Saneamiento de Salamanca", El Salmantino, no 1.101, 4 de febrero de 1914, p. 1; "Saneamiento de Salamanca", El Salmantino, no 1.102, 5 de febrero de 1914, p. 1; "Saneamiento de Salamanca", El Salmantino, n” 1.103, 6 de febrero de 1914, p. 1

400 "El alumbrado público", El Salmantino, no 871, 25 de abril de 1913, p. ; "El problema del saneamiento I", El Salmantino, no 1.225, 8 de julio de 1914, p. 1; "Saneamiento de Salamanca II", El Salmantino, n' 1.226, 9 de julio de 1914, p. 2; "Por la higiene pública", El Salmantino, no 1.230, 14 de julio de 1914, p. 1.

401 "El puente de don Enrique Estevan", El Adelanto, no 9.008, 23 de octubre de 1913, p. 1.

402 "Un proyecto importantísimo", El Adelanto, no 8.786, 4 de febrero de 1913, p. 1.

403 "Higiene y mortalidad en Salamanca", El Adelanto, no 9.175, 8 de mayo de 1914, p. 2. Esta Conferencia fue presentada en el Paraninfo de la Universidad de Salamanca. 
la permanente amenaza de desahucio para los labradores ${ }^{404}$. Por otro lado, las principales causas de mortalidad continuaron estando relacionadas, ya se habrá intuido, con infecciones gastrointestinales y respiratorias, si bien la epidemia de 1918 tuvo una fuerte incidencia en esta provincia -las estimaciones aluden a unos 3.500 afectados, elevando la tasa de mortalidad total de 1918 a cifras próximas a los 6.000 individuos $^{405}$.

Pero aquí no finalizaban las calamidades para los vecinos de Salamanca: con el estallido de la Primera Guerra Mundial, las crisis de subsistencia se agudizaron ${ }^{406}$. Las conversaciones de los cafés asimismo se volcarían, durante los primeros días de la contienda, en el comentario de la inesperada destitución de Unamuno como Rector y en los rumores sobre la inminente supresión de la facultad de Medicina, debido a su precariedad económica, y su traslado a Valladolid ${ }^{407}$. Ni tan siquiera Esperabé, en 1933, acertaba a explicar el porqué de lo ocurrido con Don Miguel: "Pasó el tiempo, las cosas cambiaron por completo, y también determinadas posiciones y actitudes. Lo que no se ha sabido todavía, ni probablemente se llegará a saber, es la verdadera causa de la destitución de Unamuno" 408.

En un principio, la solicitud catalana de creación de zonas neutrales provocó encendidas diatribas entre los sectores agrarios castellanos: porque la concesión de una franquicia para el puerto de Barcelona era contemplada como una muy peligrosa amenaza para las carnes y el cereal de la región ${ }^{409}$. Pero la neutralidad, sabido es, se tradujo en una demanda adicional de bienes por parte de los contendientes. Por eso se aumentó la superficie provincial dedicada a la producción de cereal. Sin embargo, al tiempo que se exportaba más trigo o harina, se recortaba la oferta interior. La escalada de precios fue particularmente notoria en la capital. Afectó no sólo al pan, sino también a los precios del bacalao, el azúcar y los huevos, llegando a duplicarse en el sexenio

\footnotetext{
${ }^{404}$ FERNÁNDEZ, Ricardo: Op. Cit., pp. 14-15.

405 Ibidem, p. 74.

406 “Intereses locales. La nueva subida del pan”, El Adelanto, no 9.343, 18 de noviembre de 1914, p. 1; "Don Lápiz": "A ocho días vista", El Castellano, no 30, 13 de octubre de 1914, p. 1; Sánchez: "Perdiendo el tiempo", El Castellano, no 430, 14 de julio de 1915, p. 1; "Un detective": "Salamanca al día", El Castellano, n $^{\circ} 431,15$ de julio de 1915, p. 1.

407 "La destitución de Unamuno", El Adelanto, no 9.274, 31 de agosto de 1914, p. 2; "El anuncio de la supresión de las Facultades de Medicina y Ciencias. La destitución del señor Unamuno", El Adelanto, $\mathrm{n}^{\circ}$ 9.275, 1 de septiembre de 1914, p. 1; Alfredo Rivera: "Información telegráfica", El Adelanto, nº 9.275, 1 de septiembre de 1914, p. 2; "Sobre el traslado de la Facultad de Medicina. La destitución del señor Unamuno", El Adelanto, no 9.276, 2 de septiembre de 1914, p. 1; Alfredo Rivera: "Por teléfono y por telégrafo", El Adelanto, no 9.278, 4 de septiembre de 1914, p. 1; Alfredo Rivera: "Por teléfono y por telégrafo", El Adelanto, no 9.279, 5 de septiembre de 1914, p. 1.

${ }^{408}$ ESPERABÉ DE ARTEAGA, Enrique: Op. Cit., p. 238.

409 "Intereses castellanos. Las zonas neutrales", El Adelanto, n 9.354, 1 de diciembre de 1914, p. 1; "Las zonas neutrales. Lo que son", El Adelanto, no 9.358, 5 de diciembre de 1914, p. 1; "Las zonas neutrales. La protesta de Castilla", El Adelanto, no $9.387,9$ de enero de 1915, p. 1.
} 
1914-1920. Aunque fue cierto que los salarios nominales también mejoraron en este lapso temporal, de 25,1 pesetas a la semana hasta 39,2 , el incremento no fue suficiente ${ }^{410}$.

Asimismo, desde 1915 la penuria económica del Ayuntamiento se vería agravada por la supresión de los consumos. A pesar de que ésta había sido una reivindicación clásica de los sectores obreros ${ }^{411}$, su remplazo por un nuevo sistema impositivo plantearía cuantiosos problemas a la Corporación ${ }^{412}$. Además, los presupuestos seguirían pecando de irreales ${ }^{413}$; las continuas interinidades en la alcaldía constituían motivo de permanente preocupación ${ }^{414} \ldots$ Entretanto, los movimientos huelguísticos se extendían, sobre todo, entre los panaderos, herreros y empleados de la construcción $^{415}$; y el paro estacional amenazaba a cientos de trabajadores salmantinos ${ }^{416}$. La carestía de la vida había degenerado, de forma lógica, en protestas ${ }^{417}$. La queja más constante fue la de que las tasas oficiales sobre los productos de primera necesidad se incumplían sistemáticamente. Por ejemplo, en 1915 y 1916 fueron

\footnotetext{
${ }^{410}$ ROBLEDO, Ricardo: "Dejar el campo, comprar la tierra: economía, población y sociedad (18801930)" en ROBLEDO, R. (Coord.), Historia de...Op. Cit., p. 65.

${ }^{411}$ VALLEJO POUSADA, Rafael: "El impuesto de consumos y la resistencia antifiscal en la España de la segunda mitad del siglo XIX: un impuesto no exclusivamente urbano", Revista de Historia Económica, $\mathrm{n}^{\circ}$ 2, Madrid, 1996, pp. 339-370.

412 "Lo que se debe evitar", El Adelanto, $\mathrm{n}^{\circ}$ 8.936, 31 de julio de 1913, p. 1; "La diputación y el Ayuntamiento", El Adelanto, no 8.998, 11 de octubre de 1913, pp. 1-2; "La sesión de ayer", El Adelanto, n ${ }^{\circ}$ 9.006, 21 de octubre de 1913, p. 1; "Los consumos, la Federación y el alcantarillado", El Adelanto, n ${ }^{\circ}$ 9.049, 10 de diciembre de 1913, p. 1; "La sustitución del impuesto de consumos", El Adelanto, $\mathrm{n}^{\circ}$ 9.363, 11 de diciembre de 1914, p. 1; "Todavía hay remedio", El Salmantino, no 760, 13 de diciembre de 1912, p. 1; “Arbitrios ilegales?”, El Adelanto, no 9.633, 22 de octubre de 1915, p. 1; "Así somos”, El Castellano, $\mathrm{n}^{\mathrm{o}} 81,12$ de diciembre de 1914, p. 1; “¿Deben regir los presupuestos municipales?”. El Salmantino, $\mathrm{n}^{\mathrm{o}} 1.372,2$ de enero de 1915, p. 1.

413 "Las dificultades del presupuesto", El Adelanto, no 8.731, 30 de noviembre de 1912, p. 1; "Retirada de las derechas", El Adelanto, no 8.732, 2 de diciembre de 1912, p. 1; "La sustitución del impuesto de consumos", El Adelanto, no 8.738, 9 de diciembre de 1912, p. 1; "La situación del Ayuntamiento", El Adelanto, $\mathrm{n}^{\circ} 8.742,13$ de diciembre de 1912, p. 1; "La continuación de los consumos", El Adelanto, $\mathrm{n}^{\circ}$ 8.753, 27 de diciembre de 1912, p. 1; "El presupuesto municipal", El Adelanto, ${ }^{\circ}$ 8.763, 8 de enero de 1913, p. 1; "Comienza la discusión de los presupuestos", El Adelanto, no 9.013, 29 de octubre de 1913, pp. 1-2; "El presupuesto municipal de 1914", El Adelanto, n' 9.043, 3 de diciembre de 1913, pp. 1-2; "Vicio de origen", El Adelanto, n ${ }^{\circ}$ 9.367, 16 de diciembre de 1914, p. 1; "El presupuesto de la diputación y el contingente provincial", El Castellano, no 65, 23 de noviembre de 1914, p. 1; "Los presupuestos municipales", El Castellano, no 97, 30 de diciembre de 1914, p. 1.

414 "En plena interinidad", El Adelanto, no 8.912, 3 de julio de 1913, p. 1; "La alcaldía de Salamanca", El Adelanto, $\mathrm{n}^{\circ}$ 8.978, 18 de septiembre de 1913, p. 1.

415 "Los obreros y las huelgas", El Adelanto, n' $8.969,8$ de septiembre de 1913, p. 4.

416 "Crisis del trabajo", El Salmantino, no 864, 17 de abril de 1913, p. 1

417 "Intereses salmantinos. La asamblea de ayer", El Adelanto, no 9.360, 8 de diciembre de 1914, p. 1; "Juan de Salamanca": "Vida local. Una suscripción". El Adelanto, n' 9.361, 9 de diciembre de 1914, p. 1; "Las subsistencias. De urgente remedio", El Adelanto, no 9.432, 3 de marzo de 1915, p. 1; "En la Federación Obrera. El mitin de anoche", El Adelanto, $\mathrm{n}^{\circ}$ 9.439, 11 de marzo de 1915, pp.1-2; "La crisis obrera", La Libertad, no 83, 3 de octubre de 1914, pp. 1-3. La Libertad, en lugar de alarmarse por la permanente crisis del trabajo, se decantó por atacar a Santa Cecilia y Pérez Oliva. Frente a lo que bautizaba como "caridad estatal", este periódico reprochaba a los trabajadores su desidia.
} 
numerosas las manifestaciones contra el impuesto sobre las carnes y la subida del pan $^{418}$. La tensión social sólo disminuía coincidiendo con la celebración de las tradicionales Ferias de septiembre, mientras la nota anecdótica la ponían algunos conocidos visitantes de Martín Veloz, tales como sus buenos amigos Burguete y Silvestre $^{419}$, y sus paseos turísticos por la capital del Tormes.

Con certeza, el incidente más violento tuvo lugar en mayo de 1915, cuando una muchedumbre de salmantinos enfurecidos, que primero se congregaron en la Plaza Mayor y obligaron a los comerciantes a echar el cierre por temor a posibles disturbios, se presentó en la estación y asaltó los trenes, cargados de cereal, para evitar su salida ${ }^{420}$. En el primer ejemplar de El Obrero publicado con posterioridad a estos hechos, Rafael de Castro pintaba un cuadro repleto de dramatismo para los trabajadores salmantinos:

"El precio de los artículos llamados de primera necesidad es elevadísimo; las ropas que necesitamos para cubrir nuestros cuerpos son sumamente caras; por las mismas circunstancias no podemos usar el calzado (...) se nos niega el trabajo, se consiente sucumbamos hambrientos en el arroyo de la calle, pues hasta de nuestras viviendas nos expulsarán (...) iAún nos llaman descontentadizos y exigentes! (...) Patria mía, ¿no te defendemos nosotros cuando te vemos en peligro? ¿No derramamos nuestra propia sangre porque tu inmortal nombre se respete en todas partes? ${ }^{421}$.

Y, a continuación, se publicaba otro extenso editorial en el que, ya sin ambages,

"Raf' pasaba a la justificación de lo acontecido el 10 de mayo:

"El acto del día 10 me ha llenado de orgullo, lo confieso, porque con él saco en consecuencia que en Salamanca hay fe y espíritu de emancipación y progreso. Sin que las clases directoras de las organizaciones obreras dijeran nada ni hubiera ningún acuerdo tomado por tales entidades, una porción de trabajadores abandonaron sus talleres, que se hizo extensivo por las obras y fábricas, formando una imponente manifestación (...) Los trabajos en la ciudad se paralizaron por completo. Los comercios y establecimientos públicos se cerraron. Los tipógrafos abandonaron las imprentas, prohibiendo la publicación de los periódicos (...) El triunfo ha sido grande.

\footnotetext{
418 "Los problemas del día. Las subsistencias y la crisis del trabajo en Salamanca", El Adelanto, n” 9.438, 10 de marzo de 1915, p. 1; "Sobre la cuestión de las subsistencias", El Adelanto, no 9.488, 8 de mayo de 1915, p. 1; "Las subsistencias", El Castellano, n 63, 20 de noviembre de 1914, p. 1; "El pan y las energías", El Castellano, no 64, 21 de noviembre de 1914, p. 1; "Formidable protesta contra el impuesto de las carnes", El Obrero, no 10, 10 de enero de 1915, pp. 1-3; "Grandiosa protesta”, El Obrero, no 24, 5 de marzo de 1916, pp. 1-2.

419 "Ecos de sociedad", El Castellano, no 452, 9 de agosto de 1915, p. 2.

420 "El precio del pan. Los sucesos de ayer", El Adelanto, no 9.490, 11 de mayo de 1915, pp.1-2; "Asuntos locales. Las elecciones municipales", El Adelanto, n 9.610, 25 de septiembre de 1915, p. 1. ESPERABÉ DE ARTEAGA, Enrique: Op. Cit., p. 242. El profesor nada comentaba en su repaso histórico de los asaltos a los trenes. Pero aplaudía la conducta de los obreros: "El 10 de mayo del mismo año, se verificó una imponente manifestación de todos los elementos obreros de la ciudad y en la que tomaron parte también los ferroviarios, motivada por los enormes precios que habían alcanzado los artículos de primera necesidad y ser insostenible la situación de la sufrida clase trabajadora. Se pedía (...) que se impidiera a toda costa fuesen al extranjeros trigos, arroz y ganados (...) El acto realizado en ese día por los obreros, justificadísimos en alto grado, fue secundado y aplaudido por todos".

${ }^{421}$ Rafael de Castro: “¡Trabajo, no! ¡Hambre, sí!”, El Obrero, n 15, 6 de junio de 1915, p. 1.
} 
Hemos conseguido que el gobierno se incautara del trigo existente en las paneras de la provincia y que el Ayuntamiento estableciera la tahona reguladora ${ }^{, 422}$.

En efecto, como los acaparadores de trigo se resistían a entregar las existencias a las autoridades municipales, mientras que los fabricantes de harinas se dedicaban a adulterar su producción, la Junta Municipal de Subsistencias hubo de proceder al método de las incautaciones forzosas y a la puesta en funcionamiento de una tahona municipal $^{423}$. Lógicamente, ésta atrajo los odios de los patronos panaderos de inmediato, pero también el aplauso unánime de los sectores sociales más desfavorecidos ${ }^{424}$. Sin embargo, el diario obrero omitió aportar detalles sobre el asalto ciudadano a los trenes.

Fueron, al mismo tiempo, habituales las demandas de subidas de sueldo y reducción de la jornada laboral, así como también se convirtieron en muy frecuentes las demostraciones de solidaridad con obreros despedidos. La Federación Obrera obtuvo, por todo ello, una creciente presencia pública durante estos años. Su protagonismo, sobre todo, fue destacado en muchas huelgas vinculadas con el sector de la construcción.

Un año particularmente dramático, en el terreno social y político, fue 1917. Comencemos por un fugaz repaso de la política: por la alcaldía desfilaron cinco hombres, todos ellos incapaces de librarse de la daga de la insolvencia y de combatir

\footnotetext{
422 "Raf.": "La voz del pueblo", El Obrero, no 15,6 de junio de 1915, p. 1.

${ }^{423}$ Actas de las Sesiones Municipales. Archivo Histórico Municipal, vol. 1915, fol. 85-88; 93-95; "Sesión extraordinaria del Ayuntamiento", El Adelanto, no 9.494, 15 de mayo de 1915, p. 1; "Las subsistencias y los sucesos del lunes", El Adelanto, no 9.494, 15 de mayo de 1915, p. 1; "El día en el Concejo. Las obras de saneamiento y el problema del precio del pan", El Adelanto, n' 9.496, 18 de mayo de 1915, p. 1; "Del día. El saneamiento de Salamanca y las subsistencias", El Adelanto, n 9.497, 19 de mayo de 1915, p. 1; "Sobra de trigo y falta de pan", El Salmantino, no 1.734, 17 de marzo de 1916, p. 1.

424 "Ayer, en el Ayuntamiento. El gremio de los panadero pide el cierre de la tahona municipal reguladora", El Adelanto, $\mathrm{n}^{\circ}$ 9.582, 26 de agosto de 1915, p. 1; "La cuestión del día", El Adelanto, $\mathrm{n}^{\circ}$ 9.585, 30 de agosto de 1915, p. 1; "Los panaderos anuncian el cierre de sus fábricas", El Adelanto, n ${ }^{\circ}$ 9.587, 1 de septiembre de 1915, p. 1; "Lo de los panaderos", El Adelanto, no 9.588, 2 de septiembre de 1915, p. 1; "Asuntos locales. Lo de los panaderos", El Adelanto, no 9.589, 3 de septiembre de 1915, p. 1; "El gobernador, el alcalde y los panaderos", El Adelanto, n ${ }^{\circ}$ 9.590, 4 de septiembre de 1915, p. 2; "Lo de los panaderos", El Adelanto, no 9.591, 6 de septiembre de 1915, p. 1; "En el Ayuntamiento. La sesión de ayer”, El Adelanto, no 9.595, 10 de septiembre de 1915, p. 1; “iOtra vez huelga?”, El Adelanto, no 9.614, 30 de septiembre de 1915, p. 1; "Los panaderos. Conflicto solucionado", El Adelanto, 4 de octubre de 1915, p. 1; "Vayan protestas", El Castellano, n 672, 1 de septiembre de 1915, p. 1; "No lo aplaudimos", El Castellano, n" 673, 2 de septiembre de 1915, p. 1; "El conflicto del pan", El Castellano, n' 674, 3 de septiembre de 1915, p. 1; “iSe soluciona?”, El Castellano, no 677, 7 de septiembre de 1915, p. 1; “La huelga de los panaderos", El Castellano, no 699, 29 de septiembre de 1915, p. 1. En cuanto a la satisfacción entre los obreros, véase: "La tahona municipal y los panaderos", El Obrero, no 25, 2 de abril de 1916, p. 1; "La tahona y la tabla municipal", El Obrero, no 30, 10 de septiembre de 1916, p. 1; "El proletariado español pide pan y trabajo", El Obrero, n 32,5 de noviembre de 1916, pp. 1-2.
} 
exitosamente la carestía de las subsistencias ${ }^{425}$. Emulando en el ámbito civil a las Juntas de Defensa, la convocatoria catalana de una Asamblea de Parlamentarios y, en particular, su petición de un mayor grado de autonomía para los organismos locales, despertó cuantiosos sueños de renovación entre las élites políticas salmantinas ${ }^{426}$. Aunque, sobre todo, la iniciativa caló en el hombre que entonces ocupaba la poltrona municipal: Vázquez de Parga. Enfrentado con sus correligionarios madrileños, acabó siendo remplazado, mediante Real Orden, por el también conservador Vicente Junquera. Eso sí, al acto de investidura no asistió ningún concejal ${ }^{427}$.

En el ámbito social, decíamos, 1917 tampoco fue un año venturoso para Salamanca $^{428}$. En febrero, los ebanistas se declararon en huelga para reclamar una mejora salarial y, después de dos meses de infructuosa lucha, acordaron trabajar en colectividad en un taller propio. Los patronos respondieron contratando a trabajadores foráneos, aunque finalmente tuvieron que reconocer a la asociación de obreros. En julio, además, estallaría una nueva huelga, ahora de curtidores, y pronto sería secundada por toda la Federación. La solución sería el resultado de una larga negociación, con renuncias por parte de ambas partes. En agosto, para remate, la huelga general revolucionaria dejaría paralizada la ciudad durante una semana, aunque sin llegar a detectarse incidentes violentos. También las publicaciones periódicas fueron suspendidas y personajes como Santa Cecilia, José Sánchez Rojas y Villalobos fueron

\footnotetext{
425 "Desfile de opiniones. El asunto del Ayuntamiento", El Adelanto, no 10.012, 20 de enero de 1917, p. 1; "Uno": "Salamanca y la guerra", El Adelanto, no 10.023, 2 de febrero de 1917, p. 1; "El pan nuestro", $E l$ Adelanto, $\mathrm{n}^{\circ}$ 10.032, 13 de febrero de 1917, p. 1; "El gremio de fabricantes de pan anuncia el cierre de sus tahonas", El Adelanto, no 10.037, 19 de febrero de 1917, p. 1; "Lo de los panaderos", El Adelanto, n $^{\circ}$ 10.039, 10 de febrero de 1917, p. 2; "Otro nuevo conflicto local", El Adelanto, $\mathrm{n}^{\circ}$ 10.040, 22 de febrero de 1917, p. 1; "La cuestión de los panaderos", El Adelanto, no 10. 040, 22 de febrero de 1917, p. 1; "El pan nuestro de este año", El Adelanto, $\mathrm{n}^{\circ}$ 10.043, 26 de febrero de 1917, p. 1; "Lo de los panaderos. Conflicto solucionado", El Adelanto, $\mathrm{n}^{\circ}$ 10.045, 28 de febrero de 1917, p. 1; "El conflicto de los panaderos", El Adelanto, $\mathrm{n}^{\circ}$ 10.047, 2 de marzo de 1917, pp. 1-2; "Los carniceros", El Adelanto, $\mathrm{n}^{\circ}$ 10.050, 6 de marzo de 1917, p. 1; "Subsistencias y trabajo", El Adelanto, n' 10.067, 26 de marzo de 1917, p. 1; "El Ayuntamiento y los harineros", El Adelanto, n ${ }^{\circ} 10.113,21$ de mayo de 1917, p. 1; “QQué ha hecho el Ayuntamiento en 1917?", El Adelanto, no 10.298, 1 de enero de 1918, p. 4.

426 "La proyectada gestión del Ayuntamiento de Salamanca", El Adelanto, n 10.147, 29 de junio de 1917, p. 1; "El señor Vázquez de Parga renuncia a la Alcaldía", El Adelanto, no 10.158, 12 de junio de 1917, p. 1; "Tristes consecuencias. El desamparo de Salamanca", El Adelanto, no 10.175, 1 de agosto de 1917, p. 1 .

${ }^{427}$ Actas de las Sesiones Municipales. Archivo Histórico Municipal, vol. 1917, fol. 112. También se puede seguir el nombramiento a través de las siguientes columnas: "Nuevo alcalde de Salamanca", $E l$ Adelanto, $\mathrm{n}^{\circ}$ 10.165, 20 de julio de 1917, p. 1; “¿El boicot municipal?”, El Adelanto, $\mathrm{n}^{\circ}$ 10.184, 11 de agosto de 1917, p. 1; "Palabras de aliento", El Salmantino, n n $^{\circ} .148,11$ de agosto de 1917, p. 1.

428 "El nuevo alcalde de Salamanca", El Adelanto, no 10.278, 7 de diciembre de 1917, p. 1
} 
encarcelados, al tiempo que se fortaleció la conciencia de clase obrera ${ }^{429}$. Esperabé comentó a propósito de aquellas jornadas:

"La huelga general planteada en España en agosto de 1917, repercutió enseguida en Salamanca (...) Enterado el gobernador (...) tomó militarmente las principales calles de la población y la Plaza Mayor, valiéndose de la Guardia Civil, en las primeras horas del 13.

Más de dos mil obreros huelguistas se situaron frente al Ayuntamiento, en actitud pacífica, mientras Primitivo Santa Cecilia recorría los comercios invitando al cierre (...) El gobernador hizo abrir todos los establecimientos, y nada ocurrió en esta capital, pero el trabajo se paralizó por completo por espacio de ocho días. La autoridad civil resignó el mando en la militar y se declaró el estado de guerra en Salamanca y su provincia ${ }^{, 430}$.

Por descontado, el saneamiento urbano seguiría constituyendo un problema pendiente del municipio al término del conflicto. No sólo motivaba sonadas broncas entre los ediles $^{431}$, sino que la Compañía Franco-Española continuaba resistiéndose a la ratificación del contrato y al inicio de las obras. El Consistorio, además, se mantenía a la espera de la aprobación de la ley para gravar la propiedad urbana ${ }^{432}$.

Desde principios de 1915, se había comentado que un consorcio de Valladolid remplazaría a la sociedad internacional ${ }^{433}$. Y en efecto, en mayo de aquel año, por fin, el Ayuntamiento pudo pactar unas nuevas bases con dicha empresa ${ }^{434}$. La misma debía presentar una fianza de algo más de 180.000 pesetas. Pero cuando se desplazó a Salamanca una comisión para entregar la cantidad estipulada, el acuerdo no se pudo hacer efectivo porque al Ayuntamiento le faltaba todavía la concesión de la ley

\footnotetext{
429 "La huelga general en Salamanca", El Adelanto, no 10.185, 20 de agosto de 1917, pp. 1-2; "Ejemplo a seguir. ¿Estamos, salmantinos?", El Adelanto, no 10.186, 21 de agosto de 1917, p. 1; "El estado de guerra en toda España. Revolución fracasada", El Salmantino, n ${ }^{\circ}$ 2.149, 20 de agosto de 1917, pp. 1-2. El Salmantino aprovechó la ocasión para lanzar duras diatribas contra el pensamiento socialista.

${ }^{430}$ ESPERABÉ DE ARTEAGA, Enrique: Op. Cit., p. 255.

431 "Dos cartas. Las obras de saneamiento", El Adelanto, $\mathrm{n}^{\circ}$ 9.308, 8 de octubre de 1914, p. 2. Enfrentamiento entre Pinilla y Villalobos, de una parte, y La Riva, por otro lado, sobre el precio de las obras pactado con la compañía Franco-Española; Sobre la misma materia: "La cuestión del saneamiento", La Libertad, $\mathrm{n}^{\circ}$ 86, 24 de octubre de 1914, pp. 1-2; "La cuestión del saneamiento", La Libertad, no 87, 31 de octubre de 1914, pp. 1-2. Más adelante: "Nuestra opinión", El Castellano, n 438, 23 de julio de 1915, p. 1. Un redactor de El Castellano reflexiona sobre el desprestigio moral en el que ha incurrido el Consistorio por su incapacidad económica.

432 "La comisión del Ayuntamiento de Salamanca en Madrid", El Adelanto, no 9.406, 1 de febrero de 1915, p. 1; "Lo del alcantarillado y traída de aguas", El Adelanto, no 9.429, 27 de febrero de 1915, p. 1.

433 "El saneamiento de Salamanca", El Adelanto, no 9.387, 9 de enero de 1915, p. 2; "En el Ayuntamiento. La sesión de anoche", El Adelanto, $\mathrm{n}^{\circ}$ 9.445, 18 de marzo de 1915, p. 1.

${ }^{434}$ Actas de las Sesiones Municipales. Archivo Histórico Municipal, vol. 1915, fol. 90-92; 134 (r); "Las bases para llegar a la construcción del alcantarillado y traída de aguas", El Adelanto, n 9.498, 20 de mayo de 1915, p. 1; "Junta municipal de asociados", El Adelanto, n n $^{\circ}$ 9.508, 1 de junio de 1915, p. 1; "El alcantarillado y las aguas", El Adelanto, n 9.623, 11 de octubre de 1915, p. 1.
} 
mencionada. Aún así, en diciembre de 1915, consiguieron del Consistorio la escritura de cesión $^{435}$.

El ritmo que se imprimió a los trabajos para la elevación de las aguas fue muy lento y generó un notable malestar social durante años ${ }^{436}$. Es más, en 1917 todas las obras de saneamiento estaban paralizadas, hecho justificado por la Sociedad por sufrir las huelgas de transporte y los efectos de la guerra. Las ya tirantes relaciones con el Ayuntamiento empeoraron desde este momento y se comenzó entonces a barajar la idea de rescindir el contrato.

Para concluir este esbozo urbano, la política de abastos en Salamanca también continuó generando infinidad de problemas y una tremenda crisis en la alcaldía, con Iscar Peyra y el gobernador civil, enfrentados, como protagonistas ${ }^{437}$. Con el final de la conflagración mundial, sin embargo, esta atmósfera generalizada de crispación se agravaría aún más.

\footnotetext{
435 "Intereses locales. Las aguas y el alcantarillado", El Adelanto, n ${ }^{\circ}$ 9.643, 3 de noviembre de 1915, p. 1; "Intereses locales. Las aguas y el alcantarillado", El Adelanto, n ${ }^{\circ}$ 9.644, 4 de noviembre de 1915, p. 1; "Las obras de saneamiento. ¿Un aplazamiento más?", El Adelanto, n 9.661, 24 de noviembre de 1915, p. 1; "Intereses locales. Las obras de saneamiento", El Adelanto, no 9.666, 30 de noviembre de 1915, p. 2; "Las obras del alcantarillado y la sesión del Ayuntamiento", El Adelanto, n ${ }^{\circ}$ 9.677, 13 de diciembre de 1915, p. 1; "Las obras de saneamiento. La firma de la escritura. Inauguración de los trabajos", El Adelanto, $\mathrm{n}^{\circ} 9.685,22$ de diciembre de 1915, p. 1

436 "Las obras de saneamiento y la elevación de aguas", El Adelanto, $\mathrm{n}^{\circ}$ 10.562, 6 de noviembre de 1918, p. 1; "El problema de las obras de saneamiento de Salamanca", El Adelanto, no 10.564, 8 de noviembre de 1918, p. 1; "Una campaña, una carta y una réplica", El Adelanto, no 10.566, 11 de noviembre de 1918, p. 1.

${ }^{437}$ Actas de las Sesiones Municipales. Archivo Histórico Municipal, vol. 1918, fol. 355 (r)-359; 342 (r)351 (v); 395 (r)-398 (v); 403 (r)- 409 (v); 419 (v). Vázquez de Parga acabaría retornando a la alcaldía, después de una elección en tercera vuelta. También este conflicto se puede seguir con la lectura de: “Salamanca sin pan?”, El Adelanto, n n $^{\circ} 10.307,11$ de enero de 1918, p. 1; “Junta de subsistencias", $E l$ Adelanto, $\mathrm{n}^{\circ}$ 10. 308, 12 de enero de 1918, p. 1; "El abastecimiento de pan a Salamanca", El Adelanto, $\mathrm{n}^{\circ}$ 10.310, 15 de enero de 1918, p. 2; "La cuestión del pan", El Adelanto, n' 10.313, 18 de enero de 1918, p. 1; "Los panaderos se niegan a panificar", El Adelanto, $\mathrm{n}^{\circ}$ 10. 314, 19 de enero de 1918, pp. 1-2; "El anuncio de huelga de los panaderos", El Adelanto, no 10.372, 28 de marzo de 1918, p. 1; "La dimisión del alcalde", El Adelanto, no 10.533, 2 de octubre de 1918, p. 1; "Seguimos sin alcalde", El Adelanto, no $10.536,5$ de octubre de 1918, p. 1; "Ha quedado resuelto el problema de abastecimiento de pan", $E l$ Adelanto, $\mathrm{n}^{\circ}$ 10.552, 24 de octubre de 1918, p. 2; "Espectáculo lamentable. La sesión de ayer", $E l$ Salmantino, $\mathrm{n}^{\circ} 2.477,1$ de octubre de 1918, pp. 1-2; "Las subsistencias y el alcalde", El Salmantino, $\mathrm{n}^{\circ}$ 2.480, 4 de octubre de 1918, p. 1; "Para el señor gobernador", El Salmantino, no 2.484, 9 de octubre de 1918, p. 1; "El señor Clairac nos dice...", El Salmantino, no 2.484, 9 de octubre de 1918, p. 1; "Actitudes inverosímiles", El Salmantino, no 2.482, 10 de octubre de 1918, p. 1; "La sesión de ayer", El Salmantino, $\mathrm{n}^{\mathrm{o}} 2.485,10$ de octubre de 1918, p. 1; "La sesión de ayer", El Salmantino, $\mathrm{n}^{\mathrm{o}} 2.491,17$ de octubre de 1918, p. 1. El Salmantino denunció con insistencia que los acaparadores pretendían desbancar a Iscar del Poder, deslegitimando sus gestiones, y por ello se esmeraban, como nunca, en mantener desprovista de trigo a la ciudad. Y en efecto, el susodicho personaje salmantino acabó renunciando a la poltrona municipal: "Otra vez la dimisión del señor Iscar", El Salmantino, n 2.514, 14 de noviembre de 1918, p. 1.
} 


\section{SALAMANCA Y LA CUESTIÓN MARROQUÍ DURANTE LA 1a GM}

En el ámbito internacional, el periodo transcurrido desde 1911 hasta 1914 se definió, a la vista está, por la escalada de tensión diplomática y, también, por una despiadada carrera de armamentos entre países ${ }^{438}$.

El 30 de julio de 1914, el gobierno de España, encabezado por el conservador Eduardo Dato, había insertado en la Gaceta un decreto por el que declaraba la neutralidad estricta del Estado español en la conflagración mundial. La disposición ministerial resultaba del todo comprensible porque la participación española en la política de bloques previa había sido muy marginal: los Acuerdos de Cartagena tan sólo se referían a la seguridad en el Mediterráneo; nada más. No obstante, la neutralidad también constituía una manifestación de impotencia ${ }^{439}$. Sobre todo, porque de los 140.000 hombres que integraban entonces el Ejército de tierra, 76.000 estaban en Marruecos. En tercer lugar, la neutralidad era asimismo previsible ante la ausencia de objetivos territoriales que satisfacer: el gobierno de Canalejas había experimentado un desaire en enero de 1914, cuando la Entente le presentó un proyecto de acuerdo sobre Tánger que nada le satisfacía; y el Rey había sufrido otro, en octubre de 1913, con relación a la cuestión de Portugal. Alfonso XIII había intentado negociar la participación española en una posible guerra contra Alemania ante Poincaré, durante su visita de Estado a Madrid. Sin embargo, el presidente francés le había hecho saber al monarca que Gran Bretaña sería absolutamente inflexible en este punto ${ }^{440}$. En cuarto y último lugar, la neutralidad también fue el fruto de la división de la opinión pública española en dos partes muy desiguales: una minoría intervencionista y una gran mayoría que entendía que la política exterior del país debía supeditarse a la reconstrucción interior.

A largo plazo, en cambio, en la contienda económica, España ofreció a la Entente suministros alimenticios y militares. Además, los españoles trabajaron en fábricas francesas, permitiendo así liberar manos para el frente de batalla. En estas circunstancias, Alemania, muy consciente de que España debía mostrarse amistosa ante Francia y Gran Bretaña por razones de índole geoestratégica, cifró sus esperanzas en la

\footnotetext{
${ }^{438}$ PONCE MARRERO, Javier: "La política exterior española de 1907 a 1920: entre el regeneracionismo de intenciones y la neutralidad condicionada", Historia Contemporánea, no 34, Bilbao, 2007, pp. 93-115.

${ }^{439} \mathrm{El}$ acérrimo maurista Salvador Canals, en 1915, lo expresaría del siguiente modo: "España no tiene derecho a elegir la amistad que más pudiera convenirle, sino a eludir la enemistad que más pudiera dañarle". Véase CANALS, Salvador: España y la cuestión de Marruecos ...Op. Cit., p. 28.

${ }^{440}$ SÁNCHEZ SANZ, Oscar Javier: Op. Cit., p. 752-753.
} 
neutralidad estricta del Estado español. Y para garantizarla, procedió a la práctica de la guerra submarina contra los buques españoles que comerciasen con la Entente: lucha más benévola, al menos durante los primeros años, bajo mandato de Romanones. Su voluntad de intervención junto a los aliados era de todos conocida, así que los germanos evitaban concederle un pretexto para ello; y más eficiente con Dato, García Prieto y Maura. Sin embargo, paralelamente, Berlín también recurrió al cebo de las ofertas territoriales (Gibraltar, Tánger y Portugal) con el propósito de liberar a Madrid del tutelaje de la Entente. Más que ningún otro agente político, Alfonso XIII espoleó estas ofertas alemanas, "se dejó querer", con la esperanza de poder chantajear a los otros signatarios de Cartagena y obtener recompensas similares, pero sin apartarse un ápice de la neutralidad.

Al mismo tiempo que se desencadenaba la contienda mundial, las informaciones contenidas en El Adelanto a propósito del Protectorado hispano-francés en Marruecos se empobrecieron notablemente. Sobre todo, y comparando con periodos previos, se recortó el número de editoriales relacionados con este asunto. Evidentemente, porque la guerra, en el escenario internacional, y los problemas de subsistencia, en el ámbito interno, se convirtieron en las preocupaciones de más candente actualidad durante esta etapa. Pese a ello, la cuestión marroquí no llegó a desaparecer por completo de entre las páginas de este diario.

Mientras Pallol se refería a la enorme expectación que generaba entre los salmantinos el conflicto europeo, Rivera aseguraba al terminar julio que el gobierno español se había comprometido al envío de un Ejército de 100.000 hombres a África para que, de este modo, las tropas francesas pudieran combatir frente a las alemanas ${ }^{441}$. $\mathrm{Y}$ en efecto, los soldados galos empezaron a abandonar Marruecos, mientras que la excitación se extendió por los zocos ${ }^{442}$. El Adelanto, además, fue el periódico que más se apresuró a la hora de denunciar el encarecimiento de las subsistencias y el vergonzoso comportamiento de acaparadores y adulteradores de productos ${ }^{443}$. En Salamanca, por de pronto, el gobernador civil interino, Enrique Martín y Guix, emitía una Circular sobre la prohibición de exportar cereal a los países contendientes ${ }^{444}$.

\footnotetext{
${ }^{441}$ Alfredo Rivera: "Nuestra información telegráfica de hoy", El Adelanto, $\mathrm{n}^{\circ}$ 9.247, 30 de julio de 1914, p. 3.

${ }_{442}$ Alfredo Rivera: "Información telegráfica de El Adelanto", El Adelanto, n 9.251, 4 de agosto de 1914, p. 3 .

443 "El problema de España", El Adelanto, no 9.413, 9 de febrero de 1915, p. 1; "Lo de las subsistencias", El Adelanto, $\mathrm{n}^{\circ}$ 9.417, 13 de febrero de 1915, p. 1.

444 "La guerra y las subsistencias", El Adelanto, n' 9.253, 6 de agosto de 1914, p. 2.
} 
Un apesadumbrado Pallol, al hilo de estos acontecimientos, reconocía: “Todas las naciones, las bélicas y las neutrales, sienten la honda conmoción del trágico choque geológico. A todas se extenderán las terribles salpicaduras del sangriento zarpazo. Las más lejanas y quietas habrán de sufrir hambre, peste y pavor" ${ }^{\natural 45}$. Nuestro editorialista dudaba, por consiguiente, tanto de las posibilidades del país para el autoabastecimiento como del cumplimiento de la prohibición gubernamental sobre las exportaciones ${ }^{446}$.

Prohibida la colocación de telefonemas sobre el desarrollo del conflicto en los tablones de la Plaza Mayor a principios de septiembre de $1914^{447}$, tanto Alfredo Rivera como el columnista Sánchez de Arco preferían desviar su mirada hacia Tánger y reconocían que, como ocurría desde hacía dos años, seguía muy amenazada su seguridad por los cabileños de Fahs ${ }^{448}$.

Casi al mismo que otros trece hombres de la Albuera eran destinados a Ceuta como refuerzo $^{449}$, el infatigable Pascual Meneu volvía, en octubre de 1914, a efectuar un balance de la que había de ser, ante las nuevas circunstancias europeas, la acción de España en Marruecos. González Hontoria, político liberal y conocido simpatizante de los aliados, había publicado un editorial en el $A B C$ en el que interrogaba a Eduardo Dato sobre el por qué de la presencia de un gran contingente, superior a 70.000 individuos, en Marruecos. Nuestro conocido catedrático se le adelantaba en la respuesta: hasta el momento habían ocupado Monte Arruit y esta posición sería la clave para un avance posterior. Aunque se habría de esperar por varias razones:

"El señor González Hontoria sabe mejor que otro que en verano no se deben hacer operaciones marciales en Norte de África, pues el calor y la falta de agua aconsejan conservar lo adelantado y prepararse para septiembre y octubre, especialmente para este último en que el fresco y alguna lluvia hacen más grata la vida de guerrilla y combate, Mas como no solamente lo topográfico y meteorológico hay que tener en cuenta para la campaña en Marruecos, si no lo político y diplomático, no únicamente con los indígenas, sino también con Francia, después de tener bien aprovisionadas de hombres, caballería, artillería, ametralladoras y aclimatados nuestros soldados y alistados los voluntarios indígenas y aborígenes, todos en conjunto bien organizados como medios o instrumentos, órganos que van a funcionar discretamente ya que no sabiamente, conforme al fin que se proponga la nación y que el gobierno y los generales de la patria tienen que ejecutar, entonces, y sólo entonces, será prudente adelantar algo (...) La acción de España en Marruecos es conjunta con la de Francia

\footnotetext{
445 “Argos": "Madrid al día. ¡Aún hay patria!”, El Adelanto, no 9.255, 8 de agosto de 1914, p. 2.

446 "Argos": "Madrid al día. Sin carbón y sin cisco", El Adelanto, no 9.257, 10 de agosto de 1914, p. 2.

447 "Las pizarras de El Adelanto", El Adelanto, no 9.281, 8 de septiembre de 1914, p. 1.

448 Alfredo Rivera: "Información telegráfica de El Adelanto", El Adelanto, n ${ }^{\circ}$ 9.281, 8 de septiembre de 1914, p. 5; Alfredo Rivera: "Información telegráfica de El Adelanto", El Adelanto, no 9.288, 16 de septiembre de 1914 , p. 3. La neutralidad española pareció muy amenazada a principios de octubre de 1914, cuando el diplomático marqués de Valtierra, estando en París, sufrió un bombardeo germano: Alfredo Rivera: "Por teléfono y por telégrafo", El Adelanto, n 9.304, 3 de octubre de 1914, p. 1.

449 "Soldados de Albuera a Ceuta", El Adelanto, n' 9.298, 26 de septiembre de 1914, p. 2.
} 
(...) mientras no cambien las premisas de la escuadra en construcción, visitas de Cartagena y tratados de Marruecos, que lógicamente nos llevan a Marruecos y a la Tríplice. Sin embargo, ojo avizor para estar alerta y preparados a las eventualidades que van a surgir de un momento a otro "450.

¿Qué significaba esto? Que Meneu conocía la realidad impuesta por los tratados internacionales pero, como no confiaba en la victoria militar de la Entente -ni en la capacidad operativa de los españoles a solas-, deseaba que el Ejército africanista se mantuviera allí a la espera.

Sin embargo, el escenario internacional se hacía más y más complejo con el ingreso de Turquía en la guerra, a la par que España se reafirmaba en su respeto a la neutralidad $^{451}$. Aunque Rivera señalaba que El Rasiuni estaba perdiendo muchos de sus apoyos y se alegraba por ello, nada aclaraba sobre su conducta ${ }^{452}$. La explicación de este cambio llegaba, sin embargo, de la pluma de Luis López Ballesteros: y era que la amistad hispano-marroquí tenía un precio. Los franceses habían sufrido una frustrante derrota en su Protectorado, en Jenifra, de la que también había dado parte Rivera ${ }^{453}$, y se había temido un levantamiento de todo el Sultanato a favor de la causa alemana, más previsible si cabía, debido a esa participación turca en la contienda al lado de los imperios centrales ${ }^{454}$. El pánico, entre los gobernantes de las potencias protectoras, había cundido y, por esta razón, el soborno de algunos cabecillas se presentó entonces como el camino más propicio para apaciguarlos: "La civilización y el oro de Europa no han logrado matar el sentimiento de independencia y el fanatismo religioso en el corazón del marroquí; pero es indudable que han comenzado a corromper al pueblo y a debilitarlo" 455 .

En febrero de 1915, coincidiendo con el dictamen gubernamental para el establecimiento de puertos francos ${ }^{456}$, el mismo autor, López Ballesteros, volvía a

\footnotetext{
${ }^{450}$ Pascual Meneu: "La acción de España en Marruecos”, El Adelanto, n 9.306, 6 de octubre de 1914, p. 1.

451 “Uno": "Palabras de un optimista. Éramos pocos..., El Adelanto, no 9.333, 4 de noviembre de 1914, p. 1; "El sentir nacional", El Adelanto, no 9.336, 10 de noviembre de 1914, p. 1.

${ }^{452}$ Alfredo Rivera: "Información telegráfica de El Adelanto", El Adelanto, $\mathrm{n}^{\circ}$ 9.361, 9 de diciembre de 1914, p. 3.

${ }^{453}$ Alfredo Rivera: "Información telegráfica de El Adelanto", El Adelanto, no 9.347, 23 de noviembre de 1914, p. 3. El corresponsal refirió el fallecimiento de 33 oficiales y de más de 600 soldados.

${ }^{454}$ TESSAINER Y TOMASICH, Carlos Federico: Op. Cit., p. 33. El autor insiste en que actos de fuerza tales como la visita de Guillermo II a Tánger, en 1905, o la crisis de Agadir, en 1911, habían hecho "crecer como la espuma" el prestigio alemán entre los marroquíes. Éste se vería reforzado, además, con el ingreso del Imperio Otomano en la guerra.

${ }^{455}$ Luis López Ballesteros: "Recuerdos de un viaje por Marruecos", El Adelanto, $\mathrm{n}^{\circ}$ 9.362, 10 de diciembre de 1914, p. 1.

${ }_{456}$ Alfredo Rivera: "Información telegráfica de El Adelanto", El Adelanto, no 9.417, 13 de febrero de 1915, p. 3; “¿Cuestión de nombre?”, El Adelanto, n 9.420, 17 de febrero de 1915, p. 1.
} 
colaborar con El Adelanto. En esta ocasión, explicaba que también la amistad española con la Entente debía tener un precio; no obstante, ningún beneficio territorial parecía derivarse de la ayuda a los aliados. De ahí, la reafirmación, una vez más, del principio de neutralidad.

Sin embargo, ¿cuáles serían los perjuicios de la neutralidad? Se ignoraban, pero se recelaba de una adversa reacción francesa en Marruecos:

"Una y otra nación, Francia especialmente, creían, sin duda, que el estado de nuestras relaciones, la intimidad de nuestra amistad al estallar la conflagración europea, les autorizaban a suponer que les íbamos a prestar un concurso más eficaz, más práctico que el de la neutralidad (...) En el terreno diplomático existe una orientación política que desde la entrevista de Cartagena, nos aproxima a la órbita en que se mueven Inglaterra y Francia. Estamos solidarizados con esas dos naciones en una afirmación al mantenimiento del statu quo mediterráneo. Estamos comprometidos en una obra de colaboración con Francia, aunque con independencia de acción en nuestra zona en el establecimiento y desarrollo del Protectorado en Marruecos.

El problema del equilibrio mediterráneo no se roza hasta ahora con la guerra. Prueba: la neutralidad de Italia. En África mantenemos 80.000 hombres, es decir, cumplimos con creces nuestro compromiso. Y en el terreno diplomático no hay más, y si lo hay, lo ignoramos ${ }^{, 457}$.

Aunque Pallol se hiciera eco, en las mismas fechas, de unos rumores que apuntaban al endurecimiento de las operaciones entre Ceuta y Tetuán, así como a la sustitución de Marina por Jordana en el puesto de Alto Comisario ${ }^{458}$, rápidamente hubo de desmentirlos y reconocer que la estrategia de España era puramente defensiva ${ }^{459}$. Si bien prácticamente nada hacía Dato para remediar el problema de la escasez de algunos víveres, al menos, en Marruecos, se podrían reducir los gastos militares (en 1914, se había gastado 143 millones, mientras que el presupuesto estimado para 1915 se cifraba en 125 millones de pesetas) ${ }^{460}$. Era una buena noticia.

Y mejor aún fue el anuncio del retorno del escuadrón de Cazadores de Albuera $^{461}$. El Adelanto, como de costumbre, se apresuraba para llamar al pueblo a que exteriorizase sus sentimientos de amor hacia la patria y el Ejército ${ }^{462}$. En esta ocasión, respondía el Club de Exploradores con el inicio de una suscripción ${ }^{463}$.

\footnotetext{
${ }^{457}$ Luis López Ballesteros: "Para El Adelanto. Al margen de la guerra", El Adelanto, no 9.420, 17 de febrero de 1915, p. 2.

458 "Argos": "Madrid al día. Todo negro", El Adelanto, no 9.407, 2 de febrero de 1915, p. 1.

459 “Argos": "Madrid al día. Paz y neutralidad", El Adelanto, no 9.409, 4 de febrero de 1915, p. 2.

460 "Los gastos en Marruecos", El Adelanto, n ${ }^{\circ}$ 9.414, 10 de febrero de 1915, p. 1.

461 "El regreso de Albuera", El Adelanto, no 9.442, 15 de marzo de 1915, p. 2; "El regreso de Albuera", $E l$ Adelanto, $\mathrm{n}^{\circ}$ 9.448, 22 de marzo de 1915, pp. 1-2.

462 "El escuadrón de Albuera. Deber que cumplir", El Adelanto, no 9.446, 19 de marzo de 1915, p. 1.

463 "Los exploradores salmantinos y Albuera", El Adelanto, n' 9.447, 20 de marzo de 1915, p. 1. El Adelanto informaría puntualmente de los progresos de la suscripción: "Los soldados de Albuera y la Juventud Excursionista", El Adelanto, n ${ }^{\circ}$ 9.451, 25 de marzo de 1915, p. 1; "Los soldados de Albuera y la Juventud Excursionista", El Adelanto, no 9.452, 26 de marzo de 1915, p. 1; "El homenaje a los soldados
} 
Al fin, el 23 de marzo de 1915, 131 jóvenes llegaban a la ciudad y eran recibidos con honores en la Alamedilla. Allí se congregaron el obispo, autoridades militares, académicas y cientos de paisanos para saludar a los héroes del momento. El diario de Núñez Izquierdo recordaba aquel 12 de julio de 1913 en que habían abandonado la capital y luego describía una atmósfera plagada de lágrimas y emociones: "Anoche regresaron: sanos, tostados, alegres, dando vivas a Salamanca y a la Albuera" ${ }^{\star 464}$. No faltaban, tampoco, unas palabras dedicadas a la memoria de Peral y de otros tres soldados fallecidos ${ }^{465}$.

Los franceses, mientras tanto, se mostraban intranquilos por la presencia de algún buque alemán en los alrededores de Tánger y por sus tratos con Abd-el-Malek en las cercanías de Tetuán ${ }^{466}$. Además, se hallaban con serias dificultades en el Garb y el Uarga $^{467}$, mientras que en Kudia Federico, una posición cercana a Ceuta, también los españoles sufrían cuantiosas bajas en junio de $1915^{468}$.

Tánger y Gibraltar, de hecho, se situaron en el epicentro de la estrategia madrileña de seguridad en el Mediterráneo durante la contienda ${ }^{469}$. “Argos”, como cabía imaginar, fue el primero en vaticinar que ningún éxito alcanzaríamos con estas reivindicaciones históricas:

"-Sánchez de Toca dice: "Tánger nos pertenece. Debe dársenos, sin limitación alguna". -Bueno, pues que nos lo den.

-Pero otros ilustres y poderosos hombres públicos de los que ahora están hablando como en los retratos de mérito- rehúsan Tánger y piden a gritos el Peñón de Gibraltar. -Mejor. Que nos den las dos plazas: la peninsular y la de enfrente.

-Nos van a dar... desengaños ${ }^{, 470}$.

En octubre de este año, El Adelanto volvía a subrayar que la situación de El Raisuni se tornaba, de día en día, más comprometida y cábilas como Beni Aros, Anyera

de Albuera", El Adelanto, no 9.454, 29 de marzo de 1915, p. 2; "Los soldados de Albuera y la Juventud Excursionista", El Adelanto, no 9.464, 10 de abril de 1915, p. 1. El Club recaudó 420 pesetas y obsequió a los combatientes con una comida en el Café Fornos.

464 "El regreso del escuadrón de Albuera", El Adelanto, no 9.449, 23 de marzo de 1915, p. 1.

465 "El regreso del escuadrón de Albuera", El Adelanto, no 9.450, 24 de marzo de 195, pp.1-2.

${ }^{466}$ Alfredo Rivera: "Información telegráfica de El Adelanto", El Adelanto, no 9.437, 9 de marzo de 1915, p. 3; Alfredo Rivera: "Información telegráfica de El Adelanto", El Adelanto, $\mathrm{n}^{\circ}$ 9.442, 15 de marzo de 1915 , p. 3.

${ }^{467}$ Alfredo Rivera: "Información telegráfica de El Adelanto", El Adelanto, no 9.507, 31 de mayo de 1915, p. 3; Alfredo Rivera: "Información telegráfica de El Adelanto", El Adelanto, no 9.527, 23 de junio de 1915, p. 3; Alfredo Rivera: "Información telegráfica de El Adelanto", El Adelanto, no 9.535, 2 de julio de 1915 , p. 3.

${ }^{468}$ Alfredo Rivera: "información telegráfica de El Adelanto", El Adelanto, no 9.510, 3 de junio de 1915, p. 3.

469 "El discurso de Maura", El Adelanto, no 9.473, 21 de abril de 1915, p. 1; Alfredo Rivera: "Información telegráfica de El Adelanto", El Adelanto, n $\mathrm{n}^{\circ}$ 9.482, 1 de mayo de 1915, p. 3.

470 "Argos": "Madrid al día. Peor de lo que estamos...", El Adelanto, no 9.486, 6 de mayo de 1915, p. 1. 
o Wad Ras estaban muy fraccionadas ${ }^{471}$. Pero por el momento, en cambio, se había registrado un descenso en el número de bajas y, de hecho, esa sería la tónica dominante de 1916.

Pero al iniciarse 1917, la neutralidad, otra vez, parecía más amenazada que nunca, debido al agotamiento que provocaba el constante bloqueo submarino alemán ${ }^{472}$. Por fortuna, el gobierno de Romanones aseguraba que sólo un ataque contra el territorio nacional nos arrastraría al conflicto ${ }^{473}$; su convencimiento merecía el entusiasta aplauso de Pallol ${ }^{474}$. Y, efectivamente, la agresión no tuvo lugar.

Avecinándose ya el fin de la contienda, Juan Franco, a mediados de abril de 1918, reconocía, con tono de alarma, que vislumbraba nuevos problemas en Marruecos, debido a la actitud extraña de El Raisuni; y que todos los políticos del país habían incurrido en responsabilidades allí por su ignorancia. Aunque no precisaba cuáles eran las esas dificultades la guerra africana resurgía en la mente de los lectores:

"Nuestros políticos hablan de la política francesa, inglesa, italiana, etc. como enterados, pero de Marruecos no han estudiado nada o casi nada.

Silvela, que pudo afirmar rotundamente nuestra política marroquí; pero tuvo vacilaciones incomprensibles en un hombre de su entendimiento. No lo había estudiado con la mirada puesta en el porvenir.

Maura fracasó en 1909 por acometer una empresa con precipitación imperdonable, sin estar el pueblo preparado militarmente y padecer una ignorancia de analfabeto sobre el país magrebino.

$Y$ los demás gobiernos hicieron poco y lo poco que hicieron lo hicieron mal porque temieron caer con el escandaloso fracaso que acompañó a Maura en su caída. Y el miedo en la política de Marruecos es el peor acompañante que puede llevar un gobierno. (...) El Raisuni, síntesis, compendio de toda la malicia marroquí, parece haber creído que todos los tratados que ha suscrito España sobre Marruecos y todos los sacrificios que ha realizado en hombres y dinero, no han tenido otro objeto que el de satisfacer las ambiciones del cacique moro (...) El dilema es el siguiente: el Raisuni con nosotros o contra nosotros.

Y quizás fuese mejor lo segundo ${ }^{, 475}$.

Por de pronto, el fin de las hostilidades era una formidable noticia, la más esperada $^{476}$.

Sin embargo, el fallecimiento de Gómez Jordana, víctima de un infarto en su mesa de trabajo, mientras escribía al gobierno reprochándole la funesta política

\footnotetext{
${ }^{471}$ Alfredo Rivera: "Información telegráfica de El Adelanto", El Adelanto, no 9.629, 18 de octubre de 1915, p. 3; Alfredo Rivera: "Información telegráfica de El Adelanto", El Adelanto, no 9.633, 22 de octubre de 1915 , p. 3.

472 "La situación de España", El Adelanto, no 10.026, 6 de febrero de 1917, p. 1.

473 "Argos": "Madrid al día. Tema obligado", El Adelanto, no 10.028, 8 de febrero de 1917, p. 1.

474 “Argos": "Madrid al día. Unanimidad de opiniones", El Adelanto, n 10.030, 10 de febrero de 1917, p. 1.

475 Juan Franco: "Otra vez Marruecos", El Adelanto, no 10.387, 16 de abril de 1918, p. 2.

${ }^{476}$ Máximo Gim: "Hacia el final", El Adelanto, $\mathrm{n}^{\circ}$ 10.506, 3 de septiembre de 1918. P. 2; Alfredo Rivera:

"Nuestra información telegráfica", El Adelanto, no 10.567, 12 de noviembre de 1918, pp. 3-4.
} 
adoptada ante El Raisuni, y su sustitución por Berenguer en la Alta Comisaría marcarían el inicio de una nueva etapa en la historia del Protectorado español: bajo su mando se iniciaría una auténtica guerra de conquista en la parte occidental del mismo ${ }^{477}$.

En cuanto a El Castellano, reapareció en la esfera informativa salmantina en octubre de 1914, bajo la dirección, ahora, de Claudio Gambotti ${ }^{478}$. Muy satisfecho con el mantenimiento de la neutralidad, se mostró indignado ante la actuación usurera de algunos industriales y partidario de la intervención económica directa del gobierno ${ }^{479}$.

Esta publicación dio puntualmente cuenta, durante tres meses, de los altercados en el camino entre Ceuta y Tetuán ${ }^{480}$. A lo largo de 1915, asimismo aludió a algunas operaciones militares españolas, sin demasiada envergadura, y, recogió unas declaraciones del general Marina para Heraldo de Madrid en las que Fernández Silvestre era defendido frente a unas imprecisas acusaciones de conducta indisciplinada $^{481}$. Pero, ¿qué acusaciones? Eso no lo aclaraba este periódico. Tampoco lo había hecho El Adelanto.

En realidad, el asesinato de Ali Akalai, un emisario marroquí con salvoconducto del propio Marina, no llegó a trascender entre la opinión pública salmantina. Paralelamente al estallido de la conflagración mundial, las luchas en Marruecos se habían ralentizado porque el gobierno madrileño temía que El Raisuni actuase desde la zona norte contra los franceses y se había apresurado a negociar un arreglo ${ }^{482}$. No

\footnotetext{
${ }^{477}$ Dámaso Berenguer manifestaría por escrito su confianza en la estrategia francesa de la "mancha de aceite": "Todo movimiento hacia adelante debe recibir, como sanción, la ocupación efectiva del terreno conquistado. Éste es el principio absoluto. Es el método de la mancha de aceite. No se gana terreno al frente, sino después de haber organizado el que se deja a retaguardia. Los insumisos de la víspera son los que nos ayudarán a someter a los recalcitrantes de mañana. Procediendo siempre sobre seguro; puesto recién ocupado se transforma enseguida en observatorio, desde donde el jefe del círculo, del sector o del distrito, examina la situación, procura entrar en relaciones con los elementos desconocidos que tiene ante sí, utilizando para ello los que acaban de sometérsele, determina los nuevos puntos a ocupar, y prepara, en una palabra, el salto adelante". Véase BERENGUER, Dámaso: La guerra en Marruecos (Ensayo de una adaptación táctica). Madrid: Librería Fernando Fe, 1918, p. 43.

478 “Así somos", El Castellano, no 20, 1 de octubre de 1914, p. 1.

479 "Pasando el tiempo", El Castellano, no 21, 2 de octubre de 1914, p. 3; "Pasando el tiempo", El Castellano, $\mathrm{n}^{\circ}$ 22, 3 de octubre de 1914, p. 1; "Pasando el tiempo", El Castellano, no 23, 5 de octubre de 1914, p. 1; "Pasando el tiempo", El Castellano, no 24, 6 de octubre de 1914, p. 1; Enrique H. Gutiérrez: "Deuda de España", El Castellano, n ${ }^{\circ}$ 26, 8 de octubre de 1914, p. 1; "Bendita neutralidad", El Castellano, no 49, 4 de noviembre de 1909, p. 1.

480 "Última hora", El Castellano, no 10, 1 de octubre de 1914, p. 3; "De Marruecos", El Castellano, no 57, 13 de noviembre de 1914, p. 3; "De Marruecos", El Castellano, no 77, 7 de diciembre de 1914, p. 3; "De Marruecos", El Castellano, no 78, 9 de diciembre de 1914, p. 1.

481 "Declaraciones del general Marina", El Castellano, no 437, 22 de julio de 1915, p. 1; "Información general de El Castellano. Lo que dice Silvestre”, El Castellano, n 441, 27 de julio de 1915, p. 3.

${ }^{482}$ Los franceses se quejaron en muchas ocasiones por la libertad con la que los agentes alemanes se desplazaban por la zona española de Marruecos. Los consulados alemanes de Tetuán, Larache y Melilla se convirtieron en las bases de redes de espionajes desde las que se proporcionaba dinero y armas a
} 
obstante, durante el acercamiento, este turbio incidente movería a la destitución tanto de Marina como de Silvestre (sospechoso de boicot). Este último, designado ayudante del Rey, fue alejado temporalmente del Protectorado ${ }^{483}$.

El nombramiento de Jordana como nuevo Alto Comisario, coincidió, por tanto, con un momento de notable agitación mora ${ }^{484}$. Y la misma situación era extensible a la zona francesa $^{485}$. Sin embargo, dos meses después y gracias a las hábiles gestiones del cónsul Zugasti, gran amigo del cabecilla rebelde, en septiembre de 1915 se alcanzó una tregua con El Raisuni. Éste recibiría armas y dinero a cambio de su cooperación en el sometimiento de las cábilas y ocupación de posiciones en Yebala. Se emprendía, así, un camino absurdo y contraproducente, pero definitorio de las relaciones entre España y El Raisuni: la alternancia de excesos de confianza con excesos de hostilidad y rigor. El jerife, evidentemente, sabría beneficiarse de esta incoherencia de los gobiernos españoles para rehacer su poder cuando éste se hallaba debilitado. Mientras, en la zona oriental, entre tanto, se produjeron importantes avances en la llanura del Garet, con la toma de enclaves como Tistutin y Batel.

El Obrero, que es primer rotativo socialista del que disponemos y el último de signo progresista al que nos vamos a referir, aunque brevemente, para este periodo, experimentó verdadera repugnancia coincidiendo con el estallido de la guerra mundial $^{486}$.

La ejecución de Ferrer estaba todavía bastante presente en sus editoriales, sobre todo, en aquellos dirigidos contra La Libertad, su enemigo mediático natural, pero también contra los sectores más clericales de Salamanca. Del amor a la patria profesado por estos grupos, comentaba un redactor:

"Más la aman y más patriotismo demostraron los que protestaron en 1909 de una política tan desatinada como la seguida por aquel gobierno nefasto que nunca maldecirá bastante la historia, y cuyas consecuencias todavía las están sintiendo la

líderes rebeldes como Abd-el-Malek y El Raisuni. Véase ROMERO SALVADO, Francisco J.: Op. Cit, p. 86 y 196.

${ }^{483} \mathrm{La}$ admiración que Alfonso XIII profesaba hacia el heroísmo bravucón e irreverente del coronel era bastante conocida. El Rey acostumbraba a escribir al oficial, animándole a infligir un duro castigo sobre El Raisuni y prometiéndole el envío de tropas: "Si crees que en algún momento puedo apretar por arriba (...) ya sabes que puedes contar conmigo". Este fragmento lo hemos tomado de HALL, Morgan C.: $O p$. Cit., p. 178.

484 "De Marruecos", El Castellano, no 452, 9 de agosto de 1915, p. 3; "Agitación entre los moros", El Castellano, $\mathrm{n}^{\circ}$ 453, 10 de agosto de 1915, p. 3; "Agresión de los moros", El Castellano, no 463, 21 de agosto de 1915 , p. 3.

485 "Combates entre moros y franceses", El Castellano, no 667, 26 de agosto de 1915, p. 1.

486 "La terrible lucha", El Obrero, n' 11, 7 de febrero de 1915, p. 1. 
nación, (ahí está Marruecos que puede probarlo con su continua sangría de hombres y dinero) que esos farsantes, escribas y fariseos modernos de la política", ${ }^{\text {,47 }}$.

De esta publicación también cabe destacarse que prestó publicidad con motivo de la celebración del $1^{\circ}$ de Mayo de 1915, junto con reivindicaciones estrictamente laborales y de abaratamiento de las subsistencias, al rechazo hacia la guerra de Marruecos ${ }^{488}$. Porque a aquel país, recordaba Mariano Ojeda un par de meses después, acudían los hijos de los pobres para proteger los intereses de algunos aristócratas y todo bajo el pretexto de civilizar a los marroquíes, mientras en España los analfabetos se contaban por millones ${ }^{489}$.

Al iniciarse 1916, cuando el gobierno de Eduardo Dato era remplazado por otro de Romanones, el problema marroquí cobró de nuevo actualidad en las páginas de este periódico. Siguiendo la estela trazada por España Nueva, el órgano socialista local se hacía también eco del carácter intrigante del conde y mostraba su antipatía hacia Villanueva por sus muchos intereses económicos en el territorio africano. Pero, sobre todo, temía que a él le sucediera Maura, preparado para reintegrarse en la vida política:
"Vuelve sin que nadie le llame.
No le atormentan las terribles culpabilidades que se le acusan.
No recuerda los días tristes que a España ha dado durante su carrera política.
No le importa que las víctimas de Marruecos se levanten para protestar de él.
No le importa que las mujeres españolas lloren aún la muerte de sus hijos, ${ }^{, 490}$.

Inquebrantable en sus planteamientos, en octubre de 1916, El Obrero efectuaba un nuevo y extenso alegato contra la guerra marroquí. A. Amador aseguraba que la "España pobre" desoía tanto los discursos intervencionistas de unos como las palabras de Maura. Porque esa España era, ante todo, pacifista y seguía lamentando la contienda marroquí:

"Dirijamos la vista a Marruecos. Pensad que alli hay una guerra; que lo mejor de nuestra juventud muere, que la prosperidad de la nación es imposible mientras continúe aquella sangría...

Pensad que los millones de pesetas usurpados al campesino, al obreros en general, al pequeño industrial, es el bienestar de unos pocos; pensad que hay muchas madres que lloran todavía, recordando el Barranco del Lobo; pensad que cuando la prensa monárquica de Madrid ha denunciado a los latrocinios que se cometen en tierras africanas, es que son muchos los abusos que se cometen; sabed que la mayoría de los repatriados regresan a sus lares enfermizos (...) Tened en cuenta que resultará una

\footnotetext{
487 "El último homenaje a Ferrer y Guardia", El Obrero, no 11, 7 de febrero de 1915, p. 2.

488 "Fiesta del trabajo", El Obrero, no 14, 1 de mayo de 1915, p. 1.

${ }^{489}$ Mariano Ojeda: "España agoniza", El Obrero, n ${ }^{\circ} 28,2$ de julio de 1916, pp. 1-2.

490 "Los tres ases. El que cae, el que sube, el que quiere levantarse", El Obrero, n' 22, 2 de enero de 1916, p. 1.
} 
paradoja hablar contra la guerra y oponerse a la intervención de España en el conflicto europeo, si nada decimos de Marruecos ${ }^{\text {,491 }}$.

Estaba ya aquí contenido el principal argumento empleado habitualmente por el pensamiento socialista contra la conflagración marroquí: el sufrimiento que ésta acarreaba para las familias más humildes. El tono tan directo del discurso, así como el recurso a la emotividad también fueron constantes de la estrategia comunicativa del obrerismo salmantino.

Poco antes de su cierre, El Obrero publicaba un manifiesto de llamada para la celebración del $1^{\circ}$ de Mayo. La alusión al conflicto marroquí, otra vez, no podía faltar: "Una parte principal de la responsabilidad, en el insoportable estado de miseria a que ha llegado nuestro pueblo, es debida a la persistencia de la guerra de Marruecos, execrada desde su principio por lo más sano de la raza y mantenida como un tributo a las exigencias de las oligarquías dominantes ${ }^{\$ 492}$.

Lamentablemente, esta publicación desapareció a principios de agosto de 1917. Carecemos, por consiguiente, de su testimonio sobre la huelga general de aquel verano así como de valoraciones sobre el estamento militar ${ }^{493}$.

Conviene subrayar que la ausencia, en líneas generales, de informaciones muy ideologizadas en la prensa salmantina de signo más progresista (de menos a más nos hemos referido a El Adelanto, El Castellano y El Obrero) contrastaba, de forma llamativa, con la abundancia y cohesión de las mismas en los periódicos locales más conservadores (nos referiremos, primeramente a El Salmantino, y a continuación, a La Libertad, de día en día más radicalizada). Si bien se apostaba decididamente por la preservación de la neutralidad, ya que otra conducta habría sido perseguida desde instancias oficiales, en este discurso se percibía claramente el apego hacia la causa alemana. Además, las aspiraciones históricas de España en Marruecos estuvieron muy presentes durante este periodo porque el momento de la conflagración se contempló, ante todo, como una oportunidad para la reformulación de las alianzas internacionales.

Nada más estallar el conflicto mundial, El Salmantino, de modo muy instintivo, se interrogaba sobre las derivaciones del mismo para España. Al lado de la Entente no cabía esperar ninguna recompensa territorial: Gran Bretaña jamás cedería el Peñón ni consentiría la anexión de Portugal; mientras que Francia, a todas luces, pretendía expulsarnos de Marruecos. En consecuencia, el integrismo creía, porque lo venía

\footnotetext{
${ }^{491}$ A. Amador: "Habla la España pobre", El Obrero, no 31, 1 de octubre de 1916, pp. 1-2.

492 "Manifiesto a las organizaciones obreras", El Obrero, n' 37,1 de mayo de 1917, p. 1.

${ }^{493}$ El último ejemplar corresponde al 5 de agosto de 1917.
} 
haciendo desde largo tiempo atrás, en la causa germana. Pero se resignaba ante la realidad. Uno de sus redactores había de confesar lo siguiente: “como ya es tarde para todas estas consideraciones, entendemos que los actuales momentos deben precipitarse vertiginosamente en sentido pacifista". No se trataba de una manifestación de respeto hacia los pactos internacionales adquiridos, aunque lo pareciera. Evidentemente, no. Más bien, era todo un reconocimiento de impotencia ${ }^{494}$.

Por esta razón, el periódico indignaba al hacerse eco de un rumor que circulaba con insistencia en la prensa francesa: el compromiso del gobierno de Dato para transportar a Argelia un Ejército de 70.000 hombres con el objeto de defender la soberanía gala allí. El político conservador lo había desmentido categóricamente y el integrismo salmantino confiaba en su palabra. En primer término, porque de procederse así se atentaría contra "el decoro patrio". Además, porque semejante movilización de tropas era económicamente insostenible. Y, por último, he aquí la sorpresa, porque se intentaban prevenir desórdenes entre la opinión pública -que anteriormente les había merecido muy escasa consideración- ya que "España (...) hállase cansada de sacrificar existencias y derramar su sangre por la ocupación de un territorio que es infecundo e ingrato a todo beneficio además de que nuestra misión se ha traspasado al no limitarse a la posesión de la parte exclusivamente litoral del imperio marroquî" ${ }^{495}$. Pero, ¿cuándo Marruecos había dejado de constituir esa tierra prometida para los empresarios e inversores?

Lógicamente, el diario estaba convencido de que la guerra concluiría con la derrota francesa y apostaba por no colaborar con la república vecina para evitar posteriores represalias germanas. Muy al contrario, esperaba recompensas: como ya se han mencionado, la anexión de Portugal, de Gibraltar y el ejercicio de un poder sin cortapisas en el Norte de África.

En consecuencia, el integrismo aplaudió el hecho de que Dato declarase oficialmente el mantenimiento de la neutralidad. Si bien puso en tela de juicio, inmediatamente, las posibilidades de su realización: "La codicia y otras pasiones pudieran arrastrar en determinado sentido a los que siempre andan más atentos en cuidar de los propios intereses que en mirar por los generales" ${ }^{\prime 496}$.

\footnotetext{
494 "Momentos supremos", El Salmantino, no 1.242, 29 de julio de 1914, p. 1.

495 "Neutralidad de España", El Salmantino, no 1.247, 4 de agosto de 1914, p. 1.

496 "Neutralidad y prudencia", El Salmantino, no 1.248, 5 de agosto de 1914, p. 1. En la misma idea se incidía en "Germanófilos y francófilos", El Salmantino, no 1.252, 10 de agosto de 1914, p. 1; y también “¡Duro con los acaparadores!”, El Salmantino, no 1.256, 14 de agosto de 1914, p. 1. El periódico, para
} 
Tánger y, más aún, Gibraltar representaban para este sector del conservadurismo salmantino las aspiraciones geoestratégicas básicas en el Mediterráneo, reivindicaciones insalvables para la defensa de la independencia de España; pero su posesión chocaba frontalmente tanto con las ambiciones tanto inglesas como francesas ${ }^{497}$.

Para perseverar en la idea de la enemistad natural de las potencias de la Entente, y, de paso, desacreditar a los políticos manifiestamente más intervencionistas, tales como Romanones y Lerroux, fueron habituales en El Salmantino los editoriales repletos de alusiones históricas. De hecho, ésta fue precisamente la nota definitoria de la estrategia comunicativa del integrismo durante la Primera Guerra Mundial: el recordatorio sistemático de las heridas inferidas por Francia y, sobre todo, por ser algo más novedoso, Gran Bretaña.

Así, al terminar agosto de 1914, a la par que la voracidad francesa en el Protectorado parecía fuera de toda duda, a Gran Bretaña se le achacaba el haber entorpecido la obtención de mayores réditos políticos por parte de España en Marruecos tras la Guerra de Tetuán e, incluso, se subrayó que, seguramente, el fracaso en el Barranco del Lobo podría haberse evitado de no ser por su actitud:

"Si en aquella fecha Inglaterra no hubiera obstaculizado el avance del Ejército que mandaba O'Donell, la campaña de penetración que iniciamos en julio de 1909, que nos ha costado un Barraco del Lobo (...) no hubiera existido motivo para ejecutarla, porque el imperio español, desde aquella fecha estaría asentado en Fez, sin el menoscabo territorial francés que ahora sufre, quedando para Francia la parte más rica y más extensa, y para España los riscos, las breñas y unos indígenas indomeñables ${ }^{, 498}$.

Los conocidos sueños imperialistas de El Salmantino chocaban, sin embargo, con las afirmaciones de Le Temps, que apuntaban al predominio de los aliadófilos en España $^{499}$. Indignado por la división ideológica de los españoles, que no entendía, el periódico salmantino apostaba, coyunturalmente, por la repatriación de tropas hasta las plazas africanas de soberanía. Y no más allá: consideraba que los Acuerdos de Algeciras se habían vulnerado con el estallido de la guerra mundial y, en consecuencia, no existía la obligación de salvaguardar la seguridad de las comunicaciones entre Ceuta y Tetuán ni era el momento idóneo para proseguir con la labor colonizadora - en la que, por otra

combatir a los acaparadores, era partidario exigía la comercialización forzosa de los productos de primera necesidad (correspondiendo a los ayuntamientos el cómputo y vigilancia de esas subsistencias) y el establecimiento de tasas.

497 "El famoso artículo Times", El Salmantino, no 1.252, 10 de agosto de 1914, p. 1; "La oposición geográfica de Inglaterra y Francia con España. Palabras de Castelar”, El Salmantino, n $1.263,24$ de agosto de 1914.

498 "Neutralidad española", El Salmantino, no 1.265, 26 de agosto de 1914, p. 1.

499 "España y la neutralidad", El Salmantino, no 1.268, 29 de agosto de 1914, p. 1. 
parte, nunca habían depositado demasiada fe ${ }^{500}$. De repente, cabía deducir, en Marruecos ya no había una guerra por nuestro honor. Mientras, con el muy combativo “Abel Peregrín" a la cabeza, el periódico se ensañaba con el Trust, responsabilizándolo de la fragmentación de la opinión pública, y comentaba: "En la actual guerra europea, está visto, toda la prensa del Trust, la radical, liberal, socialista y anárquica, la pornográfica a escandalosa, está decididamente al lado de los aliados, deseando y haciendo grandes campañas (...) Somos en esta contienda enemigos de Francia y de Inglaterra, lo declaramos francamente ${ }^{, 501}$.

Por su parte, de la revista África se tomaba un editorial en que Gustavo Peyra Anglada, efectuaba, a modo de cuestionario, un repaso de la historia de la monarquía hispánica desde los tiempos de los Reyes Católicos para concluir que nada podíamos esperar de la Entente:

“A. ¿Qué ideales de expansión y engrandecimiento en Europa y África tuvo España bajo los Reyes Católicos y la inmortal regencia de Cisneros?

$B$ - ¿Quiénes fueron los rivales de España en el largo periodo que abarca desde el comienzo del reinado de Carlos I hasta Carlos II?

C. ¿Qué beneficios obtuvo España de la Guerra de Sucesión?

(...)

H. ¿Quiénes se opusieron en 1860 al avance de nuestras tropas victoriosas sobre Tánger, haciéndonos malograr el fruto de aquella campaña?

(...)

K. ¿Quiénes han sido recientemente los que con más ahínco se han opuesto a nuestra legitima expansión en Marruecos?" 502.

También se convirtió en consigna del integrismo la reducción del presupuesto para Marruecos mientras durase la contienda. Incluso, la redacción llegó a adoptar el lema del socialismo con el propósito de reivindicar esta idea. El Acta suscrita en 1906 aparecía, nuevamente, en la raíz de su argumentación y esto era lo que se le recomendaba al gobierno:

"No debe prodigar ya ni un hombre ni una peseta, hasta que se resuelva la ecuación del viejo continente; pero si no, no obstante las patrióticas voces que se han recabado en las Cortes, lo mismo que nosotros demandamos en estas líneas, opta por proseguir facilitando recursos para los asuntos marroquíes, le compadecemos por la inmensa responsabilidad que contrae ante la Historia ${ }^{\text {,503. }}$.

De aquí, que el anuncio del regreso de la Albuera a Salamanca provocase enorme entusiasmo. Al igual que El Adelanto, la redacción se afanó tanto en la

\footnotetext{
500 "La cuestión marroquí", El Salmantino, no 1.337, 18 de noviembre de 1914, p. 1.

501 "Abel Peregrín": "Las falsías de un triunfo", El Salmantino, no 1.287, 21 de septiembre de 1914, p. 1.

${ }^{502}$ Gustavo Peyra Anglada: "Germanófilos y francófilos", El Salmantino, no 1.348, 1 de diciembre de 1914, p. 1. También se reprodujo en La Libertad: Gustavo Peyra Anglada: "Germanófilos y francófilos", La Libertad, $\mathrm{n}^{\circ}$ 92, 5 de diciembre de 1914, p. 3.

503 "El problema marroquí", El Salmantino, no 1.363, 19 de diciembre de 1914, p. 1.
} 
preparación de un acto cariñoso de bienvenida ${ }^{504}$; como en su relato pormenorizado, repleto de notas emotivas y un lenguaje grandilocuente:

"El Salmantino rinde su tributo de admiración patriótica a los héroes que forman el bizarro escuadrón expedicionario de África, al reintegrarse a su regimiento al regazo de esta ciudad, después de haber librado contra los enemigos de España epopéyicos combates en los inhospitalarios campos marroquíes, regados abundantemente con la sangre de los valientes albuerenses que retornan a este lar, una vez cumplida su misión afirmativa de asentar sobre base inconmovible la soberanía española; en vano repudiada por la traidora morisma ${ }^{, 505}$.

La plantilla de este periódico, por otra parte, también se entusiasmó ante la noticia, a mayor escala, de la repatriación de unos 10.000 hombres; de todos modos, se confiaba en poder elevar la cifra hasta los 40.000 soldados $^{506}$.

El domino español de Gibraltar, profundizando en lo que señalábamos más arriba, constituyó irrefutablemente el asunto que originó los editoriales más apasionados en este rotativo. "Tofail”, para empezar, negaba que España pudiera obtener beneficios de la colaboración con los aliados, pero simultáneamente, temía que la derrota de los ingleses acarrease importantes pérdidas para España en el Mediterráneo:

"Es lección que enseña la Historia, que los pueblo que lograron un largo periodo de prosperidad (...) no se avienen fácilmente a una situación de medianía, sino que procuran compensar sus pérdidas a costa de otros (...) Las dificultades han de venir por parte de los que, teniendo intereses en el Mediterráneo, crean posible aumentarlos a costa de España, cuya debilidad, como potencia militar, tanto se han ponderado; donde tanto eco halló la oposición a toda acción guerrera, oposición que, hecha con miras politicas exclusivamente, ha arraigado en la opinión "507.

En suma, el Trust continuaba siendo el responsable de todos los males de España, capaz de dar alas a la extremadamente ambiciosa política inglesa ${ }^{508}$. Pero no bastaba con Gibraltar para controlar el tráfico naval a través del Estrecho. Por eso, cuando arreciaban las voces sobre la cesión "bastarda" de Tánger a España, El Salmantino respondía con incredulidad. ¿A cambio de qué? ¿Si España abdicaba de sus pretensiones sobre Gibraltar se adueñaría de Tánger? A decir verdad, su

\footnotetext{
504 "El regreso de los soldados de Albuera", El Salmantino, n ${ }^{\circ} 1.433,16$ de marzo de 1915, p. 2; "Esperando al escuadrón de Albuera", El Salmantino, no 1.436, 20 de marzo de 1915, p. 2; "Llegada del escuadrón de Albuera", El Salmantino, no 1.437, 22 de marzo de 1915, p. 2.

505 "La llegada del regimiento de Albuera", El Salmantino, no 1.438, 23 de marzo de 1915, p. 2; "Más de la llegada de Albuera", El Salmantino, no 1.439, 24 de marzo de 1915, p. 1. Sobre el banquete organizado por la Juventud Excursionista Salmantina: "Homenaje al escuadrón de Albuera", El Salmantino, n 1.444, 29 de marzo de 1915, p. 2.

506 "Repatriación de las fuerzas de África", El Salmantino, no 1.504, 15 de junio de 1915, p. 1; "La repatriación", El Salmantino, no 1.506, 17 de junio de 1915, p. 1.

507 "Tofail": "Si vence Alemania...", El Salmantino, no 1.414, 22 de febrero de 1915, p. 1.

508 “Abel Peregrín”: "Las llaves del Mediterráneo", El Salmantino, no 1.430, 12 de marzo de 1915, pp. 12.
} 
internacionalización había sido una de las decisiones más trascendentales acordada en Algeciras y, por tanto, no podía ser empleada como moneda de cambio ${ }^{509}$.

En abril de 1915, “Abel Peregrín” aseguraba que Gran Bretaña, por este tipo de falsos ofrecimientos, se dibujaba como la gran amenaza para la independencia y soberanía española ${ }^{510}$. A los intervencionistas, además, les dirigía este comentario: "Si bien es cierto que en muchas ocasiones hay Neutralidades que Matan, no lo es menos que en muchas otras, hay intervenciones que suicidan"511. Así pues, el periódico continuaba sin comprender la lógica de la existencia de aliadófilos ${ }^{512}$. Todavía bastantes meses después, ya al concluir el año, Francisco Blanco insistía en la misma idea de la natural enemistad con los ingleses:

"Es necesario que dominemos en el Estrecho, y al león hispano se le encrespe su melena y que con formidables rugidos extienda fiero sus garras para que al través de las nieblas del mar, y del humo producido al tronar de los cañones en la tierra, vea el mundo civilizado que aún somos los mismos que lucharon contra los árabes y que todavía circula por nuestro cuerpo sangre de Daoiz y Churruca y que estamos dispuestos a morir destrozados antes que seguir viendo sobre la frente del suelo patrio la sombra de servidumbre que proyecta la bandera británica tremolando sobre Gibraltar ${ }^{, 513}$.

E incluso, a mediados de 1916, el diario integrista llegaba también a polemizar con Unamuno, que se había mostrado muy crítico, en un editorial para La Nación, con las reivindicaciones germanófilas sobre el Peñón ${ }^{514}$. El ya ex-rector había emprendido un viraje ideológico y se mostraba entonces como un convencido aliadófilo. La neutralidad, para él, era una realidad vergonzosa. Y es que, tal y como apuntaba recientemente Paloma Ortiz de Urbina, en el ámbito cultural, la conflagración mundial sirvió para que los grandes pensadores tomaran, por primera vez, parte muy activa en la política del momento: asistían a mítines, suscribían manifiestos y, en suma, creaban opinión $^{515}$.

\footnotetext{
509 “La internacionalización de Tánger”, El Salmantino, n $\mathrm{n}^{\circ}$ 1.449, 6 de abril de 1915, p. 1.

510 “Abel Peregrín": "Por dignidad y decoro debemos tomar Gibraltar", El Salmantino, n 1.450, 7 de abril de 1915, p. 1. El Salmantino, casi simultáneamente publicaba unas declaraciones de Romanones para Le Matín, manifestando claramente sus simpatías hacia la Entente: "Declaraciones del conde de Romanones", El Salmantino, no 1.450, 7 de abril de 1915, p. 2.

511 “Abel Peregrín”: "La neutralidad de España debe valer algo", El Salmantino, no 1455, 13 de abril de 1915, p. 1

512 “Tirol”: "España y Francia”, El Salmantino, no 1.471, 4 de mayo de 1915, p. 1. Para esta redacción, Vázquez de Mella era el único líder político que verdaderamente encarnaba a la opinión pública, deseosa de preservar la neutralidad: "Habló España”, El Salmantino, nº 1.496, 5 de junio de 1915, p. 1.

${ }^{513}$ Francisco Blanco: "La visión española", El Salmantino, no 1.624, 4 de noviembre de 1915, p. 1.

${ }^{514}$ Nogara: “iImproperios troglodíticos a Unamuno!”, El Salmantino, no $1.833,14$ de junio de 1914, p. 1.

515 ORTIZ DE URBINA, Paloma: "La Primera Guerra Mundial y sus consecuencias: la imagen de Alemania en España a partir de 1914", Revista de Filología Alemana, nº 15, Madrid, 2007, pp. 193-206.
} 
Pero aún con la llegada del conde de Romanones a la presidencia del gobierno, al concluir 1915, se mantuvo la neutralidad oficial española ${ }^{516}$. Sin embargo, fue éste el momento aprovechado por el órgano integrista apara endurecer, todavía más, su discurso anglófobo. Con certeza, porque no confiaban en el buen hacer del presidente liberal:

"Nunca estará bastante repetido que España, para llegar al desarrollo de su grandeza, a que tiene derecho, necesita sacudirse el yugo inglés y nuca ocasión tan favorable a ello como la presente, en que un tercero es el encargado de ponerle los cascabeles al gato, sin pedirnos en pago cosa alguna, sino que permanezcamos neutrales "\$17.

De hecho, el ingreso en la contienda parecía, al concluir 1916, inminente. O, al menos, así lo presentaba "Abel Peregrín": "Se está jugando en España con fuego, y el juego permitido, si es que no patrocinado por gobernantes afines a la intervención, llega ya a enrojecer las mejillas del pobre pueblo"518. Paralelamente, la actitud de El Raisuni era muy comentada en toda la prensa nacional, pero El Salmantino no acertaba a explicar qué ocurría: se comentaba su traición a los españoles, después de haber obtenido armamento y tropas. Nada más ${ }^{519}$.

Únicamente al terminar este año, el integrismo empezaba a vislumbrar una victoria aliada en el conflicto. Sin embargo, seguía sin contemplar posibles recompensas de la mano de la Entente y, por ello, una vez más, apostaba por la neutralidad ${ }^{520}$. De idéntico modo procedía Antonio Maura. Su multitudinario discurso pronunciado en la Plaza de Toros de Madrid, en abril de 1917, llegó a alcanzar resonancia internacional. Los intereses del líder conservador no iban más allá de la posesión de Tánger y Gibraltar. De ahí, su apuesta decidida por la paz ${ }^{521}$. "Abel Peregrín” aplaudía sus palabras:

"La campaña persistente de intervención española en la contienda europea era todo un plan de injerencia extranjera. Sus corifeos en la política y en la prensa, menudeaban sus viajes a París y Londres a recibir inspiraciones, a tomar nuevas medidas y métodos, a formular enredos, a hinchar el perro de los torpedeamientos, a meditar intrigas y a escribir soflamas patrióticas desde la prensa francesa y londinense, todo como anzuelo apetitoso con que pretender cazarnos ${ }^{\text {,522 }}$.

\footnotetext{
516 "Neutralidad ratificada", El Salmantino, no 1.745, 30 de marzo de 1916, p. 1.

517 “Tirol”: “El peligro alemán”, El Salmantino, no 1.768, 27 de abril de 1916, p. 1.

518 “Abel Peregrín”: “¿España a la guerra? ¡Eso no puede ser!”, El Salmantino, n’ 1.882, 14 de septiembre de 1916, p. 1.

519 "De la prensa", El Salmantino, no $1.905,11$ de octubre de 1916, p. 1.

520 "La neutralidad de España", El Salmantino, no 1.959, 16 de diciembre de 1916, p. 1.

521 "En cursiva”, El Salmantino, no 2.067, 30 de abril de 1917, p. 1.

522 “Abel Peregrín": "Que les devuelvan el dinero", El Salmantino, no .2070, 4 de mayo de 1917, p. 1.
} 
El desprecio hacia la Entente iba en aumento ${ }^{523}$. Mientras los franceses eran acusados, en una carta remitida desde Tetuán y escrita por un tal “T. B”, de querer apropiarse de Tánger y de maltratar allí a los colonos españoles ${ }^{524}$; en la prensa inglesa circulaba el rumor de que los españoles preparaban una vasta campaña militar para el año siguiente, y con el propósito de facilitar la gestión francesa en su zona, muy perjudicada por la libertad con la que allí operaban los alemanes. Por primera vez, El Salmantino, a través de la pluma de "X." se refería a este asunto, si bien, para desmentirlo y pedir al gobierno que desautorizase semejante rumor ${ }^{525}$. Las aspiraciones del integrismo, en suma, continuaban concretándose en la posesión de Gibraltar, Tánger y en el ejercicio de la plena soberanía en el norte de África ${ }^{526}$.

Además, los franceses también fueron acusados de actuar como conspiradores en el verano revolucionario de 1917. El periódico integrista afirmó que comprendía el malestar obrero ante la carestía de las subsistencias, pero, como en 1909, defendió que había "manos extranjeras" tras la huelga ${ }^{527}$. ¿Por qué? Porque a la república vecina le convenía una España débil de cara a la reconstrucción postbélica ${ }^{528}$.

En abril de 1918, saltaba otra vez a la primera línea de la actualidad la cuestión de Marruecos. El Salmantino responsabilizaba a The Times de haber propagado un rumor según el cual Alemania apoyaría la causa de El Raisuni y la independencia marroquí a cambio de granjearse el privilegio de explotar las minas, mientras España sería despojada de sus derechos mediante una indemnización en metálico ${ }^{529}$. El integrismo, lógicamente, rechazaba esta hipótesis y seguía sin transigir, ni un ápice, en sus aspiraciones territoriales ${ }^{530}$.

\footnotetext{
523 "Los enemigos de España", El Salmantino, no $2.077,11$ de mayo de 1917, p. 1.

524 “"T. B.": "Los franceses en Marruecos", El Salmantino, no 2.170, 15 de agosto de 1917, p. 1.

525 "X.": "La acción española en África", El Salmantino, n $2.220,15$ de noviembre de 1917, p. 1.

${ }^{526}$ J. Rodríguez de la Peña: "Gibraltar", El Salmantino, no 2.232, 28 de noviembre de 1917, p. 1; J. Rodríguez de la Peña: "La cuestión de Gibraltar", El Salmantino, nº 2.281, 28 de enero de 1918, pp. 1-2.

${ }^{527}$ J. Rodríguez de la Peña: "La mano de obra es española el capital, no", El Salmantino, no 2.117, 4 de julio de 1917, p. 1.

528 "El alcance de la revolución”, El Salmantino, n’ 2.150, 21 de agosto de 1917, p. 1. La alteración del orden social fue una preocupación recurrente de El Salmantino en este periodo. Como ejemplos: "Abel Peregrín": "Cortando por lo sano", El Salmantino, no 2.266, 10 de enero de 1918, p. 1; “Estamos locos?", El Salmantino, no 2.321, 20 de marzo de 1918, p. 1.

529 "B.": "Otra vez Marruecos", El Salmantino, no 2.343, 17 de abril de 1918, p. 1.

${ }^{530}$ Guillermo García Martínez: “¿Cuáles deben ser nuestras aspiraciones nacionales?”, El Salmantino, ${ }^{\circ}$ 2.376, 29 de mayo de 1918, p. 1; "Tánger, Ceuta y Gibraltar", El Salmantino, n 2.418, 22 de julio de 1918, p. 1.
} 
Al fin, con la derrota alemana y la firma de la paz, todas las esperanzas de este rotativo sobre el declive de la Entente se derrumbaron ${ }^{531}$. Como remedio de urgencia, impotente y desmoralizada, la redacción se desquitó con Miguel de Unamuno, tildado de "antipatriota parricida" por participar en un concurrido mitin en Madrid, junto con Pérez Galdós y Mariano de Cavia, ensalzando al bando de los aliados ${ }^{532}$.

De La Libertad, el periódico maurista, se debe señalar que, como ocurrió con $E l$ Salmantino, su primera reacción ante el inicio de la contienda fue la de preocupación por sus posibles "salpicaduras": prontamente, este periódico también se hizo eco sobre los rumores de colaboración con Francia en la seguridad de Marruecos y Argelia ${ }^{533}$. A ello respondía un redactor de la casa, dirigiéndose a los intervencionistas, de modo bastante visceral: "Dan el vergonzoso espectáculo de llorar las penas de los que han injuriado repetidamente a España, de los que no han perdonado ocasión de molestarla, y en Marruecos y en cuantas partes la Providencia nos ha unido sólo han procurado nuestra ruina" ${ }^{, 534}$.

A diferencia de El Salmantino, sin embargo, Gran Bretaña no representaba para el maurismo el mayor peligro en la defensa de los intereses nacionales: Había, en cambio, que temer a los enemigos del interior. Sobre todo, al conde de Romanones, inspirador de "Neutralidades que matan" $" 535$; y a Lerroux:

"El hombre que en unión de los demás republicanos y de los socialistas atronó el espacio y fulminó terribles amenazas contra una guerra a la que fuimos, en sus comienzos, empujados por el sagrado deber de defendernos, de repeler la agresión con que se pretendía asfixiarnos en el recinto de nuestras plazas africanas, de salvar algo nuestro, pretende ahora llevarnos, sin motivo ni fundamento alguno, alegando un patriotismo que nunca tuvo, a una guerra en la cual nada se nos ha perdido, y de la que nada podemos esperar ${ }^{, 536}$.

La campaña melillense de 1909, a la vista de este fragmento, seguía empleándose como arma arrojadiza de primer orden entre los distintos partidos ${ }^{537}$. El

\footnotetext{
531 "La paz se impone", El Salmantino, no 2.488, 14 de octubre de 1918, p. 1; G. Leibar: "El vencedor, vencido", El Salmantino, no 2.517, 18 de noviembre de 1918, p. 1. El autor anunciaba la proximidad de otro peligro mundial, acusando a la Entente de abrir "la caja de Pandora del socialismo más radical".

532 "Vanidad y exceso de exhibición”, El Salmantino, n $2.489,15$ de octubre de 1918, p. 1.

533 "La paz amenazada", La Libertad, n ${ }^{\circ} 75,1$ de agosto de 1914, p. 1.

534 “Jeremiadas", La Libertad, n ${ }^{\circ} 77,17$ de agosto de 1914, p. 3.

${ }^{535} \mathrm{La}$ autoría de este artículo ha sido bastante discutida y, por ejemplo, Romero Salvadó la atribuye a Pérez Caballero. De lo que no hay duda, es que el editorial resumía perfectamente el pensamiento intervencionista de Romanones. Véase ROMERO SALVADÓ, Francisco J.: España, 1914-1918. Entre la guerra y la revolución. Madrid: Crítica, 2002, p. 8-9.

536 "Más sobre la neutralidad", La Libertad, n $\mathrm{n}^{\circ} 79,29$ de agosto de 1914, pp. 1-2.

${ }^{537}$ Se incidía en la misma idea en "Nuestro comentario", La Libertad, no 80,5 de septiembre de 1914, p. 5. También se recordaban como capítulos humillantes de la historia española el Desastre de 1898 y el intercambio de Notas, "deslumbrados por una alianza engañadora", en Cartagena: "Neutrales", La Libertad, $\mathrm{n}^{\circ} 82,26$ de septiembre de 1914, p. 1.
} 
maurismo juzgaba un sarcasmo intolerable que, en este trance, la Conjunción siguiese proclamándose pacifista y confesaba, acto seguido, y abiertamente su apego hacia el bando germano (lo hacía de modo más explícito que El Salmantino): “Con Alemania, en el caso de vencer, podríamos obtener la natural expansión en Portugal, quién sabe si Gibraltar; y acaso parte de Marruecos" ${ }^{\text {} 538 .}$.

De todos modos, eran imperativos geoestratégicos, antes que la orden del gobierno Dato o los compromisos diplomáticos tocantes a la seguridad en el Mediterráneo, los que animaban a mantener la neutralidad:

"Hoy España se halla geográficamente colocada dentro de la órbita de acción de Francia e Inglaterra, y sometida por tanto a influencias de Estados, entre sí coaligados; incalculables serían los daños que estas naciones, que hoy cuentan con Portugal, podrían inferir a España, de adoptar nuestra nación una actitud favorable a Alemania; nos encontraríamos bloqueados por mar y por tierra por Francia, Portugal e Inglaterra, hoy dueña del Estrecho, llave del Mediterráneo; mientras que nuestro alejamiento de Alemania nos haría menos peligrosa su enemistad

Por otro lado, el rotativo no abandonaba su censura hacia la política excesivamente belicosa en Marruecos ${ }^{540}$. Valga como demostración que la redacción publicó un extenso artículo de Ángel Ossorio para $A B C$, en el que se llamaba a los lectores a reflexionar sobre el futuro porque “África y el mar Mediterráneo serán por mucho tiempo bocados para la codicia y para la pasión" ${ }^{541}$. La neutralidad se equiparaba con pasividad, con una manifestación de la degeneración racial: "Hace falta en España una campaña de afirmación nacional". Y, como conclusión:

"Nada de sueños imperialistas ni de quimeras de dominación (...) Ya hubiera sido buena ocasión la de esta guerra para rectificar nuestra equivocada política africana, trayendo de Marruecos, como tranquilidad de la península, una parte de los soldados que allí permanecen, sin provecho ni gloria, al servicio de un error. Lejos de hacerse así, cabe la duda de si a la hora presente lo habremos agravado prestándonos a suplir deficiencias de otros".

La Libertad y El Salmantino preconizaban, por consiguiente, una misma política en Marruecos, pero desde motivaciones distintas: Para el primero, la prudencia militar era una forma de reivindicación a posteriori de la obra de Antonio Maura. Desde su

\footnotetext{
${ }^{538}$ La simpatía hacia Alemania resultaba, más que nunca, notable en "Somos neutrales", La Libertad, $\mathrm{n}^{\circ}$ 84, 10 de octubre de 1914, p. 1; Edmundo González Blanco: "La democracia alemana", La Libertad, no 85, 17 de octubre de 1914, pp. 1-2; y F. de Sorel: "Por qué no odiamos a Alemania", La Libertad, no 131, 9 de septiembre de 1915, pp. 2-3. La potencia era presentada como el único país democrático de Europa, con una emergente industria, un socialismo muy bien organizado y haciéndose una distinción entre militarista, rasgo que no se le atribuía al país centroeuropeo, y cesarista.

539 "La conflagración europea y la neutralidad española", La Libertad, nº 80, 5 de septiembre de 1914, pp. 2-3.

540 "Campaña maurista. Nuestra acción en Marruecos", La Libertad, no 78, 22 de agosto de 1914, p. 3.

${ }^{541}$ Ángel Ossorio: "Neutrales, sí; inermes, no", La Libertad, no 86, 24 de octubre de 1914, pp. 2-4.
} 
fundación el periódico había renegado de la preeminencia de los militares en el Protectorado y lo seguía haciendo ahora, si bien amparándose en la pluma de una autoridad; el segundo, El Salmantino únicamente esperaba un cambio provechoso en el escenario internacional, mientras que el militarismo había sido uno de sus rasgos identitarios.

Tiempo después, en marzo de 1915, y coincidiendo con el cierre de las Cortes, el periódico maurista volvía a cargar contra los republicanos:

"Aquellos hombres que, en 1909, cuando España se vio obligada a cumplir los compromisos adquiridos por el partido liberal en el Acta de Algeciras y se mandó un puñado de soldados a África intentaron sublevar al Ejército y hacer explotar la revolución, estos mismo hombres, en 1915, enmudecen y callan ante los graves problemas nacionales; de la sangría de Marruecos no se acuerdan y de la crisis de hambre que nos amenaza no se preocupan ${ }^{\text {,542. }}$.

Ni tan siquiera el retorno del escuadrón de la Albuera sirvió de motivo para el entusiasmo. Al contrario, la pesadumbre era el estado de ánimo dominante entre la redacción:

"Los soldaditos de Albuera traen las marcas de la campaña rigurosa, pero su regreso no significa, afortunadamente para España, el abandono de un retazo nacional, ni el éxodo humillante de un Ejército de trozado. Lo que hay de triste, en esta nota de la actualidad salmantina, es la silenciosa expectación del pueblo que no siente el pasional impetu de vocear la bienvenida exaltada y contenta, si no que observa, observa y al mirar con simpatía el retorno de los soldados, parece que mira con desconfianza y abatimiento (...) Cerca de dos años han vivido los soldados de Albuera en las tierras de la morería. Dos años en que ha estado suspensa sobre la opinión militar y civil de España, la permanente interrogación de qué significa, ante la conciencia nacional, esa misteriosa guerra (...) Para nosotros lo heroico, dentro de la obra realizada por los de Albuera, no está en la innegable gallardía militar que hayan desplegado al intervenir en los incidentes guerreros; lo más heroico es cumplir, como ellos han cumplido, con un deber, aunque la conciencia individual de cada uno dudara "\$43.

El resentimiento en las filas del maurismo resultaba muy notorio. El tradicional elogio al honor militar quedaba completamente soslayado por la crítica hacia la política africana de liberales y datistas o "idóneos". El relato de la bienvenida en la Alamedilla era muy distinto al de El Adelanto y El Salmantino. Aquí no había vítores, ovaciones ni entusiasmo desbordante; tan sólo, una atmósfera de expectación. ¿Por qué? Porque no se deseaba elogiar al gobierno. Por consiguiente, incluso estos gestos de apego hacia los soldados se convirtieron en armas de la guerra de plumas, del enfrentamiento propagandístico: unos optaban por el relato exageradamente emotivo y caluroso, mientras otros cargaban las tintas en la incertidumbre experimentada por la opinión

\footnotetext{
542 "Patriotismo cotizable", La Libertad, no 104, 1 de marzo de 1915, p. 2.

543 “La llegada del escuadrón”, La Libertad, n 107, 29 de marzo de 1915.
} 
pública salmantina. El sectarismo político se anteponía a la descripción de la realidad y justificaba distorsiones por ambas partes.

Simultáneamente, el columnista Pedro Grengoire reclamaba la posesión española de Tánger. He aquí una nueva similitud con el órgano integrista: "Neutralizado Tánger por imposición de Inglaterra, nada podemos hacer que nos dé un resultado práctico (...) desde allí se abastecen de armas los cabileños rebeldes" ${ }^{\text {544. }}$; y un mes más tarde, al reproducir un famoso discurso de Maura en el Teatro Real, el periódico maurista volvía sobre la necesidad de adueñarse de esta plaza ${ }^{545}$.

Lamentablemente, la redacción de La Libertad echó el cierre a mediados de 1916, así que aquí concluyeron los paralelismos entre las publicaciones locales de signo conservador.

La guerra mundial exacerbó, en suma, una crisis ya existente en España: ensanchó la brecha entre la ciudad y el campo, entre la industria y la agricultura, entre obreros y patronos y entre la oligarquía industrial y la terrateniente. La creciente conflictividad no haría sino volcar definitivamente el equilibrio de poder hacia los militares. Su fuerza ya había quedado demostrada ante Dato, coincidiendo con el desarrollo del conflicto de las Juntas de Defensa ${ }^{546}$. Sin embargo, la monarquía liberal de Alfonso XIII logró sobrevivir al verano revolucionario de 1917. Pero lo que inclinaría, sin duda, la balanza hacia el lado castrense y en detrimento de las élites políticas sería la violencia catalana y el Desastre de Annual ${ }^{547}$.

Entretanto, Marruecos había dejado de constituir el centro neurálgico de la información internacional, si bien allí se concentraban casi todas las esperanzas de la política exterior española, al margen de las utópicas reivindicaciones conservadoras sobre Portugal y el Peñón.

La prensa local salmantina, con anterioridad a la Gran Guerra, había dado cuenta extensa tanto de la crisis de Agadir, generadora de una desmesurada tensión diplomática; como del conflicto del Kert, que no llegó a revestir la gravedad de la

\footnotetext{
${ }^{544}$ Pedro Grengoire: "Política exterior. Problemas nacionales", La Libertad, $\mathrm{n}^{\circ}$ 106, 22 de marzo de 1915, pp. 3-4.

545 "La conferencia del Teatro Real", La Libertad, n 111, 29 de abril de 1915, pp. 1-10.

${ }^{546}$ PUELL DE LA VILLA, Fernando: "Las Fuerzas Armadas en la crisis de la Restauración. Las Juntas militares de Defensa" en HERNÁNDEZ SÁNCHEZ-BARBA, M. y ALONSO BAQUER, M. (Coords.): Historia social de las Fuerzas Armadas españolas, Vol. V. La Restauración. Madrid: Alhambra, 1986, pp. 81-126. Se incluye un recorrido por las grandes reformas militares del periodo y el autor incide en la debilidad del poder civil durante el desarrollo de esta crisis.

${ }_{547}$ BALFOUR, Sebastian: El fin del imperio... Op. Cit., pp. 215-232; ROMERO SALVADÓ, Francisco, J.: Op. Cit., p. 213.
} 
anterior campaña de Melilla gracias, en buena medida, al genio propagandístico de Canalejas. Con todo, la opinión pública salmantina no se dejó arrastrar por el júbilo cuando, finalmente, se selló con Francia el tan controvertido Tratado para el establecimiento del Protectorado, en noviembre de 1912. La satisfacción y afán de persuasión pública que revelaban los artículos de Pascual Meneu chocaban frontalmente con la angustia y temor ante una previsible guerra de desgaste en las contribuciones de Benigno Pallol.

Y en efecto, la contienda marroquí, poco a poco, se fue enquistando y motivó el surgimiento de dos grandes debates entre la opinión pública local (y nacional); debates que recorrerían toda la historia de las campañas (no nos gusta eso de la historia de la "pacificación” marroquí). El primero fue el referido a las alianzas internacionales. Se trató de un asunto particularmente sensible para la opinión conservadora, convencida de la victoria alemana en la guerra y partidaria de la neutralidad estricta. Así, las relaciones con la Entente fueron muy cuestionadas desde las páginas de El Salmantino -que llegó a atenuar su militarismo con tal de no colaborar con Francia en Marruecos- y también desde el maurista La Libertad. Además, la labor de los diplomáticos fue reiteradamente desprestigiada.

El segundo dilema versó sobre la conveniencia de un régimen militar o civil para la zona asignada a España y afloró, sobre todo, a la hora de hacer frente a El Raisuni. Cuando éste atacaba a las tropas españolas, la prensa local salmantina, casi al unísono, respondía solicitando una contraofensiva. Aunque con matices, como siempre, en los discursos: lo que para El Salmantino era una cuestión de honor y decoro, para $E l$ Castellano y parte de El Adelanto no pasaba de constituir una coyuntural búsqueda de reparación. Como notas excepcionales, jamás persiguieron el desquite ni “Argos", convencido de que España caminaba hacia la debacle, ni el efímero El Obrero, que únicamente deseaba el abandono de aquella inhóspita región africana y la repatriación de las tropas. Cuando las relaciones con El Raisuni eran buenas, en cambio, Marruecos dejaba de ser “noticiable”. Pero la tensión diplomática y militar, por supuesto, se mantenía latente; sólo que a la opinión pública se le ocultaba. Ciertamente, también ella era muy propensa a desentenderse de las cuestiones internacionales tan enrevesadas.

Sin duda, la suerte de las tropas mereció un gran número de informaciones periodísticas y los gestos de socorro hacia ellas fueron continuados. Resultaba del todo lógico porque el escuadrón de Albuera hubo de hacer frente a una situación muy 
peligrosa en las inmediaciones de Ceuta durante casi dos años. Así que sus desventuras perturbaron, en repetidas ocasiones, el ánimo de la opinión pública salmantina.

La indefinición estratégica y la irritación que provocaba la sangría marroquí fueron poco a poco transformando la resignación en sonora y creciente oposición: los jóvenes eludían el servicio militar; los anuncios de agencias de deserción se multiplicaban en los diarios; las protestas socialistas contra el conflicto se hacían más frecuentes... pero desde el integrismo se continuaba apostando por la guerra rápida y feroz y, en compañía del maurismo, se insistía en la idea de que Marruecos constituía la garantía de independencia nacional.

Por su parte, los gobiernos luchaban por enviar refuerzos a África disimuladamente; anhelaban la posesión de Tánger; se desvivían por alcanzar una paz con El Raisuni; y delegaban en la prensa, otra vez, una obligación que les correspondía: la tarea de persuadir a la opinión pública sobre la conveniencia de permanecer en Marruecos.

Entendemos, sin embargo, que la prensa local salmantina, en esta ocasión, no supo desempeñar esta función. Difícilmente podía reclamar estoicismo entre sus lectores cuando se desconocían los objetivos de la contienda, el por qué de los avances, de las operaciones fallidas y, en suma, de los vaivenes ante El Raisuni. Por eso, las disensiones ideológicas entre unos periódicos y otros se iban acrecentando, mientras que los habitantes del Tormes empezaban a salir a la calle para protestar y reivindicar lo inmediato: el fin de la beligerancia. Todo lo que ocurría en el Marruecos español permanecía rodeado de misterio, más incluso que en 1909.

\section{LA GUARNICIÓN URBANA}

No deseamos concluir este capítulo sin hacer una breve mención de los avatares experimentados por la guarnición salmantina a lo largo de toda esta coyuntura. Fue éste un asunto que generó bastante preocupación entre los vecinos de esta capital meseteña.

En agosto de 1912 resurgían los rumores a propósito del desguarnecimiento de Salamanca, debido al inminente traslado de su exigua tropa a Medina del Campo ${ }^{548}$. Para los salmantinos, sin duda, este tipo de noticias, al igual que las vinculadas con el

\footnotetext{
${ }^{548}$ Se reitera, en la sesión municipal del 21 de agosto, el ofrecimiento de terrenos al ministerio de Guerra: Actas de las Sesiones Municipales. Archivo Histórico Municipal, vol. 1912, fol. 132; "La guarnición de Salamanca. Nuevo peligro", El Adelanto, no 8.639, 13 de agosto de 1912, p. 1; "La guarnición de Salamanca", El Salmantino, nº 665, 21 de agosto de 1912, p. 1.
} 
saneamiento, reflejaban el notorio estado de abandono en el que estaba sumida la ciudad. Desde la Capitanía General de Valladolid, se encarecía al Ayuntamiento para que rehabilitase el edificio del Trilingüe en que se alojaban las tropas ${ }^{549}$. Pero en este punto se planteaba un problema: el inmueble había sido cedido temporalmente por la Junta de Colegios de la Universidad de Salamanca al Consistorio, pero aquélla se negaba a acometer las obras por tratarse de un edificio que debiera estar destinado a fines benéficos. El Ayuntamiento, por su parte, también pretextaba que las obras excedían a sus obligaciones y proponía, como remedio, la cesión de unos terrenos al ministerio de la Guerra para que él acometiera la construcción ${ }^{550}$. No obstante, su oferta no hallaba una contestación oficial ${ }^{551}$.

Por este motivo, los comentarios sobre la marcha de los soldados rebrotaban periódicamente ${ }^{552}$; y mientras El Adelanto se veía forzado a reconocer el pésimo estado en que se hallaban alojados los mozos y denunciaba la desidia gubernamental para con esta urbe, en Medina se iniciaban las obras de un nuevo cuartel al finalizar $1913^{553}$.

Para El Salmantino, de igual modo, el desguarnecimiento de Salamanca era algo inconcebible, a juzgar por la situación estratégica de la ciudad. El integrismo defendió que competía al Estado la construcción de un nuevo cuartel porque ni el Ayuntamiento ni la Junta de Colegios tenía la suficiente solvencia como para restaurar el Trilingüe ${ }^{554}$. $\mathrm{Y}$, en efecto, el pleito entre ambos por eludir responsabilidades no tuvo, durante muchos meses, visos de resolverse ${ }^{555}$. De todas formas, y como remedio, en agosto de $1913 \mathrm{El}$ Salmantino también sugirió la conveniencia de que el capital para la construcción de un nuevo cuartel fuese adelantado por entidades financieras locales ${ }^{556}$. Dado que su

\footnotetext{
549 "La guarnición de Salamanca", El Adelanto, no 8.651, 28 de agosto de 1912, p. 1; "La guarnición de Salamanca", El Salmantino, n n $^{\circ}$ 671, 28 de agosto de 1912, p. 1.

${ }^{550}$ Un nuevo ofrecimiento a Guerra se registra en la sesión municipal del 13 de noviembre. Además, en esta reunión, se debate sobre la negativa de la Junta de Colegios a emprender las reformas en el Trilingüe: Actas de las Sesiones Municipales. Archivo Histórico Municipal, vol. 1912, fol. 170-171 (v); "Lo de las obras del cuartel del Trilingüe. Lo del contrato de alcantarillado", El Adelanto, nº 8.717, 14 de noviembre de 1912, pp. 1-2.

551 "Cuarteles en Salamanca", El Adelanto, no 9.100, 9 de febrero de 1914, p. 1; "Los lunes del Concejo. La sesión de anoche", El Adelanto, n ${ }^{\circ}$ 9.101, 10 de febrero de 1914, p. 1.

552 "Lo de la marcha de Albuera", El Adelanto, no 8.734, 4 de diciembre de 1912, p. 2; "La guarnición de Salamanca", El Adelanto, n ${ }^{\circ}$ 8.948, 14 de agosto de 1913, p. 1; "La guarnición de Salamanca", El Adelanto, $\mathrm{n}^{\circ}$ 9.237, 18 de julio de 1914, p. 1.

553 "La guarnición de Salamanca. Nuevo problema", El Adelanto, no 9.035, 24 de noviembre de 1913, p. 1.

554 "Sin tropa", El Salmantino, no 757, 10 de diciembre de 1912, p. 1.

555 "Salamanca desguarnecida", El Salmantino, no 959, 12 de agosto de 1913, p. 1.

556 "La marcha del regimiento de Albuera", El Salmantino, n 966, 21 de agosto de 1913, p. 1.
} 
propuesta no halló eco entre la opinión pública, el temor al desguarnecimiento permaneció como una constante de la historia salmantina ${ }^{557}$.

Al final, tras años de incertidumbre y produciendo un tremendo pesar entre los salmantinos, el 2 de agosto de 1915, un escuadrón de Albuera se marchó a Medina del Campo. Salamanca, por consiguiente, quedaba casi sin apenas tropas, con un único escuadrón ${ }^{558}$.

En El Adelanto, el creciente estado de alarma por esta cuestión se percibía desde hacía semanas ${ }^{559}$. Pero la furia estalló en la redacción cuando se conoció la orden de traslado:

"Verdad es que Salamanca, a pesar de sus excepcionales condiciones estratégicas, no cuenta, como otras capitales, con magníficos y modernos cuarteles debidos a la munificencia del Estado, que no ha querido derramar sobre nosotros ni las migajas del festín del presupuesto, pero también es cierto que nuestro Ayuntamiento ha procurado en toda ocasión dar facilidades al Poder central para el decoroso alojamiento de los defensores de la patria y ha ofrecido terrenos para cuarteles nuevos, reformas en el actual y cuanto ha estado dentro de sus condiciones económicas.

Hoy, como antes, seguramente Salamanca se habría impuesto todos los sacrificios necesarios para que Albuera, los dos escuadrones que alberga, hubiera tenido un buen cuartel, pero en vez de preguntársele que puede hacer, y después de calificar de patrañas los rumores de traslado de un escuadrón, las altas autoridades militares han optado por disminuir nuestra guarnición en vez de darnos el aviso de atención a que teníamos sobrado derecho" ${ }^{\text {"560 }}$.

Mientras que la Cámara de Comercio intentó responder a la disposición con una manifestación de protesta, finalmente suspendida porque carecía del respaldo de los concejales $^{561}$, en el Ayuntamiento, el socialista Santa Cecilia urgía a gestionar la concesión de un empréstito. Con el mismo se podría afronta tanto el asunto de los cuarteles como el del alcantarillado público ${ }^{562}$. Y, otro concejal, García Barrado apostaba por la solicitud ante el Estado de medios para la construcción de un cuartel de

\footnotetext{
557 "La guarnición de Salamanca", El Salmantino, no 1.222, 4 de julio 1914, p. 1.

${ }^{558}$ Los ofrecimientos municipales de terrenos para el ramo de Guerra se habían reiterado en una sesión celebrada el 9 de febrero de 1914: Actas de las Sesiones Municipales. Archivo Histórico Municipal, vol. 1914, fol. 26 (v).

559 "La guarnición de Salamanca. Malas noticias", El Adelanto, no 9.542, 10 de julio de 1915, p. 1; "Intereses locales. El alojamiento de las tropas", El Adelanto, no 9.545, 24 de julio de 1915, p. 1; "Lo del escuadrón de Albuera", El Adelanto, nº 9.558, 29 de julio de 1915, p. 1.

560 "El traslado del escuadrón", El Adelanto, no 9.559, 30 de julio de 1915, p. 1.

561 "El traslado del escuadrón de Albuera", El Adelanto, no 9.561, 2 de agosto de 1915, p. 1.

${ }^{562} \mathrm{La}$ sesión tuvo lugar el día 11 de agosto de 1915. Actas de las Sesiones Municipales. Archivo Histórico Municipal, vol. 1910, fol. 132 (r); "La sesión de anoche”, El Adelanto, n 9.570, 12 de agosto de 1915, p. 1; "La construcción de un cuartel y el saneamiento de Salamanca", El Adelanto, no 9.575, 18 de agosto de 1915, p. 1. El ofrecimiento fue reiterado, una vez más, en una sesión del 5 de septiembre de 1917, bajo la alcaldía de Junquera: Actas de las Sesiones Municipales. Archivo Histórico Municipal, vol. 1917, fol. 121 (r)-122 (v).
} 
Infantería (porque las cuotas eran más accesibles que en la Caballería) ${ }^{563}$. También Pérez Oliva, diputado por la capital, intentaría en Madrid abordar la cuestión tanto con Dato como con el ministro de Guerra, Fernando Primo de Rivera. Pero a las buenas palabras no le seguían los gestos ${ }^{564}$.

El Adelanto, por descontado, siguió perseverando en la idea de que la construcción de un cuartel resultaba vital para la economía salmantina ${ }^{565}$. Por su parte, en abril de 1918, el alcalde, Miguel Iscar Peyra, junto con Mirat, como representante de la Cámara de Comercio, viajaron hasta Madrid con el propósito de solicitar mejoras para la ciudad. Una de ellas, evidentemente, fue la construcción de un cuartel ${ }^{566}$. Con la cesión del Trilingüe a Guerra renacieron, por el momento, las esperanzas: este ministerio asumiría el coste de las reforman necesarias para el cómodo alojamiento de la Albuera $^{567}$. Y el entusiasmo desbordó a los salmantinos al conocerse, en agosto de 1918, la asignación a Salamanca del regimiento La Victoria $n^{\circ} 76$ en la organización divisoria regional ${ }^{568}$. Tanta fue la alegría que, en muy corto espacio de tiempo, desde el Ayuntamiento se reivindicó la necesidad de dos cuarteles, uno de Infantería y otro de Caballería, alegando que el Trilingüe no satisfacía ya las "aspiraciones modernas" de la ciudad $^{569}$. También el Consistorio reformuló su oferta de terrenos a la administración ${ }^{570}$. Por fin, había llegado la hora del entendimiento.

Al terminar julio de 1915, El Castellano asimismo lamentaba la orden de traslado de uno de los escuadrones de Albuera a Medina del Campo. Para la redacción de este periódico, el abandono que experimentaba la ciudad era, al menos en parte, el

\footnotetext{
563 "En el Ayuntamiento. La sesión de ayer”, El Adelanto, no 9.576, 19 de agosto de 1915, p. 1.

564 "Las reformas de la cárcel", El Adelanto, no 10.216, 25 de septiembre de 1917, p. 1.

565 "Fórmula de patriotismo", El Adelanto, no 10.202, 8 de septiembre de 1917, p. 1; "Ayer, en el Concejo. La cuestión de los cuarteles", El Adelanto, n ${ }^{\circ}$ 10.263, 20 de noviembre de 1917, p. 1; "El día en el Concejo", El Adelanto, no 10. 364, 19 de marzo de 1918, p. 1.

566 "El día en el Concejo", El Adelanto, no 10.386, 15 de abril de 1918, p. 1. En el Senado, el señor Jesús Sánchez y Sánchez también defendió la conveniencia de construir un cuartel en Salamanca: "Salamanca en el Senado. La cuestión de los cuarteles", El Adelanto, $\mathrm{n}^{\circ} 10.412,16$ de mayo de 1918, p. 3.

567 "El colegio del Trilingüe y el ministerio de Hacienda", El Adelanto, no 10.443, 21 de junio de 1918, p. 1; "El colegio del Trilingüe", El Adelanto, $\mathrm{n}^{\circ} 10.453,3$ de julio de 1918, p. 2; "Petición a Hacienda", $E l$ Adelanto, $\mathrm{n}^{\circ} 10.455,5$ de julio de 1918, p. 1; "El colegio del Trilingüe cedido a Guerra", El Adelanto, $\mathrm{n}^{\circ}$ 10.470, 23 de julio de 1918, p. 2.

568 "La hora definitiva", El Adelanto, $\mathrm{n}^{\circ}$ 10.495, 21 de agosto de 1918, p. 1.

569 "El día en el Concejo", El Adelanto, no 10.504, 31 de agosto de 1918, p. 2; "Lo de los cuarteles", El Adelanto, $\mathrm{n}^{\circ} 10.505,2$ de septiembre de 1918, p. 1.

570 "Una pregunta interesante", El Adelanto, $\mathrm{n}^{\mathrm{o}}$ 10.506, 3 de septiembre de 1918 pp. 1-2; "La cuestión de los cuarteles", El Adelanto, no 10.514, 11 de septiembre de 1918, p. 1; "La cuestión de los cuarteles", El Adelanto, $\mathrm{n}^{\circ} 10.523,20$ de septiembre de 1918, p. 1 .
} 
fruto de la elección de muy malos representantes en Cortes ${ }^{571}$. Pero la responsabilidad también recaía en las élites madrileñas:

"Salamanca hoy día, por su importancia comercial primero, por su situación topográfica lo segundo y por su vasta red de ferrocarriles, en una palabra, es seguramente la única capital de provincia que rayana con el vecino reino de Portugal, es la base de todo plan estratégicos (...) ¿Por qué dejarla desguarnecida? (...) Claro es que si no hay cuarteles, no puede alojarse en ellos tropa; pero también es bien cierto que el gobierno pone a contribución una suma de millones de pesetas para ferrocarriles estratégicos, que si son de suma precisión para ulteriores fines nacionales, no lo serían menos en edificar antes cuarteles para tener militares dispuestos a cualquier evento ${ }^{\text {e572 }}$.

Para concluir, tampoco se libraban de culpa los acaudalados locales, incapaces de adelantar capital a un Ayuntamiento muy endeudado para poder habilitar el Trilingüe ${ }^{573}$.

En lo tocante a El Salmantino, por descontado, esta redacción también se preocupó hondamente ante la amenaza de desguarnecimiento de la capital ${ }^{574}$. Y sintió la confirmación de la mala nueva ${ }^{575}$. Las recriminaciones al gobierno no se hicieron esperar en esta redacción:
“De qué le sirve a Salamanca satisfacer con insuperado civismo sus obligaciones económica para mejor desenvolvimiento del régimen, y para que la patria grande realice sus fines nacionales y externos sin mengua ni menoscabo de sus prestigios históricos, si continuamente se la viene postergando en el reparto de los beneficios públicos y se cercena la tutela del Estado, representada por aquellos medios protectores, que se llaman genéricamente obras públicas?
En el desamparo oficial más absoluto, vive nuestra ciudad, por no aceptar el estigma de oprobio e indignidad que significa el caciquismo, es decir, por mantener la soberanía de su conciencia, aún a costa del sacrificio de sus peculiares intereses ",576.

A partir de este momento, el integrismo prestaría particular atención a los movimientos de la Cámara de Comercio, respaldados por el Ayuntamiento y el Obispado, para lograr la cesión del Trilingüe al ministerio de Guerra ${ }^{577}$; y conservaría cierto miedo ante la posibilidad del completo desguarnecimiento urbano ${ }^{578}$. De hecho, su tono no sería tan entusiasta como el esgrimido en algunos editoriales de El Adelanto,

\footnotetext{
571 "Por Salamanca", El Castellano, no 445, 31 de julio de 1915, p. 1.

572 "Por Salamanca", El Castellano, no 464, 23 de agosto de 1915, p. 1.

573 "Por Salamanca", El Castellano, n' 466, 25 de agosto de 1915, p. 1.

574 "La guarnición de Salamanca", El Salmantino, no 1.388, 22 de enero de 1915, p. 1.

575 "Salamanca desguarnecida", El Salmantino, no 1.540, 28 de julio de 1915, pp. 1-2; "Las fuerzas de Albuera", El Salmantino, no 1.542, 30 de julio de 1915, pp. 1-2.

576 "Se aproxima la marcha", El Salmantino, no 1.543, 31 de julio de 1915 , p. 1.

577 “Otra vez lo del cuartel”, El Salmantino, no 1.585, 18 de septiembre de 1915, p. 1; “Tendremos cuartel", El Salmantino, no 1.676, 8 de enero de 1916, p. 1; "La cesión del Trilingüe", El Salmantino, no 1.698, 3 de febrero de 1916, p. 1; "Infantería a Salamanca", El Salmantino, no 1.709, 16 de febrero de 1916, p. 1; "Más sobre el cuartel", El Salmantino, no 1.793, 27 de mayo de 1916, p. 3.

578 “Se marcha el regimiento de Albuera?”, El Salmantino, no 2.057, 18 de abril de 1917, p. 1; “De interés local. La cuestión del cuartel”, El Salmantino, no 2.236, 3 de diciembre de 1917, p. 1.
} 
aunque también aplaudió el dinamismo mostrado por alcalde Iscar Peyra con el ofrecimiento de terrenos a Guerra ${ }^{579}$.

La Libertad, ya para concluir, sostuvo una postura idéntica: la de recriminar al gobierno por el estado de abandono que experimentaba Salamanca. Pero con un rasgo novedoso: la apatía ciudadana también figuraba entre las grandes responsables de la dejadez urbana general:

"Ni el alcalde, ni el Ayuntamiento, ni las diversas entidades que son y significan en la vida local, han hecho aún nada. Ni para lograr la revocación de la orden de marcha, ni para recabar la próxima vuelta, ni para encontrar un fórmula de transacción que dejara a salvo los amenazados intereses de la ciudad. Aquí nadie ha estado en su papel. Por nosotros, bien va. Somos de los que creemos que para que esto se arregle y surja vigoroso el movimiento que debe de surgir, necesita antes ponerse todo muy malo. Entonces quizá haga crisis la crónica enfermedad de indolencia y apatía que reina ha tantos años en nuestra ciudad ${ }^{, 580}$.

En Salamanca se estaba anunciando un cambio. Desidia de todos, más y más lamentaciones, ambiciones frustradas, resentimiento... iQué buen caldo de cultivo para la emergencia de un dictadorzuelo local! Porque se empezaba a reconocer el principal problema urbano. Pero, ¿estaría su solución cercana? ¿Vendría de la mano del singular Martín Veloz?

\footnotetext{
579 "Las aspiraciones salmantinas", El Salmantino, $\mathrm{n}^{\mathrm{o}}$ 2.348, 23 de abril de 1918, p. 1; "Las reformas militares y la guarnición de Salamanca", El Salmantino, n 2.406, 6 de julio de 1918, p. 1; "El asunto de los cuarteles", El Salmantino, n' 2.468, 20 de septiembre de 1918, p. 2.

580 "La marcha del escuadrón de Albuera", La Libertad, n 126, 31 de julio de 1915, p. 1.
} 


\section{LA RUTA HACIA EL DESASTRE: SALAMANCA, ANNUAL Y SU HERENCIA POLÍTICA (1918-1923)}

\section{SALAMANCA EN LOS AÑOS 20}

"Se acerca un invierno que aterra, el fantasma macabro del hambre, llama a las puertas con inusitada insistencia, no se puede oír sin asustarse. Al paso que vamos sólo hay dos caminos, o el remedio pronto y eficaz, o el desequilibrio social, el vértigo revolucionario que está conmoviendo al mundo, nos envolverá a todos y nos hundirá en el precipicio "1.

Durante la segunda década del siglo XX, los problemas de saneamiento urbano y el encarecimiento de las subsistencias continuaron presentándose como las más acuciantes amenazas, en el ámbito local, para el bienestar de los salmantinos.

Coincidiendo con el fin de la contienda mundial, la empresa contratada para el abastecimiento de agua solicitó al Ayuntamiento que se le abonase el precio de la instalación: 940.000 pesetas de suministro y 768.000 del alcantarillado. Además, a ello había que añadir 749.281 pesetas en concepto de pago de las obligaciones municipales atrasadas de $1918^{2}$.

Sin embargo, las obras deberían estar concluidas en diciembre de 1919 y ello no tenía visos de conseguirse. Aunque se había construido buena parte del alcantarillado, en concreto, 35 kilómetros de cañerías, aún faltaban las dos tuberías principales y algunos ramales. En el caso del colector del este, no se había construido porque el Ayuntamiento no había ejecutado las expropiaciones requeridas para la apertura de la Gran Vía. En el del oeste, el motivo del retraso radicaba en que estaba pendiente la aprobación de un nuevo proyecto de desviación de las aguas pluviales. Puesto que la tardanza se debía al Ayuntamiento, estaba obligado a conceder una prórroga. Y así se hizo. Con relación a los servicios de abastecimiento, se habían tendido 25 kilómetros de tuberías y estaba casi concluida la sala para los motores elevadores; pero faltaba algún tramo del conducto y la construcción de los filtros purificadores ${ }^{3}$.

\footnotetext{
1 “C.": "Las subsistencias", La Gaceta Regional, 23 de octubre de 1920, p. 1.

2 "La Sociedad de Aguas y Saneamientos plantea una grave cuestión al Municipio", El Adelanto, n ${ }^{\circ}$ 10.609, 1 de enero de 1919, p. 5.

${ }^{3}$ Las relaciones entre el Ayuntamiento y la Sociedad eran muy tensas porque ésta demandaba una revisión en los precios de las obras saneamiento, argumentando que los materiales se habían encarecido tras la Gran Guerra (lo cual era cierto; pero, al mismo tiempo, se negaba a emplear las tuberías de la vieja red de alcantarillado que se hallaban en perfecto estado. La Sociedad prefería comprar otras nuevas, con distinto calibre, y alterar así el contrato con el Municipio). Además, amenazaba con la huelga, mientras que el Consistorio se negaba a aceptar esos cambios. Para seguir los enfrentamientos, consúltese: "El problema del saneamiento", El Adelanto, no 10.650, 18 de febrero de 1919, p. 2.; "El Ayuntamiento y la Sociedad de Aguas", El Adelanto, no 10.651, 19 de febrero de 1919, p. 2; "La amenaza de un grave conflicto", El Adelanto, no 10.667, 10 de marzo de 1919, pp. 1-2; "El Ayuntamiento y la Sociedad Española de Aguas y Saneamientos", El Adelanto, no 10.682, 27 de marzo de 1919, p. 1.
} 
La Sociedad optó entonces por presentar cuatro recursos ante los tribunales como medio para bloquear la realización de las obras siguientes comprometidas. Igualmente se negó a llevar a cabo un aumento en la elevación total de agua porque acusaba al Ayuntamiento de despilfarrarla.

En vista de esta conducta, tal y como se había previsto en el contrato, en la sesión plenaria del 18 de junio de 1919, se acordó la terminación de la prórroga concedida a dicha Sociedad ${ }^{4}$. El Ayuntamiento le ofreció entonces unas nuevas bases y la respuesta fue buena ${ }^{5}$. La empresa concesionaria debería presentar el proyecto de desviación de aguas pluviales y el remate de las obras que faltaban, pero con la condición de que el Ayuntamiento actualizase sus pagos y modificase las tarifas vigentes. La compañía, además, también aceptó el plazo de ejecución de cuatro años ${ }^{6}$.

La ciudad, asimismo, tampoco se vio libre de los problemas de abastecimiento. Quizás, la situación más tensa se experimentó durante la primera quincena de noviembre de 1920, cuando la capital quedó paralizada casi por completo a causa de una huelga general. Incluso El Adelanto la secundó, no saliendo a la calle entre los días 2 y 14 de ese mes. No procedió de igual forma, en cambio, La Gaceta, cuya redacción concebía la huelga como una solución radical, ineficaz y dogmática ${ }^{7}$.

Si bien el problema de fondo residía en la carestía de las subsistencias, el detonante inmediato del conflicto fue un paro de la Federación de Obreros Ferroviarios, motivado por una reclamación de mejora salarial y rápidamente secundado por los demás trabajadores urbanos. Ni la intervención del gobernador civil, ni la del Ayuntamiento y la Junta de Reformas Sociales llegaron a buen término y el incremento

\footnotetext{
4 "En torno a las obras de saneamiento de Salamanca. Hay que resolver la situación", El Adelanto, n ${ }^{\circ}$ 10.749, 18 de junio de 1919, p. 1; "El Ayuntamiento, la Sociedad de Aguas y el vecindario", El Adelanto, $\mathrm{n}^{\mathrm{o}} 10.751,20$ de junio de 1919, p. 1.

5 "Una nueva fase en las obras de saneamiento", El Adelanto, no 10.868, 1 de noviembre de 1919, p. 1.

${ }^{6}$ Aunque algunos concejales (Paradinas, Clairac, Santa Cecilia, Iscar, Olivera y Unamuno), en sesión cerrada, reclamarían la rescisión del contrato: "El nuevo proyecto de contrato entre el Ayuntamiento y la Sociedad Española de Aguas y Saneamientos", El Adelanto, $\mathrm{n}^{\circ}$ 10.937, 22 de enero de 1920, p. 3. La reacción de El Adelanto, por medio de "Un Repórter" tampoco fue buena. Aparte de que el empréstito se presentaba como urgentísimo para lograr el saneamiento urbano, el nuevo sistema de pago por tramos era considerado como muy dañino para el consumidor. "Un Repórter": "El empréstito municipal", $E l$ Adelanto, $\mathrm{n}^{\circ} 10.869,3$ de noviembre de 1919, p. 1; "El Ayuntamiento y la Sociedad de Aguas", $E l$ Adelanto, $\mathrm{n}^{\mathrm{o}} 10.873,7$ de noviembre de 1919, p. 1 .

7"Importantísimos acuerdos de los obreros salmantinos", La Gaceta Regional, no 56, 23 de octubre de 1920, p. 1; "Del mundo social. Huelgas y boicot", La Gaceta Regional, n ${ }^{\circ}$ 59, 27 de octubre de 1920, p. 1; "El conflicto obrero", La Gaceta Regional, no 64, 3 de noviembre de 1920, p. 64; "Del vivir social. Inquietudes, salarios, producción", La Gaceta Regional, no 65, 4 de noviembre de 1920, p. 1; "Del conflicto actual. ¿Por qué no hay avenencia?”, La Gaceta Regional, nº 66, 5 de noviembre de 1920, p. 1; "El conflicto obrero en Salamanca", La Gaceta Regional, n' 67, 6 de noviembre de 1920, pp. 2-3; Buenaventura Benito: "De la huelga pasada. Analizando factores", La Gaceta Regional, no 71, 15 de noviembre de 1920 , p. 1.
} 
muy limitado en la paga, que finalmente se logró, no satisfizo a casi ninguno de los huelguistas ${ }^{8}$.

La fundación de La Gaceta Regional, en agosto de 1920, había servido, desde luego, para renovar el panorama del periodismo salmantino ${ }^{9}$. Muy vinculada con la defensa de los intereses trigueros provinciales, este diario prestó una gran cobertura al asunto de las subsistencias, conectado, a su vez, con el de la preservación del orden social:

"El acaparador es el lobo voraz que se ha entrado en la majada nacional y que a ciencia y paciencia de los pastores -léase autoridades- se va adueñando por pueblos, aldeas y regiones de producción, de todo lo que puede, sin importarle una higa que sus compatriotas se mueran de hambre y que la nación, a consecuencia de ella, se vea cualquier día envuelta en una tremenda revolución social ${ }^{\text {"10 }}$.

Aunque no sólo acaparadores y autoridades ocupaban el banco de los culpables.

A juicio del diario conservador también había que reservarle un espacio al obrero:

"Entre las pecadoras manos, culpables, aunque inconscientemente, de la carestía de la vida, está también el proletariado (...) El patrono, teniendo al obrero como una máquina más, no contaba con que esta máquina hablaba, razonaba, veía y comparaba las ganancias de amo y las escaseces del menestral. El obrero así explotado, peldaño de enormes ganancias ajenas, era imposible humanamente que conviviera con quien era su opresor y explotador.

La consecuencia fue pedir aumento de salario; ante la negativa, la huelga; con ésta, tener que transigir elevando los jornales; vino después la disminución de la jornada, que fue una precipitación del gobierno Romanones; con la disminución de horas de trabajo, siguió la escasez de producción, menor abastecimiento del mercado y por tanto, la carestía de la vida. Y si a esto añadimos la comezón o manía acaparadora que se desarrolló en los abastecedores del mercado público, tendremos suficientemente explicado todo el lúgubre panorama que ofrece la vida nacional (...) Que el obrero intervenga en las ganancias del capital industria y que el patrono intervenga en las necesidades del operario (...) ¿Se prestarán a esto los patronos, o sea el capital? ¿Es este el fin que persigue el socialismo y el sindicalismo? Desgraciadamente, no (...) Los gobiernos, que con la subida de jornales hacían el caldo gordo al socialismo, sabiendo que la vida se haría imposible, y que, tras este caos, vendría la revolución que les pondría en el trono del comunismo de Rusia","

Frente a la amenaza revolucionaria, el nuevo rotativo local contraponía la fuerza del sindicalismo católico. No obstante, la perseverante crisis de subsistencias jugaba en su contra porque contribuía a la radicalización de las clases más populares.

\footnotetext{
8 "Los conflictos obrero-patronales", El Adelanto, n' 11.181, 15 de noviembre de 1920, pp. 1-2.

${ }^{9}$ Buenaventura Benito: "Nuestra fe de vida", La Gaceta Regional, no 1, 20 de agosto de 1920, p. 1. Buenaventura Benito, en una carta de presentación, confesaba que el diario nacía alimentado por la idea de que el amor hacia la religión, la autoridad y el orden en las calles estaba decayendo.

${ }^{10}$ G. Leibar: "El problema nacional. Todos en él pusisteis vuestras manos", La Gaceta Regional, no 46, 12 de octubre de 1920, p. 1.

${ }^{11}$ G. Leibar: "Las subsistencias. La inconsciencia de unos y la perfidia de otros", La Gaceta Regional, ${ }^{\circ}$ 54, 21 de octubre de 1920, p. 1.
} 
Evidentemente, todo ello constituía la prueba de que las consecuencias de la Gran Guerra aún se dejaban ver en la provincia. La lucha por parte de algunos especuladores por mantener sus precios artificialmente elevados, contrastaba con el descenso de los mismos en el exterior ${ }^{12}$. El 22 de agosto tuvo lugar la celebración de una gran asamblea de labradores en el Bretón para solicitar el amparo del gobierno ${ }^{13}$. Encabezados por Martín Veloz, la Liga de Agricultores y Ganaderos reclamó la libre venta, contratación y circulación de trigos así como la limitación de su importación a lo estrictamente necesario y la persecución del contrabando ${ }^{14}$. Poco después, una Comisión se desplazó hasta Madrid para visitar al ministro de Fomento y entregarle las conclusiones alcanzadas. Pero su fracaso fue sonado: apenas si fueron escuchados desde las esferas gubernamentales ${ }^{15}$.

Por fortuna, a punto de efectuar otro segundo viaje a la Corte, cuando la amenaza de hambre se cernía muy seriamente sobre la población ${ }^{16}$, una Real Orden vino a entibiar el problema. En ella, se concedía más libertad de comercio a los harineros y trigueros, si bien en nada se modificaba la situación de los labradores ${ }^{17}$. La solución definitiva del conflicto, por consiguiente, se haría esperar. El Ayuntamiento intentaría salir del paso adquiriendo él mismo trigo y buscando, con notables dificultades, una

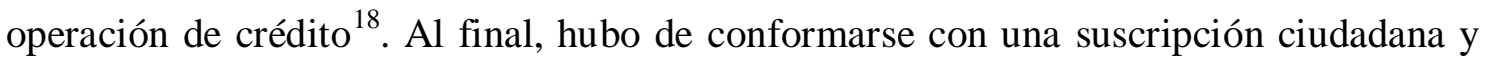

\footnotetext{
12 “El encarecimiento de las subsistencias", La Gaceta Regional, no 4, 24 de agosto de 1920, p. 1.

13 "Frente a un palpitante problema. Vientos de fronda", La Gaceta Regional, n' 3, 23 de agosto de 1920, p. 1.

14 “Asamblea de agricultores en el teatro Bretón”, La Gaceta Regional, n 3, 23 de agosto de 1920, pp. 23.

15 "Buscando la solución del problema triguero. Los agricultores salmantinos a la Corte", La Gaceta Regional, $\mathrm{n}^{\circ}$ 4, 24 de agosto de 1920, p. 8; Emilio Blanco: "Frente a un palpitante problema. Los agricultores salmantinos en la Corte", La Gaceta Regional, no 5, 25 de agosto de 1920, p. 1; "Los labradores y el gobierno", La Gaceta Regional, n 7, 27 de agosto de 1920, p. 12.

16 "El conflicto del abastecimiento de trigos y harina sigue en pie", La Gaceta Regional, no 9, 20 de agosto de 1920, p. 5; "¿Subirá el pan o careceremos de él? La sesión municipal de anoche en cuanto al problema de los trigos y harinas. Hoy, en el Gobierno. Se reanuda la sesión", La Gaceta Regional, no 10 , 31 de agosto de 1920, p. 6; "Otra solución provisional: tenemos harina hasta el domingo", La Gaceta Regional, $\mathrm{n}^{\circ} 11,1$ de septiembre de 1920, pp. 10-11.

17 “ ¿Un paso más?”, La Gaceta Regional, n 12, 2 de septiembre de 1920, p. 1; "Disposiciones oficiales”, La Gaceta Regional, $\mathrm{n}^{\circ}$ 12, 2 de septiembre de 1920, p. 11.

18 "Asamblea fructífera. Los señores Sevillano, Veloz y Capdevila solucionan el problema del pan por unos días", La Gaceta Regional, no 19, 10 de septiembre de 1920, p. 7; "Una charla con el alcalde", La Gaceta Regional, $\mathrm{n}^{\circ}$ 20, 11 de septiembre de 1920, p. 4; "Última hora. La asamblea agraria", La Gaceta Regional, $\mathrm{n}^{\circ}$ 20, 11 de septiembre de 1920, p. 8; "Notas municipales", La Gaceta Regional, n 23, 15 de septiembre de 1920, p. 1; "El problema de abastecimientos en Salamanca", La Gaceta Regional, n 36, 30 de septiembre de 1920, p. 1.
} 
con la fijación de dos precios diferenciados para el pan, en octubre de $1920^{19}$. El abastecimiento quedó así garantizado hasta agosto del año siguiente.

En el terreno político, la inestabilidad consistorial contrastó, durante todo este periodo, con la permanencia de un único hombre como representante ante las Cortes: Martín Veloz ${ }^{20}$. Don Diego logró su acta como diputado, por primera vez, en junio de 1919 y la renovó al finalizar $1920^{21}$. Sin duda, su victoria estuvo estrechamente relacionada, en el ámbito provincial, con su liderazgo sobre la Liga; y, en el territorio capitalino, con su activismo a la hora de procurar un aumento de la guarnición salmantina y al gestionar, también, una subvención de 100.000 pesetas para costear las obras de pavimentación de la Plaza Mayor ${ }^{22}$.

En efecto, a comienzos de 1921, el ambiente político y social salmantino estaba dominado por la impaciencia ante ese inminente inicio de las obras para la construcción de unos nuevos cuarteles y, sobre todo, por las huelgas recurrentes de los obreros sindicados y empleados en la pavimentación de la Plaza Mayor ${ }^{23}$. Ocupaba la alcaldía,

19 "El problema de subsistencias. Abastecimiento de trigos", La Gaceta Regional, n” 55, 22 de octubre de 1920, p. 1. El acuerdo se logró el mismo día, 22 de octubre de 1920, en que estalló una violenta protesta femenina ante la carestía de la vida: "Los sucesos de esta mañana”, La Gaceta Regional, no 55, 22 de octubre de 1920, p. 2

${ }^{20}$ Para un acercamiento a este personaje, véase INFANTE MIGUEL-MOTTA, Javier: "Diego Martín Veloz (1875-1938) Historia de un golpista”, Alcores. Revista de Historia Contemporánea, $\mathrm{n}^{\circ}$ 2, León, 2006, pp. 179-209 (asimismo, puede hallarse un trabajo sobre Veloz de este mismo autor en ROBLEDO, Ricardo (Ed.): Esta salvaje pesadilla. Salamanca en la Guerra Civil española. Madrid: Crítica, 2007, pp. 263-279). También resulta muy interesante el manuscrito, redactado en 1955, de MARTÍN ESTEBAN, Alejandro: Memorias y recuerdos. Se puede encontrar en la Biblioteca Universitaria de Salamanca.

21 "Las elecciones de ayer. El resultado de la lucha electoral en Salamanca", El Adelanto, no 10.735, 2 de junio de 1919, p. 2; "Las elecciones de diputados en la capital y en la provincia", El Adelanto, n 11.211, 20 de diciembre de 1919, p. 2.

22 "La sesión de anoche", El Adelanto, no 11.200, 7 de diciembre de 1920, p. 4; "La ciudad. Huelga de la plaza", La Gaceta Regional, no 107, 29 de diciembre de 1920, p. 3.

23 “¿Hacia una solución?”, El Adelanto, no 11.361, 15 de junio de 1921, p. 3; “Los obreros de la Plaza Mayor", El Adelanto, no 11.410, 11 de agosto de 1921, p. 1; "La huelga de la Plaza", La Gaceta Regional, no 114, 8 de enero de 1921, p. 8; "Jhean": "La huelga de la Plaza", La Gaceta Regional, no 135, 2 de febrero de 1921, p. 8; “Criterio singular", La Gaceta Regional, no 204, 27 de abril de 1921, pp. 1-2; "Las obras de la Plaza", La Gaceta Regional, no 245, 16 de junio de 1921, p. 3; "Frente a un próximo conflicto", La Gaceta Regional, n 249, 21 de junio de 1921, p. 1; "García de Roldán” (Andrés Marcos Escribano): "Las obras de la Plaza", La Gaceta Regional, no 250, 22 de junio de 1921, p. 3; "El lock-out patronal", La Gaceta Regional, no 270, 16 de julio de 1921, p. 4; "El sindicato del ramo de construcción y las obras de la Plaza", El Pueblo, n 19, 20 de junio de 1921, p. 4. Esta publicación entendió la persistente contratación de obreros libres por parte de la Patronal como una manifestación de su servilismo hacia Martín Veloz, canalizador de la subvención y empeñado en desquitarse con los sindicados por los ataques que recibía en las páginas del periódico obrero. De hecho, en febrero de 1921, el diputado llegó al extremo de irrumpir en una sesión municipal y agredir a los concejales socialistas Lucas y Santa Cecilia por juzgarlos como promotores de los ataques de El Pueblo. El ataque queda reflejado en la sesión del 2 de marzo. Consúltese Actas de las Sesiones Municipales. Archivo Histórico Municipal, vol. 1920-1921, fol. 465-472.

Véase igualmente: "Un escrito del alcalde acerca de los sucesos del lunes y del martes", El Adelanto, no 11.273, 3 de marzo de 1921, pp. 1-2; "Rasgos del día", La Gaceta Regional, no 160, 3 de marzo de 1921, p. 1; y “Después de la agresión”, El Pueblo, no 15, 9 de abril de 1921, p. 1. 
desde octubre de 1920, José María Viñuela, un conocido comerciante de filiación política conservadora ${ }^{24}$, cada vez más impotente ante el creciente empuje obrero. Su desafío mayor, sin embargo, era el ya conocido asunto de las aguas.

En vísperas del Desastre africano, las obras permanecían inconclusas y las quejas del vecindario eran continuas. Era en este ambiente en el que El Adelanto invitaba a sus lectores a dejar de lado su apatía y a luchar unidos para lograr un buen suministro de agua. Naturalmente, el periódico se mostraba entusiasta al oír hablar de "grandes reformas, de estupendas parcelaciones, de construcciones de edificios, de municipalización del alumbrado eléctrico, de reversión de las aguas, de la alineación y pavimentación de las principales calles de la ciudad", pero veía como inexcusable el previo saneamiento de la hacienda municipal mediante la unificación de la deuda y la obtención de un empréstito ${ }^{25}$.

La Gaceta, por su parte, recogía un informe de la Junta Provincial de Sanidad que relacionaba la contaminación de las aguas del Tormes con la excesiva incidencia de algunas enfermedades entre la población salmantina e incitaba al Ayuntamiento a tomar cartas en el asunto. Según cifras de 1917, en Salamanca nacían por cada mil habitantes 30,6 y fallecían 33,1, cifra únicamente superada por Sevilla y León ${ }^{26}$. Abundando en la materia, el mismo periódico denunciaba:

"Hace ya casi un mes que por los caños de las casas sale una agua rojiza y terrosa que no sirve ni para limpiar la ropa de suciedades, ni para el aseo personal, ni menos para beber. Las fuentes públicas escasean de tal modo que han de formarse colas junto al caño que arroja agua potable. Y para colmo de escasez, ni funcionan siquiera las fuentes ordinarias que antes daban sus aguas para el abasto vecinal. Es decir, que Salamanca, con tanto vecindario y tanta importancia nacional, está a punto de tasar la bebida, o exponerse a beber líquido que puede servir para barrizales, pero no para los estómagos ${ }^{, 27}$.

A finales de junio, el día 26, y bajo la iniciativa de la Cámara de Comercio se convocó una gran asamblea ciudadana a modo de gesto de protesta. Se presentó en la aludida reunión, como posibilidad inicial de actuación, la concesión de una nueva prórroga a la Sociedad, y como solución extrema, la rescisión del contrato. Si bien se optó por intentar acercar posturas con la Compañía, los vecinos abonados al servicio de

\footnotetext{
24 "La dimisión del alcalde. El concejo se la acepta", El Adelanto, n 11.170, 21 de octubre de 1920, p. 3; "La elección del alcalde. El señor Viñuela, por unanimidad", La Gaceta Regional, n' 55, 22 de octubre de 1920 , p. 5.

25 “Agua turbia para rato...", El Adelanto, no 11.364, 18 de junio de 1921, p. 1; y "El primer problema municipal a resolver", El Adelanto, no 11.366, 21 de junio de 1921, p. 1.

${ }^{26}$ Manuel H. Muriel: "Salamanca y la higiene", La Gaceta Regional, no 241, 11 de junio de 1921, p. 1.

27 "Las aguas turbias", La Gaceta Regional, no 234, 3 de junio de 1921, p. 1.
} 
aguas amenazaron, por primera vez, con dejar de pagar sus facturas mientras no se terminase con la construcción de los filtros ${ }^{28}$.

El conflicto planteado entre el Ayuntamiento y la Sociedad de Aguas adquirió desde este momento una creciente gravedad y originó insospechadas tensiones sociales. A partir del 18 de julio, la Sociedad Franco-Española decidió interrumpir el suministro de agua para alguno de sus abonados ${ }^{29}$. Esta conducta, junto con la advertencia por parte de la empresa de iniciar una demanda por un delito de responsabilidad civil en caso de procederse a la incautación del servicio de aguas, fueron las detonantes inmediatas de la dimisión de Viñuela ${ }^{30}$.

En muy corto espacio de tiempo, entre julio de 1921 y mayo de 1922, por el Consistorio desfilaron tres hombres, a cada cual más inoperante ante el problema higiénico: Ángel Benito Paradinas, quien apenas ocupó la alcaldía durante un mes; Miguel Santos Baz, un conocido relojero de la capital; y Vicente Junquera.

Destaquemos, únicamente, una decisión trascendental adoptada durante el mandato de Santos Baz. En la sesión municipal celebrada el 15 de marzo de 1922, y que hubo de prolongarse hasta el día siguiente, se aprobó, al fin, la rescisión del contrato mantenido con la Sociedad Franco-Española de Aguas y Saneamientos. Se fijó, además, como fecha para su ejecución el día 24 de $\operatorname{marzo}^{31}$. Y es que un día antes de la sesión mentada, la empresa había interrumpido, otra vez, el suministro de agua para alguno de sus abonados, que se habían negado al pago de sus recibos ${ }^{32}$.

Desde comienzos de 1922, se habían estudiado y debatido infructuosamente varias fórmulas de arreglo. Por ejemplo, en una reunión del día 25 de enero entre varios concejales y el representante de la Compañía, el señor Gómez Rodríguez, éste había sugerido como remedio dar por terminados todos los pleitos y lograr una definitiva reversión del servicio de aguas mediante el pago por parte del Ayuntamiento de

\footnotetext{
28 "La protesta del vecindario contra el actual servicio de aguas", El Adelanto, no 11.371, 27 de junio de 1921, p. 1; "No ha estado mal, pero...", La Gaceta Regional, no 254, 27 de junio, 1921, p. 1; y "La cuestión del agua", La Gaceta Regional, no 254, 27 de junio de 1921, p. 3.

29 “¿La Sociedad de Aguas ejerce represalias?”, El Adelanto, no 11.390, 19 de julio de 1921, p. 1.

30 “... Y en esta situación, dimite el alcalde", El Adelanto, n ${ }^{\circ} 11.340,20$ de julio de 1921, p. 3; "El alcalde dimite", La Gaceta Regional, n 273, 20 de julio de 1921, p. 3.

${ }^{31}$ Actas de las Sesiones Municipales. Archivo Histórico Municipal, vol. 1921-1922, fol. 430-441; "El Ayuntamiento acuerda rescindir el contrato con la Sociedad de Aguas", El Adelanto, n ${ }^{\circ}$ 11.597, 17 de marzo de 1922, p. 1.

32 "La cuestión de las aguas", La Gaceta Regional, n 472, 14 de marzo de 1922, p. 1.
} 
1.300.000 pesetas a la Sociedad. Pero la mayoría de los concejales, al final, se negaron a aceptar una cifra que rebasase el millón de pesetas $^{33}$.

El día previo a la fecha marcada para la ejecución de la rescisión, 23 de marzo de 1922, la Sociedad envió una carta certificada a cada uno de los concejales, advirtiéndoles sobre el peligro de incurrir en un delito de responsabilidad civil del funcionariado público. Pero aún con todo, el alcalde, varios concejales y el notario municipal, el señor Santiago de la Nogal, se presentaron en la sede de la Sociedad de Aguas, en la calle doctor Riesco. Entonces el notario leyó un escrito de requerimiento pero el señor Carnicero, que allí se encontraba como administrador local de la Compañía, se negó a colaborar. Llegados a este punto, los munícipes se trasladaron sin más al Ayuntamiento y se reunieron con el abogado municipal para discutir acerca del posible recurso a métodos violentos para hacer efectiva la incautación ${ }^{34}$. Se imponía, por tanto, un cambio de estrategia.

Según el criterio del letrado, el empleo de métodos radicales estaba justificado porque el Ayuntamiento no pretendía allanar un domicilio particular, sino que se trataba del domicilio de una empresa a la que se había delegado un servicio municipal. A última hora, el alcalde, señor Santos Baz, se negó a seguir este tipo de actuaciones ${ }^{35}$. Su inhibición le costó el cargo.

El 1 de abril tomó posesión de la alcaldía un viejo conocido, Vicente Junquera, figura particularmente antipática para los obreros por su actuación durante el trágico verano de $1917^{36}$. Mientras que la mayor parte de la prensa local esperaba una solución inmediata y radical ante el pleito de las aguas, las primeras gestiones del nuevo alcalde tuvieron un carácter bastante conciliador ${ }^{37}$.

La Sociedad de Aguas reclamaba el pago de la deuda de muchos de sus abonados y amenazaba con demandarlos. Así que Junquera se comprometió a que los abonados pagasen todos sus recibos atrasados, con la salvedad de los correspondientes a los dos últimos meses de verano porque el agua suministrada en aquellas semanas no

\footnotetext{
${ }^{33}$ Actas de las Sesiones Municipales. Archivo Histórico Municipal, vol. 1921-1922, fol. 450-461; "El Ayuntamiento y la Sociedad de Aguas", El Adelanto, no 11.604, 25 de marzo de 1922, p. 2.

34 "La Sociedad de Aguas se niega a entregar el servicio al Ayuntamiento", La Gaceta Regional, n 481, 24 de marzo de 1922, p. 1.

35 "Los concejales, el gobernador, el alcalde y la Sociedad de Aguas, El Adelanto, n' 11.608, 30 de marzo de 1922, pp. 1-2; y “Un dictamen”, La Gaceta Regional, no 487, 31 de marzo de 1922, p. 4.

${ }^{36}$ Actas de las Sesiones Municipales. Archivo Histórico Municipal, vol. 1922-1923, fol. 2 (r).

${ }^{37}$ Actas de las Sesiones Municipales. Archivo Histórico Municipal, vol. 1922-1923, fol. 35 (v). En la sesión municipal celebrada el 10 de abril quedó claro su rechazo hacia una posible rescisión del contrato con la Sociedad.
} 
reunía ni siquiera unas mínimas condiciones de potabilidad. Sólo así la Compañía accedería a reanudar las obras ${ }^{38}$.

Sin embargo, este proceder municipal tuvo dos consecuencias de importancia: por un lado, las peticiones de la Sociedad de Aguas se dispararon. Ésta exigió al Ayuntamiento la adquisición de unos terrenos en la Aldehuela para efectuar nuevas catas; pretendió abiertamente reemplazar los proyectados filtros por unos pozos de captación o galerías filtrantes; demandó que los exámenes técnicos del terreno fuesen aprobados conjuntamente por un ingeniero municipal y por otro al servicio de la Sociedad; y previno que si dichos trabajos de exploración no daban los resultados esperados, los gastos serían abonados a partes iguales por el Ayuntamiento y la Sociedad $^{39}$.

Además un vecindario harto, en absoluto amodorrado, mostró abiertamente su discrepancia con la autoridad. Después de conocerse las nuevas exigencias de la empresa, el 9 de abril se reunieron en el Liceo los abonados para debatir sobre las nuevas medidas a adoptar. La asamblea se convirtió, según la opinión unánime de todos los rotativos, en un magnífico ejemplo de inconformismo ciudadano. El Adelanto calificó esta reunión como "acto grandioso, de los más brillantes, de los más transcendentes que registra la historia local ${ }^{\circ 0}$. La Gaceta afirmó a propósito de la misma y su significado: "Despreciada, oprimida, tiranizada, siempre Salamanca ha sido la resignada, la casi inconsciente (...) Para su bien, deseábamos todo su mal (...) pero ayer advertimos que espumaban en la superficie los hervores de la raza",41. En particular, intervenciones como la de Anaya, Mirat e incluso Lamamié de Clairac, a pesar de su complejidad técnica, recibieron infinidad de aplausos. Sin embargo, el desarrollo de la asamblea se vio interrumpido por el abandono de muchos concejales, encabezados por el señor Real, que seguían defendiendo la vía conciliadora para la resolución de este problema.

La Junta de Defensa de los Intereses Ciudadanos, más comúnmente conocida como Acción Ciudadana era una agrupación social que venía defendiendo desde hacía bastante tiempo los intereses de los abonados bajo el amparo de las leyes públicas de

\footnotetext{
38 "En plena actividad", El Adelanto, no 11.614, 6 de abril de 1922, p. 1.

39 "Nuevas proposiciones de la Sociedad", El Adelanto, no 11.615, 7 de abril de 1922, pp. 1-2.

40 "La protesta del vecindario contra el actual servicio de aguas", El Adelanto, no 11.617, 10 de abril de 1922, p. 1.

41 "Salamanca despierta y se cuadra", La Gaceta Regional, no 495, 10 de abril de 1922, p. 1; "La asamblea magna de ayer", La Gaceta Regional, no 495, 10 de abril de 1922, pp. 6-9; e "Interino": "Los abusos de una empresa. Un Ayuntamiento que no cumple con su deber. Y un pueblo que pide cuentas a sus representantes. Asamblea monstruo", El Pueblo, no 37, 15 de abril de 1922, pp. 1-2.
} 
reunión. Aunque no se constituiría oficialmente como asociación hasta 19 de julio de $1922^{42}$, ya en el encuentro del Liceo prometió a Junquera compartir con él todas las responsabilidades civiles y económicas en caso de que pusiera fin a su fallida política de intermediación y optase por la vía de la incautación ${ }^{43}$. Pero el alcalde rechazó este ofrecimiento.

La implacable asociación vecinal, como repuesta, organizó un paro de la industria y el comercio. Desde luego, Junquera, entendiendo rápidamente el mensaje, prefirió dimitir el 27 de abril ${ }^{44}$. Qué duda cabe, con este gesto se evidenciaba que la fuerza de esta renovada forma de asociacionismo salmantino empezaba a resultar incontestable. El sucesor de Junquera, Federico Anaya, un lerrouxista, marcaría con su llegada a la alcaldía el inicio de una nueva y crucial etapa en la historia de Salamanca ${ }^{45}$.

A pesar de algunas reticencias iniciales por parte de La Gaceta Regional, la reacción de los salmantinos fue excelente. Anaya era uno de los miembros más activos de Acción Ciudadana y también uno de los concejales que más tempranamente había apostado por la rescisión del contrato con la Sociedad de Aguas. Así, se había granjeado el apoyo de las clases acomodadas salmantinas. No obstante, para el diario conservador no dejaba de resultar muy extraño que este republicano hubiese conseguido el voto de muchos concejales que hasta hacía poco más de un mes habían sido partidarios de que el ministro de Gobernación designase al alcalde y habían concedido todo su apoyo a Junquera $^{46}$. Por eso el periódico barajó la idea de que Anaya hubiese sido votado mayoritariamente por sus compañeros no para satisfacer una demanda de la opinión pública salmantina, sino con el objeto de hundirlo en un previsible pleito legal con la Sociedad de Aguas ${ }^{47}$.

Incluso, también El Pueblo aprobó este nombramiento. En efecto, aunque Anaya había sido el presidente de la Federación Patronal, el rotativo obrero lo contemplaba como un concejal bastante laborioso, comprometido y dialogante ${ }^{48}$. Y es que en una

\footnotetext{
42 “Al constituirse Acción Ciudadana", El Adelanto, no 11.702, 20 de julio de 1922, p. 1.

43 "El alcalde y el acuerdo de incautación", El Adelanto, no 11.628, 24 de abril de 1922, p. 1.

${ }^{44}$ Actas de las Sesiones Municipales. Archivo Histórico Municipal, vol. 1922-1923, fol. 69 (v); "La dimisión del alcalde", La Gaceta Regional, no 509, 28 de abril de 1922, p. 1; y "El asunto de las aguas", La Gaceta Regional, $\mathrm{n}^{\circ}$ 510, 29 de abril de 1922, p. 1.

${ }^{45}$ Actas de las Sesiones Municipales. Archivo Histórico Municipal, vol. 1922-1923, fol. 75 (v). La investidura del nuevo alcalde tuvo lugar el 29 de abril de 1922.

46 "M. J." (Juan Mirat): "El nombramiento del nuevo alcalde", La Gaceta Regional, no 512, 3 de mayo de 1922, p. 1.

47 “Cuestión del día”, La Gaceta Regional, n 516, 8 de mayo de 1922, p. 1.

48 "Uno": "Gratitud a los que cumplen bien", El Pueblo, no 44, 12 de agosto de 1922, p. 1.
} 
ciudad pequeña, como Salamanca, los personalismos eran determinantes en el juego político.

Al fin, el 4 de mayo de 1922, a las tres de la tarde, se procedió a la irreversible incautación del servicio de aguas. Para ello, fue necesario que el nuevo alcalde y sus acompañantes forzasen las puertas de los depósitos debido a que el señor Carnicero, al igual que en la anterior intentona, no se mostró nada colaborador. Y la misma actuación se repitió en la sala de máquinas ${ }^{49}$.

La euforia de El Adelanto, después de sus incontables campañas para vencer la apatía de los salmantinos, para derrotar al fantasma de la insalubridad y la muerte, se desbordó. Llegó a calificar este acto como "el más interesante de la historia municipal salmantina". Y, como demostración de esa atmósfera entusiasta, días después de la apropiación, los abonados se reunieron para acordar el modo de pago de los recibos atrasados y también para preparar un acto de homenaje hacia don Federico ${ }^{50}$.

Sin embargo, el gobernador civil lo prohibió. El Consistorio se hallaba profundamente dividido, el suministro de agua limpia tardaría en ser viable, y la Sociedad de Aguas había interpuesto una denuncia contra Anaya y otra contra Juan Mirat. El motivo: éste había publicado en La Gaceta varios artículos en defensa de las gestiones de Acción Ciudadana. De modo fulminante, su Junta, por segunda vez, anunció un cierre del comercio y una paralización de la industria y los trabajos para el 17 de mayo. Además, procedió a la elaboración de un listado de firmas de adhesión con el propósito de hacérselas llegar al alcalde ${ }^{51}$.

En estas circunstancias, con un gobernador amedrentado, el día fijado y en un ambiente de cordialidad, a juzgar por las palabras de El Adelanto, se celebró el previsto acto conmemorativo. Pero la Sociedad de Aguas respondió con una nueva denuncia, en esta ocasión contra Acción Ciudadana. Su junta ejecutiva se defendió alegando que ella había aceptado la prohibición gubernamental y que fue la ciudadanía quien de modo espontáneo se manifestó en la Plaza Mayor. En lo tocante al paro laboral, Acción

\footnotetext{
49 "El señor Anaya se incautó ayer del servicio de aguas y saneamiento", El Adelanto, no 11.637, 5 de mayo de 1922, p. 2; "El Ayuntamiento se ha incautado de los depósitos de agua", La Gaceta Regional, $\mathrm{n}^{\circ}$ 513, 4 de mayo de 1922, p. 4.

50 "Los abonados al servicio de aguas acuerdan pagar los recibos de consumo", El Adelanto, n' 11.641, 10 de mayo de 1922, p. 4; "Banquete en honor del señor Anaya", La Gaceta Regional, n 525, 16 de mayo de 1922, p. 4.

51 "El homenaje de Salamanca a su alcalde", El Adelanto, no 11. 647, 17 de mayo de 1922, p. 1; "La ciudad suspende su vida de trabajo para testimoniar al alcalde su adhesión”, El Adelanto, no 11. 648, 18 de mayo de 1922, p. 1: “¿A dónde se quiere ir?”, El Adelanto, n 11.649, 19 de mayo de 1922, p. 1; “J. E.": "Lo de la Junta de Acción Ciudadana", La Gaceta Regional, no 526, 19 de mayo de 1922, p. 1; "M. J": “De Actualidad”, La Gaceta Regional, no 527, 20 de mayo de 1922, p. 1.
} 
Ciudadana argumentó que era un derecho constitucional ${ }^{52}$. De modo un tanto hipócrita eludió reconocer que la manifestación y el paro fueron inspirados por ella.

El enfrentamiento con el gobernador civil no había concluido. Una vez que se había llevado a la práctica el acuerdo de incautación, correspondía al Ayuntamiento la terminación de las obras. Así que una de las primeras gestiones inspirada por Anaya fue la adquisición de maquinaria para poder explorar los terrenos de la Aldehuela ${ }^{53}$. Desde comienzos de julio, no obstante, se convirtió en tema estrella de todas las tertulias una resolución gubernativa contra el acuerdo municipal de incautación del servicio de aguas por la supuesta ilegalidad de la sesión municipal del 16 de marzo ${ }^{54}$. La intención del gobernador, el señor Longoria, era devolver este servicio a la Sociedad. Aunque, al final, la justicia no le acompañó ${ }^{55}$.

Otra embestida del gobernador civil contra el Ayuntamiento se produjo cuando aquél dictó una resolución de rechazo al nuevo proyecto de presupuesto extraordinario, confeccionado para atender los pagos e ingresos generados por el servicio de aguas ${ }^{56}$. Y un tercer ataque tuvo lugar, ahora contra Acción Ciudadana, cuando el gobernador prohibió la celebración de un mitin de carácter informativo en la Plaza de Toros, convocado para el 16 de julio ${ }^{57}$. Su popularidad estaba cayendo en picado y a comienzos de septiembre se marchó de modo repentino a Madrid, mientras la prensa daba por sentado que no regresaría ${ }^{58}$.

Entretanto, aunque aún no era posible el suministro de agua potable y todavía estaba pendiente en los tribunales la querella de la Sociedad de Aguas contra Anaya,

\footnotetext{
52 "M. J.": "De actualidad", La Gaceta Regional, n 535, 31 de mayo de 1922, p. 1.

${ }^{53}$ SENABRE LÓPEZ, David, Op. Cit., pp. 62-63. Las obras para la obtención de agua filtrada de la Aldehuela hubieron de abandonarse por dificultades en su realización general, pero cuando el señor Mediero, el propietario, ofreció la finca de modo gratuito, se retomó el proyecto. Las galerías filtrantes eran dos cámaras rectangulares de hormigón armado. Sobre ellas se colocó una fina capa de arena que hacía de filtro natural. Con esta instalación se aseguraba la obtención de 3.000 metros cúbicos de agua diaria.

54 "En torno al problema de las aguas", El Adelanto, n $\mathrm{n}^{\circ} 11.689,3$ de julio de 1922, p. 2; "Alumbrando una resolución gubernativa", La Gaceta Regional, no 563, 5 de julio de 1922, p. 1; y "Nuestro archivo", La Gaceta Regional, n 569, 12 de julio de 1922, pp. 3-4. Según José García Revillo, presidente de Acción Ciudadana, el Ayuntamiento no celebró dos sesiones distintas en los días 15 y 16 de marzo. La segunda sesión fue subsidiaria de la ordinaria y no tuvo carácter extraordinario ni se celebró fuera del Consistorio (Ley municipal de 1976. Artículos 57 y 103 sobre la ilegalidad de las sesiones concejiles). Véase: José García Revillo: "Examen y comentarios", La Gaceta Regional, n 569, 12 de julio de 1922, p. 3.

55 "La sesión de anoche", La Gaceta Regional, n 564, 6 de julio de 1922, p. 1; y "La sesión de anoche en el Ayuntamiento", El Adelanto, $\mathrm{n}^{\circ}$ 11.690, 6 de julio de 1922, p. 2; "Alrededor de un acuerdo municipal", El Adelanto, $\mathrm{n}^{\circ} 11.694,11$ de julio de 1922, p. 1.

56 "Lo del presupuesto extraordinario del servicio de aguas", El Adelanto, no 11.694, 11 de julio de 1922, p. 2.

57 "El gobernador prohibió la celebración de un mitin ciudadano", El Adelanto, nº 11.699, 17 de julio de 1922, p. 1.

58 "El gobernador se ha marchado", La Gaceta Regional, n 614, 5 de septiembre de 1992, p. 1.
} 
éste aprovechó las célebres ferias de septiembre para garantizarse el apoyo del vecindario con la inauguración de varias obras hasta entonces ejecutadas para mejorar el suministro de agua. Sobre todo, se celebró que se había desenterrado un kilómetro de tubería de la antigua red de canalización y se había recolocado como nueva cañería de impulsión ${ }^{59}$. En efecto, el gobernador Longoria fue reemplazado por Agustín Van Bauberghen ${ }^{60}$. En suma, tras la caída de Junquera, éste constituyó el segundo gran golpe de efecto de Acción Ciudadana.

El nuevo gobernador dedicó muchos esfuerzos a acondicionar Salamanca para la primera visita regia que tenía lugar desde 1904. Van Bauberghen supo apreciar con sagacidad las posibilidades de promoción que para Salamanca significaban los festejos con motivo del centenario de la canonización de Santa Teresa y su investidura como doctora honoris causa. Además, los días 6, 7 y 8 de octubre toda la prensa local dedicó la mayor parte de su espacio al relato pormenorizado de la estancia real: la visita a la catedral, a la Universidad, al Ayuntamiento, la corrida regia, la colocación de la primera piedra del cuartel de caballería, la procesión de Santa Teresa, las visitas al asilo de la Vega y a la Exposición Agrícola y Ganadera, la función del Bretón, el viaje a Alba de Tormes...

Tanto en El Adelanto como en las páginas de La Gaceta Regional fue constante el afán por presentar a Alfonso XIII como un personaje muy cercano a su pueblo y también se convirtió en un tópico ensalzar la generosidad y patriotismo demostrado por los salmantinos. Ambos diarios, por descontado, acompañaron con numerosas fotografías todos sus comentarios ${ }^{61}$. Por su parte, El Pueblo, a comienzos de septiembre, había expresado sus temores ante el excesivo coste económico que la visita regia significaría $^{62}$. Días después de la misma, aunque también el rotativo obrero insistía en el entusiasmo demostrado por la ciudadanía, hacía un balance bastante negativo del significado de estas fiestas:

“Aquí no hay dinero más que para cosas de relumbrón. Al marchar don Alfonso de Salamanca, tal vez lleve la impresión de que Salamanca está bien atendida y que no necesita de nada. Y eso no es así. Debe saber la verdad. Necesitamos de todo y que a

\footnotetext{
59 "El abastecimiento de agua a la ciudad está asegurado", El Adelanto, no 11.745, 10 de septiembre de 1922 , p. 1.

60 "Un telegrama del nuevo gobernador de Salamanca", La Gaceta Regional, n 624, 16 de septiembre de 1922, p. 1 .

${ }^{61}$ Los números de El Adelanto y La Gaceta Regional correspondientes a los días 6, 7, 8 y 9 de octubre se dedican de modo casi monográfico a estos festejos.

62 “Lo que procede hacer", El Pueblo, no 45, 2 de septiembre de 1922, p. 1.
} 
Salamanca se la escuche, se la oiga y no se la tenga en el más completo olvido, principalmente por los gobiernos, ${ }^{, 63}$.

Asimismo, Van Bauberghen también se volcó en el asunto de las aguas. Su intención consistía en negociar con la Compañía sin que sus gestiones fuesen conocidas por la prensa, a sabiendas de que ésta era la condición fijada por la odiada Sociedad. Pero casi todas sus actuaciones salieron a la luz debido a las indiscreciones del rotativo dirigido por Martín Veloz, La voz de Castilla ${ }^{64}$. Aún así, el nuevo gobernador fue un formidable mediador entre el Ayuntamiento y la Sociedad y a él correspondió en gran medida la anhelada solución del pleito de las aguas.

No obstante, su mandato fue muy breve y cuando se publicó la fórmula de arreglo definitivo, ya había abandonado el cargo. En cualquier caso, se ocupó de gestionar que ambas instituciones presentasen dos fórmulas de arreglo para su posterior discusión y elaboración de una conjunta. El 11 de diciembre se publicó el proyecto de acuerdo entre la alcaldía y la Sociedad Franco-Española de Aguas y Saneamientos. Por fin, se cancelaron oficialmente todas las relaciones contractuales entre ambas instituciones y se dieron también por concluidos todos los pleitos pendientes.

El Ayuntamiento otorgó entonces su visto bueno a las obras de alcantarillado realizadas hasta el momento y se comprometió también a seguir pagando las obligaciones amortizadas, a retornar la fianza a la compañía así como los recibos que se le adeudaban. El Consistorio asumió, de este modo, el servicio de suministro de aguas y, además, la obligación de abonar a la Sociedad 900.000 pesetas en concepto de reversión del servicio; 30.000 pesetas por los materiales acopiados y otras 20.000 pesetas por el producto líquido que se estimaba habría producido la explotación del servicio desde su incautación y hasta el 1 de febrero de 1923. El Ayuntamiento, por último, aceptó abonar estas cantidades en el plazo de nueve meses, y en caso de no poder cumplirlo, las cantidades devengarían el interés del $6 \%$ anual ${ }^{65}$.

Pero el documento legal, sin duda, trasladaba hasta el primer plano de la actualidad el problema municipal de fondo: la falta de solvencia económica. En febrero de 1923 se publicó una relación sumaria del presupuesto municipal para obras de saneamiento y pavimentación. Se barajaba una cifra total de 1.983 .251 pesetas, incluyendo las obras para la terminación de la red de aguas, los filtros y la depuración,

\footnotetext{
63 "No nos engañemos", El Pueblo, no 47, 14 de octubre de 1922, p. 2.

64 “M. J.": "Por una sola vez", El Adelanto, no 11.778, 24 de octubre de 1922, p. 1.

65 "La fórmula para la solución del problema de las aguas", El Adelanto, no 11.820, 12 de de diciembre de 1922, p. 4; "La cuestión de las aguas", La Gaceta Regional, nº 695, 11 de diciembre de 1922, p. 1.
} 
la finalización de la red general de alcantarillado y las obras de desviación de las aguas pluviales. Partiendo de que el presupuesto anual del curso 1923-1924 era de 1.846.345 pesetas, puede suponerse que el desembolso de esta operación era muy gravoso para el municipio. Por esta razón, en julio y por medio de una Moción, se presentó un Proyecto de Empréstito por valor de cinco millones ${ }^{66}$. Los intereses y la amortización de capital se harían consignando en los nuevos presupuestos desde 1924-25, una anualidad de trescientas cincuenta mil pesetas durante veintinueve años.

Anaya pudo así devolver la fianza a la Sociedad de Aguas, en agosto de 1923, y liquidar las obligaciones amortizadas pendiente de pago ${ }^{67}$. Pero en 1927 se haría necesaria la aprobación de unas nuevas Bases Generales y Adicionales para poder financiar el Plan Extraordinario de Mejoras Urbanas. Por primera vez, la Banca Local se hizo cargo entonces de este proyecto ${ }^{68}$. En cuanto al suministro de agua, los colectores aún tardaron en concluirse. En 1928 todavía se trabajaba en el del oeste. En el este, las obras estuvieron condicionadas por la apertura de la Gran Vía y aún continuaban los trabajos en $1935^{69}$.

En 1923, para concluir con este repaso histórico, Veloz perdió su acta de diputado por Salamanca. Desde comienzos de marzo se percibió una creciente agitación ciudadana con motivo de las elecciones de diputados a Cortes, programadas para el 29 de abril. La disputa se centró en torno a Diego Martín Veloz y el industrial Juan Mirat. Aunque éste nunca había pertenecido a ningún partido político, optó por presentarse como el candidato oficial. Ciertamente coincidían sus ideas con algunas de las pretensiones conocidas del gabinete del marqués de Alhucemas, tales como la reforma tributaria, el aumento del gasto público, el fin de la guerra de Marruecos, etc., pero no con su proyecto de modificación de las relaciones entre Iglesia y Estado ${ }^{70}$.

Durante casi dos meses Salamanca conoció sorprendentes niveles de movilización ciudadana, conjugándose de forma armónica viejas y modernas formas de entender la política $^{71}$. Se recurrió a los banquetes-homenajes ${ }^{72}$, a la publicación de

\footnotetext{
${ }^{66}$ Actas de las Sesiones Municipales. Archivo Histórico Municipal, vol. 1923-1924, fol. 165 (r)-171; y 178-184 (v); También en "La iniciación de una nueva era en la vida económica del municipio salmantino", El Adelanto, no 12.014, 27 de julio de 1923, p. 1; y Federico Anaya: "El empréstito municipal de cinco millones de pesetas", La Gaceta Regional, $\mathrm{n}^{\circ} 885,28$ de julio de 1923, p. 2.

67 "El Ayuntamiento y la Sociedad de Aguas", El Adelanto, no 12.029, 14 de agosto de 1923, p. 1.

${ }^{68}$ SENABRE LÓPEZ, David, Op. Cit., p. 66.

${ }^{69}$ DÍEZ ELCUAZ, José Ignacio, Op. Cit., p. 217.

70 "M.J.": "Las elecciones de diputados a Cortes en Salamanca y su provincia", El Adelanto, n 11.932, 22 de abril de 1923, p. 3.

${ }^{71}$ DíEZ CANO, Leopoldo Santiago y CARASA SOTO, Pedro: "Caciques, dinero y favores. La Restauración en Salamanca" en ROBLEDO, R. (Coord.), Op. Cit., pp. 102-103. El poder que hasta el
} 
manifiestos en la prensa local dirigidos a la opinión pública y a las visitas a los pueblos y secciones del distrito de Salamanca. Pero también pervivieron los cruces de acusaciones difamatorias. Por ejemplo, un tal "García de Roldán”, en realidad, pseudónimo de Andrés Marcos Escribano, sugirió que Mirat se había opuesto a la firma de un Real Decreto que autorizaba a los agricultores salmantinos a exportar lentejas ${ }^{73}$. También se acusó al candidato popular desde las páginas de La voz de Castilla de trucar los pesos en varias partidas de sacos de nitrato de sosa ${ }^{74}$. Por último, se censuró al industrial por su supuesta adquisición de acciones de La Gaceta Regional ${ }^{75}$.

Sin embargo, estos esfuerzos resultaron baldíos. La victoria fue para el industrial salmantino, aunque Veloz demostró su sólido arraigo en el medio rural ${ }^{76}$. Y no sólo eso: poco después, éste logró el acta por el distrito de Peñaranda ${ }^{77}$.

El apoyo de Acción Ciudadana, con certeza, constituyó uno de los puntos fuertes de la candidatura de Juan Mirat en estas elecciones legislativas. Como agrupación vecinal, Acción Ciudadana simbolizó probablemente el mejor ejemplo de la inusitada fuerza asociativa que conoció Salamanca en estos años. En realidad, nació de un modo un tanto improvisado, con el objeto de aunar y guiar la conducta de los abonados al servicio de aguas ante los continuos desplantes de la Sociedad suministradora. No obstante, aunque en la prensa local reiteradamente fue presentada como una organización interclasista, la mayoría de sus miembros pertenecían a los grupos

momento había ejercido Veloz, se fundamentaba, según estos autores, en el miedo al cambio y no en un contexto urbano radicalizado. Fue capaz de aunar a los grupos conservadores que contemplaban asustados el derrumbamiento del sistema, pero sus excesos generaron una enorme oposición que se aglutinó en torno a Juan Mirat.

${ }^{72}$ Sirvan como ejemplos la asamblea del Bretón del día 11 de marzo ("La asamblea de ayer en el teatro Bretón”, La Gaceta Regional, no 771, 12 de marzo de 1923, p. 4), también en el mismo emplazamiento la del 12 de abril ("Banquete en honor del señor Mirat", La Gaceta Regional, no 798, 13 de abril de 1923, p. 2) o la asamblea del día 25 ("La lucha en Salamanca y su provincia", El Adelanto, n' 11.935, 26 de abril de 1923, p. 1) o la reunión de agricultores en el Moderno el 18 del mismo mes ("La asamblea agraria de ayer", La Gaceta Regional, no 777, 19 de marzo de 1923, p. 2).

${ }_{73}$ Mirat: "Aclarando conceptos", La Gaceta Regional, no 773, 14 de marzo de 1923, p. 1.

${ }^{74}$ Hijos de Mirat: "Remitido. A los agricultores y a la opinión”, La Gaceta Regional, no 770, 10 de marzo de 1923, p. 1.

${ }^{75}$ Pablo Sánchez Enciso: "La elección por Salamanca", La Gaceta Regional, no 806, 23 de abril de 1923, p. 1. También resultan muy interesantes una serie de editoriales, publicados por estas mismas fechas en $E l$ Pueblo, bajo la firma de "Clarito".

76 "El resultado de las elecciones en Salamanca y su provincia", El Adelanto, no 11.939, 1 de mayo de 1923, p. 2; y "La lucha electoral en Salamanca y su provincia", La Gaceta Regional, n' 812, 30 de abril de 1923 , p. 2.

${ }^{77}$ Clarito: "Con la tralla en alto", El Pueblo, no 55, 24 de febrero de 1923, p. 1; y Francisco Bravo: "Por dignidad", El Pueblo, no 58, 7 de abril de 1923, p. 8. Durante todos los meses preelectorales, la campaña de descrédito de El Pueblo contra Martín Veloz se intensifica. No dudan en calificarlo como "ese bosquimano rechoncho" y "epiléptico analfabeto", sin temor ninguno a volver a enfrentarse judicialmente con él. 
económicamente más pudientes de la capital. Y, finalmente, acabó transformando en un poderoso grupo de presión política, prestando todo su cobijo a Anaya y Mirat.

La inestabilidad del poder concejil evidenciaba, de día en día, el desmoronamiento del sistema: hombres que se sucedían, impotentes ante el pleito de las aguas y también desbordados por la precariedad de la hacienda municipal. El único dispuesto a plantar cara a la Sociedad, Federico Anaya, tan sólo pudo llegar a la presidencia del Consistorio debido a un error de cálculo cometido por sus enemigos políticos. Pese a las gravísimas escisiones que atravesaba el Consistorio, Anaya dispuso siempre de la plena colaboración material y moral de Acción Ciudadana y también de un creciente respeto y admiración social, únicamente cuestionado por el obrerismo coincidiendo con el desarrollo de una larguísima huelga de la construcción durante la primavera de $1923^{78}$. Por esta razón, su mandato, no exento de algunos gestos populistas, fue el más largo de este crítico periodo y también el que más satisfacciones proporcionó a los salmantinos.

No es verdad que Acción Ciudadana tuviese como prioridad desbancar al diputado a Cortes de su escaño, pero sí que con sus gestiones hizo mella en la autoridad del "villano". Entender su caída como el fruto de las presiones de la asociación o como el resultado indeseado de sus propios excesos violentos es una cuestión de punto de vista. Quizás, sencillamente ambos factores se conjugaron.

Uno de los últimos eventos a reseñar en la historia de Salamanca antes del golpe fue la celebración del IX Congreso de Ciencias, a finales de junio. Además de que Alfonso XIII visitó nuevamente la ciudad, éste fue el último "acto de relumbrón”, bajo la alcaldía de Anaya. El 1 de octubre abandonó su cargo ${ }^{79}$.

\footnotetext{
78 "Ante el anuncio de huelga de los obreros disidentes de la Federación. Hay que evitar el conflicto", $E l$ Adelanto, $\mathrm{n}^{\circ}$ 11.922, 11 de abril de 1923, p. 1; "La Patronal del ramo de construcción planteó ayer a los trabajadores un lock-out", El Adelanto, n ${ }^{\circ} 11.945,8$ de mayo de 1923, p. 2; "El Ayuntamiento y el conflicto patronal-obrero", El Adelanto, no 11.997, 7 de julio de 1923, p. 1; “'No se soluciona?”, El Adelanto, $\mathrm{n}^{\circ} 12.001,12$ de julio de 1923, p. 1; "La huelga del ramo de construcción ha quedado definitivamente solucionada", El Adelanto, $\mathrm{n}^{\circ}$ 12.005, 17 de julio de 1923, p. 6; "El conflicto del ramo de construcción", La Gaceta Regional, no 809, 26 de abril de 1923, p. 1; "Los obreros del ramo de construcción acuerdan ir a la huelga indefinida", La Gaceta Regional, no 817, 7 de mayo de 1923, p. 1; "El Ayuntamiento y la huelga del ramo de construcción. Algunas consideraciones", La Gaceta Regional, $\mathrm{n}^{\circ}$ 867, 6 de julio de 1923, p. 1; "El conflicto del ramo de construcción", La Gaceta Regional, n 872, 12 de julio de 1923, p. 1; "El conflicto del ramo de construcción, resuelto", La Gaceta Regional, nº 875, 16 de julio de 1923, p. 2.

${ }^{79}$ Isidro Beato Sala: "El próximo Congreso de Ciencias de Salamanca", El Adelanto, $\mathrm{n}^{\circ}$ 11.927, 17 de abril de 1923, p. 1; y "El Congreso de Ciencias de Salamanca", La Gaceta Regional, n 856, 23 de junio de 1923, p. 1. El Directorio Militar aprobó, el 30 de septiembre de 1923, una Real Orden de disolución de los Ayuntamientos. El Ayuntamiento salmantino fue reemplazado por una Junta Municipal de Asociados, bajo la presidencia de Jacinto Elena Sánchez.
} 


\section{LA GUERRA DE LOS CUARTELES}

Aunque Salamanca albergaba un mal recuerdo del paso de las tropas napoleónicas por la urbe durante el siglo XIX, los vecinos del Tormes identificaban la presencia de destacamentos militares con una señal de progreso. Por esta razón, después de años de reclamaciones e incertidumbre, la asignación del regimiento de La Victoria para el guarnecimiento de la capital había generado un sentimiento desbordante de alegría.

A lo largo de todo 1919, en El Adelanto fueron muy habituales los apremios para procurar el adecuado acuartelamiento de la guarnición ${ }^{80}$. De esta forma se hacía eco el diario progresista de las aspiraciones de las fuerzas mercantiles e industriales de la capital $^{81}$. Por fin, el 27 de octubre de 1919 El Adelanto pudo anunciar que el Ayuntamiento había acordado con la Junta de Colegios la cesión del Palacio de Anaya durante tres meses para el alojamiento transitorio de La Victoria ${ }^{82}$. La escritura de cesión se firmó el 13 de noviembre y una semana después se aprobó la Real Orden que autorizaba el tan ansiado traslado de las tropas ${ }^{83}$.

Sin duda, las conversaciones entre el Consistorio y la institución universitaria no habían sido fluidas. Las voces de protesta de algunos profesores habían tenido mucho que ver en el surgimiento de asperezas. Por ejemplo, tal fue el caso de Miguel de Unamuno, convencido de que el Estado debía mostrar un mayor grado de compromiso económico con la ciudad - de nuevo, el eterno sentimiento de abandono- y de que la Universidad no tenía que prestarse a su juego ${ }^{84}$. La opinión pública salmantina, sin embargo, valoraba muy positivamente la construcción de estos cuarteles, sobre todo, porque su edificación suponía un enorme incentivo laboral para la ciudad. Enardecida por la retórica bullanguera de Diego Martín Veloz, el 2 de noviembre la gente había podido asistir a un mitin informativo en el Teatro Moderno a favor de los cuarteles. Tan efectiva había sido la propaganda del diputado a Cortes que, durante el desarrollo del

\footnotetext{
80 "El problema del acuartelamiento de tropas en Salamanca", El Adelanto, no 10.623, 17 de enero de 1919, pp. 1-2.

81 "El problema de los cuarteles", El Adelanto, no 10.625, 20 de enero de 1919, p. 1

82 "Por buen camino", El Adelanto, no 10.863, 27 de octubre de 1919, p. 1; “·El alojamiento de fuerzas de infantería en el Palacio de Anaya”, El Adelanto, $\mathrm{n}^{\circ} 10.865,29$ de octubre de 1919, p. 1. En marzo y diciembre de 1920, se autorizaron sendas prórrogas en la estancia de las tropas: "El alojamiento de las tropas de La Victoria", El Adelanto, n $\mathrm{n}^{\mathrm{0}}$ 10.989, 23 de marzo de 1920, p. 1; "El batallón de la Victoria permanecerá en el Colegio Viejo", El Adelanto, no 11.213, 22 de diciembre de 1920, p. 2. Por cierto, la gestión de esta última prórroga se la atribuyó, como éxito personal, el vicerrector Esperabé.

83 "La cesión del Palacio de Anaya", El Adelanto, no 10.878, 13 de noviembre de 1913, p. 1; "La entrega de Anaya al ramo de Guerra", El Adelanto, no 10.888, 25 de noviembre de 1919, p. 1.

${ }^{84} \mathrm{Su}$ opinión fue, además, secundada por muchos estudiantes: "El alojamiento provisional de la guarnición de Salamanca", El Adelanto, no 10.868, 1 de noviembre de 1919, p. 1.
} 
acto, incluso, se desataron los improperios de alguno que otro contra Unamuno, incluidas peticiones de ahorcamiento ${ }^{85}$.

Al ministerio de Guerra, por otra parte, acabó cediéndosele una parcela ubicada en la Glorieta, de 62.000 metros cuadrados, y un solar en la antigua Calzada de Toro (hoy Federico Anaya) de 30.000 metros cuadrados. A pesar de que la expropiación de los terrenos fue una operación rápida ${ }^{86}$, las obras del cuartel de infantería no se rematarían hasta 1926 y las del de caballería, hasta 1928. Ambos servirían para perfilar los límites de la urbanización del ensanche de la ciudad ${ }^{87}$.

Pero volviendo al año 1919, con posterioridad al anuncio de traslado del regimiento, la prensa aclaró que se había destinado a Salamanca un batallón completo, el primero, con cuatro compañías, la plana mayor y banda de música ${ }^{88}$. Por descontado, un gran despliegue de patriotismo periodístico tuvo lugar el 4 de diciembre, cuando se

${ }^{85}$ MÁlaGA GUERRERO, Jesús: "Unamuno, concejal", Salamanca. Revista de Estudios, no 41, Salamanca, 1998, pp. 177-194. El autor recoge las posturas de los dos contendientes en el asunto de los cuarteles. Martín Veloz pensaba en las ventajas económicas para la ciudad y en el incremento del número de matrículas universitarias. A decir verdad, su posicionamiento en este asunto era idéntico al sostenido por El Adelanto: "La compra de terrenos", El Adelanto, no 10.644, 11 de febrero de 1919, p. 1; "El problema de la guarnición”, El Adelanto, no 10.859, 18 de octubre de 1919, p. 1. El diario insistía, además, en que Salamanca debía procurar beneficiarse de las excelentes relaciones entre Martín Veloz y el general Tovar. El argumento de Unamuno contra el aumento de la guarnición salmantina era más simple y emotivo: él pagaría la cuota de sus hijos para evitar su alejamiento, pero temía que algún día hubieran de detenerle a él mismo. En suma, no entendía el porqué de esa obsesión con el orden público.

Un año más tarde, Unamuno, indignado porque algunos domicilios de salmantinos habían sido registrados tras el asesinato de Dato, escribía lo siguiente en El Mercantil Valenciano: "Hay aquí un pobre desequilibrado que sufre ataques de exhibicionismo histriónico, y ahora, como consecuencia de ello, de manía persecutoria, y este infeliz logra, no sabemos por qué medios sugestionar o intimidar a las autoridades gubernativos, que, sin la debida sal en la mollera se prestan a satisfacer sus caprichos frenopáticos". La alusión a Martín Veloz y a su obsesión con el orden público eran muy evidentes. Véase Miguel de Unamuno: "Epidemia de demencia", El Mercantil Valenciano, 24 de marzo de 1921.

${ }^{86}$ Lo fue más en el caso de los terrenos de La Glorieta que en el de los ubicados en la Calzada de Toro porque su propietario, Victoriano Recio, aprovechó la ocasión para especular desvergonzadamente: "El problema de los cuarteles", El Adelanto, no 10.630, 25 de enero de 1919, p. 1; "Los terrenos para cuarteles", El Adelanto, n' 10.631, 27 de enero de 1919, p. 1; "La cuestión de los cuarteles y la guarnición de Salamanca", El Adelanto, n 10.638, 4 de febrero de 1919, p. 1. Para la adquisición se precisó, además de un préstamo, una vez más, una suscripción popular: "Salamantinos: Ha llegado el momento de demostrar con hechos la sinceridad de aquellos anhelos de siempre, de poseer una guarnición en armonía con la importancia militar de Salamanca (...) Por amor a la patria, a la ciudad, al Ejército, a vuestros mismos intereses, acudid con entusiasmo a la suscripción". Véase "El obispo ha donado 5.000 pesetas", El Adelanto, no 10.645, 12 de febrero de 1919, p. 1. El coste total de los solares ascendió a 127.000 pesetas: "Lo de los cuarteles", El Adelanto, no 10.834, 23 de septiembre de 1919, p. 1.

${ }^{87}$ SENABRE LÓPEZ, David, Op. Cit., pp. 47-48. Véase también FERNÁNDEZ, Ricardo: Op. Cit., pp. 69-72.

88 "Los preparativos del recibimiento a las fuerzas del Ejército", El Adelanto, n 10.889, 26 de noviembre de 1919, p. 3; "Se destina a Salamanca el batallón completo, con cuatro compañías, plana mayor y banda de música", El Adelanto, no 10.891, 28 de noviembre de 1919, p. 1. También el diario de Núñez Izquierdo reprodujo la alocución del alcalde, Benito Paradinas: "La llegada de las tropas a nuestra ciudad. Patriótica alocución del alcalde al vecindario", El Adelanto, no 10.894, 2 de diciembre de 1919, p. 1. 
reseñó la llegada de los soldados, tantas veces soñada. Así, el diario de Núñez Izquierdo señalaba:

"Revistió la recepción tales caracteres de sublimidad, que todo cuanto aquí dejemos consignado será tan sólo un ligero y poco ajustado reflejo de la realidad viva del emocionante espectáculo de que fuimos testigos todos los salmantinos. Salamanca, ciudad poco dada a los fáciles entusiasmos y a las públicas expresiones de emoción, pero que en el pecho de cada uno de sus hijos guarda amorosamente los más puros sentimientos de amor y de sacrificio por la Patria, abrió ayer sus brazos para recibir en ellos, con todo el fervoroso cariño de españoles, a sus hermanos los soldaditos de España ${ }^{, 89}$.

Primaba, a la vista está, la exaltación del amor patrio y la euforia de un pueblo habitualmente introvertido. Después, el diario abundaba en los detalles sobre la llegada del batallón a la estación, el desfile, la estancia en la catedral y su alojamiento en Anaya.

A mediados de enero de 1921, coincidiendo con la terminación de otras obras para el acuartelamiento provisional de las tropas en el Trilingüe ${ }^{90}$, el ministerio de Guerra también autorizaría por Real Orden el traslado completo del segundo batallón del regimiento de La Victoria, que se encontraba entonces en La Granja ${ }^{91}$. Por consiguiente, otra vez se preparó un gran homenaje a las tropas llamadas a completar la guarnición de Salamanca.

Desde su nacimiento, el nuevo diario conservador, La Gaceta, consciente de que la prorrogada estancia de las tropas en Anaya sólo constituía un remedio parcial ${ }^{92}$, también se implicó con el asunto del engrandecimiento de la guarnición salmantina y el acondicionamiento de los cuarteles ${ }^{93}$. Así que ya el día 29 de enero de 1921, se apresuró

\footnotetext{
89 "Nuestra guarnición ha llegado. El pueblo de Salamanca tributa un entusiasta recibimiento a las fuerzas del regimiento de La Victoria, $\mathrm{n}^{\circ}$ 76. Detalles de los grandiosos homenajes de ayer", El Adelanto, $\mathrm{n}^{\circ}$ 10.896, 4 de diciembre de 1919, p. 1.

${ }^{90} \mathrm{El}$ retejado había sido financiado desde el ministerio de Guerra, con un crédito de 90.000 pesetas: 1675 .

91 "Real Orden", El Adelanto, no 11.234, 15 de enero de 1921, p. 2.

92 "La cuestión del Colegio de San Bartolomé", La Gaceta Regional, no 99, 18 de diciembre de 1920, p. 2; "La ciudad. Comisión de Cuarteles", La Gaceta Regional, no 107, 29 de diciembre de 1920, p. 3. La propiedad del edificio era una cuestión muy discutida entre Instrucción y Hacienda.

${ }_{93}$ La Gaceta lamentó mucho, a partir de octubre de 1920, que la Universidad de Salamanca no se pudiese beneficiar de una subvención del ministerio de Instrucción por hallarse Anaya ocupada por las tropas. Para ella, urgía su traslado al cuartel de Sancti-Spiritus. Véase "La sesión de anoche. Lo del Colegio de Anaya", La Gaceta Regional, no 48, 14 de octubre de 1920, p. 3; "La Universidad de Salamanca, postergada", La Gaceta Regional, $\mathrm{n}^{\circ}$ 49, 15 de octubre de 1920, p. 1; "La residencia salmantina de estudiantes", La Gaceta Regional, no 51, 18 de octubre de 1920, p. 2; "Z. y X.": "Acotaciones. La cuestión del Colegio de Anaya", La Gaceta Regional, no 85, 1 de diciembre de 1920, p. 2; "Comisión de cuarteles", La Gaceta Regional, no 94, 13 de diciembre de 1920, p. 11. Algo menos se resintió El Adelanto: "La Universidad y la guarnición", El Adelanto, no 11.167, 18 de octubre de 1920, p. 2; "La cuestión de los cuarteles", El Adelanto, no 11.181, 17 de noviembre de 1920, p. 1.
} 
para dar cuenta exhaustiva de todo el programa de festejos previsto ${ }^{94}$. Y al día siguiente, publicó el manifiesto de la comisión de cuarteles a los salmantinos:

"Salmantinos: Hace poco más de un año entró en Salamanca el primer batallón del regimiento de La Victoria y esta española tierra dio rienda suelta a la expresión de sus amores patrios y recibió al Ejército español con manifestaciones de concurrencia y entusiasmo como nunca presenció la ciudad. Y es que nada apasionará jamás a este viejo solar hispano, como el culto a los defensores de la patria. Por algo es terruño de uno de los más heroicos episodios nacionales. La comisión de Cuarteles desde aquella agradable fecha, no ha descansado en sus trabajos hasta ver reunido en esta ciudad al regimiento de La Victoria. Y con su diputado a la cabeza (...) ha luchado sin desmayo, venciendo resistencias y oposiciones hasta conseguir este segundo gran día de su españolismo, el de la llegada a Salamanca de todo el regimiento de La Victoria (...) La Comisión de cuarteles (...) ¡Viva España! ¡Viva el Ejército español! ¡Viva Salamanca!' ${ }^{95}$.

Desde el seno de la Junta municipal de Cuarteles, la comisión se ocuparía de preparar un rancho para los soldados costeado por esa suscripción pública, también un banquete popular en el Liceo $^{96} \mathrm{e}$, incluso, gestionaron un permiso para que el tren de la línea Medina-Salamanca llegase a esta capital el día 6 de febrero a las cuatro de la tarde, procurando así que toda la ciudad pudiera presenciar el desfile.

Pocos días antes de la venida de las tropas, la Junta municipal de cuarteles hizo entrega del reformado cuartel de la Cárcel al teniente coronel del regimiento y rogó la asistencia de los salmantinos a una velada teatral en el Bretón, con el objeto igualmente de sufragar los variados actos de homenaje ${ }^{97}$. Los diarios dedicaron un notable espacio a la publicación de los donativos en comida para el rancho y ayudas en metálico ${ }^{98}$. Pareció desatarse una competición entre las clases acomodadas para que figurasen sus nombres entre las páginas de los periódicos. Sin embargo, no dejaba de resultar chocante que también la prensa denunciase la actitud de algunos propietarios inmobiliarios, que aprovechaban el momento para elevar el precio de los alquileres ${ }^{99}$. Particularmente eufóricos se mostraron los redactores de La Gaceta. Un día antes de la llegada de los jóvenes, el entusiasmo ya era ilimitado:

“;Mañana llegan nuestros soldados! Nuestros, por haber sido creado el regimiento de La Victoria para nosotros, para Salamanca. Nuestros, porque el soldado es parte del

\footnotetext{
94 "La llegada de las tropas. Homenajes que se preparan", La Gaceta Regional, n 132, 29 de enero de 1921 , p. 1.

95 "Preparativos para recibir a las tropas", La Gaceta Regional, no 134, 1 de febrero de 1921, p. 6; "El primer batallón de La Victoria", El Adelanto, no 11.248, 1 de febrero de 1921, p. 1.

96 "Esperando la guarnición", El Adelanto, no 11.250, 3 de febrero de 1921, p. 5; "La llegada de las tropas", El Adelanto, no 11.251, 4 de febrero de 1921, p. 1.

97 "La velada en honor del nuevo batallón", El Adelanto, no 11.248, 1 de febrero de 1921, p. 1.

98 "La suscripción para el homenaje al Ejército", El Adelanto, no 11.256, 10 de febrero de 1921, p. 1.

99 “Quisicosero" (Mariano Núñez): "Quisicosas”, El Adelanto, no 11.258, 12 de febrero de 1921, p. 1; y "Nobleza obliga", La Gaceta Regional, n 146, 15 de febrero de 1921, p. 1.
} 
pueblo donde nacimos, de la familia a la que pertenecemos. Nuestros, porque junto con sus dignísimos jefes son los soldados una institución formada por la patria y para la patria misma ${ }^{, 100}$.

Y la misma tónica, más acentuada si cabe, se percibía en el editorial del día siguiente a la recepción. Las calles de la ciudad se presentaban atestadas de gente, las viviendas engalanadas con colgaduras, y los vivas a España, al Ejército y a Martín Veloz no cesaban ni por un momento ${ }^{101}$. Por todo ello, comentaba la redacción del diario conservador:

"El Ejército constituye actualmente en España la institución genuinamente más democrática del mundo. En él fraternizan todas las clases sociales: ricos y pobres, aristócratas y plebeyos, letrados y obreros, por donde ha venido a catalizarse el ideal de tan benemérita institución, guardia de honor de las verdaderas tradiciones patrias, de los valores nacionales, de la independencia y la paz, del orden y la justicia de cuanto sagrado y augusto encierra el ibérico solar ${ }^{\text {"102 }}$.

El entusiasmo en El Adelanto, a diferencia del otro diario, fue ahora bastante más comedido. Aunque indudablemente sabía que la presencia de tropas en la ciudad era un importante dinamizador de la vida económica local, parecía, no obstante, bastante cauto a la hora de contemplar a la institución armada como encarnación de todas las clases sociales.

Lamentablemente, ese frenesí urbano fue flor de un día. Una vez asentadas las tropas, en abril de 1921, resurgió el conflicto de los cuarteles al plantearse una disputa de competencia sobre la propiedad del colegio de Anaya entre los ministerios de Hacienda e Instrucción Pública. Ante la imposibilidad de privar a los soldados por el momento de ese alojamiento ${ }^{103}$, se reactivaron las gestiones para la construcción urgente de un cuartel de infantería ${ }^{104}$, mientras la alcaldía salía al quite de algunos reproches por haber dispuesto de un edificio cuya pertenencia a la Universidad era muy discutida ${ }^{105}$.

La decisión de iniciar las obras para la construcción de un cuartel de infantería fue finalmente aprobada por el gobierno en mayo, pero la asignación presupuestaria no parecía suficiente. Así que Viñuela, que entonces ocupaba la alcaldía, presionó a Martín Veloz, muy bien relacionado con los más altos círculos castrenses, para que lograse del

\footnotetext{
100 “ßBienvenidos!”, La Gaceta Regional, n’ 138, 5 de febrero de 1921, p. 2.

101 "La Victoria en Salamanca. Entusiasta recibimiento. El homenaje del pueblo al Ejército", La Gaceta Regional, $\mathrm{n}^{\mathrm{o}} 139,7$ de febrero de 1921, pp. 1-3.

102 "Impresiones y esperanzas", La Gaceta Regional, n 139, 7 de febrero de 1921, p. 1.

103 "El cuartel de Anaya", El Adelanto, no 11.313, 18 de abril de 1921, p. 1.

104 “A propósito de una Real Orden”, La Gaceta Regional, p. 197, 19 de abril de 1921, p. 1.

105 "El informe del alcalde sobre la cuestión del Palacio de Anaya", El Adelanto, n' 11.336, 17 de mayo de 1921, p. 1; y “Ayuntamiento" La Gaceta Regional, n 219, 16 de mayo de 1921, p. 2.
} 
capitán militar de la región una mayor colaboración ${ }^{106}$. Así fue y, finalmente, el edificio tuvo un coste presupuestado de algo más de tres millones de pesetas y las obras se iniciaron en marzo de $1922^{107}$.

En la misma fecha se procedió a autorizar la subasta de las obras para el cuartel de caballería ${ }^{108}$. Y aunque en octubre de ese año, Alfonso XIII colocase la primera piedra de este edificio, su terminación, ya lo sabemos, se haría mucho de rogar.

\section{SALAMANCA Y EL CAMINO HACIA EL DESASTRE MARROQUí}

El fin del conflicto europeo casi coincidió con el nombramiento de Dámaso Berenguer como nuevo Alto Comisario, el 19 de enero de 1919, y con la formación de un nuevo gobierno bajo la presidencia del conde de Romanones. Berenguer era un hombre de aspecto torpe, aunque culto, muy agudo, discreto y realista. Sin embargo, su indecisión ante las acometidas de Silvestre y las injerencias regias le restarían, ya lo anticipamos, mucha capacidad de mando ${ }^{109}$.

En el pasado, Berenguer había sido ministro de Guerra, parece que gracias a la influencia que Silvestre ejercía sobre Alfonso XIII. Durante su estancia en este ministerio, había firmado en 1918 un decreto por el que el Alto Comisario dejaba de ser general en jefe del Ejército de África. Lo que se estaba planteando entonces, por consiguiente, era la necesidad y la voluntad de avanzar hacia el establecimiento de un protectorado de carácter civil, que contase con un mayor respaldo popular y permitiese reducir los excesos presupuestarios. Pero el paso previo ineludible era la pacificación del territorio, y ello requería una considerable inversión de capital. Entre 1918 y 1920, el presupuesto militar oficial fue de 317 millones anuales. En este último año también se votó una partida suplementaria de 150 millones, y 112 más en el presupuesto especial de Marruecos. Además, el Ejército se amplió desde 190.000 hombres en 1918 hasta 216.000 en $1920^{110}$.

Para lograr la ocupación efectiva del Marruecos español, el Alto Comisario pensaba en ocupar el interior de Yebala, en un primer momento, y sólo después de lograr este objetivo, iniciar la ocupación del Rif. Su estrategia consistía en lo que se ha

106 "La construcción de los nuevos cuarteles", El Adelanto, no 11.343, 25 de mayo de 1921, p. 1; y “La Ciudad", La Gaceta Regional, n ${ }^{\circ}$ 227, 25 de mayo de 1921, p. 2.

107 "El cuartel de infantería y el de caballería", El Adelanto, no $11.588,7$ de marzo de 1922, p. 1.

108 "El nuevo cuartel de caballería", El Adelanto, no 11.596, 16 de marzo de 1922, p. 3.

${ }^{109}$ BOYD, Carolyn P.: La política pretoriana durante el reinado de Alfonso XIII. Madrid: Alianza Editorial, 1990, p. 198.

${ }^{110}$ PAYNE, Stanley G.: Los militares y la política en la España contemporánea. París: Ruedo Ibérico, 1968, p. 134. 
dado en llamar "el método de la mancha de aceite": un avance lento, siempre asegurando la retaguardia, mediante la construcción de pequeños puestos defensivos o blocaos. El sistema requería para su funcionamiento la previa "preparación política" del territorio y un despliegue muy meditado de las tropas. Resultó una estrategia espléndida, desde luego, para un país en el que la guerra desquiciaba a buena parte de la opinión pública más atenta, pero creaba la falsa imagen de ahorro de fuerzas militares $^{111}$.

En la región occidental del Protectorado marroquí, Berenguer tenía la firme voluntad de acabar con las políticas "blandas" ante El Raisuni, captando para ello la amistad de los jefes cabileños enfrentados con el jerife. Su objetivo principal era la toma de Xauen, que finalmente se produjo el 13 de octubre de 1920. Así el Alto Comisario pudo bloquear las relaciones entre el jerife y sus aliados de Gomara. A continuación, procedió a estrechar el cerco sobre El Raisuni, refugiado en Tazarut. Las tropas españolas penetraron en la cábila de Beni Aros a comienzos de julio de 1921, preparadas ya para el asalto definitivo. Pero la noticia del Desastre de Annual, en la región oriental, libró una vez más al jerife de su captura ${ }^{112}$.

En la prensa salmantina, finalizada la contienda mundial, los temas internacionales estelares fueron, sin lugar a dudas, el recrudecimiento de la lucha contra El Raisuni y las reivindicaciones a propósito de Tánger. Comenzando nuestro repaso con El Adelanto, el inesperado fallecimiento de Gómez Jordana puso sobre el tapete de la discusión política su difícil sucesión. Tras plantearse los nombres de varios candidatos $^{113}$, como quedó señalado, el elegido para el puesto fue Berenguer, que abandonaba así el ministerio Guerra. Romanones deseaba un cambio en la orientación política del Protectorado y este general era su hombre ${ }^{114}$.

Pero lo que más preocupaba en aquellos días eran las voces que apuntaban a la supresión, así sin más, del Protectorado español porque se había acordado en Versalles. Máximo Gim respondía: "Habría que liquidar cierta clase de gratitudes en relación con los agravios. La falta de gobiernos y de gobernantes nos pone en este dolorosísimo trance de ver inutilizados nuestros esfuerzos y nuestros sacrificios en Marruecos. Y no

\footnotetext{
${ }^{111}$ BOYD, Carolyn P.: Op.Cit., p. 201.

${ }^{112}$ VILLALOBOS, Federico: Op. Cit., p. 106.

${ }^{113}$ Alfredo Rivera: "Información telegráfica", El Adelanto, no 10.578, 25 de noviembre de 1918, p. 4; Alfredo Rivera: "Información telegráfica", El Adelanto, no 10.637, 3 de febrero de 1919, p. 4.

${ }^{114}$ Alfredo Rivera: "Información telegráfica”, El Adelanto, no 10.591, 10 de diciembre de 1918, p. 3.
} 
queremos decir más, que ya es bastante"115. Lógicamente, semejante disposición se contemplaba como una traición a manos de la Entente.

Con motivo de la visita oficial del conde de Romanones a París, a finales de enero de 1919, los rumores acerca de una permuta entre Ceuta y Gibraltar se dispararon. El Adelanto, muy cauto, no se posicionaba abiertamente en la materia, pero temía una excesiva injerencia inglesa en el Marruecos español:

"Convendrá que la opinión pública se ilustre concienzudamente sobre el tema para resolver en definitiva lo acertado en este gran problema internacional (...) ¿Acaso la posesión de Ceuta por Inglaterra sospeche intervención en la zona norteña marroquí? (...) ¿Tiene el gobierno un criterio definido, meditado, claro, rotundo, en la intercesión de Gibraltar y Ceuta? El asunto es de tan enorme importancia, que no pueden los hombres políticos sustraerlo al conocimiento del país, oculto en el secreto de cancillerías pasadas de moda. España necesita saber qué solución ha de darse a este problema de fecunda vitalidad en los destinos nacionales"116.

A su regreso, en el Parlamento, Romanones se veía forzado a hacer frente a las interpelaciones del republicano Rodés, contrario tradicionalmente a los tratos con El Raisuni. Señalaba, además, que por no haberse procurado la colaboración con Francia, ahora España se hallaba a expensas de los designios de Versalles. El presidente del gobierno, por su parte, se limitaba a asumir toda la responsabilidad de la política adoptada ante el cabecilla de Yebala, con el argumento de que era preferible la atracción a la violencia. Pero, simultáneamente, anunciaba cambios motivados por la variación del escenario internacional ${ }^{117}$.

En efecto, esos cambios se percibieron muy tempranamente: la actividad militar en el Marruecos español se incrementó, sobre todo, en las cercanías de Ceuta y Tetuán ${ }^{118}$. La picaresca para evitar el servicio en África reapareció de inmediato, tal y como denunció el diario liberal: muchos jóvenes "cuotas" pagaban la primera obligación, elegían cuerpo y, seguidamente, renunciaban a los privilegios de la cuota, alegando dificultades económicas. Desde el ministerio de Guerra se respondió con la aprobación de una Real Orden que estipulaba la celebración de un segundo sorteo para el continente africano con esos infractores ${ }^{119}$.

\footnotetext{
${ }^{115}$ Máximo Gim: "Comentarios políticos. El problema catalán y el de Marruecos", El Adelanto, no 10.594, 13 de diciembre de 1918, p. 2.

116 "Del momento. ¿Nos devuelven Gibraltar?", El Adelanto, no 10.635, 31 de enero de 1919, p. 1.

${ }^{117}$ Alfredo Rivera: "Información telegráfica", El Adelanto, no 10.652, 20 de febrero de 1919, p. 3; Alfredo Rivera: "Información telegráfica", El Adelanto, no 10.657, 26 de febrero de 1919, p. 3.

${ }_{118}$ Alfredo Rivera: "Información telegráfica”, El Adelanto, no 10.677, 21 de marzo de 1919, p. 3; Alfredo

Rivera: "Información telegráfica", El Adelanto, no 10.683, 28 de marzo de 1919, p. 4.

119 "Los reclutas de cuota", El Adelanto, no 10.690, 5 de abril de 1919, p. 2.
} 
A mediados de julio de 1919, finalmente, El Raisuni contraatacó en los alrededores de Larache. Si bien las tropas españolas pudieron rechazarlo, las bajas españolas fueron abundantes, con la consiguiente alarma entre la opinión pública local $^{120}$. El periodista F. Feliu, en esta coyuntura, no podía dejar de lamentar que a la grave situación de la política interior, viniera ahora a sumarse el recrudecimiento de los problemas en Marruecos. Muchas dudas rondaban por su cabeza sobre el porqué de la conducta de El Raisuni. La principal: no entendía por qué el jerife se revelaba contra España precisamente cuando Francia estaba celebrando su victoria en la contienda europea:

“¿Fue el Raisuni el agresor? El parte oficial dice que sí.

Pero es extraño, de todo punto extraño, que coincida este combate con la noticia recibida recientemente de Marruecos, dando cuenta de la muerte del pretendiente al trono, hombre que se distinguió durante varios años por su enemistad a Francia. Sólo queda ahora en Marruecos otro enemigo de Francia: El Raisuni. Éste nos hace objeto de una agresión y se le va a atacar duramente hasta intentar hacerle desaparecer.

Esto es extraño, insistimos, por cuanto al Raisuni, durante varios años, le ha estado España subvencionando y facilitándole armas y municiones como premio a su gran amistad.

¿Cómo se ha roto este pacto entre España y El Raisuni? ¿Con la reciente agresión?

En el problema de Marruecos sigue el pueblo español caminando a ciegas. Los gobiernos guardan su secreto para el final. España da su dinero y sus hombres sin tener, al parecer, derecho a que se le notifique que la verdad sobre nuestra actuación y pensamiento para el porvenir.

Nosotros insistimos en decir que no nos explicamos la agresión del Raisuni ${ }^{, 121}$.

En realidad, lo que el articulista sugería era que los agresores habían sido las tropas extranjeras y, además, ello era lo que se le adeudaba a Francia por la neutralidad en la contienda mundial. Pero casi simultáneamente otro columnista, "Ariel”, salía al quite llamando a la guerra y postergando para más tarde la discusión sobre posibles responsabilidades. Lo que se intentaba inducir en la opinión pública salmantina era una reacción visceral:

“¿Qué ha pasado en estos últimos meses para que el que era nuestro fiel aliado se convierta en el más fiero adversario?

Aún no se han explicado al país las razones que haya habido para variar de táctica (...) Ahora lo que importa saber no es si hacemos bien en mantener nuestro empeño en Marruecos ni si aquellos terrenos valen o no, ni si hemos hecho bien siendo antes amigos de este moro y luego poniéndonos en frente; todo eso, con ser digno de aclararse, no es ahora lo que interesa. Lo importante es que nos demos cuenta de que unos millares de hermanos nuestros han sido atacados por ese caíd, que ha corrido la sangre de nuestros soldados y que el honor de España pide que sea vengado el ultraje (...) Envíese a Marruecos los hombres necesarios y el material de guerra que sea

\footnotetext{
120 "El Raisuni contra España”, El Adelanto, no 10.772, 15 de julio de 1919, p. 1.

${ }^{121}$ F. Feliu: "Hay que aclarar el problema", El Adelanto, no 10.774, 17 de julio de 1919, p. 1.
} 
preciso para ayudar a aquellos hermanos nuestros y para que la honra de España no sea hollada por un aventurero ${ }^{, 122}$.

La guerra aparecía a la vuelta de la esquina. Aunque, inicialmente, la suerte sonreía a los españoles, a punto de adentrarse en la cábila de Wad-Ras ${ }^{123}$. Además, el nombramiento, a finales de julio de 1919, de Manuel Fernández Silvestre como comandante general de Ceuta fue rápidamente entendido por "Ariel" como una muy acertada medida para combatir a El Raisuni. Presentado como un buen conocedor de la lengua y las costumbres marroquíes, de él se recordaba también su destacada participación en la campaña de 1909 y, sobre todo, su paso por Larache:

"Desde el primer momento manifestó Fernández Silvestre que nuestra intervención en Marruecos no sería todo lo eficaz que debiera, mientras no se anulara la influencia que sobre los cabileños ejercía el Raisuni, y a combatir al temido cabecilla moro dedicó todas sus energías Fernández Silvestre, llegando entonces a contarse muy curiosas anécdotas que certificaban la antipatía existente entre el general español y el caíd rifeño.

Pero nuestros gobiernos creyeron necesario variar de táctica, y, como por encanto, el feroz enemigo de la dominación española en Marruecos, el temible Raisuni, se convirtió en nuestro aliado y protegido.

Fernández Silvestre tuvo que salir de Marruecos, y, aunque se le concedió un honroso cargo cerca de la persona del Rey, no se pudo acallar la maledicencia popular que aseguraba que el bravo general había sido relevado por incompatibilidad con el Raisuni.

Pasaron los años, y también por encanto, el que venía siendo nuestro amigo y aliado arremete ferozmente contra nuestras posiciones e infringe sensibles bajas a las descuidadas huestes españolas.

Aún no sabemos con certeza la importancia que para nosotros haya tenido esa agresión. El gobierno no se ha creído obligado a dar noticias exactas, con lo cual la opinión anda desorientada" ${ }^{\prime 24}$.

Silvestre, por tanto, siempre había apostado por la lucha sin cuartel, pero no había hallado respaldo en los despachos madrileños ${ }^{125}$. La opinión pública, por otro lado, no sabía a qué atenerse porque eso de que "por encanto" el panorama africano se modificase de un día para otro, no resultaba convincente. En definitiva, desde la redacción liberal se estaba poniendo sobre tela de juicio la figura del moro pensionado.

\footnotetext{
122 "Ariel": "Comentando la actualidad. Otra vez los moros", El Adelanto, n 10. 774, 17 de julio de 1919, p. 3 .

${ }^{123}$ Alfredo Rivera: “Información telegráfica”, El Adelanto, no 10.777, 21 de julio de 1919, p. 3.

124 "Ariel": "Comentando la actualidad. Hay que terminar de una vez", El Adelanto, no 10.783, 28 de julio de 1919, p. 2.

${ }^{125}$ A propósito de la antipatía de Silvestre hacia los métodos de avance ingeniados en Madrid, Payne recogía cierto lamento del general sobre lo infecundo de la obra española en Marruecos "ya que en todas las operaciones, la política dejaba en tercer lugar a las fuerzas europeas, en el segundo a las indígenas auxiliares, y confiaba el puesto de vanguardia al Banco de España". Véase PAYNE, Stanley: Op. Cit., p. 142.
} 
Aunque Pallol, desmarcándose una vez más de El Adelanto, denunciaba el silencio gubernamental y su escaso respeto hacia los familiares de los soldados ${ }^{126}$.

Al iniciarse el mes de septiembre, la desolación parecía aumentar entre los integrantes del diario progresista porque la contraofensiva ante El Raisuni no llegaba y este tiempo podía ser aprovechado por el cabecilla rebelde para rearmarse:

"No se olvide que es indudable que venceremos, pero que, reorganizadas las fuerzas del guerrero africano, la lucha será más dura, el encuentro más sangriento (...) correrá la sangre española por los peñascales de esa zona árida que, con tan buena intención, nos dejaron para nuestro Protectorado los vecinos y amigos (...) no hay que perder tiempo, pues no sabemos quién está detrás del Raisuni y le da bombas de mano del último modelo europeo, como las que utilizó en recientes combates. "127.

La práctica del contrabando se situaba así en el punto de mira de los salmantinos y en uno de los principales obstáculos, sino el mayor, para el buen desempeño de la acción española en África. Mientras, el debate sobre la conducta cambiante adoptada por los gobiernos ante El Raisuni se desplazaba a un segundo plano. El gobierno continuaba aprobando nuevos créditos para la guerra en ciernes ${ }^{128}$; mientras los altercados con las tropas moras se repetían ${ }^{129}$. Únicamente, a principios de octubre, por fin, Rivera pudo señalar que el objetivo inmediato de la nueva campaña consistía en la toma del Fondak ${ }^{130}$. Y, al mismo tiempo, aprovechando la clausura del Parlamento, el Rey emprendía un viaje, por completo improvisado, hacia Londres y París. De inmediato, se dispararon todas las alarmas entre la redacción liberal:

"Hoy no se mueve un Rey ni un presidente de República, sin que previamente sepan los pueblos respectivos el objeto y hasta dónde se puede llegar en el movimiento expansivo que realiza.

Pero aquí, en España, seguimos ciegos en materia internacional. Muchos años después de ser firmado, nos enteramos de lo que era el pacto de Cartagena. No tiene nada de extraño que en los actuales momentos se sienta algo de desconfianza sobre lo que pueda ser en su día la inteligencia internacional que se marque en este viaje (...) El sólo anuncio de este viaje en los actuales momentos y sin un previo y justificado aviso, en un pueblo cualquiera hubiera originado campañas periodísticas y discursos políticos. Aquí, sólo nos limitamos a leer el breve telegrama de París"

Realmente, nada más se comentó en la prensa salmantina a propósito de esta visita regia, pero, sin duda, la censura hacia el proceder diplomático de las instituciones

\footnotetext{
${ }^{126}$ Pallol: "Capítulo pesimista”, El Adelanto, no 10.804, 21 de agosto de 1919, p. 1.

127 "Comentarios políticos. La actuación de España en África. Problemas del momento", El Adelanto, no 10.813, 1 de septiembre de 1919, p. 1.

${ }^{128}$ Alfredo Rivera: “Información telegráfica”, El Adelanto, no 10.814, 2 de septiembre de 1919, p. 3.

${ }^{129}$ Alfredo Rivera: "Información telegráfica", El Adelanto, $\mathrm{n}^{\circ}$ 10.839, 29 de septiembre de 1919, p. 5; Alfredo Rivera: "Información telegráfica", El Adelanto, no 10.842, 2 de octubre de 1919, p. 6; Alfredo Rivera: "Información telegráfica", El Adelanto, no 10.844, 4 de octubre de 1919, p. 4; Alfredo Rivera: "Información telegráfica", El Adelanto, no 10.845, 6 de octubre de 1919, p. 4.

${ }^{130}$ Alfredo Rivera: "Información telegráfica", El Adelanto, no 10.841, 1 de octubre de 1919, p. 4.

131 "Viajes reales", El Adelanto, no 10.846, 7 de octubre de 1919, p. 2.
} 
gubernamentales iba unida a la creciente conciencia de anormalidad política ${ }^{132}$. La atención pública, sin embargo, otra vez se desvió hacia la ocupación del Fondak y hacia la urgente necesidad de poseer Tánger, centro del contrabando, para así aplastar a El Raisuni. Sólo con ella "podríamos dedicarnos a la misión civilizadora que apetecemos cumplir. Periódicos de matices opuestos lo han reconocido así, porque el problema no es político, sino nacional" ${ }^{\prime 133}$. Tanto un desconocido Lerroux, ante un periodista francés, como Romanones, en el Parlamento, clamaban, durante aquellos días, en el mismo sentido, procurando una solución amistosa para este contencioso histórico ${ }^{134}$. Por su parte, los socialistas madrileños iniciaban una nueva campaña contra el conflicto marroquí ${ }^{135}$. En Salamanca, por el momento, reinaba la calma entre la opinión pública, entretenida, un año más, con la campaña del aguinaldo del soldado ${ }^{136}$.

Los escarceos militares, con notable participación de la aviación, y los escarceos prosiguieron en la Comandancia de Ceuta durante la primera mitad de $1920^{137}$, mientras que el malestar de la colonia española tangerina, al ver a sus funcionarios, de día en día, más ninguneados por Francia, también iba en aumento ${ }^{138}$. Sin embargo, El Adelanto lamentaba que su campaña mediática en defensa de la posesión de Tánger no tuviese más calado entre la opinión pública local: “¿Cuánta atención se presta a ese interrogante para España, que representa ese movimiento que languidece, para la reivindicación del Tánger español? Y es que el individualismo impenitente del pueblo español sólo mira su pequeña parcela" ${ }^{\text {"139. }}$.

Más extensión y profundidad entrañaba la siguiente explicación a propósito de la apatía ciudadana en el asunto de Tánger:

\footnotetext{
${ }^{132}$ Esta percepción de anormalidad se ponía aún más de manifiesto en "La vida política. Balance del año”, El Adelanto, no 10.920, 2 de enero de 1920, p. 1; “¡Viva España!”, El Adelanto, no 11.025, 5 de mayo de 1920 , p. 1.

133 "Mientras se lucha. España en África", El Adelanto, no 10.848, 9 de octubre de 1919, p. 2.

134 "La política a través de la prensa", El Adelanto, no 10.859, 18 de octubre de 1919, p. 2; "Las preocupaciones de un político español en los momentos españoles", El Adelanto, n ${ }^{\circ} 10.861,24$ de octubre de 1919, p. 1; Alfredo Rivera: "Servicio telegráfico", El Adelanto, no 10.872, 6 de noviembre de 1919, p. 3.

${ }^{135}$ Alfredo Rivera: “Información telegráfica”, El Adelanto, no 10.853, 15 de octubre de 1919, p. 3.

${ }^{136}$ A. Guerra: "No olvidemos a nuestros soldados de África", El Adelanto, no 10.876, 11 de noviembre de 1919 , p. 2.

${ }^{137}$ Alfredo Rivera: "Información telegráfica", El Adelanto, no 10.932, 16 de enero de 1920, p. 4; "R.": "Alcance de Madrid", El Adelanto, no 11.016, 24 de abril de 1920, p. 3; Alfredo Rivera: "Servicio telegráfico", El Adelanto, no 11.030, 11 de mayo de 1920, p. 6; Alfredo Rivera: "Servicio telegráfico", El Adelanto, $\mathrm{n}^{\circ} 11.036,18$ de mayo de 1920, p. 5.

${ }^{138}$ Alfredo Rivera: "Información telegráfica", El Adelanto, no 10.934, 19 de enero de 1920, p. 4.

139 "La desorientación nacional", El Adelanto, no 11.064, 19 de junio de 1920, p. 1.
} 
"Cuestión tan importante para la vida exterior de España es dada, puede decirse, de lado por una inmensa mayoría de los políticos y por una gran parte de la opinión, ¿por qué?

Es posible que esto ocurra quizás por apatía y falta en el cumplimiento del deber por unos y por desrazonamiento, por incredulidad en la eficacia de la actuación de los poderes públicos, por otros (...) Desorientada la opinión del país, sin guía definitivo, sin hombres que canalicen su deseo, tiene que someterse a la voluntad del exterior, sin que para nada pese, por lo que se ve, ni su esfuerzo pasado ni su potencialidad actual, ni sus derechos proclamados.

A nuestro entender, esta actuación pro Tánger español, que se ha impuesto un puñado de hombres de buena voluntad, de nada sirve sin que de arriba del Poder público, con la decisión de las Cortes, no venga una iniciativa, una sola palabra de aliento o de indicación del camino a seguir,"140.

La opacidad diplomática, como de costumbre, se hallaba en la raíz de la desorientación de la opinión pública salmantina -y española, por extensión-. Ésta debía conformarse con las buenas impresiones que Eza estaba obteniendo de su visita al Protectorado $^{141}$; y con la esperanzadora aproximación de las tropas a Xauen ${ }^{142}$. Finalmente, el 16 de octubre, Rivera podía confirma la tan ansiada noticia de la entrada de las tropas española en la ciudad santa ${ }^{143}$.

Por otra parte, Silvestre fue trasladado a la Comandancia de Melilla en enero de 1920. Desde su mismo aterrizaje en la región, empeñado en tomar Alhucemas por tierra, emprendió una serie de rápidos avances. El Adelanto, sobre todo, celebró la toma de Tafersit ${ }^{144}$. A finales de ese mismo año, su avance por los territorios de Beni Ulichek y Beni Said parecía imparable. Berenguer entonces lo aplaudía por tratarse de un movimiento efectuado "con mucho acierto, tanto en la preparación como en el desarrollo" $" 145$. Una semana después, a mediados de diciembre, durante un viaje a la península, el Alto Comisario hablaba a los periodistas, confesando todo su entusiasmo por la toma de Xauen y divagando sobre la complejidad de una posible operación en Alhucemas. De Tánger, en cambio, prefería no comentar nada ${ }^{146}$. Los salmantinos, por

\footnotetext{
140 "Pro Tánger español”, El Adelanto, no 11.065, 21 de junio de 1920, p. 1.

${ }^{141}$ Alfredo Rivera: "Servicio telegráfico", El Adelanto, no 11.075, 2 de julio de 1920, p. 5; "Después de un viaje. Las mejoras del Ejército español en Marruecos", El Adelanto, no 11.097, 28 de julio de 1920, p. 2.

142 “Alcance de Madrid”, El Adelanto, n 11.082, 10 de julio de 1920, p. 2; "España en Marruecos. Las operaciones contra El Raisuni”, El Adelanto, $\mathrm{n}^{\circ}$ 11.083, 12 de julio de 1920; "Alcance de Madrid", El Adelanto, $\mathrm{n}^{\circ}$ 11.114, 17 de agosto de 1920, p. 3; Alfredo Rivera: "Servicio telegráfico", El Adelanto, $\mathrm{n}^{\circ}$ 11.145, 22 de septiembre de 1920, p. 5; Alfredo Rivera: "Servicio telegráfico", El Adelanto, n 11.154, 2 de octubre de 1920, p. 5.

${ }^{143}$ Alfredo Rivera: "Servicio telegráfico", El Adelanto, no 11.166, 16 de octubre de 1920, p. 5. La noticia fue seguida por el rumor, propalado desde la prensa extranjera, de su inmediata evacuación. Eza lo desmintió: "Xauen no será evacuado", El Adelanto, no 11.198, 4 de diciembre de 1920, p. 2.

${ }^{144}$ Alfredo Rivera: "Servicio telegráfico", El Adelanto, no 11.107, 9 de agosto de 1920, p. 6.

145 "R.": “Alcance de Madrid", El Adelanto, no 11.201, 8 de diciembre de 1920, p. 3.

146 "R.": "Alcance de Madrid”, El Adelanto, no 11.206, 14 de diciembre de 1920, p. 3.
} 
no faltar a la tradición, se disponían a socorrer a los combatientes con sus aguinaldos: "Podremos nosotros aquí discutir la conveniencia de nuestra intervención en Marruecos, el acierto de los directores de la campaña y cuanto pueda y deba discutirse; pero lo que no puede discutirse es la abnegación y el heroísmo"147. Y también se afanaban en la preparación de una velada literaria de carácter benéfico ${ }^{148}$.

Si nos centramos ahora en el análisis de La Gaceta Regional, ya que su fundación tuvo lugar tan sólo unos meses antes de la toma de Xauen, éste es el único evento que por ahora podemos reseñar a partir del análisis de este nuevo diario conservador, aunque no tan fervientemente católico como El Salmantino, hoy el más leído de la provincia. Desde finales de septiembre, Barreto, su corresponsal en Madrid, advirtió de que se estaban produciendo movimientos, por parte de las tropas españolas, en las cercanías de Xauen ${ }^{149}$. El 13 de octubre, el mismo periodista, mediante telefonema urgente, notificaba la toma de la ciudad santa ${ }^{150}$. Apenas tres días después, disponiendo de una notable colaboración de Emilio Blanco Izaga, la redacción celebraba la ocupación del nuevo enclave y los beneficios que a su población reportaría la llegada de los españoles:

"Es verdad que en un principio han de sentir estos últimos la nostalgia de su quietud y su exclusivismo; pero, en cambio, sabrán y podrán sentir el engrandecimiento de nuestras infiltradas costumbres, que si en el momento presente es algo que va en contra de su atavismo y de sus creencias, cuando se vaya infiltrando en sus espíritus la ductilidad y la impresión de la civilización moderna, los moros, de por sí inteligentes, sabrán apropiarse cuanto de apetecible tiene nuestra influencia" ${ }^{\prime 15}$.

El apego hacia la causa colonial quedaba ya claro. Pero los incidentes en las cercanías de la ciudad con los rebeldes de la cábila de Ajmás no se harían esperar ${ }^{152}$.

Con motivo de la llegada de las Navidades, el nuevo diario prestaría notable publicidad a los preparativos del aguinaldo del soldado. A modo de justificación, esto

\footnotetext{
147 “A.": "Del momento. El aguinaldo del soldado", El Adelanto, no 11.184, 18 de noviembre de 1920, p. 5.

148 "El aguinaldo del soldado", El Adelanto, no 11.193, 29 de noviembre de 1920, p. 1; "El aguinaldo del soldado", El Adelanto, n ${ }^{\circ} 11.194,30$ de noviembre de 1920, p. 3; "Una próxima fiesta patriótica", $E l$ Adelanto, $\mathrm{n}^{\circ} 11.196,2$ de diciembre de 1920, p. 1; "El aguinaldo para los soldados de África", $E l$ Adelanto, $\mathrm{n}^{\circ} 11.203,10$ de diciembre de 1920 pp. 1-2; "El aguinaldo del soldado", El Adelanto, $\mathrm{n}^{\circ}$ $11.208,16$ de diciembre de 1920, p. 1. La Junta de Damas logró recaudar casi 5.000 pesetas.

${ }^{149}$ Barreto: "Nuestras operaciones en Marruecos. Avance de nuestras tropas hacia Xauen", La Gaceta Regional, $\mathrm{n}^{\circ}$ 29, 22 de septiembre de 1920, p. 4.

${ }^{150}$ Barreto: "Al cerrar la edición. Conquista de Xauen por las tropas españolas. Esta tarde entrarán en la ciudad del misterio", La Gaceta Regional, no 48, 14 de octubre de 1920, p. 12.

${ }^{151}$ Emilio Blanco: "Aspectos de la vida. Xauen, la ciudad misteriosa", La Gaceta Regional, no 50, 16 de octubre de 1920, p. 1.

${ }^{152}$ Barreto: "Al cerrar la edición. Sangriento combate en Xauen", La Gaceta Regional, no 56, 23 de octubre de 1920, p. 12.
} 
señalaba uno de sus redactores: "Conviene mucho que de las cuestiones marroquíes se procure hacer una amplia propaganda y una atención detenida váyase apoderando de todo ciudadano, ya que en este aspecto político y militar, como en todos, hay no pocos tópicos admirables muy dignos de todo elogio y simpatía" ${ }^{\prime 53}$. Y, también, se dedicaría un notable espacio a la celebración de una velada artístico-literaria en el Bretón ${ }^{154}$.

Por último, el anuncio de cambios en la gestión del Protectorado por parte de Romanones también atrajo la atención de El Salmantino al concluir $1918^{155}$. Sobre todo, la noticia generaba una considerable alarma porque este sector de la opinión salmantina albergaba mucho miedo sobre las derivaciones de la futura conferencia de paz para España:

"Nunca será bastante cuanto se hable de la actitud que ha de observar España frente a las potencias que en plazo breve han de concertar las bases de la paz futura. Han sido tantos los errores cometidos por nuestros gobiernos en materia de política internacional, que si el buen sentido de los que orientan a la masa gobernada no impone el criterio de que hemos de atender ante todo a nuestras necesidades históricas y geográficas, fácil fuera que España quedara sometida en lo futuro a mayor esclavitud que la que hemos debido soportar hasta hoy (...) Opongámonos, pues, a que se repita la vergüenza de la Conferencia de Algeciras. Defendamos nuestros derechos por encima de toda consideración a ellos ajenas, ${ }^{\prime 156 .}$.

Fácilmente se perfilaba la meta de El Salmantino: asegurar la posesión de Tánger. De hecho, a mediados de enero de 1919 la redacción volvía a la carga, bastante más abiertamente, al hacerse eco de que el periodista inglés Walter Harris se estaba dedicando a desprestigiar a España, censurando nuestra mala administración del Protectorado y la protección dispensada a los agentes alemanes. Un periodista anónimo respondía, por el contrario, a su "furibunda campaña", señalando que Tánger había constituido siempre un centro de intrigas contra los españoles inspiradas, especialmente, por los agentes franceses ${ }^{157}$.

\footnotetext{
153 "Un buen propósito. Las damas salmantinas tienen la palabra", La Gaceta Regional, no 81, 26 de noviembre de 1920, p. 1; “Temas de actualidad”, La Gaceta Regional, n 93, 11 de diciembre de 1920, p. 1.

154 "Una buena idea. Alrededor de una velada patriótica", La Gaceta Regional, n ${ }^{\circ}$ 81, 26 de noviembre de 1920, p. 2; "Conde Lake": "El aguinaldo del soldado", La Gaceta Regional, n 92, 10 de diciembre de 1920 , p. 2.

155 "Conferencias telegráficas. Los asuntos de Marruecos", El Salmantino, n ${ }^{\circ} .536,10$ de diciembre de 1918, p. 3.

156 “España ante la paz”, El Salamantino, no 2.538, 12 de diciembre de 1918, p. 1.

157 “España en Marruecos. Lo de siempre”, El Salmantino, n’ 2.564, 15 de enero de 1919, p. 1.
} 
El nombramiento de Berenguer como Alto Comisario fue recibido con notable frialdad ${ }^{158}$. Por de pronto, de él se esperaba que fuese capaz de satisfacer las pretensiones de la Liga Africanista, expuestas en un extenso "documento patriótico" que comentaba el periódico: se apelaba a la tesis historicista y a la común historia geológica para defender la presencia española en Marruecos. España se presentaba como la gran salvaguarda del statu quo marroquí, roto por la apetencia de otros países; y la tarea de la Liga pasaba por movilizar a la opinión pública frente a las insidiosas campañas de la prensa extranjera ${ }^{159}$. Previsiblemente, a la cabeza de las preocupaciones de esta institución figuraba la cuestión de Tánger y, en segundo término, la comentada permuta de Ceuta y Gibraltar. La Liga la desaconsejaba por considerar que Gibraltar podía ser fácilmente atacable desde tierra, no representando una gran amenaza para la seguridad peninsular, mientras que las perspectivas comerciales de Ceuta y su puerto eran excelentes $^{160}$. Sin duda, El Salmantino secundaba todas estas ideas porque, de lo contrario, no habría reproducido de manera íntegra el texto de la Liga. No obstante, la reivindicación de Gibraltar, lo sabemos, había sido una petición constante a lo largo de su historia, pero ahora quedaba claro, jamás bajo una fórmula negociada.

Juan Carranza, por otro lado, adivinaba que a España le costaría mucho hacer valer sus derechos en Marruecos. Francia se lo impediría: “Los franceses nos adoran. Los franceses nos reverencian. Los franceses son grandes amigos nuestros (...) A eso de Marruecos llamamos nosotros un mal negocio (...) y los franceses, nuestros queridos amigos, se disponen a librarnos de este mal negocio" ${ }^{, 161}$. Por esta razón, tan pronto como se rumoreó la proximidad de nuevas operaciones contra El Raisuni, en abril de 1919, la redacción apuntó a que éstas constituirían el pago de Romanones hacia la república vecina por la neutralidad sostenida durante la Gran Guerra:

"En nuestra prensa se empieza a hablar veladamente de una serie de operaciones militares (...) Si ello es realmente así, la cuestión revista una excepcional gravedad por lo que dejaría entender; es decir: que el famoso viaje del conde de Romanones a París y la política seguida desde entonces por nuestro gobierno no habría tenido otro resultado que nuestra sumisión a los planes de Francia, dispuesta a todo para sacar en Marruecos todo el partido que las circunstancias y nuestra pasividad le permitan.

\footnotetext{
158 "Conferencias telefónicas", El Salmantino, n 2.570, 22 de enero de 1919, p. 3; "Conferencias telefónicas", El Salmantino, $\mathrm{n}^{\mathrm{o}}$ 2.572, 24 de enero de 1919, p. 3; "Conferencias telefónicas”, El Salmantino, $\mathrm{n}^{\circ} 2.573,25$ de enero de 1919, p. 3.

159 "La Liga Africanista Española", El Salmantino, no 2.596, 21 de febrero de 1919, p. 1; "La Liga Africanista Española”, El Salmantino, no 2.597, 22 de febrero de 1919, p. 1.

160 "La Liga Africanista Española”, El Salmantino, n 2.598, 24 de febrero de 1919, p. 1; "La Liga Africanista Española”, El Salmantino, no 2.600, 26 de febrero de 1919, p. 1.

${ }^{161}$ Juan Carranza: "Nuestros amigos, los franceses", El Salmantino, no 2.611, 11 de marzo de 1919, p. 1.
} 
En efecto, si España se decide a la plena acción militar, bajo el sobrado pretexto de castigar a las cábilas, acudirán a nuestra zona, ávidos de lucha, los elementos rebeldes que hoy pulular por la zona francesa ${ }^{, 162}$.

Como en sus inicios, El Salmantino seguía viendo conspiraciones francesas en cada esquina, incapaz de reconocer el fracaso de la titubeante política colonizadora española. Asimismo, estaba cada vez más obsesionado con el sindicalismo revolucionario ${ }^{163}$; vertía, de día en día, comentarios más apocalípticos sobre las consecuencias del Liberalismo ${ }^{164}$; y justificaba la conveniencia de una dictadura ${ }^{165}$. Desde finales de junio de 1919, el periódico perdió su carácter diario para transformarse en un semanario. Ya entonces se señaló que ni partidos ni personas "de significación derechista" quisieron hacerse cargo del mismo ${ }^{166}$. El 11 de septiembre, acosada por los problemas financieros, esta publicación cerró para siempre sus puertas. Desaparecía así el gran bastión del integrismo salmantino.

\section{SALAMANCA Y LA TORMENTA DE ANNUAL}

El descalabro militar en Annual, y el posterior en Monte Arruit, significaron el golpe de gracia para el agónico régimen de la Restauración.

Desde enero de 1920, como ya quedó apuntado, Silvestre, amigo del Alto Comisario pero difícilmente dominable por ser más antiguo en el escalafón, se hallaba al frente de la Comandancia de Melilla. Desde su llegada a la plaza, confiando en su tan mentada buena estrella o "baraka" 167 , había emprendido una serie de avances muy rápidos por el Rif central ${ }^{168}$. De tal modo que, a principios de 1921, sus hombres se hallaban a las puertas de las cábilas de Tensaman y Beni Urriaguel, la más belicosas de la región. A pesar de todas las prevenciones del coronel Gabriel Morales, el jefe de la

\footnotetext{
162 "España y Francia y Marruecos", El Salmantino, n n $^{\circ} .634,9$ de abril de 1919, p. 2. No obstante, cuando se produjo esa visita oficial a París, el mismo periódico tan sólo comentó que los aliados sólo codiciaban la amistad española porque su pasado aferro a la neutralidad le había granjeado mucho prestigio: "X.": "El autor de 'Neutralidades que matan' va a recoger los frutos de nuestra neutralidad", $E l$ Salmantino, $\mathrm{n}^{\circ}$ 2.551, 28 de diciembre de 1918, p. 1.

163 "Las cosas claras", El Salmantino, $\mathrm{n}^{\circ} 2.691,20$ de junio de 1919, p. 2.

164 "Rumores y cábalas", El Salmantino, no 1.641, 19 de abril de 1919, p. 1.

165 "Se habla de dictadura", El Salmantino, no 2.616, 17 de marzo de 1919, p. 1.

166 "Capítulo último", El Salmantino, no 2.699, 30 de junio de 1919, p. 1.

${ }^{167}$ SALAFRANCA ORTEGA, Jesús F.: El sistema colonial español en África. Málaga: Algazara, 2001, P. 154.

${ }^{168}$ Richard C. Pennell ha enfatizado que en estos rápidos avances desempeñaron un importante papel las penosas cosechas de aquel año en el Rif. Los cabileños no pudieron ofrecer una tenaz resistencia. Véase PENNELL, Richard C.: Op. Cit., p. 246.
} 
Oficina de Asuntos Indígenas de Melilla ${ }^{169}$, y de algunas llamadas de atención por parte de Berenguer, el 1 de junio, sin previa notificación al Alto Comisario, Silvestre ocupó Abarrán, ya en la cábila de Temsamán. Era una posición de cierto significado religioso para los cabileños y Silvestre obvió la repercusión que su ataque podía tener. Además, el acercamiento político hacia sus jefes había sido, hasta ese momento, casi nulo. Aunque oficialmente se trataba, cómo no, de una "operación de policía", el hecho de que se requiriese una columna con casi 1500 hombres más una batería de montaña indicaba que no esperaban una acogedora bienvenida. Y, en efecto, la posición tuvo que ser evacuada el mismo día de su ocupación y Sidi Dris sufrió otro serio ataque ${ }^{170}$. El 17 de julio de 1921, Igueriben, a tan sólo cinco kilómetros de Annual, quedó cercada ${ }^{171}$. Mientras que Silvestre abandonaba Melilla apresuradamente para trasladarse al frente, en la península nada se publicaba sobre lo que ocurría en Marruecos. Pero los enfrentamientos se agravaban; Igueriben caía el 21 de julio de 1921 y, un día después, le seguía Annual:

"La derrota de Annual no es una derrota militar. Por derrotas pasaron todos los pueblos, y todos de ellas se rehicieron. Annual es la derrota del Estado español. Del Estado español que no ha sabido ser en África médico, ni maestro, ni ingeniero, ni juez, ni autoridad civil ni soldado. Del Estado español que a la hora de edificar, no ha construido nada; que en la hora de luchar ha tirado las armas y ha huido; que en la hora de defender a los que no huyeron, les ha abandonado en el más punible y humillante de los abandonos" ${ }^{\text {"172 }}$.

\footnotetext{
${ }^{169}$ A propósito de este personaje Juan Pando señaló: “Morales veía el estado desastroso de la tropa española: mal entrenada, mal acomodada a la naturaleza despiadada del terreno; enferma; agotada (...) reconocía que el único Ejército español que operaba en el Rif era el suyo". Véase PANDO, Juan: Historia secreta de Annual. Madrid: Temas de Hoy, 1999, p. 34

${ }^{170}$ Berenguer y Silvestre pudieron entrevistarse el 5 de junio y, cambiadas algunas impresiones, el primero le transmitió a Eza, ministro de Guerra, que la situación se había estabilizado, pero sin demasiadas garantías. Según Regan, en esta entrevista Berenguer ordenó a Silvestre detener el avance por el Rif y el irascible comandante trató de estrangularle, siendo detenido por algunos miembros del Estado Mayor. Véase REGAN, Geoffrey: Historia de la incompetencia militar. Barcelona: Crítica, 1989, p. 349. La caída de Abarrán es una cuestión clave en el debate sobre si Annual fue un golpe por sorpresa o una derrota previsible. Mientras que historiadores como Pabón o Madariaga, apoyándose en testimonios de la época, defienden que tras lo de Abarrán, los nuevos avances tendrían que haber sido más meditados, otros, como La Porte, entienden que la tranquilidad en la Comandancia era absoluta.

${ }^{171}$ CASADO Y ESCUDERO, Luis: Igueriben. Madrid. Almena, 2007. Como ejemplo de trabajo reciente sobre el asunto, GOES, Carmen: "Igueriben. El inicio del Desastre", Serga. Historia militar del siglo XX, $\mathrm{n}^{\circ}$ 22, Madrid, 2003, pp. 33-43.

${ }^{172}$ Prólogo de Marcelino Domingo a GÓMEZ HIDALGO, Francisco: Marruecos: la tragedia prevista. Madrid: imprenta de Juan Pueyo, 1921, pp. 20-21. También Marcelino Domingo esgrimía en su época una idea a la que nosotros ya nos hemos referido (p. 11): "Ni los generales españoles que han pasado por África, ni los gobernantes que han tenido que decidir respecto a África han escrito una página (...) Para unos españoles, Marruecos aparece como una sangría, para otros como un robo, para otros como un caso morboso de imperialismo (...) Nadie, con autoridad y responsabilidad cuida de encauzar la opinión".
} 
La evacuación se convirtió en una desbandada. Silvestre pereció, no se sabe bien en qué circunstancias. Los que no cayeron tiroteados en el barranco de Izumar, desfallecidos por la huída o fueron hechos presos, llegaron a Ben Tieb. Desde aquí se desplazaron a Dar Drius, convencidos de que en esta posición podrían resistir. Pero el general Navarro, nombrado comandante en jefe de las tropas del territorio tras la desaparición de Silvestre en Annual, ordenó nuevamente la evacuación. De Drius se encaminó la tropa a Batel, seguidamente a Tistutín, y por último, a Monte Arruit. Allí resistieron hasta el 10 de agosto, cuando la carencia de agua, víveres, municiones y medicinas, les obligó a rendirse. La idea de asegurar el dominio de Melilla acabaría pesando más que la de intentar romper el cerco de ese último enclave ${ }^{173}$.

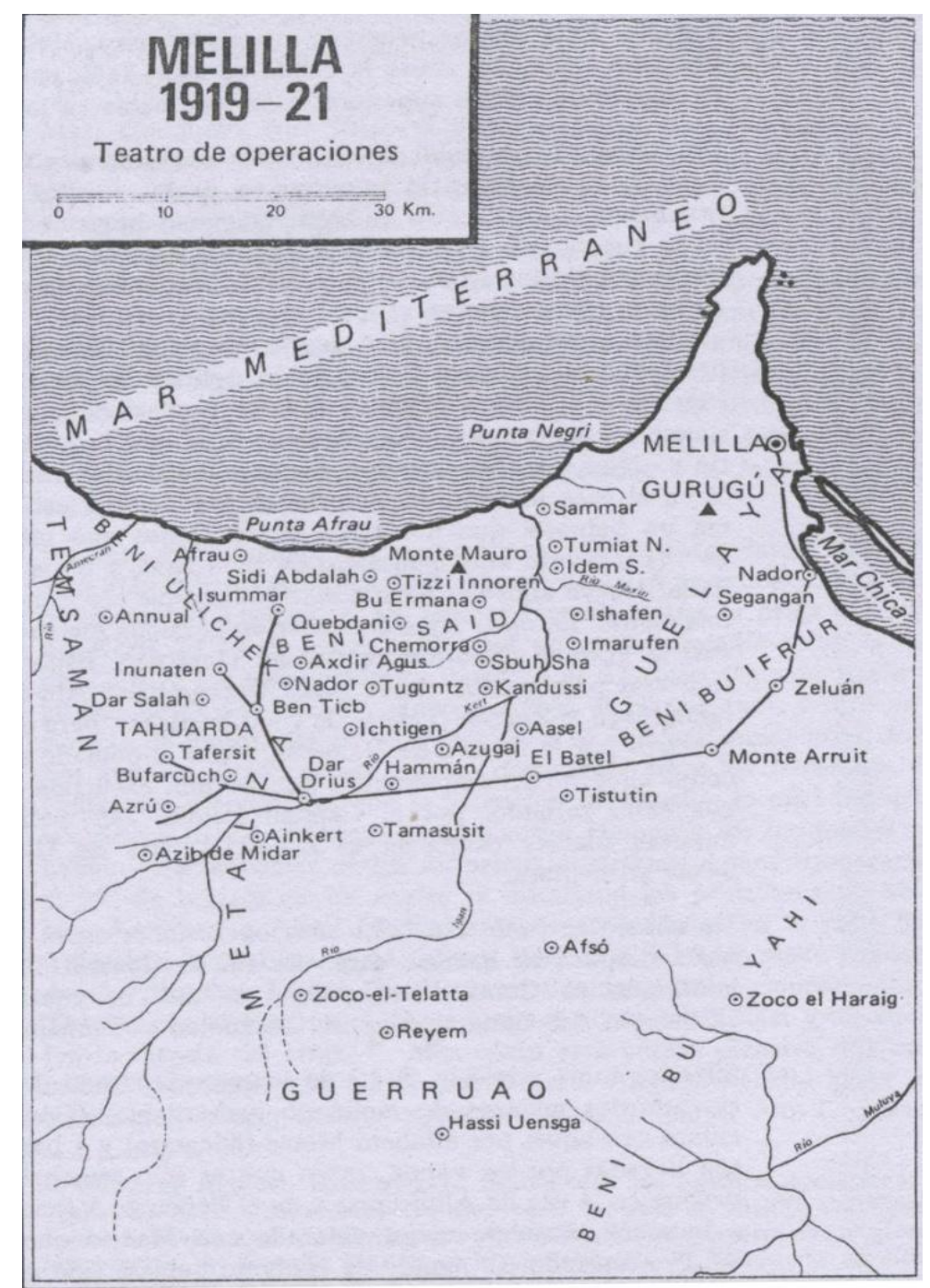

MARTÍNEZ DE CAMPOS, Carlos: Op. Cit., p. 234.

\footnotetext{
${ }^{173}$ Sobre la atmósfera de enorme excitación que se respiraba en Melilla durante aquellos días, véase MOGA ROMERO, Vicente: El soldado occidental. Ramón J. Sender en África (1923-1924). Málaga: UNED/Ciudad Autónoma de Melilla, 2004, pp. 37-43.
} 
En apenas dos semanas, se había perdido todo el territorio conquistado desde $1909^{174}$. Casi 9.000 muertos, 600 prisioneros... y un país humillado por unas tribus incivilizadas $^{175}$. Pero mientras que aquí, en España, “el cáncer marroquí” actuó como irrefrenable catalizador de todos los descontentos hacia el sistema político, Annual trajo consigo, en el territorio del Protectorado, el inicio del apogeo político de Abd-el-Krim y la aparición de un primer referente "nacional" en su historia. Por este motivo, David S. Woolman, en su estudio clásico de este personaje, subrayaría que protagonizó “la única rebelión prolongada, disciplinada y dotada de una organización central en toda la historia del Rif ${ }^{176}$.

El derrumbe casi absoluto de la Comandancia de Melilla provocó, lógicamente, en los salmantinos una tremenda angustia y desolación. Por esta razón, el afán de desquite sirvió para impulsar, como nunca antes, gran cantidad de actos de apoyo a las tropas expedicionarias del batallón de La Victoria ${ }^{177}$. Básicamente, dos fueron las instituciones encargadas de organizar la mayoría de los gestos de ayuda en pro de los combatientes: la Cruz Roja de Salamanca, bajo la presidencia del dinámico Fernando Domínguez Zaballa, y la Comisión Patriótica de apoyo a los soldados del batallón expedicionario de La Victoria.

A decir verdad, en los momentos inmediatos a la derrota militar, y para buena parte de la opinión también en los años siguientes, no importó si España debía o no estar en el Norte de África, sino que el único cometido relevante para el país, reiterado hasta

\footnotetext{
${ }^{174}$ Para una descripción detallada de las posiciones del frente oriental y del hundimiento casi completo de la Comandancia, consúltese PALMA MORENO, Juan T.: Annual 1921. 80 años después. Madrid: Almena, 2001; también MIGUEL FRANCISCO, Luis: Annual, 1921. Crónica de un Desastre. Valladolid: AF Editores, 2005.

${ }^{175}$ Alfonso de la Serna comentaría lo siguiente sobre el Desastre: "Cuesta trabajo comprender que un Ejército europeo, encuadrado por generales y oficiales formados en prestigiosas academias; lleno, por supuesto de muchos hombres valerosos y competentes, pudiera caer en la terrible sima de desorganización, inepcia y pánico que fue la desbandada de Annual ante los guerrilleros rifeños. Cuesta igualmente creer que aquellos moros de quienes con tanto desprecio y odio se hablaba en España; a quienes se consideraba salvajes e ignorantes, aquellos rifeños que no tenían aviones, barcos de guerra, tanques ni una poderosa artillería; aquellos indígenas con una fusila y una bolsa de dátiles escondida bajo la chilaba, hubieran hecho frente al Ejército de los generales y los estados mayores y lo hubieran puesto en fuga por los barrancos del Rif'. Véase SERNA, Alfonso de: Op. Cit., pp. 227-228.

${ }^{176}$ WOOLMAN, David S.: Op. Cit., p. 89. La bibliografía sobre Abd-el-Krim, su familia, el cautiverio, los tratos con los alemanes y su proyecto político es amplia. Destaquemos, por tratarse de un clásico y por la insistencia en el férreo y hábil liderazgo del cabecilla, a PENNELL, Richard C.: La Guerra del Rif... Op. Cit.; y muy posterior es el libro de MADARIAGA, María Rosa de: Abd-el-Krim El Jatabi. La lucha por la independencia. Madrid: Alianza Editorial, 2009. La autora insiste en que el caudillo rifeño jamás se opuso a la penetración comercial extranjera, pero rechazó la ocupación militar. No queremos olvidar, por último, la obra de SALAFRANCA, Jesús F.: La República del Rif. Málaga: Algazara, 2004.

${ }^{177}$ Deshumanizar al adversario fue el instrumento más efectivo para fomentar el odio. Bachoud escribía al respecto: "La guerra, podrá por tanto, realizarse sin compasión, ya que la barbarie de los adversarios justifica todos los procedimientos de un exterminio definido como justo". Véase BACHOUD, Andrée: Los españoles... Op. Cit., p. 133.
} 
la saciedad en algunos rotativos, fue "vengar la sangre derramada de nuestros hermanos españoles". Únicamente con el inicio del debate sobre las responsabilidades, este discurso se fue atemperando en algunos periódicos. Asimismo, se fueron acentuando las distancias ideológicas entre todos ellos, dando paso a la resignación, el escepticismo y la amargura ciudadana.

\section{Los periódicos locales ante el magno Desastre. Reacciones inmediatas ¿Quiénes son}

\section{los patriotas?}

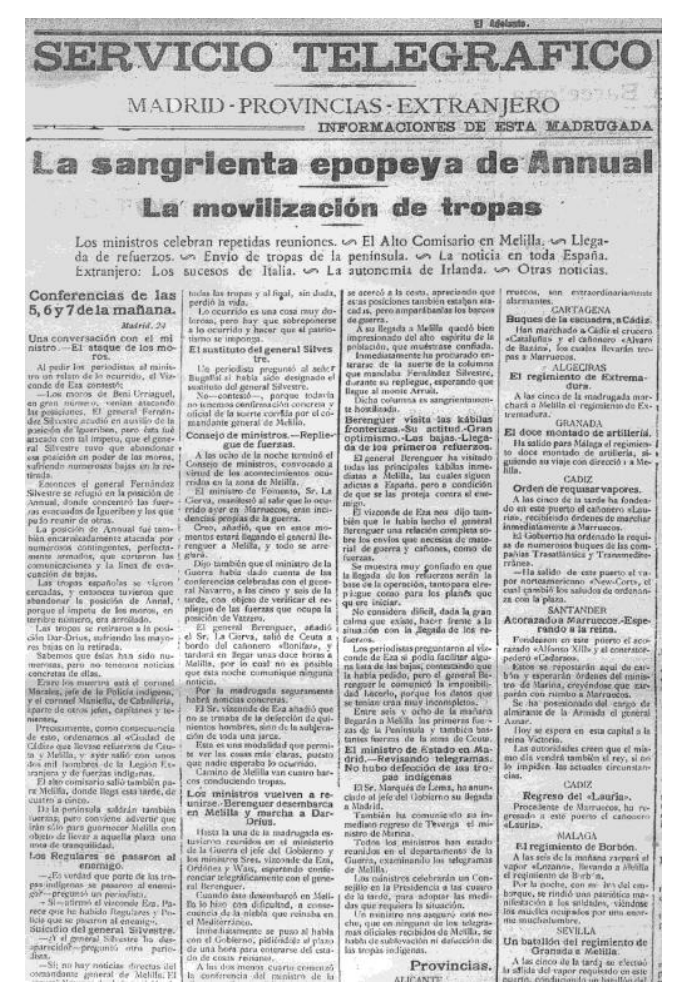

El Adelanto, $\mathrm{n}^{\circ} 11.395,25$ de julio de 1921, p. 4.

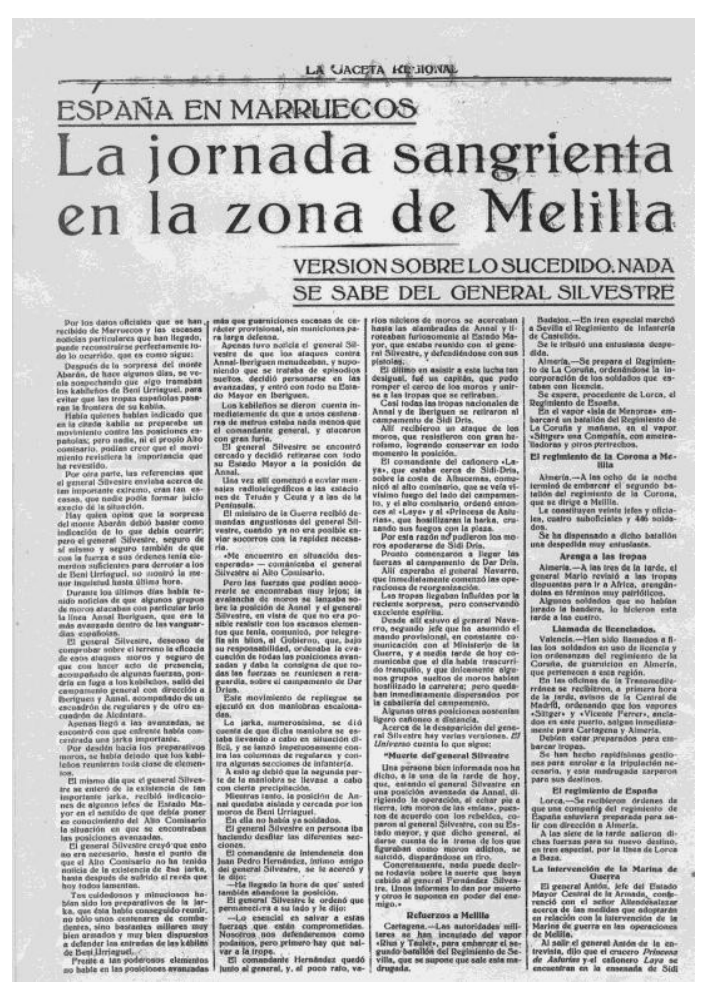

La Gaceta Regional, nº 277, 25 de julio de 1921, p. 2.

Visto el entusiasmo con que Salamanca había acogido a La Victoria y los esfuerzos desplegados para la construcción de unos cuarteles, cabía esperar la mezcolanza de tristeza y perplejidad que se impuso al conocerse el hundimiento de la región oriental del Protectorado en el Norte de Marruecos.

Pese a la fulminante instauración de la censura previa, que lógicamente afectó a los tablones en lugares públicos (fue el caso de los situados en la Plaza Mayor ${ }^{178}$ ), desde el día 25 de julio los periódicos, fundándose tanto en datos oficiales como en testimonios directos, intentaron reconstruir lo sucedido, mientras todas las tertulias de los salmantinos tenían por objeto lo ocurrido en Annual.

178 “La previa censura para la prensa”, El Adelanto, n 11.396, 26 de julio de 1921, p. 1. 
A propósito de la censura, debe señalarse que ésta tradicionalmente presentaba dos modalidades en su ejecución: la censura previa y la censura represiva. La primera se practicaba "a priori", mientras que la segunda se ejercía una vez que el ejemplar en cuestión ya había visto la luz. Evidentemente, en el primer caso era mayor la capacidad de maniobra del Poder.

Tras el Desastre de Annual y hasta el advenimiento de la dictadura, la tirantez se impuso en las relaciones entre la prensa y el Ejército. Asimismo, similar tensión dominó las relaciones entre los ejecutivos y el Ejército. Las incoherentes políticas de establecimiento y anulación de la censura previa fueron una demostración de ello: pese al comedimiento periodístico después de los sucesos del 21 y 22 de julio, durante las siguientes semanas todas las publicaciones fueron sometidas a la aprobación del censor. La crispación social y la inestabilidad política se habían convertido en los rasgos definitorios de la España de entonces. Por esta razón, para el gobierno del conservador Allendesalazar -el mismo que había sido la mano derecha de Maura en Marruecos durante su Gobierno Largo-, evitar la alarma social se convirtió en una tarea prioritaria.

Pero con el fin de borrar la pésima imagen ofrecida, sobre todo, después de la dramática rendición de Monte Arruit, su sucesor, Maura decidiría, de modo un tanto súbito, suprimir buena parte de la censura el 20 de agosto, y ello a pesar de las protestas de La Cierva. En la práctica, lo que se estableció fue un régimen de "libertad vigilada". Los africanistas también se mostraron claramente contrarios a esta medida. Y su desconfianza hacia la prensa fue en aumento. Al fin, la censura previa acabó por restablecerse el 13 de septiembre, dado que La Cierva consiguió imponerse a la par que el inicio de las operaciones de reconquista inclinaría la balanza del poder a su favor. Pero su triunfo fue breve y un mes después, el 19 de octubre, ante la creciente propagación de rumores de toda índole, se suprimió, una vez más, la censura previa por segunda vez ${ }^{179}$. Es fácil imaginar la confusión, cuando no rechazo, que estas políticas generaron.

Situándonos de nuevo en Salamanca, la desolación inicial, a su vez, pareció aumentar al conocerse el fallecimiento del general Silvestre, que era un personaje bastante conocido en Salamanca por haber sido amigo íntimo del diputado a Cortes y viejo compañero en la Guerra de Cuba.

\footnotetext{
179 ALMUIÑA FERNÁNDEZ, Celso: "La jurisdicción militar y el control de los medios de comunicación. Annual y la censura de material gráfico (1921)", Investigaciones Históricas. Departamento de Historia Moderna y Contemporánea, nº 6, Valladolid, 1986, pp. 217-235.
} 
"La impresión que los tristes sucesos desarrollados causó en Salamanca, fue tan honda como penosa. La ansiedad por conocer noticias de lo ocurrido fue grandísima. Cuando se tuvieron detalles de los tristes combates, y se supo el desgraciado fin del general Silvestre, la impresión fue aún mayor. El general Silvestre era conocido en Salamanca, por haber pasado aquí temporadas con su gran amigo el diputado señor Martín Veloz" $"$.

A la par que la Albuera limitó su programa de festejos para el día de Santiago, muy pronto se extendió el murmullo de que las tropas que guarnecían Salamanca habían de trasladarse, una vez más, a Marruecos. No obstante, por el momento sólo se tenía orden de que todos los regimientos peninsulares debían organizar sus batallones. Así que siguiendo estas instrucciones, se celebró un sorteo y resultó que el segundo batallón de La Victoria había de prepararse para una posible marcha. También se organizó un escuadrón mixto con las fuerzas de la Albuera ${ }^{181}$. Por su parte, la alcaldía decidió entretanto enviar al presidente Allendesalazar un telegrama de condolencia y admiración hacia los soldados fallecidos ${ }^{182}$.

Lo cierto era que desde comienzos del año 1921, la prensa local venía recogiendo entre sus informaciones del servicio telegráfico frecuentes alusiones a movimientos de tropas en el territorio de la Comandancia de Melilla. Tan pronto se tuvo noticia del fracaso militar, la redacción de El Adelanto se mostró muy sorprendida y apuntó a la deserción de las fuerzas indígenas como responsable del caos reinante en el momento de la retirada, a la vez que aplaudió la "inmolación heroica" de Silvestre. Apelaba al mismo tiempo y por sorprendente que resulte, al hastío que dominaba entre la opinión pública salmantina y argumentaba que si España no se hacía con el dominio de Tánger, centro de abastecimiento contrabandista, todo el Protectorado debería ser abandonado:

\begin{abstract}
"Aprovechando la clausura del Parlamento y el silencio al comentario que se ha impuesto la prensa sobre Marruecos, se han invertido más millones en créditos extraordinarios, y alli se siguen unas operaciones nuevas que ahora nos sorprenden, hiriendo profundamente nuestra alma de patriotas, la cobarde y traidora deserción de fuerzas indígenas y la inmolación heroica del general Fernández Silvestre.
\end{abstract}

\footnotetext{
180 "Los últimos sangrientos combates en Melilla", El Adelanto, no 11.395, 25 de julio de 1921, pp. 1-2.

181 "Notas militares", El Adelanto, n' $11.403,3$ de agosto de 1921, p. 1.

${ }^{182}$ Aunque esta decisión no quedó reflejada en el acta de la más inmediata sesión municipal: Actas de las Sesiones Municipales. Archivo Histórico Municipal, vol. 1921-1922, fol. 153-169 (v); "La Ciudad", La Gaceta Regional, $\mathrm{n}^{\circ}$ 277, 25 de julio de 1921, p. 5. Del mismo modo, la Diputación Provincial, en la sesión del 12 de agosto de 1921, decidió enviar un mensaje de adhesión al presidente del Consejo de Ministros y un telegrama de apoyo para el Alto Comisario. En Actas de la Diputación de Salamanca. Archivo de la Diputación provincial, vol. 1921, fol. 88 (r). En este día, en la sesión de la Comisión Permanente, se consignaron 2.000 pesetas para la suscripción que acababa de iniciar El Adelanto y otras 500 pesetas para los hombres de La Victoria: Actas de la Comisión Permanente de la Diputación de Salamanca. Archivo de la Diputación provincial, vol. 1921, fol. 85-86 (v).
} 
Como de Marruecos sólo se sabe lo oficial, que siempre es la mitad de la mitad, y lo poco que viene particular tiene que ceñirse a lo oficial, pues al que quiera decir la verdad lo echarían o algo más, con ello nos conformamos.

Sería curioso y muy instructivo poder saber el número total de muertos y heridos que le cuesta a España esa llamada obra civilizadora, iniciada en 1909, y que sigue derramando sangre al cabo de doce años. ¿A que no se atreven a ofrecerle al pueblo español ese cuadro estadístico? ¿Por qué no lo reclaman los diputados?

Ese cuadro sería el argumento más formidable para demostrar nuestra equivocación (...) Ensoberbecido el enemigo ante la tragedia en la cábila de Beni Urriaguel, la conciencia patria exige, como un ideal nacional, que si no es para que se nos otorgue Tánger lo demás no vale ni una gota más de sangre española"183.

Desafortunadamente, ésta fue la única ocasión a lo largo del verano de 1921 en que se pudo ver al diario de Núñez Izquierdo sosteniendo un pensamiento tan atípico; reivindicando el enclave tangerino con bastante más determinación que la exhibida durante la Gran Guerra; y aludiendo a la existencia de posibles responsabilidades de carácter militar. Porque tras la implantación de la censura previa, primó la idea de defender el honor patrio, "aprovechar este clamor unánime que pide venganza" ${ }^{184}$. Incluso, no faltó algún ataque hacia la indiferencia de los ciudadanos, más interesados en asistir a corridas de toros que en prestar su apoyo moral y material a los soldados ${ }^{185}$. Indudablemente, se trataba de una exageración.

Mucha más razón llevaba este diario al afirmar que Marruecos se había convertido en una obsesión. La redacción progresista, por ello, deseaba aplacar los ánimos de la opinión pública salmantina. Otra vez se equiparaba patriotismo y periodismo, mientras el rotativo sostenía que el pueblo debía luchar para mantenerse sereno y convencido de las motivaciones internas e internacionales que obligaban a España a permanecer en África:

"En vano queremos sustraernos a la obsesión que amartilla el cerebro nacional y es el ambiente que respira hoy día España: la guerra de Marruecos.

El general Berenguer tiene sobre sí la mirada del país entero y siente la grave responsabilidad que sobre él pesa, con ese crédito ilimitado de confianza que España ha puesto en sus manos.

Las altas dotes de mando serán pocas para resorte de la acción que a nosotros corresponde en Marruecos; es mandato internacional y es además un problema de permanencia vital, de instinto de conservación, el que España tiene sobre sí y que el Alto Comisario de hoy ha de despejar definitivamente.

Entre los que proclaman como un ideal nacional la españolización del Norte del imperio magrebí y los que repugnan nuestra intervención, amparándose en el previo postulado de nuestra reconstitución interior, los gobiernos españoles han necesitado de un tacto diplomático, de un oportunismo de acción y de una exquisita prudencia intranacional e internacional, sorteando difíciles escollos, hasta ahora salvados con el mínimo esfuerzo posible.

\footnotetext{
183 "Marruecos", El Adelanto, no 11.395, 25 de julio de 1921, p. 1.

184 “Así piensa España”, El Adelanto, no 11.399, 29 de julio de 1921, p. 1.

${ }^{185}$ La alegre y confiada España”, El Adelanto, n $11.398,28$ de julio de 1921, p. 5.
} 
El avance progresivo y pausado se hacía en las condiciones de afirmación utilizables, manejando los resortes de la atracción amistosa o el castigo rápido, según aconsejaban las circunstancias.

Pero ahora ya no se trata de eso (...) El general Berenguer, sereno ante la gravedad del momento, reciba sólo la sensación de que España es una tras él; que ni le espolea para nerviosismos audaces, ni le regatea elementos de acción; que ni le excita, ni le abandona $" 186$.

Fe ciega en el caudillo militar, en Berenguer. He aquí la idea articuladora de la propaganda bélica exhibida por El Adelanto. A esto había conducido Annual. Es más, muy pronto el periódico se imbuyó de entusiasmo y orgullo ante la rapidez con que las tropas acudían al Protectorado y el cariño con que eran despedidas en las estaciones de tren y muelles. Y se atrevió, incluso, a augurar que en unos meses la paz sería una realidad $^{187}$.

La censura previa recibió, no obstante, considerables ataques desde las páginas del diario de Núñez Izquierdo. Constituía una falta de seriedad por parte de los políticos que conociéndose lo esencial, el retroceso militar hasta las posiciones de 1909, se ocultase lo accesorio. Reprendía también este rotativo al gobierno el hecho de que no se explicase claramente cuál era el papel de España en Marruecos ${ }^{188}$. Pero a buenas horas... "Argos" siempre había estado sólo cuando solicitó estas aclaraciones.

En cualquier caso, desde mediados de agosto, la voluntad popular de revancha fue muy alentada por este diario mediante el recurso a los testimonios más despiadados y escabrosos del Desastre, habitualmente insertos en una sección de nueva creación bautizada como "Páginas de la guerra", y en la más efímera "Escenas de la guerra". Además, también coincidiendo con la formación del nuevo gobierno bajo la presidencia de Antonio Maura y el levantamiento de la censura previa -salvo en todo lo alusivo al movimiento de tropas ${ }^{189}$-, muy pronto se corrió la voz sobre lo vivido en Nador, Zeluán y, sobre todo, Monte Arruit. Todo ello sumado, indiscutiblemente, sirvió para espolear ese deseo de desquite.

Por primera vez, se reconocía que los rifeños no serían un enemigo fácil de derrotar. La Época había difundido que los rebeldes disponían de millares de fusiles, numerosos cañones, ametralladoras y abundantes municiones -como siempre, la “espinita” de Tánger-. El harca de Abd-el-Krim contaba, además, con jefes expertos y con unos combatientes de moral muy elevada. En efecto, la táctica del cabecilla de

\footnotetext{
186 "Un deber patriótico", El Adelanto, no 11.403, 3 de agosto de 1921, p. 1.

187 "Hasta el fin...", El Adelanto, n 11.405, 5 de agosto de 1921, p. 2.

188 “Organización y seriedad”, El Adelanto, no 11.406, 6 de agosto de 1921, p. 1.

${ }^{189}$ Alfredo Rivera: "La previa censura, suprimida", El Adelanto, no 11.418, 30 de agosto de 1921, p. 4.
} 
Axdir, en el corazón de la cábila de Beni Urriaguel, estaba resultando muy sencilla y eficaz. Únicamente había consistido en el ataque por sorpresa a los blocaos, apoyándose en esa lealtad sin condiciones de sus partidarios.

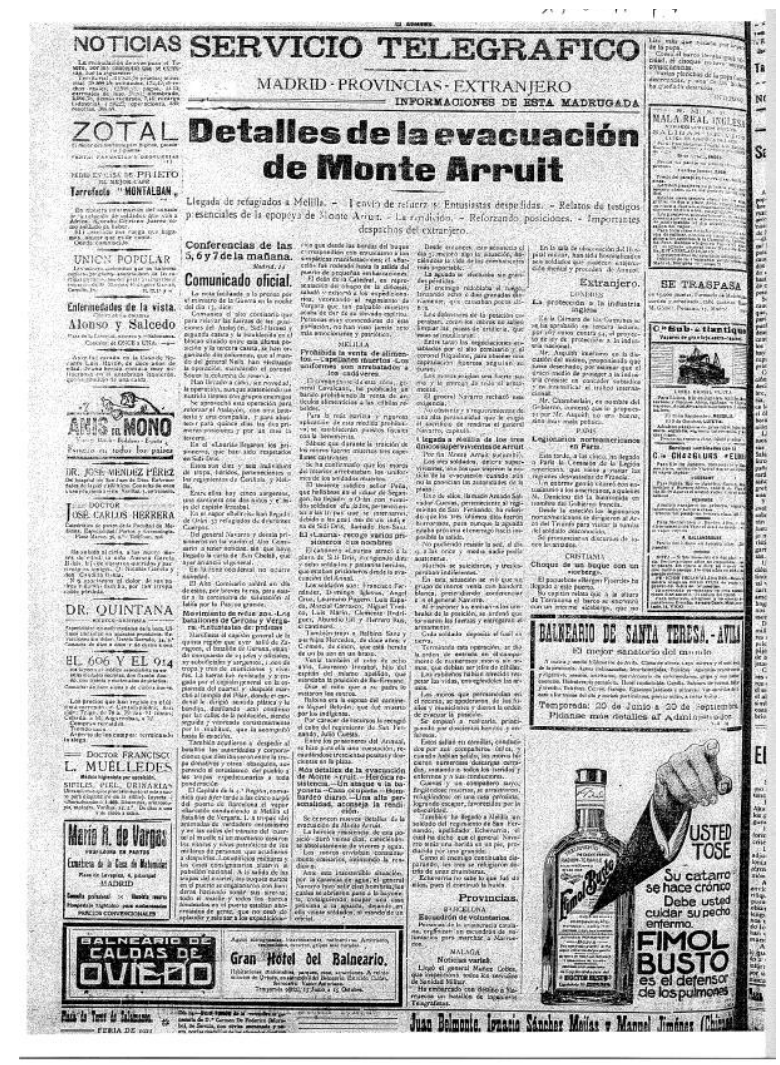

El Adelanto, $\mathrm{n}^{\mathrm{o}} 11.413,15$ de agosto de 1924, p. 4.

En definitiva, lo que se estaba planteando no era una lucha entre un Ejército de una nación civilizada y una partida de indígenas marroquíes, sino un enfrentamiento entre dos Ejércitos igualmente equipados ${ }^{190}$. Lógicamente, el alarmismo que este tipo de noticias generaba se utilizó de igual modo para combatir las actitudes derrotistas, que empezaban a cobrar fuerza. Lo que se predicaba, entiéndase bien, era resignación ante la sangre que la patria reclamaba para reponer su honor: "No es la hora de la crítica, ni de la reflexión; es la hora del corazón, que es la voz de la pasión más honda (...) Antes que preguntar por qué ha pasado esto o lo otro, que a dónde se va y por dónde y cuánto nos va a costar, hay que decir: es la honra de España"191.

En el mismo sentido, y en consecuencia, El Adelanto minusvaloró el asunto de las responsabilidades. Días antes de la dimisión del gabinete de Allendesalazar, Eza

\footnotetext{
190 “Se lucha contra un Ejército organizado?”, El Adelanto, no 11.410, 11 de agosto de 1921, p. 1. 191 "La dignidad de la raza", El Adelanto, no 11.412, 13 de agosto de 1921, p. 1.
} 
había ordenado al general Picasso la elaboración de un informe que sirviese para la depuración de las mismas. Berenguer había aceptado mantenerse en el puesto de Alto Comisario sólo a condición de que se le concediese inmunidad en estas investigaciones ${ }^{192}$. No obstante, para El Adelanto la cuestión era, por estas fechas, una preocupación absolutamente secundaria. La obsesión de este diario durante todo el verano de 1921 fue el desquite ${ }^{193}$, la revancha. Por ello, no dudó en aplaudir y sugerir continuos gestos de apoyo ciudadano hacia los combatientes, sin interrogarse acerca de las causas de la derrota. Esa generosidad siempre se entendió como una demostración de sano y moderado patriotismo; patriotismo que redacción de El Adelanto defendió y opuso al pesimismo que se apoderó del pueblo en 1909:

"El pais, dolorido y avergonzado por lo ocurrido en la zona melillense, dejando aparte para más tarde el exigir responsabilidades y atento sólo a vengar el ultraje inferido a nuestra bandera, ha despertado de su modorra (...) y la prensa, y los políticos, y los ricos, y los pobres, el país entero, dando ejemplo de entereza y de serenidad bien templada, se han levantado como un solo hombre y se han ofrecido en holocausto por la patria ${ }^{, 194}$.

La Gaceta, por su parte, presentó desde muy tempranamente todo lo ocurrido en la zona de Melilla como un incidente desgraciado e inesperado. Una de sus primeras reacciones fue interrogarse sobre cómo los rifeños habían obtenido tanto armamento. La sombra de la colaboración francesa cobraba protagonismo en el pensamiento de toda la redacción:

"No cabe duda alguna de que lo ocurrido en la zona de Melilla ha sido desgraciado (...) Pero hay cosas que importa poner en claro, y es la primera cómo pudo organizarse una harca enemiga de la importancia que supone lo sucedido, sin tener noticia de ello (...) No es hora, sin embargo, de disquisiciones acerca de eso, sino de acudir en auxilio de algo que está por encima de todas las políticas y de todas las orientaciones: la defensa de nuestra patria, y de nuestros hermanos que allí pelean. $Y$ en esto sí que ha de acudirse presto y con cuantos elementos se necesiten.

Un revés con tribus africanas, y aun en los campos de batalla, no es raro en ninguna nación del mundo; los Ejércitos coloniales, todos los han sufrido (...) Vése, desde luego, la falta, la imprevisión, lo que parece descuido; y no es más que un punto de vista subjetivo. La penetración debe hacerse de acuerdo con las tribus o

${ }^{192}$ A propósito del Expediente, consideramos muy acertado el siguiente comentario de Ángel Comalada: "Los gobernantes alfonsinos se vieron envueltos desde el principio en una contradicción que no haría sino patentizarse conforme pasaba el tiempo: la trabazón de sus reales intereses con los de un Ejército que era precisamente su gran valedor y suprema garantía de la corona frente a la ascendente marea del ciclo revolucionario; y, como lógica consecuencia, la necesidad de ponerlo a cubierto de cualquier investigación en profundidad que apuntase a sus graves vicios de estructura". Véase COMALADA, Ángel: Op. Cit., pp. 42-43.

193 Entre la publicística del momento, la misma idea puede apreciarse, por ejemplo, en la obra de Francisco Bastos Ansart: "Que no haya perdón, que serenamente comprendamos que sólo por la violencia, destruyendo, podemos actuar; que al destrozarlos, podemos decir 'ellos lo han querido asi'". Véase ANSART, Francisco: El Desastre de Annual: Melilla en julio de 1921. Barcelona: Minerva, 1921, p. 52.

194 “A.": “Concepto de un deber", El Adelanto, no 11.428, 1 de septiembre de 1921, p. 1. 
sobreponiéndose a ellas. Pues ese es el magno problema, que tiene escuelas y partidarios. Ambas han fracasado alternativamente. Se han ensayado las dos y las dos tienen piedra negra en sus fastos. ¿Qué hacer, pues?

Si ahora hubiera el general Silvestre llegado al mar y conquistado Alhucemas, sometiendo a las cábilas indómitas de la costa, que no han conocido autoridad superior a la suya, ni han reconocido más sultán que el que se han dado ellos, hubiérase dicho: Ése es el sistema; la mancha de aceite, la dádiva, el engaño (...) Pero en 48 horas, todo se ha ido a tierra por la traición de los mismos elementos en que se apoyaba el sistema. ¿Entonces?

Entonces el problema no es puramente guerrero ni de entrega, sino de psicología de las tribus y las gentes ${ }^{\prime 195}$.

En resumen, había fracasado la penetración pacífica, pero también la militar. ¿Y qué convenía entonces? Convenía, se puede deducir al leer entre líneas, acabar con las indecisiones de los gobiernos. Pero, por de pronto y al igual que en el caso de $E l$ Adelanto, o incluso de modo más pronunciado, el asunto de la búsqueda de responsables quedaba relegado ante la urgente necesidad de vengar el honor patrio. Como siempre, ésta era la piedra angular del discurso propagandístico conservador.

En cuanto a la censura de prensa, el diario rechazó la labor indiscriminada efectuada por Millán de Priego, entendiendo que éste la ejercía sin demasiado acierto y así únicamente lograba sembrar la intranquilidad:

"Basta ojear la prensa para apreciar el fenómeno unánime -o casi unánime- de la serenidad primero, de la reacción después, que se ha producido en España con ocasión de los tristes sucesos de Melilla. (...) Entusiasmo, manifestaciones en favor de la patria y adhesión fervorosa en pro del Ejército español (...) Se palpa en todas partes algo viril, algo confortante para la idealidad. El descalabro pasado no ha deprimido el ánimo, sino que lo ha encorajinado hasta tal punto que a gentes despreocupadas y hasta indiferentes a la campaña marroquí, se les oye gritar: 'Eso no puede pasar; la traición y la felonía no pueden quedar impunes. Por honor ha de buscarse el desquite y el castigo, cueste lo que cueste. Luego será ocasión de liquidar cuentas y exigir responsabilidades'. Éste es el espíritu público.

Pues acontecido todo esto, y con la opinión de la prensa, que es el vehículo y el arma más poderosa de acción sobre las masas populares, la censura policíaca del señor Millán de Priego que se ejerce en las conferencias telefónicas y telegráficas de provincias es capaz de dar al traste con el buen deseo (...) Nosotros -aunque sometidoshemos de protestar de esa censura analfabeta y estúpida",196.

De todos modos, La Gaceta no fue contraria a la práctica de la censura como tal, pero sí que lamentó el hecho de que desde el gobierno se entorpeciese su esfuerzo por "levantar el espíritu patriótico"197. Y es que, por descontado, el diario entendía que ésta era su prioritaria obligación moral. Por este motivo, varios de sus editoriales durante los meses inmediatos al Desastre fueron encabezados con el título "El sentir público". Su

\footnotetext{
195 "Claridad y firmeza", La Gaceta Regional, n 278, 26 de julio de 1921, p. 1.

${ }^{196}$ Buenaventura Benito: "Voces en el desierto. El espíritu público", La Gaceta Regional, no 280, 28 de julio de 1921, p. 1.

197 "Teoría de actualidad", La Gaceta Regional, n 289, 8 de agosto de 1921, p. 1.
} 
objetivo era procurar la adhesión de la opinión ciudadana para con la política revanchista que estaba a punto de poner en funcionamiento Dámaso Berenguer, una vez que lograse un mínimo grado de instrucción para los soldados que continuamente partían hacia Marruecos.

Como ejemplo, Buenaventura Benito, uno de los periodistas más destacados de la redacción, presentaba ante sus lectores a unos tertulianos de café y mostraba cómo los salmantinos, al igual que el resto del país, estaban divididos y enfrentados: unos defendían el abandono inmediato; otros, la guerra a toda costa; y un tercer grupo, el desquite urgente aunque carente de reflexiones acerca del futuro. Curiosamente, la escena recuerda muchísimo a otra que, años atrás, esbozaba Juan de Salamanca. Sin embargo, la situación marroquí había cambiado de manera significativa desde entonces, desde 1909: el Sultanato había perdido su independencia, mientras que España y Francia, aliadas aunque también rivales, habían adquirido un creciente compromiso en la administración de aquel territorio. La opinión pública salmantina, por su parte, seguía muy desorientada ante la cuestión marroquí, pero infinitamente más harta a causa de la prolongación del conflicto. Si bien la siguiente cita es muy extensa, consideramos que merece la pena su reproducción. Tenemos la convicción de que el estilo costumbrista es el que con mayor facilidad nos permite aproximarnos a la atmósfera del momento, al clima de la opinión pública local:

"Como todos los días, hoy me he sentado junto a una mesita de la terraza y he pedido café. El camarero ha traído la copa con el azúcar y ha servido puntual. Los amigos han preguntado por noticias y la conversación ha recaído sobre la guerra contra los rifeños y sobre la política (...) Pronto se han descubierto los tres tipos representativos de la opinión española: el radical, el moderado y el guerrero. Ha pedido el primero la abstención absoluta, el abandono fulminante de la zona marroquí. No quiere oír hablar de guerra civilizadora, ni de operación de policía, ni de necesidades nacionales, ni de mandatos europeos, ni de tratados firmados, ni de nada. Para él, no hay agravio que vengar, ni Desastre que corregir, ni traición que castigar. Su fórmula no puede ser más simplista: 'cada uno en su casa manda'. Bastante Marruecos -exclama-tenemos en España.

Ha estallado el tipo guerrero, sin poderse contener. Califica de fementida, cobarde y deshonrosa la opinión anterior. Invoca el nombre de la patria, menoscabado por lo ocurrido; no comprende el espíritu abstencionista del abandono; la sangre de los hermanos -dice- reclama intervención y venganza. España es mandataria de la Europa civilizada en esa zona; se han firmado convenios internacionales que han de cumplirse; necesitamos dar la sensación de pueblo fuerte y digno; tenemos tradición histórica hacia la frontera, y no podemos consentir que frente a un Gibraltar se levante otro y perdamos el dominio del Estrecho. Antes que eso -resume- deben agotarse todos los medios y emprender la conquista, cueste lo que cueste, de todo el territorio, desarmando a las cábilas y sometiéndolas con las armas sin cuartel. No quiere oír hablar de paz, ni de retiradas, guerra dura y cruenta para escarmiento de traidores.

$Y$ la polémica se ha enardecido, y (...) ha intervenido un tercero, demandando calma. 
Él ha vivido estos días en el pueblo; ha oído y palpado el sentir de los campesinos; ha escuchado conversaciones de gentes sencillas y resume su impresión con estas frases: 'El pueblo no sabe si necesitamos o no Marruecos; no conoce tratados, ni discute nada de eso; ignora si debe ser o no frontera, pero se ha percatado de que hijos suyos han muerto a traición; que los soldados españoles han sufrido bochornos inmerecidos y afrentas de ignominia, y quiere reparación, y pide que eso no quede así, y por eso desea que se vengue -asi dice el pueblo- que se vengue lo sucedido. Por eso acude con ofrecimientos al gobierno, y asiste con emoción a la salida de las tropas; ofrece lo que le piden, porque en su alma ha sentido el latigazo del Desastre. No hay que darle vueltas -termina diciendo-. El pueblo habrá pensado antes lo que pensara; habrá querido que se abandonase antes; hoy no. Hoy no quiere más que se castigue, y se remedie rápidamente lo hecho. Después... será otra cosa,",198.

Prevalecía, sin duda, la tercera opción: porque la primera, la abandonista, pecaba de simplismo; mientras que la segunda apelaba a razones demasiado abstractas para el pensamiento popular. Por consiguiente, el desquite, el posicionamiento más emotivo y menos analítico, se convertía la opción triunfante.

Para reforzar esa misma idea, no dudó la redacción en dedicar, en repetidas ocasiones, la oportunamente creada sección “España en Marruecos” a presentar al rifeño como un individuo traidor por naturaleza y fanático. Intentaban nuevamente atraer a la opinión pública salmantina hacia las posiciones más belicosas:

"El descalabro sufrido exige una reparación inmediata, repiten todos los periódicos de la Península, y así en efecto lo han comprendido los que manejan las riendas de la nación y, sobre todo, el Alto Comisario, que organiza ya la ofensiva, y a cuyo llamamiento acuden los soldados hispanos, llenos de ardor bélico, que empuñan las armas, impacientes por vengar tanta injuria "199.

Por último, en las páginas del periódico conservador también se buscó la exacerbación del sentimiento patriótico mediante el aplauso dirigido hacia los salmantinos solidarios:

"Es hermosa esta florescencia de patriotismo salmantino. La ciudad quieta, pacifica, severa, se agita en estos días, y sus autoridades, sus asociaciones, sus prestigios, el pueblo en masa, imagina y encuentra medios de manifestar que ama a la patria, que admira y adora a los soldados que van a defenderla, que siente sus penalidades, y que en cuanto de Salamanca dependa, no ha de faltar nada a nuestros soldados, y que a donde no lleguen nuestros recursos, llegará nuestro amor, que es omnipotente,"200.

\footnotetext{
${ }^{198}$ Buenaventura Benito: "El espíritu público y la guerra", La Gaceta Regional, $\mathrm{n}^{\circ} 302,24$ de agosto de 1921 , p. 1.

${ }^{199}$ Luciano S. Fraile: "Sin sacrificio no hay patriotismo", La Gaceta Regional, no 304, 26 de agosto de 1921, p. 1.

200 “¡Bien por Salamanca!”, La Gaceta Regional, n 293, 12 de agosto de 1921, p. 1. En la misma línea, unos días después, al aproximarse la fecha para la marcha del batallón de La Victoria, el diario reproducía unas palabras de Vázquez de Mella: "Dios misericordioso, protégelos (...) Van a defender la honra de la Patria (...) Es la eterna lucha del cristianismo contra el infiel; es la Patria y la Religión contra la horda y el fanatismo", "A nuestros soldados. Que Dios os proteja. iViva España!", La Gaceta Regional, $\mathrm{n}^{\circ} 297,18$ de agosto de 1921, p. 1.
} 
Buenaventura Benito intentaba explicar a qué obedecía esta unánime reacción y concluía así:

"El pueblo español desea la revancha en Melilla, como castigo a una traición (...) Resulta curioso este cambio psicológico de las multitudes, que han maldecido cien veces la guerra africana, que presentaban hosca repugnancia a estos problemas, que no comprendían, y ahora ofrecen, en dádiva generosa, cuanto se necesita para la campaña. Ha sido indudablemente el resorte sentimental la causa de esta actitud. La traición de gentes que han vivido al amparo y protección de nuestros soldados, que han convivido con los nuestros, partiendo el pan en paz, ha sublevado a las almas sencillas, que en el fondo conservan vigoroso y radiante el sentimiento de lealtad. La sangre y muerte de hermanos reclama castigo en todos los códigos y leyes del mundo (...) Es estas horas de inquietud, y en tanto se liquida la empresa, el frente debe ser uno, y el único, en Marruecos y en España,"201.

Debe señalarse que, aunque este diario aplaudía gran parte de la ideología maurista, en lo tocante a la gestión del Protectorado, excepcionalmente, La Gaceta se mostró muy recelosa. Incluso, durante varios días se tomó la molestia de publicar, de forma sesgada, un extenso discurso que Maura había pronunciado en el Congreso, en 1914, con el propósito de desacreditar la idea de que España debía limitarse a la ocupación de las costas africanas para garantizar su independencia ${ }^{202}$. De hecho, éste constituyó el inicio de una campaña contra los bautizados como "derrotistas agoreros", que no hacían sino obstaculizar la generosidad hasta entonces mostrada por Salamanca $^{203}$.

Por último, para El Pueblo, nuevo órgano de la Federación Obrera Salmantina, el derrumbe de la Comandancia de Melilla fue, ante todo, una desgracia previsible. Pero si bien esta publicación negó el factor sorpresa de la debacle militar, lo cierto es que con anterioridad a julio de 1921 no hemos podido localizar en este periódico ninguna alusión a lo que ocurría en el Protectorado. El mismo periódico se justificaba afirmando que había procurado reservar su opinión ante todo lo sucedido desde 1909, para así evitar la previsible actuación del censor. Como cabía prever, al igual que El Adelanto, el rotativo obrero también mostró toda su hostilidad hacia la censura ministerial. Por eso, un irónico Rueda Pardo exclamaba: “inclinémonos ante el lápiz rojo!”204. El mismo columnista tildó de incoherencia el hecho de ocultar información a la ciudadanía,

\footnotetext{
201 "El aviso de Melilla", La Gaceta Regional, no 305, 27 de agosto de 1921, p. 1.

202 "La visión del problema de Marruecos", La Gaceta Regional, n 306, 29 de agosto de 1921, p. 3; "La visión del problema de Marruecos", La Gaceta Regional, n 308, 31 de agosto de 1921, p. 3; "La visión del problema de Marruecos", La Gaceta Regional, no 316, 9 de septiembre de 1921, p. 3; y "El discurso del señor Maura", La Gaceta Regional, n 382, 26 de noviembre de 1921, p. 3.

203 "Del espíritu salmantino. Refulge el patriotismo", La Gaceta Regional, n 312, 5 de septiembre de 1921, p. 1.

${ }^{204}$ Rueda Pardo: "La cuestión de Marruecos y la mordaza ministerial", El Pueblo, n 22,7 de agosto de 1921, p. 4.
} 
cuando su entrega era tan constantemente aplaudida, y reivindicó una depuración inmediata de las responsabilidades de toda índole.

Aunque el discurso de la Federación Obrera no se fundó en un rechazo ético hacia el paternalismo subyacente de toda política imperialista, sino en la constatación de la incapacidad -intelectual y económica- española y en la oposición ante un injusto sistema de reclutamiento militar. Así lo plasmaba, a principios de agosto de 1921, "Don Ruperto" en un editorial que llevaba por título "Paz a los muertos":

"En cuantas ocasiones se ha empleado la frase que encabeza estas líneas, tal vez no tuviera la apropiación que en las actuales circunstancias.

Es en estos días luctuosos ante la tragedia marroquí el tema que late, mordaz, en el alma española. Acaso por vez primera este pueblo entumecido por la contumacia servil haya despertado el espíritu ciudadano para darse cuenta de la magnitud del problema que se nos ha impuesto en ese país; panteón donde yace sepultada la juventud española, el vigor de la raza y la economía nacional.

Estamos conformes en que a esas tribus salvajes se les ponga en contacto y relación directa con los pueblos cultos y civilizados (...) Pero eso no ha sabido hacerlo España en doce años que llevamos de permanente protectorado (...) No podemos creer que los que nos comprometieron a esa empresa, ignoraban la situación económica de España y la falta interior de reconstitución nacional; por tanto, la responsabilidad moral y material de cuanto nos ocurre en la zona de Marruecos obra suya es; que el pueblo, el verdadero soberano, ignora en absoluto a los que alli estamos comprometidos; y él, que da su sangre y su dinero, tiene derecho a saber en qué se emplea.

Hoy vive latente en el corazón de todos los españoles, la horrible tragedia; y de antemano no faltan espíritus mezquinos que carguen la responsabilidad de lo sucedido en los que allí sucumbieron "205.

El general Silvestre, por consiguiente, quedaba exculpado, pero el obrerismo ya

adivinaba que su figura iba a ser instrumentalizada como chivo expiatorio del Desastre.

La llegada de Maura y La Cierva al gobierno fue muy mal acogida por este sector de la opinión, ya que a ambos personajes se responsabilizaba del anterior tropiezo de 1909:

"Siempre ha sido España la nación de los saltos mortales, de los fracasos ruidosos sin ninguna responsabilidad para nadie (...) A un incapaz, a un inepto, no se le puede pedir responsabilidades como no se puede pedir juicio a un irracional. Y como no puede pedirse esta responsabilidad a los políticos de los fracasos, éstos vuelven tranquilamente a ser usufructuadores del Poder y a exponerse al ruidoso salto mortal que ponga en peligro, no sus reputaciones, sino acaso la vida de los demás.

(...) Que Maura y Cierva -los hombres de 1909- sean los llamados en estos momentos angustiosos de España para solucionar el problema de Marruecos no tiene nada de importancia. Tras de un fracaso pueden volver a fracasar y así aumentan un mayor número de éstos a su historia ya larga de ellos. Lo que nos extraña no es que ellos acepten -ipor patriotismo siempre!- este sacrificio de gobernar. Lo que sí extraña es que puedan ser llamados a este sacrificio dichos hombres ya luengamente nefastos y que no se tenga en cuenta sus errores anteriores, no para pedirles cuenta de ellos por su carácter de irresponsables, sino para comprometerse a que reincidan "206.

\footnotetext{
205 "Don Ruperto": "Paz a los muertos", El Pueblo, no 23, 28 de agosto de 1921, p. 4.

${ }^{206}$ Rufino Aguirre: "El sentido de la responsabilidad”, El Pueblo, no 24, 11 de septiembre de 1921, p. 1.
} 
La irresponsabilidad, en definitiva, alcanzaba a todos porque todos adolecían de una notable ausencia de cultura política. Y como síntoma, todos los actos de apoyo a los combatientes, "la epidemia de las suscripciones", no hacían sino divulgar un concepto equívoco de patriotismo y se alimentaban de un visceral y primario afán de revancha potenciado por la "prensa burguesa"207.

\section{La Victoria en la guerra. El afecto salmantino hacia sus expedicionarios}
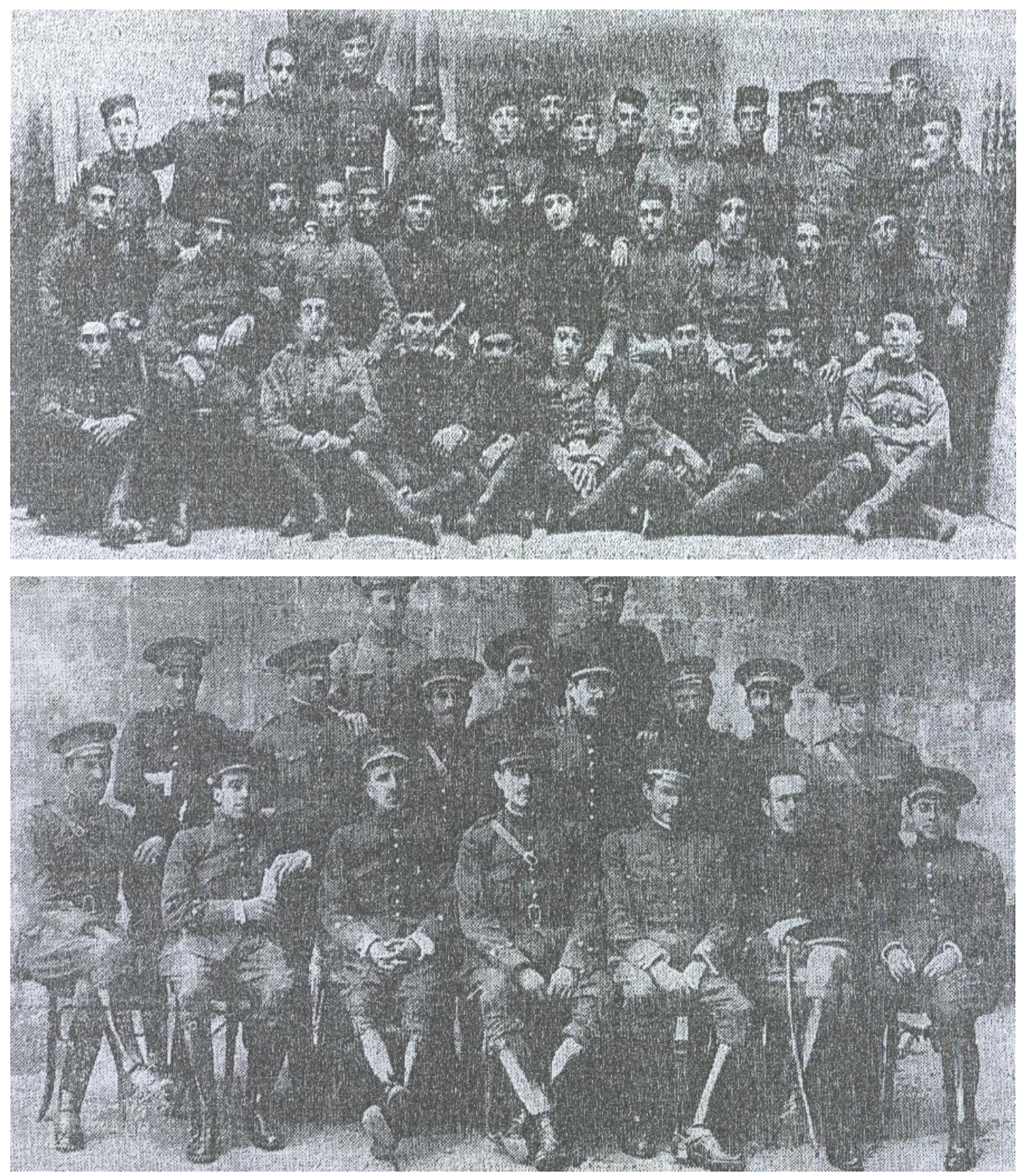

Fotografías publicadas en El Adelanto, no 11.423, 26 de agosto de 1921, p. 1.

\footnotetext{
${ }^{207}$ Rueda Pardo: "Patriotismo mal entendido", El Pueblo, no 24,11 de septiembre de 1921, p. 4.
} 
A mediados de agosto se confirmó, finalmente, la noticia más temida. El segundo batallón del regimiento de La Victoria debía trasladarse a Ceuta. Así comunicó el alcalde, Benito Paradinas, la noticia ante su gente:

“'Salmantinos! El segundo batallón del regimiento de La Victoria, de guarnición en esta plaza, ha sido destinado al Ejército de operaciones en África, para donde saldrá dentro de pocas horas.

Va a cumplir su deber defendiendo el honor de España y acude en auxilio de nuestros hermanos, que así lo desean.

Ante lo irreparable, no cabe más que una opinión y una voluntad; España tiene que triunfar y su bandera que ser enarbolada en toda la zona de África, que ha sido regada con nuestra sangre, cuyas manchas señalan hoy el límite de la patria y cuya tierra, bendita porque cobija restos de nuestros heroicos soldados, no puede ser mancillada por la cábila rifeña.

Acudid todos a la estación (a la hora que se anunciará oportunamente) para despedir al batallón de La Victoria, en el momento de emprender su viaje para tan patriótica empresa.

El sentimiento en despedirlos se compensa con la esperanza segura de que pronto podamos volver a esperarlos victoriosos ${ }^{\text {"208. }}$.

El batallón expedicionario quedó, poco después, constituido por 1.040 individuos de tropa, todos los del primer y segundo año de servicio. Sorprende que casi 700 hombres fueran "cuotas" (desconocemos qué porcentaje representa esta cifra sobre el total de mozos del primer y segundo año que entonces guarnecían la ciudad. Pero no dudamos del valor aleccionador/narcotizador de este dato). A ellos había que sumar la oficialidad, una compañía de ametralladoras del regimiento de Isabel II, que entonces guarnecía Valladolid, las ordenanzas de la Capitanía General y de los gobiernos militares de Ciudad Rodrigo y Cáceres, y por último, dos compañías más de La Victoria que se hallaban destacadas en Béjar ${ }^{209}$.

La ansiedad se convirtió en la nota dominante de la capital hasta que se confirmó la fecha de la partida, que habría de producirse el 25 de agosto. Mientras tanto, Salamanca estaba abarrotada de gente que acudía a despedir a sus familiares; y la prensa intentaba calmar los ánimos al presentar el territorio de la Comandancia de Ceuta como la zona más pacífica del Protectorado, aunque sin renunciar por un instante a estimular el deseo de revancha ${ }^{210}$.

\footnotetext{
208 "Proclama del alcalde al público salmantino", La Gaceta Regional, n 293, 12 de agosto de 1921, p. 11.

209 "La marcha a Marruecos de las fuerzas de La Victoria”, El Adelanto, n 11.411, 12 de agosto de 1921, p. 3 .

210 "La marcha de las tropas de La Victoria a Ceuta", El Adelanto, n' 11.422, 25 de agosto de 1921, p. 1. La Gaceta, paralelamente, publicaba insistentemente en estas fechas copillas de inspiración similar a la que sigue: "Las ofensas a la patria / no se pueden aguantar / dame el cuchillo, madre / que me voy a pelear", "La marcha de los soldados", La Gaceta Regional, no 299, 20 de agosto de 1921, p. 7.
} 
Con un idéntico propósito tranquilizador, pocos días antes de la marcha, la redacción de El Adelanto informaba de que el soldado de cuota Ricardo Pedraza se ocuparía de relatar para los lectores salmantinos cómo se desarrollaba la vida en campaña de los soldados de La Victoria ${ }^{211}$. Y unos días después, también La Gaceta anunciaba que el cabo de cuota Jerónimo García de la Cruz enviaría periódicamente crónicas para el rotativo conservador ${ }^{212}$. La Victoria se convirtió así en el principal nexo, y sobre todo, el más emotivo, entre los salmantinos y la Guerra del Rif, de tal modo, que sus avatares en África tuvieron un impacto decisivo en el posicionamiento de la opinión pública local ante este conflicto (consúltese, en el apéndice, el historial de la campaña). No obstante, conviene tener presente que, además de en este regimiento, algunos salmantinos también viajaron hasta el Protectorado, como integrantes de otros regimientos que apenas recibieron atención desde la prensa local.

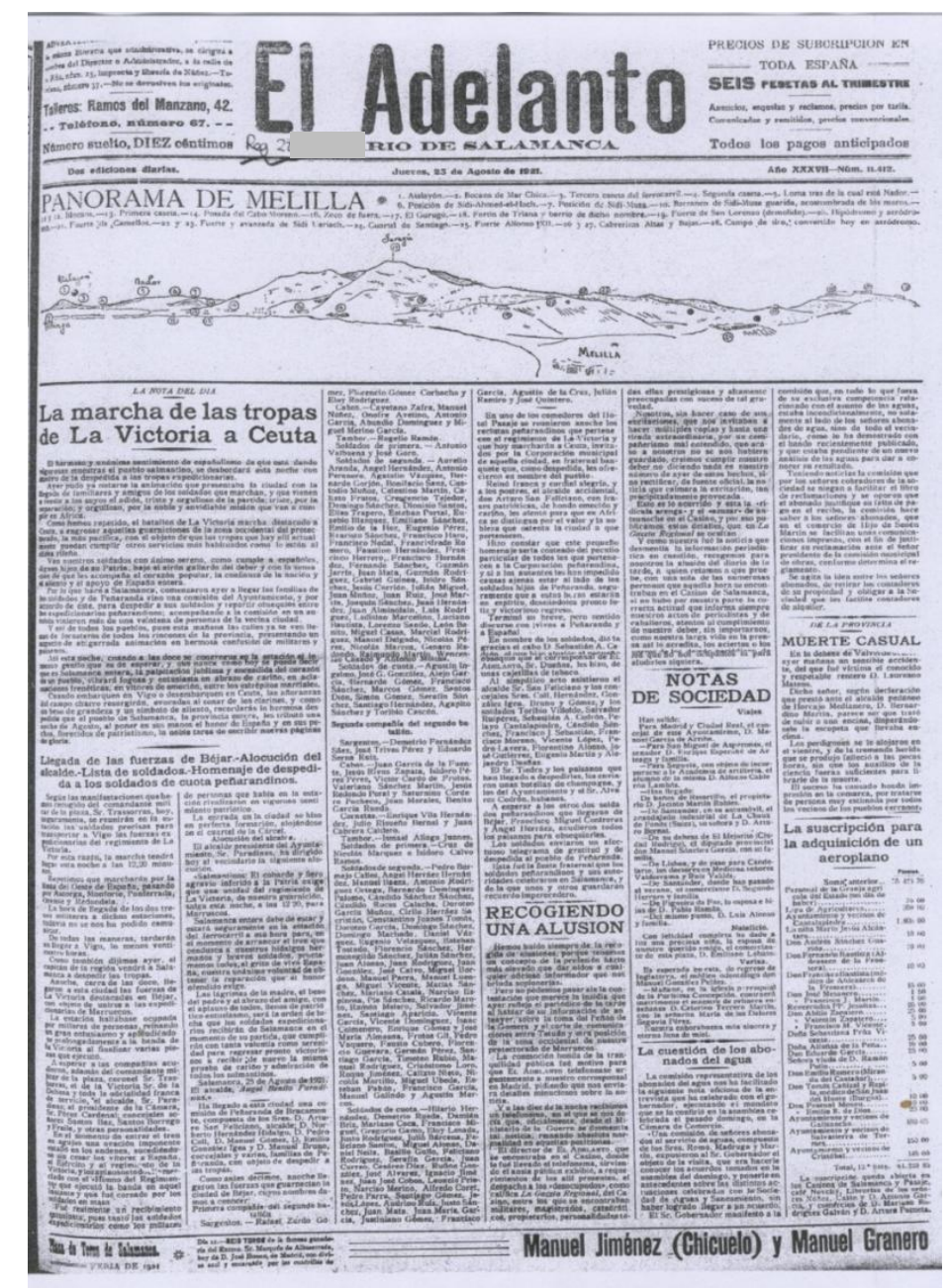

El Adelanto, n 11.422, 25 de agosto de 1921, p. 1.

211 “A.": "Cuando parta la tropa", El Adelanto, no 11.419, 22 de agosto de 1921, p. 3.

212 “La Ciudad”, La Gaceta Regional, no 304, 26 de agosto de 1921, p. 11. 
Como cabía esperar, la noche de la despedida fue un momento de confusa mezcla de tristeza, entrega y, ante todo, orgullo. Desde El Adelanto, alguien comentaba:

"Quien dijera de la impopularidad de la cuestión de Marruecos, quien creyera en la apática frialdad de nuestro pueblo, quien estimara acorchada, adormecida, la sensibilidad cívica de Salamanca, habrá sido arrollado por la torrentera desbordada de corazones, henchidos de sentimiento patriótico, que anoche simbolizó la despedida del batallón expedicionario de La Victoria (...) Salamanca tributó anoche a los soldados de La Victoria una despedida saturada de patriotismo, excitante, estimuladora y ejemplar ${ }^{213}$.

\section{Y en La Gaceta se insertaba este otro comentario:}

"Entre vítores y aclamaciones, vestida de gala la ciudad, iluminada, con la animación y efervescencia de los días grandes, Salamanca ha despedido a sus soldados. Jamás en la ciudad serena y reposada, se hubo contemplado tan grande entusiasmo, escenas tan emocionantes, clamores tan patrióticos. El genio de la raza, el alma nacional, todas las virtudes sociales y todos los esplendores de nuestra historia, han revivido unas horas en nuestra ciudad, y se ha sentido grande, heroica, dominadora, invencible ${ }^{, 214}$.

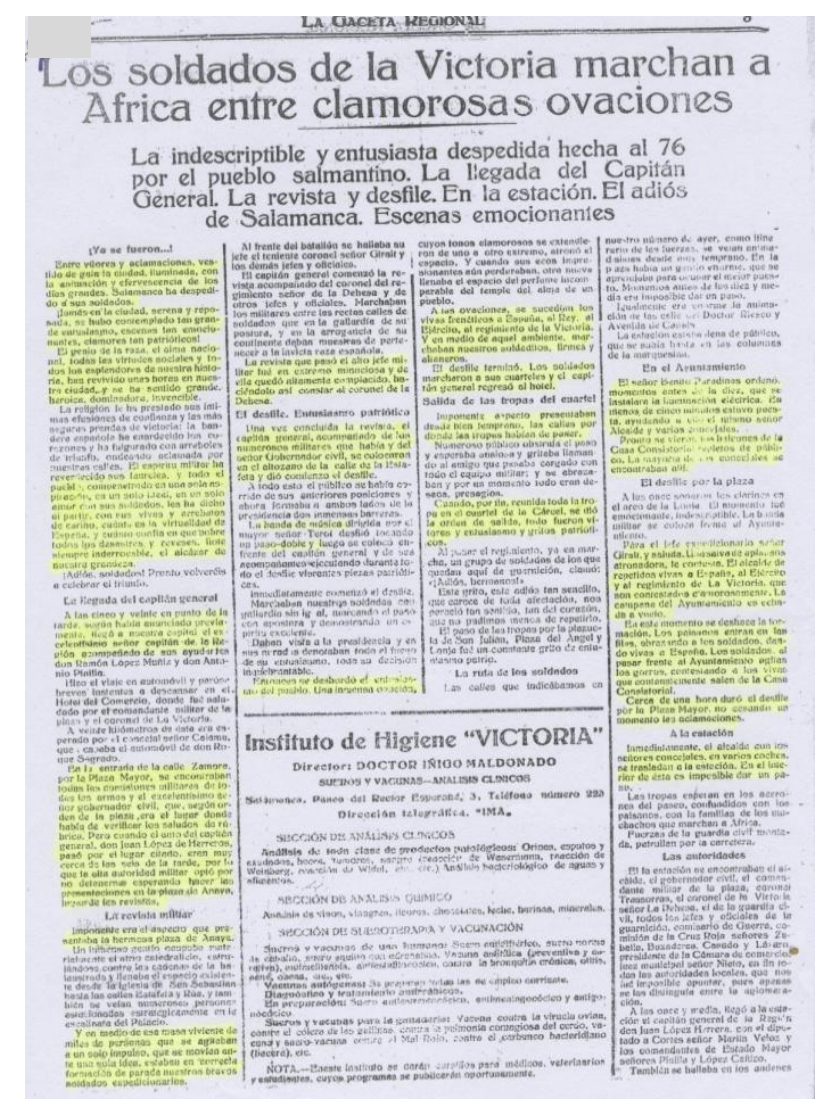

La Gaceta Regional, n 304, 26 de agosto de 1921, p. 3.

\footnotetext{
213 "La grandiosa despedida de Salamanca al batallón de La Victoria que marcha a Ceuta", El Adelanto, $\mathrm{n}^{\circ}$ 11.423, 26 de agosto de 1921, pp. 1-2. Seguidamente, el diario de Núñez Izquierdo describía el desarrollo del banquete de despedida, los obsequios recibidos por la tropa, el desfile hasta la estación, y la partida. Todas estas informaciones se acompañaban con una foto de la oficialidad del batallón expedicionario y con otra en la que aparecían un grupo de soldados.

214 "Los soldados de La Victoria marchan a África entre clamorosas oraciones", La Gaceta Regional, ${ }^{\circ}$ 304, 26 de agosto de 1921, pp. 3-4.
} 
La salida del batallón estaba prevista para pasada la media noche, aunque hubo de retrasarse porque los familiares retenían a sus soldados más de lo esperado ${ }^{215}$. Siguieron estas fuerzas la conocida como Línea del Oeste, pasando por Astorga, Monforte, Ponferrada, Orense y Redondela, y siendo siempre acogidos entre clamores y con incontables donativos ${ }^{216}$. En Vigo, la tropa y la oficialidad debían embarcar con destino a Ceuta ${ }^{217}$, pero el día 29 se supo que el batallón había recibido una nueva orden de dirigirse a Larache ${ }^{218}$. Al fin, el 31 de agosto llegó La Victoria al campamento de Nador $^{219}$ (no confundir con el de la Comandancia de Melilla).

Los primeros comunicados y crónicas de Pedraza y de García de la Cruz sobre esta posición estuvieron repletos de detalles costumbristas, quizá por la sorpresa que acarreó el cambio de destino a última hora. Nador era presentada como una posición tranquila y la vida que allí llevaban los salmantinos era bastante relajada. Ocupaban casi todo su tiempo en tareas de instrucción y baños en la playa, mientras que su salud era estupenda $^{220}$. Lamentablemente, a la calma le sucederían varias noticias tempestuosas.

Además de las informaciones sobre el dramático hundimiento de la zona oriental del Protectorado y del exhaustivo seguimiento de la reacción gubernamental, la prensa salmantina, con la notoria salvedad de El Pueblo, dejó detalladísima constancia de todos los gestos, ya fuesen individuales o colectivos, a título particular u oficialmente, de apoyo a los combatientes en tierras africanas. Y es que las manifestaciones populares de solidaridad con los soldados, y más concretamente, con el batallón salmantino, fueron incontables, alcanzando proporciones hasta entonces desconocidas.

Ya en la tempranísima fecha del 29 de julio, la Comisión Provincial de la Cruz Roja comunicó que se disponía a ofrecer a los familiares de los soldados combatientes

${ }^{215}$ ESPERABÉ DE ARTEAGA, Enrique: Op. Cit., p. 286. También este profesor de la Universidad describió la despedida como "patriótica, estimuladora y ejemplar".

${ }^{216}$ García de la Cruz: "El batallón de La Victoria”, La Gaceta Regional, no 306, 29 de agosto de 1921, p. 1.

${ }^{217}$ García de la Cruz: "El batallón de La Victoria", La Gaceta Regional, nº 313, 6 de septiembre de 1921, p. 1.

218 “El batallón de La Victoria recibe orden de variar su destino e ir a Larache”, El Adelanto, no 11.426, 30 de agosto de 1921, p. 3.

219 "La llegada a Larache del batallón de La Victoria", El Adelanto, n 11.429, 2 de septiembre de 1921, p. 1; y "La Ciudad", La Gaceta Regional, no 310, 2 de septiembre de 1921, p. 11.

${ }^{220}$ Pedraza: "El batallón de La Victoria en Larache", El Adelanto, $\mathrm{n}^{\circ} 11.431,5$ de septiembre de 1921, p. 1; Pedraza: "La estancia del batallón de La Victoria en Larache", El Adelanto, no 11.434, 8 de septiembre de 1921, p. 2; Pedraza: "Nuestro parte diario", El Adelanto, no 11.435, 9 de septiembre de 1921, p. 2; García de la Cruz: "El batallón de La Victoria", La Gaceta Regional, n 315, 8 de septiembre de 1921, p. 2; y García de la Cruz: "El batallón de La Victoria", La Gaceta Regional, n 317, 10 de septiembre de 1921, p. 3. 
en África la posibilidad de recibir informes sobre su paradero y estado de salud ${ }^{221}$. Por eso se convirtieron en habituales en la prensa los espacios dedicados a notificar el destino de centenares de jóvenes. Aunque no faltaron algunas quejas ocasionadas por la lentitud del servicio, comprensible, por otro lado, dado que el caos de la región melillense era enorme. De todas formas, la Cruz Roja se mostró reiteradamente como una institución que se desvivía por satisfacer a las familias salmantina. Y así lo recogió, sobre todo, la prensa de signo conservador ${ }^{222}$ :

"La Cruz Roja Salmantina, dispuesta en cualquier instante a sacrificarse en loor de sus hermanos y de su España, en la sesión celebrada el martes último, se ha ofrecido en cuerpo y alma a la superioridad, para acudir con su material, con su personal, con sus fuerzas todas allí donde se la reclama; y se dará el caso que mientras las nobles damas de nuestra buena sociedad, esas sacerdotisas de albo ropaje, de brazo rojo, de grandeza de alma y espíritu, instalan en la localidad un hospital de sangre, o posta sanitaria, de la Cruz Roja, en local y con camas adecuados, los caballeros se trasladarían en busca de paisanos nuestros a las proximidades de la catástrofe, donde éstos hubieran sido heridos, haciéndose allí cargo de ellos, mimándolos, animándolos y alabándolos su valor, para que el pobre soldado herido, rodeado hasta entonces de extraños y con el alma transida por la pena del alejamiento de los suyos, echando de menos las lágrimas consoladoras de su madre, que hubieran obrado de bálsamo sedante a su honda aflicción, se encontraría en su desembarco con personas conocidas de Salamanca, de su tierra querida que le hablarían de su pueblo, de su familia, de su madre, y que ya no le abandonarían hasta reintegrarlo a ésta, con los honores y cuidados que se deben a los héroes, ${ }^{, 223}$.

A decir verdad, ya con anterioridad al Desastre, La Gaceta había dedicado cuantiosos editoriales a elogiar este organismo y a repasar la historia de sus primeras actuaciones, remontándose incluso hasta la época de la Guerra de Tetuán ${ }^{224}$. Y muy pronto, dicha entidad ofreció al comandante militar de la zona la posibilidad de solicitar al Ayuntamiento de Salamanca la cesión de un local para la futura instalación de una Posta Sanitaria o un Hospital de Sangre. En efecto, Antonio Calama, secretario de la

\footnotetext{
221 "La Cruz Roja", El Adelanto, no 11.399, 29 de julio de 1921, p. 1; y "Obra meritoria. La Cruz Roja", La Gaceta Regional, $\mathrm{n}^{\mathrm{o}}$ 281, 29 de julio de 1921, p. 5. Para lograr esta información, los interesados debían dirigirse al presidente de la comisión provincial de la Cruz Roja, don Fernando Zaballa (Plaza Mayor, $\mathrm{n}^{\circ}$ 35), y comunicarle las señas exactas del individuo, nombre y dos apellidos, naturaleza, regimiento, compañía, batería o escuadrón de destino y punto donde se encontraba antes de la derrota militar.

${ }^{222}$ Sobre los orígenes e historia de la Cruz Roja Española, véase CLEMENTE, Joseph Carles: Historia de la Cruz Roja Española. Madrid: Cruz Roja Española, 1990; o del mismo autor: Tiempo de humanidad. La labor sanitaria de Cruz Roja Española (1864-1997). Madrid: Fundamentos, 2003. En ambas obras puede el lector encontrar cifras generales sobre los servicios prestados por la Cruz Roja Española en las sucesivas campañas militares.

${ }^{223}$ Antonio Calama Sanz: "La Cruz Roja”, La Gaceta Regional, nº 292, 11 de agosto de 1921, p. 1.

${ }^{224}$ Ángel Herreras de Burgos: "La Cruz Roja", La Gaceta Regional, no 175, 22 de marzo de 1921, p. 2; y también del mismo redactor: "La Cruz Roja", La Gaceta Regional, no 183, 2 de abril de 1921, p. 10; y "La Cruz Roja", La Gaceta Regional, n ${ }^{\circ}$ 385, 5 de abril de 1921, p. 4; Por último, y también a propósito de las labores desempeñadas por la Cruz Roja: "Su Majestad la reina visitará el hospital de sangre de Salamanca", La Gaceta Regional, nº 390, 6 de diciembre de 1921, p. 2.
} 
institución humanitaria, además de concejal, presentó una moción de cesión del edificio del Molassín. El objetivo consistía en atender allí a los soldados de Salamanca y su provincia heridos en Marruecos porque, hasta el momento, éstos tenían que ser socorridos en la fonda de la estación y en algunas casas adyacentes. El Ayuntamiento, por su parte, no puso ningún tipo de traba e inmediatamente donó este viejo e inutilizado edificio $^{225}$.

Además, una segunda iniciativa de trascendencia a favor de los combatientes salmantinos fue la adquisición de un aeroplano ${ }^{226}$. Tan pronto como empezaron a difundirse los rumores sobre la inminente marcha de La Victoria a África, se sugirió la posibilidad de abrir una suscripción popular, de carácter provincial, para costear el instrumento bélico más eficiente de la época. Fue el capitán de ingenieros Felipe Rodríguez quien remitió a El Adelanto unas cuartillas en las que recogía tan feliz idea, lanzada al viento por un capitán de la Guardia Civil de Murcia: que cada provincia regalase un avión para el Ejército, con el nombre de la misma en la chapa del aparato para así levantar el espíritu bélico de los combatientes.

La iniciativa fue comunicada a la Diputación Provincial y el presidente González Cobos la aceptó de inmediato ${ }^{227}$; idéntica fue la reacción de Martín Veloz, mientras que el Ayuntamiento decidió votar la cantidad de 5.000 pesetas a su favor ${ }^{228}$. Como ocurrió con los informes de la Cruz Roja sobre el paradero de los combatientes, también las listas con los nombres de los suscriptores para el aeroplano, y luego para otros muchos utensilios, se convirtieron en notas recurrentes de la prensa local ${ }^{229}$.

\footnotetext{
${ }^{225}$ Actas de las Sesiones Municipales. Archivo Histórico Municipal, vol. 1921-1922, fol. 190 (r)- 191 (v); Antonio Calama Sanz: "La Cruz Roja y los heridos de Melilla", El Adelanto, no 11.410, 11 de agosto de 1921, p. 1; y "La Cruz Roja de Salamanca", La Gaceta Regional, no 309, 1 de septiembre de 1921, p. 8. La sección de Damas de la Cruz Roja, bajo la presidencia de Casilda Blanco, se proponía dispensar todo tipo de cuidados a los ocupantes de las dieciocho camas que se preveían instalar en el Molassín.

${ }^{226}$ ESPERABÉ DE ARTEAGA, Enrique: Op. Cit., p. 285.

${ }^{227}$ Boletín Oficial de la Provincia de Salamanca, ${ }^{\circ} 111,12$ de agosto de 1921. Se inserta una carta de González Cobos en la que acepta de muy buen grado este proyecto.

${ }^{228}$ Actas de las Sesiones Municipales. Archivo Histórico Municipal, vol. 1921-1922, fol. 190 (r)- 191 (v); El Ayuntamiento tardó muchísimo en hacer efectiva esta donación. Hay que esperar hasta la sesión municipal del 31 de mayo de 1922 para que, durante su desarrollo, se lea una carta de la Cruz Roja en la que se notifica la recepción de 4.261 pesetas: Actas de las Sesiones Municipales. Archivo Histórico Municipal, vol. 1922-1923, fol. 148 (r).

229 "Salamanca se propone adquirir un aeroplano par el Ejército de África", El Adelanto, no 11.408, 9 de agosto de 1921, p. 1. Se incluía una primera lista de suscriptores y se anunciaba que ésta quedaba abierta en los Casinos de Salamanca y Pasaje, en el Café Novelty, en las librerías de los señores Núñez, Catón y Antonio García y, para finalizar, en los comercios de Mariano Rodríguez Galván y Arturo Pozuela. El periódico conservador también se mostró muy orgulloso ante esta iniciativa: "Una aeronave para el Ejército español”, La Gaceta Regional, nº 289, 8 de agosto de 1921, p. 1. Dos días después, Pedro M. Serrano Piedecasas: "Salamanca regalará un aeroplano a nuestro Ejército", La Gaceta Regional, no 291, 10 de agosto de 1921, pp. 2-3.
} 
No se debe perder de vista que la aviación desempeñó un papel crucial en el desarrollo de las operaciones de reocupación del territorio marroquí. La fotografía aérea permitió localizar el emplazamiento de cañones enemigos, depósitos de armas y concentraciones de combatientes. A la potencia destructora de los bombardeos había que sumar el daño psicológico que ocasionaban ${ }^{230}$. Consecuentemente, la donación de aeroplanos, mediante la apertura de suscripciones provinciales, se convirtió en una forma habitual de apoyo a los soldados. Salamanca no fue una excepción y, de hecho, la colecta tuvo una brillante acogida. Pero aunque la prensa local frecuentemente alabó la enorme capacidad destructiva de los aviones y de las bombas explosivas, espoleando así el deseo de desquite entre la opinión, fueron mínimas las alusiones a los bombardeos con gases tóxicos ${ }^{231}$.

El 11 de agosto se celebró una primera magna asamblea para materializar este proyecto y así nació, sin una excesiva premeditación, la Comisión Gestora o Patriótica de apoyo al batallón expedicionario de La Victoria ${ }^{232}$. Ésta, bajo la presidencia del gobernador civil, quedó integrada por el entonces presidente de la Diputación Provincial, el señor González Cobos; Andrés P. Cardenal, como presidente de la Cámara de Comercio; los redactores José Sánchez Gómez y Mariano Serrano Piedecasas; el capitán de ingenieros Felipe Rodríguez; y el concejal González Lago. No

\footnotetext{
${ }^{230}$ A partir de 1921, la guerra de África se caracterizó por el empleo de medios modernos de combate aviación, carros y vehículos blindados, armas automáticas, etc.) y por la utilización de tácticas y estrategias precursoras de las que se generalizarían durante la Segunda Guerra Mundial (bombardeos aéreos, operaciones anfibias, tácticas irregulares de contrainsurgencia). Pero, sobre todo, desde 1921, la conflagración dejó de contemplarse como un simple medio para la implantación del protectorado; ganar la contienda pasó a ser el único propósito de la presencia española en África. Véase VILLALOBOS, Federico: Op. Cit., pp. 149-150.

${ }^{231}$ En efecto, únicamente hemos podido hallar dos tímidas alusiones al empleo de estas sustancias. El 8 de mayo de 1921, Rivera aludió a que la cábila de Ajmás, en la zona de Larache, había sido "rociada", aunque sin precisar con qué sustancia. Y el 12 de septiembre de 1921, trascurridos casi dos meses tras la catástrofe militar, La Gaceta, en su sección "España en Marruecos" insertó una relación del material de guerra enviado recientemente a Melilla. En ella se incluían "gases venenosos para emplear por la infantería, bombas de gases para la aviación y cañones de trinchera para lanzar gases". Recuérdese que entonces existía un régimen de "libertad vigilada" sobre la prensa. Por ello, no deja de sorprender el hecho de que se filtrasen noticias alusivas al empleo de gases tóxicos, cuya utilización había quedado prohibido en Versalles. Para abundar en los efectos de la iperita, el fosgeno y la cloropicrina así como en la fundación de La Marañosa, consúltese MADARIAGA, Rosa María de y LÁZARO ÁVILA, Carlos: "Guerra química en el Rif", Historia 16, no 324, Madrid, 2003, pp. 50-85; también MANRIQUE GARCÍA, José María y MOLINA FRANCO, Lucas: Antes que Sadam.... Las armas de destrucción masiva y la protección civil en España. 1924-2000. Madrid: Quirón, 2003, pp. 18-45.

232 "La suscripción para adquirir un aeroplano para el Ejército de África", El Adelanto, $\mathrm{n}^{\circ} 11.411,12 \mathrm{de}$ agosto de 1921, p. 2. A propósito de esta primera reunión, comentaba la redacción de El Adelanto: "Fue la breve asamblea expresión máxima del sentimiento patriótico de todos los asistentes a ella... Sintiendo profundamente el deber de español y el hondo dolor que la patria experimenta por los desgraciados reveses de Marruecos, el diputado por la capital, señor Martín Veloz, hizo, acaso, el mejor discurso, fogoso y cálido, de exaltación patriótica que haya podido pronunciar en su vida". La suscripción ya entonces reunía 20.000 pesetas.
} 
es difícil imaginar el entusiasmo que esta iniciativa despertó entre los salmantinos a tenor de la recaudación: una semana después de la apertura de la suscripción, ya se habían reunido casi sesenta mil pesetas y se barajaba la posibilidad de regalar un segundo aeroplano ${ }^{233}$. Mientras, Mariano Núñez escribía:

"Diga lo que quiera / la termometría, / nuestra Salamanca / tiene bizarría. / Sabe dar la nota / de alto patriotismo, / pues en ocasiones / procede lo mismo / y con su dinero, / como lo más llano, / regala cuarteles / y compra aeroplano. / Tributa a los hijos / de su noble tierra / que con entusiasmo / marchan a la guerra, / tiernas despedidas / que a los corazones / llevan el encanto / de las emociones. / Muestra un grato empeño len que el pueblo todo / se una en noble empresa, / encontrando el modo / de que en los instantes / duros para España, / Salamanca entera / viril le acompaña. / Desde esta Castilla / de nuestros amores, / pongo el pensamiento / lleno de fervores, / en que el aeroplano / que da Salamanca / (que en donar la gente / veo no se estanca), / cuando hacia Marruecos / por hábiles manos / parta, lleve a todos, / amigos y hermanos, / no aprestos, ni bombas, / que al hombre estremecen / -aunque los rifeños / bien se lo merecen- / sino ya el mensaje / de salutación, / por tener la guerra / feliz conclusión ",234

Incluso, intentando realizar un "alarde de patriotismo" se sugirió la conveniencia de que el piloto del "Salamanca" fuese un salmantino ${ }^{235}$.

Al finalizar agosto, la Comisión Gestora acordó la adquisición de un modelo Havilland Page. La euforia institucional iba en aumento porque, por un lado, la recaudación alcanzaba cifras inimaginables, faltando aún la contribución de 230 pueblos de la provincia y de muchos terratenientes; y por otro lado, se confiaba en que Salamanca fuese la primera provincia española en entregar este espléndido donativo ${ }^{236}$. Además, el remanente podría emplearse en multitud de objetos igualmente útiles para los soldados.

Muy pocos días antes del inicio de las operaciones de reconquista en la Comandancia de Melilla, se confirmó que Salamanca sería la primera provincia en entregar dos aviones al Ejército de África. Y aunque, finalmente, otra provincia (Zaragoza) fue más rápida en el momento de contactar con la casa Havilland, la Comisión Patriótica de Salamanca fue la que antes pudo clausurar la recaudación para los aviones, reuniendo un total algo superior a las 80.000 pesetas. Como todos los

\footnotetext{
233 "Salamanca y el día patriótico", El Adelanto, no 11.404, 16 de agosto de 1921, p. 1.

${ }^{234}$ Mariano Núñez, "Quisicosero”: “Quisicosas”, El Adelanto, no 11.415, 17 de agosto de 1921, p. 1.

235 "El piloto ideal para el 'Salamanca”", La Gaceta Regional, n' 295, 16 de agosto de 1921, p. 5.

236 "La comisión del aeroplano 'Salamanca'”, El Adelanto, no 11.424, 27 de agosto de 1921, p. 2; "El patriotismo de la provincia", El Adelanto, no 11.428, 1 de septiembre de 1921, p. 1; y "A propósito de la aeronave 'Salamanca'”, La Gaceta Regional, no 307, 30 de agosto de 1921, p. 1.
} 
trámites se realizaron, además, con la mediación del ministerio de Guerra, Salamanca esquivó el pago de derechos de exportación desde Inglaterra y de Aduanas en España 237.

Por último, entre las iniciativas particulares, además de la presentación de voluntarios para cubrir plazas en los tres escuadrones de la Albuera que se organizaron como precaución $^{238}$, cabría destacar la velada y suscripción organizada por un grupo de jóvenes para costear el traslado hasta Salamanca de la esposa y la hija de un fallecido en la posición de $\mathrm{Afrau}^{239}$; los abundantes obsequios de la Acción Católica de la Mujer, así como la solemne misa que estas damas organizaron en la Catedral el 13 de agosto, unos días antes de la marcha de La Victoria ${ }^{240}$; los donativos del Ayuntamiento también destinados a los expedicionarios ${ }^{241}$; o la tómbola colocada en la Plaza Mayor por la Sociedad Deportiva Helmántica, coincidiendo con las ferias de septiembre, para destinar su producto a los soldados ${ }^{242}$. Ilustrativo también fue el hecho de que unos niños del colegio San Vicente, aquél en el que había trabajado Meneu, participasen activamente en la colecta para los aeroplanos ${ }^{243}$; o que el obispo de Salamanca, Julián de Diego y García Alcolea, animase a todo el clero provincial a ceder un día de su haber en beneficio de la suscripción:

"Para aliviar la situación de nuestros pobres soldados que valientemente defienden los intereses de la patria en la inculta e inhospitalaria tierra africana, el Eminentísimo Cardenal Primado, por recomendación de varios Prelados, interesa a todo el Episcopado español que invite a su respectivo Clero que figure en nómina a que ceda un día de haber por una sola vez, reservándose el hacer nuevas invitaciones o procurar

\footnotetext{
${ }^{237}$ Ruy-González: "Salamanca será la primera provincia que regala al Ejército dos aeroplanos Havilland", El Adelanto, n 11.430, 3 de septiembre de 1921, p. 2.

238 "Soldados voluntarios en África", El Adelanto, no 11.407, 8 de agosto de 1921, p. 1. No obstante, mientras que en la prensa local fue habitual el aplauso a la figura del voluntario, en los boletines oficiales de la provincia era habitual la publicación de largos listados con el nombre de los desertores.

239 "Próxima velada benéfica por el héroe de Afrau", El Adelanto, no 11.405, 5 de agosto de 1921, p. 4; y “¿Quién es el soldado desconocido?”, La Gaceta Regional, no 285, 3 de agosto de 1921, p. 5. Se trataba de un tal Mariano García, que acaparó bastante atención mediática en el verano de 1921. Corrochano había escrito para el $A B C$ una crónica sobre este soldado del regimiento de Ceriñola, origen de la iniciativa mencionada. Pero a finales de agosto, La Gaceta Regional desmintió la historia de su "gloriosa" muerte, señalando que este individuo seguía vivo y facilitando el que los donantes pudiesen recuperar sus contribuciones ("La Ciudad", La Gaceta Regional, no 301, 23 de agosto de 1921, p. 11).

240 "X.": "El aeroplano 'Salamanca' debe llevar un piloto salmantino", El Adelanto, no 11.411, 12 de agosto de 1921, p. 3; "La grandiosa fiesta del sábado en la catedral", El Adelanto, no 11.413, 15 de agosto de 1921, pp. 1-2; "La fiesta patriótica de la catedral", La Gaceta Regional, no 294, 13 de agosto de 1921, p. 11. Esa asociación envió al cuartel de Anaya un total de 300 escapularios y 75 opúsculos titulados "La bandera y el soldado".

${ }^{241}$ Las fuerzas de La Victoria y su próxima marcha", El Adelanto, no 11.413, 15 de agosto de 1921, p. 3; y "Homenaje a las tropas", La Gaceta Regional, no 295, 16 de agosto 1921, p. 5. Además, el 14 de agosto, el Ayuntamiento salmantino hizo entrega al coronel del regimiento de 6080,03 pesetas, procedentes de una suscripción municipal, además de nueve cajas de habanos para los jefes y oficiales de La Victoria.

242 "Una patriótica idea de la Sociedad Helmántica", El Adelanto, no 11.426, 30 de agosto de 1921, p. 1; "La tómbola a beneficio de los soldados de África", El Adelanto, no 11.435, 9 de septiembre de 1921, p. 3; "Fin patriótico", La Gaceta Regional, n' 307, 30 de agosto de 1921, p. 3.

243 “Actitud patriótica de unos niños", El Adelanto, no $11.413,15$ de agosto de 1921, p. 1.
} 
recursos por algún otro medio, si la guerra se prolongase más de lo que se supone que dure (...) Y ya que no podemos ir al África, acompañando a nuestros soldados, ayudémosles con nuestras humildes plegarias y fervorosos ruegos, implorando con asiduas súplicas al Dios de los Ejércitos, árbitro y Señor de la victoria, que aparte de nosotros el azote de la guerra, confundiendo con la humillación de la derrota la fiereza y orgullo de los que, insensatos, nos provocaron "244.

Fueron, en definitiva, muchísimos los gestos de socorro puestos en marcha durante el verano de 1921, mientras que las voces discordantes apenas se dejaron escuchar.

\section{EL CIELO NO ESCAMPA: LA CIUDAD, SUS SOLDADOS, LOS PRISIONEROS Y LA BÚSQUEDA DE RESPONSABLES}

El inicio de las operaciones de reconquista, a principios de septiembre de 1921, supuso un cambio en el tono discursivo de gran parte de la prensa nacional y también en la actitud ciudadana ante la política ejecutada en el Protectorado. El Desastre de Annual había provocado, como es sobradamente conocido, una honda conmoción con inimaginables consecuencias políticas y militares.

El gobierno de Allendesalazar había dimitido cuatro días después de la caída de Monte Arruit. En el seno del Ejército, la primera consecuencia fue el recrudecimiento de los métodos violentos de lucha, llegándose al extremo de emplear armamento químico. En segundo lugar, tras la derrota se acentuaron las discrepancias entre las distintas familias de la institución armada, ya muy escindida desde que en 1917 se planteara el conflicto con las Juntas de Defensa.

Aunque la opinión pública salmantina -y española, por extensión- compartió inicialmente con el Ejército el deseo de venganza, la oleada de entusiasmo patriótico tuvo una duración y un alcance social limitados. Tan pronto como el informe Picasso salió a la luz, el gobierno no pudo ya ocultar que en África imperaba el abuso de poder y la corrupción ${ }^{245}$. Fue así como la opinión pública salmantina fue tomando conciencia de que el fin del régimen de la Restauración estaba próximo.

\footnotetext{
${ }^{244}$ Boletín Oficial del Obispado de Salamanca, 1 de septiembre de 1921, nº 9 . En el mismo Boletín, se incluía el listado de sacerdotes que participaron en la colecta (consúltese en el Apéndice); Julián, obispo de Salamanca: "Palabras del prelado", La Gaceta Regional, no 311, 3 de septiembre de 1921, p. 1.

${ }^{245}$ El desfalco más sonado fue el conocido como el escándalo del "millón de Larache", caso destapado por el corresponsal López Rienda. Aquellos oficiales que iban a África para "chupar del bote" eran los bautizados como "caponíferos", diferenciados de los que pretendían hacer una carrera rápida y gloriosa, los "jabatos". Véase MADARIAGA, Rosa María de: En el Barranco del Lobo... Op. Cit., p. 258.
} 


\section{Patriotismos que flaquean. Las variadas actitudes de la prensa local}

El Adelanto, aunque siguió mostrando su orgullo ante la serenidad y los incontables ofrecimientos realizados por los salmantinos, pareció comprender que se hallaba ante el inicio de una nueva etapa en el desarrollo del conflicto y del sentir popular, y no sabía con precisión cómo posicionarse. El pueblo había demostrado al gobierno de Allendesalazar su entereza al no escatimar hombres ni dinero en las semanas inmediatas al Desastre, y, todo ello, pese a la desinformación que envolvía su existencia. No obstante, el pesimismo iba ganando terreno entre la multitud, mientras que la incredulidad y el recelo se convertían en las reacciones imperantes al recibirse noticias sobre éxitos militares más allá del Estrecho ${ }^{246}$.

Por ello, El Adelanto intentó reafirmarse en la convicción de que el Ejército español era infinitamente superior a la fuerza rifeña ${ }^{247}$. Tampoco faltaron los aplausos para los hombres del Tercio ${ }^{248}$. Desde mediados de octubre, en la sección a la que ya se ha aludido titulada "Páginas de la guerra", comenzaron a aparecer relatos costumbristas sobre los marroquíes ${ }^{249}$. Al igual que en el caso de La Gaceta Regional, estos eran presentados con una fuerte carga de fanatismo y xenofobia. Pero aunque el diario progresista intentaba y deseaba de este modo combatir las actitudes derrotistas y confiar en la autoridad y capacidad de mando de Dámaso Berenguer (idéntica estrategia a la adoptada en 1909: fe ciega en el héroe del momento, el general Marina), las circunstancias no parecían acompañarle ${ }^{250}$.

Asimismo, al finalizar 1921, “A.” recomendaba a la opinión pública salmantina resignación y confianza en los mandatarios. Se necesitaba:

"Los españoles, por idiosincrasia o por lo que sea, somos propensos a la locuacidad y queremos entender el todo. Ahora mismo, y por los que se refiere a la campaña de Marruecos, difícil será que haya un español que no tenga su plan guerrero, y lo peor

\footnotetext{
246 “A.": "Directores y dirigidos", El Adelanto, no 11.640, 8 de octubre de 1921, p. 3.

247 “A.": "El nefando pesimismo", El Adelanto, no 11.641, 10 de octubre de 1921, p. 1.

248 “A.": "Los hombres del Tercio", El Adelanto, no 11.466, 15 de octubre de 1921, p. 3. Para combatir el rechazo popular hacia el envío de tropas peninsulares a Marruecos; en 1909 se creó la Policía Indígena; dos años después se organizaron las primeras Fuerzas Regulares Indígenas; y, en 1920, se fundó la Legión. María Rosa de Madariaga caracteriza a esta última destacando la nostalgia de Millán Astray por el pasado imperial; la creencia en la redención a través de la muerte; la severa instrucción militar; la sublimación de conceptos como la disciplina y la obediencias; y la ritualidad. Véase MADARIAGA, M ${ }^{\mathrm{a}}$ Rosa de: Los moros que trajo Franco... La intervención de las tropas coloniales en la Guerra Civil. Barcelona: Ediciones Martínez Roca, 2002.

249 "Páginas de la guerra", El Adelanto, n' 11.462, 11 de octubre de 1921, pp. 2-3; "D.V”: "Páginas de la guerra", El Adelanto, no 11.464, 13 de octubre de 1921, p. 3; "Páginas de la guerra", El Adelanto, n' 11.468, 18 de octubre de 1921, p. 3; "Postales marroquíes", El Adelanto, n 11.780, 26 de octubre de 1922, p. 3; y A. Rodríguez Valdés: "Las mujeres de Marruecos", El Adelanto, no 11.810, 1 de diciembre de 1922 , p. 3.

250 “A.": "Balance general”, El Adelanto, no 11.529, 28 de diciembre de 1921, p. 1.
} 
del caso es que cada uno creemos que nuestros proyectos son los mejores y que el Rif no será dominado si no atienden nuestras inspiraciones (...) a muy pocos se les ocurre pensar que los que mandan, por lo mismo que están en posesión de secretos que no conviene divulgar, son los llamados a orientar a la opinión y que a ésta no la corresponde más que obedecer,"251.

Las escisiones en el seno del gobierno, que se pusieron de manifiesto con motivo de la celebración de la Conferencia de Pizarra, en febrero de 1922, no presagiaban ninguna estabilidad política ${ }^{252}$. Por entonces, el Ejército de África ya había recuperado Nador, Zeluán, Monte Arruit y las cábilas de Ulad Settut y Quebdana. El 10 de enero, finalmente, se había recuperado Dar Drius y llegaba el momento de la reflexión a propósito de las futuras operaciones. Aunque Maura era proclive a una ocupación militar muy parcial, la situación del Ejército colonial era en esos momentos muy débil. El presidente conservador pretendía satisfacer a los africanistas, especialmente a Berenguer, y también a La Cierva, mediante un desembarco en Alhucemas, a modo de sucedáneo de una ofensiva generalizada, mientras que el ministro de Estado, González Hontoria, defendía el aislamiento del Rif central con respecto a Yebala y al territorio de la Comandancia de Melilla y una acción negociadora en la primera de las zonas, en lugar de la intervención directa ${ }^{253}$. A causa de estas discrepancias, apenas trascurrido un mes se produjo la renuncia al completo del gabinete. Y poco después de la retirada del gobierno maurista, se intensificaron los rumores sobre la inminente dimisión del Alto Comisario debido a que sus planteamientos no concordaban con los de Olaguer, el nuevo ministro de Guerra ${ }^{254}$.

Por fotuna, el anuncio de que muy pronto se iba a avanzar hacia el protectorado civil y se emprendería la repatriación de tropas y la recluta voluntaria, en cuanto se finalizasen las operaciones contra El Raisuni, pudo rescatar a la redacción de $E l$ Adelanto del pesimismo en que también ella se estaba hundiendo ${ }^{255}$. Con renovadas energías, este diario siguió defendiendo la imposibilidad de que España abandonase Marruecos, ya que varios compromisos nacionales e internacionales convertían su permanencia en el Protectorado en una obligación. Así lo expuso “C.” en dos extensos

\footnotetext{
251 “A.": "Hay que ser prudentes", El Adelanto, no 11.520, 17 de diciembre de 1921, p. 1.

252 "Marruecos", El Adelanto, no 11.561, 3 de febrero de 1922, p. 1; "El importante consejo de ministros de anoche", El Adelanto, no 11.561, 3 de febrero de 1922, p. 4.

${ }^{253}$ BOUARFA, Mohamed: Op. Cit., pp. 142-143; PANDO, Juan: "Un año después de Annual. La pesadilla africana en la España de 1922”, Historia 16, Año XXII, n 260, Madrid, 1997, pp. 8-17. ${ }^{254}$ Alfredo Rivera: “Dimisión del Alto Comisario", El Adelanto, n' 11.590, 9 de marzo de 1922, p. 4.

255 “Cambio de política en Marruecos?”, El Adelanto, no 11.628, 24 de abril de 1922, p. 4; y Alfredo Rivera: "El proyecto de presupuesto. Ha comenzado la repatriación de tropas", El Adelanto, no 11.639, 8 de mayo de 1922, p. 6.
} 
artículos, síntesis de toda la historia de los tratados internacionales suscritos por España hasta $1912^{256}$. En conjunto, este columnista pretendía demostrar la conveniencia de una acción combinada, civil y militar, así como la formación de un Ejército colonial que permitiese el ahorro de sangre y dinero de los españoles.

No obstante, coincidiendo con la reaparición de más diferencias gubernamentales, en esta ocasión entre Cambó, Bergamín y Romanones ${ }^{257}$, otra vez cundió la desesperación entre los escritores de este diario:

"Quince años de actuación constante, centenares de miles de vidas sacrificadas, siete u ocho mil millones de pesetas consumidas y un desprestigio colonial que ninguna cancillería en el mundo desconoce... He aquí el lamentable balance de nuestra acción en África (...) Como en América, hemos tenido en África diversidad de planes, multitud de jefes y un río de oro que se ha vertido en aquellas arenas abrasadas, y un río de sangre que ha enrojecido caminos, valles y montañas. Más lo esencial no cambió nada, continuando en la aventura con absoluta falta de lógica, con desproporcionado exceso de ligereza y con un desconocimiento increíble de la región donde se opera y de la psicología de sus habitantes. Cuantas veces se anunció cambio de conducta, otras tantas se persistió en el error. Por eso hay que esperar a ver en qué quedan las nuevas medidas que se adopten "258.

Por fortuna otra vez para la redacción liberal, la aceptación de la dimisión de Berenguer y su sustitución por Burguete fueron noticias muy bien acogidas, ante todo por las declaraciones pacifistas de éste ${ }^{259}$. Por descontado, el retorno a la política de pactos con El Raisuni tuvo el aprobado de $E_{\text {Adelanto }}{ }^{260}$, pero en la región oriental los propósitos civilistas del gobierno chocaron con la cruda realidad, de inmediato denunciada por Burguete: el desarme y la sumisión todavía eran sueños inalcanzables. Una vez más, se vislumbraba una nueva división de pareceres entre el ejecutivo y el Alto Comisario:

"El estancamiento de nuestra acción militar en Marruecos y el viaje del Comisario Superior a Madrid han motivado que se vuelva a hablar y escribir largo y tendido acerca de lo que debe ser nuestra intervención en África, habiendo salido a relucir todas las teorías imaginables (...) Estas opiniones encontradas han sido las que han obligado a los gobiernos todos a ir gastando no en un grande, decisivo y fecundo sacrificio, sino en repetidas pero no en continuadas acciones cívico-militares, millones y vidas hasta que, sea por lo que quiera, vino el desastre que culminó en Annual

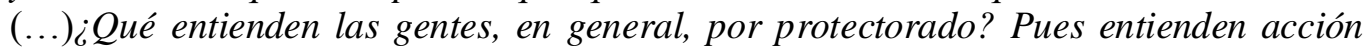

\footnotetext{
256 "C.": "La colonización marroquí", El Adelanto, no 11.646, 16 de mayo de 1922, p. 2; y "C.”: "La colonización marroquí", El Adelanto, no 11.651, 22 de mayo de 1922, p. 1.

${ }^{257}$ Alfredo Rivera: "El discurso de Cambó", El Adelanto, no 11.688, 1 de julio de 1922, p. 5; y "El debate sobre Marruecos en el Congreso", El Adelanto, n $11.689,3$ de julio de 1922, p. 3.

${ }_{258}$ "Nuestra acción de guerra en Marruecos", El Adelanto, no 11.690, 4 de julio de 1922, p. 1.

259 "El nuevo Alto Comisario, general Burguete", El Adelanto, no 11.699, 17 de julio de 1922, p. 2.

260 "La sumisión de Raisuni. Las condiciones pactadas", El Adelanto, no 11.729, 23 de agosto de 1922, p.

6; "Antes de enero serán repatriadas todas las fuerzas que operan en Marruecos", El Adelanto, no 11.770,

10 de octubre de 1922, p. 6; y Rivera: "El día en Madrid", El Adelanto, n 11.826, 19 de diciembre de 1922, p. 5.
} 
puramente civil (...) y, en el peor de los casos, que suene la bolsa y que callen las armas. Pero esto no puede ser (...) El concepto de protección y de tutela envuelve el de superioridad (...) He ahí el caso del general Burguete. Fue éste a Marruecos decidido a no hablar otro lenguaje que el pacifista (...) pero, ;ah!, en la práctica (...) esto explica la proclama guerrera del general Burguete: 'Hay que arrancarles (a los rifeños) los prisioneros por la fuerza si no los entregan de grado' (...) Dígase de una vez y para siempre la verdad, que es esta: que demos cuanto antes la mano a la acción militar, para que empiece y prevalezca la civil ${ }^{1261}$.

Evidentemente, El Adelanto deseaba creer en el protectorado civil: nada objetaba ante la política de pactos con El Raisuni, pero se desquiciaba cuando fijaba su mirada en la zona oriental e intentaba justificar las declaraciones, cada vez más militaristas, de Burguete. La opinión progresista salmantina perdió muy pronto la fe en el Alto Comisario porque con sus declaraciones parecía olvidar el enorme déficit que acarreaban las campañas sostenidas desde $1909^{262}$. Los vaivenes de la redacción no eran más que un indicio de pánico, incrementado por las caricaturescas amenazas de Millán Astray contra las Juntas (caricaturescas, pero exitosas porque logró la disolución de las mismas) ${ }^{263}$, y de desorientación informativa.

Además, las frecuentes visitas de Burguete a Madrid generaban mucha inquietud. Al terminar 1922 se lamentaba el órgano de Núñez Izquierdo de que "Marruecos vuelve a ser un peligroso avispero (...) y parece deseo del gobierno afrontar de una vez el arduo problema, herencia de tantos años, pesadilla de la nación y semillero de irreparables pérdidas". La política de Burguete se había definitivamente malogrado y el país demandaba un plan eficaz y el final de "la engañosa literatura guerrera oficial" 264 . Además, a estas alturas y como más adelante se explicará, el tema de las responsabilidades ya estaba originando muchos dolores de cabeza al gobierno de Sánchez Guerra.

El gabinete dimitió en diciembre de 1922, mientras que Burguete intentó justificar su fracaso descargando la culpa en el presidente dimisionario:

"La vida es un continuo desengaño. De ello pueden dar fe en estos días el general Berenguer y el señor Sánchez Guerra. Quizá no haya habido en España un general en jefe que haya gozado de las atribuciones del ex-Comisario Superior de Marruecos.

(...) Pero cierto día se le ocurrió relevar el señor Sánchez Guerra al general Berenguer $y$, desde entonces, comenzó para éste una campaña de insidias (...) Sucedió a

\footnotetext{
261 "Nuestro Protectorado en Marruecos, El Adelanto, n 11.741, 6 de septiembre de 1922, p. 1.

${ }^{262}$ Alfredo Rivera: "El general Burguete sale para Marruecos", El Adelanto, no 11.772, 12 de octubre de 1922, p. 5; y “Cuatro mil trescientos millones de déficit", El Adelanto, no 11.781, 27 de octubre de 1922, p. 1 .

${ }^{263}$ Alfredo Rivera: "El gravísimo documento que Millán Astray ha enviado al Rey razonando su petición de retiro del Ejército", El Adelanto, no 11.793, 10 de noviembre de 1922, p. 5; “A.”: El peligro de la indisciplina", El Adelanto, no 11.795, 12 de noviembre de 1922, p. 2.

264 "El penoso problema", El Adelanto, no 11.827, 20 de diciembre de 1922, p. 1.
} 
Berenguer el general Burguete, quien, en un momento de arrogancia, como él mismo ha confesado, declaró públicamente que para enero de 1923 se habría terminado la pesadilla de Marruecos (...) Pero he aquí que el tiempo ha transcurrido y Burguete no sólo no ha podido llevar a cabo lo que se prometía, sino que nuestra situación en el Rif es más comprometida que hace seis meses.

Llamado por el nuevo gobierno, el general Burguete se encuentra por estos días en Madrid y, para explicar su fracaso, ha declarado que si no ha cumplido todo lo que prometió, se debe a que el gobierno anterior no le prestó la ayuda necesaria.

¡Qué desengaño para el señor Sánchez Guerra, que había puesto toda su confianza en el general Burguete! ¡Y qué conducta más distinta la de éste acusando a sus protectores en cuanto ha tenido ocasión, comparada con la de Berenguer, que no ha despegado sus labios ni para defenderse...! ${ }^{265}$.

¿Qué se estaba insinuando en este editorial? Para empezar, se apuntaba a que el mismo ejercicio del poder exculpaba de responsabilidad ante la ley: ni Berenguer había sufrido censuras a su gestión ostentando la Alta Comisaría, ni Sánchez Guerra ocupando la presidencia del gobierno. Ahora bien, la situación había dado un vuelco, incluso permitiéndose el linchamiento público del primero, en el momento en que ambos habían sido desplazados de sus puestos. Pero, ¿por qué razón Dámaso Berenguer no intentaba defenderse?

Seamos un poco maliciosos: si Burguete se desquitaba con sus protectores tan pronto como éstos habían sido relegados del gobierno, ¿acaso Berenguer no callaría porque su defensor/es aún mandaba/n? Obviamente, lo sabemos, el ex-Comisario no había sido respaldado por el ejecutivo de Sánchez Guerra. Al contrario, éste lo había relevado por Burguete. Así pues, ¿sería descabellado pensar que esa figura protectora del general, tal vez, se ubicara en esferas más elevadas? Lógicamente, no. Con este tipo de comentarios, insidiosos y en una enrarecida atmósfera, muy impregnada de miedo y por completo determinante a la hora de descodificar el mensaje periodístico, se conseguía difundir entre la opinión pública salmantina las sospechas contra el excesivo afán intervencionista de Alfonso XIII en Marruecos. Aunque éstas no eran novedosas, tan sólo escasas. Aún así, en 1909, no se olvide, ya recogimos un curiosísimo comentario de Genero Alas en esta misma dirección.

Pero, ¿cuál fue el papel del Rey en el Desastre de Annual? ¿Actuó en la sombra, amparando los avances de Silvestre? ¿Qué hubo de cierto en los rumores sobre la existencia de un comprometedor telegrama regio en el que se ordenaba el avance sobre Alhucemas ${ }^{266}$ ? Obviamente, estos interrogantes constituyen uno de los aspectos más

\footnotetext{
265 "F.": "Berenguer-Burguete", El Adelanto, no 11.832, 26 de diciembre de 1922, p. 1.

${ }^{266}$ CARDONA, Gabriel: El poder militar en la España Contemporánea hasta la Guerra Civil, Madrid: Siglo XXI, 1983, p. 72; Cuando Silvestre se vio perdido en Annual, envió su hijo a Melilla para que se ocupase de descerrajar los cajones de su despacho y llevarse toda la documentación. Véase
} 
turbios de la historia de España en Marruecos. Para comprender el interés del monarca en el Sultanato, la historiografía frecuentemente alude al profundo impacto que tuvo sobre él la derrota de 1898, cuando sólo contaba con 12 años de edad ${ }^{267}$. Pero todas sus preocupaciones, sostenemos, no habrían tenido consecuencias efectivas si no hubiese dispuesto de amplísimas prerrogativas políticas, que sólo se explican en un contexto de quiebra del sistema. Al margen de la polémica, sin duda, con la publicación de estas opiniones la atención de la opinión pública salmantina se empezó a dirigir hacia el asunto de las responsabilidades del Desastre. Y, de esta manera, entre la prensa local (y no sólo ésta) y el ejecutivo se empezó a abrir una peligrosa fractura.

Para la redacción liberal, este proceso resultaría muy doloroso. Las eternas vacilaciones de sus columnistas, las escisiones ideológicas, ese permanente debate entre el "querer" y el "poder" (implantar un protectorado civil) llegaba a su apoteosis final: y la desesperación le arrastraría a la aceptación de las tesis más militaristas. Aunque habría resistencias, empeños premeditados por recuperar la fe en la labor de los gobiernos. Esto es lo que ocurrió, de hecho, coincidiendo con el nombramiento de Miguel Villanueva como nuevo Alto Comisario. La elección fue considerada como un enorme acierto desde la redacción salmantina, dada la larga experiencia de este hombre en tierras africanas y también porque eran conocidas sus intenciones negociadoras y su propósito de acabar con los muchos intereses del Ejército en África ${ }^{268}$. Igualmente, este periódico se mostró muy satisfecho ante la seriedad exhibida por el recién formado gabinete de García Prieto. El hecho de que se preocupase por exponer al país sin ambages la totalidad de su programa de gobierno, y en particular su futura actuación en África, fue muy aplaudido. Éste era el análisis que efectuaba “A.”:

"Al país no se le ha dicho nunca claramente cuáles eran nuestros compromisos, ni siquiera se le ha referido toda la verdad de lo acaecido en la zona de Melilla en julio de 1921. Hasta esa fecha, el país no se preocupó seriamente de Marruecos y no se percató, porque nadie se lo explicó, de cuál era nuestra misión en África, y así se vio sorprendido por una catástrofe que ni remotamente pudo prever. Comprendió entonces que el honor nacional había sufrido rudo quebranto y, para restañar la herida, dio cuanto se le pidió y más.

Pero este pueblo, que tan alto ejemplo de civismo dio por aquellos días, vio que los gobernantes no correspondían seriamente al esfuerzo (...) Mas he aqui que el nuevo

MADARIAGA, Rosa María de: En el Barranco del Lobo... Op. Cit., pp. 161-162. Por su parte, Boyd se hace eco de que en uno de sus viajes a la península, durante un banquete, en la Academia de Caballería de Valladolid, Silvestre prometió al Rey la toma de Alhucemas el día de Santiago. Véase BOYD, Carolyn P. Op. Cit., p. 215.

${ }^{267}$ Las posiciones oscilan desde la agresividad exhibida por autores tales como Miguel Martín o Rafael Borrás Betriu, hasta actitudes condescendientes como la de Carlos Seco Serrano.

268 "J. S. -G.": "Don Miguel Villanueva, Alto Comisario civil", El Adelanto, no 11.832, 26 de diciembre de 1922 , p. 1 . 
gobierno, haciendo honor a los compromisos contraídos por sus hombres en la oposición, se ha apresurado, después de muy detenidas deliberaciones, a lanzar al país el programa que piensa desarrollar en Marruecos (...) Con la designación de un hombre civil para la Comisaría Superior en Marruecos, manifiesta el gobierno su decisión de acabar con la supremacía militar en África. Esta ha de ser, sin duda, la parte más discutida (...) España no puede tolerar ni un día más que se gasten sus hombres y su dinero en tierras extrañas y de fecundidad muy discutida, mientras que aquí, en la Península, los hombres tienen que emigrar ${ }^{, 269}$.

Recuérdese que, desde el mismo momento del hundimiento de Annual, este diario había censurado el hecho de que los políticos jamás hubiesen explicado a los ciudadanos cuál era el papel de España en Marruecos. No obstante, con semejantes planes, García Prieto unía su suerte a la de la guerra africana y el diario era consciente de que terminar con la supremacía militar en el Protectorado era una misión harto compleja.

Lamentablemente, la prolongada enfermedad de Villanueva supuso un nuevo y duro golpe para los miembros de El Adelanto. Aunque su cargo fue desempeñado interinamente por el hasta entonces Secretario de la Alta Comisaría, López Ferrer ${ }^{270}$, desde mediados de enero de 1923, se barajaron varios nombres para su reemplazo. Una interinidad prolongada del Alto Comisario podría animar a los rebeldes rifeños a avivar su resistencia, y si a estas vacilaciones políticas se añadía la impaciencia popular ante la lentitud de las negociaciones para el rescate de los supervivientes de julio de 1921, se puede entender la urgencia del marqués de Alhucemas por buscar un nuevo hombre de confianza en Marruecos ${ }^{271}$. Aunque sonaba con fuerza el nombre de Silvela, por entonces ministro de Marina, Santiago Alba, una de las figuras más controvertidas y con mayor peso en el gobierno de concentración liberal, apostaba por la candidatura de López Ferrer ${ }^{272}$. Al final, éste, ofendido por considerar que sus gestiones para el rescate de los prisioneros no estaban teniendo reconocimiento oficial, renunció a su cargo a mediados de febrero ${ }^{273}$. También Villanueva reconoció que, pese a haber mejorado algo su salud, no deseaba volver a África ${ }^{274}$.

A resultas de todo ello, el nombramiento de Silvela se confirmó el 15 de febrero de 1923. El Adelanto, muy frustrado por la definitiva retirada de Villanueva, contempló al nuevo Alto Comisario con desconfianza y cierta amargura. Aunque pudiera pensarse

\footnotetext{
269 “A.”: "España sobre todo", El Adelanto, no 11.834, 28 de diciembre de 1922, p. 2.

270 Alfredo Rivera: "Tarde y noche", El Adelanto, no 11.838, 2 de enero de 1923, p. 5.

271 "Nota del día", El Adelanto, no 11.852, 18 de enero de 1923, p. 1.

${ }^{272}$ Alfredo Rivera: “QQuién es el Alto Comisario de Marruecos?”, El Adelanto, no 11.853, 19 de enero de 1923 , p. 5.

${ }^{273}$ Alfredo Rivera: "El día en Madrid", El Adelanto, no 11.874, 13 de febrero de 1923, p. 5.

${ }^{274}$ Alfredo Rivera: “Al cerrar”, El Adelanto, no 11.873, 11 de febrero de 1923, p. 5.
} 
que el carácter también civil de este hombre sería un punto a su favor, muy pronto este periódico censuró la falta de preparación práctica de Silvela y juzgó que lo que se estaba procurando era "dar categoría” al cargo de Alto Comisario ${ }^{275}$.

La desazón de la opinión progresista fue incluso a mayores al conocerse en marzo un plan para la toma de Alhucemas. Pero al menos por el momento, el gobierno lo rechazó, consciente de que ello significaría el definitivo divorcio de la opinión pública $^{276}$. Por otra parte, aunque había abundantes rumores sobre el próximo inicio de la repatriación de tropas porque las negociaciones entre Castro Girona y los rifeños tendentes a lograr la definitiva sumisión del territorio marchaban por buen camino, éstas se rompieron ${ }^{277}$. Muchas esperanzas se derrumbaron, explicando el desconsuelo ciudadano que reinaba en la primavera de 1923. Por último, en las mismas fechas, Abdel-Krim había solicitado el reconocimiento oficial de la República del Rif. En un editorial de El Adelanto, Martínez Oriol comentaba:

"No creemos que sea necesario esforzarse para demostrar que el problema de Marruecos constituye la pesadilla de todos los españoles.

Por lo que quiera que sea, no se ha sabido aprovechar en África el tesoro de elementos de todo género, morales y materiales, que España dio, sin regateo, en un momento en que soñó con la revancha del agravio que se le había inferido. No se supo aprovechar, repetimos, y ya es tarde para intentarlo. La nación ha rectificado su juicio. Ya no aspira a revancha de ningún género. Desencantada de todo y de todos, quiere acabar de una vez aquella desdichada empresa, empezando por negarse a nuevos sacrificios y reclamando la repatriación inmediata de los miles de hombres que permanecen estancados en África, con gran quebranto de las energías, ya harto debilitadas, del país.

Aspira éste solamente a mantener posiciones tradicionales ${ }^{\text {,278. }}$.

Diríase, únicamente a tenor de lo expuesto, que la posición de alguno de los redactores de El Adelanto empezaba a aproximarse a las de El Pueblo. Además, coincidiendo con el inicio del verano, las vacilaciones en la política marroquí alcanzaron su punto álgido: mientras que los rumores sobre la dimisión de Silvela se intensificaban, los enfrentamientos entre Alcalá-Zamora y Santiago Alba se hicieron más frecuentes ${ }^{279}$; y también se convirtieron en habituales las advertencias del ministro de Hacienda ante el peligro de nuevas aventuras bélicas ${ }^{280}$.

\footnotetext{
275 “J. S. -G.": "Nota del día. Ante el nombramiento", El Adelanto, no 11.876, 15 de febrero de 1923, p. 1. 276 "Nota del día. Ante el consejo de hoy", El Adelanto, no 11.913, 31 de marzo de 1923, p. 1.

${ }^{277}$ Alfredo Rivera: "Tarde y noche", El Adelanto, no 11.930, 20 de abril de 1923, pp. 3-4; y Alfredo Rivera: "Al cerrar", El Adelanto, n' 11.933, 24 de abril de 1923, p. 3.

${ }^{278}$ Martínez Oriol: "El problema de Marruecos”, El Adelanto, no 11.952, 16 de mayo de 1923, p. 1.

${ }^{279}$ Alfredo Rivera: “Al cerrar”, El Adelanto, no 11.959, 24 de mayo de 1923, p. 4.

280 “Nota del día. ¿En vísperas de una crisis?”, El Adelanto, n 12.020,3 de agosto de 1923, p. 1.
} 
Los propósitos pacificadores del marqués de Alhucemas a su llegada al gobierno, apenas hacía siete meses, parecían entonces una entelequia y el nombramiento de Martínez Anido, cuyas violentas actuaciones en Barcelona eran sobradamente conocidas, como comandante general de Melilla no hizo sino demostrar que el gobierno estaba abandonando sus propósitos iniciales en el Protectorado ${ }^{281}$. Ciertamente, el nuevo plan del comandante para la ocupación de Alhucemas fue también rechazado, e incluso se barajó la posibilidad de retroceder hasta la línea del Kert. Ante ello, respondió “A.”:

"Hay que suponer que el gobierno, a quien en esta ocasión acompaña el voto favorable del Estado Mayor Central, debe tener razones poderosas para no autorizar el avance sobre Alhucemas; pero, ¿se ha pensado seriamente en lo que supondría el retroceso hacia la línea del Kert?

No es sólo que esto envalentonaría a Abd-el-Krim y sus secuaces, ya de suyo ensoberbecidos con nuestras eternas indecisiones, sino la situación que esto crearía a las cábilas amigas que habitan desde el Kert a Tizzi-Azza (...) Y ¿cuál sería nuestra posición al replegarnos sobre el Kert?

La misma o peor que ahora (...) ¿Qué debemos hacer, pues?

Diga el gobierno lo que quiera, tal como ha planteado el problema de nuestra actuación en el Rif, aquello resulta un verdadero lío, que nadie entiende, y menos que nadie la opinión pública, a la que no se le alcanza que para no hacer nada y para vivir en pactos vergonzosos con los moros sea necesario mantener en Marruecos un Ejército numeroso.

O avanzamos de una vez, o retrocedemos; pero no a la línea del Kert, que eso sería absurdo, sino más mucho más acá, hasta el mismo Melilla"282.

La tesis del protectorado civil se estaba desacreditando: los pactos se tildaban de vergonzosos y el margen de maniobra en Marruecos se estrechaba: o la guerra o el abandono. Y es que muy poco antes, en julio, se había intentado un acercamiento más, otra vez infructuoso, con Abd-el-Krim ${ }^{283}$. Sin embargo, el cabecilla rifeño tenía muy bien aprendida la lección: tras la conflagración mundial, el rencor había hecho mella en él y ya no podría volver a comportarse como "moro amigo" de los españoles ${ }^{284}$.

Oficialmente el gabinete no había abandonado sus propósitos civilistas. Sin embargo, hallaba muchas dificultades para lidiar con la opinión pública. Idéntica

\footnotetext{
281 “La difícil situación del gobierno", El Adelanto, n 11.990, 24 de junio de 1923, p. 1.

282 “A.”: “¿Qué hacemos allí?”, El Adelanto, no 12.027, 11 de agosto de 1923, p. 6.

${ }^{283}$ Alfredo Rivera: “Al cerrar”, El Adelanto, no 11.999, 10 de julio de 1923, p. 4; y Rivera: “Al cerrar”, El Adelanto, $\mathrm{n}^{\circ} 12.003,14$ de julio de 1923, pp. 3-4.

${ }^{284}$ Para conocer la opinión de Abd-el-Krim sobre el colonialismo español, es sumamente interesante una de sus cartas, conocida como "el manifiesto anticolonial", que aparece reproducida en MADARIAGA, Rosa María de: "Algunas consideraciones sobre el Estado Rifeño" en LORING GARCÍA, Ma . I.: Historia social, pensamiento historiográfico y Edad Media. Homenaje al profesor Abilio Barbero de Aguilera. Madrid: Ediciones del Orto, 1997, pp. 511-536. El caudillo rifeño no se opuso a la penetración comercial extranjera, pero sí rechazó la ocupación militar.
} 
situación atravesaba El Adelanto ante sus lectores: porque deseaba el fin de la pelea, que no el abandono de Marruecos:

"Para algunos no sólo nuestra intervención en Marruecos es una locura, sino que entienden que no debemos intervenir para nada en la política exterior, debiendo resignarnos al triste y oscuro vegetar interior, con el que hasta primeros de este siglo fuimos tirando tan honorablemente de la vida (...) Pero la verdad es todo lo contrario. (...) Se pretendía vivir lo mejor posible y con el mayor relajo posible (...) ¿Quiénes vivían? ¿Quiénes prosperaban? Las familias privilegiadas de los políticos (...) Fuimos en 1859 a África. Ganamos las batallas y perdimos la guerra. Fuimos en 1894 a Marrakech y no quedó ni huella de nuestro paso en Marruecos. Volvimos de América y de Asia, punto menos que un cadáver que arrastran las olas, y los sensatos y los prudentes gritaban: "Ahora a vivir; gastemos aquí nuestras energías." ¿Qué conseguimos? Desde entonces hasta lo de Melilla en 1909, España fue un criadero de sangre, un río de sangre que iba a fertilizar otras patrias (...) Tenemos pues que este sistema de dejar al pueblo sin ideales más allá de las fronteras, o el de reducir sus aspiraciones a la mera vida vegetativa en el interior de la península, no ha resuelto absolutamente nada, ${ }^{, 285}$.

Evidentemente, el camino a seguir en el Protectorado se vislumbraba ya sin atajos: tan sólo restaba la guerra sin cuartel. Y el hecho de que el gobierno desoyera el plan de Martínez Anido, que finalmente había renunciado a su cargo, suponía, según el criterio de El Adelanto, una total inconsecuencia, dado que no se entendía que conociéndose sus métodos belicosos se le hubiese reclamado desde Melilla para, acto seguido, ignorar su proyecto ${ }^{286}$.

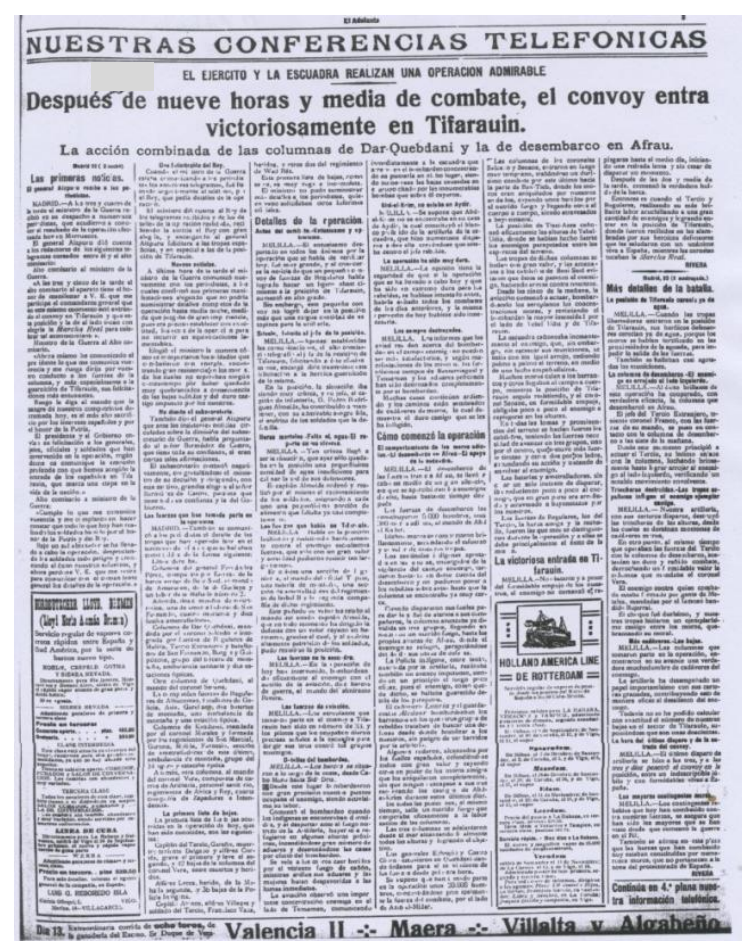

El Adelanto, $\mathrm{n}^{\circ} 12.037,23$ de agosto de 1923, p. 3.

\footnotetext{
285 "El valor de los ideales", El Adelanto, no 11.984, 22 de junio de 1923, p. 6.

286 “¿Para qué se le envió?”, El Adelanto, no 12.030, 15 de agosto de 1923, p. 2.
} 
Sin embargo, la alarma social cundió entre los salmantinos cuando se conocieron los ataques rifeños sobre el frente de Tizzi-Azza, Tafersit y Tifarauin ${ }^{287}$, en agosto de 1923. Esta posición ya había sido hostilizada en noviembre de 1922 y en mayo de 1923. Su ocupación sólo era comprensible en caso de que luego se avanzara sobre la bahía de Alhucemas. En cambio, su abandono podía tener repercusiones adversas tanto en el resto de frente como en la moral militar. ${ }^{288}$. Desde el periódico de Núñez Izquierdo se aseguraba que el país deseaba el fin del problema, no importando ya el cómo. Se reclamaba, por esto mismo, la posesión de Tánger con más apasionamiento que nunca: "Tánger debe ser nuestro porque se encuentra rodeado de territorio español (...) En Tánger debe ondear la bandera roja y gualda, solamente, porque es necesaria esa ciudad a nuestros intereses" 289 . Aunque la voluntad nacional únicamente había sido partidaria de la acción bélica contundente en los meses inmediatos al Desastre, aceptaría una decisión de esta índole si así lo acordaba el Estado Mayor del Ejército ${ }^{290}$. He aquí la razón:

"Grave, muy grave es lo ocurrido estos días en aquella zona, y, aunque no es de temer que tengamos otro desastre como el de hace dos años, porque los medios con que contamos no permiten temerlo, es una vergüenza que un Ejército numeroso y con poderosos medios de combate, esté inactivo y esperando cada día un ataque del enemigo, sin que se le autorice a avanzar de una vez. Así no podemos continuar. Es preciso que España entera decida de una vez cuál ha de ser nuestra actuación en el Rif. ¿Hay que avanzar y se puede avanzar? Pues adelante,291.

Los últimos artículos de El Adelanto a propósito de la gestión del Protectorado en los momentos inmediatos al golpe de Primo de Rivera insistieron en esta idea. La amargura y la frustración acabó por justificar un pensamiento muy radical, que no encajaba en su habitual trayectoria de moderación ideológica: "La guerra es la guerra y no hay guerra sin quebrantos. Mas el país prestaría de nuevo y de buen grado su esfuerzo, si supiera de antemano que sería el último, el decisivo, el eficaz, para llegar

\footnotetext{
${ }^{287}$ En esta última posición el harca de Abd-el-Krim desplegó el mayor número de efectivos visto hasta el momento, cerca de 9.000 combatientes. La operación para liberar la posición constituyó el primer ejemplo de cooperación de fuerzas de tierra, mar y aire de la historia española. Ver VILLALOBOS, Federico: Op. Cit., p. 240. Uno de los máximos protagonistas de esta acción bélica fue un salmantino, el capitán Rodríguez Almeida, al que más adelante nos referiremos.

${ }^{288}$ En agosto de 1923, incluso se presagiaba un cambio de régimen: "Todo menos permanecer indecisos, que es lo más perjudicial para la moral de un Ejército. Manteniendo unos meses más la incongruencia, indecisión y pasividad reinantes, podrán sorprendernos nuevos y sensibles accidentes de honda repercusión en la política nacional”. En "A.”: “Marruecos!”, El Adelanto, n ${ }^{\circ}$ 11.561, 3 de agosto de 1922, p. 1

289 "A.": "O Tánger es español o tenemos que retirarnos definitivamente de África", El Adelanto, no $12.028,12$ de agosto de 1923 , p. 5

290 "La angustia de Marruecos", El Adelanto, no 12.034, 19 de agosto de 1923, p. 1.

291 "De mal en peor", El Adelanto, no 12.036, 22 de agosto de 1923, p. 1.
} 
cuanto antes a una honrosa y digna paz, de la que España es merecedora"292. Tal remedio no era más que una forma moderna del viejo dicho "Si vis pacem, para bellum".

El diario conservador, si cambiamos ya de rotativo, presentó el inicio de las operaciones para la reocupación de las posiciones perdidas en 1921 como si se tratase de una nueva guerra de religión o, con más exactitud, una continuación de los seculares enfrentamientos entre cristianos y musulmanes. Así, al menos, lo confesaba Andrés Marcos Escribano:

"No hay que disimularlo. Nos hallamos ante una guerra que aparece como sucesión legítima de las guerras africanas de nuestros siglos dorados, y más remotamente, de las guerras medievales de reconquista.

¡El moro! He ahí el nombre que sonaba como clarín de pelea en los oídos y en los corazones hispanos (...) ¿Es la guerra de hoy continuación de la de ayer?

Materialmente, sí; los mismos enemigos, la misma perfidia, los mismos móviles por parte de los moros, la misma crueldad y la misma matanza. Pero moral y espiritualmente... no lo sabemos. $Y$ no lo sabemos porque en los actos oficiales y oficiosos no hay jamás claros indicios que nos demuestren la continuidad de esta lucha con las luchas que forman los cantos inmortales de la epopeya nacional ${ }^{\text {"293. }}$.

Ya se ha dicho que desde el mismo momento en que se conoció la derrota española a manos del harca de Abd-el-Krim, el diario conservador había encorajinado a la opinión pública salmantina contra los rifeños censurando su fanatismo. Y meses más tarde, como hemos comprobado, también El Adelanto recurrió a esta estrategia.

Sin embargo, presentar la Guerra del Rif como una lucha religiosa no fue la tónica habitual del pensamiento conservador. De ahí, lo chocante que resulta esta conducta del diario derechista. Por norma, los partidos dinásticos habían justificado la permanencia en el continente africano apelando a la tesis de la garantía de la independencia nacional y a los múltiples compromisos internacionales. Asimismo, también, persistentemente, en sus páginas de este diario se había argumentado la conveniencia de atraer a los vecinos del sur hacia la civilización. Su fanatismo era esgrimido como un componente más de su carácter indómito o incivilizado. Pero identificar la contienda rifeña con una clásica guerra de "moros y cristianos" suponía poco menos que equiparar al soldado español con el viejo caballero medieval de hondas creencias católicas. En el pasado, huir de este estereotipo se había convertido en una

\footnotetext{
292 “Ante la entrada del convoy a la posición de Tifarauin", El Adelanto, no 12.080, 23 de agosto de 1923, p. 1.

293 “García de Roldán" (Andrés Marcos Escribano): "Solución de continuidad", La Gaceta Regional, no 320, 14 de septiembre de 1921, p. 5.
} 
forma de justificar ante la opinión pública las pretensiones colonizadoras, que no de conquista, de España en Marruecos. Ahora la tónica se rompía.

Apuntada esta nota excepcional, se puede deducir que la peyorativa imagen del musulmán sustentada desde el periódico conservador invalidaba todo proyecto de implantación próxima de un protectorado civil. Del mismo modo, la tibia política colonizadora del programa maurista había chocado de bruces con una absoluta incomprensión en las páginas de La Gaceta ${ }^{294}$. Todo su empeño consistía en el castigo duro y ejemplar del marroquí, a la par que constantemente se elogiaba el patriotismo demostrado por los salmantinos ${ }^{295}$. Su discurso no presentaba fisuras: se había convertido, en esta materia, en el sucesor natural de El Salmantino. La opinión conservadora estaba convencida de la necesidad de un sacrificio urgente que pusiese fin a la guerra. El columnista Juan Bautista Sastre, sin embargo, renegaba de toda gloria militar; ninguna se derivaba de la campaña:

“iLa guerra! ¡La gloria! Anacronismos funestos en una época como la actual (...) Gloriosa nos parece la figura de Colón descubriendo un Mundo. Gloriosa la figura de Cervantes legando a las generaciones su Quijote (...) Eso es, a nuestro entender, la única gloria. Lo demás, eso mismo que está pasando en Marruecos, será necesario, será inevitable, será de justicia, pero no es glorioso. ¡Glorioso morir matando como chacales rabiosos, como lobos carniceros! ;Glorioso el asesinato, siquiera caigan sobre él todas las sanciones y todas las disculpas de lo legal! No. Eso tiene su nombre propio. Eso se llama barbarie, incultura, insensatez, falta de sentimientos humanitarios, trogloditismo.

¡Nador! ¡Zeluán! ¡Monte Arruit! ¡Páginas gloriosas! Ahí están los horrorosos destellos de esa falsa gloria, de esas tragedias espeluznantes. Ahí están los muertos, los restos del bárbaro festín rifeño. Ahí está la sangre de los mártires, de los defensores de la patria.

¡Venguémosles! Pero sin acordarnos de la gloria. La gloria en este caso será poner en práctica ese bárbaro y compensador aforismo que será implacable y justiciero: Ojo por ojo y diente por diente ${ }^{1296}$.

A pesar de tan indisimulado anhelo de resarcimiento, La Gaceta desconfiaba de la capacidad de gestión del gobierno de Maura en Marruecos. El diario, a través de la pluma de "Helmán", se mostraba plenamente consciente de que las disparidades de criterio entre Cambó, ministro de Hacienda, y La Cierva, en Guerra, harían imposible la solución del problema:

"Es deber ciudadano y meritorio ilustrar a los ignorantes y despertar a durmientes y despreocupados (...) Mientras que unos, los exterminadores, son partidarios de un régimen terrorista, de arrasamiento, de guerra sin cuartel, quemando casas y haciendas, incendiando cosechas y despreciando los más elementales preceptos de

\footnotetext{
294 “Del problema marroquí. No lo entendemos", La Gaceta Regional, n’ 331, 27 de septiembre de 1921, p. 1.

295 "Estamos conformes", La Gaceta Regional, no 345, 13 de octubre de 1921, p. 1.

296 Juan Bautista Sastre: "Páginas de gloria", La Gaceta Regional, no 353, 22 de octubre de 1921, p. 1.
} 
humanitarismo, hay otros, los pacíficos, que creen disponer de una sin igual panacea; mucha cultura, atracción de paz, desarrollo de comercio hasta régimen autónomo para los indígenas.

¿De parte de quiénes está la razón? (...) Entendemos que unos y otros tienen razón; esta afirmación que parecerá absurda e incongruente no lo es e intentaremos probarlo. Entre los moros hay que distinguir dos clases o categorías perfectamente aisladas. Los campesinos (el moro salvaje), verdaderos hombres primitivos de cuya fiereza y crueldad no se tenía noción en España, que llevan inculcado en su sangre, el odio a lo extraño, fanático, ciego a toda obra civilizadora, selvático y de inteligencia atrofiada, y, el moro que por habitar cerca de poblados adonde llegó la civilización, pudiéramos llamar, convencionalmente, ilustrado ${ }^{, 297}$.

¿Se aprecia alguna diferencia con relación a las consideraciones vertidas en $E l$ Adelanto a propósito del "sentir popular"? No la hay: el fracaso en África se explicaba aludiendo, en exclusiva, a la naturaleza mora, pero mientras tanto se desviaba la atención de la opinión pública salmantina del asunto de las responsabilidades.

Coincidiendo con la celebración de la Conferencia de Pizarra, el periódico insistió en las razones históricas y estratégicas que obligaban a España a permanecer en el Protectorado, y también, apeló a la dignidad: "Son muchos los cadáveres de españoles enterrados en África; es mucha la sangre española que ha regado el territorio marroquí; son muchos los millones que se han consagrado a nuestra acción africana, para que el país se desentienda de tan grave problema"298.

De todos modos, la crisis resultó inevitable. Al producirse el cambio de gobierno y la sustitución de La Cierva por Olaguer, La Gaceta insistió nuevamente en la conveniencia de una acción bélica contundente ${ }^{299}$, y más en concreto, sugirió un desembarco en Alhucemas, aún a sabiendas de que la situación de los prisioneros de Axdir impedía tal procedimiento ${ }^{300}$ :

"La posesión de esta bahía sería una satisfacción para el amor nacional, un éxito cotizable en la galería de la opinión, un realce de España en el juicio extranjero. Todo eso es bastante: pero además se necesita que el litoral sea nuestro para evitar contactos rifeños con el contrabando. Por ello hay que ir a Alhucemas. Ese sentimiento de la opinión, favorable a la empresa, hay que cultivarlo, excitarlo y aprovecharlo. Ahora bien: ¿es tan urgente la empresa que debe acometerse precisamente en estos momentos? Eso es seguramente lo que dilucidará el gobierno. Y así es como debe plantearse el problema. No se trata de ir o no a Alhucemas. Se trata sólo, o debe tratarse, de si se va ahora o se va más adelante. Las ventajas de ir ahora pueden sintetizarse diciendo: que se aproveche el esfuerzo militar ya realizado y el estado de ánimo en el que el país se encuentra; que se da al mundo una impresión de capacidad militar si el éxito nos acompaña; que podemos esgrimir tal éxito en una negociación

\footnotetext{
297 “Helmán”: "Nuestra acción en África”, La Gaceta Regional, n 337, 4 de octubre de 1921, p. 1.

298 "La Conferencia de Pizarra", La Gaceta Regional, n 441, 6 de febrero de 1922, p. 1.

${ }^{299}$ Hacia el Protectorado. Hablan dos ilustres jefes del Ejército", La Gaceta Regional, no 458, 25 de febrero de 1922, p. 3.

300 "Un reservista": "Hacia el Protectorado. La campaña de Marruecos", La Gaceta Regional, no 472, 14 de marzo de 1922, p. 3.
} 
que se avecina sobre Tánger. Los inconvenientes se hallan en que el esfuerzo ahora realizado no será bastante, y será preciso acumular las tropas en Melilla, ${ }^{301}$.

En lo tocante a Tánger, pocos días después de la publicación del anterior fragmento, un columnista precisaba: "El problema de Tánger es para nosotros de tal naturaleza que se pude afirmar rotundamente que es cuestión de vida o muerte (...) Tánger, sin ser español, es la negación de la eficacia de nuestro Protectorado (...) Tánger es para España un avispero de donde nos vienen la mayor parte de los picotazos que recibimos" ${ }^{302}$.

A la espera de que el sueño tornase en realidad, las protestas socialistas por la prolongación del conflicto iban en aumento y la redacción contraatacaba ferozmente: "Nosotros no lo entendemos. Se combate en África; se derrocha heroísmo, se agota el dinero y manan sangre española los campos marroquíes, y aquí, en España, se deja que todo el mundo, así tirios como troyanos, hablen contra ello, peroren, protesten y levanten tempestades. No lo entendemos" ${ }^{\text {303. }}$.

Además, las noticias que circulaban desde mayo de 1922 sobre un cercano inicio de la repatriación de fuerzas eran acogidas con recelos. Aunque en su fuero interno los redactores desearan el regreso de los combatientes, admitirlo suponía un desprestigio para las armas españolas, para su labor. Así que el diario permanecía obcecado en defender el comportamiento de los africanistas: la campaña de Marruecos no era una imposición del Ejército, sino un deber impuesto a él:

"Es un error muy generalizado creer que el Ejército sostuvo la guerra por sistema, siendo así que la campaña de Marruecos fue y es hija de la perpetua rebeldía contra todo poder, en que vivieron siempre las cábilas de la zona del Protectorado, y consecuencia del carácter indómito de los bereberes.

¿Quién ha de querer la guerra por la guerra misma? El patriotismo del Ejército no puede ponerse en duda. Sería ofenderlo, agraviarlo, afirmar que él impone la guerra, con todos sus horrores y enormes gastos ${ }^{, 304}$.

\footnotetext{
301 "Hacia el Protectorado. Alhucemas", La Gaceta Regional, no 449, 15 de febrero de 1922, p. 3. Tampoco los africanistas dudaban de la urgencia de marchar sobre Alhucemas. Así, Franco escribió: "Alhucemas es el foco de la rebelión antiespañola, es el camino a Fez, la salida cota al Mediterráneo, y allí está la clave de muchas propagandas que terminarán el día que sentemos el pie en aquella costa". Véase FRANCO, Francisco: Op. Cit., p. 174. Los militares africanistas nos han dejado muchos escritos sobre su visión de la política marroquí. En general, se consideraron como una élite intelectual, si bien raras veces sus obras destacan por su calidad literaria.

302 "Hacia el Protectorado", La Gaceta Regional, n' 469, 10 de marzo de 1922, p. 2; También "Hacia el Protectorado", La Gaceta Regional, no 484, 28 de marzo de 1922, p. 2. Es bastante posterior, pero se barajan las mismas ideas en "E.": "La posesión de Tánger", La Gaceta Regional, n 782, 24 de marzo de 1923 , p. 1.

303 "Tanto va el cántaro a la fuente", La Gaceta Regional, no 509, 28 de abril de 1922, p. 2.

304 "Hacia el Protectorado", La Gaceta Regional, n' 530, 24 de mayo de 1922, p. 2.
} 
De todos modos, al mismo tiempo la redacción optaba por atemperar su propaganda guerrera. Y, desde esta óptica, se insistía en que los Altos Comisarios que se habían sucedido desde 1912 siempre habían anhelado la convivencia cordial de españoles y marroquíes pero, por aquellas fechas, se había demostrado que ello resultaba impracticable: "El Alto mando ha empleado la fuerza en casos extremos, cuando no pudo convencer a los indígenas de que aceptaran el protectorado". La persuasión política había sido un recurso insuficiente. Se necesitaba una "penetración política armada", tal y como pregonaba Romanones: hacer uso de la fuerza sólo cuando la preparación política del territorio hubiera resultado insuficiente. Más coloquialmente, esta estrategia sería conocida como la política "del palo y la zanahoria".

No obstante, los planteamientos de La Gaceta acostumbraban a ser más radicales. Sencillamente, creemos que si ahora moderaba su postura, intentando contemporizar con la tesis de la penetración política, era porque temía distanciarse de la opinión pública salmantina, hastiada del conflicto. ¿Cómo no reconocer y temer su creciente fuerza política?

Tras la conmoción inicial provocada por el Desastre, reaparecían las discrepancias en torno a la gestión de la política africana. Por ello, particularmente irascible se mostraba el diario conservador cuando aludía a la prensa de izquierdas. Sus continuas mentiras provocaban el aburrimiento como primera reacción, luego pena y, finalmente, indignación. Los lectores de esos rotativos, según su criterio, vivían contaminados al considerar la guerra bajo el único prisma de la bonanza económica nacional. Además, la redacción conservadora se mostró especialmente herida al escuchar que Berenguer no deseaba el rescate de Navarro porque sus declaraciones podrían hundirlo en el debate responsabilista. Por ello, llegó al extremo de insinuar al gabinete de Sánchez Guerra el restablecimiento de la censura previa para acallar estas acusaciones:

"Se llegó a descender hasta las heces, se amasó cieno bochornoso y se lanzó al rostro de nuestros soldados... de nuestro caudillo el Alto Comisario. Él fue imprevisor, desoyó a sus cooperadores, les negó adrede los auxilios, los lanzó a la muerte. ¡Y si hubiera sido siquiera a la muerte! Pero los arrojó al cautiverio y en él se complacía y parecía estar anhelante de que poco a poco fueran atormentados y consumidos.

Esto y mucho más decían los periódicos, y cuando veíamos a ese gobierno que, por adularlos, quitó la censura, y por temerlos, no se atrevería al castigo de semejantes excesos, se nos llenaba el pecho de indignación y esta indignación venía a degenerar en pena, en asco y tedio profundo al advertir que el pueblo sano, representado por la prensa derechista tampoco reaccionaba ante tales apósitos de ignominia ${ }^{, 305}$.

305 "La verdad ante todo", La Gaceta Regional, n 567, 10 de julio de 1922, p. 1. 
En esta turbia y violenta atmósfera se produjo la dimisión del Alto Comisario y el nombramiento de Burguete. Además, la marcha de Berenguer coincidió cronológicamente con el primer aniversario del derrumbe de Annual y Monte Arruit ${ }^{306}$. No resultó difícil, en estas circunstancias, atizar el odio al rifeño con la publicación de varios artículos llenos de emotividad. Veamos uno de ellos. En él se hacía memoria del sangriento hundimiento de la Comandancia de Melilla, del desquite subsiguiente y el articulista terminaba lamentando el estado de amargura que había acabado embargando a todos:

“;Ya venció el año trágico! (...) El 22 de julio se ha cumplido el primer aniversario de aquel convoy de Igueriben; de aquella espantosa retirada de Annual que cubrió de cadáveres españoles las tierras resecas e ingratas del Rif; de aquellos gritos de dolor y de aquellos espasmos de amargura que resonaron en la nación entera; de aquellos gritos de venganza; de aquellos propósitos de desquite; de aquellos patrióticos movimientos de las provincias hispanas (...) ;Luego ya vino el cansancio!

La guerra nos comenzó a cansar (...) Salieron a flote las responsabilidades. ¿Qué cosa más natural? El castigo, primero; la responsabilidad, después (...) Tras un año de lucha, aún no se ha hecho la reconquista, no se han rescatado los cautivos, no se han efectuado las responsabilidades, no se ha elaborado el plan definitivo de Marruecos, no sabemos qué protectorado implantar, no sabemos..., ni lo que nos traemos entre manos. Presenciamos las campañas de los padres de los soldados de cuota, de las madres de los soldados, de las crisis ministeriales, de los relevos de mando, de las cuestiones militares, de los debates parlamentarios, de los movimientos abandonistas.

¡Y qué tristes, pero qué elocuentes son estas manifestaciones de lo que piensa y de lo que quiere un pais!' 307.

Por si no bastara con esa atmósfera de suma crispación, el aterrizaje de Burguete

en la Alta Comisaría y sus anuncios de cambio, de regreso al diálogo con los cabecillas rebeldes, en la política del Protectorado, suscitaron el inmediato rechazo de La Gaceta:

"Por lo visto, ha fracasado nuestra acción militar en Marruecos, que el estado de nuestra hacienda no permite prolongar y se va a implantar una acción política y civil de protectorado, que en todo caso debió haber seguido a la victoria militar, y que no siendo así, habrá que establecerla con la cooperación interesada, pagada y pactada con los principales jefes de los beniurriagueles ${ }^{, 308}$.

La redacción salmantina temía que Francia aprovechase este cambio de orientación para emprender una lucha diplomática y hacerse con Tánger e intentaba persuadir nuevamente a la opinión salmantina de que España estaba capacitada para la

\footnotetext{
${ }^{306}$ Barreto: “Berenguer ha dimitido. ¿Barrera, Alto Comisario?”, La Gaceta Regional, $\mathrm{n}^{\mathrm{o}} 568,11$ de julio de 1922, p. 3; y Barreto: "Última hora", La Gaceta Regional, no 572, 15 de julio de 1922, p. 6.

307 "El año de la tragedia", La Gaceta Regional, $\mathrm{n}^{\circ} 579,24$ de julio de 1922, p. 1.

308 "Hacia el Protectorado", La Gaceta Regional, n 596, 14 de agosto de 1922, p. 2.
} 
toma de Alhucemas ${ }^{309}$. Por eso recibió con disgusto la anulación de un nuevo proyecto de desembarco ${ }^{310}$. Por suerte, la decisión de disolver definitivamente las Juntas de Defensa, como respuesta del gobierno de Sánchez Guerra a una muy teatral dimisión de Millán Astray, fue una estupenda noticia, que convirtió a los africanistas en el cuerpo hegemónico en el seno del Ejército español ${ }^{311}$.

Pero la alegría duró un suspiro. La indignación resurgió al conocerse el ascenso a la poltrona presidencial del marqués de Alhucemas, así como el nombramiento para el cargo Alto Comisario de Miguel Villanueva y su programa civilista. Blas de la Rúa Guzmán se interrogaba sobre los propósitos de esta decisión:

\begin{abstract}
“QQué es lo que pretende el gobierno hacer con el hueso del Rif que le adjudicaron a España las potencias firmantes de la Conferencia de Algeciras, en la desastrosa subasta del imperio del Magreb? ¿Protectorado pacifista? ¿Colonia civil militarizada? (...) ¡Oh!, empero eso del Marruecos civil era la médula de los 'concentrados' cuando estaban en la oposición y en vísperas del escalamiento del Poder; y, una vez en las poltronas ministeriales, no se pudo menos de acordar su implantación (...) Y ésta, desgraciadamente, se llevó a la práctica; empero, un alto imprevisto ha dejado aplazada la implantación inmediata en nuestro Protectorado, del régimen civil.

El señor Villanueva, nombrado Comisario Superior de Marruecos, apenas indicado para el cargo, se puso enfermo (...) Estos días también, precisamente se habló de que había serios disgustos militares a consecuencia del cambio de directriz política de Marruecos. El marqués de Alhucemas dice que entre el elemento militar no pasa nada...; cuando lo dice Alhucemas, se debe creer a cierra ojos... (...) En todo nuestro territorio de Marruecos, la noticia de la implantación del protectorado civil cayó como una bomba.

Desde allí se piensa que en España puede haber impulso, pero que el gobierno ha perdido la cabeza.

¿Perdido la cabeza? Por asociación de ideas pensamos en estos momentos en el caso griego...

Con que jentendámonos! ${ }^{, 312}$.
\end{abstract}

Las insinuaciones de este editorial eran muy claras: el protectorado civil era un disparate; el mero proyecto de su implantación había espoleado a los rebeldes y la enfermedad de Villanueva resultaba de lo más oportuno.

Toda esta bochornosa situación había culminado, según La Gaceta y para colmo de males, con el pago de un rescate por los prisioneros. Tras presenciarlo, el tono discursivo del periódico se volvió más y más agresivo. Por eso, desde febrero de 1923,

\footnotetext{
309 “¿Vamos o no vamos o no vamos a Alhucemas?”, La Gaceta Regional, $\mathrm{n}^{\circ}$ 607, 28 de agosto de 1922, p. 1; "Hay en España cuestión mayor que Marruecos", La Gaceta Regional, n $\mathrm{n}^{\circ}$ 625, 18 de septiembre de 1922 , p. 1.

310 "Hacia el Protectorado. La verdad sobre la paz de Abd-el-Krim", La Gaceta Regional, n 632, 26 de septiembre de 1922, p. 2; "Hacia el Protectorado", La Gaceta Regional, n 650, 17 de octubre de 1922, p. 2; y "El Paladín": "La toma de Granada", La Gaceta Regional, no 721, 12 de enero de 1923, p. 1.

311 "Lo de siempre. ¡Pobre España!", La Gaceta Regional, n 682, 24 de noviembre de 1922, p. 1.

${ }^{312}$ Blas de la Rúa Guzmán, “El Paladín”: “Charlas marroquíes: ¿un alto imprevisto? ¡Entendámonos!”, La Gaceta Regional, $\mathrm{n}^{\circ}$ 714, 4 de enero de 1923, p. 1.
} 
muchos editoriales de la primera plana, firmados por un tal "E.", se dirigieron a relegitimizar la acción bélica decidida y urgente:

"Nuestro Protectorado sobre Marruecos constituye un deber nacional que no podemos regir, si hemos de mirar a nuestra independencia futura (...) Existe otro motivo superior a los demás que nos obliga, con imperativo categórico, a una intervención en África: el cumplimiento del testamento de Isabel I y la evangelización de aquellos territorios (...) Después de los Desastres de julio del año de 1921 en la zona oriental, todo espíritu patriota, todo español consciente de su deber y celoso del honor nacional, puso, por encima de cualquier otra aspiración, el castigo inmediato de Abd-elKrim ${ }^{, 313}$.

El protectorado civil resultaba, se reiteraba, humillante porque requería un entendimiento con Abd-el-Krim, mientras que la opinión conservadora seguía reclamando una urgente actuación sobre el peñón de Alhucemas.

El nuevo nombramiento de otro civil, Silvela, para la Alta Comisaría fue interpretado, por descontado, como una total incoherencia ${ }^{314}$. Pero el endurecimiento progresivo de su discurso, mostrándose cada vez más partidario de la acción conjunta civil y militar, le granjearía una creciente simpatía de la opinión conservadora: "El Comisario Superior señor Silvela, por muy demócrata y muy civilista que sea, teóricamente, ha tenido que rendirse a la realidad" ${ }^{\text {315. }}$. No obstante, la operación sobre Alhucemas continuó siendo descartada:

"Estamos cansados de escribir acerca de este problema, que constituye un cáncer para España (...) Desde hace años se está engañando a la nación en todo lo que se refiere a nuestra política y a nuestra gestión militar en África. Porque no se nos dice que la política, por inmoral y por fracasada, cayó desde hace mucho en el mayor desprestigio; y porque con la táctica seguida hasta ahora, en el aspecto militar, sin planes fijos, sin orientaciones definitivas, sin los elementos necesarios, hemos ido de fracaso en fracaso, sin conseguir el dominio de verdad del territorio ocupado y pagando esa precaria actuación, con torrentes de sangre y con torrentes de oro (...) El problema de Marruecos está hoy vinculado a la zona oriental y circunscrito a este dilema: o se va a Alhucemas o no se va. Y el gobierno, dividido por odios y antagonismos y ambiciones bastardas irreconciliables, sostiene la política del engaño y del miedo y no dice a España esta verdad, que para nosotros es meridiana. O a Alhucemas, o al abandono de Marruecos (...) El procedimiento político, desacreditado y en pleno fracaso, es, además, deshonroso y caro ${ }^{1316}$.

\footnotetext{
313 "E.": "El problema de Marruecos. Ligeras consideraciones", La Gaceta Regional, no 744, 8 de febrero de 1923, p. 1.

314 "E.": "Nuevo Comisario Superior. Algunas consideraciones", La Gaceta Regional, no 749, 14 de febrero de 1923, p. 1; "E.": "El problema de Marruecos. La causa de su gravedad", La Gaceta Regional, $\mathrm{n}^{\mathrm{o}}$ 752, 17 de febrero de 1923, p. 1; "E.": "El problema de Marruecos. Continuemos...", La Gaceta Regional, 757, 23 de febrero de 1923, p. 1.

315 "E.": "El problema de Marruecos. Aciertos y desaciertos del Comisario Superior", La Gaceta Regional, $\mathrm{n}^{\circ}$ 787, 31 de marzo de 1923, p. 5. La misma idea ya había sido expuesta, más tibiamente, en "E.": "El problema de Marruecos. La sumisión de El Raisuni", La Gaceta Regional, no 769, 9 de marzo de 1923, p. 1; "E.": "El problema de Marruecos. Manifestaciones del señor Silvela", La Gaceta Regional, $\mathrm{n}^{\mathrm{o}} 775,16$ de marzo de 1923, p. 1.

316 "E.": "De Marruecos", La Gaceta Regional, no 892, 6 de agosto de 1923, p. 1.
} 
Obviamente, la dimisión de Martínez Anido se recibió con aflicción ${ }^{317}$. Pero aún así, los editoriales de "E." anteriores al golpe militar revelaban bastante confianza y entusiasmo ante la proximidad de un cambio en la orientación de la política marroquí ${ }^{318}$. Tal vez, porque presagiaba que el fin del gobierno de concentración liberal estaba muy próximo:

"Las medias tintas, las componendas con los moros, no sirven para otra cosa que para engreír, para que nos engañen y para hacer interminable una situación que nos desprestigia y arruina (...) España tiene arrestos para sobreponerse a sus desventuras, tiene instinto de conservación, posee en alto grado la fe y la confianza en su Ejército y con esas virtudes por bandera y con el recuerdo de su historia gloriosísima, sabrá seguir, tranquila y consciente de su elevada misión, el derrotero que le marca su honor y su deber, 319 .

El puerto de arribo era idéntico para El Adelanto y La Gaceta: ambos apostaron por una guerra fulminante. Sin embargo, el camino había sido mucho más tortuoso para la redacción de Núñez Izquierdo.

Para El Pueblo, y ya terminamos, la gestión política del Protectorado no fue una historia de vacilaciones más o menos disculpables y constantes titubeos, como parecía traslucir la prensa dinástica, sino de desastrosos e incoherentes tumbos.

Puesto que esta publicación, rechazaba la contienda marroquí de un modo visceral, evitó ceder su espacio para la publicidad de la misma. Además, temía al censor. Por esta razón, cuesta precisar o incluso barajar, mediante el análisis de las opiniones publicadas en este rotativo, las reacciones de la opinión obrera ante los planes, proyectos y actuaciones de los sucesivos Altos Comisarios. Aunque en líneas generales, El Pueblo secundó sin objeciones los famosos discursos parlamentarios de Indalecio Prieto.

Más que preocuparse por la administración del Marruecos español, el diputado socialista se convirtió en el abanderado en la exigencia de responsabilidades. Su discurso se fundamentó en el rechazo de los tres argumentos clásicos esgrimidos por los africanistas para justificar la expansión española en Marruecos: el Protectorado no era

\footnotetext{
317 "E.": "Lo de Marruecos", La Gaceta Regional, no 899, 14 de agosto de 1923, p. 1.

318 "E.": "El problema de Marruecos. Situación grave", La Gaceta Regional, no 809, 26 de abril de 1923, p. 1; "E.": "El caos marroquí", La Gaceta Regional, no 837, 1 de junio de 1923, p. 1. "E.": "Situación difícil", La Gaceta Regional, no 865, 4 de julio de 1923, p. 1; "E.": "La tragedia marroquí", La Gaceta Regional, $\mathrm{n}^{\circ}$ 902, 18 de agosto de 1923, p. 1 (acaba de producirse el ataque sobre Tizzi-Azza); "E.": "Acción bélica en Marruecos", La Gaceta Regional, no 905, 22 de agosto de 1922, p. 1; y "E.": "Nuestra acción en Marruecos. Ante las resoluciones del gobierno", La Gaceta Regional, no 911, 29 de agosto de 1923, p. 2. En todos estos editoriales se repiten las mismas ideas: la demonización del gabinete del marqués de Alhucemas y la necesidad de un desembarco.

319 “E.": "Nuestra acción en Marruecos", La Gaceta Regional, n 907, 24 de agosto de 1923, p. 1.
} 
necesario para la expansión de la agricultura española porque en la metrópoli existían muchas tierras incultas y de mejor calidad que las marroquíes; Marruecos no era una zona de expansión financiera, ya que España no tenía ni exceso de producción industrial ni capitales sobrantes; y, por último, Marruecos no representaba una frontera ante Francia, sino un frente generador de nuevos conflictos.

Pero Indalecio Prieto no cuestionó el hecho de la colonización de Marruecos, sino el proceder del gobierno español. Por ello, exigió la derogación de la Ley de Jurisdicciones, la supresión del cuerpo de Intendencia y la clausura de todas las academias militares ${ }^{320}$.

Para el socialismo salmantino, asimismo, resultó irónico que España pretendiese desempeñar una misión civilizadora en Marruecos, teniendo en cuenta la miseria del propio país. Apelar al patriotismo de la ciudadanía constituía, por ese mismo motivo, un desatino. La redacción obrera creía que la palabra "patriotismo" se empleaba de modo abusivo en los momentos de angustia. El falso patriotismo se inculcaba desde la infancia como si se tratase de un conjunto de acciones chulescas que otorgaban a España superioridad sobre otros pueblos. Y desde esta óptica, la historia nacional se convertía en una sucesión de épicas batallas, que habían presenciado su fin en 1898.

Entonces no se había rectificado ninguna conducta ni se habían exigido responsabilidades. El problema, por tanto, había permanecido latente, enquistado, sobre todo dada la falta de memoria histórica de los españoles, hasta que la catástrofe se repitió $^{321}$. A resultas de todo ello, la actitud obrera con respecto a Marruecos fue siempre abandonista. He aquí un primer ejemplo, un artículo escrito con motivo de la visita de Alfonso XIII a las Hurdes, y con un tono bastante ponderado:

"Hasta ahora y posiblemente, por desgracia, también en lo sucesivo, los hombres que en sus manos han tenido y tienen las riendas de la gobernación del país, no han querido, no sabemos por qué causas, fijar su atención, para aplicar remedio, en el Marruecos de dentro, en este Marruecos de caza, más inculto e incivilizado que aquel otro (...) Y hay que olvidar el Marruecos extraño, hay que abandonarlo (...) Atendamos a este Marruecos de dentro, al Marruecos de casa, que el otro, el otro, que tantos millones, y tantos hombres nos cuesta, ese no lo necesitamos.

¿Civilización? Sí, civilización y cultura, pero para el Marruecos nuestro, para el que lleva nuestra sangre, ${ }^{, 322}$.

\footnotetext{
${ }^{320}$ Véase PRIETO, Indalecio: Con el Rey o contra el Rey: la guerra de Marruecos (2 vols.). Barcelona: Planeta, 1990. Entre las obras más recientes, COMALADA, Ángel: Op. Cit., pp. 131-132. Consideramos que esta obra, y la de Elisa Pérez Molina, son las que más nos aproximan al desarrollo de los debates parlamentarios sobre los asuntos marroquíes durante el reinado de Alfonso XIII.

321 "El patriotismo", El Pueblo, n' 31, 7 de enero de 1922, pp. 1-2.

322 "El Marruecos de dentro", El Pueblo, no 41, 24 de junio de 1922, p. 1.
} 
Al cumplirse el primer aniversario del Desastre, no obstante, el discurso se agrió, llegando a adquirir un estilo extremadamente duro, incluso insultante. Mientras que $\mathrm{La}$ Gaceta reclamaba sin tapujos la guerra, el socialismo salmantino ansiaba el abandono:

"Contra la voluntad del pueblo español, señores gobernantes o mangoneadores del cotarro nacional, se está sosteniendo una guerra suicida e impopular, en ese trágico suelo africano, al que odiamos de todas veras, siquiera sea, porque al llevar su nombre a nuestros labios nos recuerda dolores y heridas muy dificiles de cicatrizar (...) Nuestros gobernantes son de hierro; son inflexibles; contra viento y marea, sostienen una guerra caprichosa y fatal. Seguramente lo hacen, porque a ella no mandan sus hijos y si los tienen están bien seguros de que a ellos no les llegan las balas. ¿Que los hombres mueren a millares, que padecen hambre, que están mal alimentados y mal vestidos? ¡Qué les importa a ellos! (...) Son tan desaprensivos, que cubrirán sus oídos de algodones para no escuchar el clamor del pueblo, que no poca culpa tiene de tal estado de cosas, y muy especialmente las gentes de derechas, a quienes no se les ha ocurrido nunca protestar de la guerra de Marruecos, hasta que no han llegado a ellos las salpicaduras, hasta que no han visto que sus hijos, a los que libraban con sus pesetas, han partido también a los campos africanos para empuñar un fusil y poner su vida en peligro.

Ahora sí protestan (...) Nosotros sí, hemos querido siempre, la terminación de esa guerra injusta (...) Y al pedir su terminación, no distinguimos de clases; pedimos para todos, para nosotros y para los que compran con dinero la suerte.

Conste que nada conseguiremos con nuestras protestas y peticiones de pordiosería. En el Parlamento se hacen las leyes, el Parlamento puede dar por terminada, si quiere, esa guerra; el Parlamento se forma con representantes del pueblo, que dicen llevar allí su voz y su representación (...) Pues si queréis que termine la guerra, sabed también a quien votáis. De lo contrario, no os quejéis ${ }^{\text {,323. }}$.

Las implicaciones de este último comentario, evidentemente, eran colosales: porque el rechazo hacia el conflicto marroquí estaba alimentando el descrédito de todo sistema caciquil (incluido el Rey, aunque no se mencionase). Por de pronto, sin embargo, el tributo de sangre para el pobre, el argumento más emotivo contra la conflagración, se situaba una vez más en el centro del discurso propagandístico del socialismo. Y de nulo consuelo servía la movilización de los "cuotas". Aunque sobre este asunto volveremos más adelante.

323 “Andrés de España”: “O ellos o nosotros”, El Pueblo, no 42, 8 de julio de 1922, p. 1. 


\section{La Victoria y los salmantinos}

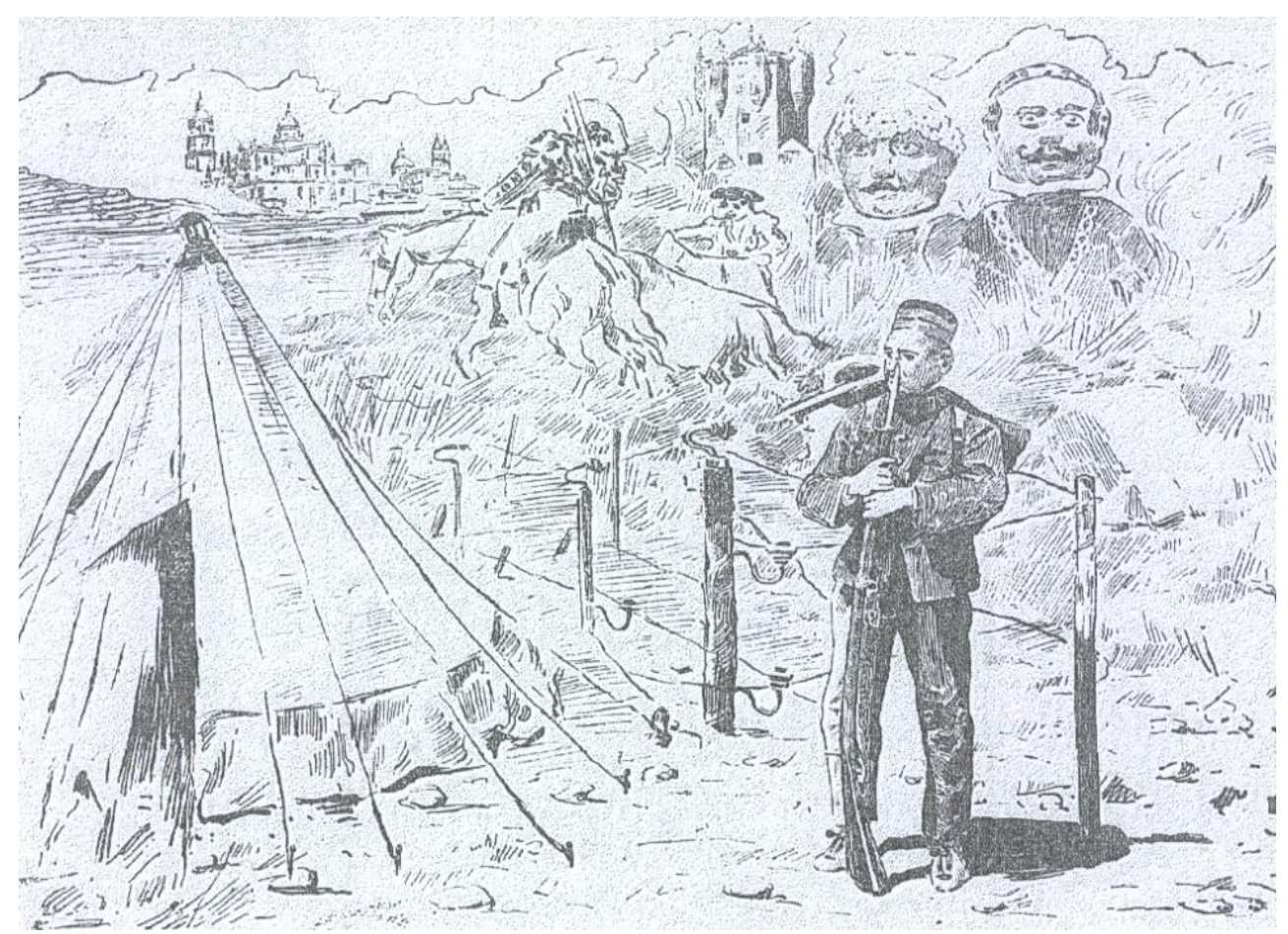

El Adelanto, $\mathrm{n}^{\circ} 11.438,13$ de septiembre de 1921, p. 1.

Recordemos que La Victoria, con su millar de expedicionarios, había quedado instalada en las cercanías de Larache. A mediados de septiembre, sin embargo, Pedraza notificó que el batallón expedicionario se trasladaría a la plaza como fuerza de guarnición e inspección de la zona, sustituyendo al regimiento de León y abandonando la vida en tiendas de campaña a favor de la más cómoda estancia en barracones ${ }^{324}$. También aquí el tiempo transcurría lentamente entre los ejercicios de instrucción, tiro y los paseos militares; pero las fiebres palúdicas empezaron a ensombrecer la sosegada vida del batallón e hicieron que la llegada del correo ya no fuese el único medio de ruptura del ambiente monótono ${ }^{325}$.

Además del "cuota" mencionado, también José Luis Trigo, Enrique Gómez Parra y el doctor Monge enviaron sucesivas crónicas para El Adelanto, con un tono,

\footnotetext{
${ }^{324}$ Pedraza: "El Adelanto en Larache", El Adelanto, no 11.438, 13 de septiembre de 1921, p. 1; Pedraza: "Salamanca en Marruecos", El Adelanto, no 11.431, 16 de septiembre de 1921, p. 2 (obsérvese que hay un error en la numeración de los diarios); Pedraza: "El batallón de La Victoria", El Adelanto, no 11.432, 17 de septiembre de 1921, p. 4; y García de la Cruz: "El batallón de La Victoria", La Gaceta Regional, nº 332, 28 de septiembre de 1921, p. 1.

${ }^{325}$ García de la Cruz: "El batallón de La Victoria", La Gaceta Regional, no 324, 19 de septiembre de 1921, p. 1; y García de la Cruz: "El batallón de La Victoria”, La Gaceta Regional, no 326, 21 de septiembre de 1921, p. 1. A propósito de las difíciles condiciones higiénicas a las que se enfrentaban los soldados en África Trigo solicitó el auxilio en Larache de médicos y estudiantes de Medicina: "Las enfermedades aquí son temibles, violentísimas y casi siempre de funesto desenlace por el clima, la deficiente alimentación y la escasez de personal y material sanitario", José Luis Trigo: "Para la Cruz Roja salmantina. Desde Larache", La Gaceta Regional, no 342, 10 de octubre de 1921, p. 3.
} 
igualmente, bastante tranquilizador ${ }^{326}$. Por su parte, La Gaceta Regional dispuso de las narraciones de García de la Cruz y del aludido Trigo, de las nuevas colaboraciones del piloto de aviación Gutiérrez Flores, de Enrique Navarro de Errazquin ("Conde de BeniHosmar"), que era un catedrático del Instituto de Salamanca y del Centro “América”, y de su hijo, Elías ${ }^{327}$.

La permanencia en Larache, sin embargo, fue breve. El 7 de noviembre el batallón al completo se trasladó, de nuevo, en unas durísimas jornadas de marcha, a la posición de Nuader para relevar al regimiento de Cuenca ${ }^{328}$. Nuader era el campamento general más avanzado de la Comandancia, ubicado en primera línea de fuego. Aglutinaba, además, esta posición y sus blocaos subordinados un total de cinco mil hombres. Mientras que la cuarta compañía del batallón de La Victoria permaneció en Nuader, la primera y segunda fueron desplazadas hasta las posiciones más descubiertas. Por último, la tercera compañía, que fue trasladada algunos días más tarde que el resto del batallón, permaneció junto a la cuarta. Entre funciones más habituales figuraron la protección de la aguada, caminos y la guardia de parapetos ${ }^{329}$. Una vez más el peligro se cernía sobre los salmantinos.

De hecho, cuando no había transcurrido demasiado tiempo desde su traslado, el 6 de diciembre de 1921, el batallón recibió su bautismo de fuego. Un convoy fue atacado por un grupo de marroquíes, resultando tres soldados muertos y otros varios heridos, mientras se dirigía a uno de los blocaos más avanzados, Ain-Hedid, para avituallarlo $^{330}$. Obviamente, la triste nueva tuvo un impacto colosal en la opinión salmantina y poco pudieron hacer los “cuotas"-cronistas, en esta ocasión, por calmar los ánimos:

"Por cartas recientemente recibidas, nos consta que en muchas de nuestras casas están alarmadísimos a causa de las noticias, demasiado cruentas y un tanto imprudentes, que particulares de aquí han enviado a los suyos, quienes, a su vez, se han encargado de divulgarlas corregidas y aumentadas, como es natural.

\footnotetext{
${ }^{326}$ Pedraza: "La Victoria en Larache", El Adelanto, no 11.456, 4 de octubre de 1921, p. 3; El doctor Monge: "En la toma de Zeluán intervienen los aeroplanos 'Salamanca"”, El Adelanto, no 11.466, 15 de octubre de 1921 , p. 2.

327 "Nuestras informaciones en Marruecos", La Gaceta Regional, no 319, 13 de septiembre de 1921, p. 4.

${ }^{328}$ José Luis Trigo: "La Victoria en Larache", El Adelanto, no 11.485, 7 de noviembre de 1921, p. 2; A. Hernández Martín: “Crónicas de Melilla”, La Gaceta Regional, no 391, 7 de diciembre de 1921, p. 4.

${ }^{329}$ José Luis Trigo: "Los soldados salmantinos en campaña", El Adelanto, no 11.496, 19 de noviembre de 1921, p. 2; E. Gómez Parra: "El desarme y las nuevas posiciones", El Adelanto, no 11.527, 26 de diciembre de 1921, p. 2; y "El salmantino T.": "La cuarta compañía de la Victoria en Nuader", El Adelanto, $\mathrm{n}^{\circ} 11.528,27$ de diciembre de 1921, p. 2.

330 "El batallón expedicionario de La Victoria sufre algunas bajas", El Adelanto, no 11.513, 9 de diciembre de 1921, p. 2; José Luis Trigo: "Cómo ocurrió, el día 6, la agresión de unos moros", El Adelanto, no 11.517, 14 de diciembre de 1921, p. 1; y "La actuación del batallón de La Victoria en África”, La Gaceta Regional, no 392, 9 de diciembre de 1921, p. 2.
} 
No me propongo, con esta croniquilla familiar y con las que a ésta, Dios mediante, seguirán, desmentir totalmente esas voces alarmantes; me propongo, únicamente, despojar esas noticias que las han revestido y hacer que la tranquilidad y la esperanza vuelvan a nuestros hogares.

Hará unos veintitantos días vinimos de Larache a relevar al batallón de Cuenca, que guarnecía esta posición de Nuader y algunas otras posiciones y blocaos cercanos (...) Nuestra vida se ha reducido, hasta el presente, a las protecciones de aguadas y caminos, que vienen a ser unos paseos militares (...) Semejantes a estos son los entretenimientos en que se ocupan los compañeros de los destacamentos, añadiendo los convoyes que frecuentemente tienen que organizar con el fin de abastecerse de las provisiones necesarias. Son de poca exposición (...) Lo cierto es que el clima de Nuader es mucho más saludable que el de Larache, como se ve por el reducido número de enfermos (...) Es también cierto que el espíritu de los soldados es excelente (...) Han disminuido notablemente las endiabladas pulgas (...) Mientras tanto, en vez de afligiros y de gemir por nuestra suerte, rogad, rogad al cielo a fin de que pronto y terminada, gloriosa y felizmente para nuestra patria, la presente guerra, podamos estrecharos contra nuestro corazón ${ }^{, 331}$.

Los efectos de la pelea se dejaban sentir otra vez entre algunas familias de la ciudad: cierto que el capitán Flores insistía en que la exposición de los salmantinos ante los marroquíes era escasa; y cierto igualmente que se empeñaba en dulcificar la estancia de La Victoria en África; pero, en realidad, la protección de aguadas era un trabajo muy arriesgado y la opinión pública salmantina lo sabía. ¿Conseguiría el cronista engañar a alguien? Evidentemente, no. Porque la historia se repetía y los tristes recuerdos se agolpaban en la mente de los lectores, solapándose con la reciente y dramática experiencia: y es que esa misma tarea, la de salvaguardar los convoyes en los trabajos de avituallamiento, la había desempeñado, años atrás, La Albuera. Así que muchos revivirían ahora la agonía de Peral y el durísimo paso de aquellos hombres por el Protectorado. Por fin, aquel escepticismo del perspicaz y desaparecido "Argos" se estaba convirtiendo en una actitud generalizada ${ }^{332}$.

La angustia ciudadana aumentó cuando apenas una semana después, el 17 de diciembre, se comunicó la intervención de parte de las compañías tercera y cuarta de La Victoria en las operaciones militares del sector de Beni-Arós, último reducto de El Raisuni. Aunque no hubo víctimas mortales entre el batallón salmantino en esta ocasión, puede imaginarse el clima de sorpresa y nerviosismo que se impuso en

\footnotetext{
${ }^{331}$ Flores: "Desde Nuader", La Gaceta Regional, no 392, 9 de diciemabre de 1921, p. 4.

${ }^{332}$ La última contribución suya para El Adelanto es del 6 de septiembre de 1919. Desconocemos los motivos de su retirada.
} 
Salamanca durante estos días ${ }^{333}$. A decir verdad, desde este momento, la alarma cundiría de modo intermitente, coincidiendo con cada nueva operación ${ }^{334}$.

Repasemos de corrido su periplo africano: en marzo de 1922, se produjo un primer relevo de tropas salmantinas ${ }^{335}$. Y un mes después, los ataques sobre Beni-Arós recobraron intensidad, mientras La Victoria fue trasladada sucesivamente a Megaret, Rokba el Gozal, a la conocida Nuader y finalmente a Bab-el-Sol ${ }^{336}$.

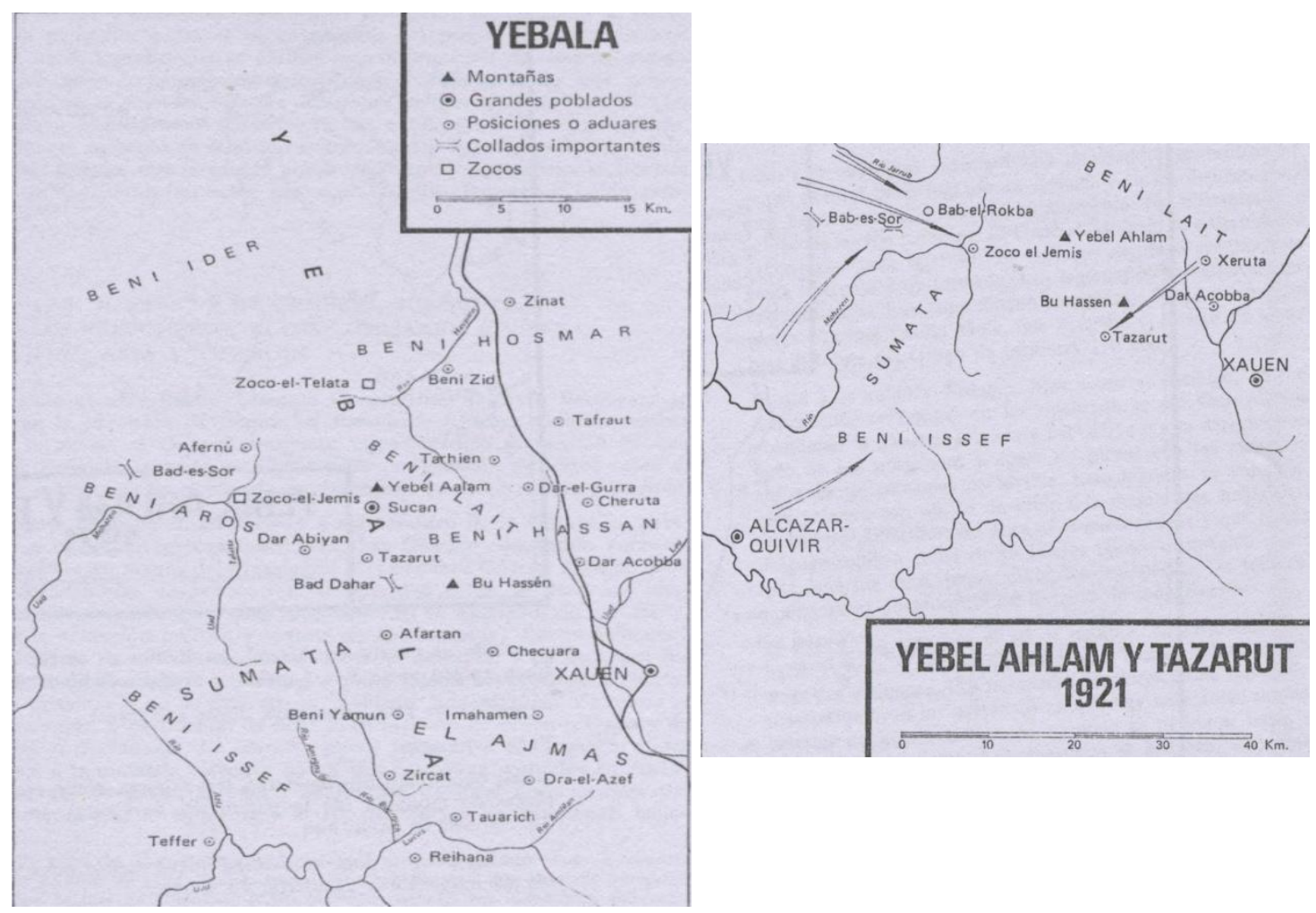

MARTÍNEZ DE CAMPOS, Carlos: Op. Cit., p. 265 y 268.

A mediados de mayo, Pedraza llegó a Salamanca como integrante del primer convoy de heridos salmantinos que habían sido repatriados ${ }^{337}$. Como anotación más triste, al finalizar junio de 1922, tanto Rivera, en el caso de El Adelanto, como

\footnotetext{
${ }^{333}$ Prieto-Trigo: "Los soldados salmantinos del batallón de La Victoria y las operaciones de Beni-Arós", El Adelanto, no 11.540, 10 de enero de 1922, p. 1; Flores: "Desde Ber-bex", La Gaceta Regional, nº 407, 27 de diciembre de 1921, p. 7.

${ }_{334}^{334}$ Flores: "Desde Nuader", La Gaceta Regional, no 432, 26 de enero de 1922, p. 2.

335 José Luis Trigo: "Desde Nuader. Las tropas del batallón de La Victoria", El Adelanto, no 11.606, 28 de marzo de 1922, p. 1.

336 "El corresponsal": "Las fuerzas de La Victoria", El Adelanto, no 11.635, 3 de mayo de 1922, p. 1; y García de la Cruz: "El batallón de La Victoria", La Gaceta Regional, nº 506, 25 de abril de 1922, p. 4.

337 "Regreso de los soldados de La Victoria", El Adelanto, no 11.644, 13 mayo de 1922, p. 1; "La Cruz Roja", La Gaceta Regional, no 523, 16 de mayo de 1922, p. 4; Flores: "Desde Megaret", La Gaceta Regional, $\mathrm{n}^{\circ}$ 538, 3 de junio de 1922, p. 2; y "El corresponsal": "Desde Bab-el-Sol", La Gaceta Regional, no 545,12 de junio de 1922, p. 2.
} 
Barreto $^{338}$, corresponsal en Madrid para La Gaceta Regional, se hicieron eco en sus respectivas secciones del fallecimiento de otros catorce hombres de La Victoria en el camino a la ya tristemente célebre posición de Ain-Hedid ${ }^{339}$.

Hubo que esperar a finales de agosto de 1922 para que los salmantinos recibiesen con entusiasmo la deseada noticia de la repatriación de los 337 hombres de La Victoria pertenecientes a la quinta del $19^{340}$. Lamentablemente, en las mismas fechas le fue comunicado también a Federico Anaya que un nuevo relevo de La Victoria debía trasladarse al Protectorado. Dada la carencia de tiempo para preparar un solemne acto de despedida, el alcalde se limitó a rogar a los salmantinos que acudiesen a la estación de ferrocarril. Atrás habían quedado los numerosos festejos y grandilocuentes palabras de hacía apenas un año ${ }^{341}$.

¡Y qué lejano parecía, incluso, todo aquello! Tanto que, con motivo de la partida, que finalmente se produjo en la madrugada del 31 de agosto, en la prensa no faltó el recuerdo emotivo de los actos de despedida de 1921 y algún que otro comentario sobre la incidencia del problema marroquí en la vida nacional. Sin duda, se intentaba así persuadir a la opinión salmantina sobre la conveniencia de proseguir con el esfuerzo bélico y, lo que entonces importaba más, se luchaba por evitar el decaimiento moral de los expedicionarios, una vez que el afán de desquite empezaba a remitir:

"Dentro de pocas horas emprenderán su viaje a Marruecos las tropas del regimiento de La Victoria, que van a relevar a sus camaradas de la quinta del 19.

$Y$ un año hizo por ahora -el día 25 de agosto-Salamanca, en noche de imborrables recuerdos, despidió, con el más desbordante de los entusiasmos, unidos por patriótica vibración todos sus sectores sociales, a los soldados que iban a ofrendar su vida por la patria, palpitante aun la carne de sus hermanos, los soldados españoles inmolados en tierras africanas, por la más cobarde de las traiciones.

Desde entonces, el problema marroquí, en su trayectoria con el vivir patrio, que no ha puesto en la empresa más que abnegaciones y desprendimientos, ha tomado aspectos que ponen como un cendal de desilusión y cansancio en lo que fue, o debió ser, obra de arrolladora y viril revancha. (...) iSon soldados de España, son salmantinos, y pese a

\footnotetext{
${ }^{338}$ Por cierto, desde La Acción, este periodista se destacaría al tildar de vergonzoso el hecho de pactar el rescate de los prisioneros y señaló como origen del Desastre la existencia de contratos mineros entre Abdel-Krim y los comerciantes de las minas del Rif, entre ellos, Echevarrieta. Inmediatamente, sus palabras fueron desmentidas por Santiago Alba, desde La Libertad. Para un conocimiento más exhaustivo, véase SÁNCHEZ MORALES, Jorge: Manuel Delgado Barreto. Las Palmas de Gran Canaria: Ediciones Idea, 2008.

339 "Del trágico convoy de Ain-Hedid", El Adelanto, no 11.682, 27 de junio de 1922, p. 1; Barreto: "Por teléfono", La Gaceta Regional, n 556, 26 de junio de 1922, p. 3.

340 "Los 337 soldados de La Victoria que vienen de Larache", El Adelanto, no 11.727, 20 de agosto de 1922, p. 4; "Soldados que regresan”, La Gaceta Regional, n 601, 21 de agosto de 1922, p. 2.

${ }^{341}$ Federico Anaya: "Los soldados de La Victoria que marchan a Larache", El Adelanto, no 11.728, 22 de agosto de 1922, p. 5; "La marcha de los soldados", La Gaceta Regional, no 609, 30 de agosto de 1922, p. 1; "La despedida de los soldados de La Victoria que marchan a Larache", La Gaceta Regional, n 610, 31 de agosto de 1922, p. 1. Los soldados fueron obsequiados con un rancho extraordinario, además de sesenta tartas, cuatrocientos cigarros puros, cuatrocientas cajetillas y veinte botellas de coñac.
} 
todos los fracasos de la política, que no es de oportunidad discutir, Salamanca está en el deber de ser, como siempre, hidalga y patriótica!"’342.

Resultaba evidente que los salmantinos se hallaban entonces embargados por la pena, y los periódicos, más que hacerse eco del apoyo social a los futuros combatientes, se esforzaban por convencer a la opinión de la necesidad, o incluso el deber, de seguir colaborando moral y económicamente con el cometido de La Victoria en África. Así, El Adelanto abundaba en la idea:

"Por las circunstancias que hoy rodean a la acción de España en Marruecos, por el cambio de criterio de la opinión española sobre el problema africano, se hace más precisa la despedida cordial, el adiós entusiasta, el homenaje de un pueblo a esos centenares de bizarros jóvenes que marchan a la guerra, cuando la guerra aparece en una fase definitiva y ofrece un aspecto de mayor incertidumbre e inquietud por desconocerse las proporciones de su desarrollo y de los nuevos planes de afirmación de España en la zona de su Protectorado" ${ }^{\text {343 }}$.

También una postura muy similar era la defendida desde las filas conservadoras:

"La reconquista se ha hecho en gran parte, el estricto espíritu de venganza y desquite ha quedado cumplido. Además, un año de guerra incesante ha llevado al seno de la nación un gesto de impaciencia. Sin embargo, por encima de todas las particulares conveniencias y de todas las privadas opiniones, está el interés de la patria, que aún exige a sus hijos nuevos sacrificios (...) Todo el pueblo salmantino esta noche en la estación debe estar, sin ninguna excepción" ${ }^{\prime 344}$.

Si bien la prensa local aportó bastantes detalles sobre el momento de la despedida y los actos de homenaje, fue algo parca a la hora de describir el entusiasmo ciudadano $^{345}$. El “cuota” Dionisio Beña, por su parte, se ocupó de informar a los lectores salmantinos sobre los incidentes del viaje hasta Cádiz y seguidamente, hasta el zoco El-Jemis, en el territorio de Beni-Arós ${ }^{346}$.

Todo lo contrario, infinitamente más conmovida se mostró la ciudad coincidiendo con el regreso de la quinta de 1919, el día 9 de septiembre ${ }^{347}$. Aunque de nuevo en los periódicos se instrumentalizaba su despedida, la de agosto de 1921, el sentimiento de alegría era, de manera lógica, desbordante y no se requería mucho

342 “Ante la marcha a África de las tropas de La Victoria”, El Adelanto, no 11.734, 29 de agosto de 1922, p. 1.

343 "La marcha a África de los soldados de La Victoria", El Adelanto, n 11.735, 30 de agosto de 1922, p. 2.

344 "La despedida", La Gaceta Regional, no 609, 30 de agosto de 1922, p. 1.

345 "Los actos de ayer en honor del Ejército y la marcha de las fuerzas a Larache" El Adelanto, no 11.736, 31 de agosto de 1922, p. 2.

${ }^{346}$ Dionisio Beña: "Los soldados de La Victoria que han llegado a Larache", El Adelanto, $\mathrm{n}^{\circ}$ 11.747, 13 de septiembre de 1922, p. 3; y Dionisio Beña: "Los soldados de La Victoria", El Adelanto, no 11.765, 4 de octubre de 1922, p. 3.

347 "La llegada de los soldados del regimiento de La Victoria", El Adelanto, $\mathrm{n}^{\circ} 11.744,9$ de septiembre de 1922, p. 2; "La llegada de los veteranos de La Victoria del cupo de 1919", El Adelanto, no 11.745, 10 de septiembre de 1922, p. 2. 
empeño para animar a los salmantinos a que preparasen una cálida acogida. De este modo lo evidenciaba El Adelanto:

"Vuelven los soldados de La Victoria. La vuelta va a coincidir con las fiestas de la gran feria de la ciudad. No vuelven, por desgracia, todos los que, en aquella noche caliginosa de Agosto, irrumpieron en la estación, acompañados del entusiasmo popular y marcharon a África; la nación entera, transida de dolor por el horrendo Desastre, entregaba sin vacilar sus hijos y dineros, en aras de la venganza, en deseos fervientes del duro castigo a que se había hecho acreedor un enemigo cargado de odios, de traiciones y de salvajismo.

Fue aquella despedida una despedida inolvidable, de hondo y sentido fervor patriótico (...) Hay que hacer algo. Hay que organizar el recibimiento. Todos tenemos la obligación de cumplir con este deber, como los de La Victoria cumplieron con el suyo, en aquellas inhóspitas tierras africanas.

Al Ayuntamiento, como representación genuina del pueblo, corresponde tomar la iniciativa. Mañana celebra sesión. iQue de ella salga la proclama ardorosa y española, para que el día 9, o el que a punto fijo lleguen los expedicionarios, Salamanca premie a sus hijos, en justa correspondencia a la fatigosa y dura jornada de doce meses de vida en el campo de batalla! 348 .

La euforia, en efecto, se convirtió en la nota dominante de la ciudad durante los días siguientes y también La Gaceta hubo de reconocerlo: “¡Oh, la alegría del que de la guerra vuelve, salvado el honor y la vida! ¡Dichosas, y bien dichosas, las madres atribuladas durante tantos meses de campaña, alborozadas y plenas de regocijo hoy, en el regreso del hijo amado, que estrecha entre sus brazos piadosos y sagrados y estampa en su frente el puro beso maternal!" 349 . Aunque, seguramente, el discurso más vibrante fue el de Piedecasas:

"El pueblo de Salamanca, que en su historial magnífico aparece escrito en letras de oro el patriotismo acendrado y la caridad ardiente, que ha patentizado en hechos tan parleros como recientes, la peregrinación espiritual más noble y generosa, recibió hoy a los militares, encarnación del honor nacional, con el mismo entusiasmo que otra noche inolvidable, con lágrimas y dolores, les despidió para que se alistasen en la Cruzada de España. Abrazos, alegría, bienvenidas, felicitaciones y regocijos, esto es cuanto hoy en Salamanca impera" ${ }^{\$ 350}$.

Aunque desde finales de 1922 se multiplicaron los rumores que aludían también a una pronta repatriación del remplazo de 1920 de La Victoria, alimentados por el cambio que el marqués de Alhucemas deseaba imprimir a la política africana, estas

\footnotetext{
348 "Ante la vuelta de África de los soldados de La Victoria", El Adelanto, n 11.740, 5 de septiembre de 1922, p. 1.

349 "Las fuerzas de La Victoria saldrán hoy de Larache para Salamanca", La Gaceta Regional, n 615, 6 de septiembre de 1922, p. 1.

${ }^{350}$ Pedro M. Serrano Piedecasas: "Salamanca toda recibe a los soldados de La Victoria que regresan", La Gaceta Regional, nº 618, 9 de septiembre de 1922, p. 1.
} 
voces tuvieron que ser reiteradamente desmentidas ${ }^{351}$. Aún así, las especulaciones se avivaron a finales de mayo de 1923, cuando todo el batallón fue concentrado en AinGrana $^{352}$. Sin embargo, nada tenía que ver esto con el anhelado retorno de los salmantinos: todo lo contrario, el esfuerzo por acercar posturas con El Raisuni estaba generando muchísimos recelos y lo continuaría haciendo hasta el momento del golpe militar. Así que, por esta razón, el batallón salmantino era empleado en estrechar la vigilancia sobre el cabecilla rebelde ${ }^{353}$.

Después de reflexionar sobre la actitud de la opinión pública salmantina ante el reinicio de los avances, sostenemos que ésta fue, a tenor de las concentraciones en la estación, ya descritas, y de sus múltiples gestos caritativos, que ahora veremos, de visceralidad. Y aquí va el inicio, tan sólo eso, de la explicación: pudiera pensarse, a priori y equivocadamente, en una reacción inmediata entre conformista y eufórica, en la aceptación de la campaña de reconquista y el respaldo unánime para con los combatientes. Un conformismo, eso sí, distinto al exhibido durante la contienda de 1909, cuando el Ejército español sufrió su otro gran traspié en Marruecos, aquél en el Barranco del Lobo; un conformismo acompañado de resentimiento, de un encendido y furioso afán de desquite - la euforia a la que apelaba Javier Ramiro de la Mata-, comprensible a juzgar por las colosales dimensiones de la catástrofe militar y política.

Sí; sin duda, se necesitaba entereza para conocer cuánta había sido la sangre derramada y, más aún, la que habría de correr por la Comandancia de Melilla; por de pronto, ciertamente, la opinión pública salmantina mostró su templanza: nadie salió a la calle para protestar; sino para secundar al Ejército. Para socorrerle con más ahínco que nunca. Y, además, el pueblo lo hizo espontáneamente, sin precisar demasiados requerimientos desde la prensa. Ésta, de hecho, se limitó a actuar únicamente como su comparsa, a sugerir formas de socorro y a aplaudir la generosidad ciudadana: y es que en aquellos momentos, apenas días, de máxima tensión guerrera, no hacía falta más. Ni siquiera era menester el empleo de la propaganda periodística para lograr la unanimidad de pareceres.

\footnotetext{
351 “¿Repatriación del batallón expedicionario de La Victoria?”, El Adelanto, $\mathrm{n}^{\mathrm{o}}$ 11.824, 16 de diciembre de 1922, p. 1; y "El regreso de las fuerzas de La Victoria", El Adelanto, n 11.882, 22 de febrero de 1923, p. 1 .

${ }^{352}$ Dionisio Beña: "Los soldados de La Victoria de 1920 se cree sean pronto repatriados", El Adelanto, $\mathrm{n}^{\circ}$ 11.957, 22 de mayo de 1923, p. 6.

${ }^{353}$ Dionisio Beña: "La Victoria frente al palacio del Raisuni en los campos de Yebala", El Adelanto, ${ }^{\circ}$ 11.964, 30 de mayo de 1923, p. 6.
} 
A pesar de lo enunciado, desde luego, eso no significó que la opinión pública salmantina contemplase con buenos ojos la "aventura marroquí"; ni muchísimo menos. A nuestro entender, el Desastre de Annual, después de muchos años de incontables sinsabores, provocó tales sentimientos de desengaño y amargura, que resulta insatisfactorio compaginarlo tan sólo con la tesis de la euforia. No; otro elemento subyacía a esa voluntad de desquite. Defendemos, por consiguiente, que hay que perseverar en la búsqueda de una explicación: hasta dar con un sentimiento de miedo tan intenso, que difícilmente podemos imaginar.

La guerra era ahora contemplada, ante todo, como un mal necesario; pero mal, al fin y al cabo ${ }^{354}$. Por ello, los gestos de apoyo para los soldados, vayamos ya concretando, no cesaron e incluso se mantuvo cierta rivalidad institucional por ofrecerles un creciente número de auxilios ${ }^{355}$ :

"Es verdaderamente admirable la actitud generosa de España para con el Ejército de África. Los que entre los rudos peñascales de estas tierras africanas luchan y mueren noblemente en defensa de nuestro quebrantado prestigio nacional, aprecian y agradecen estas generosidades, porque en ellas prueban que España está espiritualmente con sus hijos y observa sus progresos con maternales solicitudes, sin cuidarse de otra cosa que del peligro que les rodea (...) Si surgen dificultades para la gobernación de la cosa pública, no será ciertamente por la actitud de España, sino por el desacierto y la falta de capacidad de las esferas directoras; nación que tan generosamente se conduce tiene, por fuerza, que ser materia propicia para que los gobernantes encaucen sus energías por el camino de la rehabilitación ",356.

No obstante, al mismo tiempo la opinión era cada vez más consciente de que no constituía obligación suya cubrir tantas necesidades de los combatientes:

"(Existe) un común denominador de denuncias o acusaciones. Ello es 'que los haberes de la Cruz Roja y de suscripciones particulares no debieran emplearse en objetos que, como trajes de campaña, tiendas, etc., tiene el Estado el deber de proporcionar'. ¿Qué vamos a decir a esto, sino que es cierto que el Estado debiera proporcionar todas esas cosas? (...) Pero, el pero no maduro es la triste realidad de que el Estado no lo hace, o si lo hace no lo hace pronto, y si lo hace pronto no lo hace bien. Y entre tanto la necesidad de los efectos dichos crece y urge y llama a las puertas del Ejército con necesidad imperativa. Por lo tanto, adonde no llega el Estado, siendo preciso llegar a todo trance, llega la Cruz Roja, llegan los particulares. Y esto, amigos nuestros, está bien y es un timbre de gloria inmarcesible ${ }^{\text {"357. }}$.

\footnotetext{
354 "La hora de la serenidad", El Adelanto, no 11.436, 10 de septiembre de 1921, p. 1; "Estamos conformes", La Gaceta Regional, n ${ }^{\circ}$ 345, 13 de octubre de 1921, p. 1. Este comportamiento de los salmantinos fue, en buena medida, inducido por los cuotas-redactores de La Victoria, que frecuentemente insistían en que la ofensa inferida a los españoles no había sido suficientemente reparada: E. Gómez Parra: "La línea del Kert y nuestros políticos africanistas", El Adelanto, no 11.501, 25 de noviembre de 1921, p. 1; y E. Gómez Parra: "Desde Melilla. Las entrañas de la política", El Adelanto, n 11.563, 6 de febrero de 1922, p. 2.

355 "Doctor Amalac" (Antonio Calama Sanz): “Anhelo justísimo", El Adelanto, no 11.459, 7 de octubre de 1921, p. 1.

${ }^{356}$ E. Gómez Parra: "Los donativos al Ejército", El Adelanto, no 11.559, 1 de febrero de 1922, p. 2.

357 “Usted tiene razón, pero...", La Gaceta Regional, n 375, 18 de noviembre de 1921, p. 1.
} 
Aunque tanto El Adelanto como La Gaceta Regional continuaron dedicando muchas de sus informaciones a reseñar las más variadas iniciativas de apoyo solidario, no fue ésta la conducta adoptada por El Pueblo. Su oposición visceral a la guerra le había conducido, primero, al silencio y, posteriormente, a confesar que las incontables suscripciones populares le parecían vergonzosas. A mayores, a esta publicación le resultaba absurdo que, mientras Salamanca carecía de agua potable y sus calles estaban llenas de baches, sus gentes rivalizasen por costear un bombardero ${ }^{358}$.

Por otro lado, fueron ganando peso en la ciudad, paulatinamente, las voces que clamaban por la exigencia de responsabilidades. Así, el soldado Gómez Parra escribía esto en El Adelanto:

"Toda España, reaccionando contra el estupor de la catástrofe, acudió conmovida en socorro de sus hijos (...) El Desastre de Annual repercutió en los corazones españoles y los hizo desbordarse de dolor y de ira (...) Y ahora que estamos en camino de conseguir la justa reparación de los agravios inferidos por unos bárbaros, piensa la opinión, y piensa bien, que en este Desastre tiene que existir responsabilidad. Aquí, en Melilla, nadie se explica que nuestras oficinas de información no se hubiesen enterado con la oportunidad debida del levantamiento general de las cábilas. Este movimiento no fue espontáneo, ${ }^{\text {,359 }}$.

También en La Gaceta Regional, de un modo infinitamente más sutil, se empezó a dar cabida al tema de las responsabilidades:

“Ese patriotismo y explosión de ciudadanía que respecto al Ejército está asombrando, a quien siga el movimiento de donativos y ofrendas, es, por desgracia, flor de un día (...) Es preciso que no sólo remediemos los dolorosos efectos, cuando la nación y por tanto el estado de que somos ciudadanos, está herido; sino que evitemos también las causas cuando está normal, que cuidemos su higiene y nos preocupemos de la defensa contra los desarreglos interiores o extraños ataques $\$ 360$.

Desde principios de 1922, en definitiva, entre la opinión pública salmantina cobraron pujanza los pensamientos más negativos respecto al futuro del Protectorado ${ }^{361}$. El creciente rechazo a la prolongación de la guerra se articularía, de hecho, alrededor de tres cuestiones: además de la exigencia de responsabilidades, otra crucial aspiración de la opinión local fue el rescate de los prisioneros y, por último, se generalizaron las protestas de los padres de "cuotas" ante la prolongada e ilegal ausencia de éstos.

\footnotetext{
358 "Puro patriotismo", El Pueblo, no 23, 28 de agosto de 1921, p. 2; y Rafael de Castro: "Cúmplase el mandato de Dios", El Pueblo, no 25, 24 de septiembre de 1921, p. 1.

${ }^{359}$ E. Gómez Parra: “¿Quedará todo en el olvido?”, El Adelanto, n 11.488, 10 de noviembre de 1921, p. 1.

${ }^{360}$ A. Antón: “Ciudadanía del momento", La Gaceta Regional, no 316, 9 de septiembre de 1921, p. 1.

361 "Un saludo a los soldados de La Victoria", El Adelanto, no 11.525, 23 de diciembre de 1921, p. 1; "Un balance sentimental", El Adelanto, no $11.533,2$ de enero de 1922, p. 1.
} 
Sobreponiéndose al malestar, la Comisión Provincial de la Cruz Roja continuó con su incesante labor de apoyo a los soldados y sus familiares: el servicio de información sobre los expedicionarios funcionaba a pleno rendimiento (y se complementó desde octubre de 1921 con las notificaciones sobre los salmantinos hospitalizados ${ }^{362}$ ) y una nueva forma de auxilio, consistente en el envío de dinero para los soldados de modo totalmente gratuito, también recibió una formidable acogida ${ }^{363}$.

Igualmente, esta institución canalizó el envío a los jóvenes salmantinos de bolsitas individuales de cura. Muchos farmacéuticos inmediatamente donaron el material de más urgente necesidad para el combatiente ${ }^{364}$. Y, coincidiendo con el inicio de la época de lluvias en el Protectorado, se puso en marcha un servicio para suministrar a los expedicionarios ropa de abrigo ${ }^{365}$.

Al finalizar del verano de 1921, la Cruz Roja Salmantina, atendiendo a la voluntad del Ayuntamiento, nombró como madrina del batallón a Laura Rodríguez Vega, esposa de Blanco Cobaleda (uno de los máximos accionistas de La Gaceta Regional). La función de las madrinas de guerra, figura habitual en todas las provincias españolas, era servir como enlace entre los ofrecimientos y donativos populares y las necesidades militares del momento ${ }^{366}$. Así, muy pronto se insertó en la prensa un listado con las necesidades más acuciantes de los luchadores. Eran, además, numerosas:
"I
Medicinas contra la disentería y paludismo. Elixir para limpieza y desinfección de la boca. Cepillos de dientes y uñas, esponjas, jabón sublimado y de la Toja, máquinas de afeitar, bolsas individuales de curación.
Mosquiteros, fundas de colchonetas para dormir, almohadas individuales pequeñas, toalla y pañuelos de bolsillo, ropa interior de abrigo, calzado de goma cómodo y ligero, hornillos individuales para hervir agua, alcohol sólido y gasolina.
II
Tanques de agua, petróleo para aguas estancadas, hornillos modelo inglés, para quemar basuras y excrementos, telas para revestir estacadas de servicios higiénicos, mantas impermeables forma ponche ${ }^{, 367}$.

\footnotetext{
362 "La Cruz Roja", La Gaceta Regional, no 349, 18 de octubre de 1921, p. 7.

${ }^{363}$ Ruy-González: "La obra de la Cruz Roja salmantina", El Adelanto, no 11.433, 19 de septiembre de 1921 , p. 1.

${ }^{364}$ Un repórter: "Soldados salmantinos en África. Ofrecimientos y donativos patrios", El Adelanto, $\mathrm{n}^{\circ}$ 11.435, 21 de septiembre de 1921, p. 2.

365 "Un nuevo servicio de la Cruz Roja. Lista de soldados", El Adelanto, n' 11.451, 28 de septiembre de 1921 , p. 1. La ropa se remitiría en paquetes con un peso inferior a cinco kilogramos. Los familiares podían entregarlo en la oficina de la Cruz Roja, abonando 1,3 pesetas.

366 "La madrina del batallón expedicionario de La Victoria", El Adelanto, no 11.434, 20 de septiembre de 1921 , p. 1. Como figura histórica, la madrina de guerra aparece en Francia durante la $1^{\mathrm{a}} \mathrm{GM}$. Su papel fue el de reforzar el papel tradicionalmente asignado a la mujer en la guerra, como consoladora en la retaguardia y con cierto impacto positivo sobre la moral del soldado. RAMÓN, Manuel de y ORTIZ, Carmen: Madrinas de guerra. Cartas desde el frente. Madrid: La esfera de los libros, 2003, pp. 24-26.

367 “La Cruz Roja”, La Gaceta Regional, no 357, 27 de octubre de 1921, p. 8.
} 
Otra de las iniciativas humanitarias que mejor acogida recibió fue la solicitud de libros, fundamentalmente con contenidos morales y patrióticos, para el entretenimiento de los soldados convalecientes ${ }^{368}$. Y al aproximarse las celebraciones navideñas, las Damas de la Cruz Roja aceleraron los preparativos de regalos para el tradicional "aguinaldo del soldado"369.

Mientras tanto, también esta fundación humanitaria ultimaba algunos detalles para el buen acondicionamiento de la futura Posta Sanitaria en el Molassín ${ }^{370}$. Por entonces se desistió del propósito original de hospitalizar únicamente en ella a los soldados heridos y enfermos salmantinos. Ante el caos existente, se decidió, de modo lógico, que se auxiliaría a todos los soldados de paso por la provincia ${ }^{371}$. Porque, en realidad, su desfile por la estación ejercía un duro impacto psicológico sobre los salmantinos:

"Después de luchar en el campo africano, inhospitalario y traidoramente asesino, por el honor de la patria, regresan los hombres fuertes que fueron, abatidos, enfermos, decrépitos, ateridos por la fiebre, convulsos en sus dolores, desfigurados con sus heridas; sin que aquellos gritos patrióticos y aquellas aclamaciones y socorros y donativos que les acompañaron en su marcha, les ayuden a mejor pasar el horrible camino de su regreso, yerto de ilusiones, ayuno de dulces esperanzas" ${ }^{372}$.

Sintomático del entusiasmo ciudadano ante este proyecto de ayuda fue la aparición de algunas descripciones del edificio en la prensa. En ellas se subrayaba su cercanía con respecto a la estación de ferrocarril y su dotación con dieciocho camas sostenidas por Damas destacadas de la sociedad salmantina, un servicio completo de ropas, biblioteca, material de curación, estufas de desinfección y cuartos de baño ${ }^{373}$.

Además, muy pocos días antes de su inauguración oficial, varias Damas solicitaron la concesión de la Gran Cruz de la Beneficencia para la duquesa de La Victoria, que ya llevaba varios meses instalada en Melilla ${ }^{374}$.

\footnotetext{
368 "La labor de la Cruz Roja salmantina", El Adelanto, no 11.464, 13 de octubre de 1921, pp. 1-2; "La Cruz Roja", La Gaceta Regional, n 346, 14 de octubre de 1921, p. 2.

369 "Junta de la Cruz Roja salmantina", El Adelanto, n' 11.470, 20 de octubre de 1921, p. 3; "El aguinaldo del soldado", La Gaceta Regional, n 371, 14 de noviembre de 1921, p. 1.

370 "La velada pro Cruz Roja", El Adelanto, $\mathrm{n}^{\circ} 11.484,5$ de noviembre de 1921, p. 2; "La fiesta a beneficio de la Cruz Roja", El Adelanto, $\mathrm{n}^{\circ}$ 11.487, 9 de noviembre de 1921, p. 3; "La Cruz Roja", La Gaceta Regional, $\mathrm{n}^{\circ}$ 384, 29 de noviembre de 1921, p. 6. Por citar un ejemplo, el 8 de noviembre la sección de Damas organizó una velada en el Liceo a beneficio de la Posta.

371 "La Cruz Roja", El Adelanto, no 11.488, 10 de noviembre de 1921, p. 4; "La bendición de la Posta Sanitaria de la Cruz Roja Salmantina", El Adelanto, n 11.513, 9 de noviembre de 1921, p. 3.

${ }_{372}$ Pedro M. Serrano Piedecasas: "El sábado en la estación. Por Salamanca ha pasado un convoy de soldados heridos y enfermos", La Gaceta Regional, no 365, 7 de noviembre de 1921, pp. 6-7. Estos comentarios coincidían con la llegada de 60 heridos a la estación.

373 "La Cruz Roja", El Adelanto, n' 11.488, 10 de noviembre de 1921, p. 4;

374 "Premio merecido", El Adelanto, no 11.505, 30 de noviembre de 1921, p. 1; y "Una nobilísima iniciativa", La Gaceta Regional, no 385, 30 de noviembre de 1921, p. 8. Los donativos serían de una
} 
Finalmente, el 8 de diciembre fue inaugurada por el obispo la Posta Sanitaria (y dos meses después fue validada por Real Orden como Hospital de la Cruz Roja). No obstante, el ambiente festivo de este día, incluida una solemne misa en San Esteban en honor de la Virgen de la Inmaculada, patrona de la Infantería, resultó bastante ensombrecido por el triste suceso de Ain-Hedid que ya referimos ${ }^{375}$.

Desde la apertura, se convirtió en una información recurrente de todos los rotativos, el cómputo de los soldados que diariamente desfilaban por la Posta. Del cariño con que los salmantinos contemplaban las actuaciones de la Cruz Roja tenemos varias pruebas. He aquí un ejemplo: "Buen recuerdo de Salamanca llevan los que en ella tocaron llenos de dolor, de hambre, de frío. Y con qué ansia piden que se renueve un vendaje, putrefacto y supurado de largas horas de aplicación. Y la Cruz Roja, atenta siempre a mitigar tanta pena, sin ruido ni alharacas, sin miras egoístas",376.

Apenas transcurrido un mes desde la inauguración de la Posta, el 12 de enero de 1922, La Gaceta Regional destacaba que en ella ya habían sido socorridos 1.500 hombres y hospitalizados un total de 44 individuos $^{377}$. Y al terminar dicho mes, la cifra de auxiliados ya rozaba los 2.000 individuos, mientras que los internados eran $80^{378}$. Probablemente, una de las más significativas demostraciones de afecto hacia la institución fue un homenaje popular a mediados de 1922. Así lo presentó El Adelanto:

"Majestuosa, soberana y de recuerdo imborrable, es la manifestación patriótica que ayer realizó Salamanca entera, rindiendo un tributo de admiración a la Cruz Roja salmantina (...) A las seis de la mañana, dos beneméritas señoras, de la más distinguida sociedad salmantina, estuvieron en el Ayuntamiento, doña Laura Rodríguez de Blanco Cobaleda y doña Celia González de Esperabé, para dirigir la creación del altar, en el que había de celebrarse la misa de campaña.

La confección a primera vista delataba la intervención artística y delicada que había planeado el trono del sublime sacrificio (...) Media hora antes de dar principio la misa de campaña, la Plaza Mayor simulaba un hormiguero por los millares de personas de todas las clases sociales que en ella habíanse congregado para tributar a la Cruz Roja el testimonio viril de su adhesión al soberano acto que iba a tener lugar ${ }^{, 379}$.

peseta y se deberían entregar, o bien al Presidente de la Comisión Salmantina (Plaza Mayor, $n^{\circ}$ 35), o en el Dispensario (Pérez Pujol, 11).

375 "La Inmaculada y el regimiento de infantería de La Victoria", El Adelanto, $\mathrm{n}^{\mathrm{o}} 11.513,9$ de diciembre de 1921, p. 4; y Pedro M. Serrano Piedecasas: "La inauguración de la Posta Sanitaria de tránsito de la Cruz Roja", La Gaceta Regional, no 392, 9 de diciembre de 1921, p. 8.

${ }^{376}$ Antonio Calama Sanz: "Laborar por caridad", El Adelanto, no 11.533, 2 de enero de 1922, p. 5. Poco tiempo después, se reproducía una carta de un soldado anónimo, en la que también se alababa el trabajo de las Damas de la Cruz Roja: "Una enfermera, la mujer que viene a nosotros, no es para el soldado sino la encarnación de la madre ausente", "La Cruz Roja", El Adelanto, no 11.591, 10 de marzo de 1922, p. 1. 377 "La Cruz Roja", La Gaceta Regional, n 420, 12 de enero de 1922, p. 4.

378 "Junta General de los socios de la Cruz Roja", La Gaceta Regional, no 436, 31 de enero de 1922, p. 2.

379 "El día de la Cruz Roja", El Adelanto, no 11.681, 25 de junio de 1922, p. 1. 
No obstante, esta institución no se vio libre de algunas censuras, fundamentalmente procedentes del pensamiento obrero. Este sector de la opinión pública salmantina argumentó, una vez superada la conmoción inicial tras el Desastre, que los proyectos caritativos de las Damas y Caballeros de la Cruz Roja estaban únicamente alimentados por su vanidad y censuraron, ya lo hemos comprobado más atrás, la hipocresía que suponía el entregar constantemente donativos al Ejército de África mientras que se esforzaban por evitar, a toda costa, que sus hijos fueran a la guerra mediante el pago de la cuota ${ }^{380}$.

De todas formas, el activismo de sus componentes no se resintió. Durante el verano de 1922, la delegación local de la Cruz Roja solicitó la entrega a Fernando Zaballa de la Gran Cruz del Mérito Militar. Enrique Esperabé encabezó las gestiones necesarias en el Senado y también solicitó un permiso ante la Asamblea Suprema de la Cruz Roja, que se confirmó en octubre, coincidiendo con la visita regia a Salamanca ${ }^{381}$. Para costear la insignia, cómo no, se abrió una nueva suscripción ${ }^{382}$.

El entusiasmo popular ante la labor de la Cruz Roja además permaneció, en gran medida, intacto. Aunque El Adelanto ya requirió el fogoso discurso de un ex-legionario:

“ ¡La Cruz Roja! Este es el sello que distingue a Salamanca en la presente época (...) Fue en los días aciagos de julio, cuando los peñascos bravíos, las lomas rojizas y los llanos estériles, eran como una tumba en la que yacía el valor asesinado a mansalva, por la perfidia y la ingratitud. España despertó de su sueño, herida en su dignidad, y llenos de optimismo contemplamos la corriente renovadora de una nueva espiritualidad que la agitaba y conmovía. Se fundaron asociaciones, se abrieron imprevistos hospitales, y se ingeniaron de mil peregrinas maneras con que allegar recursos para el Ejército combatiente (...) La Cruz Roja se encargó de encauzar este movimiento, para que no se malgastaran estos chispazos de patriótica caridad"383.

Por añadidura, coincidiendo con inició la repatriación de la quinta de 1919 de La Victoria, la Cruz Roja se apresuró a organizar un homenaje, consistente en una función

\footnotetext{
380 "Piedad, señores, piedad", La Gaceta Regional, n 413, 3 de enero de 1922, p. 1. El diario conservador defiende en este artículo a los miembros de la Cruz Roja frente a los reproches de algunos sectores de la izquierda.

381 "La Cruz Roja", El Adelanto, no 11.564, 7 de octubre de 1922, p. 1.

382 "El pueblo de Salamanca pide para don Fernando D. Zaballa la Gran Cruz del Mérito Militar", El Adelanto, $\mathrm{n}^{\circ}$ 11.685, 30 de junio de 1922, p. 1; "Salamanca en el Senado. Una petición del señor Esperabé", El Adelanto, no 11.697, 14 de julio de 1922, p. 2; "La Gran Cruz del Mérito Militar para el señor Domínguez Zaballa", El Adelanto, no 11.712, 1 de agosto de 1922, p. 2; "La gratitud de un pueblo", El Adelanto, $\mathrm{n}^{\mathrm{o}} 11.731,25$ de agosto de 1922, p. 1.

${ }^{383}$ Aníbal Calero: "La Cruz Roja", El Adelanto, no 11.760, 28 de septiembre de 1922, p. 4.
} 
teatral en el Bretón ${ }^{384}$. Asimismo, se ocupó del reparto de donativos de 25 pesetas para cada uno de los repatriados ${ }^{385}$.

Al finalizar el año 1922, la prensa recordaba que en poco más de doce meses de vida, la Cruz Roja había atendido a más de cuatrocientos soldados en la Posta, y otros diez mil habían recibido atención primaria en la estación de ferrocarril ${ }^{386}$. Más minucioso, sin embargo, había sido el balance publicado en su órgano oficial y referido al periodo comprendido entre octubre de 1921 y el 15 de junio de 1922:

"A nuestro Ejército. Tres mil ochocientos cincuenta y dos soldados enfermos y heridos procedentes de África, socorridos en tránsito por la Cruz Roja salmantina a su paso por la estación férrea, dándoles de comer o cenar en la fonda de la estación: dos platos, pan, vino y café.

Mil doscientos cincuenta y siete soldados licenciados de la quinta de 1918, socorridos del mismo modo que los anteriores, según orden del excelentísimo señor ministro de la guerra, procedentes todos de nuestro Ejército de África.

Cuatrocientos cincuenta y siete soldados licenciados de la quinta de 1919, socorridos del mismo modo que los anteriores, procedentes de los regimientos de la península.

Ciento treinta y siete soldados enfermos y heridos procedentes de África, que han sido hospitalizados en la Posta Sanitaria de la Cruz Roja salmantina, por impedirles su estado de salud continuar el viaje al punto del destino, habiendo sido atendidos por el personal facultativo y sanitario de dicha Institución.

Seiscientos quince soldados procedentes de África, que no enlazando con los trenes que les conducían a su destino, fueron albergados en la Posta Sanitaria de la Cruz Roja salmantina, no causando estancia completa, pero sí coste de lavado de ropas, desinfección y desayuno.

Diecinueve soldados enfermos y heridos que, habiéndoseles cumplido la licencia temporal que disfrutaban y no estando aún restablecidos para incorporarse a sus respectivos regimientos de África, fueron hospitalizados en la Posta Sanitaria, previo reconocimiento de la Sanidad militar y orden de ingreso del señor comandante militar de la plaza.

A gran número de todos estos individuos relacionados, se les ha facilitado por la Cruz Roja salmantina ropa completa interior, calzado, chalecos de bayona, prendas de abrigo, mantas, y en gran mayoría a los de tránsito, medicamentos, en especial, quinina, en previsión al paludismo que la mayoría vienen sufriendo.

Información: Novecientas veintiocho informaciones del estado, situación y paradero de soldados naturales de la provincia y Salamanca, que prestaban sus servicios en África.

Ciento noventa y seis informaciones de soldados hospitalizados en África y la Península, para tranquilidad de sus padres y familia.

Mil veintiocho cartas recibidas por la Cruz Roja salmantina para hacerlas llegar a su destino, de soldados hospitalizados y en campaña, dirigidas a sus padres, novias y amigos.

Cuatrocientas treinta y dos cartas enviadas a África por mediación de la Cruz Roja de Salamanca, para soldados de la provincia que están en los diferentes campamentos de Marruecos.

Envíos. Mil ciento veintidós paquetes postales enviados a África por mediación de la Cruz Roja de Salamanca, destinados a los soldados naturales de la provincia.

\footnotetext{
384 “La Cruz Roja obsequiará a los licenciados del 19”, La Gaceta Regional, n 617, 8 de septiembre de 1922, p. 1.

385 "La Comisión Patriótica", La Gaceta Regional, no 353, 22 de octubre de 1922, p. 9.

${ }^{386}$ José Luis Trigo: "La Cruz Roja salmantina en el primer año de su fundación", El Adelanto, n 11.817 , 8 de diciembre de 1922, p. 1.
} 
Trescientos ochenta y cuatro envíos militares lo mismo que los anteriores.

Setecientos ochenta y tres giros en metálico de cantidades entregadas por las familias y enviados a los soldados de la provincia residentes en toda la zona de nuestro Protectorado en Marruecos.

Ciento treinta y seis telegramas cursados para la cumplimentación necesaria de algunos servicios relacionados.

El coste de todos estos servicios ha sido satisfecho por la Cruz Roja salmantina, siendo gratuito para los interesados ${ }^{1387}$.

Las cifras ofrecidas resultaban abrumadoras. El despliegue económico y logístico de esta institución fue enorme, aunque lamentablemente carecemos de datos para lo que restaba de 1922.

Sí nos consta, en cambio, que con motivo de la liberación de los cautivos de Axdir, la Cruz Roja Salmantina entregaría al primer ex-cautivo de la capital, en cuanto éste regresase a la ciudad, una cartilla de ahorro del Banco del Oeste con una primera imposición de 125 pesetas $^{388}$.

Según El Adelanto, la Cruz Roja provincial ocupó el primer puesto de Castilla y León en labores de auxilio a favor de los combatientes, y el séptimo de toda España ${ }^{389}$. Pero semejante despliegue tuvo un alcance temporal limitado. En diciembre de 1923, saltamos por consiguiente a la etapa del Directorio militar de Primo de Rivera, Zaballa habría de notificar a la prensa local la clausura del Hospital. La afluencia de heridos y enfermos había descendido sensiblemente desde el invierno de 1921. Atrás quedaban las imágenes más amargas del conflicto. Desde entonces, los enfermos y heridos fueron desplazados hacia el Dispensario de la urbe ${ }^{390}$.

Por lo que respecta a la otra gran gestora de las iniciativas asistenciales con sello salmantino, la Comisión Patriótica de apoyo a La Victoria, ésta utilizó el remanente de los aeroplanos, para la adquisición de 1.200 sombreros de fieltro impermeable. Su directiva barajó también la adquisición de unos filtros de agua individuales y termógenos y acordó reservar algo de dinero por si se daba la circunstancia de que la Albuera tuviera que marchar también a África ${ }^{391}$.

\footnotetext{
${ }^{387}$ La Cruz Roja. Revista Mensual Ilustrada, no 241, Año 24, Madrid, julio 1922, pp. 570-571.

388 "La Cruz Roja y el gobernador socorren al ex-cautivo de Tejares", El Adelanto, n' 11.890, 3 de marzo de 1923, p. 1.

${ }^{389}$ Los servicios de la Cruz Roja", El Adelanto, no 12.070, 30 de septiembre de 1923, p. 5.

${ }^{390}$ Fondo Documental de la Cruz Roja Española, Caja 579, Carta de Fernando D. Zaballa, 22 de diciembre de 1923. También "El día 31 cesará el servicio sanitario en la estación. Se cerrará el Hospital "Posta Sanitaria de Tránsito", El Adelanto, no 12.141, 22 de diciembre de 1923, p. 1.

391 "Nota oficiosa de la Comisión Gestora del aeroplano 'Salamanca", El Adelanto, no 11.436, 10 de septiembre de 1921, p. 1; "La Comisión Gestora", La Gaceta Regional, n 318, 12 de septiembre de 1921, p. 4.
} 
Los trabajos para la adquisición de los bombarderos seguían, además, por buen camino y la Comisión se esforzaba para que el Rey acudiese al acto de donación ${ }^{392}$. A finales de septiembre los dos aeroplanos llegaron a Cuatro Vientos. Sin embargo, la entrega hubo de posponerse unos días ante la ausencia del director general de aeronáutica para África ${ }^{393}$. En tanto, los comisionados acordaron la adquisición de 1.200 colchonetas de campaña (finalmente fueron 1.050 debido a que parte del dinero se prefirió invertir en la fabricación de cincuenta capas impermeables, muy útiles para los servicios a cielo raso ${ }^{394}$ ) y cinco carros-cubas, además de los ya mencionados filtros individuales ${ }^{395}$.

La deseada donación de los aviones se realizó, al fin, con la presencia regia. Al acto acudió la Comisión Patriótica, el presidente de la Diputación Provincial y Diego Martín Veloz. El Adelanto comentaba que "Salamanca, faro de la ciencia, Zaragoza, cuna del patriotismo, han sido las dos provincias que más gallardamente han levantado su sentimiento de vigor (...) Es la hora del obrar callado, en labor silenciosa y fecunda"396. Con un tono muy similar, desde La Gaceta, se concebía el acto como "un triunfo más de gloria que tiene que añadir a los muchos conquistados esta ciudad de recia estirpe castellana"397.

\footnotetext{
392 “Su entrega al Ejército no podría ser una solemnidad regia en Salamanca?”, El Adelanto, n 11.431, 16 de septiembre de 1921, p. 1.

393 "La inmediata entrega de los aeroplanos 'Salamanca", El Adelanto, n' 11.436, 22 de septiembre de 1921 , p. 1 (obsérvese nuevamente el equívoco en la numeración de los diarios).

394 "Los obsequios a nuestros soldados en África", El Adelanto, n' 11.504, 29 de noviembre de 1921, p. 1; y "Adquisición de impermeables para los soldados de La Victoria", La Gaceta Regional, n 384, 29 de noviembre de 1921, p. 6. Ello fue una sugerencia del comandante segundo jefe del batallón expedicionario de La Victoria, Isidro Cerdeño.

${ }_{395}$ "La suscripción patriótica provincial", El Adelanto, no 11.450, 27 de septiembre de 1921, p. 1; y "La Comisión Gestora", La Gaceta Regional, nº 322, 16 de septiembre de 1921, p. 5.

396 "Solemne entrega en Cuatro Vientos, con asistencia de los Reyes don Alfonso y doña Victoria", El Adelanto, $\mathrm{n}^{\circ} 11.453,30$ de septiembre de 1921, p. 1.

397 "Realidad confortadora", La Gaceta Regional, n 335, 1 de octubre de 1921, p. 1.
} 


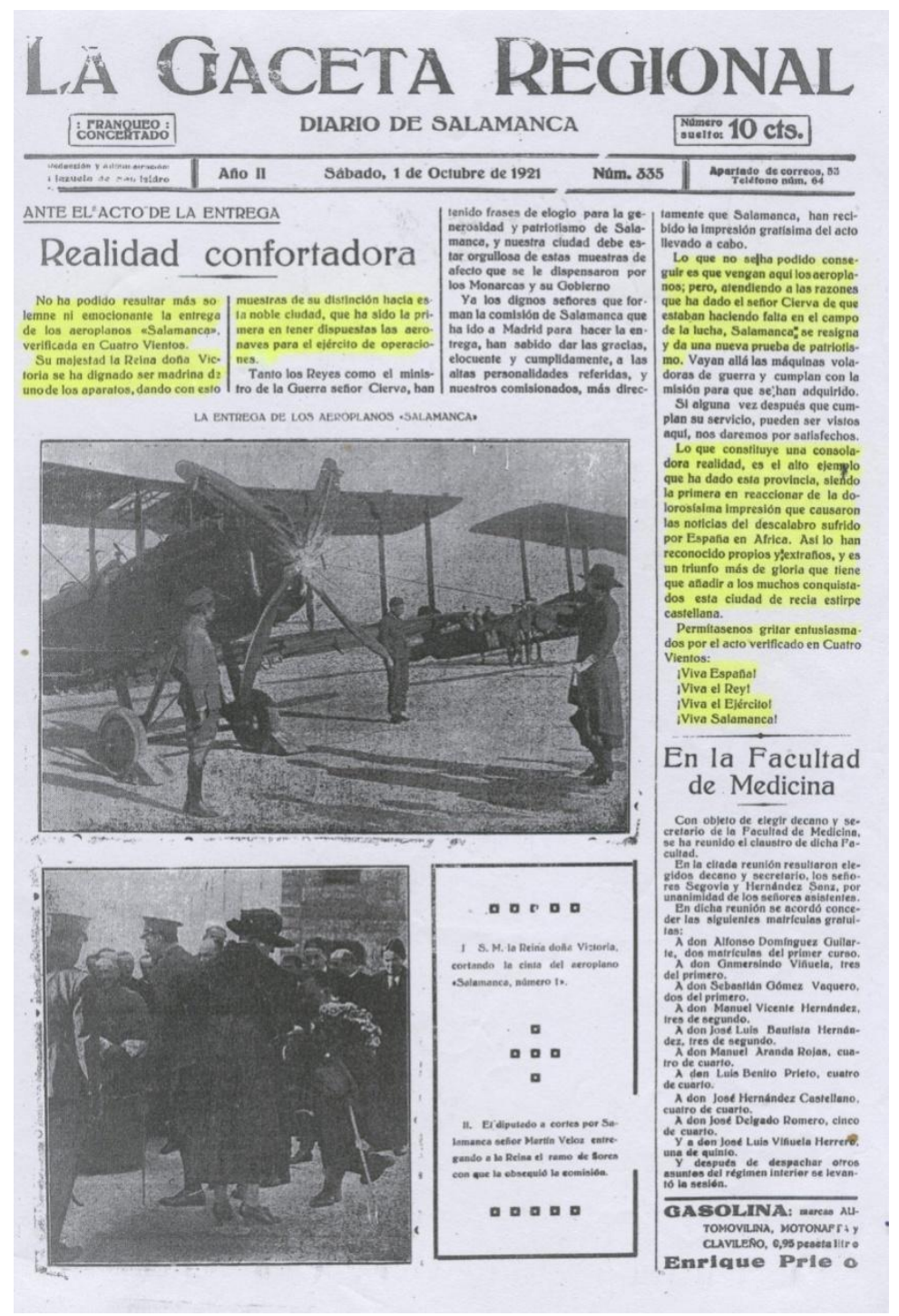

La Gaceta Regional, $\mathrm{n}^{\circ} 335,1$ de octubre de 1921, p. 1.

Asimismo, la prensa, a la par que describió ampliamente el desarrollo del acontecimiento, incluyó en sus páginas el cuadro de honor con el nombre de los principales suscriptores de la provincia y las cantidades abonadas (lo incluimos en el apéndice). Encabezaban dicho listado el obispo de Salamanca, el Casino, el Ayuntamiento, Enrique Esperabé y el diputado a Cortes por la capital ${ }^{398}$.

Después de la entrada del general Cavalcanti en Tiza, la siguiente decisión reseñable de la Comisión Patriótica fue la concesión de treinta premios de cincuenta pesetas cada uno para los soldados que destacaron en dicha operación. También la Comisión se comprometió a conceder un premio de 5.000 pesetas para el primer

\footnotetext{
398 "Cuadro de honor", El Adelanto, n n $^{\circ} 11.453,30$ de septiembre de 1921, p. 1; y Pedro M. Serrano Piedecasas: "Las aeronaves 'Salamanca'. La reina de España y la infanta doña Isabel han apadrinado los aeroplanos", La Gaceta Regional, nº 334, 30 de septiembre de 1921, p. 2.
} 
salmantino que obtuviese una laureada de San Fernando. Y en la misma sesión, se acordó el cierre definitivo de la suscripción patriótica para el 8 de octubre de $1921^{399}$.

Coincidiendo con el inicio de la época de lluvias en Marruecos, también los comisionados, en estrecha colaboración con la madrina del batallón, se ocuparon de la recolección de ropa de abrigo ${ }^{400}$. Y, además, la Comisión, por boca del gobernador Polo de Bernabé, ofreció a la Cruz Roja el sostenimiento de cuarenta camas en el futuro Hospital del Asilo de Vega. Pero desde Guerra nunca llegó el reconocimiento oficial de este ofrecimiento, que acabó por convertirse en papel mojado. Así que el dinero destinado a este proyecto acabó siendo entregado a los soldados ${ }^{401}$.

Al igual que en el caso de la Cruz Roja, al aproximarse la Navidad de 1921, los comisionados empezaron a organizar los regalos y donativos en metálico para el "Aguinaldo del soldado" 402 . Seguidamente se detalla cuál fue el fruto del esfuerzo desplegado este trágico año con motivo del "aguinaldo":

"La noble, generosa y altruista dama doña Laura R. Vega de Blanco Cobaleda, compenetrándose con su honroso cargo de madrina de los soldados de La Victoria que luchan en África, ha apurado en su desempeño todas las energías y todos sus entusiasmos, a su ímprobo trabajo ha unido su generoso donativo de 2.000 pesetas, con destino al Aguinaldo del soldado.

La parte metálica de la recaudación se ha invertido en lo siguiente:

Trescientos chalecos de Bayona, 363 pares de calcetines, 10 fanegas de nueces, 10 fanegas de castañas, 70 kilos de higos, 300 kilos de escabeche, 120 botellas anisadas, 130 kilos de chorizo y 12 cajas de galletas.

También se han adquirido para los señores jefes y oficiales:

Dos latas mortadela de dos kilos cada una, 18 latas varios pescados, tres lomos en tripa, un jamón de dulce, 12 cajas de turrón variado, ocho cajas de mantecadas, seis latas de frutas, dos cajas puros, 122 botellas jerez y licores.

El resultado total de la suscripción del aguinaldo es el siguiente:

10 fanegas de nueces, 10 de castañas, 20 arrobas de higos, 12 cajas de escabeche (360 kilos), 12 cajas de aguardiente anisado (120 botellas), 3 cajas de chorizo (150 kilos), 12 latas de galletas, un cajón de chocolate de desayuno (30 cajas), 283 chalecos de Bayona, 44 camisas y elásticas, 21 cuellos Pirineos, 1.000 pares de calcetines (...) Todo esto irá en un vagón en unión de los impermeables y colchonetas que hoy serán entregadas, y todo ello será remitido a Larache"403.

\footnotetext{
399 "Premios y auxilios a los soldados salmantinos en África", El Adelanto, n ${ }^{\circ} 11.459,7$ de octubre de 1921, p. 3; y “La Comisión Gestora”, La Gaceta Regional, n 340, 7 de octubre de 1921, p. 4.

400 "La Comisión Gestora", La Gaceta Regional, no 360, 31 de octubre de 1921, p. 7.

401 "La Comisión Gestora", La Gaceta Regional, no 353, 22 de octubre de 1921, p. 9; "Donativos a los soldados salmantinos en África", La Gaceta Regional, n 424, 17 de enero de 1922, p. 2.

402 "Envíos y donativos para nuestros soldados", El Adelanto, n' 11.479, 31 de octubre de 1921, p. 1. Además de productos típicamente navideños y ropa de abrigo, en el "aguinaldo" se incluyó un donativo de 1.000 pesetas para las tropas de infantería y 500 , para la marina.

403 "El resultado de la suscripción para el aguinaldo del soldado", La Gaceta Regional, no 391, 7 de diciembre de 1921, p. 2.
} 
Incluso, se abrió otra nueva suscripción popular para costear un altar portátil ${ }^{404}$. Al finalizar 1921, éste era el estado de cuentas de la Comisión:

"La comisión administradora de los fondos recaudados en la provincia para adquisición de dos aeroplanos y para otras donaciones al Ejército de África, publica como justificante de su gestión administrativa el siguiente extracto de cuentas de sus gastos hasta el día de hoy.

1921. Septiembre, 28. Coste de dos aeroplanos tipo Havilland... 63. 886, 20 pesetas.

Octubre, 12. Gastos de propaganda provincial...191 pesetas.

Gastos en Madrid de la Comisión...406,25 pesetas.

Octubre, 18. Escudos para los aeroplanos...400 pesetas.

Por cuarenta filtros individuales... 360 pesetas.

Octubre, 25. Por cinco kilos de quinina...1.250 pesetas.

Enviado al general Vives para los soldados ingenieros...1.800 pesetas.

Noviembre, 7. Por 1.150 sombreros...8.050 pesetas.

Noviembre, 10. Por dos ponchos filtros... 970 pesetas.

Noviembre, 24. Para el Aguinaldo del Soldado, 1.000 pesetas.

Para el altar del batallón de la Victoria... 500 pesetas.

Para el aguinaldo del marino... 500 pesetas.

Imprenta Núñez, factura circulares, 175 pesetas.

Suma y sigue: $79.488,45$ pesetas ${ }^{, 405}$.

A ello tendría que sumársele el importe de las colchonetas e impermeables, que ascendía a 25.000 pesetas y que fueron entregadas unos días después de realizarse este balance económico ${ }^{406}$.

A pesar del activismo de la Comisión -que solicitó a todos los alcaldes de la provincia un listado con los nombres de los licenciados de 1918 para hacer efectivos unos donativos de 25 pesetas $^{407}$; e hizo entrega, en febrero de 1922, de los cinco carroscubas prometidos, con un coste de 5.150 pesetas ${ }^{408}$-, ésta también topó con las presiones de algunos padres de "cuotas" y con la protesta de varios soldados que, por no pertenecer al batallón expedicionario de La Victoria, no fueron beneficiarios de ningún donativo $^{409}$.

En febrero de 1922, finalmente, la Comisión acordó poner término a los donativos de material para el Ejército. El remanente de la suscripción, unas 50.000 pesetas, se acordó distribuirlo entre los expedicionarios salmantinos ${ }^{410}$. Por este motivo,

\footnotetext{
404 “Los donativos al Ejército de África", El Adelanto, no 11.500, 24 de noviembre de 1921, p. 1.

405 "Comisión Patriótica", El Adelanto, n" 11.507, 2 de diciembre de 1921, p. 3.

406 "Salamanca y el Ejército", El Adelanto, no 11.512, 8 de diciembre de 1921, p. 2; "La entrega de colchonetas e impermeables", La Gaceta Regional, $\mathrm{n}^{\circ} 392,9$ de diciembre de 1921, p. 2.

407 "El reparto de donativos", El Adelanto, no 11.567, 10 de febrero de 1922, p. 2.

408 "Los carros-aljibes destinados a La Victoria", El Adelanto, no 11.753, 17 de febrero de 1922, p. 1; y "La entrega de los carros-cubas", La Gaceta Regional, no 453, 20 de febrero de 1922, p. 1.

409 "La Comisión Patriótica de donativos al Ejército", El Adelanto, no 11.546, 16 de enero de 1922, pp. 12; Varios soldados: "Lo que acuerdan unos cuantos salmantinos", El Adelanto, $\mathrm{n}^{\mathrm{o}} 11.569,13$ de febrero de 1922, p. 3.

410 "Los carros-cubas para el batallón de La Victoria", El Adelanto, n 11.575, 20 de febrero de 1922, p. 2.
} 
a mediados de mayo, Pérez Cardenal recibió unos listados, procedentes de las Comandancias Generales de Melilla y Larache, con los nombres de 610 soldados de las cajas de reclutamiento de Salamanca y Ciudad Rodrigo, pertenecientes a las quintas de 1919, 1920 y $1921^{411}$. Ellos serían los beneficiarios de la colecta. También otros regimientos, con varios salmantinos en sus filas, fueron merecedores de estas entregas en metálico y lo mismo ocurrió con treinta y cinco individuos que habían reclamado apoyo económico $^{412}$.

El 6 de agosto de 1922 se celebró la última reunión oficial de la Comisión Patriótica. En caja quedaban casi 4.000 pesetas. También éstas fueron distribuidas entre los treinta y cinco reclamantes aludidos, otra vez, y -he aquí algo que nos sorprendeentre los funcionarios de la Diputación y la Cruz Roja ${ }^{413}$.

Entre las más tardías gestiones de auxilio a cargo de la Comisión Patriótica, figuraron variados obsequios para el relevo salmantino de 1922 y otro banquetehomenaje para los repatriados de $1919^{414}$. Asimismo, los comisionados giraron algo más de 1.000 pesetas para López Ferrer, con el propósito de que fuesen distribuidas entre los rescatados de Axdir, y entregaron 100 pesetas más al primer ex-cautivo salmantino ${ }^{415}$. Muy poco antes del golpe militar, por iniciativa extraordinaria de la Comisión, se abrió una última suscripción a beneficio del capitán Rodríguez Almeida, natural de Villar de Ciervo, que destacó en la defensa de Tifarauin ${ }^{416}$.

A modo de gesto particular de apoyo a los combatientes, no puede faltar en estas páginas una alusión al viaje de Diego Martín Veloz a las Comandancias de Larache y

\footnotetext{
411 “Comisión Patriótica salmantina”, El Adelanto, no 11.647, 17 de mayo de 1922, p. 3; La Comisión: "Hacia el Protectorado", La Gaceta Regional, no 489, 3 de abril de 1922, p. 3.

412 "Comisión Patriótica", El Adelanto, no 11.676, 20 de junio de 1922, p. 1; "La Comisión Patriótica", El Adelanto, $\mathrm{n}^{\circ}$ 11.716, 8 de agosto de 1922, p. 4; y "Comisión Patriótica", La Gaceta Regional, $\mathrm{n}^{\circ}$ 228, 22 de mayo de 1922, p. 1 . Los beneficiarios fueron: el regimiento de Artillería a Caballo, $11^{\circ}$, regimiento de Artillería Ligera, regimiento lanceros de Farnesio, regimiento Almansa, número 18; $7^{\mathrm{a}}$ Comandancia de Tropas de Intendencia , Batallón de Radio-Telegrafía de Campaña, regimiento de Guipúzcoa, número 53, y el regimiento de Granada, número 34.

413 "Al poner con nuestra pluma el punto final que cierra para siempre este capítulo hermoso de patrias manifestaciones, creemos obligado con este recuerdo despedir una era de tiempo que señala para nuestra amada ciudad uno de los momentos de mayor gloria y esplendor", "La última reunión de la Comisión Patriótica", La Gaceta Regional, n 590,7 de agosto de 1922, p. 5.

414 "El Ayuntamiento y la marcha de los soldados del regimiento de La Victoria", El Adelanto, no 11.734, 29 de agosto de 1922, p. 2; y "La llegada de los soldados del regimiento de La Victoria", El Adelanto, n 11.744, 9 de septiembre de 1922, p. 2.

415 "La Comisión Patriótica. Donativos a los prisioneros rescatados", El Adelanto, $\mathrm{n}^{\mathrm{o}} 11.865,2$ de febrero de 1923, p. 1; "Comisión Patriótica", El Adelanto, no 11.891, 4 de marzo de 1923, p. 3; "Salamanca, a los prisioneros", La Gaceta Regional, no 789, 2 de febrero de 1923, p. 1.

416 "El homenaje al capitán señor Rodríguez Almeida", El Adelanto, $\mathrm{n}^{\circ}$ 12.046, 2 de septiembre de 1923, p. 1; "Suscripción", La Gaceta Regional, no 438, 29 de septiembre de 1923, p. 1. Se habían recaudado 210 pesetas el 29 de septiembre.
} 
Melilla, en octubre de 1921, para llevar a las tropas palabras de ánimo, quinina y obsequios de sus familiares ${ }^{417}$; la velada teatral de un grupo de ferroviarios para costear una cama en la que acoger a un ferroviario herido en el Rif $^{418}$; las recolecciones estudiantiles de libros para "La Biblioteca del Soldado" (unos seiscientos al finalizar $1921)^{419}$; una suscripción iniciada por la Asociación General de Ganaderos ${ }^{420}$; y otra suscripción de los estudiantes de Medicina en beneficio del personal sanitario de La Victoria $^{421}$.

La simple formulación de las iniciativas de socorro ya resulta, qué duda cabe, agotadora. Pero, a diferencia de periodos previos, casi todos los gestos caritativos que siguieron al Desastre de Annual se presentaron encauzados desde, únicamente, dos instituciones; instituciones que, además, estaban integradas por personajes con relevancia política o muy estrechamente vinculados con el Poder. De aquí, las alusiones y repudio de El Pueblo al "patriotismo burgués". Las ideas humanitarias, en esta ocasión, no brotaron en la mente de ocurrentes periodistas, deseosos de reconocimiento entre la opinión pública local. Y ello, evidentemente, nos induce a interrogarnos sobre el por qué.

En efecto, la derrota militar afectó hondamente al sistema de la Restauración; dañó irreparablemente las relaciones entre el Poder y buena parte de los periódicos; y coadyuvó, al fin, al advenimiento de la Dictadura.

La prensa fue ahora, en gran medida, la creadora de un estado de opinión marcado por la incredulidad y la hostilidad hacia los viejos partidos políticos. Porque temas tan delicados como el de las responsabilidades, el del rescate de los prisioneros y las repatriaciones fueron instrumentalizados por los periódicos para apoyar una determinada postura política. Mientras unos combatieron por responsabilizar al Ejército

\footnotetext{
${ }^{417}$ José Luis Trigo: "En Larache se necesita, con toda urgencia, quinina", El Adelanto, $\mathrm{n}^{\circ} 11.573,24$ de octubre de 1921, p. 5; García de la Cruz: "El batallón de La Victoria", La Gaceta Regional, n 329, 24 de octubre de 1921, p. 4. Hecha la visita, el diputado a Cortes solicitó el envío urgente de quinina contra el paludismo y las autoridades salmantinas muy pronto se pusieron manos a la obra.

418 "Por los ferroviarios que luchan en África", El Adelanto, n' 11.466, 15 de octubre de 1921, p. 3; y "Para los heridos ferroviarios de África", La Gaceta Regional, n 345, 13 de octubre de 1921, p. 1.

419 "El libro del soldado y los alumnos salmantinos", El Adelanto, $\mathrm{n}^{\circ} 11.468,18$ de octubre de 1921, p. 2; y "La biblioteca del soldado", El Adelanto, no 11.493, 16 de noviembre de 1921, p. 1. El desarrollo de esta iniciativa planteó algunos problemas. La Gaceta Regional responsabilizó de la desmoralización de las tropas a quien envió libros con contenidos "antipatrióticos": "García de Roldán" (Andrés Marcos Escribano): "Escrúpulos", La Gaceta Regional, n ${ }^{\circ} 359,29$ de octubre de 1921, p. 1. Estos comportamientos marginales, no por su representatividad sino por su escasa cabida en la prensa, son los que anunciaban un cambio en la actitud ciudadana ante la guerra.

420 "Los ganaderos y los soldados de África", El Adelanto, $\mathrm{n}^{\mathrm{o}} 11.503,28$ de noviembre de 1921, p. 3.

421 "L. B.": "El aguinaldo del soldado y los estudiantes de Medicina", El Adelanto, no 11.504, 29 de noviembre de 1921, p. 1.
} 
y al Rey y así conseguir el advenimiento de una república (Unamuno sería en Salamanca el abanderado de esta causa), otros atacaron a los políticos del turno con el propósito de lograr la implantación de una dictadura militar. Si, además, valoramos que la suspensión de garantías constitucionales distorsionó el marco legal en el que se desarrollaba la información, el resultado fue un estado generalizado de confusión.

\section{¿Merecemos estos gobiernos?}

Desde finales de 1921, vencida la resaca de la derrota, entre la opinión salmantina ganaron pujanza los pensamientos más pesimistas respecto al futuro del Protectorado. La "aventura marroquí" resultaba tradicionalmente agotadora y, para muchos salmantinos, incluso irritante. La desinformación y la propaganda, los continuos malentendidos y los conflictos militares parecían no tener fin, pero ello no acarreó el surgimiento de un pensamiento anticolonialista.

Después del Desastre de Annual y tras un primer momento de estupor, la campaña patriótica del gobierno Maura logró la adhesión de la mayoría de las ciudades españolas. El líder conservador había aprendido la lección y ya no se amparó únicamente en el empleo de la censura. La opinión pública fijó, además, única y ávidamente su mirada, durante algunos días, en la suerte de los luchadores de Monte Arruit; así que la movilización de los refuerzos se practicó de modo más efectivo que en 1909, sin afectar a los reservistas (tiempo después, cuando se intentase dilucidar el nombre de los responsables de la catástrofe, la controversia sobre la posibilidad de haber socorrido a Monte Arruit traería mucha cola); y tanto la prensa como la izquierda se hallaron atónitas, con nula capacidad de reacción. Por todo ello, compartimos con Pablo La Porte la idea de que Annual ofreció una ocasión idónea para poner en marcha un cambio de rumbo en la vida política de la Restauración. Sin embargo, no se aprovechó $^{422}$.

Los sucesivos gobiernos se mostraron impotentes en lo tocante a las operaciones militares, la liberación de los prisioneros, la repatriación de los soldados y la exigencia de responsabilidades políticas. A resultas de todo ello, las esperanzas ciudadanas fueron mermando, así como su compromiso de apoyo a la política del protectorado.

Ante este hecho, cabe preguntarse si realmente la aversión de la opinión pública salmantina hacia la guerra se evaporó en los meses inmediatos al Desastre. ¿Por qué?,

\footnotetext{
${ }^{422}$ LA PORTE, Pablo: "Marruecos y la crisis de la Restauración", Ayer, nº 63, Madrid, 2006. La misma explicación, pero más extensa, también puede encontrarse en su tesis doctoral, ya comentada (pp. 232234).
} 
¿qué papel asumió el Poder en este vuelco de la opinión pública?, ¿o el vuelco fue tan sólo aparente?, ¿puso la prensa cierto empeño en convertir este sentimiento de malestar en invisible?, ¿actuaría por puro convencimiento o reaccionando ante las presiones del censor de turno?

Según nuestro parecer, y después de examinar la gran cantidad de información publicada, la reacción de los salmantinos ante la derrota militar fue instintiva -el vocablo que empleamos anteriormente fue "visceral" - y los periodistas no tuvieron inicialmente que esforzarse demasiado para convencer a la opinión de la necesidad de responder al ataque rifeño. Lo hizo aquel escalofrío que sacudió al país. Tras la estupefacción y paroxismo de las primeras jornadas, tras la carnicería de Monte Arruit, el desquite sirvió como motor de la opinión pública.

Por cierto, abundando en la idea del desquite, desde una perspectiva exclusivamente militar, autores como Dionisio Viscarri lo vinculan directamente con el nacimiento del fascismo en España. Según este investigador, Annual significó el nacimiento de "un Ejército colonial brutalizado y endurecido, sin límites de comportamiento. Marroquíes y españoles hicieron la guerra total. Mutilaciones, violaciones y otras crueldades inimaginables, formaron parte de la conducta habitual de los combatientes. El deseo de venganza tras la carnicería de Annual fue el gran motivador de la contraofensiva española, pero sirvió para justificar los peores excesos y represalias ${ }^{\prime 423}$.

No obstante, una vez que se reanudaron los debates parlamentarios, iniciada la reconquista y conocidas las primeras estimaciones sobre el número de víctimas, la belicosidad ciudadana empezó a decaer. Y fue entonces cuando la prensa dinástica intentó asumir como propia la tarea de mantener viva la llama de la venganza entre los salmantinos. Pero su eficacia no fue comparable, ni por asomo, a la lograda en 1909.

Una evidencia: los rotativos habían descrito, hagamos memoria, la primera despedida de La Victoria en la estación ferroviaria, durante el verano de 1921, como un momento sumamente emotivo, en una atmósfera de ansiedad, cierto, aunque sin incidentes. Tanto para El Adelanto como para La Gaceta Regional la presencia masiva de gentes en la estación fue una clara demostración de que la voluntad de resarcir el honor de la patria imperaba sobre cualquier lamento de los familiares. He aquí un ejemplo tomado del órgano del liberalismo salmantino, la carta de una madre anónima:

423 VISCARRI, Dionisio: Nacionalismo autoritario y orientalismo. La narrativa prefascista de la guerra de Marruecos (1921-1927). Bolonia: EDITORIAL, 2004, P. 55. 
"Nosotros, que hemos sido esclavos tuyos toda la vida, que hemos cifrado toda nue stra felicidad en tu felicidad, nuestra dicha en la tuya, te ofrendamos hoy de corazón a la patria, a la que todo debemos. Porque, ¿qué significan nuestras lágrimas de pena y un distanciamiento, ante las de aquellas madres y esposas que han sufrido el rudo golpe de la pérdida de un ser querido en la guerra? Nada"424.

Resultaba más lógico, en cambio, entender la multitudinaria asistencia de gentes a la estación ferroviaria como un gesto de pura compasión, una sentida despedida para aquéllos que eran enviados al "matadero". Y desde una perspectiva comparada, de hecho, un año después, con motivo del envío de más soldados salmantinos al Rif, la población acudió nuevamente a la estación pero ya entonces El Adelanto, tras un ejercicio interno de reflexión y después de varios desencantos, obvió cualquier referencia al fervor patriótico de las masas. Ocultar el rechazo que la conflagración generaba se estaba convirtiendo, por tanto, en una tarea progresivamente más difícil. Y más para una redacción con tan marcada tendencia a las fracturas ideológicas como ésta.

En realidad, el diario progresista, una vez superada la conmoción inmediata al descalabro militar, no cuestionó el derecho que asistía a los españoles para intervenir en el territorio marroquí, pero sí admitió la posibilidad de que las políticas hasta entonces desempeñadas hubiesen sido erróneas:

“Creemos nosotros que el rifeño no es noble, ni generoso, ni leal; al contrario, en todos sus actos se refleja la villanía, la deslealtad y la sordidez (...) Ahora acata nuestras disposiciones porque no le queda otro recurso para poderse salvar del hambre y de la miseria que le atosiga (...) La empresa de penetrar pacíficamente en el Rif no ha sido nunca un problema, sino sencillamente una cuestión difícil, de identificación, de habilidad, de un estudio previo y sincero (...) Deberíamos haber empezado por respetar y robustecer las costumbres rifeñas y dar autoridad a sus propios jefes, sin querer ni pretender bruscamente imponer nuestro criterio" ${ }^{, 25}$.

El descontento fue dando paso a la amargura y los temas más espinosos de la vida nacional pasaron a ocupar la primera plana informativa. Toda la prensa local analizada, al unísono aunque con distintos intereses y expectativas, acabó subiéndose al carro de la exigencia de responsabilidades. Se aproximaba, consecuentemente, el fin de la tregua con Antonio Maura.

Para la opinión liberal-republicana las prolongadas discusiones parlamentarias condujeron a la más absoluta desolación. Acerca del expediente Picasso y de los debates ministeriales y parlamentarios sobre las causas de la derrota militar, los salmantinos

424 “A. C. S.": "Para ti, hijo mío", El Adelanto, no 11.423, 26 de agosto de 1921, p. 3.

${ }^{425}$ E. Gómez Parra: "El desarme y las nuevas posiciones", El Adelanto, no 11.527, 26 de diciembre de 1921, p. 2. 
dispusieron de las frecuentes aunque breves informaciones de las secciones de noticias telefónicas y telegráficas. En ellas se reseñaron las controversias generadas por el empleo de tropas indígenas; se refirió el estado de desabastecimiento de muchos blocaos y el pésimo funcionamiento de los servicios sanitarios; se discutió la actuación de las Juntas de Defensa; se polemizó a propósito de las difíciles relaciones entre los generales Berenguer y Silvestre, las habituales confrontaciones entre los ministerios de Guerra y Estado; se reprodujeron algunos de los más incisivos discursos de Indalecio Prieto... De este modo, la opinión pública salmantina pudo conocer que en la línea avanzada de Melilla había casi 130 posiciones, defendidas por soldados bisoños, con pésimo armamento, y que la mayoría tenía enormes dificultades para abastecerse de agua ${ }^{426}$.

Muy prontamente, sin embargo, desde finales de 1921, el debate ya se percibía como algo inútil y hasta perjudicial. Éste no hacía sino ensanchar la brecha entre la opinión pública y los políticos: "Se han cerrado las Cortes por decreto, y ahí queda muerto ese debate, como se suponía, sin que se vislumbre nada de depuración de responsabilidades" ${ }^{427}$.

Y de hecho, a lo largo de 1922, cada vez que afloró este asunto entre las páginas de la redacción liberal, se convirtieron en habituales las alusiones a la "malhadada aventura marroquí"; también se intensificaron los ataques al incoherente ejercicio de la censura; y el rechazo al enorme coste que suponía la prolongación de la guerra ${ }^{428}$. El 18 de abril de este año, la comisión Picasso concluyó su investigación ${ }^{429}$. Ésta se limitaba al análisis de los errores técnicos que condujeron a la derrota, pero obviaba de modo intencionado cualquier responsabilidad política. A punto de cumplirse el primer aniversario de Annual, El Adelanto supo que varios mandos militares serían procesados. Su reacción fue de incredulidad:

"El sólo anuncio de que, como consecuencia del examen que el Tribunal Supremo de Guerra y Marina ha hecho del expediente instruido por el consejero togado señor Picasso con motivo del Desastre ocurrido el pasado Julio en Melilla, van a ser procesados varios jefes y oficiales y hasta es posible que se sumarie al Alto Comisario, ha producido en el país grandísima impresión.

\footnotetext{
${ }^{426}$ A propósito del calvario de la sed, véase MADARIAGA, M ${ }^{\text {a }}$ Rosa de: En el Barranco del Lobo... Op. Cit., p. 150. Los soldados combatían la escasez de agua machacando y chupando patatas, recurriendo al líquido de los botes de pimientos y tomates, bebiendo agua de colonia e, incluso, sus propios orines. ${ }^{427}$ "El cerrozajo", El Adelanto, no 11.526, 24 de diciembre de 1921, p. 1.

${ }^{428}$ Mariano de Santiago Cividanes: "El sacrificio de un héroe conocido", El Adelanto, no 11.623, 18 de abril de 1922, p. 1; Mariano de Santiago Cividanes: "La heroica duquesa", El Adelanto, no 11.625, 20 de abril de 1922, p. 1; y Aníbal Calero: "Crónicas de Marruecos", El Adelanto, no 11.668, 10 de junio de 1922, p. 2. Bergamín, ministro de Hacienda, lamentaba que entre 1916 y 1922 el ministerio de Guerra y Marruecos habían absorbido casi 3.500 millones de pesetas. Véase "Nuestra acción de guerra en Marruecos", El Adelanto, no 11.690, 4 de julio de 1922, p. 1.

${ }^{429}$ PICASSO, Juan: El expediente Picasso: las sombras de Annual. Madrid: Almena, 2003.
} 
Es tal la poca fe que tenemos los españoles en la administración de justicia y mucho más cuando se trata de personajes de viso que, cuando a raíz de la derrota de Melilla, se dijo que se iban a exigir seriamente responsabilidades, el país acogió con un gesto de incredulidad la noticia y, atento sólo a vengar el honor nacional, no se preocupó de que se exigieran o no esas responsabilidades, a pesar de que la sangre de tantos millares de españoles bárbaramente asesinados pedía a gritos que no quedase impune tan tremenda catástrofe ${ }^{, 430}$.

En efecto, el mencionado órgano judicial, bajo la presidencia del general Aguilera $^{431}$, y después de estudiar durante tres meses el Expediente, aprobó el informe provisional de la comisión Picasso. Acordó procesar a treinta y nueve militares más de los ya citados en el informe, que sumaban treinta y siete; y recomendó el procesamiento de Berenguer y de Navarro, en caso de ser éste rescatado. Berenguer dimitió en el acto.

El 21 de julio de 1922, casualmente un año después de la desbandada de Annual, una comisión especial de las Cortes, integrada por once conservadores y diez liberales, fue designada, por iniciativa de Sánchez Guerra y ante las continuas embestidas de Indalecio Prieto, para estudiar el informe Picasso y emprender la investigación de las responsabilidades políticas. En este contexto, se exacerbarían divergencias, arrastradas desde hacía años, entre junteros y africanistas ${ }^{432}$.

Es fácil, sin duda, atisbar en este fragmento anterior que tras la desconfianza se ocultaba una mala conciencia de la redacción por su respuesta inmediata tras el Desastre. Por eso, “A.” intentaba evadir las posibles responsabilidades de la prensa, y también de la opinión pública, apelando a la obligación de los gobiernos de orientar a su país:

"Cuando Berenguer tomó por su cuenta la dirección de las operaciones, ¿qué sucedió? Esta es la pregunta que dirigiríamos a los que tanto le ensalzaron y hoy le denigran. Durante varios años, bajo media docena de gobiernos, este hombre no halló en la prensa sino juicios lisonjeros, frases inapreciables en boca de los gobernantes y un prestigio en la opinión pública de que a muy pocos, en nuestros días, le es dable gozar (...) se debió a que el nuevo Alto Comisario fue presentado a España como un militar prudente, sin vacilaciones ni temores, como un profundo conocedor de la cuestión (...)

\footnotetext{
430 “A.": "Las responsabilidades del Desastre", El Adelanto, no 11.695, 12 de julio de 1922, p. 1.

${ }^{431}$ Sobre este personaje, tildado de "niño mimado de las izquierdas", véase ALÍA MIRANDA, Francisco: Duelo de sables. El general Aguilera, de ministro a conspirador contra Primo de Rivera (1917-1931). Madrid: Biblioteca Nueva, 2006.

${ }^{432}$ Para profundizar en las escisiones ideológicas y modo de vida de los africanistas remitimos a las obras, ya mencionadas, de Balfour, Cardona, Mas Chao y Payne. No nos hemos referido todavía, sin embargo, a los siguientes trabajos: BUSQUETS BRAGULAT, Julio: El militar de carrera en España. BarcelonaCaracas: Ariel, 1967. Procedente del campo de la Sociología, este investigador fue el que acuñó el concepto de generación militar de 1925; y NERÍN, Gustau: La guerra que vino de África. Barcelona: Crítica, 2005. Según su criterio, opuesto al sostenido por investigadores como La Porte, los africanistas fueron los máximos responsables de la derrota militar. El abandono u olvido en que los habían dejado los sucesivos gobiernos no era tal. Su superioridad tecnológica y numérica respecto a los rifeños resultaba indiscutible. Pero Annual puso de manifiesto la incompetencia del Ejército colonial español. Desde entonces, su relación con la prensa fue ambigua, ya que la necesitaban a la par que la temían.
} 
Y en Julio de 1921 (...) de la confianza absoluta pasamos a la impresión dolorosa de un derrumbamiento que aturdía a la nación (...) La responsabilidad, más que de Berenguer, es de sus valedores (...) Un gobierno, que tiene un cuerpo consular y diplomático, un ministerio de Estado y un ministerio de Guerra a su disposición, no puede padecer engaños, por lo menos, durante largo tiempo. $Y$ si esto no debe ocurrirle a un gobierno, a seis, muchísimo menos ${ }^{\text {"433 }}$.

Todos los gobernantes que habían amparado a Berenguer eran situados, así pues, en el punto de mira de los lectores. Pero ¿se darían éstos cuenta de que el mandato del Alto Comisario tampoco jamás había sido cuestionado desde la prensa? Se cumplía un año del Desastre y El Adelanto ya no estaba dispuesto a secundar, a todo trace, al Poder $^{434}$. Era el sálvese quien pueda.

Y es más, seguramente para poner remedio a esa mala conciencia, a los pocos días, el 28 de julio de 1922, “A. R. A.” sacaba a la luz la más dolorosa derivación del debate sobre las responsabilidades. Esto es, el controvertido rescate a Monte Arruit:

"Hace un año que la conciencia nacional española se sintió hondamente conmovida por una espantosa tragedia (...) Unos millares de soldados españoles habían sido cercados en Monte Arruit (...) En los primeros instantes, nadie pudo darse cuenta de lo que ocurría. Se sabía sólo que unos hermanos nuestros estaban rodeados por los moros (...) Al frente de la Alta Comisaría figuraba el general Berenguer. Como comandante general de Melilla había llegado Cavalcanti, que tenía en su historia militar fama de bravo.

En ellos confiábamos todos, cuando hoy hace un año, el general Navarro puso su primer heliógrafo dando cuenta de que los socorros eran tan urgentes que no admitían un día de dilación.

Un año hace que comenzó de hecho, la tragedia cruenta de Monte Arruit, baldón de España, que tiene que ser esclarecido para que se sepa lo que alli ocurriera (...) Y todavía no se ha aclarado quién fue el culpable de que no se socorriera a Monte Arruit, ni se ha demostrado que no pudo socorrérseles.

$Y$ por eso, en esta fecha de aniversario luctuoso, nosotros queremos recoger el anhelo del país de que las responsabilidades sean depuradas, ${ }^{, 435}$.

Pero, ¿de verdad los responsables se limitaban a los nombres de Berenguer,

Cavalcanti y Navarro? Obviamente, no. Así que lo que se hacía era apuntar más alto, hacia el ámbito político. Por eso, aunque los procesamientos de Berenguer y Navarro fueron bien recibidos, la desesperación fue la nota dominante entre los redactores del diario de Núñez Izquierdo:

“¿Qué de particular tiene que se pretenda y se quiera hacer pagar sus culpas a los que no supieron defender el honor nacional, causaron la muerte y el martirio de 20.000 españoles y maltrataron la Hacienda Pública? (...) Bien procesado está el general Berenguer, como procesados deben ser los demás generales y todos los políticos, sean

\footnotetext{
433 “A.": "Marruecos y Berenguer", El Adelanto, no 11.701, 19 de julio de 1922, p. 1.

434 “A.": "El comienzo de la tragedia", El Adelanto, no $11.705,24$ de julio de 1922, p. 3.

435 “A. R. A.”: "Entregados a su suerte", El Adelanto, n 11. 709, 28 de julio de 1922, p. 4.
} 
del matiz que fueren, que le acompañaron en la dirección de la campaña. Una vez procesados, que se defiendan como puedan y que caiga el que caiga"436.

El escepticismo se ponía muy de manifiesto tan sólo unos días después:

"Estando todos convencidos de que no se pueden exigir las responsabilidades y no queremos exigirlas, se representa en ambas Cámaras una función de espectáculo (...) Esto puede ocurrir por entregarse a una ficción que, como todas, pugna con la realidad de las cosas, por haber hecho al pueblo, a raíz de la derrota y para aplacar sus iras, una promesa de justicia que envolvía un castigo, y una ejemplaridad, pero que llegada la hora, se convertirá en burla,"437.

En efecto, los trabajos de la Comisión de las Cortes estaban resultando infructuosos. Mientras que los conservadores negaron la existencia de responsabilidades políticas, los liberales propusieron tan sólo una moción de censura contra el gobierno Allendesalazar. Tras las vacaciones veraniegas, la gran ofensiva de Prieto contra el Rey en el Congreso y la intervención de Maura, también en el sentido de hacer efectivas las responsabilidades políticas, acabaron echando abajo el gabinete de Sánchez Guerra.

A finales de 1922, la celebración en Salamanca de una manifestación proresponsabilidades, recibió una notable atención en las páginas de este diario y de ella se efectuó un balance bastante positivo. Encabezada por Miguel de Unamuno, partió de la Alamedilla y recorrió la Avenida Mirat y la Calle Zamora hasta la Plaza Mayor. El alcalde, Anaya, respondía así a una iniciativa del Ateneo de Madrid y encontraba pronto el apoyo de casi todas las asociaciones ciudadanas, organismos políticos, la Universidad y el vecindario ${ }^{438}$. El acto, que concluyó con la entrega al gobernador civil de unas conclusiones para que se las hiciera llegar al marqués de Alhucemas, no fue tan concurrido como se esperaba debido al frío y la lluvia. O, al menos, eso subrayó El Adelanto $^{439}$.

Pero, desde luego, semejantes gestos reivindicativos por parte de la opinión pública no bastaron para hacer efectiva la depuración de responsabilidades. En el caso de El Adelanto sus demandas se endurecerían: la redacción terminaría apostando por un

\footnotetext{
436 "El concepto de responsabilidad", El Adelanto, no $11.818,1$ de diciembre de 1922, p. 1.

437 "M.": "La comedia de las responsabilidades", El Adelanto, no 11.812, 2 de diciembre de 1922, p. 1.

${ }^{438}$ Aunque la iniciativa del Ateneo había sido trasladada hasta el Ayuntamiento por el concejal Santa Cecilia: Actas de las Sesiones Municipales. Archivo Histórico Municipal, vol. 1922-1923, fol. 469 (r)-470 (v).

439 "El Desastre de Marruecos. El Ayuntamiento, con todos los organismos locales, organiza la manifestación en pro de las responsabilidades", El Adelanto, n ${ }^{\circ}$ 11.830, 23 de diciembre de 1922, p. 1; Junta directiva de Acción Ciudadana: "La manifestación de las responsabilidades", El Adelanto, $\mathrm{n}^{\circ}$ 11.835, 29 de diciembre de 1922, p. 1; "La manifestación popular de mañana en pro de las responsabilidades del Desastre de Annual. ¡Salmantinos: a la manifestación!”, El Adelanto, n $11.836,30$ de diciembre de 1922, pp. 1-2; "La manifestación en pro de las responsabilidades por el Desastre de Annual", El Adelanto, no 11.838, 2 de enero de 1923, p. 3.
} 
proceso de revisión de las grandes fortunas. Pero nunca confió en las posibilidades de la misma:

"De boca en oído corre entre todos los españoles la versión de que, en la Península unos y en África otros, muchos militares y paisanos se han enriquecido indebidamente con parte del dinero que el país aportó para el Ejercicio de operaciones (...) conocer los ingresos lícitos de los encartados y después, que hablen los libros de los Registros de la Propiedad de treinta años hasta hoy. La cosa no puede ser más clara, y téngase en cuenta que, cuando unos cuantos de esos individuos sean desenmascarados, ellos mismos se encargarán de descubrir a los demás.

Mientras que esto no se haga, mientras que el pueblo vea que gozan y triunfan unos cuantos vividores y hasta que estos mismos, en muchos casos como en los que se refieren a las responsabilidades administrativas y políticas, han de ser los que han de intervenir, no puede confiar en que se haga verdadera justicia ${ }^{, 440}$.

Al cumplirse el segundo aniversario del Desastre, El Adelanto seguía implorando justicia, pero su tono resultaba desolador: "El pueblo español pide cuentas a los que dispusieron de sus vidas y de sus dineros. No ha olvidado la tragedia, y sabe que sin gravísimas faltas directrices, no se hubiera producido. Quiere y pide que la Patria no vuelva a verse en trance tan amargo y tan trágico. No reclama crueles venganzas, pero sí justicia para todos" ${ }^{441}$.

Junto al tema de las responsabilidades, el asunto de los "cuotas" también desgastó enormemente a los gobiernos. En el caso particular de Salamanca, conociendo la fuerte presencia de los mismos en el batallón expedicionario de La Victoria, no cabe duda de la enorme trascendencia de las reivindicaciones de sus familiares como condicionante de la actitud ciudadana ante el conflicto.

La legislación sobre el servicio militar había topado tradicionalmente con la oposición del movimiento obrero, para el que la diferenciación entre el soldado de haber y el soldado de cuota equivalía a convertir la guerra en una esclavitud para el pobre. Lo novedoso fue que después del Desastre de Annual, también los sectores sociales económicamente más pujantes sufrieron las penalidades de la lucha armada y su deseo de venganza comenzó a entibiarse. Por esta razón, desde que se extendieron los primeros rumores sobre la inminente implantación de un protectorado de índole civil en el momento del remplazo de Berenguer por Burguete-, los padres de los soldados de cuota intensificaron sus demandas a favor del pronto retorno de sus hijos. En particular,

\footnotetext{
440 "Las verdaderas responsabilidades", El Adelanto, no 11.943, 11 de mayo de 1923, p. 1.

441 "A los dos años del Desastre", El Adelanto, no 12.008, 20 de julio de 1923, p. 1. Similar era el editorial de “A.”: “Está clara la maniobra?”, El Adelanto, no 12.031, 16 de agosto de 1923, p. 1.
} 
las madres de estos jóvenes se vincularon estrechamente con el movimiento conocido como Cruzada de Mujeres Españolas, presidido por Carmen de Burgos ${ }^{442}$.

El 30 de julio de 1922 organizaron un mitin multitudinario en el Teatro de la Comedia. Siguiendo su ejemplo, también las madres y hermanas de expedicionarios salmantinos quisieron organizar una manifestación para solicitar el fin de la guerra. Pero toparon con la prohibición del gobernador civil, que amenazó con juzgarlas militarmente. Desde El Liberal, por cierto, Unamuno, al que le dedicaremos mayor atención en breve, se apresuró a acusar a Martín Veloz por actuar en la sombra para impedir el acto: "Aquí no hay peligro alguno mayor que en Madrid para el orden público (...) Ni aunque algún pobre supuesto cacique, más grotesco que terrible, y atacado de manía persecutoria, se crea otra cosa" ${ }^{\text {443 }}$. Aún así, el 25 de marzo de 1923 tuvo lugar, y en esta ocasión exitosamente, una asamblea multitudinaria en la Cámara de Comercio de los padres de "cuotas" correspondientes a los reemplazos de 1920 y 1921. Como éste ya era su tercer año de servicio en filas, los demandantes se dirigieron al ministro de Guerra para exigir su repatriación ${ }^{444}$. Muy implicados con el movimiento análogo que se desarrollaba a escala nacional, pronto también reclamaron de Alcalá Zamora una fecha exacta para el regreso de los soldados ${ }^{445}$.

La fecha, sin embargo, hubo de retrasarse en varias ocasiones porque las negociaciones de Castro Girona con las cábilas rifeñas no marchaban por buen camino. El resultado de todo ello fue un creciente desconsuelo ciudadano Pese a que el ministro se comprometió, a mediados de mayo, a firmar urgentemente la repatriación y licenciamiento de los soldados del reemplazo de 1920, finalmente, ello no ocurrió antes del golpe ${ }^{446}$. Al margen de este movimiento, y con un apoyo mediático muy inferior y no correspondido con su representatividad social, también los familiares de los soldados de haber iniciaron una campaña reivindicando el pronto retorno de sus seres queridos y el abandono del Protectorado ${ }^{447}$.

\footnotetext{
442 "Las madres de los soldados", El Adelanto, no 11.704, 22 de julio de 1922, p. 1.

${ }^{443}$ Miguel de Unamuno: “¿La última cruzada?”, El Liberal, 4 de agosto de 1922.

444 "Los padres de los reclutas de 1920-1921 piden la repatriación”, El Adelanto, n 11.910, 27 de marzo de 1923, p. 5.

445 "A favor de los soldados de cuota", El Adelanto, $\mathrm{n}^{\circ}$ 11.917, 5 de abril de 1923, p. 7; La Comisión: "A los padres de los soldados de cuota", El Adelanto, no 11.919, 7 de abril de 1923, p. 6; "Por la repatriación de los soldados de los años 1920-1921", El Adelanto, no 11.920, 8 de abril de 1923, p. 6.

446 "Júbilo en Salamanca", El Adelanto, n' 11.949, 12 de mayo de 1923, p. 2.

447 "E.": "En el Círculo Obrero. Las madres salmantinas piden la terminación de la guerra", El Adelanto, $\mathrm{n}^{\mathrm{o}}$ 11.695, 12 de julio de 1922, p. 2; "Las madres de los soldados", El Adelanto, $\mathrm{n}^{\mathrm{o}}$ 11.704, 22 de julio de 1922, p. 1; "La reunión de las madres salmantinas en el Círculo Obrero", El Adelanto, no 11.721, 13 de agosto de 1922, p. 1; "Mitin contra la guerra", El Adelanto, n' 12.047, 4 de septiembre de 1923, p. 1. Es una pena que El Pueblo ya no se editase en estas fechas, dado que sería un instrumento idóneo para
} 
A mediados de 1923, por ejemplo, esto era lo que comentaba la redacción a propósito de la suerte de estos jóvenes, tanto tiempo alejados de sus familias:

"Más de treinta mil familias de soldados de cuota de los reemplazos de 1920 y 1921, que en la actualidad prestan sus servicios en tierras africanas, sienten hoy la intranquilidad y el desasosiego de quienes, víctimas de un inconcebible abuso, han apurado la paciencia en larga e infructuosa espera de una justicia que no llega (...) No se quiere sustituir a aquellos jóvenes sufridos para no dar la sensación de que se envían allá nuevos soldados. Una piadosa mentira para la opinión, como si ésta no estuviera percatada de que hay en Marruecos cerca de ciento cincuenta mil hombres inactivos e infecundos (...) Se pretende al mismo tiempo, por ciertos miedos quitar pretexto para que puedan decir que la campaña de Marruecos se hace solamente a costa de los pobres... iY para esta vana apariencia se prolonga el sacrificio y se menosprecia el derecho de millares de ciudadanos, la mayoría tan pobres como puedan ser sus compañeros los soldados de filas, pero cuyas familias, por razones complejísimas, hicieron, Dios sabe a costa de cuantas amarguras, el sacrificio de unos cientos de pesetas para ampararse en un precepto legal que el gobierno declara con su conducta que es letra muerta!, 448 .

El 9 de agosto de 1923, retrasándolo por tanto unos días, Salamanca recordaba a las víctimas de Annual, guardando dos minutos de silencio en su honor. Al columnista "A." le flaqueaban entonces las fuerzas al escribir: "Nada decimos cuando nos injurian, nada cuando nos roban lo más amado, nada cuando la sangre brota de nuestras heridas abiertas. ¡Silencio siempre! Minutos de silencio, no; obras de queja y de protesta, $s \hat{\imath}{ }^{\$ 449}$. La opinión pública salmantina deseaba, aseguraba El Adelanto a la luz de todo lo expuesto, "la imposición del debido castigo a los responsables (...) también pide que acaben las locas aventuras guerreras y comience una nueva y anhelada era de paz y de tranquilidad" ${ }^{450}$. Ahora bien, ¿cómo? Sólo de un modo que ya dejamos apuntado: finalmente, el diario de Núñez Izquierdo se convenció de la necesidad de abandonar las políticas de medias tintas y de optar por una acción contundente.

De hecho, en los días inmediatamente previos al golpe, la apuesta por la fuerza bruta parecía clara:

"Por no entender lo que significa Marruecos para España, nuestros políticos, sin dar importancia a los convenios internacionales, dejaron que Francia se apoderara de la

conocer con amplitud el estado de la opinión obrera en estos controvertidos meses. De todos modos, se puede suponer su entusiasmo ante esta vigorosa reacción ciudadana, si se recuerdan los comentarios formulados en julio de 1922, a propósito del mitin suspendido por el gobernador civil: "Es el colmo de la imbecilidad pretender llevar a las tierras extranjeras una civilización de la que nosotros carecemos (...) Seguid, mujeres nobles, pidiendo la terminación de la guerra y exigiendo los hijos de vuestra sangre, creados para fines más nobles y beneficiosos que el de matar o ser matado", José S. Alfaraz: "La voz de las madres", El Pueblo, no 43, 22 de julio de 1922, p. 4. Y en el siguiente número, ya aparecía un triste augurio: "La guerra de Marruecos es ya en España una pesadilla dolorosa que enciende de iras los pechos y que será quizás la chispa que haga arder el carcomido sitial del régimen", José S. Alfaraz: "La voz de las madres", El Pueblo, no 44, 12 de agosto de 1922, p. 1.

448 "M.": "Los soldados de cuota", El Adelanto, no 12.002, 13 de julio de 1923, p. 6.

449 "A.": "Minutos de silencio", El Adelanto, no 12.010, 22 de julio de 1923, p. 2.

450 "En camino de la justicia", El Adelanto, no 12.028, 12 de agosto de 1923, p. 1. 
mejor parte de la zona asignada al Protectorado, y nos dejara la parte más infecunda y más difícil de sojuzgar; por no entender cuál era nuestra verdadera misión en Marruecos y cuáles eran los fines del Protectorado, emprendimos la política que se inició en el Barranco del Lobo en 1909 y culminó en Annual en 1921; por no entender cuál era nuestra significación en Marruecos, dejamos transcurrir los años de la guerra europea, cuando sin sangre y sin enredos internacionales pudimos y debimos ocupar toda nuestra zona de Protectorado, y resolver como era justo la cuestión de Tánger, incluyendo esta plaza en nuestra zona de influencia, a lo que tenemos derecho, por reconocerlo así tácticamente los tratados; por no entender lo que pasa en Marruecos, y por incomprensión del carácter rifeño, seguimos de mal en peor desde 1921 acá, pendientes sólo de la voluntad de Abd-el-Krim, y de que éste quiera atacarnos o no, manteniendo en Marruecos un Ejército peninsular numerosísimo y derrochando centenares de millones, sin gloria ni provecho para nadie... (...) Mientras tanto, los rebeldes se entienden cada vez mejor y se unen cada vez más (...) Después de doce años de sacrificios en Marruecos, no hay mas plan que la indecisión ",451.

Las reuniones de salmantinos contra la guerra concentraron buena parte de la actualidad informativa en los meses inmediatos al inicio de la Dictadura: en junio se celebró una asamblea de Cámaras de Comercio en Valladolid. Como representante de la institución salmantina, asistió el señor Zurdo, que disertó largamente sobre el problema, recalcando lo doloroso que resultaba para la opinión pública salmantina ${ }^{452}$. Y al inicio de septiembre de 1923 se registraron otros dos actos organizados por la Federación Obrera: hubo una protesta el día 2, en la Casa del Pueblo; y otra, el día 5, en el Centro Ferroviario $^{453}$. El Adelanto, indignado, sostuvo con determinación que el abandono constituía una burla, una traición a la memoria de los fallecidos:

"Anoche se celebró el segundo mitin de la serie que han organizado las clases trabajadoras y populares de Salamanca, para protestar contra la guerra de Marruecos (...) Esta campaña de protesta contra la guerra ha de encontrar, a buen seguro, eco en la opinión, identificada con todo lo que sea la terminación del actual estado de cosas.

Piden los oradores que hasta ahora han tomado parte en estos actos, el abandono de Marruecos. Es natural que los trabajadores coincidan en esto con el partido socialista, que hace ya tiempo enarboló esta bandera del abandono. Respetando este criterio creemos que hay que pensar en los compromisos y en la misión que España tiene que cumplir en África y que no es, precisamente, el abandono total de la zona española, lo que hay que pedir para obtener resultados prácticos, sino la repatriación del Ejército peninsular, la implantación del voluntariado y de un Ejército indígena, retrocediendo la línea a los terrenos pacificados para conservar sin peligro y sin grandes dispendios, la costa y las plazas españolas africanas (...) el abandono total de Marruecos, sería una burla más ${ }^{, 454}$.

\footnotetext{
451 "Pecado de incomprensión", El Adelanto, no 1.2046, 2 de septiembre de 1923, p. 1.

452 "Asamblea de Cámaras de Comercio. La ponencia de Salamanca sobre el problema de Marruecos", $E l$ Adelanto, $\mathrm{n}^{\mathrm{o}} 11.978,15$ de junio de 1923, p. 6.

${ }^{453}$ Ambas fueron reseñadas en "Mitin contra la guerra", El Adelanto, n 12.047, 4 de septiembre de 1923, p. 1.

454 "Los trabajadores de Salamanca y la guerra de Marruecos", El Adelanto, n ${ }^{\circ}$ 12.049, 6 de septiembre de 1923, p. 1; También "Otro mitin contra la guerra", El Adelanto, n' 12.049, 6 de septiembre de 1923, p. 2.
} 
Abundando en la materia, coincidiendo con los actos de insubordinación militar vividos en Málaga, el diario progresista ya se había cebado con la propaganda derrotista, pero también contra el gabinete de Alhucemas:

"Los incidentes ocurridos en Málaga (...) envuelven trascendental importancia por lo que tienen de sintomático (...) No son ya sólo esas campañas criminales proseguidas por determinados elementos políticos, que, a la vez que intentan desmoralizar al Ejército, son los más severos para enjuiciarlo cuando estiman que no ha estado a la altura de su misión; son esas otras campañas derrotistas, en las que, la maldad de unos y la candidez de otros, nos pintan a Abd-el-Krim como invencible, al Ejército desmoralizado y falto de todos los elementos para la lucha, nuestra actuación en Marruecos como una justificación para defender intereses particulares y el no emprender el avance sobre Alhucemas ni castigar a los beniurriagueles, por no convenir así al grupo de plutócratas que, según esos derrotistas, aspira a la explotación de los yacimientos mineros cercanos a Axdir (...) Y, en otro orden, esa perpetua indecisión de los gobiernos en lo que a Marruecos se refiere (...)ino ha de repercutir en el ánimo de los que se quiere que vayan a África sin saber concretamente a qué? ",455.

Las vacilaciones tenían, en suma, que acabar y El Adelanto, quizás para dar ejemplo, se ponía manos a la obra: pocos días antes del golpe militar, el periódico se reafirmaba en su fe africanista y le dirigía serios reproches al político liberal.

Para concluir con este repaso del diario de Núñez Izquierdo, debe subrayarse, antes que nada, que las dilatadísimas gestiones para el rescate de los prisioneros de Axdir generaron entre los salmantinos muchísima ansiedad y expectación. Las iniciativas públicas y privadas se sucedieron, sin éxito, desde el verano de $1921^{456}$, pero únicamente se vislumbró un cambio con la llegada de la concentración liberal al Poder. El ministro de Estado y personaje controvertido donde los haya, Santiago Alba, confió oficialmente a Horacio Echevarrieta las gestiones para la liberación. Llegó éste a la bahía de Alhucemas el 24 de enero de 1923 y en menos de una semana logró la liberación de los 367 cautivos supervivientes ${ }^{457}$.

El Adelanto defendió en varias ocasiones y prontamente la necesidad de proceder al rescate urgente de los soldados supervivientes de la Comandancia de Melilla: “Es que alguno de esos desgraciados no supo cumplir con su deber? Eso no es razón para dejarlos en el cautiverio; después de salir de él, se le hará pagar su

\footnotetext{
455 "Síntomas alarmantes", El Adelanto, no 12.041, 28 de agosto de 1923, p. 1.

${ }^{456}$ Algunos rescates fueron gestionados desde la Oficina Central de Asuntos Indígenas de Melilla; otros, por los propios familiares; también cabe mencionar los trabajos de Manuel Fernández Almeida, delegado de la Cruz Roja, y las labores del marqués de Cabra y el padre Revilla.

${ }^{457}$ BOUARFA, Mohamed: Op. Cit., pp. 146-147.
} 
culpa. ¿Es que se teme que alguno de ellos pueda, después de ser rescatado, enredar con sus declaraciones la madeja de las responsabilidades?"458.

De hecho, fue habitual la publicación testimonios en los que se relataban las circunstancias de su penosa existencia: el limitado espacio del que disponía cada individuo, la paupérrima alimentación, la insalubridad del alojamiento, los maltratos inferidos por los guardianes, los trabajos forzados ${ }^{459}$, etc. Se pretendía convencer a la opinión de la necesidad de una actuación inmediata al respecto, aunque, al mismo tiempo, se seguía alimentando la voluntad de revancha y caracterizando al rifeño como un enemigo cruel que merecía un brutal castigo. Sobre todo, se combatió con estos relatos la tradicional imagen que presentaba a Abd-el-Krim como un hombre culto y refinado ${ }^{460}$.

En la práctica, estas noticias generaron mucho alarmismo. Ciertamente, las posibles consecuencias que la liberación del general Navarro pudiera tener en el pleito de las responsabilidades no parecieron preocupar en exceso a la opinión liberal local. Pero sí hubo división de pareceres entre los salmantinos al conocerse el método con el que finalmente Alba y Echevarrieta hicieron efectivo el rescate en enero de 1923: El Adelanto lo aplaudió: "Era ya hora del rescate; iba siendo vergonzoso para una potencia europea, el suplicio de unos soldados españoles sometidos a prisión por unas cábilas del Rif. Había, además, en este retardar del rescate, algo sospechoso, o, por lo menos, algo que hacía sospechar al país, y que se relacionaba con el pleito de las responsabilidades". ${ }^{461}$. Durante algunas semanas, concedió bastante de su espacio a los testimonios de los rescatados $\mathrm{y}$, sobre todo, a los relatos de los tres salmantinos liberados: el soldado Pedro de Dios, natural de Tejares; el aviador José García Peña y el también soldado Sotero Villalba, ambos de la capital ${ }^{462}$.

458 “¡Hay que rescatarlos!”, El Adelanto, n 11.481, 2 de noviembre de 1921, p. 1; También, E. Gómez Parra: "Teorías peregrinas", El Adelanto, $\mathrm{n}^{\circ}$ 11.515, 12 de diciembre de 1921, p. 1.

${ }^{459}$ E. Gómez Parra: "La aflictiva situación de los prisioneros", El Adelanto, $\mathrm{n}^{\circ}$ 11.508, 3 de diciembre de 1921, p. 2; E. Gómez Parra: "La cuestión del rescate de los prisioneros", El Adelanto, no 11.513, 9 de diciembre de 1921, p. 1; "J. A.": "La triste historia de unos pobres cautivos", El Adelanto, no 11.722, 15 de agosto de 1922, p. 3; "J. A.": "Los prisioneros", El Adelanto, n' 11.725, 18 de agosto de 1922, p. 2 (Los dos artículos son comentarios de la entrevista de Luis de Oteyza con Abd-el-Krim).

460 “A.": "Exaltaciones vergonzosas", El Adelanto, no 11.419, 22 de agosto de 1921, p. 2. Efectivamente, había sido educado en Fez para la interpretación de la ley coránica y poseía mucha experiencia trabajando junto a españoles, sobre todo, en la redacción de El Telegrama del Rif.

461 "Nota del día. El rescate de los prisioneros", El Adelanto, n' 11.857, 24 de enero de 1923, p. 2; La primera notificación del rescate se halla en Alfredo Rivera: "Al cerrar", El Adelanto, no 11.856, 23 de enero de 1923, p. 6.

462 "El regreso de los tres salmantinos prisioneros en Axdir", El Adelanto, n' 11.862, 30 de enero de 1923, p. 5; Castro: "El rescate de los prisioneros de Axdir", El Adelanto, $\mathrm{n}^{\circ} 11.861,28$ de enero de 1923, pp. 12; Castro: "Los espantosos detalles del cautiverio de los prisioneros", El Adelanto, n 11.862, 30 de enero 


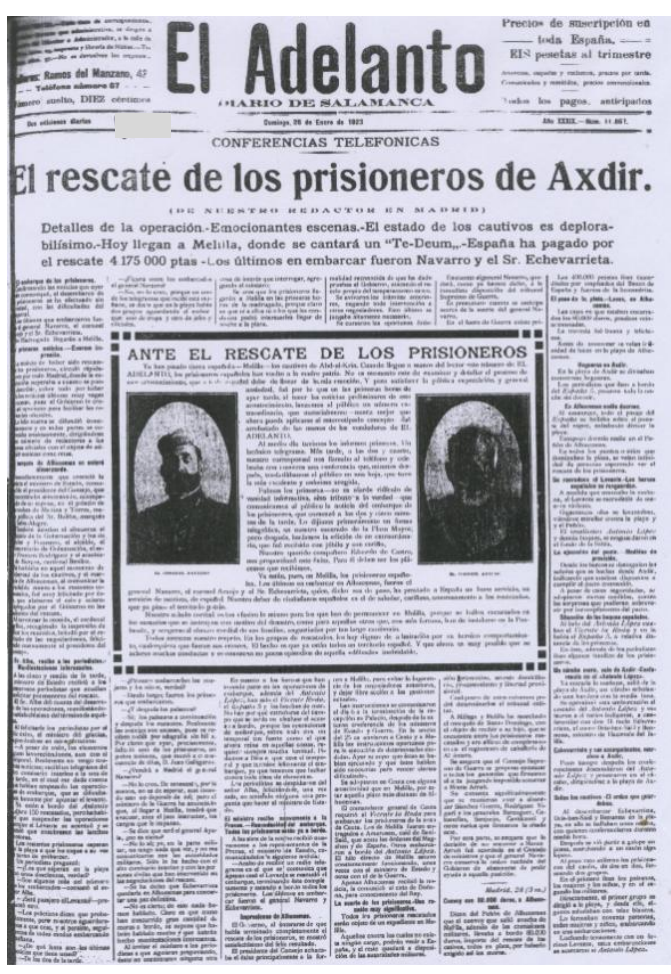

El Adelanto, $\mathrm{n}^{\mathrm{o}} 11.861,28$ de enero de 1923, p. 1.

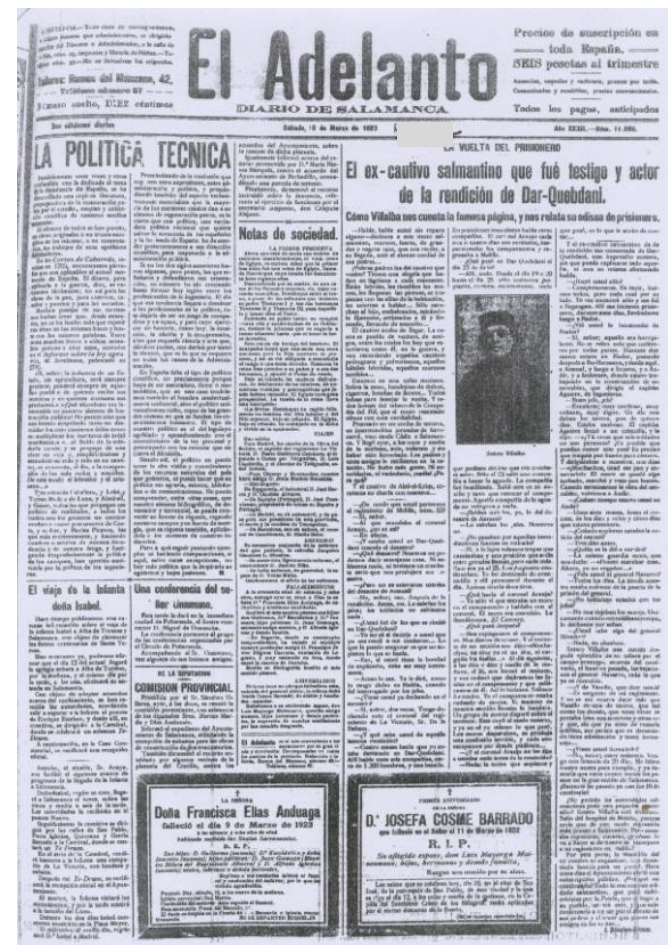

El Adelanto, n 11.896, 10 de marzo de 1923, p. 1.

Más que interesarse por los debates sobre el honor nacional, el diario de Núñez Izquierdo se volcó en argumentar, por enésima pero última vez (porque ya no habrá más noticias satisfactorias antes del alzamiento militar), intentándose convencer a sí mismo, que había llegado el momento de implantar el protectorado civil: "Ahora no hay más que aceptar el hecho, consumado y patriótico, del rescate, y dejar que el gobierno lleve a su implantación el protectorado civil ${ }^{, 463}$.

En el caso de La Gaceta Regional, nunca tan proclive como El Adelanto para adentrarse en el tortuoso sendero del relativismo ideológico, fueron prácticamente inexistentes las señales que revelaron un sentimiento de rechazo público hacia la guerra. No merecieron más que desprecio. De hecho, este fue el diario salmantino que más se esforzó por alimentar el deseo popular de desquite.

De entrada, su atención hacia el asunto de las responsabilidades fue algo más tardía que la prestada por el órgano de Núñez Izquierdo, pero su preocupación resultó

de 1923, pp. 1-2; También son interesantes las siguientes entrevistas: "El ex-cautivo que vio morir al coronel Morales. La derrota de Annual y el cautiverio de Axdir", El Adelanto, $\mathrm{n}^{\circ}$ 11.886, 27 de febrero de 1923, p. 6; "El ex-cautivo salmantino que fue testigo y actor de la rendición de Dar-Quebdani", El Adelanto, $\mathrm{n}^{\circ} 11.896,10$ de marzo de 1923, p. 1.

463 "Nota del día. El horizonte político se va despejando", El Adelanto, no 11.869, 7 de febrero de 1923, p. 1. 
mayor $^{464}$. Además de la sección de informaciones telefónicas y telegráficas, muchos editoriales de primera página e informaciones de "Hacia el Protectorado" redundaron en el tema y, también, se reprodujeron bastantes fragmentos del expediente militar. De la lectura de todas estas páginas, se deducía que la implicación de los militares africanistas, y muy especialmente del general Dámaso Berenguer, en la derrota fue una cuestión secundaria, incluso disculpable, ante las responsabilidades políticas, la inmoralidad reinante en la vida pública y la errónea actuación de las Juntas de Defensa:

“iLas causas del Desastre! ¿No son otras que las que se citan en el expediente y las que proclaman los oradores? ¿Están, como ayer se decía, en las malversaciones sin castigo, en los jefes de Cuerpo que sufren vahídos antes de entrar en fuego $y$ abandonan su puesto de honor, en los vicios que corroían al Ejército de África, tales como el juego y otros de los que enervan el espíritu? Ciertamente. De esa situación radica el Desastre; pero esa situación hay que buscarla en las verdaderas causas, mejor dicho, en una sola causa: el total olvido de los deberes del hombre para con Dios, para con la Patria y para con la sociedad",465.

En efecto, la noticia del procesamiento de Berenguer había generado extraordinaria sorpresa entre los miembros de la redacción; nada parecido al relativo alivio experimentado en $E l$ Adelanto ${ }^{466}$. Pero pronto descubrieron que apuntando hacia esferas superiores del Poder, la responsabilidad de éste quedaría diluida. De todas formas, la desesperación también haría mella en este diario:

"No sé por qué razón temíamos lo que está sucediendo. Lleva muchos días perorando ya todo quisque en el Parlamento y se hace imposible ver luz alguna en el horizonte de las responsabilidades.

Cada discurso de oposición es una nube de polvo, que lejos de ser una tempestad arrolladora que destruye, no es más que un velo negro y tupido que oculta la visión de las realidades. Por eso viene luego el sedante y la calma de los discursos gubernamentales y se advierte enseguida que el fondo del asunto no sólo no ha sido resuelto, mas ni siquiera ha sido tocado.

¿Es posible que nadie tenga culpas, que nadie se halle ligado por negligencias, desórdenes, cobardías, yerros y malas voluntades a la desgracia de nuestra inmensa e histórica derrota del año 1921? (...) Y es que el Parlamento no vale absolutamente para nada, ni para bien legislar, ni para juzgar, ni para inspeccionar, ni para cosa alguna de provecho ${ }^{, 467}$.

También al socialismo le tocaría su parte de culpa. Así, coincidiendo con el anuncio de la manifestación pro-responsabilidades de diciembre de 1922, La Gaceta no

\footnotetext{
464 "Rectitud y serenidad. Investigación necesaria", La Gaceta Regional, n 291, 10 de agosto de 1921, p. 1.

465 “Lo de siempre. ¡Pobre España!”, La Gaceta Regional, no 682, 24 de noviembre de 1922, p. 1. Sobre el posicionamiento del diario conservador contra las Juntas, véase "Hay algo en Dinamarca", La Gaceta Regional, $\mathrm{n}^{\circ}$ 379, 23 de noviembre de 1921, p. 1; y “Quosque tandem...?”, La Gaceta Regional, $\mathrm{n}^{\circ}$ 498, 15 de abril de 1922, p. 1.

466 "El Alto Comisario, los generales Navarro y Silvestre, numerosos jefes y oficiales, acusados de culpabilidad en el Desastre de julio", La Gaceta Regional, n 566, 8 de julio de 1922, p. 3.

467 "Las responsabilidades se esfuman", La Gaceta Regional, nº 689, 2 de diciembre de 1922, p. 1.
} 
escatimaba comentarios críticos por considerar que el acto estaba alimentado por grupos revolucionarios, causantes de la desmoralización del Ejército:

"Se quiere pedir con esa manifestación que se exijan responsabilidades por el Desastre de Marruecos, y son sus organizadores los primeros que están incursos en responsabilidad (...) No se puede exculpar el desacierto de gobernantes y de generales (...) Pero, es también causa muy próxima de cuanto ocurre, las ideas y propagandas de los manifestantes de ahora, que mucho han contribuido a producir el estado de descomposición nacional.

Recuérdese cómo procedieron en 1909 los elementos revolucionarios; cuál fue su actitud, oponiéndose violenta y antipatrióticamente a la salida de las tropas; cómo produjeron la depresión moral del soldado; cómo mataron en él los ideales que podían darle la convicción del deber, sin la cual no es fácil ir en busca de la victoria.

$Y$ de entonces acá, recuérdese la campaña tenaz, mantenida año tras año, minando la disciplina militar con la propaganda sindicalista ${ }^{, 468}$.

Desde esta óptica, el Ejército y su oficialidad, más que culpables, eran víctimas $^{469}$; y de la denuncia de la corrupción del sistema político a la apuesta por la dictadura, evidentemente, había un paso. En abril de 1923, por ejemplo, "E." señalaba:

"Los fallos del Tribunal Supremos de Guerra y Marina, imponiendo castigos severos a cuantos, más directa o indirectamente, tuvieron parte en la derrota de Annual, están llevando la zozobra y el miedo a las altas esferas de la política, donde se hallan los sempiternos responsables de todas las calamidades que afligen a la nación. De sus derrotas; de su pobreza; del vilipendio en que vivimos; del despilfarro arriba, de la ruina y la angustia en todas partes. Lo de Annual fue un detalle, todo lo triste que se quiera, pero un detalle solamente, del drama que el sistema político actual, que todo lo corrompe con sus impurezas, venía preparando ${ }^{, 470}$.

Además, el Vizconde de Eza quedaba libre de cualquier tacha ${ }^{471}$; y la investigación de fortunas, argumentaba también "E.", no conduciría a ninguna parte ${ }^{472}$. "El moro Muza", con notable descaro, trivializaba incluso sobre la importancia de la investigación:

"Así como en la plaza de toros el público, alocado y sediento de sangre, en algunos momentos vocifera: ";Caballos, caballos!", así también el pueblo español, desde hace cerca de dos años, no cesa de gritar: "iResponsabilidades, responsabilidades!". He dicho el pueblo, y he dicho mal. El pueblo, afectado por el Desastre de Annual, sufre y llora en silencio su dolor, y si ciertamente entre los que gritan habrá hombres sinceros, que piden justicia a voces, porque entienden que su deber es pedirla, abundan aquellos que creen llegada la ocasión de arrimar el ascua de las responsabilidades a la sardina

\footnotetext{
468 "No desviarse!”, La Gaceta Regional, $\mathrm{n}^{\circ}$ 691, 5 de diciembre de 1922, p. 1; "Anoche en el Ayuntamiento", La Gaceta Regional, n 698, 14 de diciembre de 1922, p. 1; "La manifestación pro responsabilidades", La Gaceta Regional, no 711, 30 de diciembre de 1922, p. 1; y "La manifestación pro responsabilidades", La Gaceta Regional, $\mathrm{n}^{\mathrm{o}} 712$, 2 de enero de 1923, p. 2.

${ }^{469}$ Cándido Lobera: "Hacia el Protectorado", La Gaceta Regional, no 728, 20 de enero de 1923, p. 2.

470 "E.": "Las responsabilidades", La Gaceta Regional, no 799, 14 de abril de 1923, p. 1.

471 "E.": "El problema de Marruecos. Las responsabilidades y el Vizconde de Eza", La Gaceta Regional, $\mathrm{n}^{\mathrm{o}} 803,19$ de abril de 1923 , p. 1.

472 “E.”: "Más sobre las responsabilidades", La Gaceta Regional, nº 817, 17 de mayo de 1923, p. 1.
} 
de sus ambiciones... iQuién sabe si en el río revuelto que se forme no podrán ellos saciar su sed de medrar!,473.

La ferocidad exhibida contra el pensamiento obrero al hilo del debate sobre las responsabilidades se incrementó significativamente a lo largo del verano de 1923: "Subleva el ánimo la mojiganga de las responsabilidades; el ver convertidos en fiscales y juzgadores a los delincuentes de tanto y tanto atentado contra la paz pública" ${ }^{\text {"74 }}$. Más aún, en agosto, tras el acto de insubordinación en Málaga, Mirabal volcaba su ira contra los propagandistas y defensores de la sedición militar:

"Lo que se dice y lo que se escribe, no se dice ni se escribe para que el viento se lo lleve, ni se dice ni escribe para inconscientes. El que oye y el que lee, retiene y asimila las ideas; y las ideas son para mover la voluntad con arreglo a ellas; de ahí la ilicitud de las nocivas, de ahí la delincuencia del pensamiento, y la responsabilidad gravísima que contraen los propagandistas de ideas, que al fructificar en el hombre le determinan al hecho punible ${ }^{, 475}$.

De paso, obviamente, enfatizaba la enorme influencia política de la prensa y de los líderes de opinión. No obstante, la campaña contra el pensamiento socialista llegó a su culmen en septiembre, muy pocos días antes del alzamiento militar y con motivo de la celebración de las dos manifestaciones obreras en Salamanca ${ }^{476}$. Y es que esta redacción siempre concibió el abandono como una utopía y fue constante en su demanda de una acción militar rápida, enérgica y decidida:

"No sabemos si espontáneamente o por obediencia a órdenes emanadas de las organizaciones socialistas, los obreros salmantinos han celebrado dos actos públicos, de protesta contra el gobierno, por su actuación en Marruecos y pidiendo el abandono por España de nuestra zona protegida (...) Estamos de acuerdo con los trabajadores en la primera parte de sus peticiones. Hay que terminar la contienda marroquí, con toda rapidez y con toda eficacia. No puede la Nación soportar por más tiempo esta sangría suelta y este dispendio, que aniquila y arruina a España. Pero no podemos suscribir, sino combatirla, esa tendencia abandonista que significaría el desprestigio de la Patria, la pérdida de nuestra independencia en el concierto de las naciones, la anulación de nuestro ideal histórico; y traducido todo ello a lo que es interés material, el renunciamiento a todo propósito de reintegrarnos, con las riquezas mineral del país, de los cuantiosos sacrificios que hemos realizado (...) No se dejen, pues, llevar los obreros por irresponsables apóstoles ${ }^{477}$.

\footnotetext{
473 "El moro Muza": "El Desastre de Annual", La Gaceta Regional, n 830, 23 de mayo de 1923, p. 1. De este mismo autor hemos hallado otro editorial, publicado algunos meses más tarde, en el que se comparaba la obra española en Marruecos con la francesa, en Argelia. Su propósito: desprestigiar a esta última. Véase "El moro Muza": "El Desastre de Annual. Una comparación muy elocuente", La Gaceta Regional, $\mathrm{n}^{\circ}$ 852, 19 de junio de 1923, p. 1.

474 "La comedia de las responsabilidades", La Gaceta Regional, no 873, 13 de julio de 1923, p. 1.

${ }^{475}$ Mirabal: “¡Responsabilidades!”, La Gaceta Regional, n 908, 25 de agosto de 1923, p. 1.

476 "E.": "El mitin de ayer", La Gaceta Regional, no 915, 3 de septiembre de 1923, p. 1.

477 "E.": "Los obreros y la cuestión de Marruecos", La Gaceta Regional, no 919, 7 de septiembre de 1923, p. 1.
} 
Excepcionalmente, y cambiando ya de materia, en el seno de La Gaceta se produjo una escisión en lo tocante al asunto de los "cuotas". Así, de una parte, encontramos a algún redactor que defendía esta figura legal y privilegios, contradiciendo los estereotipos pregonados desde el mundo obrero:

"Se dice que no se pueden establecer categorías para ir a la guerra (...) Si se hiciese una estadística profesional de estos soldados, se vería cuántos obreros hay entre ellos (...) Es una maniobra hábil decir que se defiende a los ricos contra los pobres. Se defiende a los pobres, a los más pobres de todos, los soldados, porque son los que sufren más intensamente las penalidades de la vida de campaña.

Sostener ilegalmente en Marruecos a estos soldados que ya han cumplido sus plazos, es arruinar al país más de lo que se creen los señores que se empeñan en no licenciarlos (...) Se ha privado de sus alumnos a los centros de enseñanza; a las oficinas, de sus más entusiastas empleados, a las fábricas, de sus obreros más meritorios; a los hogares, de los hijos que van labrando el porvenir. Eso es lo que se ha llevado a Marruecos y lo que se sostiene ilegalmente, pretextando que esos son los ricos. ;Los ricos!, ${ }^{478}$.

El 16 de abril de 1922, los padres de "cuotas" celebraban un mitin multitudinario

en el Teatro Moderno. Como colofón, he aquí la carta que los organizadores del acto remitieron a Sánchez Guerra:

"Excelentísimo señor presidente del Consejo de Ministro.

La campaña de Marruecos ha venido a remover los cimientos de la economía nacional; el hecho de tener inactivos miles de brazos, es causa de cada día que pasa se sientan más necesarios para el fomento de la Agricultura, Industria, las Artes y la Cultura. El prescindir por tiempo indefinido de estos fundamentales factores de la riqueza nacional obliga al país a preocuparse seriamente sobre la suerte de nuestra querida patria y de nuestros hijos; sobre todo, de aquellos que, acogidos a los beneficios del artículo XX de la ley de reclutamiento no se les licencia, siendo así que tienen cumplido con exceso.

Por preocuparnos hondamente de los extremos apuntados, los padres de los soldados de cuota de esta provincia, reunidos en magna asamblea el día de la fecha, han acordado elevar al gobierno de Su Majestad las siguientes conclusiones:

$1^{\circ}$ El abandono de Marruecos por ser la ruina de España.

$2^{\circ}$ Que si no se abandona Marruecos, que no vayan a luchar alli los soldados de la península.

$3^{\circ}$ Que se cumpla inmediatamente la ley, licenciando a los soldados cumplidos de la quinta de 1919 1920, resolviendo la instancia presentada al excelentísimo señor ministro de la Guerra, el día 10 de Marzo.

Salamanca, 16 de Abril 1922.

Excelentísimo señor:

En nombre de 700 padres de soldados de cuota de Salamanca y su provincia, la Comisión: Nicasio Rodríguez, Arturo Holgado, Antonio Peláez, Siro Gay y Luis Fernández ${ }^{, 479}$.

Desde luego, ya mediaba un abismo entre estas peticiones y el afán de revancha

exhibido en el verano de 1921. Sin embargo, también en La Gaceta hallamos a otro

\footnotetext{
478 "Los soldados de cuota. Remitido", La Gaceta Regional, no 483, 27 de marzo de 1922, p. 3.

479 "El mitin de ayer en el Teatro Moderno", La Gaceta Regional, n 499, 17 de abril de 1922, p. 4.
} 
columnista que se opuso a semejantes iniciativas de los padres de "cuotas", ya que, según su criterio, anteponían su conveniencia particular al honor de la patria:

"Sobreponiendo su dolor respetable y sagrado de madre al más sagrado y respetable de su patria, pensaron que, mejor que llorar en las soledades tristes de su hogar, era el agruparse, el unirse, el bullir en la vida pública e imponer su dolor a la sociedad entera, para que ésta lo apagara en los términos que solicitaban (...) Las guerras no se hacen nunca, no pueden sostenerse nunca y se pierden siempre cuando el pueblo las odia, cuando no les presta el maravilloso talismán de su entusiasmo (...) Piensen que su actitud desmoraliza al soldado (...) Saber esperar es la más grande de todas las virtudes" ${ }^{\text {, }}$.

Sin duda, el aterrizaje en la presidencia de García Prieto aunó pareceres y el diario conservador también se apuntó a la oleada popular que exigía su repatriación urgente. Semejante conducta constituyó, sin duda, un instrumento sencillo y muy eficaz para desprestigiar a la concentración de izquierdas. Por esta razón, en las navidades de 1922, desde este órgano, alguien se preguntaba: "Si como se está viendo, las Juntas disuelven los elementos voluntarios, que tan buenos resultados han dado en la campaña de África, ¿qué va a hacer para cubrir los efectivos que allí necesitamos imperiosamente? (...) ¿Se ha pensado bien en lo que esto significa de sangre y de lágrimas?" $" 481$.

En abril de 1923, los padres de los “cuotas" volvían a presionar al ministro de Guerra, reclamando la pronta repatriación ${ }^{482}$. Y en junio, con motivo de la celebración en la ciudad de un Congreso de Ciencias, también el malestar era trasladado al mismo Alfonso XIII. Así, Mirat le hizo entrega de un memorial en el que nuevamente se solicitaba la repatriación ${ }^{483}$. Apenas transcurridos unos días tras el golpe militar, esta reivindicación también llegaría al presidente del Directorio ${ }^{484}$.

En lo tocante al asunto de los cautivos de Axdir, la satisfacción producida por su liberación resultó muy pasajera ya que el proceder del gobierno español en esta cuestión fue, en opinión de la redacción conservadora, vergonzoso ${ }^{485}$. Además de que el dinero

\footnotetext{
480 "Las madres de los soldados", La Gaceta Regional, no 581, 27 de julio de 1922, p. 1.

481 "El aspecto sangriento de la cuestión africana. Pobres madres", La Gaceta Regional, nº 705, 22 de diciembre de 1922, p. 1. A principios de febrero de 1923, el diario conservador señalaba que aún quedaban en territorio africano 247 "cuotas" de La Victoria pertenecientes al remplazo de 1920 y otros 47 jóvenes del remplazo siguiente. Véase: "La Cruz Roja", La Gaceta Regional, n 739, 2 de febrero de 1923 , p. 1.

482 "Por la pronta repatriación", La Gaceta Regional, n 794, 9 de abril de 1923, p. 3.

483 "El Rey y los cuotas", La Gaceta Regional, no 857, 25 de junio de 1923, p. 5.

484 "Los padres de los soldados", La Gaceta Regional, no 35, 26 de septiembre de 1923, p. 1.

${ }^{485}$ Barreto: "El tema del día. El rescate de los prisioneros. ¿Su libertad es un hecho?", La Gaceta Regional, $\mathrm{n}^{\circ}$ 730, 23 de enero de 1923, p. 3; Claudio Zardaín: "La redención de los mártires", La Gaceta Regional, $\mathrm{n}^{\circ}$ 738, 1 de febrero de 1923, p. 1; y M. García: "El rescate", La Gaceta Regional, nº 751, 16 de febrero de 1923, p. 3 .
} 
entregado a Abd-el-Krim podría emplearse en la adquisición de armamento, la opinión conservadora juzgó el pago de un rescate como algo humillante, más aún a sabiendas de que el caudillo rifeño sólo aceptó recibirlo de manos de un particular: "Abd-el-Krim ha concluido, sellado y agrandado con esto su triunfo sobre España, y la sangre de ésta no queda vengada, y su corona yace manchada entre el lodo marroquí, sin que haya osado ningún español a levantarla"486.

Por último, El Pueblo encabezó en Salamanca, en buena medida (junto con Miguel de Unamuno), la campaña periodística contra la Guerra del Rif y contra la multitud de actos patrioteros desarrollados en aquellos días posteriores a la debacle de Annual. Pero, como ya se ha afirmado, su oposición a la contienda no se fundamentó en ningún tipo de argumento defensor del derecho del pueblo marroquí a la independencia, sino en la repudia hacia el injusto sistema de reclutamiento de la época: "No solo priva a millares de madres de sus queridos hijos, a la hacienda nacional exhausta con seis millones diarios de gastos, a la industria y al comercio de valiosos artistas, y al campo yermo por falta de brazos para cultivarlo, envejeciendo España, porque nuestra juventud perece en los campos del Rif" ${ }^{487}$.

La redacción obrera consideró el expediente Picasso como una entelequia de la que no se derivaría ningún responsable serio. En realidad, desde el mismo momento en que se conocieron las noticias desastrosas de la Comandancia de Melilla, ya lo sabemos, había exigido responsabilidades. No obstante, no emprendió una campaña reivindicativa constante, a sabiendas de que habría topado con la inmediata actuación del censor. Aunque, eso sí, la manifestación pro-responsabilidades, en diciembre de 1922, fue presentada como un éxito; pero más que obrero, institucional:

"Por iniciativa del Ayuntamiento, se celebró en ésta la manifestación proyectada, por cuyo éxito tanto empeño y celo ha desplegado el alcalde señor Anaya.

$Y$ dicho sea, en honor a la verdad, en la manifestación estaban representadas todas las entidades y organismos que constituyen la vida activa de nuestra ciudad, aun cuando la manifestación, a pesar de ser bien nutrida, no lo fue tanto como el acto requería.

$Y$ es que este pueblo tiene el defecto de la despreocupación, de permanecer indiferente a todo problema nacional. Parece que vivimos -como diría el señor Unamuno-, en un 'cautonismo' lamentable.

Ni las mujeres siquiera, las madres que perdieron a sus hijos, han tenido la gallardía de salir a la calle, para unirse a la veintena de mujeres, que con su estandarte a la cabeza, pedian justicia.

\footnotetext{
486 "Redimidos", La Gaceta Regional, no 735, 29 de enero de 1923, p. 1.

${ }^{487}$ M. Lozano: “¿Hay pueblo?”, El Pueblo, n’ 34, 4 de marzo de 1922, p. 2; Muy similares ideas esgrimía en su editorial "Andrés de España": "No nos conformamos", El Pueblo, no 37, 15 de abril de 1922, p. 4.
} 
Hay más aún. Se da el caso estupendo, que quizá los que con más derecho se encuentran para exigir la reparación de tanto agravio recibido, tienen la osadía, de desempeñar el papel de espectadores al paso de la manifestación ",488.

Abundando en el significado de la manifestación, "Un manifestante" llegó a calificarla de "acto de suicidio colectivo" ¿Por qué? Porque rechazaba los sentimientos que alimentaban a los manifestantes no socialistas:

"Y para demostración que Salamanca entera conservaba las llagas de tan crueles aventuras y se disponía a reforzar la línea de conducta que trazó la minoría socialista en el Parlamento se manifiestan mil personas, de las cuales no cabe dudar como una gran parte iba forzada por el peso tan enorme de la vergüenza que supone su indiferencia, pero que en su alma no ha existido un átomo de sentimiento humanitario ni para sus mismas entrañas que estarán podridas a estas horas en el maldito cementerio africano ${ }^{, 489}$.

Annual y el debate responsabilista subsiguiente habían servido, qué duda cabe, para ahondar la brecha y los resentimientos entre la "Salamanca burguesa", la de Martín Veloz, y la "Salamanca obrera", a ratos liderada por el esquivo Unamuno. La fractura se manifestaba, incluso, a la hora de reivindicar algo deseado por todos: la depuración de responsabilidades. Evidentemente, porque se hallaba en juego, en el fondo, el futuro del régimen político.

Para concluir, El Pueblo se limitó a recibir con alivio la tan esperada noticia del rescate de los prisioneros:

"Se ha llevado la alegría a no pocas madres, esposas e hijos, que durante los largos meses del cautiverio, tanto lloraron la triste desgracia de sus deudos. Demos, pues, todo por bien empleado, y ojalá se hubiera llevado antes a efecto tal medida, con lo que hubiéramos ganado mucho dinero, y más que dinero, la vida de no pocos desventurados que perecieron agotados ante los castigos y sufrimientos de que eran objeto.

Después de la hecatombe, después del Desastre, del que existen no pocos responsables, con el rescate de los prisioneros ha llegado un poco de alegría "490.

Pero sólo un poco, en efecto; porque el problema africano estaba lejos de resolverse en sus vertientes tanto militar como política. De todos modos, aquí concluye nuestro análisis de este semanario. Si bien subsistió hasta 1927, durante los años de la dictadura, muy vigilado por la censura, mantuvo una actitud de completo silencio ante el problema africano.

\footnotetext{
488 "Lo de las responsabilidades", El Pueblo, n 53, 13 de enero de 1923, p. 1.

489 "Un manifestante": "Un comentario a la manifestación pro-responsabilidades", El Pueblo, no 53, 13 de enero de 1923, p. 4.

490 “Andrés de España": "Libertad a los prisioneros de la redacción”, El Pueblo, n 55, 24 de febrero de 1923, p. 1.
} 


\section{Miguel de Unamuno: líder anticolonialista en la Salamanca de los años 20}

Miguel de Unamuno fue una figura de gran trascendencia para la literatura, la filosofía, la universidad, la política, el periodismo e, incluso, muy habilidoso con el dibujo y la papiroflexia. Hombre increíblemente polifacético, fue además el más genial "estratega de café" de nuestra historia.

Acerca del periodismo, creía Unamuno que un buen diario debía ser sugerente, de acuerdo con el espíritu comercial de los nuevos tiempos, pero tenía también que procurar la conservación de su carácter instructivo. En líneas generales, concebía la profesión como una tarea delicada, que exigía dotes científicas. De lo contrario, el simple aluvión de noticias desorganizadas únicamente generaría confusión ${ }^{491}$. Siempre muy satisfecho por haber logrado "hacerse un público", en una ocasión confesó: "Un escritor público puede siempre hablar en nombre de una fuerza social; la de su público. Un publicista que escriba de política llega siempre a representar una fuerza social. Muchas veces, la gran parte de aquellos que, profesando abominar de la política, de lo que en realidad abominan es del régimen" ${ }^{492}$. El pensador defendía, por lo tanto, una común identidad entre sus lectores: la del los que, sobrepasados por un potente sentimiento de amargura y derrotismo, maldecían el caciquismo.

Paradójicamente, sus colaboraciones en la prensa local, abordando los asuntos marroquíes, fueron nulas. No es algo que nos deba sorprender: por una parte, le resultaba económicamente más ventajoso publicar en los periódicos de tirada nacional; por otro lado, estamos convencidos de que tampoco los rotativos salmantinos podían tener excesivo interés en pregonar las controvertidas opiniones del ex-rector en una materia, por sí misma, tan polémica; ni, muchísimo menos, querían darse de bruces con la Ley de Jurisdicciones.

Pero, aún así, Don Miguel tuvo mucha, muchísima, voz en Salamanca. Para bien o para mal, sus opiniones eran escuchadas y muy comentadas. No dejaban indiferente a nadie. Y menos aún, a sus más acérrimos detractores. Así lo manifestaba, con evidente sorna, un columnista anónimo de El Salmantino al término de 1918:

"Somos de los que piensan que cada pueblo tiene y es natural que tenga los gobernantes que se merece. A Salamanca, emporio de la sabiduría y centro cultural de

\footnotetext{
${ }^{491}$ Miguel de Unamuno: "La cátedra de la prensa", La Época, 2 de septiembre de 1898. Advertimos que, aunque hemos consultado prácticamente todos los editoriales originales del profesor (también alguna recopilación), no podemos indicar ni el número ni la página de los periódicos correspondientes porque en la Casa-Museo Unamuno tan sólo se almacenan estas colaboraciones recortadas, no los ejemplares periodísticos completos y tan voluminosos.

${ }^{492}$ Miguel de Unamuno: "La representación política del escritor”, El Liberal, 14 de abril de 1920.
} 
la democrática España, debe dársele por consiguiente para alcalde suyo, un hombre cumbre como dice que es don Miguel.

La presidencia del Ayuntamiento salmantino corresponde de derecho al señor Unamuno, ya que en mítines y asambleas se presenta siempre como el oráculo y guía de las multitudes, porque otros que pudieran y debieran hacerlo no las ilustran y dirigen (...) ¿Fracasar? Don Miguel no fracasa nunca. Quienes fracasamos somos nosotros, los del montón, los que no tenemos entendederas para comprender sus frases sentenciosas, ni casacas con la que cambiar la vieja y raída que traemos puesta, ni espíritu capaz de adentrarse hasta las profundidades del ser para crear lo que vemos, incluso, ni el mismo Dios con quien el señor Unamuno tiene místicas e íntimas relaciones ${ }^{, 493}$.

Iluminado "chaquetero" (mientras que los integristas no se desprendían de su "vieja y raída" casaca), según algunos, y genial, para otros, hoy los estudiosos de su figura enfatizan, al unísono, el liderazgo que don Miguel ejerció sobre la capital. Sólo equiparable al de Veloz, pero infinitamente más duradero por la riqueza, complejidad, y originalidad de sus argumentos. Conocemos, de igual modo, la afición del profesor, diríase que impresa en sus genes, por zarandear al pueblo, por divulgar sus conocimientos y opiniones. Así lo hacía con los tertulianos que frecuentaban El Novelty. Y también con demás amigos, colegas en el Consistorio, en la Universidad y alumnos; y sabemos, por último, que esa incipiente sociedad salmantina de masas no era algo desestructurado. Al fin y al cabo, desearíamos que ésta fuese una de las principales conclusiones a extraer de la presente investigación: la información no se digiere en soledad, sino que las redes ideológicas y sociales así como la coyuntura histórica definen los marcos de comunicación. Todas ellas - y no sólo: también los prejuicios, las experiencias, las expectativas...- resultan determinantes para entender el porqué de la opinión pública.

Por todo esto, no podemos prescindir de esta insigne figura en nuestro trabajo. Aunque para ahondar en su pensamiento (anti)africanista, tengamos que recurrir a la prensa nacional.

Miguel de Unamuno nunca había ocultado la repugnancia que le producía la obra pedagógica del anarquista Francisco Ferrer. Sin embargo, la lectura de Los sucesos de España en 1909, escrito por Salvador Canals, junto con la experiencia de la huelga general de 1917 y sus muchos problemas judiciales desde esta fecha y a raíz de sus colaboraciones con El Mercantil Valenciano, le harían cambiar de perspectiva. Acabaría

493 “Que nombren a Unamuno", El Salmantino, n 2.519, 20 de noviembre de 1918, p. 1. 
por admitir que pecó “contra la santidad de la justicia” y reconoció que la implicación de Ferrer en la Semana Trágica nunca quedó probada ${ }^{494}$.

El lapso temporal transcurrido entre las dos grandes hecatombes africanas, asimismo, fue determinante en la configuración del nuevo pensamiento unamuniano: un lustro después del descalabro en el Barranco del Lobo, el pensador no pudo permanecer impasible ante el estallido de la Guerra Mundial. Conocida su apuesta por los aliados, comenzó a arremeter contra los ambiciosos germanófilos españoles, a los que bautizó como "los trogloditas"

Por último, el Desastre de Annual reactivó sobremanera el antimilitarismo de Unamuno, aletargado en la campaña de 1909. Mejor tarde que nunca. Lamentablemente, fue precisa una masacre, después de infinidad de pequeños tropiezos, para que éste finalmente alzase su voz. El dato no deja de constituir, claro está, un indicio de la descomunal fuerza de la propaganda dinástica y del buen funcionamiento de la espiral del silencio.

Durante 1898, con motivo del conflicto cubano, muchos de los artículos del filósofo para La Lucha de Clases habían sido juicios contra el discurso nacionalista que glorificaba el embarque de los jóvenes quintos ${ }^{496}$. Estaba convencido de que había que abandonar Cuba y le asqueaba la reivindicación de los derechos históricos. Le hartaba igualmente el culto al héroe y rechazaba el "militarismo militante", pero más si cabía “el estúpido militarismo de los paisanos”. Además, también la barbarie de 1921 hizo reverdecer su anticolonialismo -ahora sí encontramos repugnancia hacia la posibilidad de que un pueblo, sin importar cuál, "civilice" a otro-y su antibelicismo.

Entendemos, sin embargo, que el antimilitarismo de Unamuno no fue absoluto. Su análisis de la crisis suscitada por las Juntas de Defensa, en 1917, le abrió los ojos: así que consciente de la división existente en el seno del Ejército, exhibió todo su odio hacia los africanistas, pero en las Juntas vio, en su etapa germinal, un espíritu regenerador - por el desafío que planteaban a Alfonso XIII y a su política de ascensos en África- que mereció su aplauso. Así se explicaba Unamuno al finalizar 1922:

“Otra vez las Juntas de Defensa (...) No sirve llamar a la disciplina a los discípulos cuando no hay magisterio en quien les llama (...) Los sublevados del $1^{\circ}$ de junio de 1917 no supieron resistir las solicitaciones del Poder público que les corrompió (...) Ahora se dice que las famosas Juntas se agitan y se dice que se agitan ahora en que se

\footnotetext{
${ }^{494}$ Miguel de Unamuno: "Confesión de culpa”, El Día, 7 de diciembre de 1917.

${ }^{495}$ RABATÉ, Colette y Jean-Claude: Op. Cit., p. 346. También a Guillermo II lo apodó como el "histrión bufón" y "Calígula".

${ }^{496}$ LÓPEZ GARCÍA, Bernabé: "Marruecos en el pensamiento de Unamuno y Azaña" en LÓPEZ GARCÍA, B.: Marruecos y España... Op. Cit., pp. 229-243.
} 
arrastra todavía en la clandestinidad el Expediente Picasso y que el gobierno de su majestad inventa dilaciones" $"$,97.

Unamuno intentaba denunciar el recurso a las Juntas como chivo expiatorio del Desastre. Pero, sobre todo, la nueva guerra colonial le otorgó el pretexto para pedir la cabeza del Rey. Ya el 26 de julio de 1921, en el diario Juventud, se incluyó una carta y un artículo en el que expresaba su renovada opinión sobre Marruecos:

"En estos días ha sufrido la Corona de España un rudo revés en Marruecos, donde un general dinástico se ha metido en una aventura sin contar ni con su jefe inmediato ni con el gobierno. Aunque aquí no lo hay. Que no es gobierno un cotarro de lacayos de la camarilla militarista que mantiene el actual despotismo del Reino de España, régimen de clandestinidad y de engaño, ${ }^{, 498}$.

Y simultáneamente a Azaña le confesó también que "lo de África es una bendición si de ahí viene el derrumbe de esta vil monarquía de tahúres y de agiotistas ${ }^{499}$. De hecho, en varias ocasiones más, se referiría a la derrota de julio de 1921 como una desgracia "providencial”.

Pese a la persecución de la censura, Unamuno no detuvo sus ataques contundentes. Así, en El Liberal de Madrid escribió, ya en abril de 1922:

"España donde tiene una misión civilizadora es en España misma (...) Y el elemento más activo de la descivilización de España, de que se esté deshaciendo la civilidad española, es la campaña de Marruecos (...) esa campaña es una diversión estratégica para apartar nuestra atención del problema nacional. Que es el de este régimen de podredumbre y de negocios, de caciquerías y de clandestinidades, que nos está consumiendo. El reino está podrido ${ }^{\text {}, 500 .}$

Sus contribuciones para este diario eran, en efecto, cada vez más duras. En julio de 1922 se ensañaba contra la Ley de Jurisdicciones: "Toda profesión que se constituye en casta (...) acaba por tener un lenguaje esotérico y una ideología aisladora. Y en el caso de la milicia española, ha contribuido a ello esa absurda, despótica y antipatriótica ley" ${ }^{\prime 51}$. Y a mediados de noviembre volvía a denunciar la sangría y el derroche en la guerra: "Esa absurda campaña de Marruecos es, sí, una escuela de patriotismo, pero no del que invocan los accionistas de la patriotería del Reino (...) no de aquél con que trafica la camarilla megalomaníaca, patrimonial e imperialista (...)

\footnotetext{
${ }^{497}$ Miguel de Unamuno: “¿Disciplina?”, El Liberal, 15 de octubre de 1922; y, menos explícito, Miguel de Unamuno: "El Ejército nacional", El Mercantil Valenciano, 30 de agosto de 1921.

${ }^{498}$ ROBLES, Laureano: Epistolario americano (1890-1936). Salamanca: Ediciones Universidad de Salamanca, 1996, pp.471-473.

${ }^{499}$ RABATÉ, Colette y Jean-Claude: Op. Cit., p. 421.

${ }^{500}$ Miguel de Unamuno: “De actualidad. Descivilización”, El Liberal, 27 de abril de 1922.

${ }^{501}$ Miguel de Unamuno: "De actualidad. Que hablen en cristiano", El Liberal, 9 de julio de 1922.
} 
sino del otro, del que ansía la civilización de España"502. Tras estos comentarios, llegó a darse el caso de que Miguel Moya le tuvo que rogar que no le enviase artículos en los que figurara la más mínima alusión a Alfonso XIII ${ }^{503}$.

Evidentemente el pensamiento africanista de Unamuno nada tenía que ver ahora con el discurso del Paraninfo, pronunciado en aquel lejano 1910, o con sus declaraciones a Nuevo Mundo, de 1913. Mediaba un abismo. Para empezar, nuestro personaje sostenía que África estaba descivilizando España y que a Marruecos se había ido para procurar negocios: “ ¿Se va a entregar al actual Reino de España la ciudad de Tánger para que haga de ella otro coto de bárbaras peleas? No; el Africano carece de autoridad para ir a civilizar África cuando deja que se esté descivilizando, barbarizando a España"504. Contra la rapacidad de Occidente luchaban los "moros", presentados como combatientes valerosos. Más concretamente, Unamuno rechazaba que Abd-el-Krim fuese un fanático; únicamente repudiaba la presencia militar española en el Rif. Sus acciones, además, tan sólo eran una "justa y humana protesta contra las atrocidades cometidas en el dintel de la bahía de Alhucemas"

Ahora bien, ¿por qué esa alusión a la entrega de Tánger? A mediados de 1920, gobernando Dato, Unamuno se había referido ya a este asunto y también había aprovechado la ocasión para desquitarse con el trabajo de los diplomáticos y de muchos periodistas:

"Es lamentable, sin duda, casi todo lo que a propósito de eso de Tánger en relación con el préstamo de tantos o cuantos millones que España hizo a Francia, se escribe (...) El principio de la diplomacia ha sido, es y nos tememos que seguirá siendo el secreto, y el principio de la prensa popular tiene que ser la publicidad (...) No queremos decir con esto que en lo de Tánger esté actuando la diplomacia secreta y bajo la dirección de Dato, el canciller que fue de la neutralidad a todo trance y costa, bajo la que se escondía (...) otra cosa que neutralidad (...) En el caso de Tánger, lo que aquí se ha llamado (...) la nerviosidad francesa, alega la actitud que el Reino de España guardó durante la Gran Guerra respecto a Francia. Porque el Reino de España fue (...) en su gran mayoría, germanófilo (...) Dícese que cuando Romanones, nuestro canciller francófilo, vio a Clemenceau, fue entre otras cosas, para rogarle que se pasara la esponja del olvido sobre ciertas... 'equivocaciones' (...) Y cuéntase que el tigre le dijo a nuestro zorro, que el porvenir tiene sus raíces en el pasado y que no se puede ni se debe olvidar éste (...) Lo que no se debe hacer es tratar de falsear lo pasado (...) Malo, muy malo, es que se siga con aquella vieja diplomacia de

\footnotetext{
${ }^{502}$ Miguel de Unamuno: "Oración fúnebre”, El Liberal, 15 de noviembre de 1921; con similares ideas, pero más emotivo, Miguel de Unamuno: "El pobre padre", El Liberal, 3 de diciembre de 1921.

${ }_{503}$ RABATÉ, Colette y Jean-Claude: Op. Cit., p. 422.

${ }^{504}$ Miguel de Unamuno: “Accionistas del patrimonio", El Mercantil Valenciano, 6 de julio de 1921. Este artículo, obsérvese, es anterior a la derrota de Annual.

${ }^{505}$ Miguel de Unamuno: "Sigue el lío del Protectorado", El Socialista, 15 de julio de 1922; y Miguel de Unamuno: "Protectorado senil", El Mercantil Valenciano, 1 de mayo de 1923. En este editorial señalaba: "Hay que reconocer la injusticia de la santiagada. No que salió mal, no; sino que se emprendió mal".
} 
clandestinidad, pero peor es que la prensa trate de enturbiar la fuente de la verdad histórica ${ }^{, 506}$.

Recuérdese que Gran Bretaña siempre había defendido la internacionalización del enclave tangerino para así garantizar la libertad de circulación en el Estrecho de Gibraltar, mientras que Francia procuró el reconocimiento de la soberanía del Sultán sobre todo el Imperio, a sabiendas de que éste se hallaba bajo la órbita de su influencia. En cambio, la posición española fue la más frágil ${ }^{507}$.

En primer lugar, por su debilidad legal, porque su presencia en Marruecos era subsidiaria de la francesa; y en segundo lugar, debilidad práctica, muy notoria después de la guerra mundial, ya que sus reclamaciones apenas tuvieron resonancia exterior. Por todo ello, las esperanzas de los sucesivos ejecutivos, que no de la opinión pública salmantina (apenas fue informada sobre esta materia), se depositaron en el retraso de la reunión internacional a propósito de Tánger. Así, tal vez las diferencias entre Gran Bretaña y Francia ocasionadas por el fin de la Primera Guerra Mundial aflorarían. Y a río revuelto...

Sin embargo, las conversaciones internacionales sobre el futuro Estatuto de la ciudad, reanudadas tras la contienda, no pintaban bien para España. Su neutralidad aparente iba a tener un precio. Pero, ¿sabría la clase política resignarse?

Un año después, ya en 1921, el ex-rector aseguró que el Desastre de Annual fue la última salpicadura del "trogloditismo francófobo". Expongamos primero, sumariamente, su razonamiento: a pesar de esa neutralidad oficial, insistía el profesor, abundaron en España los "sanchopancescos" que esperaron del "Don Quijote tudesco" demasiados beneficios territoriales. De hecho, España no llegó a suscribir un Estatuto de Tánger en 1914, junto con la Entente, con la esperanza de obtener mayores ventajas tras la victoria alemana en la contienda. O lo que es lo mismo, la diplomacia confió y depositó sus esperanzas, equivocadamente, en la construcción, a expensas del káiser Guillermo II, de un nuevo imperio, el bautizado por Unamuno como "Vice-Imperio íbero-africano": "Esperó el Reino de España que le entregase la ínsula Barataria el don

\footnotetext{
${ }^{506}$ Miguel de Unamuno: "Diplomacia y publicidad", El Liberal, 22 de junio de 1920. Muy similares a éstas, serían las ideas expuestas por el conocido Juan Guixé tres años después: "Síntoma fatal para un pueblo es falsificar su historia, y peor aún, no tenerla (...) ¿Es historia ese sentimentalismo (...) ese histérico sacudimiento del ardor bélico ante las represalias del infiel marroquí?". En GUIXÉ, Juan: El Rif en sombras. Lo que yo he visto en Melilla. Madrid: s. n., 1922, p. 219.

507 PEREIRA CASTEÑARES, Juan Carlos: "El contencioso de Tánger en las relaciones hispanofrancesas (1923-1924)" en VVAA: Españoles y franceses en la primera mitad del siglo XX. Madrid: CSIC, 1986, pp.303-322.
} 
Quijote tudesco (...) iPero como el pobre don Quijote tudesco llevó el gran batacazo!" 508 .

Al no conseguirlo, el mismo Alfonso XIII, desesperado, procuró obtener por la fuerza el anhelado protectorado sobre Tánger. ¿Cómo? Creyó que con una demostración de fuerza, con la toma de Alhucemas, tendría una baza a su favor para exigir la modificación de los tratados internacionales en beneficio de España. Pero ahí fue cuando sobrevino la catástrofe, llevándose por delante a uno de sus favoritos, al general Silvestre:

"Todos deberíamos recordar, aunque no lo recordemos lo debido, que aquella trágica marcha sobre Alhucemas que costó a España el inolvidable Desastre de Annual, fue ocasionada principalmente por lo que se llama el problema de Tánger, el de su protectorado. Precedióla una pequeña algarada colonial -y consular- española en Tánger y luego un cierto viaje extra-constitucional -por no decir anticonstitucional, que estaría mejor- a Londres y a París ",509.

Nada le importó a Unamuno si el general Silvestre se suicidó o lo mataron ${ }^{510}$. En cambio, sí se esforzó, y mucho, en pregonar ese “¡olé los hombres!” del misterioso y supuesto telegrama que Alfonso XIII dirigió al entonces comandante general de Melilla:

"La nación no quiere guerra en Marruecos -ni Protectorado-, pero la quiere el reino. $Y$ para salir del paso proclaman, sí, la continuación de la guerra (...) No se sabe cómo confesar su derrota. La derrota de aquella acción que empezó en vísperas de Santiago Matamoros del año pasado, cuando se le hizo avanzar al desgraciado general $F$. Silvestre. Y ¡olé los hombres! ¡Así se hacen las cosas!"511.

Siguiendo con la argumentación de Unamuno, señalemos que de ese sueño, o más bien obsesión, imperial derivaba el estado de ruina por el que atravesaba España. La guerra dificultaba la resolución de las inevitables luchas obreras, distraía esfuerzos y, lo más preocupante, servía en la península para legitimar el empleo del Ejército para corregir las ineptitudes del poder civil: "El mayor daño que nos trae esa desatinada guerra de Marruecos, acción militar y policiaca, y no civil ni política, es que impide

\footnotetext{
${ }^{508}$ Miguel de Unamuno: "Neurosis troglodítica", El Mercantil Valenciano, 16 de septiembre de 1922. Más extensamente, todas estas ideas son formuladas en Miguel de Unamuno: "El Vice-Imperio íberoafricano", Hojas Libres, 1 de abril de 1927 (puede encontrarse, íntegro, en los Apéndices).

${ }^{509}$ Miguel de Unamuno: "De actualidad. El logogrifo del protectorado", El Liberal, 30 de junio de 1922. Previamente, ya hallamos idénticas acusaciones en Miguel de Unamuno: "Santiago, elemento", El Liberal, 5 de octubre de 1921.

${ }^{510}$ Los testimonios de la época fueron muy contradictorios. Acerca de la actitud del general en el momento de la retirada, autores como Pérez Ortiz señalaron que su comportamiento fue "sereno, impasible". Otros, como Bastos Ansart, señalaron que el militar presionaba a sus hombres para que se marchasen con el grito: "iHuid, huid, soldaditos, que viene el Coco!". Véase PÉREZ ORTIZ, Eduardo: De Annual a Monte Arruit y diez y ocho meses de cautiverio. Crónica de un testigo. Melilla: Artes Gráficas Post-Exprés, 1923, p. 23; y BASTOS ANSART, F.: Op. Cit., p. 145.

${ }^{511}$ Miguel de Unamuno: "La acción civil en África", El Socialista, 2 de junio de 1922. Otra alusión al "jolé los hombres!", anterior pero menos efusiva, en Miguel de Unamuno: "De actualidad. Hespanholadas", El Liberal, 9 de octubre de 1921.
} 
encauzar las inevitables luchas civiles de dentro de España, que impide gobernar la lucha social, la lucha de clases"512.

Unamuno defendió, lo reiteramos, que la derrota fue, por triste que pareciese, casi milagrosa: "Cuando se estudie la historia íntima del régimen político de España en estos años, se verá que el Desastre de Annual ha sido una fortuna. Sin él habríase intentado el golpe que se anunció en Córdoba",513. Y he aquí otro ejemplo: "Si no llega ese Desastre providencial habríamos llegado a otro desastre mayor" ${ }^{\text {"514 }}$. Pero, ¿por qué? Porque la victoria militar sobre Alhucemas habría apuntalado a Alfonso XIII en el trono, sirviéndole en bandeja de plata la oportunidad para instaurar una dictadura regia. Al fin y al cabo, detestaba a casi todos los políticos que le rodeaban. La prueba: en la ciudad andaluza mentada, un par de meses antes de la derrota, el Rey había mostrado públicamente su hastío hacia el sistema parlamentario y había dejado caer la posibilidad de suprimir la Constitución. Evidentemente, La Cierva, muy astuto y consciente de las implicaciones de semejante confesión, se apresuró a prohibir a los periodistas de la sala, por medio del gobernador civil, que telegrafiasen el mensaje regio. Pero, a pesar de sus esfuerzos, se produjeron las indeseadas filtraciones ${ }^{515}$.

En síntesis, ésta era la historia-ficción, sobre la que Unamuno reflexionaba al concluir $1921^{516}$. Resulta curioso el hecho de que, hoy en día, para muchos historiadores, se haya convertido en lugar común afirmar que el Desastre de Annual precipitó el golpe de Estado de Primo de Rivera. Unamuno, en cambio, defendió que esa batalla lo retrasó. Además, muy mediatizado por el odio que venía engendrando desde que no le explicaron su destitución del Rectorado, también creyó que su protagonista no había de ser Primo de Rivera.

A ciencia cierta, al profesor salmantino siempre le había disgustado el hecho de que el Rey vistiese el uniforme de capitán en actos públicos. Y aunque inicialmente responsabilizó a la Reina Madre y a Romanones de su despido, desde bien avanzado 1915, cuando no logró ser entrevistado en Palacio después de que el propio Rey se lo solicitase en Guernica, empezó a criticarlo ferozmente ${ }^{517}$.

\footnotetext{
${ }^{512}$ Miguel de Unamuno: "De actualidad. Guerra en la paz”, El Liberal, 4 de enero de 1922.

${ }^{513}$ Miguel de Unamuno: "La hora de la libertad", El Socialista, 22 de marzo de 1922

${ }^{514}$ Miguel de Unamuno: "Las dos campañas”, El Socialista, 27 de marzo de 1922.

${ }^{515}$ CARDONA, Gabriel: Alfonso XIII... Op. Cit., p. 183.

${ }^{516}$ A propósito del desprecio de Alfonso XIII hacia sus ministros, véase Miguel de Unamuno: "La soledad del Rey", El Mercantil Valenciano", 9 de febrero de 1921. También este editorial es anterior al Desastre de Annual.

${ }^{517}$ RABATÉ, Colette y Jean-Claude: Op. Cit., p. 423.
} 
En el interior del país, claro parece, el monarca perseguía su afianzamiento en el trono. Ahora bien, en el terreno internacional, ¿cuál era la conexión entre las aspiraciones regias sobre Tánger, frustradas al finalizar 1919, y la conquista de Axdir, que se intentó efectuar en julio de 1921? Aparentemente ninguna. ¿Por qué Alfonso XIII podría exigir una modificación de los tratados? ¿Acaso la derrota de Abd-el-Krim reportaría algún beneficio a la Entente? El cabecilla rifeño no estaba todavía abiertamente enfrentado con Francia. Al contrario, incluso Lyautey procuraba mantener un trato distante con las tropas españolas para evitar cualquier "efecto contagio" ${ }^{\text {"518 }}$. No; Alfonso XIII no podía exigir nada. Por consiguiente, el avance español sobre Alhucemas constituyó una advertencia, una amenaza si se prefiere, dirigida a los franceses: una demostración de fuerza para informar de que España no abandonaría Marruecos sin luchar (en el terreno diplomático, por supuesto; pero también con las armas).

La similitud con lo acontecido en 1909, vista así la historia, resultaba evidente. La vieja rivalidad entre vecinos europeos, una vez más y ya hemos perdido la cuenta, se hallaba en la génesis del conflicto africano. Pero, en esta ocasión no se había producido ninguna "carrera" para posesionarse de unas minas, sino un contencioso diplomático. Y, como de costumbre, éste apenas si había hecho saltar las alarmas mediáticas.

Las semejanzas que Unamuno encontraba entre la situación española de 1898 y 1921 eran muchas. Sobre todo, le repugnaba la perseverancia en lo que él bautizaba como "el defenderla y no enmendarla" o "la filosofía del carnero" 519 . Y le indignaba la práctica de la censura: "Quieren reacciones medulares, instintivas, y no cerebrales, reflexivas, y al no poder quitarnos los sesos para que no discurramos, nos tapan la boca para que no proclamemos la verdad" ${ }^{520}$. La guerra de Marruecos estaba deshonrando a España en el extranjero, al igual que anteriormente lo había hecho la de Cuba: "Han pasado veintitrés años y la tragedia íntima, la del alma de la parte de la

\footnotetext{
${ }^{518}$ HOISINGTON, William A.: Lyautey and the French conquest of Morocco. Nueva York: Macmillan, 1995, pp. 186-187; BOUARFA, Mohamed: Op. Cit., p. 153: "La tolerancia de Francia y la pasividad de las autoridades marroquies que de ella dependían permitieron que Tánger, en principio internacional desde 1914, se convirtiera en capital diplomática del Emirato del Rif. La acción emprendida en esta ciudad por algunos rifeños permitió que varios ciudadanos británicos, hombres de negocios y corresponsales de prestigiosos periódicos, apoyaran públicamente la guerra de liberación liderada por Abd-el-Krim".

${ }^{519}$ Consúltese Miguel de Unamuno: "De actualidad. Defenderla y no enmendarla", El Liberal, 10 de agosto de 1921.

${ }^{520}$ Miguel de Unamuno: "El tenorismo a frente del quijotismo y una consecuencia de la neutralidad observada durante la guerra europea", La Nación, 23 de octubre de 1921. Había aquí otra alusión más al telegrama misterioso de Alfonso XIII.
} 
nación que la tenga, que tenga alma, de los que sienten la españolidad, la nacionalidad española, esa tragedia sigue como entonces. Porque la vesanía del desquite, la locura del ex futuro Vice-imperio Ibérico hace continuar el desastre ${ }^{, 521}$. Por eso, los que se empecinaban en proseguir con la campaña militar merecían el más visceral desprecio público.

La voluntad de desquite era tildada de enorme "botaratada" y el empleo de gases tóxicos, absolutamente vergonzoso: “Civilizar es asfixiar con veneno (...) Gases asfixiantes son los que desde esa campaña de Marruecos están cayendo sobre la pobre trabajada conciencia pública española. La están envenenando con los más pérfidos sofismas (...) ¡Hay que abrir caminos a la civilización!”,522. Únicamente se pretendía defender el honor militar supuestamente mancillado porque la centenaria mentalidad de cruzada mantenía todo su histórico vigor ${ }^{523}$.

Pero frente a esa idea del decoro castrense ultrajado, Unamuno empezó a contraponer la del honor nacional insultado. Y esto constituyó el auténtico centro neurálgico de todas sus afirmaciones. Entendemos, contrariando la tesis de Bouzalmate ${ }^{524}$, que el pensamiento obsesivo del prestigioso profesor no consistió en hacer efectiva la depuración de las responsabilidades. El análisis de los editoriales escritos por el ex-rector nos anima a pensar que creía saber muy bien quiénes eran los culpables. Alfonso XIII, qué duda cabe, lideraba la lista ${ }^{525}$. Presentado abiertamente como un loco, su trabajo como agente diplomático resultaba nefasto:

"Lo más característico del loco en relación al cuerdo no es su lógica -Don Quijote era
un razonador lógico formidable- sino que parte, como de premisas, de alucinaciones. Y
aun cuando el cuerdo, puede también sufrirlas, tiene el correctivo de las apreciaciones
ajenas (...) Figurémonos, por ejemplo, un soberano (...) Podría ocurrir después de una
gran guerra en que su pueblo no tomó parte, y que él siguió con el interés deportivo de
un aficionado, teniendo sus mapas, con sus banderitas, y ejerciendo de profeta y de
crítico estratégico. Lo que es muy expuesto a que luego se sienta llamado a demostrar
de lo que él es capaz y a proyectar operaciones y a decir 'iasí se hacen las cosas!',
cuando parece salir bien una jugada para tener que recogerse cuando sale mal",526.

Lógicamente, también el hecho de que se rodease de malos consejeros era una tremenda desgracia nacional, dado que el dinastismo estaba hundiendo el auténtico patriotismo: "El dinastismo español de hoy está reñido con el Liberalismo, pues que no

\footnotetext{
${ }^{521}$ Miguel de Unamuno: "23 años después”, El Mercantil Valenciano, 3 de agosto de 1921; Similares comentarios aparecían en Miguel de Unamuno: "Desquite suicida", El Liberal, 3 de agosto de 1921; y Miguel de Unamuno: "Calaveradas", El Mercantil Valenciano, 21 de septiembre de 1921.

${ }_{222}$ Miguel de Unamuno: "Gases asfixiantes”, El Mercantil Valenciano, 30 de abril de 1922.

${ }^{523}$ Miguel de Unamuno: "Para que acabe el juego", El Socialista, 23 de julio de 1922.

${ }^{524}$ BOUZALMATE, Alhoucine: Op. Cit., p. 451.

${ }^{525}$ Miguel de Unamuno: "Lo más fatal", El Mercantil Valenciano, 30 de abril de 1922.

${ }^{526}$ Miguel de Unamuno: "Una crisis gravísima”, El Mercantil Valenciano, 17 de enero de 1922.
} 
es sino servilismo" $" 527$. En el banquillo de los acusados Don Miguel también sentaría a La Cierva, por imponer un silencio que nada tenía de beneficioso y cuyo proyecto de recompensas militares juzgaba como vergonzoso ${ }^{528}$; a Maura, quien exigió decoro entiéndase, venganza- tras el fracaso de Annual, pero no lo mostró cuando firmó el Tratado de 1904 con Francia ${ }^{529}$; a Vázquez de Mella y su nada disimulada germanofilia ${ }^{530}$; a Romanones, con sus "apestosos" intereses mineros; a los dóciles Melquiades Álvarez, Lerroux, Alcalá-Zamora, a la Iglesia, los africanistas... Y, en definitiva, a todos los que sostenían una concepción militarista de la historia de España, visión que tristemente había calado entre la opinión pública:

"A la guerra de la reconquista contra el moro, y a la otra guerra de reconquista también, contra el francés, se reduce todo lo que ha llegado de nuestra historia y nuestra leyenda a las más hondas capas de nuestro pueblo (...) Siendo mozo, oí a un aldeano de mi tierra que, viéndome examinar una vieja sepultura, en Arrigorriaga, me dijo: 'Ahi está enterrado un rey moro, al que le mataron en tiempo de la francesada' ¡Admirable resumen de nuestra más honda historia legendaria popular! Nuestro pueblo de conquistadores por la fuerza del destino, y a su pesar, no ha sentido más que la reconquista ${ }^{, 531}$.

En contraposición, el filósofo vasco defendía que no se debía hacer del amor propio del Ejército la clave de la política española. Y, sin embargo, eso era lo que se estaba practicando desde que se aprobara la famosa Ley de Jurisdicciones...

Ahora bien, ¿dónde residía ese honor de la nación? En el respeto del "espíritu público" (un concepto más ético que estrictamente político). Unamuno argumentó que antes que vengar la sangre española derramada, había que entender por qué se produjo un sacrificio tan grande y estéril de vidas. Sin embargo, la conquista del Rif se había emprendido sin el consentimiento de la nación. Muy poco se le dijo a ésta sobre la firma de los tratados internacionales que condujeron a la creación del Protectorado y por eso:

"El pueblo español de hoy no tiene noción de la finalidad de la campaña (...) Ni sirven esas paparruchas del castigo y del honor nacional (...) Nuestro pueblo hoy no es valiente, sino cobarde, extremadamente cobarde (...) Dicen los accionistas de la patriotería financiera (...) que las cosas no están ahora como en 1909 (...) y no hay nada de eso. Lo que hay es que se ha llevado a Marruecos a los señoritos de cuotas, a los hijos de los que, aunque protestando en su interior contra esa campaña y no creyéndola justa, se doblegan (...) para mantener sus privilegios (...) No; no es el honor nacional. Es que se les ha hecho creer que el desistimiento de la aventura marroquí es el fracaso del Poder que impide que España caiga acaso en el bolcheviquismo" ${ }^{532}$.

\footnotetext{
${ }^{527}$ Miguel de Unamuno: “¿Liberalismo dinástico?”, El Mercantil Valenciano, 20 de noviembre de 1921.

${ }^{528}$ Miguel de Unamuno: "Honorarios”, El Socialista, 10 de septiembre de 1921.

${ }^{529}$ Miguel de Unamuno: "Decoro, prestigio, honor", El Mercantil Valenciano, 29 de noviembre de 1921.

${ }^{530}$ Miguel de Unamuno: “Tradiciones”, El Mercantil Valenciano, 6 de septiembre de 1921.

${ }^{531}$ Miguel de Unamuno: "Remachando", El Socialista, 25 de agosto de 1923.

${ }^{532}$ Miguel de Unamuno: “¡Agua y letras!”, El Socialista, 12 de noviembre de 1921.
} 
Unamuno incidía en que el conflicto provocado por los deseos imperiales de una minoría para distraer a los españoles estaba avocado, consecuentemente, al fracaso:

"Los atudescados que buscan el desquite de Annual, los técnicos del trogloditismo, que no vacilarían en acabar de hundir a la nación con tal de que se intentara lo que ellos creen el restablecimiento del prestigio de las armas; esos incorregibles técnicos no cuentan nunca con el espíritu público. Para ellos no existe el espíritu. Y no quieren saber que la principal causa del merecido Desastre de la santiagada fue que se emprendió ésta contra la voluntad del pueblo, y que el modo de protestar de un pobre pueblo degradado es dejarse derrotar (...) El cordero no protesta, pero se deja sacrificar, y es inútil que se le quiera imbuir la idea de que se defienda y ataque ${ }^{\text {"533 }}$.

Evidentemente, en este último punto mentía el ex-rector: claro que se podía imbuir esa idea. Para eso había servido y servía la propaganda bélica. Sencillamente, él lo sabía y respondía con la práctica de la contra-propaganda, con ese "alfilerazo" al lector tildado de "cordero".

El problema de fondo residía, sigamos con los juicios de Unamuno, en que nadie entendía qué era un protectorado. Y no se entendía porque se trataba de un simple "camelo", una fórmula bajo la que ocultar la voracidad internacional y el sueño colonial español. Secundando unas palabras del periodista norteamericano W. G. Sumnes, nuestro personaje subrayaba que "la gran razón por la que todas las empresas que empiezan por decir a alguien: 'Sabemos lo que es bueno para ti mejor que tú mismo, y vamos a dártelo' son falsas y malas; es que violan la libertad (...) Lo claro y franco es la conquista",534.

Por fin, había aquí una censura hacia el darwinismo social imperante en aquella época. A decir verdad, menos idea se tenía aún de cómo implantar ese régimen protectorado en Marruecos: "Si el protectorado ha de ser verdadero protectorado, ¿qué más le puede dar a España que los moros del Rif se gobiernen por sí mismos, en República o que aparezcan sometidos a una autoridad puramente ficticia $y$ nominal?" ${ }^{535}$. Particularmente detestable le parecía, además, la idea del protectorado civil. No era más que un instrumento cobarde para no admitir el fracaso de la acción conquistadora en Marruecos: "Es indefinido e indefinible, porque es un embuste, porque nadie cree en él"536.

Los africanistas, los "cesarianos" sobre los que tanto escribió Unamuno, exclusivamente intentaban imponer un régimen castrense en el Rif, un fácil recurso para

\footnotetext{
${ }^{533}$ Miguel de Unamuno: “Trogloditismo en acción”, El Socialista, 17 de agosto de 1923.

${ }^{534}$ Miguel de Unamuno: "Camelo", El Liberal, 14 de mayo de 1922.

${ }_{535}$ Miguel de Unamuno: "De actualidad. El Sultanato ficticio", El Liberal, 16 de agosto de 1922.

${ }^{536}$ Miguel de Unamuno: “Otra vuelta al protectorado", El Liberal, 14 de junio de 1923.
} 
dar salida a su ardor guerrero. Y aunque el Ejército debiera ser la encarnación de la nación en armas, el Ejército español no era un Ejército nacional. Sin embargo, en la historia reciente de España se habían presentado dos intentos de nacionalización de la institución armada: "Desde que los soldados llamados de cuota -los hijos de la clase media- tienen que ir a dar su sangre, se va haciendo preciso nacionalizar las empresas bélicas (...) Y en el primitivo Manifiesto de las Juntas de Defensa militares (...) se veía ese anhelo de democratización" ${ }^{\prime 537}$. Ambos esfuerzos, no obstante, estaban resultando fallidos porque no se entendía el interés de la guerra marroquí. Así, el Ejército se hallaba desmoralizado, sin fuerza para el combate. Por eso, y terminaba su reflexión, Unamuno creía que Monte Arruit fue abandonado a su suerte: porque Berenguer desconfió de la instrucción y valentía de los soldados expedicionarios que llegaban a Melilla en los últimos días de julio de $1921^{538}$. Muy pocos días antes del golpe, de nuevo al referirse a la moral militar imperante tras el Desastre, Unamuno sentenciaba: "Iban como borregos (...) Aquella marcha, sin un grito, ni de adhesión ni de protesta, fue algo más terrible que el Desastre. Iban como borregos y como borregos han seguido yendo (...) El pueblo en armas que está en Marruecos no quiere la guerra, y aunque se deje llevar a ella, se dejará derrotar otra vez",539.

De nuevo, don Miguel intentaba despertar a sus lectores. La guerra de Marruecos ni se entendía ni se sentía. Lo único que se sabía la opinión pública, con certeza, era que la juventud moría física y, sobre todo, anímicamente en Marruecos:

"Nosotros, los españoles, tenemos hoy nuestra guerra; no sabemos bien si colonial o civil; pero de cierto que no nacional. Porque podrá discutirse si la guerra de Marruecos es una guerra colonial, o una operación de policía, o una conquista dinástica, o acaso una guerra civil; pero que no es una guerra nacional nos parece evidente (...) hoy hay en las filas del Ejército que sufre en África un fuerte elemento de muchachos que se enteran, que tienen conciencia civil y conciencia patria, y a su contacto los otros se enteran también (...) Vuelven con los ojos secos, pero enrojecidos. Vuelven con el alma ennegrecida (...) Vuelve de África nuestra mocedad con el alma lacerada y henchida de un amargo desconsuelo" ${ }^{540}$.

Mientras, a los padres no les quedaba más opción que 1lorar. Poco más, escribía el filósofo, podían hacer con las garantías constitucionales en suspenso. Pero, ¿cómo

\footnotetext{
${ }_{537}^{537}$ Miguel de Unamuno: "La nacionalización del Ejército", El Mercantil Valenciano, 8 de junio de 1921.

${ }^{538}$ Unamuno se estaba haciendo eco aquí de sus lecturas. Entre los libros de su biblioteca, con anotaciones de su puño y letra, figuraba el de Ayensa. En él se recogían unas declaraciones de Berenguer sobre el pésimo estado de instrucción de los soldados que llegaban a Melilla. Aunque el general no dudó de su entusiasmo. En AYENSA, Emilio: Del Desastre de Annual a la presidencia del Consejo. Madrid: Rafael Caro Raggio, 1930, p. 138.

${ }^{539}$ Miguel de Unamuno: "Lo primero que un técnico militar debe saber es psicología de la muchedumbre. El pueblo en armas no quiere la guerra", El Liberal, 5 de septiembre de 1923.

${ }_{540}$ Miguel de Unamuno: "La nueva conciencia nacional”, El Socialista, 5 de julio de 1922.
} 
habría reaccionado el pueblo si el avance de Silvestre hubiera terminado triunfalmente? El profesor retornaba a la práctica de la historia-ficción: muy posiblemente, entonces, se hubiese callado; y es que Unamuno, aparentemente, sostuvo una visión bastante peyorativa del proceder de la opinión pública: "Lo más del pueblo asiste impasible, frívolo también más que resignado, a ese desangre trágico. Es como si asistiera a una corrida de toros, escuela de frivolidad sanguinaria"541. Acaso, ¿no lo estaba llamando para tomar las calles?

Muy poco después de la derrota militar, había manifestado que buena parte del público, pero no la mayoría, estaba "idiotizado" y que la responsabilidad de "hacer" así a la opinión recaía en los periódicos:

"Para la mayor parte de los españoles que se fijan en ello, los moros no son bandoleros, ni traidores, ni canalla vil. Esto, a lo sumo, es opinión que trata de hacer una parte de la prensa, la más leída. Para la inmensa mayoría de los españoles, que son los inconscientes, los fatalistas, los rendidos, esta guerra es una calamidad más, como la sequía o las tormentas, o la lagarta ${ }^{, 542}$.

La causa de los españoles debiera haber sido la total independencia del Rif porque los guerrilleros rifeños no hacían sino emular a los viejos guerrilleros antifranceses, al igual que el Sultán, por vender su reino a los extranjeros, se asemejaba a la figura de Carlos IV. Pero ahora ya únicamente se podía gritar: "Cuando en años venideros repase algún español curioso e inteligente la historia de estos días (...) llegará a preguntarse si en este final del año 1921 lo que no había era hombres o pueblo (...) Juan Soldado (...) es carne de cañón o de fusil (...) es carne de gallina (...) ¡Y tan gallina, pues que soporta a quien soporta" ${ }^{\text {543 }}$. Esta alusión a la carne de gallina, por otro lado, no tenía nada de gratuita: cuando Antonio Maura le comunicó a Alfonso XIII lo que Abd-el-Krim exigía por el rescate de los prisioneros de Axdir, su desvergonzada contestación fue "¿Qué cara se vende la carne de gallina!”.

Unamuno también animó a sus lectores a protestar todo lo posible por la prolongada suspensión de sus derechos y por la lentitud en la gestión del rescate de los prisioneros de Axdir ${ }^{544}$. Aunque, al final, los disculpó en la medida en que barajó que si

\footnotetext{
${ }^{541}$ Miguel de Unamuno: "Jugar con sangre”, El Socialista, 26 de mayo de 1922.

${ }^{542}$ Miguel de Unamuno: "El meteoro bélico", El Socialista, 21 de agosto de 1921.

${ }^{543}$ Miguel de Unamuno: "Hay que gritar", El Socialista, 19 de diciembre de 1921.

${ }^{544}$ Miguel de Unamuno: "El rescate, principio de civilización”, El Liberal, 8 de diciembre de 1921; Miguel de Unamuno: "Otra vez lo del rescate", El Liberal, 23 de mayo de 1922; y Miguel de Unamuno: "La derrota del reino", El Socialista, 7 de febrero de 1923.
} 
los españoles tuviesen tantas armas como los rifeños, seguramente lucharían igual que ellos $^{545}$. Ambos vivían, en suma, bajo un régimen explotador.

Finalmente, después de años de acusaciones y en un ambiente muy caldeado, el 5 de abril de 1922 en presencia de Romanones, Unamuno fue entrevistado por el Rey. Si el ex-rector observaba con claridad lo que ocurría en Palacio era porque contaba con un informador de lujo, médico de varios miembros de la realeza: Gregorio Marañón ${ }^{546}$. Aunque buena parte de la prensa nacional y regional comentó que se le había ofrecido la cartera de Instrucción en un futuro gobierno liberal, él también deseó justificar este episodio. ${ }^{547}$ Alegó que continuaría siendo enemigo de la realeza y, de hecho, cuando el 6 de octubre de 1922, Alfonso XIII y Ena visitaron Salamanca y colocaron la primera piedra del nuevo cuartel de caballería, don Miguel no asistió.

Al terminar este año Unamuno publicaba el desconsolador editorial "La crisis de la irresponsabilidad". Había aquí un furioso ataque contra todos los políticos encubridores de la responsabilidad regia en el Desastre: "Lo que es inmoral, profundamente inmoral, es servir en Palacio a una política absolutista o despótica, de irrefrenada actuación personal, y negarse luego en el Parlamento a responder constitucionalmente ${ }^{\mathrm{9} 548}$.

El único camino a seguir, "lo único digno" era el abandono de Marruecos. De 1919 databa su primera reivindicación en esta dirección porque ya entonces estaba muy persuadido Unamuno de que España carecía de sentido de misión histórica:

"Eso de Marruecos no ha logrado interesar a los pueblos que habitan España. Y es ello naturalísimo. Eso de Marruecos es, en realidad, un problema internacional, y lo internacional no puede interesar donde falta el sentido de la nacionalidad (...) Lo mejor, pues, es abandonar un mal negocio (...) que a ningún pueblo se le debe imponer gobierno alguno contra su general voluntad ${ }^{, 549}$.

Bochornosa le resultaba la apelación a la "fatalidad" para evadir responsabilidades. Jamás creyó que el Parlamento pudiese hacer efectiva la depuración del las mismas porque el régimen se encontraba totalmente corrompido. Algo más, eso

\footnotetext{
${ }^{545}$ Miguel de Unamuno: “De actualidad. ¿Protectorado?”, El Liberal, 4 de noviembre de 1921.

${ }^{546}$ RABATÉ, Colette y Jean-Claude: Op. Cit., p. 426. Roberts también asegura que Unamuno contaba con otro informador que le mantenía al tanto de la marcha de las sesiones parlamentarias, Indalecio Prieto. Véase ROBERTS, Stephen G. H.: "Miguel de Unamuno y su relación con el socialismo entre 1914 y 1924: una primera aproximación”, Cuadernos de la Cátedra Miguel de Unamuno, n 43, Salamanca, 2007, p. 96.

${ }^{547}$ Miguel de Unamuno: "Un episodio", El Mercantil Valenciano, 8 de abril de 1922.

${ }^{548}$ Miguel de Unamuno: "La crisis de la irresponsabilidad", Semanario de la vida nacional, 2 de diciembre de 1922.

${ }^{549}$ Miguel de Unamuno: “¿Es España nación? Eso de Marruecos”, La Lucha, 10 de marzo de 1919.
} 
sí, confió en la voluntad del general Aguilera y en las gestiones del Consejo Supremo de Guerra y Marina ${ }^{550}$.

Sostenemos, a tenor de lo expuesto, que el deseo último de Unamuno, como propagandista de raza que fue, consistió en convencer para vencer, para retornar a la opinión pública el poder del que estaba siendo despojada. Eso sí, una opinión a la que él se sentía moralmente obligado a guiar, ilustrar y fortalecer. Quizás por este motivo, presidió en Salamanca la manifestación pro-responsabilidades, celebrada el 31 de diciembre de $1922^{551}$.

A modo de conclusiones para este capítulo, señalemos que en Salamanca, el Desastre de Annual ofreció una magnífica oportunidad para constatar que la tan reiterada apacibilidad de sus vecinos era una percepción errónea. La reacción salmantina ante la derrota militar fue, al contrario, sumamente visceral y estuvo alimentada por un fuerte sentimiento de compromiso. Esta ciudad meseteña destacó como una de las capitales más volcadas en obsequiar a sus soldados, sin reparar apenas en si competía al Estado o al pueblo suplir las carencias del Ejército de África; no obstante, también fue una urbe muy implicada en el movimiento de exigencia de responsabilidades y, sobre todo, de la pronta repatriación de tropas.

¿Podemos por ello afirmar que la sociedad salmantina estaba profundamente escindida entre "belicosos" y "abandonistas"?

Sí que encontramos, es cierto, en Salamanca irreconciliables opiniones, como las de Veloz y Unamuno. Pero también hubo entre la opinión local ideas muy ampliamente compartidas: esa imagen tan negativa del moro, la histórica animadversión hacia Francia, el dolor provocado por la "espinita" de Tánger o la generalizada desconfianza hacia los diplomáticos. Porque la opinión pública era, y es, intrínsecamente escurridiza; pero maleable. ¿Cómo darle forma? Fabricando héroes y, sobre todo, diseñando monstruos a los que aniquilar. La opinión se convierte así en un instrumento al servicio de la política exterior. No bastaba con lograr el éxito en el campo de batalla; primero había que ganar la guerra sobre el papel (del periódico). Lippmann, en efecto, ya había intuido esto cuando estudió el conflicto ruso-japonés y lo plantearía por escrito, por primera vez, en 1922. La propaganda, con el tiempo, acabaría siendo inseparable de la

\footnotetext{
${ }^{550}$ Miguel de Unamuno: "Improcesables", El Socialista, 6 de abril de 1923; Miguel de Unamuno: "Fatalidad; irresponsabilidad", El Mercantil Valenciano, 24 de abril de 1923.

${ }^{551}$ Ya nos referimos a "La manifestación en pro de las responsabilidades por el Desastre de Annual", $E l$ Adelanto, 2 de enero de 1923; "Lo de las responsabilidades", El Pueblo, 13 de enero de 1923; y "La manifestación pro responsabilidades", La Gaceta Regional, 2 de enero de 1923.
} 
práctica de la democracia. Porque el esfuerzo por transmitir a otros las propias convicciones, por hacer creer lo que uno de verdad cree, implica entusiasmo, confianza en el futuro. La propaganda no es dañina per se; sí lo es la ausencia de pluralismo ideológico.

Ahora bien, para el caso que nos ocupa, ¿esos monstruos se movían por los peñascos del Rif? ¿O sólo había un ogro que vivía en Madrid y llevaba corona? ¿Cuál era el mayor desastre de España? ¿Tener como vecinos a los marroquíes? ¿O el propio régimen de gobierno? Propaganda de guerra y, ipor fin!, una decidida contrapropaganda, con un discurso muy claro (más si pensamos en Unamuno que en $E l$ Pueblo) contribuyeron a desperezar a la opinión pública local. Pero no sólo hallamos eso en Salamanca: se abusó de la censura de algunas informaciones (el déficit estatal, las bajas de la campaña, los planes de avance, las motivaciones de Abd-el-Krim), de la reiteración de otras (la elevada moral de los soldados españoles; la necesidad de cumplir unos compromisos internacionales que no se entendían) y, sobre todo, se saturó a la opinión con los partes de campaña. Todo ello condujo, paradójicamente, a la desinformación. Y por esta razón, la auténtica brecha, esa a la que aludíamos más arriba y que sí era detectable con facilidad entre los líderes, donde en realidad se acabó localizando fue entre la opinión publicada y la opinión pública salmantina (y nacional, por extensión).

El deseo público de revancha existió, en efecto, y fue prioritario entre la opinión local durante algunos meses. Inicialmente, mientras se prolongó el asedio sobre Monte Arruit y un escalofrío sacudió al país, el más elemental instinto de supervivencia se impuso de modo espontaneo. Ni tan siquiera fue precisa entonces la propaganda de guerra. Pero rendida esta plaza, tal y como temía el incombustible Unamuno, para el gobierno de Maura, empeñado en restaurar el prestigio de las armas, se impuso la necesidad de fomentar la emoción frente a la razón.

¿Cómo fue posible eso? ¿Y hasta cuándo?

El investigador Pablo La Porte, por ejemplo, señalaba que la sintonía de pareceres entre monarquía, gobierno, militares y opinión pública resultó efectiva hasta finales de $1921^{552}$. En verdad, Maura gozó de mayores apoyos que cualquier otro presidente del largo reinado de Alfonso XIII. Y lo mismo ocurrió con Dámaso Berenguer. Las dramáticas circunstancias del momento imperaban. Sin embargo, comenzaron luego, efectivamente al concluir el año, a pasarle factura al gobierno

${ }^{552}$ LA PORTE, Pablo: El Desastre de Annual... Op. Cit., p. 287. 
asuntos como el de las responsabilidades y los prisioneros. Pero no sólo eso: también generó mucho rechazo, sobre todo entre las filas socialistas, un proyecto de recompensas militares presentado por La Cierva ${ }^{553}$. Y, por último, pero no menos importante, fue entonces, al acercarse las festividades navideñas, cuando más se recordó a los soldados ausentes.

Si continuamos con el razonamiento de La Porte, y ya aludimos a ello en el inicio de nuestro trabajo, se conjugaron una multitud de factores para explicar esa unanimidad de criterios. A saber: la actitud de las fuerzas políticas, capaces de ofrecer una imagen cohesionada; el papel asumido por la prensa, muy prudente y abnegada; el respaldo de la Iglesia Católica, manifiesto en multitud de actos caritativos; la marcha de los "cuotas" a África, factor al que este investigador otorga una importancia capital; la relativa pasividad de la CNT y del PSOE (el PCE, recién fundado, tenía muy escasa entidad y operatividad entonces); y, para concluir, el apoyo de las corporaciones municipales y de infinidad de particulares, a través de sus donativos al Ejército.

Evidentemente, todos estos elementos resultan más o menos familiares cuando los aplicamos al caso de Salamanca. En particular, si pensamos en los donativos de las instituciones públicas y privadas: los gestos de la Comisión Patriótica, la ayuda prestada desde la Cruz Roja, las iniciativas de las damas salmantinas, el día de haber del clero, etc.

Pero ¿por qué razón efectuar donaciones en beneficio de los soldados fue sinónimo de apostar por el desquite? ¿Por qué hay que entender esos gestos como síntoma de respaldo al gobierno? ¿Acaso no fueron los combatientes, simultáneamente, verdugos y víctimas? ¿Y si la prensa burguesa intentó adueñarse del éxito de las suscripciones y demás donaciones? ¿Por eso, tal vez, El Pueblo se revolvió contra su concepto de patriotismo? ¿No fue éste instrumentalizado para vender más y más ejemplares, para satisfacer pequeños egos al ver algunos sus nombres, como suscriptores, en letra de molde?

La Victoria, y por extensión, todos los soldados de origen salmantino, conformaron el vínculo sentimental más potente entre esta ciudad y Marruecos. El bienestar de los expedicionarios se convirtió casi en una obsesión urbana. Por ello, se procuró sin descanso surtirlos con todo el material personal y bélico imaginable. Asimismo, las despedidas en la estación ferroviaria se convirtieron en actos

\footnotetext{
${ }^{553}$ La idea, que hubo de aparcarse temporalmente en el Parlamento, les parecía impúdica cuando estaba pendiente el asunto de las responsabilidades. Véase BOYD, Carolyn P.: Op. Cit., p. 238.
} 
multitudinarios (aunque con variables grados de entusiasmo). Pero antes que la defensa del honor y decoro patrio o que el cumplimiento de unos compromisos internacionales, a los que machaconamente apeló la prensa local, el más primitivo sentimiento de solidaridad y compasión para con unos conciudadanos fue la semilla de todos estos emotivos episodios.

En cuanto al papel asumido por la prensa salmantina, las generalizaciones no son válidas en este terreno: La Gaceta, ciertamente, no tuvo ningún problema a la hora de respaldar todo revanchismo; El Adelanto también lo hizo, pero únicamente endureció su posición y se inclinó hacia las tesis militaristas tras experimentar numerosos desengaños. Porque el diario de Núñez Izquierdo buscaba un héroe, un caudillo, si bien se resistía a creer que éste fuese Berenguer. En su lugar, intentó depositar sus esperanzas en los sucesivos Altos Comisarios de carácter civil. Y acabó sintiéndose defraudado; El Pueblo, para terminar, renegó siempre del conflicto africano. Pero fue una publicación minoritaria y jamás llegó a sostener una ideología anticolonial.

Finalmente, desde luego, no consideramos la movilización de los "cuotas" como un elemento inductor de la calma tras la tempestad, sino como una nueva fuente de preocupación para gobernantes y gobernados. $\mathrm{Su}$ embarque, además, tampoco constituyó un consuelo para las clases más humildes. Desde el pensamiento obrero salmantino no se aplaudió semejante decisión. Al contrario, se censuró, recordemos, las estrechas miras de aquellos padres, que únicamente protestaban cuando sufrían en sus carnes la guerra. Unamuno, por su parte, habló de la cobardía de un pueblo, del fracaso en la "nacionalización" del Ejército y del temor a las hordas revolucionarias. En definitiva, de mala conciencia.

El hastío y la indiferencia habían sido las posiciones imperantes entre los vecinos del Tormes con anterioridad a los sucesos de Annual y Monte Arruit. Sobre todo, porque la política de titubeos adoptada ante El Raisuni no se había entendido ${ }^{554}$. Pero julio de 1921 marcó un antes y un después, un punto de inflexión, en la concepción

\footnotetext{
${ }^{554}$ Ese agotamiento era, en realidad, una sensación bastante extendida: "Es axiomático que no hay empresa colonial posible sin el amparo de una fe, de una atmósfera favorable en la opinión pública; en nuestro país, jamás se preocupó nadie de crear ese ambiente favorable, ni en las clases populares, ni en las que pudiéramos llamar directoras. Si entre nosotros se ha hablado mucho de Marruecos, hay que reconocer que sólo se hizo con el criterio actualista, cuando los sucesos sangrientos de carácter bélico hacían de los asuntos de África el tema de la inquietud o el dolor nacional (...) Consecuencia lógica de esta falta de ambiente y de comprensión de la obligación internacional adquirida por España en el problema europeo-marroquí, fue el constante recelo que en torno de los sucesos registrados en África se suscitó siempre". Véase ESPAÑA, Juan de: La actuación de España en Marruecos. Apuntes de historia y estudios sobre la política y situación actual del problema hispano-marroquí. Madrid: s. n., 1926.
} 
de la campaña. Aquel ya rutinario pero desencantado discurso sobre el Marruecos español, el del imperativo geográfico e histórico, desapareció durante algunas semanas en la prensa burguesa (y pensamos, sobre todo, en El Adelanto), cediendo su espacio a vigorosas y épicas narraciones sobre la conducta del Ejército en África. Más fructífera que cualquier alusión a las glorias del pasado imperial, resultó la difusión de una imagen muy estereotipada del rifeño, como un luchador salvaje y fanático, que merecía un castigo ejemplar.

Difícilmente podía ser escuchado, en aquellas semanas, el discurso abandonista de Unamuno o de El Pueblo. La opinión pública salmantina se encontraba afectada por lo que, desde la teoría de la Comunicación Política y la psicología de las masas, se conoce como el síndrome Rally Round the Flag ${ }^{555}$. Nos estamos refiriendo a esa extraña, tan calurosa acogida dispensada al gobierno de concentración de Antonio Maura y posterior a la masacre en Monte Arruit. Sobre ella escribió Jesús Pabón: “En un primer tiempo, no hay cuestión. En todas partes, Annual parece haber producido una unidad de entusiasmo y pareceres (...) apiña, por raro caso, a los españoles en torno al poder público, con edificante unanimidad de entusiasmos y colaboraciones" Calurosa, sí; pero también efímera ${ }^{557}$.

${ }^{555}$ GROELING, Tim y BAUM, Matthew A.: "Crossing the Water's Edge: Elite rhetoric, media coverage, and rally-round-the-flag phenomenon", The Journal of Politics, Vol. 70, n ${ }^{\circ} 4,2008$, pp. 1065-1085; BAUM, Matthew A. y POTTER, Philip B. K.: "The relationships between mass media, public opinion, and foreign policy: toward a theoretical synthesis", Annual Review of Political Science, n 11, 2008, pp. 39-65.

${ }^{556}$ PABÓN, Jesús: $O p$. Cit., p. 238. Tan sólo hemos localizado a un autor que relativiza la importancia de la política africana para el gobierno maurista: "El elemento fundamental que servía de aglutinante al gabinete y que le otorgaba su razón de ser no era un determinado programa marroquî". Véase GÓMEZ OCHOA, Fidel: "Por una nueva interpretación de la crisis final de la Restauración: el gobierno Maura de agosto de 1921 y la reforma económica de Cambó", Investigaciones Históricas. Departamento de Historia Moderna y contemporánea, $\mathrm{n}^{\circ}$ 11, Valladolid, 1991, p. 259.

${ }^{557}$ Así lo apreció ya entonces, y lo empleó interesadamente en su defensa, Eza, durante una sesión en el Congreso el 22 de noviembre de 1921: "Bueno será recordar que en el primer mes que siguió al Desastre de Annual nadie atacó a aquel gobierno (...) Después, y respondiendo al sentimiento muy humano y natural de que cada uno procure descargar en el vecino las culpas que le sean imputadas, comenzó a surgir el rumor conducente a la inculpación contra el ministro de la Guerra". MARICHALAR, Luis de: Mi responsabilidad en el Desastre de Melilla como ministro de la Guerra. Madrid: Gráficas Reunidas, 1923, pp. 483-484. Otro testigo de los acontecimientos, pero sin implicación en los mismos, fue Francisco Hernández Mir, quien señalaría: "La opinión pública española, que abnegadamente acudió con todo el esfuerzo demandado a la gran empresa de desquite (...) al verse defraudada en sus anhelos por la tímida y lenta campaña de reconquista, fue víctima de una depresión que dio preponderancia al criterio de pacifismo a todo trance". Consúltese Del Desastre a la victoria (1921-1926). El Rif por España. Madrid: Librería Fe, 1926, pp. 216-217. Otro publicista que insistió en la misma idea fue el Tebib Arrumi: "Hubo una crisis (...) Advino al Poder el señor Maura con un conglomerado político que no dejó de sorprender al país. Y entre estas andanzas de la crisis, se diluyó la atención pública, y aquello de Monte Arruit". El fragmento procede de RUIZ ALBÉNIZ, Víctor: Las responsabilidades del Desastre. Ecce Homo (Prueba documental y aportes inéditos sobre las causas del derrumbamiento y consecuencia de él). Madrid: Biblioteca Nueva, 1922, p. 437. 
El investigador Ángel Comalada apuntó, hace también muchos años, cuando apenas se empezaba a cuestionar aquello del Spain is different, que el consenso desapareció porque "diversos factores contribuyeron a ello, auspiciados por la vaguedad informativa y los complejos rasgos de psicología colectiva que aquí, como en otros países meridionales de idénticas estructuras, suelen operar en su lugar en el plano social, y que, cegados los auténticos cauces de participación ciudadana, afloran en los mil canales del rumor, la exageración, la insidia; las reducciones frustradas de la política en las tertulias de café y los corrillos callejeros; la búsqueda de cabezas de turco que personifiquen y paguen las malformaciones de un sistema",558.

Pero, ¿cómo, después de la triste experiencia en el Barranco del Lobo, cómo tras la Semana Sangrienta barcelonesa, pudo gozar de tantos apoyos el político mallorquín?

Volvamos sobre el Rally Round the Flag: en primer término, éste se explicó por el natural empeño de la opinión pública, arrastrada por el pánico, por el miedo en su expresión más extrema, en contemplar al presidente como encarnación de la unidad nacional (Teoría de la Escuela de Patriotismo). En segundo lugar, por la ausencia inicial de críticas desde la oposición política (Teoría del Liderazgo sobre la Opinión). Ambos elementos redundaron, por consiguiente, en un incremento de la popularidad del gobierno. Annual no sólo significó el "sálvese quien pueda" entre las filas del Ejército de África; sino que la dramática muerte de aquellos soldados colocó al país también al borde del precipicio. De ahí la paradoja: la parálisis de la opinión no fue un indicador de conformidad, sino de terror. Por eso utilizamos la palabra visceralidad, aplicándola al comportamiento de la opinión pública salmantina; y de ahí la indignación de Unamuno, primero, ante la "imbecilidad" de su pueblo, y después, frente a la nociva propaganda de la prensa burguesa.

El aspecto más controvertido del fenómeno Rally Round the Flag reside, obviamente, en la idea de que la guerra puede ser empleada transitoriamente para obtener réditos políticos, distrayendo a la opinión pública de las preocupaciones domésticas. Ciertamente, eso sucedió con Antonio Maura, pero también con la oficialidad africanista y con el mismo Alfonso XIII. ¡Qué visionario fue Unamuno ${ }^{559}$ !

Las tesis del profesor lograron mucha resonancia social a medida que se tramitó el asunto de las responsabilidades, cristalizó el conflicto entre junteros y africanistas y

\footnotetext{
${ }^{558}$ COMALADA, Ángel: Op. Cit., p. 15.

${ }^{559}$ En el mismo sentido apuntaba la cita de Romero Basart con la que iniciamos el capítulo anterior de esta tesis.
} 
se acrecentó la impaciencia por el retorno de los cautivos. Incluso desde el Ayuntamiento de Salamanca, como concejal, Don Miguel encabezó la manifestación pro-responsabilidades. Por primera vez, la ciudad salió a la calle no sólo para protestar por la prolongación de la guerra, sino para exigir el nombre de los culpables. Marruecos únicamente podía contemplarse como un destino fatal porque muchos de los jóvenes que eran despedidos en la estación, se presentía, no regresarían a su provincia natal.

Por esta razón, inútil resultó que casi todos los redactores (y nos vienen a la cabeza, sobre todo, “A.” y “E.”) endureciesen su discurso argumentando la necesidad de una acción militar contundente. La fractura entre la prensa y la opinión pública salmantina era innegable. Mientras para la primera urgía el desembarco en Alhucemas y la clarificación del estatuto de Tánger, la segunda únicamente anhelaba la repatriación de los soldados. La desolación, la amargura, el desengaño se acabaron convirtiendo en las notas más destacadas del clima de opinión y finalmente, la dictadura se vislumbró como una solución de urgencia.

El golpe de Primo de Rivera no pareció sorprender en absoluto a Unamuno. En La Tribuna fue publicado "Ante el nuevo curso", donde aconsejaba: "No caigáis, estudiantes españoles, en la dementalidad del carnero, el macho de la oveja, indigentísimo en seso y opulentísimo en sexo. Sea vuestro ideal el discreto y casto don Quijote y no el botarate de don Juan Tenorio, peliculero y héroe de casino. Es la inteligencia lo que ha de salvar la patria"560. Durante algunos meses, el pensador fue tratado en la prensa salmantina con bastante indulgencia, porque el censor del gobierno militar sabía que "Unamuno es mucho Unamuno" así que "puede hablar y escribir a su antojo" ${ }^{561}$. Pero duraría poco; tan poco como se hizo esperar la orden de destierro que conmocionó a Salamanca.

En efecto, al margen del tono de sus editoriales, que en bastantes ocasiones rozó lo insultante, los análisis del ex-rector no se habían limitado a injuriar al monarca. No; sus escritos habían puesto en entredicho la legitimidad del sistema -porque había cuestionado sus pilares, con aquella denuncia de la diplomacia clandestina, de la ineficacia judicial y, ante todo, de la inexistencia de una auténtica representatividad

\footnotetext{
${ }^{560}$ Miguel de Unamuno: “Ante el nuevo curso", La Tribuna. Revista estudiantil, 30 de septiembre de 1923.

${ }^{561}$ RABATÉ, Colette y Jean- Claude: $O p$. Cit. p. 443.
} 
parlamentaria ${ }^{562}-$. Además, su tremendo poder de convocatoria pública lo convertía en un personaje temible.

Aunque las ideas abandonistas de Primo de Rivera le habían permitido al dictador disponer de un considerable grado de aceptación social, no tardaría en abdicar de sus propósitos ante las presiones de los africanistas y de la diplomacia francesa. En seguida se comprobará.

\footnotetext{
562 o podemos olvidar que aquí, exclusivamente, estamos centrando nuestra atención en el pensamiento de Unamuno respecto al problema africano. Pero, en realidad, hubo poquísimos asuntos de actualidad que escaparan a su mordaz pluma.
} 


\section{EL FINAL DE LA PESADILLA. SALAMANCA Y EL DESEMBARCO DE} $\underline{\text { ALHUCEMAS (1923-1925) }}$

\section{EL GOLPE MILITAR EN SALAMANCA}

“Todo era, en España, Marruecos. La vida entera de la nación se hallaba mediatizada por ese problema, y en él, lejos de encontrarse soluciones o de dar al país la necesaria sensación de que al menos había un pensamiento directivo en la magna cuestión y la firme voluntad de seguir un plan seriamente pensado y ponderado, se volvió a la época de las contradicciones de hechos, del 'tejer y destejer', de promulgar hoy lo que ayer se reputara absurdo y peligroso; y se pasó por los intentos del Comisario Civil, cuando la situación real era de más guerra que nunca, y se volvió a los pactos con El Raisuni (...) Al margen de todo esto, una campaña sistemática, pidiendo el abandono de Marruecos (...) Tal era el panorama que ofrecía España la víspera del 13 de septiembre".1.

El verano de 1923, uno de los más turbulentos del reinado de Alfonso XIII, estuvo dominado por el nerviosismo desatado a raíz del debate sobre las responsabilidades del Desastre. De hecho, al inicio del otoño, mientras Salamanca se preparaba para la celebración de sus tradicionales ferias, la permanencia del gabinete del marqués de Alhucemas en el Poder pendía de un hilo, más aún, al conocerse las dimisiones de Villanueva, Chapaprieta y Gasset ${ }^{2}$.

Según El Adelanto, la crisis parcial tenía una clarísima explicación. A saber, "el desconocimiento y la falta de orientación en el problema de Marruecos"3. El gobierno encontraba incontables obstáculos para lograr la instauración de un protectorado civil y para acelerar la deseada repatriación de tropas. Desde el ascenso a la presidencia de García Prieto, el diario de Núñez Izquierdo no había ocultado su escasa confianza en esta concentración. Veía diferencias de carácter irreconciliable entre los ministros ${ }^{4}$.

Por su parte, los juicios del diario conservador, La Gaceta Regional, también eran muy negativos: "Nos hallamos frente a una situación que no acertamos a comprender y que no sabemos si tomarla en serio o a broma. Porque aun siendo, a nuestro juicio, muy graves las circunstancias, parece que lo bufo se une a lo trágico, o que Dios ha dejado de su mano a estos políticos a quienes por la fuerza de sus culpas,

\footnotetext{
${ }^{1}$ ESPAÑA, Juan de: $O p$. Cit., p. 36. Evidentemente, tanto o más que la guerra marroquí, preocupaba al país la situación catalana.

2 "Presagios de borrasca", El Adelanto, no 12.054, 12 de septiembre de 1923, p. 1; y "E.": "La lógica se ha impuesto", La Gaceta Regional, 790, 4 de abril de 1923, p. 1. Poco antes, además, habían abandonado sus cargos Pedregal y Alcalá-Zamora.

3 "Al margen de la crisis", El Adelanto, $\mathrm{n}^{\circ}$ 12.047, 4 de septiembre de 1923, p. 1.

4 “¿Qué queda de la concentración?”, El Adelanto, n 12.048, 5 de septiembre de 1923, p. 1
} 
ha de perder" ${ }^{\prime 5}$. También para este rotativo, el mayor problema del ejecutivo radicaba, indiscutiblemente, en la política a desarrollar en el territorio del Protectorado ${ }^{6}$.

El 14 de septiembre, en la sección dedicada a las informaciones de carácter telegráfico y telefónico, Rivera se hacía eco de unos "gravísimos sucesos" que se desarrollaban en Barcelona. No obstante, la confusión era enorme, y la censura no presagiaba nada bueno. El Adelanto, haciendo uso de una buena dosis de valentía, advertía del peligro de cualquier imposición del poder militar sobre el civil, aunque igualmente, desconsolado, mostraba su repudia hacia la política practicada en los últimos años:

"La situación de España es, por lo crítica, y por el silencio a que nos obligan, doblemente dolorosa. No tenemos apenas noticias de lo que puede ocurrir en Barcelona y en el resto de la nación. Estamos incomunicados con Madrid (...) Es evidente que el país está harto de que se gobierne con los resortes de la vieja política (...) Pero el problema de Marruecos, de una parte, y los actos antipatrióticos desarrollados en Barcelona, de otra, han formado el estado de opinión que ha lanzado al marqués de Estella a adoptar su peligrosa, crítica y sorprendente actitud (...) Por su parte, el gobierno, en la nota oficiosa hecha pública, se dispone a afrontar la situación manteniéndose en sus puestos, en defensa del principio de autoridad, ante otra autoridad declarada en rebeldía, y en aras de la supremacía del poder civil ",

En la misma página del periódico también se incluía la nota oficiosa del Consejo de ministros y un extracto muy censurado de un primer manifiesto de Primo de Rivera dirigido a la opinión ${ }^{8}$.

Aquella noche, las fuerzas estacionarias del regimiento de La Victoria, acompañadas por su banda de música y recibidas en la Plaza Mayor con vivas al Ejército y a España, entre aplausos, leyeron un bando de aplicación en la capital y en la provincia. Quedaba declarado el Estado de Guerra en Salamanca y se anunciaba la dimisión del gobernador civil. Asumió entonces el gobierno militar Luis de Navarro y Alonso de Celada ${ }^{9}$. Aún con todo esto, si atendemos a los juicios del diario progresista, la situación social era de absoluta serenidad, aunque se advertía ya, cómo no, que la censura previa para la prensa había sido restablecida ${ }^{10}$.

\footnotetext{
5 “E.": "Otra baja en la conjunción liberal", La Gaceta Regional, nº 915, 3 de septiembre de 1923, p. 1.

6 “¿Y el interés nacional?”, La Gaceta Regional, no 917, 5 de septiembre de 1923, p. 1.

${ }^{7}$ Alfredo Rivera: "Nuestras conferencias telefónicas. Gravísimos sucesos en Barcelona", El Adelanto, ${ }^{\circ}$ 12.056, 14 de septiembre de 1923, p. 5.

${ }^{8}$ Alfredo Rivera: "Última hora", El Adelanto, no 12.056, 14 de septiembre de 1923, p. 5.

9 "Los sucesos de actualidad", La Gaceta Regional, no 927, 17 de septiembre de 1923, pp. 1-2. Este día se conoce el nombramiento del nuevo gobernador militar de Salamanca para uno de los puestos del Directorio Militar y su reemplazo por el coronel de la zona, Manuel García Calvo.

10 "Se declara el estado de guerra en Salamanca y el gobernador civil resigna el mando", El Adelanto, $\mathrm{n}^{\circ}$ 12.057, 15 de septiembre de 1923, p. 1. Se reproducen al completo el bando leído en la Plaza Mayor en el que se declaraba el estado de Guerra y también el manifiesto de Primo de Rivera.
} 
En las sucesivas jornadas, El Adelanto modificó su original discurso de preocupación y disgusto y se mostró bastante esperanzado ante el comportamiento del Ejército. Deseaba que éste fuese el inicio de una nueva era en la vida de España. Por eso, no tardó demasiado en identificar el golpe militar de Miguel Primo de Rivera con "una obra de patriotismo"11. A modo de ejemplo, he aquí un editorial del 18 de septiembre:

"El movimiento actual, que es indudablemente uno de los más transcendentales por los que ha pasado y pasa España, ha sembrado de esperanza el espíritu ciudadano. El pueblo español, aparte tendencias y doctrinas, se venía mostrando en completo y manifiesto divorcio con los políticos profesionales (...) Ante la exaltación al poder de los militares, como resultado de su actitud de oposición a los políticos de turno, la opinión pública pone en sus labios una frase gráfica y esperanzadora, en la que concreta sus verdaderos anhelos: -iQue acierten! iQue Dios ilumine a los nuevos gobernantes! ${ }^{\text {,12. }}$.

Con mayor premura, el mismo día 13 de septiembre, bajo el ilustrativo título “Consecuencias de graves errores", "E." se había referido en las páginas de La Gaceta $^{13}$, por vez primera, al levantamiento militar iniciado en Cataluña:

"Hemos visto al gobierno dejar que todos los conflictos nacionales se desarrollen y nos asfixien, mientras sólo se ha preocupado en las numerosas crisis que ha sufrido (...) $Y$ esas debilidades e incompetencias de arriba, han hecho que fructifiquen y reconduzcan las llagas; y es en Cataluña y en Marruecos, donde elementos tan análogos separatistas y beniurriagueles- combaten con más encono a España, que sólo ha pecado por sus condescendencias, protecciones y sacrificios en favor de unos y otros. Hasta aquí íbamos escribiendo, cuando recibimos las conferencias telegráfica y telefónica de nuestros corresponsales en Madrid, que en el lugar correspondiente verán nuestros lectores. Con la más viva emoción hemos trascrito el texto de aquéllas que anoche tuvieron su iniciación en la capital de Cataluña. Sólo diremos que no habrán sorprendido a nadie, aunque su conocimiento haya impresionado. Creyentes y patriotas, sólo hemos de poner como comentario a los históricos episodios que se inician, estos gritos que salen de nuestra alma como explosión de los sentimientos que dominan: ¡Viva España! ;Viva el Rey! ;Viva el Ejército!’"14.

Desde La Gaceta Regional, en los días inmediatamente posteriores a la sublevación militar, se puso de manifiesto la creciente satisfacción de la redacción al hilo del desarrollo de los acontecimientos:

"El golpe asestado por el elemento militar a la situación política que venía ocupando el poder ha parado en seco la vida del desprestigiado y caduco sistema, contra el cual se alzaba la repulsa unánime de la nación (...) La tranquilidad que reina es hija de la

\footnotetext{
11 “El país espera el comienzo de la obra”, El Adelanto, no 12.058, 16 de septiembre de 1923, p. 1.

12 “A.": "Del momento actual", El Adelanto, no 12.059, 18 de septiembre de 1923, p. 1.

${ }^{13}$ En este último capítulo vamos a referirnos, por norma, primero a El Adelanto y, seguidamente a La Gaceta. Pero la vocación empresarial de ambos diarios es perfectamente equiparable. Aunque la cobertura de la guerra marroquí, estrictamente fue más amplia en el diario liberal. Además, como a lo largo de esta tesis el periódico de Núñez Izquierdo ha ido encabezando nuestros análisis, en esta ocasión, también nos guiamos por el hábito.

14 “E.": “Consecuencias de graves errores”, La Gaceta Regional, no 924, 13 de septiembre de 1923, p. 1.
} 
satisfacción y de la confianza que inspira el movimiento: y lo que la opinión española desea es ver implantado y llevado a la práctica el propósito expuesto en su programa, de moralizar la gobernación del Estado y las costumbres públicas, acabando de una vez y sin términos dilatorios con la situación anárquica en que España venía viviendo, si tal situación puede decirse que sea vivir ${ }^{, 15}$.

Particularmente, este periódico experimentó un notable regocijo al conocer la huída de Santiago Alba, el ministro responsable de la liberación de los prisioneros de Axdir ${ }^{16}$.

La prensa local, además de dar cuenta de forma muy detallada del desarrollo del alzamiento militar, también se ocupó de dejar constancia de la reacción de las principales autoridades salmantinas ante el golpe. Así, El Adelanto publicó una carta de Juan Mirat en la que abogaba por la colaboración ciudadana para el triunfo de este movimiento armado y confesaba su desengaño ante la política seguida por García Prieto $^{17}$. La Gaceta, a su vez, reprodujo un mensaje de felicitación al nuevo dictador redactado por varios concejales (Viñuela, Real, Junquera, Santos Baz, Martínez Ortega, García y García, Lucas, Barrado, Lago, Cabezas, Vicente, Sánchez Pérez y Martín Morán) y también un telegrama remitido desde la Liga de Agricultores. De igual modo, se dejó constancia de la comedida disposición hacia el dictador de personajes como Federico Anaya o Esperabé. Pero, con todo, finalmente en la sesión municipal del 19 de septiembre, se acordó que el Ayuntamiento no se adheriría oficialmente al nuevo régimen ${ }^{18}$.

Ya con anterioridad, en la prensa salmantina habían sido habituales las referencias a la situación de descrédito por la que atravesaba el sistema turnista. Los Desastres de Annual y Monte Arruit, en gran medida, echaron por tierra el poco crédito que entonces conservaban los partidos dinásticos. Al finalizar 1921, El Adelanto afirmaba que "en España hay muchas cosas que huelen a podrido"19. Los problemas planteados por las Juntas de Defensa y la incertidumbre suscitada por las reformas hacendísticas de Cambó, generaron asimismo mucha incertidumbre entre los miembros

\footnotetext{
15 "E.": "Momentos decisivos", La Gaceta Regional, no 926, 15 de septiembre de 1923, p. 1.

16 "Los sucesos de actualidad", La Gaceta Regional, no 927, 17 de septiembre de 1923, pp. 1-2; y "E.": "El anverso", La Gaceta Regional, n' 932, 22 de septiembre de 1923, p. 1.

17 "M. J.": "Comentarios de actualidad", El Adelanto, no 12.060, 19 de septiembre de 1923, p. 1.

18 Actas de las Sesiones Municipales. Archivo Histórico Municipal, vol. 1923-1924, fol. 260 (r); "Anoche, en el Ayuntamiento. Se acuerda no tomar en consideración la proposición de adherirse al nuevo gobierno", La Gaceta Regional, no 930, 20 de septiembre de 1923, p. 2.

19 “A.": "Balance general”, El Adelanto, no 11.529, 28 de diciembre de 1921, p. 1.
} 
de la redacción liberal ${ }^{20}$. La conciencia de vivir en una situación de excepcionalidad política permanente resultaba cada vez más clara. Así, “A.” escribía:

"Y es que en España vivimos en permanente anormalidad... Nos hemos habituado a estar quietos cuando debiéramos andar; a hacerlo todo al revés, y a no sorprendernos de las cosas más extravagantes e inmorales. Nuestra normal anormalidad nos ha dado cierto equilibrio, que nos pone al abrigo de las caídas rápidas que un cuerpo social más sano no podría eludir en una súbita anormalidad (...) De lo que va de siglo, ¿qué diríamos? Marruecos es tumba en la que, sujeto nuestro pueblo a una especie de embrujamiento, va dejando año tras año, hondamente enterradas, ilusiones de gloria, recuerdos de añejas victorias, reputación, respeto, honra, vida y hacienda",21.

En La Gaceta Regional, desde principios de 1921 se intuía ese deseo de que se produjese un cambio radical en el panorama político:

"Cien veces, o cien mil, se habrá dicho que la crisis que padece España fue provocada $y$ viene sostenida por la falta de preparación y aún de dignidad política en los hombres encargados de gobernarla... El 'mesianismo' nos sostiene y conforta en los momentos de desmayo, esperando con fe un poco ya tibia y cansada, el advenimiento sorprendente de las grandes figuras que hayan de salvarnos ${ }^{, 22}$.

En junio, el diario conservador expresaba ya sin tapujos la conveniencia del advenimiento de un dictador y lo intentaba justificar:

"En la historia de los pueblos se registran casos de dictaduras beneficiosas para el país, y en muchas ocasiones ha de reconocerse que es medida quirúrgica para evitar la gangrena, o combatir radicalmente los males sociales (...) Las actuales circunstancias por que atraviesa el pueblo español, casi sin pulso, con un Parlamento que en varios años no ha sabido legislar, ni fiscalizar; con unos partidos políticos tamizados, que sólo muestran fuerzas para el estorbo (...) convida todo a que se hable de la dictadura, sin que las gentes se inmuten (...) No correría la sangre como en otros tiempos en pro de un ideal, que presenta todos los caracteres de estar durmiente, con sueño de casi moribundo, ${ }^{23}$.

La actitud ciudadana era, en definitiva y a la luz de los comentarios vertidos en la prensa, de absoluta resignación. Una resignación alimentada por la amargura, la falta de expectativas y el miedo:

"Los españoles nos hemos habituado a todo y nada nos espanta, nos lamentamos, eso sí; no se reúnen dos españoles que no se lamenten y despotriquen contra este estado de cosas, que no se cuenten centenares de casos concretos y que no digan que lo que pasa es una vergüenza intolerable, pero todos la toleramos, y una de dos; o no sabemos lo que es vergüenza, o estamos completamente dejados de la mano de Dios, cuando no ponemos remedio, teniéndolo en nuestras manos, ${ }^{, 24}$.

\footnotetext{
20 "La cuestión militar provoca la dimisión total del gabinete Maura", El Adelanto, $\mathrm{n}^{\circ} 11.542,12$ de enero de 1922, p. 4; “¿Se perderá el tiempo?”, El Adelanto, no 11.582, 28 de febrero de 1922, p. 1; y “Ante la apertura de las Cortes", El Adelanto, no 11.585, 3 de marzo de 1922, p. 1.

21 "A.": "Anormalidad permanente", El Adelanto, no 11.743, 8 de septiembre de 1922, p. 1.

22 "F.": "Perfil del día. Odiosas comparaciones", La Gaceta Regional, nº 123, 19 de enero de 1921, p. 1.

23 "Sobre la dictadura", La Gaceta Regional, n' 245, 16 de junio de 1921, p. 1.

24 "M. J.": "La intrincada y lamentable situación política", El Adelanto, no 11.796, 14 de noviembre de 1922, p. 1.
} 
La desesperación, al final, había logrado que el golpe contase con el respaldo general de la prensa y de los salmantinos. La ciudadanía responsabilizaba al caciquismo del desastre en que estaba sumido el país. No obstante, la simplicidad del mensaje regeneracionista de Primo de Rivera hizo renacer las esperanzas de la gente. Ni siquiera le faltó el beneplácito regio.

En cuanto a Unamuno, al que no olvidamos, una orden del destierro en Fuerteventura se emitió cuando Don Miguel se hizo eco del incidente de La Caoba (una prostituta implicada en un caso de tráfico de estupefacientes y relacionada con el dictador) en una carta que escribió a Américo Castro y que fue publicada en diciembre de 1923 por la revista Nosotros, de Buenos Aires ${ }^{25}$.

El 20 de febrero de 1924, un telefonema expuesto en la plaza anunció su expulsión ${ }^{26}$. Así que aquí comenzó una nueva etapa para el ex-rector en Fuerteventura y, posteriormente, en Francia. Durante su exilio, siguió siempre perfectamente al tanto de la marcha de la guerra de Marruecos ${ }^{27}$. Su hijo Fernando le mantuvo al corriente de la misma ${ }^{28}$. Pero ya habrá ocasión de volver sobre este personaje.

Como ya se anunció, el Directorio Militar había aprobado el 30 de septiembre de 1923, una Real Orden de disolución de los Ayuntamientos. En el caso salmantino, Anaya y los demás concejales fueron reemplazados por una Junta Municipal de Asociados, bajo la presidencia de Jacinto Elena Sánchez, un afín a Martín Veloz. Se iniciaba aquí un proceso de cambio de equilibrios conducente a la construcción de un nuevo bloque de poder hegemónico. Mientras que la élite socioeconómica no varió, en la esfera política sí se registró una importante mutación a raíz del golpe: emergería una renovada élite en torno al gobernador civil, icono de las aspiraciones centralistas del dictador, frente a los "Anayas", de día en día más fuera de juego. Finalmente, éstos terminarían perdiendo a su líder en el verano de $1925^{29}$.

\footnotetext{
${ }^{25}$ RABATÉ, Colette y Jean-Claude: $O p$. Cit., p. 446.

26 "El hecho produjo disgusto y la natural sensación, pero la dictadura militar, que se ejercía con todo rigor, y la falta por tanto de libertad, impidió al Claustro y a las Sociedades obreras reunirse y tomar acuerdos. Los estudiantes, sin embargo, protestaron con energía, planteando la huelga, y Salamanca acudió a la estación el día de la marcha". En ESPERABÉ DE ARTEAGA, Enrique: Op. Cit., p. 315.

${ }^{27}$ ARCO LÓPEZ, Valentín del: "Unamuno frente a Primo de Rivera. De Salamanca al exilio, 19231924", Studia Histórica. Historia Contemporánea, Vol. IV, no 4, Salamanca, 1986, p. 161. El autor reproduce una entrevista concedida a la revista portuguesa $O$ Mundo, en mayo de 1924 . El ex-rector atacaba a Primo y sentenciaba que había destruido, precisamente, aquello que deseaba salvar: el Ejército y el Rey.

${ }^{28}$ Ibidem, p. 481.

${ }^{29}$ HERNÁNDEZ HERNÁNDEZ, Carlos Ernesto: A tiros y a alcaldes. Élites políticas y conflictos de poder: la dictadura de Primo de Rivera y su Directorio militar en Salamanca (1923-1925). Memoria de Licenciatura inédita, Universidad de Salamanca, 1997, p. 108. Remitimos a esta investigación para
} 


\section{PRIMEROS PASOS DEL DIRECTORIO EN MARRUECOS: SALAMANCA, EL PLEITO DE LAS RESPONSABILIDADES Y LA RETIRADA DE XAUEN}

El apoyo que el Ejército colonial prestó a Primo de Rivera pudiera resultar, a primera vista, bastante incomprensible, ya que sus ideas abandonistas eran bien conocidas y sus contundentes y apasionados discursos sobre la cuestión le habían ocasionado más de un disgusto. Muchos recordaban cuando, en 1921, siendo capitán general de Madrid, había declarado en el Parlamento: "Yo opino, desde mi punto de vista estratégico, que un soldado más allá del Estrecho es perjudicial para España"30. Sin embargo, Primo de Rivera apostaba firmemente por acabar con todo el ambiente responsabilista y en él, además, era muy perceptible el rechazo hacia la clase política española, sentimientos ambos compartidos con la oficialidad africanista.

En lo relativo a la estrategia a seguir en Marruecos, ante la imposibilidad de retirar a España de sus compromisos internacionales, el general optaría por intentar negociar la paz con El Raisuni y con Abd-el-Krim. De este modo, se pudo renovar en octubre de 1923 el compromiso de colaboración con el jerife de Yebala. Pero mucho más dificultoso, en cambio, resultó el acercamiento al rebelde de Axdir. Éste no se planteaba aceptar ningún acuerdo sin el previo reconocimiento de la independencia completa del Rif.

En efecto, al iniciarse 1924, el dictador, disponiendo una vez más de la colaboración de Horacio Echevarrieta, procuró un arreglo cordial con Abd-el-Krim (sin el conocimiento francés). Pero el Emir del Rif, además de la independencia y la evacuación de los territorios ocupados, solicitó una indemnización de veinte millones de pesetas, la entrega de 15 aviones y 120 baterías de montaña. El general, no obstante, únicamente estaba dispuesto a reservar a Abd-el-Krim y a su familia un estatuto especial. No podía ir más allá sin chocar con las pretensiones de su Ejército y de Gran Bretaña $^{31}$.

conocer las disputas municipales de este periodo. Jacinto Elena fue rápidamente sustituido por Íñigo Villoria. A éste le sucederían Arturo Núñez, Francisco Torres y Florencio Sánchez Hernández hasta el momento de la instauración del Directorio Civil. Aparte los trabajos de Javier Infante, también se incluye aquí un breve análisis de la figura de Diego Martín Veloz y de sus enfrentamientos con Mirat, Anaya, Núñez Izquierdo e Íscar Peyra. Sobre todo, a raíz de un violento enfrentamiento que protagonizó con Pepe Núñez, en enero de 1924, en el Casino de Salamanca: el director de El Adelanto disparó al cacique durante el desarrollo de una turbulenta reunión entre socios de la institución (el tema político estelar de la historiografía salmantina para los años 20).

${ }^{30}$ La cita procede de BOUARFA, Mohamed: Op. Cit., p. 158.

${ }^{31}$ Ibidem, p. 160. 
Aún así, Primo de Rivera guardó un as en la manga. No pudiendo ceder ni retroceder y vislumbrando el fracaso de estas negociaciones, se dispuso a retirar las tropas coloniales hasta un nuevo frente, la conocida como línea de Estella. Lo que pretendía el dictador con esta operación ha hecho correr ríos de tinta, una vez más, entre los historiadores: para algunos, se trataba de llevar a cabo una campaña de bombardeos con TNT, bombas incendiarias y gases tóxicos. Retirar a las tropas era necesario para protegerlas de los efectos de estas sustancias nocivas ${ }^{32}$. Curiosamente, los militares más entusiastas ante el empleo de gases tóxicos fueron los africanistas ideológicamente más progresistas. Entendieron que ésta era la forma más humanitaria de hacer la guerra, pero no cayeron en la cuenta de que los más perjudicados fueron los civiles.

Otros investigadores, en cambio, entienden que lo que el general procuraba era dejar al descubierto el flanco galo para así obligar a Francia, ante un enemigo común, a una colaboración militar ${ }^{33}$. Por último, hay quien apuesta por la idea de que lo que se deseaba era una revisión de los acuerdos internacionales: que España consiguiese librarse de parte de su Protectorado a cambio de la cesión de Tánger. Susana Sueiro, principal defensora de esta tesis, defiende que Primo no era un estadista metódico, sino un hombre muy pragmático, que actuaba guiado, en buena medida, por las circunstancias del momento. Desde esta óptica, el semiabandono permitió puntualmente aliviar la tensión militar en el frente occidental y, además, hizo posible la repatriación de millares de soldados, y con ello, el consiguiente aumento de popularidad en beneficio del presidente del Directorio ${ }^{34}$.

El plan sería aprobado por el directorio militar en mayo de 1924. La línea de Estella fue, a la postre, una sinuosa barrera de posiciones fortificadas que, en el oeste del Protectorado, protegían las comunicaciones entre Tánger y Fez, y también entre Tánger, Tetuán y Ceuta, aunque para ello hubiese que renunciar a la ocupación de Xauen; y en la parte este, significó un retroceso militar de quince kilómetros.

El semiabandono no estuvo ni bien planteado ni ejecutado. De hecho, la operación pudo costar sólo en la zona occidental un número de bajas próximo a 15.000

\footnotetext{
${ }^{32}$ BALFOUR, Sebastián, Op.Cit., p. 200.

${ }^{33}$ GONZÁleZ CALBET, M ${ }^{\mathrm{a}}$ Teresa: La Dictadura de Primo de Rivera. El Directorio Militar. Madrid: El Arquero, 1987, p. 198 y 278.

${ }^{34}$ SUEIRO SEOANE, Susana: España en el Mediterráneo. Primo de Rivera y "la cuestión marroqui", 1923-1930. Madrid: UNED, 1992, pp. 131-156. La autora desmonta aquí lo que bautizó como "el mito del estratega" e incide, un poco más adelante (p. 192) en que la idea del desembarco en Alhucemas no chocaba con las tesis abandonistas del dictador.
} 
individuos ${ }^{35}$. Los rifeños, convencidos de que esta retirada era una manifestación de debilidad, respondieron llegando hasta las puertas de Ceuta y bombardeando Tetuán. Además, en enero de 1925, los hombres de Abd-el-Krim apresaron a El Raisuni, quien finalmente falleció en cautiverio pocos meses después. Los partidarios del cabecilla de Axdir no le habían perdonado su pacto con Burguete.

Ante el fracaso de la operación, que no logró aplastar a los rebeldes rifeños, y tras el famoso enfrentamiento verbal algunos meses antes entre el dictador y la Legión en Ben Tieb ${ }^{36}$, se impuso la necesidad de buscar una nueva estrategia. Ésta sería la del desembarco aéreo-naval de Alhucemas y la ocupación de Axdir, sede del recién fundado Estado Rifeño. Todo ello contando, además, con la colaboración francesa ${ }^{37}$.

La benevolencia de Lyautey hacia el titulado Emir del Rif se hallaba bajo mínimos llegados al verano de 1923, ya que el general temía un excesivo envalentonamiento del jefe marroquí habida cuenta de su genio militar y habilidad diplomática $^{38}$. A la operación conjunta le seguiría la rendición de Abd-el-Krim, en junio de 1926, y las últimas campañas para el definitivo sometimiento del territorio. Y es que el más carismático e indómito rebelde de los habidos en Marruecos cometió el error de sobrevalorar sus fuerzas y emprender un ataque contra los franceses en dirección a Fez y Taza. Fue entonces cuando Francia, que hasta entonces había contemplado con pasividad e, incluso, con cierto regocijo, los descalabros españoles en Marruecos, optó por unir sus fuerzas a las del dictador.

En Salamanca, las primeras informaciones publicadas en El Adelanto a propósito de los asuntos del Protectorado y con posterioridad al golpe tuvieron una evidente finalidad narcotizadora. Visadas por la censura, todas las conferencias telefónicas de Alfredo Rivera insistían en que la situación en el territorio africano era de $\operatorname{tranquilidad}^{39}$ : las obras públicas se ejecutaban a buen ritmo ${ }^{40}$, se conmemoraba la

\footnotetext{
${ }^{35}$ Ibidem, p. 208. El gobierno español evitó ofrecer un número oficial de bajas para no alarmar a la opinión pública. VILLALOBOS, Federico: Op. Cit., p. 246.

${ }^{36}$ Se cuenta (las versiones varían ligeramente según el autor) que el 19 de julio de 1924, en una cena de gala que la Legión ofreció al dictador, en Ben Tieb, Franco, que entonces era teniente coronel al mando de esta guarnición, ordenó que se le sirviesen a Primo de Rivera únicamente platos cocinados a base de huevo. Cuando el dictador preguntó el por qué de tan peculiar menú, el futuro dictador le respondió que los que permanecían en el Protectorado no los necesitaban y por ello, se los entregaban a quien veían un poco "falto de hombría".

${ }^{37}$ Quien esté interesado en los aspectos técnicos y estratégicos del desembarco de Alhucemas puede ver GARCÍA, Dionisio: "El desembarco de Alhucemas", Serga. Revista de Historia militar del siglo XX, $\mathrm{n}^{\circ}$ 7, Ediciones Almena, Madrid, 2000, pp. 49-54.

${ }^{38}$ SUEIRO SEOANE, Susana: Op. Cit., pp. 39-40.

${ }^{39}$ Alfredo Rivera: "Nuestras conferencias telefónicas", El Adelanto, no 12.073, 4 de octubre de 1923, p. 5.

${ }^{40}$ Alfredo Rivera: "Nuestras conferencias telefónicas", El Adelanto, no 12.074, 5 de octubre de 1923, p. 3.
} 
ocupación de Xauen y se avanzaba en la búsqueda de una solución para el contencioso de Tánger ${ }^{41}$. Aizpuru, además, como nuevo Alto Comisario -había sido nombrado pocos días antes del golpe, cuando Silvela dimitió por sus desacuerdos con el gobierno y tras la liberación de Tifarauin ${ }^{42}$ - se complacía porque la hostilidad de los marroquíes ahora se volcaba contra los franceses ${ }^{43}$. Pero sus declaraciones quedaban en entredicho al conocerse, a mediados de octubre, varios altercados en las inmediaciones de Melilla y Tetuán ${ }^{44}$. Asimismo, también se hacía pública semanas después una notificación del ministerio de Guerra, según la cual se estaban procediendo a la concentración de fuerzas, a modo de reserva, en Alicante y Almería ${ }^{45}$.

Aquí, en la ciudad castellana, seguía abierta la suscripción para costearle una medalla al capitán Rodríguez Almeida, el héroe de Tifarauin ${ }^{46}$. El nuevo gobernador, García Calvo, había anunciado el retorno del militar a la ciudad para finales del mes de octubre y, también, su propósito de dispensarle una entusiasta bienvenida ${ }^{47}$. Y mientras la discusión sobre las responsabilidades parecía languidecer ${ }^{48}$, una nota oficiosa del Directorio Militar auspiciaba, como en la etapa previa, la perseverancia en la política de penetración pacífica en Marruecos y en la adopción de medidas de austeridad ${ }^{49}$.

Al concluir 1923, Alfredo Rivera anunciaba la terminación de unas conversaciones internacionales sobre Tánger habidas en el Quai D'Orsay ${ }^{50}$. Se intentaba dotar a la ciudad de un nuevo estatuto. Pero las valoraciones que la redacción recogía

\footnotetext{
${ }^{41}$ Alfredo Rivera: "Nuestras conferencias telefónicas", El Adelanto, no 12.076, 7 de octubre de 1923, p. 3; Alfredo Rivera: "Noticias telefónicas de última hora", El Adelanto, no 1.2076, 7 de octubre de 1923, p. 4; Alfredo Rivera: "Noticias telefónicas de última hora", El Adelanto, n 12.083, 16 de octubre de 1923, p. 4.

${ }^{42}$ VILLALOBOS, Federico: Op. Cit., p. 241.

${ }^{43}$ Alfredo Rivera: "Nuestras conferencias telefónicas", El Adelanto, no 12.077, 9 de octubre de 1923, p. 3.

${ }^{44}$ Alfredo Rivera: "Noticias telefónicas de última hora", El Adelanto, no 12. 082, 14 de octubre de 1923, p. 4; Alfredo Rivera: "Noticias telefónicas de última hora", El Adelanto, $\mathrm{n}^{\circ} 12.085,18$ de octubre de 1923, p. 4; Alfredo Rivera: "Noticias telefónicas de última hora", El Adelanto, no 12.090, 24 de octubre de 1923, p. 4.

${ }^{45}$ Alfredo Rivera: "Nuestras conferencias telefónicas", El Adelanto, n 12.098, 2 de noviembre de 1923, p. 3.

46 "El heroico capitán salmantino señor Rodríguez Almeida", El Adelanto, n 12.079, 11 de octubre de 1923 , p. 1.

47 “El homenaje al capitán señor Rodríguez Almeida", El Adelanto, no 12.086, 19 de octubre de 1923, p. 1. Éste homenaje tuvo lugar, al final, tanto en Salamanca, como en Ciudad Rodrigo y Villar de Ciervo: "Homenaje al héroe de Tifarauin, capitán don Pedro Rodríguez Almeida", El Adelanto, no 12.094, pp. 12; "Llegada a Salamanca del capitán señor Rodríguez Almeida", La Gaceta Regional no 963, 29 de octubre de 1923, p. 2.

${ }^{48}$ Alfredo Rivera: "Nuestras conferencias telefónicas", El Adelanto, nº 12.100, 4 de noviembre de 1923, p. 3 .

${ }_{49}^{4}$ Alfredo Rivera: "Nuestras conferencias telefónicas", El Adelanto, n 12.101, 6 de noviembre de 1923, p. 3 .

${ }_{50}$ Alfredo Rivera: "Noticias telefónicas de última hora", El Adelanto, no 12.138, 19 de diciembre de 1923, p. 4.
} 
sobre esta materia eran contradictorias. Con seguridad, los lectores salmantinos hubieron de sentirse confusos. Mientras el corresponsal madrileño aludía a una ordenación armónica de los intereses españoles y franceses en la ciudad ${ }^{51}$, en un editorial sin firma se vertía una opinión bastante más pesimista:

"La costumbre seguida por nuestros politicos de mantener en secreto cuanto se ha relacionado con Marruecos ha tenido funestísimas consecuencias (...) Así nos cogió cuando la hecatombe de julio de 1921, y así casi nos ha cogido cuando ahora se ha sabido que en la conferencia celebrada recientemente en París, Inglaterra y Francia han acordado entregar la plaza de Tánger a la soberanía del Sultán de Marruecos, que, por estar éste sometido a Francia, es lo mismo que haber entregado a ésta la plaza y el puerto tangerinos. Y decimos que esto nos ha sorprendido casi como la nota de 1921, pues aunque en estos últimos años se había hecho campaña en pro de nuestros derechos sobre Tánger, las negociaciones diplomáticos se habían llevado con tanto secreto, que el acuerdo adoptado por Inglaterra y Francia nos ha sorprendido a todos, pues si no oficialmente, se había dejado correr la especie de que Inglaterra apoyaba nuestros intereses.

Ahora el Directorio autoriza para que se pueda hablar de este asunto (...) lo que se quiere es conocer la opinión del país (...) Todos los españoles estamos también convencidos de que, mientras tengamos esa cuña metida dentro de nuestra zona de influencia, no habrá en ella paz ${ }^{, 52}$.

El mensaje parecía obvio: el diario liberal creía que el Directorio no debía refrendar el trato adoptado entre los países de la Entente porque la opinión pública, de la que el mismo periódico se alzaba como portavoz ("todos los españoles estamos convencidos..."), no lo deseaba. Esta forma de adulación de la opinión para "fabricar" un consenso constituía, qué duda cabe, una forma muy efectiva de control de la misma.

La cuestión de Tánger no había salido a relucir ni en Versalles ni en los Tratados de Saint- Germain y del Trianon, pero desde principios de 1920 Gran Bretaña se había esforzado para lograr un régimen jurídico que fuera verdaderamente internacional. Si bien la diplomacia francesa respondió sugiriendo que el Majzén ejerciese nuevamente el poder legislativo y las funciones de administración en la ciudad, el gobierno de Londres rechazó la idea e insistió en la necesidad de celebrar una conferencia de expertos para sentar las bases de un sistema más funcional. En efecto, las reuniones entre tres altos funcionarios de Francia, España y Gran Bretaña, junto con el representante en Tánger de ésta última potencia, se iniciaron a finales de junio de 1923, aunque el borrador del

\footnotetext{
${ }^{51}$ Alfredo Rivera: "Noticias telefónicas de última hora", El Adelanto, no 12.165, 20 de enero de 1924, p. 5.

52 "La cuestión de Tánger", El Adelanto, n 12.149, 2 de enero de 1924, p. 1.
} 
nuevo estatuto no quedó elaborado hasta el 9 de octubre y firmado, el 18 de diciembre del mismo año ${ }^{53}$.

La delegación española lo ratificó ad referendum dos meses más tarde y después de que los países de la Entente aceptasen algunas pequeñas modificaciones. Aunque el documento, cierto era, no hacía sino consolidar las facultades francesas sobre la ciudad. Con todo, si al final el dictador tomó esa decisión, quedaba un consuelo:

"Ceuta es, por razones políticas, geográficas y naturales, sobre todo, la verdadera cabeza ferroviaria del Magreb (...) En dos años y con muy pocos millones, puede acabarse el puerto de Algeciras, el de Ceuta, trocar en acho internacional la vía que hoy corre de Cauta a Tetuán y prolongar este trazado hasta el límite sur de Melilla por Alcazarquivir (...) Tánger será lo que le deje ser Ceuta. Ceuta es la clave "54.

No eran palabras baladís, sino que se trataba del comentario de uno de los cronistas más autorizados del momento, Víctor Ruiz Albéniz, el Tebib Arrumi ${ }^{55}$. Con su contribución periodística, El Adelanto efectuaba un ejercicio de "autobombo" y, además, demostraba la preocupación que el asunto generaba. La renuncia a Tánger se percibía como un ultraje.

Sin embargo, pronto la atención de los salmantinos se desvió, por una parte, hacia la noticia del viaje de Aizpuru a la Corte. El general venía con el propósito de entregarle a Primo un estudio sobre una próxima reorganización del Protectorado. Porque si bien las relaciones con El Raisuni, cada vez más viejo y enfermo, eran buenas, en el sector oriental persistían las agresiones de los cabileños contra las tropas ${ }^{56}$. Había, por tanto, que actuar.

Por otro lado, generó una considerable expectación y angustia el recrudecimiento de los combates en Tizzi Azza, de continuo cercada y con problemas en su avituallamiento. Aunque el gobierno militar intentó salir del paso con una tranquilizadora nota oficiosa, la alarma entre la opinión salmantina, previsiblemente, fue considerable $^{57}$. El Directorio denunciaba la existencia de una campaña difamatoria

\footnotetext{
${ }^{53}$ Para una explicación mucho más extensa, SUEIRO SEOANE, Susana: Op. Cit., pp. 66-75. Esta autora hace particular hincapié en la indignación que experimentaban los africanistas por la lectura tan interesada que el partido colonialista francés efectuaba de los tratados internacionales.

${ }^{54}$ Víctor Ruíz Albéniz: "Los problemas reales de España en Marruecos", El Adelanto, no 12.202, 4 de marzo de 1924, p. 1.

${ }^{55}$ La expresión significa "médico cristiano". MARTÍN ESCORZA, Antonio: El Tebib Arrumi. El médico español que se hizo periodista en el Rif para vivir la historia y contarla. Madrid: Editorial Tichel, 2003.

${ }_{56}$ Alfredo Rivera: "Nuestras conferencias telefónicas", El Adelanto, no 12.184, 12 de febrero de 1924, p. 3; Alfredo Rivera: "Nuestras conferencias telefónicas", El Adelanto, $\mathrm{n}^{\circ}$ 12.185, 13 de febrero de 1924, p. 3; Alfredo Rivera: "Nuestras conferencias telefónicas", El Adelanto, $\mathrm{n}^{\circ} 12.186,14$ de febrero de 1924, p. 3; Alfredo Rivera: "Nuestras conferencias telefónicas", El Adelanto, no 12.201, 2 de marzo de 1924, p. 7.

${ }^{57}$ Alfredo Rivera: "Nuestras conferencias telefónicas", El Adelanto, no 12.202, 4 de marzo de 1924, p. 3; Alfredo Rivera: "Nuestras conferencias telefónicas", El Adelanto, n 12.206, 8 de marzo de 1924, p. 3.
} 
contra sus gestiones en Marruecos. En su defensa, alegaba que se limitaba a hacer frente a un problema heredado: "Lo ocurrido en Tizzi-Azza es lo que ocurre siempre en Marruecos. Ocurre lo que con Tifarauin: es una mala posición esta de Tizzi Azza que se ocupó en días de propósitos de avance, y que hoy no hay más remedio que sostener" También argumentaba que si se había movilizado aquella brigada del litoral, la de Alicante y Almería, creada como reserva, ello obedecía a que anteriormente se habían repatriado 20.000 hombres. Pero lo cierto era que la situación del frente oriental empezaba a adquirir un carácter muy preocupante y se atisbaba, en consecuencia, un cambio en las directrices militares ${ }^{59}$. Como primer indicio del mismo, unas comentadas declaraciones de Primo para el Daily Mail sobre una futura colaboración ofrecida por Poincaré ${ }^{60}$. El segundo indicador consistió en el nombramiento de Sanjurjo como nuevo comandante general de Melilla ${ }^{61}$.

Desde mediados de junio de 1924, recobró buena parte de la actualidad informativa la causa contra los generales Berenguer y Navarro en el Senado ${ }^{62}$. Mientras ésta se desarrolló, la sección telefónica de Rivera ofreció una muy pormenorizada y extensa descripción de la misma. Con lo cual, los salmantinos tuvieron noticias muy extensas de los contradictorios testimonios, entre otros, de Fernández Tamarit, Riquelme, Ben Chelal, Núñez de Prada, Sánchez Monje, Jordana, Sanjurjo o Pérez Ortiz. En las páginas de El Adelanto quedaron así recogidas varias acusaciones de desidia contra Berenguer; denuncias sobre la ausencia de crédito, la inutilidad operativa de Annual y la pésima instrucción de los refuerzos que llegaron a Melilla después del Desastre; quedó sembrada la duda a propósito del estado de las comunicaciones entre Silvestre, el Alto Comisario y Eza; también se planteó el interrogante de si hubiese sido posible socorrer a Monte Arruit; se discutió acerca de lo ocurrido con el cajón

\footnotetext{
${ }^{58}$ Alfredo Rivera: "Nuestras conferencias telefónicas", El Adelanto, no 12.211, 14 de marzo de 1924, p. 3. 59 "La nueva ley de reclutamiento", El Adelanto, $\mathrm{n}^{\circ}$ 12.230, 5 de abril de 1924, p. 5; Alfredo Rivera: "Nuestras conferencias telefónicas de hoy", El Adelanto, $\mathrm{n}^{\circ}$ 12.257, 9 de mayo de 1924, p. 1; Alfredo Rivera: "Nuestras conferencias telefónicas", El Adelanto, no 12.268, 22 de mayo de 1924, p. 4.

${ }^{60}$ Alfredo Rivera: "Nuestras conferencias telefónicas", El Adelanto, n' 12.217, 21 de marzo de 1924, p. 3. Susana Sueiro Seoane argumenta, al hilo de estas manifestaciones, que el dictador quería ya entonces lanzar a la publicidad una posible cooperación para que la noticia fuera conocida por Abd-el-Krim, lector empedernido de la prensa extranjera, y así frenar la belicosidad de sus seguidores. También la misma autora subraya que la colaboración militar podía ser instrumentalizada ante el país, presentada como un éxito diplomático que compensase, y ayudase a digerir, el previo ultraje por la firma del estatuto de Tánger. En SUEIRO SEOANE, Susana: Op. Cit., pp. 128-130.

${ }^{61}$ Alfredo Rivera: "Nuestras conferencias telefónicas", El Adelanto, no 12.259, 11 de mayo de 1924, p. 6.

${ }^{62}$ Alfredo Rivera: "Nuestras conferencias telefónicas", El Adelanto, n' ${ }^{\circ} .12 .289,15$ de junio de 1924, p. 5.
} 
descerrajado del fallecido general, etc ${ }^{63}$. Una mezcolanza de profunda rabia y vergüenza ajena, por fuerza, hubo de provocar entre la opinión pública salmantina la lectura de todas esas interesadas confesiones.

Pero también bastante desconcierto. Porque en contraste con la saturación de testimonios individuales, el capital tema de las responsabilidades únicamente mereció ahora un editorial:

"Celébrase en estos días ante el Consejo Supremo de Guerra y Marina, la vista de la causa instruida a los generales Berenguer y Navarro, como consecuencia del Desastre ocurrido en la Comandancia general de Melilla en el verano de 1921.

El tiempo transcurrido y el cambio de sistema político han aplacado los apasionamientos (...) Por la confianza de que el general era reclamado por el más alto Tribunal de su fuero, no nos explicamos entonces la campaña en contra de la concesión del suplicatorio.

No puede caber duda a nadie, porque los hechos están en la memoria de todos, que el general, a raíz del Desastre, actuó con eficacia y fortuna (...) \{un espacio en blanco: censura\} Hubiera querido ir a Monte Arruit, como hubieran querido ir todos y cada uno de los españoles, y se le tuvo entonces, no hay que olvidarlo, por el hombre prudente que no quiso arriesgar más vidas, aunque fuera para seguir el movimiento hidalgo de toda una nación.

Con todos estos antecedentes, y, sobre todo, con los anteriores al Desastre, parecía inexplicable la actitud de los que querían denegar el suplicatorio, declarando al general indiscutible, discutiendo de paso al tribunal que lo reclamaba, para que ni ese prestigio quedara en pie, haciendo un poco por la obra de disociación y de disolución a que entonces estaban entregados todos.

Al fin triunfó el buen sentido y se concedió el suplicatorio, habiendo llegado la hora de que el Tribunal Supremo militar haya creído conveniente la vista de esa causa. El prestigio de ese tribunal es indiscutible, y en su fallo debemos confiar todos ${ }^{1,64}$.

De nuevo, había en este fragmento un poco disimulado esfuerzo por ganarse el favor de la opinión lectora. ¿Cómo? Contraponiendo los viejos tiempos, los de los profesionales de la política que impidieron el procesamiento del Alto Comisario, con los nuevos, los de la dictadura justiciera y reparadora. Ahora bien, también se advertía de que tras Berenguer, secundando sus actuaciones, había estado todo un país. Y, por tanto, ¿no quedaban así sus posibles responsabilidades diluidas? Sí, sin duda eso pretendía.

\footnotetext{
${ }^{63}$ Alfredo Rivera: "Nuestras conferencias telefónicas. La vista del proceso contra los generales Berenguer y Navarro", El Adelanto, no 12.290, 17 de junio de 1924, p. 3; Alfredo Rivera: "Nuestras conferencias telefónicas. La vista del proceso de los generales Berenguer y Navarro", El Adelanto, $\mathrm{n}^{\circ}$ 12.291, 18 de junio de 1924, p. 3; Alfredo Rivera: "Nuestras conferencias telefónicas. El general Navarro cuenta la resistencia y rendición de Monte Arruit", El Adelanto, n ${ }^{\circ} 12.292,19$ de junio de 1924, p. 3; Alfredo Rivera: "Nuestras conferencias telefónicas. La vista del proceso de Berenguer-Navarro", El Adelanto, no 12.294, 21 de junio de 1924, p. 4; Alfredo Rivera: "Nuestras conferencias telefónicas. Los días angustiosos del Desastre y los errores sufridos, según el general Picasso", El Adelanto, no 12.294, 22 de junio de 1924, p. 5; Alfredo Rivera: "Nuestras conferencias telefónicas. La acusación contra los generales señores Berenguer y Navarro y los escritos de la defensa", El Adelanto, $\mathrm{n}^{\circ} 12.295,24$ de junio de 1924, p. 3; Alfredo Rivera: "Nuestras conferencias telefónicas. El proceso Berenguer-Navarro", El Adelanto, ${ }^{\circ}$ 12.296, 25 de junio de 1924, p. 5; Alfredo Rivera: "Nuestras conferencias telefónicas. La sentencia de Berenguer-Navarro", El Adelanto, no 12. 298, 27 de junio de 1924, p. 3.

${ }^{64}$ "La cuestión Berenguer", El Adelanto, no 12.292, 19 de junio de 1924, p. 1.
} 
Además, no dejaba de constituir éste un pasmoso giro ideológico por parte de $E l$ Adelanto. Al fin y al cabo, sus vacilaciones acerca del antiguo mando habían sido notorias. Cuando, finalmente, se hicieron públicas las sentencias contra Berenguer y Navarro, de hecho, el periódico calló. Mientras se acordó separar al primero del servicio militar, el segundo general resultó absuelto. Pero, de inmediato, al conocerse la noticia, Primo de Rivera anunció un nuevo proyecto de amnistía ${ }^{65}$.

Curiosamente, coincidió este anuncio con el del endurecimiento de las operaciones: "Lo que deseo en Marruecos es un plan que no sea esporádico (...) Queremos que este problema no sea una carga ni sea tampoco el constante obstáculo para el desenvolvimiento de la vida española"66. El general manifestaba, a la par, que Marruecos no planteaba un problema de conquista, sino de perseverancia y método. En efecto, muy poco después, la posición de Tizzi Azza volvía a cobrar protagonismo informativo, cuando los Regulares de Tetuán lograron romper el cerco rebelde sobre ella ${ }^{67}$. Asimismo, Primo señaló que se había empezado a estudiar un proyecto de decreto con vistas a la ampliación de facultades del Alto Comisario ${ }^{68}$.

Un redactor del diario de Núñez Izquierdo, entretanto, se mostraba bastante esperanzado ante los cambios que se vislumbraban ya:

"La persistencia hasta ahora seguida, en no tener plan alguno (...) precisaba de una honda y radical transformación (...) El general Primo de Rivera, después de su viaje a la zona de nuestro Protectorado, ha declarado que el plan que tiene estudiado el gobierno, acerca de nuestra intervención en Marruecos, va a ser puesto en práctica lo antes posible, y que el problema africano va a marchar por cauces firmes $y$ permanentes.

No ha detallado el presidente del Directorio el pensamiento del gobierno en esta cuestión, porque sería imprudencia (...) Bueno o malo, ese plan será una norma a que nos atendremos todos (...) Si hemos, por tanto, de cumplir los compromisos internacionales en África, hagámoslo con toda seriedad (...) Y como a esto tienden los propósitos manifestados por el Directorio, en su empeño le acompañará la simpatía y el aplauso de todo el país ${ }^{, 69}$.

\footnotetext{
${ }^{65}$ Alfredo Rivera: "Nuestras conferencias telefónicas”, El Adelanto, no 12.299, 28 de junio de 1924, p. 5.

${ }^{66}$ Alfredo Rivera: "Nuestras conferencias telefónicas", El Adelanto, no 12.298, 27 de junio de 1924, p. 3. Miguel Primo de Rivera pronunció estas palabras en Málaga, durante el desarrollo de un viaje para visitar el Protectorado. El general estuvo en Xauen, Tetuán, Monte Arruit, Tafersit... En Alfredo Rivera: "Nuestras conferencias telefónicas", El Adelanto, no 12.311, 12 de julio de 1924, p. 4; Alfredo Rivera: "Noticias de última hora", El Adelanto, no 12.312, 13 de julio de 1924, p. 7; Alfredo Rivera: "Nuestras conferencias telefónicas", El Adelanto, no 12.319, 22 de julio de 1924, p. 3; Alfredo Rivera: "Noticias de última hora", El Adelanto, no 12.320, 23 de julio de 1924, p. 6.

${ }^{67}$ Alfredo Rivera: "Nuestras conferencias telefónicas", El Adelanto, no 12.303, 3 de julio de 1924, p. 3.

${ }^{68}$ Alfredo Rivera: "Nuestras conferencias telefónicas", El Adelanto, no 12. 309, 10 de julio de 1924, p. 3.

69 "La actualidad. La cuestión de Marruecos y el plan a seguir", El Adelanto, no 12.323, 26 de julio de 1924, p. 1.
} 
El objetivo no era otro que el de procurar la resignación de la opinión pública, con una estrategia algo burda, muy fácilmente perceptible, pero que no dejaba de revelar el temor que ya entonces suscitaba una cada vez más fortalecida -aunque miedosa y desinformada- sociedad de masas. Y la entereza, en efecto, se iba a necesitar a juzgar por las notas oficiosas de aquellos días, a mediados de agosto de 1924:

“'La situación es bastante delicada'... y que 'se trata de un levantamiento general de las cábilas'. Así, sin literatura innecesaria, escuetamente, se ha enterado a la opinión de lo que ocurre por tierras de África, y de la gravedad de la situación.

El país, como siempre, prestará su apoyo (...) Pero el pueblo, siempre ingenuo, se pregunta y reflexiona del siguiente modo: Ahora tendremos unos días de combates más o menos sangrientos; nuestras tropas, como siempre, derrocharán los actos de valor (...) y, a la postre, todo terminará con un acto de sumisión de los rebeldes... y hasta otra, que no se dejará esperar mucho... ¿Y cómo puede ocurrir esto? (...) Preguntas y reflexiones son estas que no pueden ser, ni más sencillas ni más racionales; pero que aún no han sido contestadas (...) Mientras que todo eso no se explique, continuará la desorientación en la empresa marroquí (...) Es lo menos que puede pedir el país y es lo menos que se le debe explicar, ya que ni siquiera se mete a curiosear de dónde procede el armamento que se facilita a los rebeldes",70.

Este tan empecinado esfuerzo por contemporizar con la opinión pública salmantina no era más que la prueba del distanciamiento existente entre el Poder, la prensa y la opinión local. No bastarían los halagos para solicitar más sacrificios. Pero este diario estaba preparando el terreno, elaborando un argumento con el que luego poder exigir cuentas al Directorio. En otras palabras, de Primo de Rivera se esperaba una explicación, un plan claro, sobre la cuestión marroquí. Pero si éste no llegaba, la prensa tendría un pretexto para empezar a cuestionar el servilismo que se le demandaba e imponía con la censura.

$\mathrm{Y}$, en efecto, la espera se hacía excesivamente larga y, a mediados de agosto de 1924, saltaba al periódico liberal un primer comentario crítico:

"Los días han pasado y nuestra situación en Marruecos es la misma de antes: las mismas incertidumbres, las mismas sorpresas; en una palabra, la misma falta de plan que desde hace quince años y continuar siempre expuestos a lo que los rebeldes quieran que se haga. Cuando ellos quieren paz, paz; cuando el cuerpo les pide guerra, a pelear.

$Y$ eso no puede continuar así (...) Naturalmente, y por eso, sin duda, el jefe del gobierno anunció al país que el gobierno tenía ya estudiado ese plan y que se implantaría cuanto antes (...) pero el pueblo español quiere saber de una vez cuál va a ser nuestra actuación en África, y, sobre todo, quiere estar libre de esa pesadilla ",11.

El Directorio, sin embargo, centraba entonces todos sus esfuerzos en la defensa de Xauen. Las notas oficiosas informaban de la seriedad de los combates, pero no

\footnotetext{
70 “La pesadilla marroquí”, El Adelanto, no 12.341, 16 de agosto de 1924, p. 1.

71 “Comentarios de actualidad. Venga ese plan", El Adelanto, no 12.343, 19 de agosto de 1924, p. 1.
} 
dejaban de subrayar que, por decoro -iqué concepto tan arraigado en nuestra historia!-, había que hacer frente decididamente contra los rebeldes ${ }^{72}$. Los planes de futuro, por de pronto, quedaban así pospuestos: "No se trata en estos momentos de estudiar el problema de Marruecos (...) Trátase sólo de que varios moros se han puesto en alzamiento de armas y en movimiento contra gran número de posiciones, a las que han declarado la guerra, y a estos moros hay que contestarles con la guerra"73. Las luchas se tornaban encarnizadas y, por eso, Primo decidió asumir personalmente el cargo de Alto Comisario el 16 de octubre de 1924.

Además se había trasladado semanas antes a Tetuán para organizar y supervisar, desde aquí, el repliegue del Ejército de ocupación a lugares menos vulnerables que las colinas de Beni Arós o la ciudad santa ${ }^{74}$. Mientras, el anunciado y deseado retorno de la quinta de 1921 hubo de retrasarse ${ }^{75}$; y en Europa se empezaba a murmurar que el general quería abandonar Marruecos ${ }^{76}$.

La alarma de la cancillería inglesa fue inmediata, tal y como se hacía eco Alfredo Rivera. Los intereses de ésta en Tánger se verían amenazados si la rebelión cabileña se generalizaba y por eso temía que, en el fondo, Primo, con el retroceso parcial, estaba presionando a la diplomacia para lograr una revisión de los tratados sobre Marruecos $^{77}$. Más aún, Gran Bretaña temía que si España dejaba un vacío en el norte de Marruecos, Francia aprovecharía para instalar su Ejército muy cerca de Gibraltar ${ }^{78}$.

En el frente oriental, mientras tanto, el intento por acercar posturas con Abd-elKrim parecía infructuoso y el desembarco sobre Alhucemas se presentaba, a la postre, como la única opción viable ${ }^{79}$. El rebelde de Axdir había empezado a intensificar su propaganda contra la ocupación en la zona francesa del Uarga ${ }^{80}$, al tiempo que $E l$

\footnotetext{
${ }^{72}$ Alfredo Rivera: "Nuestras conferencias telefónicas", El Adelanto, no 12.349, 26 de agosto de 1924, p. 3; Alfredo Rivera: "Nuestras conferencias telefónicas", El Adelanto, no 12.355, 2 de septiembre de 1924, p. 5; Alfredo Rivera: "Nuestras conferencias telefónicas", El Adelanto,", no 12.358, 5 de septiembre de 1924, p. 3; Alfredo Rivera: "Nuestras conferencias telefónicas", El Adelanto, n' 12.360, 7 de septiembre de 1924, p. 4; Alfredo Rivera: "Nuestras conferencias telefónicas", El Adelanto, n' 12.372, 21 de septiembre de 1924, p. 5.

${ }^{73}$ Alfredo Rivera: "Nuestras conferencias telefónicas", El Adelanto, no 12.357, 4 de septiembre de 1924, p. 3 .

${ }_{74}$ BOURFA, Mohamed: Op. Cit., p. 161.

${ }^{75}$ Alfredo Rivera: "Nuestras conferencias telefónicas", El Adelanto, no 12.416, 12 de noviembre de 1924, p. 4. Aunque la promesa de la repatriación, finalmente, se hizo realidad poco antes de las Navidades de 1924: "La alegría de los que vuelven", El Adelanto, no 12.449, 20 de diciembre de 1924, p. 1.

${ }^{76}$ Alfredo Rivera: "Nuestras conferencias telefónicas", El Adelanto, no 12.421, 18 de noviembre de 1924, p. 5.

${ }_{77}$ Alfredo Rivera: "Última hora”, El Adelanto, no 12.445, 16 de diciembre de 1924, p. 6.

${ }^{78}$ BOUARFA, Mohamed: Op. Cit., p. 160.

${ }^{79}$ Alfredo Rivera: "Nuestras conferencias telefónicas", El Adelanto, no 12.481, 28 de enero de 1925, p. 5.

${ }^{80}$ Alfredo Rivera: "Nuestras conferencias telefónicas", El Adelanto, no 12.575, 20 de mayo de 1925, p. 5.
} 
Adelanto se interrogaba sobre la procedencia de sus armas ${ }^{81}$. Precisamente, esta nueva actitud del cabecilla rifeño sería el detonante del acercamiento hispano-francés. Pero a la espera de una decisión sobre cómo proceder y cuándo ${ }^{82}$, las murmuraciones acerca de El Raisuni, capturado por los hombres de Abd-el-Krim y enfermo, concentraron durante algunas jornadas casi todos los comentarios de la actualidad ${ }^{83}$.

Finalmente, en abril de 1925, fallecía el gran caudillo de Yebala. De este modo comentaba Ramón Jerez la noticia:

"Su figura, harto conocida en el mundo musulmán, atraía la atención y por largo tiempo ha mantenido latente la curiosidad del pueblo español.

Su ingenio maquiavélico, su espíritu sagaz, su prestigio religioso y guerrero, han sido siempre pesadilla de nuestros gobiernos.

Nuestra torpe política en el Protectorado, de continuos y desacertados cambios, que tantos rencores nos ha acarreado y hasta el descrédito en las cábilas, giró siempre en torno de esta relevante figura" ${ }^{\text {". }}$.

Apenas pudo provocar cierta conmoción la noticia. A punto de entrar en vigor, tras años de discusión, el Estatuto de Tánger, la tensión militar en ambas zonas del Protectorado alcanzaba cuotas muy preocupantes ${ }^{85}$. Ésta constituía la auténtica actualidad informativa. Abd-el-Krim amenazaba con avanzar sobre Fez y llamaba a los trabajadores en Argelia para retornar al Rif $^{86}$. Sus hombres se empeñaban en construir aceleradamente líneas, trincheras; diseñaban abrigos subterráneos y montaban redes telefónicas. El ataque se presentía inminente ${ }^{87}$. La colaboración entre Francia y España, aunque objeto de gran secretismo, era más real que nunca. A nadie se le ocultaba que se avanzaba hacia una alianza militar y El Adelanto se congratulaba por ello:

"Desde que los pactos y tratados internacionales comprometieron a Francia y a España a ejercer el protectorado en determinadas zonas de Marruecos, se vio que, para que la labor y el esfuerzo de las dos naciones fuera fructífero, era imprescindible una

\footnotetext{
81 “Comentarios de actualidad. ¿De dónde viene el dinero”, El Adelanto, no 12.398, 22 de octubre de 1924, p. 1.

${ }^{82}$ Alfredo Rivera: "Nuestras conferencias telefónicas”, El Adelanto, no 12.510, 3 de marzo de 1925, p. 5.

${ }^{83}$ Alfredo Rivera: "Nuestras conferencias telefónicas", El Adelanto, no 12.485, 1 de febrero de 1925, p. 5; Alfredo Rivera: "Nuestras conferencias telefónicas", El Adelanto, no 12.489, 6 de febrero de 1925, p. 5; "Figuras marroquíes. El Raisuni", El Adelanto, no 12.490, 7 de febrero de 1925, p. 3; Alfredo Rivera: "Nuestras conferencias telefónicas", El Adelanto, no 12.515, 8 de marzo de 1925, p. 5.

${ }^{84}$ Ramón Jerez: "Muerte de El Raisuni”, El Adelanto, no 12.549, 18 de abril de 1925, p. 3.

${ }^{85}$ Alfredo Rivera: "Nuestras conferencias telefónicas", El Adelanto, no 12.594, 11 de junio de 1925, p. 5.

${ }^{86}$ Alfredo Rivera: "Nuestras conferencias telefónicas", El Adelanto, no 12.595, 12 de junio de 1925, p. 5.

${ }^{87}$ Alfredo Rivera: "Nuestras conferencias telefónicas", El Adelanto, no 12.596, 13 de junio de 1925, p. 5; Alfredo Rivera: “Al cerrar la edición”, El Adelanto, no 12.615, 5 de julio de 1925, p. 8. Simultáneamente, un redactor de El Adelanto comentaba que en la Conferencia de Ginebra se había prohibido el empleo de armas químicas en las contiendas. El escritor, sin embargo, dudaba profundamente de la efectividad de la medida. En José Luis Salazar: "La guerra química", El Adelanto, no 12.616, 7 de julio de 1925, p. 3. Otro columnista, mientras, recogía unas declaraciones de Romanones para El Liberal sobre la necesidad de cooperar con Francia. El conde, además, censuraba agriamente la retirada de Xauen. Véase Alfredo Rivera: "Nuestras conferencias telefónicas", El Adelanto, no 12.632, 25 de julio de 1925, p. 4.
} 
estrecha y leal colaboración de ambas. Sin embargo, no sólo no se intentó, sino que hubo quienes se dedicaron a poner frente a frente los intereses de las dos naciones protectoras y hasta hubo momentos en que los hicieron antagónicos. Tal ha sido la labor de varios años del partido colonialista (...) Desde hace diez y seis años España ha venido sufriendo las consecuencias, sin atreverse, por decoro, a plantear la cuestión de una colaboración, que, seguramente, en los tiempos difíciles porque hemos pasado en Marruecos, nos habría sido denegada. Es ahora, al tocar Francia esos resultados y tener que soportar la agresión de los rifeños, cuando a la vecina república, por conducto de su prensa y de sus políticos, le parece conveniente el llegar a un acuerdo con España para, mancomunadamente, abatir la soberbia audaz de los rifeños.

No es hora para examinar los (...) El acuerdo interesa por igual a España y a Francia $y$ hay que ir a él con lealtad y sin titubeos ${ }^{, 88}$.

El prestigio que había adquirido Abd-el-Krim hacía imprescindible una acción común $^{89}$. Por este motivo, para agilizar las conversaciones con Francia ${ }^{90}$, el dictador regresaba a Madrid ${ }^{91}$. Además, tocaba ahora "fabricar" el consenso en torno a esa cooperación militar $^{92}$. Aunque desde una premisa ya muy clara. A saber, la república vecina había de ser la aliada de España, pero no dejaba de constituir también una enemiga en potencia. Porque, incluso, ahora, cuando las tropas galas atravesaban momentos bastante críticos en Marruecos, su prensa seguía censurando la falta de entusiasmo español ante la próxima acción conjunta:

"Algunos periódicos franceses se muestran sorprendidos porque, según su juicio, parte de la prensa española no ha acogido con gran entusiasmo la celebración de la Conferencia en que se está estudiando una inteligencia entre Francia y España (...) No hemos visto por parte alguna esa falta de entusiasmo que nos achacan los periódicos franceses. Al contrario, desde que se hizo público que el viaje de Mr. Malvy tenía por

\footnotetext{
88 “El problema marroquí. Colaboración conveniente", El Adelanto, n 12.580, 26 de mayo de 1925, p. 1.

89 "La colaboración franco-española", El Adelanto, no 12.586, 2 de junio de 1925, p. 1; Alfredo Rivera: "Nuestras conferencias telefónicas", El Adelanto, n $\mathrm{n}^{\circ} 12.589,5$ de junio de 1925, p. 5; Alfredo Rivera: "Nuestras conferencias telefónicas", El Adelanto, no 12.593, 10 de junio de 1925, p. 5. El Adelanto, emulando al Heraldo de Madrid, también recogía las opiniones acerca de la colaboración de viejos políticos como Pérez Caballero o Romanones: Alfredo Rivera: "Nuestras conferencias telefónicas", $E l$ Adelanto, $\mathrm{n}^{\circ}$ 12.590, 6 de junio de 1925, p. 5; Alfredo Rivera: "Nuestras conferencias telefónicas", $E l$ Adelanto, $\mathrm{n}^{\circ} 12.592,9$ de junio de 1925, p. 5.

${ }^{90}$ La Conferencia de Madrid se desarrollaría a lo largo de seis sesiones celebradas entre el 17 de junio y el 11 de julio de 1925. Los grandes acuerdos se refirieron a la vigilancia marítima y terrestre, la protección de Tánger, el trazado de las fronteras y un acuerdo político de cooperación. Una síntesis de la misma puede hallarse en RAMIRO DE LA MATA, Javier: "La Conferencia de Madrid en 1925 sobre el Protectorado de Marruecos", Estudios Africanos, Vol. XII, no 22-23, Madrid, 1998, pp. 157-172. Un análisis algo más extenso se incluye en su tesis doctoral, RAMIRO DE LA MATA, Javier: Op. Cit., pp. 274-291.

${ }^{91}$ Alfredo Rivera: "Nuestras conferencias telefónicas", El Adelanto, no $12.598,16$ de junio de 1925, p. 5. Una de las materias más discutidas, tal y como lo plasmó Rivera, fue la vigilancia contra el contrabando por mar: Alfredo Rivera: "Nuestras conferencias telefónicas", El Adelanto, $\mathrm{n}^{\circ} 12.599,17$ de junio de 1925, p. 5; Alfredo Rivera: "Última hora", El Adelanto, no 12.601, 19 de junio de 1925, p. 6; Alfredo Rivera: "Nuestras conferencias telefónicas", El Adelanto, no 12.604, 23 de junio de 1925, p. 5.

${ }^{92} \mathrm{La}$ acusación más grave que desde España se dirigía entonces contra Francia era la del contrabando de armamento a favor de los rifeños. Véase SUEIRO SEOANE, Susana: Op. Cit., pp. 19-39. Esta investigadora reconoce la existencia de cierto tráfico clandestino de armas, tolerado que no alentado por las autoridades galas, pero nada comparable con el volumen de armas que los rifeños adquirían legalmente en el mercado argelino.
} 
objeto intentar un acuerdo entre ambas naciones, todos los periódicos acogieron con simpatía el propósito y prestaron franco apoyo a la idea.

Lo que pasa es que el pueblo español, que viene soportando desde hace diez y seis años la furia rifeña, a costa de imponderables sacrificios cruentos y económicos, sabe muy bien cuáles son las principales causas de la osadía rifeña, y está también percatado de cómo podrían haberse evitado esas causas (...) Por ser todo esto del dominio público y por estar convencidos los españoles de que sólo se podía llegar a la pacificación de Marruecos, mediante una leal y sincera colaboración de las dos naciones protectoras, la opinión ha adoptado una actitud de prudente expectación ",93.

De todas formas, El Adelanto decía sentirse muy satisfecho ante el posicionamiento del socialismo francés, que había reconocido los derechos españoles sobre el Uarga y Tánger ${ }^{94}$. Abundaba en ese asunto "A.”:

"Nuestros intereses son, en la ciudad, los primeros por su cuantía, y Tánger no puede dejar de constituir para una imaginación como la nuestra, algo que es inherente a nosotros mismos (...) Mientras Tánger esté sujeto a influencias diversas, constituirá para España un motivo de grave preocupación. ¿Habrá que demostrarlo? (...) La cordialidad de relaciones que, por fortuna, tenemos con Francia, y la Gran Bretaña, puede facilitar la solución de un pleito que tanto nos afecta, que nos afecta más que a nadie y que constituye una aspiración por parte de la opinión española muy legítima.

¿Será este el momento de plantear de lleno este pleito? No lo sabemos ni pretendemos penetrar en secretos que corresponden de lleno a las respectivas cancillerías, "95.

Tan sólo a mediados de agosto, después de semanas de secretos a voces ${ }^{96}$, el Directorio admitía que la vía negociadora con el cabecilla de Axdir había sido descartada y convenía ahora "ilustrar a la opinión nacional" ante lo que se avecinaba. Pero, con certeza, la opinión salmantina se hallaba en aquellos días absolutamente conmocionada por el repentino fallecimiento de Federico Anaya ${ }^{97}$. Los rumores a propósito de la existencia de esos tratos se habían disparado cuando El Liberal reseñó la entrevista mantenida, a mediados de junio de 1925, entre el cabecilla rebelde y Horacio Echevarrieta (ahora sí con conocimiento y consentimiento galo ${ }^{98}$ ), aunque sin adelantar nada sobre su contenido ${ }^{99}$. Tampoco por medio de la prensa francesa fue posible el

\footnotetext{
93 "La Conferencia hispano-francesa. La opinión española", El Adelanto, nº 12.607, 26 de junio de 1925.

94 “A.": "Del momento. La colaboración franco-española", El Adelanto, no 12.618, 9 de julio de 1925, p. 1. 95“"A.”: "Del momento. La colaboración franco-española”, El Adelanto, no 12.622, 14 de julio de 1925, p. 1.

96 "Una información interesante. El actual estado del problema de Marruecos", El Adelanto, n 12.618, 9 de julio de 1925, p. 3.

97 "En Santa Teresa, ha muerto Federico Anaya Simón, el alcalde que fue de Salamanca", El Adelanto, n ${ }^{\circ}$ 12.646, 11 de agosto de 1925, p. 3.

${ }^{98}$ SUEIRO SEOANE, Susana: Op. Cit., p. 241.

99 "Cómo se efectuó la entrevista de don Horacio Echevarrieta con Abd-el-Krim. Tres días en las costas de Alhucemas", El Adelanto, no 12.643, 7 de agosto de 1925, p. 3.
} 
acceso a estas negociaciones de paz. Eso sí, tanto el gobierno español como el francés se apresuraron a desmentir ante la opinión pública la existencia de tal acercamiento ${ }^{100}$.

La táctica dilatoria de Abd-el-Krim había terminado con la paciencia de las cancillerías europeas. Así que la guerra, por fin, se convertía en una obligación impuesta. A la par que Primo de Rivera regresaba a África, El Adelanto, y en particular “A.", presentía el inicio de una nueva etapa en la historia de España en Marruecos: " $L a$ colaboración franco-española, por todos anhelada y tan en poca cuenta tenida hasta ahora por nuestros vecinos los franceses, ha sido impuesta por las circunstancias"101. También este diario advertía:

"Los propósitos del gobierno son derrotar a Abd-el-Krim, dispersar sus huestes (...) Conviene prevenir al país que conseguir esto cuesta algunos cientos de millones y algunas bajas europeas, pero conviene prevenir también al país que, de desistir, pueden ocurrir una de estas dos cosas: que Francia, más interesada en el problema, nos sustituya en nuestra zona del Protectorado, o que Francia desista también, y entonces Marruecos se constituya en nación independiente, que sería centro de bolcheviques, nido de aventureros y foco de destrucción situado frente a España, contando con un excelente refugio que lo constituye la bahia "102.

Culminaba de este modo la estrategia propagandística del diario liberal, la misma de siempre, la que había señalado Lippmann como vital para crear un clima propicio a la guerra: la de la falsificación de la historia. Porque otra vez se aparentaba que con la embestida lo que estábamos haciendo, en realidad, era defendernos de unos monstruos.

Para La Gaceta Regional, mucho menos pendiente de Marruecos que El Adelanto durante los primeros meses de la dictadura, el contencioso sobre Tánger constituyó su máxima preocupación en materia de política exterior ${ }^{103}$. Por ejemplo, Mariano S. de Enciso se pronunciaba radicalmente en contra del último estatuto elaborado:

"Frente a la sinrazón del reciente estatuto (¿el último?), elaborado en París, firmado por los agentes diplomáticos españoles, 'ad referendum', se alza nuestra conciencia de patriotas y periodistas católicos. Y es conciencia, que es bien conocida de nuestros lectores, por tenaces campañas en pro de nuestros derechos inalienables africanos, nos impele aconsejar a los hombres no menos patriotas y bien intencionados que manejan

\footnotetext{
${ }^{100}$ Alfredo Rivera: "Lo que dice el general Gómez Jordana sobre las informaciones de paz que publica Le Matin", El Adelanto, n' $12.643,7$ de agosto de 1925, p. 5.

101 "A.": "Del momento. Después de la Conferencia", El Adelanto, no 12.635, 29 de julio de 1925, p. 1.

${ }^{102}$ Alfredo Rivera: “Al cerrar la edición”, El Adelanto, no 12.645, 9 de agosto de 1925, p. 6.

103 “Tánger, el separatismo y Marruecos", La Gaceta Regional, n 1.014, 29 de diciembre de 1923, p. 2. Se reproducía una muy extensa nota del Directorio en la que se entreveían sus dudas a propósito del futuro Estatuto y la voluntad de "pulsar" la opinión.
} 
las riendas del gobierno, que no aprueben ese atentado histórico, geográfico y jurídico" ${ }^{\text {104. }}$.

Además de estas razones esgrimidas, el columnista aportó explicaciones de índole cultural: "Contra lo que se supone generalmente (...) no es sólo el ruido de las armas el que un observador de buena fe puede percibir como consecuencia de nuestra actuación en Marruecos. Nuestra acción expansiva y educadora, se ha extendido a todas las manifestaciones culturales" ${ }^{\prime 105}$. Hubo, en consecuencia, aunque con distintos tonos, coincidencia de pareceres en la prensa salamantina y también, en altas dosis, entre los periódicos nacionales. Pero, con todo, el general se adhirió al documento ${ }^{106}$.

A la espera de un plan para gestionar el Protectorado ${ }^{107}$, la creciente presión rebelde sobre Tizzi Azza anunciaba una nueva fase de combates y, desde luego, nuevos sacrificios: "El Directorio sabe que se dirige a un pueblo digno y viril, al que no tiene por qué ocultar lo ocurrido ni lo contingente, confiando en que, con serenidad patriótica, se sepa esperar el resultado las operaciones encomendadas al castigo de los alarmistas o derrotistas, si desgraciadamente los hubiera, a la propia conciencia ciudadana ${ } 108$. En efecto, a medida que los combates se iban recrudeciendo, el dictador se esmeraba por llamar a la calma con sus demagógicas notas ${ }^{109}$.

Y también en este sentido actuaba un redactor salmantino, José Luis:

"Las circunstancias de que sea un Directorio militar el que asume hoy las responsabilidades del Poder, constituyen una garantía de aciertos en la marcha de los asuntos de África (...) Nuestra política en Marruecos no pudo ser más desacertada. Fue un continuo tejer y destejer; fue una política de zig-zag, en orden a nuestra misión de protectorado y esta política desacertada y estúpida contribuyó no poco a hacer impopular nuestra campaña de África, que no es una guerra de conquista, sino el cumplimiento de una obligación contraída por España de incorporar a las civilizaciones modernas una parte del territorio marroquí, obligación inexcusable por razones geográficas y que de no cumplirla Estaña tendría que cumplirla otro país (...) Para proteger hay que dominar y cuando no se domina por la persuasión, debe dominarse por la fuerza $" 110$.

\footnotetext{
${ }^{104}$ Mariano S. de Enciso: "La cuestión de Tánger. El Directorio no debe firmar el Estatuto", La Gaceta Regional, $\mathrm{n}^{\mathrm{o}} 1.027,15$ de enero de 1924, p. 1.

${ }^{105}$ Mariano S. de Enciso: "Tánger, ciudad española", La Gaceta Regional, no 1.034, 23 de enero de 1924, p. 1.

106 "Nota oficiosa sobre el Estatuto de Tánger”, La Gaceta Regional, n 1.033, 22 de enero de 1924, p. 2.

${ }^{107}$ Delgado Barreto: "El Alto Comisario llegará a Madrid dentro de breves días", La Gaceta Regional, $\mathrm{n}^{\circ}$ $1.045,5$ de febrero de 1924, p. 1.

108 "Los sucesos de África", La Gaceta Regional, no 1.069, 4 de marzo de 1923, p. 4.

${ }^{109}$ Delgado Barreto: "Por teléfono. Falsos rumores sobre Marruecos", La Gaceta Regional, no 1.072, 7 de marzo de 1924, p. 1; Delgado Barreto: "Noticias de la campaña de Marruecos", La Gaceta Regional, no $1.073,8$ de marzo de 1924, p. 3.

${ }^{110}$ José Luis: "El problema de Marruecos", La Gaceta Regional, n 1.075, 11 de marzo de 1924, p. 1.
} 
Se presentía, de algún modo, el fin de la larga guerra de desgaste y esta era la idea que se intentaba transmitir a la opinión pública salmantina: se requería un esfuerzo final. No faltaban, por otro lado, los elogios hacia el Tercio ${ }^{111}$; y las alusiones al desaliento entre los rebeldes ${ }^{112}$.

Entretanto, el Directorio ultimaba la nueva reglamentación del servicio militar. Y aunque La Gaceta no aportaba excesivos detalles, sí admitía que se pretendía combatir a los prófugos y la picaresca existente en las Comisiones Mixtas de Reclutamiento $^{113}$.

Además, tal y como ya se ha apuntado, el proceso para el esclarecimiento de las responsabilidades había quedado casi interrumpido. Aún con todo, la dictadura perseguía un lavado de la imagen castrense y a ello se encomendaba este diario salmantino. Por eso algún redactor subrayaba que ningún militar se opuso al esclarecimiento de lo ocurrido en Annual, pero sí a que "el supremo interés de la justicia fuera vilmente suplantado por el bajo interés de los enemigos del trono"114. La tramitación de las causas contra los generales Berenguer y Navarro mereció muy poca atención en las páginas de este diario, nada comparable a la de El Adelanto. De hecho, en reiteradas ocasiones Barreto refirió el desinterés del asunto: "Las tribunas están casi desiertas y en el salón sólo se ven los ayudantes de los generales que forman el Tribunal" $" 115$. Y, en otro momento, señaló: "La desanimación por parte del público es igual que en días anteriores" "116. También al final de proceso, el corresponsal madrileño se hizo eco, evidentemente sin emitir ningún tipo de juicio, de las sentencias dictadas para ambos mandos militares, así como de la amnistía otorgada ${ }^{117}$.

Asimismo, Barreto, al cumplirse el primer aniversario del golpe, recogió la proclama del dictador ante el país: "Al reparar hoy en la obra realizada, tenemos que

\footnotetext{
111 “Los haberes del Tercio de Extranjeros", La Gaceta Regional, no 1.083, 21 de marzo de 1924, p. 2; Mariano Arenilla Sainz: “Ante la bandera”, La Gaceta Regional, no 1.084, 22 de marzo de 1924, p. 1.

${ }^{112}$ Delgado Barreto: "La acción española en Marruecos", La Gaceta Regional, no 1.088, 27 de marzo de 1924 , p. 3.

113 José Luis: "La nueva ley de reclutamiento", La Gaceta Regional, no 1.093, 2 de abril de 1924, p. 1. Se publicaría íntegramente la ley más adelante: Delgado Barreto: "Nuestras conferencias telefónicas de esta mañana", La Gaceta Regional, n 1.372, 6 de marzo de 1925, p. 2.

114 “Gobernando", La Gaceta Regional, no 1.036, 25 de enero de 1924, p. 1.

115 Delgado Barreto: "Por teléfono. La causa contra los generales Berenguer y Navarro", La Gaceta Regional, n'. 1.155, 17 de junio de 1924, p. 4.

${ }^{116}$ Delgado Barreto: "El consejo de guerra contra los generales Berenguer y Navarro", La Gaceta Regional, no 1.157, 20 de junio de 1924, p. 4.

${ }^{117}$ Delgado Barreto: "El consejo de guerra contra los generales Berenguer y Navarro", La Gaceta Regional, $\mathrm{n}^{\circ}$ 1.160, 24 de junio de 1924, p. 1: Delgado Barreto: "La absolución del general Navarro", La Gaceta Regional, no 1.163, 27 de junio de 1924, p. 4: Delgado Barreto: "La sentencia contra Berenguer", La Gaceta Regional, no 1.164, 28 de junio de 1924, p. 2; "La amnistía alcanza a Berenguer", La Gaceta Regional, $\mathrm{n}^{\circ} 1.171,7$ de julio de 1924, p. 5.
} 
reconocer que hay que continuarla, hasta que la patria se sienta libre de las influencias nefastas que amenazaban llevarla a la ruina" ${ }^{\text {118 }}$. El problema marroquí se presentaba como el único serio, pero además, Primo unía su suerte a la de su resolución. Por descontado, había que apelar únicamente a las armas: “De lo contrario, la actitud decidida del enemigo, el cual está envalentonado porque cuenta con abundantes medios de guerra, no supondría tan sólo la pérdida del territorio, sino que dependerá también la vida de nuestros hermanos, la virilidad de nuestra raza".

Con este propósito, en octubre de 1924 el dictador asumió personalmente la Alta Comisaría ${ }^{119}$. Mientras que estas operaciones fueron, de nuevo, tratadas con gran parquedad en las páginas del diario conservador, las declaraciones del general emplearon un tono optimista y siempre tranquilizador ${ }^{120}$. Lo previsible.

Sin embargo, ya que había unido su fortuna a la terminación de la guerra, a finales de 1924 algún redactor reconocía que se empezaban a escuchar voces demandando el retorno a la normalidad constitucional. Él, el columnista, no obstante, lo consideraba un paso prematuro, en falso:

"Partiendo del hecho de que el advenimiento del Directorio a la gobernación del país representó una solemne y enérgica condenación de los viejos sistemas políticos y un intento laudable de transformación y de adecentamiento en nuestras costumbres políticas, sería cosa de averiguar si ese intento generoso del Directorio se ha conseguido en todas sus partes, teniendo en cuenta, sobre todo, que durante este período de tiempo, en el que el problema de Marruecos exigió toda la atención de nuestros gobernantes, no pudieron prodigarse a los problemas de política interior iguales atenciones y actividades.

Deseo de todos, lo mismo del Directorio que de la opinión pública es, sin duda alguna, el retorno a la normalidad política y constitucional de España; pero, después del golpe del 13 de Septiembre del pasado año, ese retorno debe hacerse escalonadamente "121.

Otro periodista, Axel, intentando ganar tiempo, dedicaba algunas palabras de elogio a los cronistas de guerra y sus escritos:

"Esta literatura destinada a los periódicos, es influida por motivaciones que para nada tienen que ver con la épica. Sus autores lo hacen para un diario y para un público determinado, los cuales adoptaron, frente al problema de Marruecos, posiciones

\footnotetext{
${ }^{118}$ Delgado Barreto: "Nuestras conferencias telefónicas", La Gaceta Regional, no 1.223, 8 de septiembre de 1924 , p. 5.

${ }^{119}$ Delgado Barreto: "Nuestras conferencias telefónicas", La Gaceta Regional, no 1.259, 20 de octubre de 1924 , p. 3.

${ }^{120}$ Delgado Barreto: "Nuestras conferencias telefónicas de esta mañana", La Gaceta Regional, $\mathrm{n}^{\circ} 1.288$, 24 de noviembre de 1924, p. 2; Delgado Barreto: "Nuestras conferencias telefónicas de esta mañana", $L a$ Gaceta Regional, $\mathrm{n}^{\circ}$ 1.291, 27 de noviembre de 1924, p. 2. Idéntico era el tono también de Gómez Jordana, uno de los vocales del Directorio. Particularmente, se mostraba muy confiado con la utilidad de la aviación: Delgado Barreto: "Nuestras conferencias telefónicas de esta tarde", La Gaceta Regional, $\mathrm{n}^{\circ}$ 1.312, 23 de diciembre de 1924, p. 5.

121 "Aspectos políticos. Con los pies de plomo", La Gaceta Regional, no 1.308, 16 de diciembre de 1924, p. 1 .
} 
determinadas, e influidas muchas veces, por una finalidad política en vez de por un sentimiento nacional. Y claro es, estas narraciones están hechas para figurar más bien como documentos políticos, que como muestras de literatura de guerra.

Pero también entre nuestros soldados que han hecho la campaña, los hubo que escribieron de la guerra, con desligamiento de toda opinión política sobre el problema. (...) Rebuscando en los diarios españoles de estos diez años últimos, puede apreciarse la labor literaria de estos escritores (...) El que quiera hallar la tónica verdadera del pueblo que luchó en África, no tiene sino leer estas crónicas de escaso valor literario, las más de las veces, donde resplandece la sinceridad más escueta, sobre los episodios todos de la campaña ${ }^{, 122}$.

Su propósito no era otro que el de elogiar la labor desempeñada por Ramón Jerez, el soldado que por entonces relataba a los salmantinos las andanzas de La Victoria por África. Aunque no quedaba claro en qué grupo ubicaba Axel a este "cuota". En las notas oficiales, por su parte, el Directorio insistía en que era preciso continuar castigando a los rebeldes. Pretextando, además, que así lo deseaban los españoles, a principios de 1925 Primo aseguraba que no abandonaría el Poder ${ }^{123}$.

El periodista Antonio Monedero, al hilo de estas manifestaciones, se empeñaba en demostrar el acierto de la decisión. Diríase que intentaba persuadir a los lectores de que, nunca antes, el sueño marroquí se había contemplado como tan próximo a convertirse en realidad, tan al alcance de la mano:

"Es indudable que nuestra zona de influencia, considerada en conjunto, es un hueso inhospitalario y árido, de cuyas hostiles montañas sólo puede esperarse el agotamiento de la nación y la muerte de numerosos hijos.

Pero reducido ahora a una porción relativamente pequeña, es indudable también que esta porción es la menos mala (...) Nosotros, como agricultores (...) nos vamos a limitar a indicar (...) lo que creemos que puede hacerse en la agricultura.

Desde luego nos hemos de fijar en la parte mejor de lo que nos ha quedado: de Larache a Alcazarquivir, en todo el rincón que limita el Atlántico y la frontera francesa hay terrenos de grandísima riqueza y otros que, con algún saneamiento, pueden serlo también; terrenos pertenecientes, en gran parte, al Majzén y que pueden colonizarse con grandísima utilidad y a poco coste.

Hay también algunos trozos alrededor de Arcila y cercanos a Ceuta y Tetuán, más algo de la zona oriental por Nador ${ }^{, 124}$.

El autor sugería, a continuación, la posibilidad de ocupar todo este territorio con vides y olivos. Pero, ¿cuántos salmantinos no creerían que esto se publicaba a destiempo? ¿Cómo pensar en el largo plazo si lo que se presumía era un nuevo conflicto?

\footnotetext{
${ }^{122}$ Delgado Barreto: "Nuestras conferencias telefónicas de esta tarde", La Gaceta Regional, n 1.326, 12 de enero de 1925 , p. 5.

${ }^{123}$ Joaquín Arrarás: "Interesantísimas declaraciones del general Primo de Rivera", La Gaceta Regional, $\mathrm{n}^{\mathrm{o}} 1.333,20$ de enero de 1925, p. 1. Estas declaraciones del dictador estaban tomadas de El Debate.

${ }^{124}$ Antonio Monedero: "De colaboración. ¿Puede ser Marruecos fuente de ingresos?", La Gaceta Regional, $\mathrm{n}^{\circ} 1.341,29$ de enero de 1925, p. 1.
} 
A finales de marzo, Barreto, de hecho, amparándose en las palabras El Debate, que juzgaban la línea de Estella como infranqueable, señalaba que el momento era el propicio para la ofensiva final ${ }^{125}$. Sin embargo, el entendimiento con Francia, que ya en julio de 1924 había ocupado el valle del Uarga para frenar los llamamientos a la guerra santa de Abd-el-Krim ${ }^{126}$, no figuraba entre los planes de la redacción conservadora. Impotente, el periódico sabía que había que olvidar las heridas del pasado. Y se dolía por ello. Así, poco después del fallecimiento de El Raisuni ${ }^{127}$, una de las figuras que tantas tiranteces internacionales había ocasionado, Pérez Alfonso escribía:

"Contra la barbarie teutónica, se nos ofreció dejarnos las manos libres en Marruecos y considerar, por descontado, como parte integrante de nuestra zona, Tánger. Y la aceptación en aquellas circunstancias, de semejante ofrecimiento, equivalía a la ruptura de la neutralidad.

Pero ni antes ni después de la guerra hemos comprobado que sintiesen los gobiernos de Francia, influidos por un partido colonialista absorbente y ambicioso, no ya deseos vehementes, pero ni aun simples deseos de una inteligencia cordial, y no hay que decir que en los días de nuestro gran infortunio de 1921, si por cortesía se nos alargó la mano, no nos fue mostrado ni un pedacito de corazón.

No importa esto, ni sería juicioso tenerlo en cuenta, para que nosotros coincidamos con cuantos sin más que poner en ejercicio el buen sentido, entienden que, pues se trata de un enemigo común, de una dificultad semejante, y se les tiene atribuida igual misión, Francia y España deben entenderse en todo lo que quepa inteligencia",28.

Qué duda cabe, tantos años de propaganda francófoba, de acopio de agravios, rencores, tratos desdeñosos y, en suma, de relaciones muy envenenadas habían fomentado un estado generalizado de constantes recelos entre la opinión pública salmantina (y nacional también). Pero ahora tocaba "confeccionar" un cambio de actitud porque Abd-el-Krim, ya sin ambages, aparecía como un enemigo tremendamente peligroso y carismático. A su lado combatían algunos europeos, muy bien instruidos, y no sólo harqueños "desarrapados" y fanáticos ${ }^{129}$. La tarea de desarmar el Rif, por tanto, iba a requerir un considerable esfuerzo, una notable concentración de poderes en el $\operatorname{dictador}^{130}$, y por ello, había que preparar al país. Así lo admitía Primo en unas

\footnotetext{
${ }^{125}$ Delgado Barreto: "Nuestras conferencias telefónicas de esta mañana", La Gaceta Regional, $\mathrm{n}^{\mathrm{o}}$ 1.386, 24 de marzo de 1925, p. 2.

${ }^{126}$ Delgado Barreto: "Por teléfono. Abd-el-Krim actuó en la zona francesa", La Gaceta Regional, no $1.188,28$ de julio de 1924, p. 2.

${ }^{127}$ Delgado Barreto: "Nuestras conferencias telefónicas de esta mañana", La Gaceta Regional, $\mathrm{n}^{\circ}$ 1.406, 17 de abril de 1925, p. 2.

128 "P. A.": "Inteligencia franco-española", La Gaceta Regional, no 1.443, 2 de junio de 1925, p. 1.

129 "El avispero de Marruecos. ¿Quién proporcionó armas a los rifeños", La Gaceta Regional, no 1.422, 20 de mayo de 1925, p. 2; "Abd-el-Krim y sus apoyos", La Gaceta Regional, n 1.445, 4 de junio de 1925, p. 1.

130 "P. A.": "Por sí mismos", La Gaceta Regional, nº 1.457, 19 de junio de 1925, p. 1.
} 
declaraciones, muy comentadas, para Le Figaro $^{131}$. Lo mismo, con más locuacidad si cabía y agradeciendo la colaboración francesa, hacía en una nota oficiosa a mediados de julio de $1925^{132}$. Por su parte, “Ariel” reincidía en los mismos argumentos, pero sin pasar por alto las habituales rencillas entre países y en la necesidad de arrojo militar y público, en este sugerente editorial:

"Nuestro carácter, cazurro y desconfiado, teniendo presente la sentencia bíblica 'Dios nos libre de la hora de las alabanzas', porque suele ser esa hora la de exigir algún sacrificio (...) nos lleva a pensar en que se nos prodigan cuando Francia ha tenido que volver los ojos a nosotros en Marruecos (...) Ahora se dice de nosotros que hemos sido la nación más sabiamente colonizadora (...) y que nuestro Ejército es modelo de disciplina, de valor y de heroísmo, como lo demuestra lo que viene sufriendo y soportando en África. ¡Muchas gracias, señores! Así, al menos, se dejará de denigrarnos en el extranjero pintándonos como un país moribundo (...) Sabemos que la historia de nuestros colonizadores está muy por encima de la antigua Roma y de la Gran Bretaña de hoy; nosotros fuimos siempre a los países nuevos para sacarlos de la esclavitud, para civilizarlos, para hacerlos libres, sin mirar que esto arruinaba nuestra Hacienda y consumía nuestras energías, mientras que otros pueblos, que tienen fama de colonizadores, sólo buscaron en sus colonias la riqueza y el apoyo material (...) Como también sabemos que al aceptar el protectorado en una zona de Marruecos, para llevar allá la civilización, nos imponíamos enormes sacrificios, que se han hecho aisladamente, aumentados y agravados por quienes debieran de ayudarnos, sin perjuicio de ofrecer nosotros nuestra ayuda al que siempre nos la negó, cuando ahora se encuentra en período de apuro.

Porque esa ha sido y será siempre España, hidalga, noble, generosa"133.

Las viejas heridas no acababan de cicatrizar. A. de Mirabal fue el columnista que más lo puso en evidencia: "La realidad demuestra que la influencia de Francia en el Rif era ficticia. Pudo decir, mejor, que España ha venido taponando el paso de los rifeños, soportando la guerra continua, mientras Francia, en paz, por nuestro esfuerzo, levantaba ciudades modernas" ${ }^{134}$. Asimismo, fue este cronista el que más atención dedicó a las conversaciones con la república a propósito de la cuestión marroquí. De hecho, pocos más lo hicieron ${ }^{135}$, afectados como estaban por la noticia de la muerte de Anaya $^{136}$. Aunque Mirabal hubo de esperar a la terminación de las mismas:

\footnotetext{
${ }^{131}$ Delgado Barreto: "Nuestras conferencias telefónicas de esta tarde", La Gaceta Regional, no 1.451, 12 de junio de 1925 , p. 5.

${ }^{132}$ Delgado Barreto: "Nuestras conferencias telefónicas", La Gaceta Regional, $\mathrm{n}^{\circ} 1.475,11$ de julio de 1925 , p. 5.

133 “Ariel”: "Cómo nos ven ahora en el extranjero", La Gaceta Regional, n 1.496, 5 de agosto de 1925, p. 1.

${ }^{134}$ Mirabal: "No todo lo que reluce es oro. Un momento favorable para el interés de España y su justicia en Marruecos", La Gaceta Regional, $\mathrm{n}^{\circ}$ 1.475, 11 de julio de 1925, p. 1. Mirabal, sobre todo, se complació de ver cómo ahora le tocaba a Francia lidiar con la propaganda antimilitarista: Mirabal: "Analogía franco-española", La Gaceta Regional, nº 1.478, 15 de julio de 1925, p. 1.

135 "Alrededor de la Conferencia franco-española”, La Gaceta Regional, n 1.498, 7 de agosto de 1925. Vicente Sánchez Ocaña también recogió la opinión de un militar anónimo sobre estas conversaciones y aplaudió la renovada voluntad de entendimiento.

136 "Don Federico Anaya", La Gaceta Regional, n’ 1.500, 10 de agosto de 1925, p. 1.
} 


\begin{abstract}
"Se ha dado a conocer, lo esencial de lo convenido, con una lealtad que tal vez no hubiera sido tan diáfana en el Parlamento. Y hoy tiene la nación para orientarse y esperanzarse, el vaticinio del general Primo de Rivera, según el cual, dentro de dos meses, el problema marroquí habrá entrado en vía de resolución, para dejar de ser pesadilla en los hogares, amenaza para la tranquilidad nacional y dificultad de gobierno, fácil para ser explotada en el juego de las conveniencias partidistas.

Aclaremos, poniéndolo al alcance vulgar el lenguaje diplomático. Se ha convenido entre Francia y España, el bloqueo marítimo y terrestre en Marruecos, para impedir el contrabando de armas, para restar elementos de lucha al enemigo; se ha convenido que en la zona francesa haya puertos españoles y en la zona española puertos franceses, para mayor garantía de mutua lealtad en la persecución de conspiradores contra la paz en los territorios del Protectorado; se ha convenido el derecho de persecución y sobrevuelo, es decir la facultad de picar al enemigo común, por aquellas tropas que con él luchen, cuando el enemigo se interne en una u otra zona de influencia; y se han aquilatado y reglamentado los derechos de vigilancia de Tánger (...) Tenía el Directorio que corregir yerros (...) Quijotescamente nuestras tropas se habian encerrado en la ratonera de Xauen ${ }^{, 137}$.
\end{abstract}

No obstante, el mismo columnista se impacientaba ante el retraso de las operaciones y el temor a las lluvias ${ }^{138}$. Y sentenciaba: "No deben asustar, aunque preocupen, las operaciones militares contra los moros rebeldes. Son necesarias" $" 139$.

Pensemos, para terminar este epígrafe, que El Adelanto apenas refirió el desarrollo de la Conferencia de Madrid. Y, al contrario, el diario conservador lo que escasamente reseñó, fue la retirada de Xauen. ¿Por qué estos silencios selectivos? Porque El Adelanto no quería dispensar demasiados halagos a Primo como agente diplomático. Prefería cargar las tintas sobre el tradicional acierto de la opinión pública, partidaria de la acción común. El silencio se convertía, por consiguiente, en un indicio de malestar, aunque pasivo, hacia el dictador. Mientras La Gaceta, aunque entendió y aprobó el repliegue parcial de las tropas, no deseó relatar el desarrollo de una operación nada épica. Prefería la autocensura a la deshonra militar. Evidentemente, sólo a través de estos comportamientos, tan marginales, la prensa salmantina luchaba por conservar su identidad en un régimen con escasas libertades.

\title{
LOS SOLDADOS SALMANTINOS EN MARRUECOS
}

El cerco sobre Tazarut, la guarida de El Raisuni, se había estrechado mucho en el momento del advenimiento del golpe. Pero aún así, por las mismas fechas, cuando

\footnotetext{
${ }^{137}$ A. de Mirabal: "La guerra con el moro. En el plazo de dos meses dejará de ser una pesadilla la cuestión de Marruecos", La Gaceta Regional, n 1.490, 29 de julio de 1925, p. 1. La nota oficiosa sobre el encuentro entre Primo y Pétain en Algeciras también se reprodujo poco después: "R. G.": "Temas de actualidad. La política del porvenir", La Gaceta Regional, n' 1.527, 10 de septiembre de 1925, p. 1.

${ }^{138}$ Mirabal: "Un artículo de El Telegrama del Rif", La Gaceta Regional, no 1.503, 13 de agosto de 1925, p. 1 .

${ }_{139}$ Mirabal: "La operaciones militares en África", La Gaceta Regional, no 1.508, 17 de agosto de 1925, p. 1 .
} 
desde Ain-Grana, Ramón Jerez se dirigía a los lectores de El Adelanto, lo hacía para comunicarles la sensación de aburrimiento y la nostalgia imperante entre sus compañeros $^{140}$.

Por suerte para los expedicionarios de La Victoria y sus familias, la acometida final no llegó a producirse. Las primeras actuaciones del Directorio en Marruecos se dirigieron a agilizar la repatriación de los remplazos de 1920 y $1921^{141}$. Primo estaba muy al tanto del malestar público generado por este asunto, el de la prolongada ausencia de los expedicionarios. Así que mientras se reanudaron las conversaciones con el jerife de Yebala ${ }^{142}$, Salamanca recibió, a mediados de octubre, una formidable nueva, la del retorno de los hombres del primer remplazo y de su oficial al mando, el teniente coronel Serviá:

“Ayer, por la mañana, tuvimos noticia de que, según comunicaban de Ain Grana, a los soldados del reemplazo de 1920, pertenecientes al batallón expedicionario del regimiento de La Victoria, número 76, se les había dado las oportunas órdenes para su repatriación a la península, y que, desde las posiciones donde estaban destacados, se dirigían a Larache para embarcar.

Tan grata nueva, pues como es sabido casi todos los referidos soldados son naturales de Salamanca y su provincia, la dimos a conocer en nuestra cartera de la Plaza Mayor, causando el natural regocijo.

De los soldados del 20 que repatrían de Larache, le corresponden a La Victoria, 492 individuos, de los cuales hay que descontar los que han venido ya con licencias y los que estén enfermos alli en los hospitales, ${ }^{, 143}$.

Los diarios salmantinos llamaban al Ayuntamiento para que se les dispensase a estos jóvenes un merecido homenaje ${ }^{144}$. Asimismo, anunciaban que el día 24 de octubre se produciría su embarque ${ }^{145}$; y rectificaban la cifra inicialmente publicada: retornarían 540 hombres ${ }^{146}$. Al tiempo que se les preparaba un fastuoso rancho en el Palacio de

\footnotetext{
${ }^{140}$ Ramón Jerez: "El Adelanto en Marruecos. El batallón de La Victoria en Tazarut", El Adelanto, ${ }^{\circ}$ 12.074, 5 de octubre de 1923, p. 6.

${ }^{141}$ Alfredo Rivera: "Nuestras conferencias telefónicas", El Adelanto, no 12.079, 11 de octubre de 1923, p. 3; "Por los soldados del remplazo del 20 que aún se encuentran en Marruecos", La Gaceta Regional, no 990, 30 de noviembre de 1923, p. 3; "La repatriación de soldados del 20 de La Victoria", La Gaceta Regional, $\mathrm{n}^{\mathrm{o}}$ 1.003, 15 de diciembre de 1923, p. 1; “¿Licenciamientos de los cuotas del 21?”, La Gaceta Regional, $\mathrm{n}^{\circ} 1.138,27$ de mayo de 1924, p. 1.

${ }^{142}$ El Adelanto tan sólo tuvo conocimiento de la entrevista final en Sidi-Musa entre Aizpuru y el jefe de Yebala: Ramón Jerez: "La conferencia histórica de Sidi-Musa", El Adelanto, n 12.115, 22 de noviembre de 1923, p. 3; Ramón Jerez: "La conferencia histórica de Sidi-Musa", El Adelanto, no 12.119, 27 de noviembre de 1923 , p. 5.

143 "Los soldados del remplazo de 1920 del batallón de La Victoria, repatriados", El Adelanto, n 12.085, 18 de octubre de 1923, p. 1. La Gaceta comunicó la misma noticia al día siguiente: "El regreso de las fuerzas de La Victoria”, La Gaceta Regional, nº 955, 19 de octubre de 1923, p. 1.

144 “Ante el regreso de los soldados de La Victoria", El Adelanto, no 12.086, 19 de octubre de 1923, p. 1.

${ }^{145}$ Alfredo Rivera: "Noticias telefónicas de última hora", El Adelanto, no 12. 087, 20 de octubre de 1923, p. 4.

146 "El regreso de las tropas de La Victoria", El Adelanto, $\mathrm{n}^{\circ}$ 12.089, 23 de octubre de 1923, p. 1; "Repatriación de los soldados de La Victoria", La Gaceta Regional, n 958, 23 de octubre de 1923, p. 1.
} 
Anaya $^{147}$, el alcalde, Jacinto Elena, se dirigía a los salmantinos para que se dispusieran a recibir a sus combatientes:

"Salmantinos: Desde el puesto de honor que por ministerio de la Ley desempeño, me considero obligado a dirigirme a vosotros para informaros de la hora de llegada a esta capital de los soldados del reemplazo de 1920, pertenecientes al regimiento La Victoria, de guarnición en esta plaza.

El recuerdo del entusiasmo con que fueron despedidos cuando salieron para África, es garantía segura del grandioso recibimiento que estáis dispuestos a tributar a los bizarros soldados de La Victoria que han cumplido con la lealtad y abnegación que todos esperábamos sus sagrados deberes para con la Patria",148.

Qué duda cabe, la noticia tenía que producir satisfacción; aquellos infortunados habían permanecido en África veintisiete meses, desde agosto de 1921. Pero a pesar de este dato, a la ciudad ya no le restaban fuerzas para las celebraciones. La prensa, en el pasado, había identificado estos actos de bienvenida/despedida como explosiones del patriotismo, con relatos más o menos emotivos. Sin embargo, semejante instrumentalización de la más simple compasión se había practicado dentro de unos límites: inicialmente, durante las primeras campañas militares, los periódicos se habían hecho eco de la asistencia masiva de las gentes a la estación, sin más; después de Annual, no obstante, el protagonismo a la hora de organizar estos actos, así como las donaciones, había recaído, fundamentalmente, en la Comisión Patriótica y en la Cruz Roja; ahora, por último, ese viejo afecto ciudadano hacia el Ejército, como institución, casi ni se apreciaba ni era posible "diseñar". Al contrario, emanaba del propio Poder y de los periódicos. La opinión pública salmantina seguía acudiendo, por descontado, a socorrer a sus tropas cuando éstas precisaban su auxilio económico y con motivo de las tradicionales y tan arraigadas campañas en pro del aguinaldo, pero ya no respondía de igual modo cuando se les llamaba para mostrar su satisfacción y agradecimiento ante la labor desempeñada por el Ejército de África.

\footnotetext{
147 "La llegada de los soldados de La Victoria", El Adelanto, no 12.090, 24 de octubre de 1923, p. 1.

148 “Los repatriados de La Victoria", El Adelanto, no 12.092, 26 de octubre de 1923, p. 2.
} 


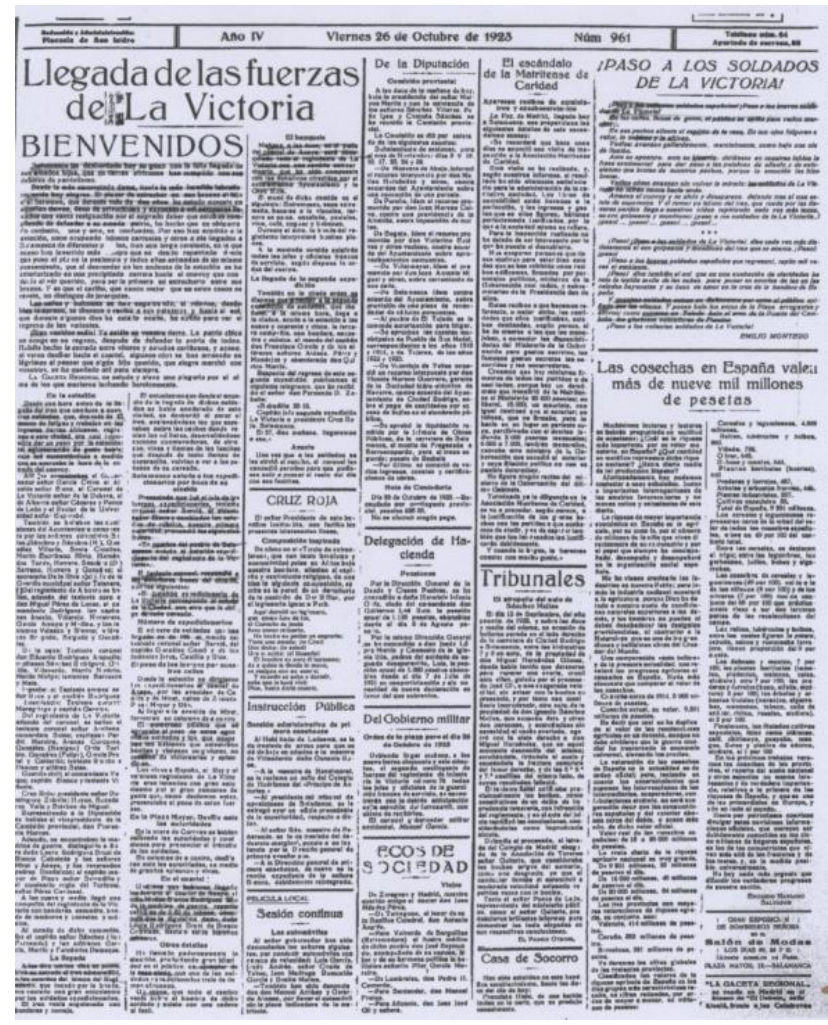

La Gaceta Regional, nº 961, 26 de octubre de 1923, p. 1.

Desde el diario liberal, la recepción, que tuvo lugar el 26 de octubre, tan sólo se describió como "cordial" "149. El pretexto, la llegada escalonada de los mozos motivada por deficiencias en el transporte ${ }^{150}$. No hubo, además, ninguna palabra de agradecimiento hacia Primo por la repatriación. La única nota de entusiasmo ciudadano se registró en la Plaza Mayor y sólo porque, he aquí el dato más pintoresco de la historia, los recién llegados vinieron acompañados con un mono que hizo las delicias del público. Desde La Gaceta, con un relato algo más efusivo, se recalcó, es cierto, la asistencia de multitud de gente a la estación y su presencia en las calles esperando el desfile ${ }^{151}$. Pero se evitó describir las expresiones y actitudes de ese público: “En las

\footnotetext{
149 "Salamanca recibe a los infantes del regimiento de La Victoria con acendrado patriotismo", $E l$ Adelanto, $\mathrm{n}^{\circ}$ 12.093, 27 de octubre de 1923, p. 1. El titular, evidentemente, sí procuraba impactar sobre el público.

${ }^{150}$ Continuaron llegaron a Salamanca soldados de La Victoria durante los días 27 y 28 de octubre de 1923: "La segunda expedición de las fuerzas de La Victoria", El Adelanto, n 12.094, 28 de octubre de 1923, p. 6; "Llegada de la segunda expedición de soldados de La Victoria", La Gaceta Regional, n 962, 27 de octubre de 1923, p. 1. También, otros setenta hombres, que habían estado dispersos por la zona oriental, llegaron, a principios de enero de 1924: "Repatriación de los soldados de cuota del 21", El Adelanto, $\mathrm{n}^{\circ}$ 12.277, 1 de junio de 1924, p. 1; "La llegada de los soldados de La Victoria", La Gaceta Regional, 5 de enero de 1924, p. 1.

151 "La llegada de las fuerzas de La Victoria. Bienvenidos", La Gaceta Regional, n 961, 26 de octubre de 1923, p. 1.
} 
calles, llenas de gente, el público se apiña para verlos marchar. En sus pecho alienta el espíritu de la raza"152.

Lo que no se echó de menos en el periódico conservador salmantino fue, en cambio, el recuerdo de las catorce víctimas de la tragedia de Ain-Hedid. Habían pasado dos años desde aquella desgracia:

"Es dolorosamente posible que de ellos sólo se acuerden las familias a congojadas (...) Pero casi todos los que, impotentes, nos encontrábamos cerca del sitio maldito donde perecieron aquellos camaradas, tendremos hoy para ellos, un recuerdo piadoso, que nos brotará espontáneo del mismo meollo del alma.

Muchas veces nos condolimos de nuestra falta de sensibilidad para los que cayeron sirviendo a España en el terruño ingrato del Magreb. Como si estuvieran agotadas las fuentes de caridad y de sentimentalismo en todos nosotros, nadie ha pensado en tributar un homenaje a los pobres caídos de la Victoria. En la medida de nuestras fuerzas queremos nosotros subsanar la ingratitud que reprochamos consagrando a los catorce soldados que hoy hace dos años perecieron, un recuerdo fervoroso y sentido ${ }^{, 153}$.

La melancolía se había adueñado del clima de opinión. Desafortunadamente, ante el recrudecimiento de los combates y la necesidad de cubrir bajas, en agosto de 1924 otras dos compañías del regimiento de La Victoria, encabezadas de nuevo por Serviá, marcharon a Larache. Integraban la expedición 421 soldados ${ }^{154}$. La despedida en la estación fue de las más tristes habidas. Así era el relato de El Adelanto:

"Marcharon anoche a Larache las fuerzas expedicionarias del regimiento de La Victoria. Por las calles de la ciudad desfilaron los soldados. Y, a su paso, las gentes los despedían cariñosamente. La emoción de la marcha, anidó en todos los pechos salmantinos. Y fue tan severa, como sencilla y sobria la despedida.

Una vez más Salamanca ha visto marchar a sus soldados a África (...) Tuvo el acto de ayer, serio y breve, sin grandes estruendos ni alharacas, la ejemplaridad de la raza española, de tan fuerte temple como pródigo espíritu de sacrificio" ${ }^{\text {"155. }}$.

La Gaceta, en cambio, prefirió jugar al despiste reproduciendo una extensa arenga del coronel Pérez Fernández a las tropas ${ }^{156}$. En octubre, por si no fuera suficiente, otro escuadrón con 150 individuos, en esta ocasión de La Albuera, salió para Larache. Excepcionalmente, el adiós tuvo más relumbrón del acostumbrado porque se

\footnotetext{
152 “¡Paso a los soldados de La Victoria!”, La Gaceta Regional, n 961, 26 de octubre de 1923, p. 1.

153 "In memoriam. El convoy de Ain-Hedid", La Gaceta Regional, no 1.160, 24 de junio de 1924, p. 1.

154 Actas de la Comisión Permanente de la Diputación de Salamanca. Archivo de la Diputación provincial, vol. 1924, fol. 75 (r)-76 (v). En la sesión celebrada el 19 de agosto de 1924, se acordó obsequiar a las tropas con 500 pesetas. "Esta noche, a las ocho, marchan a Larache dos compañías del regimiento La Victoria", El Adelanto, no 12.343, 19 de agosto de 1924, p. 3; "Despedida", La Gaceta Regional, $\mathrm{n}^{\circ}$ 1.206, 19 de agosto de 1924, p. 1; "Soldados de La Victoria en África", La Gaceta Regional, $\mathrm{n}^{\mathrm{o}} 1.206,19$ de agosto de 1924, p. 6.

155 "Aspectos de la ciudad. Despedida", El Adelanto, n' 12.344, 20 de agosto de 1924, p. 1.

156 “La marcha de los soldados de La Victoria”, La Gaceta Regional, no 1.207, 20 de agosto de 1924, p. 2.
} 
hallaba en la capital con motivo de la inauguración del curso escolar, en aquellos días, el príncipe de Asturias. Por eso un redactor del diario liberal salmantino escribía:

"La premura de tiempo ha impedido organizar debidamente la despedida; sin embargo, el Ayuntamiento y la Diputación han entregado cada uno 500 pesetas, para ser repartidas entre los soldados expedicionarios.

También el presidente de la Cruz Roja, en nombre de esta institución, ha donado 200 pesetas.

Los soldados de Albuera, como decimos anteriormente, fueron despedidos con gran entusiasmo, habiendo producido su marcha gran impresión ",157.

La Gaceta, por su parte, reparaba en la actitud de los soldados: "Tan animados se hallaban éstos de un gran espíritu militar, y tan llenos de entusiasmo, que uno de ellos (...) abrazó y besó a su coronel, con el encargo que lo transmitiese a su madre, en el supuesto de que él no volviese de África" ${ }^{\text {"158. }}$.

Al aproximarse la Navidad, como de costumbre, la nostalgia, sin embargo, pesaba como una losa sobre la opinión pública salmantina. Así que de la Cruz Roja surgió la idea de abrir una suscripción para costear una suculenta cena a todos los salmantinos combatientes en Marruecos ${ }^{159}$. Se constituyó, como en 1921, una Junta Patriótica, integrada por el gobernador militar, el presidente de la Diputación y el de la Cruz Roja, pero su poder de convocatoria no fue, ni por asomo, parecido al de entonces $^{160}$. En la prensa ya no aparecieron aquellos largos listados de suscriptores ${ }^{161}$.

\footnotetext{
157 “Un escuadrón de Albuera sale para Larache. El príncipe de Asturias en la estación”, El Adelanto, n ${ }^{\circ}$ 12.380, 1 de octubre de 1924, p. 6.

158 "Sale para África un escuadrón del regimiento de Albuera", La Gaceta Regional, $\mathrm{n}^{\circ} 1.243,1$ de octubre de 1924, p. 4.

159 "Homenaje a nuestros soldados de La Victoria y Albuera", El Adelanto, n' 12.403, 28 de octubre de 1924, p. 1; "Una atención de simpatía. Por nuestros soldados combatientes", La Gaceta Regional, n 1.262, 23 de octubre de 1924, p. 1; "Nuestra gratitud", La Gaceta Regional, $\mathrm{n}^{\circ} 1.263,24$ de octubre de 1924, p. 1; "El homenaje de simpatía a nuestros soldados combatientes", La Gaceta Regional, no 1.265, 27 de octubre de 1924, p. 1.

160 "Homenaje a los soldados de Albuera y de La Victoria que luchan en África", El Adelanto, n' 12.406, 31 de octubre de 1924, p. 1; "El aguinaldo del soldado", El Adelanto, no 12.409, 4 de noviembre de 1924, p. 1; "Por nuestros soldados expedicionarios", La Gaceta Regional, $\mathrm{n}^{\circ}$ 1.269, 31 de octubre de 1924; "Para los soldados de Albuera y La Victoria en África", La Gaceta Regional, n' 1.270, p. 3; "El aguinaldo del soldado. Por nuestros soldados combatientes", La Gaceta Regional, $\mathrm{n}^{\circ}$ 1.297, 4 de diciembre de 1924, p. 1. La Diputación fue la institución local que más se volcó en la preparación de este homenaje en honor de La Albuera: Actas de la Comisión Permanente de la Diputación de Salamanca. Archivo de la Diputación provincial, vol. 1924, fol. 97 (r)-98 (v). En la sesión del 28 de octubre de 1924 se aprueba la donación de 500 pesetas. Entretanto, en el Ayuntamiento se aprobaron dos donativos, pero no a favor de los salmantinos. Se consignaron 100 pesetas para homenajear a la duquesa de La Victoria; y otras 50 pesetas para la Junta de Damas de Ceuta. Actas de las Sesiones Municipales. Archivo Histórico Municipal, vol. 1923-1924, fol. 267.

${ }^{161}$ Curiosamente, La Gaceta sí reprodujo una carta que se remitió a algunas destacadas personalidades salmantinas para "animarles" -coaccionándolos- a participar en la colecta y dar ejemplo: "Muy señor nuestro: la comisión nombrada para organizar el homenaje que ha de tributarse a los soldados de los regimientos de Albuera y de La Victoria, que se encuentran en Marruecos, y del que ya tendrá usted conocimiento por la prensa local, conociendo, como conoce, sus sentimientos caritativos, su patriotismo y el afecto y amor que le inspira todo lo que a esta noble ciudad se refiere-cuyas cualidades son innatas
} 
Tan sólo la recaudación final: 15.000 pesetas ${ }^{162}$. En cambio, sí que se denunció el desconsuelo de aquellas madres que todavía esperaban el regreso del remplazo de $1921^{163}$. Y también se reprodujo la carta de protesta de algunos soldados que, una vez más, por no pertenecer ni a La Victoria ni a La Albuera iban a quedar excluidos del aguinaldo $^{164}$.

Ramón Jerez, al término de 1924, notificaba a La Gaceta que las fuerzas de infantería salmantina iban a iniciar un repliegue ${ }^{165}$. Y a principios de 1925 , ahora en sus crónicas para El Adelanto, daba cuenta extensa de cómo se había producido el mismo hasta el campamento de Teffer: "Emplazado a media falda del macizo de Ahl Serif, es el punto de unión de las cábilas de Ahl Serif, Sumata y Beni Issef, y cuyas cábilas separa

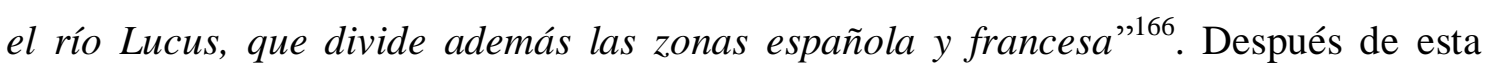
retirada, a mediados de marzo, al fin, se pudo anunciar la repatriación de la quinta de $1921^{167}$. Compuesta por 475 hombres que "cumplieron todos con su deber (...) ¿qué menos que mostrarles el más acendrado amor y el agradecimiento más profundo?"168.

e inherentes a todos sus hijos- acude a usted, una vez más, y una vez más confía y espera que, haciendo uso de sus nobilísimos sentimientos de amor, caridad y patriotismo, de los que tan reiteradas pruebas tiene dadas, se apresurará a tomar parte en la suscripción". En "Para los soldados de Albuera y La Victoria", La Gaceta Regional, no 1.276, 10 de noviembre de 1924, p. 1.

162 "Distribución del aguinaldo del soldado", El Adelanto, no 12.449, 20 de diciembre de 1924, p. 1; "El aguinaldo del soldado", La Gaceta Regional, no 1.309, 19 de diciembre de 1924, p. 1; "El aguinaldo del soldado", La Gaceta Regional, no 1.309, 19 de diciembre de 1924, p. 1. En la sesión del 15 de noviembre de 1924, el Cabildo Catedralicio decidió contribuir a esta campaña del aguinaldo con la donación de 100 pesetas. Véase Actas Catedralicias, n 80, años 1919-1945. También desde el Obispado se requirió la colaboración de las parroquias de la provincia, que llegaron a recaudar 6.213 pesetas. Consúltese Boletín Oficial del Obispado de Salamanca, 1 de enero de 1925, nº 1.

163 "Las madres de los soldados del remplazo de 1921 visitan a los gobernadores civil y militar", El Adelanto, $\mathrm{n}^{\circ}$ 12.422, 19 de noviembre de 1924, p. 1. Aunque, como ya se subrayó, pocos días después el Directorio anunció el comienzo de las repatriaciones.

164 “Los soldados salmantinos en África dicen...", El Adelanto, no 12.441, 11 de diciembre de 1924, p. 1.

${ }^{165}$ Ramón Jerez: "Las operaciones en Larache”, La Gaceta Regional, no 1.301, 10 de diciembre de 1924, p. 1; Ramón Jerez: "Crónica de la guerra”, La Gaceta Regional, no 1.305, 15 de diciembre de 1924, p. 1; Ramón Jerez: “Crónica de la guerra”, La Gaceta Regional, no 1.1312, 23 de diciembre de 1924, p. 1.

${ }^{166}$ Ramón Jerez: "El Adelanto en la guerra. Retirada de nuestras tropas a la línea definitiva”, El Adelanto, $\mathrm{n}^{\circ}$ 12.450, 2 de enero de 1925, p. 2; También Ramón Jerez: “El Adelanto en la guerra”, El Adelanto, n' 12.487, 4 de febrero de 1925, p. 1 .

167 "Repatriación del batallón expedicionario de La Victoria", La Gaceta Regional, n" 1.380, 16 de marzo de 1925, p. 1; "La repatriación del batallón de La Victoria", La Gaceta Regional, no 1.381, 17 de marzo de 1925 , p. 1.

168 "El batallón de La Victoria, que está en Arcila, va a regresar a Salamanca", El Adelanto, no $12.522,17$ de marzo de 1925 , p. 1 . Sobre los pormenores del viaje: "El regreso de las fuerzas de La Victoria", El Adelanto, $\mathrm{n}^{\mathrm{o}}$ 12.526, 21 de marzo de 1925, p. 1; "El batallón de La Victoria va a regresar de África y debe tributársele el recibimiento que merece", El Adelanto, n ${ }^{\circ}$ 12.530, 26 de marzo de 1925, p. 3; "Esta noche, a las once, llegará el batallón expedicionario de La Victoria", El Adelanto, no 12.534, 31 de marzo de 1925, p. 1. En cuanto a La Gaceta, Ángel Moisés refirió la alegría de los expedicionarios: Ángel Moisés: "Crónicas de Marruecos. El regreso de los soldados de La Victoria", La Gaceta Regional, no 1.382, 18 de marzo de 1925, p. 6. También desde este periódico, por descontado, se alimentó la idea de prepararles un homenaje: "El regreso del batallón de La Victoria", La Gaceta Regional, nº 1.383, 20 de marzo de 1925, p. 6. 
El 1 de abril llegaban, en efecto, a la capital los expedicionarios salmantinos, tras casi cuatro años de ausencia. Un día antes, en la primera plana de La Gaceta, un editorialista recordaba:

"Desde la noche del 25 de agosto de 1921, en que partía para África el batallón de La Victoria, hasta el día de su regreso a Salamanca, han desfilado por los cuadros expedicionarios centenares de hombres jóvenes que aprendieron en duras jornadas toda la significación e importancia de los deberes para con la patria.

Los soldados del Vencedor han conocido de toda clase de fatigas y peligros, de la dureza de las grandes marchas, del cansancio de las interminables noches de parapeto, de los tormentos del hambre y de la sed, de la desesperación de las plúmbeas horas de aburrimiento, de las balas y las gumias del enemigo siempre en acecho (...) Estos cuarenta y tres meses de campaña con sus variaciones y trastornos, han servido para evidenciar las condiciones guerreras de los soldados de La Victoria, lo mismo (...) en los días en que las bayonetas españolas se adentraban en el corazón de Beni Arós, hasta Tazarut y Ain-Grana, los últimos cubiles de El Raisuni, como en los otras más recientes del repliegue

Aunque los andenes de la estación estuvieran repletos de gente, la atmósfera que describió la prensa local fue de "expectación de recogimiento", no de alegría. Y tampoco en esta ocasión faltó la nota pintoresca, o más bien repulsiva: "Trae el batallón, permítasenos la frase, su especie de mascota, un lindo morito de pocos años, vestido a la usanza de su raza, que ha estado siempre con el batallón en campaña, que procede del poblado de Tazarut ${ }^{\prime 170}$. Efectivamente, con su chilaba, babuchas y el gorro de los Regulares, un niño de trece años, Alí, acaparó todas las miradas de los salmantinos. Y también con sus declaraciones. A un periodista, con notables dificultades para hacerse entender, le contó que iba a cambiarse el nombre por, nada menos, que el de Manuel Español. La bienvenida, al margen de estos detalles, consistió en la celebración de un Te Deum en la plaza de Anaya y un banquete, para los jefes y la oficialidad, en el Hotel Comercio ${ }^{171}$. La Gaceta, en esta ocasión, intentó salir del paso con una colaboración de Pérez Alfonso, un último intento por justificar la tan duradera contienda ante la opinión: "Con la imaginación hemos acompañado a estos bravos en su viaje a la tierra marroquí, que, por atavismos de la historia y por razones de orden geográfico y político, necesitamos mirar con la debida atención y cuidado, para que las generaciones venideras no estampen sobre nuestra tumba el estigma de la ineptitud y

\footnotetext{
169 "El regreso del batallón de La Victoria", La Gaceta Regional, n 1.391, 30 de marzo de 1925, p. 1.

170 "La llegada del batallón de La Victoria", El Adelanto, no 12.535, 1 de abril de 1925, pp. 1-2.

171 "Los actos celebrados ayer en honor de los expedicionarios de La Victoria", El Adelanto, $\mathrm{n}^{\circ}$ 12.536, 2 de abril de 1925, p. 1. Durante el banquete, pronunciaron sonoros discursos Ceferino Pérez Fernández y Servía, coroneles del regimiento, y el ya conocido Ramón Jerez. En "El homenaje a la oficialidad del batallón expedicionario de La Victoria", El Adelanto, no 12.537, 3 de abril de 1925, pp. 1-2; "El regreso del batallón de La Victoria. Salamanca le tributa un entusiasta y cariñoso recibimiento", La Gaceta Regional, $\mathrm{n}^{\circ} 1.393,1$ de abril de 1925, p. 1.
} 
falta de previsión" ${ }^{172}$. Días después, los treinta y tres soldados que más se habían destacado en África fueron obsequiados con cartillas de ahorro, con un valor de 25 pesetas, donadas por la Cruz Roja y el Banco del Oeste ${ }^{173}$.

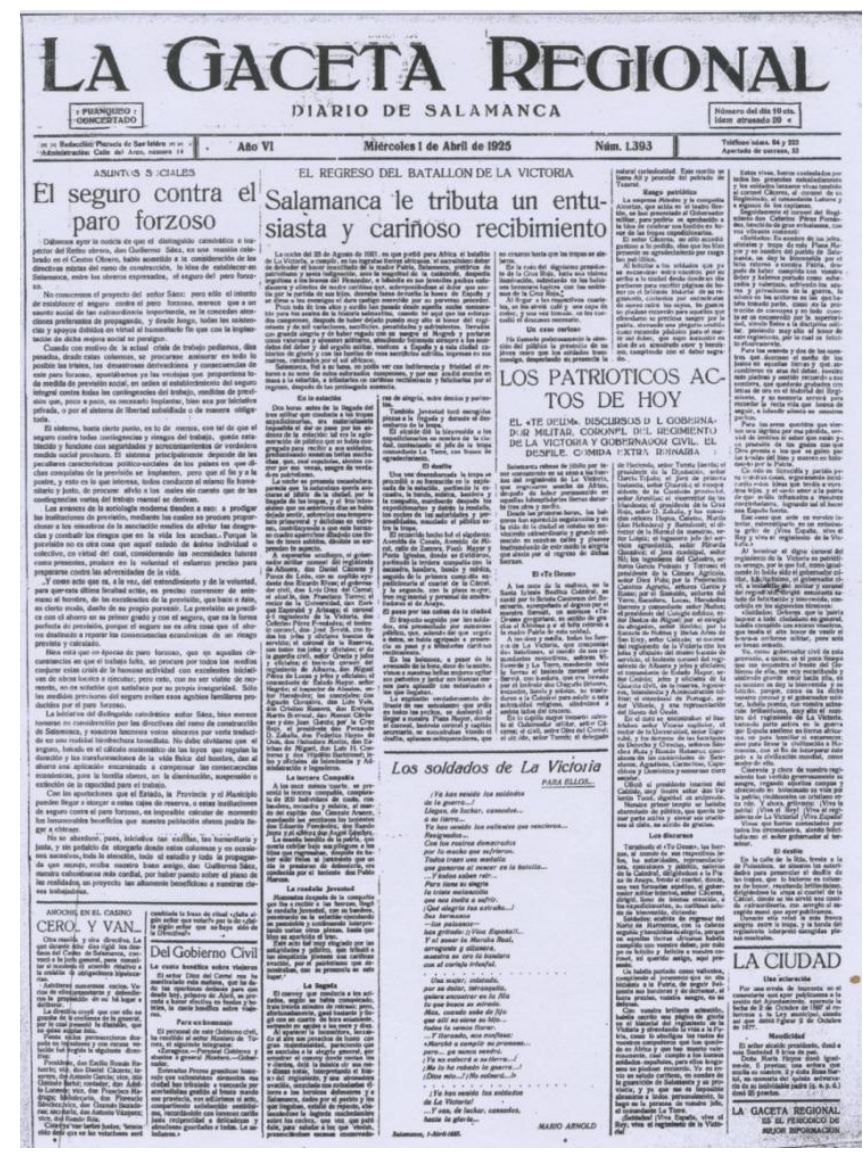

La Gaceta Regional, $\mathrm{n}^{\mathrm{o}} 1.393,1$ de abril de 1925, p. 1.

Apenas un mes después, a principios de mayo, también La Albuera regresó a la capital del Tormes y asimismo se procuró desde la prensa que la ciudadanía la acogiese como correspondía:

"Hace poco, Salamanca, con sus autoridades y corporaciones recibió como merecía a las tropas de infantería de La Victoria, que en Marruecos cumplieron también con su deber.

Dentro de unos días, regresará un puñado de soldados de caballería de Albuera, merecedores, asimismo, de iguales honores y consideraciones. Y es de esperar, una vez más, que dándose de ello cuanta nuestras autoridades, y pensado, necesariamente, por amor patrio y al Ejército, del mismo modo que nosotros dejamos expresado, estén ya

\footnotetext{
${ }^{172}$ Pérez Alfonso: "Soldados de La Victoria. Bienvenidos seáis", La Gaceta Regional, n 1.394, 2 de abril de 1925 , p. 1.

173 "En honor de los soldados de La Victoria que se distinguieron en África", El Adelanto, n ${ }^{\circ} 12.541,8$ de abril de 1925, p. 1; "El reparto de cartillas de ahorro a los soldados del batallón expedicionario de La Victoria", La Gaceta Regional, n 1.398, 7 de abril de 1925, p. 1.
} 
apercibidos de la llegada y preparando, en honor de los combatientes, la recepción y los agasajos a que se hicieron acreedores ${ }^{, 174}$.

No obstante, cuando los 123 jóvenes llegaron a la ciudad, el 10 de mayo de 1925, el recibimiento tampoco fue todo lo festivo que se esperaba ${ }^{175}$. De nuevo, a la impuntualidad del tren y a la lluvia se les achacó la discreción del acto ${ }^{176}$.

\section{SALAMANCA Y EL DESEMBARCO DE ALHUCEMAS}

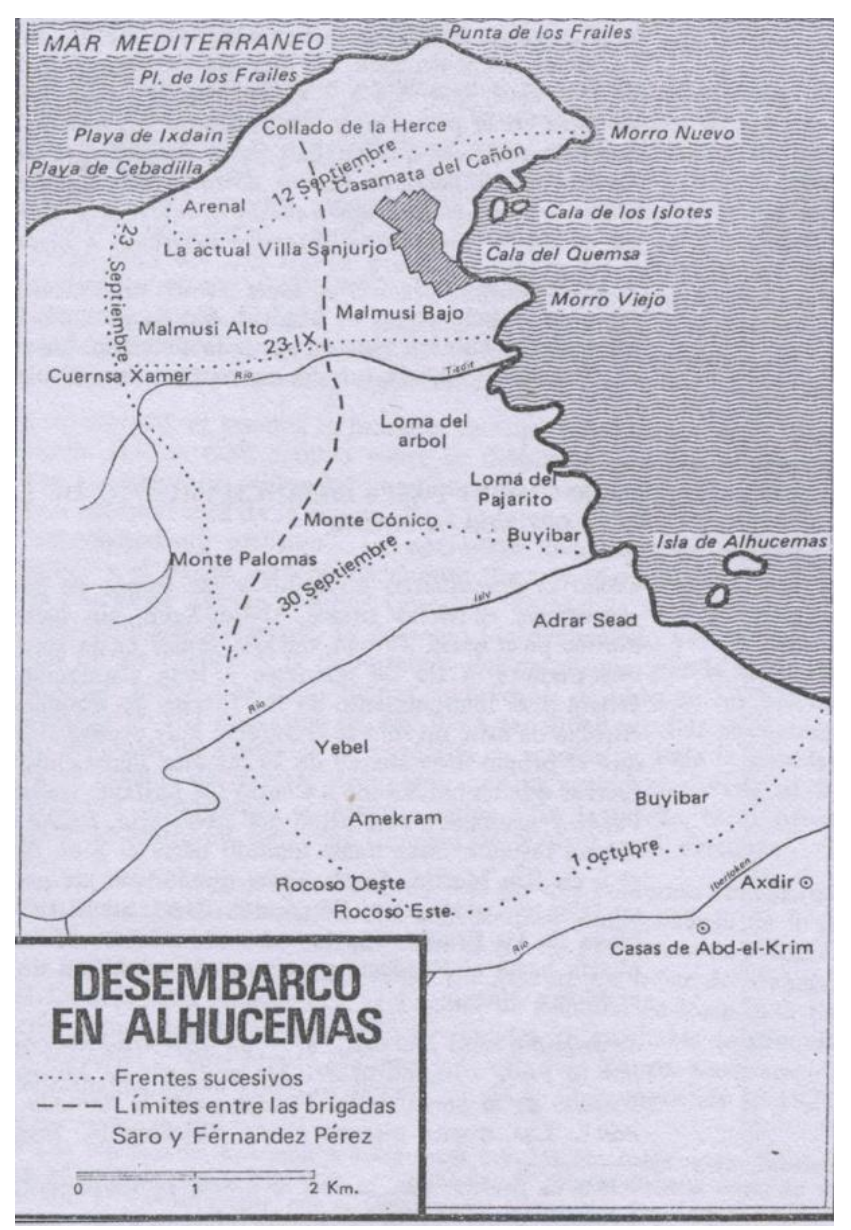

MARTÍNEZ DE CAMPOS, Carlos: Op. Cit., p. 306.

Se hallaba Salamanca atestada de gente, expectante ante el inicio de sus tradicionales ferias y comentando el cartel taurino, cuando el 9 de septiembre de 1925

\footnotetext{
174 “Ante el regreso de unos soldados", El Adelanto, no 12.564, 7 de mayo de 1925, p. 1. La Gaceta también recogió idéntica noticia: "La repatriación del escuadrón de Albuera", La Gaceta Regional, 8 de mayo de 1925, p. 1.

175 “El escuadrón de Albuera llegará esta tarde", El Adelanto, n 12.567, 10 de mayo de 1925, p. 1; "El escuadrón de Albuera llegará mañana, a las seis de la tarde", La Gaceta Regional, no 1.424, 9 de mayo de 1925 , p. 1.

176 "La llegada del escuadrón de Albuera", El Adelanto, no 1.2.568, 12 de mayo de 1925, p. 3; "Regreso del escuadrón de Albuera", La Gaceta Regional, n 1.425, 11 de mayo de 1925, p. 2.
} 
Alfredo Rivera encabezó su sección periodística con un gran titular: "Las tropas españolas desembarcan en territorio de Alhucemas con escasas bajas" ${ }^{177}$. Y lo propio hacía Barreto, aunque con un tono más efectista, llamando la atención sobre el papel desempeñado por la aviación y el coraje de los combatientes en África. Así, escribía para La Gaceta: "Detalles del desembarco en Morro Nuevo; nuestros soldados entusiasmados se lanzan a la orilla con el agua al cuello"178.

Muy sorprendentemente, sin embargo, de lo que no dió cuenta El Adelanto (tampoco el diario conservador) un día antes -el 7 de septiembre- fue de que, una vez más, un batallón de La Victoria partía hacia África. Parece improbable, de todos modos, que se pudiese ocultar semejante información, dado que en una ciudad pequeña las noticias evidentemente corrían de boca en boca. Pero habría que esperar hasta el 24 de septiembre para que Luciano Martín, el soldado-escritor de turno, relatase a los lectores del periódico liberal el momento de la despedida, todas las incidencias del viaje en tren hasta Málaga y del traslado hasta la posición de Laucién, ubicada a tan sólo ocho kilómetros de Tetuán, en la carretera hacia Tánger ${ }^{179}$. Un ejemplo pasmoso de ocultamiento de información, sin duda, para no alertar a la opinión pública local.

Porque lo primero, lo que se antepuso a todo lo demás, fue el triunfo. En efecto, los soldados españoles habían ocupado la bahía de la Cebadilla, en la península de Morro Nuevo, y el júbilo gubernamental parecía del todo indescriptible. Sin embargo, curiosamente, en el mismo ejemplar de El Adelanto, no había ni la más mínima mención sobre la atmósfera generada por esta sensacional noticia en la ciudad del Tormes.

Pero, ¿por qué no hubo una celebración ciudadana similar a aquélla, ya casi olvidada, tras la toma de Atlatén? ¿Sería ésta, de verdad, la definitiva campaña en Marruecos?

El "espíritu público" se mostraba, qué duda cabe, ya muy distante de aquel viejo fervor belicoso que tradicionalmente acompañaba a los conquistadores. Pero también, por suerte, más interesado, alertado si se prefiere, por la contienda. Marruecos estaba desempeñando un importante papel en el proceso, siempre lento, de concienciación política de los salmantinos.

\footnotetext{
177 Alfredo Rivera: "Conferencias telefónicas", El Adelanto, no 12.671, 9 de septiembre de 1925, p. 5.

${ }^{178}$ Delgado Barreto: "Nuestras conferencias telefónicas de esta tarde", La Gaceta Regional, 9 de septiembre de 1925, p. 5.

${ }^{179}$ Luciano Martín: "El batallón de La Victoria en África", El Adelanto, no 12.684, 24 de septiembre de 1925, p. 3.
} 
Únicamente el 3 de octubre de 1925, cuando se produjo la efectiva entrada del Ejército de África en Axdir, las calles salmantinas se engalanaron con colgaduras, aunque sólo después de los llamamientos del entonces alcalde, Florencio Sánchez, y del gobernador militar, Daniel Cáceres ${ }^{180}$. Se habían necesitado tres semanas para vencer la resistencia de los Beni Urriaguel. Además, desde El Adelanto, un columnista terminaba su reseña del "día patriótico" con un oscuro recuerdo: "La victoria definitiva cerrará para siempre las etapas sangrientas registradas en Marruecos, principalmente, desde $1909 " 181$. Todo, en resumen, muy comedido.

Consciente del atractivo mediático de la campaña, El Adelanto aprovechó la ocasión para recoger en sus páginas las opiniones y crónicas de dos autoridades en la materia, dos de los corresponsales de guerra más reputados de esta época. Uno de ellos fue Antonio de Lezama (1882-1971). Este periodista vasco se había iniciado escribiendo en El Liberal, si bien su figura se había consolidado gracias a sus colaboraciones con $L a$ Libertad, de Luis de Oteyza. De conocidas ideas republicanas, anticlerical y antimilitarista, acabaría exiliándose a Chile durante el Franquismo, regresaría a su tierra natal en 1970 y fallecería un año más tarde.

Entre las mayores virtudes de sus crónicas destacaron, consideramos, las observaciones acerca del proceder de sus colegas. Su primera colaboración con el diario salmantino, redactada en vísperas de la operación anfibia, fue publicada el 12 de septiembre de 1925. Había volado hasta Algeciras con Sanjurjo y, posteriormente, se había desplazado hasta Tetuán. En esta plaza, como en Alhucemas, a la espera de un contraataque rifeño, los preparativos españoles eran incesantes. Y también el ajetreo de los periodistas:

"La prensa española ha enviado a esta abominables tierras, redactores especializados, y es ahora cuando, vestidos arbitraria y pintorescamente, nos lanzamos a la aventura, ávidos de emociones, soñando con informar minuciosamente a nuestros periódicos de cuanto por aquí ocurre, sin ocultar nada, haciendo justicia que, si de algo peca, es de benigna y generosa", ${ }^{\prime 182}$.

Esta avidez por la obtención de noticias pretendía inculcar en el público lector, con seguridad, entusiasmo. Al fin y al cabo, insistía el reportero, en su crónica del día 8 , ahora escrita desde un barco frente a Sidi-Dris y publicada en Salamanca cinco días más tarde, el nombre de Alhucemas "despierta en nosotros profundas resonancias y no

\footnotetext{
180 "El día patriótico de ayer por la conquista de Axdir", El Adelanto, n 12.693, 4 de octubre de 1925, p. 3.

${ }^{181}$ Ibidem.

182 Antonio de Lezama: "Nuestras crónicas de la guerra", El Adelanto, n $12.674,12$ de septiembre de 1925 , p. 3.
} 
podemos olvidar que alrededor de él ha girado desde hace varios años buena parte, la más importante acaso, de la política española" ${ }^{183}$. Su relato del desembarco, que continuaba en primera persona, tuvo que resultar, por fuerza, de lo más conmovedor:

"Nuestros gemelos de campaña se dirigen ahora hacia la playa de Cebadilla.

Las barcazas se van acercando. Dentro bullen los hombres, inclinados hacia adelante, donde se refleja su voluntad inflexible de avanzar. Con ellos va tal vez la muerte, pero la muerte parece en esta ocasión una compañera amable que les enardece, que les empuja hacia la playa.

Tienen prisa por llegar, tanta, que no esperan a que las barcazas atraquen y se tiran al agua, porque sus pies ágiles pueden correr más, llevados por su ímpetu heroico, aún hundidos en la arena y con agua hasta más arriba de la cintura.

Ese momento en que los legionarios van saliendo del mar, con el fusil en alto y dando vivas clamorosos, en tanto truena la metralla por todas partes y la tierra que van a hollar semeja un volcán en erupción, es de una grandeza trágica inenarrable.

Legionarios y harqueños invaden la playa (...) Victoria completa (...) Después de la batalla, al anochecer, el silencio y la serenidad son sedantes que aquietan nuestra sensibilidad alterada".

Y no sólo eso. El 9 de septiembre, acompañando a dos banderas del Tercio, él mismo arribó a la playa de la Cebadilla: "No puedes imaginarte, lector, de qué modo cantan los legionarios, los niños grandes, los indisciplinados de la vida que voluntariamente se someten a la mayor y más dura disciplina. Cantan con el corazón más que con la garganta" ${ }^{\text {"184. }}$

De nuevo, el día 13, Lezama remitía otra, y muy extensa crónica a El Adelanto. Publicada cinco días después en Salamanca, el cronista confesaba que la improvisación había estado siempre presente en el desarrollo del desembarco porque el ataque de Abdel-Krim sobre Tetuán había obligado a ello: "Las sucesivas modificaciones del plan de desembarco, efectuadas según repetidamente se ha dicho para desorientar al enemigo, casi terminaron por desorientarnos a nosotros" ${ }^{\$ 185}$. En cualquier caso, no sólo la fortuna había acompañado al Ejército de África.

Por eso, otra técnica empleada para generar satisfacción entre la opinión pública salmantina, fue el simple elogio de la más moderna tecnología militar: "La aviación, con sus hidroplanos, y las escuadras, con sus acorazados fuertes y los submarinos, son elementos que garantizan la independencia nacional" ${ }^{186}$. Como consecuencia, evidentemente, las inversiones en la operación quedaban así justificadas.

\footnotetext{
${ }^{183}$ Antonio de Lezama: "El desembarco visto desde El Lázaro", El Adelanto, n 12.675, 13 de septiembre de 1925 , p. 3.

${ }^{184}$ Antonio de Lezama: "Nuestras crónicas de la guerra. Los novios de la muerte", El Adelanto, n 12.677, 16 de septiembre de 1925 , p. 1.

${ }^{185}$ Antonio de Lezama: "El factor imprevisto", El Adelanto, no 12. 679, 18 de septiembre de 1925, p. 3.

186 “La marina de guerra y la aviación”, El Adelanto, no 12.676, 15 de septiembre de 1925, p. 1.
} 
Por descontado, tampoco faltó el aplauso hacia el heroísmo de la tropa, ensalzado, más si cabía, por la resistencia y preparación del enemigo a batir:

"El enemigo no es un grupo de salvajes, sino un Ejército, aunque rudimentariamente organizado, lo bastante numeroso y lo suficientemente inteligente para demostrar que guerrea iluminado por la táctica militar. Entre los rebeldes se encuentran europeos diestros en las artes de la guerra que han aleccionado, y en cierto modo, civilizado, a los rifeños combatientes. Disponen éstos de material de guerra abundante, cañones, bombas de mano y hasta es posible que hayan intentado poseer aviación propia (...) Estamos todavía algo lejos del fin de la campaña de Marruecos, pero sea pronto o tarde, con más o menos provecho, cuando pongamos la palabra fin en nuestra obra de colonización en Marruecos, ninguna nación podrá entonces poner en duda que desde el mismo instante en que España aceptó un compromiso de intervención en Marruecos, puso cuanto estaba de su parte, en heroísmo, en hombres y en dinero",187.

En sus crónicas, además, Lezama seguía esbozando una atmósfera repleta de impaciencia: "El público español, a pesar de lo repetido de la experiencia, mira de nuevo ansiosamente hacia África (...) Espera diariamente la impresión de los cronistas con la esperanza de hallar, en un detalle, en un dato concreto, en una pincelada la sensación cabal de lo que ocurre" $" 188$. Y advertía a los lectores acerca de las dificultades para desempeñar su oficio:

"Característica de esta fase de la campaña de Marruecos es la dificultad con que tropezamos los periodistas que hemos traído aquí la misión de informar (...) Nuestros artículos han de ir 'necesariamente' a Melilla por mar y para eso hay que aguardar a que haya ocasión (...) El lector no debe olvidar que entre él y mi pluma existe en todo momento un lápiz rojo (...) Meridionales siempre, los españoles hemos desembarcado con un entusiasmo y un impulso capaz de hacernos llegar al fin del mundo. Pero, como siempre, la natural indolencia nos han aplatanado, y en los riscos de Morro Nuevo, en las playas de la Cebadilla, en las barrancadas inhóspitas permanecemos días y días, aguantando, estoicamente, el fuego de cañón, de ametralladora, de bombas de mano y de fusil que nos hace incesantemente el enemigo, causándonos bajas lamentables y desgastando nuestras energías ${ }^{\text {"189. }}$.

Diríase que también el ánimo de este corresponsal de guerra empezaba a decaer.

Reconocía sentirse prisionero, aislado del mundo porque "carecemos de telégrafo y el correo es algo inseguro y problemático por el temporal y la falta de barcos" ${ }^{190}$.

Denunciaba, asimismo, que muchos colegas de profesión no se desplazaban hasta los lugares peligrosos, limitándose al empleo de partes oficiales.

Pero hasta finales de septiembre no se reanudó el avance por el territorio de Alhucemas: "Va a encontrarse el enemigo entre dos fuegos y entre dos potentes

\footnotetext{
187 “Enseñanzas de la guerra”, El Adelanto, no 12.680, 19 de septiembre de 1925, p. 1.

${ }^{188}$ Antonio de Lezama: "Nuestras crónicas de la guerra. Axdir, Axdir", El Adelanto, no 12.681, 20 de septiembre de 1925, p. 1 .

${ }^{189}$ Antonio de Lezama: "Nuestras crónicas de la guerra. Con la misma piedra", El Adelanto, n 12.683, 23 de septiembre de 1925, p. 1.

${ }^{190}$ Antonio de Lezama: "Nuestras crónicas de la guerra. Ante el avance", El Adelanto, no 12.687, 27 de septiembre de 1925, p. 1 .
} 
Ejércitos que en pleno avance, el francés y el español, van a darse la mano después de aplastar al adversario. Tengamos fe y confianza"191. Lezama rápidamente celebró la ocupación de Morro Nuevo e, incluso, a pesar de recibir una herida de metralla, conmovido aseguró: "Lo que ha hecho agolpar las lágrimas en mis ojos es el valor (...) de estos soldados que asisten a esta lucha cruenta estoicamente"192.

En Laucién, entretanto, los soldados de La Victoria dedicaban su tiempo a la instrucción militar y rompían con la monotonía de la vida en campaña, viajando ocasionalmente hasta Tetuán ${ }^{193}$. Su estancia en África parecía ser de lo más relajada, únicamente pendiente de que se estabilizasen las posiciones en el frente oriental.

Para el diario liberal, indudablemente, las colaboraciones de un célebre cronista como Lezama habían redundado en un incremento de sus ventas. Así que dispuesto a aprovechar el renacido tirón público de la campaña marroquí, el periódico también contrató los servicios de Rafael López Rienda (1887-1928). Además de tratarse de un conocido periodista de El Defensor de Granada y El Sol, también fue un sargento de los legionarios, voluntario y con una larguísima trayectoria en África (aunque acabaría, paradójicamente, muriendo lejos del frente, en un accidente automovilístico).

Frente a esa tónica escasamente descriptiva de los movimientos militares propia de los trabajos de Lezama, un abandonista convencido, por cierto, los escritos de López Rienda se definieron por su carácter muy técnico. Por eso, en conjunto, se complementaron bastante bien y permitieron que la cobertura del desembarco, efectuada desde El Adelanto, fuese la mejor de la prensa local.

En su primera colaboración, publicada por El Adelanto el 29 de septiembre, este otro afamado corresponsal relataba el asalto a Yebel Malmusi, aclarando a los lectores que desde este enclave se podría controlar tanto Morro Nuevo como la Cebadilla ${ }^{194}$. En la siguiente, dirigía palabras de encomio hacia Abd-el-Kader y reconocía entusiasmado que "la leyenda de Axdir va desapareciendo como una nubecilla, según nuestras guerrillas avanzan" ${ }^{\prime 195}$. Y, ya a principios de octubre, López Rienda se refería a los

\footnotetext{
${ }^{191}$ Antonio de Lezama: "El avance", El Adelanto, no 12.684, 24 de septiembre de 1925, p. 1.

192 Antonio de Lezama: "El cronista, herido", El Adelanto, no 12.686, 26 de septiembre de 1925, p. 1.

${ }^{193}$ Luciano Martín: "Los de La Victoria en Laucién”, El Adelanto, no 12.695, 7 de octubre de 1925, pp. 1-

2; Luciano Martín: "El batallón de La Victoria en Laucién”, El Adelanto, no 12.706, 20 de octubre de 1925, p. 3; Luciano Martín: "El batallón de La Victoria en Laucién y las fiestas a su patrona”, El Adelanto, $\mathrm{n}^{\circ} 12.75313$ de diciembre de 1925, p. 5.

${ }^{194}$ Rafael López Rienda: "De nuestro corresponsal en la columna Saro. El asalto al Yebel Malmusi”, El Adelanto, $\mathrm{n}^{\circ} 12.688,29$ de septiembre de 1925, p. 1.

${ }^{195}$ Rafael López Rienda: "Nuestras crónicas de la guerra. Los efectos del avance”, El Adelanto, no 12.690, 1 de octubre de 1925, p. 1. Antonio de Lezama conoció la buena nueva, y así lo refirió, estando de reposo
} 
preparativos para avanzar sobre Axdir, objetivo del tercer gran asalto sobre la bahía de Alhucemas. Los españoles habrían de ocupar el Monte de las Palomas, tradicionalmente conocido por su riqueza en hierro, mientras que a los franceses le correspondía ir estrechando el cerco por tierra sobre la república rifeña ${ }^{196}$.

En efecto, el asalto de esta posición fue muy celebrado tanto por López Rienda como por un recuperado Lezama ${ }^{197}$. Asimismo, el prolífico “A.” no desperdició el momento para verter también sus juicios sobre los movimientos efectuados:

"Bajas muy sensibles nos ha costado la ocupación de Alhucemas, pero es de confiar que la sangre generosa de los heroicos oficiales y soldados españoles no haya sido derramada inútilmente en holocausto de España (...) Necesitamos permanecer en el Norte de África para que nadie pueda allí suplantarnos (...) Es de suponer que Francia y España llegarán hasta el fin y mantendrán, una vez dominado el enemigo, la inteligencia pactada. No hacerlo así significaría para muy en breve el retorno a la lucha ${ }^{, 198}$.

López Rienda, además, reparaba durante estos días en la reacción de la opinión pública: "Si España en lo que se refiere a Marruecos, no estuviese ya curtida por el dolor e insensibilizada por el desgaste de esta guerra, la entrada en Axdir la hubiese celebrada jubilosa" ${ }^{199}$. Y abundaba en las causas del escaso entusiasmo ciudadano posterior a la victoria en otro editorial, uno de los más logrados de entre los publicados por la prensa salmantina:

"El pueblo tiene derecho a que se le cuente bien el desarrollo de los acontecimientos africanos (...) El no decirle la verdad muchas veces, despistó a la opinión, desconcertó a los que se interesaban por la marcha de nuestra intervención aquí, como protectores, y terminó aburriendo a todos.

A esto se debe que España acoja ya los triunfos africanos, un poco fríamente. Diríase que recela, que desconfia de verse libre, al fin, de la larga pesadilla...

Hubo, en principio, una falta de preparación y propaganda del problema (...) Manos inhábiles intervinieron en la confección de los tratados (...) Lo que ahora nos sucede, lo que nos lleva costado África, hay que agradecérselo a quienes en el terreno diplomático así supieron defender los derechos de España...

en Melilla. Véase Antonio de Lezama: "Nuestras crónicas de la guerra. En los picos de Malmusi", El Adelanto, $\mathrm{n}^{\circ}$ 12. 692, 3 de octubre de 1925, p. 1.

${ }^{196}$ Rafael López Rienda: "Nuestras crónicas de la guerra. El tercer salto sobre Axdir", El Adelanto, no 12.693, 4 de octubre de 1925, pp. 1-2.

${ }^{197}$ Rafael López Rienda: "Nuestras crónicas de la guerra. La ocupación del monte de las Palomas", El Adelanto, $\mathrm{n}^{\circ}$ 12.694, 6 de octubre de 1925, p. 1; Antonio de Lezama: "Nuestras crónicas de la guerra. Con las fuerzas de choque", El Adelanto, $\mathrm{n}^{\mathrm{o}}$ 12.695, 7 de octubre de 1925, p. 1; Antonio de Lezama: "La casa del caid Hadu", El Adelanto, no 12.696, 8 de octubre de 1925, p. 3; Antonio de Lezama: "Nuestras crónicas de la guerra. Al salir del avispero", El Adelanto, no 12.701, 14 de octubre de 1925, p. 1.

198 “A.": "Del momento. El problema palpitante", El Adelanto, no 12.696, 8 de octubre de 1925, p. 1.

${ }^{199}$ Rafael López Rienda: "Nuestras crónicas de la guerra. Ya estamos en Axdir", El Adelanto, no 12.697 , 9 de octubre de 1925, p. 1. 
Mas no es hora de lamentaciones (...) En este momento en que la opinión se siente regocijada en parte (...) es cuando más necesita de la verdad (...) que no es sino la reducción del problema a un plano más favorable ${ }^{\text {,200 }}$.

Aunque, en efecto, las hostilidades no habían concluido ${ }^{201}$, al menos, en el campo enemigo empezaban a registrarse los primeros síntomas de desunión ${ }^{202}$. Además, el prestigio del Ejército español había quedado restaurado, o así se creía desde el diario salmantino ${ }^{203}$. López Rienda aplaudía el funcionamiento de los servicios sanitarios en Marruecos $^{204}$. Y con esto, sin más comentarios, terminaba su serie de crónicas para $E l$ Adelanto $^{205}$.

Por su parte, Antonio de Lezama, más prolífico, insistía también en que la contienda no había concluido y se indignaba porque creía que algunos periodistas engañaban descaradamente a los lectores, infundiéndoles falsas esperanzas: "Decirle al país que la campaña ha acabado es burlarse de él y jugar con el corazón de las madres, henchido de alegría al leerlo, para que luego se destroce de dolor cuando se enteren de la triste verdad con el telegrama, dándole cuenta del hijo muerto o desaparecido" 206 . De regreso ya a Madrid, lo recalcaba: "La guerra continúa siendo una obsesión y casi un martirio constante ${ }^{\text {207 }}$. Pero no sólo eso, sino que releía sus crónicas y lamentaba:

"Me consta que a cuantos fueron como corresponsales de guerra les han mutilado sus artículos o los han suprimido por completo; pero no sé de nadie que haya, en este respecto, sufrido tanto como yo. Mi pobre, pero honrada y verídica labor, es un triste guiñapo de lo que mandé en servicio de mi profesión y de mis periódicos. Sin contar extravios, más del 75 por 100 de lo escrito, sufrió los rigores de doña Anastasia, cuyos pies no beso".

\footnotetext{
${ }^{200}$ Rafael López Rienda: "Nuestras crónicas de la guerra. Frente al éxito del momento", El Adelanto, $\mathrm{n}^{\mathrm{o}}$ 12.698, 10 de octubre de 1925, p. 3. Don Rafael volvería a aludir al desinterés de parte de la opinión pública. En Rafael López Rienda: "Notas y rasgos de la ocupación de Beni Urriaguel", El Adelanto, no 12.699, 11 de octubre de 1925, p. 3.

${ }^{201}$ Así lo argumentó Villanueva en una entrevista concedida a Heraldo de Madrid y muy comentada por toda la prensa. En Alfredo Rivera: "Conferencias telefónicas", El Adelanto, n 12.702, 15 de octubre de 1925 , p. 5.

${ }^{202}$ Alfredo Rivera: “Conferencias telefónicas”, El Adelanto, no 12.698, 10 de octubre de 1925, p. 5.

203 "A.": "Del momento. Después de la victoria", El Adelanto, no 12.702, 15 de octubre de 1925, p. 1; "A.": "Del momento. Después de un homenaje", El Adelanto, n' 12.708, 22 de octubre de 1925, p. 1.

${ }^{204}$ Rafael López Rienda: "Nuestras crónicas de la guerra. Los hospitales flotantes", El Adelanto, no 12.703, 16 de octubre de 1925 .

${ }^{205}$ El Adelanto, semanas después, reseñó su libro Del Uarga a Alhucemas. En Benjamín: "Del Uarga a Alhucemas", El Adelanto, no 12.732, 19 de noviembre de 1925, pp. 1-2.

${ }^{206}$ Antonio de Lezama: "Nuestras crónicas de la guerra. Por los fueros de la verdad", El Adelanto, no 12.706, 20 de octubre de 1925, p. 1.

${ }^{207}$ Antonio de Lezama: "Nuestras crónicas de la guerra. En Madrid", El Adelanto, 27 de octubre de 1925, p. 1.
} 
Decepcionado, al poco tiempo, en noviembre de 1925, este cronista se despedía de sus lectores. Primeramente, reseñaba el nombramiento de un nuevo jalifa para la zona española y las designaciones de Sanjurjo para el cargo de Alto Comisario, Castro Girona como nuevo comandante general de Melilla y Federico Berenguer, de Ceuta. Y, luego, concluía:

"Se ha abierto un largo compás de espera que será mayor o menor, según sea el cariz del tiempo, más o menos afortunadas las negociaciones políticas o se agudice o no la agresividad de Abd-el-Krim (...) Y como a mí me parece insostenible tan largo calderón, cierro por ahora la boca y doy por terminada mi campaña informativa que, ¡ojalá no se reanude jamás, para bien de España!’208.

Los cambios políticos en el Protectorado, desde luego, no se hicieron esperar: en la zona francesa Steeg remplazó a Lyautey. Y, tal vez por esto, desde El Adelanto se manifestó abiertamente el deseo de que el Directorio Militar desapareciera, sustituido por un régimen civil $^{209}$. Pero ¿encabezado por quién? Sorprendentemente, por el mismo Primo de Rivera, ya que su capacidad de adaptación se presentaba como la mejor baza a su favor: "No ha habido para el marqués de Estella reparo alguno en rectificar convicciones anteriores (...) fue abandonista en cuanto a Marruecos, y ello le costó la Capitanía General de Madrid, y fue regionalista. Hoy opina todo lo contrario, y se comprende ${ }^{210}$. El Adelanto, anteriormente vacilante, terminaba sucumbiendo a los encantos del dictador, reconociendo sus éxitos.

En el periódico conservador, y nos centramos ya en el comentario y análisis de las opiniones publicadas en La Gaceta, además de Barreto, Alfredo Pérez Rebollo también se ocupó de elogiar al Ejército de África por su desembarco en la bahía de Alhucemas. En su editorial a propósito de la buena nueva no faltaron las palabras de agradecimiento hacia el dictador: "Que en memorable fecha dio al traste con la repugnante y nefasta política que nos hundía para siempre en el abismo, y ahora llevado de su elevado patriotismo, quiere librarnos de la pesadilla de Marruecos"211. Ramón de Olascoaga, de la misma forma, se refería a la llegada del Directorio como

\footnotetext{
${ }^{208}$ Antonio de Lezama: "Nuestras crónicas de la guerra. Punto final", El Adelanto, no 12.726, 12 de noviembre de 1925.

209 "A.": "Del momento. Orientaciones patrióticas", El Adelanto, no 12.714, 29 de octubre de 1925, p. 1.

210 "A.": "Del momento. Cuestiones fundamentales", El Adelanto, no 12.734, 21 de noviembre de 1925, p. 1.

${ }^{211}$ Alfredo Pérez Rebollo: "España en Marruecos. Una jornada gloriosa", La Gaceta Regional, no 1.529, 12 de septiembre de 1925, p. 5. Asimismo, La Gaceta tomó de La Correspondencia Militar un extenso editorial de Jaime Mariscal de Gante y en el que se aludía a las primeras divisiones entre los cabileños. En "Ha comenzado la liberación de los prisioneros", La Gaceta Regional, n 1.533, 17 de septiembre de 1925, p. 1.
} 
algo providencial y recalcaba que finalmente se había roto la leyenda acerca de la inaccesibilidad de Alhucemas ${ }^{212}$.

Se guardó silencio, sin embargo, a propósito de la nueva partida de soldados salmantinos hacia África. Tan sólo el 23 de septiembre, por tanto un día antes que El Adelanto, Pérez Alfonso les envió un saludo afectuoso:

"Los vimos marchar con la frente erguida y el aire marcial del soldado español, a quien no aventaja ninguno del mundo.

A mi lado se hallaba una mujer del pueblo, de tipo espartano. Al paso de los muchachos, los arengaba cual si fuera María Pita o Agustina de Aragón.

Yo no pude decir públicamente jadiós! a nuestros soldados. En tiempo de guerra nos exige la Patria una prudencia exquisita. Proceder de otro modo sería favorecer los planes del enemigo. Y es necesario no perder de vista que el marroquí es pérfido, astuto $y$ cruel, estando dirigidos por elementos extraños, que persiguen finalidades sospechosas ${ }^{, 213}$.

Evidentemente, con ese "yo no pude decir públicamente ¡adiós!", el columnista estaba reconociendo que el gobierno militar había prohibido entonces la circulación de la noticia.

No podían faltar, previsiblemente, las apelaciones al honor nacional resarcido:

"Los bravos soldados de España han clavado sus garras en el corazón del Rif. La montañas y los valles de Beni Urriaguel, que no lograron dominar ni los propios Sultanes y que durante siglos fueron cubiles donde engendró sus odios contra Europa la gente más fanática del Magreb, han sido hollados por la planta de nuestros soldados, que en las puntas de sus bayonetas llevaban el orgullo de una raza invencible al mismo tiempo que una misión de paz y de cultura (...) Es obligado en los días actuales, el que todo buen español sienta imbuido el espíritu de satisfacción y de orgullo. De esta manera serán rescatados repetidos pecados de indiferencia hacia la juventud que en África se ha sacrificado por los destinos de la patria. Y también podrá aprovecharse el entusiasmo de estos momentos triunfales para dedicar un cristiano piadoso recuerdo a nuestros mártires, víctimas de la crueldad berberisca, que tanto padecieron por España,"214.

En La Gaceta, sin embargo, no hallamos un despliegue periodístico comparable con el de El Adelanto. Fue "Teresa de Castilla", una colaboradora ocasional, quien se ocupó de reseñar, con un discurso bastante encendido, la toma de Axdir:

"Tan grande me parecía la notica, de tanta transcendencia, que no se me alcanzaba que lo dijeran con esa sencillez y llaneza: me parecía a mí que debía ponerse en titulares grandes... enormes, para que los vieran las madres españolas (...) Y no es que las madres españolas sean cobardes, que titubeen un instante en sacrificar su alma -en

\footnotetext{
${ }^{212}$ Ramón de Olascoaga: "El esfuerzo militar de España", La Gaceta Regional, no 1.535, 19 de septiembre de 1925, p. 1.

${ }^{213}$ Pérez Alfonso: "Los soldados del batallón expedicionario de La Victoria", La Gaceta Regional, $\mathrm{n}^{\circ}$ 1.538, 23 de septiembre de 1925, p. 4.

214 "Nuestras victorias en Alhucemas", La Gaceta Regional, $\mathrm{n}^{\circ}$ 1.547, 3 de octubre de 1925, p. 1. En la misma noticia, se recogía el telegrama de felicitación que el gobernador civil había remitido a Primo, pero tampoco en La Gaceta se reseñó ninguna celebración pública local con motivo de la victoria.
} 
holocausto a la patria, no; es que esta guerra no la sienten y así su sacrificio es más heroico, por ser menos voluntario...

Ya el honor de España lo llevan en la punta de las banderas, ondeando orgullosas sobre la tierra, regada con sangre española..., ya se vengaron afrentas que hacían vibrar el alma con crispaduras de odio y de dolor... ya ha demostrado el soldado español (jtodos, que todos lo son, desde el general al bravo hijo del cantinero!), que sin trabas y bien atendido..., llega donde llega el primero..., jmás allá, que el alma española es más grande que ninguna!',215.

También Matilde E. Mayor, con un muy semejante estilo, celebraba la conquista de este enclave:

“Al pronunciar esta palabra un frío estremecimiento sacude nuestro ser (...) Un Ejército de leones, que así puede y debe considerarse a nuestros soldados, se propuso un día, mientras sentía arder su sangre por un santo sentimiento de venganza, hacer pagar a un traidor todas sus felonías y recobrar el lugar donde sufrieron los rigores del cruel cautiverio un grupo numeroso de españoles. No se consideraban tranquilos ni satisfechos hasta tanto de ver bajo el cetro de España aquel rincón de África, cuya tierra más agradecida que el fiero beni-urriguel, acogió piadosa en su seno a parte de los mártires cautivos...

$Y$ ayudado de Dios y dirigidos por sabios jefes lo han conseguido (...) El cabecilla, incapaz de luchar frente a frente y falto de toda defensa no halló en su cobardía otro medio más seguro de salvación que la huída (...) ¡Alegraos, pues, españoles! La madre Patria terminó de sufrir ${ }^{, 216}$.

Mientras, otro columnista de la casa, "P. Y. L.”, un mes después del inicio del desembarco, por primera y única vez en la prensa conservadora, se refirió a la conducta de la opinión pública española:

"Tanto y tanto se habla de la aversión con que España mira la pesadilla de Marruecos que un franco desvio por todo lo que aquel país afecta se había apoderado de la pública opinión española (...) Aunque no con el entusiasmo desbordante que el hecho merece, el público acogió con vivísima satisfacción las gratas nuevas. A medida que lleguen a nosotros relatos de los numerosos actos de heroísmo realizados por nuestro Ejército conforme se vayan recogiendo los frutos de la victoria el fervor patriótico subirá de punto. La llegada a la patria del batallón del Infante, el distinguido entre los distinguidos, dará ocasión para que la satisfacción popular se exteriorice clamorosamente $^{, 217}$.

Tampoco faltaron los comentarios a propósito del cambio de actitud, para bien, registrado entre las páginas de la prensa francesa. Sobre todo, en el caso de Le Temps, que finalmente reconocía la valentía hispana y la acertada dirección de Primo ${ }^{218}$.

\footnotetext{
215 "Teresa de Castilla": "Nuestras victorias en Alhucemas", La Gaceta Regional, n 1.547, 3 de octubre de 1925, p. 1.

${ }^{216}$ Matilde E. Mayor y López: “iAxdir!”, La Gaceta Regional, no 1.555, 13 de octubre de 1925, p. 1.

217 "P. Y. L": "Impresión del momento actual. El triunfo de España", La Gaceta Regional, nº 1.548, 5 de octubre de 1925, p. 1.

218 "Hispanus": "Lo que Le Temps opina de los últimos acontecimientos marroquíes", La Gaceta Regional, $\mathrm{n}^{\circ}$ 1.559, 17 de octubre de 1925, p. 1; "Hispanus": "Otro artículo de Le Temps sobre Marruecos", La Gaceta Regional, n ${ }^{\circ} 1.562,21$ de octubre de 1925, p. 1. Se publicaban aquí dos extensos artículos del periódico francés que abundaban en esas ideas.
} 
La Gaceta concluía 1925 publicando alguna que otra carta pintoresca del soldado Gonzalo G. y Gallardo desde Laucién ${ }^{219}$; informando sobre los cambios en la dirección del Protectorado ${ }^{220}$; desmintiendo rumores a propósito de las perseverantes tensiones entre Francia y España ${ }^{221}$; refiriéndose, con una fuerte carga costumbrista, a la vida en el Tercio ${ }^{222}$; y, una vez más, llamando a los posibles colonizadores para acudir a Marruecos:

"Asegurada la paz en el territorio ocupado en Marruecos, y llegado el momento de iniciar la acción del protectorado, colonizando aquellas tierras, ¿qué procedimiento se va a seguir? (...) Toda esa corriente emigratoria que va en busca de trabajo y de tierra a la Argelia francesa, o a las Repúblicas Americanas, bien puede dirigirse al norte africano, prolongación de España (...) Los millones de obreros sin trabajo que en la península luchan con la miseria y con el hambre, acudirían esperanzados a posesionarse de su propiedad y resueltos a defenderla con más tesón, con más energía, con más valor que el moro, que pudiera atacarla. Y una población civil numerosa se crearía en seguida y las distancias entre blocao y blocao irían desapareciendo, porque las irían acortando las casas campesinas, las granjas de cultivo, hasta cubrir la tierra hoy solitaria, extendiendo hacia el interior la ocupación pacífica, que sería a la vez base para el Ejército protector de los nuevos intereses de España, puestos en manos de españoles. Y el pueblo tocaría las ventajas, y percibiría el premio de los sacrificios, de los dispendios, del heroísmo que ha costado esa faja de tierras, frontera de la patria, prolongación de la península, complemento de la nación, necesario para su independencia, seguridad y soberanía. Porque Marruecos será español”223.

Había terminado, o casi, la sangrienta quijotada (qué pocas palabras encierran tanto significado como ésta en castellano). Y aunque quedaba pendiente el desarme completo de las cábilas, el optimismo ministerial había renacido ${ }^{224}$. Abd-el-Krim terminaría entregándose a los franceses, no a los africanistas, en mayo de 1926 y sería, finalmente, confinado en la isla de Reunión. El término definitivo de las operaciones españolas, sin embargo, no sería anunciado por Sanjurjo hasta el 10 de julio de 1927, tras el completo sometimiento del macizo de Yebel Alam y la recuperación de Xauen. Además, las reivindicaciones españolas sobre Tánger persistirían hasta que en julio de 1928 se ratificase un nuevo estatuto para la ciudad. Así España, por fin, pudo adquirir

\footnotetext{
${ }^{219}$ Gonzalo G. y García: “Crónicas de Marruecos”, La Gaceta Regional, no 1.556, 14 de octubre de 1925, p. 4; Gonzalo G. y García: "Crónicas de Marruecos. La vida del campamento", La Gaceta Regional, no $1.572,2$ de noviembre de 1925 , p. 4.

${ }^{220}$ Delgado Barreto: "Nuestras conferencias telefónicas de esta mañana", La Gaceta Regional, no 1.568 , 28 de octubre de 1925, p. 2; Delgado Barreto: "Nuestras conferencias telefónicas de esta tarde", La Gaceta Regional, $\mathrm{n}^{\circ} 1.584,16$ de noviembre de 1925, p. 5.

221 "La colaboración franco-española", La Gaceta Regional, no 1.595, 28 de noviembre de 1925, p. 1.

${ }^{222}$ Mario Arcadio Sala: "Cosas del Tercio", La Gaceta Regional, n" 1.600, 4 de diciembre de 1925, p. 4.

${ }^{223}$ Mirabal: "La colonización de Marruecos", La Gaceta Regional, no 1.595, 28 de noviembre de 1925, p. 1.

${ }^{224}$ Alfredo Rivera: "Conferencias telefónicas", El Adelanto, $\mathrm{n}^{\circ}$ 12.759, 20 de diciembre de 1925, p. 5; Delgado Barreto: "Nuestras conferencia telefónicas de esta mañana", La Gaceta Regional, no 1.605, 10 de diciembre de 1925, p. 6; "La paz que pide Abd-el-Krim", La Gaceta Regional, no 1.621, 30 de diciembre de 1925, p. 6.
} 
algunas competencias en el control de actividades subversivas a través de la creación de una Oficina Mixta de Información ${ }^{225}$.

No reinaría, por el contrario, semejante regocijo entre la opinión pública local. Aunque Salamanca tenía algo por lo que alegrarse. A principios de noviembre, oficiosamente, se anunció que la quinta de 1922 de La Victoria -186 hombres de los algo más de 800 que integraban el batallón- retornaría a su hogar ${ }^{226}$. Y pocos días antes de las Navidades, se confirmó el regreso, en realidad, de casi todo el batallón ${ }^{227}$. La ciudad, por consiguiente, se dispuso a recibirlos ${ }^{228}$. Con excitación ante el retorno de los seres queridos, pero sin alharacas, sin elogios para el dictador, con sobriedad. Al final, su entrada en la capital del Tormes tuvo lugar el 28 de diciembre de $1925^{229}$. Los jóvenes fueron obsequiados, por última vez, con habanos y dinero procedentes de la campaña del aguinaldo ${ }^{230}$. Podrían empezar el nuevo año en compañía de sus familiares.

En total, volvieron 515 individuos, todos "cuotas" de los remplazos de 1922 a 1924, además de diez oficiales y dos jefes. Los que menos, habían permanecido en África tres meses ${ }^{231}$. Debido a las injusticias del sistema de reclutamiento, sin embargo, una compañía de soldados de "haber" con 270 hombres, los más olvidados, todavía se quedaría en Laucién ${ }^{232}$. Seguía habiendo clases.

Pero, desde luego, a partir de este preciso momento, Marruecos desaparecería del horizonte de preocupaciones de los salmantinos y perdería protagonismo mediático.

\footnotetext{
${ }^{225}$ BOUARFA, Mohamed: Op. Cit., p. 192.

226 "Regreso de las fuerzas de La Victoria", El Adelanto, no 12.728, 3 de noviembre de 1925, p. 1.

227 "El batallón de La Victoria reconcentrado para embarcar", El Adelanto, $\mathrm{n}^{\circ}$ 12.761, 23 de diciembre de 1925 , p. 1; "La repatriación de las fuerzas del batallón expedicionario de La Victoria", La Gaceta Regional, $\mathrm{n}^{\mathrm{o}}$ 1.591, 24 de noviembre de 1925, p. 1; "La repatriación de las fuerzas de La Victoria. Cómo se supo la noticia en el batallón expedicionario", La Gaceta Regional, nº 1.598, 2 de diciembre de 1925, p. 1.

228 "La llegada del batallón de La Victoria", El Adelanto, no 12.763, 25 de diciembre de 1925, p. 1.

229 "Llegada de las fuerzas expedicionarias del regimiento de La Victoria a Salamanca", El Adelanto, $\mathrm{n}^{\circ}$ 12.765, 29 de diciembre de 1925, p. 2; "El regreso de las fuerzas de La Victoria. Entusiasta recibimiento", La Gaceta Regional, $\mathrm{n}^{\circ}$ 1.619, 28 de diciembre de 1925, p. 1.

${ }^{230}$ Se habían recaudado casi 3.600 pesetas: "Salamanca secunda la iniciativa de Barcelona para el aguinaldo del soldado", El Adelanto, $\mathrm{n}^{\mathrm{o}}$ 12.732, 19 de noviembre de 1925, p. 1; "El aguinaldo del soldado", El Adelanto, no 12.733, 20 de noviembre de 1925, p. 1; "Comisión de recaudar fondos para el aguinaldo del soldado", El Adelanto, n $\mathrm{n}^{\circ}$ 12.737, 25 de noviembre de 1925, p. 2; "El aguinaldo del soldado", El Adelanto, no 12.745, 4 de diciembre de 1925, p. 5; "El aguinaldo del soldado", El Adelanto, $\mathrm{n}^{\mathrm{o}}$ 12.766, 30 de diciembre de 1925, p. 2; "Por el aguinaldo del soldado", La Gaceta Regional, no 1.587, 19 de noviembre de 1925, p. 1; "Para el aguinaldo del soldado", La Gaceta Regional, no 1.591, 24 de noviembre de 1925, p. 6; Juan P. Criado y Domínguez: "Cruz Roja", La Gaceta Regional, no 1.600, 4 de diciembre de 1925, p. 2; "El aguinaldo del soldado", La Gaceta Regional, $\mathrm{n}^{\mathrm{o}}$ 1.601, 5 de diciembre de 1925, p. 1; "Para el aguinaldo del soldado", La Gaceta Regional, no 1.620, 29 de diciembre de 1925, p. 2. 231 "Esta tarde llega el batallón de La Victoria", El Adelanto, $\mathrm{n}^{\circ}$ 12.764, 27 de diciembre de 1925, p. 1; "Repatriación de fuerzas del regimiento de La Victoria", La Gaceta Regional, $\mathrm{n}^{\circ}$ 1.618, 26 de diciembre de 1925, p. 2.

${ }^{232}$ Regresaron a Salamanca a finales de septiembre de 1927 (Consúltese el historial de La Victoria, en el Apéndice).
} 
Lo adquiriría, en cambio, durante algunos días, el juicio contra Pepe Núñez Alegría por los disparos contra Veloz en el Casino. En prisión desde aquel día, el proceso se celebró entre los días 22 y 29 de septiembre de 1925. Al final, aunque Veloz no halló respaldo a sus sospechas acerca de la existencia de un complot contra él, sí logró que ninguna alegación de la defensa fuese aceptada por el tribunal. Ni tan siquiera la contundente retórica del mismo Indalecio Prieto pudo evitar una pena muy severa para el director de El Adelanto: doce años de cárcel y 20.000 pesetas de multa ${ }^{233}$.

En cuanto a Unamuno, a principios de septiembre de 1925, carteándose con su esposa, había reconocido que "ahora todo depende del resultado de la aventura africana" ${ }^{234}$. Y poco después del desembarco, en su correspondencia privada con su amigo Jean Cassou se había interrogado sobre las causas de la guerra de Marruecos, concluyendo: "Todo eso de la civilización y de los tratados es mentira"235. Incluso desterrado, siguió arremetiendo también contra "la dementalidad imperialista de los duelistas internacionales" y "el hipócrita y a la vez cínico protectorado de los mercenarios del honor nacional'. Le comentó también a Cassou que deseaba hacer algo "sobre la concepción pretoriana española de la conquista de Marruecos, sin violencia de lenguaje, pero claro, muy claro". Sin embargo, no lo llegó a hacer. Temía que le tachasen de bolchevique o comunista. Y, por otro lado, estaba harto de la censura.

Se conformó colaborando con Hojas Libres, una revista fundada en Hendaya por Eduardo Ortega y Gasset en abril de 1927. Aquí publicó, en 1928, "De nuevo lo de las responsabilidades", uno de los artículos más célebres de toda la historia del periodismo español, además de culminación de su campaña letal contra Alfonso XIII ${ }^{236}$. Aseguraba el anciano profesor en él que la dictadura impidió esclarecer quién estuvo tras la catástrofe de Annual y, a partir de ahí, describía el régimen como putrefacto e inmoral. El tono, por último, era absolutamente incendiario, cargado de insultos al general y al monarca.

A raíz de la publicación de este artículo, Hojas Libres fue el objeto de un conflicto diplomático con el gobierno francés, ya que el Directorio exigió la supresión

\footnotetext{
${ }^{233}$ HERNÁNDEZ HERNÁNDEZ, Carlos Ernesto: Op. Cit., p. 266. Sobre las declaraciones de Indalecio Prieto, la reseña periodística más extensa que aparece es la siguiente: "Continúa la vista-causa por el Suceso del Casino de Salamanca”, La Gaceta Regional, no 1.541, 26 de septiembre de 1925, pp. 1-2. ${ }^{234}$ RABATÉ, Colette y Jean-Claude: Op. Cit., p. 505.

${ }^{235}$ Véase BÉCARUD, Jean: "Jean Cassou y Miguel de Unamuno, a través de su correspondencia" en VVAA, Jean Cassou y sus amigos. Madrid: Ayuntamiento de Madrid, 2001, pp. 35-43.

${ }^{236}$ Miguel de Unamuno: "De nuevo lo de las responsabilidades", Hojas Libres, 1 de mayo de 1928.
} 
de la revista ${ }^{237}$. Sin embargo, las autoridades galas se sentían agradecidas con Unamuno por su colaboración con los aliados durante la Primera Guerra Mundial.

Don Miguel tenía, consecuentemente, cubiertas sus espaldas.

A día de hoy, para concluir este capítulo, continúa la polémica historiográfica a propósito del significado del golpe y consiguiente dictadura. Muchos historiadores, sobre todo investigadores extranjeros, consideran la actuación de Miguel Primo de Rivera como una reacción conservadora ante los esfuerzos democratizadores del gabinete de Alhucemas. Esfuerzos tales como la llegada del asunto de las responsabilidades a las Cortes; el establecimiento de la libertad de cultos; la nueva reglamentación del sufragio; la legalización de todas las organizaciones obreras; la reforma del Senado; la reactivación de muchas obras públicas; un proyecto de reforma agraria; o la imposición de un impuesto extraordinario sobre los beneficios generados por la guerra. Al contrario, la idea más aceptada entre la historiografía nacional es la de que el golpe acabó con un sistema ya agotado. El fracaso de la Restauración se materializó en la desacertada política marroquí y el enquistamiento del debate de las responsabilidades; las carencias presupuestarias para cumplir el programa liberal de obras públicas y reformas sociales; y en una crisis interna de la concentración liberal.

Por nuestra parte, consideramos que toda la propaganda utilizada en el verano de 1923 contra el gobierno dio sus frutos. El golpe militar no generó sorpresa, pero sí expectación. La aceptación popular del mismo fue inicialmente amplia porque el Manifiesto de Primo al país, con un encendido tono regeneracionista, caló entre la opinión.

$\mathrm{Y}$ antes de que las protestas contra el régimen se convirtieran en una preocupación recurrente del dictador, éste pudo poner término a la contienda de Marruecos. También, no hay que olvidarlo, su política económica cosechó notables triunfos.

Dada la escasa representatividad del régimen de la Restauración, el papel de los periódicos, no importa si de tirada nacional o provincial, como órganos de la opinión ha sido reiteradamente puesto en entredicho tanto por historiadores como por estudiosos del proceso de comunicación. En efecto, y así lo hemos querido reflejar, las relaciones entre la opinión publicada y la pública eran muy complejas. Pero no por ello hemos dudado de la existencia de una conexión. Al contrario, todo nuestro esfuerzo se ha orientado precisamente a descifrar las razones de ese nexo en un caso concreto, el de 
Salamanca. Durante la dictadura, sostenemos, el Poder pretendía sencillamente suplantar a la opinión.

La prensa de esta provincia, en efecto, no plantó una excesiva resistencia. En cambio, los rotativos fueron bastante benevolentes con el dictador. Más, eso sí, La Gaceta que El Adelanto. Pensemos que éste abogó, aunque sólo momentáneamente, por la supremacía de la autoridad civil en septiembre de 1923 y se impacientó, de modo coyuntural, ante la falta de una solución para el conflicto africano. Pero ni la censura ni la intervención directa del general en los periódicos por medio de sus famosas notas suscitaron, como en otras ocasiones, el más mínimo comentario. Además, sorprende el enorme paralelismo, superior a cualquier otro periodo, en la oferta de informaciones, y en sus tiempos. Se trataba de un indicador clarísimo del estrecho control que el Poder ejercía sobre las agencias de noticias.

En cuanto a la problemática marroquí, los dos diarios, aunque más si cabía $L a$ Gaceta, se conformaron con pasar de puntillas sobre asuntos espinosos tales como la retirada de Xauen, las causas abiertas contra Berenguer y Navarro, las conversaciones con Francia o los tratos con Abd-el-Krim. Apenas merecieron editoriales. La cuestión de Tánger, al contrario, no les dejó indiferentes porque el discurso francófobo había adquirido mucha resonancia entre la opinión publicada y la pública; algo que al Directorio le tocó combatir. El despliegue de El Adelanto al abordar las operaciones para la dominación de la bahía de Alhucemas fue muy superior al del periódico conservador. En cambio, ésta celebró mucho más la conquista de Axdir.

Finalmente, ambos se mostraron bastante parcos a la hora de describir la reacción ciudadana tras el desembarco y satisfechos, más que orgullosos, al conocerse la noticia de la repatriación de los combatientes salmantinos. 


\section{CONCLUSIONES}

En 1909, la campaña de Melilla, presentada ante la opinión pública española e internacional como una rutinaria operación de policía, supuso en realidad el comienzo de una larga y extenuante guerra entre el Ejército español y los resistentes del norte de Marruecos a la dominación extranjera.

En aquellos días, el sistema político creado por Antonio Cánovas del Castillo atravesaba sus horas más bajas. Desde la derrota militar ante EEUU en 1898, se había puesto de manifiesto que España era una modesta nación, sin apenas relevancia en el escenario internacional. El Desastre había provocado una honda crisis de la conciencia nacional, un profundo resentimiento entre los militares y el surgimiento de múltiples exigencias de renovación. Por eso, a lo largo del reinado de Alfonso XIII, la política se impregnó de regeneracionismo.

Pero el nuevo tropiezo en el Barranco del Lobo vino a arrojar más leña al fuego, reabriendo viejas heridas entre el gobierno, la milicia y el pueblo. Al fracaso militar se le unía la revuelta, sobre todo catalana, contra la movilización de los reservistas. Además, ante la oleada de protestas internaciones desencadenadas a raíz de la ejecución del anarquista Ferrer y Guardia, Antonio Maura perdió la confianza regia. Su célebre "revolución desde arriba" había chocado, al final, con su carácter intransigente.

El año 1912 marcó, asimismo, un hito en esta historia de la presencia colonial española en Marruecos. Fue entonces cuando, a remolque de Francia, el gobierno de José Canalejas obtuvo un Protectorado en la desconocida e inhóspita región del Rif. Desde mediados de la centuria anterior, y mucho más intensamente a partir de 1898, el sentimiento africanista, aquél que había visto cortadas sus alas después del descubrimiento de América, venía ganando adeptos entre diversos colectivos peninsulares. A saber: grupos empresariales, que soñaban con las legendarias riquezas minerales de la zona; un Ejército anímicamente abatido y socialmente aislado, que contemplaba Marruecos como el escenario en que reconstituirse; y, por último, un Rey, Alfonso XIII, secundado por unos partidos políticos bastante fragmentados e inoperantes, educado en los principios más rancios del militarismo prusiano y convencido de que la milicia era la más pura representación de la voluntad popular así como de que de su presencia al sur de Tarifa pendían la seguridad y el decoro patrios.

Con sus esfuerzos combinados, y en el momento de gestación de un nuevo orden internacional, el que precedió al estallido de la Gran Guerra, España logró a muy duras 
penas sumarse a la carrera imperialista por el reparto de África. En este sentido, las relaciones con Francia, siempre plagadas de recelos, y con Gran Bretaña, entorpecidas permanentemente por el contencioso de Gibraltar, ejercieron una descomunal fuerza coercitiva en nuestra política exterior. Aún así, los gobiernos dinásticos pudieron suscribir varios tratados internacionales, negociados, casi siempre, con el mayor de los secretismos.

Desde muy tempranamente, los oficiales africanistas consiguieron un papel preponderante en el control de la organización política y administrativa del territorio marroquí. Sin embargo, la noción de protectorado suponía la conservación y el respeto de las formas de gobierno tradicionales del Sultanato, aunque tuteladas por los colonizadores a través de la figura del interventor. La realidad, ya lo sabemos, resultó muy distante de estos presupuestos teóricos.

Tras años de tropiezos militares, coqueteos con los alemanes y titubeos gubernamentales, sobre todo los exhibidos frente al jerife El Raisuni, en el verano de 1921 la sociedad española se vio brutalmente sacudida por las alarmantes noticias que llegaban desde Annual. Los rifeños habían infligido una colosal derrota a las tropas españolas y se hablaba de que los resistentes sobrevivían, a muy duras penas, en Monte Arruit. Se imponía, por consiguiente, frente al feroz Abd-el-Krim sólo una vía de actuación: la del desquite, la misma que conduciría al desembarco hispano-francés en Alhucemas. También la misma que permitiría el afianzamiento en el Poder, una vez aplacada la violencia catalanista y enterrado el Expediente Picasso, de Miguel Primo de Rivera.

Desde una perspectiva exclusivamente castrense, si bien la modernidad tecnológica acompañaría al Ejército africanista, en el plano ideológico, la brutalización de la contienda hispano-marroquí sirvió como poso de unos valores profundamente conservadores: los herederos de la frustración, rencor y el aislamiento propios de la generación militar del 98; y los precursores, a su vez, del fascismo. Porque frente a los progresos del socialismo y de los movimientos regionalistas y ante el creciente antimilitarismo de la opinión pública, ellos encarnaron, eso creían, la auténtica identidad nacional.

Antimilitarismo generalizado, sí. Porque éste había sido, primero, la consecuencia del rechazo hacia un injusto sistema de reclutamiento y andando el tiempo, además, el fruto de una larga, cara y sanguinaria historia de desengaños. El anticolonialismo, por el contrario, fue un pensamiento que requirió una más cuidada 
elaboración. Nada fácil era poner en tela de juicio los fundamentos del darwinismo social cuando esta filosofía triunfaba en buena parte de Europa. Así las cosas, durante años, en un contexto de enorme analfabetismo y con un régimen político caciquil, las campañas más allá del Estrecho toparon con la tradicional indiferencia, o si se prefiere resignación (Unamuno, por ejemplo, comparaba la guerra con la lagarta, una más de las calamidades del país), de gran parte de la prensa y, sobre todo, de la opinión pública.

Sin embargo, Marruecos constituía claramente, ya en los años veinte, la pesadilla de miles de españoles. De allí nunca llegaban buenas noticias así que, mientras más y más gentes clamaban a favor del abandono y la depuración de responsabilidades, entre los círculos oficiales, atentos al cumplimiento de los acuerdos con la Entente, acabó imponiéndose la idea de actuar con contundencia frente a los insurrectos. Después vendría la colaboración militar con Francia.

Encuadrado así el problema, cabe subrayar que la prensa, en verdad, desempeñó un papel crucial en la historia política de todo este periodo y, particularmente, en la "digestión" y "regurgitación" de las luchas africanas. El manejo de periódicos es, por tanto, fundamental para aproximarnos, aunque sea con dificultades, a la opinión pública ante las guerras de Marruecos. Ésta no se halla, desde luego, contenida en los archivos. Lo que encontramos aquí es sólo la opinión de las instancias oficiales.

Lejos de constituir aquel pariente pobre de los estudios históricos, la prensa es una fuente preciosa, con su infinidad de editoriales, telegramas y crónicas remitidas desde el frente de batalla. Sirvió en su momento como instrumento al servicio de unas élites y, en menor medida, pero también e incluso visada por la censura, como órgano por antonomasia de la opinión pública. Actuó, en otras palabras, más como faro que como espejo. Pero espejo, al fin y al cabo. Y favoreció, aún con estas trabas, la creciente concienciación política de su clientela y del auditorio de los estrategas de café.

Verdaderamente complejo resulta, de hecho, precisar la naturaleza de ese maridaje entre la opinión publicada y la pública: desde los periódicos se contribuye a moldear una sociedad no a través del poder, sino de la influencia (un poder blando, pero un poder fáctico); se pretende, al seleccionar, jerarquizar e interpretar la noticia, inculcar unos valores que generen confianza, credibilidad, prestigio y, en suma, autoridad. Se busca conformar la fuerza más poderosa de una sociedad abierta: la opinión pública. Pero para que un diario sea escuchado, comercializado y patrocinado por unos anunciantes, necesita interactuar con sus lectores, procurar algo así como una “comunión de almas". En esto radica su éxito. En otras palabras, necesita crear una 
marca de prestigio con profesionales serios; convertirse en un proyecto ideológico con una identidad perfectamente reconocible.

Teoría de la bala mágica, espiral del silencio, función agenda setting, etc. Nuestro método, reparemos ya en el caso salmantino, que no era el de una sociedad abierta, ha bebido un poco de todas estas propuestas. Únicamente ha consistido en la acumulación, primero, de todas las informaciones publicadas sobre Marruecos en los periódicos de Salamanca más leídos a lo largo de veintitrés años, los comprendidos entre 1902 y 1925.

Hemos podido conocer, aclarémoslo, cuáles eran los negocios informativos más exitosos, en cada fase de la intermitente contienda, a partir de los relatos de las sesiones municipales; porque a éstas siempre acudían, y así se plasmaba en El Adelanto -que por su continuidad nos ha servido siempre como vector para el desarrollo argumental de esta tesis-, un corresponsal de cada una de las publicaciones más señeras. Tal vez haya quien se sorprenda por la utilización de este criterio de selección, un tanto heterodoxo, sin duda, pero lo consideramos más fiable y operativo que las incompletas y trampeadas Estadísticas de Prensa.

En una segunda fase, hemos procurado el análisis comparado de todas esas noticias y su contraste, también, con las informaciones emanadas de algunas instituciones locales (la Iglesia, la Universidad, el Ayuntamiento, la Diputación y la delegación de la Cruz Roja) y con las opiniones vertidas en los best-sellers de la época, es decir, en las crónicas de los más reputados conocedores de las campañas marroquíes.

Con esta mecánica de trabajo se ha procurado, por tanto, la combinación de un seguimiento longitudinal y transversal para el examen de las opiniones publicadas. Sólo desde este presupuesto hemos buscado un acercamiento, no sabemos si acertado pero sí coherente, a la opinión pública salmantina. Sin olvidar, por descontado, el recurso a la bibliografía más reciente. Hemos creido que un análisis longitudinal, sistemático y pormenorizado, de un número tan grande de columnas y editoriales, reflejo de muy diversas sensibilidades, permitía la eliminación de bastantes distorsiones. En cambio, consideramos los exámenes transversales más condicionados por los apasionamientos del momento y personalismos del autor.

En ocasiones el procedimiento ha resultado frustrante, debido al carácter tan fragmentado y disociado de la fuente principal. El propio Unamuno reparó en su momento en esta circunstancia, denunciando sobre todo, el "aluvión" confuso de telegramas. Pero aunque en un periódico todo sea subjetivo, y si bien los columnistas 
jugaron en más ocasiones de las debidas con lo verosímil antes que con lo verdadero, no abundaron los accidentes. Al contrario, las empresas periodísticas más sólidas fueron aquéllas con una visión más pragmática del negocio.

Atrás quedaban los tiempos en los que se apostaba por la misión sacerdotal del periodismo. Aunque ello no se les contase a las claras, ni mucho menos, a los lectores. Así, José Luis, uno de los columnistas de La Gaceta al que ya nos hemos referido en más ocasiones, escribía en 1924 lo que sigue. Es la última de las citas de esta investigación:

"Se ha creído por muchos, que servir a la opinión, desde las columnas de la prensa, es halagar la vanidad, prodigar el elogio muchas veces inmerecido de personas y cosas (...) Esta creencia a todas luces es errónea en cuanto a que dicha creencia constituya la clave formal, la razón fundamental, el nervio íntimo de lo que debe ser la prensa en sus relaciones con la opinión. Ello estará bien, bajo el punto de vista industrial, pero no es menos cierto, que entonces el periódico no puede en momento alguno intitularse órgano de la opinión, porque ni la orienta, ni la educa, ni la guía por los senderos de la imparcialidad, de la sobriedad y de la sinceridad; entonces puede asegurarse que la prensa no sirve a la opinión, sino que la suplanta.

La prensa, como órgano de opinión, es como cumple su más importante, su más transcendental finalidad. Sin negar que tiene otros fines más elevados, es indudable que su misión más inmediata, su oficio más noble es el de ser órgano de la opinión. Si esta opinión se manifiesta, la prensa debe reflejarla y al reflejarla debe procurar su mejoramiento y transformación por medio de un estudio concienzudo, de un comentario razonable, ya que el comentario periodístico no es otra cosa que el examen minucioso, el análisis delicado de la misma opinión reflejada.

Si la prensa cumpliera fielmente su finalidad altísima de servir a la opinión, como la opinión debe ser servida, la opinión estaría educada y perfeccionada en grado tal, que se manifestaría pujante en cualquier momento; pero como abandonando sus derroteros más nobles y más elevados, sólo se reduce a halagar pasiones, vanidades e intereses, de aquí que entre nosotros no exista una verdadera opinión de mejoramiento intelectual y moral, y sí sólo esa opinión instintiva, esa opinión pasional de pequeñeces y ruindades $"$.

Reflexiones, sin duda, excesivamente utópicas en tiempos de dictadura y de abuso del lápiz rojo. Nos llevan, irremediablemente, a pensar en la figura de Walter Lippmann. Porque él fue el primero en formular, por escrito, esa estrecha relación existente entre los medios de comunicación de masas -aunque la salmantina no dejase de constituir, insistimos, un ejemplo muy incipiente-, la política exterior y la opinión pública. Por su condena de la teoría democrática tradicional y enjuiciamiento de la labor de muchos periodistas, este personaje y su obra fueron tachados de antidemocráticos. Sin embargo, Lippmann fue un demócrata convencido, el padre de la columna periodística y alguien que durante casi cuarenta años trabajó como formidable

\footnotetext{
${ }^{1}$ José Luis: "Periódicos y periodistas", La Gaceta Regional, nº 1.110, 23 de abril de 1924, p. 1.
} 
comentarista político, explicando a sus lectores, al hombre de la calle, los pormenores de la realidad en que vivían inmersos.

Junto con las ideas del insigne decano de la prensa americana, y muy vinculadas con ellas, otra gran inspiración metodológica para nosotros ha sido la tesis del Rally Round the Flag. Porque el vocablo "euforia" aplicado a los momentos de mayor tensión bélica no nos complacía en absoluto. Creíamos que bajo esas aparentes explosiones de patriotismo subyacía algo más complejo. En particular, valoramos de esta tesis -hoy en día bastante en boga entre los politólogos estadounidenses para el estudio de las repercusiones públicas de los ataques terroristas- el acento que pone en el hecho de que las opiniones funcionen con distintas dinámicas en el corto y largo plazo. En el corto plazo el ciudadano responde de forma muy positiva (visceral porque la guerra se hace "con las tripas") a los compromisos internacionales de los gobiernos; en el largo, no. Se impone entonces el recurso a la propaganda bélica, la fabricación de héroes y monstruos, la censura y la desinformación.

No queremos dejar de mostrar nuestro convencimiento acerca de que la información se digiere socialmente, más si cabe en las coyunturas dramáticas. De ahí que hayamos reparado, para el caso salmantino, en la figura de Unamuno y, en menor medida, puesto que su pensamiento era infinitamente más lineal, en la de Martín Veloz. Ambos desempeñaron un papel vital, estelar, a la hora de canalizar los mensajes periodísticos/propagandísticos. Fascinantes nos han resultado algunos comentarios del primero; sorprendentes sus cambios de criterio; y admirables, algunas de sus deducciones.

El marco local ha sido el instrumento que nos ha permitido acotar la acción de un sujeto histórico tan apasionante como la opinión pública. Salamanca no era, a principios del siglo XX, una ciudad ajena a los problemas nacionales. Esa imagen de una capital de provincia moribunda y de aspecto desolado, semejante a un "aduar africano", de hecho, era continuamente desmontada por los testimonios de una prensa de lo más variopinta y por las acciones de algunos de sus grandes hombres. Ciertamente, esta urbe poseía un sector industrial muy arcaico; una Universidad con escasa solvencia económica; topamos con el predominio de unas clases populares sumidas en la precariedad laboral frente a una oligarquía terrateniente; y conocemos sus elevadísimas tasas de emigración, etc. Pero Salamanca también tenía una enorme vitalidad política, mezclándose las viejas y nuevas formas de entender esta actividad, y considerable fuerza intelectual. 
La prensa provincial sobre todo destacó en la campaña de ayuda para los soldados, siempre víctimas y verdugos; animó a la participación ciudadana en estos gestos caritativos; alabó algunas iniciativas de las instituciones y particulares; transmitió las informaciones proporcionadas por la Cruz Roja...

Pero no sólo eso: como vehículo idóneo para la transmisión de la propaganda de guerra y campo fecundo para las más diversas técnicas de desinformación, la prensa hizo de la opinión pública un instrumento al servicio de la política exterior. Ocurrió así, por ejemplo, en los meses posteriores al Desastre de Annual, cuando tanto se alimentó aquel deseo de revancha. En otras ocasiones, a la inversa, fue la política exterior un instrumento para ganarse el favor de la opinión pública. Piénsese ahora en cómo Primo de Rivera utilizó el repliegue de 1924 para apuntarse el tanto de la soñada repatriación de miles de soldados.

La cobertura del proceso diplomático y militar para el asentamiento de España en Marruecos fue, en cualquier caso, limitada, coaccionada por la discreción de los diplomáticos; irregular; muchas veces carente de pluralismo y siempre condicionada por el partido que ocupase la presidencia del gobierno. Porque el Protectorado sirvió como tema recurrente en la confrontación política. Y así lo supo ver El Adelanto, a pesar de sus titubeos; también El Salmantino, militarista como ningún otro periódico local; El Lábaro, bastante oportunista; un comedido El Castellano; La Gaceta, muy próxima igualmente a las tesis de los africanistas; El Pueblo, con su abandonismo, etc.

Por las páginas de la prensa salmantina desfilaron decenas de columnistas más o menos enterados de la marcha de los asuntos africanos y más o menos talentosos: Francisco Romero, “Uno”, “Un Repórter”, “Argos”, “Juan de Salamanca”, Berrueta, “Abel Peregrín”, “E.”, “A.”, “Mirabal”, Teresa de Castilla, etc. También merecieron un considerable espacio las informaciones telegráficas de Rivera y, más adelante, Barreto. Por último, no faltaron las colaboraciones de afamados periodistas del momento y expertos en la materia, tales como Peyra Anglada, Leopoldo Alas, Pascual Meneu, Cándido Lobera, El Tebib Arrumi, Lezama o López Rienda.

Las polémicas ideológicas y contradicciones entre las opiniones publicadas fueron continuas: afectaron al contenido de los convenios, las intenciones de Maura, el porqué de los vaivenes ante El Rogui o El Raisuni, las pretensiones francesas, la reglamentación del servicio militar, la conveniencia de una acción civil o militar, el mando de Berenguer, el carácter de Silvestre y Abd-el-Krim, el alcance del asunto de las responsabilidades... y tuvieron su efecto entre la opinión local. 
Intentemos recopilar, para finalizar, algunas de las conclusiones ya señaladas en los capítulos previos: los tratados iniciales que sancionaron el reparto de Marruecos, particularmente el capital Tratado hispano-francés de 1904, apenas fueron conocidos por la opinión pública salmantina. La diplomacia se cuidó mucho de publicitarlos, a sabiendas de que una política exterior muy activa sería percibida por el país como un riesgo, sobre todo, con posterioridad al Desastre de Cuba.

Del encuentro de Algeciras, por otra parte, lo que se enfatizó, más que nada, fue la necesidad de evitar un choque franco-germano. Presentado como un acto de relumbrón, lo mismo que el posterior encuentro regio en Cartagena, no llegó a captar la atención de los vecinos del Tormes, más interesados en la solución de sus problemas domésticos. No obstante, los incidentes de Casablanca, por primera vez, fueron los responsables de que los salmantinos tomaran tímida conciencia y se alarmaran ante lo que ocurría en el otro continente y ante el juego de alianzas internacionales que se estaba desarrollando en Europa. Pero como ya apuntamos en su momento, aunque los periódicos de la provincia efectuaron un seguimiento bastante exhaustivo de los acontecimientos marroquíes, también éste pecó por su carácter extremadamente caótico.

Con motivo de la Guerra de Melilla, en 1909, si bien Maura se despreocupó por informar y convencer a la opinión pública acerca de su proceder, limitándose a la instauración de la censura, la prensa salmantina no lo emuló. Al contrario, fue la gran responsable de que la actitud de los salmantinos fuese, sobre todo, resignada. Tan sólo experimentaron rechazo hacia la contienda aquellos que se vieron más afectados por la misma. Pero del antimilitarismo no se llegó a transitar hacia el anticolonialismo porque se requería una mucha mayor familiaridad con los asuntos marroquíes; una atmósfera social más opresiva aún; y una prensa local mucho más plural que la existente por entonces. Sin embargo, casi todos los negocios informativos confundieron patriotismo con periodismo y tendieron a simplificar enormemente sus informaciones sobre el conflicto.

La crisis de Agadir generó nuevamente una gran tensión internacional, mientras que la Guerra del Kert, aunque no llegó a suscitar la preocupación de la anterior campaña melillense, también fue merecedora de bastantes editoriales, algunos con un tono muy persuasivo, entre la prensa salmantina. Pero la campaña africana continuó sin resultar simpática a ojos de la opinión. La resignación, como en 1909, fue la nota dominante después la firma del Tratado para el establecimiento del Protectorado, en 1912, y también tras la conquista de Tetuán, un año después. 
El enquistamiento del conflicto marroquí durante la Gran Guerra, sin duda, estuvo en la génesis de dos grandes debates que salpicaron muchos de los enfrentamientos políticos y periodísticos de aquellos años. Y que tanto confundieron a la opinión pública salmantina: el referido a las alianzas internacionales, particularmente preocupante para las corrientes de opinión conservadora; y la polémica en torno a la conveniencia de un régimen militar o civil para el Protectorado, asunto que salió especialmente a relucir cuando se trató de hacer frente a El Raisuni.

El estoicismo que los periódicos reclamaban de sus lectores chocaba con el misterio que envolvía a toda la cuestión africana: con la indefinición estratégica de los sucesivos gobiernos, con ese continuo y disimulado envío de refuerzos a África, con el empecinamiento por adueñarse de Tánger... por eso la resignación y el hastío fueron cediendo su protagonismo a nuevas formas de protesta contra la guerra - no contra la ideología colonial- y más sonoras: aumentaba el número de prófugos, las reclamaciones de los socialistas, se generalizaban las trampas para eludir el servicio militar... Cada día resultaba más difícil, en suma, persuadir a la opinión pública sobre la conveniencia de permanecer en Marruecos. Porque, al final, su instinto más profundo la animaba a desentenderse de una cuestión que no acababa de entender.

Annual, pese a todo, sirvió para que la opinión pública salmantina retornase a la cruda realidad, a la del embrollado Protectorado. La reacción de los salmantinos ante el Desastre fue, como ya se apuntó, muy visceral: esta ciudad se volcó a la hora de obsequiar a sus soldados -recuérdese, sobre todo, la donación de dos aviones-, pero también fue una urbe muy implicada en el movimiento de exigencia de responsabilidades y de la urgente repatriación de tropas.

La derrota de 1921 sirvió, además, como acicate para Miguel de Unamuno y para su contra-propaganda de guerra. Aunque, en realidad, su viraje ideológico se había iniciado en 1917, cuando se produjo la crisis de las Juntas de Defensa. La hostilidad que albergaba hacia la figura de Alfonso XIII, reflejada en decenas de editoriales injuriosos, se hizo implacable y, a la postre, le conduciría al destierro. Porque a partir del análisis de la derrota, el prestigioso profesor acabó poniendo en cuestión la legitimidad de todo el edificio de la Restauración: denunciando el funcionamiento de una diplomacia secreta, recelando del poder judicial y rechazando el carácter representativo del sistema parlamentario.

Al margen de los rotundos argumentos esgrimidos contra la guerra y el colonialismo por este líder de opinión y gran maestro de los estrategas de café, el clima 
de la opinión pública salmantina se caracterizó por poseer una naturaleza algo más opaca, sobre todo, a medida que transcurrieron las jornadas tras el Desastre. Hubo entre los vecinos del Tormes pensamientos muy extendidos. A saber: la imagen tan peyorativa del combatiente rifeño, habitualmente retratado con las notas del salvajismo y el fanatismo; la histórica animadversión hacia Francia, siempre acusada de poseer un apetito colonial insaciable y actuar de mala fe; el dolor suscitado por el pleito de Tánger, puerta para la entrada del contrabando... Todos estos elementos eran el fruto de años y años de campañas periodísticas, unas más persuasivas y constantes que otras, empeñadas en demostrar la capacidad colonizadora de España.

Pero, sobre todo, una idea se impuso a las restantes entre la opinión pública salmantina: la del desquite, la del ojo por ojo y diente por diente. El deseo de revancha fue prioritario, en efecto, entre la opinión local durante el segundo semestre de 1921, hasta que saltaron a la palestra política asuntos muy espinosos como el de las responsabilidades, los prisioneros o los ascensos militares. En un primer momento, mientras duró el asedio rifeño sobre Monte Arruit, la petrificación de todo el país hizo que el más básico instinto de supervivencia se impusiera a cualquier otra consideración. Todo sacrificio quedó justificado per se. No se requirió, por tanto, la propaganda de guerra para provocar una sintonía de pareceres entre gobernantes y gobernados.

En una fase posterior, rendida esta plaza y sentada la necesidad de restablecer el honor de las armas españolas en el Rif, sí que se precisó el concurso de todas las fuerzas posibles alrededor de las figuras de Antonio Maura y Dámaso Berenguer. Casi todas las opciones políticas y buena parte de la prensa - pese a confesar su incomodidad ante la práctica de la censura- cumplieron con esta misión. La excepción, en el caso salmantino, vino de la mano de Unamuno y de El Pueblo, pero sus discursos, durante estos primeros meses de la nueva fase militar, tuvieron una escasa acogida pública.

Había entrado en funcionamiento en la conformación de la opinión local el ya citado efecto Rally Round the Flag. El pánico impulsaba a los vecinos de Salamanca a contemplar al presidente como máxima encarnación de la unidad nacional, sin someter apenas sus actuaciones a un juicio racional. Por eso, con tanta facilidad, la solidaridad ciudadana pudo ser instrumentalizada como señal del respaldo público hacia el gobierno.

Constantemente se procuró surtir a los soldados de la provincia con todo tipo de material y también se intentó arroparlos en la estación de trenes. Aunque, como era de esperar, este esfuerzo colectivo se prolongó bastante más allá de las Navidades de 1921. 
Por eso hemos defendido que antes que la defensa del decoro patrio, lo que primó entre los salmantinos fue la compasión hacia unos paisanos.

Al contrario, el fenómeno Rally Round the Flag no pudo presumir de tan larga vida y la tesis del desquite empezó a perder seguidores. Con el transcurso de los meses, tanto el discurso abandonista de El Pueblo como, sobre todo, los juicios de don Miguel, lograron una creciente resonancia social. El año 1922, como ejemplo ilustrativo, culminó con la celebración de una manifestación en Salamanca bastante concurrida y en la que se demandaba el esclarecimiento de las responsabilidades del Desastre.

Marruecos, convertido en una pesadilla para miles de jóvenes, también era objeto de agrias polémicas parlamentarias y el discurso periodístico ya no bastaba para que el gobierno se granjease la confianza de los ciudadanos. Annual, en suma, había ensanchado la brecha existente entre el Poder y las masas; entre la opinión publicada y la pública.

En esta atmósfera responsabilista (y cargada de preocupación alrededor de la cuestión del orden social), la implantación de la dictadura de Miguel Primo de Rivera significó el empeño más decidido por aplastar a la opinión pública y suplantarla. Ni los salmantinos ni los periódicos locales se resistieron ante su discurso regeneracionista; si bien tampoco mostraron excesivo entusiasmo después de la operación anfibia sobre Alhucemas. Con alivio y excitación, claro que sí, recibieron a casi todo el batallón de La Victoria al término de 1925.

Las intermitentes campañas de Marruecos ejercieron, en conclusión, un impacto notable sobre la opinión pública salmantina. Por una parte, sirvieron para su creciente concienciación política a costa de muchos desengaños; por otro lado, dejaron también su triste huella en algunos centenares de mozos que hubieron de acudir al frente de la batalla.

Eso es lo que hemos buscado plasmar a lo largo de esta tesis. Pero el deseo de encorsetar a la opinión pública local dentro de conceptos como "a favor", "en contra", "mayoritaria" y "minoritaria" siempre lo hemos considerado como un esfuerzo vano. No, la opinión pública es una realidad más etérea; inabarcable, como el océano; desmovilizada durante muchos años. Diríase que como ese océano sin olas; aunque peligrosa, igualmente. Porque bajo esa superficie, se ocultaban, sin duda, muchas corrientes y remolinos. Confiamos haberlo puesto en claro con nuestro trabajo. 


\section{APÉNDICES}

\section{Los telegramas de El Adelanto sobre la Conferencia de Algeciras}

-Animación y enorme expectación ante el inicio de la Conferencia ${ }^{1}$.

-Inauguración de las sesiones. Designación de Almodóvar del Río como presidente ${ }^{2}$.

-Primeras visitas turísticas de los delegados ${ }^{3}$.

-Discusión de la proposición española sobre la represión del contrabando de armas. Pérez Caballero defiende la disponibilidad española para ejercer esta tarea en la zona que a España le ha sido asignada en los tratados previos. Alemania respalda su argumentación, mientras que Bélgica desea que no se entorpezca demasiado la entrada de armas destinadas a la caza. Los delegados del Sultán se oponen a esto último ${ }^{4}$.

-Preparativos de una fiesta prevista para el 23 de enero a modo de homenaje hacia los diplomáticos. Aunque se denuncia la parquedad de Segismundo Moret ante los periodistas, se rumorea que a él corresponden unas declaraciones afirmando que el cuerpo diplomático cederá a España la represión del contrabando ${ }^{5}$.

-Alusiones a la tranquilidad imperante entre los plenipotenciarios alemanes. Visita de Llavería a los conferenciantes para denunciar que el Raisuni impide a los carboneros españoles cortar leña ${ }^{6}$.

-Mínima mención de la violenta sesión habida el 23 de enero. Descripción de los festejos a bordo del buque "Carlos V" y de otra celebración con la que los periodistas franceses agasajan a la prensa española. Rivera desmiente, considerando el desenvolvimiento de las últimas reuniones, que Alemania pretenda apoderarse de territorios en Marruecos ${ }^{7}$.

\footnotetext{
${ }^{1}$ Alfredo Rivera: "Telegramas", El Adelanto, no 6.670, 16 de enero de 1906, p. 4.

2 Alfredo Rivera: "Telegramas", El Adelanto, no 6.671, 17 de enero de 1906, p. 4.

3 Alfredo Rivera: “Telegramas", El Adelanto, no 6.672, 18 de enero de 1906, p. 4.

${ }^{4}$ Alfredo Rivera: "Telegramas", El Adelanto, no 6.673, 19 de enero de 1906, p. 4. El comercio de armas se efectuaba, hasta la fecha, sin ningún tipo de restricción y a pesar de los peligros que entrañaba para el mantenimiento del orden interior marroquí. En este asunto se aprobaría un cuestionario preparado por España y que prohibía para los marroquíes la posesión de cualquier tipo de armas y municiones. Se necesitaron, sin embargo, algunas aclaraciones sobre la introducción de explosivos para la industria y los trabajos públicos, así como sobre el armamento de las tropas marroquíes. Atendiendo a las peticiones de Bélgica, para las municiones de lujo y caza se acordó que el cuerpo diplomático de Tánger elaboraría un reglamento.

5 Alfredo Rivera: “Telegramas”, El Adelanto, no 6.674, 20 de enero de 1906, p. 4.

${ }^{6}$ Alfredo Rivera: “Telegramas”, El Adelanto, no 6.675, 23 de enero de 1906, p. 4.

${ }^{7}$ Alfredo Rivera: “Telegramas”, El Adelanto, no 6.677, 24 de enero de 1906, p. 4.
} 
-Nuevos detalles sobre los procedimientos para la represión del contrabando. El Mokri, delegado marroquí, hace constar su deseo de que las armas incautadas se subasten públicamente y lo obtenido revierta en beneficio del Sultán. Este proyecto se da por finalizado. La prensa española invita a la extranjera a una nueva celebración ${ }^{8}$.

-Discusiones sobre el régimen impositivo marroquí, con particular hincapié en los tributos para la adquisición de suelo agrícola. Nicholson, delegado británico en la Conferencia, argumenta que este cometido debiera ser asumido por la burocracia marroquí al tiempo que solicita facilidades para que los extranjeros puedan adquirir terrenos en el país. El Mokri rechaza la proposición. Es preciso convencerle de que los impuestos religiosos no experimentarán cambios, al tiempo que se fijan otros nuevos para los consumos, el tabaco... Se anuncia un viaje de Almodóvar y Pérez Caballero a Ceuta ${ }^{9}$.

-Suspensión de una corrida de toros debido a las torrenciales lluvias ${ }^{10}$. Jornada de descanso de los periodistas. El Mokri comenta ante los periodistas el proyecto marroquí para la recaudación de impuestos. Destaca de él que no simboliza la aspiración de un pueblo salvaje, sino que es el fruto de meditados estudios. Manifiesta, al mismo tiempo, que es una incongruencia de la diplomacia europea exigir reformas a la administración marroquí, pero procurar eximir a los súbditos europeos de tributaciones, pues así sólo se consigue dificultar la marcha de esas reformas ${ }^{11}$.

-Resumen de la larguísima sesión del 29 de enero. Se discutió la proposición marroquí de elevación de las tarifas aduaneras y se produjeron algunos incidentes. No se alcanzó ningún acuerdo, así que los diplomáticos deben permanecer a la espera para recibir instrucciones de sus respectivos gobiernos. Se debatió seguidamente sobre la creación de algunos nuevos impuestos, sugeridos por los marroquíes y se acordó la formación de un comité encargado de ultimar un proyecto de impuesto sobre el ejercicio de las industrias. Además, los marroquíes desean la fijación de un impuesto sobre la

\footnotetext{
${ }^{8}$ Alfredo Rivera: “Telegramas", El Adelanto, $\mathrm{n}^{\mathrm{o}}$ 6.678, 25 de enero de 1906, p. 4.

${ }^{9}$ Alfredo Rivera: "Telegramas", El Adelanto, $\mathrm{n}^{\circ}$ 6.679, 26 de enero de 1906, p. 4.

${ }^{10}$ Únicamente El Adelanto aludió a esta cancelación. Los otros dos periódicos salmantinos no hicieron ninguna mención del evento. Sin embargo, gracias a la obra de Manuel Fernández Mota sabemos que la fiesta sí que tuvo lugar: se celebró el 4 de febrero en la plaza de La Perseverancia. El espectáculo resultó bastante sangriento, así que casi todos los embajadores y periodistas abandonaron, un tanto escandalizados, la plaza. Al día siguiente, toda la prensa europea calificó el espectáculo como "bárbaro", "repugnante", "primitivo" o "españolada". No obstante, hubo un plenipotenciario, conocido entusiasta de la Fiesta Nacional, bastante satisfecho con la faena: el Mokri. Véase FERNÁNDEZ MOTA, Manuel: Memoria histórica de una Conferencia (Algeciras, 1906). Algeciras: Fundación Municipal de Cultura "José Luis Cano", 2001, p. 119.

${ }^{11}$ Alfredo Rivera: "Telegramas", El Adelanto, no 6.681, 29 de enero de 1906, p. 4.
} 
pesca, al que se opuso Pérez Caballero, y nuevos gravámenes sobre correos y telégrafos, el alumbrado eléctrico y espectáculos. No se alcanza ningún acuerdo ${ }^{12}$.

-Los ponentes han concluido su labor y se sigue discutiendo a propósito de las tributaciones. El Mokri viaja a Gibraltar, donde curiosamente coincide con los delegados alemanes ${ }^{13}$.

-Insatisfacción del pueblo marroquí con El Mokri. Debiera mostrar mayor resistencia ante los delegados europeos ${ }^{14}$.

-Descontento entre los plenipotenciarios marroquíes porque ha sido rechazado su proyecto de creación de nuevos impuestos sobre electrificación, correos y telégrafos. Si bien los representantes del Sultán exigen que la cobranza del impuesto agrícola recaiga en la administración marroquí, Pérez Caballero manifiesta su desconfianza. Los restantes delegados europeos le secundan y también el representante norteamericano así que nuevamente los planes jerifianos se ven frustrados ${ }^{15}$.

-Rivera se hace eco de un artículo de Le Matin: el gobierno parisino se opone rotundamente a que la policía sea internacionalizada ${ }^{16}$.

-En la sesión del 9 de febrero, el Sultán aprueba el proyecto para la represión del contrabando. Únicamente se le añade, como aclaración, que las armas apresadas no serán destruidas, sino comercializadas. En la misma sesión, los delegados marroquíes reclaman la libertad del Sultán para comprar armas a la potencia que más le satisfaga ${ }^{17}$.

-Una delegación de europeos residentes en Tánger se dispone a enviar una comisión a Algeciras para exponer sus reclamaciones sobre el funcionamiento del servicio de aduanas ${ }^{18}$.

-Alemania parece dispuesta a transigir en lo tocante a la organización de la policía. Los delegados marroquíes solicitan la aplicación de medidas de extrema dureza

\footnotetext{
${ }^{12}$ Alfredo Rivera: "Telegramas", El Adelanto, no 6.682, 30 de enero de 1906, p. 4. Para la reforma fiscal del Imperio jerifiano, también España había elaborado un cuestionario, muy discutido por El Mokri. La delegación marroquí aspiraba a que se pudiesen cobrar impuestos sobre ciertas actividades mantenidas por los extranjeros y también deseaba levantar la hipoteca que tenía el cuerpo diplomático sobre el tertib desde 1903. Almodóvar del Río quiso evitar esta discusión, pero el resto de plenipotenciarios no lo aceptaron y transigieron con la idea de que dicho impuesto agrícola sería efectivamente exigido a los súbditos europeos. Por otro lado, España sería el país más afectado por los nuevos impuestos sobre correos, telégrafos... De ahí, el permanente "tira y afloja".

${ }_{13}$ Alfredo Rivera: “Telegramas”, El Adelanto, no 6.683, 31 de enero de 1906, p. 4.

${ }_{15}^{14}$ Alfredo Rivera: “Telegramas”, El Adelanto, no 6.684, 1 de febrero de 1906, p. 4.

${ }^{15}$ Alfredo Rivera: “Telegramas”, El Adelanto, no 6.685, 2 de febrero de 1906, p. 4.

${ }^{16}$ Alfredo Rivera: "Telegramas", El Adelanto, no 6.691, 9 de febrero de 1906, p. 4.

${ }_{17}^{17}$ Alfredo Rivera: “Telegramas”, El Adelanto, no 6.692, 10 de febrero de 1906, p. 4.

${ }^{18}$ Alfredo Rivera: “Telegramas”, El Adelanto, no 6.693, 12 de febrero de 1906, p. 4.
} 
para la represión del contrabando, pero las delegaciones española e italiana les ruegan cierta moderación ${ }^{19}$.

-Comentarios optimistas de la prensa francesa sobre la marcha de las sesiones ${ }^{20}$.

-En la sesión del 15 de febrero dan comienzo los trabajos para la organización y reglamentación bancaria ${ }^{21}$.

-Próxima terminación de las discusiones sobre el funcionamiento aduanero. El siguiente tema a abordar será el de las obras públicas. La diplomacia italiana confía en que la Conferencia finalizará en los últimos días de febrero ${ }^{22}$.

-Rivera informa de que Revoil, el delegado francés, ha enviado un telegrama directamente a Radowitz. La diplomacia francesa reconoce la soberanía del Sultán, pero no cede en la cuestión de la policía. Ésta habrá de ser exclusivamente francesa y española ${ }^{23}$.

-Alarmantes noticias sobre preparativos militares porque la guerra está muy próxima $^{24}$.

-Resumen de la larga sesión celebrada el 27 de febrero. Las discusiones se centran en la creación de un Banco de Marruecos, al tiempo que Francia continúa insistiendo en que su aspiraciones sobre Marruecos son justas ${ }^{25}$.

-La ruptura diplomática es inminente. Tattenbach reniega de acuerdos ya adquiridos. Nicholson, el delegado inglés, se desplaza hasta Ceuta porque parece necesitar un respiro. Los delegados norteamericano, italiano y ruso intentan mediar, pero la cuestión del Banco está generando nuevos incidentes. También los gobiernos parisino y berlinés están negociando la cuestión de la policía, pero sigue sin haber $\operatorname{acuerdo}^{26}$.

-Un creciente número de delegados apuestan por la paralización de la Conferencia como medio para evitar una guerra ${ }^{27}$.

-Trascendental sesión del 5 de marzo. Radowitz reclama que el ejercicio de la policía es una competencia marroquí, mientras que Pérez Caballero le contradice ${ }^{28}$.

\footnotetext{
${ }^{19}$ Alfredo Rivera: “Telegramas”, El Adelanto, no 6.694, 13 de febrero de 1906, p. 4.

${ }^{20}$ Alfredo Rivera: “Telegramas", El Adelanto, no 6.696, 15 de febrero de 1906, p. 4.

${ }^{21}$ Alfredo Rivera: “Telegramas”, El Adelanto, no 6.697, 16 de febrero de 1906, p. 4.

${ }^{22}$ Alfredo Rivera: “Telegramas”, El Adelanto, no 6.698, 17 de febrero de 1906, p. 4.

${ }^{23}$ Alfredo Rivera: "Telegramas”, El Adelanto, no 6.699, 19 de febrero de 1906, p. 4.

${ }^{24}$ Alfredo Rivera: “Telegramas”, El Adelanto, no 6.704, 24 de febrero de 1906, p. 4.

${ }^{25}$ Alfredo Rivera: “Telegramas", El Adelanto, no 6.706, 27 de febrero de 1906, p. 4.

${ }^{26}$ Alfredo Rivera: "Telegramas", El Adelanto, no 6.710, 3 de marzo de 1906, p. 4.

${ }^{27}$ Alfredo Rivera: "Telegramas", El Adelanto, no 6.711, 5 de marzo de 1906, p. 4.

${ }^{28}$ Alfredo Rivera: "Telegramas", El Adelanto, no 6.712, 6 de marzo de 1906, p. 4.
} 
-Aplazamiento de sesiones hasta el 19 de marzo. Revoil entiende que Francia ya no puede hacer más concesiones en la Conferencia y descarga responsabilidades, si ésta fracasa, en Alemania. Circulan rumores sobre el deseo italiano por apoderarse de Trípoli $^{29}$.

-El 23 de marzo, por fin, se consigue la elaboración de unas bases sobre la cuestión de la policía, mientras que la delegación austriaca está preparando otro proyecto con un carácter conciliador ${ }^{30}$.

-En la sesión del 3 de abril se revisa el protocolo último que habrá de firmar el Sultán ${ }^{31}$.

-Los plenipotenciarios viajan de regreso a sus países ${ }^{32}$.

\section{Los telegramas de El Castellano sobre la Conferencia de Algeciras}

-Designación de Almodóvar del Río como presidente de la Conferencia ${ }^{33}$.

-Se desmiente que en la sesión del 18 de enero se hablase del tiroteo sufrido por un buque español en aguas de la Mar Chica ${ }^{34}$.

-La sesión del día 24 de enero se ocupa del contrabando. Los periodistas franceses organizan una fiesta en honor de los españoles y les ruegan el fiel reflejo de las conversaciones diplomática. ${ }^{35}$

-Mínima alusión a la reglamentación del impuesto agrícola ${ }^{36}$.

-En la sesión del 3 de febrero, la delegación rusa reclama para el Sultán la recaudación de los impuestos. Debido a las presiones españolas, esta enmienda es retirada. Se rechaza la creación de nuevos impuestos sobre teléfonos, telégrafos y $\operatorname{correos}^{37}$.

-Taillandier llega a Algeciras para aportar noticias de primera mano sobre la situación interior del imperio marroquí. Estudio de los derechos marroquíes sobre exportaciones, libertad de cabotaje y un proyecto marroquí de aumento de tributaciones sobre el opio ${ }^{38}$.

\footnotetext{
${ }^{29}$ Alfredo Rivera: "Telegramas", El Adelanto, no 6.723, 19 de marzo de 1906, p. 4.

${ }^{30}$ Alfredo Rivera: "Telegramas", El Adelanto, no 6.728, 24 de marzo de 1906, p. 4.

${ }^{31}$ Alfredo Rivera: "Telegramas", El Adelanto, no 6.736, 3 de abril de 1906, p. 4.

${ }^{32}$ Alfredo Rivera: “Telegramas", El Adelanto, no 6.741, 9 de abril de 1906, p. 4.

33 “Telegramas. Última hora", El Castellano, no 1.041, 13 de enero de 1906, p. 2.

34 “Telegramas. Última hora", El Castellano, no 1.046, 19 de enero de 1906, p. 2.

35 “Telegramas", El Castellano, no 1.051, 25 de enero de 1906, p. 2.

36 “Telegramas", El Castellano, no 1.053, 27 de enero de 1906, p. 2.

37 “Telegramas", El Castellano, no 1.059, 3 de febrero de 1906, p. 2.

38 “Telegramas”, El Castellano, no 1.064, 8 de febrero de 1906, p. 2.
} 
-Alusiones a la insistencia con que Le Matin reclama para Francia el derecho a organizar la policía ${ }^{39}$.

-La diplomacia alemana exige la internacionalización de la policía, con la salvedad de los próximos a las posesiones españolas. Alemania únicamente aceptará una policía con oficialidad francesa si ésta, a su vez, admite la supervisión de un general alemán, austriaco o italiano ${ }^{40}$.

-Proyecto austriaco sobre la cuestión de policía. Claudicación de Radowitz ${ }^{41}$.

-Negociaciones directas entre los gobiernos de París y Berlín ${ }^{42}$.

-Moderada satisfacción de Bülow ante el proyecto austriaco de policía ${ }^{43}$.

\section{Los telegramas de $E l$ Lábaro sobre la Conferencia de Algeciras (Agencia}

\section{Mencheta)}

-Los plenipotenciarios pronto llegarán a Algeciras. La prensa de toda Europa ya se ha desplazado hasta la localidad, mientras que Almodóvar del Río les ha transmitido que todo lo relacionado con la Conferencia debe abordarse con gran reserva ${ }^{44}$.

-Trabajos en la Mar Chica a cargo de una rica compañía dirigida por alguien llamado coronel This. Promete a El Rogui lograr la independencia de sus territorios. Mencheta reconoce que hay que acabar con el statu quo marroquí porque, de lo contrario, la celebración de la Conferencia no es más que un enorme gesto de hipocresía. El objetivo de la reunión debería ser garantizar la paz en el imperio ${ }^{45}$.

-Francia no va a obtener las competencias para la organización de la policía. Ésta le será asignada a España por indicación de Alemania y con el beneplácito inglés. Anuncio de que en la sesión del 19 de enero se tratará del contrabando, pero sin carácter aún oficial. Se precisa limar antes algunas discrepancias. Se desmiente que un buque español haya sido hostilizado en la Mar Chica. Pero los trabajadores de la factoría acusan a los marroquíes ${ }^{46}$.

-Prosecución de las conversaciones sobre el contrabando. Buena disposición entre los delegados españoles y marroquíes para reconocer el derecho a la libertad religiosa ${ }^{47}$.

\footnotetext{
39 “Telegramas", El Castellano, no 1.065, 9 de febrero de 1906, p. 2.

40 “Telegramas", El Castellano, no 1.088, 8 de marzo de 1906, p. 2.

41 “Telegramas", El Castellano, no 1.089, 9 de marzo de 1906, p. 2.

42 “Telegramas", El Castellano, no 1.096, 13 de marzo de 1906, p. 2.

43 “Telegramas", El Castellano, no 1.104, 24 de marzo de 1906, p. 2.

44 "La Conferencia de Algeciras", El Lábaro, no 2.679, 15 de enero de 1906, p. 2.

45 "La Conferencia de Algeciras", El Lábaro, no 2.682, 18 de enero de 1906, p. 1.

46 "La Conferencia de Algeciras", El Lábaro, no 2.683, 19 de enero de 1906, p. 1.

47 "La Conferencia de Algeciras", El Lábaro, no 2.684, 20 de enero de 1906, p. 2.
} 
- Incomodidad francesa por una declaración soberanista española. El gobierno parisino cree que su homólogo madrileño ha olvidado el Convenio franco-español ante las presiones alemanas ${ }^{48}$.

- Marroquíes y alemanes han mantenido estrechos contactos durante las sesiones iniciales de la Conferencia. Los "moros" son muy reservados y reticentes con todo lo referido al contrabando de armas ${ }^{49}$.

-Los periodistas franceses obsequian a los españoles coincidiendo con la onomástica del Rey. El Mokri reclama libertad para la importación de $\operatorname{armas}{ }^{50}$.

-Los excesivos aumentos impositivos que solicitan los delegados marroquíes para productos de lujos constituyen una vía indirecta para anular las ventajas del régimen de puerta abierta. El Mokri siempre actúa bajo inspiración alemana. Los africanistas desconfían del éxito de un programa de reformas para Marruecos y sospechan que a España le conviene luchar por la preservación del status quo ${ }^{51}$.

-Alemania presta su completo apoyo a la delegación marroquí para lograr un aumento de los aranceles ${ }^{52}$.

-El Sultán habrá de someter a aprobación los derechos de fondeadero y anclaje. Conservará el monopolio sobre el opio y el kif ${ }^{53}$.

-Los conferenciantes habrán de ocuparse de la creación de una caja especial de moneda del Banco de España. Mencheta está convencido de que las discrepancias entre los plenipotenciarios no serán el origen de una guerra ${ }^{54}$.

-Comunicaciones directas entre París y Berlín. Enorme intransigencia francesa en la cuestión de policía ${ }^{55}$.

-Celebración de una fiesta en honor de los Reyes portugueses ${ }^{56}$.

\footnotetext{
48 "La Conferencia de Algeciras", El Lábaro, no 2.685, 22 de enero de 1906, pp. 1-2.

49 "La Conferencia de Algeciras", El Lábaro, no 2.686, 23 de enero de 1906, p. 1.

50 "La Conferencia de Algeciras", El Lábaro, no 2.688, 25 de enero de 1906, p. 1.

51 "La Conferencia de Algeciras", El Lábaro, no 2.691. 29 de enero de 1906, p. 2.

52 "La Conferencia de Algeciras", El Lábaro, no 2.693, 31 de enero de 1906, pp. 1-2.

53 "La Conferencia de Algeciras", El Lábaro, no 2.699, 8 de febrero de 1906, p. 2.

54 "La Conferencia de Algeciras", El Lábaro, no 2.702, 12 de febrero de 1906, pp. 1-2.

55 "La Conferencia de Algeciras", El Lábaro, no 2.705, 15 de febrero de 1906, pp. 1-2.

56 "La Conferencia de Algeciras", El Lábaro, no 2.747, 13 de marzo de 1906, p. 2.
} 
Boletín Oficial de la provincia de Salamanca, $\mathrm{n}^{\circ}$ 173, 11 de diciembre de 1910, p. 4.

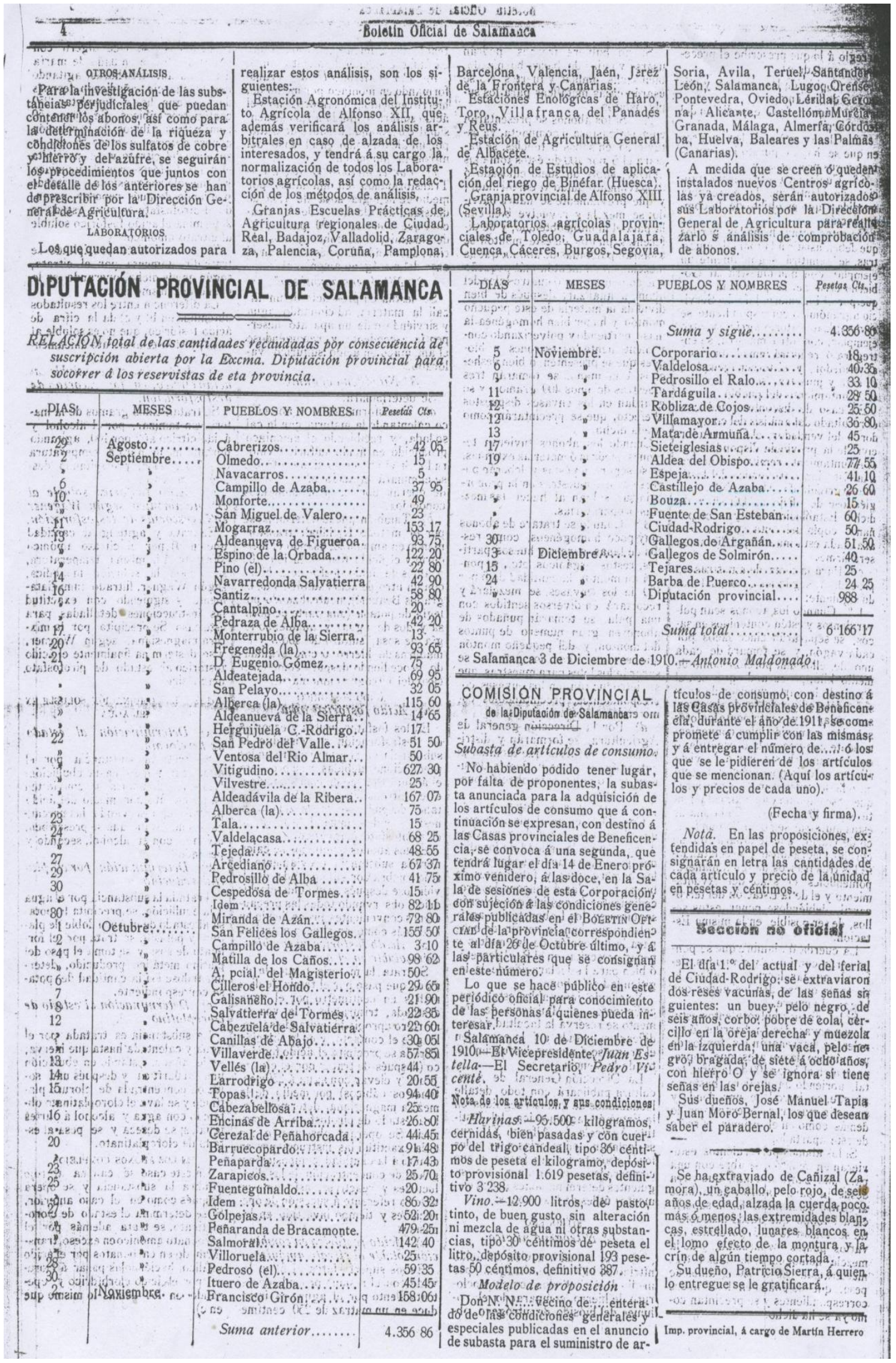


Boletín Oficial de la provincia de Salamanca, $\mathrm{n}^{\circ}$ 174, 13 de diciembre de 1910, pp. 5-6

De Real orden lo digo á V. I. para su conocimiento y demás efectos. Madrid 4 de Noviembre de 1910.Burell.-Sr. Subsecretario de este Ministerio

Gaceta del 16 de Noviembre de 1910.

Real orden ampliando el plazo paraque los Ayuntamientos puedan senalar las cantidades con que han de suscribirse para me-

$\mathrm{Sr}$. Vistas las peticione

formuladas. Vor diversos tyunta formuladas por diversos Ayuntamientos;solicitando ampliación del plazo que señala la Real orden de sentar instancias relativas álas presentar instancias relativas á las con. diciones de los locales-escuelas, mepara llegar á su mejoramiento sobre la base de la subvención que puede concederse con arreglo á la mencionada disposición, y teniendo en cueñta las razones de carácter pedagógico $\mathrm{y}$ de higiene que alegan la importancia de los servicios que comprende, que hacen más necesario un detenido estudio por los sohan de formular la petición y ofrecimiento, y precisado además esperar á que se aprueben y sancionen los proyectos, que en todo caso no serán de aplicación hasta el año proximo, por cuyo motivo no exissin perjuicio alguno, accederse á lo solicitado;

S. M. el Rey (Q. D. G.) ha tenido á bien disponer que se prorrogue el plazo indicado hasta el

De Real orden lo digo á V. ra su conocimiento y dés. I paDios guarde á $V$ y demás efectos. Madrid 31 de Octubre de 1910 $-B$. rell.-Excmo Sr. Subsecretario este Ministerio.

(Gaceta de 13 de Noviembre de 1910). Lo que se pone en conocimiento de los Ayuntamientos por medio de esta circular para los efectos consiguientes.

Salamanca 9de Diciembre de 1910 zil Gobernador edvil,

Antonio Cembrano Muñz $*^{*} *$

Habiéndose publicado en el BoLBin Oficial de esta provincia, número 173, correspondiente al día de ayer, la relación total de las cantidades recaudadas por virtud de la suscripción abierta por la Excelentísima Diputación provincial, para socorrer á los reservistas de esta provincia, con motivo de la campaña de Melilla, y cuya cantidad as. ciende a la suma de $6.166^{\prime} 17$ pesetas, la Junta provincial nombrada para distribuirla, ha acordado que se verifique en la forma siguiente: $10^{\circ}$ Se conceden 150 pesetas á las familias de los soldados muertos en campaña, cuyos nombres y vecindad se expresan á continuación, cuyas cantidades percibirán por puesto á que correspondan, previo puesto a que correspondan, previo recibo autorizado al efecto.

2. Se conceden 75 pesetas á los reservistas heridos en campaña que yas cantidades percibirán ma forma que se indiran tn la misro anterior. ro anterior.

3. El remanente de la cantidad enciados ?. ${ }^{\circ}$, se distribuirá entre los indivi- duos que han solicitado socorro en concepto de reservistas, cuyos nombres y vecindad igualmente se publican á continuación, haciéndose saber á éstos, que para percibir los socorros que le correspondan tienen que justificar con documento oficial, expedido por autoridad militar que fueron reservistas y movilizados por consecuencia de la campaña de Melilla, antes mencionada. Para acreditar este extremo, se concede un plazo de treinta días, á contar desde la fecha de inserción de esta circular, pasado el cual, se entenderán caducadas todas las peticiones que no hayan sido justifiSalamanca 12 de Diciembre de 910.

\section{E1 Gobernador etrli,} Antonio Cembrano

Nombres de los fallecidos San Esteban de la Sierra, Serao Gómez Martín.

Belena, Román de Obarro SánArabayona de Mógica, Francisco Hernández Martín. Alberca. Bernabé Mancebo Piés.
Rágama, Juan Sánchez González. Salamanca, Santiago González. Salan
Santos.

Santos (los), Pelegrín Aparicio de Arriba. gado.

Navarredonda de la Rinconada, Francisco Pérez Jiménez.

Linares, Benito de la Iglesia

Alba de Tormes, Cirilo Fernández Serrano.

Murió en Valladolidundo Durán.de habérsele disparado un fusil un compañero.

Nombres de los heridos Gallegos de Solmirón, Julián Díaz Parra.

Aldeanueva de Figueroa, Primo Béjar, Silviano Moreno Rodríruez.

Paradinas-Huerta, Juan Martín Salvador.

Huerta, Jesús González Barbero. Arabayona de Mógica, Simón Poveda Recio.

Vitigudino, Julio Rodríguez

Salamanca, Francisco Muñoz García y Bernabé Sánchez.

Ledesma, José Manuel Boyero tín.

Monforte, Felix de Arriba Cascón.

Arcediano, Francisco Gómez Villoria, Felipe Cascón González. Individuos que han solacitado so. corros en concepto de reservis las, a que hace referencia el ni mero $3 .^{\circ}$ de la presente circu-

Gallegos de Solmirón, Moisés Martín Vela y Diego González Ló. pez.

Calzada de Valdunciel, Antonio illanueva Terrero.

Ejeme, Antonio Hernández Gon-

Villar de la Yegua, Eusebio Gon ález Bravo

Saucelle, Bartolomé Bordallo

Aldeanueva de Figueroa, Celes tino Albarrán Vergara y José Sán chez González

Bocacara (Ciudad-Rodrigo), Jos-
Castillejo de Martín Viejo, Seundo Sánchez Garduño.

Salamanca, Mariano Gallo.

Espino de la Orbada, Antonio Cornejo Diéguez y Atanasio de astro Alvarez.

Calbarrasa de Abajo, Gabino de an Conrado.

Serranillo (Barquilla), Gumersindo Hernández Ramos.

Salmoral, Antonio Plaza Nieto,

Antonio Plaza Cuesta, Miguel Nie-

to Nieto y Eugenio García García.

Aldea del Obisoo, Juan Hernán-

dez Vicente é Hilario Salicio Fiueredo.

Cerralbo, Bernardo Gómez Ma y Manuel Herrero Pereira.

Encinas de Arriba, Domingo Pin. to Vicente.

Villarmuerto, Juan San Juan Sánchez.

Boadilla, Andrés Regalado Gon-

Cerralbo, Canuto Gordo González, José Gómez'Holgado y Dominoo Rubio Martín.

Endrinal, Miguel García de Arri-

Topas, Santos Ledesma Martín y Saturnino Huerta Martín. Tamames, Nicolás Escudero Fon-
seca. Cubo de Don Sancho, Adolfo Nieto Pascual y Gabriel Moreno Hernández.
Pedrosillo el Ralo; Pedro Martín Pedrosillo el Ralo; Pedro Martín
González. Alba de Tormes, Matías Vicente Villiar de Ciervos, Julián Martín
Vil Benito

Aldehuela de Yeltes, Policarpo Guijo de Avila, Domingo Martín González y Nemesio García Delgado.

Aldeavieja, Andrés Aguilar CasEndrinal, Manuei Sousa Morato. Fuenteguinaldo, Marcelo Martín Casillas, Ramón Rodríguez Gómez, Juan Francisco Castallo Sevilla y ulián Salvador Sánchez.

Beleña, Marín Franco Sánchez. Alba de Tormes, Juan Gonzáles Alcalde.

Morille, Fabián Hernández Rodríguez y José Francos Velázquez. Cabeza del Caballo, Santiago Gonzalo Pando

Cabeza de Framontanos, Isidoro Sardón Pacho y Amador Benito Hernández.

Fuente de San Esteban, Tomás Colmenero Bernal.

Navarredonda de Salvatierra, Juan Vivas Bazo.

Boada, Fernando Domínguez Sañ̄, Severiano Moro Hernández, Luciao Sánchez Muñoz y Juan HernánCiperez.

Cipérez, Abel López Alonso.

Fuenterroble de Salvatierra, DeBé González Briz.

Béjar, Felipe Muñoz de la Peña, Gabriel Ingelmo Sánchez, Nicanc lez. San Esteban de la Sierra, Aleandro López Asensio y Tomás La

Valdecarros, Honorio García Vicente, Perfecto Hernández Sánchez Jacinto Santos Borrego, Lorenz García Hernández y Sigifredo $\mathrm{Ce}$ -
lador Ingelmo.

Béjar, Victor Sánchez Martín. Guijo de Avila, Santos Diaz. Muñoz, Genuario Alvarez Her-

Cabeza de Béjar, Daniel Sánchez
Muñoz.

Buenavista, Román Ramos Sán chez.

Villalba de los Llanos, Lisardo García Tocino.

San Martín del Castañar, Orencio Sanz Torres.

Cabrillas, Genuario Calzada $\mathrm{Ca}$

Guijuelo, Adrián Nieto Hernández.

ejares, Alejandro Martín López. Aldehuela de Yeltes, Juan Moro Varcos.

Vellés. Juan Macías de Dios y ntonio Mz cías Pierna.

Alba de Tormes, Domingo de los olores y Juan Gómez Sánchez.

Villoruela, Victoriano Cortés Manjón.

Aldeaseca, Dionisio Iglesias MoParada de Rubiales, Nicolás Calo Hernández.

Veguillas, Manuel Boyero GarAlba de Yeltes, Jesús Sánchez y Sánchez.

Navasfrías, Pedro Moreiro Cle-

Sanchotello, Maximino Sánchez y Sánchez, Faustino Matas Redondo 
Martiago, Bernardo Calvo Man
chád'o? San Esteban de la. Sierra, Ma nuél'teuengo'Berrocal

Nayasfrías, Ciriaco Alfonso $\mathrm{Ca}$
ballero

Bongasoli Emílio Alonso Calvo José Puente Martín.

Vinásecó dé los Gámitos, Jesú Gåḉ Herrnández y Adolfo Vicen

Ardehuela de Yeites, Miguel Va

ras García.

Bejạ? Gregóriơ Sánchez y Sán chez Félix Tapia. Téllez y Matías Villagơnez' Bérez:

Béjar (Valdesangil), Aniceto'R'ó dills ealle y'Antonio' Bôrdona Gon

Cérèzal decpeñàiórcada, Joäquín Pérez Rodríguez.

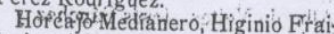
le Aparicio y, Jacinto Martín HerCandelario, Sebastián Santos Péreż $y^{\circ}$ Sebastiatry Villagomez CamTejares, Miguel Vicente Cruz Jose'sanichét Romo.

Belena, Benedicto Vicente $\mathrm{Ma}$ teos, from Gajates Germtd Rdoriguez Jimez, 1 i López Ruano y San Tag Hill Per Carabias.

Santos Díaz Sánchez é Isaac Re-

Valero Felipe Redondo Sánchez y êturts Cañete Alonso.

Bơơn. Entique Gómez Hertero y José. Diego Plaza.

Rodríguez y Victorian Hernándéz Rodríguez y Victoriano Paramás Villanueva der Conde, $\mathrm{Pablo} \mathrm{Ma}$.

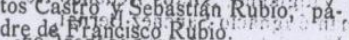
-Sahjesteban' de la Sierra, Ma. nuel Rgzas Navarro.
Garcibuey, Bartolomé 'Apaticía de la Iglesia,
Castillejo de Martín Viejo, Miguel,Honorato Sánchęz.

Aldeantueva de la 'Sierra, Juan José Martín Sánchez.

Cuádraillas, Juan José Rodríguez Cuadrado, padre de Lorenzo Rodríguez

Goj Santos, Melchor Merino Ro. Maltín del Rî́, Franciseo Ratero Benito.

Herguîjuela' de Ciudad-Rodrigo, Raimyndó Gónzalo González. dreguillas 'Agapito Sánchez, pa-

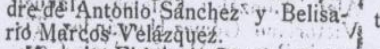
Montejón Florencio Sánchéz Ber"Alldearritubia, Daniel Rodrígue\%

Valdelàdsa; Sandalio Gómez

'Cep̉eđáa, Braulio-Sânchéz'Válero. sTardágutila; Constantino Manza no Esteban.

'Bucacara (Ciudad-Rodrigo), Juán Pérez Sánchez.

El' Pino, Heliodoro Petiscu Garis.

Eandelarió. José Martín Góme y Mlariano Muñoz y Muñoz Boeficira (Ciudad-Rodrigo), Je sús Berrócál González.

Santa-María de Sando, Juan HernándezıGarcia.

celipérez A Agustín Salvador Ro

Atalaya, Eugenio Benito Elvira. Vallejo Marcos, Tórmes, Alejandrò̀ Salamanca, Bernabé Muñoz Jua- | tes. nes, Gregoriou Barragán Martín, Manuel Matíás Palazúelo, Leonides pad́re de Sarítiago Sútil, Evéncio, Peralvo Díez, Francisco Gómez Fiz: Bernardo Requéna Martínez, Juan Francisco Guevara García, Quíntin: Gärcíal Gonźález, Isidrò Ríos Pescador, Casimiro Díez Gärcía. Baldomerd García Mendo, Ig nació Martín Hernández, Vicente Colmenar Garếa, natural de. CiuManuel Garrido Vicente Tomás Hetnán dez, iAlfonso Bollas: Izquierdo, Lo renzo . Barrado Holgado, Betriabé, Herriández:Mádruga; Ignació, Gont zálezHernández, FranciscoSánchéz Migual, Agústín iGil Gómezi, Jeș́s Bustos Fernández, Isidoro Bustas $\mathrm{n}$ a, Rafael Almeida Rodrígue Léon Labrador Mulas, Pedro Pinto Próim Dipnisio Alqunso, Kadrígyez Pedro Sánchez Garcíar, Ramón Garreía Cruzic Jose Mulas Martín ra. Pablos, Justo López Rincón R que Collado Santos, Maurició Pèrez Martín Germán García Laso, Angel Grande Sánchez, Sảlvador López Navarro Nemesio García Enrique Velasco Marcos Antonio Salgado Martín. José San Juan Santos, José Gonzalez Cabrera. Franciscu Huerta Cordovilla. An Vaquero Moreno, Aureliano Cea García. Juan Juanés Varas. Diónisio González Martín, Gaspair García Rodríguéz y Manuel Ramos amos

Cilleros el Hondo, Delfín Mateos .Véguillas „. Manuel Sánchęz García. Gantalápiedra, Faustino Alvare y Buengventura Sánchez García.
El Pino, Remigio Delgado García. Relayos Pedro Arévalo Bustos ras. Bóveda del Ría Almar, Críspúlo Mesonero Hernández

Ledesma, Julián. Hernández Le desma.

Gallegos de Argananán. Luciano Sánchez Plaza y Angel Martín Vilvestre, Manuel Rivero Ródriguez, Manuel Gorjón Notario, Toal González y. iLorenzo, Martín Fernạndez.

Payo.(el), Vicente Pascual Mar-r tín Ve Cristóbal, Basilio Carrasco García, Primo Luengo Cabaco y Va. entín Sáncheż Gatcía.

Carhajosá de Armúña, Juan rancisco Marcos González.

Fuentes de Oñoro, José Cardoso

Calzada de Béjar, Jerónimo Lópe Vicente, Maximiano Blazquez.R driguez é Hi pólito González García. Arabayona de Mógica, Santos Morán Ramos.

Alaráz, Juan González García Julián Albarrán Albarrán, Marcial Albarrán Martín, Diego García García. Fernando Sánchez Prieto Segundo Rojo Herrera y José Brión García

tes. Fernández, Digpisio Pérez García Arapiles, Belisario Vélázquez Ri-

Monleón, Frarcisco de Arriba

Garcían Eulogio Hernández
Tornadizon Francisco Bonilla Sánchez. Aldeaseça de la Frontera, Pláci do.González Pérez y Manuel Ferández Griñón.

Álberguería dè,Argañân; Ramón Aldegnueva de Eiguero, Isidoro Arias Bustos.

Monleón: Celedonio Pérez Benita, hez Hernández yiMelquiades Her-

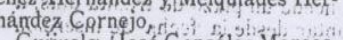
Guviuelo il osé González Marcos. Alaráz-Sebastián RubiolCericón. Pedrosa iz Eustaquio González Herrero y Alejandro Gonzalez Rodríguez San Felices de los Gallegrin, Ar. mando Fernándezu y ternández. La Maxa, Elías Fernández. Santa María de Sando, Juan Ma tín Regalado in Mersagaga, Aveling Yelasco No.

guera. chez Casado y José Santos' Cepa Salvatięras de ilFormes, Juliăn

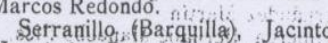
Hernández Ramos Saantibáñez de la Sierra, Juan
Manuel Sánchez Maillo. Vjllar $/$ den Reralonso Laureano
Zurdo Martín.

Himojosa de Duero Isidro Esteban Holgado

Sap Redro:de, Rozados, Baldome. ro lñigo Gonzálęzi! suti, dez y Serafin Castañ San Felices de los.Gullegos, José Gajate Hernández, Jesús Gajate Holgado, Victoriano Gnnzález Hol. gado Relix-Muñaz Corral y Esta, nislao Centen, Gurta

teos González.

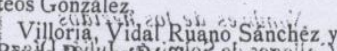
Morínigo, Manuel Sánchez CrésVilloria Felipe

Villoria, Felipe Casénn GonzáAnaya de Alba, Antonio Jimé. néż Sänchez:

Mogarráz, Domingo López Maillo, Agùstín Puerto Críado $y$ : Vic toriano Iglesias Martín.

Aldealengua, Agustín Picado Honso

Barba de Puerco, Francisco Si-

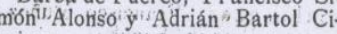
priano.

Nayacarros, Teodoro Marcos Lo. Vecinos, Pedro Garrido Hernán-

Robleda, Matías Boyero Sánchez Malipartída, Jóséé Hernández: Cordovilla, Inocencio' Barbéro Gălianō.

Torresmenudas, Ignacio Blanco Santos:

Pen̂aparda, Eusebío Mateos Benito, Clpriano Mateos Benito y Eusebio Collado Mateos.

Roblèdan i losé Matéos Roldán y ndrés Gutiêrrez Montero:

nánde

Villares de Yeltes, Avelino Sán chez Plaża.

Pelabravo, Benito Rivero Mar

Ciudad-Rodrigo, Antonio Sánchez lez.

Pelabravo, Juan José Ramos Gó-

Morínigo, Florencio Pablos $\mathrm{Bar}$

Santic Santiago i derila/ Puebla a Nicasio García González, Juan Lorenzo

Garcia, Tomás Rodriguè G Gáccia y Emeterio Conde Delgado. Navarredonda de la Rinconalda Tordillos,' Juan Blázqueź y Bâlz: quez y Antonio Gómez Alónso. Linares. Fulg encio Rodriguez Hernández. Blás Grande Rodriguez y Cecilio Martínj: Pisonero Machacón Andrés Lopez'Martín lo. Pedrosillo de Alba, Manuepi Mi San Miguel dec Valero, Domingo

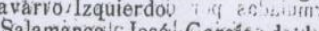
la Tornadizo, Miguel Péreż Cásque.

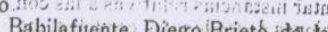
glesir yra ndrés Baro Arieto ides ca Trabarna Vicente: Vic Gater.

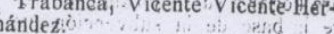
Pedrosillo ide Alba; Venáneio Rity Salero. Alcond, Getor Garela Garcia Vilitorio Villoria, Felipe Caseón Gonza lez. Salamanca, Francisco Pirrna Sánchez, 'Manuel Iglesias: Vicenter. Adrián Sierra Domínguez, (Pedroi Ramos: Gonzalez'Isiddro Doming ưeź Martín y Vicente Martín Gonzalez: Peñarañda! Lucio Miguél Cabà llo: Lumbrales, Leopoldơ Benito Sảni Ca Cabeza de Béjar, Juan Nieto Gono Salamanca, Santiago Casanuepooht Ba.jo. Cabeza de Bejár Juan Sánchęio

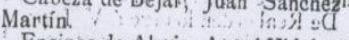
Encinas de Abajo, Anǵgel'Hidaligos?

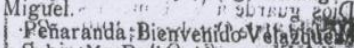

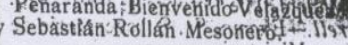
ArUn TUNTAMIDNTO CONSTITUOIONAL derValencia de Donifutum o.I Anulada por el : Exemo: Ayuntavb 
Historial Militar de la Albuera: Archivo General Militar de Madrid, Caja $\mathrm{n}^{\mathbf{o}}$ 33, Legajo 1/037

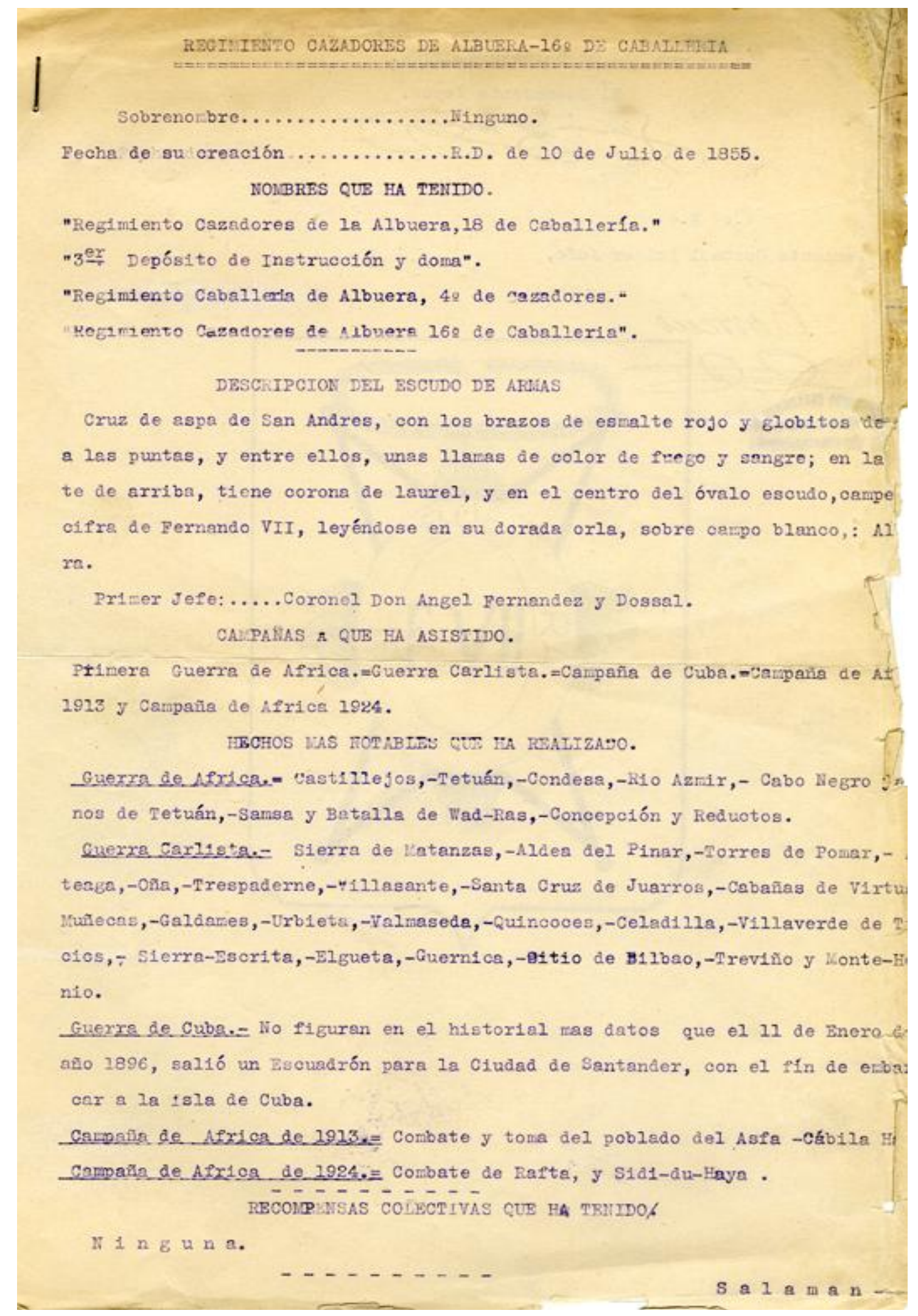




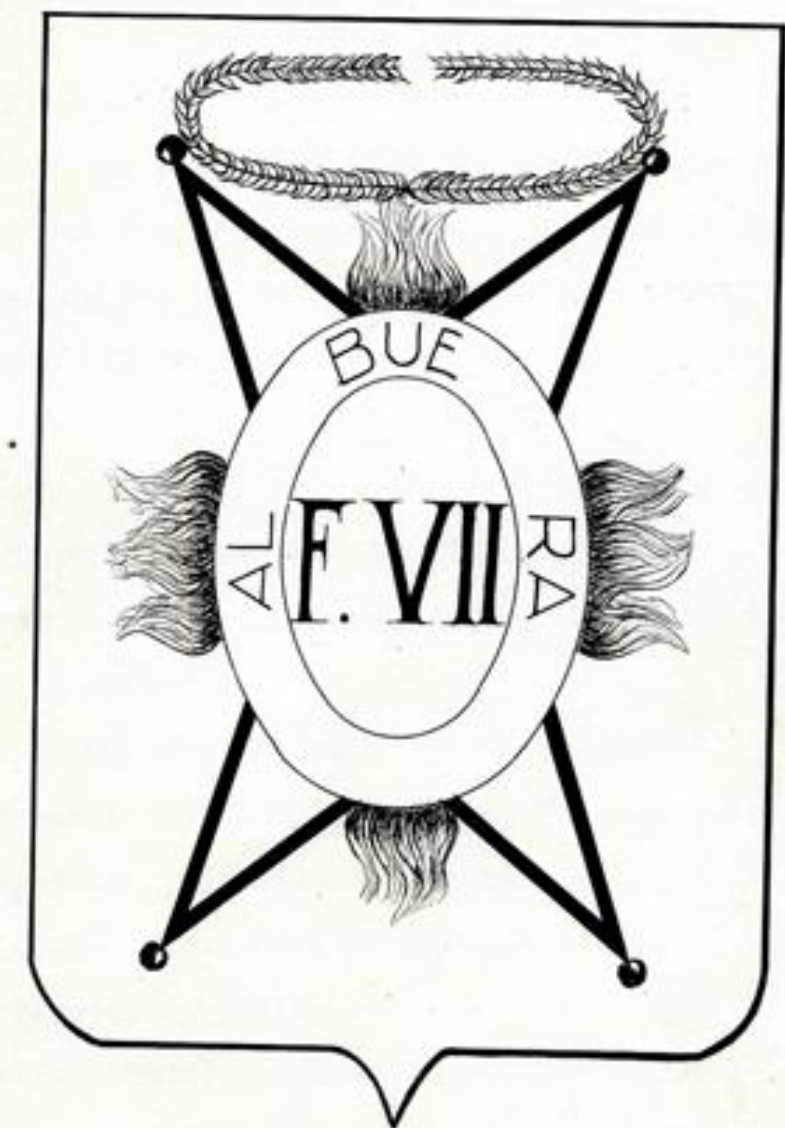


Indivlduos de tropa oon exnuo dres $\mathrm{g}$ nueve caballos.

Regreso el 17 de Noviembre de Bilbao por jomadas ordinarlas, al mando del Comandante señor Don Santiago Pernandez Santos, in fuerza del primer escusdron compuesta de sels ofloiales y ofnowente $y$ ocho individuos de tropa con sesenta y slete caballos, quedando en dicha Plaza en concepto de destacada le fuerza del segundo.

Para incoorporarse a este, salio el dia venticuatro de Novlembre por jornadas oxdinurias la fuerza del mismo que quedó en esta plaza, compuesta de ocho Individuos y alete caballos.

Iogroño 31 de D1o1embre de 1903,=E1 Comindante Mayór.

40 TIPTESTRE DE 1904 .

Se Incoorporaron el dis seis de Octubre por fornadss ordinarias las escoltaa relevadas de santander y Santora compuestas de cinco $y$ dos Individuos montsdos respectivamente.

Varcharon el 41a slete de Octubre por ferrocarril a Salasanca un Capi tan y doa individuos con el fin de hacerse cargo del cuartel que hable de ocupar el Reglmiento.

Distinado el 10 de potubre el Reglmento por R.0, telegraflca del sxcmo. Señor Mnistro de la Gerra fecha 30 de Septiembre anterfor a la Caja de SaIamnoa, salio de Logroño la fuerza dispontbto del mismo conpunata de Iu Jefes y offolales y doscientos ouarenta y dos individuos de tropa on dosolentos sesenta y sels cabullos al mando del Comandante sefior dos Tristan Cabezas Norinigo en direccion a Nagera primer punto de etapa efectuando la war ha a razon de siete kilowetros por hora alternando al trote $\mathrm{y}$ paso $\mathrm{y}$ habiendo dado un deacaneo dé media hora en tavarrete llego al fin de la jormada a las cuatro de la tarde. Ie guardia de prevencibn, arros y 108 potros llegaron a las oinoo y media.

El 11 de Octubre a las ocho continuaron ls marcha los escuadrones para Granion segundo pueblo de etapa. La marcha como el dia anterior se hizo alternando trote ypaso aprovechando las horlzontales para el primero, y recorriendo siete kilometros proximamente por hora. In Sento Domingo se dio un descanso prra dar agua al ganado llegando a las lz a Grañon donde se pernocto. La Guerdia con 100 cerros $y$ potros antloxparon la salida medi- to- 
ra a las del Regimento. Kn este dia salieron por ferrocarril a Medica del Campo un ofiolal $y$ dos Individuos de tropa con el fin de hacerse cargo del Cumtel que habia de ocupar el escuadron desagnado para destacarlo en diche Cludad.

Continuó el dia la do octubre la marcha, el Regimiento, saliendo de Grañón a las ocho en direccion a Villafranca de Montes de oca, en Belorado se dio ague al ganado continuanđo despues para llegar a su destino a las doce. Como el dia anterior la Guardia de prevencion, los oarros y los potros salieron media hora antes que $10 s$ escuadrones. Bn este dia sal1o de Logrof̆o por Ferrocarr11 para incoorporarse a su destino la fuerza desmontada que quedaba en dicha Pla-

za.

Bl Regimiento salio de V1liafranoa el dia siete de ootubre a las siete $y$ media con direccion a Burgos; A las jo llegon el Regimiento a Zalduendo londe se hizo alto para dar agua al ganado y pienso, que comiese la fuerza continuando a las doce para entra en Burgos a las tres donde despues de desfilar en columna de honor por delante del Ixcmo. Sefior Capitan Gral de la Regton se alejo ls fuerza en el assco de la poblaolon.

Desoanso en Burgos el dia catoroe de Ootubre dedicandose la tropa a la limpieza del armanento vestuario $\mathrm{y}$ monturas.

Se continuo el dia quince de octubre'la sarcha a las nueve en direccion a Bstepar fin de esta jornada que se hizo en tres horas al trote $\mathrm{y}$ paso por un pequel̃o descanso 1legando a Bstepar a las doce donde despues de dar agua se alojo la fuerzs para pernoctar. Bl cuarto escuadron y los potros siguleron hasta Celada, por no haber en Estepar cuadras sufioientes para alojar todo el ganado.

EI dia diez $\mathrm{y}$ sels de Ootubre etprendiose la marcha por $10 \mathrm{~s}$ esouadrones a las ocho con direcoion a V1llodrigo. In Villanueva de las Carretas se dio un descanso de media hora continuando para V1llodrigo donde se 11 go a las 12. Bl priber escuadron siguio hasta Revilla donde pernocto por no poder alo jar todo el ganado en Villodrigo.

A las siete y media del dia diez $\mathrm{y}$ siete de Ootubre salieron los escuaarones de villodrigo despues de incoorporarse el primer escuadron se continuo la marcha para Torquemada. La Guardia, carros y potros, como en dias anteriores salieron media hora antes. En Quintana se dio un descanso de media hora llegando a Torquemada a las doce. 
certátien el poote Jao1nto Benavente, priner dranatureo agnanol de este t1empo $\mathrm{y}$ obtuvo el prinolpal premlo de la "vlor natural" el Poeta Don...

Otros premios hubo entre ellos el de 250 pesetas entregadas por este Fegimiento al autor de una peroxis sobre - La cooperación de 10 s guerrilleros Bspifoles en las catpañas sobre la frontera portuguesa y biografía del més 1mportande de ellos DON JuhIan samcere ("el Charro") de 1808 a $1813 "$, cuyo premio le fué concedido al Cap1tán de Infantería Don ...

Bn Estos días se realizaron vuelos en aeroplenos, espect6́culo nuevo para cas tods la gente.

El día 18, antes de epararse las Comisiones de los Regimientos de Albuera (Infanteria y Caballería) brindaron atbos Coroneles, convinienao en pruebs de compañeriswo y comun recuerdo en que todos los nlos ol dia 16 de "ayo, cambiarian ambos Cuerpos un telegrama de Salutac1on y que ello guede condignado en el libro historial de cada uno, para que no calea en desuso Como así se hace.=intonio Reina.=Rubricado.

Salamanca 30 vunio de 1912. EL. Comandante Layox.=Gusllerwo Solis, =Rubricado.

\section{TATUESTRE DE 1912}

maล

E1 9 de Diclerbre, marcharon por jormadas ordinarias, a Ciudad-Rodrigo, destacados, el capitín D. José Torres, con su Bscuadrón, según lo ordenado por el Exomo.Sx.Capitán Ceneral de la Reglon en 6 del miswo, llegando a dicha Plaza el 11.

Salananca 31 de Diclombre de 1912.=11 Comendante Kayor,=Gujliermo solis. Rubricado.

3er TRTYTSTRS DE 1913.

Bn virtud de 10 dispuesto on R.0. telegrafica de 6 de Julio se formo un escuadron expedicionario para Afrioa.

SI dia 7 de Julio se incoorporaron de León un cabo y tres soldados con el fin de formar porte de la fuerza del escuadron antes citado.

Bl dis 810 cerificaron un sargento, tres cabos, un trompeta, un herrador de pritera y once soldados de segunda con treinta y seis caballos de c1udadRodxigo sels soldados de Valladolld, dos de Oviedo y uno de Zamora con el indiosdo fín.

B1 910 efeotuaron de Nedins, tres cabos, un trompta y 21 soldados de segunds con 16 cabalios de Ciudad rodrigo un cabo y 10 soldados y de Valladolid 
un herredor de segunda todos ellos para roriar parte del eltedo escuadron.

Bl dia 12 emprendio in marcha por ferrocarril el oftado escuadron, segun orden recibida el $10 \mathrm{del}$ mian de la Superioridad de la Fegion compuesto de cinoo ofioreies un Veterinario tercero y olento treinta y cuatro clases e Individuos de tropa, con clento ventiocho caballos y un cabo a las ordenes del capitan don Gufllerwo Laá Rute llegando aAlgeolras el 15 embarcando en el vapor -VICMUTz FmpBr".

B2 dia 16 de julio llego el escuadron a Ceuta y desembarcando se Instalo al anochecer en Ios Barrancones de "La Punti1la" .

Bl dia 18 al amanecer salio el esouadron a prestar el servicio en la Carretera de Ceuta a Ietuan; al llegar a la Concesa tuvo notlolas de una agresion de los boros; avanzo el escuadron al trote encontrandose a la 1zquierda de la Carretera y frente a la primera ourba del Rio Negro a ocho cadaveres de soldados españoles; desplegó el escuadron reconociendo el terreno sin encontrar al enemigo; prosigul hasta la Restinga, dejando cublerto el servicio de la Condesa a la Restinga; regreso de la Restinga a Condesa escoltando el convoy del Fuerte de lonte Negrón desplego al galope en Ios llanos de "LOS CASTILIEJOS para proteger un convoy que bajaba de Kudi. Peder1: retirandose $10 \mathrm{~s}$ que persegulan; contramarcho el esouadron escoltando el convoy de Fuerte de honte Negrón regresando de noche de la Restinga a la punti1la.

Dl dia 19 y 20. de reten en la Puntilla.

B1 zl de julio se sal1o formando una columa mixta a las ordenes del Teniente Coronel de Estado layór señor Priego; vadeando con el escuadron en Rio llegro, reconociendo este $y$ todas las marismas de su 1zquierda; comiose el ranchon junto al blockan de su deserbocadura, talando y quenando las or1zlas del $\mathrm{n} 10$ gue domfnabu la Carreters; sel10 el escusdron a Kudia Federik, escoltando hasta la Condesa un convoy de bajas regresando de noche a Ia puntiza.

Los dias $2 \mathbb{Z}$ y 23 de reter en la Puntilia.

E1 24 se sailo de madrugada prestonáo el servioio do arretera estendiendolo hasta Uad $\operatorname{Smf} z$ escoltando un convoy; regresando de noche a la Punt1218.

BI dia 25 festiviad de santiago = Misa. 
El dia 26 presto el servio:0 de reten por la linea exterior $*=y$ luego misa por los dffuntos del arma.

Il dia ventisiete misa y se salio a prestar el servicio de Carretera; antes de llegar a la Condesa tuvo noticias de que la culuma mixta del comandante Gavarran sosteniaflego con el enerigo, avanzo el escuadron al galope y deJando sobre la Carretera la tercera seccion (Tentente Lecanda) desplegando las otras tres; avanzó el Capitan con la primera (Merifente Castro) hasta ocupar una loma que proteglendo al flanco 1zquierdo de la columa dominaba las barrancadas por donde pudiera huir el enemigo que ere del poblado de Asfa Kab1la el Hajz. Roto el fuego, por el enemgo, en vista de su intensidad $y$ duracion ordenase el avance de la segunda secolon (Tentente fercal) y al llegar este $y$ estando recibiendo ordenes del Capitan, oayo el Teniente atravesado de un balazo, tomando de esta sección el mando el surgutito Pabio Cortés, nutrida la Euerrilla con estos tiradores; se llano luego a la tercera sección (Teniente Lecanda). Dominando el fuego contrar1o, y retirado el oplcial herido que fue curado en la linea de fuego por el cabo practicante unnuel Hartin, recibio el escuadron la orden de mantenerse en posicion protegierido el paso de la columna; prosiguiendo luego sn marcha hasta la Restinga te donae regreso de noohe a la puntilla.=Segun el parte ofioial las fuerzas tuvieron dos oficiales heridos uno do ellos ed tentento don Germen Gonzalez peral y de trops sels muertos $y$ olnoo heridos uno de ellos el soldado del esouadro josé Reguelro herido leve y los moros 23 bajas.

B1 28 de Junlo de reten en la Puntilla.

E1 29 serviolo de Carretera hasta la Restinga, a la ida el escuadron tuvo que hechar ple a twerra; rompiendose el fueso por la priwera secoton (teniente Castro) para repeler la agresión de los de Asra; continuando a ultiwa hora el Iuego por unos tiradores escogldos de la primera, segunda y tercera secolbn.= Cesando el luego enomigo cubriose el sorvioio haste la restringo regresondo al anochecer ha la Runtilla; sin novedad en el tiroteo anterior, y luego al ser tieroteado el puesto del Teniente Solmayo (Cuarta secolon).

BI dis 30 de reter en la puntilla.

B1 dia 31 serviolo de Carretera hasta la Restringa; sin novedad; degde el dis sale prestanco servioro en el esouadron en sustitucion del Tenfente 
Persl, el primer teniente del cuadro de eventualidades de esta Plaza don Bdusrdo Gonzalez Camp1110; cesando por el10 el mando de la segunda secoton el sargento Pabio Cortes.

Bl dia primero de Agosto en la Puntilla, Revista de Colalsario.

El 2 de reten en la Puntilla.

BI 3 Serviolo de Carretera hasta el Negrón.

B1 5 De reten en ia Punt11la.

B1 6 en la Carretera, servicio de proteccion hasta Negrón.

BI 8 De reten en la Punt111a.

El 9 en la Carretera, servicio de protecoion hasta el Negroh.

BI 11 de Reten en la Puntilla.

B1 12 en Carretera,

Bl 14 de reten en la Puntilla.

Bl is sallo el escuadron a proteger la carretera hasta el Rlo liegro; $y$ t1roteada la segunda sección la reforzó la Gran Guardia con el Capitán tercera $\mathrm{y}$ cuarta secolones rompiendo el fuego contra el Poblado del Asfa; duro el tiroteo de la segunda y pritaeras secolones mas de dos horas; siendo herido grave el soldado Benito Quintas, y herido un caballo, dominando el fuego contrario se llamo a la primera secoion para distribuir muntciones llegando la columa de refuerzo del Comandante sel̃or Gabarran; y roto el fuego por la Artilleria dispuso que la primera seccion con las fuerzas indigenas nontadas se corriese sobre la izquierda, prolongando as1 la linea de fuego formada por la segunda $y$ tercera, ordeno luego se retirase el servicio de la Carretera y se replegasen todas las fuerzas. Para cumplir tal orden con el Capltan segunda $y$ tercera marcharon por 1 a playa; pero enfilados por el fuego enemigo hubo que recurrir por tres veces al combate a pié para evitar que el enemigo llegase a coitar la linea de fuego covo intento varlas veces. Retirado el puesto del Negron; se fue recubriendo y retirando todo el escuadron bajo el fuego violento enendgo que causo la muerte del soldado Gago, las heridos de 10 soldados José Perez y Ricardo Lartin, la muerte de tres caballos, y no pualendose recuperar del enejigo el caballo del soldado Gullón que tuvo que segulx al escusdron pribero a plé y montar despues a la grupa de otro, las heridas bajo el fuego enemigo fueron ouradas por el profesor veterinario 
tercero don Teogenes DLaz, eabo de practicante vanuel Nartin $y$ herrador de primera kufino komero. reconcentrada toda la columa y bajo la proteccion de Albuera se prosiguio la marcha a Ceuta 1legando de noohe a los campamentos.

3116 de Agosto de reten en la Puntilla y munioionandose.

B1 dia 17 de servicio en la carratera hasta el Negron a las ouatro se retiro de servicio desplegando el esouadron á tomar el contacto con la retaguardia de la columa del Exomo. Selior General Arralz de la Condesa, cuya retaguardia habria el paso de la columa que se tiroteaba con 108 moradores de el Hajz desde entonces cubrio el escuadron la retaguardia de la expresada columa hastasu instataolon en el poblado de Asfa recibida orden de retirarse el esouadron a su compamento fue tiroteada en 103 altos proximos a] Tarafal siondo heridos en 12 primera descarga un caballo, hecho pie a tlerra el escuadroncubriondo las lomas $y$ pasando hora $y$ media de fuego biendo el Capitan que la noche se hechaba enoima ordeno waroharon los caballos de mano al compamento de la Puttilla protegiendo con el fuego enomigo se retiro Ia fuerze pie a tierxa por escalones hasta la Puntilla a donde se llego sin mas novedad que el cabo Zorrilla y soldado Secundido Iopez heridos leves.

3118 de Agosto de reten en la Puntilla fnmunionandose.

E1 dia 19 serviclo de proteccion hasta rogrón, sin novedad; subiendo el Capitan al poblado de Asfa a recibir brdenes del Excmo. Señor Arralz de la Condesa; proteglendo luego el escuadron sin novedad la evacuscion de los muertos $y$ heridos de $1 \mathrm{a}$ expresada columa.

Bl dia 21 de reten en la Puntilis.

E1 dia 22 de Servicio de Carretera escoltando al regreso un convoy de heridos a celta.

El dis 23 formó el escuadron'a rendir honores a la llegada del Bxcno/sefor Capitan General Marina saliendo despues a la una de la tarde con dos companlas y una bateria en socorro del escuadron de villarobledo regresando sin novedad a esta Plaza.

X1 dia 24 de servio1o de Carretera, teniendo sin novedad pequeño tiroteo con 10 poblados de Asfa.

El 25 de reten en la Punt1lla; el 26 salio el esouadron formando parte de 
de Is columa del Excno. Seftor General santa coloma; oubriendo is carretera hasta Kudia Fahams para el paso del Resldente Gral Bxcmo. Señor General karina, regresando a la pleza sin novedad.

Bl dia 27 de serviolo de carreteras, sin novedad.

B1 28 de reten en la Puntilis.

Bl 29 de carretera sosteniendo tiroteo con grupos enemigos que se retiraron sin cousar baja slguns.

B1 30 , de reten en la Punt1lia.

BI 31, de serviolo de carretera sin novedad.

B1 10. de Septiembre, de retén en la Puntilla.

B1 día 2, servicio de carretera apoyando por el penidak el flanoo $1 z$ quierdo de la columa del Bxomo. Sr. General Santa Coloma, que lleva un convoy a las Cudias.

Bl día 3 , de retén en la puntilla.

Bl df́ 4, serviolo de carretera y subida al poblado dol Asfa, flanqueando 21 columa del Exono. Sr. General Arraiz.

El día 5, agregado el Bscuadron a la Columa del Exomo. Sr. Sr. D. DominGo Arraiz de la Conderena, sube a Cudia Federik escoltando un convoy a Condesa, donde se pernocta.

El día 6, sube el Escuadrón a Cudia Pederik y escoltando a S.B. reconoce el boquete de Anghera y las kudias hasta Condesa regresando a Venisla donde pernoct6, sin novedad, a pesar del t1roteo sostenido.

21 dia 7 astste el Escuadrón sin novedad al combate del Biutz, escoltando a la artilleria que baja a Condesa a muniolonarse, regreanano a Kudia Pederik, donde se pernocta.

Los días, 8, 9, 10 y 11, se pernocta en Uenisla, praoticándose disrlos reconocimientos en las Cudias, Valles de Brenimesala, Uenisla, etc. eto.

$B 1$ dí 12, escoltando al Excno. Sx, Comandante General, reconoce las 10mas altas del Asfa, Unfak, hasta llegar a Aln-el-Hhaindra, pernoctando en Uerisisia.

Los dias, $13,14,15,16, y 17$ se pernocta en Jenisia reconociendo diarlasente Ias Kudias y posidones, hasta Kudia-Pederlk, Boquete de Anghera eto.etc.

31 18, con S.E. se reconoce hasta la Restinga Las posiofones para continuar el blockaus. 
B1 dis 19 de Septiembre se practica un reconoclmiento porel penidak perriootando en Dar-RIIIen.

Los d1as z0 21 y 22 se practicaron reconoclmentos por el Fenidak, Yebel Xueder, KudiarAyenale, Haffa del West Yebel del West,Boquete de Anyera, Kudia Pederik, Afresignan, Hama,-del-Aldra, Hauma del Hals de Benimesala, Benimesals, Uenista, Lons del Mufak; Lomas del Asfa sigutendo por Usd regro y Burch Negro, hasta el Vad Snla, pernoctando en Dar-Riffrien,10o dias 43, $24 \times 5,26,28: y 89$.

B1 29 escoltando a S.B. se reconotoron todas las lomas de Asfa hasta, MhatAra, y Vad Negro regresando sin novedad Dar-Rlfrien.

E1 30 en Dar-Refrien por la Iluvia.

Salamanos 30 de Septi embre de 1914.=51 vomandante, Hayor.

\section{TRIILSTRE DE 191 .}

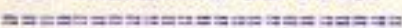

BI dis uno de Octubre, doa $y$ tres, slgue el escuadro agregado al cuartel General del General hrraiz, prestando el miswo serviczo que en el mes anterior.

B1 d1a trea, escostanuo al uxcco. Seifor Gral Arraiz se efectú un reconoc1miento por Uad Penldak, Kudia alta Benlmesala, Vlveros, Guardianas y Mezqufta, a posioion A $\mathrm{y}$ desde alli a las ordenes del General zensoho por boquete de Anyera y Bensu al poblado de Benzu, Yebel, Kinder, Salut al Tarajal regresando a Pernootar a Dar Rifien ain mas novedad que la caida del caballo del Soldado Ilbrolo Babano fracturandoseeste ung pierna.

31 dia 4 presta el servicio de descubierta, reconocratentos $\mathrm{y}$ proteccion desde rebel S1ndex, Boquete de nnyera, Kudia federico y restantes Kudias, Valleg de Venisola y Penlaak, lomag altag y bajas del Asfa, valles del Negrón, reetinga,zeu seu hasta Uad Smir pernoctando en Condesa, Dar Riffien valie del Hegrón, Restings etc.

Destinado el escuadron segun la nueva organizacion al Cuartel Gral del General Agullern, recibe orden de regresar ol Campanento de la Puntilla, para roorganlzarge a marchar a Tetuan por ello hasta final de mes, se dedica a reponer el ganado, a recomponerse los equipos $y$ adiestrar al personál; precticando el dis diez y alete un reconoc-michto sobre el Benzá el 21 otro sobre Rudis altn, el 25 sobre Dejebel, Xulder, el ef sobre el Boquete de Anyera y el 31 sobre Venisla. 
En el wes de loviembre del presente allo sibuio ol escuadron pertenealendo al Cuartel ceneral del Excmo. Sefior General AEuilera y contanua acampado en Is purtilia practiondo reconocimientos.

Por las Kualas desde of rensdak por vomisla y Bent Usala hasta ls posioton a. $y$ ol Benzk; escultundo al zxomo. Sefior Ceneral ttenecho en $10315 \mathrm{y} 17$ hasta Yebel; Xinder, $y$ posicion A.

5el uno an se1s de Diolembre sigue el escuudro perteneciondo a Curtel Gral del Exomo. Sellor General Agutlera y continua soampado en la Puntilla, practiando reconocimientos por el frente de la linea exterior.

Bl dia 9 salio todo el esouadron con las baterias del decimo mont_au las ordenes del General Arratz hasta la Restinga; dejando deatacada la primera seccion (Teniente Lecanda) $y$ cuarta (Tentente castro) on $I$ aposiolon de Montenegrón regresando el "regto del uscuadrón con las baterias do lu Puntilis saliendo esta fuerza con dos buterlas.

BI 11 a reconocer las lomss del zem - Zem.

BI 13 escoltó al Dxcmo. Señor General Menacho al Serallo posiolon A. y Benzน́.

Bl 16 con una beteria se praotica reconocinlento por el Zer-Zem Gejandoen el Lonte Hegron a las secolones primeras (Teniente Sol Hayo) y segunda(Teniente Camp110)recogiendo en camb1o teroere y cunrta que oun otru bateria, habia saliào el quince $y$ alez y bela hota Uad Sudz.

B2. dia 1819 y 20 se salio por el Benzu.

Z1 23, llega a Zem-Zem, se recogieron las secolones destacaAss regresendo todas a la Puntilla. Las secolones privera y segunda con la bateria valieron ol 17, 18 y 20 hasta sudz y el 21 a Riffien.

B1 26 remidu el osoudron en Ia putilis practica reconociulento por la linea exterior.

BI $30, y$ despues de reconocer el esouadron con la bateria hasta la Restinga, regresa a la Puntilla con ella; dejandy destacado ex Wontenegron la cuarta secolon al pie de la Guerra, (Tenlente Castro).

Salamance, sI de Diolembre de 1913 .mDI Comandante Hayor.= MES DE BNMRO DE 1914 .

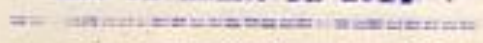

contlnua eate escuadron perteneciendo al cuartel General del Bxano. Señor General Aguilera, salienáo la secoion al pio de guerra (4s) que estaba en 
el Vonte legrón con la batoria el dia 3 al Smx, el 5 al Minoón $y$ el 6 a lenisla continundio las perajas destaosdas en la Restings, en el Hayar y companento del Smlr, prestando el serviolo de estefete, $y$ in fuerzs restante del mismo en la puntilia asliento el dos $y$ el cinoo por Xebil-rinder $y$ la Nezquits.

El 7 sale el escuadron haste el Zem zem con la bateria recogiendo todas sus fuersas vuelve a la Puntilla donde pernoota anliendo el 10 a Benzu $\mathrm{y}$ 12 a Hon1elu instelando los dias 13 y 14 el nuevo campamento del escudron en tiendas de campara.

B1 $15 \mathrm{y}$ con la batoris sale el eecuadron, haolendose oargo ya definitivamente del destacamento del Negro $\mathrm{y}$ serviofo de Bstafetas hasts el Smr, y dejando la segunda secoton regresa al campanento, saliendo el 16 por Jadu, el 17 por Bengú el 22 con la bateria a relevar la segunda seccion por le tercera el 26 por Jolú el 29 a relevar la tercera por la primera $y$ el 30 por Aranguren.

El destacamento del Jegrón, con la bateria sal1o el 16 y ly al Sulr, el 25 a Yenlsia $y$ el 27 al Smb.

Ceuta 31 de Bnero de 1914.mBI capitan Gúllermo Iaś.Rubricado. MES DE FYBRYRO DE 1914 .

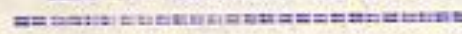

Continua el escuadron en 1gual forta que el nes anterior, prestando con sus parejas el gervic1o de estafeta heste el Smir; la secolon destecads en el Hegro y la bateria del Negro, fue relevada en los 410.8 ounco, daco, dez $y$ nuove y ventiocho; saliendo esta seccion con su bateria el 15 a los Castillejos, y ventiáos a Riflen. 31 escuadron sallo con las bateries al relevo los dias dinco, doce, diez y nueve $y$ ventiocho; el nueve al kegro con uns baterie rodade del mixto; el catorce al el Hayar con las dos del deolmo; saliendo as1 mismo en los diss dos, cuatro, siete, once dicz y slete $y$ ventluno; aslatiendo el ventielete a ln jura $y$ no tenlendo novedsd la secoion deatacsda en el tiroteo del ventisiete.

Ceute 28 de-Febrero de 1914.=I Capitan Gujllermo Laa.Rubricado.

MES DE MARZO DE 1914.

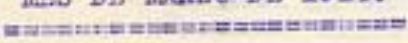

Cont1nue el escuadron en 1 gurl forita, con el destecesento del llonte Negron $y$ las estufetas hasta el rio Smir; la seccion destacsda y la bateria 
fueron relevedos los diss $20 \mathrm{y}$ 18. $\mathrm{KL}$ escuadron sàeras de sal1r al xelevo los dias 10 y 18 sallo los dias $4,5,7,9,12,14,17,21,23$, y 26, en que reooglendo el servicio retornó todo unido a la Puntilla, salio todo el los dias ventiglete y treinta. Ia secolon destacada salio el dia venticinoo. (Segunda Tenfente cang1120) Jon la cuarta Bateria del Declmo montado, reconocienao hasta Sara Torres dedae donde romplo el fuego la bateria sobre el enengo que habla egredido a los reductos $y$ retirando este regreso a Nontenegron sin novedad.

Ceuta 31 de Marzo de 1914, $=\mathbf{M 1}$ Cap1tan Guillermo Lá=Rubrioado. IES DE ABRII DE 1914.

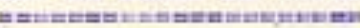

Continus el escuadron prestando sus serviolos, saliendo, para ello los diss dos, cuatro sels trece diez y sels diez $\mathrm{y}$ ocho ventidos venticuatro ventialete, ventiocho y treinte; saliendo ademss con el Excro. Seĩor General Nenacho el 7 por la Playa hasta Bensu el 14 por las Guardianas $y$ Arroyo del Infierno a la Plazs de CaLamocarlos, el 23 a la varadura del vapor S,S. Slegenla; matrioula Jatelin $y$ el 25 al Venzu al rescate del Conandante Garbia del Valle.

Ceuta 30 de Abril de 1914.=\$1 Cap1tan Guillerno Lá. Anubriondo. IES DE WAYO DE 1924 .

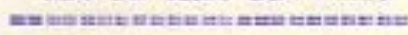

Continua el escuadron prestando sus serviolos, sal1endo para ello $10 s$ d1as dos, siete, nueve, doce y ventlocko; yendo el tres al alnoon del Led1k escoltando convoyes de artilleria; asistiendo el oinoo con el Excmo. Seflor Gral Lenacho a la operacion sobre BI Hanidra y cafioneo de tos Aduaree del valle del rlo liegro, el ventisels con el mismo General de reconocimento por las Gunrdianas y Zebel - Xalder y el 30 con las baterlas del Jegro. Coute 31 de rayo de 1914.=K1 Capitan Gu1llermo Laá,=Rubrioado.

\section{IES DE JUIO DE 1919 .}

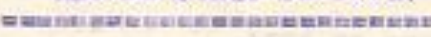

Frests el escuadro, on dias alternos el sorvicio de un cabo y cuatro soldedos en el Serallo y ourinvendo el restante servioio, sal1o los dias 4, $6,9,15,16,18$ y $20, x 1 \times 3,26$, y 30 y con lag baterias al liegrón 105 dias 1 y 5.

Ceuta 30 de Jun1o de 1914.=\$1 Capitan.Gu11lermo Laḱ.=Rtubricado. 
ZES DS TUIO DE 1914.

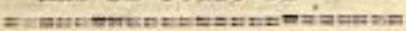

Continus el escuadron perteneciendo a la zons de Tetusn tanaada ahora,por el Excmo.Sefior General de D1vision don Josquin Mlans Ael Bosch; pero, por conventene1a del servicio, acampado en la zona exterior de ceuta a las inmediatas ordenes del Excmo. Señor Cokandante General de Ceuta Excmo.Sefior Don Ramon Garola lenacho; prosigui ondo con el servicio del Serallo, saliendo el escuadron 105 dias $4,6,8,11,13,15,18,20, z z, z 3, z t, z y, y$; ; eacoltando batertas el pritero $y$ diez $y$ seis al Negro y el meve a fiffien.

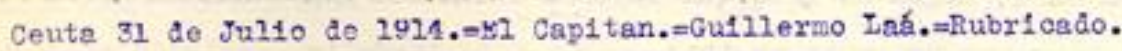
IIS DY AGOSTO DE 1914 .

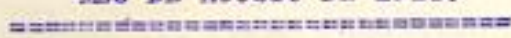

continue el escladron, prestmao el servicio del Serallo, y saliendo los dias, $1,3,5,7,10,1 z, 14,15,17,29, x 1, x 4,26,28,29, y 30$.

Ceuta 31 de Agosto de 1914.=S1 Capitan Guillermo Lak.=Rubricado.

mes $\mathrm{DE}$ SxYmIE:BHE DS 1914 .

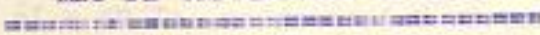

Continus el escuadron prestando el serviclo del Serallo $\mathrm{y}$ saliendo $10 \mathrm{~s}$ Glas $3,4,7,11,18,14,19,21,26,28$ y 30; esooltando bater1as a Dar Riffrien el $9 \mathrm{y}$ al Negro los dias 1, al $16 \mathrm{y}$ saliendo con el Bxomo. Señor General Henaoho los dias 5 y 23; ambos dias a los saltos de Djebel - Xu1der por la posicion A, regresando el primero por las Guardianas y el vorav1to.

Ceuts 30 de Septiembre de 1914.=B1 Capitan. Guillermo Laá.=Rubricado. IRS DE OCTUBRE DE 1914.

Continue el escuadron prestando el servicio de el Serallo y saliendo $10 s$ dias $1,3,5,7,10,13,17,19,21$, ks, k4, $27,29,31,9,15$ y 26 10s tres wtinos a Dur Hiffien.

Tetuan 31 de Ootubre de 1914.=B1 Cap1tan.-Gu1l2ermo Iná. Rubricado. wes DE nOVIV:BRE DE 1914.

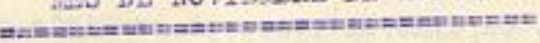

Pasa al esouadro la revista en 1 gual forma $y$ el da 3 gale a ponerse a las ordenes del Excmo. Señor Don Iransito Sanclez langón General de Ir Brigade de Centa, quedando la tercera secolon (Teniente Lecanda) acompada en la Conueas para la descubierta y seguridad del barrio del tregro, y la primera y segunda con el Capitan en el Canpazento de Dar Rierrien; 
ZTES DE JUYYO DE 2914.

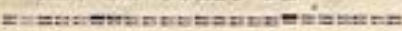

Continus el escuadron perteneciendo a la zona de Tetuan manada ahora,por el Exomo.Señor General de Division don Josquin \#lans del Bosch; pero, por convenienela del servicio, acampado en la zona exterior de ceuta a las lnmediatas ordenes del Bxcho.Señor Comandante General de Ceuta Excro.Señor Don Ramon Garcia Menacho; prosigui ondo con el servicio del Serallo, saliendo el escuadron los d1as $4,6,8,11,13,15,18,20, z x, z 3, z 7, z y, y 31$; escoltando baterias el primero $\mathrm{y}$ diez $\mathrm{y}$ sels al Negro $\mathrm{y}$ el nueve a Ilffien.

Ceute 31 de Jul1o de $1914 . m \leq 1$ Cap1tan.=Gu1llermo Iaŕ.=Rubricado.

IBS DY AGOSTO DE 1914.

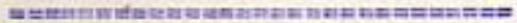

Continue el escradron, prestmao el servicio del Serallo, y saliendo los d1as, $1,3,5,7,10,12,14,15,17,17, x 1, x 4,26, x 8,2 y, 530$.

Ceuta 31 de Agosto de 1924.=KI Capitan Guillermo Laḱ.=Rubrioado.

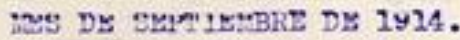

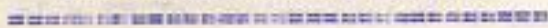

Continus el escusdron prestando el servicio del Serallo y saliendo los dias $3,4,7,11,18,14,19,21,26,28$ y 30; escol,tando bater1as a Dar Riferien el $9 \mathrm{y}$ al Negro los diss 1 , al $16 \mathrm{y}$ saliendo con el Excmo. Señor General Nenacho $10 s$ dias 5 y 23; ambos dias a $10 s$ saltos de DJebel - Xulder por la posicion A, regresando el primero por las Guardionas y el Moravito.

Ceuts 30 de Septieabre de 1914.=B1 Capitan. Guilicrmo Lá́.mRubricado.

IES DE OCTUBIE DB 1914.

Continus el esousdron prestando el serviclo de el Serallo y saliendo los dias $1,3,5,7,10,13,17,19,21, x 3,64,47,29,81,9,15$ y 26 los tres ultinos a Dur Hiffrien.

Tetuan 31 de Ootubre de 1914.=B1 Cap1tan.=Gu1lermo Lak. Rubricado. mes DE HOVITuBRs DE 1914.

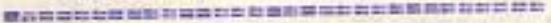

Pasa el escundro ls revista en 1 gual forma $y$ el dia 3 sale a ponerse a las ordenes del Jxcmo. Sefior Don Iransito Sanciez hanjón General de Ir Brigade de Cente, cuedando la tercera secolon (Feniente Lecanda) acaspada en la Conuese para la desaublerta y seguridad del barrio del Iiegro, y la primera y segunda con el Capitan en el Casparento de Der Rirrrien; 
esta secciones ademas de escoltur a S.X. en sus salldas, eubren durante ol wos el zervlo10 de estufeta $y$ conboyes de las Guardianns, Alburran, arfu, del West Kudia, Pederik, $y$ toda lalinva por la Restinga, el Hwyar, hasta el Smir;

Dar Rirf len 30 de Noviembre do 1ylm, 11 Capitan Gulllermo Lak.=Rubricado.

IES DE DICIBMBFE DE 1Y14.

Pasa el egcuadron la revista en el cumpo an la misma forma en que 11nalizo el wes anterior y el dos se reune regresando al canton de la punt11la, donde s1gue prestunao el servico de Serrallo, saliendo ademas 108 dias $4,6,9,10,14,14,16,17,28,14,21,23,26,28,30$ у 31.

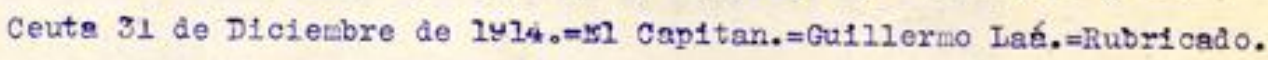
IES DE ENBRO DB 1Y15.

=ม"

Comlenza el escuadron el ario en la mism form en que finmlizo en 1914, en Ia Puntilla; prestando el servio1o del Serallo y saliendo los dias, $1, \Delta, 7,9,11,13,15,18,20,22,25,29,29$ у 00.

Ceuta 31 de Snero de,Io15.=\$1 Capitan.=Gutỉlerio Laá.mRubricado. IES DE PESRYHO DE IY15.

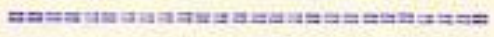

Pasa el escuadron la revista en la Puntilla y el dia 2 sale a ponerse a las ordenes del Bxomo.Señor Don Prancisco Sanchez lanjón. General de la Brigada de Ceuta, queâando la segunda seccion ( $T$ cnlente Camp1110) aaampada en la Condese pera ló descublerta y seguridad del Valle de los Casillejos y la tercera (Teniente Lecanaa) en hontenegrón para la descubierta del Valle del Negro, y la primera y cuarta con el Capitan en el Campamento de Dar Riffien; estas secolones ademas de escoltar a S.E. en sus salidas los dias tres a Bent - Mzaln, el 4 a Ceuta, 5 a Hegro, $\mathrm{y}$ Negron, el 8 a Ceuta, el 16 a Negro g Negron, el 17 al Albarran, Kenisla y el Hazd, el 18 a Benl Mzala, el $23 \mathrm{y}$ el 24 al Excmo.Sefior Comadaante Gral de Ceuta, el primer dia a la Mezquita de Sidi - Hrrahtn y el segundo a Kudia Federik y Casa del Hadz y el 19 al Bxomo. Señor Comundante Gral de Ceuta y General Pernandez S1lvestre á Negrón y de practicar los dias 9,11 15, 27, y 28 reconoandento por Guardianas, Albarranz, Lainuma, Las Fudias, Fandak y hufak cubre durante el més el sexvic1o de estafetas y 
convoyes de las Guardianas, Albarran, Haffa de west, Kudia Pederik, y toda la linea por la Restinga, el Hayar, hasta el Smir.

En los serviclos de novhe $y$ embiscadas la tercera seccion sostuvo t1roteo sin novedad los dias cuntro, diea, doce, trece, catorce, quince, vent1oinco, ventisiete, y ventiocho y la segunda el siete $\mathrm{y}$ ventidós; el dia tres en el reconoclmento a Beni - Mzala se produjo heridas leves el Cabo clodosido caro por caer con el caballo a la barrancada $y$ en la noche del DIBZ AL OHCE se escaparon del Campamento de las Guardianas 108 caballos Harrdafe y Abedul de la pareja de estafetá sin ser hab1dos.

Dar Blffien ze de Febrero de 1915.=Bl Cap1tan Guillermo Laá.=Rubrioado. 


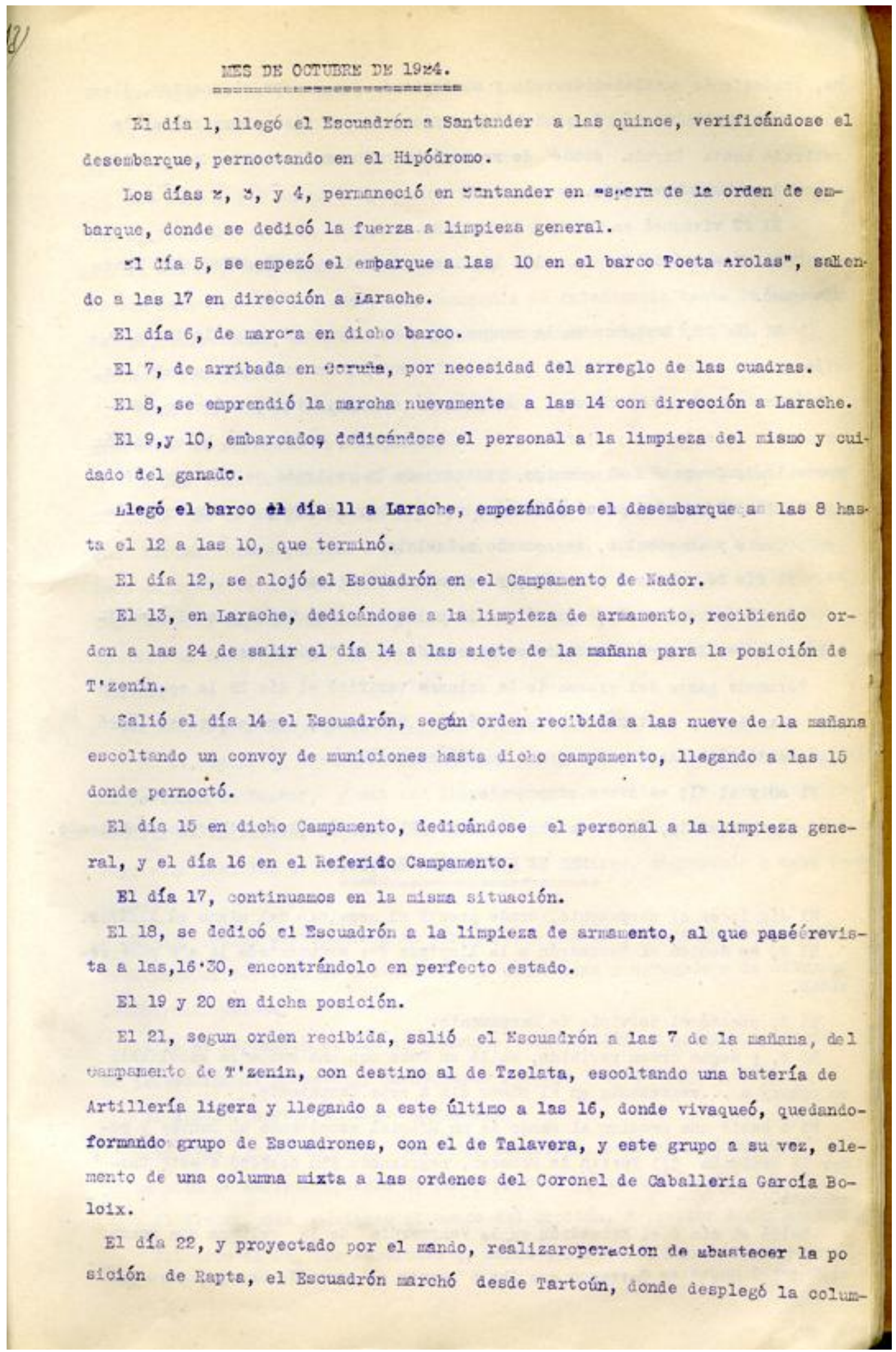


na, protegiendo su flanco derecho y sosteniendo fuego con el enerigo, 1legó a realizar su misión de protecolón, efeotuando el mismo dervioio en la retirads hasta Taroin donde de replegó la, columna, no habiendo ocurrido novedad on esta operaotón.

B1 23 vivagues en Tzlata de Ralxana.

Bl 24 salió de Tzlata a las 14, llegando a las 16.30 a Tarlezin donde vivagueó.

El dí 25, formando en la vanguardia de la colunna apoyó la instalaab́n de una tienda fortiflcads en S1d1-d1r-Heys, $y$ en unión de la lehal-1a, 2ogxó dar acceso de un convoy, a la posiclón de Sid1-0tmar, así collo la evacuación de enformos y el relovo de in guamiotón, objeto de la operaolón sosteniendo evezo con el enemigo, protegiendo la retirada de las otras fuerzas de la column; en esta operación, resultó herido leve, el Sargento B=eterio curto y un caballo, regresando a Tzelata.

YI dia 26, en esta posición; $y$ el e7 en la misma.

B1 28 en vanguardia, marchó con la columna desde Tzelats a Ioura-clTolba, donde viraqueb, haciendo un recorrido de 19 mínetros.

Pormando parte del grueso de la columa verifios el día 29 la operación para abastecer y fortificar la posición de Talaganda, cuyo objeto se logró regresando a Alcazarquivir, donde quedó acampado.

E1 $50 \mathrm{y}$ el 31, en dioho oampamento.

Alcazarquivir, 31 de Octubre de 19:4.=11 Capitín.=Antoniokartin.=Rubricado. IBS DE WOYTE:BRE DE 1924.

$==-=$ =

81 afa 1, en el campamento, donde prest6 el servicio del mismo en Alcázar.

B1 2, se deâló el Escuadrón a la $11 \mathrm{mpleze}$ del armumentode la que pasé revista.

Bl 3, prestó el servicio de Campamento.

\$1 4, y seghn orden recibida, sal1s un Cabo con una esouadra escoltando un convoy a ...regresando en el mismo dia a eate Campesento.

DI 5 sallo una secolon al mando de un opicial escoltando un convoy y poner la poslción del portin do Mehacer, regresnndo sin novedad a este Camoascente.

Salió el da 6 el Escuadrón en la vanguardia de la columa que manda 97 Comna] copsález Carrasco que 1ba a ronper el cerco de liaraya, para po- 
der convoyar dicha posición, pernoctando en Yelma-el-malba.

Bl día 7, por el mal t1empo no se realizó la operacínanteriox, regresando con la colume a este Campamento.

Los disa 8 y 8 en el vampasento, prestando el serv1c10 del mismo, y el resto, dedicándose a la 11 mieza de equipos y ganado.

E1 dia 10, cuapliendo orden recibida, sellendo el Escuadrón proteglendo dos baterise de montañs y wa coamañia de intendencla husta la posiolón Taator, regresando el mfsno afa, sin haberocurrido alguns novedad, en ol servicio prestado.

I1 dis 11, en ol companento, dedichndore a la limpieza de arramento y prestando el serviolo de camapamento.

A las 7 de la mantana del dia 12, se destacaion del Escuadrón ic hombres al mando de un sargento, con objeto de protejer a una seccion de lezionarios que hablan defncorporarse a la columa on Tastof, tana esougdra a la mama hora al mando de ur cabo, trmbien on pronenclón de una acémla con artolag para evecusr un onferso de la posición de Yelm,-el-taiba; a y log $z$, una Sección al mando de un oflolal, escostando une batería a in posiolón de Tastor;

E1 día 13, en dicha postolón.

B1 14, sali6 el vscuadron pruteglendo dos batallones de infanteria hasta la posición de Tautor, y une vez llegado a esta, prusto ol servioio de;protecoión de carretera, en este día, presto el servicio de protecosón de un con voy, a la posicion de Gorra, un Sargento y li hombres, segresando a eate compamento.

E1 15, gais el Sscuadron en Airecolon a Featof, donde queds acampado, preatando el gervicio de protecolon de carreteras y agregado a Ir columa del Coronel Retern.

Salib el Escuadron el dia 16 al mondo del Cap1tan a prestar gervic10 de proteccion do carretera, desde Yayua y zorja hasta Scrh-el-Seb.

I d1a 17, presto el mismo servio10.

Los dias $18,19,20$ y 21, sal1s el Bscuadrón, prestando el servicio de protacoión de curreters desde el Canapemnto ni l, al Bosele sagrado.

Bl Aia z\%, dos sedolones al mando del Capitán, a prestar dioho serviclo $1 e z$

Salieron el 23, dos secclones al mando del Alférez Don Severtano Gonź́- 
a prestar el servicio anterior.

Bl 24, el Capitán al mando de dos seociones, presto el serv1olo de protecaton de carreteras.

Bl 25, dos secolones al mando del Alférez Don Severfano Conatiez a prestur dioho servicio.

Bl 26, salleron dos secciones al mando del Capitan, a prestar el serv1010 anterior

Salleron el dfa 27.al mando del Alférez Don SeverianonGonzález, dos secolones a prestar el servicio de proteccion de carreteras.

21 -9, sal1ó el Capitán al mando de dos secciones, a prestar d1cho serviolo.

Bl 29, el Alférez don Severiano González, al mando de dos secotones prestó el servicio anterior.

B1 df́ 3o, el capltán al mando de dos secolones, prestó el serviolo de protecolon de carretera,

Tantof, 30 de Hoviembre de 1,924. - Bl Capitán.= Antonso llartân.=Rubriogdo.

\section{LES DY DICIEIBRB DB 1924 . м}

Bl día 1, salló el Bscuadron de proteccion de cerretera, con dos secclones al mando del Alférez Bragado, desde Kudia-Sapta hasta Bosque Sagrado.

S1 2, el maso servicio con las secclones de los Alféreces Garala ott1z y Fernandez Rodriguez.

B1 3, el servicio de protección oon dos secolones al rando de los Aletreces D. Severlano Gonź́lez y D. José uliguel Bragado, hasta el referido Bosque.

51 dfa 4, prestó el miano servioio de proteocion al mundo del Capitan y Alfereces D. Rugerto Nartin y D. Cesar Zermundez.

El día 5 salló el escuadrón al mando delCapltán, con los alfereces D.kuperto Lartin y D.Andres Gazća Or:Iz, prestando el serviolo de protecoión.

Bl dfa 6 , el Cap1tín al mando de las Secciones de los alforeces D. José ulguel Bragado y D. César Pernandez, prestó el servicio de protecctón. 
S1 dia biete al mismo serviolo al mando del nutoraz yon upporto liartin con las secciones de los Alfereces don Andres Garcla y Don Cesar Fernandez.

El Ala ocho dos secolonos mandadas por los Alfereces Don Severiano Gonzalez y don José Miguel Bragado prestaron el mismo serviolo.

Bl dia nueve el Capitan al mando de las secolones de los Alforeces don José uguel Bragado y Don Andres Garoia Iortız prestando el referido servicio.

El dia 10 presto el escuadron el serviono de Carretera.

Bl dia 11 el Capitan al mando del escuadron presto el mismo serviolo.

El dia 12 el Alferez don Ruperto lartin con el Alferez don Andres Garcia presto el serviolo de protecolón.

Bl dia 13 el Capitan al mindo del escundrbn con los Alfereces don josé Hguel Bragado y Don Cesar Permandez de protecoion de carretera hasta Bosque Sagrado.

El escusdron al mando del Capltan formb parte de la columa del coronél Carrasco de la posioion de Taffer reconociendo Bosque - Sagraco en el que establecio el serviclo de vigilancia hasta la llegada del Batalion de Infanteria de Ciudad-nolrigo que establecio como guerrillas on dicho bosque retire dose a proteger una vaguada a retaguardia del referido bosque, regresanå al campatsento sin habex courrido novedad.

BI dia 15 lo pasaron en el Camamontodedioados a la 11mploza de armamento $y$ equipo.

Sal1o el escuadron protegiendo un convoy para abnstecer las posiolones de Borja Sahasa y Corsano pudieridose verificar nuda ma que en la primera a causa del temporal de lluvias, regresando al campamento, segum orden vorbal del Coronel Carrasco, y otra seccion sl mando del Alferez don Cesar Pernandez dio escolta al Ixcmo. Sefior Coronel de este Territorlo.

Bl dia 17 el Capitan al mando de las secolones de los Alfereoes don Jose at guel Bragado, y don José Garcia abastecleron las posesiones de Saasa y Forra.

El dia 18 se dedi.0o a la límieza de armamento.

BI dia 19 y zO en dicho oampamento.

El dia 21 Sallo un oflcial al mando de una sección por la carretera de Aloazar hasta el kllometro oinco desde donde proteglo un conboy de munfolo- 
blan de servir pare convoyar las poslolones que se indioan en dias secesivos.

21 dia veinte $y$ en union de la Faroa del AI - Zerif, formo la vanguardia de une columa constitulda con los anteriores elementos $y$ el batallón de Cludad Rodrigo numero siete, convoyendo las posiolonea de Buardú numero 1 , 2, y 3, Ext1gna y Ducey; In extrena vanguardia o soa la citada farc a sostuvo fuego con el enembo; se regr so aoto seguido al campanento de Inna el Iol- . ba sin novedad para el escuadrón donde se pernoct6.

3121 en el campamento anterior.

BI 22 formando la vanguardia de 1- culurma oltas el dis velnte, se comvoyaron las posiciones de Guezula-Art1liada y Guezula-Posicion, avanzadilla y bloca numero uno, regresando a Inme el Tolba sin novedad.

BI 23 estuvo el escuadron dispuesto a salir para apoyar a la farca gue sallo a transportar material de fortifiescion a la posiofon de Buhondo $\mathrm{y}$ no hablendo sido necesaria su intervencion sededico a le l1mpleza personal $\mathrm{y}$ de armamento.

B1 dia venticuatro y foriando parte de la coluna citada en dias anteriores, se llevo wn cosvoy de material de fortifiosción a la posiofon de Guezula Art1llade regresando a Inma, sin novedad.

BI dia venticinco, con el mismo cuerpo de colocacion y en la misma columa que en dias anteriores, se convoyaron las posiolones de Hayera Iuila, Blocao de Jehasen y Burila, a esta ult1ma, 10 condujo solo ol esourdron, regresando desde esta ultita ol campasento general de Alcazar, cesando en el mando el Alferez don Andres Garoia Ortiz.

B1 dia ventisels en el oamamento de Aloszar donde presto el servicio de guardis del sur.

Sal10 el dia ventiofete el escuabron al mando del Alferez don Andres Garola ort1z (por enfermedad del Capitan) stendo mandada la seccion por el klerea por Cesar Fernandez y Sargento Paulino Garola, al campamento de Taator, donde formo con la faroa de Al Xerif la vanguarda de una colwma integrada adeas por el Batalion de Cludad Rodrigo numero slete, wa compania de Tenerife numera sesenta y cuatro una de Siolila nuero siete, una de Ingenferos con el tasterial Suflalente para establecer las posictones de Ba Búfares, Beni Sald, y avonzadila, no pudiendose realizar dicha operaolon, por la intensidsd de 1. niebla.

B1 dis ventiocho y formando la columa del dis anterior en el ampamento 
de Taatof, se destacado el escuadron con objeto de efoctuar un reconociHento por la plete que conduce al sitio donde hablan de ponerse las posiciones antorzoemente indlcadas, pero por efeoto de una niebla muy densa, tuvo que regresar el escuadron gomo asi tilemo ia columa a su base de Taator.

BI dis ventinueve formando is vanguardia de la columa oitada en dias anteriores se llevo hasta el boquete de Borha, donde se desplegaron las dos secciones pare impedir ol paso al citedo boquete y servir a la vez de proteocion a los trabajos de fortificacion que se realizaban para eatablecer las posiciones Indicadas en el dia ventiaiete establecidas las cusies, proteglo $\mathrm{y}$ monto la retaguardia de la columa regresando a este caspariento sin novedad.

Por orden del Feniente Coronel del camad - Rodrigo regreso ol escuadron al campazento general de Alcazar, cesando en el mando del mismo el Alferez don Andres Garola Ortiz.

El dis 31 oumplimentendo la orden reciblda del Comandante General salio el escuadron pare Larache pernoctando en Hadór, en espera de ordenes para incoorporarse a Tzelata.

Larache 31 de Bnero de 1925.= 21 Cap1tan.mantonio Nart1n.Rubricado.

\section{IISS DE PEBRERO DE 1925}

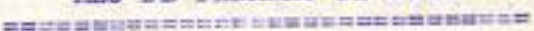

B1 dila uno, alojados el oampamento de Nador de esta Ma za dedicandose Is fuerza 81 ievantamidento de tiendss $y$ azoyamiento del ganado.

Bl dia $z$, descanso en el campamento.

Bl dis 3, se dedico el escuedron a la limpleza general de vestusrio $\mathrm{y}$ equipo.

B1 dia 4 fue revistado por el Jxomo. Seffor General de esta Zona quedando formando parte deuna columna, compuesta de un batalion una bateriu de obuses una secolon opt1ca de ingenieros uns seccion de Sanided $y$ otra de Intencla al mando del menínte Coronel del Batalion de León.

El día cinco se dedico a la limpieza de armamento.

31 dia seis fue revistado por el Teniente Coronel de Le6n, Jefe de la colunina.

III dia slete formo parte de la vanguardi- de dicha columna para efectuar un reconocimdento a 10 largo de la carretera de Ambes hasta el blocso nuworo tres regresando al campawento de Nador una vez efectuado dicho reso- 
nocini ento.

Bl dia ocho descanso en el campamento.

Salio el dí nueve el escuáron formando parte de la columa al mando del Teniente Coronel de Leon y formando la vanguardia se estableolo un blocao. a la derecha, de la posiclón Gennis de Sahel, wontando la correspondinzte protección; se regreso al oampament. de frador de esta Plaza sin novedad. BI dia 10 se dedioo a la limoleza de equipos,

B1 11 descunso en -1 camperento.

Bl 12 Instruccion a cabalio en la esplanada del campawento.

L1 13 se p so revi_ta de armamento.

Bl 14 revista del personal, formando el escuadron.

Asistio el da 15 el escuadron pie a tierra por el mal tieapo reinante al aste de prestar Juramento de fldelidad a la bandera de los roclutas on el campanento de liador.

B1 dis 16 en el campanento dedicandose a nomcholaturas de caballos y equipos bajo la direccion del Oricial de Semuna.

k1 1\% paseo del ganado de ooho kilometros de recorrido.

m Iy dedicandose a la liupleza de cquipos.

B1 19 paseo del ganado de 10kilowetros de recorrido.

BI 20 en el campamento dedoandose a la lectura de leyes permles $y$ obligachunecdel soldado bsjo la drecolon del Oplolal de Serana.

E1 21 Instruccion a cabello en la explanada de Nador.

Las dias 22,23, y 24 , en el Campamento.

El 25 paseo del ganado de ocho xllometros de $r$ corrido.

B1 26 en el oampamento dedicanaose al aseo personal.

B1 27 y nor of mal tiempo se susnendio el paseo de ganndo, dedicandose 1a fuerza del escuadron a nosenclaturas del armamento $y$ culdados que requiere su entreteniedento.

E1 28 paseo del ganado.

Larache 28 de vebrero 4 e 1925.=B1 Capitan Antonto Nartin.=Rubricado. IES DE \#ARZO DY 1925 .

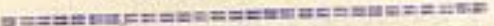

Il dis 1 en el campamento.

31 dis dos paseo del gansdo.

Il dia tres en el capamento dedicandose al aseo personal. 
nocimiento.

Bl dia ocho desoanso en el ogmamento.

Salio el dia nueve el escusáron formanào parte de la columna al mando del Teniente Coronel de Leon y formando la vengusalia se estableolo un blocao. a ls derecha, de la posictón Gennis de Sahel, wontando la correspondrnte protección; se regreso al onmament. de fador do esta Plaza sin novedad.

BI dia 10 se dedico a 12 limoleza de equipos,

B1 11 descunso en -1 camparanto.

Bl 12 Instruccion a cabalio en la esplanada del campatiento.

DI 13 se p 80 revi_ta de armamento.

El 14 revista del personal, formando el escuadron.

Asistio el dia 15 el escuadron pie a tierra por el mal tieapo reinante al adto de prestar Juramento de fldelidad a la bandera de los roclutas on el campamento de liador.

B1 d1a 16 en el campamento dedicandose a nomcholaturas de caballos y equipos bajo la direccion del Oricial de Semuna.

k1 1\% paseo del ganado de ooho klometros de recorrido.

MI Is dedicandose a la liupieza de cquipos.

B1 19 paseo del ganado de loklowetros de recorrido.

BI 20 en el onmamento dedoandose a la lectura de leyes permles y obligactunecdel soldado bsjo la direcolon del Oploial de Semana.

El 21 Instruccion a cabello en la explanada de Nador.

Las dias 22,23, y 24 , en el Campamento.

El 25 paseo del ganado de ocho xlometros de $r$ corrido.

B1 26 en el oampamento dedicanaose al aseo personal.

B1 $27 \mathrm{y}$ nor of mal tiempo se susnerdio el paseo de ganndo, dedicandose 1a fuerza del escuadron a nocenclaturas del armamento $y$ ouldados que requiore su entreteniedento.

E1 28 paseo de1 ganado.

Larache $x 8$ de vebrero 4 e 1925.=B1 Capitan Antonto Lartin.=Rubricado.

$$
\text { IES DE \#ARZO DY } 2925 \text {. }
$$

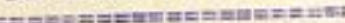

Bl dia 1 en el cangamento.

B1 dis dos paseo del ganado.

Il dia tres on el capamento dedicandose al aseo personal. 
Ga hasta el btocho Husallt nusero dos.

Bl Ata 17 en el campamento dedicandose la fuerza il la $11 m p i e z a$ del alsmo.

Bl dia 18 una seocion 31 mendo del Alferez don Cesar Zermandez presto el aerviolo de proteccion en la carretera de Aulef.

BI dia 19 en el gampamento.

B1 20 una seceí́n al mando del Alferez don Andres Garcia Ortiz presto el serviolo de proteccion en la carretera de Aule?.

3121 revista de equipo.

B1 22 uns scolion al mando del Alferes don Cesar Pernandez prosto el servicio de protecolon en la carretera de Aulef.

3123 el escusdron al mando del Capltán formo parte de la cotuma que panda el Ieniente Coronel del Batallon Cazadores de Cludad-Rodrigo numero siete para randir honores al Bxomo.Señor General en Jefe don ulguel Primo de R1vera y orbaneja desfliando aoto seguido y siendo fellottado por el buen estado en que se present6.

DI 24 wa secolon al mandodel Alferez don Andres Garola Ortiz presto el servicio de proteccion en la Carretera de Aulet desde el Aduar de *egarge hasta el blocao Busafi numero $Z$.

8125 en el campamento.

B1 26 el esouadron al mndo del Capltán presto el sezviolo de proteoolón en 1 cerretera de Tze-nin con notivo del paso del General en Jefe por Dicha Carretera pars Inspecionar desde Negaret la linea definitiva de posiolones.

El 27 una secolón al mando del Alerez don Cesar Fernandez presto el serviolo de protecolon en la carretera de Aulef.

Bl 28 una seccion al mando del Alferez don Andres Garola Ort1z presto el servioso a proteccion en la carretora de Aulef.

B1- 29 en el campamento de descanso.

31 30 una secolon al mando del hlferez don Cesar Pernandez presto el sernoio de protecclon en la carretera de Aulef.

B1. 31 en el campamento.

Iarsche 32 de Narzo de 1925.=B1 Cap1tan Antonto liartinutubrtoado, VIAS DE ABRIL DB 1925.

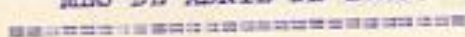

Bl dia uno $y$ en virtud deorden de la Comandancia General do esta zona a las slete de la matrana sal10 el escuadron al mando del Alferez don fndres Garcia Ortiz y las secolones mandadas por el Alferez don Cesar pornandez 
7 el Sargento ysulino Gavia en direcoion dol chmpanento de AOx estabroptao en las lmadiaotones de la Plaza de Arclla, donde llego a las 16 horas, quedando establectio.

S1 Ala dos una sección al mando del Alferez don Andres Garola Ortiz, montoel servicio de protecolon de la Carretera de Tanger deade el blocso de Andin hasto Meylain en este dis otro secolon al mando del hlferez don Cessx Pernandez marcho al zoco el Tad en proteocion deuna seccion te ametralladoras de Infanterla que maroho destaosda a dioha posiolon.

SI dia tres uns secolon al mando del Alferez don Cesar Pernandez presto el servicio de proteccion en la Carretera de Tanger, desde el bloca de Andin hasta el de -eylen.

El 4 une seccion al nando del Alferez don Andres Gar la Ortiz presto el servioio de protecolon en la carretera de Tanger aesde el blocao de Andin hasta el de Woylain.

21 cinco una seccion al tando del Alfer $z$ don Cesar Pernandez presto el servicio de proteccion en la carretera de Tanger desde el blocao de Andin hata el de Keylain.

E1 selo una seooion al mando del Alferez don fndres Garola Ort1z, presto el serviolo de protecolon en la carretera de Fanger desde el blocso de Andin husta el de Keylain; el resto del escusdron al zando del Capitan ealio destacado al campamento del zoco - el - Had de la Sarvia en VIxtua de orden recibia el dia onterior del General de la zona.

BI dia siete la seccion de servicio de protecolon prestado el dis anterior emprendio la marchs a las nueve de la manana para incoorporarse al escuadron; $y$ otra al mando del Alferez don Cesar Pernandez preato el serviolo de proteocion desde el Blocao del Puente de Heseff hasta las Inmediaciones de Buixa.

Bl dia 8 el Capitan al mando del escuadron presto el servicio de protecolon en la carretera de Tanger desde el blocao del Puente de Haseff hreta las inmediaciones de Buixa.

yl dia nueve el sargento paulno farcla presto el serviofo de protecaion de la Carretera de Tanger at mana de una sección.

sl din to el alforez don Andres Garia Ortiz al tando de una secolón presto el serv1c2o de protección de la Carretera de Ianger.

Il 12 una secoión al mando del Alferez don Andres Garcia ort1z pres- 
toel serviolo de protecoson de cnrrotera degdo el bloono dol mente finaelf, hasta las proxinldades de Bulxa; la posioron de........ avisó por mediaolon - de una pareja de la sección que estaba puesta en las inmediacionos de dicha posioon, que tenian un prianonero; saliendo la reserva de la seccion en su b usca, el cual fue conálido al campamento de zoco - el Had alendo entregado cioho prisionero al Jefe del Campamento.

El dia 13 ung secolon at mando del Sargento Paulino Garcla presto el servido de protección en la carretera de Tanger.

Bl dis 14 uns seocion al mando del Alferez don Andres Garcis Ort1z presto el servicio de proteccion en Ia Carreterade Tanger.

Bl dia quince uns seccion al mando del sa Bento Paulino Garola presto el serviolo de protecolon en la carretera de Tanger.

Bl dia 16 una secoion al mando del Alferez ton Cesar Pernandez presto el servicio de protecolon en la carreters de cunger.

II dia dez y slete una secoión al tando del sargento Paulino Carcla presto el servicio de protección en la carretera de qenger.

B2 dia elez y ocho salio todo el escuadron a prestar el serviolo de protecolón.

Bl dala diez y nueve una seccion al mando del Alfer $z$ don Cesar Ternundez presto el serviolo de protecoion en la carretera de Tanger.

B1 dia veinte una secoión al mando del ilferz don Andres Garcia Oxtiz, prestó el servicio de proteccion en la carretera de Tanger.

El dis venti uno sal10 touo el esoundro; una secoion al sando del Alferez aon Andres Garcia de proteccion del convoy de municiones a Buja $y$ otra secolón al manio ciel Sub Oficial Don Rafael Vartin dio la protecolón en 1a Carretera de Ianger.

Bl dia venxicos, una secoión al aundo del Alferez don Cesar Pernandez presto el servicio de protecolon en la Carreters de Tanger.

Bl dis ventatres una secolon al mando del Alferez don Andres Garois ortiz prestó el servicio de protecoion en la carrutora de langer.

El dia venticuatro uns sección al mando del sub oflolal don Rafael rartin Alonso presto el servioio de protecoion en la carretera de Tanger.

E1 dia ventioinco el escuudro salio de zooo - el Had en direcolón a Iaraolve en virtud de orden de la Comandancia General de Ia zona llegando el mata dia. 
I1 dia vents sois descanso en el oumpanto de ltador.

II dis ventioiete revista de Armainento.

B1 QLa ventiocho so dedico a la limpieza personal y surpo.

BI dia ventinueve por orden reclbida de la Comandanola General de la zone salio el escusdron en union del de Talavera en direcolon de Deuts pernoctan do en Aroila.

*1 dia treinta descanso en el campamento de Aax (Aro11a).

Aroila 30 de Abril de 19r5.=B1 Capitan Antonio lartin.Rubricsdo.

VES DE HAYO DE 1925.

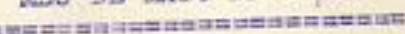

31 ala varo sallo de Arcila el esouadron llegando a R'gaia dondepernocto.

El 2 salio de R'gale en Airecolion a Fetuan, Llegando a esta Plazs a las

18 horae, pernootando en el Cuartel de Caballerta.

B1 3, descanso en Tetuan.

S1 4, sallo de Tetun el escuadron wn direcoion a Ceuta on la cual Plaze pernooto on el Cuertel del negilento Cazadores de Vitoria, 28 de Caballeria.

$81 \mathrm{~d}=5$, se reciblo orden del Istndo layor de 1 Comandanola deneral de Ceuta, de hacer entrega de 103 caballos af Reglalento Vitorla 28 de Caba1leria.

El dis 6 se hizo la entregg de los crbanlos al oftado Regimlento, segun or den recibids del Yatsdo May6r.Terinads diohe entrege = las 10, a las le 50 se comenzo el embarque de la impoluents en el Vapor Reina flotoria elbaroando la tropa a las 19,50 despues de ser revistude por el ceneral....... A Lng 10.50 salio el Vapor'con ruabo a Larache a donde se 11 ge de Vadrugads.

SI d1a slete despues de embarcar los escuadrones de Almanas y Alfonso XIIr salifo el Vapor con rumbo a Cadiz a le cual se 1100 a 1 as 16.

B1 8 dedicandoge la fuerza al desembarque del material y equfpos del barco $\mathrm{y}$ al respectivo exbarque en el tren militar que se organizo on dicha Plaza y que salio a las 16.50 , conduclendo 10 s escuadrones de Albuera, Tulavere, Almansa y Alfonso XIII,

Bl dia nueve de Camino en el tron $* 11$ tar comfendose ol priter rancho en Santa Cruz y el segundo on Aloazar de San Juan, Legando en la madrugada a betrie. 


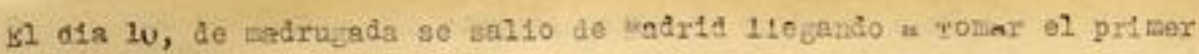
rancio a Mealns del Csupo y tamnao ol tron de Hedina - Salumanou se Ilego a esta Capital a las diez $y$ ocho conouenta.

Salamnoa 10 de tayo de 1925.=R1 Capitan.
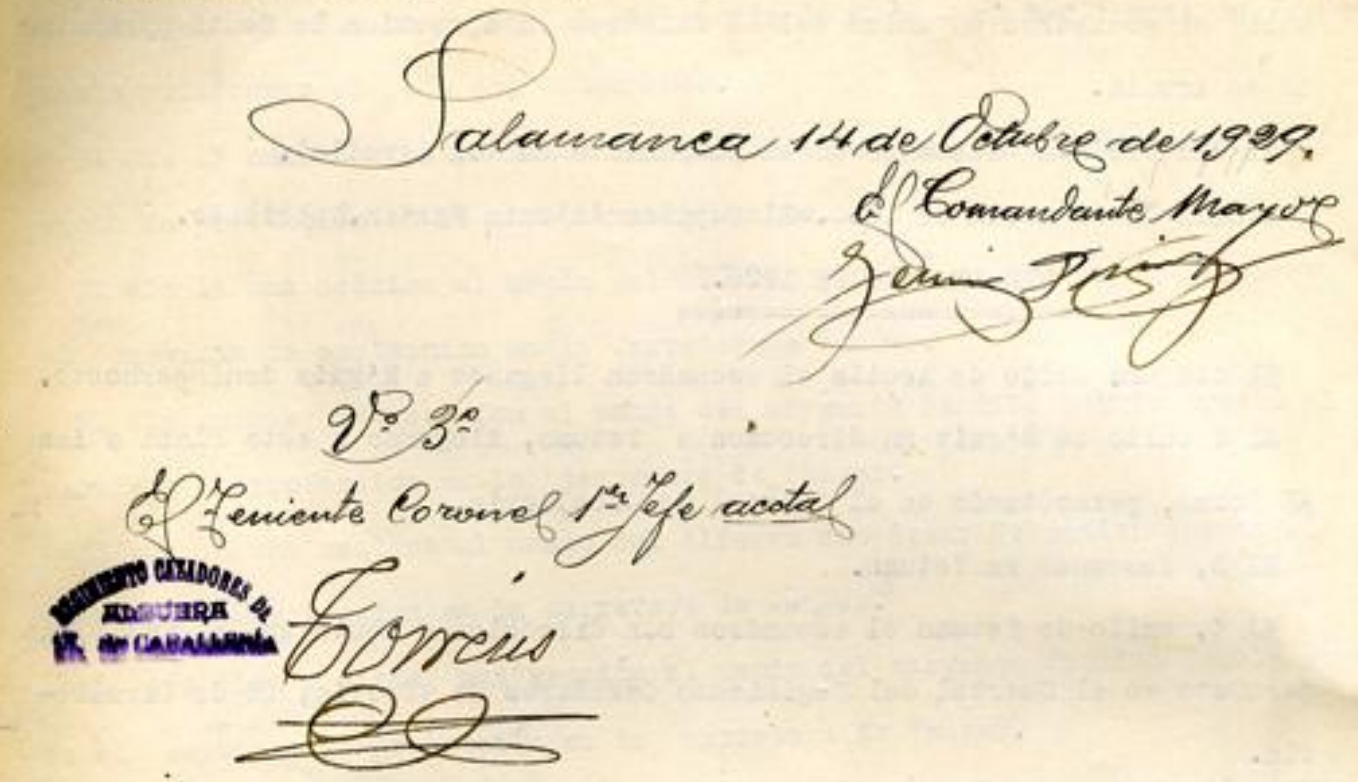
El Adelanto, 30 de septiembre de 1921, p. 1.

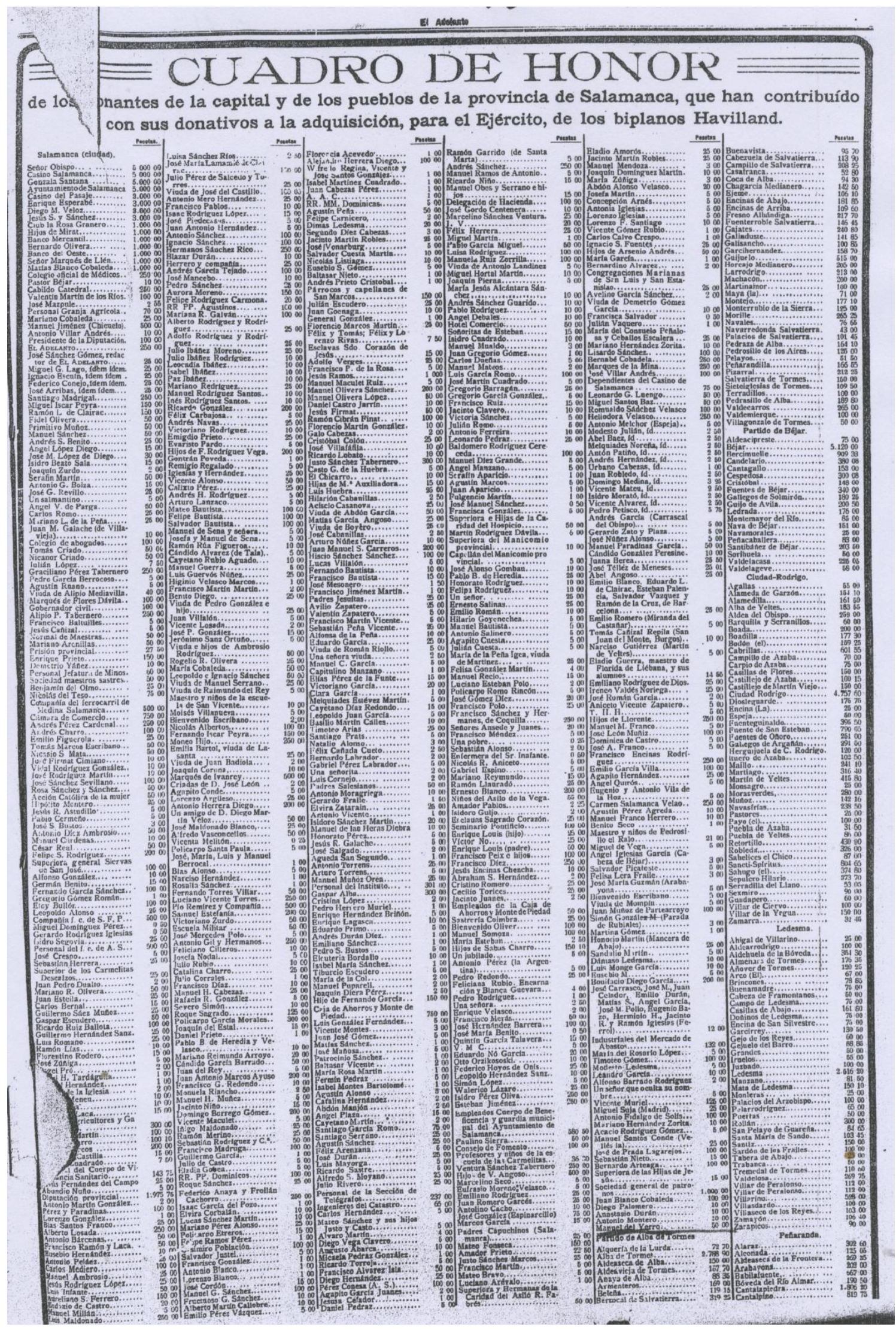


Boletín Oficial del Obispado de Salamanca, 1 de septiembre de 1921, nº 9.

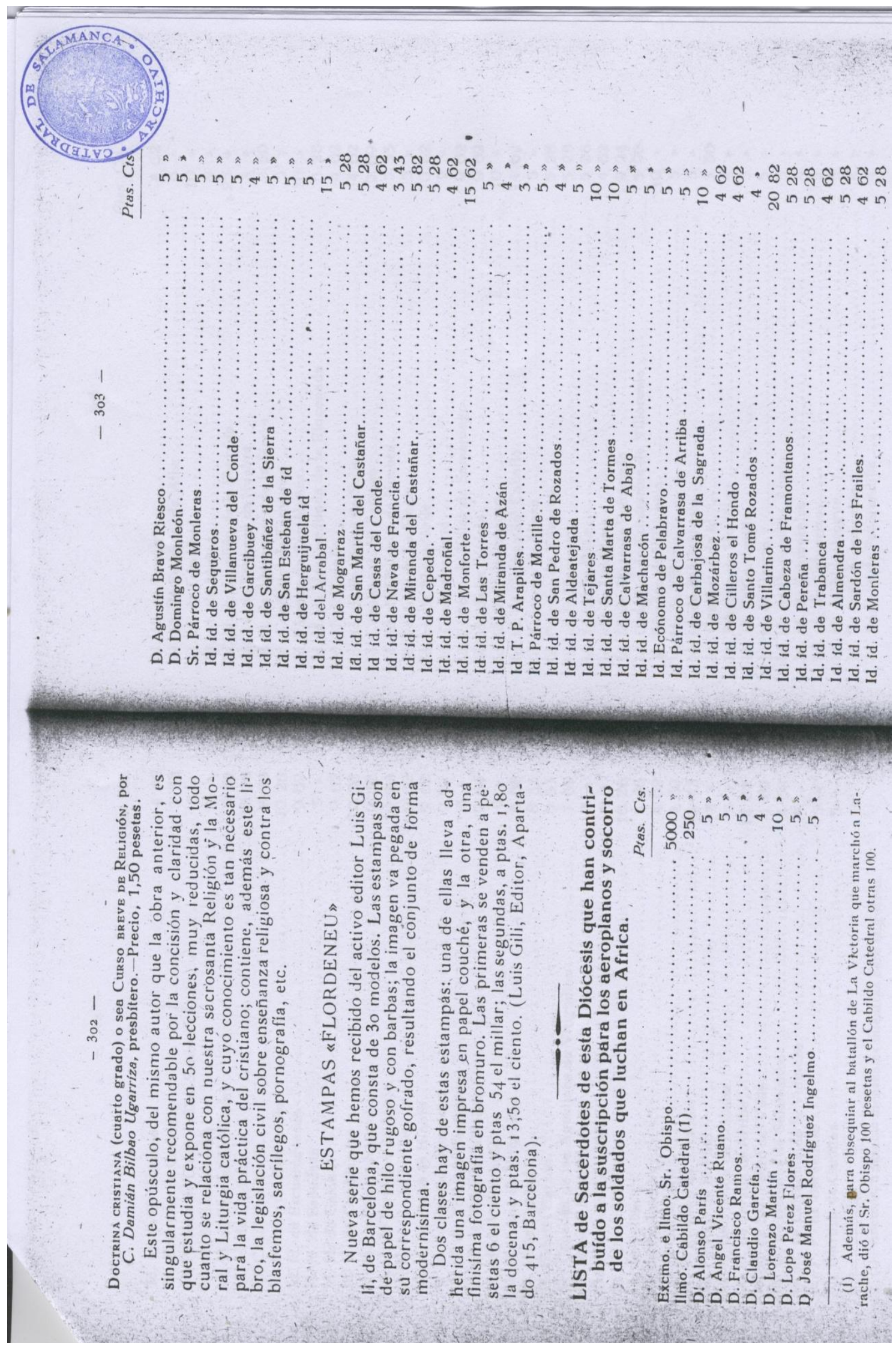




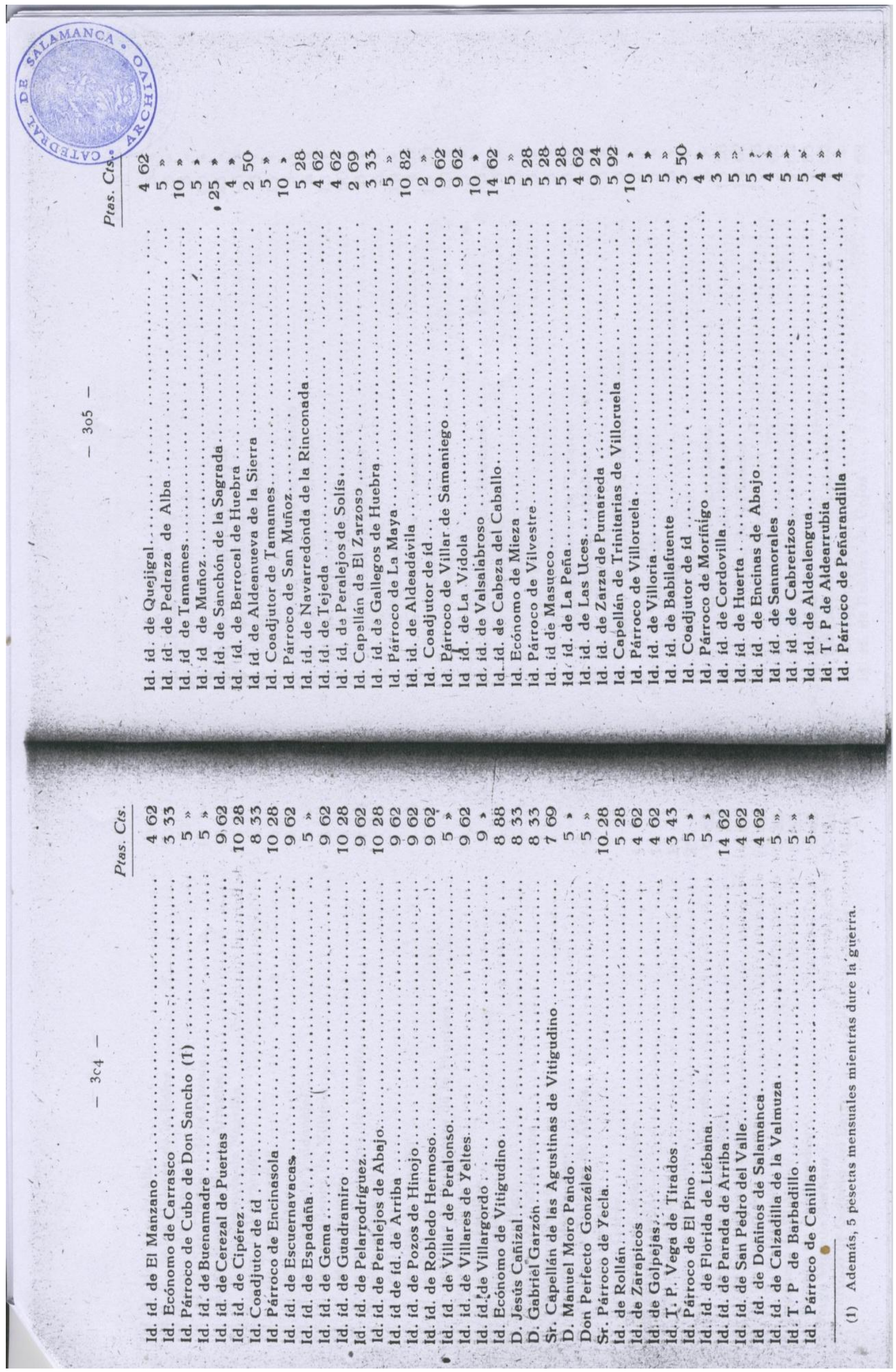




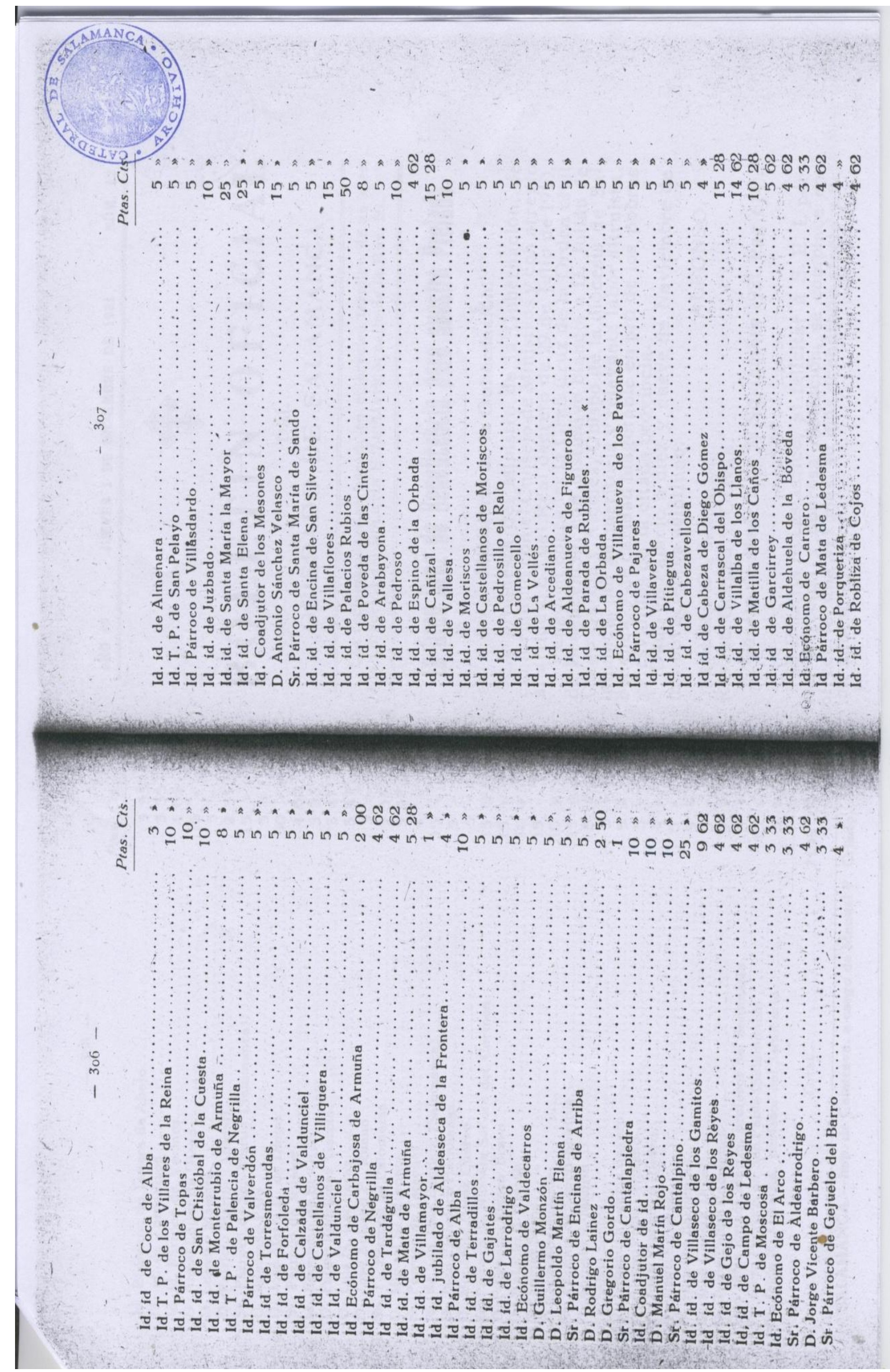




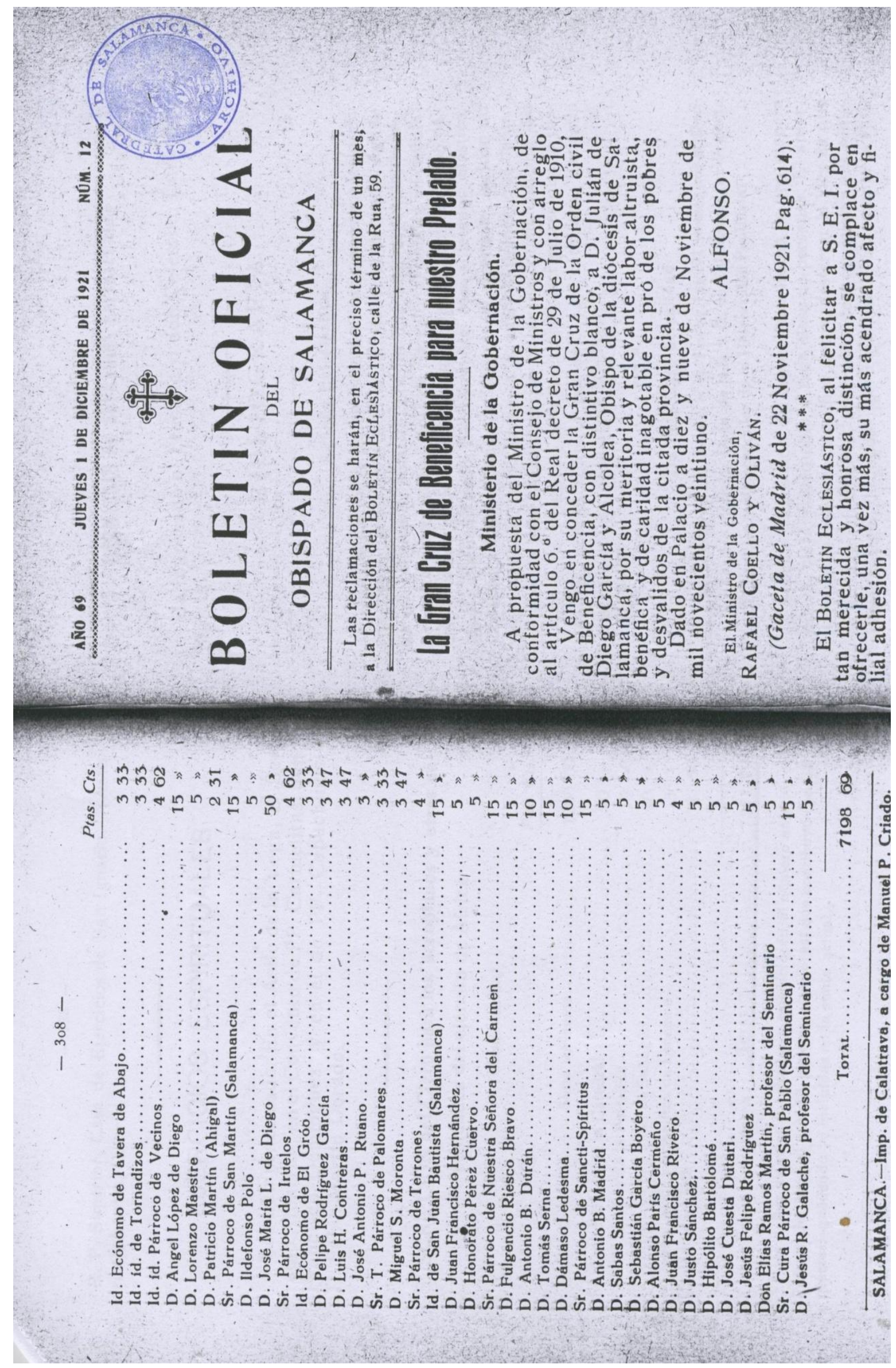


Historial militar de La Victoria: Archivo General Militar de Madrid, Caja $\mathrm{n}^{\mathbf{0}}$ 13, Legajo $1 / 016$

Se desarrollaron los ejercicios en el Valle de Sangusín del término de Bejar por espacio de diez dias, del 6 al 15, regresando las fuerzas el 16 y por ferrocarril, a las plazas de procedencia, donde cohtinuaron prestando servicio de guarnición hasta fin de ar̃o.

\section{A $\hat{N} 0 \quad$ 上, 921 .}

Continua el Regimiento de guarnición en las plazas de San Ildefonso y Salamanca hasta el 6 de Febrero que salió la fuerza de San Ildefonso par Segovia en cuya estación embarcó para Salamanca, donđe llegó el mismo día y que đó de guarnición, distribuyénãose el alojamiento de la tropa y dependencias entre al Colegio de Anaya,ya ocupado,y el Cuartel de Sancti-Spíritus.

El día 8 marcharon a Béjar, destacadas, las compañias la y $2^{\mathbf{a}}$ del $2^{2}$ Batallón al mando de un Comandante en cuya plaza quedaron prestando servicio de guarnición hasta el día 25 de Agosto que por F.C. regresaron a Salamanca.

Con motivo de los sucesos ocurridos en el Territorio de Melilla en el mes de Julio levantándose en armas todas las Kábilas y hacien do traición los iná́genas que se hallaban al servicio de Espanara, co metiendo los asesinatos y crímenes mas horrendos, âispuso el Gobierno el envio de refuerzos al Terriorio marroquí con el fin de contener la arrolladora avalancha y castigar mas tarde a la mirisma que con tan inicuo proceder habia ocasionado tantas víctimas sin respetar las leyes mas elementales de la guerra.

A este fín y para cumplimentar lo dispuesto en la R.o. comunicada del día 29 del citado Julio, se aganizódé toda la fuerza del Regimiento un Batallón a la bese del $2 \&$ que salió, con la compañia de Ametralladoras del' Regimiento de Isabel $2^{a}$, afecta al mismo, el día 26 de Agosto, al mando del Teniente Coronel D. Arturo Giral Fortuño en dos trenes militares llegando a Vigo el $27 \mathrm{y}$ embarcando el día 27. en el vapor Navarra quedando en el puerto hasta el 29 que zarpó con destinoaLareche a cuya Bahia llegó el 31. 
(56)

Desembarcó el Batalión el día lo de Septiembre y marchó al Campamento de Nador (a 2 kilometros de Larache) donde se dedicó a prestar servicios de campaña, ejercicios de tiro, instrucciones y marchas hasta el día 13 que se dispuso por la superioridad que la fuerza presta ra servicios de guardias de plaza, nombrándose diariamente una compa ñia para dichos servicios y los de retén, dedicándose el propio tiempo a efectuar marchas y supuestos tácticos hata el día 7 de Noviembre que salió el Batallón menos la 3 a compañia al mando de su Tenien te Coronel con objeto de incorporarse al Sector de liuader y relevar a las fuerzas del Batalión de Cuenca. Este día pernoctó en la posieí ción de T'zelatzael 8 en la de Anlef y el 9 llegó a liuader donde prestando servicios de guardias, retenes, protección de convoyes y aguadas continuó hasta el 15 que las compañas $1^{\text {a }} \mathrm{y}$ 2a fueron a relevar las fuerzas del Batalión de Cuenca destacadas en posiciones del Sector.

La tercera compania recibió la órden de incorpozarse al resto del Batallón, saliendo el 22 que pernoctó en la posición de T'zelatza,el 23 en T'zenin, el 24 en Megaret, llegando el 25 a ruader donde que dó prestando servicios de campaña como el resto del Batallón.

El día 6 de Diciembre fueron atacadas simultáneamente las posiciones de Ain-Hedir y Maisera, los servicios de protección de aguadas y los convoyes de ambas posiciones que se dirigian a Nuader para apro visionarse. Todas las fuerzas de las posiciones y servicios rechazaron con su fuego eficaz al enemigo que dejó en el campo muertos y heridos. De Nueder salieron el resto de las fuerzas del. Batalion para auxiliar las posiciones y servicios, contribuyendo a rechazar al enemi go persiguiéndole en su huida. El Batalión tuvo que lamentar la muerte de los soldados Antonio Besedas Ortigosa, Segundo Hernandez y Felipe Andrés Sanchez y otros tres soldados heridos, habie ndo sido felicitadas las fuerzas del Batallón por el Comandante General del Territorio por su buen comportamiento.

El día 17 se organizó en livader una columna a la órden del Jefe del Batalión de Iuchana, de la que tomaron parte fuerzas de este Bata- 
llón yendo a pernoctar a Barbex;el 19 formanâo parte de la columna mandada por el Jefe del Grupo de Regulares de Larache, tomó parte la fuerza del Batallón en la toma de las posiciones del Collado de Afarmin y de Aín-Gorra, habiendo tenido fuego con el enemigo, quedando en esta destacados un Capitan, un Teniente y noventa y dos de $\frac{t}{6}$ tropa y regresando el resto a Barbex. Il día 22 formando parte de la misma columna, en marcha hacia el Collado de Afermin, sostuvo fue go con el en migo y fueran las fuerzas del Batallón las encargadas de proteger la retirada de la columna hasta Barbex, donde pernoctaron. El día 26 regresó a Nuader la fuerza donde quedó prestando toda clase de servicios.

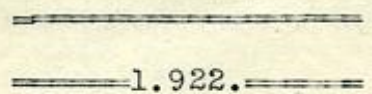

La P.M., primer Batallón en armas y tercero en cuedro de guarnición en Salamanca todo el año.

El Batallón Expedicionario continua en el campamento de Fuader y posiciones destacadas prestando servicios de campaña. Il día 13 de Rnero una sección de Ametralladoras, formando parte de una columna, sostuvo violento fuego con el enemigo en la marcha al zoco el Jenis para la toma de Chunma y avanzadilla Xorquia, regresando el mismo dia al campamento. Fl día 18 las fuerzas del Batallón al mando de su Te niente Coronel marcharon a la línea de fuego de las posiciones Rof-Alto y Rop-Bajo sosteniendo todo el día violento fuego, resultando herido el Comandante del Batallón D. Isiaro Cerdeño. el aía 21 salieron todas as fuerzas del Batalión par repeler la agresión a un convoy en las proximidades de las posiciones de Tax y Jarax, rechazando al enemigo con' bajas vistas.

El 17 de Febrero marchó une compañia a establecer el Blokans Chel ha, sosteniendo ligero tiroteo y regresando a Nuader despues de dejar allí destacado un oficial y veentiseis de tropa.

Continuan en ea mes de Marzo las fuerzas en Nuader y sus posiciones, efectuándose en ellas los relevos siendo suprimidas unas y au mentadas otras en el sector asignado al Batallón. 
(58)

En el mes de Abril las fuerzas del Batallón en Nueder se traslada ron el día 19 al campamento de liegaret donde quedaron acampadas y de servicio de protección de caminos, continuando el resto del Batallón en posiciones. El día 29 regresaron a Nuader las fuerzas del Batallón que se habian trasladado a Hegaret, marchando el 31 al Zono el Jenis de Beni-Aros y el 2 de Junio a Bab-es-Ser donde quedaron acampadas y prestando los servicos de protección de caminos.

El 24 de Junio fué atacada la posición de Aín-Hedir despues de haber salioo las fuerzas del servicios del convoy logrando rechazar al enemigo;pero atacado tambien el convoy por fuerzas superiores en número, lograron matar al cabo y 14 soldados que 10 componian los que lu charon valientemente hasta sucumbir. Sus nombres figuran en el cuadro de honor para imperecedera memoria.

El día 7 de Julio fué atacada la posición de R'koba el Gozal, sienảo repelida ła agresión. El día 15 de incorporó a Bab-es-Sor el Teniente Coronel D. Antonio Crehuet del Amo nombrado para mandar el Batallón, to mando el mando de sus fuerzas.

Cuntinua el Batlión en Bab-es-Sor y en posiciones hasta fin de año prestando toda clase de servicios de campaña.

\section{923}

Ia P.M., primer Batalión en armas y tercero en cuadro de guarnición en Salamanca todo el año. El Teniente Coronel del 22 Batallón y dos compañias effcuadro, regresados de Africa, desde el día 22 de octubre has ta $f$ in de año de guarnición en Salamanca.

Continua el Batalión Expedicionario en Bab-es-Sor con varios destacamentos en posiciones. El día 19 de Abril marcharon al campamento de Aín-Grana las fuerzas que estaban en Bab-es-Sor. El 17 de Agosto se in corporó a Aín-Grana el Teniente Coronel D. José Serviá Sanchez nombrado par manaar el Batalión, haciéndose cargo el citado día.

Con motivo de la repatriación de los individuos del reemplazo de 1.920 se ordena que quede el Batallón reducido a dos compañias de fusiles,una de Ametralladoras $\mathrm{y}$ el Tren Regimental al mando cel Comanan- 
te D. Roberto Latorre Gonzalez que se hace cargo del mando el día 18 de octubre. In este día emprenden la marcha para Larache el Teniente Coronel, Oficiales y clases sobrantes, con motivo de la reducción de plantilla,y los individuos del reemplazo de 1.920 con el fin de em barcar en dicho Puerto para la Peninsula.

Las fuerzas del Batalión no repatriadas continuaron en Aín-Grana y destacamentos prestando servico de campaña.

El día 7 de Diciembre se ordenó el relevo de las posiciones con el in de que las fuerzas se trasladaran al campemento de Kuâia-Ruida (Arcila) emprendiendo la marcha el día 11 llegando el 13 y el día 14 se mandó destacado a Dar-Bris un sargento y quince de tropa, continuan do hasta fin de año prestando todos las servicios de campaña.

\subsection{4.}

La P.lf.,primer Batalión en armas y tercero en cuadro de guarnición en Salamanca todo el año. Il Teniente Coronel del 22 Batallón y una compañia en cuadro en Salamanca de guarnición hasta el día $\mathbf{1 9}$ de Agos to que marcharon a Africa con fuerzas de la Peninsula para unirse a las expedicionarias y organizadas en un Batallón de tres compañias de fusiles, una de ametraliadoras y tren regimental.

Por R.O.C. de 28 de Mayo (D.0. IN 120) fué destinado a mandar el Re gimiento el Coronel D. Ceferino Perez Fernandez el que se hizo cargo del mando el día 17 de Junio.

Las fuerzas expedicionarias se encuentran al comenzar este año en Kudia-Ruida con el destacamento de Dar-Bries. Il día 3 de Enero fueron trasladados en camiones automóviles, excepto la compañia de ametra lladorasque hizo la marcha a pié,al campamento de Nador (Larache) dọn de que dó prestando el servicio de płaza; la compariia de ametralladoras, marchando el resto de la fuerza el día 4 al campemento de Aulef para guarnecer desde allí 7 posiciones que lo efectuó el día 5 , continuando en esta situación hasta el 15 de liayo que se encontraron todas las fuerzas en el campamento de Aulef. En este día marchó la compañia de ametralladoras al campamento de kenxak (Alcazarquivir) y al día si - 
(60)

guiente 10 efectuó el resto de las fuerzas, donde quedaron todas de servicio ordinario. El día 26 marcharon a Larache para ser repatria dos los individuos agogidos al Capítulo XX de la Ley de Reclutamiento.

El día 3 de Julio las dos compañias de fusiles al thando del Coman dante, marcharon en ferrocarril a Larache $\mathrm{y}$ desde este punto en Camio nes automdviles al campamento de Aox (Arcila), quedando de servicio del mismo. La Compañia de Ametralladoras y Tren Regimental salieron por jornadas ordinarias pernoctanto el 3 en Larache $y$ el 4 en Aox unientose al resto de la fuerza. El día 11 marcharon a relevar posiciones dos offeciales y sesenta y cuatro de tropa al objeto de cubrir el sector de Arcila. El día 17 revistadas las fuerzas por el Excmo. Sr. Teniente General Presidente del Territorio Militar D. Miguel Primo de Rivera y Orbeneja, siendo felicitadas por dicha autoridad por su buen espíritu, marcialidad y aseo.

Desembarcaron el día 22 de Agosto procedentes de la Peninsula al objeto de tonar parte del Batallón Expedicionario y se trasladaron en el mismo día en camiones automóviles a Aox,el Teniente Coronel D. José Serviá Sanchez,4 Oficiales, 1 Teniente Médico, 1 Maestro Armero y 428 de tropa,encargándose del mando del Batallón el Teniente coronel, que queda organizado con tres compañias de fusiles, una de ametralladoras y Tren Regimental.

La segunda compañia presta servicio de protección a una bateria de Artilleria los días 23, 24 y 25. La la marcha el 23 hacia el T'zenin a relevar fuerzas expedicionarias de Soria. La 3 a sale el dáa 29 para el Zoco el Jenis, pernoctando este día en T'zenin y el 30 fué trasladada en camiones automóviles, saliendo el 31 formando la retaguardia de una columna en dirección a Ras-Buturaca, sosteniendo fuego con el enemigo en la retirada, habiendo resultado heridos dos soldados.

In el mes de Septiembre fueron constantemente asediadas las posi ciones de I'Jhudi y Chumma habiéndose encontrado en dificiles situra ciones por impedir el enemigo la aguada y llegada de convoyes teniendo que ser puestos a ración sus defensores. En el convoy a Chumma tuvo el Batallón el día 6 que lamenter la muerte del soldado Francisco 
Pablos. El día 18 fué agredida la aguada de Bab-es-Sor resultando muerto el soldado Teodoro Luceño y otro herido.

El día 24 fué agredida por unos 50 moros la escolta de protece ción a la aguada de T'zelatzaconstituida por un cabo y 7 soldados. A las primeras descargas cayeron heridos tres soldados, defendiéndo se los que quedaban con tanto ardor, hasta que liegaron fuerzas en su auxilio, que fueron citados en la órden general del día 30 por su buen comportamiento.

Continua el Batallón en el mes de octubre prestando servicios de campaña en Adx, destacamentos y posiciones teniendo que lamentar la muerte de los soldados Antonio Rodriguez y Teodoro García en el convoy a T'zelata; Jesús Segura y Juan Hernandez en Chumma el día 12,y Romual do Zamorano, Eulogio García, Estanislao de Castro,Bonifacio Gonzalez y Diego Peral en Sihuana el día 16. Todos sucumbieron victimas de su deber y sus nombres figuran en el cuadro de honor.

En el mes de Dieiembre sigue prestando idénticos servicdos. El dia 15 fueron transportados en Camiones a Larache los individuos del reem plazo de 1.921 para ser repatriados y licenciados.

$$
\text { 1.925. }
$$

La P.ut., primer Batallón en armas y 3 en cuadro de guarnición en Salamanea todo el año. Il Teniente Coronel del 20 Batallón, una compariia de fusiles y una sección de ametralladoras, en cuadro en Salamanea hasta el día 7 de Septiembre, y el Comandante, dos compañias de fusiles, una sección de ametralladoras y el Tren Regimental, en caadro en Salamanca, desde el 31 de Marzo hasta el 7 de Septiembre.

Con motivo de la repatriación de los individuos del reemplazo de 1.921 se redujo la plantilla del Batllón Expedicionario a dos compa Ĩias de fusiles, una sección de ametralladoras y tren regimental al mando del comandante por cuyo motivo se hizo cargo del mando de las fuerzas el Comandante D. Roberto Latorre cesando el Teniente Coronel para incorporarse a la P.M. del Regimiento con los oficiales y clases excedentes de plantilla. 
(62)

Estas fuerzas expedicionarias en primero de año se encuentran en Aox y en diferentes posiciones prestando toda clase de servicios de campaña hasta el día 25 de Marzo que, relevadas de sus posiciones, Pueron trasladadas en camiones automóviles a Larache embarcando el 28 en el Vapor Isla de Henorca con rumbo a Sevilla, donde llegaron el día 29, continuando el 30 por ferrocarril para llegar el 31 a Salaman ca donde quedaron de guarnición con las demás fuerzas del Regimie nto.

Por R.0. telegráficalde 5 de septiembre de dispuso que se organmara, de toda la fuerza del Regimiento un Batallón Expedicionario de tres compañias de fusiles y una de ametralladoras y tren Regimental.

El 7 del mismo salió el Batallón al mando del Teniente Coronel Don José Serviá Sanchez en ferrocarril con dirección a Algeciras a cuya plaza llegó el 10 embarcando el misno día para Ceuta en el vapor Isle ño y marchando seguidamente en ferrocarril a Tetuán donde llegó el ci tado día 10.

Presta el día 13 proteción a una baterias de Artileria que se establecen en los picos de Gorgues y Ben-Karrich;marcha el día 14 hacia las posicione cuyo cerco se levantó dias antes para recoger los despo jos de la retirada y enterrar los muertos, pernoctando en Ben-Karrich y regresando el día siguiente a Tetuán;se traslada el 17 al campamento de Laucién donde queda guarneciéndolo,prestando el servicio de convoyes, protección de carreteras, etc contimando en esta situación hasta el mes de Diciembre que habiendose dispuesto se organizase una compañia de 270 hombres se constituyó a la base de la $1^{a}$ mandada por el Capitan D. Fran cisco García que el ấa 12 quedó establecida en varias posiciones procimas a Laucién.

El Jefe del Batalión con el personal sobrante marcharon el 21 a Tetuan el 22 en ferroarril a Ceuta, el 22 en el vapor Cabañal a Algeciras, el 25 en ferrocarril a Salamanca donde llegaron el 27 incorporandose a la P.M. y quedando de guarnición.

$$
\text { 1.926. }
$$

La P.M. del Regimiento, primer Batallón en armas, 28 en cuadro, (menos 
la compañia expedicionariá) y 32 en cuadro de guarnición en Salamanca todo el año.

Por R.O.C. de $3 I$ de Enero fué destinado a manaar el Regimiento el Coronel D. José Rasa Alpón que se encargó del mando el día 6 de Febrero.

Continua la compañia expedicionaria destacada en el sector de Laucien prestando toda clase de servicios de campaña. El día 7 de Abril se encargó del mando de la compañía el Capitan D. Recarảo lian cebo Iúque que habia sido nombrado por baja del anterior.

\subsection{7.}

La P.M. del Regimiento, primer Batallón en armas, 22 en cuadro (menos la compañia expedicionaria) y 32 en cuadro de guarnición en Salamanca todo el año.

Continua destacada la compañia expedicionaria en el sector de Laucién prestando el servicho propio de campaña.

El día 20 de Marzo el enemigo protegido de las vistas y fuego a fa vor de las quebraduras del terreno y la g-aba rompió el fuego simultáneamente sobre todas las posiciones de la compania, el servicio de la aguada y las fuerzas de la protección de un convoy que se llevaba. a la compañia. Regresaban de hacer un viaje de agua 4 soldados del blo kans Piedras cayendo muertes Eusebio Garcíá Dominguez y Francisco Ra mos Rodriguez; inmediatamente unos moros se beharon encima para hacer prisioneros a los otros dos soldados; pero estos se defendieron tan valientemente que consiguienon llegar ilesos a la posición. En la po sición de Loma Verd Ne 1 resultó herido un cabo. Todas las posicio nes contestaron con su fuego a la agresión l granào hacer huir al enemigo al que se le hicieron ocho bajas. El comportamiento de la fuerza de la compañia fué tan ejemplar que fué apreciado por el alto mando con Prases laudatorias.

El día 22 de Abril al montar el servicio de aguada de la posición de Telefta salieron en vanguardia un cabo y cuatro soldados para ocu par un primer puesto. In gmipo de moros a diez metros del puesto, per 
(64)

fectamente a cubierto, hizo una descarga matando al cabo Valentin Pa ramio Paramio y a los soldados Anastasio Frades Gordillo, llatias del Rio Rodriguez y Jesus Hernandez Sanchez e hiriendo a otro soldado, echandose inmediatamente sobre ellos para despojarlos y matar al herido; pero la rápi đisima intervención de la fuerza de apozo, con granadas de mano consiguió auyentar al enemigo al que se le vió retirar algunas bajas. Fueron felicitados por el Jefe del sector por su brillante actuación al repeler la agresión,el sargen o Vicente Calvo Carcía; los cabos Julio Collantes Fernandez, Pablo Arroyo Gareía y Je sús Herrero Sanchez y el corneta Juan Picatoste García.

En la tarde del dia 30 de Abril la guarnición del blokau Arboli to, mandada por el sargento de este Regimiento Agustín Ruiz Hidalgo, repelió una agresión del enemigo al convoy de municipiones para la Harka de Beniurriaguel, haciéndole cuatro muertos y un prisionero.

Por disposición de la superioridad el dia 25 de Agosto empeza ron las fuerzas de la Compañía a desmantelar las posiciones que ocupaban concentrándose sus guarniciones en Telefta Principal. El día 29 marchó la Compañia al mando de su Capitán a Ben Karrich, donde = pernoctó. El día 30 marchó al Fondalillo relevando a la Compañía del Regimiento de Soria, continuando en dicho campamento prestando servicio de campaña hasta el dia 20 de Septiembre que marchó a Tetuán donde quedó en espera de órdenes para la pepatriación. El día 24 marchó por ferrocarril a Ceuta y el dia 25 embarcó en el vapor Primo de Ri vera llegando el mismo dia a Algeciras. Continuó su marcha el dia 26 por ferrocarril llegando a Salaman ca el dia 27 del referido mes de sep tiembre quedando la Compañía en cuadro en la revista de Octubre si guiente por haber sido destinada la tropa a nutrir las compañías del primer Batalión en Armas.

I928

La P.M. del Regimiento primer Batallón en armas y 22 y 32 en $=$ cuadro, de guarnición en Salamanca todo el año.

I929

La P.M. del Regimiento, primer Batallón en armas y segundo y 
tercero en cuadro, de guarnición en Salamanca.

$\cdot$ 


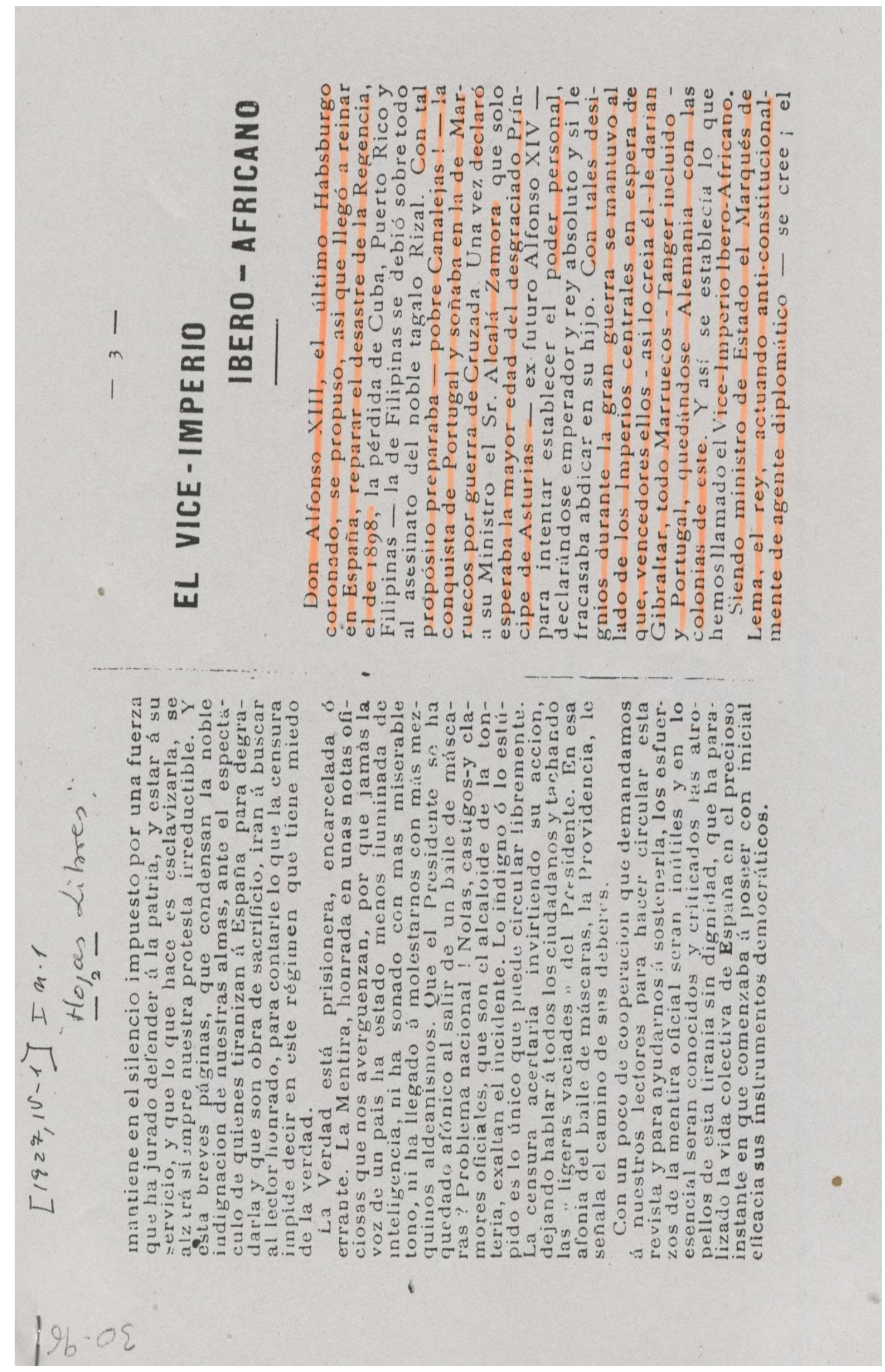




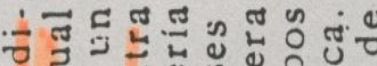

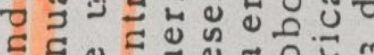

=

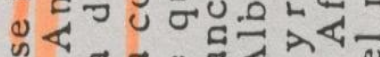

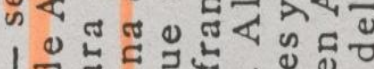

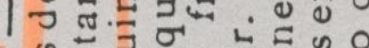

คำ

곤.

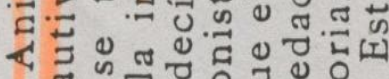
$\sum$ 范

그음

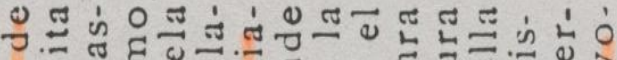

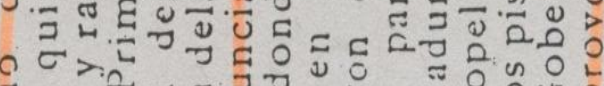

ส

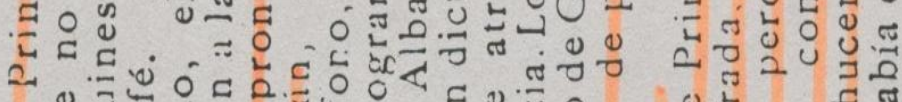

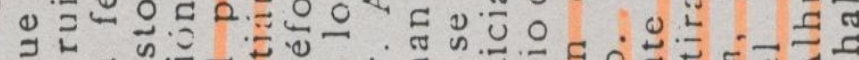

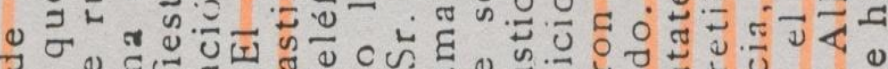

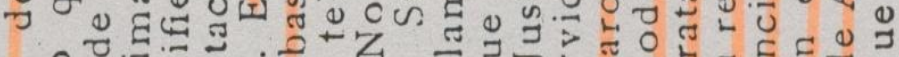

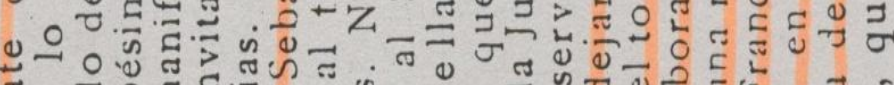

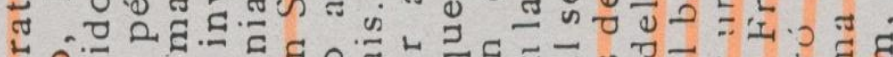

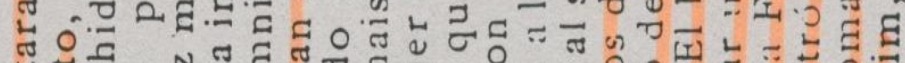
ช 내의

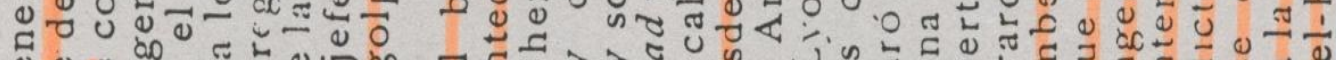
U - U ब की กเ

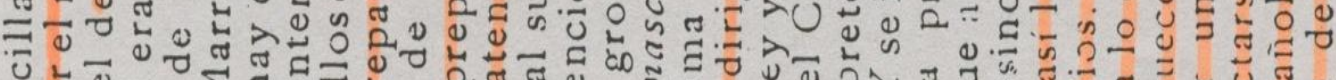

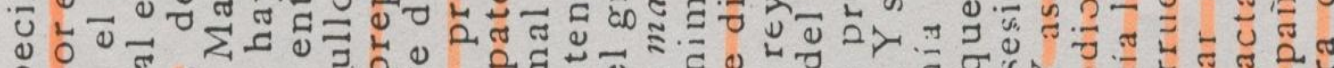

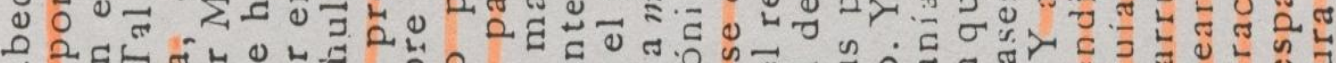

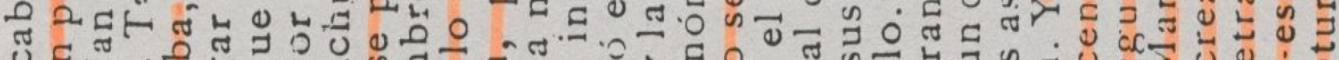

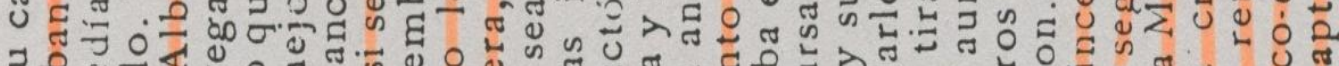
कै คิ ป气

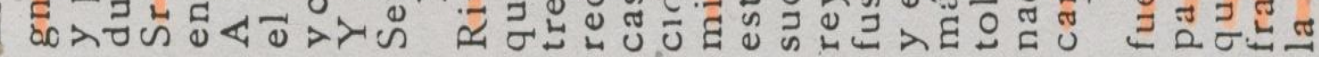

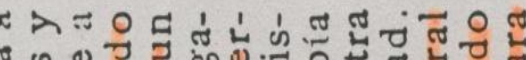
กึ

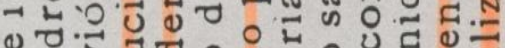
\&

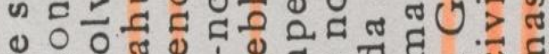
$\exists \mu>$ 出

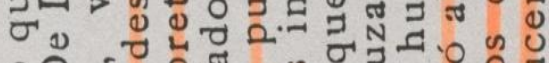
○ :

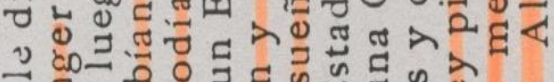

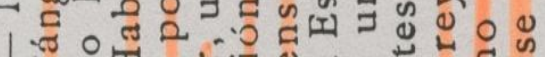
$\mapsto \gg$ 工 - సี

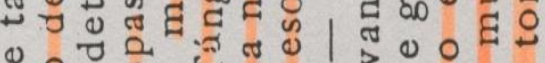

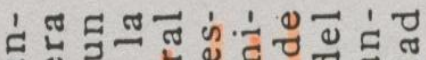

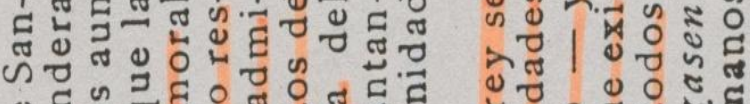
ง ช马 भก

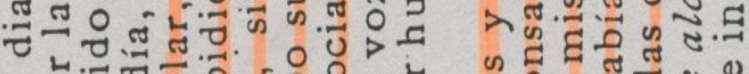

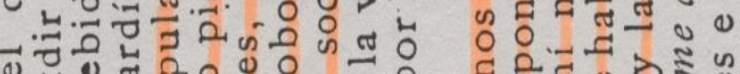

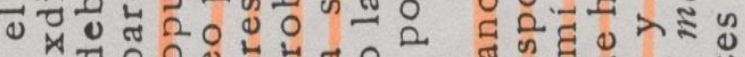

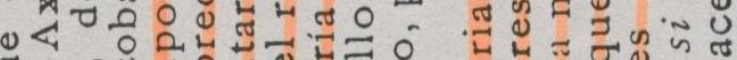

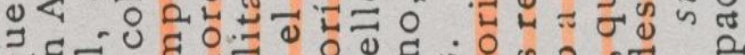
चี त

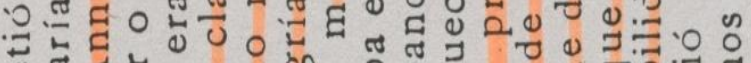

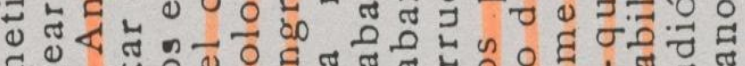

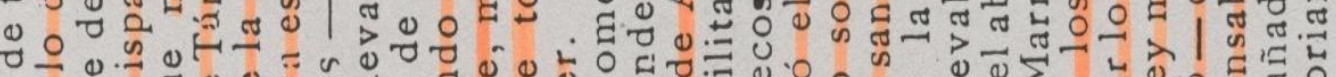

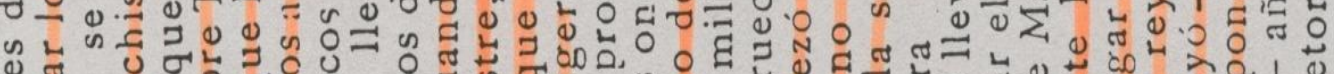

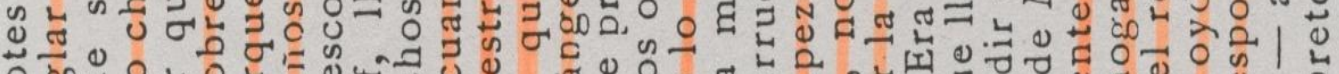

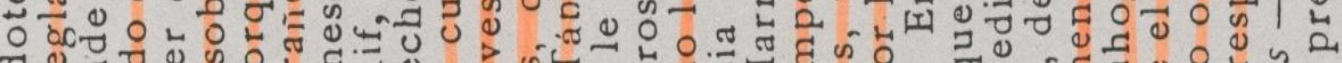

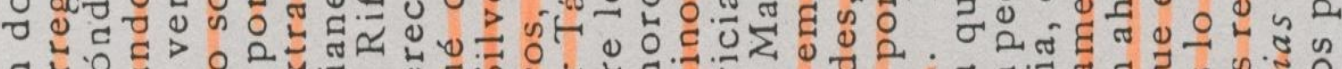
대유.

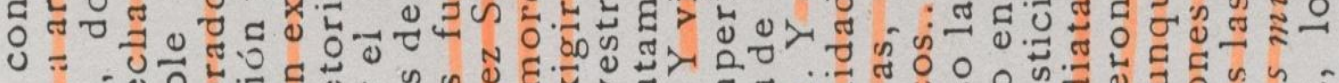

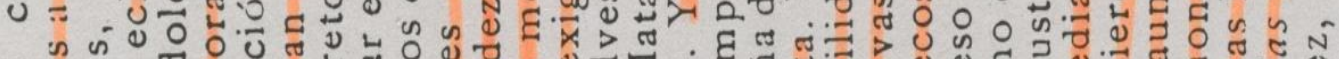
- थ.

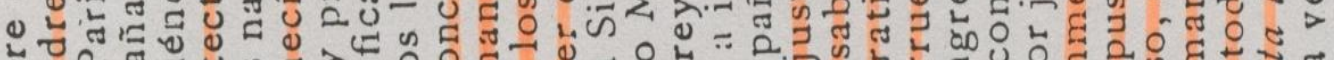
L

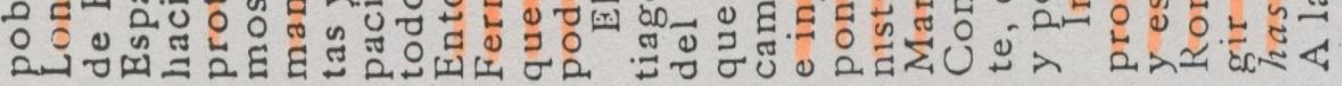




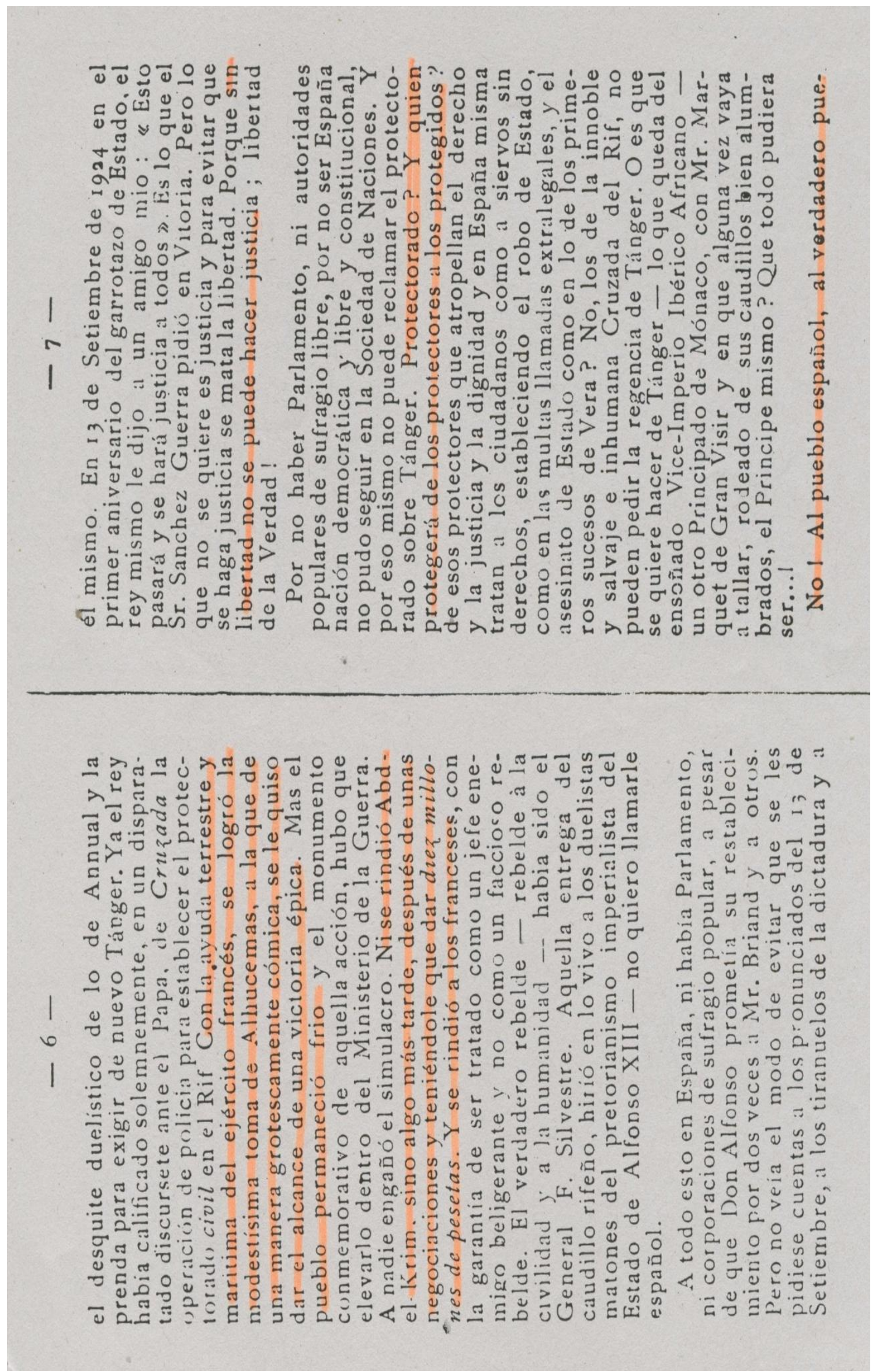




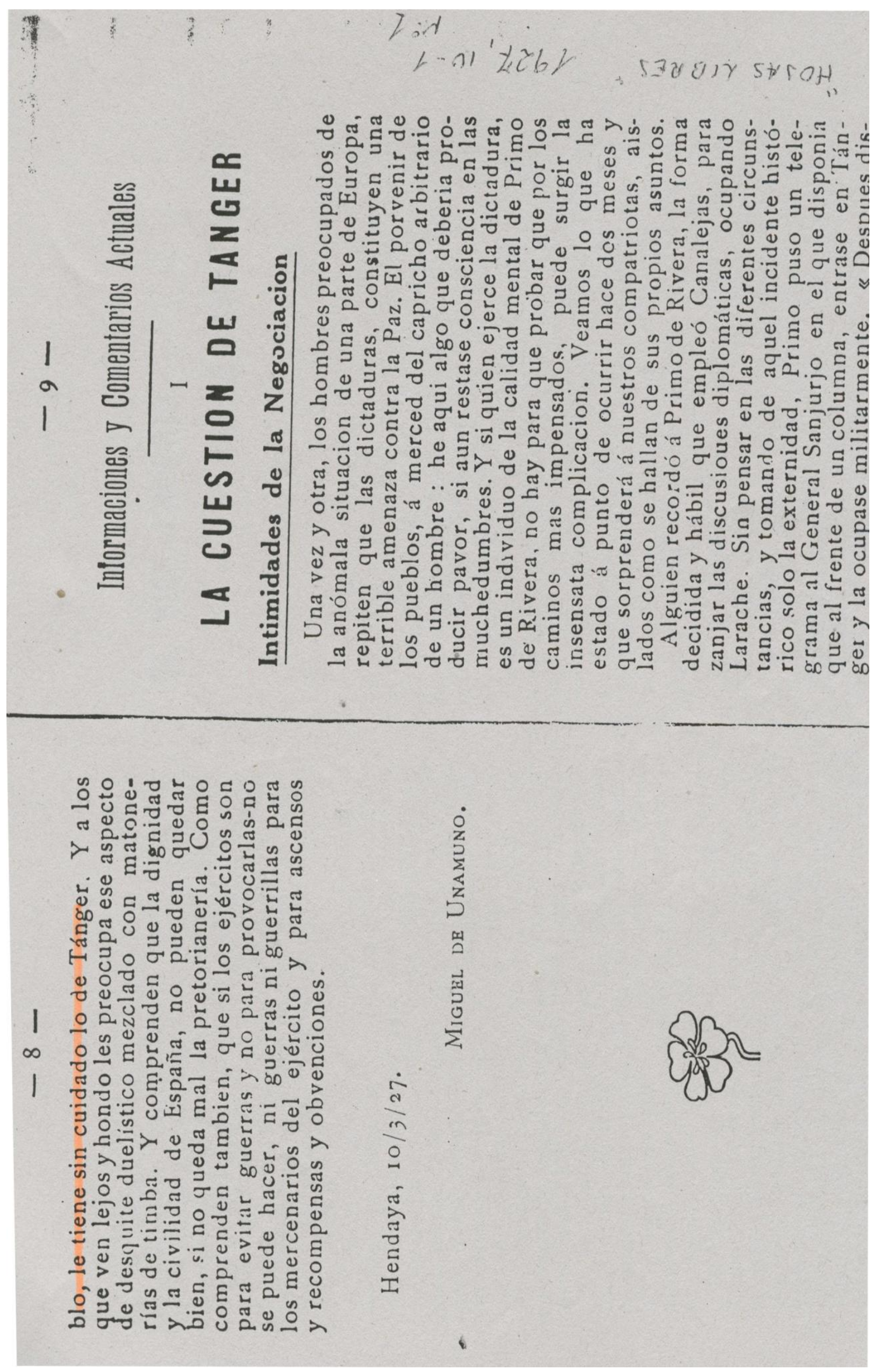


El Adelanto, 27 de marzo de 1925, p. 1.

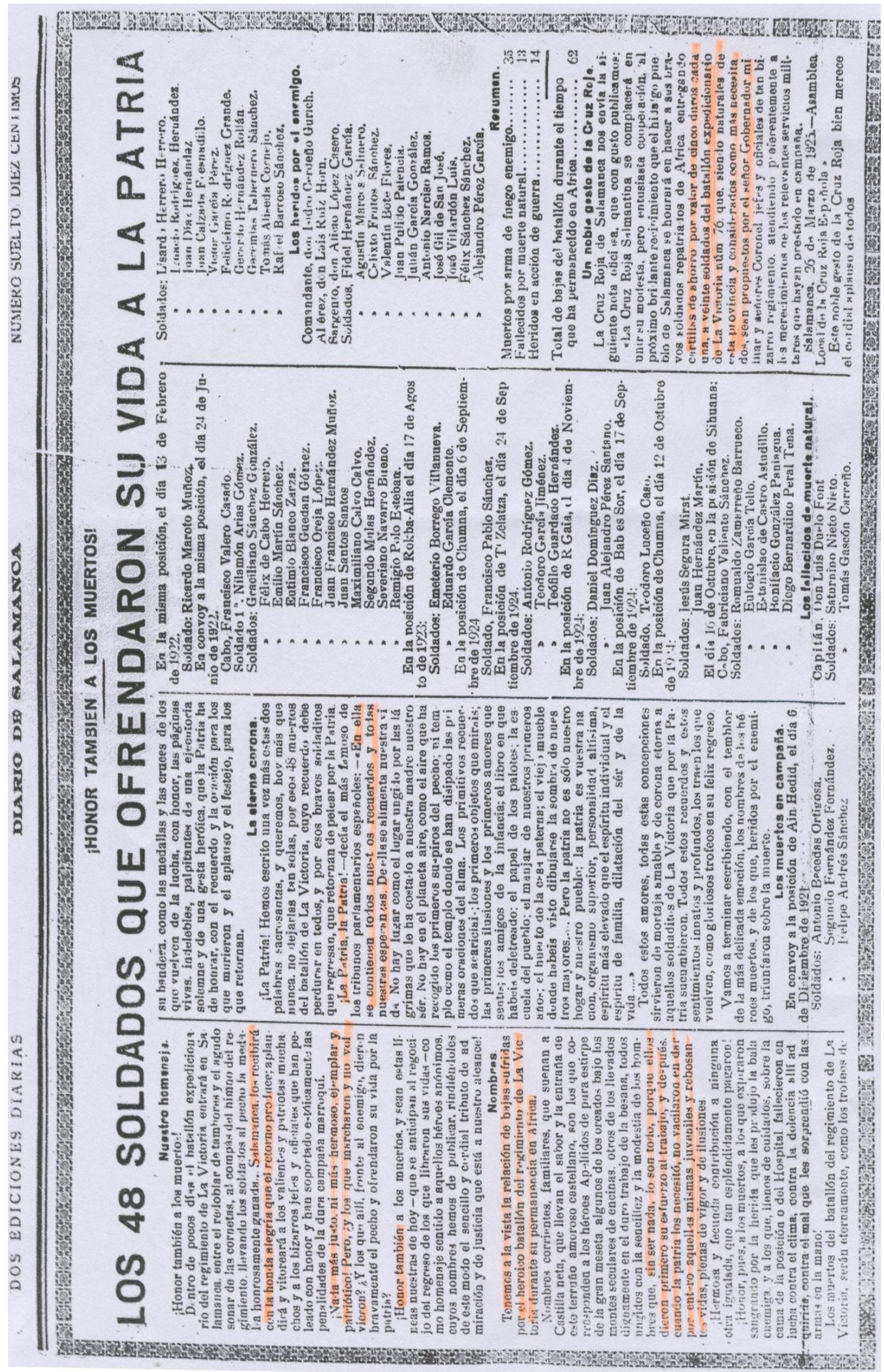


Boletín del Obispado de Salamanca, n 2, 2 de febrero de 1925.

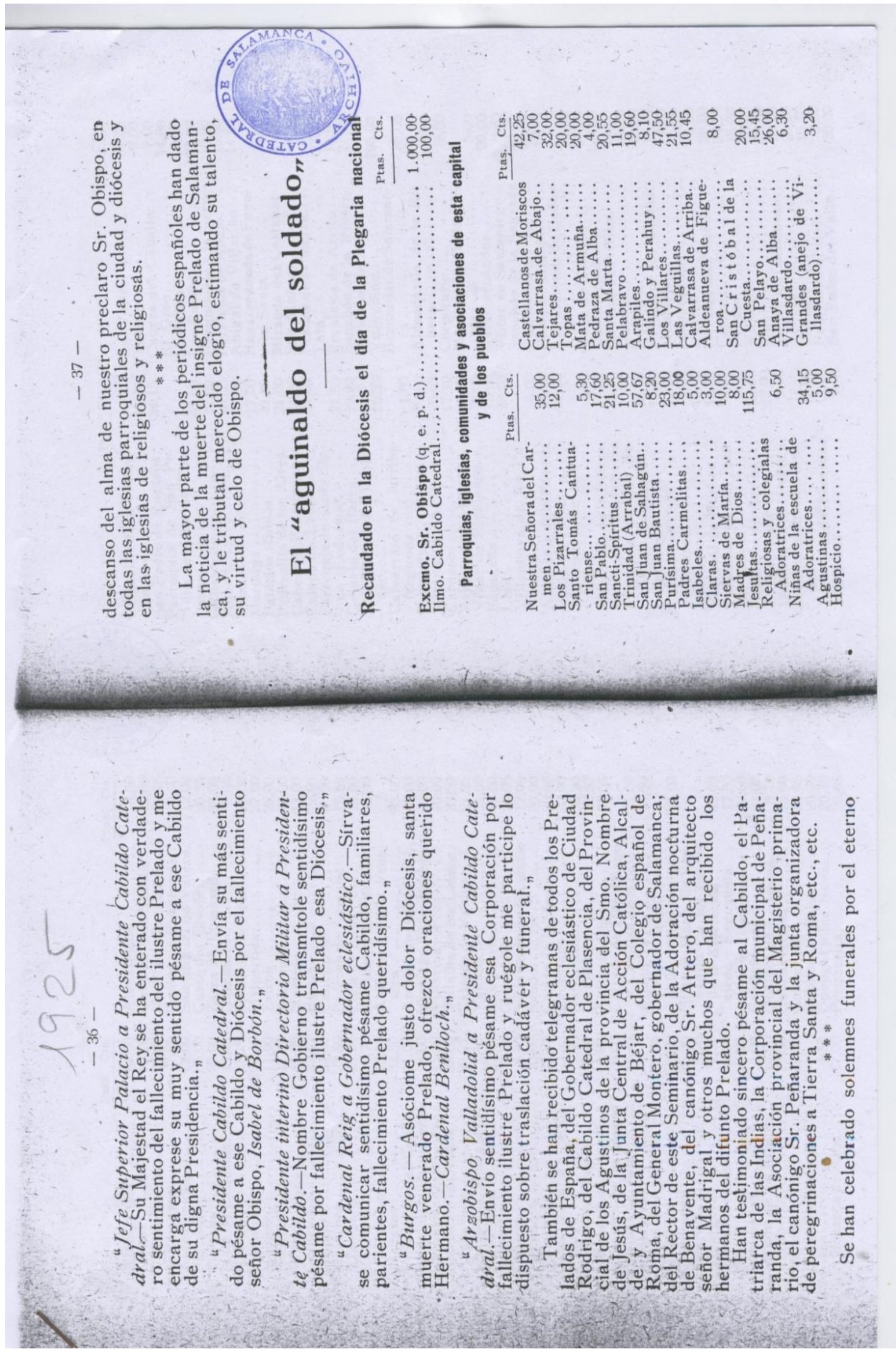




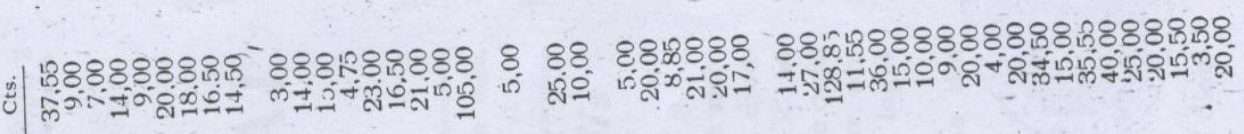

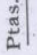

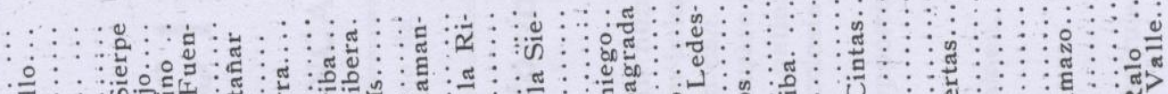

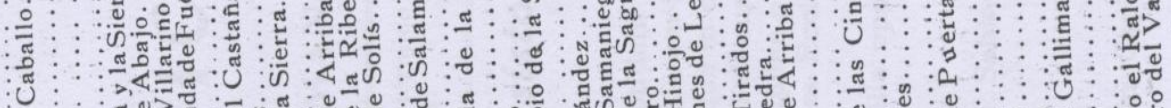

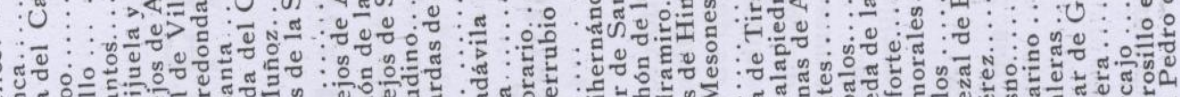

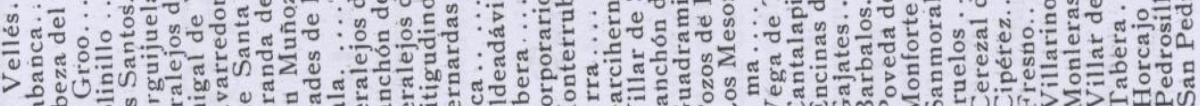

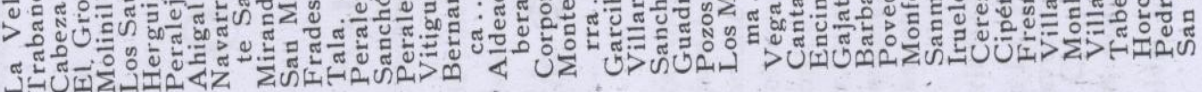

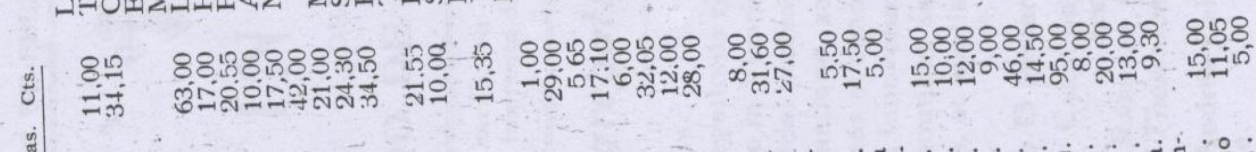
离

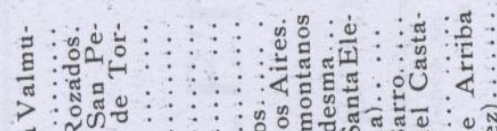

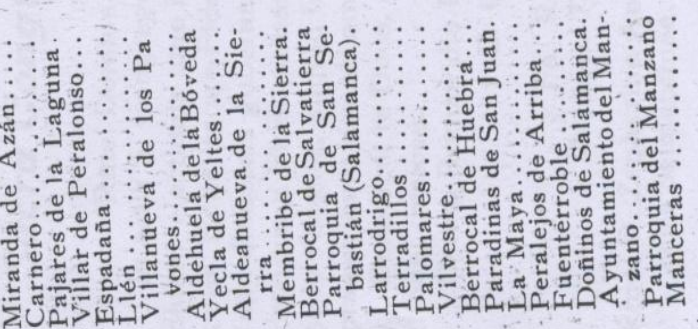
(5)

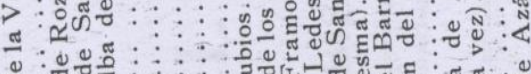
o

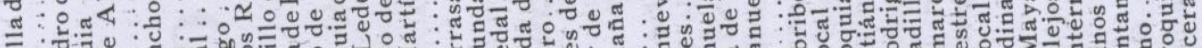

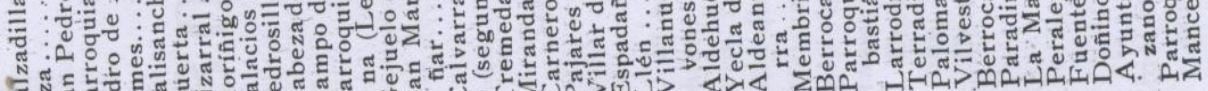

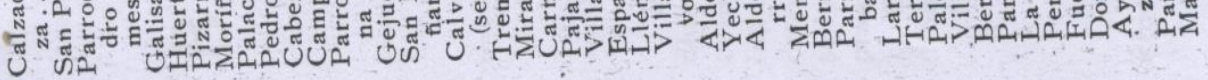

QRavo.

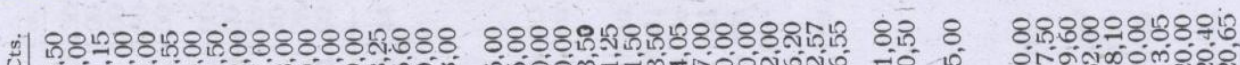
:

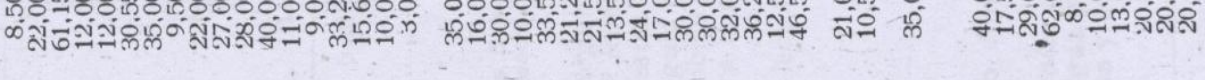

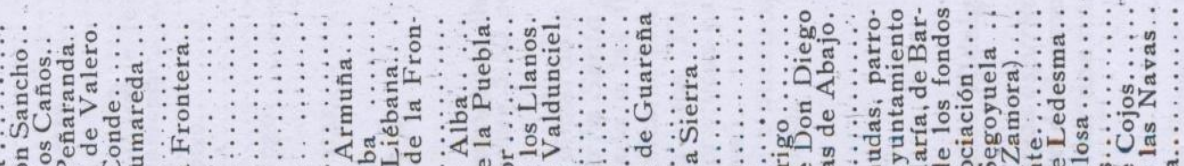

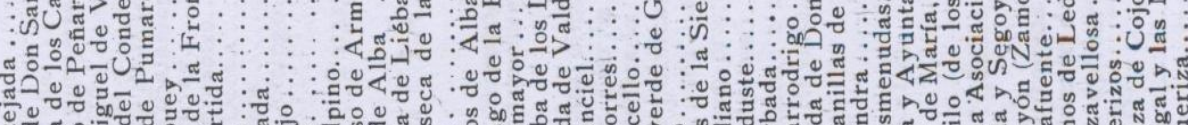

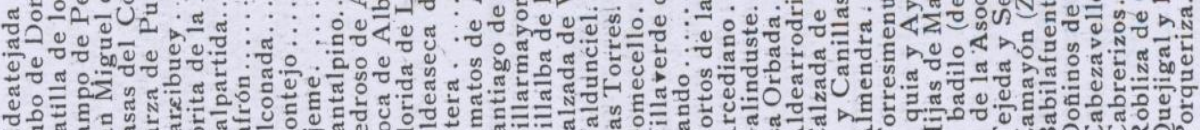

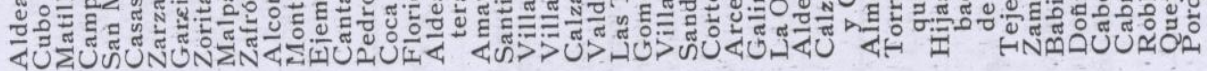

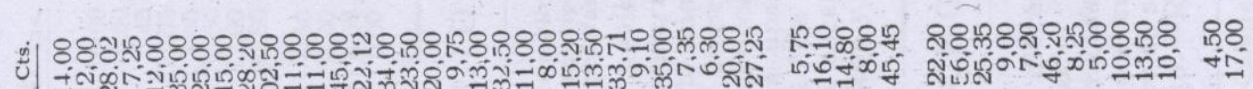

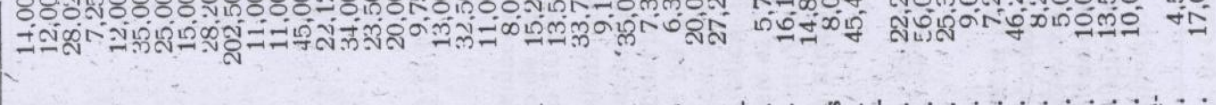
(1)

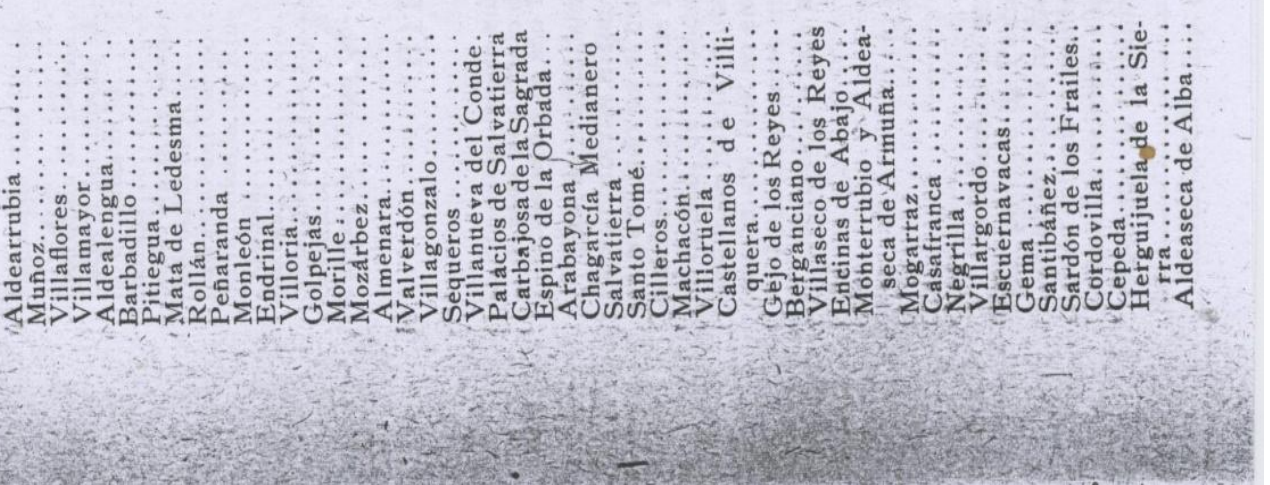




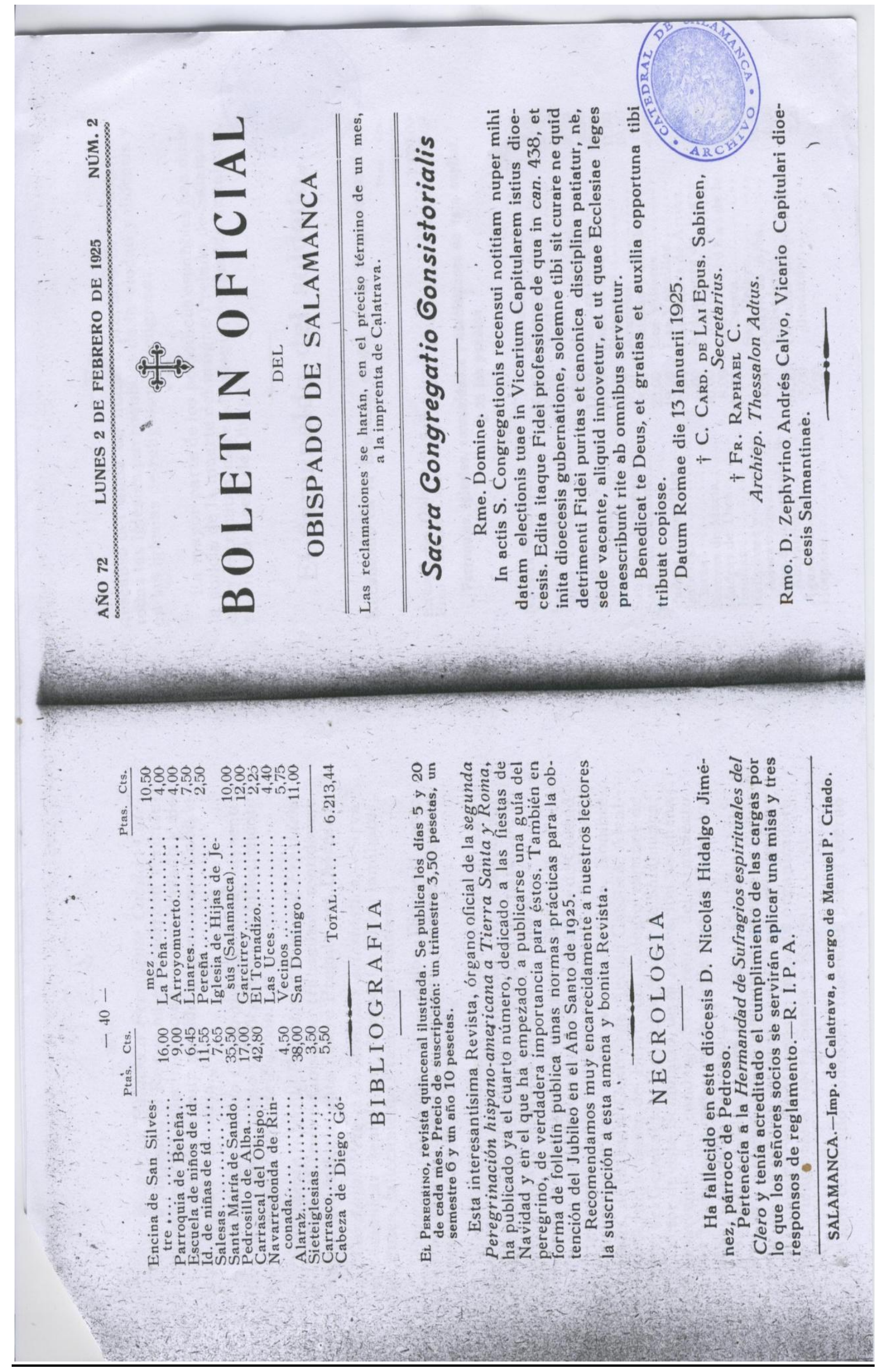




\section{FUENTES Y BIBLIOGRAFÍA.}

\section{A. Archivos consultados}

Biblioteca General de la Universidad de Salamanca

Archivo General de la Universidad de Salamanca

Archivo Catedralicio de Salamanca

Archivo Diocesano de Salamanca

Archivo Municipal de Salamanca

Archivo de la Diputación Provincial de Salamanca

Casa-Museo Unamuno, Salamanca

Centro de Documentación de la Cruz Roja Española, Madrid

Biblioteca Nacional Española, Madrid

CSIC-Biblioteca Tomás Navarro Tomás, Madrid

Archivo General Militar de Madrid

\section{B. Publicaciones periódicas}

El Adelanto

La Gaceta Regional

El Salmantino

El Castellano

El Lábaro

La Libertad

La Ciudad

La Verdad

El Obrero

La Lucha

El Pueblo

El Socialista

El Mercantil Valenciano

La Nación

La Cruz Roja. Revista mensual ilustrada

Boletín Oficial de la provincia de Salamanca

Boletín del Obispado de Salamanca 


\section{Libros, folletos y monografías}

-ALARCÓN, Pedro Antonio de: Dos días en Salamanca. Madrid: Imprenta de A. Pérez Dubrul, 1883.

-ANÓNIMO: La Guerra en el Rif. Historia general de la acción de España en Marruecos. (Sin datos de edición).

-AYENSA, Emilio: Del Desastre de Annual a la presidencia del Consejo. Madrid: Rafael Caro Raggio, 1930.

-AZPEITÚA, Antonio: Marruecos, la mala semilla (Ensayo de análisis objetivo de cómo fue sembrada la Guerra en África). Madrid: Imprenta clásica española, 1921.

-BANÚS Y COMAS, Carlos: Reflexiones acerca de las enseñanzas de la campaña del Rif en 1909. Madrid: Imprenta del Memorial de ingenieros del Ejército, 1912.

-BARADO, Francisco: Nuestros soldados. Narraciones y episodios de la vida militar en España. Barcelona: Imprenta de Henrich y Compañía, 1909.

-BASALLO, Francisco: Memoria del cautiverio (julio 1921 a enero 1923). Madrid: Editorial Mundo Latino, 1924.

-BASTOS ANSART, Francisco: El Desastre de Annual: Melilla en julio de 1921. Barcelona: Minerva, 1921.

-BERENGUER, Dámaso: La guerra en Marruecos (Ensayo de una adaptación táctica). Madrid: Librería Fernando Fe, 1918.

-BESTEIRO, Julián: El Partido Socialista y el problema de Marruecos. México: Editorial Pablo Iglesias, s. f.

-CABANILLAS, Alfredo: La epopeya del soldado. Desde el Desastre de Annual hasta la reconquista de Monte Arruit. Madrid: Imprenta Clásica Española, 1922.

-CAMPOAMOR, José María: La actitud de España en la cuestión de Marruecos. Madrid: Instituto de Estudio Africanos, 1951.

-CANALS, Salvador: Los sucesos de España en 1909. Crónica documentada. Madrid: Imprenta Alemana, 1911.

—: España y la cuestión de Marruecos. Análisis de un debate parlamentario (Artículos publicados en la revista Nuestro Tiempo). Madrid: Imprenta "Alrededor del mundo", 1915.

-CAPITÁN X: Verdades amargas (La campaña de 1909 en el Rif). Madrid: Imprenta artística española, 1910.

-CAPDEQUÍ Y BRIEU, Mauricio: Apuntes sobre la zona occidental del Protectorado marroquí español. Madrid: Editorial San Fernando, 1923.

-CEDRÚN DE LA PEDRAJA, Gonzalo: Los soldados de cuota. El Ejército de operaciones en Marruecos. Madrid: Victoriano Suárez, 1914.

-CEREZO GARRIDO, Manuel: El rescate de los prisioneros (Libro de la verdad). Melilla: Editorial Artes Gráficas Postal Exprés, 1922.

-CIGES APARICIO, Manuel: Entre la paz y la guerra (Marruecos). Madrid: Imprenta de Juan Pueyo, 1912.

-DÍAZ DE VILLEGAS, José: Lecciones de la experiencia (enseñanzas de las campañas de Marruecos). Toledo: Sebastián Rodríguez, 1930. 
-ESCORIAZA, Teresa de: Del dolor de la guerra (Crónicas de la campaña de Marruecos). Madrid: Pueyo, 1921.

-Estado Mayor Central del Ejército: Enseñanzas de la campaña del Rif en 1909. Madrid: Talleres del Depósito de la Guerra, 1911.

-ESPAÑA, Juan de: La actuación de España en Marruecos. Apuntes de historia y estudios sobre la política y situación actual del problema hispano-marroquí. Madrid: s. n., 1926.

-ESPERABÉ DE ARTEAGA, Enrique: Salamanca Contemporánea. La vida de la ciudad desde 1868 hasta 1933. Sus principales acontecimientos. Sus políticos. Salamanca: Imprenta de Francisco Núñez Izquierdo, 1933.

-FIGUEROA, Álvaro de (Conde de Romanones): Las responsabilidades del Antiguo Régimen, 1875-1923. Madrid: Renacimiento, 1923.

-GALLEGO RAMOS, Eduardo: La campaña del Rif de 1909: orígenes, desarrollo y consecuencias. Madrid: Imprenta de A. Marzo, 1909.

-GÁLVEZ, Pedro Luis de y MARTínEZ, Francisco: Por los que lloran (Apuntes de la guerra). Madrid: Imprenta de Gabriel López del Horno, 1910.

-GARCÍA FIGUERAS, Tomás: Historia de la acción de España en Marruecos. Desde 1904 a 1927. Barcelona: Ediciones Fe, 1939.

-GIMÉNEZ CABALLERO, Ernesto: Notas marruecas de un soldado. Madrid: s. n., 1923.

-GÓMEZ HIDALGO, Francisco: La tragedia prevista (Con prólogo de Marcelino Domingo). Madrid: Imprenta de Juan Pueyo, 1921.

-GOY DE SILVA, Ruy: Borrón y cuenta nueva. Crónicas de Marruecos. Alcoy: s. n., 1923.

-GUIXÉ, Juan: El Rif en sombras. Lo que yo he visto en Melilla. Madrid: s. n., 1922.

-HABLA UN SOLDADO: El problema de Marruecos. Un cuarto de espadas. Madrid: Imprenta Helénica, 1914.

-HARRIS, Walter: France, Spain and the Rif. Londres: Edward Arnold, 1927.

-HERNÁNDEZ MIR, Francisco: La tragedia del cuota (Una escuela de ciudadanos). Madrid: Pueyo, 1922.

—: Del Desastre al fracaso. Un mando funesto. Madrid: Pueyo, 1922.

—: Del Desastre a la victoria (1921-1926). Madrid: Librería Fe, 1926. Se incluyen cuatro volúmenes: Ante las hordas del Rif; Del Rif a Yebala; Alianza contra el Rif; El Rif por España.

-LOBERA, Cándido: El problema rifeño. Melilla: Imprenta de El telegrama del Rif, 1909.

-LÓPEZ RIENDA, Rafael: Frente al fracaso. Raisuni, de Silvestre a Burguete. Madrid: Sociedad General española de Librería, 1923.

-MAINAR, Rafael: El arte del periodista. Barcelona: José Gallach Editor, 1906.

-MARICHALAR, Luis de: Mi responsabilidad en el Desastre de Melilla como ministro de la Guerra. Madrid: Gráficas Reunidas, 1923. 
-MAURA GAMAZO, Gabriel: La cuestión de Marruecos desde el punto de vista español. Madrid: Imprenta de M. Romero, 1905.

-MOLA VIDAL, Emilio: Dar Akkoba. Páginas de sangre, dolor y de gloria, en Obras Completas. Valladolid: Santarén, 1940.

-MUÑOZ OREA, Manuel: Datos para la geografía médica de Salamanca. Tesis doctoral, Barcelona, 1911.

-NOEL, Eugenio: Notas de un voluntario. Madrid: Imprenta de P. Fernández, 1910 (2 edición).

—: Lo que vi en la guerra. Diario de un soldado. Barcelona: La Neotipia, 1912.

-PÉREZ ORTIZ, Eduardo: De Annual a Monte Arruit y diez y ocho meses de cautiverio. Crónica de un testigo. Melilla: Artes Gráficas Post-Exprés, 1923.

-PEYRA ANGLADA, Gustavo: España en el Rif (1909). Barcelona: Pons y Compañía, 1910.

-RIERA, Augusto: España en Marruecos. Crónica de la campaña de 1909. Barcelona: Maucci, 1910.

-RÍOS, Antonio: Una tesis sobre nuestro Protectorado en Marruecos. Madrid: Tip. Anónima Mefar, 1922.

-RODRÍGUEZ DE VIGURI Y SEOANE, Luis: La retirada de Annual y el asedio de Monte Arruit (Escrito en defensa del general don Felipe Navarro y Ceballos, barón de Casa Davalillo, leído ante el Consejo Supremo de Guerra y Marina, reunido en sala de justicia). Madrid: Sucesores de Rivadeneyra, 1924.

-ROMERO BASART, Luis: La guerra de Marruecos o cómo se engaña a un pueblo. Tetuán: Casa Gomariz, 1930.

-RUBIO FERNÁNDEZ, Eduardo: Melilla, al margen del Desastre. Barcelona: Cervantes, 1921.

-RUIZ ALBÉNIZ, Víctor: Las responsabilidades del Desastre. Ecce Homo (Prueba documental y aportes inéditos sobre las causas del derrumbamiento y consecuencia de él). Madrid: Biblioteca Nueva, 1922.

-SERRA ORTS, Antonio: Recuerdos de la Guerra del Kert de 1911-1912. Barcelona: Elzeviriana de Borrás, 1914.

-UN AFRICANISTA MÁS: La guerra y el problema de África. Unas cuantas verdades. Burgos: Tipografía de Marcelino Miguel, 1914.

-SORIANO, Rodrigo: ¡Guerra, guerra al infiel marroquí! Madrid: Tip. El Día de Cuenca, 1921.

-VILA SAN-JUAN: Lo que no tiene nombre (Crónicas de Marruecos). Barcelona: Antonio López, 192?

-VIVERO, Augusto: El derrumbamiento. La verdad sobre el Desastre del Rif. Madrid: Rafael Caro Raggio, 1922.

\section{Bibliografía publicada recientemente}

-AGUIRREAZKUENA, Josefa y URQUIJO, Miquel (Eds.): Storia locale $e$ microstoria: due visione in confronto. Bilbao: Universidad del País Vasco, 1993. 
-AKMIR, Youssef: De Algeciras a Tetuán, 1875-1906. Orígenes del proyecto colonialista español en Marruecos. Rabat: Instituto de Estudios HispanolusosUniversidad Mohammed V, 2009.

-ALARCÓN, Pedro Antonio de: Diario de un testigo de la Guerra de África. Ceuta: Biblioteca Municipal de Ceuta, 2009.

-ALÍA MIRANDA, Francisco: Duelo de sables. El general Aguilera, de ministro a conspirador contra Primo de Rivera (1917-1931). Madrid: Biblioteca Nueva, 2006.

-ALLENDESALAZAR, José Manuel: La diplomacia española y Marruecos, 1907 1909. Madrid: MAE y Agencia Española de Cooperación Internacional, 1990.

—: "Notas sobre una gestión diplomática. Allendesalazar, ministro de Estado (19071909)", Historia Contemporánea, no 15, Bilbao, 1996, pp. 86-106.

-ALMUIÑA FERNÁNDEZ, Celso: "Prensa y Poder en la España contemporánea", Investigaciones Históricas. Departamento de Historia Moderna y Contemporánea, $\mathrm{n}^{\mathrm{o}} 1$, Valladolid, 1979, pp. 297-323.

-: "La jurisdicción militar y el control de los medios de comunicación. Annual y la censura del material gráfico (1921)", Investigaciones Históricas. Departamento de Historia Moderna y Contemporánea, no 6, Valladolid, 1986, pp. 215-255.

—: "El Desastre de Annual (1921): su proyección sobre la opinión pública española", Investigaciones Históricas. Departamento de Historia Moderna y Contemporánea, $\mathrm{n}^{\circ}$ 8, Valladolid, 1988, pp. 181-245.

-ALMUIÑA, Celso y SOTILLOS, Eduardo (Coords.): Del periódico a la sociedad de la información. 3 Volúmenes. Madrid: España Nuevo Milenio, 2002.

-ALONSO BAQUER, Miguel: "La Guerra hispano-americana de 1898 y sus efectos sobre las instituciones militares españolas", Revista de Historia Militar, Año XXVII, ${ }^{\circ}$ 54, Madrid, 1984, pp. 127-151.

- : "La mentalidad patriótica del militar español contemporáneo", Revista de Historia Militar, $\mathrm{n}^{\mathrm{o}}$ extraordinario, Madrid, 2005, pp. 133-157.

-ÁLVAREZ GUTIÉRREZ, Luis: “¿Un proyecto de reparto de Marruecos entre España y Francia a finales de los años 1880?" en DÍEZ TORRE, Alejandro R.: Ciencia y memoria de África: Actas de las III jornadas sobre expediciones científicas y africanismo. Madrid: Servicio de Publicaciones de la Universidad de Alcalá de Henares, 2002, pp. 145-196.

-: "Intentos alemanes para contrarrestar la influencia francesa sobre la opinión pública española en los años precedentes a la Primera Guerra Mundial" en VVAA: Españoles y franceses en la primera mitad del siglo XX. Madrid: CSIC, 1986, pp. 1-21.

-ÁLVAREZ JUNCO, José y PÉREZ LEDESMA, Rafael: "Historia del movimiento obrero. ¿Una segunda ruptura?”, Revista de Occidente, no 12, Madrid, 1982, pp. 20-36.

-ÁLVAREZ JUNCO, José: "El nacionalismo español como mito movilizador: cuatro guerras" en PÉREZ LEDESMA, M. y CRUZ, R. (Coords.): Cultura y movilización en la España Contemporánea. Madrid: Alianza Editorial, 1997, pp. 35-67.

-ANGUERA, Pere: "Introducción a la historia local catalana" en RÚJULA, P. y PEIRÓ, I. (Coords.): La historia local en la España contemporánea. Barcelona: L'Avenç, 1999, pp. 9-17. 
-ARCO LÓPEZ, Valentín del: "Unamuno frente a Primo de Rivera. De Salamanca al exilio, 1923-1924”, Studia Histórica. Historia Contemporánea, Vol. IV, n ${ }^{\circ}$ 4, Salamanca, 1986, pp. 129-179.

—: "El siglo XX, 1: 1900-1936" en VVAA: La Universidad de Salamanca. Vol. I. Historia y Proyecciones. Salamanca: Ediciones Universidad de Salamanca, 1989, pp. 229-286.

-ARIAS GONZÁLEZ, Luis: Alfredo García García, Adeflor. En la Guerra de África (1921). Gijón: Vtp Editorial, 2008.

—: "El sentimiento popular ante la guerra de Marruecos" en GIRÓN GARROTE, J. (Ed.): Historia militar de Asturias. Oviedo: Silverio Cañada editor, 2006, pp. 116-134.

-ARROYO CABELLO, María: El artículo como arma política. La prensa y el declive de la Restauración (1905-1930). Comentarios de textos periodísticos. Granada: Port Royal Ediciones, 2001.

-ARROYO VÁZQUEZ, Ma Luz: Industria y trabajo en el New Deal de Franklin D. Roosevelt a través de la prensa española, 1932-1936. Tesis doctoral inédita, Universidad Complutense de Madrid, 2001.

-ASPIZÚA, Jorge, CACHINERO, Jorge y JENSEN, Geoffrey: "La historia militar: una carencia intelectual en España", Ayer, n 10, Madrid, 1993, pp. 63-76.

-AUBERT, Paul: "Los intelectuales y la cuestión marroquí (1914-1918)”, Bulletin du Département de Recherches hispaniques Pyrenaica, nº 30, Pau, 1984, pp. 19-32

- : "Crisis del papel y consecuencias de la industrialización de la prensa (1902-1931)" en DESVOIS, Jean-Michelle: Prensa, impresos, lectura en el mundo hispano contemporáneo. París: PILAR, 2005, pp. 73-95.

-AVILÉS, Juan (et al.): Historia política y social moderna y contemporánea. Madrid: UNED, 2001.

-AZIZA, Mimoun: La sociedad rifeña frente al Protectorado español en Marruecos, 1912-1956. Barcelona: Bellaterra. Colección Alborán, 2006.

-BACHOUD, Andrée: Los españoles ante las campañas de Marruecos. Madrid: Espasa-Calpe, 1988.

—: "Los intelectuales y las campañas de Marruecos (1909-1913)" en TUÑóN DE LARA, Manuel, ELORZA, A. y LEDESMA, M. (Eds.): Prensa y sociedad en España. Madrid: Edicsa/Cuadernos para el Diálogo, 1975, pp. 271-181.

-BALBÉ, Manuel: Orden público y militarismo en la España Constitucional (18121983). Madrid: Alianza, 1983.

-BALFOUR, Sebastián: El fin del Imperio Español (1898-1923). Barcelona: Crítica, 1997.

—: Abrazo mortal. De la guerra colonial a la Guerra Civil en España y Marruecos (1909-1939). Barcelona: Ediciones Península (Historia, Ciencia y Sociedad), 2002.

-: "El otro moro en la guerra colonial y la Guerra Civil" en GONZÁLEZ ALCANTUD, J. L. (Ed.): Marroquíes en la Guerra Civil española. Campos equívocos. Barcelona: Anthropos, 2003, pp. 95-110. 
-BARCELÓ SICILIA, Ricardo J.: "La actitud del Cherif Mulay Ahmed Raisuni ante el desembarco españolen Larache y toma de Alcazarquivir en 1911", Estudios Africanos, n 18-19, Madrid, 1996, pp. 101-107.

-BAREA, Arturo: La forja de un rebelde. Barcelona: Plaza y Janés, 1986.

-BARRIO JALA, Manuel del: "Reflexiones sobre la Guerra de África", Revista de Historia Militar, Año XLVI, nº 92, Madrid, 2002, pp. 209-255.

-BASTENIER, Miguel Ángel: "La Conferencia de Algeciras. El reparto de Marruecos", Los grandes hechos del siglo XX, nº 69, Madrid, 1982, pp. 97-108.

-BAUM, Matthew A. y POTTER, Philip B. K.: "The relationships between mass media, public opinion, and foreign policy: toward a theoretical synthesis", Annual Review of Political Science, no 11, 2008, pp. 39-65.

-BÉCARUD, Jean: “Jean Cassou y Miguel de Unamuno a través de su correspondencia" en VVAA, Jean Cassou y sus amigos. Madrid: Ayuntamiento de Madrid, 2001, pp. 35-43.

-BERAMENDI, Justo G.: "Aproximación a la historiografía reciente sobre los nacionalismos en la España Contemporánea”, Estudios de historia social, n ${ }^{\circ}$ 28-29, Madrid, 1984, pp. 49-76.

- : "La historiografía de los nacionalismos en España", Historia Contemporánea, $\mathrm{n}^{\mathrm{o}} 7$, Bilbao, 1992, pp. 135-154.

-BONAMUSA, Francesc: "España y las guerras de África" en VVAA: La guerra en la historia. Salamanca: Universidad de Salamanca, 1998, pp. 287-319.

-BONILLA, José Antonio, HERNÁNDEZ, José María y MARTÍN MARTÍN, José Luis: Historia de Salamanca. Salamanca: La Gaceta Regional de Salamanca, 1996.

-BORRÁS BETRIU, Rafael: El Rey perjuro. Don Alfonso XIII y la caída de la monarquía. Barcelona: Ediciones B, 2007.

-BORREGUERO BELTRÁN, Cristina: El reclutamiento militar por quintas en la España del siglo XVIII. Orígenes del servicio militar obligatorio. Salamanca: Servicio de Publicaciones de la Universidad de Valladolid, 1989.

- : "Nuevas perspectivas para la historia militar: la 'new military history' en Estados Unidos", Hispania, LIV/1, nº 186, 1994, pp. 145-177.

-BORRELL MERLÍN, Ma Dolores: "Visión progresista de las relaciones EspañaMarruecos: El antecedente de Pablo Iglesias", Anduli. Revista Andaluza de Ciencias Sociales, $\mathrm{n}^{\mathrm{o}} 2$, Sevilla, 2003, pp. 59-76.

-BOUARFA, Mohamed: Marruecos y España. El eterno problema. Málaga: Algazara, 2002.

-BOUTBOUQALT, Tayeb: La Guerre du Rif et la réaction de l'opinion internationale, 1921-1926. Casablanca: Najah El Jadida, 1992.

-BOUZALMATE, Alhoucine: Marruecos y los intelectuales y publicistas españoles 1912-1923. Tesis doctoral inédita, Universidad Autónoma de Madrid, 2002.

—: "Marruecos y los intelectuales y publicistas españoles (1921-1923)" en RAMÍREZ, A. y LÓPEZ GARCÍA, B. (Eds.): Antropología y antropólogos en Marruecos. Homenaje a David M. Hart. Barcelona: Bellaterra, 2002, pp. 279-236. 
-BOYD, Carolyn P.: La política pretoriana en el reinado de Alfonso XIII. Madrid: Alianza, 1990.

-BUSQUETS BRAGULAT, Julio: El militar de carrera en España. Barcelona-Caracas: Ariel, 1967.

-CABALLERO DOMÍNGUEZ, Margarita: "La cuestión marroquí y su corolario de Annual como causa y consecuencia de la crisis del sistema restauracionista", Investigaciones Históricas. Departamento de Historia Moderna y Contemporánea, $\mathrm{n}^{\circ}$ 17, Valladolid, 1997, pp. 219-242.

-CACHINERO, Jorge: "Intervencionismo y reformas militares en España a comienzos del siglo XX", Cuadernos de Historia Contemporánea, n 16, Madrid, 1988, pp. 155184.

-CALLE VELASCO, María Dolores de la: “Aspectos de la vida cotidiana salmantina a principios del siglo XX” en KENT, C. (Coord.): Salamanca en el siglo XX. Delaware: Ohio; Salamanca: Librería Cervantes, 1997, pp. 53-65.

-CAMPOS MARTÍNEZ, José $\mathrm{M}^{\mathrm{a}}$ : Abd-el-Krim y el Protectorado. Málaga: Algazara, 2000.

-CÁNOVAS DEL CASTILlO, Antonio: Apuntes para la historia de Marruecos. Málaga: Editorial Algazara, 1991.

-CAPELLÁN DE MIGUEL, Gonzalo y GARRIDO MARTÍN, Aurora: “Los intérpretes de la opinión. Uso, abuso y transformación del concepto Opinión Pública en el discurso de la Restauración (1875-1902)", Ayer, no 80, Madrid, 2010, pp. 87-114.

-CARASA SOTO, Pedro (Dir.): Élites. Prosopografía Contemporánea. Valladolid: Universidad de Valladolid, 1994.

- (Dir.): Élites castellanas de la Restauración. Una aproximación al poder político en Castilla, Vol. II. Valladolid: Junta de Castilla y León. Consejería de Educación y Cultura, 1997.

- (Coord.): Ayuntamiento, Estado y Sociedad. Los poderes municipales en la España Contemporánea. Valladolid: Excelentísimo Ayuntamiento de Valladolid, 2000.

- (Dir.): El poder local en Castilla. Estudios sobre su ejercicio durante la Restauración (1874-1923). Valladolid: Universidad de Valladolid, 2003.

- (Coord.): La memoria histórica de Castilla y León. Historiografía castellana en los siglos XIX y XX. Salamanca: Junta de Castilla y León, 2003.

-CARASA SOTO, Pedro y DÍEZ CANO, Leopoldo Santiago: "La élite parlamentaria salmantina de la Restauración”, Studia Histórica. Historia Contemporánea, no 13-14, Salamanca, 1995-1996, pp. 39-61.

-CARASA SOTO, Pedro y DÍEZ CANO, Leopoldo Santiago: "Epilogo: La Restauración (1875-1898)" en ROBLEDO, R. (Coord.): Historia de Salamanca, Vol. IV. El siglo XIX. Salamanca: Centro de Estudios Salmantinos, 2001, pp. 523-535.

-CARDONA, Gabriel: El poder militar en la España contemporánea hasta la Guerra Civil. Madrid: Siglo XXI, 1983.

-: Historia del Ejército. El peso de un grupo social diferente. Barcelona: Editorial Humanitas, 1987.

—: El problema militar en España. Madrid: Alba Libros S.L., 2005. 
—: Alfonso XIII, el Rey de espadas. Barcelona: Planeta, 2010.

-CARRASCO GARCÍA, Antonio: Annual, 1921. Madrid: RBA Coleccionables, 2007.

-CARRASCO GONZÁLEZ, Antonio M.: La novela colonial hispanoafricana. Las colonias africanas de España a través de la historia de la novela. Madrid: Casa de África/Sial Ediciones, 2000.

—: "Notas sobre el Desastre de Annual", Estudios Africanos, no 18-19, Madrid, 1996, pp. 155-170.

-CARRERAS ARES, Juan José: Razón de historia. Estudios de historiografía. Madrid: Marcial Pons, 2000.

-: "La regionalización de la historiografía: histoire regionale, Landesgeschite e historia regional" en VVAA: Encuentro en las tierras turolenses. Actas. Teruel: Instituto de Estudios Turolenses, 1986, pp. 19-25.

-CASADO Y ESCUDERO, Luis: Igueriben. Madrid: Almena, 2007.

-CASANOVA, Julián: "Historia local, historia social y microhistoria” en RÚJULA, P. y PEIRÓ, I. (Coords.): La historia local en la España contemporánea. Barcelona: L'Avenç, 1999, pp. 17-28.

-CERRO AGUILAR, Enrique: Camino de Annual. Albacete y el Desastre de 1921. Albacete: Instituto de Estudios Albacetenses "Don Juan Manuel”, 2007.

-CHAPA, Álvaro: La construcción de los Saltos del Duero, 1903-1970. Historia de una epopeya colectiva. Pamplona: Ediciones Universidad de Salamanca /Enusa, 1999.

-CHOMSKY, Noam: Cómo nos venden la moto. Información, Poder y concentración de medios. Barcelona: Icaria, 2002.

-CLEMENTE, Joseph Carles: Historia de la Cruz Roja Española. Madrid: Cruz Roja, 1990.

-: Tiempo de humanidad. La labor sanitaria de Cruz Roja Española (1864-1997). Madrid: Fundamentos, 2003.

-COLOMAR CERRADA, Vicente Pedro: La forja de una tragedia (El Rif, 1920-1921). Madrid: CEP Editorial, 2008.

-COMALADA, Ángel: España: El ocaso de un Parlamento, 1921-1923. Barcelona: Ediciones Península, 1985.

-COX HAN, Lori y HEITH, Diane: In the Public Domain: Presidents and the Challenges of Public Leadership. New York: State University of New York Press, 2005.

-CRESPO, Ricardo: “Sender en El Telegrama del Rif”, Azalet, no 1, Granada, 1998, pp. 7-28.

-DADER GARCÍA, José Luis: El periodista en el espacio público. Barcelona: Bosch, 1992.

—: "La documentación de la opinión pública (fuentes bibliográficas y estructuración temática)", Documentación de las Ciencias de la Información, $\mathrm{n}^{\circ}$ 14, Madrid, 1991, pp. 145-180.

-DARDÉ MORALES, Carlos: La idea de España en la historiografía del siglo XX. Santander: Universidad de Cantabria, 1999. 
-DELGADO IDARRETA, José Miguel: "La prensa: fuente historiográfica” en VVAA: Investigación humanística y científica en la Rioja. La Rioja: Aróspide/Instituto de Estudios Riojanos, 2003, pp. 245-255.

-DESVOIS, Jean-Michel: La prensa española (1900-1931). Madrid: Siglo XXI, 1977.

- : "La prensa frente al Desastre de Marruecos, de Annual a Monte Arruit" en VVAA: Metodología de la Historia de la prensa española. Madrid: Siglo XXI, 1982, pp. 233244.

-DEUTSCH, Karl: El análisis de las relaciones internacionales. Buenos Aires: Paidos, 1970.

-DÍAZ, Elías: Unamuno. Pensamiento político. Madrid: Tecnos, 1965.

-DÍAZ FERNÁNDEZ, José: El blocao. Madrid: Viamonte, 1998.

—: Crónicas de la guerra de Marruecos (1921-1922). Antología. Gijón: Ateneo Obrero de Gijón, 2004.

-DÍEZ CANO, Leopoldo Santiago: “Aproximación a los grupos dominantes en la Salamanca de la Restauración”, Salamanca. Revista de Estudios, n 31-32, Salamanca, 1993, pp. 155-181.

-DÍEZ ELCUAZ, José Ignacio: Arquitectura y urbanismo en Salamanca (1890-1939). Salamanca: Colegio Oficial de Arquitectos de León, 2003.

-DÍEZ SÁNCHEZ, Juan: “Melilla, 1909. Álbum gráfico”, Aldaba, no 15, Melilla, 1990, pp. 115-169.

-DJBILUO, Abdellah: Crónicas del Norte (Viajeros españoles en Marruecos). Tetuán: Publicaciones de la Asociación de Tetouán Asmir, 1998.

-EAUDE, Michael: Arturo Barea. Triunfo en la medianoche del siglo. Badajoz: Editora Regional de Extremadura, 2001.

-ESPADAS BURGOS, Manuel: "El factor ultramarino en la formación de la mentalidad militar español", Estudios de Historia Social, no 1-4, Madrid, 1988, pp. 311-325.

-ESTEBAN DE VEGA, Mariano: “Católicos contra liberales: notas sobre el ambiente ideológico salmantino de la Restauración”, Studia Histórica. Historia Contemporánea, Vol. IV, no 4, Salamanca, 1986, pp. 51-69.

-: "Propietarios y proteccionistas en la Restauración; Salamanca, 1883-1892", Salamanca. Revista de estudios, no 20-21, Salamanca, 1986, pp. 201-216.

-ESTEBAN DE VEGA, Mariano y LÓPEZ SANTAMARÍA, Jesús: "El reformismo de la Comisión de Reformas Sociales en las provincias: el caso de Salamanca", Studia Histórica. Historia Contemporánea, Vol. II, no 4, Salamanca, 1984, pp. 151-155.

-ESTEBAN DE VEGA, Mariano y LÓPEZ SANTAMARÍA, Jesús: “El Congreso Agrícola de Salamanca de 1887. Un episodio de la movilización proteccionista castellana", Studia Histórica. Historia Contemporánea, Vol. IV, nº 4, Salamanca, 1986, pp. 71-86.

-ESTEBAN DE VEGA, Mariano, GONZÁLEZ GÓMEZ, Santiago y REDERO SAN ROMÁN, Manuel: Salamanca, 1900-1936: la transformación limitada de una ciudad. Salamanca: Diputación de Salamanca, 1992. 
-FARAMIÑÁN GILBERT, Juan Manuel de y GUTIÉRREZ CASTILLO, Víctor Luis: La Conferencia de Algeciras y las relaciones internacionales. Sevilla: Fundación Tres Culturas, 2007.

-FERNÁNDEZ, Ricardo: Salamanca. Crónica Siglo XX. Salamanca: Diputación de Salamanca, 2001.

-FERNÁNDEZ BASTARRECHE, Fernando: "El soldado ante la guerra de Marruecos" en VVAA: A la memoria de Agustín Díaz Toledo. Almería: Servicio de Publicaciones de la Universidad de Almería, 1995, pp. 351-360.

-FERNÁNDEZ CLEMENTE, Eloy y FORCADELL ÁLVAREZ, Carlos: "El estado de la cuestión en la historia regional y local" en TUÑ́́N DE LARA, M.: Historiografía española contemporánea. X coloquio del Centro de Investigaciones Hispánicas de la Universidad de Pau. Balance y resumen. Madrid: Siglo XXI, 1980, pp. 449-456.

-FERNÁNDEZ MOTA, Manuel: Memoria histórica de una Conferencia (Algeciras, 1906). Algeciras: Fundación Municipal de Cultura "José Luis Cano", 2001.

-FERNÁNDEZ DE LA REGUERA, Ricardo y MARCH, Susana: El Desastre de Annual. Barcelona: Planeta, 1985.

-FERNÁNDEZ TRILLO, Manuel y MCINIIS, Elisabeth: "Implantación obrera: socialistas y comunistas en Salamanca durante la II República", Salamanca. Revista de Estudios, no 15, Salamanca, 1985, pp. 87-163.

-FERNÁNDEZ VARGAS, Valentina: Sangre o dinero: el mito del Ejército nacional. Madrid: Alianza, 2004.

-FERRERA CUESTA, Carlos: "Formación de la imagen monárquica e intervencionismo regio: los comienzos del reinado de Alfonso XIII (1902-1910)", Hispania, LXIV/1, no 216, 2004, pp. 237-266.

-FLORES, A. y CICUÉNDEZ, J. M.: 1913-1927. Guerra aérea sobre el Marruecos español. Madrid: Museo del Aire, 1990.

-FORBES, Rosita: El Raisuni, Sultán de las montañas. Madrid: Almuzara, 2010.

-FORCADELL ÁLVAREZ, Carlos: "Sobre desiertos y secanos: los movimientos sociales en la historiografía española", Historia Contemporánea, n 7, Bilbao, 1992, pp. 101-116.

-: "La fragmentación espacial en la historiografía contemporánea: la historia regional/local y el temor a la síntesis", Studia Histórica. Historia Contemporánea, $\mathrm{n}^{\circ}$ 13-14, Salamanca, 1995-1996, pp. 7-27.

-FRANCIA, Ignacio: "Periodismo salmantino en el siglo XX", Salamanca. Revista de Estudios, $\mathrm{n}^{\circ}$ 45, Salamanca, 2000, pp. 377-400.

-FRANCO, Francisco: Papeles de la guerra de Marruecos. Madrid: Fundación Nacional Francisco Franco, 1986.

-FUENTES, Juan Francisco y FERNÁNDEZ SEBASTIÁN, Javier: Historia del periodismo español. Prensa, política y opinión pública en la España Contemporánea. Madrid: Síntesis, 1997.

-FUSI AIZPÚRUA, Juan Pablo: "Revisionismo crítico e historia nacionalista (a propósito de un artículo de Borja de Riquer)", Historia Social, no 7, Valencia, 1990, pp. 127-136. 
-GALÁN, Fermín: La barbarie organizada. Novela del Tercio. Madrid: Galland Books, 2008.

-GALLEGO, José Andrés: El socialismo durante la Dictadura, 1923-1930. Madrid: Tebas, 1977.

- (Coord.): Historia de la historiografía española. Madrid: Ediciones Encuentro, 1999.

-GARCÍA, Dionisio: "El desembarco de Alhucemas", Serga. Historia militar del siglo $X X, \mathrm{n}^{\circ}$ 7, Madrid, 2000, pp. 49-54.

-GARCÍA BEAUDOUX, Virginia y D’ADAMO-FLAVIA, Orlando: “Opinión pública y comunicación: El doble flujo de la comunicación política”, Iconos. Revista de Ciencias Sociales, $\mathrm{n}^{\circ}$ 7, Quito, pp. 136-146.

-GARCÍA GALINDO, Juan Antonio. "Estudios de periodismo. Los primeros tratadistas españoles" en DESVOIS, Jean-Michelle: Prensa, impresos, lectura en el mundo hispano contemporáneo. París: PILAR, 2005, pp. 179-191.

-GARCÍA GARCÍA, José María: Prensa y vida cotidiana en Salamanca (siglo XIX). Salamanca: Universidad de Salamanca, 1990.

-GARCÍA MORENO, José F.: Servicio militar en España (1913-1935). Madrid: Servicio de Publicaciones del EME, 1988.

-GARCÍA NIETO, Carmen, DONEZAR, Javier Ma y LÓPEZ PUERTA, Luis: Bases documentales de la España Contemporánea. La crisis del sistema canovista (18981923). Madrid: Guadiana de Publicaciones, 1972.

-GARCÍA DE LA RASILLA ORTEGA, Ma del Carmen: Los problemas de Marruecos y la opinión pública Vallisoletana (1898-1927). Memoria de Licenciatura inédita, Universidad de Valladolid, 1985.

—: "Repercusión del problema marroquí en la vida vallisoletana (1909-1927)", Investigaciones Históricas. Departamento de Historia Moderna y Contemporánea, $\mathrm{n}^{\circ}$ 6, Valladolid, 1986, pp. 179-208.

—: "Palencia y la guerra de Marruecos (1909-1927)" en VVAA: Actas del I Congreso de Historia de Palencia. Tomo III. Edad Moderna y edad Contemporánea. Palencia: Diputación Provincial de Palencia, 1987, pp. 715-723.

-GARCÍA DEL RÍO FERNÁNDEZ, Juan y GONZÁLEZ ROSADO, Carlos: Blocaos. Vida y muerte en Marruecos. Madrid: Almena, 2009.

-GARCÍA ZARZA, Eugenio: Salamanca. Evolución, estructura, forma de poblamiento y otros aspectos demográficos (1900-1970). Salamanca: Universidad de Salamanca, 1976.

-GIL ANDRÉS, Carlos: Echarse a la calle: amotinados, huelguistas y revolucionarios (La Rioja, 1890-1936). Zaragoza: Prensas Universitarias de Zaragoza, 2000.

—: “ ¡Abajo la guerra! Repercusiones de la Semana Trágica de 1909 en Calahorra”, Kalakorikos, no 3, Calahorra, 1998, pp. 127-138.

-GOES, Carmen: "Igueriben. El inicio del Desastre", Serga. Historia militar del siglo $X X, \mathrm{n}^{\circ} 22$, Madrid, 2003, pp. 33-43.

-GÓMEZ APARICIO, Pedro: Historia del periodismo español. De las guerras coloniales a la Dictadura. Madrid: Editora Nacional, 1974. 
-GÓMEZ JORDANA, Francisco: La tramoya de nuestra actuación en Marruecos. Madrid: Editora Nacional, 1976.

-GÓMEZ OCHOA, Fidel: "Por una nueva interpretación de la crisis final de la Restauración: el gobierno Maura de agosto de 1921 y la reforma económica de Cambó", Investigaciones Históricas. Departamento de Historia Moderna y contemporánea, $\mathrm{n}^{\circ}$ 11, Valladolid, 1991, pp. 251-271.

-GONZÁlEZ ALCANTUD, José Antonio: Marroquíes en la Guerra Civil Española. Campos equívocos. Barcelona: Antrhopos, 2003.

-GONZÁLEZ ALCANTUD, José Antonio y MARTíN CORRALES, Eloy (Eds.): La Conferencia de Algeciras en 1906: un banquete colonial. Barcelona: Bellaterra, 2007.

-GONZÁLEZ HERNÁNDEZ, Ma Jesús: El universo conservador de Antonio Maura. Biografía y proyecto de Estado. Madrid: Biblioteca Nueva, 1997.

-GONZÁLEZ-POLA DE LA GRANJA, Pablo: La configuración de la mentalidad militar contemporánea (1868-1909). Madrid: Ministerio de Defensa, 2003.

-GONZÁLEZ PÉREZ, Bernardino: Narrativa española en torno a la guerra de Marruecos. Tesis doctoral microfilmada, Universidad de Oviedo, 1992.

-GÓMEZ FERRER, Guadalupe y SÁNCHEZ, Raquel (Eds.): Modernizar España. Proyectos de reforma y apertura internacional (1898-1914). Madrid: Biblioteca Nueva, 2007.

-GONZÁLEZ CALBET, Ma Teresa: La Dictadura de Primo de Rivera. El Directorio Militar. Madrid: El Arquero, 1987, p. 198 y 278.

-GONZÁLEZ SEGURA, Andrés Alberto: "La condición del periodista católico en las Asambleas de la Buena Prensa (1904-1924), El Argonauta Español, no 4, 2007 (http://argonauta.imageson.org/document88.html).

-GONZÁLEZ VELILLA, María del Carmen: Orientación general de la política exterior española entre 1898 y 1907: los compromisos internacionales. Tesis doctoral Inédita, Universidad Complutense de Madrid, 1998.

-GRANJA SAINZ, José Luis de: "La historiografía española reciente: un balance" en BARROS, C. (Ed.): Historia a debate, Vol. I. Santiago de Compostela: Historia a Debate, 1995, pp. 299-308.

-GUTIÉRREZ POCH, Miquel: "Control de mercado y concentración empresarial: La Papelera Española, 1902-1935”, Revista de Historia Industrial, n 10, Barcelona, 1996, pp. 183-199.

-GUERRERO ACOSTA, José Manuel: El Ejército Español en campaña, 1643-1921. Glorias y miserias del soldado español. Madrid: Almena, 1998.

-HABERMAS, Jürgen: Historia y crítica de la opinión pública. México: Gustavo Gili, 1986.

-HALL, Morgan C.: Alfonso XIII y el ocaso de la monarquía liberal, 1902-1923. Madrid: Alianza, 2005.

-HERNÁNDEZ DÍAZ, José Ma: La educación en Salamanca durante la Restauración (1875-1900). Tesis doctoral inédita, Universidad de Salamanca, 1980. 
—: "Entre las resistencias al cambio y la universidad deseada, 1900-1936" en VVAA: Historia de la Universidad de Salamanca, Vol. I. Trayectoria y vinculaciones. Salamanca: Universidad de Salamanca, 2002, pp. 283-312.

-HERNÁNDEZ HERNÁNDEZ, Carlos Ernesto: A tiros y a alcaldes. Élites políticas y conflictos de poder: la dictadura de Primo de Rivera y su Directorio militar en Salamanca (1923-1925). Memoria de Licenciatura inédita, Universidad de Salamanca, 1997.

-HERNÁNDEZ SÁNCHEZ, Galo: "Las empresas de prensa diaria en Castilla y León”, Salamanca. Revista de Estudios, no 35-36, Salamanca, 1995, pp. 213-242.

-HERNÁNDEZ SÁNCHEZ-BARBA, Mario y ALONSO BAQUER, Miguel (Coords.): Historia social de las Fuerzas Armadas españolas, Vol. V. La Restauración. Madrid: Alhambra, 1986.

-HIDALGO DE CISNEROS, Ignacio: Cambio de rumbo. Vitoria-Gasteiz: Ikusager Ediciones, 2001.

-HOISINGTON, William A.: Lyautey and the French conquest of Morocco. Nueva York: Macmillan, 1995.

-HOYO APARICIO, Andrés: “Análisis regional e historia económica” en RUEDA, G. (Ed.): Doce estudios de historiografía contemporánea. Santander/Madrid: Universidad de Cantabria/Asamblea Regional de Cantabria, 1991, pp. 242-251.

-INFANTE MIGUEL-MOTTA, Javier: "Diego Martín Veloz (1875-1938). Historia de un golpista", Alcores. Revista de Historia Contemporánea, n 2, León, 2006, pp. 179209.

-IRADIEL, Paulino: "Història local i història geral: entre política i cultura del territori" en VVAA: L'Espai viscut. Col-loqui internacional d'història local. Valencia: Diputación de Valencia, 1989, pp. 47-70.

-JULIÁ, Santos: Los socialistas en la política española, 1879-1982. Madrid: Taurus, 1996.

—: "La historia social y la historiografía española" en MORALES MOYA, A. y ESTEBAN DE VEGA, M. (Eds.): La historia contemporánea en España. Salamanca: Universidad de Salamanca, 1992, pp. 183-196.

—: "La historia social y la historiografía española", Ayer, no 10, Madrid, 1993, pp. 2946.

—: "Protesta, liga y partido: tres maneras de ser intelectual", Ayer, n ${ }^{\mathbf{0}}$ 28, Madrid, 1997, pp. 163-192.

-KADDUR, Mohamed: Antología de textos sobre la Guerra del Rif. Málaga: Algazara, 2005.

-LAARBI, Alí Mohamed: "El Rif y el Protectorado español”, Aldaba, n 22, Melilla, 1993, pp. 293-303.

-LA PORTE, Pablo: El Desastre de Annual y la crisis de la Restauración en España (1921-1923). Tesis doctoral inédita, Universidad Complutense de Madrid, 1997.

—: La atracción del imán. El Desastre de Annual y sus repercusiones en la política europea (1921-1923). Madrid: Biblioteca Nueva, 2001. 
—: "La respuesta urbana ante la crisis de Annual (1921-1923)", Estudios Africanos, no 18-19, Madrid, 1996, pp. 109-124.

-: “El Desastre de Annual, ¿un olvido historiográfico?”, Cuadernos de Historia Contemporánea, $\mathrm{n}^{\circ}$ 19, Madrid, 1997, pp. 223-229.

- : "Liberalismo y política colonial en la Restauración: la zona de influencia de España en Marruecos (1898-1931)" en SUÁREZ CORTINA, M.: Las máscaras de la libertad. El liberalismo español, 1808-1950. Madrid: Parcial Pons, 2003, pp. 471-490.

—: "Marruecos y la crisis de la Restauración, 1917-1923", Ayer, nº 63, Madrid, 2006, pp. 53-74.

-LA ROSA, Tristán: “Alfonso XIII, Rey de España”, Los grandes hechos del siglo XX, no 65, Madrid, 1982, pp. 49-60.

-LEGUINECHE, Manuel: Annual, 1921. El Desastre de España en el Rif. Madrid: Alfaguara, 1996.

-LIPPMANN, Walter: La opinión pública. Langre: Madrid, 2003.

-LÓPEZ BARRANCO, Juan José: El Rif en armas. La narrativa española sobre la guerra de Marruecos (1859-2005). Madrid: Marenostrum, 2006.

-LÓPEZ DE ZUAZO, Antonio: Catálogo de periodistas españoles del siglo XX. Madrid: Universidad Complutense, 1988.

-LÓPEZ GARCÍA, Bernabé: Marruecos y España. Una historia contra toda lógica. Sevilla: RD Editores, 2007.

- : "Arabismo y orientalismo en España: radiografía y diagnóstico de un gremio escaso y apartadizo", Awraq. Estudios sobre el mundo árabe e islámico contemporáneo, Vol. XI, Madrid, 1990, pp. 35-69.

—: "Correspondencia de Julián Ribera a Pascual Meneu: una amistad en una etapa decisiva del arabismo", Sharq Al-Andalus, no 10-11, Teruel, 1993-1994, pp. 499-526.

—: "La cuestión de Marruecos. Julián Ribera y Tarragó (1858-1934)", Revista de Estudios Internacionales Mediterráneos, nº 6, Madrid, 2008, pp. 172-190.

-LÓPEZ GARCÍA, Bernabé y HERNANDO DE LARRAMENDI, Miguel (Coords.): Historia y memoria de las relaciones hispano-marroquies. Un balance en el cincuentenario de la independencia de Marruecos. Madrid: Ediciones del Oriente y de Mediterráneo, 2007.

-LÓPEZ GARCÍA, David: El blocao y el oriente: una introducción al estudio de la narrativa del siglo XX de tema marroquí. Murcia: Universidad de Murcia, 1994.

-LUIS MARTÍN, Francisco de: Filiberto Villalobos. Obra escrita. Textos, colaboraciones periodísticas e intervenciones parlamentarias. Salamanca: Caja Duero, 2005.

—: "La quiebra de la monarquía (1917-1923)" en PAREDES, J. (Coord.): Historia Contemporánea de España. Barcelona: Ariel, 2004, pp. 431-460.

-LLEIXÁ CHAVARRÍA, Joaquín: "Funciones políticas del Ejército en la última centuria", Revista de Estudios Políticos, no 42, Madrid, 1984, pp. 189-209. 
-MADALENA CALVO, José Ignacio: "El socialismo durante la dictadura de Primo de Rivera, 1923-1930" en VVAA: Socialistas y ugetistas en España, 1879-1939. Salamanca: Agrupación principal de Salamanca PSCL-PSOE, 1988, pp. 121-145.

-MADARIAGA, María Rosa de: España y el Rif. Crónica de una historia casi olvidada. Melilla: La Biblioteca de Melilla, 1999 (existe una tercera edición del 2008).

- : Luis de Oteyza, un periodista liberal. Melilla: Servicio de Publicaciones de la Ciudad Autónoma de Melilla, 2000.

-: Los moros que trajo Franco... La intervención de las tropas coloniales en la Guerra Civil. Barcelona: Ediciones Martínez Roca, 2002.

—: En el Barranco del Lobo. Las guerras de Marruecos. Madrid: Alianza Editorial, 2005.

—: Abd-el-Krim El Jatabi. La lucha por la independencia. Madrid: Alianza Editorial, 2009.

—: "Le Parti socialiste espagnol et le Parti communiste d'Espagne face à la révolte rifaine", en VVAA: Abd-el-Krim et la République du Rif. París: François Maspero, 1976, pp. 308-366.

—: "Melilla y la fiebre minera en el primer cuarto del siglo XX", Aldaba, no 19, Melilla, 1990, pp. 183-202.

—: "Algunas consideraciones sobre el Estado Rifeño" en LORING GARCÍA, M. I. (Ed.): Historia social, pensamiento historiográfico y Edad Media. Homenaje al profesor Abilio Barbero. Madrid: Ediciones del Orto, 1997, pp. 511-536.

-: "Nacionalismos vasco y catalán frente a la revolución de Abd-el-Krim", Historia 16, Año XXII, no 268, Madrid, 1998, pp. 69-77.

—: "Imagen del moro en la memoria colectiva del pueblo español y retorno del moro en la Guerra Civil", Historia 16, Año XXVI, n 319, Madrid, 2002, pp. 8-36.

-: "La guerra colonial llevada a España: las tropas marroquíes en el Ejército franquista" en GONZÁLEZ ALCANTUD, J. A. (Ed): Marroquíes en la Guerra Civil española. Campos equívocos. Barcelona: Anthropos, 2003, pp. 58-94.

—: "E1 Protectorado español en Marruecos: algunos rasgos distintivos y su proyección en el presente", Anales de Historia Contemporánea, Murcia, nº 23, 2007, pp. 171-182.

-MADARIAGA, María Rosa de y LÁZARO ÁVILA, Carlos: “Guerra química en el Rif (1921-1927), Historia 16, Año XXVI, no 324, Madrid, 2003, pp. 50-85.

-MÁlAGA GUERRERO, Jesús: "Unamuno, concejal", Salamanca. Revista de Estudios, no 41, Salamanca, 1998, pp. 177-194.

-MANRIQUE GARCÍA, José María y MOLINA FRANCO, Lucas: Antes que Sadam.... Las armas de destrucción masiva y la protección civil en España. 1924-2000. Madrid: Quirón, 2003.

-MARCOS DEL OLMO, M $\mathrm{M}^{\mathrm{a}}$ Concepción: Voluntad popular y urnas. Elecciones en Castilla y León durante la Restauración y la Segunda República (1907-1936). Valladolid: Universidad de Valladolid, 1995.

-MARÍN, Manuela: "Un encuentro colonial: viajeros españoles en Marruecos (18601912)”, Hispania, XVI/1, no 192, 1996, pp. 93-114. 
—: "Orientalismo en España: estudios árabes y acción colonial en Marruecos (18931943)”, Hispania, LXIX/1, no 231, 2009, pp. 117-146.

-MARÍN ARCE, José María: "El gobierno de la concentración liberal: el rescate de prisioneros en el poder de Abd-el-Krim", Espacio, tiempo y forma, n ${ }^{\circ}$, Madrid, 1988, pp. 163-181.

-MARÍN GELABERT, Miquel: "Por los infinitos rincones de la patria... La articulación de la historiografía local en los años cincuenta y sesenta" en RÚJULA, P. y PEIRÓ, I. (Coords.): La historia local en la España contemporánea. Barcelona: L'Avenç, 1999, pp. 341-378.

-MARTÍ, Manuel: "Historias locales e historias nacionales" en RÚJULA, P. y PEIRÓ, I. (Coords.): La historia local en la España contemporánea. Barcelona: L’Avenç, 1999, pp. 51-61.

-MARTÍN CORRALES, Eloy: La imagen del magrebí en España. Una perspectiva histórica: siglo XVI-XX. Barcelona: Bellaterra, 2002.

- (Ed.): Marruecos y el colonialismo español (1859-1912): de la Guerra de África a la "penetración pacifica". Barcelona: Bellaterra, 2002.

- (Ed.): Semana Trágica: entre las barricadas de Barcelona y el Barranco del Lobo. Barcelona: Bellaterra, 2011.

—: "El cine español y las guerras de Marruecos (1896-1994)", Hispania, LV/2, no 190, 1995, pp. 893-708.

- : "Intereses catalanes en la expansión colonial española en el norte de África (18601912)" en DÍEZ TORRE, Alejandro R.: Ciencia y memoria de África: Actas de las III jornadas sobre expediciones científicas y africanismo. Madrid: Servicio de Publicaciones de la Universidad de Alcalá de Henares, 2002, pp. 91-110.

—: "El orientalismo malagueño" en GONZÁLEZ ALCANTUD, J. A. (Coord.): El orientalismo desde el sur. Barcelona: Anthropos, pp. 192-216

—: "Marruecos y los marroquíes en la propaganda oficial del Protectorado", Melanges de la Casa Velázquez, nº 37, Madrid, 2007, pp. 83-108.

-MARTÍN, Miguel: El colonialismo español en Marruecos. París: Ruedo Ibérico, 1973.

-MARTÍNEZ ANTONIO, Francisco Javier: "Medicina y sanidad en el Protectorado de España en Marruecos. Resistencia, hibridación y transformación metropolitana" en MARTÍNEZ PÉREZ, J. et al.: La medicina ante el nuevo milenio: una perspectiva histórica. Cuenca: Universidad de Castilla-La Mancha, 2004, pp. 381-394.

-MARTÍNEZ DE CAMPOS, Carlos: España bélica. El siglo XX. Marruecos. Madrid: Aguilar, 1969.

-MARTÍNEZ CARRERAS, José U. (Coord.): Relaciones entre España y Marruecos en el siglo XX. Madrid: Asociación Española de Africanistas, 2000.

-: "El marco histórico hispano-marroquí: el Protectorado de España en Marruecos" en FERRER BENIMELI, J. A. (Coord.): La masonería en la España del siglo XX. Vol. II. Toledo: Universidad y Cortes de Castilla-La Mancha, 1996, pp. 859-870.

-MARTÍNEZ GALLEGO, Francesc A.; CHUST CALERO, Manuel y HERNÁNDEZ GASCÓN, Eugenio: Valencia, 1900. Movimientos sociales y conflictos políticos 
durante la guerra de Marruecos, 1906-1914. Castellón de la Plana: Universitat Jaume I, 2001.

-MARTÍN DE LA GUARDIA, Ricardo M. y PÉREZ SÁNCHEZ, Guillermo A.: "Opinión pública y medios de comunicación" en PEREIRA, J. C. (Coord.): La política exterior de España (1800-2003): historia, condicionantes y escenarios. Barcelona: Ariel, 2003.

-MARTÍN ESCORZA, Antonio: El Tebib Arrumi. El médico español que se hizo periodista en el Rif para vivir la historia y contarla. Madrid: Editorial Tichel, 2003.

-MARTÍNEZ SALAZAR, Ángel: "Pero no, la guerra no es bonita. Aproximación a la figura del corresponsal de guerra", Sancho el Sabio: Revista de cultura e investigación vasca, $\mathrm{n}^{\mathrm{o}}$ 7, Vitoria-Gasteiz, 1997, pp. 107-130.

-MARTÍNEZ SANZ, José Luis: "Prisión, humillación y castigo: los frutos del 98 para los militares", Cuadernos de Historia Contemporánea, no 20, Madrid, 1998, pp. 191203.

-: "La historia militar como género histórico", Cuadernos de Historia Contemporánea, $\mathrm{n}^{\circ}$ extraordinario, Madrid, 2003, pp. 37-47.

-MAS CHAO, Andrés: La formación de la conciencia africanista en el Ejército español (1909-1926). Madrid: SGE, 1988.

-MATEO DIESTE, Joseph Lluis: La "hermandad" hispano-marroquí. Política y religión bajo el Protectorado español en Marruecos (1912-1956). Barcelona: Bellaterra. Colección Alborán, 2003.

-MENÉNDEZ PÉREZ, Jesús: "La guerra de Marruecos en la novelística española", Estudios Africanos, no 25-26, Madrid, 1999-2000, pp. 125-145.

-MENÉNDEZ PIDAL, Ramón: Historia de España. Vol. XXIX. La edad de plata de la cultura española (1898-1936). Madrid: Espasa-Calpe, 1994.

-MESA, José Luis et al.: Las campañas de Marruecos, 1909-1927. Almena: Madrid, 2001.

-MIGUEL FRANCISCO, Luis: Annual, 1921. Crónica de un Desastre. Valladolid: AF Editores, 2005.

-MIRALLES GARCÍA, Enrique: "La guerra de la escritura: elecciones discursivas de los escritores-soldados en la campaña militar sobre Marruecos (1920-1924)", Salina, no 19, Tarragona, 2005, pp. 115-120.

-MOGA ROMERO, Vicente: El soldado occidental. Ramón J. Sender en África (19231924). Málaga: UNED/Ciudad Autónoma de Melilla, 2004.

-: La cuestión marroquí en la escritura africanista. Una aproximación a la contribución bibliográfica y editorial española al conocimiento del norte de Marruecos (1859-2006). Melilla: Bellaterra, 2008.

-MOHA, Edouard: Las relaciones hispano-marroquíes. Málaga: Editorial Algazara, 1992.

-MOLINA LUQUE, J. Fidel: Quintas y servicio militar: Aspectos sociológicos y antropológicos de la conscripción (Lleida, 1878-1960). Tesis doctoral inédita, Universidad de Lleida, 2001.

-MONTES RAMOS, José: El Tercio. Madrid: Agualarga, 2001. 
-MONTGOMERY HART, David y RAHA AHMED, Rachid (Eds.): La sociedad beréber del Rif marroquí. Sobre la teoría de la segmentariedad en el Magreb. Granada: Editorial Universidad de Granada, 1999.

-MORALES LEZCANO, Víctor: El colonialismo hispano-francés en Marruecos (18981927). Madrid: Siglo XXI, 1976.

—: España y el mundo árabe: imágenes cruzadas. Madrid: Agencia Española de Cooperación Internacional, 1993.

-: Las relaciones hispano-marroquíes en el marco de la historia de las relaciones internacionales contemporáneas. Madrid: UNED, 2004.

- : Historia de Marruecos. De los orígenes tribales y las poblaciones nómadas a la independencia y la monarquía actual. Madrid: La Esfera de los Libros, 2006.

-MORALES MOYA, Antonio: "Salamanca y sus hombres: una visión de la ciudad", Salamanca. Revista de estudios, n 33-34, Salamanca, 1994, pp. 13-28.

-MORENO JUSTE, Antonio: “El Socialista y el Desastre de Annual: opinión y actitud socialista ante la derrota”, Cuadernos de Historia Contemporánea, $\mathrm{n}^{\circ}$ 12, Madrid, 1990, pp. 103-132.

-MUÑOZ ALONSO, Alejandro et alii: Opinión pública y comunicación política. Madrid: Eudema, 1990.

-MUÑOZ BOLAÑOS, Roberto: "Las campañas de Marruecos" en VVAA: Aproximación a la historia militar de España. Volumen 2. Madrid: Ministerio de Defensa, pp. 599-614.

-NAVAJAS ZUBELDIA, Carlos: "Historiografía militar española en el siglo XX (1940-1989)", Hispania L/3, nº 176, 1990, pp. 1361-1371.

—: “Consideraciones sobre la historia militar", Hispania, LVI/2, n 193, 1996, pp. 739753.

—: "La salvaguardia de lo permanente. Las extremas derechas militares en la España del siglo XX", Hispania, LXI/1, n 207, 2001, pp. 69-98.

-NERÍN, Gustau: La guerra que vino de África. Barcelona: Crítica, 2005.

-NIETO SORIA, José Manuel; ENCISO RECIO, Luis Miguel et allii: Propaganda y opinión pública en la historia. Valladolid: Universidad de Valladolid, 2007.

-NOGUÉ, Joan y VILLANOVA, José Luis (Eds.): España en Marruecos (1912-1956). Discursos geográficos e intervención territorial. Lleida: Editorial Milenio, 1999.

-NÚÑEZ FLORENCIO, Rafael: "La mentalidad militar en el marco de la Restauración canovista", Cuadernos de Historia Contemporánea, no 14, Madrid, 1992pp. 31-53.

-NÚÑEZ RUIZ, Diego y RIBAS RIBAS, Pedro: Unamuno y el socialismo. Artículos recuperados (1886-1928). Granada: De Guante Blanco, 1997.

-ORTEGA Y GASSET, Eduardo: Annual. La Coruña: Ediciones El Viento, 2008.

-ORTIZ DE URBINA, Paloma: "La Primera Guerra Mundial y sus consecuencias: la imagen de Alemania en España a partir de 1914", Revista de Filología Alemana, no 15, Madrid, 2007, pp. 193-206. 
-OTERO CARVAJAL, Luis Enrique: "Las telecomunicaciones en la España Contemporánea, 1855-2000", Cuadernos de Historia Contemporánea, no 29, Madrid, 2007, pp. 119-152.

-OUIMETTE, Víctor: De patriotismo espiritual. Artículos en La Nación de Buenos Aires, 1901-1914. Salamanca: Ediciones Universidad de Salamanca, 1997.

-PABÓN, Jesús: Cambó. Barcelona: Editorial Alpha, 1952.

-PALMA MORENO, Juan T.: Annual 1921. 80 años después. Madrid: Almena, 2001.

-PANDO, Juan: Historia secreta de Annual. Madrid: Temas de Hoy, 1999.

—: Hombres de América que lucharon en África. Madrid: Casa de América, 2000.

- : "La hora de las responsabilidades. Otoño de 1921: España pide cuentas por la derrota en el Rif', Historia 16, Año XXI, no 248, Madrid, 1996, pp. 21-27.

—: “Un año después de Annual. La pesadilla africana en la España de 1922”, Historia 16, Año XXII, nº 260, Madrid, 1997, pp. 8-17.

-PAPA MAMOUR, Diop: "Sobre la literatura de guerra: aproximación a crónicas de la guerra de Marruecos (1921-1922) y El Blocao de José Díaz Fernández", Ogigia, revista electrónica de estudios hispánicos, nº 4, 2008, pp. 25-36.

-PARDO, Rosa: "Colonización e imperialismo", en VVAA: Historia política y social moderna y contemporánea. Madrid: UNED, 2001, pp. 395-421.

-PASAMAR ALZURIA, Gonzalo: La historia contemporánea. Aspectos teóricos e historiográficos. Madrid: Síntesis, 2000.

—: "Maestros y discípulos: algunas claves de la renovación de la historiografía española en los últimos cincuenta años" en RÚJULA, P. y PEIRÓ, I. (Coords.): La historia local en la España contemporánea. Barcelona: L’Avenç, 1999, pp. 62-77.

-PASAMAR ALZURIA, Gonzalo y PEIRÓ MARTÍN, Ignacio: "Historia nacional e historia local: problemas epistemológicos y práctica social en España" en VVAA: Encuentro en las tierras turolenses. Actas. Teruel: Instituto de Estudios Turolenses, 1986, pp. 29-47.

-PASCUAL MARTÍNEZ, Pedro: Escritores y editores en la Restauración Canovista. Tesis doctoral inédita, Universidad Complutense de Madrid, 1992.

-: "Prensa, Ejército y Parlamento en la guerra de Marruecos", Historia 16, n 276, Madrid, 1999, pp. 63-77.

-PASTOR GARRIGUES, Francisco Manuel: España y la apertura de la cuestión marroquí (1897-1904). Tesis doctoral inédita, Universidad de Valencia, 2006.

-PAYNE, Stanley: Los militares y la política en la España Contemporánea. París: Ruedo Ibérico, 1968.

-PEDRAZ MARCOS, Azucena: Quimeras de África. La Sociedad Española de Africanistas y Colonialistas. El colonialismo español a finales del siglo XIX. Madrid: Polifemo, 2000.

-PELAZ LÓPEZ, José-Vidal: Caciques, apóstoles y periodistas. Medios de comunicación, Poder y sociedad en Palencia (1898-1939). Valladolid: Universidad de Valladolid, 2000. 
-: Prensa y sociedad en Palencia durante el siglo XIX (1808-1898). Valladolid: Universidad de Valladolid, 2002.

-PENNELL, Richard C.: La Guerra del Rif. Abd-el-Krim el-Jattabi y su estado rifeño. Melilla: Biblioteca de Melilla, 2001.

—: Marruecos. Del imperio a la independencia. Madrid: Alianza editorial, 2003.

-PEREIRA CASTEÑARES, Juan Carlos: "El contenciosos de Tánger en las relaciones hispano-francesas (1923-1924)" en VVAA: Españoles y franceses en la primera mitad del siglo XX. Madrid: CSIC, 1986, pp. 303-322.

-PEREIRA CASTEÑARES, Juan Carlos y NEILA HERNÁNDEZ, José Luis: "La España de Alfonso XIII en el sistema internacional de posguerra (1919-1931), Historia Contemporánea, $\mathrm{n}^{\circ}$ 34, Bilbao, 2007, pp. 117-154.

-PÉREZ MOLINA, Elisa: El norte de Marruecos, de la Conferencia de Algeciras al Protectorado. Su repercusión en las Cortes española (1906-1912). Tesis doctoral inédita, Universidad Autónoma de Madrid, 1986.

-PICASSO, Juan: El expediente Picasso: las sombras de Annual. Madrid: Almena, 2003.

-PIZARROSO QUINTERO, Alejandro: Historia de la propaganda. Notas para un estudio de la propaganda política y de guerra. Madrid: Eudema, 1993.

-: "Justificando la guerra. Manipulación de la opinión pública en los conflictos más recientes", Comunicación. Revista internacional de comunicación audiovisual, publicidad y estudios. Vol. 1, nº 6, Sevilla, 2008, pp. 3-19.

-PONCE MARRERO, Javier: "La política exterior española de 1907 a 1920: entre el regeneracionismo de intenciones y la neutralidad condicionada", Historia Contemporánea, $\mathrm{n}^{\circ}$ 34, Bilbao, 2007, pp. 93-115.

-PRIETO, Indalecio: Con el Rey o contra el Rey: la guerra de Marruecos (2 vols.). Barcelona: Planeta, 1990.

—: Crónicas de la Guerra de Melilla. Málaga: Editorial Algazara, 2001.

-: Discursos parlamentarios sobre la guerra de Marruecos. Málaga: Editorial Algazara, 2003.

-PRO RUIZ, Juan: "Sobre el ámbito territorial de los estudios de historia" en BARROS, C. (Ed.): Historia a debate, Vol. III. Santiago de Compostela: Historia a Debate, 1995, pp. 59-64.

-PUELL DE LA VILLA, Fernando: El soldado desconocido. De la leva a la mili. Madrid: Biblioteca Nueva, 1996.

—: Historia del Ejército en España. Madrid: Alianza, 2000.

—: "El Ejército" en ESPADAS BURGOS, M. (Coord.): La época de la Restauración (1875-1902). Vol. 1. Estado, política e islas de ultramar. Madrid: Espasa Calpe, 1996, pp. 179-196.

—: "La historiografía militar en el tiempo presente" en VVAA: Hacer la historia del siglo XX. Madrid: Biblioteca Nueva, 2004, pp. 147-170.

—: "La educación de adultos en el servicio militar", Revista de Historia Militar, no 95, Madrid, 2004, pp. 67-94. 
—: "La institución militar como objeto de análisis histórico", Revista de Historia Militar, n” 100, pp. 47-54, 2006.

- QUIROGA VALLE, María Gloria: El papel alfabetizador del Ejército de Tierra español (1893-1954). Madrid: Ministerio de Defensa, 1999.

-RABATÉ, Jean-Claude: 1900 en Salamanca. Salamanca: Universidad de Salamanca, 1997.

-: "Estudiantes católicos contra estudiantes liberales en la Salamanca de 1900", Salamanca. Revista de Estudios, no 38, Salamanca, 1997, pp. 169-189.

-RABATÉ, Colette y Jean-Claude: Miguel de Unamuno. Biografía. Madrid: Taurus, 2009.

-RAMIRO DE LA MATA, Javier: Origen y dinámica del colonialismo español en Marruecos. Ceuta: Ciudad Autónoma de Ceuta, Archivo Central, 2001.

—: "La Conferencia de Madrid en 1925 sobre el Protectorado de Marruecos", Estudios Africanos, Vol. XII, no 22-23, Madrid, 1998, pp. 157-172.

—: "Los prisioneros españoles cautivos de Abd-el-Krim: un legado del Desastre de Annual”, Anales de Historia Contemporánea, no 18, Murcia, 2002, pp. 341-353.

-: "España y el Protectorado en Marruecos. Aproximación a un proceso colonial", Anales de Historia Contemporánea, nº 24, Murcia, 2007, pp. 291-305.

-RAMÓN, Manuel de y ORTIZ, Carmen: Madrinas de guerra. Cartas desde el frente. Madrid: La esfera de los libros, 2003.

-REGAN, Geoffrey: Historia de la incompetencia militar. Barcelona: Crítica, 1989.

-REIG CRUAÑES, José: Opinión pública y comunicación politica en la Transición democrática. Tesis doctoral inédita, Universidad de Alicante, 2000.

-REPOLLÉS DE ZALLAS, Julio y GARCÍA AGUD, Arturo (Dirs.): Historia de las campañas de Marruecos, Vol. 3. Madrid: Servicio Histórico Militar, 1981.

-RIESCO PÉREZ-DUEÑO, Juan M.: "Imán y Ramón J. Sender", Cuadernos de Historia Contemporánea, no 14, Madrid, 1992, pp. 183-192.

-RIQUER I PERMANYER, Borja de: "Sobre el lugar de los nacionalismosregionalismos en la historia contemporánea española”, Historia Social, n 7, Valencia, 1990, pp. 105-126.

-ROBERTS, Stephen G. H.: "Miguel de Unamuno y su relación con el socialismo entre 1914 y 1924: una primera aproximación", Cuadernos de la Cátedra Miguel de Unamuno, no 43, Salamanca, 2007, pp. 89-98.

-ROBLEDO, Ricardo (Coord.): Historia de Salamanca. Vol. IV y V. Salamanca: Centro de Estudios Salmantinos, 2001.

—: Sueños de concordia. Filiberto Villalobos y su tiempo histórico, 1900-1955. Salamanca: Caja Duero, 2005.

-ROBLEDO, Ricardo (Ed.): Esta salvaje pesadilla. Salamanca en la Guerra Civil española. Madrid: Crítica, 2007.

-ROBLES, Laureano y URRUTIA LEÓN, Manuel: Artículos desconocidos en El Mercantil Valenciano (1917-1923). Valencia: Colección Ideas, 2003. 
-ROBLES, Laureano: "El arabista castellonense Pascual Meneu, amigo de Unamuno (Cartas inéditas)", Boletín de la Sociedad Castellonense de Cultura, no 70, Castellón, 1994, pp. 197-240.

-: "Nuevas aportaciones sobre Meneu", Boletín de la Sociedad Castellonense de Cultura, nº 80, Castellón, 2004, pp. 355-399.

-ROBLES MUÑOZ, Cristóbal: 1898. Diplomacia y opinión. Madrid: CSIC, 1991.

—: “Guerra de Melilla y reajustes en Europa (1893-1894)", Hispania, LIX/3, no 203, 199, pp. 1033-1061.

—: "España y Marruecos: antecedentes de los Acuerdos con Francia (1898-1904)" en DÍEZ TORRE, Alejandro R.: Ciencia y memoria de África: Actas de las III jornadas sobre expediciones científicas y africanismo. Madrid: Servicio de Publicaciones de la Universidad de Alcalá de Henares, 2002, pp. 197-228.

-RODA FERNÁNDEZ, Rafael: Medios de comunicación de masas. Su influencia en la sociedad y en la cultura contemporáneas. Madrid: Centro de Investigaciones Sociológicas, 1989.

-RODRÍGUEZ MEDIANO Y HELENA DE FELIPE: El Protectorado español en Marruecos. Gestión colonial e identidades. Madrid: CSIC, 2002.

-RODRÍGUEZ URIBES, J. Manuel: Opinión pública. Concepto y modelos históricos. Madrid: Marcial Pons, 1999.

-ROMERO SALVADÓ, Francisco J.: España, 1914-1918. Entre la guerra y la revolución. Madrid: Crítica, 2002.

-ROSAS LEDEZMA, Enrique: "Las declaraciones de Cartagena (1907): Significación en la política exterior de España y repercusiones internacionales", Cuadernos de Historia Contemporánea, $\mathrm{n}^{\circ}$ 2, Madrid, 1981, pp. 214-229.

-: "Las relaciones hispano-británicas a comienzos del siglo XX: los caminos del entendimiento", Revista de Estudios Internacionales, $\mathrm{n}^{\mathrm{o}}$ 1, Madrid, 1980, pp. 53-60;

-RUBIO CAMPAÑA, Antonio: Periodistas españoles en la Guerra del Rif (Marruecos): 1921-1923. Origen del periodismo de investigación en España. Tesis doctoral inédita (aunque pendiente de una próxima edición), Universidad Complutense de Madrid, 2005.

-RUIPÉREZ ALMAJANO, Ma Nieves: El Colegio Mayor de San Bartolomé o de Anaya. Salamanca: Universidad de Salamanca, 2003.

- RUIZ ACOSTA, María José: “Oposición y colaboración: la prensa sevillana ante los sucesos de Barcelona de 1909”, Revista Latina de Comunicación social, $\mathrm{n}^{\circ} 24$, La Laguna, 1999. http://www.ull.es/publicaciones/latina/a1999adi/04mjruiz.htm.

-RUIZ TORRES, Pedro: "Microhistoria i història local” en VVAA: L'Espai viscut. Col-loqui internacional d'història local. Valencia: Diputación de Valencia, 1989, pp. 71-92.

-SÁENZ GUALLAR, Francisco Javier: "La perspectiva etnográfica en la historia local" en RÚJULA, P. y PEIRÓ, I. (Coords.): La historia local en la España contemporánea. Barcelona: L'Avenç, 1999, pp. 466-489. 
-SAHAGÚN, Felipe: El mundo fue noticia. Corresponsales españoles en el extranjero: La información internacional en España. Madrid: Fundación Banco Exterior. Colección Investigaciones, 1986.

-SALAFRANCA ORTEGA, Jesús F.: El sistema colonial español en África. Málaga: Algazara, 2001.

—: La República del Rif. Málaga: Algazara, 2004

-SALAS LARRAZÁBAL, Ramón: El Protectorado de España en Marruecos. Madrid: MAPFRE, 1992.

-SALES, Nuria: Sobre esclavos, reclutas y mercaderes de quintos. Barcelona: Ariel, 1974.

-SAMANIEGO BONEU, Mercedes et alii: Publicaciones periódicas salmantinas, 1793-1936. Salamanca: Universidad de Salamanca, 1984.

-SÁNCHEZ DÍAZ, Ramón: "Retablo biográfico de Abd-el-Krim el-Jatabi”, Revista de Historia Militar, nº 60, Madrid, 1986, pp. 129-156.

-SÁNCHEZ ILLÁN, Juan Carlos: Prensa y política en la España de la Restauración. Rafael Gasset y El Imparcial. Madrid: Biblioteca Nueva, 1999.

-SÁNCHEZ MARCO, Luis José: "La identidad nacional y la guerra de Marruecos" en VVAA: Actas III de Historia de Llerena. Llerena: Sociedad Extremeña de Historia, 2002, pp. 296-315.

-SÁNCHEZ MARROYO, Fernando: "1898. Guerra en las colonias y crisis social en España”, Anales de Historia Contemporánea, no 14, Murcia, 1998, pp. 179-193.

-SÁNCHEZ MORALES, Jorge: Manuel Delgado Barreto. Las Palmas de Gran Canaria: Ediciones Idea, 2008.

-SÁNCHEZ PASCUAL, Rafael: Episcopologio salmantino. Obispos del siglo XX. Salamanca: Publicaciones del Cabildo de la Catedral de Salamanca, 2006.

- SÁNCHEZ SANZ, Oscar Javier: Diplomacia y política exterior. España, 1890-1914. Tesis doctoral inédita, Universidad Complutense de Madrid, 2006.

—: “La formación del diplomático, 1890-1914: ¿elitismo o profesionalismo?", Cuadernos de Historia Contemporánea, nº 23, Madrid, 2001, pp. 241-270.

-SANTAMARÍA, Jesús L.: "Señora de gran nobleza a la que le huelen los pies. La ciudad de Salamanca a finales del siglo XIX", Studia Histórica. Historia Contemporánea, Vol. IV, $\mathrm{n}^{\circ}$ 4, Salamanca, 1986, pp. 87-112.

-SANTANDER, Teresa (Dir.): Publicaciones periódicas salmantinas existentes en la Biblioteca Universitaria (1793-1981). Salamanca: Biblioteca Universitaria, 1986.

-SANTONJA, Gonzalo: Del lápiz rojo al lápiz libre. La censura previa de publicaciones periódicas y sus consecuencias editoriales durante los últimos años del reinado de Alfonso XIII. Barcelona: Anthropos, 1986.

SARO GANDARILLAS, Francisco: "Los orígenes de la campaña del Rif de 1909", Aldaba, $\mathrm{n}^{\circ}$ 22, Melilla, 1993, pp. 97-129.

-SECO SERRANO, Carlos: La España de Alfonso XIII. Madrid: Espasa-Calpe, 2005.

—: "Relaciones entre la corona y el Ejército", Revista de estudios políticos, no 55, 1987, pp. 27-54. 
-SENABRE LÓPEZ, David: Salamanca en 1898. Salamanca: Ayuntamiento de Salamanca, 1998.

-: Desarrollo urbanístico de Salamanca en el siglo XX. Planes y proyectos en la organización de la ciudad. Salamanca: Junta de Castilla y León. Consejería de Fomento, 2003.

-SÉNDER, Ramón J.: Imán. Madrid: Destino, 2003.

-SEOANE, M M Cruz y SÁIZ, M Molores: Historia del periodismo en España. El siglo XX: 1898-1936. Alianza: Madrid: 1996.

-SERNA, Alfonso de la: Al sur de Tarifa: España-Marruecos, un malentendido histórico. Madrid: Marcial Pons, 2001.

-SERNA, Justo y PONS, Anaclet: “El ojo de la aguja. ¿De qué hablamos cuando hablamos de microhistoria?, Ayer, n 12, Madrid, 1993, pp. 93-133.

-SERRANO, Carlos y SALAÜM, Serge: Los felices años veinte: España, crisis y modernidad. Madrid: Marcial Pons Historia, 2006.

-SERRANO, Carlos: "El PSOE y las cuestiones coloniales (1898-1914), Hispania, LVIIII/1, no 98, 1998, pp. 283-304.

-SEVILLANO CALERO, Francisco: "La historia contemporánea en España: viejas polémicas y nuevos enfoques historiográficos", Ayer, no 43, Madrid, 2001, pp. 225244.

-SOLÉ TURA, Jorge: "Historiografia y nacionalismo. Consideraciones sobre el concepto de nación" en VVAA: Once ensayos sobre la historia. Madrid: Fundación Juan March, 1976, pp. 89-104.

-STONE, Lawrence: El pasado y el presente (traducción de Lorenzo Aldrete Bernal). México D.F.: Fondo de Cultura Económica, 1986.

-SUEIRO SEOANE, Susana: España en el Mediterráneo. Primo de Rivera y "la cuestión marroqui'", 1923-1930. Madrid: UNED, 1992.

—: "La incorporación de Tánger, una batalla perdida de la dictadura primorriverista", Espacio, tiempo y forma, $\mathrm{n}^{\circ}$ 2, Madrid, 1989, pp. 69-88.

—: "El mito del estratega: Primo de Rivera y la resolución del problema de Marruecos", Cuadernos de Historia Contemporánea, no 16, Madrid, 1994, pp. 113-130.

—: "La política mediterránea", Ayer, no 49, Madrid, 2003, pp. 185-202.

—: "La historia de las relaciones internacionales en España. Un balance. Tendencias actuales y perspectivas de futuro" en VVAA: Hacer la historia del siglo XX. Madrid: Biblioteca Nueva, 2004, pp. 95-118.

-TALLMAN, Mark: "Patriotism, or Bread and Circuses? A Brief Discussion of the September-October 2001 Rally Round the Flag Effect", Critique: a worldwide student journal of politics, $\mathrm{n}^{\mathrm{o}}$ 13, Illinois, 2007, pp. 64-80.

-TELLECHEA IDÍGORAS, José: "Unamuno en Hendaya", Cuadernos de la Cátedra Miguel de Unamuno, no 34, Salamanca, 1999, pp. 133-159.

-TEMSAMANI, Abdelaziz Khallouk: País Yebala: Majzén, España y Ahmed Raisuni. Granada: Universidad de Granada, 1999. 
-TESSAINER Y TOMASICH, Carlos Federico: El Raisuni, aliado y enemigo de España. Málaga: Algazara, 1998.

—: "El Raisuni, secuestrador de extranjeros", Estudios Africanos, n 6, Madrid, 1989, pp.25-31.

—: “¿Por qué El Raisuni no pactó con Abd-el-Krim?”, Estudios Africanos, n 8-9, Madrid, 1990, pp. 101-106.

-TOLEDANO MOLINA, Juana: "La guerra de Marruecos (1920-1921): crónicas y novelas" en VVAA: Actas del XIV Congreso de la Asociación de Hispanistas. Vol. III. Nueva York: AIH, 2001.

-TORRE DEL RÍO, Rosario de: "La política exterior española en el año de la crisis de 1911 a través de la correspondencia del marqués de Alhucemas" en VVAA: Estudios históricos. Homenaje a los profesores José Ma Jover Zamora y Vicente Palacio Atard. Madrid: Universidad Complutense, 1990, pp. 381-406.

-: "Preparando la Conferencia de Algeciras: el Acuerdo hispano-francés de 1 de septiembre de 1905 sobre Marruecos", Cuadernos de Historia Contemporánea, $\mathrm{n}^{\circ}$ extraordinario, Madrid, 2007, pp. 311-320.

—: "Entre 1898 y 1914: La orientación de la política exterior española" en VVAA: Política española y política naval tras el Desastre (1900-1914). Cuadernos monográficos del Instituto de Historia y Cultura Naval, no 15, Madrid, 1991, pp. 7-21.

-TUSELL, Javier y QUEIPO DE LLANO, Genoveva: Alfonso XIII. El Rey polémico. Taurus: Madrid, 2001.

-ULLMAN, Joan C.: La Semana Trágica. Barcelona: Ariel, 1972.

-URRUTIA, Luis: Obras completas. Madrid: Escelicer, 1971

-URRUTIA LEÓN, Manuel Ma: "Unamuno y la revista Nuevo Mundo (artículos desconocidos)", Cuadernos de la Cátedra Miguel de Unamuno, n 34, Salamanca, 1999, pp. 161-203.

-: "Unamuno en El Adelanto de Salamanca (textos desconocidos)", Cuadernos de la Cátedra Miguel de Unamuno, no 38, Salamanca, 2003, pp. 141-176.

—: "Artículos salmantinos disperso de Unamuno", Cuadernos de la Cátedra Miguel de Unamuno, no 39, Salamanca, 2004, pp. 209-247.

-: "La colaboración de Unamuno en El Liberal de Madrid", Cuadernos de la Cátedra Miguel de Unamuno, no 41, Salamanca, 2006, pp. 213-282.

-URRUTIA SALAVERRI, Luis: Artículos en La Nación de Buenos Aires (1919-1924). Salamanca: Ediciones Universidad de Salamanca, 1994.

-VAL CID, Consuelo del: Opinión pública y opinión publicada. Los españoles y el referéndum de la OTAN. Madrid: CIS/Siglo XXI, 1996.

-VALDEÓN BARUQUE, Julio: "La historiografía española de finales del siglo XX: miseria de la teoría" en BARROS, C. (Ed.): Historia a debate, Vol. I. Santiago de Compostela: Historia a Debate, 1995, pp. 310-317.

—: "La elaboración del discurso histórico en Castilla" en GARCÍA DE CORTÁZAR, J.A.: Memoria histórica de Cantabria. Santander/Salamanca: Universidad de Cantabria/Asamblea Regional de Cantabria, 1996, pp. 219-226. 
-VALLE, Alejandro del y VERDÚ, Jesús (Dirs.): España y Marruecos en el centenario de la Conferencia de Algeciras. FMV: Madrid, 2007.

-VALLE, José Antonio del: "La censura gubernativa de prensa en España (19141931)", Revista de Estudios políticos, n 21, Madrid, 1981, pp. 73-126.

- VALLEJO POUSADA, Rafael: "El impuesto de consumos y la resistencia antifiscal en la España de la segunda mitad del siglo XIX: un impuesto no exclusivamente urbano", Revista de Historia Económica, no 2, Madrid, 1996, pp. 339-370.

-VARGAS GONZÁLEZ, Alejandro: La guerra de Marruecos en la literatura. Málaga: Algazara, 2001.

-VÁZQUEZ HERNÁNDEZ, Vicente: “Cine y propaganda en la guerra de Marruecos", Historia 16, n 296, Madrid, 2000, pp. 70-79.

-VILANOVA RIBAS, Mercedes y MORENO JULIÁ, Xavier: Atlas de la evolución del analfabetismo en España de 1887 a 1981. Madrid: Ministerio de Educación y Ciencia, 1992.

-VILLALOBOS, Federico: El sueño colonial. Las guerras de España en Marruecos. Barcelona, Ariel, 2004.

-VILlanOVA VALERO, José Luis: El Protectorado de España en Marruecos. Organización política y territorial. Barcelona: Bellaterra, 2004.

- : Los interventores. La piedra angular del Protectorado de España en Marruecos. Barcelona: Bellaterra, 2006.

—: "La Sociedad Geográfica de Madrid y el colonialismo español en Marruecos (18761956)", Documents d'anàlisi geogràfica, nº 34, Barcelona, 1999, pp. 161-187.

-: "Los interventores del Protectorado español en Marruecos (1912-1956) como agentes geopolíticos", Ería, nº 66, Gerona, 2005, pp. 93-111.

- : "La pugna entre militares y civiles por el control de la actividad interventora en el Protectorado español en Marruecos (1912-1956)", Hispania, LXI/2, no 220, 2005, pp. 683-716.

-VISCARRI, Dionisio: Nacionalismo autoritario y orientalismo. La narrativa prefascista de la guerra de Marruecos (1921-1927). Il Capitello del sole: Bolonia, 2004.

-VOLTES, Pedro: La Semana Trágica. Madrid: Espasa-Calpe, 1995.

-VVAA: Metodología de la historia de la prensa española. Madrid: Siglo XXI, 1982.

-VVAA: Análisis crítico de una bibliografía básica de sociología militar en España. 1980-1990. Madrid: Cuadernos de Estrategia, CESEDEN, 1991.

-VVAA: Fuentes y métodos de la historia local. Actas. Zamora: Instituto de Estudios Zamoranos "Florián Ocampo", 1991.

-VVAA: I Congreso de Historia de Salamanca, 1989, Vol. III. Salamanca: Diputación de Salamanca/Universidad de Salamanca, 1992.

-VVAA: Periodismo y periodistas. De las Gazetas a la red. Barcelona: España Nuevo Milenio, 2001.

-VVAA: Revista de Historia Militar, Año XLVI, Número extraordinario, Madrid, 2002.

-VVAA: Propaganda en guerra. Salamanca: Consorcio Salamanca 2002. 
-VVAA: Actas del Congreso Internacional. La Conferencia de Algeciras de 1906. Cien años después. Algeciras: Fundación Municipal de Cultura José Luis Cano, 2008.

-WOOLMAN, David S.: Abd-el-Krim y la Guerra del Rif. Barcelona: Biblioteca Tau, 1971.

-ZEMON DAVIS, Natalie: "Las formas de la historia social", Historia Social, no 10, Valencia, 1990, pp. 177-182. 